\title{
DE AANSPRAKELIJKHEID OP GROND VAN EEN
}

403-VERKLARING

Een studie naar de uitleg van de 403-aansprakelijkheid in het licht van de functie van deze aansprakelijkheid bij de compensatie van crediteuren van een 403-maatschappij 
Verkorte citeerwijze: Van Dooren, De aansprakelijkheid op grond van een 403-verklaring (IVO nr. 122) 2021/[paragraafnummer].

Volledige citeerwijze: E.A. van Dooren, De aansprakelijkheid op grond van een 403-verklaring (Uitgaven vanwege het Instituut voor Ondernemingsrecht nr. 122), Deventer: Wolters Kluwer 2021.

Ontwerp omslag: Hans Roenhorst, www.h2rplus.nl

ISBN 9789013162172

NUR $827-715$

(C) 2021, Wolters Kluwer Nederland BV; E.A. van Dooren

De klantenservice van Wolters Kluwer Nederland BV kunt u bereiken via: www.wolterskluwer. $\mathrm{nl} /$ klantenservice.

De auteur houdt zich aanbevolen voor inhoudelijke opmerkingen en suggesties. Deze kunt $u$ sturen naar: boeken-NL@wolterskluwer.com.

Alle rechten zijn voorbehouden. Niets uit deze uitgave mag worden verveelvoudigd, opgeslagen in een geautomatiseerd gegevensbestand, of openbaar gemaakt, in enige vorm of op enige wijze, hetzij elektronisch, mechanisch, door fotokopieën, opnamen of enige andere manier, zonder voorafgaande schriftelijke toestemming van de auteur.

Voor zover het maken van kopieën uit deze uitgave is toegestaan op grond van art. $16 \mathrm{~h} \mathrm{t} / \mathrm{m} 16 \mathrm{~m}$ Auteurswet jo. Besluit van 27 november 2002, Stb. 575 is de daarvoor wettelijk verschuldigde vergoeding verschuldigd, te voldoen aan de Stichting Reprorecht (www.reprorecht.nl).

Hoewel aan de totstandkoming van deze uitgave de uiterste zorg is besteed, aanvaarden de auteur, redacteur(en) en Wolters Kluwer Nederland BV geen aansprakelijkheid voor eventuele fouten en onvolkomenheden en evenmin voor de gevolgen hiervan.

Op alle aanbiedingen en overeenkomsten van Wolters Kluwer Nederland BV zijn van toepassing de Algemene Voorwaarden van Wolters Kluwer Nederland BV. U kunt deze raadplegen via: www.wolterskluwer.nl/algemene-voorwaarden.

Indien Wolters Kluwer Nederland BV persoonsgegevens verkrijgt, is daarop het privacybeleid van Wolters Kluwer Nederland BV van toepassing. Dit is raadpleegbaar via www.wolterskluwer. $\mathrm{nl} /$ privacy-cookies.

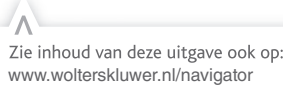

NAVIGATOR 


\section{De aansprakelijkheid op grond van een 403-verklaring}

Een studie naar de uitleg van de 403-aansprakelijkheid in het licht van de functie van deze aansprakelijkheid bij de compensatie van crediteuren van een 403-maatschappij

\section{The liability under a 403-declaration}

A study into the 403-liability in view of the function of this liability with regard to the compensation of creditors of a 403-company

(with a summary in English)

\section{Proefschrift}

ter verkrijging van de graad van doctor aan de Universiteit Utrecht op gezag van de rector magnificus, prof. mr. H.R.B.M. Kummeling, ingevolge het besluit van het college voor promoties in het openbaar te verdedigen op woensdag 3 maart 2021 des middags te 2.30 uur

$$
\text { door }
$$

\section{Etzel Alcuin van Dooren}

geboren op 16 december 1985

te Maastricht 
Promotoren:

Prof. mr. G.J.C. Rensen

Prof. mr. M.A. Verbrugh 


\section{Woord vooraf}

Op 3 maart 2021 is mr. E.A. (Etzel) van Dooren gepromoveerd aan de Universiteit Utrecht op zijn studie naar de aansprakelijkheid op grond van een 403-verklaring. Als promotoren traden op prof. mr. G.J.C. Rensen en prof. mr. M.A. Verbrugh.

De aansprakelijkheid van een moedermaatschappij op grond van een 403-verklaring is een van de voorwaarden waaraan moet zijn voldaan opdat een groepsmaatschappij, een zogenoemde '403-maatschappij', gebruik mag maken van de jaarrekeningvrijstelling ex art. 2:403 BW. De 403-maatschappij is daardoor onder meer vrijgesteld van de verplichting om de jaarrekening openbaar te maken.

In zijn dissertatie onderzoekt Van Dooren hoe de aansprakelijkheid van een moedermaatschappij op grond van een 403-verklaring moet worden uitgelegd in het licht van de functie van deze aansprakelijkheid bij de compensatie van crediteuren omdat zij de jaarrekening van de 403-maatschappij niet kunnen inzien. De studie ziet op de vier belangrijkste thema's met betrekking tot de 403-aansprakelijkheid. Ten eerste de reikwijdte van de aansprakelijkheid. Voorts de civielrechtelijke duiding van een vordering van een crediteur op grond van een 403-verklaring. Het derde thema dat aan de orde komt, betreft de intrekking van een 403-verklaring en de beëindiging van de overblijvende aansprakelijkheid. Tot slot onderzoekt Van Dooren de gevolgen van een fusie of een splitsing van de moeder- of de 403-maatschappij voor de 403-aansprakelijkheid.

Met betrekking tot ieder thema geeft Van Dooren een uitgebreide analyse van het huidige recht, waarbij hij onder meer verwijst naar de wet, wetsgeschiedenis, jurisprudentie en literatuur met betrekking tot het desbetreffende onderwerp. Daarnaast maakt hij waar relevant vergelijkingen met regelingen uit andere rechtsgebieden, de bepalingen in Europese richtlijnen waarvan art. 2:403 BW de implementatie is, en de equivalenten van art. 2:403 BW in Luxemburg, Ierland en Duitsland. Van Dooren onderwerpt het huidige recht aan een kritische analyse aan de hand van een door hem bepleit uitgangspunt voor de compensatie van de crediteuren van een 403-maatschappij. Op basis van deze beschouwingen komt hij tot een geïntegreerde uitleg van de verschillende onderwerpen ten aanzien van de 403-aansprakelijkheid, wat inzicht biedt in de onderlinge wisselwerking daartussen. 
Waar het huidige recht naar zijn mening crediteuren onvoldoende compenseert voor het niet kunnen inzien van de jaarrekening van de 403-maatschappij, of de compensatie ertoe leidt dat zij 'overgecompenseerd' worden, doet Van Dooren aanbevelingen om het desbetreffende onderwerp anders uit te leggen of om de wet te wijzigen. Daarnaast bevat het onderzoek diverse aanbevelingen voor partijen in de praktijk om naar huidig recht hun positie te versterken of mogelijk nadeel te voorkomen. Door deze aanbevelingen biedt dit onderzoek niet enkel voor wetenschappers stof tot overdenking, maar is het ook een waardevolle bron van inspiratie voor de wetgever, rechters, advocaten, notarissen, bedrijfsjuristen en andere praktijkjuristen. Wij nemen dit proefschrift met genoegen op in de reeks van Uitgaven vanwege het Instituut voor Ondernemingsrecht.

C.A. Schwarz

J.B. Wezeman 


\section{Inhoud}

Woord vooraf

Lijst met afkortingen $\quad$ XVII

Hoofdstuk 1. Inleiding 1

1.1 Het onderwerp van het onderzoek 1

1.1.1 Het groepsregime 1

1.1.2 Aandachtspunten voor de moedermaatschappij en crediteuren met betrekking tot de 403-aansprakelijkheid

1.2 Probleem- en doelstelling van het onderzoek 8

1.2.1 Probleemstelling $\quad 8$

$\begin{array}{lr}\text { 1.2.2 Doelstelling en onderzoeksvraag } & 10\end{array}$

$\begin{array}{lll}1.3 & \text { Onderzoeksmethode } & 12\end{array}$

$\begin{array}{ll}1.4 \text { Afbakening } & 14\end{array}$

$\begin{array}{lll}1.5 & \text { Verantwoording } & 16\end{array}$

$\begin{array}{lll}1.6 & \text { Het plan van behandeling } & 17\end{array}$

Hoofdstuk 2. Het groepsregime 21

$\begin{array}{lll}2.1 & \text { Inleiding } & 21\end{array}$

2.2 De wetsgeschiedenis van het groepsregime 21

2.2.1 Art. 13 lid 3 WJO 21

2.2.2 Art. 42c WvK 22

$\begin{array}{lll}2.2 .3 & \text { Art. 38a WJO } & 23\end{array}$

2.2.4 Art. 2:343 (oud) BW 23

$\begin{array}{ll}2.2 .5 & \text { Europese richtlijnen }\end{array}$

2.2.6 Art. 2:403 BW 25

2.3 Voorwaarden om gebruik te mogen maken van de
jaarrekeningvrijstelling

2.3.1 Rechtspersonen die gebruik mogen maken van de

2.3.2 Groepsband tussen de moeder- en de 403-maatschappij 29

2.3.3 De balans en winst- en verliesrekening van de

403-maatschappij $\quad 33$

2.3.4 Instemming door de leden of aandeelhouders $\quad 35$

2.3.4.a Inleiding 35

2.3.4.b Instemmingsgerechtigden $\quad 36$

2.3.4.c De verklaring van instemming 38

2.3.4.d Instemming onder voorwaarden en herroeping van de instemming 40 
2.3.4.e Zijn nieuwe aandeelhouders gebonden aan een eerder gegeven instemming?

2.3.5 De geconsolideerde jaarrekening van de moedermaatschappij

2.3.6 De 403-verklaring

2.3.6.b Intrekking van de 403-verklaring en beëindiging van de overblijvende aansprakelijkheid

2.3.6.c De 'ontoereikende 403-verklaring'

2.4 Het moment dat uiterlijk aan de voorwaarden moet zijn voldaan

2.5 De jaarrekeningvrijstelling van het groepsregime

2.6 Redenen om gebruik te maken van de jaarrekeningvrijstelling

2.6.1 Voorkomen dat derden zich baseren op vertekende gegevens in de jaarrekening

2.6.2 Beperken van het verschil tussen een groepsmaatschappij en een onderdeel van een rechtspersoon

$\begin{array}{lll}2.6 .3 & \text { Verlagen van de administratieve lasten } & 65 \\ 2.6 .4 & \text { Afschermen van informatie } & 66\end{array}$

2.7 Conclusie

Hoofdstuk 3. De compensatie van crediteuren

3.2 Een crediteur heeft belang bij inzicht in de financiële positie van de rechtspersoon

3.3 Voor welk nadeel moet een crediteur worden gecompenseerd? 72

$\begin{array}{lll}3.4 & \text { De compensatie voor crediteuren } & 73\end{array}$

3.4.1 De compensatie bestaat uit twee onderdelen die elkaar aanvullen: aansprakelijkheid en inzicht in een jaarrekening

3.4.2 De enkelvoudige jaarrekening van de moedermaatschappij

3.4.3 Crediteuren komen niet in een nadeliger positie als de moedermaatschappij er financieel minder goed voor staat dan de 403-maatschappij

3.5 De aansprakelijkheid op grond van een 403-verklaring staat niet op zichzelf

3.5.1 Inleiding

3.5.2 Koppeling in art. 2:403 BW tussen de 403-aansprakelijkheid en de mogelijkheid om de geconsolideerde jaarrekening van de moedermaatschappij in te zien

3.5.3 Intrekking van de 403-verklaring en beëindiging van de overblijvende aansprakelijkheid

3.5.4 Geen voorwaarden met betrekking tot de financiële positie van de moedermaatschappij

3.5.5 Tussenconclusie: aansprakelijkheid uitleggen als onderdeel van de compensatie 
3.6 Een crediteur heeft geen instemmingsrecht en mag daarom niet in een nadeliger positie komen

3.6.1 Een crediteur mag niet in een nadeliger positie komen

3.6.2 Voorkomen van overcompensatie

3.7 Mijn uitgangspunt voor de compensatie van crediteuren $\quad 87$

$\begin{array}{lll}3.7 .1 & \text { Grondbeginselen } & 87\end{array}$

3.7.2 Een andere afweging is mogelijk 88

3.8 Kanttekeningen bij het belang van een jaarrekening voor het inzicht van crediteuren

3.9 Conclusie

Hoofdstuk 4. De materiële reikwijdte van de 403-aansprakelijkheid 101

$\begin{array}{lll}4.1 & \text { Inleiding } & 101\end{array}$

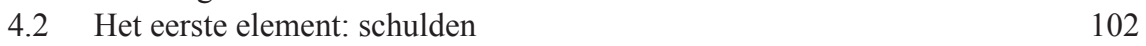

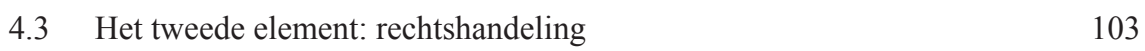

$\begin{array}{lll}\text { 4.3.1 Rechtshandelingen } & 103\end{array}$

$\begin{array}{ll}\text { 4.3.2 Geen aansprakelijkheid voor schulden die uit de wet } & 105 \\ \text { voortvloeien } & 108\end{array}$

$\begin{array}{lll}4.4 & \text { Het derde element: voortvloeien } & 108\end{array}$

$\begin{array}{lll}4.4 .1 & \text { Primaire en secundaire schulden } & 108\end{array}$

$\begin{array}{ll}4.4 .2 \text { Voortvloeien } & 110\end{array}$

$\begin{array}{lll}4.5 & \text { Verschillende schulden nader beschouwd } & 113\end{array}$

$\begin{array}{lll}4.5 .1 & \text { Inleiding } & 113\end{array}$

$\begin{array}{lll}\text { 4.5.2 Intercompany schulden } & 114\end{array}$

4.5.3 Handelen namens een vennootschap in oprichting 115

$\begin{array}{ll}\text { 4.5.4 Bestuurdersaansprakelijkheid } & 118\end{array}$

$\begin{array}{lll}\text { 4.5.4.a Inleiding } & 118\end{array}$

4.5.4.b Interne bestuurdersaansprakelijkheid 119

4.5.4.c Externe bestuurdersaansprakelijkheid 121

4.5.4.d Tussenconclusie 123

$\begin{array}{ll}\text { 4.5.5 Lidmaatschapsverplichtingen } & 124\end{array}$

$\begin{array}{lll}\text { 4.5.6 Vennoot in een personenvennootschap } & 127\end{array}$

$\begin{array}{ll}\text { 4.5.6.a Inleiding } & 127\end{array}$

4.5.6.b Standpunten in de literatuur 128

4.5.6.c Eigen standpunt en het onderscheid tussen interne en externe aansprakelijkheid 130

$\begin{array}{ll}\text { 4.5.6.d Het voorontwerp modernisering } & \\ & \text { personenvennootschappen }\end{array}$

$\begin{array}{lll}\text { 4.5.7 Wettelijke rente } & 137\end{array}$

$\begin{array}{lll}\text { 4.5.8 Salaris van de curator } & 138\end{array}$

$\begin{array}{ll}\text { 4.5.9 Leegstandschade bij faillissement } & 140\end{array}$

4.5.10 Schadevergoeding wegens onveilige arbeidsomstandigheden 142

$\begin{array}{lll}\text { 4.5.11 Sociaal plan } & 143\end{array}$

4.6 Tussenconclusie; vier algemene regels ter beoordeling of een schuld uit een rechtshandeling voortvloeit 
4.7 Voorrecht verbonden aan een vordering 148

4.8 Contractuele achterstelling verbonden aan een vordering 155

4.9 Een overeenkomst ter afwikkeling van een schuld uit de wet 160

$\begin{array}{ll}4.10 \text { Conclusie } & 163\end{array}$

Hoofdstuk 5. De temporele reikwijdte van de 403-aansprakelijkheid 167

$\begin{array}{lll}5.1 & \text { Inleiding } & 167\end{array}$

$\begin{array}{ll}\text { 5.2 Vijf standpunten ten aanzien van de temporele reikwijdte van de } & \\ \text { 403-aansprakelijkheid } & 168\end{array}$

$\begin{array}{lll}5.2 .1 & \text { Inleiding } & 168\end{array}$

5.2.2 Schematisch overzicht 168

5.2.3 Ingangsdatum in een 403-verklaring 171

5.2.4 Overige standpunten ten aanzien van de temporele reikwijdte van de 403-aansprakelijkheid en jurisprudentie die ik buiten beschouwing laat

5.2.5 Het onderzoek naar de temporele reikwijdte van de 403-aansprakelijkheid bestaat uit het beantwoorden van twee vragen

5.3 Is de 403-aansprakelijkheid gerelateerd aan het verrichten van de rechtshandeling of het opeisbaar worden van de schuld?

$\begin{array}{lll}\text { 5.4.1 } & \text { Inleiding } & 176 \\ \text { 5.4.2 } & \text { De parlementaire geschiedenis van het groepsregime } & 176\end{array}$

$\begin{array}{ll}\text { 5.4.3 Bestaande crediteuren hebben geen gebrek aan inzicht } & 180\end{array}$

5.4.4 Kritiek: mogelijk misbruik van het groepsregime 181

5.5 De 403-aansprakelijkheid werkt terug tot het begin van het boekjaar

5.5.1 Nauwe verbondenheid tussen de jaarrekeningvrijstelling en de 403-aansprakelijkheid

5.5.2 Kritiek: willekeur en niet alle crediteuren die nadeel ondervinden worden gecompenseerd

5.6 De 403-aansprakelijkheid werkt onbeperkt terug in het verleden 187

5.6.1 Inleiding

5.6.2 De tekst en de parlementaire geschiedenis van art. 2:403 lid 1 sub f BW

$\begin{array}{lll}\text { 5.6.3 Toelichting op de jurisprudentie } & 191\end{array}$

5.6.4 Compensatie voor alle crediteuren die nadeel ondervinden 193

5.7 Conclusie

Hoofdstuk 6. De duiding van de 403-vordering 197

$\begin{array}{lll}6.1 & \text { Inleiding } & 197\end{array}$

6.2 Vier duidingen van de 403-vordering 199

6.2.1 Duiding van de 403-vordering als een hoofdelijke vordering 199

6.2.2 Duiding van de 403-vordering als een dynamische vordering 199 6.2.2.a Inleiding 
6.2.2.b De gevolgen van de duiding van de 403-vordering als een dynamische vordering

6.2.2.c Hoe verhoudt de dynamische 403-vordering zich tot de jurisprudentie van de Hoge Raad?

6.2.3 Analoge toepassing van art. 6:142 BW

6.2.4 Analoge toepassing van de bepalingen inzake borgtocht 207

6.2.5 Het verhaalsrecht op grond van een 403-verklaring als wilsrecht

6.3 De gevolgen van de verschillende duidingen van de 403-vordering

6.3.2 De crediteur doet afstand van de vordering op de 403-maatschappij

6.3.3 Overeengekomen moment van nakoming, uitstel van betaling en opschorting van nakoming

\subsection{3.a Inleiding}

6.3.3.b Duiding van de 403-vordering als een hoofdelijke vordering

6.3.3.c Duiding van de 403-vordering als een dynamische vordering en analoge toepassing van art. 6:142 BW

6.3.3.d Analoge toepassing van de bepalingen inzake borgtocht

6.3.4 De vordering op de 403-maatschappij is verjaard

6.3.5 Subsidiaire aansprakelijkheid van de moedermaatschappij

6.3.6 Zelfstandig cederen van de vorderingen op de moeder- en de 403-maatschappij

6.3.6.a Duiding van de 403-vordering als een hoofdelijke vordering

6.3.6.b Duiding van de 403-vordering als een dynamische vordering

6.3.6.c Analoge toepassing van art. 6:142 BW

6.3.6.d Analoge toepassing van de bepalingen inzake borgtocht

6.3.7 Zelfstandig verpanden van de vorderingen op de moederen de 403-maatschappij

6.3.7.a Duiding van de 403-vordering als een hoofdelijke vordering

6.3.7.b Duiding van de 403-vordering als een dynamische vordering

6.3.7.c Analoge toepassing van art. 6:142 BW

6.3.7.d Analoge toepassing van de bepalingen inzake borgtocht

6.4 Uitkomsten volgens het door mij bepleite uitgangspunt voor compensatie

6.4.1 De crediteur doet afstand van de vordering op de 403-maatschappij 
6.4.2 Overeengekomen moment van nakoming, uitstel van betaling en opschorting van nakoming

6.4.3 De vordering op de 403-maatschappij is verjaard 233

6.4.4 Subsidiaire aansprakelijkheid van de moedermaatschappij 234

6.4.5 Zelfstandig cederen van de vorderingen op de moeder- en de 403-maatschappij

6.4.6 Zelfstandig verpanden van de vorderingen op de moeder- en de 403-maatschappij

6.5.4 Duiding van de 403-vordering als een dynamische 403-vordering

6.5.5 Duiding van de 403-vordering als een hoofdelijke vordering

Hoofdstuk 7. De intrekking van een 403-verklaring 247

$\begin{array}{lll}7.1 & \text { Inleiding } & 247\end{array}$

$\begin{array}{ll}\text { 7.2 Intrekken van de 403-verklaring } & 248\end{array}$

$\begin{array}{lll}7.2 .1 & \text { De intrekking } & 248\end{array}$

7.2.2 De moedermaatschappij kan de 403-verklaring op ieder moment eenzijdig intrekken

7.2.3 Het moment dat de moedermaatschappij een beroep kan doen op de intrekking van de 403-verklaring

7.2.4 Een 403-verklaring met een einddatum

7.3 De periode tussen het doen van een beroep op de intrekking en de openbaarmaking van een jaarrekening door de 403-maatschappij

7.4 Toekomstige intrekking

7.5 Kan de 403-verklaring tevens gelden als een intrekkingsverklaring? 263

7.6 Vergeten de 403-verklaring in te trekken 266

$\begin{array}{lll}\text { 7.6.1 Inleiding } & 266\end{array}$

$\begin{array}{lll}\text { 7.6.2 Toelichting op de jurisprudentie } & 267\end{array}$

7.6.3 Omstandigheden die mede bepalen of een beroep op de vergeten 403-verklaring onaanvaardbaar is naar maatstaven van redelijkheid en billijkheid

7.6.3.b De groepsband tussen de moeder- en de 403-maatschappij is verbroken

7.6.3.c De 403-maatschappij heeft een jaarrekening openbaar gemaakt

7.6.3.d Professionele partijen

7.6.3.e De crediteur heeft een nauwe band met de 403-maatschappij 
7.6.4 Een beroep op een vergeten 403-verklaring en het door mij bepleite uitgangspunt voor compensatie

7.7 Preventief limiteren van de aansprakelijkheid op grond van een

vergeten 403-verklaring

7.7.1 Inleiding

7.7.2 Een 403-verklaring met de groepsband als voorwaarde voor aansprakelijkheid

7.7.3 Een 403-verklaring met een einddatum

7.7.4 Preventief intrekken van de 403-verklaring 286

$\begin{array}{lll}\text { 7.7.5 Tussenconclusie } & 287\end{array}$

7.8 Misbruik van de intrekking van de 403-verklaring 288

$\begin{array}{lll}7.9 & \text { Conclusie } & 292\end{array}$

Hoofdstuk 8. De beëindiging van de overblijvende aansprakelijkheid 295

$\begin{array}{lll}8.1 \text { Inleiding } & 295\end{array}$

8.2 De reikwijdte van de overblijvende aansprakelijkheid 296

8.2.1 Bestaande en toekomstige schulden 296

8.2.2 Standpunten ten aanzien van de reikwijdte van de overblijvende aansprakelijkheid

8.2.3 De periode tussen het doen van een beroep op de intrekking en de openbaarmaking van een jaarrekening door de 403-maatschappij

8.3 Voorwaarden voor de beëindiging van de overblijvende aansprakelijkheid

8.4 De groepsband tussen de moeder- en de 403-maatschappij is verbroken

8.5 Mededeling en aankondiging van het voornemen om de overblijvende aansprakelijkheid te beëindigen

8.5.1 Deponeren van een mededeling en het plaatsen van een aankondiging in een landelijk verspreid dagblad

8.5.2 Een landelijk verspreid dagblad 309

8.5.3 Informatie in de mededeling en de aankondiging 311

8.5.4 De moedermaatschappij hoeft de crediteuren niet individueel in te lichten dat zij de procedure voor de beëindiging is gestart $\quad 313$

8.6 Verzet instellen tegen het voornemen om de overblijvende aansprakelijkheid te beëindigen

8.6.1 Het recht van verzet en de mogelijkheid om een vervangende $\begin{array}{ll}\text { waarborg te verzoeken: drie vraagstukken } & 316\end{array}$

$\begin{array}{ll}\text { 8.6.2 Het recht van verzet } & 317\end{array}$

$\begin{array}{lll}\text { 8.6.3 De verzetstermijn } & 318\end{array}$

8.7 Partijen die verzet kunnen instellen tegen het voornemen om de
overblijvende aansprakelijkheid te beëindigen

8.7.1 Een crediteur voor wiens vordering nog aansprakelijkheid loopt 
8.7.2 Het verzetsrecht van een crediteur met een niet-vaststaande vordering

8.7.3 Het verzetsrecht van een pandhouder 326

8.8 Heeft de crediteur recht op een vervangende waarborg? 330

8.8.1 Een crediteur heeft geen recht op een vervangende waarborg als hij voldoende andere waarborgen heeft

8.8.2 Een crediteur heeft recht op een vervangende waarborg als zijn positie verzwakt

8.8.3 Beoordelen of een crediteur recht heeft op een vervangende waarborg nadat de 403-maatschappij een jaarrekening openbaar heeft gemaakt

$\begin{array}{lll}8.9 & \text { De vervangende waarborg } & 337\end{array}$

$\begin{array}{lll}8.9 .1 & \text { Inleiding } & 337\end{array}$

8.9.2 Een vervangende waarborg voor toekomstige vorderingen 338

8.9.3 De omvang van de vervangende waarborg 340

8.9.4 Het vaststellen van de omvang van de vervangende waarborg nadat de 403-maatschappij een jaarrekening openbaar heeft gemaakt

8.9.5 Complicaties bij het vaststellen van de vervangende waarborg volgens het door mij bepleite uitgangspunt voor compensatie

8.10 Een vervangende waarborg en de hoofdelijke aansprakelijkheid

8.11 Het verzetsrecht en de vervangende waarborg: drie rekenvoorbeelden

8.12 Aankondiging plaatsen in een landelijk verspreid dagblad nadat de moedermaatschappij een beroep kan doen op de intrekking

8.13 Geen vaste volgorde waarin aan de voorwaarden voor de beëindiging van de overblijvende aansprakelijkheid moet worden voldaan

8.14 Schrappen van de voorwaarde dat de groepsband tussen de moederen de 403-maatschappij is verbroken

8.15 Conclusie

$\begin{array}{lll}\text { Hoofdstuk 9. Fusie, splitsing en omzetting } & 367\end{array}$

$\begin{array}{lll}9.1 & \text { Inleiding } & 367\end{array}$

9.2 Overgang onder algemene titel van de 403-aansprakelijkheid 369

9.2.1 Het vermogen gaat onder algemene titel over 369

9.2.2 Overgang onder algemene titel van de 403-aansprakelijkheid 370

9.2.3 Onderscheid tussen overgang van de bestaande en toekomstige 403-aansprakelijkheid

9.2.4 Overgang onder algemene titel van de overblijvende aansprakelijkheid

9.3 Verzet tegen het voorstel tot fusie of splitsing 376

9.3.1 Het recht om in verzet te komen en een waarborg te verlangen 376

9.3.2 Verschil met het instellen van verzet tegen de beëindiging van de overblijvende aansprakelijkheid

9.4 Het verbreken van de groepsband tussen de moeder- en de 403-maatschappij 
9.4.1 Uitleg van de voorwaarde ex art. 2:404 lid 3 sub a BW dat de groepsband is verbroken

9.4.2 Beëindiging van de overblijvende aansprakelijkheid op het moment van de fusie of de splitsing

9.5 Verschillende casus met betrekking tot een fusie of splitsing van de moeder- of de 403-maatschappij

9.6 Fusie waarbij de moeder- of de 403-maatschappij vermogen verkrijgt 387

9.6.1 Fusie waarbij de 403-maatschappij vermogen verkrijgt 387

9.6.2 Fusie waarbij de moedermaatschappij vermogen verkrijgt 389

$\begin{array}{lll}9.7 & \text { Fusie waarbij de 403-maatschappij verdwijnt } 390\end{array}$

9.7.1 Fusie van de 403-maatschappij met de moedermaatschappij 390

$\begin{array}{lll}\text { 9.7.1.a Inleiding } & 390\end{array}$

9.7.1.b Aansprakelijkheid op grond van de 403-verklaring 390

9.7.1.c Beëindiging van de overblijvende ansprakelijkheid 393

9.7.2 Fusie van de 403-maatschappij met een andere rechtspersoon

dan de moedermaatschappij $\quad 394$

$\begin{array}{lll}\text { 9.7.2.a Inleiding } & 394\end{array}$

9.7.2.b Aansprakelijkheid op grond van de 403-verklaring 395

9.7.2.c Beëindiging van de overblijvende aansprakelijkheid 396

9.8 Fusie waarbij de moedermaatschappij verdwijnt 397

9.8.1 Fusie van de moedermaatschappij met de 403-maatschappij 397

$\begin{array}{lll}\text { 9.8.1.a Inleiding } & 397\end{array}$

9.8.1.b Aansprakelijkheid op grond van de 403-verklaring 398

9.8.1.c Beëindiging van de overblijvende aansprakelijkheid 400

9.8.2 Fusie van de moedermaatschappij met een andere rechtspersoon dan de 403-maatschappij 401

9.8.2.a Inleiding 401

9.8.2.b Aansprakelijkheid op grond van de 403-verklaring 402

9.8.2.c Beëindiging van de overblijvende aansprakelijkheid 403

9.9 Zuivere splitsing van de moeder- of de 403-maatschappij 406

9.9.1 Zuivere splitsing van de 403-maatschappij 406

9.9.1.a Inleiding 406

9.9.1.b Aansprakelijkheid op grond van de 403-verklaring 407

9.9.1.c Subsidiaire aansprakelijkheid van de verkrijgende rechtspersoon op wie een schuld niet is overgegaan $\quad 408$

9.9.1.d Beëindiging van de overblijvende aansprakelijkheid 408

9.9.1.e Een van de verkrijgende rechtspersonen behoort tot een andere groep 409

9.9.2 Zuivere splitsing van de moedermaatschappij 411

9.9.2.a Inleiding 411

9.9.2.b Aansprakelijkheid op grond van de 403-verklaring 411

9.9.2.c Subsidiaire aansprakelijkheid van de verkrijgende rechtspersoon op wie een schuld niet is overgegaan $\quad 412$

9.9.2.d Beëindiging van de overblijvende aansprakelijkheid 413 
INHOUD

$\begin{array}{lll}9.10 & \text { Afsplitsing } & 417\end{array}$

9.10.1 Afsplitsing van vermogen van de 403-maatschappij 417

9.10.1.a Inleiding 417

9.10.1.b Aansprakelijkheid op grond van de 403-verklaring 418

9.10.1.c Subsidiaire aansprakelijkheid van de 403-maatschappij en de verkrijgende rechtspersoon $\quad 418$

9.10.1.d Beëindiging van de overblijvende aansprakelijkheid 419

9.10.2 Afsplitsing van vermogen van de moedermaatschappij 421

9.10.2.a Inleiding 421

9.10.2.b Aansprakelijkheid op grond van de 403-verklaring 422

9.10.2.c Subsidiaire aansprakelijkheid van de moedermaatschappij en de verkrijgende rechtspersoon 423

9.10.2.d Beëindiging van de overblijvende aansprakelijkheid $\begin{array}{r}425 \\ 428\end{array}$

9.12 Grensoverschrijdende fusie, splitsing en omzetting 429

$\begin{array}{lll}9.13 \text { Conclusie } & 432\end{array}$

Hoofdstuk 10. Conclusies en aanbevelingen 437

10.1 Het groepsregime en de problematiek rond de 403-aansprakelijkheid 437

10.2 Het groepsregime (hoofdstuk 2) 440

10.3 De compensatie van crediteuren (hoofdstuk 3) 440

10.4 De materiële reikwijdte van de 403-aansprakelijkheid (hoofdstuk 4) 442

10.5 De temporele reikwijdte van de 403-aansprakelijkheid (hoofdstuk 5) 444

10.6 De duiding van de 403-vordering (hoofdstuk 6) 445

10.7 De intrekking van een 403-verklaring (hoofdstuk 7) 447

10.8 De beëindiging van de overblijvende aansprakelijkheid (hoofdstuk 8) 449

10.9 Fusie, splitsing en omzetting (hoofdstuk 9) 451

10.10 Aanbevelingen $\quad 454$

10.10.1 Inleiding $\quad 454$

10.10.2 Aanbevelingen aan de praktijk $\quad 455$

10.10.3 Aanbevelingen aan de wetgever 457

10.10.4 Aanbevelingen aan de rechterlijke macht 459

10.10.5 Aanbeveling aan de Kamer van Koophandel 461

10.11 Mogelijk vervolgonderzoek 462

$\begin{array}{ll}\text { English summary } & 465\end{array}$

$\begin{array}{ll}\text { Literatuurlijst } & 477\end{array}$

$\begin{array}{ll}\text { Rechtspraakregister } & 505\end{array}$

$\begin{array}{ll}\text { Curriculum Vitae } & 511\end{array}$ 


\section{Lijst met afkortingen}

$\begin{array}{ll}\text { 2eNvW } & \text { Tweede Nota van Wijzigingen } \\ \text { 3eNgvvW } & \text { Derde Nader gewijzigd voorstel van Wet } \\ \text { A-G } & \text { Advocaat-Generaal } \\ \text { AA } & \text { Ars Aequi } \\ \text { aant. } & \text { aantekening } \\ \text { afl. } & \text { aflevering } \\ \text { ARO } & \text { Actuele Rechtspraak Ondernemingsrechtpraktijk } \\ \text { art. } & \text { artikel } \\ \text { Bb } & \text { Nieuwsbrief Bedrijfsjuridische berichten } \\ \text { BV } & \text { besloten vennootschap met beperkte aansprakelijkheid } \\ \text { BW } & \text { Burgerlijk Wetboek } \\ \text { cao } & \text { collectieve arbeidsovereenkomst } \\ \text { CBb } & \text { College van Beroep voor het bedrijfsleven } \\ \text { De NV } & \text { de Naamlooze Vennootschap } \\ \text { diss. } & \text { dissertatie } \\ \text { e.a. } & \text { en anderen } \\ \text { e.v. } & \text { en volgende } \\ \text { EEG } & \text { Europese Economische Gemeenschap } \\ \text { EER } & \text { Europese Economische Ruimte } \\ \text { EU } & \text { Europese Unie } \\ \text { FIP } & \text { Financiering, Zekerheden \& Insolventierechtpraktijk } \\ \text { FW } & \text { Faillissementswet } \\ \text { GmbH } & \text { Gesellschaft mit beschränkter Haftung } \\ \text { HR } & \text { Hoge Raad der Nederlanden } \\ \text { HvJ EG } & \text { Hof van Justitie van de Europese Gemeenschappen } \\ \text { JA } & \text { Jurisprudentie Aansprakelijkheid } \\ \text { JAR } & \text { Jurisprudentie Arbeidsrecht } \\ \text { JBN } & \text { Juridische Berichten voor het Notariaat } \\ \text { JIN } & \text { Jurisprudentie in Nederland } \\ \text { jo. } & \text { juncto } \\ \text { JOR } & \text { Jurisprudentie Onderneming \& Recht } \\ \text { JutD } & \text { Juridisch up to date } \\ \text { KG } & \text { Kort Geding } \\ \text { LLC } & \text { Limited Liability Company } \\ \text { m.comm. } & \text { met commentaar } \\ \text { m.nt. } & \text { met noot } \\ \text { MAB } & \text { Maandblad voor Accountancy en Bedrijfseconomie } \\ & \end{array}$




$\begin{array}{ll}\text { MvA } & \text { Memorie van Antwoord } \\ \text { MvO } & \text { Maandblad voor Ondernemingsrecht } \\ \text { MvT } & \text { Memorie van Toelichting } \\ \text { MvV } & \text { Maandblad voor Vermogensrecht } \\ \text { NAI } & \text { Nederlands Arbitrage Instituut } \\ \text { NJ } & \text { Nederlandse Jurisprudentie } \\ \text { NJB } & \text { Nederlands Juristenblad } \\ \text { NMvA } & \text { Nadere Memorie van Antwoord } \\ \text { NnavhEV } & \text { Nota naar aanleiding van het Eindverslag } \\ \text { NnavhV } & \text { Nota naar aanleiding van het Verslag } \\ \text { nr. } & \text { nummer } \\ \text { NTBR } & \text { Nederlands Tijdschrift voor Burgerlijk Recht } \\ \text { NV } & \text { naamloze vennootschap } \\ \text { O\&F } & \text { Onderneming \& Financiering } \\ \text { OK } & \text { Ondernemingskamer van het Gerechtshof Amsterdam } \\ \text { ORP } & \text { Tijdschrift overeenkomst in de rechtspraktijk } \\ \text { OvW } & \text { Ontwerp van Wet } \\ \text { p. } & \text { pagina } \\ \text { q.q. } & \text { qualitate qua } \\ \text { r.o. } & \text { rechtsoverweging } \\ \text { Rb. } & \text { Rechtbank } \\ \text { red. } & \text { redactie } \\ \text { RI } & \text { Rechtspraak Insolventierecht } \\ \text { RO } & \text { Rechtspraak Ondernemingsrecht } \\ \text { rolnr. } & \text { rolnummer } \\ \text { Rv } & \text { Wetboek van Burgerlijke Rechtsvordering } \\ \text { S\&V } & \text { Stichting \& Vereniging } \\ \text { SCE } & \text { Europese coöperatieve vennootschap } \\ \text { SE } & \text { Europese naamloze vennootschap } \\ \text { SER } & \text { Sociaal-Economische Raad } \\ \text { Stb. } & \text { Staatsblad van het Koninkrijk der Nederlanden } \\ \text { Stcrt. } & \text { Staatscourant } \\ \text { TOP } & \text { Tijdschrift voor de Ondernemingsrechtpraktijk } \\ \text { TvA } & \text { Tijdschrift voor Arbitrage } \\ \text { TvI } & \text { Tijdschrift voor Insolventierecht } \\ \text { TvJ } & \text { Tijdschrift voor Jaarrekeningenrecht } \\ \text { TvOB } & \text { Tijdschrift voor Ondernemingsbestuur } \\ \text { TVR } & \text { Tijdschrift voor Vennootschaps- en Rechtspersonen- } \\ \text { TVVS } & \text { recht } \\ \text { vgl. } & \text { Tijdschrift voor Vennootschappen, Verenigingen en } \\ & \text { Stichtingen } \\ & \end{array}$




\section{LIJST MET AFKORTINGEN}

VV

Wft

WJO

WOR

WTZi

WvK

Wwft
Voorlopig Verslag

Wet op het financieel toezicht

Wet op de jaarrekening van ondernemingen

Wet op de ondernemingsraden

Wet toelating zorginstellingen

Wetboek van Koophandel

Wet ter voorkoming van witwassen en financiering van terrorisme 



\section{Hoofdstuk 1. Inleiding}

\subsection{Het onderwerp van het onderzoek}

\subsubsection{Het groepsregime}

Veel ondernemingen maken gebruik van een groepsstructuur waarbij de activiteiten van de onderneming zijn ondergebracht bij verschillende groepsmaatschappijen. Een dergelijke structuur kent diverse voordelen. ${ }^{1}$ Hierdoor worden bijvoorbeeld de risico's en aansprakelijkheden gecompartimenteerd. Als een van de groepsmaatschappijen failleert, leidt dit niet automatisch tot het faillissement van de overige groepsmaatschappijen. ${ }^{2}$ Daarnaast biedt een groepsstructuur transparantie en flexibiliteit met betrekking tot de juridische organisatie van de onderneming, kan het fiscale voordelen met zich brengen, zijn er meer mogelijkheden voor saldering van kredietrekeningen, kunnen kredieten mogelijk tegen gunstigere voorwaarden worden aangetrokken en zijn er eventueel meer mogelijkheden voor het verschaffen van zekerheden aan de kredietgever.

Een groepsstructuur brengt echter ook nadelen met zich. Iedere groepsmaatschappij is bijvoorbeeld verplicht om een eigen jaarrekening openbaar te maken. Dit is in de eerste plaats een administratieve lastenverzwaring ten opzichte van de situatie dat één rechtspersoon alle werkzaamheden verricht en er maar één jaarrekening openbaar hoeft te worden gemaakt. Een ander nadeel van het feit dat alle groepsmaatschappijen een eigen jaarrekening openbaar moeten maken, is dat derden hierdoor meer inzicht hebben in de financiële gegevens van de onderneming. Hiervan is in het bijzonder sprake als de werkzaamheden van de groepsmaatschappijen zijn toegespitst op een specifiek (onderdeel van een) product of een bepaald gedeelte van de markt. In een dergelijk geval zijn de posten in de jaarrekening minder divers en kunnen derden daaruit eenvoudiger informatie over onder meer de kostenopbouw, winstmarge of voorwaarden van transacties achterhalen. ${ }^{3}$ Concurrenten zouden deze informatie bijvoorbeeld

1. Asser/Maeijer, Van Solinge \& Nieuwe Weme 2-II* 2009/815 en Assink/Slagter 2013/115.2.

2. Als een groepsmaatschappij failleert, kan dit er wel toe leiden dat schulden an andere groepsmaatschappijen niet volledig worden voldaan. Dit kan weer tot financiële problemen leiden bij de desbetreffende groepsmaatschappijen.

3. L. Timmerman 1988b, p. 312 en Houwen, Schoonbrood-Wessels \& Schreurs 1993, p. 821. 
kunnen gebruiken om hun eigen strategie of werkzaamheden aan te passen. Daarnaast zou een afnemer bij de onderhandelingen een prijsverlaging kunnen eisen als hij weet dat een groepsmaatschappij een grote winstmarge hanteert. ${ }^{4}$

Het groepsregime ex art. 2:403 BW biedt groepsmaatschappijen de mogelijkheid om onder voorwaarden gebruik te maken van een jaarrekeningvrijstelling. De groepsmaatschappij (hierna: '403-maatschappij') is dan onder meer vrijgesteld van de verplichting om haar jaarrekening overeenkomstig de voorschriften van titel 9 van Boek 2 BW in te richten, zij hoeft deze ook niet te laten controleren door een accountant en de openbaarmaking van de jaarrekening mag achterwege blijven. De jaarrekeningvrijstelling van het groepsregime maakt het mogelijk om de twee bovengenoemde nadelen van een groepsstructuur (deels) ongedaan te maken. De vrijstelling biedt in de eerste plaats een administratieve lastenverlichting. ${ }^{5}$ Daarnaast zorgt het niet openbaar maken van de jaarrekening ervoor dat de 403-maatschappij kan voorkomen dat derden daaruit informatie halen over onder meer haar omzet, marges, activa, deelnemingen en resultaten. ${ }^{6}$

Een voorbeeld van een partij die gebruikmaakt van de jaarrekeningvrijstelling van het groepsregime om financiële gegevens niet openbaar te hoeven maken, is Bol.com. Zij heeft begin 2020 verklaard concurrent Amazon niet wijzer te willen maken door haar jaarrekening openbaar te maken. ${ }^{7}$ Door gebruik te maken van de jaarrekeningvrijstelling kan Bol.com bijvoorbeeld verhinderen dat Amazon ziet hoe groot de Nederlandse markt voor online verkopen is - waardoor deze misschien eerder de Nederlandse markt zou hebben betreden dan zij heeft gedaan - en kan worden voorkomen dat bekend wordt dat de omzet van Bol.com eventueel is gedaald als gevolg van de concurrentie van Amazon.

Om gebruik te mogen maken van de jaarrekeningvrijstelling van het groepsregime moet op grond van art. 2:403 BW aan verschillende voorwaarden worden voldaan. Hiervoor is onder meer vereist dat de financiële gegevens van de

4. L. Timmerman 1988b, p. 312.

5. SER-advies 1974, nr. 14, p. 12, SER-advies 1979, nr. 12, p. 22, Kamerstukken II 1981/82, 16326, 8, p. 20 (MvA) en 13, p. 4 (NnavhEV), Raaijmakers 1985, p. 273, Houwen, Schoonbrood-Wessels \& Schreurs 1993, p. 820, Beckman 1995b, p. 89, Asser/Maeijer \& Kroeze $2-I^{*}$ 2015/581, Van der Sangen 2017, p. 204, E.C.A. Nass 2019, p. 12 en Hof Amsterdam (OK) 30 september 2010, JOR 2010/306, m.nt. Bartman (Jones Lang LaSalle/BosGijze), r.o. 3.11.

6. Raaijmakers 1976, p. 287, De Neve 2002, p. 235, Asser/Maeijer \& Kroeze 2-I* 2015/581, Van der Sangen 2017, p. 204, Van Zoest 2019, p. 9, E.C.A. Nass 2019, p. 13-14 en Hof Amsterdam (OK) 30 september 2010, JOR 2010/306, m.nt. Bartman (Jones Lang LaSalle/ BosGijze), r.o. 3.11.

7. J. Braaksma en L. Van der Velden, 'Prestaties Bol.com blijven geheim uit angst voor rivaal Amazon', Het Financieele Dagblad 11 februari 2020. 
403-maatschappij zijn geconsolideerd in de geconsolideerde jaarrekening van een rechtspersoon binnen de groep (hierna: 'moedermaatschappij'), ${ }^{8}$ en dat de moedermaatschappij schriftelijk heeft verklaard dat zij hoofdelijk aansprakelijk is voor de schulden die voortvloeien uit de rechtshandelingen van de 403maatschappij (hierna: '403-verklaring'). ${ }^{9}$ Als gevolg van deze ansprakelijkstelling wordt bovengenoemd voordeel van een groepsstructuur dat risico's en aansprakelijkheden zijn gecompartimenteerd teniet gedaan - voor zover het betreft schulden die uit een rechtshandeling voortvloeien.

Als een 403-maatschappij gebruikmaakt van de jaarrekeningvrijstelling van het groepsregime, kunnen derden haar jaarrekening niet inzien. Hierdoor ontbreekt het bijvoorbeeld de crediteuren aan de mogelijkheid om (mede) aan de hand van de jaarrekening te schatten hoe groot het risico is dat hun vorderingen niet (volledig) zullen worden voldaan. De crediteuren - van wie de vordering voortvloeit uit een rechtshandeling van de 403-maatschappij - worden voor dit gebrek aan inzicht gecompenseerd, doordat zij op grond van de 403-verklaring een aanvullende vordering hebben op de moedermaatschappij van wie zij de geconsolideerde jaarrekening wel kunnen inzien. Een crediteur kan (mede) aan de hand van deze geconsolideerde jaarrekening schatten hoe groot het risico is dat de moedermaatschappij deze vordering niet (volledig) zal voldoen.

Dat de omvang van de (potentiële) aansprakelijkheid voor een moedermaatschappij op grond van een 403-verklaring niet moet worden onderschat, blijkt onder meer uit de geconsolideerde jaarrekeningen van verschillende AEX of AMX genoteerde vennootschappen ${ }^{10}$ over het boekjaar 2019. Uit de geconsolideerde jaarrekeningen van Akzo Nobel NV, Koninklijke Phillips Electronics NV en Signify NV volgt dat zij op 31 december 2019 uit hoofde van verschillende 403 -verklaringen tot een bedrag van $€ 400$ miljoen, $€ 1.458$ miljoen, respectievelijk $€ 1.211$ miljoen aansprakelijk zijn voor schulden die voortvloeien uit rechtshandelingen van 403-maatschappijen. ${ }^{11}$

Het zijn overigens niet alleen beursgenoteerde vennootschappen die zich aansprakelijk stellen op grond van een 403-verklaring. Op 31 december 2019 zijn bij het handelsregister 16.719403 -verklaringen gedeponeerd. ${ }^{12}$

8. Zie art. 2:403 lid 1 sub c BW.

9. Zie art. 2:403 lid 1 sub $\mathrm{fBW}$.

10. Op basis van de samenstelling van de AEX en AMX op 20 mei 2020.

11. Andere AEX of AMX genoteerde vennootschappen hebben geen 403-verklaring gedeponeerd (zie § 2.3.6.a waar ik een overzicht geef welke van de AEX en AMX genoteerde vennootschappen zich wel of niet op grond van een 403-verklaring aansprakelijk hebben gesteld) of noemen in de geconsolideerde jaarrekening niet een bedrag van de aansprakelijkheid op grond van de 403-verklaring(en). Waarom deze laatste groep dit niet doet is mij niet bekend.

12. Op 22 april 2020 per e-mail aan mij meegedeeld door de afdeling Databeheer Orderbehandeling van de Kamer van Koophandel. Daarnaast heeft een medewerker van de Kamer van 
Ik merk op dat het gebruik van de termen 403-maatschappij en moedermaatschappij in dit onderzoek strikt genomen niet altijd correct is. Indien een groepsmaatschappij nog niet of niet meer gebruikmaakt van de jaarrekeningvrijstelling van het groepsregime, is er geen sprake (meer) van een 403-maatschappij en een moedermaatschappij in de zin van het groepsregime. Omwille van de leesbaarheid kies ik ervoor om beide termen ook in een dergelijke situatie te gebruiken.

\subsubsection{Aandachtspunten voor de moedermaatschappij en crediteuren met betrekking tot de 403-aansprakelijkheid}

Als een moedermaatschappij zich door middel van een 403-verklaring aansprakelijk stelt, is het aan te raden dat zij en de crediteuren - van de 403-maatschappij - met een vordering op grond van deze verklaring, de aansprakelijkheid regelmatig evalueren. Zonder uitputtend te zijn, ga ik hieronder eerst in op drie aandachtspunten voor de moedermaatschappij met betrekking tot de 403-aansprakelijkheid en het risico dat dit met zich brengt voor de groep als geheel. Daarna wijs ik erop dat het voor de crediteuren van de 403-maatschappij van belang is dat zij zich ervan bewust zijn dat de 403 -aansprakelijkheid geen 'reguliere' aansprakelijkheid is, maar een onderdeel van de compensatie die zij krijgen omdat zij de jaarrekening van de 403-maatschappij niet kunnen inzien.

Een eerste aandachtspunt voor de moedermaatschappij is dat door de aansprakelijkheid op grond van een 403-verklaring de compartimentering van risico's en aansprakelijkheden binnen de groep grotendeels tenietgaat. Ik heb eerder opgemerkt dat een voordeel van een groepsstructuur is dat als een van de groepsmaatschappijen failleert, dit niet automatisch leidt tot het faillissement van de overige groepsmaatschappijen. ${ }^{13}$ Indien echter een 403-maatschappij failleert, zullen de crediteuren die onbetaald zijn gebleven zich op grond van de 403-verklaring verhalen op de moedermaatschappij. Het is mogelijk dat het faillissement van een 403-maatschappij leidt tot financiële problemen bij of zelfs het faillissement van de moedermaatschappij. Dit kan weer leiden tot financiële problemen en faillissementen bij andere groepsmaatschappijen. ${ }^{14}$ De vergelijking met een kaartenhuis waar een van de kaarten wegvalt, is snel gemaakt.

Bovengenoemd scenario dreigde zich begin 2013 voor te doen bij de SNS-groep. Door de afwaardering van haar vastgoedportefeuille zou SNS Property Finance BV (hierna: 'Property Finance') haar verplichtingen niet

Koophandel op 10 februari 2017 telefonisch aan mij meegedeeld dat er op 31 december 2016 bij het handelsregister 16.956 403-verklaringen zijn gedeponeerd.

13. Zie $\S 1.1 .1$.

14. Nagelkerke 1985, p. 212, Ten Voorde 2011, p. 196 en E.C.A. Nass 2019, p. 15-16. 
meer kunnen nakomen. Zowel SNS REAAL NV (hierna: 'SNS REAAL') als SNS Bank NV (hierna: 'SNS Bank') had zich door middel van een 403-verklaring aansprakelijk gesteld voor de uit rechtshandelingen van Property Finance voortvloeiende schulden. ${ }^{15}$ De vrees bestond dat een faillissement van Property Finance zou leiden tot een faillissement van SNS Bank en SNS REAAL. ${ }^{16}$ Dit zou grote gevolgen hebben voor het financiële stelsel in Nederland. Om dit te voorkomen heeft de Staat der Nederlanden effecten en vermogensbestanddelen van SNS REAAL en SNS Bank genationaliseerd. ${ }^{17}$

Een volgend aandachtspunt voor de moedermaatschappij met betrekking tot de 403-aansprakelijkheid, is de mogelijke exponentiële groei van deze aansprakelijkheid. De moedermaatschappij is op grond van de 403-verklaring aansprakelijk voor de schulden die voortvloeien uit de rechtshandelingen van de 403-maatschappij. Als de 403-maatschappij zich op haar beurt aansprakelijk stelt voor de schulden van een derde - bijvoorbeeld omdat zij zich tot borg stelt -, is de moedermaatschappij ook voor deze schulden medeaansprakelijk. De aansprakelijkstelling van de 403-maatschappij is een rechtshandeling en dus vallen de schulden die daaruit voortvloeien onder de aansprakelijkheid van de moedermaatschappij op grond van de 403-verklaring. Op die manier kan de omvang van de aansprakelijkheid van de moedermaatschappij snel groter worden. Ook als de 403-maatschappij een overeenkomst met een lange looptijd aangaat - bijvoorbeeld de huur van een kantoorruimte voor tien jaar - kan dat in een keer veel aansprakelijkheid met zich brengen voor de moedermaatschappij. Alle schulden die in de toekomst uit deze overeenkomst voortvloeien, vallen onder de reikwijdte van de 403-aansprakelijkheid. Ook als de moedermaatschappij tussentijds de 403 -verklaring intrekt. ${ }^{18}$

15. Het is opmerkelijk dat zowel SNS REAAL als SNS Bank een 403-verklaring heeft gedeponeerd ten aanzien van Property Finance. Als een 403-maatschappij gebruikmaakt van de jaarrekeningvrijstelling van het groepsregime hoeft er maar één 403-verklaring ten aanzien van haar te zijn gedeponeerd. Dit is slechts anders als de moedermaatschappij en een andere groepsmaatschappij nevengeschikt zijn. Daarvan is bij SNS REAAL en SNS Bank echter geen sprake. Zie $\S$ 2.3.6.a.

16. Zie Kamerstukken II 2012/13, 33532, 1 (Brief van de Minister van Financiën), bijlage 3, nrs. 29 en 30. Ik merk op dat Property Finance vrijwel volledig gefinancierd was door SNS Bank. Property Finance was niet in staat om deze lening volledig terug te betalen aan SNS Bank. Dit zou mogelijk ook tot het faillissement van SNS Bank hebben kunnen leiden.

17. Stcrt. 2013, 3018.

18. Kamerstukken II 1983/84, 16551, 11, p. 15 (NnavhEV), Van Achterberg 1989, p. 229, Bartman 2002, p. 24-25, Van Wijngaarden 2006a, p. 619, Zwemmer 2012, p. 238-239, Beckman - SDU Commentaar Ondernemingsrecht 2019, art. 2:404 BW, aant. C.1, Van Zoest 2019, p. 32-33, E.C.A. Nass 2019, p. 141 en 231 en Bartman, Dorresteijn \& Olaerts 2020, p. 226227. Zie art. 2:404 lid $2 \mathrm{BW}$ en $\S 8.2 .1$. 
Een derde en laatste aandachtspunt voor de moedermaatschappij waar ik op wijs, is dat de 403-aansprakelijkheid een doorlopende aansprakelijkheid betreft. Als een moedermaatschappij een 403-verklaring heeft gedeponeerd, blijft zij aansprakelijk voor de schulden die uit (nieuwe) rechtshandelingen van de 403-maatschappij voortvloeien totdat zij deze verklaring intrekt. ${ }^{19}$ Uit de jurisprudentie zijn verschillende gevallen bekend waarbij een moedermaatschappij is vergeten de 403-verklaring in te trekken nadat de 403-maatschappij niet meer gebruikmaakt van de jaarrekeningvrijstelling van het groepsregime. ${ }^{20}$ De moedermaatschappij blijft dan aansprakelijk voor de schulden die voortvloeien uit (nieuwe) rechtshandelingen van de 403-maatschappij. Zelfs als de 403-maatschappij al 21 jaar niet meer gebruikmaakt van de jaarrekeningvrijstelling. ${ }^{21}$ Slechts onder bijzondere omstandigheden is een beroep van een crediteur op een vergeten 403-verklaring onaanvaardbaar naar maatstaven van redelijkheid en billijkheid ex art. 6:2 lid 2 BW.22

Naast bovengenoemde aandachtspunten voor een moedermaatschappij, wijs ik ook op een aandachtspunt voor de crediteuren met betrekking tot de 403-aansprakelijkheid. Voor hen is het van belang dat zij zich ervan bewust zijn dat de aansprakelijkheid van de moedermaatschappij op grond van de 403-verklaring geen reguliere aansprakelijkheid is, maar dat dit samen met de mogelijkheid om de geconsolideerde jaarrekening van de moedermaatschappij in te zien, de compensatie vormt die zij ontvangen omdat ze de jaarrekening van de 403maatschappij niet kunnen inzien. Kort gezegd wordt een crediteur gecompenseerd voor het feit dat hij een vordering heeft op een debiteur - de 403-maatschappij - van wie hij de jaarrekening niet kan inzien, met een aanvullende vordering op een andere debiteur - de moedermaatschappij - van wie hij de geconsolideerde jaarrekening wel kan inzien. ${ }^{23}$

Een crediteur dient zich er bijvoorbeeld van bewust te zijn dat de functie die de 403-aansprakelijkheid vervult bij de compensatie voor het niet kunnen inzien

19. Zie art. 2:404 lid 1 en lid 2 BW.

20. Hof Amsterdam 24 december 1992, rolnr. 863, 91 (Hypo/Kap) aldus Bartman, Dorresteijn \& Olaerts 2020, p. 230, Rb. Utrecht 31 juli 1996, JOR 1996/96 (Manning q.q./Haverkort Bouwgroep), Rb. Rotterdam 15 april 1999, JOR 1999/119 (Lely Industries/Netagco Holding), Rb. Almelo 24 juni 2008, JOR 2008/227, m.nt. Bartman (Hoeveholding), Rb. Rotterdam 16 april 2009, JOR 2009/161, m.nt. Van der Zanden (BosGijze/Jones Lang LaSalle), Hof Amsterdam (OK) 12 januari 2010, JOR 2010/94, m.nt. Bartman (Hoeveholding), Hof Amsterdam (OK) 30 september 2010, JOR 2010/306, m.nt. Bartman (Jones Lang LaSalle/BosGijze), Rb. Utrecht 10 november 2010, JOR 2011/16, m.nt. Bartman (De With/ Lekkerkerker) en Hof Amsterdam (OK) 23 juli 2014, JOR 2014/233, m.nt. Bartman (Van Lieshout/Koks).

21. Hof Amsterdam (OK) 23 juli 2014, JOR 2014/233, m.nt. Bartman (Van Lieshout/Koks), r.o. 2.11 en 3.10 .

22. Ik kom hier uitgebreid op terug in $\S 7.6$.

23. Zie $\S 3.4 .1$. 
van de jaarrekening van de 403-maatschappij, meebrengt dat deze aansprakelijkheid een tijdelijk karakter heeft. De aansprakelijkheid is gerelateerd aan de jaarrekeningvrijstelling voor de 403-maatschappij. Zolang de 403-maatschappij gebruikmaakt van deze vrijstelling, is het van belang dat de crediteuren voor het gebrek aan inzicht worden gecompenseerd doordat zij op grond van de 403verklaring een aanvullende vordering hebben op de moedermaatschappij van wie zij de geconsolideerde jaarrekening kunnen inzien. Maar als de 403-maatschappij geen gebruik meer maakt van de jaarrekeningvrijstelling hoeven nieuwe crediteuren niet te worden gecompenseerd. Ook voor de crediteuren die al een vordering op de moedermaatschappij hebben op grond van de 403-verklaring, geldt dat zij in dat geval de jaarrekening van de 403-maatschappij weer kunnen inzien. Onder bepaalde voorwaarden is het mogelijk dat zij hun verhaalsrecht op de moedermaatschappij verliezen.

In verband met bovengenoemde koppeling tussen de 403-aansprakelijkheid van de moedermaatschappij en de jaarrekeningvrijstelling voor de 403-maatschappij, kan de moedermaatschappij de 403-verklaring intrekken. ${ }^{24} \mathrm{Zij}$ blijft dan aansprakelijk voor de schulden die voortvloeien uit de rechtshandelingen die de 403-maatschappij heeft verricht tot het moment dat de moedermaatschappij tegenover de crediteur een beroep kan doen op de intrekking. ${ }^{25}$ Deze overblijvende aansprakelijkheid kan de moedermaatschappij beëindigen als aan bepaalde voorwaarden wordt voldaan. ${ }^{26}$ Een van deze voorwaarden is dat de crediteuren verzet kunnen instellen tegen het voornemen van de moedermaatschappij om de overblijvende aansprakelijkheid te beëindigen en onder omstandigheden recht hebben op een vervangende waarborg. ${ }^{27}$ Een crediteur die er geen rekening mee houdt dat de 403-verklaring kan worden ingetrokken, of die vergeet om verzet in te stellen tegen de beëindiging van de overblijvende aansprakelijkheid, kan voor de onaangename verrassing komen te staan dat hij zich niet (meer) op de moedermaatschappij kan verhalen terwijl hij daar wel van uitging.

Een voorbeeld dat in de praktijk commotie kan ontstaan als de moedermaatschappij de 403-verklaring intrekt, deed zich begin 2018 voor met betrekking tot Shell Nederland BV (hierna: 'Shell') en de Nederlandse Aardolie Maatschappij BV (hierna: 'NAM'). ${ }^{28}$ Shell heeft zich in 1985 op grond van een 403-verklaring hoofdelijk aansprakelijk gesteld voor de schulden die voortvloeien uit een rechtshandeling van de NAM. ${ }^{29}$ Als gevolg van aardgasboringen door de NAM in Groningen is schade ontstaan. Verschillende

24. Zie art. 2:404 lid $1 \mathrm{BW}$ en $\S 7.2$.

25. Zie art. 2:404 lid $2 \mathrm{BW}$ en $\S 8.2$.

26. Zie art. 2:404 lid $3 \mathrm{BW}$ en $\S 8.3$.

27. Zie art. 2:404 lid 4 en lid 5 BW en $\S 8.6$ tot en met $\S 8.10$.

28. Zie over de Shell-casus ook $\S 3.5 .3, \S 4.9$ en $\S 7.8$.

29. Zie E.C.A. Nass 2018, p. 167. 
gedupeerden hebben de NAM aansprakelijk gesteld tot vergoeding van hun schade.

Op 31 januari 2018 meldt de Minister van Economische Zaken en Klimaat aan de Tweede Kamer dat de overheid de vergoeding van de schade voor de gedupeerden in Groningen verder afhandelt. ${ }^{30}$ De minister deelt ook mee dat de Staat een overeenkomst met de NAM heeft gesloten op grond waarvan de NAM verplicht is zorg te dragen voor de financiering van de afhandeling van deze schadevergoedingen. Rond dezelfde tijd berichten verschillende media dat Shell haar 403-verklaring medio 2017 heeft ingetrokken. ${ }^{31}$ Shell is daardoor niet aansprakelijk voor de schulden van de NAM die voortvloeien uit de overeenkomst met de Staat. De algemene tendens van de berichtgeving in de media is dat Shell de NAM ongemerkt 'op afstand heeft geplaatst', en dat zij (de schijn heeft gewekt dat zij) bewust onder de aansprakelijkheid voor de schulden van de NAM in verband met de schadevergoedingen in Groningen probeert uit te komen. In deze berichtgeving wordt echter het bovengenoemde tijdelijke karakter van de 403-aansprakelijkheid van een moedermaatschappij over het hoofd gezien. Aangezien de NAM in het voorjaar van 2017 weer een jaarrekening openbaar heeft gemaakt, hoeven (nieuwe) crediteuren niet gecompenseerd te worden voor een gebrek aan inzicht. De intrekking van de 403-verklaring door Shell sluit daarom aan bij de functie van de 403 -aansprakelijkheid bij de compensatie van de crediteuren van de 403-maatschappij. ${ }^{32}$

\subsection{Probleem- en doelstelling van het onderzoek}

\subsubsection{Probleemstelling}

Sinds de introductie van het groepsregime in de jaren zeventig van de vorige eeuw bestaat er in de literatuur discussie ten aanzien van deze regeling. Deze discussie ziet in het bijzonder op de uitleg van de ansprakelijkheid van de moedermaatschappij. Ik wijs bijvoorbeeld op de verdeeldheid over het

30. Kamerstukken II 2017/18, 33529, 423 (Brief aan de voorzitter van de Tweede Kamer).

31. Zie Van Dooren 2018a, p. 61 en E.C.A. Nass 2020, p. 141, en de daar aangehaalde berichten in de media.

32. Zie Van Dooren 2018a, p. 62. Zie ook E.C.A. Nass 2020, p. 145, 146, 148 en 149, waar zij erop wijst dat de Staat en (onder meer) Shell een akkoord op hoofdlijnen hebben gesloten op grond waarvan Shell garanties zal geven waardoor de NAM haar verplichting tot vergoeding van schade te allen tijde kan nakomen (zie Kamerstukken II 2017/18, 33529, 493 (Brief aan de voorzitter van de Tweede Kamer), en Bijlage 1 Akkoord op Hoofdlijnen met Shell en ExxonMobil). Bartman betwijfelt of dit voldoende zekerheid biedt voor de gedupeerden. Zie S.M. Bartman, 'NAM-akkoord: garanties Shell en ExxonMobil bieden maar beperkte zekerheid', Het Financieele Dagblad 2 juli 2018 en J. Kleinnijenhuis, 'Hoogleraar: 'Wiebes liet zich afbluffen bij gasdeal met Shell”, Trouw 1 augustus 2018. 
antwoord op de vraag of een moedermaatschappij aansprakelijk is voor de schulden die voortvloeien uit rechtshandelingen die de 403-maatschappij heeft verricht voordat de 403 -verklaring is gedeponeerd. ${ }^{33} \mathrm{Er}$ is ook geen eensgezindheid over de civielrechtelijke duiding van een vordering op grond van een 403-verklaring, ${ }^{34}$ over de reikwijdte van de aansprakelijkheid van de moedermaatschappij als zij de 403-verklaring heeft ingetrokken, ${ }^{35}$ en over de gevolgen van een fusie of een splitsing van de moeder- of de 403-maatschappij voor de 403-aansprakelijkheid. ${ }^{36}$ Tot slot wijs ik op de verdeeldheid met betrekking tot het antwoord op de vraag welke partijen verzet kunnen instellen tegen het voornemen van de moedermaatschappij om de overblijvende aansprakelijkheid na intrekking van de 403 -verklaring te beëindigen, ${ }^{37}$ en onder welke omstandigheden zij recht hebben op een vervangende waarborg voor de voldoening van hun vordering. ${ }^{38}$

Vanaf de jaren negentig van de vorige eeuw heeft ook de jurisprudentie met betrekking tot het groepsregime een vlucht genomen, waarbij rechtsvragen niet altijd op dezelfde manier zijn beantwoord. Het valt op dat er tot 2014 slechts één arrest is gewezen dat specifiek betrekking heeft op de aansprakelijkheid op grond van een 403-verklaring: het $A k z o / I N G$-arrest uit 2002. ${ }^{39}$ Sindsdien zijn er echter verschillende procedures gevoerd bij de Hoge Raad, te weten: het arrest $U W V /$ Econcern,${ }^{40}$ de beschikking Minister van Financiën $/ V E B$ c.s., ${ }^{41}$ het arrest Eikendal q.q./Lentink ${ }^{42}$ en de beschikking SNS/Curatoren. ${ }^{43}$ Deze uitspraken hebben onder meer betrekking op de verhouding tussen de vorderingen van een crediteur op de moeder- en op de 403-maatschappij, en het recht van een crediteur om verzet in te stellen tegen het voornemen van de moedermaatschappij om de overblijvende aansprakelijkheid na intrekking van de 403-verklaring te beëindigen.

\section{Zie $\S 5.2$.}

34. Zie $\S 6.2$.

35. Zie $\S 8.2 .2$.

36. Zie hoofdstuk 9.

37. Zie $\S 8.7 .2$.

38. Zie $\S 8.8 .2$.

39. HR 28 juni 2002, NJ 2002/447, m.nt. Maeijer (Akzo/ING). Ook gepubliceerd in JOR 2002/136, m.nt. Bartman.

40. HR 11 april 2014, NJ 2014/309, m.nt. Van Schilfgaarde (UWV/Econcern). Ook gepubliceerd in JOR 2014/199, m.nt. Van Dooren. Gelijkluidend: HR 11 april 2014, JOR 2014/198 (X/Econcern).

41. HR 20 maart 2015, NJ 2015/361, m.nt. Winter en Van Schilfgaarde (Minister van Financiën/ VEB c.s.). Ook gepubliceerd in JOR 2015/140, m.nt. Josephus Jitta.

42. HR 3 april 2015, NJ 2015/255, m.nt. Van Schilfgaarde (Eikendal q.q./Lentink). Ook gepubliceerd in JOR 2015/191, m.nt. Faber en Vermunt.

43. HR 31 maart 2017, NJ 2018/26, m.nt. Van Schilfgaarde (SNS/Curatoren). Ook gepubliceerd in JOR 2017/221, m.nt. De Haan. 
De discussies in de literatuur, de uitspraken in de jurisprudentie die van elkaar afwijken en het feit dat de laatste jaren verschillende procedures bij de Hoge Raad zijn gevoerd, laten zien dat zeker nog niet alle rechtsvragen met betrekking tot de aansprakelijkheid van een moedermaatschappij op grond van een 403-verklaring zijn beantwoord. Deze onduidelijkheid is onwenselijk. Een moedermaatschappij moet bijvoorbeeld zekerheid hebben voor welke schulden van de 403-maatschappij zij op grond van een 403-verklaring aansprakelijk is en omgekeerd moeten de crediteuren van de 403-maatschappij kunnen weten of zij zich ook op de moedermaatschappij kunnen verhalen. Daarnaast is het van belang dat de moedermaatschappij en de crediteuren weten onder welke voorwaarden een moedermaatschappij de 403-verklaring kan intrekken en de overblijvende aansprakelijkheid kan beëindigen.

Voorts leidt duidelijkheid omtrent de civielrechtelijke duiding van een vordering op grond van een 403-verklaring er bijvoorbeeld toe dat een crediteur weet of hij deze vordering onafhankelijk van de vordering op de 403-maatschappij kan cederen of verpanden, en of hij zich nog steeds op de moedermaatschappij kan verhalen als de 403-maatschappij de nakoming van haar schuld opschort of als de vordering op de 403-maatschappij is verjaard. Tot slot moeten partijen bij een fusie of een splitsing van de moeder- of de 403-maatschappij kunnen weten wat de gevolgen voor de 403 -aansprakelijkheid zijn. Gaat deze aansprakelijkheid bijvoorbeeld onder algemene titel over op een verkrijgende rechtspersoon en is het mogelijk om de overblijvende aansprakelijkheid na intrekking van de 403 -verklaring te beëindigen?

\subsubsection{Doelstelling en onderzoeksvraag}

Dit onderzoek bevat een analyse van de aansprakelijkheid van een moedermaatschappij op grond van een 403-verklaring, naar huidig en wenselijk recht. Kort gezegd komen er vier grote thema's met betrekking tot de 403-aansprakelijkheid aan de orde. Ten eerste de reikwijdte van de aansprakelijkheid van de moedermaatschappij. ${ }^{44}$ Dit betreft het antwoord op de vraag voor welke schulden van de 403-maatschappij de moedermaatschappij aansprakelijk is. Daarnaast ga ik in op de civielrechtelijke duiding van een vordering op grond van een 403 -verklaring. ${ }^{45}$ Hoe een vordering op grond van een 403 -verklaring wordt geduid, is van belang voor het antwoord op de vraag hoe deze vordering zich verhoudt ten opzichte van de vordering van de crediteur op de 403-maatschappij. Dit bepaalt onder meer of een crediteur beide vorderingen al of niet onafhankelijk van elkaar kan cederen aan een derde.

44. Zie hoofdstuk 4 en 5.

45. Zie hoofdstuk 6 . 
Het derde grote thema dat aan de orde komt, betreft de intrekking van een 403 -verklaring en de beëindiging van de overblijvende aansprakelijkheid. ${ }^{46} \mathrm{Als}$ een moedermaatschappij de 403-verklaring intrekt, blijft zij aansprakelijk voor de schulden die voortvloeien uit de rechtshandelingen die de 403-maatschappij heeft verricht tot het moment dat de moedermaatschappij tegenover de crediteur een beroep kan doen op de intrekking. De moedermaatschappij kan deze overblijvende aansprakelijkheid beëindigen als zij aan een aantal voorwaarden voldoet. Tot slot onderzoek ik de gevolgen van een fusie of een splitsing van de moeder- of de 403-maatschappij voor de 403-aansprakelijkheid. ${ }^{47}$ Daarbij ga ik onder meer na of er na de fusie of de splitsing nog nieuwe aansprakelijkheid op grond van de 403-verklaring kan ontstaan, wat er gebeurt met de bestaande aansprakelijkheid, en of de overblijvende aansprakelijkheid na intrekking van de 403-verklaring kan worden beëindigd.

Het doel van dit onderzoek is om ten aanzien van bovengenoemde vier thema's na te gaan hoe de 403 -aansprakelijkheid moet worden uitgelegd in het licht van de functie die deze aansprakelijkheid vervult bij de compensatie van de crediteuren omdat zij de jaarrekening van de 403-maatschappij niet (hebben) kunnen inzien. Ik neem in mijn overwegingen omtrent de uitleg van de 403-aansprakelijkheid mee, dat crediteuren geen invloed hebben op de keuze van de 403-maatschappij om gebruik te (blijven) maken van de jaarrekeningvrijstelling, noch op de keuze van de moedermaatschappij om de 403-verklaring in te trekken en om de overblijvende aansprakelijkheid te beëindigen. ${ }^{48}$ Indien blijkt dat het huidige recht niet leidt tot een situatie waarbij de crediteuren van de 403-maatschappij worden gecompenseerd voor het niet (hebben) kunnen inzien van de jaarrekening van de 403-maatschappij of als zij overgecompenseerd worden, doe ik een voorstel om het huidige recht op het desbetreffende punt te wijzigen.

Gelet op het voorgaande luidt mijn centrale onderzoeksvraag:

Hoe moet de 403-aansprakelijkheid worden uitgelegd in het licht van de functie van deze aansprakelijkheid bij de compensatie van de crediteuren omdat zij de jaarrekening van de 403-maatschappij niet (hebben) kunnen inzien, waarbij rekening wordt gehouden met het feit dat crediteuren geen invloed hebben op de keuze van de 403-maatschappij om gebruik te (blijven) maken van de jaarrekeningvrijstelling, noch op de keuze van de moedermaatschappij om de 403-verklaring in te trekken en om de overblijvende aansprakelijkheid te beëindigen?

46. Zie hoofdstuk 7 en 8 .

47. Zie hoofdstuk 9.

48. Zie hoofdstuk 3. 


\subsection{Onderzoeksmethode}

De aansprakelijkheid van een moedermaatschappij op grond van een 403 -verklaring is niet los te zien van de jaarrekeningvrijstelling van het groepsregime. Als een 403-maatschappij gebruikmaakt van deze vrijstelling kunnen de crediteuren de jaarrekening niet inzien. Zij worden voor dit gebrek aan inzicht gecompenseerd doordat zij op grond van de 403-verklaring een aanvullende vordering krijgen op de moedermaatschappij van wie zij de geconsolideerde jaarrekening wel kunnen inzien.

Om te kunnen onderzoeken hoe de 403-aansprakelijkheid moet worden uitgelegd in het licht van de functie die deze aansprakelijkheid vervult bij de compensatie van de crediteuren van de 403-maatschappij, moet eerst worden vastgesteld welk nadeel een crediteur ondervindt als de 403-maatschappij gebruikmaakt van de jaarrekeningvrijstelling van het groepsregime. Daarnaast is het van belang om na te gaan wat de compensatie voor de crediteuren inhoudt en welke functie de 403-aansprakelijkheid daarbij vervult in samenhang met de mogelijkheid voor de crediteuren om de geconsolideerde jaarrekening van de moedermaatschappij in te zien.

De functie van de 403-aansprakelijkheid bij de compensatie van de crediteuren is de eerste pijler waarop ik de uitleg van deze aansprakelijkheid baseer. De tweede pijler hangt samen met het feit dat de crediteuren geen invloed hebben op de keuze van de 403-maatschappij om gebruik te (blijven) maken van de jaarrekeningvrijstelling van het groepsregime, noch op de keuze van de moedermaatschappij om de 403-verklaring in te trekken en om de overblijvende aansprakelijkheid te beëindigen. Ik betoog daarom dat de compensatie voor een crediteur zodanig moet zijn dat het nadeel dat hij ondervindt ten opzichte van de situatie dat de 403-maatschappij geen gebruik zou maken van de jaarrekeningvrijstelling volledig is weggenomen. Daarnaast meen ik dat een crediteur door de intrekking van de 403-verklaring en de beëindiging van de overblijvende aansprakelijkheid niet in een nadeliger positie mag komen in vergelijking met de situatie dat deze verklaring niet zou zijn ingetrokken, respectievelijk dat de aansprakelijkheid niet zou zijn beëindigd. Omgekeerd moet mijns inziens ook zo veel mogelijk worden voorkomen dat een crediteur door de compensatie die hij ontvangt in een voordeliger positie komt.

Bovenstaande twee pijlers vormen samen het door mij bepleite uitgangspunt voor de compensatie van de crediteuren van een 403-maatschappij. Voor ieder van de vier eerdergenoemde thema's met betrekking tot de 403-aansprakelijkheid ${ }^{49}$ onderzoek ik aan de hand van dit uitgangspunt hoe deze aansprakelijkheid mijns inziens moet worden uitgelegd of hoe het huidige recht moet worden aangepast. Dit onderzoek verloopt telkens op dezelfde wijze.

49. Zie $\S 1.2 .2$.

12 
De methode van onderzoek is juridisch-dogmatisch van aard. Per onderwerp onderzoek ik eerst hoe de aansprakelijkheid op grond van een 403-verklaring naar huidig recht wordt uitgelegd. Daarbij verwijs ik onder meer naar de wet, wetsgeschiedenis, jurisprudentie en literatuur met betrekking tot het desbetreffende onderwerp. Daarnaast wordt op plaatsen waar dat relevant is de aansprakelijkheid van een moedermaatschappij op grond van een 403-verklaring vergeleken met regelingen uit andere rechtsgebieden, de bepalingen in Europese richtlijnen waarvan art. 2:403 $\mathrm{BW}$ de implementatie is,${ }^{50}$ en de equivalenten van het groepsregime in Luxemburg, ${ }^{51}$ Ierland ${ }^{52}$ en Duitsland ${ }^{53}$ Ik vergelijk de verschillende standpunten ten aanzien van de uitleg van de 403-aansprakelijkheid met elkaar door een overzicht te geven van de argumenten voor en tegen iedere uitleg, en door na te gaan tot welke gevolgen iedere uitleg in verschillende situaties leidt.

Vervolgens onderzoek ik tot welke uitkomst het door mij bepleite uitgangspunt voor de compensatie van de crediteuren leidt. Tot slot ga ik na welk van de huidige standpunten ten aanzien van de uitleg van de 403-aansprakelijkheid overeenkomt met de uitkomst volgens mijn uitgangspunt. Als geen van de standpunten tot deze uitkomst leidt, doe ik op basis van het door mij bepleite uitgangspunt een voorstel hoe de aansprakelijkheid op grond van de 403verklaring moet worden uitgelegd of hoe het huidige recht moet worden gewijzigd om tot deze uitkomst te komen.

Bovenstaande onderzoeksmethode leidt tot een gestructureerd onderzoek ten aanzien van de uitleg van de aansprakelijkheid op grond van een 403-verklaring. Hierdoor ontstaat een overzicht hoe het huidige recht moet worden uitgelegd of gewijzigd op basis van één overkoepelend uitgangspunt. Omdat ieder onderwerp op basis van dit uitgangspunt wordt onderzocht, wordt ook de wisselwerking tussen de verschillende onderwerpen inzichtelijk. Daarnaast biedt deze werkwijze de mogelijkheid om in de toekomst onderwerpen die niet in dit onderzoek aan de orde zijn gekomen op dezelfde manier en op basis van hetzelfde uitgangspunt te onderzoeken.

50. Respectievelijk art. 57 van de Vierde EEG-richtlijn, art. 43 van de Zevende EEG-richtlijn en art. 37 van de richtlijn 2013/34/EU (de richtlijn jaarrekeningen). Zie $\S 2.2 .5$.

51. Zie art. 70 Loi du 19 décembre 2002, Mémorial A-N 149, 31 décembre 2002, met inachtneming van de wijzigingen bij Loi du 18 décembre 2009, art. 99 onder nr. 3, Mémorial A-N 22, 10 février 2010, bij Loi du 30 juillet 2013, onder nr. 29, Mémorial A-N 177, 2 octobre 2013 en bij Loi du 27 mai 2016, art. 1er onder nr. 24, Mémorial A-N 94, 30 mai 2016. Zie ook E.C.A. Nass 2019, p. 31-33.

52. Zie section 357 Companies Act 2014. Zie ook E.C.A. Nass 2019, p. 33-34.

53. Zie $\S 264$ Absatz 3 \& 4 Handelsgesetzbuch. Zie ook E.C.A. Nass 2019, p. 35-38. 


\subsection{Afbakening}

Dit onderzoek is niet rechtsvergelijkend opgezet. De reden hiervoor is dat de probleemstelling van het onderzoek op goede wijze kan worden onderzocht aan de hand van Nederlandse rechtsbronnen. Dit neemt echter niet weg dat op verschillende plaatsen wordt verwezen naar de bepalingen in Europese richtlijnen waarvan art. 2:403 $\mathrm{BW}$ de implementatie is en de equivalenten van het groepsregime in Luxemburg, Ierland en Duitsland.

Empirisch onderzoek naar het gebruik van de jaarrekeningvrijstelling van het groepsregime, de aansprakelijkheid van een moedermaatschappij op grond van een 403-verklaring, de intrekking van een 403-verklaring en de beëindiging van de overblijvende aansprakelijkheid blijft grotendeels buiten beschouwing. Op enkele plekken wordt verwezen naar cijfers van de Kamer van Koophandel met betrekking tot het aantal bij het handelsregister gedeponeerde 403-verklaringen, verklaringen van de leden of aandeelhouders van een 403-maatschappij dat zij instemmen met de afwijking van de jaarrekeningvoorschriften, verklaringen tot intrekking van een 403 -verklaring en mededelingen van het voornemen om de overblijvende aansprakelijkheid te beëindigen.

Daarnaast is het onderzoek beperkt tot de juridische aspecten van de compensatie die de crediteuren ontvangen omdat zij de jaarrekening van de 403-maatschappij niet kunnen inzien. Doordat de crediteuren deze jaarrekening niet kunnen inzien, kunnen zij niet (mede) aan de hand daarvan schatten hoe groot het risico is dat hun vordering op de 403-maatschappij niet (volledig) zal worden voldaan. Op grond van de 403-verklaring hebben de crediteuren ook een vordering op de moedermaatschappij. Zij kunnen de geconsolideerde jaarrekening van de moedermaatschappij wel inzien en (mede) aan de hand daarvan schatten hoe groot het risico is dat deze vordering niet (volledig) zal worden voldaan. Ik laat in dit onderzoek buiten beschouwen op welke wijze en op basis van welke maatstaven een crediteur aan de hand van een jaarrekening kan schatten hoe groot het risico is dat een vordering niet (volledig) zal worden voldaan. Ik ga bijvoorbeeld niet in op de waardering van activa, het beoordelen van zekerheidsrechten, het bepalen van de liquiditeit of het vaststellen van de rangorde van vorderingen. Ik richt mij enkel op de (on)mogelijkheid voor een crediteur om de jaarrekening van de moeder- en de 403-maatschappij te kunnen inzien. 
De in art. 2:360 BW genoemde rechtspersonen ${ }^{54}$ die niet een rechtspersoon van openbaar belang zijn in de zin van art. 2:398 lid $7 \mathrm{BW},{ }^{55}$ kunnen gebruikmaken van de jaarrekeningvrijstelling van het groepsregime. Ik beperk mij echter in beginsel tot NV's en BV's die gebruikmaken van de jaarrekeningvrijstelling. De reden daarvoor is dat mij uit de jurisprudentie geen gevallen bekend zijn waarbij de 403-maatschappij niet een NV of een BV is. Slechts op plekken waar dit relevant is, behandel ik de mogelijkheid dat de 403-maatschappij een andere rechtsvorm heeft dan een NV of een BV.

Op grond van art. 2:403 lid 1 sub c BW moeten de financiële gegevens van de 403-maatschappij zijn geconsolideerd in de geconsolideerde jaarrekening van de moedermaatschappij die is opgemaakt aan de hand van wetgeving waarop krachtens het toepasselijke recht van toepassing is: Verordening (EG) 1606/2002 ${ }^{56}$ (hierna: de verordening EU IFRS), richtlijn 2013/34/EU (de richtlijn jaarrekeningen), de richtlijn betreffende de (geconsolideerde) jaarrekening van banken en andere financiële instellingen ${ }^{57}$ of de richtlijn betreffende de (geconsolideerde) jaarrekening van verzekeringsondernemingen. ${ }^{58}$ Als een 403-maatschappij rechtsgeldig gebruik wil maken van de jaarrekeningvrijstelling van het groepsregime, is vereist dat de moedermaatschappij op grond van het Unierecht aan deze voorschriften is gebonden. ${ }^{59}$ Van Zoest merkt op dat de genoemde jaarrekeningvoorschriften van toepassing zijn op de meest bekende en veelvoorkomende Europese commerciële rechtsvormen. ${ }^{60}$ Evenals bij een 403-maatschappij beperk ik mij echter in beginsel tot de gevallen dat de moedermaatschappij een NV of een BV is. Uit de jurisprudentie zijn mij namelijk ook geen gevallen bekend waarbij de moedermaatschappij niet een NV of een $\mathrm{BV}$ is. Slechts op plekken waar dit relevant is, zal ik ingaan op de mogelijkheid dat de moedermaatschappij een andere (Nederlandse of niet-Nederlandse) rechtsvorm heeft.

54. Daaronder vallen ook Europese vennootschappen (SE's) en Europese coöperatieve vennootschappen (SCE's) met een statutaire zetel in Nederland, en formeel buitenlandse vennootschappen die niet aan het recht van een andere lidstaat zijn onderworpen. Hoewel stichtingen in art. 2:360 BW worden genoemd, kunnen deze geen gebruikmaken van de jaarrekeningvrijstelling omdat deze niet kunnen voldoen aan het vereiste van art. 2:403 lid 1 sub b BW dat de leden of aandeelhouders hebben ingestemd met de afwijking van de jaarrekeningvoorschriften. Zie $\$ 2.3 .1$

55. Daarnaast kan het gebruikmaken van de jaarrekeningvrijstelling krachtens sectorale of andere bijzondere wetgeving zijn verboden.

56. Verordening (EG) 1606/2002 van het Europees Parlement en de Raad van 19 juli 2002 betreffende de toepassing van internationale standaarden voor jaarrekeningen, $P b E G$ 2002, L 243/1.

57. Richtlijn 86/635/EEG van de Raad van 8 december 1986 betreffende de jaarrekening en de geconsolideerde jaarrekening van banken en andere financiële instellingen, $P b E G$ 1986, L 372/1.

58. Richtlijn 91/674/EEG van de Raad van 19 december 1991 betreffende de jaarrekening en de geconsolideerde jaarrekening van verzekeringsondernemingen, $P b E G$ 1991, L 374/7.

59. Zie $\S 2.3 .5$.

60. Van Zoest 2019, p. 21-22. 


\subsection{Verantwoording}

De proefschriften van Beckman ${ }^{61}$ en Nass ${ }^{62}$ uit 1995, respectievelijk 2019 zijn uitgebreide studies met betrekking tot het groepsregime. Naar mijn mening bestaat er naast beide onderzoeken nog ruimte voor een aanvullende studie ten aanzien van het groepsregime. Beckman en Nass hebben in de eerste plaats onderzoek gedaan naar de aanvaardbaarheid van de jaarrekeningvrijstelling. Zij hebben de voorwaarden onderzocht waaraan moet worden voldaan opdat een 403-maatschappij gebruik mag maken van de jaarrekeningvrijstelling van het groepsregime. Mijn onderzoek ziet daarentegen specifiek op een van deze voorwaarden: de aansprakelijkheid van de moedermaatschappij op grond van de 403-verklaring.

In mijn onderzoek besteed ik veel minder aandacht aan de voorgangers van art. 2:403 BW dan Beckman, en ook de vergelijking met de Europese richtlijnen en de equivalenten van het groepsregime in Luxemburg, Ierland en Duitsland is aanzienlijk minder uitgebreid dan in het onderzoek van Nass. In plaats daarvan biedt mijn onderzoek in het bijzonder inzicht in onderwerpen die gerelateerd zijn aan de 403-aansprakelijkheid van een moedermaatschappij, zoals de reikwijdte van deze aansprakelijkheid, de civielrechtelijke duiding van een vordering op grond van een 403-verklaring, de intrekking van deze verklaring en de beëindiging van de overblijvende aansprakelijkheid. Deze onderwerpen hebben tot op heden in de literatuur en de jurisprudentie ook de meeste aandacht gekregen. Vooral de reikwijdte van de aansprakelijkheid van de moedermaatschappij is veel aan de orde gekomen, maar sinds de jaren tien van deze eeuw is de focus - mede door verschillende arresten en beschikkingen van de Hoge Raad ${ }^{63}$ - meer en meer verschoven naar de civielrechtelijke duiding van een vordering op grond van een 403 -verklaring, de intrekking van deze verklaring en de beëindiging van de overblijvende aansprakelijkheid.

Ik meen dat mijn onderzoek complementair is aan die van Beckman en Nass - waarbij er vanzelfsprekend enige overlap bestaat. Door de combinatie van deze drie onderzoeken bestaat er een bijzonder uitgebreid en diepgaand inzicht ten aanzien van een regeling die uiteindelijk is terug te voeren tot twee wetsartikelen: art. 2:403 en art. 2:404 BW.

61. Beckman 1995a.

62. E.C.A. Nass 2019.

63. HR 11 april 2014, JOR 2014/199, m.nt. Van Dooren (UWV/Econcern), HR 20 maart 2015, JOR 2015/140, m.nt. Josephus Jitta (Minister van Financiën/VEB c.s.), HR 3 april 2015, JOR 2015/191, m.nt. Faber en Vermunt (Eikendal q.q./Lentink) en HR 31 maart 2017, JOR 2017/221, m.nt. De Haan (SNS/Curatoren). 


\subsection{Het plan van behandeling}

Het onderzoek is onderverdeeld in tien hoofdstukken. In hoofdstuk 2 geef ik een algemene beschouwing van het groepsregime. Ik ga in op de voorwaarden waaraan moet zijn voldaan als een 403-maatschappij gebruik wil maken van de jaarrekeningvrijstelling van het groepsregime. Vervolgens geef ik een uiteenzetting van deze jaarrekeningvrijstelling en tot slot noem ik verschillende redenen waarom een 403-maatschappij gebruikmaakt van de vrijstelling.

In hoofdstuk 3 staat mijn uitgangspunt voor de compensatie van de crediteuren van een 403-maatschappij centraal. Aan de hand van dit uitgangspunt onderzoek ik in de daaropvolgende hoofdstukken hoe de aansprakelijkheid op grond van een 403-verklaring mijns inziens moet worden uitgelegd. Het uitgangspunt is gebaseerd op twee onderdelen. Ten eerste de functie die de 403-aansprakelijkheid vervult in combinatie met de mogelijkheid voor de crediteuren om de geconsolideerde jaarrekening van de moedermaatschappij in te zien, bij de compensatie van de crediteuren omdat zij de jaarrekening van de 403-maatschappij niet kunnen inzien. Daarnaast wijs ik erop dat de crediteuren geen invloed hebben op de keuze van de 403-maatschappij om gebruik te (blijven) maken van de jaarrekeningvrijstelling van het groepsregime, noch op de keuze van de moedermaatschappij om de 403-verklaring in te trekken en om de overblijvende aansprakelijkheid te beëindigen. Ik hanteer daarom als maatstaf voor de compensatie dat hierdoor het nadeel moet worden weggenomen dat een crediteur ondervindt doordat de 403-maatschappij gebruikmaakt van de jaarrekeningvrijstelling, de moedermaatschappij de 403-verklaring intrekt, of doordat de moedermaatschappij de overblijvende aansprakelijkheid beëindigt. Omgekeerd meen ik ook dat zo veel mogelijk moet worden voorkomen dat een crediteur hierdoor in een voordeliger positie komt.

De omvang van de aansprakelijkheid van een moedermaatschappij op grond van een 403-verklaring komt in hoofdstuk 4 en 5 aan de orde. Op grond van art. 2:403 lid 1 sub f BW dient een moedermaatschappij zich uit hoofde van een 403-verklaring aansprakelijk te stellen voor de schulden die voortvloeien uit de rechtshandelingen van de 403-maatschappij. In hoofdstuk 4 ga ik in op drie elementen van deze bepaling met betrekking tot de aansprakelijkheid van een moedermaatschappij: 'schulden', 'rechtshandelingen' en 'voortvloeien'. Ik onderzoek hoe ieder element volgens het door mij bepleite uitgangspunt voor compensatie moet worden uitgelegd. Vervolgens ga ik in op verschillende schulden ten aanzien waarvan in de literatuur of de jurisprudentie de vraag is gesteld of deze al of niet onder de reikwijdte van de 403-aansprakelijkheid vallen, waarbij ik onderzoek of een moedermaatschappij naar huidig recht hiervoor aansprakelijk is en of zij dit volgens het door mij bepleite uitgangspunt zou moeten zijn. Tot slot wordt antwoord gegeven op de vraag of een aan een vordering op de 403-maatschappij verbonden voorrecht of achterstelling, meebrengt 


\section{HOOFDSTUK 1}

dat ook de vordering op de moedermaatschappij is bevoorrecht, respectievelijk is achtergesteld.

In hoofdstuk 5 staat de vraag centraal of, en zo ja in hoeverre, een moedermaatschappij op grond van de 403-verklaring (ook) aansprakelijk is voor schulden die voortvloeien uit rechtshandelingen die de 403-maatschappij heeft verricht voordat deze verklaring is gedeponeerd. Ik ga in op vijf standpunten ten aanzien van het antwoord op deze vraag, en ik onderzoek hoe deze vraag volgens het door mij bepleite uitgangspunt moet worden beantwoord.

De civielrechtelijke duiding van een vordering op grond van een 403-verklaring komt aan de orde in hoofdstuk 6 . Voor vier mogelijke duidingen van een dergelijke vordering wordt nagegaan tot welke uitkomsten deze leiden in verschillende situaties. Ik stel onder meer vast of een crediteur zich op de moedermaatschappij kan verhalen als de vordering op de 403-maatschappij is verjaard, als de crediteur afstand heeft gedaan van deze vordering, en als de 403-maatschappij de nakoming van haar verplichting heeft opgeschort. Daarnaast ga ik na of de crediteur zijn vorderingen op de moeder- en de 403-maatschappij onafhankelijk van elkaar kan cederen en verpanden. Vervolgens onderzoek ik voor deze situaties tot welke uitkomst het door mij bepleite uitgangspunt voor de compensatie van crediteuren leidt. Ik vergelijk deze uitkomsten met de gevolgen van de vier onderzochte duidingen en concludeer hoe een 403-vordering mijns inziens moet worden geduid.

Een moedermaatschappij kan haar 403-verklaring intrekken door de deponering van een daartoe strekkende verklaring. ${ }^{64} \mathrm{Zij}$ blijft aansprakelijk voor de schulden die voortvloeien uit de rechtshandelingen die de 403-maatschappij heeft verricht tot het moment dat de moedermaatschappij tegenover de crediteur een beroep kan doen op de intrekking. ${ }^{65}$ In hoofdstuk 7 ga ik onder meer na op welk moment de moedermaatschappij een beroep kan doen op de intrekking, en of zij de 403-verklaring zodanig kan vormgeven dat deze tevens heeft te gelden als een intrekkingsverklaring - op grond waarvan de 403-verklaring op een datum in de toekomst wordt ingetrokken. Vervolgens ga ik in op de situatie dat de 403-maatschappij niet meer gebruikmaakt van de jaarrekeningvrijstelling van het groepsregime, maar de moedermaatschappij is vergeten de 403-verklaring in te trekken. Ik onderzoek onder welke omstandigheden een beroep van een crediteur op de vergeten 403-verklaring onaanvaardbaar is naar maatstaven van redelijkheid en billijkheid, en hoe een moedermaatschappij preventief de aansprakelijkheid op grond van de 403-verklaring kan limiteren voor het geval zij vergeet deze verklaring in te trekken.

64. Zie art. 2:404 lid $1 \mathrm{BW}$.

65. Zie art. 2:404 lid 2 BW. 
In hoofdstuk 8 onderzoek ik allereerst de reikwijdte van de overblijvende aansprakelijkheid nadat de moedermaatschappij de 403-verklaring heeft ingetrokken. Vervolgens ga ik in op de voorwaarden waaraan moet worden voldaan om deze overblijvende aansprakelijkheid te beëindigen. ${ }^{66} \mathrm{Ik}$ onderzoek onder meer welke crediteuren verzet kunnen instellen tegen het voornemen van de moedermaatschappij om de overblijvende aansprakelijkheid te beëindigen, onder welke omstandigheden een crediteur recht heeft op een vervangende waarborg voor de voldoening van zijn vordering op de 403-maatschappij, en hoe de omvang van een dergelijke waarborg moet worden vastgesteld. ${ }^{67}$ Vervolgens ga ik na of er een vaste volgorde is waarin moet worden voldaan aan de voorwaarden om de overblijvende aansprakelijkheid te beëindigen, en of het verbreken van de groepsband tussen de moeder- en de 403-maatschappij moet worden geschrapt als voorwaarde voor de beëindiging van deze aansprakelijkheid.

Als een moeder- of een 403-maatschappij fuseert of splitst, kan dit gevolgen hebben voor de aansprakelijkheid op grond van de 403-verklaring. In hoofdstuk 9 onderzoek ik in de eerste plaats of de 403-aansprakelijkheid onder algemene titel op een verkrijgende rechtspersoon kan overgaan als de moedermaatschappij fuseert of splitst. Daarna ga ik na hoe de aansprakelijkheid van de moedermaatschappij op grond van de 403-verklaring van invloed is op het recht van een crediteur om in verzet te komen tegen een voorgenomen fusie of splitsing van de moeder- of de 403maatschappij, en of hij recht heeft op een waarborg voor de voldoening van zijn vordering. Voorts onderzoek ik hoe de voorwaarde voor de beëindiging van de overblijvende aansprakelijkheid dat de groepsband tussen de moeder- en de 403-maatschappij is verbroken, moet worden uitgelegd in het licht van een fusie of een splitsing van een van beide.

Aansluitend werk ik verschillende casus uit waarbij een moeder- of een 403-maatschappij fuseert, zuiver splitst of afsplitst. Ten aanzien van iedere casus ga ik na wat de gevolgen zijn met betrekking tot de aansprakelijkheid op grond van de 403-verklaring op het moment van de fusie of de splitsing, of er nadien nog nieuwe aansprakelijkheid kan ontstaan op grond van deze verklaring, en of de overblijvende aansprakelijkheid na intrekking van de 403-verklaring kan worden beëindigd. Met betrekking tot deze laatste vraag onderzoek ik in het bijzonder of door de fusie of de splitsing is voldaan aan de voorwaarde ex art. 2:404 lid 3 sub a BW dat de groepsband tussen de moederen de 403-maatschappij is verbroken.

Vervolgens geef ik antwoord op de vraag of een (grensoverschrijdende) omzetting, en een grensoverschrijdende fusie of splitsing van de moeder- of de

66. Zie art. 2:404 lid 3 BW.

67. Zie art. 2:404 lid 4 en 5 BW. 


\section{HOOFDSTUK 1}

403-maatschappij ertoe leidt dat de (rechtsopvolger van de) 403-maatschappij geen gebruik mag maken van de jaarrekeningvrijstelling van het groepsregime.

Ieder hoofdstuk wordt afgesloten met een conclusie, waarin ik de belangrijkste bevindingen uit het desbetreffende hoofdstuk kort samenvat. In hoofdstuk 10 geef ik tot slot een samenvatting van de belangrijkste uitkomsten van het onderzoek en doe ik verschillende aanbevelingen aan partijen in de praktijk, de wetgever, de rechterlijke macht en de Kamer van Koophandel.

Het onderzoek is afgesloten op 1 juli 2020. Nadien verschenen literatuur en jurisprudentie is in een enkel geval verwerkt. 


\section{Hoofdstuk 2. Het groepsregime}

\section{$2.1 \quad$ Inleiding}

In dit hoofdstuk behandel ik allereerst de wetsgeschiedenis van het groepsregime (§ 2.2). Vervolgens ga ik in op de voorwaarden waaraan moet zijn voldaan om gebruik te mogen maken van de jaarrekeningvrijstelling van het groepsregime ( $\$ 2.3$ en $\S 2.4)$. Voorts geef ik een uiteenzetting van deze jaarrekeningvrijstelling ( $\S 2.5$ ). Tot slot behandel ik verschillende redenen die in de parlementaire geschiedenis en de literatuur worden genoemd waarom een groepsmaatschappij gebruikmaakt van de jaarrekeningvrijstelling van het groepsregime (§ 2.6).

\subsection{De wetsgeschiedenis van het groepsregime}

\subsubsection{Art. 13 lid 3 WJO}

Het groepsregime kent een tumultueuze geschiedenis. ${ }^{1}$ De regeling heeft in verschillende wetsartikelen gestaan en is door de jaren heen diverse keren gewijzigd. In eerste instantie was de regeling opgenomen in art. 13 lid 3 van de Wet op de jaarrekening van ondernemingen (hierna: 'WJO'). ${ }^{2}$ Op grond van deze bepaling was een onderneming die haar jaarrekening niet bij het handelsregister hoefde neer te leggen, en waarin de moedermaatschappij rechtstreeks of middellijk voor meer dan de helft van het geplaatste kapitaal deelnam, van rechtswege vrijgesteld van de vereisten omtrent de inrichting van de jaarrekening indien al haar aandeelhouders of leden daarmee hadden ingestemd en de financiële gegevens waren geconsolideerd in de geconsolideerde jaarrekening van de moedermaatschappij.

Bij de introductie van art. 13 lid 3 WJO merkt de minister op dat de regeling is bedoeld voor de praktische gang van zaken. Als voorbeeld wijst de minister op het geval dat een moedermaatschappij alle aandelen in een andere

1. Zie voor een uitgebreidere beschrijving van de wetsgeschiedenis van het groepsregime Beckman 1995a.

2. Stb. 1970, 414 . 
rechtspersoon houdt of dat er slechts een beperkt aantal minderheidsaandeelhouders is. Indien de moedermaatschappij en de eventuele minderheidsaandeelhouders bekend zijn met de financiële gegevens van deze rechtspersoon en zij geen behoefte hebben aan een uitgebreide jaarrekening overeenkomstig alle voorschriften uit de wet, kan volgens de minister worden volstaan met een versimpelde jaarrekening. ${ }^{3}$

De minister merkt op dat ondernemingen die verplicht zijn om hun jaarrekening bij het handelsregister neer te leggen geen gebruik mogen maken van de jaarrekeningvrijstelling ex art. 13 lid 3 WJO. ${ }^{4}$ Derden hebben een rechtmatig belang bij het kunnen inzien van de jaarrekening, dat niet door een besluit van de aandeelhouders of leden van de desbetreffende onderneming mag worden aangetast. Maar omdat de jaarrekening van een individuele onderneming in een concern volgens de minister op zichzelf genomen veelal een vertekend beeld schetst van de financiële positie van deze onderneming in het geheel van het concern, is hij voornemens om dergelijke ondernemingen onder voorwaarden ook gebruik te laten maken van de jaarrekeningvrijstelling. ${ }^{5}$

\subsubsection{Art. $42 c W v K$}

Bovengenoemd voornemen van de minister is onderdeel geworden van het wetsvoorstel Regeling van de besloten vennootschap met beperkte aansprakelijkheid. Op grond van het voorgestelde art. 42c Wetboek van Koophandel (hierna: 'WvK') zou een NV onder voorwaarden van rechtswege zijn vrijgesteld van de verplichting om een jaarrekening openbaar te maken. ${ }^{6}$ Kort gezegd was hiervoor vereist dat de financiële gegevens van de NV moesten zijn geconsolideerd in de geconsolideerde jaarrekening van de moedermaatschappij en dat deze moedermaatschappij zich hoofdelijk aansprakelijk had gesteld voor de aangegane schulden van de NV. Als de NV niet (meer) verplicht zou zijn om de jaarrekening openbaar te maken, zou zij ook op grond van art. 13 lid 3 WJO met instemming van de aandeelhouders mogen afwijken van de voorschriften uit de WJO inzake de inrichting van de jaarrekening. ${ }^{7}$

Bovenstaande vrijstelling zou volgens de Commissie Vennootschapsrecht niet in strijd zijn met de openbaarmakingsplicht voor NV's uit de Eerste EEGrichtlijn. ${ }^{8}$ Aan deze openbaarmakingsplicht zou worden voldaan door de

\footnotetext{
3. Kamerstukken II 1967/68, 9595, 3, p. 16 (MvT).

4. Kamerstukken II 1967/68, 9595, 3, p. 16 (MvT).

5. Kamerstukken II 1967/68, 9595, 3, p. 11 (MvT).

6. Kamerstukken II 1969/70, 10689, 2, p. 4-5 (OvW).

7. Beckman 1995a, p. 121-122.

8. Eerste Richtlijn van de Raad van 9 maart 1968 (68/151/EEG), PbEG 1968, L 65/8. Hierna: 'de Eerste EEG-richtlijn'.
} 
openbaarmaking van de geconsolideerde jaarrekening van de moedermaatschappij. ${ }^{9}$ De Commissie der Europese Gemeenschappen had echter twijfels bij deze redenering. ${ }^{10}$ Daarom besloot de minister om de voorgestelde regeling aan te passen. ${ }^{11}$ De vrijstelling van de openbaarmakingsplicht zou komen te vervallen en worden vervangen door een vrijstelling van de verplichting om de jaarrekening overeenkomstig de WJO in te richten. De NV zou dan kunnen volstaan met een vereenvoudigde jaarrekening.

\subsubsection{Art. 38a WJO}

Het voorgestelde art. $42 \mathrm{c} \mathrm{WvK}$ is nooit in de wet opgenomen. De voorgestelde regeling en die uit art. 13 lid $3 \mathrm{WJO}$ zijn samengevoegd en in aangepaste vorm opgenomen in art. 38a WJO. ${ }^{12}$ Op grond van art. 38a WJO was een groepsmaatschappij onder voorwaarden vrijgesteld van de verplichting om de jaarrekening overeenkomstig de vereisten uit de WJO in te richten. ${ }^{13}$ Kort gezegd moesten alle leden of aandeelhouders hiermee hebben ingestemd en dienden de financiële gegevens van de groepsmaatschappij te zijn geconsolideerd in de geconsolideerde jaarrekening van de moedermaatschappij.

Een belangrijke wijziging ten opzichte van art. 13 lid 3 WJO was dat de vrijstelling ook van toepassing was op groepsmaatschappijen die verplicht waren om een jaarrekening openbaar te maken. ${ }^{14}$ Voor die gevallen gold echter als aanvullende eis dat de moedermaatschappij zich hoofdelijk aansprakelijk had gesteld voor de aangegane schulden van de groepsmaatschappij, of dat het werkterrein van de groepsmaatschappij zich (nagenoeg) uitsluitend buiten het grondgebied van de lidstaten van de Europese Gemeenschappen bevond.

\subsubsection{Art. 2:343 (oud) BW}

In 1976 is art. $38 \mathrm{a}$ WJO vervangen door art. 2:343 (oud) BW. ${ }^{15}$ De regeling bleef daarbij vrijwel hetzelfde. De grootste verandering betrof de toevoeging dat als de groepsmaatschappij verplicht was om haar jaarrekening openbaar te maken, de moedermaatschappij ook verplicht moest zijn om de geconsolideerde jaarrekening openbaar te maken. ${ }^{16}$

9. Kamerstukken II 1969/70, 10689, 4, p. 29 (bijlage 2 MvT).

10. Aldus Kamerstukken II 1970/71, 10689, 12, p. 2 (NnavhEV).

11. Kamerstukken II 1970/71, 10689, 12, p. 2 (NnavhEV).

12. Stb. 1971, 286.

13. Kamerstukken II 1970/71, 10689, 13, p. 5 (2eNvW).

14. Winkel 2004, p. 185.

15. Stb. 1976, 228 .

16. Winkel 2004, p. 185. 


\section{HOOFDSTUK 2}

\subsubsection{Europese richtlijnen}

Met art. 57 van de Vierde EEG-richtlijn is voor lidstaten de mogelijkheid geïntroduceerd om een onder hun recht vallende dochteronderneming onder voorwaarden vrij te stellen van de voorschriften uit de richtlijn betreffende de inhoud, controle en openbaarmaking van de jaarrekening. ${ }^{17}$ Deze regeling is later opgenomen in art. 43 van de Zevende EEG-richtlijn ${ }^{18}$ en staat thans in art. 37 van de richtlijn 2013/34/EU (hierna: 'de richtlijn jaarrekeningen'). ${ }^{19}$ De genoemde voorwaarden houden onder meer in dat de aandeelhouders of vennoten van de dochteronderneming hebben ingestemd met het gebruikmaken van de vrijstelling, de financiële gegevens van de dochteronderneming zijn opgenomen in de geconsolideerde financiële overzichten van de moederonderneming ${ }^{20}$ die overeenkomstig de richtlijn zijn opgesteld, de moederonderneming heeft verklaard garant te staan voor de aangegane verplichtingen van de dochteronderneming en de moederonderneming onder het recht van een lidstaat valt.

Nederland heeft in 1983 van bovengenoemde mogelijkheid gebruikgemaakt met de implementatie van art. 57 van de Vierde EEG-richtlijn in art. 2:403 BW. ${ }^{21}$ Naast Nederland is de regeling ook geïmplementeerd in de Luxemburgse, ${ }^{22}$

17. Vierde Richtlijn van de Raad van 25 juli 1978 op de grondslag van artikel 54, lid 3, sub g) van het Verdrag betreffende de jaarrekening van bepaalde vennootschapsvormen (78/660/ EEG), PbEG 1978, L 222/11. Hierna: ‘de Vierde EEG-richtlijn'. Zie Beckman 2015c, p. $19-22$.

18. Zevende Richtlijn van de Raad van 13 juni 1983 op de grondslag van artikel 54, lid 3, sub g) van het Verdrag betreffende de geconsolideerde jaarrekening (83/349/EEG), $P b E G$ 1983, L 193/1. Hierna: 'de Zevende EEG-richtlijn'. Zie Beckman 2015c, p. 22-25.

19. Richtlijn 2013/34/EU van het Europees Parlement en de Raad van 26 juni 2013 betreffende de jaarlijkse financiële overzichten, geconsolideerde financiële overzichten en aanverwante verslagen van bepaalde ondernemingsvormen, tot wijziging van Richtlijn 2006/43/EG van het Europees Parlement en de Raad en tot intrekking van Richtlijnen 78/660/EEG en 83/349/ EEG van de Raad, PbEU 2013, L 182/19. Zoals gewijzigd bij Richtlijn 2014/95/EU van 22 oktober 2014 tot wijziging van Richtlijn 2013/34/EU met betrekking tot de bekendmaking van niet-financiële informatie en informatie inzake diversiteit door bepaalde grote ondernemingen en groepen, PbEU 2014, L 330/1.

20. In art. 57 van de Vierde EEG-richtlijn werd niet verwezen naar de moeder- en dochteronderneming maar naar de beheersende en de afhankelijke vennootschap. In art. 43 van de Zevende EEG-richtlijn en thans in art. 37 van de richtlijn jaarrekeningen wordt wel verwezen naar de moeder- en dochteronderneming. Omwille van de duidelijkheid hanteer ik hier de huidige termen.

21. Stb. 1983, 663 .

22. Zie art. 256bis Loi du 10 août 1915, Mémorial A-N 40, 10 mai 1984, gewijzigd bij Loi du 11 juillet 1988, art. IV, Mémorial A-N 45, 18 août 1988 (waarbij art. 256bis is verdwenen en de regeling is opgenomen in art. 256-1 en art. 256-2), thans art. 70 Loi du 19 décembre 2002, Mémorial A-N 149, 31 décembre 2002, met inachtneming van de wijzigingen bij Loi du 18 décembre 2009, art. 99 onder nr. 3, Mémorial A-N 22, 10 février 2010, bij Loi du 30 juillet 2013, onder nr. 29, Mémorial A-N 177, 2 octobre 2013 en bij Loi du 27 mai 2016, 
Ierse $^{23}$ en Duitse ${ }^{24}$ wetgeving. Nass merkt op dat verschillende andere lidstaten geen gebruikmaken van deze mogelijkheid omdat de in die lidstaten geldende fiscale wetgeving, vennootschapswetgeving en/of de voorgeschreven toepassing van boekhoudstelsels dit belet. ${ }^{25}$

\subsubsection{Art. 2:403 BW}

Ik wijs op drie belangrijke verschillen tussen art. 2:403 BW en art. 2:343 (oud) BW. In de eerste plaats is het op grond van art. 2:403 BW mogelijk dat de 403-maatschappij niet alleen is vrijgesteld van de voorschriften omtrent de inrichting van de jaarrekening, maar ook van de openbaarmakingplicht. Voorts zijn in art. 2:403 BW de uitzonderingen voor de hoofdelijke aansprakelijkheid van de moedermaatschappij komen te vervallen. De moedermaatschappij moet zich sindsdien bijvoorbeeld ook hoofdelijk aansprakelijk stellen als het werkgebied van de 403-maatschappij (nagenoeg) uitsluitend buiten het grondgebied van de lidstaten van de Europese Gemeenschappen - thans de Europese Unie (hierna: 'EU') - ligt. Tot slot is ook het toepassingsbereik van het groepsregime verruimd. Op grond van art. 2:403 BW kunnen ook 403-maatschappijen waarvan de moedermaatschappij in een andere EU-lidstaat is gevestigd, gebruikmaken van de jaarrekeningvrijstelling. ${ }^{26}$

Daarnaast wijs ik op drie verschillen van art. 2:403 BW ten opzichte van de regeling uit de Europese richtlijnen. Ten eerste is de jaarrekeningvrijstelling ex art. 2:403 BW van toepassing op groepsmaatschappijen, ${ }^{27}$ waar de regeling uit de richtlijnen betrekking heeft op dochterondernemingen. ${ }^{28} \mathrm{Ik}$ kom later terug op dit onderscheid. ${ }^{29}$ Ten tweede is op grond van de regeling uit de richtlijnen vereist dat de moederonderneming verklaart dat zij garant staat voor de aangegane verplichtingen van de dochteronderneming. Krachtens art. 2:403 BW dient de moedermaatschappij daarentegen een verklaring te deponeren op grond waarvan zij zich hoofdelijk aansprakelijk stelt voor de schulden die voortvloeien uit een rechtshandeling van de 403-maatschappij. ${ }^{30}$ Tot slot kent

art. $1^{\text {er }}$ onder nr. 24, Mémorial A-N 94, 30 mai 2016. Zie E.C.A. Nass 2019, p. 31-33, waar zij uitgebreider ingaat op deze regeling.

23. Zie section 17 Companies (Amendment) Act 1986. Thans section 357 Companies Act 2014. Zie E.C.A. Nass 2019, p. 33-34, waar zij uitgebreider ingaat op deze regeling.

24. Zie $§ 264$ Absatz 3 \& 4 Handelsgesetzbuch. Zie E.C.A. Nass 2019, p. 35-38, waar zij uitgebreider ingaat op deze regeling.

25. Zie E.C.A. Nass 2019, p. 3, waar zij enkele voorbeelden geeft.

26. Kamerstukken II 1979/80, 16326, 3, p. 39 (MvT).

27. Zie Kamerstukken II 1981/82, 16326, 8, p. 21 (MvA).

28. In art. 57 van de Vierde EEG-richtlijn werd niet verwezen naar een dochteronderneming maar naar een afhankelijke vennootschap. In art. 43 van de Zevende EEG-richtlijn en thans in art. 37 van de richtlijn jaarrekeningen wordt de term dochteronderneming wel gebruikt.

29. Zie $\S 2.3 .2$.

30. Zie $\S 6.1$. 
het groepsregime de mogelijkheid dat de moedermaatschappij deze verklaring intrekt en haar overblijvende aansprakelijkheid beëindigt. ${ }^{31}$ Een dergelijke bepaling is niet terug te vinden in de Europese richtlijnen.

Art. 2:403 BW is door de jaren heen een aantal keer gewijzigd. Hieronder noem ik vier aanpassingen. De eerste wijziging heeft betrekking op de intrekking van de 403-verklaring en de beëindiging van de overblijvende aansprakelijkheid van de moedermaatschappij op grond van de ingetrokken verklaring. Oorspronkelijk was dit geregeld in het tweede lid van art. 2:403 BW. In 1985 is deze bepaling echter overgezet naar art. 2:404 BW.32,33 Daarbij zijn ook de voorwaarden voor de beëindiging van de overblijvende aansprakelijkheid gewijzigd. Voorheen eindigde deze aansprakelijkheid van een moedermaatschappij drie jaar na de verbreking van de groepsband tussen de moeder- en de 403-maatschappij. Aan deze regeling kleefden volgens de minister twee bezwaren. ${ }^{34}$ Ten eerste was het voor crediteuren niet altijd bekend wanneer de groepsband was verbroken en daarnaast hadden zij geen mogelijkheid om zich te verzetten tegen het verlies van hun verhaalsrecht. Om deze bezwaren weg te nemen, is de regeling aangepast in die zin dat sindsdien de aansprakelijkheid van een moedermaatschappij tegenover een crediteur is beëindigd als aan een viertal cumulatieve voorwaarden is voldaan. Hiervoor is vereist dat de groepsband tussen de moeder- en de 403-maatschappij is verbroken. Daarnaast moet een mededeling van het voornemen van de moedermaatschappij om de aansprakelijkheid te beëindigen twee maanden ter inzage hebben gelegen bij het handelsregister. Voorts dienen er twee maanden te zijn verlopen na de aankondiging in een landelijk verspreid dagblad dat en waar deze mededeling ter inzage ligt. Tot slot mag de crediteur tegen het voornemen tot beëindiging geen verzet hebben ingesteld, dan wel moet diens verzet zijn ingetrokken of door de rechter ongegrond zijn verklaard.

In 1988 is art. 2:403 BW opnieuw gewijzigd. ${ }^{35}$ Vanaf dat moment konden ook NV's en rechtspersonen die ter beurze genoteerde effecten hebben uitgegeven, gebruikmaken van de jaarrekeningvrijstelling van het groepsregime. Volgens de minister was de eerdere uitsluiting van NV's gebaseerd op een omstreden uitleg van de Eerste en de Vierde EEG-richtlijn ${ }^{36}$ en kenden andere lidstaten een dergelijke beperking niet. ${ }^{37}$ Beckman heeft er terecht op gewezen dat op dat moment naast Nederland alleen Luxemburg de desbetreffende bepaling

31. Zie $\S 7.2 .1$ en $\S 8.3$.

32. Stb. 1985, 656 .

33. Zie ook Stb. 2012, 300, waarbij de bepaling is komen te vervallen dat de moedermaatschappij de 403-verklaring slechts kan intrekken behoudens art. 2:204a lid 4 en art. 2:204c lid 7 BW.

34. Kamerstukken II 1983/84, 16551, 11, p. 15 (NnavhEV). Zie $\S 8.3$.

35. Stb. 1988, 517.

36. Zie ook Beckman 2015c, p. 20.

37. Kamerstukken II 1987/88, 19813, 9, p. 6 (2eNvW). 
uit de richtlijn had geïmplementeerd. ${ }^{38}$ Daarnaast zag de minister geen reden waarom rechtspersonen die ter beurze genoteerde effecten hebben uitgegeven geen gebruik zouden mogen maken van de jaarrekeningvrijstelling. ${ }^{39}$

De volgende wijziging van art. 2:403 BW hield in dat ook banken ${ }^{40}$ en verzekeringsmaatschappijen ${ }^{41}$ gebruik konden maken van de jaarrekeningvrijstelling van het groepsregime. De minister wijst erop dat art. 2:403 BW is gebaseerd op art. 57 van de Vierde EEG-richtlijn en dat deze richtlijn ook van toepassing is op banken en verzekeringsmaatschappijen. Om die reden moeten banken en verzekeraars volgens hem ook gebruik kunnen maken van de jaarrekeningvrijstelling van het groepsregime. ${ }^{42}$

In 2015 is een deel van bovengenoemde wijzigingen weer teruggedraaid. In lijn met art. 40 van de richtlijn jaarrekeningen werd aan art. 2:403 BW toegevoegd dat deze bepaling niet van toepassing is op rechtspersonen van openbaar belang. ${ }^{43}$ Kort gezegd houdt dit in dat beursvennootschappen, banken en verzekeringsmaatschappijen sindsdien geen gebruik meer kunnen maken van de jaarrekeningvrijstelling van het groepsregime. ${ }^{44}$

\subsection{Voorwaarden om gebruik te mogen maken van de jaarrekeningvrijstelling}

\subsubsection{Rechtspersonen die gebruik mogen maken van de jaarrekeningvrijstelling}

In beginsel kunnen alle in art. 2:360 BW genoemde rechtspersonen gebruikmaken van de jaarrekeningvrijstelling van het groepsregime. ${ }^{45}$ Daaronder vallen ook Europese vennootschappen $(\mathrm{SE} \text { 's })^{46}$ en Europese coöperatieve

38. Beckman 1995b, p. 82-83.

39. Kamerstukken II 1987/88, 19813, 5, p. 9 (MvA).

40. Stb. 1993, 258.

41. Stb. 1993, 517.

42. Kamerstukken II 1990/91, 22169, 3, p. 21 (MvT) en Kamerstukken II 1992/93, 22896, 3, p. 25 (MvT).

43. Stb. 2015, 349 en Kamerstukken II 2014/15, 34176, 3, p. 40 (MvT). Zie art. 2:403 lid 4 jo. art. 2:398 lid 7 BW.

44. En andere bij algemene maatregel van bestuur aangewezen rechtspersonen.

45. Van Wijngaarden 2006a, p. 611, Berk 2007, p. 12, Asser/Maeijer \& Kroeze 2-I* 2015/581 en E.C.A. Nass 2019, p. 5. Zie E.C.A. Nass 2019, p. 27-38, voor een bespreking van het toepassingsbereik van de regeling in de richtlijn jaarrekeningen, de Luxemburgse regeling, de Ierse regeling en de Duitse regeling.

46. Zie art. 61 Verordening (EG) 2157/2001 van de Raad van 8 oktober 2001 betreffende het statuut van de Europese Vennootschap (SE), PbEG 2001, L 294/1. 
vennootschappen (SCE's) ${ }^{47}$ met statutaire zetel in Nederland, en formeel buitenlandse vennootschappen ${ }^{48}$ die niet aan het recht van een andere lidstaat zijn onderworpen. Er is echter een aantal uitzonderingen.

Ten eerste is het voor bepaalde rechtspersonen verboden om gebruik te maken van de jaarrekeningvrijstelling van het groepsregime. Hierboven wees ik er al op dat rechtspersonen van openbaar belang ongeacht hun rechtsvorm geen gebruik mogen maken van de jaarrekeningvrijstelling. Kort gezegd betreft dit beursgenoteerde vennootschappen, banken en verzekeringsmaatschappijen. ${ }^{49}$ Nass merkt op dat het gebruikmaken van de jaarrekeningvrijstelling daarnaast krachtens sectorale of andere bijzondere wetgeving kan zijn verboden. ${ }^{50} \mathrm{Zij}$ wijst er bijvoorbeeld op dat een zorginstelling op grond van art. 2 van de Regeling verslaggeving WTZi geen gebruik mag maken van deze jaarrekeningvrijstelling.

Ten tweede merk ik op dat hoewel stichtingen in art. 2:360 BW worden genoemd, deze geen gebruik kunnen maken van de jaarrekeningvrijstelling van het groepsregime. Aangezien een stichting geen leden of aandeelhouders heeft, kan niet worden voldaan aan het vereiste van art. 2:403 lid 1 sub b BW dat deze hebben ingestemd met de afwijking van de jaarrekeningvoorschriften. ${ }^{51}$ Dit geldt strikt genomen ook voor de in art. 2:360 lid 2 BW genoemde commanditaire vennootschappen en vennootschappen onder firma waarvan alle vennoten die volledig jegens schuldeisers aansprakelijk zijn voor de schulden, kapitaalvennootschappen naar buitenlands recht zijn. Ook zij hebben geen leden of aandeelhouders, maar vennoten. Met Nass meen ik echter dat art. 2:403 lid 1 sub b BW zo moet worden uitgelegd dat deze bepaling ook van toepassing is op de vennoten van een commanditaire vennootschap en vennootschap onder firma. ${ }^{52}$ Ik kom hier later op terug. ${ }^{53}$

Bovenstaande in acht nemend, staat de mogelijkheid om gebruik te maken van de jaarrekeningvrijstelling van het groepsregime open voor NV's, BV's,

47. Zie art. 68 lid 1 Verordening (EG) 1435/2003 van de Raad van 22 juli 2003 betreffende het statuut van de Europese Coöperatieve Vennootschap (SCE), PbEU 2003, L 207/1.

48. Zie art. 5 lid 2 Wet op de formeel buitenlandse vennootschappen.

49. En andere bij algemene maatregel van bestuur aangewezen rechtspersonen. Zie art. 2:403 lid 4 jo. art. 2:398 lid 7 BW en Kamerstukken II 2014/15, 34176, 3, p. 39 (MvT).

50. Zie E.C.A. Nass 2019, p. 132-133. Zie ook E.C.A. Nass 2019, p. 40, waar zij erop wijst dat op grond van art. 2:401 lid $1 \mathrm{BW}$ bij of krachtens de Wft van art. 2:403 BW kan worden afgeweken voor een beheerder van een beleggingsinstelling, een beheerder van een icbe, een beleggingsmaatschappij en een maatschappij voor collectieve belegging in effecten. Zij merkt onder meer op dat art. 2:403 BW op grond van art. 4:51 lid $3 \mathrm{Wft}$ is uitgezonderd voor een beheerder van een icbe.

51. Asser/Maeijer \& Kroeze 2-I*2015/581 en E.C.A. Nass 2019, p. 57.

52. E.C.A. Nass 2019, p. 52-53.

53. Zie $\S 2.3 .4 . b$. 
bepaalde commerciële verenigingen, ${ }^{54}$ coöperaties, onderlinge waarborgmaatschappijen, ${ }^{55}$ commanditaire vennootschappen en vennootschappen onder firma waarvan alle vennoten die volledig jegens schuldeisers aansprakelijk zijn voor de schulden kapitaalvennootschappen naar buitenlands recht zijn, ${ }^{56} \mathrm{SE}$ 's en SCE's met statutaire zetel in Nederland, en formeel buitenlandse vennootschappen die niet aan het recht van een andere lidstaat zijn onderworpen.

\subsubsection{Groepsband tussen de moeder-en de 403-maatschappij}

De 403-maatschappij moet deel uitmaken van de groep van de moedermaatschappij. ${ }^{57}$ Op grond van art. 2:24b BW is een groep een economische eenheid waarin rechtspersonen organisatorisch zijn verbonden. Uit deze definitie zijn twee elementen op te maken: organisatorische verbondenheid en economische eenheid. Daarnaast is in de parlementaire geschiedenis nog een derde voorwaarde genoemd: centrale leiding. ${ }^{58}$

De organisatorische verbondenheid heeft betrekking op de juridisch-organisatorische banden tussen de moeder- en de 403-maatschappij. Hierbij is bijvoorbeeld van belang of de moedermaatschappij (middellijk) aandelen houdt in de 403-maatschappij. Maar ook statutaire en contractuele voorzieningen spelen mee. ${ }^{59}$ Een voorbeeld van een dergelijke statutaire voorziening betreft de

54. Die een of meer ondernemingen in stand houden die in het handelsregister moeten worden ingeschreven en die aan bepaalde financiële drempelwaarden voldoen. Zie art. 2:360 lid 3 BW.

55. Ik merk op dat een onderlinge waarborgmaatschappij waarbij in de statuten niet de verplichting voor de leden om bij te dragen in een tekort of de vermindering van hun schadevergoedingsplicht is uitgesloten, niet kwalificeert als een verzekeringsmaatschappij in de zin van artikel 2, lid 1, van richtlijn 91/674/EEG van de Raad van 19 december 1991 betreffende de jaarrekening van verzekeringsondernemingen, $P b E G$ 1991, L 374/7. Een dergelijke onderlinge waarborgmaatschappij is daarom niet op grond van art. 2:398 lid $7 \mathrm{BW}$ uitgesloten om gebruik te maken van de jaarrekeningvrijstelling van het groepsregime.

56. De wetgever heeft ervoor gekozen om gebruik te maken van de mogelijkheid op grond van art. 38 lid 2 sub b van de richtlijn jaarrekeningen om titel 9 van Boek 2 BW niet van toepassing te verklaren op vennootschappen onder firma en commanditaire vennootschappen met de facto beperkte aansprakelijkheid waarvan de financiële gegevens zijn opgenomen in de jaarrekening van een onbeperkt aansprakelijke vennoot. Zie E.C.A. Nass 2019, p. 38.

57. Zie E.C.A. Nass 2019, p. 27-38, voor een bespreking van de groepsvoorwaarde in de richtlijn jaarrekeningen, de Luxemburgse regeling, de Ierse regeling en de Duitse regeling.

58. Kamerstukken II 1969/70, 10751, 3, p. 13 (MvT), Kamerstukken II 1979/80, 16326, 3, p. 42 (MvT) en Kamerstukken II 1987/88, 19813, 5, p. 4 (MvA). Zie ook Honée 1981, p. 52, L. Timmerman 1988a, p. 54-55, Van Achterberg 1989, p. 82, Asser/Maeijer, Van Solinge \& Nieuwe Weme 2-II* 2009/816, Krol 2015, p. 144, Asser/Maeijer \& Kroeze 2-I* 2015/261, Van Limpt, Pronk \& Visser 2019, p. 813, E.C.A. Nass 2019, p. 41 en Bartman, Dorresteijn \& Olaerts 2020, p. 33.

59. Krol 2015, p. 143, Asser/Maeijer, Van Solinge \& Nieuwe Weme 2-II* 2009/816, Asser/ Maeijer \& Kroeze 2-I*2015/261, Van Limpt, Pronk \& Visser 2019, p. 813-814 en Bartman, Dorresteijn \& Olaerts 2020, p. 33-34. 
bevoegdheid van de moedermaatschappij tot het doen van een bindende voordracht voor de benoeming van bestuurders van de 403-maatschappij. ${ }^{60}$

De moedermaatschappij dient op basis van de organisatorische verbondenheid beslissende zeggenschap te hebben ten aanzien van de 403-maatschappij. Dit is doorgaans het geval als de moedermaatschappij direct of uit hoofde van een overeenkomst met een andere aandeelhouder de meerderheid van de stemmen in de algemene vergadering kan uitoefenen. Indien echter statutair is vastgelegd dat besluiten met een twee derde meerderheid moeten worden genomen, is een gewone meerderheid niet voldoende om beslissende zeggenschap te hebben. Maar ook als de moedermaatschappij niet de vereiste wettelijke of statutaire meerderheid van de stemmen kan uitoefenen, kan zij nog steeds beslissende zeggenschap hebben ten aanzien van de 403-maatschappij. Bijvoorbeeld als zij meer dan de helft van de bestuursleden of toezichthouders kan benoemen en ontslaan of als er sprake is van een personele unie tussen het bestuur van de moeder- en de 403-maatschappij.

Ik wijs nog op twee aandachtspunten met betrekking tot het stemrecht van de moedermaatschappij in de algemene vergadering. Ten eerste moet bij de beoordeling van de organisatorische verbondenheid ook rekening worden gehouden met potentiële stemrechten. In de literatuur wordt het voorbeeld gegeven dat een vennootschap twee aandeelhouders heeft die respectievelijk $40 \%$ en $60 \%$ van de aandelen houden. ${ }^{61}$ Als de minderheidsaandeelhouder een call-optie heeft om op elk moment tegen een vooraf vastgestelde prijs $30 \%$ van de aandelen van de meerderheidsaandeelhouder te kopen, heeft hij de beslissende zeggenschap ten aanzien van de vennootschap - ondanks dat hij op het moment zelf de minderheid van de aandelen houdt. Indien er een besluit dreigt te worden genomen in de algemene vergadering waar de minderheidsaandeelhouder het niet mee eens is, kan deze de call-optie inroepen en alsnog zijn eigen standpunt doordrukken.

Ten tweede merk ik op dat als de moedermaatschappij haar aandelen in de 403-maatschappij verpandt of er een recht van vruchtgebruik op vestigt waarbij is overeengekomen dat de pandhouder of vruchtgebruiker het stemrecht op de aandelen toekomt of onder opschortende voorwaarde toekomt, ${ }^{62}$ dit gevolgen kan hebben voor de groepsband met de 403-maatschappij. Als de moedermaatschappij niet meer het stemrecht op de aandelen kan uitoefenen, heeft zij mogelijk geen beslissende zeggenschap meer ten aanzien van de 403-maatschappij. ${ }^{63}$

60. Zie bijvoorbeeld art. 2:243 BW voor het geval dat de 403-maatschappij een BV is.

61. Van Limpt, Pronk \& Visser 2019, p. 816.

62. Zie met betrekking tot de BV art. 2:198 lid 3 BW, respectievelijk art. 2:197 lid 3 BW.

63. Van Limpt, Pronk \& Visser 2019, p. 814. 
De organisatorische verbondenheid tussen de moeder- en de 403-maatschappij moet leiden tot een economische eenheid. Dit houdt in dat de (bedrijfs)economische werkelijkheid binnen het organisatorische verband zodanig is dat de moeder- en de 403-maatschappij als een economische eenheid onder een gemeenschappelijke leiding optreden. ${ }^{64} \mathrm{Krol} \mathrm{noemt} \mathrm{als} \mathrm{aanwijzingen} \mathrm{voor} \mathrm{het}$ bestaan van een economische eenheid dat de activiteiten van de groepsmaatschappijen elkaar aanvullen en dat er een gemeenschappelijk beleid en beheer is ten aanzien van de financiën. ${ }^{65}$ Andere aanwijzingen zijn bijvoorbeeld dat gezamenlijke activiteiten van groepsmaatschappijen ook (voornamelijk) voor gemeenschappelijke rekening komen, dat gezamenlijk naar derden wordt opgetreden, dat transacties tussen groepsmaatschappijen niet op zakelijke voorwaarden plaatsvinden en dat groepsmaatschappijen gefinancierd worden door onderlinge leningen, garanties of aansprakelijkstellingen. ${ }^{66}$

De derde en laatste voorwaarde voor een groepsband is dat er sprake is van een centrale leiding. Daarvoor is niet alleen de juridisch-organisatorische verbondenheid tussen de moeder- en de 403-maatschappij van belang, maar vooral de (bedrijfs-)economische werkelijkheid tussen hen. ${ }^{67}$ Verschillende auteurs merken op dat voor een centrale leiding is vereist dat er een gemeenschappelijke strategie is waarbij de moedermaatschappij het beleid van 403-maatschappij plant, coördineert en controleert. Daarnaast moet de moedermaatschappij dit beleid eventueel kunnen afdwingen. ${ }^{68}$ Het bestaan van een centrale leiding komt bijvoorbeeld tot uitdrukking door een gecentraliseerd of gecoördineerd budgetterings- en rapportagesysteem, gecoördineerd beleid met betrekking tot de productie en verkoop, en overlegstructuren vanuit een centrale afdeling met de subafdelingen. ${ }^{69}$

Met betrekking tot het vereiste van een centrale leiding wijs ik nog op de hierboven genoemde mogelijkheid dat een aandeelhouder een call-optie heeft om tegen een vooraf vastgestelde prijs aandelen te nemen in een vennootschap. Een dergelijke call-optie kan meespelen bij de beoordeling of de desbetreffende aandeelhouder de centrale leiding heeft ten aanzien van deze vennootschap. Indien er namelijk een besluit dreigt te worden genomen in de algemene vergadering waar de aandeelhouder het niet mee eens is, kan hij de call-optie

64. Van Limpt, Pronk \& Visser 2019, p. 814

65. Krol 2015, p. 143.

66. Van Limpt, Pronk \& Visser 2019, p. 815.

67. Asser/Maeijer, Van Solinge \& Nieuwe Weme 2-II* 2009/816 en Asser/Maeijer \& Kroeze $2-I^{*} 2015 / 261$.

68. Honée 1981, p. 52, L. Timmerman 1988a, p. 54-55, Van Achterberg 1989, p. 82, Asser/ Maeijer, Van Solinge \& Nieuwe Weme 2-II* 2009/816, Krol 2015, p. 144, Asser/Maeijer \& Kroeze 2-I*2015/261.

69. Van Limpt, Pronk \& Visser 2019, p. 815. 
inroepen om (extra) aandelen te nemen en zijn eigen standpunt door te drukken. Of de call-optie de aandeelhouder de mogelijkheid biedt om zijn eigen standpunt door te drukken in de algemene vergadering, hangt onder meer af van de voorwaarden die daaraan zijn verbonden. Bijvoorbeeld of de aandeelhouder zelf kan besluiten om de call-optie uit te oefenen of dat hij daarvoor goedkeuring nodig heeft van een derde, en op welke termijn de vennootschap de aandelen moet uitgeven aan de aandeelhouder.

De minister heeft erop gewezen dat in verband met het vereiste van een centrale leiding een 50/50-joint venture met twee gelijkwaardige partners niet tot de groep van een van hen behoort - mits de partners niet tot dezelfde groep behoren. ${ }^{70} \mathrm{Om}$ diezelfde reden is bijvoorbeeld ook een franchiseketen geen groep en bestaat er geen groepsband tussen een pure beleggingsmaatschappij en een vennootschap waarvan deze maatschappij de meerderheid van de aandelen houdt. ${ }^{71}$ Tot slot merk ik op dat het vereiste van de centrale leiding met zich brengt dat een rechtspersoon maar tot één groep kan behoren. ${ }^{72}$

Het is van belang om groepsmaatschappijen te onderscheiden van dochtermaatschappijen. Hoewel een groepsmaatschappij doorgaans ook een dochtermaatschappij is, hoeft dit niet altijd het geval te zijn. Op grond van art. 2:24a BW is een dochtermaatschappij een rechtspersoon waarin de moedermaatschappij, of een of meer van haar dochtermaatschappijen, al dan niet krachtens een overeenkomst met andere stemgerechtigden de helft van de stemrechten in de algemene vergadering kan uitoefenen of meer dan de helft van de bestuurders of commissarissen kan benoemen of ontslaan. Waar een groepsband een feitelijke relatie tussen de moeder- en de groepsmaatschappij betreft, gaat het bij een moeder-dochterverhouding om een juridisch-organisatorische band. Hierboven wees ik erop dat er geen groepsband bestaat tussen een pure beleggingsmaatschappij en een vennootschap waarin deze maatschappij de meerderheid van de aandelen houdt. Deze vennootschap is daarentegen wel een dochtermaatschappij van de beleggingsmaatschappij.

Ik merk tot slot nog op dat in het oorspronkelijke wetsvoorstel voor de introductie van art. 2:403 BW niet werd verwezen naar een groepsmaatschappij, maar naar een dochtermaatschappij. ${ }^{73}$ Die term correspondeert met het in art. 57 van

70. Kamerstukken II 1981/82, 16326, 7, p. 18 (VV) en Kamerstukken II 1987/88, 20583, 3, p. 12 (MvT). Zie ook Van Achterberg, 1989, p. 74-75, E.C.A. Nass 2019, p. 46, E.C.A. Nass 2020 , p. 149 en Bartman, Dorresteijn \& Olaerts 2020, p. 35. Anders Raaijmakers 1976, p. 295, die meent dat een 50/50-joint venture tot twee groepen behoort.

71. Asser/Maeijer, Van Solinge \& Nieuwe Weme 2-II* 2009/816, Asser/Maeijer \& Kroeze 2-I* 2015/261 en Bartman, Dorresteijn \& Olaerts 2020, p. 34.

72. Van Limpt, Pronk \& Visser 2019, p. 815.

73. Kamerstukken II 1981/82, 16326, 2, p. 18 (OvW). 
de Vierde EEG-richtlijn gebruikte 'afhankelijke vennootschap'. De minister wees er echter op dat bij de besprekingen inzake de Zevende EEG-richtlijn was geopperd om de term afhankelijke vennootschap te veranderen in een omschrijving van een vennootschap van wie de financiële gegevens moesten zijn geconsolideerd in de geconsolideerde jaarrekening van de moedermaatschappij. ${ }^{74} \mathrm{De}$ minister heeft daarom het voorgestelde art. 2:403 BW aangepast en de term dochtermaatschappij vervangen door 'tot een groep behorende rechtspersoon' omdat dit volgens hem beter aansluit bij de vereiste geconsolideerde jaarrekening van de moedermaatschappij. De definitieve tekst van art. 43 van de Zevende EEG-richtlijn kende echter de term 'dochteronderneming'. Deze term is later gehandhaafd in art. 37 van de richtlijn jaarrekeningen ${ }^{75}$ en komt ook terug bij de Luxemburgse, Ierse en Duitse equivalenten van het groepsregime. ${ }^{76}$ De Nederlandse wetgever heeft er desondanks voor gekozen om in art. 2:403 $\mathrm{BW}$ te verwijzen naar een groepsmaatschappij.

Nass wijst er terecht op dat het vereiste van een groepsband in art. 2:403 BW in plaats van een moeder-dochterverhouding, zowel een verruiming als een beperking is van het groepsregime ten opzichte van de unitaire regeling. ${ }^{77}$ Een dochtermaatschappij die niet tevens tot de groep van de moedermaatschappij behoort, kan geen gebruikmaken van de jaarrekeningvrijstelling van het groepsregime. Omgekeerd kan een groepsmaatschappij die geen dochtermaatschappij is wel gebruikmaken van de jaarrekeningvrijstelling. Om de Nederlandse regeling op dit punt in overeenstemming te brengen met de richtlijn jaarrekeningen en de Luxemburgse, Ierse en Duitse equivalenten van het groepsregime, en om deze zo beter af te stemmen op de mogelijke verwachtingen die partijen van buiten Nederland hierover hebben, kan art. 2:403 BW worden gewijzigd. In deze bepaling kan worden opgenomen dat het gebruik van de jaarrekeningvrijstelling open staat voor dochtermaatschappijen in plaats van groepsmaatschappijen. ${ }^{78}$

\subsubsection{De balans en winst- en verliesrekening van de 403-maatschappij}

Als een 403-maatschappij gebruikmaakt van de jaarrekeningvrijstelling van het groepsregime, is zij van rechtswege vrijgesteld van de verplichting om haar jaarrekening overeenkomstig de voorschriften van titel 9 van Boek 2 BW in te richten. Desondanks gelden er op grond van art. 2:403 lid 1 sub a BW

74. Kamerstukken II 1981/82, 16326, 8, p. 21 (MvA).

75. Zie E.C.A. Nass 2019, p. 31, waar zij opmerkt dat een dochteronderneming in de zin van de richtlijn jaarrekeningen een onderneming is die door een moederonderneming wordt beheerst.

76. Zie E.C.A. Nass 2019, p. 31-38.

77. E.C.A. Nass 2019, p. 43.

78. E.C.A. Nass 2019, p. 43. 
bepaalde voorschriften met betrekking tot de inrichting van de balans en de winst- en verliesrekening. Ten eerste moet de balans de som van de vaste en vlottende activa vermelden. Daarnaast moeten daarin de bedragen van het eigen vermogen, de schulden en de voorzieningen zijn opgenomen. Tot slot moet in de winst- en verliesrekening het resultaat uit de gewone bedrijfsuitoefening na belasting en de overige baten en lasten na belastingen zijn vermeld. ${ }^{79}$

Beckman merkt op dat bovenstaande voorschriften met betrekking tot de balans en winst- en verliesrekening van de 403-maatschappij ten onrechte door de wetgever zijn overgenomen uit art. 38a WJO en art. 2:343 (oud) BW. ${ }^{80}$ Deze bepalingen kenden geen vrijstelling van de openbaarmakingplicht waardoor een groepsmaatschappij die gebruikmaakte van de jaarrekeningvrijstelling verplicht was om de jaarrekening te deponeren. Beckman vindt het begrijpelijk dat er toen voorwaarden werden gesteld aan de inrichting van de balans en winsten verliesrekening. Art. 2:403 BW kent echter wel een vrijstelling van de openbaarmakingsplicht. Ik sluit mij daarom bij Beckman aan dat er op dit punt geen noodzaak (meer) bestaat voor bovengenoemde voorschriften met betrekking tot de balans en winst- en verliesrekening van een 403-maatschappij en dat deze bepaling kan worden geschrapt uit art. 2:403 BW.

Ik merk op dat als een 403-maatschappij andere aandeelhouders of leden heeft naast de moedermaatschappij, deze wel belang kunnen hebben bij inzicht in de balans en de winst- en verliesrekening van de 403-maatschappij. Voor hen kan het daarom van belang zijn dat de balans en de winst- en verliesrekening aan de voorschriften van art. 2:403 lid 1 sub a BW voldoen. Voor deze aandeelhouders en leden hoeft het schrappen van art. 2:403 lid 1 sub a BW echter geen bezwaar te zijn aangezien de 403-maatschappij niet zonder hun instemming mag afwijken van de jaarrekeningvoorschriften ${ }^{81}$ - dit instemmingsrecht komt in de volgende paragraaf uitgebreid aan de orde. Zij kunnen als voorwaarde voor de instemming eisen dat hen informatie wordt gegeven over de vermogenstoestand van de 403-maatschappij en dat deze voldoet aan bepaalde vereisten met betrekking tot de inrichting.

79. Zie Beckman - Compendium jaarrekening, § 3.8.3.15, voor een voorbeeld van een dergelijke balans en winst- en verliesrekening. Zie ook E.C.A. Nass 2019, p. 19 en 58, die opmerkt dat de 403-maatschappij op grond van art. 31 a lid 2 WOR deze jaarrekening na de vaststelling moet overleggen aan een eventuele ondernemingsraad.

80. Beckman 1995b, p. 85 .

81. Zie art. 2:403 lid 1 sub b BW. 


\subsubsection{Instemming door de leden of aandeelhouders}

\subsection{4.a Inleiding}

Op grond van art. 2:403 lid 1 sub b BW moeten alle leden of aandeelhouders van de 403-maatschappij schriftelijk ${ }^{82}$ instemmen met de afwijking van de jaarrekeningvoorschriften. ${ }^{83}$ De minister merkt op dat het instemmingsrecht voorkomt dat de leden of aandeelhouders tegen hun wil worden geconfronteerd met deze afwijking. ${ }^{84}$ Houwen spreekt van een vorm van concernrechtelijke minderheidsbescherming. ${ }^{85}$

De instemming moet na aanvang van het boekjaar en voor de vaststelling ${ }^{86}$ van de jaarrekening over het desbetreffende boekjaar worden gegeven. Dit brengt mee dat het niet is toegestaan dat de leden of aandeelhouders instemmen met de afwijking van de jaarrekeningvoorschriften voor de jaarrekeningen over eerdere boekjaren of de boekjaren die nog niet zijn aangevangen. Uitgaande van boekjaren die gelijklopen met het kalenderjaar, kunnen de leden of aandeelhouders van een 403-maatschappij in het jaar 2020 dus instemmen met de afwijking van de jaarrekeningvoorschriften met betrekking tot de jaarrekening over het boekjaar 2019 - mits deze nog niet is vastgesteld - en die over 2020. Omdat de leden of aandeelhouders voor ieder boekjaar dat de 403-maatschappij gebruik wil maken van de jaarrekeningvrijstelling moeten instemmen met de afwijking van de jaarrekeningvoorschriften, bestaat het risico dat dit een keer wordt vergeten en de 403-maatschappij met betrekking tot het desbetreffende boekjaar onterecht gebruikmaakt van de vrijstelling. De 403-maatschappij schendt dan de openbaarmakingsplicht en haar bestuur kan daarvoor eventueel aansprakelijk worden gesteld. Om dit te kunnen voorkomen is het mijns inziens wenselijk dat art. 2:403 BW wordt aangepast, zodat het mogelijk wordt dat de leden of aandeelhouders van de 403-maatschappij een doorlopende instemming kunnen geven. Mocht een lid of aandeelhouder op een gegeven moment niet meer akkoord zijn met de afwijking van de jaarrekeningvoorschriften dan kan hij zijn instemming intrekken.

82. Bij de voorlopers van art. 2:403 BW gold geen schriftelijkheidsvereiste. De instemming kon toen ook mondeling of stilzwijgend worden gegeven. Zie E.C.A. Nass 2019, p. 58-59. Zie ook $\S 2.2$ voor een bespreking van de wetsgeschiedenis van het groepsregime.

83. Zie E.C.A. Nass 2019, p. 49-52, voor een bespreking van de instemmingsvoorwaarde in de richtlijn jaarrekeningen, de Luxemburgse regeling, de Ierse regeling en de Duitse regeling.

84. Kamerstukken II 1967/68, 9595, 3, p. 16 (MvT).

85. Houwen, Schoonbrood-Wessels \& Schreurs 1993, p. 817

86. Bij de voorlopers van art. 2:403 BW gold dat de instemming moest zijn verleend uiterlijk voor afloop van het boekjaar waarover de groepsmaatschappij een jaarrekening wilde opmaken waarbij zij gebruik zou maken van de jaarrekeningvrijstelling van het groepsregime. Zie E.C.A. Nass 2019 , p. 59 . Zie ook $\S 2.2$ voor een bespreking van de wetsgeschiedenis van het groepsregime. 
Beckman en Nass wijzen erop dat het mogelijk is dat er in anticipatie op de instemming een jaarrekening is opgemaakt en aan de algemene vergadering is voorgelegd, waarbij is gebruikgemaakt van de jaarrekeningvrijstelling van het groepsregime. ${ }^{87}$ Indien vervolgens toch niet wordt ingestemd met de afwijking van de jaarrekeningvoorschriften moet er alsnog een jaarrekening worden opgemaakt volgens het reguliere jaarrekeningregime. Volgens hen kan een dergelijke situatie worden voorkomen als art. 2:403 lid $1 \mathrm{sub}$ b BW wordt aangepast zodat de instemming uiterlijk moet zijn gegeven met het verlopen van de (verlengde) termijn voor het opmaken van de jaarrekening. ${ }^{88}$

\subsection{4.b Instemmingsgerechtigden}

Ik heb er eerder op gewezen dat aangezien in art. 2:403 lid 1 sub b BW staat geschreven dat de leden of aandeelhouders van de 403-maatschappij moeten instemmen met de afwijking van de jaarrekeningvoorschriften, een commanditaire vennootschap en vennootschap onder firma in de zin van art. 2:360 lid 2 $\mathrm{BW}$, volgens een strikte lezing van deze bepaling geen gebruik kunnen maken van de jaarrekeningvrijstelling van het groepsregime. ${ }^{89} \mathrm{Zij}$ hebben namelijk geen leden of aandeelhouders, maar vennoten. Evenals Nass zie ik geen reden voor de uitsluiting van deze vennootschappen en meen ik met haar dat deze bepaling daarom ruimer moet worden uitgelegd zodat het instemmingsrecht ook van toepassing is op de desbetreffende vennoten. ${ }^{90} \mathrm{Ik}$ heb er daarnaast op gewezen dat aangezien een stichting geen leden of aandeelhouders - of vennoten - heeft, deze niet kan voldoen aan de voorwaarde van art. 2:403 lid 1 sub b BW en dus niet gebruik kan maken van de jaarrekeningvrijstelling van het groepsregime. Opnieuw sluit ik mij aan bij Nass dat er geen rechtvaardiging is voor een dergelijke uitsluiting. Zij en Beckman wijzen erop dat de wetgever er zelf in art. 2:300 lid $1 \mathrm{BW}$ vanuit lijkt te gaan dat een stichting gebruik kan maken van de jaarrekeningvrijstelling van het groepsregime. ${ }^{91} \mathrm{Ik}$ deel de mening van Nass dat het wenselijk is dat art. 2:403 BW wordt aangepast zodat ook stichtingen gebruik kunnen maken van de vrijstelling. ${ }^{92} \mathrm{Zij}$ stelt voor om lid $1 \mathrm{sub} b$ aan te vullen, in die zin dat bij een stichting degenen die deel uitmaken van het orgaan dat de jaarrekening vaststelt, moeten instemmen met de afwijking van de jaarrekeningvoorschriften. Ik kan mij hierin vinden.

87. Beckman 1995a, p. 250 en E.C.A. Nass 2019, p. 60.

88. Zie voor de openbaarmakingstermijn bij een NV en BV respectievelijk art. 2:101 BW en art. 2:210 BW. Zie voor een vereniging, coöperatie en onderlinge waarborg maatschappij art. 2:49 BW.

89. Zie $\S 2.3 .1$.

90. E.C.A. Nass 2019, p. 52-53

91. Asser/Maeijer \& Kroeze 2-I*2015/581 en E.C.A. Nass 2019, p. 57.

92. E.C.A. Nass 2019, p. 57. 
Ik heb opgemerkt dat dit onderzoek in beginsel is beperkt tot NV's en BV's die gebruikmaken van de jaarrekeningvrijstelling van het groepsregime of aansprakelijk zijn op grond van een 403 -verklaring. ${ }^{93}$ De reden daarvoor is dat mij uit de jurisprudentie geen gevallen bekend zijn waarbij de 403-maatschappij of de moedermaatschappij niet een NV of een BV is. Slechts op plekken waar dit relevant is, behandel ik de mogelijkheid dat de 403-maatschappij een andere rechtsvorm heeft. In het vervolg van dit onderzoek verwijs ik daarom in beginsel alleen naar het instemmingsrecht van de aandeelhouders van een 403-maatschappij.

Het is niet de aandeelhoudersvergadering die als orgaan moet instemmen met de afwijking van de jaarrekeningvoorschriften. Het instemmingsrecht komt toe aan iedere aandeelhouder afzonderlijk. ${ }^{94}$ In het geval dat de 403-maatschappij eigen aandelen houdt, is het naar mijn mening niet nodig dat zij zichzelf toestemming geeft om af te wijken van de jaarrekeningvoorschriften. Ontbreekt echter de instemming van één (van de andere) aandeelhouder(s) - ook als deze niet reageert op het verzoek om in te stemmen of als niet bekend is wie de aandeelhouder is - dan kan de 403-maatschappij niet (rechtsgeldig) gebruikmaken van de jaarrekeningvrijstelling van het groepsregime..$^{95}$ Indien de moedermaatschappij $95 \%$ of meer van de aandelen in de 403-maatschappij houdt, kan zij de aandeelhouders die weigeren in te stemmen uitkopen ${ }^{96}$ zodat de 403-maatschappij alsnog gebruik kan maken van de jaarrekeningvrijstelling. ${ }^{97}$

Het instemmingsrecht is niet verbonden aan het stemrecht van de aandeelhouder. Ook aandeelhouders zonder stemrecht moeten instemmen met de afwijking van de jaarrekeningvoorschriften. Hierbij kan worden gedacht aan een aandeelhouder van wie het vergaderrecht is geschorst, een aandeelhouder die zijn aandelen heeft verpand waarbij is overeengekomen dat de pandhouder het stemrecht op de aandelen toekomt of de houder van een aandeel zonder stemrecht. ${ }^{98}$ Voorts wijs ik erop dat als aandelen aan toonder in een $\mathrm{NV}$ door een statutenwijziging of van rechtswege op naam worden gesteld, een aandeelhouder de aan die aandelen verbonden rechten pas kan uitoefenen

93. Zie $§ 1.4$.

94. Assink/Slagter 2013/140.1 en E.C.A. Nass 2019, p. 53

95. Beckman - SDU Commentaar Ondernemingsrecht 2019, art. 2:403 BW, aant. C.3.2.

96. Zie art. 2:92a en 2:201a BW.

97. Zie Beckman 1990, p. 309 en E.C.A. Nass 2019, p. 54, die opmerken dat de problematiek van het niet reageren van een of meer aandeelhouders kan worden voorkomen door art. 2:403 lid 1 sub b BW aan te passen zodat slechts instemming is vereist van $95 \%$ van de aandeelhouders van de 403-maatschappij. Nass merkt op dat dit ook vraagt om een wijziging van het instemmingsrecht ex art. 37 richtlijn jaarrekening.

98. Zie met betrekking tot een BV respectievelijk art. 2:192 lid 4, art. 2:227 lid 6, art. 2:198 lid 3 en art. 2:228 lid 5 BW. 
na inlevering van het aandeelbewijs aan de vennootschap..$^{99}$ Ik sluit mij aan bij Nass die opmerkt dat dit niet wegneemt dat de desbetreffende aandeelhouder in dat geval de instemmingsgerechtigde blijft in de zin van art. 2:403 lid 1 sub b BW. ${ }^{100}$ Tot slot merk ik op dat indien de aandelen in de 403-maatschappij zijn gecertificeerd, het administratiekantoor als aandeelhouder moet instemmen met de afwijking van de jaarrekeningvoorschriften. ${ }^{101}$ De certificaathouders hebben geen instemmingsrecht. Evenals Beckman en Nass meen ik dat aangezien de positie van een certificaathouder aan wier certificaten vergaderrecht is gekoppeld vergelijkbaar is met die van een houder van stemrechtloze aandelen, het voor de hand ligt om ook dergelijke certificaathouders instemmingsrecht toe te kennen - in plaats van het administratiekantoor. ${ }^{102}$

\subsection{4.c De verklaring van instemming}

De aandeelhouders van de 403-maatschappij moeten schriftelijk verklaren dat zij instemmen met de afwijking van de jaarrekeningvoorschriften. Naar mijn mening wordt (ook) aan dit vereiste van schriftelijkheid voldaan als de instemming elektronisch is vastgelegd, bijvoorbeeld doordat de aandeelhouder een e-mail heeft gestuurd aan het bestuur van de 403-maatschappij. Om te voorkomen dat een derde ten onrechte namens een aandeelhouder instemt met de afwijking van de jaarrekeningvoorschriften, kan het bestuur ter verificatie van de identiteit van de aandeelhouder bijvoorbeeld eisen dat deze de verklaring van de instemming met zijn handtekening ondertekent en ingescand per e-mail verstuurt. Hoewel de mogelijkheid van een elektronische instemming niet uit art. 2:403 $\mathrm{BW}$ volgt - in tegenstelling tot verschillende andere wetsbepalingen waar wel expliciet is genoemd dat aan de eis van schriftelijkheid is voldaan door een elektronische vastlegging ${ }^{103}$ - zie ik hiertegen geen bezwaar aangezien de instemming een mededeling betreft van de aandeelhouder aan het bestuur van de 403-maatschappij. Ter verduidelijking zou aan art. 2:403 lid 1 sub b BW kunnen worden toegevoegd dat tenzij de statuten anders bepalen, aan de eis van schriftelijkheid is voldaan indien de instemming elektronisch is vastgelegd.

99. Zie art. 2:82 lid 5 BW. Indien een aandeelbewijs niet uiterlijk op 31 december 2020 is ingeleverd, verkrijgt de NV op grond van art. 2:82 lid $6 \mathrm{BW}$ van rechtswege het aandeel. Als de aandeelhouder zich binnen vijf jaar meldt met het aandeelbewijs, heeft hij op grond van art. 2:82 lid $9 \mathrm{BW}$ recht op een vervangend aandeel op naam in de NV.

100. E.C.A. Nass 2019, p. 53.

101. Beckman 1995a, p. 385-386, Asser/Maeijer \& Kroeze 2-I* 2015/581, E.C.A. Nass 2019, p. 53-54 en Beckman - Compendium jaarrekening, § 3.8.3.7.

102. Beckman 1995a, p. 385-386 en E.C.A. Nass 2019, p. 53-54.

103. Zie bijvoorbeeld met betrekking tot een BV art. 2:206a lid 4, art. 2:220 lid 3, art. 2:224a lid 3 en art. 2:227a lid 5 BW. 
Een verklaring van de instemming van de aandeelhouders moet worden gedeponeerd bij het handelsregister. ${ }^{104}$ Per 403-maatschappij moet een aparte instemmingsverklaring worden gedeponeerd. Als een moedermaatschappij verschillende groepsmaatschappijen heeft die gebruik willen maken van de jaarrekeningvrijstelling, zal zij dus met betrekking tot iedere 403-maatschappij afzonderlijk moeten verklaren dat zij instemt met de afwijking van de jaarrekeningvoorschriften. In het jaar 2019 zijn bij het handelsregister 13.603 instemmingsverklaringen gedeponeerd. ${ }^{105,106}$ Een (mogelijk nadelig) gevolg van de deponering van een instemmingsverklaring is dat extern bekend wordt wie de aandeelhouders van de 403-maatschappij zijn. ${ }^{107}$ Beckman en Nass stellen daarom voor om - in navolging van het Ierse equivalent van het groepsregime - art. 2:403 BW aldus te wijzigen dat niet een verklaring openbaar moet worden gemaakt met de identiteit van de aandeelhouders die hebben ingestemd met de afwijking van de jaarrekeningvoorschriften, maar een verklaring van het bestuur dat zij de vereiste instemming van de aandeelhouders heeft ontvangen. ${ }^{108}$

Er wordt geen eis gesteld aan de te hanteren taal in de instemmingsverklaring. Ik meen met Nass dat het aanbeveling verdient om art. 2:403 BW op dit punt aan te passen en voor te schrijven dat de instemmingsverklaring in dezelfde taal moet zijn gesteld of vertaald als de geconsolideerde jaarrekening,

104. Zie art. 2:403 lid 1 sub g BW. Zie Van Zoest 2019, p. 27-28, die een voorbeeld geeft van een dergelijke instemmingsverklaring. Zie E.C.A. Nass 2019, p. 113-119, voor een bespreking van de openbaarmaking van de instemming van de aandeelhouders volgens de richtlijn jaarrekeningen, de Luxemburgse regeling, de Ierse regeling en de Duitse regeling.

105. Op 22 april 2020 per e-mail aan mij meegedeeld door de afdeling Databeheer Orderbehandeling van de Kamer van Koophandel. Daarnaast heeft een medewerker van de Kamer van Koophandel op 10 februari 2017 telefonisch aan mij meegedeeld dat er gedurende het jaar 2016 bij het handelsregister 12.680 instemmingsverklaringen zijn gedeponeerd.

106. Ik merk op dat er op 31 december 2019 en 2016 bij het handelsregister 16.719, respectievelijk 16.956 403-verklaringen zijn gedeponeerd (op 22 april 2020 per e-mail aan mij meegedeeld door de afdeling Databeheer Orderbehandeling van de Kamer van Koophandel, respectievelijk op 10 februari 2017 telefonisch aan mij meegedeeld door een medewerker van de Kamer van Koophandel). Uit deze cijfers blijkt dat ten aanzien van ongeveer een vijfde deel van de 403-maatschappijen wél een 403-verklaring, maar geen (jaarlijkse) instemmingsverklaring is gedeponeerd. Zie $\S 7.6 .1$ waar ik mogelijke redenen noem voor deze discrepantie.

107. Ik wijs erop dat een NV of BV op grond van art. 15a Handelsregisterwet 2007 bepaalde informatie ten aanzien van de natuurlijke persoon of personen die de uiteindelijke belanghebbende(n) zijn van de vennootschap moet vermelden in het handelsregister. Op grond van art. 3 lid 1 sub a Uitvoeringsbesluit Wwft 2018 moet als uiteindelijk belanghebbende in ieder geval worden aangemerkt een natuurlijk persoon die (in)direct houder is van meer dan 25 procent van de aandelen, van de stemrechten of van het eigendomsbelang in de vennootschap.

108. Beckman 1995a, p. 388 en E.C.A. Nass 2019, p. 120-121. 
de accountantsverklaring en het bestuursverslag van de moedermaatschappij - zijnde het Nederlands, Frans, Duits of Engels - (zie § 2.3.5). ${ }^{109}$

\subsection{4.d Instemming onder voorwaarden en herroeping van de instemming}

Als de moedermaatschappij alle aandelen in de 403-maatschappij houdt, zal de instemming geen probleem opleveren. Indien er echter ook andere aandeelhouders zijn, kan het anders zijn. Het is toegestaan dat een aandeelhouder voorwaarden verbindt aan zijn instemming, bijvoorbeeld dat hem ieder jaar een financieel overzicht wordt gegeven dat overeenkomstig titel 9 van Boek $2 \mathrm{BW}$ is ingericht. ${ }^{110}$ Indien de aandeelhouder onder opschortende voorwaarde instemming verleent, moet mijns inziens aan deze voorwaarde zijn voldaan uiterlijk op het moment dat de summiere jaarrekening van de 403-maatschappij in de zin van art. 2:403 lid $1 \mathrm{sub}$ a BW wordt vastgesteld of - als de jaarrekening nog niet is vastgesteld - uiterlijk twaalf maanden na afloop van het boekjaar. ${ }^{11}$

Het staat een aandeelhouder in beginsel vrij om niet in te stemmen met de afwijking van de jaarrekeningvoorschriften door de 403-maatschappij of om een eerdere instemming te herroepen. ${ }^{112}$ Een aandeelhouder heeft een wettelijk recht op informatie en hoeft geen reden op te geven als hij daar niet van wil afwijken. Ik deel de mening van Beckman en Nass dat het onthouden of herroepen van instemming slechts onder bijzondere omstandigheden op grond van art. 2:8 BW naar maatstaven van redelijkheid en billijkheid onaanvaardbaar is. ${ }^{113}$ Hierbij kan worden gedacht aan de situatie dat een aandeelhouder een eerder gegeven instemming herroept vlak voordat de summiere jaarrekening van de 403-maatschappij in de zin van art. 2:403 lid $1 \mathrm{sub}$ a BW wordt vastgesteld of nadat hij eerder heeft verklaard de instemming niet te zullen herroepen. In een dergelijk geval is de herroeping van de instemming naar maatstaven van redelijkheid en billijkheid onaanvaardbaar, en is de aandeelhouder gebonden aan zijn eerdere instemming.

109. E.C.A. Nass 2019, p. 59 en 125.

110. E.C.A. Nass 2019, p. 56-57 en Beckman - Compendium jaarrekening, § 3.8.3.5a.

111. Zie $\S 2.4$, waar ik tot de conclusie kom dat aan alle voorwaarden om gebruik te maken van de jaarrekeningvrijstelling moet zijn voldaan uiterlijk op het moment dat de aandeelhouders van de 403-maatschappij de summiere jaarrekening in de zin van art. 2:403 lid 1 sub a BW vaststellen of - als de jaarrekening nog niet is vastgesteld - uiterlijk twaalf maanden na afloop van het boekjaar.

112. E.C.A. Nass 2019 , p. 64-65.

113. Beckman 1995a, p. 251-252 en E.C.A. Nass 2019, p. 56. 


\subsection{4.e Zijn nieuwe aandeelhouders gebonden aan een eerder gegeven} instemming?

Tot slot merk ik met betrekking tot het instemmingsrecht op dat het onduidelijk is of nieuwe aandeelhouders van de 403-maatschappij al of niet zijn gebonden aan een eerder gegeven instemming - door de toenmalige aandeelhouders van de 403-maatschappij. Ten aanzien van het Duitse equivalent van het groepsregime wordt voor het antwoord op deze vraag een onderscheid gemaakt tussen twee situaties. Ten eerste dat een derde aandelen heeft overgenomen van een aandeelhouder, en ten tweede dat er nieuwe aandelen zijn uitgegeven - aan anderen dan de bestaande aandeelhouders.

Indien een derde aandelen heeft overgenomen, wordt over het algemeen in de Duitse literatuur aangenomen dat deze in de rechtspositie van de oud-aandeelhouder is getreden en daarom is gebonden aan de eerder gegeven instemming. ${ }^{114}$ In het geval dat er nieuwe aandelen zijn uitgegeven, wordt er een onderscheid gemaakt of de aandelen zijn uitgegeven in het boekjaar waarover de vennootschap een jaarrekening wil opmaken waarbij zij gebruikmaakt van de jaarrekeningvrijstelling, of in het daaropvolgende boekjaar - maar voordat de desbetreffende jaarrekening is vastgesteld. In de eerste situatie wordt ervan uitgegaan dat de nieuwe aandeelhouders moeten instemmen met de afwijking van de jaarrekeningvoorschriften. ${ }^{115}$ In het tweede geval wordt daarentegen aangenomen dat de nieuwe aandeelhouders geen instemmingsrecht hebben, omdat zij doorgaans niet delen in het resultaat over het boekjaar waarover de vennootschap een jaarrekening wil opmaken waarbij zij gebruikmaakt van de jaarrekeningvrijstelling. ${ }^{116}$

114. Adler/Düring \& Schmaltz 2001, § 264 Handelsgesetzbuch nF, nr. 38, Förschle \& Deubert 2012, Beck'scher Bilanz-Kommentar, Handels- und Steuerbilanz, § 264 Handelsgesetzbuch, nr. 123, Graf \& Bisle 2013, Münchener Kommentar zum Bilanzrecht, § 264 Handelsgesetzbuch, nr. 116 en Ruppelt 2020, Beck'scher Online-Kommentar, § 264 Handelsgesetzbuch, nr. 86.2. Anders Kraft 2001, p. 474 en 477, die van mening is dat de nieuwe aandeelhouder zelf ook moet instemmen, omdat de oud-aandeelhouder niet het instemmingsrecht van zijn opvolger kan ontnemen. Overigens wijs ik erop dat op 23 juli 2015 § 264 Absatz 3 \& 4 Handelsgesetzbuch deels zijn gewijzigd ter aanpassing aan de richtlijn jaarrekeningen. De bepaling inzake het instemmingsrecht is daarbij niet inhoudelijk gewijzigd maar enkel de formulering.

115. Kraft 2001, p. 477, Adler/Düring \& Schmaltz 2001, § 264 Handelsgesetzbuch nF, nr. 39, Förschle \& Deubert 2012, Beck'scher Bilanz-Kommentar, Handels- und Steuerbilanz, § 264 Handelsgesetzbuch, nr. 124, Graf \& Bisle 2013, Münchener Kommentar zum Bilanzrecht, $\S 264$ Handelsgesetzbuch, nr. 116 en Ruppelt 2020, Beck'scher Online-Kommentar, § 264 Handelsgesetzbuch, nr. 86.2.

116. Kraft 2001, p. 477-478, Adler/Düring \& Schmaltz 2001, § 264 Handelsgesetzbuch nF, nr. 39, Förschle \& Deubert 2012, Beck'scher Bilanz-Kommentar, Handels- und Steuerbilanz, § 264 Handelsgesetzbuch, nr. 124 en Graf \& Bisle 2013, Münchener Kommentar zum Bilanzrecht, $\S 264$ Handelsgesetzbuch, nr. 116. 
Nass wijst erop dat uit de tekst van art. 2:403 BW en de parlementaire geschiedenis geen eenduidig antwoord is op te maken of nieuwe aandeelhouders al of niet zijn gebonden aan een eerder gegeven instemming. ${ }^{117} \mathrm{Zij}$ zoekt daarom aansluiting bij het doel van de instemmingsvoorwaarde: het bieden van een waarborg voor aandeelhouders dat zij niet tegen hun wil worden geconfronteerd met een afwijking van de jaarrekeningvoorschriften. Nass is van mening dat deze waarborg meebrengt dat nieuwe aandeelhouders niet zijn gebonden aan een eerdere instemming. De 403-maatschappij mag volgens haar dus niet zonder de instemming van de nieuwe aandeelhouders gebruikmaken van de jaarrekeningvrijstelling van het groepsregime. Dit geldt zowel bij een overdracht van aandelen ${ }^{118}$ als bij een uitgifte van nieuwe aandelen.

Ik kan mij slechts ten dele vinden in het standpunt van Nass. Naar mijn mening is doorslaggevend of een nieuwe andeelhouder is gebonden aan een reeds gegeven instemming of deze nieuwe aandelen of bestaande aandelen in de 403-maatschappij heeft gekregen. Bij een emissie van - nieuwe - aandelen zie ik geen reden waarom de nieuwe aandeelhouders gebonden zouden zijn aan de eerder door de andere aandeelhouders gegeven instemming. Een andere uitkomst zou neerkomen op een beperking van het recht op informatie van de nieuwe aandeelhouders omtrent de financiële positie van de 403-maatschappij buiten hun macht om. In tegenstelling tot het standpunt dat in de Duitse literatuur wordt verdedigd, maakt het daarbij naar mijn mening geen verschil of de aandelen zijn uitgegeven in het boekjaar waarover de 403-maatschappij een jaarrekening wil opmaken waarbij zij gebruikmaakt van de jaarrekeningvrijstelling, of in het daaropvolgende boekjaar. Het argument dat aandeelhouders aan wie de aandelen zijn uitgegeven in het laatste boekjaar doorgaans niet meedelen in de in het resultaat over het voorgaande boekjaar overtuigt mij niet. Dit doet niet af aan hun recht op informatie en daarmee aan de waarborg die zij hebben dat slechts met hun instemming mag worden afgeweken van de jaarrekeningvoorschriften. Er zou nog kunnen worden betoogd dat de aandeelhouders wisten dat de vennootschap gebruik wil maken van de jaarrekeningvrijstelling toen zij de aandelen hebben genomen en dat zij daarom zijn gebonden aan de eerdere instemming van de overige aandeelhouders. Ook dat argument doet naar mijn mening niet af aan het recht van aandeelhouders op informatie inzake de vermogenstoestand van de vennootschap en daarmee de waarborg dat daarvan niet zonder hun instemming mag worden afgeweken. Nieuwe aandeelhouders zouden naar mijn mening - evenals de bestaande aandeelhouders - de mogelijkheid moeten hebben om af te wijken van eerdere keuzes die zijn gemaakt. Een andere uitkomst zou tot de opmerkelijke situatie leiden dat de bestaande aandeelhouders wel hun eerder gegeven instemming kunnen

117. E.C.A. Nass 2019, p. 62.

118. Zie ook Beckman - Compendium jaarrekening, § 3.8.3.9. 
herroepen, maar dat de nieuwe aandeelhouders zonder meer zijn gebonden aan de eerdere instemming van die aandeelhouders.

Indien daarentegen - bestaande - aandelen in de 403-maatschappij worden overgedragen aan een derde, is de nieuwe aandeelhouder naar mijn mening wel gebonden aan een eerder gegeven instemming. In lijn met het in de Duitse literatuur verdedigde standpunt, meen ik dat de nieuwe aandeelhouder de rechtspositie van de oud-aandeelhouder inneemt en daarmee ook gebonden is aan de instemming van laatstgenoemde. De nieuwe aandeelhouder staat echter niet met lege handen als hij niet wil dat de 403-maatschappij gebruikmaakt van de jaarrekeningvrijstelling van het groepsregime. Dat hij is gebonden aan de eerder gegeven instemming, betekent ook dat hij deze instemming kan herroepen - net zoals de oud-aandeelhouder had kunnen doen als hij de aandelen niet had overgedragen. Daarbij teken ik wel aan dat een herroeping van de instemming onder omstandigheden op grond van art. 2:8 BW onaanvaardbaar kan zijn naar maatstaven van redelijkheid en billijkheid. ${ }^{119}$

Om bovengenoemde discussie over het eventuele instemmingsrecht van nieuwe aandeelhouders te beëindigen, kan art. 2:403 lid 1 sub b BW worden gewijzigd naar het voorbeeld van het Ierse equivalent van het groepsregime. ${ }^{120}$ In tegenstelling tot de regeling ex art. 2:403 BW is er bij het Ierse equivalent geen sprake van een periode waarbinnen de aandeelhouders moeten instemmen met de afwijking van de jaarrekeningvoorschriften. In plaats daarvan moet de instemming worden gegeven door degenen die op een vastgesteld moment aandeelhouder zijn van de vennootschap. ${ }^{121}$ In lijn daarmee zou bijvoorbeeld aan art. 2:403 lid 1 sub b BW kunnen worden toegevoegd dat moet worden ingestemd met afwijking van de jaarrekeningvoorschriften door degenen die aandeelhouder zijn ten tijde van de vaststelling van de summiere jaarrekening van de 403-maatschappij in de zin van art. 2:403 lid 1 sub a BW, of - als de jaarrekening dan nog niet is vastgesteld - door degenen die twaalf maanden na afloop van het boekjaar aandeelhouder zijn. ${ }^{122}$ Dit neemt overigens niet weg dat de desbetreffende aandeelhouders eerder al kunnen instemmen met de afwijking van de jaarrekeningvoorschriften.

119. Zie $\S 2.3 .4$.d. Ik heb onder meer als voorbeeld gegeven dat een aandeelhouder de instemming herroept vlak voordat de summiere jaarrekening van de 403-maatschappij in de zin van art. 2:403 lid 1 sub a BW wordt vastgesteld.

120. Zie section 357 (1)(a) Companies Act 2014.

121. Zie E.C.A. Nass 2019, p. 51, die opmerkt dat moet worden ingestemd door degenen die aandeelhouder zijn op de dag van de eerste jaarlijkse algemene vergadering of de eerste annual return date na afloop van het boekjaar - afhankelijk van wat eerder is. Er moet jaarlijks een algemene vergadering plaatsvinden, doch uiterlijk binnen vijftien maanden na de laatste jaarvergadering. De annual return date is een Ierse bepaling en is de eerste keer zes maanden na de oprichtingsdatum en daarna telkens iedere twaalf maanden.

122. E.C.A. Nass 2019, p. 62 en 64. 


\subsubsection{De geconsolideerde jaarrekening van de moedermaatschappij}

De financiële gegevens van de 403-maatschappij moeten zijn geconsolideerd in de geconsolideerde jaarrekening van de moedermaatschappij. ${ }^{123}$ Dit brengt met zich dat de moeder- en de 403-maatschappij in het boekjaar waarover de 403-maatschappij een jaarrekening wil opmaken waarbij zij gebruikmaakt van de jaarrekeningvrijstelling van het groepsregime tot dezelfde groep moeten horen. Anders kan de moedermaatschappij de financiële gegevens van de 403-maatschappij niet consolideren in haar geconsolideerde jaarrekening over het desbetreffende boekjaar. ${ }^{124}$ Indien de 403-maatschappij gedurende het boekjaar tot de groep van de moedermaatschappij is toegetreden, wordt aan de consolidatievoorwaarde voldaan als de financiële gegevens vanaf het toetredingsmoment zijn geconsolideerd in de geconsolideerde jaarrekening. ${ }^{125}$

Beckman wijst erop dat in art. 2:403 lid 1 sub c BW bewust wordt verwezen naar de financiële gegevens van de 403-maatschappij en niet naar de jaarrekening. Dit is om consolidatie mogelijk te maken in het geval dat in de jaarrekeningen van de moeder- en de 403-maatschappij verschillende grondslagen worden gebruikt of als de boekjaren niet gelijklopen aan elkaar. ${ }^{126}$

De geconsolideerde jaarrekening van de moedermaatschappij moet zijn gesteld of vertaald in het Nederlands, Frans, Duits of Engels. ${ }^{127}$ De bijbehorende accountantsverklaring en het bestuursverslag moeten in dezelfde taal zijn gesteld of vertaald als de geconsolideerde jaarrekening. ${ }^{128}$ Alle stukken dienen binnen zes maanden na de balansdatum of binnen een maand na een geoorloofde latere openbaarmaking bij het handelsregister te zijn gedeponeerd. ${ }^{129}$

123. Zie E.C.A. Nass 2019, p. 67-76, voor een bespreking van de consolidatievoorwaarde in de richtlijn jaarrekeningen, de Luxemburgse regeling, de Ierse regeling en de Duitse regeling.

124. Beckman 2019, p. 189 en E.C.A. Nass 2019, p. 150.

125. E.C.A. Nass 2019 , p. $80-81$.

126. Asser/Maeijer \& Kroeze 2-I* 2015/581 en Beckman - SDU Commentaar Ondernemingsrecht 2019, art. 2:403 BW, aant. C.3.4.

127. Zie E.C.A. Nass 2019, p. 6-7, die opmerkt dat voor uitgevende instellingen met Nederland als lidstaat van herkomst (in de zin van art. 1:1 Wft en art. 5:25a lid $1 \mathrm{sub} \mathrm{c} \mathrm{Wft}$ ), de taaleisen gelden van art. 5:25p lid 1 tot en met lid $3 \mathrm{Wft}$. Afhankelijk van het antwoord op de vraag of van hen effecten zijn toegelaten tot de handel op een in Nederland gelegen of functionerende gereglementeerde markt en/of tot de handel op een gereglementeerde markt in een andere lidstaat, moeten de stukken zijn gesteld in het Nederlands of Engels en/of in een taal die door de toezichthoudende instantie van die andere lidstaat wordt aanvaard of een taal die in de internationale financiële kringen gebruikelijk is.

128. Zie art. 2:403 lid 1 sub d en e BW. Op grond van art. 5:25p lid $4 \mathrm{Wft}$ is de verplichte taalkeuze van art. 2:403 lid $1 \mathrm{sub}$ d en e BW niet van toepassing op de gereglementeerde informatie die een uitgevende instelling openbaar maakt in een taal als bedoeld in art. 5:25p lid 1,2 en $3 \mathrm{Wft}$.

129. Zie art. 2:403 lid 1 sub g BW. Zie E.C.A. Nass 2019, p. 113-119, voor een bespreking van de openbaarmaking van de geconsolideerde jaarstukken volgens de richtlijn jaarrekeningen, de 
Ten aanzien van de openbaarmaking van de geconsolideerde jaarrekening van de moedermaatschappij wijs ik nog op de eind 2018 in de media genoemde boekhoudkundige constructie met betrekking tot het vermogen van de familie Blokker. ${ }^{130}$ Met deze constructie werd getracht om de omvang van het vermogen van de familie Blokker uit HB Capital - de investeringsmaatschappij van de familie Blokker - te verhullen. Kort gezegd hield deze constructie in dat telkens na iets minder dan twee jaar een nieuwe holdingmaatschappij werd opgericht boven HB Capital. Deze holdingmaatschappijen stelden zich door middel van een 403-verklaring hoofdelijk aansprakelijk ten aanzien van HB Capital, waardoor laatstgenoemde gebruik zou kunnen maken van de jaarrekeningvrijstelling van het groepsregime - mits ook aan de andere voorwaarden hiervoor werd voldaan. De termijn van twee jaar was gekozen omdat uiterlijk op dat moment de holdingmaatschappijen een geconsolideerde jaarrekening - waarin de financiële gegevens van HB Capital zouden zijn geconsolideerd openbaar zouden moeten maken. Doordat HB Capital gebruikmaakte van de jaarrekeningvrijstelling van het groepsregime en de holdingmaatschappijen werden ontbonden voordat ze een geconsolideerde jaarrekening openbaar moesten maken, zou de financiële positie van HB Capital nergens zijn terug te vinden.

Evenals Beckman meen ik echter dat de bovenstaande constructie niet werkt. ${ }^{131}$ Een van de constitutieve voorwaarden om gebruik te mogen maken van de jaarrekeningvrijstelling van het groepsregime is dat de geconsolideerde jaarrekening van de moedermaatschappij bij het handelsregister is gedeponeerd. ${ }^{132}$ Bij de hierboven beschreven werkwijze werden deze jaarrekeningen niet gedeponeerd en zou HB Capital dus geen gebruik mogen maken van de vrijstelling. Zij was daarom verplicht om een jaarrekening openbaar te maken. Ook de minister heeft er in een reactie op Kamervragen op gewezen dat de openbaarmakingsplicht van een 403-maatschappij niet vervalt als de moedermaatschappij nalaat de geconsolideerde jaarrekening te deponeren. ${ }^{133} \mathrm{Er}$ zou dus hoogstens kunnen worden gesteld dat HB Capital haar financiële positie verbergt door niet aan haar openbaarmakingsplicht te voldoen. ${ }^{134} \mathrm{Zij}$ loopt daardoor wel een risico op sancties. ${ }^{135}$

Luxemburgse regeling, de Ierse regeling en de Duitse regeling.

130. G. de Groot en J. Bos, 'Familie Blokker verhult omvang vermogen via nieuwe boekhoudkundige truc', Het Financieele Dagblad 1 november 2018.

131. Beckman 2018, p. 733-734 en Beckman 2019, p. 189. Zie ook Bartman 2019, p. 188.

132. Zie art. 2:403 lid 1 sub g jo. sub d BW.

133. Aanhangsel Handelingen II 2018/19, 909.

134. Bartman 2019, p. 189.

135. Het niet voldoen aan de openbaarmakingsplicht is bijvoorbeeld een economisch delict in de zin van art. 1 onder $4^{\circ}$ Wet op de economische delicten en het bestuur van HB Capital kan aansprakelijk worden gesteld op grond van art. 2:9 en art. 2:248 BW. 
Op grond van art. 2:403 lid 1 sub c BW moet de geconsolideerde jaarrekening zijn opgemaakt aan de hand van wetgeving waarop krachtens het toepasselijke recht van toepassing is: Verordening (EG) 1606/2002 ${ }^{136}$ (hierna: de verordening EU IFRS), de richtlijn jaarrekeningen, ${ }^{137}$ de richtlijn betreffende de (geconsolideerde) jaarrekening van banken en andere financiële instellingen ${ }^{138}$ of de richtlijn betreffende de (geconsolideerde) jaarrekening van verzekeringsondernemingen. ${ }^{139}$ Ik sluit mij aan bij Nass die betoogt dat, hoewel dit niet expliciet uit art. 2:403 BW volgt, ervan mag worden uitgegaan dat deze voorschriften ook van toepassing zijn op het bestuursverslag van de moedermaatschappij. ${ }^{140}$

Bovenstaande houdt in dat een 403-maatschappij geen gebruik kan maken van de jaarrekeningvrijstelling van het groepsregime als haar moedermaatschappij niet op grond van het Unierecht aan de genoemde voorschriften is gebonden ook niet indien de moedermaatschappij een rechtspersoon is naar het recht van een land dat geen lidstaat is, maar wel vrijwillig zijn wetgeving aan de desbetreffende voorschriften heeft aangepast. ${ }^{141}$ Van Zoest merkt op dat de genoemde jaarrekeningvoorschriften van toepassing zijn op de meest bekende en veelvoorkomende Europese commerciële rechtsvormen. ${ }^{142}$ Het is dus mogelijk dat de financiële gegevens van een 403-maatschappij worden geconsolideerd in de geconsolideerde jaarrekening van een niet-Nederlandse moedermaatschappij. ${ }^{143}$

Uit art. 2:403 BW is niet eenduidig op te maken wie de geconsolideerde jaarrekening van de moedermaatschappij met accountantsverklaring en bestuursverslag moet deponeren. Het is de vraag of (ook) de 403-maatschappij de

136. Verordening (EG) 1606/2002 van het Europees Parlement en de Raad van 19 juli 2002 betreffende de toepassing van internationale standaarden voor jaarrekeningen, $P b E G$ 2002, L 243/1.

137. Richtlijn 2013/34/EU van het Europees Parlement en de Raad van 26 juni 2013 betreffende de jaarlijkse financiële overzichten, geconsolideerde financiële overzichten en aanverwante verslagen van bepaalde ondernemingsvormen, tot wijziging van Richtlijn 2006/43/EG van het Europees Parlement en de Raad en tot intrekking van Richtlijnen 78/660/EEG en 83/349/ EEG van de Raad, PbEU 2013, L 182/19. Zoals gewijzigd bij Richtlijn 2014/95/EU van 22 oktober 2014 tot wijziging van Richtlijn 2013/34/EU met betrekking tot de bekendmaking van niet-financiële informatie en informatie inzake diversiteit door bepaalde grote ondernemingen en groepen, PbEU 2014, L 330/1.

138. Richtlijn 86/635/EEG van de Raad van 8 december 1986 betreffende de jaarrekening en de geconsolideerde jaarrekening van banken en andere financiële instellingen, $P b E G$ 1986, L 372/1.

139. Richtlijn 91/674/EEG van de Raad van 19 december 1991 betreffende de jaarrekening en de geconsolideerde jaarrekening van verzekeringsondernemingen, $P b E G$ 1991, L 374/7.

140. E.C.A. Nass 2019 , p. 81.

141. E.C.A. Nass 2019, p. 76-77.

142. Van Zoest 2019, p. 21-22.

143. Kamerstukken II 1979/80, 16326, 3, p. 39 (MvT). Zie ook Assink/Slagter 2013/140.1 en Beckman - SDU Commentaar Ondernemingsrecht 2019, art. 2:403 BW, aant. C.3.4. 
geconsolideerde stukken moet deponeren zodat crediteuren deze kunnen inzien als ze bij het handelsregister de informatie ten aanzien van de 403-maatschappij opvragen, of dat het voldoende is als alleen de moedermaatschappij deze stukken deponeert. In het laatste geval is het mogelijk dat als de moedermaatschappij een rechtspersoon naar buitenlands recht is, de stukken alleen worden gedeponeerd bij het equivalent van het Nederlandse handelsregister van het desbetreffende land. Het zal dan voor de meeste crediteuren van de 403-maatschappij geen eenvoudige opgave zijn om de stukken op te vragen. Om ervoor te zorgen dat een crediteur de geconsolideerde jaarrekening van de moedermaatschappij met accountantsverklaring en bestuursverslag kan inzien als hij bij het handelsregister de informatie over de 403-maatschappij opvraagt, meen ik met Nass dat in lijn met art. 37 lid 4 en lid 7 van de richtlijn jaarrekeningen, aan art. 2:403 lid 1 sub g BW moet worden toegevoegd dat de 403-maatschappij de in art. 2:403 BW genoemde stukken ${ }^{144}$ - waaronder de geconsolideerde stukken van de moedermaatschappij - moet deponeren. ${ }^{145}$

Op 31 januari 2020 is het Verenigd Koninkrijk uit de EU getreden. Tot en met 31 december 2020 was er een overgangsperiode waarin de regelgeving van de EU bleef gelden voor het Verenigd Koninkrijk. ${ }^{146} \mathrm{Na}$ verloop van deze overgangsperiode zijn de hierboven genoemde richtlijnen en de verordening EU IFRS niet meer van toepassing op rechtspersonen naar het recht van het Verenigd Koninkrijk. ${ }^{147}$ Een 403-maatschappij waarvan de financiële gegevens worden geconsolideerd in de geconsolideerde jaarrekening van een dergelijke moedermaatschappij kan dan dus geen gebruik meer maken van de jaarrekeningvrijstelling van het groepsregime. Om toch gebruik te kunnen blijven maken van deze vrijstelling kan er een subholding worden opgericht waar de desbetreffende richtlijnen of verordening wel op van toepassing zijn, die de nieuwe moedermaatschappij van de 403-maatschappij wordt. Op deze laatste opmerking kom ik later in deze paragraaf terug.

Ik merk op dat de voorwaarde dat de financiële gegevens van de 403-maatschappij zijn geconsolideerde in de geconsolideerde jaarrekening van de moedermaatschappij ook geldt als de moedermaatschappij op grond van het toepasselijke recht daar niet toe verplicht is. De moedermaatschappij moet in die gevallen vrijwillig een geconsolideerde jaarrekening opmaken. Doorgaans

144. Naar huidig recht zijn dit: de instemmingsverklaring, de geconsolideerde jaarrekening met accountantsverklaring en bestuursverslag, en de 403-verklaring. Zie art. 2:403 lid 1 sub g jo. sub b, sub d, sub e en sub f BW.

145. E.C.A. Nass 2019, p. 124

146. Art. 126 Terugtrekkingsakkoord van het Verenigd Koninkrijk. Zie Mededeling 2019/C 384 I/01 van de Europese Raad van 12 november 2019 betreffende het akkoord inzake de terugtrekking van het Verenigd Koninkrijk van Groot-Brittannië en Noord-Ierland uit de Europese Unie en de Europese Gemeenschap voor Atoomenergie, PbEU 2019, C 384 I/1.

147. Van Zoest 2019, p. 21-22. 
is een moedermaatschappij wel consolidatieplichtig, maar het is mogelijk dat zij hiervan is vrijgesteld. Nass wijst erop dat op grond van art. 2:407 lid 2 BW consolidatie achterwege mag blijven als in de geconsolideerde jaarrekening de financiële drempelwaarden die gelden voor een kleine onderneming in de zin van art. 2:396 BW niet zouden worden overschreden, geen van de betrokken rechtspersonen een rechtspersoon van openbaar belang is in de zin van art. 2:398 lid $7 \mathrm{BW}$ en de algemene vergadering van de moedermaatschappij daartegen geen bezwaar heeft gemaakt. ${ }^{148}$ Daarnaast is een niet-beursgenoteerde tussenhoudstermaatschappij op grond van art. 2:408 lid 1 sub b BW vrijgesteld van de consolidatieplicht indien - onder meer - de te consolideren financiële gegevens zijn geconsolideerd in de geconsolideerde jaarrekening van een groter geheel.

De financiële gegevens van de 403-maatschappij kunnen worden geconsolideerd in de geconsolideerde jaarrekening van iedere rechtspersoon binnen de groep die hiertoe krachtens art. 2:406 BW bevoegd is. Dit hoeft dus niet een rechtspersoon te zijn die zelf aandeelhouder is van de 403-maatschappij of de rechtspersoon die aan het hoofd van de groep staat. ${ }^{149}$ Ik licht dit toe aan de hand van onderstaand voorbeeld van een aantal maatschappijen die in een groep is verbonden:

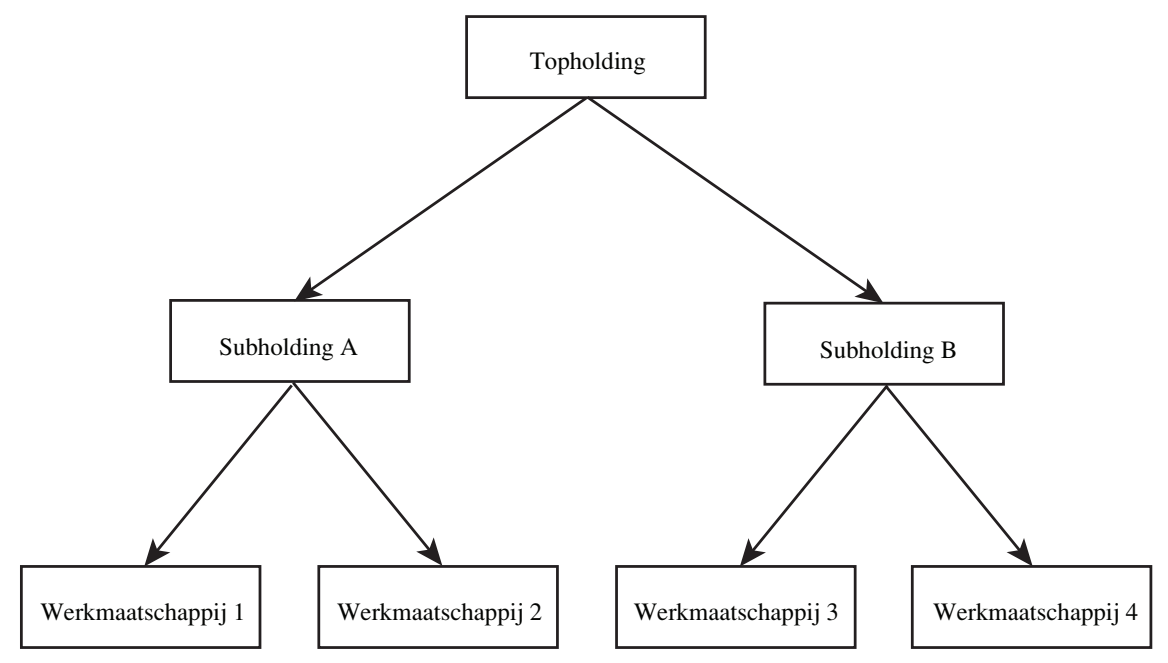

Afbeelding 2.1

Indien Werkmaatschappij 1 gebruik wil maken van de jaarrekeningvrijstelling van het groepsregime, kunnen haar financiële gegevens worden geconsolideerd in de geconsolideerde jaarrekening van Subholding A of van Topholding. De

148. E.C.A. Nass 2019 , p. $77-80$.

149. Kamerstukken II 1979/80, 16326, 3, p. 39 (MvT) en E.C.A. Nass 2019, p. 7. 
rechtspersoon in wiens geconsolideerde jaarrekening de financiële gegevens van de 403-maatschappij zijn geconsolideerd, dient ook degene te zijn die op grond van een 403-verklaring hoofdelijk aansprakelijk is voor de schulden die voortvloeien uit een rechtshandeling van de 403-maatschappij. ${ }^{150}$

Het feit dat de financiële gegevens van een 403-maatschappij kunnen worden geconsolideerd in een geconsolideerde jaarrekening die betrekking heeft op een deel van de groep, maakt het mogelijk dat een groepsmaatschappij die behoort tot een groep van een topholding die niet op grond van het Unierecht is gebonden aan de in art. 2:403 lid 1 sub c BW genoemde richtlijnen of verordening, toch gebruik kan maken van de jaarrekeningvrijstelling van het groepsregime. De topholding kan daartoe een subholding oprichten op wie de desbetreffende richtlijnen of verordening wel op van toepassing zijn. Deze subholding wordt dan de (nieuwe) moedermaatschappij van de 403-maatschappij.

Een Amerikaanse LLC die alle aandelen in een Nederlandse BV houdt, kan bijvoorbeeld niet voldoen aan het vereiste van art. 2:403 lid 1 sub c BW dat de financiële gegevens van de BV zijn geconsolideerd in een geconsolideerde jaarrekening waar krachtens het toepasselijke recht de in deze bepaling genoemde Europese richtlijnen of de verordening EU IFRS op van toepassing zijn. Als de BV toch gebruik wil maken van de jaarrekeningvrijstelling van het groepsregime kan de LLC een subholding oprichten op wiens geconsolideerde jaarrekening deze voorschriften wel van toepassing zijn. ${ }^{151}$ De subholding kan vervolgens de financiële gegevens van de 403-maatschappij consolideren in een geconsolideerde jaarrekening in de zin van art. 2:403 lid 1 sub c BW. Als ook aan de andere voorwaarden van art. 2:403 BW wordt voldaan - waaronder dat de subholding zich op grond van een 403 -verklaring aansprakelijk stelt voor de schulden die voortvloeien uit een rechtshandeling van de $\mathrm{BV}^{152}-$, kan de BV gebruikmaken van de jaarrekeningvrijstelling van het groepsregime. Hetzelfde geldt voor een Curaçaose NV die alle aandelen in een Nederlandse BV houdt. Hoewel Curaçao onderdeel is van het Koninkrijk der Nederlanden is een dergelijke NV niet onderworpen aan het Unierecht en kan deze dus niet voldoen aan het vereiste van art. 2:403 lid 1 sub c BW. Ook in dat geval moet er dus een subholding worden opgericht die wel aan deze voorwaarde kan voldoen, om de $\mathrm{BV}$ gebruik te mogen laten maken van de jaarrekeningvrijstelling.

Hierboven heb ik opgemerkt dat het Verenigd Koninkrijk op 31 januari 2020 uit de EU is getreden, en dat er tot en met 31 december 2020 een overgangsperiode was waarin de regelgeving van de EU van toepassing was op het Verenigd

150. Zie $\S 2.3 .6$.

151. Bartman 1986, p. 105 en Bartman, Dorresteijn \& Olaerts 2020, p. 216.

152. Zie $\S 2.3 .6$. 


\section{HOOFDSTUK 2}

Koninkrijk. ${ }^{153}$ Na verloop van deze overgangsperiode, kunnen 403-maatschappijen die behoren tot de groep van een moedermaatschappij naar het recht van het Verenigd Koninkrijk met bovenstaande constructie toch gebruik blijven maken van de jaarrekeningvrijstelling van het groepsregime.

Tot slot merk ik op dat een topholding bewust een subholding - zonder verdere activa - kan oprichten die de aansprakelijkheid op grond van de 403-verklaring op zich neemt. ${ }^{154}$ Hierdoor ontloopt de topholding - die wel activa heeft - de 403-aansprakelijkheid en kan de 403-maatschappij alsnog gebruikmaken van de jaarrekeningvrijstelling van het groepsregime. Het is daarom van belang voor de crediteuren van een 403-maatschappij dat zij zich niet direct rijk rekenen als een moedermaatschappij zich op grond van een 403 -verklaring aansprakelijk stelt voor de schulden die voortvloeien uit een rechtshandeling van de 403-maatschappij. Zij doen er verstandig aan om de geconsolideerde jaarrekening van de moedermaatschappij op te vragen en (mede) aan de hand daarvan het risico te schatten dat de moedermaatschappij hun vordering op grond van de 403-verklaring niet (volledig) zal voldoen. Ik kom hier in hoofdstuk 3 op terug. ${ }^{155}$

In het vervolg van dit onderzoek beperk ik mij tot moedermaatschappijen waarop het Nederlandse recht van toepassing is.

\subsubsection{De 403-verklaring}

\subsection{6.a Algemeen}

De moedermaatschappij moet schriftelijk hebben verklaard dat zij hoofdelijk aansprakelijk is voor de schulden die voortvloeien uit een rechtshandeling van de 403-maatschappij. ${ }^{156}$ Deze zogenoemde 403-verklaring moet de moedermaatschappij bij het handelsregister deponeren. ${ }^{157}$ Op 31 december 2019 zijn

153. Art. 126 Terugtrekkingsakkoord van het Verenigd Koninkrijk. Zie Mededeling 2019/C 384 I/01 van de Europese Raad van 12 november 2019 betreffende het akkoord inzake de terugtrekking van het Verenigd Koninkrijk van Groot-Brittannië en Noord-Ierland uit de Europese Unie en de Europese Gemeenschap voor Atoomenergie, PbEU 2019, C 384 I/1.

154. Zie Bartman 1986, p. 105 en Burgert, Timmermans \& Joosten 1990, p. 553-555, Winter 1992, p. 26, Beckman 1995b, p. 92-93, E.C.A. Nass 2019, p. 18 en Beckman - Compendium jaarrekening, §3.8.4.15.

155. Zie $\S 3.5 .4$.

156. Zie art. 2:403 lid $1 \mathrm{sub} f$ BW. Zie E.C.A. Nass 2019, p. 85-92, voor een bespreking van de aansprakelijkstellingsvoorwaarde in de richtlijn jaarrekeningen, de Luxemburgse regeling, de Ierse regeling en de Duitse regeling.

157. Zie art. 2:403 lid 1 sub g BW. Zie E.C.A. Nass 2019, p. 113-119, voor een bespreking van de openbaarmaking van de aansprakelijkstelling volgens de richtlijn jaarrekeningen, de Luxemburgse regeling, de Ierse regeling en de Duitse regeling. 
bij het handelsregister 16.719 403-verklaringen gedeponeerd. ${ }^{158}$ Hoewel niet is vereist dat de 403 -verklaring is ondertekend, merkt Nass op dat dit doorgaans wel het geval zal zijn. ${ }^{159} \mathrm{Zij}$ wijst erop dat bij de deponering van de 403verklaring de Kamer van Koophandel verplicht is om na te gaan of dit gebeurt door een daartoe bevoegde partij. Hieraan wordt invulling gegeven door te controleren of de verklaring is ondertekend door een of meer in het handelsregister ingeschreven vertegenwoordigingsbevoegde bestuurders van de moedermaatschappij.

Behalve dat de 403-verklaring schriftelijk moet zijn opgesteld, gelden er verder geen vormvereisten. ${ }^{160}$ Nass betoogt dat het daarom mogelijk is dat de 403-verklaring openbaar wordt gemaakt door deze op te nemen in de geconsolideerde jaarrekening van de moedermaatschappij. Hoewel deze wijze van openbaarmaking naar de letter van de wet is toegestaan, spreek ik een sterke voorkeur uit voor het openbaar maken van de 403-verklaring als een apart document. Een crediteur moet anders de geconsolideerde jaarrekening van de moedermaatschappij opvragen en daarin de 403-verklaring opzoeken om de precieze tekst van deze verklaring te achterhalen. In het geval dat de 403-maatschappij meerdere jaren achtereen gebruikmaakt van de jaarrekeningvrijstelling, zal de crediteur ieder jaar opnieuw de geconsolideerde jaarrekeningen van de moedermaatschappij moeten controleren om er zeker van te zijn dat daarin niet een verklaring is opgenomen op grond waarvan de eerdere 403-verklaring is ingetrokken ${ }^{161}$ en er een nieuwe 403-verklaring met een afwijkende aansprakelijkstelling is opgenomen. Het is mijns inziens daarom wenselijk dat de wetgever in art. 2:403 BW opneemt dat de 403-verklaring als een apart document moet worden gedeponeerd bij het handelsregister.

De bevoegdheid om te besluiten om namens de moedermaatschappij een 403-verklaring te deponeren, komt toe aan het bestuur van de moedermaatschappij. ${ }^{162}$ Hoewel de aansprakelijkheid van de moedermaatschappij op grond van de 403-verklaring een weerslag kan hebben op haar vermogenstoestand,

158. Op 22 april 2020 per e-mail aan mij meegedeeld door de afdeling Databeheer Orderbehandeling van de Kamer van Koophandel. Daarnaast heeft een medewerker van de Kamer van Koophandel op 10 februari 2017 telefonisch aan mij meegedeeld dat er op 31 december 2016 bij het handelsregister 16.956403 -verklaringen zijn gedeponeerd.

159. E.C.A. Nass 2019 , p. 93-94.

160. E.C.A. Nass 2019, p. 121.

161. Zie art. 2:404 lid $1 \mathrm{BW}$ en $\S 7.2$. Zie ook $\S 7.5$, waar ik verdedig dat op grond van art. 2:404 lid $1 \mathrm{BW}$ is vereist dat een intrekkingsverklaring als zodanig moet kunnen worden herkend bij het handelsregister en de intrekking niet 'verstopt' mag zitten in een ander document. Hoewel een 403-verklaring naar mijn mening dus niet is ingetrokken in de zin van art. 2:404 lid $1 \mathrm{BW}$ als de moedermaatschappij een dergelijke verklaring opneemt in haar geconsolideerde jaarrekening, heeft deze 'intrekking' wel civielrechtelijke werking.

162. Houwen, Schoonbrood-Wessels \& Schreurs 1993, p. 838, Asser/Maeijer \& Kroeze 2-I* 2015/583, E.C.A. Nass 2019, p. 103 en Beckman - Compendium jaarrekening, § 3.8.3.25. 


\section{HOOFDSTUK 2}

hebben de aandeelhouders van de moedermaatschappij ten aanzien van deze aansprakelijkheid geen instemmingsrecht zoals de aandeelhouders van de 403-maatschappij dat hebben met betrekking tot de afwijking van de jaarrekeningvoorschriften. ${ }^{163}$ De aandeelhouders van de moedermaatschappij kunnen vanzelfsprekend wel hun zorgen en bezwaren kenbaar maken aan het bestuur, en zij kunnen in het uiterste geval het bestuur ontslaan en een nieuw bestuur benoemen.

Het bestuur van de moedermaatschappij moet een voorgenomen besluit om een 403-verklaring te deponeren op grond van art. 25 lid 1 sub j WOR ter advies voorleggen aan een eventueel door de moedermaatschappij ingestelde (centrale of groeps-) ondernemingsraad. ${ }^{164}$ Daarnaast is het mogelijk dat in de statuten van de moedermaatschappij voorwaarden zijn opgenomen met betrekking tot de besluitvorming omtrent het deponeren van een 403-verklaring. Bijvoorbeeld dat het bestuur het voorgenomen besluit vooraf ter goedkeuring moeten voorleggen aan de raad van commissarissen. Een dergelijke statutaire voorwaarde heeft enkel interne werking. ${ }^{165}$ Het desbetreffende bestuursbesluit kan worden vernietigd en de bestuurders kunnen aansprakelijk worden gesteld voor de eventuele schade. ${ }^{166}$ Maar als de 403 -verklaring reeds is gedeponeerd, kunnen de crediteuren van de 403-maatschappij daar onverminderd een beroep op doen.

Het is mogelijk dat een derde onbevoegdelijk in naam van de moedermaatschappij een 403-verklaring deponeert. Nass merkt op dat de moedermaatschappij de 403-verklaring dan niet kan intrekken, maar dat zij de Kamer van Koophandel moet verzoeken om de inschrijving in het handelsregister te wijzigen. ${ }^{167}$ Om een dergelijke situatie te voorkomen, is het volgens haar niet voldoende om in art. 2:403 BW de voorwaarde op te nemen dat een 403-verklaring moet zijn ondertekend door een of meer vertegenwoordigingsbevoegde bestuurders. Een handtekening kan immers ook worden vervalst. Zij stelt daarom voor dat een 403-verklaring moet worden ondertekend met legalisatie van de handtekening(en) of dat de 403-verklaring als een notariële akte moet worden gedeponeerd. Hoewel ik onderken dat het mogelijk is dat een derde onbevoegdelijk in naam van de moedermaatschappij een 403 -verklaring deponeert, is mij slechts één procedure bekend waarbij dit is voorgekomen. ${ }^{168}$ Daarbij heeft de rechter

163. E.C.A. Nass 2019, p. 20.

164. Beckman 1995a, p. 725, Van het Kaar 2005, p. 36, De Jager 2006, p. 22, Buijn \& Storm 2013 , p. 810 , Asser/Maeijer \& Kroeze 2-I* 2015/642, Van Zoest 2019, p. 26, E.C.A. Nass 2019, p. 107-108 en Van het Kaar in zijn annotatie onder Hof Amsterdam (OK) 13 juli 2000, JOR 2000/174 (OR EBS/HES Beheer I).

165. E.C.A. Nass 2019, p. 105.

166. Zie art. 2:15 lid 1 sub a BW, respectievelijk art. 2:9 BW.

167. E.C.A. Nass 2019 , p. $122-123$ en 128 .

168. Rb. Rotterdam 16 januari 1997, KG 1997, 55 (Wannemakers/Vetus den Ouden), r.o. 3.1-3.3. 
overigens het beroep van de crediteur op de 403-verklaring afgewezen omdat deze wist of behoorde te weten dat de 403-verklaring onbevoegdelijk was gedeponeerd. Ik meen dat de door Nass voorgestelde vereisten een moedermaatschappij onnodig belasten, om een probleem op te lossen dat er vrijwel niet is.

In tegenstelling tot de eerdergenoemde geconsolideerde jaarrekening van de moedermaatschappij, ${ }^{169}$ hoeft de 403 -verklaring niet te zijn gesteld of vertaald in het Nederlands, Frans, Duits of Engels. ${ }^{170}$ In verband met de samenhang tussen de aansprakelijkheid van de moedermaatschappij op grond van de 403-verklaring en de mogelijkheid voor een crediteur om (mede) aan de hand van de geconsolideerde jaarrekening te kunnen schatten hoe groot het risico is dat de moedermaatschappij een vordering op grond van deze verklaring niet (volledig) zal voldoen, is het mijns inziens wenselijk dat wordt voorgeschreven dat de 403-verklaring in dezelfde taal is gesteld of vertaald als de geconsolideerde jaarrekening. ${ }^{171}$ Daartoe zou bijvoorbeeld aan art. 2:403 lid 1 sub e BW kunnen worden toegevoegd dat niet alleen de accountantsverklaring en het bestuursverslag, maar ook de 403-verklaring in dezelfde taal moeten zijn gesteld of vertaald als de geconsolideerde jaarrekening.

Op grond van art. 2:414 lid 5 BW moet de moedermaatschappij in haar geconsolideerde jaarrekening vermelden ten aanzien van welke groepsmaatschappij(en) zij een 403-verklaring heeft gedeponeerd. Deze bepaling kan naar mijn mening niet anders worden uitgelegd dan dat de moedermaatschappij expliciet moet verwijzen naar de desbetreffende groepsmaatschappij(en). ${ }^{172}$ De moedermaatschappij kan niet volstaan met de enkele opmerking dat zij zich ten aanzien van een of meer groepsmaatschappijen aansprakelijk heeft gesteld op grond van een 403-verklaring, zonder te vermelden om welke groepsmaatschappij(en) het gaat. Een crediteur moet anders zelf bij het handelsregister de informatie van alle groepsmaatschappijen opvragen om na te gaan of ten aanzien van hen een 403-verklaring is gedeponeerd. Uit de geconsolideerde jaarrekeningen over het boekjaar 2019 van de AEX en AMX genoteerde vennootschappen, ${ }^{173}$ volgt dat niet altijd expliciet wordt verwezen naar de groepsmaatschappij(en) ten aanzien waarvan de moedermaatschappij een 403-verklaring heeft gedeponeerd. ${ }^{174}$ Dergelijke geconsolideerde jaarrekeningen voldoen

169. Zie art. 2:403 lid $1 \mathrm{sub} d \mathrm{BW}$ en $\S 2.3 .5$.

170. E.C.A. Nass 2019, p. 125.

171. Reimers, in: GS Rechtspersonen, art. 2:403 BW, aant. 9.1.

172. Zie Bartman in zijn annotatie onder Rb. Groningen 27 juni 2012, JOR 2012/350 (De Heer) KHE).

173. Op basis van de samenstelling van de AEX en AMX op 20 mei 2020.

174. Van de AEX genoteerde vennootschappen verwijzen Akzo Nobel NV, Koninklijke Phillips Electronics NV, Randstad Holding NV en Wolters Kluwer NV in de geconsolideerde jaarrekening over het boekjaar 2019 niet expliciet naar de groepsmaatschappij(en) ten aanzien waarvan een 403-verklaring is gedeponeerd. Daarnaast wordt in de geconsolideerde jaarrekening over het boekjaar 2019 van Koninklijke KPN NV verwezen naar een bij het 
naar mijn mening niet aan het vereiste van art. 2:376 BW dat melding moet worden gemaakt van de aansprakelijkstellingen voor schulden van derden. ${ }^{175}$

De meldplicht op grond van art. 2:414 lid 5 BW was oorspronkelijk opgenomen in art. 2:403 lid 1 sub e BW. ${ }^{176}$ Deze had daardoor te gelden als constitutief vereiste voor het gebruikmaken van de jaarrekeningvrijstelling van het groepsregime door de 403-maatschappij. Dit sloot aan bij de richtlijn jaarrekeningen en de Luxemburgse, Ierse en Duitse equivalenten van het groepsregime - waar de meldplicht nog steeds een constitutieve voorwaarde is. ${ }^{177}$ In 1988 heeft de Nederlandse wetgever de bepaling echter overgezet naar art. 2:414 lid 5 BW. ${ }^{178}$

Nass wijst erop dat het mogelijk is dat een moedermaatschappij op grond van het toepasselijke recht niet is gehouden aan de meldplicht van art. 2:414 lid 5 BW. ${ }^{179}$ Dit is bijvoorbeeld het geval als de moedermaatschappij de geconsolideerde jaarrekening inricht overeenkomstig de voorschriften uit de verordening EU IFRS ${ }^{180}$ of als de moedermaatschappij een rechtspersoon is die valt onder het recht van een andere lidstaat. Aangezien de meldplicht van art. 2:414 lid 5 BW geen constitutief vereiste meer is om gebruik te mogen maken van de jaarrekeningvrijstelling van het groepsregime, ${ }^{181}$ kan het voorkomen dat de 403-maatschappij van deze vrijstelling gebruikmaakt zonder dat in de geconsolideerde jaarrekening van de moedermaatschappij staat vermeld dat deze zich op grond van de 403-verklaring ten aanzien van de 403-maatschappij aansprakelijk heeft gesteld. Dit is een onwenselijke situatie. De melding in de geconsolideerde jaarrekening is bijvoorbeeld van belang voor de crediteuren van de moedermaatschappij - van wie de vordering niet op de 403-verklaring is gebaseerd. Zij moeten kunnen weten welke risico's de moedermaatschappij loopt. De

handelsregister gedeponeerde lijst van groepsmaatschappij(en) ten aanzien waarvan een 403-verklaring is gedeponeerd. Van de bij de AMX genoteerde vennootschappen verwijzen Aalberts NV, Arcadis NV, BE Semiconductor Industries NV, Corbion NV, Intertrust NV, NSI NV, Pharming group NV, Signify NV en TKH Group NV in de geconsolideerde jaarrekening over het boekjaar 2019 niet expliciet naar de groepsmaatschappij(en) ten aanzien waarvan een 403-verklaring is gedeponeerd. Daarnaast wordt in de geconsolideerde jaarrekening over het boekjaar 2019 van Koninklijke Vopak NV verwezen naar een bij het handelsregister gedeponeerde lijst van groepsmaatschappij(en) ten aanzien waarvan een 403-verklaring is gedeponeerd.

175. Ramanna 2008, p. 21.

176. Stb. 1983, 663 .

177. E.C.A. Nass 2019, p. $73-76$ en 82.

178. Stb. $1988,517$.

179. E.C.A. Nass 2019, p. 82.

180. Verordening (EG) 1606/2002 van het Europees Parlement en de Raad van 19 juli 2002 betreffende de toepassing van internationale standaarden voor jaarrekeningen, $P b E G 2002$, L 243/1.

181. Zie ook Hof Amsterdam (OK) 14 oktober 2011, ARO 2011, 161 (Bioseutica BV), r.o. 3.5, waar de OK heeft geoordeeld dat het ontbreken van de melding in de geconsolideerde jaarrekening van de moedermaatschappij niet afdoet aan de geldigheid van de 403-verklaring 
403-aansprakelijkheid van de moedermaatschappij leidt ertoe dat meer partijen zich op hetzelfde verhaalsobject - het vermogen van de moedermaatschappij kunnen verhalen. Bij een gelijkblijvend eigen vermogen van de moedermaatschappij, vermindert daardoor haar solvabiliteit. ${ }^{182}$ Dit kan voor de crediteuren een reden zijn om aanvullende zekerheden van de moedermaatschappij te eisen, geen nieuwe overeenkomsten met de moedermaatschappij meer aan te gaan of de bestaande relatie te beëindigen. Ik deel daarom de mening van Nass dat het wenselijk is dat de meldplicht weer als constitutieve voorwaarde voor het gebruikmaken van de jaarrekeningvrijstelling wordt opgenomen in art. 2:403 BW. ${ }^{183}$

Als een moedermaatschappij een vordering van een crediteur op grond van de 403-verklaring voldoet, krijgt zij doorgaans een regresvordering op de 403-maatschappij en wordt zij gesubrogeerd in de rechten van de (voormalig) crediteur. ${ }^{184}$ Dit is slechts anders als de desbetreffende schuld de moedermaatschappij geheel of gedeeltelijk aanging. Nass geeft als voorbeeld dat de moeder- en de 403-maatschappij onderling afspraken hebben gemaakt over de interne draagplicht. ${ }^{185}$ Overigens verhaalt een crediteur zich doorgaans slechts op de moedermaatschappij als de 403-maatschappij zelf niet kan nakomen. ${ }^{186}$ De moedermaatschappij zal daarom een eventuele regresvordering in de regel niet te gelde kunnen maken, tenzij zij deze kan verrekenen met een schuld tegenover de 403-maatschappij. ${ }^{187}$

Indien een moedermaatschappij binnen de groep samen met een andere groepsmaatschappij leiding geeft aan (een deel van) de groep, dient de nevengeschikte rechtspersoon zich ook door middel van een 403 -verklaring hoofdelijk aansprakelijk te stellen voor de schulden die voortvloeien uit een rechtshandeling van de 403-maatschappij. ${ }^{188}$

182. E.C.A. Nass 2019, p. 16 en 20.

183. E.C.A. Nass 2019, p. 83.

184. Houwen, Schoonbrood-Wessels \& Schreurs 1993, p. 830-833, Asser/Maeijer \& Kroeze 2-I* 2015/583 en E.C.A. Nass 2019, p. 233-234. Als de 403-maatschappij in staat van faillissement verkeert, kan de moedermaatschappij krachtens art. 136 lid 2 Fw haar vordering voorwaardelijk indienen, ook al heeft zij nog geen vordering(en) op grond van de 403-verklaring voldaan.

185. E.C.A. Nass 2019, p. 234.

186. Asser/Maeijer \& Kroeze $2-I^{*} 2015 / 583$.

187. E.C.A. Nass 2019, p. 236.

188. Burgert, Timmermans \& Joosten 1990, p. 556 en Buijn \& Storm 2013, p. 808. Zie art. 2:403 lid 2 BW. 
2.3.6.b Intrekking van de 403-verklaring en beëindiging van de overblijvende aansprakelijkheid

De moedermaatschappij kan haar 403-verklaring intrekken door een daartoe strekkende verklaring te deponeren. ${ }^{189} \mathrm{Zij}$ blijft dan aansprakelijk voor de schulden die voortvloeien uit de rechtshandelingen die de 403-maatschappij heeft verricht tot het moment dat de moedermaatschappij tegenover de crediteur een beroep kan doen op de intrekking. ${ }^{190}$ De moedermaatschappij kan deze overblijvende aansprakelijkheid jegens een crediteur beëindigen als aan vier cumulatieve voorwaarden wordt voldaan. ${ }^{191}$ Hiervoor is vereist dat de groepsband tussen de moeder- en de 403-maatschappij is verbroken. Daarnaast moet een mededeling van het voornemen om de overblijvende aansprakelijkheid te beëindigen twee maanden ter inzage hebben gelegen bij het handelsregister. Voorts dienen er twee maanden te zijn verlopen na de aankondiging in een landelijk verspreid dagblad dat en waar deze mededeling ter inzage ligt. Tot slot mag tegen het voornemen tot beëindiging geen verzet zijn ingesteld door de crediteur, dan wel moet diens verzet zijn ingetrokken of door de rechter ongegrond zijn verklaard. Een crediteur die verzet heeft ingesteld, heeft onder omstandigheden recht op een vervangende waarborg.

De intrekking van de 403-verklaring en de beëindiging van de overblijvende aansprakelijkheid komen uitgebreid aan de orde in hoofdstuk 7, respectievelijk hoofdstuk 8 .

\subsection{6.c De 'ontoereikende 403-verklaring'}

Er moet een onderscheid worden gemaakt tussen het aansprakelijkheids- en het jaarrekeningaspect van een 403-verklaring. ${ }^{192}$ Het aansprakelijkheidsaspect ziet op de omvang van de aansprakelijkheid van de moedermaatschappij op grond van de concrete verklaring zoals zij deze heeft gedeponeerd. De Hoge Raad heeft in zijn $A k z o / I N G$-beschikking geoordeeld dat een crediteur geen rechten kan ontlenen aan art. 2:403 BW zelf, maar slechts aan de door de moedermaatschappij gedeponeerde verklaring van aansprakelijkheid. ${ }^{193} \mathrm{De}$ moedermaatschappij is dus slechts aansprakelijk voor zover dit uit de verklaring volgt. Het jaarrekeningaspect betreft het antwoord op de vraag of de desbetreffende verklaring voldoet aan art. 2:403 lid 1 sub f BW en of de 403-maatschappij dus rechtsgeldig gebruik kan maken van de jaarrekeningvrijstelling van het groepsregime.

189. Zie art. 2:404 lid $1 \mathrm{BW}$ en $\S 7.2$.

190. Zie art. 2:404 lid $2 \mathrm{BW}$ en $\S 8.2$

191. Zie art. 2:404 lid $3 \mathrm{BW}$ en $\S 8.3$.

192. Beckman 1987, p. 532, Gülcher 1989a, p. 162 en A.G.S. Nass \& E.C.A. Nass 2014, p. 736.

193. HR 28 juni 2002, $N J$ 2002/447, m.nt. Maeijer (Akzo/ING), r.o. 3.4.3. Ook gepubliceerd in JOR 2002/136, m.nt. Bartman. 
Een voorbeeld dat bovengenoemd onderscheid goed illustreert is de uitspraak van de Rechtbank Arnhem uit 2002 inzake Resila/Spectro. In casu heeft de moedermaatschappij een ansprakelijkheidsverklaring gedeponeerd die luidt: ${ }^{194}$

\section{'AANSPRAKELIJKHEIDSVERKLARING EX ART. 2:403, LID 1, LETTER F BW}

Spectro Holding B.V., ten deze vertegenwoordigd door haar directeur, de heer R.P. Veenstra, verklaart zich hiermede tot wederopzegging hoofdelijk aansprakelijk voor de uit de met ingang van heden aangegane rechtshandelingen van Spectro, Import en exporthandelmaatschappij B.V., alsmede Cloud Sports Nederland B.V., voortvloeiende schulden in de zin van artikel 2:403 lid, 1 letter $f B W$.

\section{Gouda, 31 december 1991'}

De rechtbank wijst erop dat de aansprakelijkstelling door moedermaatschappij Spectro Holding afwijkt van de wettekst van art. 2:403 lid 1 sub f BW. ${ }^{195}$ Op grond van deze bepaling dient een moedermaatschappij zich hoofdelijke aansprakelijk te stellen 'voor de uit rechtshandelingen van de [403-maatschappij] voortvloeiende schulden'. Dit betreft volgens de rechtbank alle schulden die uit een rechtshandeling van de 403-maatschappij voortvloeien en zijn voortgevloeid. ${ }^{196}$ Uit de gedeponeerde verklaring volgt echter dat Spectro Holding zich slechts aansprakelijk stelt voor de schulden die voortvloeien uit de rechtshandelingen die Spectro, Import en exporthandelmaatschappij en Cloud Sports Nederland vanaf 31 december 1991 verrichten.

De rechtbank oordeelt dat de beperking van de aansprakelijkheid meebrengt dat de verklaring niet heeft te gelden als een 403-verklaring in de zin van art. 2:403 lid 1 sub f BW. Dit heeft twee gevolgen. Ten eerste is Spectro Holding slechts aansprakelijk voor zover dat uit de desbetreffende verklaring volgt. De rechtbank volgt daarmee het oordeel van de Hoge Raad in de $A k z o / I N G-$ beschikking ${ }^{197}$ dat crediteuren geen rechten kunnen ontlenen aan art. 2:403 BW, maar uitsluitend aan de gedeponeerde verklaring. In casu is Spectro Holding dus niet aansprakelijk voor de schulden die voortvloeien uit de rechtshandelingen die Spectro, Import en exporthandelmaatschappij en Cloud Sports vóór 31 december 1991 hebben verricht. Ten tweede wijst de rechtbank erop dat niet is voldaan aan alle voorwaarden om rechtsgeldig gebruik te maken van de jaarrekeningvrijstelling van het groepsregime. In de literatuur worden deze

194. Rb. Arnhem 10 oktober 2002, JOR 2003/31, m.nt. Bartman (Resila/Spectro), r.o. 1.5.

195. Rb. Arnhem 10 oktober 2002, JOR 2003/31, m.nt. Bartman (Resila/Spectro), r.o. 3.6-3.13.

196. Zie $\S 5.6$.

197. HR 28 juni 2002, JOR 2002/136, m.nt. Bartman (Akzo/ING), r.o. 3.4.3. 
twee gevolgen van het deponeren van een zogenoemde 'ontoereikende 403-verklaring' eensgezind onderschreven. ${ }^{198}$

Het feit dat Spectro Holding een verklaring van aansprakelijkheid heeft gedeponeerd die niet voldoet aan het vereiste van art. 2:403 lid 1 sub f BW had in casu echter geen gevolgen. Zowel Spectro, Import en exporthandelmaatschappij als Cloud Sports Nederland maakte geen gebruik van de jaarrekeningvrijstelling van het groepsregime. Indien zij wel gebruik zouden hebben gemaakt van deze vrijstelling, zouden zij ten onrechte geen jaarrekening openbaar hebben gemaakt. Dit zou een economisch delict zijn geweest in de zin van art. 1 onder $4^{\circ}$ Wet op de economische delicten en de besturen van Spectro, Import en exporthandelmaatschappij en Cloud Sports Nederland zouden eventueel aansprakelijk kunnen worden gesteld op grond van art. 2:9 en art. 2:248 BW. ${ }^{199}$

Als een moedermaatschappij in het verleden een ontoereikende 403-verklaring heeft gedeponeerd en zij deze wil aanpassen, is het mijns inziens niet nodig om de oude verklaring in te trekken en een nieuwe 403-verklaring te deponeren. Ik meen dat de moedermaatschappij in plaats daarvan een addendum kan deponeren op grond waarvan zij zich ruimer aansprakelijk stelt.

In het vervolg van dit onderzoek ga ik onder meer in op het antwoord op de vraag hoe art. 2:403 lid 1 sub fBW moet worden uitgelegd en aan welke eisen de aansprakelijkheid van de moedermaatschappij (minimaal) moet voldoen zodat aan de voorwaarde uit deze bepaling is voldaan. Ik onderzoek voor welke soorten schulden de moedermaatschappij zich aansprakelijk moet stellen (hoofdstuk 4), op welke periode de aansprakelijkstelling betrekking moet hebben (hoofdstuk 5) en hoe de hoofdelijke aansprakelijkheid van een moedermaatschappij op grond van een 403-verklaring moet worden uitgelegd (hoofdstuk 6). Indien een moedermaatschappij een verklaring deponeert op grond waarvan zij zich beperkter aansprakelijk stelt, is er mijns inziens sprake van een ontoereikende 403-verklaring. Als een moedermaatschappij er zeker van wil zijn dat haar 403-verklaring voldoet aan het vereiste van art. 2:403 lid 1 sub f BW, kan zij het beste een verklaring deponeren die aansluit bij de tekst uit deze bepaling. ${ }^{200}$ Daarnaast merk ik op dat het bestuur van een 403-maatschappij er verstandig

198. Schoonbrood-Wessels 1996, p. 3, Van der Arend 1999, p. 153, Niels 2010, p. 36, Van der Kraan 2013, p. 152, Assink/Slagter 2013/140.3, Van Zoest 2015, p. 40, Huiskes 2015, p. 40, Asser/Maeijer \& Kroeze 2-I*2015/583, Kiersch - T\&C Burgerlijk Wetboek, art. 2:403 BW, aant. 1, Beckman - SDU Commentaar Ondernemingsrecht 2019, art. 2:403 BW, aant. C.5.3, E.C.A. Nass 2019, p. 99 en Van der Kraan in zijn annotatie onder Hof Amsterdam 22 oktober 2019, JIN 2019/179 (Maison Zen beheer/Pauw).

199. Van Zoest 2019, p. 29-30.

200. Van Olffen 2001, p. 834. Zie Van Zoest 2019, p. 25 en E.C.A. Nass 2019, p. 98, die een voorbeeld geven van een dergelijke 403 -verklaring. 
aan doet om zelf de tekst van de 403-verklaring te controleren om er zeker van te zijn dat wordt voldaan aan de voorwaarde van art. 2:403 lid 1 sub fBW en de 403-maatschappij niet onterecht gebruikmaakt van de jaarrekeningvrijstelling.

Tenzij anders vermeld, ga ik in het vervolg van dit onderzoek uit van een 403-verklaring in de zin van art. 2:403 lid 1 sub fBW.

\subsection{Het moment dat uiterlijk aan de voorwaarden moet zijn voldaan}

Art. 2:403 BW biedt geen uitsluitsel over het antwoord op de vraag op welk moment uiterlijk aan alle voorwaarden moet zijn voldaan zodat de 403-maatschappij met betrekking tot de jaarrekening over een bepaald boekjaar gebruik mag maken van de jaarrekeningvrijstelling van het groepsregime. In de literatuur worden op dit punt twee standpunten verdedigd.

Houwen en Zwemmer merken op dat de aansprakelijkheid van de moedermaatschappij op grond van de 403-verklaring en de mogelijkheid om haar geconsolideerde jaarrekening in te zien, compenserende waarborgen zijn voor de crediteuren voor het niet kunnen inzien van de jaarrekening van de 403-maatschappij. ${ }^{201}$ Om die reden moet de 403-verklaring volgens hen zijn gedeponeerd uiterlijk op het moment dat de 403-maatschappij haar jaarrekening openbaar zou moeten maken als zij geen gebruik zou maken van de jaarrekeningvrijstelling. ${ }^{202}$ Dit betekent dat de moedermaatschappij de 403-verklaring acht dagen nadat de aandeelhouders de summiere jaarrekening in de zin van art. 2:403 lid 1 sub a BW hebben vastgesteld of - als de jaarrekening nog niet is vastgesteld - uiterlijk twaalf maanden na afloop van het boekjaar moet hebben gedeponeerd. ${ }^{203} \mathrm{Ik}$ interpreteer deze redenering van Houwen en Zwemmer aldus dat uiterlijk op dat moment ook aan de andere voorwaarden van art. 2:403 BW moet zijn voldaan.

Ik sluit mij echter aan bij Beckman en Nass die van mening zijn dat aan alle voorwaarden moet zijn voldaan uiterlijk op het moment dat de aandeelhouders

201. Houwen, Schoonbrood-Wessels \& Schreurs 1993, p. 839-841, Zwemmer 2011, p. 223-224 en Zwemmer 2012, p. 227.

202. Zie ook Koning 1991, p. 29 en Kiersch - T\&C Burgerlijk Wetboek, art. 2:403 BW, aant. 1, die een gelijkluidend standpunt innemen maar uitsluitend verwijzen naar de aansprakelijkheid van de moedermaatschappij op grond van de 403-verklaring als compenserende waarborg voor de crediteuren. Naar mijn mening bestaat de compensatie die een crediteur ontvangt echter niet enkel uit de aansprakelijkstelling door de moedermaatschappij, maar is deze aansprakelijkheid complementair aan de mogelijkheid die een crediteur heeft om de geconsolideerde jaarrekening van de moedermaatschappij in te zien (zie § 3.4.1 en $\S 3.5$ ).

203. Zie art. 2:394 lid 1 en 3 BW. 
van de 403-maatschappij de summiere jaarrekening in de zin van art. 2:403 lid 1 sub a BW vaststellen. ${ }^{204}$ De voorwaarden van art. 2:403 BW zijn constitutief. Pas als aan alle voorwaarden is voldaan, is de 403-maatschappij bevoegd om gebruik te maken van de jaarrekeningvrijstelling. Dit brengt mee dat de aandeelhouders ten tijde van de vaststelling van de summiere jaarrekening in de zin van art. 2:403 lid 1 sub a BW de zekerheid moeten hebben dat aan de voorwaarden daarvoor is voldaan. De vaststelling van de jaarrekening is zelf echter geen constitutief vereiste om gebruik te mogen maken van de jaarrekeningvrijstelling van het groepsregime. Nass wijst erop dat als de 403-maatschappij geen gebruik zou maken van de jaarrekeningvrijstelling zij, ondanks dat haar jaarrekening nog niet is vastgesteld, deze jaarrekening uiterlijk twaalf maanden na afloop van het boekjaar openbaar zou moeten maken. ${ }^{205}$ Toegepast op het groepsregime betekent dit volgens haar dat ondanks dat de aandeelhouders van de 403-maatschappij de summiere jaarrekening in de zin van art. 2:403 lid 1 sub a BW nog niet hebben vastgesteld, uiterlijk op het moment dat de twaalfmaandstermijn verloopt aan alle voorwaarden moet zijn voldaan om gebruik te maken van de jaarrekeningvrijstelling van het groepsregime. ${ }^{206}$ Dit lijkt mij een juiste redenering.

Evenals bij het eerstgenoemde standpunt kan er dus tot uiterlijk twaalf maanden na afloop van het boekjaar worden voldaan aan de voorwaarden voor het gebruikmaken van de jaarrekeningvrijstelling. Het verschil is echter dat als de aandeelhouders voor het verstrijken van de twaalfmaandstermijn de summiere jaarrekening in de zin van art. 2:403 lid 1 sub a BW vaststellen, volgens het door mij onderschreven standpunt van Beckman en Nass voordien aan alle voorwaarden moet zijn voldaan. Volgens het standpunt van Houwen en Zwemmer hoeft in een dergelijk geval pas uiterlijk acht dagen na de vaststelling aan de voorwaarden te zijn voldaan.

Indien de 403-maatschappij na verloop van de openbaarmakingstermijn van twaalf maanden geen jaarrekening openbaar heeft gemaakt en ook niet (rechtsgeldig) gebruik heeft gemaakt van de jaarrekeningvrijstelling van het groepsregime, schendt zij de openbaarmakingsplicht van art. 2:394 BW. ${ }^{207}$ Dit is een

204. Beckman 1990, p. 309, Beckman 1995a, p. 494, Beckman 2011, p. 254-255, Beckman SDU Commentaar Ondernemingsrecht 2019, art. 2:403 BW, aant. C.3 en E.C.A. Nass 2019, p. 135 en 157. Zie ook Jansz 1973, p. 38, Tuit 1985, p. 191, Berk 2007, p. 16 en Van der Heijden/Van der Grinten \& Dortmond 2013/324.3, die een dergelijk standpunt innemen met betrekking tot de aansprakelijkstelling door de moedermaatschappij op grond van de 403-verklaring. Zij zijn van mening dat aan de aansprakelijkstellingsvoorwaarde moet zijn voldaan uiterlijk op het moment dat de aandeelhouders van de 403-maatschappij de summiere jaarrekening in de zin van art. 2:403 lid $1 \mathrm{sub}$ a BW vaststellen.

205. Zie art. 2:394 lid 2 en 3 BW.

206. E.C.A. Nass 2019, p. 135 en 157.

207. Asser/Maeijer \& Kroeze 2-I*2015/583 en E.C.A. Nass 2019, p. 136. 
economisch delict in de zin van art. 1 onder $4^{\circ}$ Wet op de economische delicten. Daarnaast kunnen de bestuurders van de 403-maatschappij eventueel aansprakelijk worden gesteld voor een onbehoorlijke taakvervulling ${ }^{208}$ en indien de 403-maatschappij binnen drie jaar failleert, zijn de bestuurders mogelijk hoofdelijk aansprakelijk voor het tekort in faillissement omdat vaststaat dat zij hun taak kennelijk onbehoorlijk hebben vervuld en er wordt vermoed dat dit een belangrijke oorzaak is van het faillissement. ${ }^{209}$ De 403-maatschappij kan de schending van de openbaarmakingsplicht niet ongedaan maken door nadien alsnog gebruik te maken van de jaarrekeningvrijstelling van het groepsregime. ${ }^{210}$

Nass wijst erop dat als een belanghebbende van mening is dat de 403-maatschappij onterecht gebruikmaakt van de jaarrekeningvrijstelling van het groepsregime omdat niet (tijdig) aan alle voorwaarden daarvoor is voldaan, deze op grond van art. 2:448 jo. art. 2:447 BW een jaarrekeningprocedure kan instellen bij de OK. ${ }^{211}$ Een dergelijke procedure kan tot uiterlijk twee maanden na de vaststelling van de jaarrekening worden ingesteld. ${ }^{212}$ Daarnaast kan de belanghebbende op grond van art. 2:394 lid $7 \mathrm{BW}$ bij de rechter van de woonplaats van de 403-maatschappij een vordering instellen tot nakoming van de openbaarmakingsplicht. Als laatstgenoemde vordering wordt toegewezen en de 403-maatschappij de summiere jaarrekening in de zin van art. 2:403 lid 1 sub a BW openbaar zou maken, kan de crediteur alsnog een jaarrekeningprocedure instellen bij de OK en verzoeken dat de jaarrekening overeenkomstig de voorschriften van titel 9 van Boek 2 BW wordt ingericht. Daarbij geldt echter opnieuw dat deze procedure uiterlijk binnen twee maanden na de vaststelling van de jaarrekening moet zijn ingesteld. Deze termijn zal vaak al verlopen zijn.

Tot slot wijs ik nog op de mogelijkheid dat de 403-maatschappij gebruikmaakt van de jaarrekeningvrijstelling, en op het moment dat de summiere jaarrekening in de zin van art. 2:403 lid 1 sub a BW wordt vastgesteld of de twaalfmaandstermijn verloopt, de aandeelhouders van de 403-maatschappij al hebben verklaard in te stemmen met de afwijking van de jaarrekeningvoorschriften en de moedermaatschappij zich al aansprakelijk heeft gesteld door middel van

208. Zie art. 2:9 BW

209. Zie art. 2:138 BW (NV), art. 2:248 BW (BV) en art. 2:50a BW (schakelbepaling voor een commerciële vereniging, coöperatie en onderlinge waarborgmaatschappij).

210. Houwen, Schoonbrood-Wessels \& Schreurs 1993, p. 844-845, Asser/Maeijer \& Kroeze 2-I* 2015/583, Van der Kraan 2017, p. 326, Van Schilfgaarde/Winter, Wezeman \& Schoonbrood 2017, p. 375-376 en Beckman - SDU Commentaar Ondernemingsrecht 2019, art. 2:403 BW, aant. C.3.

211. E.C.A. Nass 2019, p. 136-138. Nass is van mening dat dit voor een belanghebbende ontoereikende rechtsmiddelen zijn om te toetsen of aan de voorwaarden is voldaan voor gebruikmaking van de jaarrekeningvrijstelling door de 403-maatschappij. Zij stelt daarom voor dat wordt vereist dat een externe accountant een verklaring deponeert dat aan deze voorwaarden is voldaan.

212. Zie art. 2:449 lid 1 en 2 BW. 
een 403-verklaring, maar beide verklaringen nog niet zijn gedeponeerd bij het handelsregister. Ik meen met Nass dat als een belanghebbende in een dergelijk geval nakoming van de openbaarmakingsplicht van art. 2:394 BW vordert, de 403-maatschappij niet een jaarrekening openbaar hoeft te maken volgens het reguliere jaarrekeningregime, maar dat zij de desbetreffende verklaringen alsnog kan deponeren. ${ }^{213}$ Indien de twaalfmaandstermijn al is verlopen, neemt dit echter niet weg dat art. 2:394 BW is geschonden.

\subsection{De jaarrekeningvrijstelling van het groepsregime}

Als een 403-maatschappij gebruikmaakt van de jaarrekeningvrijstelling van het groepsregime, is zij op grond van art. 2:403 lid 1 aanhef BW vrijgesteld van de verplichting om haar jaarrekening overeenkomstig de voorschriften van titel 9 van Boek $2 \mathrm{BW}$ in te richten. ${ }^{214}$ De 403 -maatschappij is echter niet helemaal vrij in de inrichting van haar jaarrekening. Ik heb er eerder op gewezen dat op grond van art. 2:403 lid 1 sub a BW in de balans en de winst- en verliesrekening van de 403-maatschappij nog steeds bepaalde posten moeten zijn opgenomen. ${ }^{215}$ Daarnaast heeft de minister opgemerkt dat de jaarrekening moet voldoen aan het altijd toepasselijke inzichtvereiste op grond van art. 2:362 lid $1 \mathrm{BW}^{216}$

Op grond van art. 2:403 lid $3 \mathrm{BW}$ is de 403-maatschappij ook vrijgesteld van de verplichtingen uit art. 2:391 tot en met art. 2:394 BW. Dit houdt in dat de 403-maatschappij haar bestuursverslag niet overeenkomstig de voorschriften van art. 2:391 BW hoeft in te richten. Het verslag hoeft ook niet ten kantore voor de aandeelhouders ter inzage te worden gelegd. ${ }^{217}$ Daarnaast hoeft de 403-maatschappij niet de gegevens uit art. 2:392 BW toe te voegen aan haar jaarrekening en bestuursverslag, zoals een weergave van de statutaire regeling omtrent de bestemming van winst, een lijst van degenen aan wie een bijzonder statutair recht inzake de zeggenschap toekomt en een overzicht van eventuele nevenvestigingen. Voorts is de 403-maatschappij vrijgesteld van de verplichting uit hoofde van art. 2:392a BW om onder omstandigheden een verslag op te

213. E.C.A. Nass 2019, p. 136.

214. Zie SER-advies 1979, nr. 12, p. 15-16, Berk 2007, p. 13 en Buijn \& Storm 2013, p. 805-806, die opmerken dat het onduidelijk is in hoeverre mag worden afgeweken van de algemene regels ten aanzien van de inrichting van de jaarrekening. Ik wijs erop dat de SER naar een voorloper van art. 2:403 BW verwijst: art. 2:343 (oud) BW.

215. Zie $\S 2.3 .3$.

216. Kamerstukken II 1992/93, 22896, 3, p. 25 (MvT).

217. Zie art. 2:101 lid 1 BW (NV) en art. 2:210 lid 1 BW (BV). Zie ook art. 2:49 lid 1 BW (commerciële vereniging) en art. 2:58 lid $1 \mathrm{BW}$ (coöperatie en onderlinge waarborgmaatschappij). Burgert, Timmermans \& Joosten 1990, p. 559, Beckman - SDU Commentaar Ondernemingsrecht 2019, art. 2:403 BW, aant. C.2.3 en Beckman - Compendium jaarrekening, $\S 3.8 .2 .3$. 
stellen en openbaar te maken met betrekking tot betalingen aan overheden. Tevens hoeft zij niet op grond van art. 2:393 BW haar jaarrekening te laten controleren door een accountant, en is zij vrijgesteld om haar jaarrekening krachtens art. 2:394 BW openbaar te maken. ${ }^{218}$

Ik maak tot slot nog een drietal afsluitende opmerkingen met betrekking tot de jaarrekeningvrijstelling van het groepsregime. Ten eerste heeft een 403-maatschappij ingevolge het groepsregime de bevoegdheid om gebruik te maken van de jaarrekeningvrijstelling. Zij is niet verplicht om van (alle onderdelen van) de vrijstelling gebruik te maken. ${ }^{219}$ Daarnaast is de 403-maatschappij niet vrijgesteld van verplichtingen buiten titel 9 van Boek 2 BW en eventuele statutaire verplichtingen. ${ }^{220}$ Dit betekent bijvoorbeeld dat de 403-maatschappij nog steeds op grond van art. 2:10 en art. 3:15i BW een administratie moet bijhouden. $^{221}$ Tot slot merk ik op dat hoewel de 403-maatschappij zelf is vrijgesteld van de verplichting om haar jaarrekening te laten controleren door een accountant, haar financiële gegevens moeten worden geconsolideerd in de geconsolideerde jaarrekening van de moedermaatschappij ${ }^{222}$ die wel door een accountant moet worden gecontroleerd. ${ }^{223}$

\subsection{Redenen om gebruik te maken van de jaarrekeningvrijstelling}

\subsubsection{Voorkomen dat derden zich baseren op vertekende gegevens in de jaarrekening}

De minister heeft verschillende keren opgemerkt dat de jaarrekening van een groepsmaatschappij dikwijls geen betrouwbaar beeld en soms zelfs een misleidend beeld geeft van de financiële positie van de groepsmaatschappij. ${ }^{224}$ Er kan volgens hem slechts een zinvol oordeel worden gevormd ten aanzien van de financiële positie van de groep als geheel. Een deel van de Sociaal-Economische Raad (hierna: 'SER') onderschrijft dit standpunt van de minister en noemt

218. Anders: Reimers, in: GS Rechtspersonen, art. 2:403 BW, aant. 2, die de vrijstelling zo uitlegt dat de 403-maatschappij de summiere jaarrekening in de zin van art. 2:403 lid 1 sub a BW openbaar moet maken.

219. Beckman 1990, p. 308, Beckman \& Marseille 2013, p. 284, Assink/Slagter 2013/140.1 en Asser/Maeijer \& Kroeze 2-I* 2015/581.

220. Beckman \& Marseille 2013, p. 283 en Beckman - SDU Commentaar Ondernemingsrecht 2019, art. 2:403 BW, aant. C.2.1

221. Asser/Maeijer \& Kroeze 2-I*2015/581, Talacko \& Van Wijngaarden 2016, p. 16-17 en Van Zoest 2019, p. 17.

222. Zie art. 2:403 lid $1 \mathrm{sub} \mathrm{c} \mathrm{BW}$ en $\S 2.3 .5$.

223. Beckman 1995b, p. 89, Ten Voorde 2011, p. 196, Assink/Slagter 2013/140.3 en E.C.A. Nass 2019, p. 13

224. Kamerstukken II 1967/68, 9595, 3, p. 11 (MvT), Kamerstukken II 1969/70, 10689, 3, p. 14 (MvT) en Kamerstukken II 1981/82, 16326, 8, p. 20-21 (MvA). 
een vijftal redenen waarom de jaarrekening van een groepsmaatschappij een vertekend beeld kan geven. ${ }^{225}$ In de eerste plaats kan een groepsmaatschappij doorgaans een hoger bankkrediet krijgen omdat de moedermaatschappij in de regel instaat voor de terugbetaling. Ten tweede draagt een moedermaatschappij binnen de groep bepaalde algemene kosten die niet worden omgeslagen over de overige groepsmaatschappij(en). Daarnaast hebben leveringen van grondstoffen, materialen en halffabricaten binnen de groep een vertekenende invloed op de omzet en de resultaten van de groepsmaatschappijen. Voorts wordt erop gewezen dat transacties tussen groepsmaatschappijen die tot eenzelfde fiscale eenheid behoren vaak niet tegen commerciële voorwaarden worden afgerekend. Tot slot geschiedt de financiering van een groepsmaatschappij doorgaans door middel van een renteloos rekening-courantkrediet van de moedermaatschappij.

Als een groepsmaatschappij gebruikmaakt van de jaarrekeningvrijstelling van het groepsregime wordt voorkomen dat derden zich baseren op de eventueel vertekende gegevens uit de jaarrekening. ${ }^{226}$

Ik sluit mij aan bij Houwen, Beckman en Nass die kritisch staan tegenover bovenstaande redenering. ${ }^{227}$ Beckman erkent dat de financiële positie van een groepsmaatschappij over het algemeen afwijkt van die van een rechtspersoon die niet tot een groep behoort. ${ }^{228}$ Als een rechtspersoon tot een groep behoort, brengt dit doorgaans bepaalde voordelen met zich die een rechtspersoon die niet tot een groep behoort niet heeft. Dit betekent echter niet dat de jaarrekening van de groepsmaatschappij een vertekend beeld geeft van haar financiële positie. Er zijn veel meer omstandigheden waardoor de jaarrekeningen van rechtspersonen niet altijd goed vergelijkbaar zijn. Beckman denkt daarbij onder meer aan de locatie van de onderneming, de kwaliteit van de machines, de opleiding van het personeel en het management. Daarnaast wijs ik zelf op het gebruik van verschillende winstbegrippen in jaarrekeningen, waardoor cijfers moeilijker zijn te vergelijken. ${ }^{229}$

225. SER-advies 1974, nr. 14, p. 10-11, SER-advies 1976, nr. 20, p. 22 en SER-advies 1979, nr. 12 , p. $20-21$.

226. Nagelkerke 1985, p. 211, Van Achterberg 1989, p. 218, Houwen, Schoonbrood-Wessels \& Schreurs 1993, p. 822 en Asser/Maeijer \& Kroeze 2-I* 2015/581.

227. Houwen, Schoonbrood-Wessels \& Schreurs 1993, p. 824, Beckman 1995a, p. 674-675 en Beckman 1995b, p. 90 en E.C.A. Nass 2019, p. 11.

228. Beckman 1995a, p. 674-675 en Beckman 1995b, p. 90.

229. De International Accounting Standards Board heeft om die reden op 17 december 2019 een Exposure Draft inzake General Presentation and Disclosures gepubliceerd waarin zij voorstelt om drie nieuwe vaste winstbegrippen te introduceren die ieder een subtotaal van de winst weergeven. 
Houwen wijst daarnaast op het optionele karakter van de jaarrekeningvrijstelling van het groepsregime. ${ }^{230} \mathrm{Ik}$ ben het met hem eens dat als de jaarrekening van een groepsmaatschappij daadwerkelijk een vertekend beeld zou geven van de financiële positie, het veel meer voor de hand ligt om alle groepsmaatschappijen per definitie vrij te stellen van de verplichting om een jaarrekening openbaar te maken en niet om hen hiervan slechts onder voorwaarden vrij te stellen.

\subsubsection{Beperken van het verschil tussen een groepsmaatschappij en een onderdeel van een rechtspersoon}

Het bovengenoemd deel van de SER merkt ook op dat de keuze om een gedeelte van de activiteiten van een rechtspersoon al of niet onder te brengen in een groepsmaatschappij, doorgaans berust op overwegingen en omstandigheden die losstaan van de jaarrekeningverplichting voor een groepsmaatschappij. ${ }^{231}$ Als een rechtspersoon een gedeelte van zijn activiteiten afsplitst naar een aparte groepsmaatschappij, ontstaat daardoor volgens dit deel van de SER een niet gerechtvaardigde extra belasting voor de groepsmaatschappij ten opzichte van de situatie dat de activiteiten onderdeel zouden zijn gebleven van de (oorspronkelijke) rechtspersoon. De jaarrekeningvrijstelling van het groepsregime biedt de groepsmaatschappij de mogelijkheid om deze extra belasting (deels) weg te nemen.

Evenals Beckman vind ik deze redenering niet overtuigend. ${ }^{232}$ Een belangrijk verschil tussen de situatie dat activiteiten zijn ondergebracht in een groepsmaatschappij of onderdeel zijn van een grotere rechtspersoon, is dat de groepsmaatschappij zelfstandig aansprakelijk is. De crediteuren kunnen zich slechts verhalen op het vermogen van de groepsmaatschappij - en niet op de groep als geheel. Een crediteur heeft daarom belang bij inzicht in de financiële positie van de groepsmaatschappij. Dit inzicht wordt hem mede geboden doordat de groepsmaatschappij ieder jaar een jaarrekening openbaar moet maken. ${ }^{233}$

\subsubsection{Verlagen van de administratieve lasten}

Als een 403-maatschappij gebruikmaakt van de jaarrekeningvrijstelling van het groepsregime, leidt dat tot een verlaging van haar administratieve lasten. ${ }^{234}$ Ik heb eerder opgemerkt dat de 403-maatschappij onder meer is vrijgesteld

230. Houwen, Schoonbrood-Wessels \& Schreurs 1993, p. 824

231. SER-advies 1974, nr. 14, p. 9 en SER-advies 1979, nr. 12, p. 23.

232. Beckman 1995b, p. 88-89.

233. Zie $\S 3.2$.

234. SER-advies 1974, nr. 14, p. 12, SER-advies 1979, nr. 12, p. 22, Kamerstukken II 1981/82, 16326, 8, p. 20 (MvA) en 13, p. 4 (NnavhEV), Raaijmakers 1985, p. 273, Houwen, Schoonbrood-Wessels \& Schreurs 1993, p. 820, Beckman 1995b, p. 89, Asser/Maeijer \& Kroeze $2-I^{*} 2015 / 581$, Van der Sangen 2017, p. 204, E.C.A. Nass 2019, p. 12 en Hof Amsterdam 
van de verplichting om haar jaarrekening door een accountant te laten controleren, dat zij de gegevens uit art. 2:392 BW niet hoeft toe te voegen aan haar jaarrekening en bestuursverslag, dat de balans en de winst- en verliesrekening beperkt kunnen blijven tot enkele posten en dat de jaarrekening niet openbaar hoeft te worden gemaakt. ${ }^{235}$

De jaarrekeningvrijstelling levert echter een minder grote verlaging van de administratieve lasten op dan op het eerste gezicht wellicht wordt gedacht. Ik wijs op drie nuanceringen. Ten eerste is een 403-maatschappij niet vrijgesteld van de verplichting om een administratie bij te houden. ${ }^{236}$ Daarnaast hoeft de 403-maatschappij weliswaar zelf haar jaarrekening niet door een accountant te laten controleren, maar haar financiële gegevens moeten worden geconsolideerd in de geconsolideerde jaarrekening van de moedermaatschappij die wel door een account moet worden gecontroleerd. ${ }^{237}$ Tot slot zijn de administratieve lasten de afgelopen decennia al aanzienlijk verminderd door automatisering, waardoor de jaarrekeningvrijstelling tegenwoordig relatief minder oplevert. ${ }^{238}$

Hoewel de lastenverlichting die de jaarrekeningvrijstelling van het groepsregime oplevert dus moet worden genuanceerd, kan niet worden ontkend dat er wel sprake is van enige verlichting van de administratieve lasten voor de 403-maatschappij. Vooral bij een grote groep waarbij veel groepsmaatschappijen gebruikmaken van de jaarrekeningvrijstelling kan dit voor de groep als geheel een merkbare lastenverlichting opleveren.

\subsubsection{Afschermen van informatie}

Een laatste reden die ik noem waarom een 403-maatschappij gebruik zou willen maken van de jaarrekeningvrijstelling van het groepsregime, is dat zij hierdoor informatie kan afschermen van derden. Doordat de 403-maatschappij haar jaarrekening niet openbaar hoeft te maken, kan zij voorkomen dat derden daaruit informatie kunnen halen over onder meer haar omzet, marges, activa, deelnemingen en resultaten. ${ }^{239}$ Een voorbeeld hiervan is Bol.com dat gebruikmaakt van de jaarrekeningvrijstelling van het groepsregime en begin

(OK) 30 september 2010, JOR 2010/306, m.nt. Bartman (Jones Lang LaSalle/BosGijze), r.o. 3.11.

235. Zie $\S 2.5$.

236. Asser/Maeijer \& Kroeze 2-I* 2015/581, Talacko \& Van Wijngaarden 2016, p. 16-17, Van Zoest 2019, p. 17 en E.C.A. Nass 2019, p. 13. Zie ook $\S 2.5$.

237. Beckman 1995b, p. 89, Ten Voorde 2011, p. 196, Assink/Slagter 2013/140.3 en E.C.A. Nass 2019, p. 13.

238. E.C.A. Nass 2019, p. 13.

239. Raaijmakers 1976, p. 287, De Neve 2002, p. 235, Asser/Maeijer \& Kroeze 2-I*2015/581, Van der Sangen 2017, p. 204, Van Zoest 2019, p. 9, E.C.A. Nass 2019, p. 13-14 en Hof Amsterdam (OK) 30 september 2010, JOR 2010/306, m.nt. Bartman (Jones Lang LaSalle/ BosGijze), r.o. 3.11. 
2020 heeft verklaard dat zij dit doet om concurrent Amazon niet wijzer te willen maken door haar jaarrekening openbaar te maken. ${ }^{240}$ Door gebruik te maken van de jaarrekeningvrijstelling kan Bol.com bijvoorbeeld verhinderen dat Amazon ziet hoe groot de Nederlandse markt voor online verkopen is - waardoor deze misschien eerder de Nederlandse markt zou hebben betreden dan zij heeft gedaan - en kan worden voorkomen dat bekend wordt dat de omzet van Bol.com eventueel is gedaald als gevolg van de concurrentie van Amazon.

Een 403-maatschappij kan er in het bijzonder belang bij hebben om informatie af te schermen van derden als zij zich binnen haar groep richt op een specifiek (onderdeel van een) product of een bepaald gedeelte van de markt. Timmerman en Houwen wijzen erop dat in een dergelijk geval de posten in de jaarrekening minder divers zijn en dat derden daaruit eenvoudiger informatie over de kostenopbouw, de winstmarge of de voorwaarden van transacties kunnen achterhalen. ${ }^{241}$ De concurrenten van de 403-maatschappij zouden deze informatie bijvoorbeeld kunnen gebruiken om hun eigen strategie of werkzaamheden aan te passen. Daarnaast zou een afnemer bij de onderhandelingen met de 403-maatschappij een prijsverlaging kunnen eisen als hij weet dat de 403-maatschappij een grote winstmarge hanteert. ${ }^{242}$

Ten Voorde nuanceert de toegevoegde waarde om door gebruik te maken van de jaarrekeningvrijstelling van het groepsregime informatie af te schermen van derden. ${ }^{243}$ Ten eerste merkt hij op dat derden doorgaans niet de jaarrekening gebruiken om informatie over een rechtspersoon in te winnen. De informatie in een jaarrekening is namelijk verouderd, ${ }^{244}$ waardoor je geen up-to-date beeld krijgt. Daarnaast wijst Ten Voorde erop dat informatie over een rechtspersoon (ook) via marktonderzoeksbureaus of brancheorganisaties kan worden verkregen. Derden hoeven deze informatie dus niet uit de jaarrekening te halen.

In aanvulling op Ten Voorde merk ik nog op dat een rechtspersoon ook - als alternatief voor het gebruikmaken van de jaarrekeningvrijstelling uit het groepsregime - informatie kan afschermen van derden door gebruik te maken van de jaarrekeningvrijstellingen voor micro-bedrijven, kleine bedrijven en middelgrote bedrijven op grond van respectievelijk art. 2:395a, art. 2:396 en art. 2:397 BW. Krachtens deze bepalingen kan een rechtspersoon die onder bepaalde

240. J. Braaksma en L. Van der Velden, 'Prestaties Bol.com blijven geheim uit angst voor rivaal Amazon', Het Financieele Dagblad 11 februari 2020.

241. L. Timmerman 1988b, p. 312 en Houwen, Schoonbrood-Wessels \& Schreurs 1993, p. 821.

242. L. Timmerman 1988b, p. 312.

243. Ten Voorde 2011, p. 196.

244. Zie $\S 3.8$. Op grond van art. 2:394 lid 3 BW moet een rechtspersoon uiterlijk twaalf maanden na afloop van het boekjaar de jaarrekening openbaar maken. 
(financiële) drempelwaarden blijft, volstaan met een minder uitgebreide jaarrekening dan onder het reguliere jaarrekeningregime. De rechtspersoon is echter niet vrijgesteld van de verplichting om de jaarrekening openbaar te maken. Als een 403-maatschappij te groot is om van een van deze jaarrekeningvrijstellingen gebruik te maken, kan zij zich opsplitsen in verschillende kleinere rechtspersonen die wel van de vrijstelling gebruik mogen maken.

Ondanks bovengenoemde kanttekeningen blijft de jaarrekeningvrijstelling van het groepsregime een mogelijkheid voor een 403-maatschappij om informatie uit de jaarrekening af te schermen van derden. ${ }^{245}$ De kanttekeningen nemen niet weg dat een jaarrekening interessante informatie kan bevatten voor derden en dat het niet openbaar maken van de jaarrekening hen de mogelijkheid ontneemt om daarvan kennis te nemen. Ik sluit mij aan bij Beckman dat het aannemelijk is dat de belangrijkste reden voor een 403-maatschappij om gebruik te maken van de jaarrekeningvrijstelling van het groepsregime is om informatie af te schermen van derden. ${ }^{246}$ Dat dit daarnaast een (beperkte) administratieve lastenverlichting oplevert, zal in de meeste gevallen slechts een bijkomend voordeel zijn.

\subsection{Conclusie}

Een groepsmaatschappij kan onder voorwaarden gebruikmaken van de jaarrekeningvrijstelling van het groepsregime. In dit hoofdstuk is allereerst de wetsgeschiedenis van het groepsregime behandeld. De regeling heeft in verschillende artikelen gestaan en is door de jaren heen diverse keren gewijzigd (§ 2.2). Daarna ben ik ingegaan op de voorwaarden waaraan moet worden voldaan als een groepsmaatschappij rechtsgeldig gebruik wil maken van de jaarrekeningvrijstelling. Vooruitlopend op de rest van dit onderzoek zijn de twee belangrijkste voorwaarden dat de moedermaatschappij een geconsolideerde jaarrekening deponeert en dat zij zich door middel van een 403-verklaring hoofdelijk aansprakelijk stelt voor de schulden die voortvloeien uit een rechtshandeling van de 403-maatschappij ( $\$ 2.3$ en $\S 2.4$ ). Voorts heb ik een uiteenzetting gegeven van de jaarrekeningvrijstelling van het groepsregime $(\S 2.5)$. Tot slot zijn verschillende redenen aan bod gekomen die in de parlementaire geschiedenis en de literatuur zijn genoemd waarom een groepsmaatschappij gebruikmaakt van de jaarrekeningvrijstelling van het groepsregime. Zij kan daardoor informatie afschermen van derden en het levert daarnaast een administratieve lastenverlichting op (§ 2.6).

245. Houwen, Schoonbrood-Wessels \& Schreurs 1993, p. 824, Beckman 1995a, p. 689 en Beckman 1995b, p. 88 .

246. Beckman 1995a, p. 689 en Beckman 1995b, p. 88. 


\section{Hoofdstuk 3. De compensatie van crediteuren}

\section{$3.1 \quad$ Inleiding}

Als een 403-maatschappij gebruikmaakt van de jaarrekeningvrijstelling van het groepsregime, kan een crediteur de jaarrekening van de 403-maatschappij niet inzien. In dit hoofdstuk behandel ik de compensatie die een crediteur ontvangt voor dit gebrek aan inzicht. Allereerst zet ik uiteen welk belang een crediteur heeft bij het kunnen inzien van de jaarrekening van de 403maatschappij (§ 3.2). Vervolgens ga ik in op het nadeel dat een crediteur ondervindt als de 403-maatschappij gebruikmaakt van de jaarrekeningvrijstelling van het groepsregime ( $\$ 3.3)$. Daarna noem ik de twee onderdelen van de compensatie die een crediteur voor dit nadeel ontvangt: de aansprakelijkheid van de moedermaatschappij op grond van de 403-verklaring en de mogelijkheid voor de crediteur om de geconsolideerde jaarrekening van de moedermaatschappij in te zien. Deze onderdelen staan niet op zichzelf maar vullen elkaar aan $(\S 3.4$ en $\S 3.5)$.

Aan het einde van dit hoofdstuk ga ik in op het feit dat een crediteur geen invloed heeft op de keuze van de 403-maatschappij om gebruik te maken van de jaarrekeningvrijstelling van het groepsregime, en de keuze van de moedermaatschappij om de 403-verklaring in te trekken en om de overblijvende aansprakelijkheid te beëindigen. Ik betoog dat een crediteur daarom op een zodanige wijze moet worden gecompenseerd, dat het nadeel dat hij ondervindt ten opzichte van de situatie dat de 403-maatschappij geen gebruik zou maken van de jaarrekeningvrijstelling, respectievelijk dat de 403-verklaring niet zou zijn ingetrokken of de overblijvende aansprakelijkheid niet zou zijn beëindigd volledig is weggenomen $(\S 3.6)$. Dit standpunt in combinatie met de wisselwerking tussen de twee bovengenoemde onderdelen van de compensatie voor een crediteur, vormen de basis van het door mij bepleite uitgangspunt voor compensatie ( $\$ 3.7)$. Aan de hand van dit uitgangspunt beantwoord ik in de volgende hoofdstukken van dit onderzoek diverse vraagstukken met betrekking tot de aansprakelijkheid van een moedermaatschappij op grond van een 403-verklaring. Ik onderzoek daarbij hoe verschillende wettelijke bepalingen moeten worden uitgelegd of gewijzigd, bezien vanuit dit uitgangspunt ten aanzien van de compensatie van de crediteuren. 


\section{HOOFDSTUK 3}

Tot slot wijs ik aan het einde van dit hoofdstuk op enkele kanttekeningen met betrekking tot het belang van een jaarrekening voor het inzicht van een crediteur in de financiële positie van de rechtspersoon (§ 3.8).

\subsection{Een crediteur heeft belang bij inzicht in de financiële positie van de rechtspersoon}

Dat een crediteur van een rechtspersoon belang heeft bij inzicht in de financiele positie van deze rechtspersoon staat niet ter discussie. ${ }^{1}$ Een rechtspersoon is zelfstandig aansprakelijk voor zijn verplichtingen, wat inhoudt dat een crediteur zich alleen op het vermogen van de rechtspersoon zelf kan verhalen. Voor de crediteur is het daarom van belang dat hij de mogelijkheid heeft om inzicht te krijgen in de financiële positie van de rechtspersoon zodat hij kan schatten hoe groot het risico is dat zijn vordering niet (volledig) zal worden voldaan

Inzicht in de financiële positie van een rechtspersoon is in de eerste plaats van belang voor degenen die eventueel een relatie met de rechtspersoon willen aangaan. ${ }^{2} \mathrm{Zij}$ kunnen (mede) aan de hand van deze informatie bepalen of zij de relatie al of niet willen aangaan en zo ja, onder welke voorwaarden. Als een leverancier bijvoorbeeld weet dat een rechtspersoon er financieel slecht voor staat, kan hij besluiten dat hij de goederen alleen wil leveren als er wordt vooruitbetaald, hij bepaalde zekerheden krijgt of als een derde zich garant stelt voor de nakoming. ${ }^{3}$

Voor crediteuren die reeds een vordering hebben op een rechtspersoon, biedt de informatie omtrent de financiële positie vanzelfsprekend geen bescherming tegen (gedeeltelijke) onverhaalbaarheid van de vordering. ${ }^{4}$ Voor hen is deze informatie echter van belang om bij te kunnen houden hoe de financiële positie van de rechtspersoon zich met de tijd ontwikkelt. Als blijkt dat de financiële positie van de rechtspersoon (te veel) is verslechterd - bijvoorbeeld omdat

1. Winter 2001, p. 98-99, Lennarts \& Schutte-Veenstra 2004, p. 114, Schutte-Veenstra 2005, p. 27, De Jong \& Nieuwe Weme 2006, p. 30, Kamerstukken II 2008/09, 31508, 6, p. 5 en 6 (NnavhV), Hijink 2010, p. 118 en Pitlo/Raaijmakers 2017, p. 605-606. Zie ook HvJ EG 9 maart 1999, NJ 2000/48, m.nt. Vlas (Centros), r.o. 36, ook gepubliceerd in JOR 1999/117, m.nt. Van Solinge en HvJ EG 30 september 2003, JOR 2003/249, m.nt. Vossestein (Inspire $A r t$ ), r.o. 135, waar het Hof opmerkt dat crediteuren zich kunnen beroepen op bepaalde jaarrekeningrechtelijke regels van gemeenschapsrecht die hen beschermen, waaronder de Vierde EEG-richtlijn.

2. Beckman 2003, p. 63, Beckman 2004, p. 24, Schutte-Veenstra 2005, p. 28, Hijink 2010, p. 118 en 120 en Van Zoest 2019, p. 11-12.

3. Van Zoest 2019, p. 12

4. Beckman 2003, p. 63, Beckman 2004, p. 24, Lennarts \& Schutte-Veenstra 2004, p. 115, Schutte-Veenstra 2005, p. 28, De Jong \& Nieuwe Weme 2006, p. 30 en Hijink 2010, p. 118. 
deze dividenduitkeringen heeft gedaan, leningen heeft verstrekt, zich garant heeft gesteld voor schulden van een derde of omdat zijn activa zijn afgewaardeerd - kan een crediteur besluiten om aanvullende zekerheden te eisen, bestaande zekerheidsrechten uit te oefenen, de relatie met de rechtspersoon proberen aan te passen of te beëindigen, of het faillissement aan te vragen. ${ }^{5}$ Een bank kan bijvoorbeeld besluiten om een rekening-courantkrediet stop te zetten omdat uit de jaarrekening van de rekeninghouder blijkt dat het eigen vermogen onder een bepaald bedrag is gekomen.

Een rechtspersoon biedt onder meer inzicht in zijn financiële positie door jaarlijks een jaarrekening openbaar te maken. De gedachte is dat derden de jaarrekening bij het handelsregister kunnen opvragen en zich (mede) aan de hand daarvan een beeld kunnen vormen omtrent de financiële positie van de rechtspersoon. ${ }^{6}$ Om jaarrekeningen te kunnen vergelijken en te doorgronden zijn er wettelijke voorschriften hoe deze moeten worden ingericht, en moeten deze door een accountant worden gecontroleerd.

Ik merk op dat er in de literatuur enkele kritische kanttekeningen worden geplaatst bij het idee dat het jaarlijks openbaar maken van een jaarrekening (voldoende) inzicht biedt aan derden omtrent de financiële positie van de rechtspersoon. Er wordt bijvoorbeeld op gewezen dat aangezien een rechtspersoon tot twaalf maanden na afloop van het boekjaar de tijd heeft om de jaarrekening openbaar te maken, ${ }^{7}$ de informatie daarin al verouderd is op het moment van de openbaarmaking en door verloop van tijd alleen maar meer verouderd raakt. ${ }^{8}$ Een ander kritiekpunt is dat het bestuursverslag onvoldoende informatie biedt ten aanzien van het toekomstige bestuursbeleid en de te verwachten continuïteit(srisico's) - informatie die in het bijzonder van belang is voor crediteuren en partijen die eventueel een relatie met de rechtspersoon willen aangaan. ${ }^{9}$ Aan het einde van dit hoofdstuk kom ik uitgebreid terug op deze kanttekeningen. ${ }^{10}$

5. Lennarts 2006, p. 27, Hijink 2010, p. 120 en 399 en Van Zoest 2019, p. 12.

6. Houwen, Schoonbrood-Wessels \& Schreurs 1993, p. 754-755, Winter 2001, p. 98-99, Lennarts \& Schutte-Veenstra 2004, p. 114, De Jong \& Nieuwe Weme 2006, p. 29-30, Hijink 2010, p. 115-116, Beckman \& Marseille 2013, p. 78 en Pitlo/Raaijmakers 2017, p. 605.

7. Zie art. 2:394 lid 3 BW.

8. Houwen, Schoonbrood-Wessels \& Schreurs 1993, p. 768, Winter 2001, p. 99, Beckman 2003, p. 63, Beckman 2004, p. 24, Lennarts \& Schutte-Veenstra 2004, p. 114, Schutte-Veenstra 2005, p. 27, Lennarts 2006, p. 26, De Jong \& Nieuwe Weme 2006, p. 30, Hijink 2010, p. 121-122 en Pitlo/Raaijmakers 2017, p. 601 en 605-606.

9. Bier 2006, p. 47-48, Hijink 2010, p. 112 en Brouwer 2019, p. 218.

10. Zie $\S 3.8$. 


\subsection{Voor welk nadeel moet een crediteur worden gecompenseerd?}

Om iets te kunnen zeggen over de compensatie van de crediteuren van de 403-maatschappij, moet allereerst worden vastgesteld welke nadeel zij ondervinden als de 403-maatschappij gebruikmaakt van de jaarrekeningvrijstelling van het groepsregime en waarvoor zij dus moeten worden gecompenseerd. Het gevolg voor de crediteuren als de 403-maatschappij gebruikmaakt van de jaarrekeningvrijstelling, is dat zij de jaarrekening van de 403-maatschappij niet kunnen inzien. Als de 403-maatschappij geen gebruik zou maken van de vrijstelling zouden haar crediteuren ieder jaar een nieuwe jaarrekening kunnen inzien. Zij zouden (mede) aan de hand daarvan het risico kunnen schatten dat hun vordering niet (volledig) zal worden voldaan. Het nadeel dat een crediteur dus ondervindt als de 403-maatschappij gebruikmaakt van de jaarrekeningvrijstelling, is dat hij niet de mogelijkheid heeft om de jaarrekening van de 403-maatschappij in te zien en (mede) aan de hand daarvan kan schatten hoe groot het risico is dat zijn vordering niet (volledig) zal worden voldaan. Het ontbreken van deze mogelijkheid is hetgeen dat moet worden gecompenseerd.

Het is van belang om een onderscheid te maken tussen enerzijds de (on)mogelijkheid voor een crediteur om de jaarrekening van de 403-maatschappij in te zien en anderzijds of de vordering van de crediteur zal worden voldaan. De compensatie die een crediteur ontvangt, houdt niet in dat hij de zekerheid krijgt dat zijn vordering wordt voldaan. Deze zekerheid zou hij ook niet hebben als de 403-maatschappij geen gebruik zou maken van de jaarrekeningvrijstelling van het groepsregime. Het gebruikmaken van de jaarrekeningvrijstelling door de 403-maatschappij kan overigens indirect wel gevolgen hebben in hoeverre de vordering van de crediteur op de 403-maatschappij zal worden voldaan. Dit kan zowel een positief als een negatief gevolg hebben. Een positief gevolg van het gebruikmaken van de jaarrekeningvrijstelling kan zijn dat de 403-maatschappij makkelijker en tegen gunstigere voorwaarden financiering krijgt van een bank, omdat de moedermaatschappij op grond van de 403 -verklaring hoofdelijk aansprakelijk is voor de schulden van de 403-maatschappij die uit de financieringsovereenkomst met de bank voortvloeien. Een negatief gevolg kan zijn dat de 403-maatschappij binnen de groep (meer) waarborgverplichtingen voor andere groepsmaatschappijen op zich neemt omdat derden deze niet kunnen achterhalen via de jaarrekening en ze ook niet blijken uit de geconsolideerde jaarrekening van de moedermaatschappij. De compensatie die de crediteuren ontvangen, staat echter los van dergelijke indirecte gevolgen van het gebruikmaken van de jaarrekeningvrijstelling van het groepsregime door de 403-maatschappij. 


\subsection{De compensatie voor crediteuren}

\subsubsection{De compensatie bestaat uit twee onderdelen die elkaar aanvullen: aansprakelijkheid en inzicht in een jaarrekening}

De compensatie die een crediteur volgens de wet ontvangt, bestaat uit twee onderdelen die elkaar aanvullen. ${ }^{11}$ Ten eerste is de moedermaatschappij op grond van een 403-verklaring hoofdelijk aansprakelijk voor de schulden die voortvloeien uit een rechtshandeling van de 403-maatschappij. ${ }^{12}$ Daarnaast heeft de crediteur de mogelijkheid om de geconsolideerde jaarrekening van de moedermaatschappij in te zien. ${ }^{13}$ De combinatie van beide onderdelen houdt in dat de crediteur er een vordering bij krijgt op een debiteur ${ }^{14}$ - de moedermaatschappij -, van wie hij de geconsolideerde jaarrekening kan inzien.

Kort gezegd wordt een crediteur gecompenseerd voor het feit dat hij een vordering heeft op een debiteur - de 403-maatschappij - van wie hij de jaarrekening niet kan inzien, met een aanvullende vordering op een andere debiteur - de moedermaatschappij - van wie hij de geconsolideerde jaarrekening wel kan inzien. Met andere woorden: het gebrek aan inzicht in de financiële positie van de ene debiteur wordt gecompenseerd met een aanvullende vordering op en inzicht in de financiële positie van een andere debiteur.

Voor de compensatie van een crediteur is het niet van belang of hij al of niet bij het handelsregister is nagegaan of de 403-maatschappij gebruikmaakt van de jaarrekeningvrijstelling van het groepsregime en of de moedermaatschappij zich door middel van een 403-verklaring aansprakelijk heeft gesteld. Een crediteur wordt gecompenseerd omdat hij niet de mogelijkheid heeft om de jaarrekening van de 403-maatschappij in te zien. Hij wordt voor dit gebrek aan inzicht gecompenseerd met een aanvullende vordering op de moedermaatschappij ten aanzien van wie de crediteur wel de mogelijkheid heeft om de geconsolideerde jaarrekening in te zien.

11. Kamerstukken II 1969/70, 10689, 3, p. 14 (MvT), Honée 1971, p. 202, Raaijmakers 1976, p. 286, Houwen, Schoonbrood-Wessels \& Schreurs 1993, p. 823 en 825-826, A-G Wesseling-van Gent in haar conclusie onder nr. 2.19 bij HR 28 juni 2002, NJ 2002/447, m.nt. Maeijer, ook gepubliceerd in JOR 2002/136, m.nt. Bartman (Akzo/ING), Berk 2007, p. 15, Niels 2010, p. 32, Van der Kraan 2012, p. 27, Asser/Maeijer \& Kroeze 2-I*2015/583 en Van Zoest 2019, p. 12. Zie ook Hof Amsterdam (OK) 30 september 2010, JOR 2010/306, m.nt. Bartman (Jones Lang LaSalle/BosGijze), r.o. 3.11.

12. Zie art. 2:403 lid 1 sub $f B W$.

13. Zie art. 2:403 lid $1 \mathrm{sub} c$ en $\mathrm{g}$ BW.

14. Mits de vordering op de 403-maatschappij onder de reikwijdte van de 403-aansprakelijkheid valt. Zie hoofdstuk 4 en 5. 
De compensatie die een crediteur ontvangt, betekent niet dat zijn vordering altijd volledig wordt voldaan. De crediteur heeft geen garantie dat de moedermaatschappij de vordering op grond van de 403-verklaring geheel of gedeeltelijk zal voldoen. De compensatie houdt in dat de crediteur zich kan verhalen op een debiteur van wie hij de jaarrekening kan inzien en (mede) aan de hand daarvan kan beoordelen hoe groot het risico is dat de vordering niet (volledig) zal worden voldaan. Het is uiteindelijk aan de crediteur zelf of hij dit risico accepteert en al of niet een relatie met de 403-maatschappij aangaat, dan wel dat hij een bestaande relatie al of niet continueert. Dit is niet anders als wanneer de 403-maatschappij geen gebruik zou maken van de jaarrekeningvrijstelling van het groepsregime. Het enige verschil is dat de crediteur niet de jaarrekening van de 403-maatschappij zelf kan opvragen en (mede) aan de hand daarvan kan schatten hoe groot het risico is dat de 403-maatschappij de vordering niet (volledig) zal voldoen, maar dat hij in plaats daarvan de geconsolideerde jaarrekening van de moedermaatschappij kan opvragen en (mede) aan de hand daarvan kan schatten hoe groot het risico is dat de moedermaatschappij de vordering niet (volledig) zal voldoen.

\subsubsection{De enkelvoudige jaarrekening van de moedermaatschappij}

Uit bovengenoemde uitleg van de compensatie van de crediteuren van een 403-maatschappij volgt dat het voor hen van belang is dat zij de mogelijkheid hebben om te schatten hoe groot het risico is dat de moedermaatschappij de vordering op grond van de 403 -verklaring niet (volledig) zal voldoen. Als de 403-maatschappij geen gebruik zou maken van de jaarrekeningvrijstelling zouden de crediteuren aan de hand van haar enkelvoudige jaarrekening kunnen schatten hoe groot het risico is dat de 403-maatschappij de vordering niet (volledig) zal voldoen. Voor een vergelijkbaar inzicht met betrekking tot het risico dat de moedermaatschappij de vordering op grond van de 403-verklaring niet (volledig) zal voldoen, zou een crediteur de enkelvoudige jaarrekening van de moedermaatschappij moeten kunnen inzien. Op grond van art. 2:403 BW is echter alleen vereist dat de geconsolideerde jaarrekening van de moedermaatschappij is gedeponeerd bij het handelsregister en niet (ook) haar enkelvoudige jaarrekening. In de praktijk levert dit overigens doorgaans geen bezwaar op voor de crediteuren. Ik kom hier later in deze paragraaf op terug.

In de geconsolideerde jaarrekening van de moedermaatschappij zijn de financiële gegevens van de diverse groepsmaatschappij als een geheel opgenomen, ook van groepsmaatschappijen voor wie de moedermaatschappij zich niet op grond van een 403-verklaring aansprakelijk heeft gesteld. Daarnaast zijn uit de geconsolideerde jaarrekening eventuele waarborgverplichtingen tussen de groepsmaatschappijen onderling niet op te maken. ${ }^{15}$ De enkelvoudige

15. E.C.A. Nass 2019, p. 12. 
jaarrekening bevat daarentegen alleen de gegevens van de moedermaatschappij zelf. Om die reden kan uit de enkelvoudige jaarrekening - in tegenstelling tot uit de geconsolideerde jaarrekening - onder meer de liquiditeit, solvabiliteit en rentabiliteit van de moedermaatschappij worden opgemaakt. De informatie in de enkelvoudige jaarrekening stelt een crediteur dus beter in staat om te schatten hoe groot het risico is dat de moedermaatschappij de vordering op grond van de 403-verklaring niet (volledig) zal voldoen, dan de informatie in de geconsolideerde jaarrekening. ${ }^{16}$

Dat op grond van art. 2:403 BW niet is vereist dat de enkelvoudige jaarrekening van de moedermaatschappij is gedeponeerd bij het handelsregister, zal overigens bij een Nederlandse moedermaatschappij geen groot bezwaar zijn. Nass en Nass wijzen erop dat een Nederlandse moedermaatschappij krachtens art. 2:394 BW verplicht is om haar enkelvoudige jaarrekening openbaar te maken. ${ }^{17}$ Een crediteur van de 403-maatschappij kan om die reden alsnog de enkelvoudige jaarrekening van de moedermaatschappij inzien. Om deze jaarrekening in te zien, moet de crediteur bij het handelsregister wel de informatie over de moedermaatschappij opvragen in plaats van over de 403 -maatschappij. ${ }^{18}$ In het geval van een buitenlandse moedermaatschappij ligt dit echter anders. Nass en Nass merken op dat de verplichting ex art. 2:394 BW niet geldt voor een moedermaatschappij naar buitenlands recht. Dit betekent dat het afhankelijk is van het op de buitenlandse moedermaatschappij toepasselijke recht, of deze al of niet verplicht is om een enkelvoudige jaarrekening openbaar te maken. Het is mogelijk dat een moedermaatschappij naar buitenlands recht hier niet toe is gehouden. Daarnaast geldt dat als een buitenlandse moedermaatschappij op grond van het op haar toepasselijke recht een enkelvoudige jaarrekening moet deponeren, de crediteuren van de 403-maatschappij deze jaarrekening moeten opvragen bij het equivalent van het Nederlandse handelsregister van het desbetreffende land. Dit zal voor de meeste crediteuren geen eenvoudige opgave zijn.

Om ervoor te zorgen dat crediteuren altijd eenvoudig inzicht kunnen hebben in de enkelvoudige jaarrekening van de moedermaatschappij zou art. 2:403 BW naar mijn mening op twee plekken moeten worden gewijzigd. Evenals Nass en Nass meen ik dat de deponering van de enkelvoudige jaarrekening van de moedermaatschappij als constitutief vereiste voor het gebruikmaken van de jaarrekeningvrijstelling door de 403-maatschappij aan art. 2:403 BW moet worden

16. Beckman 1995 b, p. 85 en $92-93$, Assink/Slagter 2013/140.3, A.G.S. Nass \& E.C.A. Nass 2014, p. 736 en E.C.A. Nass 2019, p. 12. Zie ook Houwen, Schoonbrood-Wessels \& Schreurs 1993, p. 826-828, waar wordt opgemerkt dat de geconsolideerde jaarrekening van de moedermaatschappij niet alle functies overneemt van de jaarrekening van de 403-maatschappij.

17. A.G.S. Nass \& E.C.A. Nass 2014, p. 736 en E.C.A. Nass 2019, p. 12.

18. E.C.A. Nass 2019, p. 12. 
toegevoegd. ${ }^{19}$ Om er daarnaast voor te zorgen dat een crediteur deze enkelvoudige jaarrekening kan inzien als hij bij het handelsregister de informatie over de 403-maatschappij opvraagt, deel ik de mening van Nass dat in art. 2:403 lid 1 sub g BW moet worden opgenomen dat de 403-maatschappij de in art. 2:403 BW genoemde stukken ${ }^{20}$ moet deponeren. ${ }^{21}$ Deze laatste wijziging sluit aan bij het vereiste ex art. 37 lid 4 en lid 7 van de richtlijn jaarrekeningen. Overigens merk ik op dat als art. 2:403 BW op de genoemde wijze wordt aangepast en een 403-maatschappij verplicht is om de enkelvoudige jaarrekening van de moedermaatschappij te deponeren als zij gebruik wil maken van de jaarrekeningvrijstelling van het groepsregime, dit geen afbreuk doet aan een op de moedermaatschappij rustende verplichting om deze jaarrekening zelf te deponeren volgens het op haar van toepassing zijnde jaarrekeningregime.

\subsubsection{Crediteuren komen niet in een nadeliger positie als de moedermaatschappij er financieel minder goed voor staat dan de 403-maatschappij}

Er zou mogelijk kunnen worden betoogd dat de crediteuren die al een vordering op de 403-maatschappij hebben voordat deze gebruikmaakt van de jaarrekeningvrijstelling, door de compensatie die zij ontvangen in een nadeliger positie komen als de moedermaatschappij er financieel slechter voor staat dan de 403-maatschappij. Dit is mijns inziens echter niet juist. Ik zal dit toelichten aan de hand van een voorbeeld. Stel dat een 403-maatschappij tot en met het boekjaar 2019 het reguliere jaarrekeningregime heeft gevolgd en jaarrekeningen openbaar heeft gemaakt. Met betrekking tot de jaarrekening over het boekjaar 2020 maakt zij voor de eerste keer gebruik van de jaarrekeningvrijstelling van het groepsregime. Een crediteur van wie de vordering daarvoor is ontstaan, heeft zijn keuze om een relatie met de 403-maatschappij aan te gaan of te continueren (mede) kunnen baseren op de eerder openbaar gemaakte jaarrekeningen. Hij heeft (mede) aan de hand daarvan kunnen schatten hoe groot het risico is dat de 403-maatschappij de vordering niet (volledig) zal voldoen. Dit is het risico dat hij (onbewust) heeft geaccepteerd.

Over het boekjaar 2020 maakt de 403-maatschappij geen jaarrekening openbaar. De crediteur kan dus niet (mede) aan de hand daarvan schatten hoe groot het risico is dat zijn vordering niet (volledig) zal worden voldaan. Ter compensatie van dit gebrek aan inzicht krijgt de crediteur op grond van de 403-verklaring ook een vordering op de moedermaatschappij, van wie hij de

19. A.G.S. Nass \& E.C.A. Nass 2014, p. 736.

20. Naar huidig recht zijn dit: de instemmingsverklaring, de geconsolideerde jaarrekening met accountantsverklaring en bestuursverslag, en de 403-verklaring. Zie art. 2:403 lid 1 sub g jo. sub b, sub d, sub e en sub f BW. Hieraan moet naar mijn mening de enkelvoudige jaarrekening van de moedermaatschappij worden toegevoegd.

21. E.C.A. Nass 2019, p. 124 
geconsolideerde jaarrekening wel kan inzien. De crediteur kan (mede) aan de hand van de geconsolideerde jaarrekening schatten hoe groot het risico is dat de moedermaatschappij de vordering op grond van de 403-verklaring niet (volledig) zal voldoen. Dit is het risico dat de crediteur (onbewust) accepteert als hij de relatie met de 403-maatschappij continueert.

Als de moedermaatschappij er financieel slechter voor staat dan de 403-maatschappij, is het risico dat de moedermaatschappij de vordering op grond van de 403-verklaring niet (volledig) zal voldoen groter dan het risico dat de 403-maatschappij de vorderingen niet (volledig) zal voldoen. Toch is de positie van de crediteur mijns inziens niet verslechterd ten opzichte van de situatie dat de 403-maatschappij geen gebruik zou maken van de jaarrekeningvrijstelling van het groepsregime. Doordat de 403-maatschappij gebruikmaakt van deze vrijstelling is zij van rechtswege vrijgesteld van verschillende verplichtingen met betrekking tot de verslaggeving omtrent haar financiële positie. ${ }^{22}$ Maar de crediteur kan zich nog steeds op de 403-maatschappij verhalen. Het verschil is slechts dat de crediteur de jaarrekening van de 403-maatschappij niet kan opvragen om de gegevens van de 403-maatschappij omtrent haar financiële positie in te zien. Aangezien de crediteur naast zijn vordering op de 403-maatschappij ook een vordering op de moedermaatschappij heeft gekregen, loopt hij zelfs minder risico dat hij zijn vordering niet (volledig) voldaan krijgt. ${ }^{23}$

\subsection{De aansprakelijkheid op grond van een 403-verklaring staat niet op zichzelf}

\subsubsection{Inleiding}

In de literatuur en jurisprudentie wordt soms ten onrechte opgemerkt dat het feit dat een crediteur de jaarrekening van de 403-maatschappij niet kan inzien, wordt 'afgeruild' tegen de ansprakelijkheid van de moedermaatschappij op grond van de 403-verklaring: aansprakelijkheid voor inzicht. ${ }^{24}$ Dit is echter te kort door de bocht. Het is belangrijk om de aansprakelijkheid van een moedermaatschappij op grond van de 403-verklaring niet op zichzelf te zien, maar als een onderdeel van de compensatie die een crediteur ontvangt omdat hij de jaarrekening van de 403-maatschappij niet kan inzien. Deze aansprakelijkheid

22. Zie $\S 2.5$.

23. In totaal kan de crediteur vanzelfsprekend maar één keer volledig worden voldaan.

24. Zie bijvoorbeeld Van Achterberg 1989, p. 221, Van het Kaar in zijn annotatie onder Hof Amsterdam (OK) 13 juli 2000, JOR 2000/174 (OR EBS/HES Beheer I), Bartman 2002, p. 22, Winkel 2004, p. 186, Bartman 2004, p. 52 en Blom 2005, p. 178. Zie ook Rb. Den Haag 5 juli 2006, JOR 2007/53, m.nt. Verdaas (NCM/Den Heijer Beheer), r.o. 3.4. 
is complementair aan de mogelijkheid die een crediteur heeft om de geconsolideerde jaarrekening van de moedermaatschappij in te zien. ${ }^{25}$

Dat de 403-aansprakelijkheid niet op zichzelf staat, is af te leiden uit drie onderdelen van de regeling van het groepsregime. Ten eerste wordt in art. 2:403 BW expliciet een koppeling gemaakt tussen de 403-aansprakelijkheid en het kunnen inzien van de geconsolideerde jaarrekening van de moedermaatschappij (§ 3.5.2). Ten tweede kan een moedermaatschappij de 403-verklaring intrekken en haar aansprakelijkheid onder voorwaarden beëindigen ( $\$ 3.5 .3)$. Tot slot is de 403-verklaring een eenzijdige verklaring van aansprakelijkheid, maar gelden er geen voorwaarden met betrekking tot de financiële positie van de moedermaatschappij (§ 3.5.4).

\subsubsection{Koppeling in art. 2:403 BW tussen de 403-aansprakelijkheid en de mogelijkheid om de geconsolideerde jaarrekening van de moedermaatschappij in te zien}

In art. 2:403 BW wordt expliciet een koppeling gemaakt tussen de 403-aansprakelijkheid en de mogelijkheid voor de crediteuren om de geconsolideerde jaarrekening van de moedermaatschappij te kunnen inzien. Op grond van lid 1 sub c en sub $\mathrm{f}$ van deze bepaling moet de rechtspersoon die aansprakelijk is op grond van de 403-verklaring tevens de financiële gegevens van de 403-maatschappij consolideren in zijn geconsolideerde jaarrekening. Daarnaast moet de geconsolideerde jaarrekening uit hoofde van lid 1 sub $d$ en sub g van art. 2:403 BW worden gedeponeerd bij het handelsregister. Op deze manier is gewaarborgd dat de crediteuren van de 403-maatschappij ${ }^{26}$ een aanvullende vordering krijgen op een debiteur - de moedermaatschappij -, van wie zij de geconsolideerde jaarrekening kunnen inzien.

\subsubsection{Intrekking van de 403-verklaring en beëindiging van de overblijvende aansprakelijkheid}

Dat de 403-aansprakelijkheid niet op zichzelf staat maar complementair is aan de mogelijkheid om de geconsolideerde jaarrekening van de moedermaatschappij in te zien, komt ook naar voren uit het feit dat de 403 -verklaring kan worden ingetrokken en de overblijvende aansprakelijkheid kan worden beëindigd.

25. Zie $\S 3.4 .1$.

26. Van wie de vordering onder de reikwijdte van de 403 -aansprakelijkheid valt. Zie hoofdstuk 4 en 5. 
De moedermaatschappij kan de 403-verklaring op ieder moment eenzijdig intrekken. ${ }^{27} \mathrm{Na}$ de intrekking blijft de moedermaatschappij aansprakelijk voor de schulden die voortvloeien uit de rechtshandelingen die de 403-maatschappij heeft verricht tot het moment dat de moedermaatschappij tegenover de crediteur een beroep kan doen op de intrekking. ${ }^{28}$ Deze overblijvende aansprakelijkheid kan de moedermaatschappij beëindigen als zij aan een viertal voorwaarden voldoet ${ }^{29}$ - deze voorwaarden komen in hoofdstuk 8 uitgebreid aan de orde en laat ik hier verder buiten beschouwing.

Uit de mogelijkheid om de 403-verklaring in te trekken en de overblijvende aansprakelijkheid te beëindigen, volgt dat de 403-aansprakelijkheid een tijdelijk karakter heeft en niet een op zichzelf staande aansprakelijkheid is. De aansprakelijkheid vervult samen met de mogelijkheid om de geconsolideerde jaarrekening van de moedermaatschappij in te zien, een specifieke functie in het licht van de jaarrekeningvrijstelling voor de 403-maatschappij. Hierdoor krijgt een crediteur van de 403-maatschappij ook een vordering op een debiteur - de moedermaatschappij - van wie hij de geconsolideerde jaarrekening wel kan inzien.

Zolang de 403-maatschappij gebruikmaakt van deze vrijstelling, is het van belang dat de crediteuren voor het gebrek aan inzicht worden gecompenseerd doordat zij op grond van de 403-verklaring een aanvullende vordering hebben op de moedermaatschappij van wie zij de geconsolideerde jaarrekening kunnen inzien. Als de 403-maatschappij echter niet meer gebruikmaakt van de jaarrekeningvrijstelling hoeven nieuwe crediteuren niet te worden gecompenseerd. De moedermaatschappij hoeft daarom geen nieuwe aansprakelijkheid meer op zich te nemen. Zij kan de 403-verklaring intrekken. Maar ook voor de crediteuren die al een vordering op de moedermaatschappij hebben op grond van de ingetrokken 403-verklaring, geldt dat zij de jaarrekening van de 403-maatschappij weer kunnen inzien. Mits de moedermaatschappij aan bepaalde voorwaarden voldoet, kan daarom ook deze overblijvende aansprakelijkheid worden beëindigd.

Een voorbeeld dat in de praktijk commotie kan ontstaan als de moedermaatschappij de 403-verklaring intrekt, deed zich begin 2018 voor met betrekking tot Shell en de NAM. ${ }^{30}$ Shell heeft zich in 1985 op grond van een 403-verklaring hoofdelijk aansprakelijk gesteld voor de schulden die voortvloeien uit een rechtshandeling van de NAM. ${ }^{31}$ Als gevolg van aardgasboringen door de NAM in Groningen is schade ontstaan. Verschillende gedupeerden hebben de NAM

27. Zie art. 2:404 lid $1 \mathrm{BW}$ en $\S 7.2 .2$.

28. Zie art. 2:404 lid $2 \mathrm{BW}$ en $\S 8.2$.

29. Zie art. 2:404 lid $3 \mathrm{BW}$ en $\S 8.3$.

30. Zie met betrekking tot de Shell-casus ook $\S 4.9$ en $\S 7.8$.

31. Zie E.C.A. Nass 2018, p. 167. 
aansprakelijk gesteld tot vergoeding van hun schade. Deze schulden vloeien voort uit een onrechtmatige daad van de NAM - de beweging van de bodem als gevolg van de aardgaswinning ${ }^{32}-$ en niet uit een rechtshandeling. Shell is daarom niet op grond van de 403 -verklaring aansprakelijk voor deze schulden. ${ }^{33}$

Shell heeft medio 2017 haar 403-verklaring ingetrokken. Zij is daardoor niet aansprakelijk voor de schulden die voortvloeien uit de rechtshandelingen die de NAM heeft verricht vanaf het moment dat Shell tegenover de crediteur een beroep kan doen op de intrekking. ${ }^{34}$ Op 31 januari 2018 meldt de Minister van Economische Zaken en Klimaat aan de Tweede Kamer dat de overheid de vergoeding van de schade voor de gedupeerden in Groningen verder afhandelt. ${ }^{35}$ De NAM is niet inhoudelijk betrokken bij de afhandeling van de schadevergoedingen, maar draagt wel zorg voor de financiering ervan. Hiertoe hebben de Staat der Nederlanden en de NAM een overeenkomst gesloten. Het sluiten van deze overeenkomst is wel een rechtshandeling van de NAM. Als Shell haar 403-verklaring niet zou hebben ingetrokken, zou zij aansprakelijk zijn geweest voor alle schulden die uit deze overeenkomst voortvloeien. ${ }^{36}$

Ongeveer op hetzelfde moment dat de minister bekendmaakt dat de Staat bovengenoemde overeenkomst met de NAM heeft gesloten, maken verschillende media melding van het feit dat Shell de 403-verklaring een half jaar daarvoor heeft ingetrokken. De algemene tendens van deze berichtgeving is dat Shell de NAM ongemerkt 'op afstand heeft geplaatst', en dat zij (de schijn heeft gewekt dat zij) bewust onder de aansprakelijkheid voor de schulden van de NAM in verband met de schadevergoedingen in Groningen probeert uit te komen. ${ }^{37}$ In deze berichtgeving wordt echter het eerdergenoemde tijdelijke karakter van de 403-aansprakelijkheid van een moedermaatschappij over het hoofd gezien.

32. Zie art. 6:177 lid 1 sub b BW.

33. Kamerstukken II 2017/18, 33529, 422, p. 2 (Brief aan de voorzitter van de Tweede Kamer), Van Dooren 2018a, p. 61, E.C.A. Nass 2018, p. 168 en E.C.A. Nass 2020, p. 148. Zie § 4.3.2.

34. Zie Van Dooren 2018a, p. 62.

35. Kamerstukken II 2017/18, 33529, 423 (Brief aan de voorzitter van de Tweede Kamer).

36. Zie Van Dooren 2018a, p. 62 en E.C.A. Nass 2018, p. 168. Zie ook E.C.A. Nass 2020, p. 145, 146, 148 en 149, waar zij erop wijst dat de Staat en (onder meer) Shell een akkoord op hoofdlijnen hebben gesloten op grond waarvan Shell garanties zal geven waardoor de NAM haar verplichting tot vergoeding van schade te allen tijde kan nakomen (zie Kamerstukken II 2017/18, 33529, 493 (Brief aan de voorzitter van de Tweede Kamer), en Bijlage 1 Akkoord op Hoofdlijnen met Shell en ExxonMobil). Bartman betwijfelt of dit voldoende zekerheid biedt voor de gedupeerden. Zie S.M. Bartman, 'NAM-akkoord: garanties Shell en ExxonMobil bieden maar beperkte zekerheid', Het Financieele Dagblad 2 juli 2018 en J. Kleinnijenhuis, 'Hoogleraar: 'Wiebes liet zich afbluffen bij gasdeal met Shell”, Trouw 1 augustus 2018.

37. Zie Van Dooren 2018a, p. 61 en E.C.A. Nass 2020, p. 141, en de daar aangehaalde berichten in de media. 
Als de 403-maatschappij niet meer gebruikmaakt van de jaarrekeningvrijstelling van het groepsregime hoeven nieuwe crediteuren niet te worden gecompenseerd en hoeft de moedermaatschappij dus geen nieuwe aansprakelijkheid meer op zich te nemen. Aangezien de NAM in het voorjaar van 2017 zelf weer een jaarrekening openbaar heeft gemaakt, hebben nieuwe crediteuren geen gebrek aan inzicht en is het niet nodig dat Shell op grond van de 403-verklaring nieuwe aansprakelijkheid op zich neemt. ${ }^{38}$ De intrekking van de 403 -verklaring door Shell past dus naadloos in het systeem van de compensatie van de crediteuren van de 403-maatschappij.

Er zou overigens kunnen worden betoogd dat de intrekking van de 403-verklaring door Shell misbruik van recht is omdat hierdoor de belangen van de Staat der Nederlanden onevenredig zouden zijn benadeeld. ${ }^{39}$ Dit standpunt houdt mijns inziens echter geen stand. Hoewel het voor de Staat vanzelfsprekend gunstig zou zijn geweest als hij zich (ook) op Shell zou kunnen verhalen, is zijn belang door de intrekking van de 403-verklaring niet onevenredig geschaad. Aangezien de NAM in het voorjaar van 2017 weer een jaarrekening openbaar heeft gemaakt, heeft het de Staat ten tijde van het sluiten van de overeenkomst met de NAM - en daarna - niet aan inzicht ontbroken. De intrekking heeft er slechts toe geleid dat de Staat geen beroep kan doen op de compensatie voor een nadeel dat hij niet heeft ondervonden.

In hoofdstuk 7 ga ik uitgebreid in op de intrekking van een 403-verklaring en onderzoek ik ook onder welke omstandigheden dit misbruik van recht kan zijn. $^{40}$

\subsubsection{Geen voorwaarden met betrekking tot de financiële positie van de moedermaatschappij}

De derde en laatste omstandigheid waaruit blijkt dat de 403-aansprakelijkheid van een moedermaatschappij niet op zichzelf staat maar samenhangt met de mogelijkheid voor een crediteur om de geconsolideerde jaarrekening in te zien, is dat de 403-verklaring een eenzijdige verklaring van aansprakelijkheid is maar er geen voorwaarden gelden met betrekking tot de financiële positie van de moedermaatschappij. Het is bijvoorbeeld mogelijk dat de moedermaatschappij een subholding is zonder verdere activa ${ }^{41}$ Daarnaast is er geen beperking aan het aantal 403-maatschappijen waarvoor een moedermaatschappij

38. Zie Van Dooren 2018a, p. 62. Zie ook E.C.A. Nass 2020, p. 148, die opmerkt dat deze verklaring niet alle argwaan wegneemt.

39. Zie art. 3:13 BW.

40. Zie $\S 7.8$.

41. Bartman 1986, p. 105, Burgert, Timmermans \& Joosten 1990, p. 553-555, Winter 1992, p. 26, Beckman 1995b, p. 92-93, E.C.A. Nass 2019, p. 18, en Beckman - Compendium jaarrekening, §3.8.4.15. 
zich op grond van een 403 -verklaring aansprakelijk mag stellen. ${ }^{42}$ Als een moedermaatschappij zich ten aanzien van verschillende 403-maatschappijen aansprakelijk stelt, is de kans groter dat zij niet voor alle crediteuren verhaal biedt. Het ontbreken van voorwaarden met betrekking tot de financiële positie van de moedermaatschappij maakt duidelijk dat de 403-aansprakelijkheid onder omstandigheden van beperkte waarde kan zijn. De crediteur heeft geen garantie dat de moedermaatschappij de vordering op grond van de 403-verklaring zal voldoen.

Net zo belangrijk als het feit dat de crediteur een vordering krijgt op de moedermaatschappij, is het antwoord op de vraag in hoeverre de moedermaatschappij deze vordering kan voldoen als zij aansprakelijk wordt gesteld. Om dit te beoordelen kan de crediteur de geconsolideerde jaarrekening inzien en (mede) aan de hand daarvan schatten hoe groot het risico is dat zijn vordering niet (volledig) zal worden voldaan. Het is vervolgens aan de crediteur zelf om te bepalen of hij dit risico accepteert of niet. Dit is hetzelfde als wanneer de 403-maatschappij geen gebruik zou maken van de jaarrekeningvrijstelling van het groepsregime. Ook dan heeft de crediteur geen zekerheid dat de 403-maatschappij zijn vordering zal voldoen. Hij kan (mede) aan de hand van de jaarrekening van de 403-maatschappij schatten hoe groot het risico is dat zijn vordering niet (volledig) zal worden voldaan en hij moet vervolgens zelf bepalen of hij dit risico al of niet accepteert.

Aangezien er geen voorwaarden gelden met betrekking tot de financiële positie van de rechtspersoon die zich door middel van de 403-verklaring aansprakelijk stelt, lijkt het verleidelijk voor de topholding binnen de groep waartoe de 403-maatschappij behoort, om een subholding op te richten zonder verdere activa die de 403-aansprakelijkheid op zich neemt. Hierdoor kan de 403-maatschappij gebruikmaken van de jaarrekeningvrijstelling van het groepsregime, maar ontloopt de topholding - die wel activa heeft - de ansprakelijkheid op grond van de 403-verklaring. Toch zal een dergelijke constructie niet snel worden toegepast. Als een crediteur de jaarrekening van de subholding opvraagt en ziet dat bij voorbaat vaststaat dat hij zijn vordering op grond van de 403-verklaring niet voldaan zal krijgen, zal hij mogelijk geen nieuwe overeenkomsten meer aangaan met de 403-maatschappij of zegt hij bestaande overeenkomsten op. Indien bijvoorbeeld een belangrijke leverancier besluit om geen goederen meer te leveren, brengt dat de continuïteit van de 403-maatschappij in gevaar.

42. Beckman 1995b, p. 75-76 en 92, Niels 2010, p. 31 en E.C.A. Nass 2019, p. 18. 


\subsubsection{Tussenconclusie: aansprakelijkheid uitleggen als onderdeel van de compensatie}

De aansprakelijkheid van een moedermaatschappij op grond van de 403-verklaring staat niet op zichzelf. Deze aansprakelijkheid vormt samen met de mogelijkheid om de geconsolideerde jaarrekening van de moedermaatschappij in te zien de compensatie die de crediteuren van de 403-maatschappij ontvangen omdat zij de jaarrekening van laatstgenoemde niet kunnen inzien. ${ }^{43}$ Het feit dat een crediteur een vordering heeft op een debiteur - de 403-maatschappij - van wie hij de jaarrekening niet kan inzien, wordt gecompenseerd met een aanvullende vordering op een andere debiteur - de moedermaatschappij - van wie hij de geconsolideerde jaarrekening wel kan inzien. De crediteur heeft geen garantie dat de moedermaatschappij de vordering volledig voldoet. De 403-aansprakelijkheid zorgt er slechts voor dat de crediteur een vordering heeft op een debiteur - de moedermaatschappij - van wie hij de geconsolideerde jaarrekening kan inzien. Het is aan de crediteur zelf om (mede) aan de hand van deze geconsolideerde jaarrekening te schatten hoe groot het risico is dat zijn vordering niet (volledig) zal worden voldaan en te besluiten of hij dit risico al of niet accepteert.

De hierboven beschreven functie van de aansprakelijkheid van een moedermaatschappij op grond van de 403-verklaring bij de compensatie van de crediteuren van de 403-maatschappij, is van belang voor de beantwoording van vraagstukken met betrekking tot deze aansprakelijkheid. In de volgende hoofdstukken onderzoek ik hoe verschillende wettelijke bepalingen met betrekking tot de 403-aansprakelijkheid moeten worden uitgelegd of gewijzigd, bezien vanuit de functie die deze aansprakelijkheid vervult bij de compensatie van de crediteuren van de 403-maatschappij. Ik ga onder meer in op de reikwijdte van de 403 -aansprakelijkheid, ${ }^{44}$ de duiding van een vordering van een crediteur op grond van de 403 -verklaring ${ }^{45}$ en onder welke omstandigheden het beroep van een crediteur op de 403-verklaring onaanvaardbaar is naar maatstaven van redelijkheid en billijkheid indien de moedermaatschappij is vergeten deze verklaring in te trekken. ${ }^{46}$ Daarnaast onderzoek ik welke omvang een vervangende waarborg voor een crediteur ex art. 2:404 lid 4 en 5 BW (minimaal) moet hebben als de moedermaatschappij de overblijvende aansprakelijkheid

43. Kamerstukken II 1969/70, 10689, 3, p. 14 (MvT), Honée 1971, p. 202, Raaijmakers 1976, p. 286, Houwen, Schoonbrood-Wessels \& Schreurs 1993, p. 823 en 825, A-G Wesseling-van Gent in haar conclusie onder nr. 2.19 bij HR 28 juni 2002, JOR 2002/136, m.nt. Bartman (Akzo/ING), Berk 2007, p. 15, Niels 2010, p. 32, Van der Kraan 2012, p. 27, Asser/Maeijer \& Kroeze 2-I*2015/583 en Van Zoest 2019, p. 12. Zie ook Hof Amsterdam (OK) 30 september 2010, JOR 2010/306, m.nt. Bartman (Jones Lang LaSalle/BosGijze), r.o. 3.11.

44. Zie $\S 4.5$ en $\S 5.6$.

45. Zie $\S 6.4$.

46. Zie $\S 7.6 .4$. 
na intrekking van de 403 -verklaring wil beëindigen ${ }^{47}$ en of de voorwaarde ex art. 2:404 lid 3 sub a BW dat de groepsband tussen de moeder- en de 403-maatschappij is verbroken al of niet moet worden gehandhaafd als vereiste voor een dergelijke beëindiging. ${ }^{48}$

\subsection{Een crediteur heeft geen instemmingsrecht en mag daarom niet in een nadeliger positie komen}

\subsubsection{Een crediteur mag niet in een nadeliger positie komen}

De crediteuren van een 403-maatschappij hebben geen invloed op de keuze van de 403-maatschappij om gebruik te maken van de jaarrekeningvrijstelling van het groepsregime. ${ }^{49}$ In tegenstelling tot de aandeelhouders ${ }^{50}$ hebben zij geen instemmingsrecht met betrekking tot de afwijking van de jaarrekeningvoorschriften. De crediteuren worden daar als het ware mee 'geconfronteerd'. Ik betoog daarom dat als een 403-maatschappij gebruikmaakt van de jaarrekeningvrijstelling van het groepsregime, haar crediteuren daardoor niet in een nadeliger positie mogen komen in vergelijking met de situatie dat de 403-maatschappij geen gebruik zou maken van deze vrijstelling. Dit houdt in dat de crediteuren die nadeel ondervinden van het feit dat ze de jaarrekening van de 403-maatschappij niet kunnen inzien hiervoor moeten worden gecompenseerd en dat deze compensatie zodanig moet zijn dat het nadeel wordt weggenomen. ${ }^{51}$

Ik breng in herinnering dat een crediteur wordt gecompenseerd voor het feit dat hij de jaarrekening van de 403-maatschappij niet kan inzien, met een aanvullende vordering op een andere debiteur - de moedermaatschappij - van wie hij de geconsolideerde jaarrekening wel kan inzien. ${ }^{52}$ Daarmee is niet gegarandeerd dat de vordering van de crediteur volledig wordt voldaan. De crediteur wordt gecompenseerd doordat hij de mogelijkheid heeft om de geconsolideerde jaarrekening van de moedermaatschappij in te zien en hij vervolgens (mede) aan de hand daarvan kan schatten hoe groot het risico is dat zijn vordering niet (volledig) zal worden voldaan. Het is uiteindelijk aan de crediteur zelf of hij dit risico accepteert en al of niet een relatie met de 403-maatschappij aangaat, dan wel dat hij een bestaande relatie al of niet continueert.

47. Zie $\$ 8.9 .3$.

48. Zie $\S 8.14$.

49. Een crediteur kan vanzelfsprekend wel contractueel met een rechtspersoon overeenkomen dat deze geen gebruik zal maken van de jaarrekeningvrijstelling van het groepsregime.

50. Zie art. 2:403 lid 1 sub b BW en $\S 2.3 .4$.

51. Zie bijvoorbeeld $\S 5.6 .4$, met betrekking tot de reikwijdte van de aansprakelijkheid van een moedermaatschappij op grond van de 403-verklaring.

52. Zie $\S 3.4 .1$. 
Er zou kunnen worden betoogd dat het compenseren van alle crediteuren die nadeel ondervinden van het feit dat ze de jaarrekening van de 403-maatschappij niet kunnen inzien, een (te) zware belasting is voor de moedermaatschappij en dat de aansprakelijkheid op grond van een 403-verklaring daarom terughoudend moet worden uitgelegd. Deze redenering overtuigt mij echter niet. Ik wijs op een drietal punten. Ten eerste is het de moedermaatschappij zelf die zich door middel van een 403-verklaring hoofdelijk aansprakelijk stelt voor de schulden die voortvloeien uit een rechtshandeling van de 403-maatschappij. Zij heeft als moedermaatschappij de beschikking over de financiële gegevens van de 403-maatschappij en kan dus weten welk risico zij loopt als zij zich aansprakelijk stelt. Als zij dit risico te groot vindt in verhouding tot het voordeel dat het gebruikmaken van de jaarrekeningvrijstelling door de 403-maatschappij oplevert, moet zij zich niet op grond van een 403-verklaring aansprakelijk stellen. Ik zie niet in waarom een deel van de crediteuren niet zou hoeven worden gecompenseerd voor een nadeel dat zij buiten hun macht om ondervinden, zodat het voor de moedermaatschappij minder belastend is om aan een van de voorwaarden te voldoen waardoor de 403-maatschappij gebruik kan maken van de jaarrekeningvrijstelling - waardoor het nadeel voor de crediteuren ontstaat.

Ten tweede staat het de moedermaatschappij vrij om de 403-verklaring op ieder moment eenzijdig in te trekken als zij niet langer bereid is aansprakelijk te zijn voor schulden die voortvloeien uit nieuwe rechtshandelingen van de 403-maatschappij. ${ }^{53} \mathrm{Zij}$ blijft dan wel aansprakelijk voor de schulden die voortvloeien uit de rechtshandelingen die de 403-maatschappij heeft verricht tot het moment dat de moedermaatschappij tegenover de crediteur een beroep kan doen op de intrekking. ${ }^{54}$ Deze overblijvende aansprakelijkheid kan de moedermaatschappij onder bepaalde voorwaarden beëindigen. ${ }^{55}$

Tot slot is een moedermaatschappij doorgaans een partij die de mogelijkheid heeft om deskundig advies in te winnen - bijvoorbeeld omdat zij een eigen juridische afdeling heeft of omdat zij zich laat bijstaan door juridische adviseurs. Hierdoor mag van haar worden verwacht dat zij zich bewust is van de consequenties die de aansprakelijkheid op grond van de 403-verklaring met zich brengt.

Naast het feit dat de crediteuren geen invloed hebben op de keuze van de 403-maatschappij om gebruik te maken van de jaarrekeningvrijstelling van het groepsregime, hebben zij ook geen invloed op de keuze van de moedermaatschappij om de 403-verklaring in te trekken. Als de moedermaatschappij vervolgens haar overblijvende aansprakelijkheid wil beëindigen, kan een crediteur

53. Zie art. 2:404 lid $1 \mathrm{BW}$ en $\S 7.2$.

54. Zie art. 2:404 lid $2 \mathrm{BW}$ en $\S 8.2$.

55. Zie art. 2:404 lid $3 \mathrm{BW}$ en $\S 8.3$. 
weliswaar tegen dit voornemen verzet instellen en heeft hij onder omstandigheden recht op een vervangende waarborg voor de voldoening van zijn vordering op de 403-maatschappij, ${ }^{56}$ maar als deze vervangende waarborg wordt gegeven kan de crediteur de beëindiging van de overblijvende ansprakelijkheid niet tegenhouden. Ik betoog daarom ook dat de bestaande crediteuren door de intrekking van de 403-verklaring en de beëindiging van de overblijvende aansprakelijkheid niet in een nadeliger positie mogen komen in vergelijking met de situatie dat deze verklaring niet zou zijn ingetrokken, respectievelijk dat de aansprakelijkheid niet zou zijn beëindigd. ${ }^{57}$

\subsubsection{Voorkomen van overcompensatie}

Hierboven heb ik betoogd dat crediteuren niet in een nadeliger positie mogen komen door gebruikmaking van de jaarrekeningvrijstelling door de 403-maatschappij of doordat de moedermaatschappij de 403-verklaring intrekt of de overblijvende aansprakelijkheid beëindigt. Het nadeel dat de crediteuren hierdoor ondervinden moet worden weggenomen. Maar het is ook niet nodig dat een crediteur voordeel heeft omdat de 403-maatschappij gebruikmaakt of heeft gemaakt van de jaarrekeningvrijstelling. 'Overcompensatie' van de crediteuren moet daarom zo veel mogelijk worden voorkomen.

Het voorkomen van overcompensatie kent drie aspecten. Ten eerste moeten de crediteuren die geen nadeel ondervinden van het feit dat ze de jaarrekening van de 403-maatschappij niet kunnen inzien geen beroep kunnen doen op de aansprakelijkstelling door de moedermaatschappij. ${ }^{58}$ Daarnaast moet de compensatie voor de crediteuren die wel nadeel ondervinden omdat ze de jaarrekening van de 403-maatschappij niet kunnen inzien, zodanig worden vormgegeven dat zij een aanvullende vordering krijgen op een andere debiteur - de moedermaatschappij - van wie zij de geconsolideerde jaarrekening wel kunnen inzien. Voor het overige is er vanuit het oogpunt van de compensatie geen reden dat de verhaalsrechten van een crediteur op de 403-maatschappij en op de moedermaatschappij verschillend zijn. Het is niet de bedoeling dat een crediteur op grond van de 403-verklaring een sterker verhaalsrecht heeft tegenover de moedermaatschappij, dan het verhaalsrecht dat hij heeft tegenover de 403-maatschappij. ${ }^{59}$

56. Zie art. 2:404 lid 4 en $5 \mathrm{BW}$ en $\S 8.6$ tot en met $\S 8.10$.

57. Zie bijvoorbeeld $\S 8.2$, met betrekking tot de reikwijdte van de overblijvende aansprakelijkheid als de moedermaatschappij de 403-verklaring heeft ingetrokken.

58. Zie bijvoorbeeld $\S 6.4 .5$, waar ik met betrekking tot de cessie van de vordering op de moeder- of de 403-maatschappij betoog dat de vordering op de moedermaatschappij altijd zou moeten toekomen aan degene met de corresponderende vordering op de 403-maatschappij.

59. Zie bijvoorbeeld $\S 4.8$, met betrekking tot het geval dat de vordering van de crediteur op de 403-maatschappij contractueel is achtergesteld ten aanzien van de vorderingen van de andere crediteuren. 
Tot slot is het voorkomen van overcompensatie van belang als de 403-maatschappij niet meer gebruikmaakt van de jaarrekeningvrijstelling van het groepsregime. Dit betekent dat als een crediteur de jaarrekening van de 403-maatschappij weer kan inzien en zijn verhaalsrecht zodanig is gewaarborgd dat hij door de intrekking van de 403-verklaring en de beëindiging van de overblijvende aansprakelijkheid niet in een nadeliger positie komt, er verder niets in de weg mag staan aan deze intrekking en beëindiging. ${ }^{60}$

\subsection{Mijn uitgangspunt voor de compensatie van crediteuren}

\subsubsection{Grondbeginselen}

De in dit hoofdstuk gegeven uiteenzetting van de compensatie van de crediteuren van een 403-maatschappij en het standpunt dat zij niet in een nadeliger positie mogen komen doordat de 403-maatschappij gebruikmaakt van de jaarrekeningvrijstelling of doordat de moedermaatschappij de 403-verklaring intrekt of de overblijvende aansprakelijkheid beëindigt, vormen samen het door mij bepleite uitgangspunt voor compensatie. Dit uitgangspunt is de rode draad van dit onderzoek. Aan de hand hiervan beantwoord ik diverse vraagstukken met betrekking tot de aansprakelijkheid van een moedermaatschappij op grond van de 403-verklaring. Daarbij onderzoek ik hoe verschillende wettelijke bepalingen moeten worden uitgelegd of gewijzigd, bezien vanuit de functie die deze aansprakelijkheid heeft bij de compensatie van de crediteuren en zodat is gewaarborgd dat de crediteuren niet in een nadeliger positie komen.

Het door mij bepleite uitgangspunt voor de compensatie van de crediteuren van een 403-maatschappij is samen te vatten in vier grondbeginselen:

- Het doel van de compensatie is om het nadeel ongedaan te maken dat crediteuren ondervinden omdat zij de jaarrekening van de 403-maatschappij niet kunnen inzien en niet (mede) aan de hand daarvan kunnen schatten hoe groot het risico is dat hun vordering niet (volledig) zal worden voldaan $(\S 3.3)$.

- De compensatie die een crediteur ontvangt, bestaat uit twee onderdelen die elkaar aanvullen: een vordering op de moedermaatschappij op grond van de 403-verklaring en de mogelijkheid om de geconsolideerde jaarrekening van de moedermaatschappij in te zien. Het feit dat een crediteur een vordering heeft op een debiteur - de 403-maatschappij - van wie hij

60. Zie bijvoorbeeld $\S 8.14$, of de voorwaarde ex art. 2:404 lid 3 sub a BW dat de groepsband tussen de moeder- en de 403-maatschappij is verbroken al of niet moet worden gehandhaafd als vereiste om de overblijvende aansprakelijkheid te kunnen beëindigen. 
de jaarrekening niet kan inzien, wordt gecompenseerd met een aanvullende vordering op een andere debiteur - de moedermaatschappij - van wie hij de geconsolideerde jaarrekening wel kan inzien (§ 3.4 en § 3.5).

- Een crediteur mag niet in een nadeliger positie komen door gebruikmaking van de jaarrekeningvrijstelling door de 403-maatschappij of doordat de moedermaatschappij de 403-verklaring intrekt of de overblijvende aansprakelijkheid beëindigt ( $§ 3.6 .1)$.

- Het moet zo veel mogelijk worden voorkomen dat een crediteur in een voordeliger positie komt door gebruikmaking van de jaarrekeningvrijstelling door de 403-maatschappij of doordat de moedermaatschappij de 403-verklaring intrekt of de overblijvende aansprakelijkheid beëindigt (§ 3.6.2).

\subsubsection{Een andere afweging is mogelijk}

Het door mij bepleite uitgangspunt voor de compensatie van de crediteuren van een 403-maatschappij volgt niet dwingend uit art. 2:403 BW. Een andere afweging is mogelijk. Er zou bijvoorbeeld kunnen worden betoogd dat niet alle crediteuren die nadeel ondervinden doordat ze de jaarrekening van de 403-maatschappij niet kunnen inzien, moeten worden gecompenseerd, maar alleen degenen die hierdoor 'onevenredig' worden benadeeld. Vervolgens zou kunnen worden verdedigd dat alleen die crediteuren onevenredig worden benadeeld van wie de vordering voortvloeit uit een rechtshandeling die de 403-maatschappij sinds de openbaarmaking van de laatste jaarrekening heeft verricht. In dat geval zou de aansprakelijkheid van een moedermaatschappij op grond van de 403-verklaring zo moeten worden uitgelegd, dat slechts deze crediteuren daar een beroep op kunnen doen. De crediteuren van wie de vordering voortvloeit uit een rechtshandeling die de 403-maatschappij daarvoor heeft verricht, krijgen geen aanvullende vordering op de moedermaatschappij en worden dus niet gecompenseerd voor het feit dat ze de jaarrekening van de 403-maatschappij niet kunnen inzien.

Een andere mogelijkheid is om de 403-aansprakelijkheid niet uit te leggen vanuit de functie om de crediteuren van de 403-maatschappij te compenseren, maar als een waarborg tegen misbruik door de moedermaatschappij. A-G Timmerman merkt in zijn conclusie bij het arrest UWV/Econcern op dat de ratio van de aansprakelijkheid van een moedermaatschappij op grond van een 403-verklaring wellicht daarin kan worden gezocht dat het voorkomt dat de moedermaatschappij kan profiteren van de eventuele omstandigheid dat de 403-maatschappij onvoldoende verhaal biedt zonder dat de crediteuren dit uit de jaarrekening kunnen opmaken. ${ }^{61}$ Vanuit die functie bezien, zou

61. A-G Timmerman in zijn conclusie onder nr. 2.8 bij HR 11 april 2014, NJ 2014/309, m.nt. Van Schilfgaarde (UWV/Econcern). Ook gepubliceerd in JOR 2014/199, m.nt. Van Dooren. 
de 403-aansprakelijkheid zo kunnen worden uitgelegd dat een crediteur zich slechts op de moedermaatschappij kan verhalen indien de 403-maatschappij zelf de schuld niet kan voldoen.

Bovengenoemde - en andere - benaderingen van de aansprakelijkheid van een moedermaatschappij op grond van de 403-verklaring komen in dit onderzoek aan de orde bij de bespreking van de verschillende standpunten ten aanzien van de te behandelen vraagstukken. Het speerpunt van dit onderzoek blijft echter de beantwoording van de vraag hoe de 403-aansprakelijkheid moet worden uitgelegd volgens het door mij bepleite uitgangspunt voor de compensatie van de crediteuren van de 403-maatschappij.

\subsection{Kanttekeningen bij het belang van een jaarrekening voor het inzicht van crediteuren}

De verplichting voor een rechtspersoon om over ieder boekjaar een jaarrekening op te maken en openbaar te maken, heeft verschillende doeleinden. Zonder uitputtend te willen zijn, wijs ik erop dat het bestuur en een eventuele $\mathrm{RvC}$ mede aan de hand daarvan rekening en verantwoording afleggen voor het gevoerde beleid, ${ }^{62}$ dat dit een hulpmiddel is ten behoeve van kapitaal- en vermogensbescherming, ${ }^{63}$ en dat het betrokkenen bij de rechtspersoon informeert zodat deze beter in staat zijn om bevoegdheden inzake de corporate governance uit te oefenen. ${ }^{64}$ Daarnaast stelt een jaarrekening verschillende overheidsinstanties - zoals de belastingdienst - in staat om hun taak uit te oefenen ${ }^{65}$ draagt het bij aan het vertrouwen van investeerders ${ }^{66}$ en aan de accuraatheid en efficiëntie van de prijsvorming op de effectenmarkt. ${ }^{67}$ Voor dit onderzoek richt ik mij echter vooral op de mogelijkheid die het opmaken en openbaar maken van een jaarrekening biedt aan de crediteuren en zij die eventueel een relatie met de rechtspersoon willen aangaan, om de jaarrekening bij het handelsregister op te vragen en zich op basis van de informatie daarin een

62. Winter 2001, p. 98, De Jong \& Nieuwe Weme 2006, p. 27, Hijink 2010, p. 108, Beckman \& Marseille 2013, p. 78, Pitlo/Raaijmakers 2017, p. 603-604, Van Schilfgaarde/Winter, Wezeman \& Schoonbrood 2017, p. 357 en Hijink \& In 't Veld 2019b, p. 208. Zie Hijink 2010, p. 111, die opmerkt dat de rol van de jaarrekening bij het afleggen van rekening en verantwoording niet moet worden overschat omdat deze slechts een weergave is van de financiële uitkomsten van het gevoerde beleid.

63. Beckman 2003, p. 51, De Jong \& Nieuwe Weme 2006, p. 29, Beckman \& Marseille 2013, p. 78-79, Pitlo/Raaijmakers 2017, p. 601 en Hijink \& In 't Veld 2019b, p. 208.

64. Hijink 2010, p. 127-130 en 135-136.

65. Pitlo/Raaijmakers 2017, p. 604.

66. Hijink 2010, p. 123-127.

67. De Jong \& Nieuwe Weme 2006, p. 28, Hijink 2010, p. 113-114 en Hijink \& In ’t Veld 2019b, p. 208. 
beeld te kunnen vormen omtrent de financiële positie van de rechtspersoon. ${ }^{68}$ Zij kunnen (mede) aan de hand daarvan een schatting maken van het risico dat zij lopen dat hun vordering niet (volledig) zal worden voldaan.

Het is opvallend dat laatstgenoemde functie van een jaarrekening voor de crediteuren van de rechtspersoon veelvuldig wordt onderschreven in de Nederlandse en Europese parlementaire geschiedenis en jurisprudentie, terwijl er in de literatuur juist twijfels over bestaan of het jaarlijks openbaar maken van een jaarrekening een nuttig middel is voor de crediteuren om inzicht te krijgen in de financiële positie van de rechtspersoon. De minister merkt bijvoorbeeld op dat de verplichting om een jaarrekening op te maken en openbaar te maken transparantie bevordert en bescherming biedt aan belanghebbenden. ${ }^{69}$ Aangezien een rechtspersoon zelfstandig aansprakelijk is voor zijn verplichtingen kan een crediteur zich slechts verhalen op het vermogen van de rechtspersoon zelf. Volgens de minister is het daarom voor een crediteur van belang dat hij de mogelijkheid heeft om inzicht te krijgen in de financiële positie van de rechtspersoon zodat hij kan schatten of zijn vordering zal worden voldaan of niet.

Een bepaling waaruit het belang van het openbaar maken van een jaarrekening blijkt, is art. 2:248 lid $2 \mathrm{BW}^{70}$ Als het bestuur van een BV in de drie jaren voorafgaand aan een faillissement een of meer keren niet aan haar openbaarmakingsplicht heeft voldaan, staat vast dat zij haar taak onbehoorlijk heeft vervuld en wordt vermoed dat dit een belangrijke oorzaak is van het faillissement. ${ }^{71}$ Tenzij een bestuurder dit laatste vermoeden kan ontkrachten door aannemelijk te maken dat andere feiten en omstandigheden een belangrijke oorzaak zijn geweest van het faillissement, ${ }^{72}$ is hij jegens de boedel hoofdelijk aansprakelijk voor het bedrag van de schulden voor zover deze niet door vereffening van de overige baten kunnen worden voldaan. Deze bepaling laat zien dat de wetgever veel waarde hecht aan de - veronderstelde - derdenbescherming voor crediteuren die uitgaat van de openbaarmaking van een jaarrekening.

68. Winter 2001, p. 98-99, Lennarts \& Schutte-Veenstra 2004, p. 114, De Jong \& Nieuwe Weme 2006, p. 29-30, Hijink 2010, p. 115-116, Beckman \& Marseille 2013, p. 78 en Pitlo/Raaijmakers 2017, p. 605.

69. Kamerstukken II 2008/09, 31508, 6, p. 5 en 6 (NnavhV).

70. Pitlo/Raaijmakers 2017, p. 600-601 en 605-606 en E.C.A. Nass 2019, p. 15.

71. Ik merk op dat op grond van art. 2:248 lid 2 BW een onbelangrijk verzuim van de openbaarmakingsplicht niet in aanmerking wordt genomen. Zie bijvoorbeeld HR 11 juni 1993, NJ 1993/713, m.nt. Maeijer (Kempers en Sarpers), r.o. 3.3, waar de Hoge Raad oordeelt dat een overschrijding van de openbaarmakingstermijn met enkele dagen een onbelangrijk verzuim is.

72. Zie Van Schilfgaarde/Winter, Wezeman \& Schoonbrood 2017, p. 209, waar wordt verwezen naar HR 23 november 2001, NJ 2002/95, m.nt. Maeijer (Mefigro), r.o. 3.7, ook gepubliceerd in JOR 2002/4, m.nt. Blanco Fernández. 
Ook in de considerans van de Eerste EEG-richtlijn wordt erop gewezen dat vennootschappen geen andere waarborg bieden dan het vermogen van de vennootschap zelf en dat de openbaarmaking van de jaarrekening derden in de gelegenheid stelt om hiervan kennis te nemen. ${ }^{73}$ Dit is later in de considerans van de Vierde EEG-richtlijn in soortgelijke bewoording herhaald. ${ }^{74}$

Dat crediteuren er belang bij hebben om de jaarrekening van een rechtspersoon te kunnen inzien, wordt ook in de jurisprudentie onderschreven. De Hoge Raad heeft in zijn arrest Naba beheer geoordeeld dat een crediteur eventueel als belanghebbende in de zin van art. 2:394 lid 7 BW nakoming kan vorderen van de openbaarmakingsplicht omdat zijn belang daarbij onder meer in kan zijn gelegen dat hij (mede) aan de hand van de jaarrekening wil vaststellen of de rechtspersoon verhaal biedt voor zijn vordering. ${ }^{75}$ Ook het Hof van Justitie van de Europese Gemeenschappen heeft in zijn arresten Centros en Inspire Art overwogen dat crediteuren zich kunnen beroepen op bepaalde jaarrekeningrechtelijke regels van gemeenschapsrecht die hen beschermen, waaronder de hierboven reeds aangehaalde Vierde EEG-richtlijn. ${ }^{76}$

In de literatuur worden kanttekeningen geplaatst bij het idee dat crediteuren aan de hand van een jaarrekening een goed beeld kunnen krijgen van de financiële positie van de rechtspersoon. Ik wijs op vijf punten.

Ten eerste zijn Hijink, Beckman en Marseille van mening dat de redenering dat de zelfstandige aansprakelijkheid van een rechtspersoon meebrengt dat deze een jaarrekening openbaar moet maken zodat derden aan de hand daarvan inzicht hebben in de financiële positie, niet opgaat. ${ }^{77}$ Als de informatie in een jaarrekening nuttig zou zijn voor crediteuren zou de openbaarmakingsplicht moeten gelden voor alle deelnemers aan het handelsverkeer, ongeacht of deze rechtspersoonlijkheid hebben of niet. Als een crediteur van een BV zich niet alleen op de BV zelf maar ook op het privévermogen van de aandeelhouders zou kunnen verhalen, is alsnog onbekend of dit privévermogen verhaal biedt aangezien de aandeelhouders zelf geen jaarrekening openbaar hoeven te maken.

73. Zie de derde en vierde overweging van de considerans van de Eerste EEG-richtlijn.

74. Zie de eerste en tweede overweging van de considerans van de Vierde EEG-richtlijn.

75. HR 3 februari 1988, NJ 1989/225, m.nt. Maeijer (Naba Beheer), r.o. 4.3. Zie ook Beckman 1997, p. 166, Assink/Slagter 2013/138.1 en Asser/Maeijer \& Kroeze 2-I* 2015/570. Zie ook Asser/Maeijer \& Kroeze 2-I* 2015/590, waar wordt opgemerkt dat een crediteur als zodanig niet kwalificeert als een belanghebbende in de zin van art. 2:448 lid 1 sub a BW in een jaarrekeningprocedure. Daarvoor zijn aanvullende omstandigheden vereist. Hierbij kan onder meer worden gedacht aan een crediteur die een winstafhankelijke vordering heeft op de desbetreffende rechtspersoon.

76. HvJ EG 9 maart 1999, NJ 2000/48, m.nt. Vlas (Centros), r.o. 36, ook gepubliceerd in JOR 1999/117, m.nt. Van Solinge en HvJ EG 30 september 2003, JOR 2003/249, m.nt. Vossestein (Inspire Art), r.o. 135.

77. Hijink 2010, p. 119-120 en Beckman \& Marseille 2013, p. 661. 
Rechtspersoonlijkheid alleen brengt volgens hen dus geen openbaarmakingsplicht met zich.

Dat de wetgever niet vereist dat natuurlijke personen die deelnemen aan het handelsverkeer een jaarrekening openbaar maken, kan mogelijk worden verklaard doordat het faillissement van een natuurlijk persoon in privé grotere gevolgen voor hem heeft, dan wanneer hij bijvoorbeeld bestuurder of aandeelhouder is van een rechtspersoon die failliet gaat. Een bestuurder of aandeelhouder verliest zijn functie in de rechtspersoon of raakt zijn aandelen kwijt, maar het faillissement van de rechtspersoon leidt niet direct tot het faillissement van de natuurlijke persoon zelf - dit neemt niet weg dat bijvoorbeeld een bestuurder van een failliete rechtspersoon wel aansprakelijk kan worden gesteld indien hij zijn taak onbehoorlijk heeft vervuld. Mogelijk heeft de wetgever het niet nodig geacht dat ook natuurlijke personen die deelnemen aan het handelsverkeer een jaarrekening openbaar moeten maken, omdat hij ervan uitgaat dat natuurlijke personen minder risico's nemen wanneer ze zelf aansprakelijk zijn dan in het geval dat ze namens een rechtspersoon handelen. Hierdoor zouden crediteuren minder risico lopen dat hun vordering onbetaald blijft waardoor de belasting voor een natuurlijk persoon om een jaarrekening openbaar te moeten maken niet opweegt tegen het voordeel voor de crediteuren dat zij (mede) aan de hand van deze jaarrekening kunnen schatten welk risico zij lopen dat hun vordering niet (volledig) wordt voldaan.

Een tweede kanttekening met betrekking tot het idee dat crediteuren aan de hand van een jaarrekening een goed beeld kunnen krijgen van de financiële positie van de rechtspersoon, heeft betrekking op de snelheid van het handelsverkeer. Dit kan meebrengen dat een partij geen tijd heeft om de jaarrekening van zijn wederpartij op te vragen en nauwkeurig onderzoek te doen naar de financiële positie. $^{78}$ Het is natuurlijk mogelijk om te weigeren een overeenkomst te tekenen totdat je de tijd hebt gehad om de jaarrekening van de wederpartij te bestuderen of om te eisen dat de wederpartij aanvullende informatie geeft over zijn financiële positie. Maar alleen partijen met een sterke onderhandelingspositie zullen dit kunnen afdwingen. Als bijvoorbeeld een bank een verzoek tot financiering in behandeling heeft, zal zij geen genoegen nemen met alleen de jaarrekening van de verzoeker. Zij zal aanvullende eisen stellen om een beter beeld te krijgen van de financiële positie van de verzoeker, zodat zij preciezer de risico's kan schatten die zij loopt als zij instemt met de financiering. ${ }^{79}$ In veel gevallen zullen partijen echter op korte termijn een besluit moeten

78. Commissie Vennootschapsrecht 1973, p. 5 en Houwen, Schoonbrood-Wessels \& Schreurs 1993, p. 769. Zie ook L. Timmerman 1990, p. 16, die opmerkt dat van een 'normale' crediteur niet mag worden verwacht dat hij de jaarrekening van een rechtspersoon raadpleegt voordat hij een overeenkomst met deze rechtspersoon aangaat.

79. Pitlo/Raaijmakers 2017, p. 601. 
nemen zonder dat zij de jaarrekening van de wederpartij uitgebreid hebben kunnen bestuderen en aanvullende informatie hebben kunnen verzamelen.

Een derde kanttekening is dat de informatie in een jaarrekening is verouderd. ${ }^{80}$ De balans geeft een overzicht van de bezittingen, schulden en het eigen vermogen van de rechtspersoon aan het einde van het boekjaar en de winst- en verliesrekening toont het resultaat over het desbetreffende boekjaar. Op grond van art. 2:394 lid $3 \mathrm{BW}$ heeft een rechtspersoon echter tot twaalf maanden na afloop van het boekjaar de tijd om de jaarrekening openbaar te maken - voor een beursgenoteerde vennootschap geldt dat deze uiterlijk vier maanden na afloop van het boekjaar de jaarrekening algemeen verkrijgbaar moet stellen. ${ }^{81}$ Uit een onderzoek van Vergoossen en Meershoek naar de jaarrekeningen van 1067 grote en middelgrote niet-beursgenoteerde NV's en BV's over het boekjaar 2015, blijkt dat de onderzochte grote vennootschappen gemiddeld 223 dagen na de balansdatum de jaarrekening hadden gedeponeerd bij het handelsregister en de middelgrote vennootschappen gemiddeld 232 dagen na de balansdatum. ${ }^{82}$

Op het moment dat de jaarrekening openbaar wordt gemaakt, zijn de cijfers dus al verouderd en deze zullen door verloop van tijd alleen maar meer verouderd raken. Beckman vergelijkt het nemen van een beslissing op basis van de gegevens uit een jaarrekening met een sprong in het duister. ${ }^{83}$ Raaijmakers meent dat een partij naast het beoordelen van de cijfers in de jaarrekening ook altijd aanvullend onderzoek moet doen naar de gegoedheid van zijn wederpartij. ${ }^{84}$ Als bijvoorbeeld een bank een belangrijk krediet wil verlenen aan een rechtspersoon, handelt deze volgens Raaijmakers nogal lichtzinnig als hij deze beslissing slechts zou baseren op de jaarrekening.

In de literatuur zijn enkel voorstellen gedaan om (deels) tegemoet te komen aan het bezwaar van de verouderde cijfers. Ten eerste zou de huidige termijn van twaalf maanden om een jaarrekening openbaar te maken, kunnen worden verkort. ${ }^{85}$ Ik sluit mij aan bij Schutte-Veenstra die in 2005 al betoogde dat het gezien de technologische ontwikkelingen mogelijk is om een jaarrekening eerder openbaar te maken - dit argument heeft sindsdien alleen maar aan kracht gewonnen. ${ }^{86}$ Daarnaast merkt Winter op dat het zelfs mogelijk moet zijn om

80. Houwen, Schoonbrood-Wessels \& Schreurs 1993, p. 768, Winter 2001, p. 99, Beckman 2003, p. 63, Beckman 2004, p. 24, Lennarts \& Schutte-Veenstra 2004, p. 114, Schutte-Veenstra 2005, p. 27, Lennarts 2006, p. 26, De Jong \& Nieuwe Weme 2006, p. 30, Hijink 2010, p. 121-122 en Pitlo/Raaijmakers 2017, p. 601 en 605-606.

81. Zie art. 5:25c lid $1 \mathrm{Wft}$.

82. Vergoossen \& Meershoek 2018, p. 98-101.

83. Beckman 2004, p. 24.

84. Pitlo/Raaijmakers 2017, p. 601 en 605-606.

85. L. Timmerman 2003, p. 42, Schutte-Veenstra 2005, p. 27 en Lennarts 2006, p. 27.

86. Schutte-Veenstra 2005, p. 27. Zie ook Winter 2001, p. 98. 
meerdere keren per jaar een verkorte balans en winst- en verliesrekening openbaar te maken - in aanvulling op het jaarlijks openbaar maken van een jaarrekening. ${ }^{87}$ Deze twee aanpassingen zouden kunnen worden bereikt door enkele bepalingen met betrekking tot de openbaarmakingsplicht voor beursvennootschappen van toepassing te verklaren op alle rechtspersonen voor wie de openbaarmakingsplicht geldt. Ten eerste zou art. 5:25c lid $1 \mathrm{Wft}$ van toepassing kunnen worden verklaard. Op grond van deze bepaling dient een beursvennootschap de jaarrekening uiterlijk vier maanden na afloop van het boekjaar algemeen verkrijgbaar te stellen. Hetzelfde geldt voor art. 5:25d lid $1 \mathrm{Wft}$ op grond waarvan een beursvennootschap zo snel mogelijk, maar uiterlijk drie maanden na afloop van de eerste zes maanden van het boekjaar de halfjaarlijkse financiële verslaggeving algemeen verkrijgbaar moet stellen. Tot slot zou de op 1 januari 2016 afgeschafte verplichting voor beursvennootschappen om kort gezegd over het eerste en derde kwartaal van het boekjaar een tussentijdse verklaring op te stellen met betrekking tot de financiële positie en de belangrijkste gebeurtenissen, weer kunnen worden ingevoerd en van toepassing kunnen worden verklaard op alle rechtspersonen voor wie de openbaarmakingsplicht geldt. $^{88}$

Ik merk op dat bovengenoemde extra verplichtingen met betrekking tot de openbaarmakingsplicht vanzelfsprekend zouden leiden tot een administratieve lastenverzwaring voor rechtspersonen. De minister heeft laatstgenoemde verplichting dat een beursvennootschap over het eerste en derde kwartaal van het boekjaar een tussentijdse verklaring moet opstellen met betrekking tot de financiële positie en de belangrijkste gebeurtenissen, zelfs bewust geschrapt met het doel om de administratieve lasten voor beursvennootschappen te verlichten. ${ }^{89}$ Het is uiteindelijk aan de wetgever om een afweging te maken tussen het inzicht dat een rechtspersoon aan derden moet bieden met betrekking tot haar vermogenstoestand, en de administratieve lasten die dit voor de rechtspersoon meebrengt.

Een vierde kanttekening waar ik op wijs, is het toegenomen belang van immateriële activa. Onder meer Hijink en In 't Veld wijzen er terecht op dat het vermogen van een rechtspersoon aanvankelijk in hoofdzaak werd bepaald door materiële activa zoals onroerend goed, machines en voorraden, maar dat tegenwoordig in toenemende mate belang toekomt aan immateriële activa zoals patenten, octrooien, goodwill en reputatie. ${ }^{90}$ Dergelijke immateriële activa zijn

87. Winter 2001, p. 100-102.

88. Deze verplichting was opgenomen in art. 5:25e lid $1 \mathrm{Wft}$ (zie Stb. 2008, 476), maar is per 1 januari 2016 komen te vervallen (zie $S t b .2016,31$ ).

89. Zie Kamerstukken II 2014/15, 34232, 3, p. 20 (MvT).

90. Brouwer 2019, p. 216-217, Hijink \& In 't Veld 2019a, p. 6 en Hijink \& In 't Veld 2019b, p. 209-2010. 
naar hun aard moeilijk(er) te waarderen wat het lastiger maakt om het vermogen van de rechtspersoon te bepalen.

Een vijfde en laatste kanttekening met betrekking tot het belang van een jaarrekening voor het inzicht van crediteuren in de financiële positie van de rechtspersoon, heeft betrekking op de informatie in de jaarrekening ten aanzien van het toekomstige bestuursbeleid en de te verwachten continuiteit(srisico's). Deze informatie is belangrijk voor crediteuren omdat hun vorderingen (deels) onbetaald zullen blijven als de rechtspersoon failliet gaat. Naar huidig recht moeten op grond van art. 2:391 BW in het bestuursverslag mededelingen worden gedaan omtrent de te verwachten gang van zaken in de toekomst. ${ }^{91}$ Tenzij gewichtige belangen zich daartegen verzetten, dient daarbij in het bijzonder aandacht te worden besteed aan de investeringen, de financiering, de personeelsbezetting en de omstandigheden waarvan de ontwikkeling van de omzet en de rentabiliteit afhankelijk is. Daarnaast moeten er mededelingen worden gedaan over de werkzaamheden op het gebied van onderzoek en ontwikkeling.

Bier, Hijink en Brouwer pleiten ervoor om de verplichting tot het doen van mededelingen omtrent het toekomstige bestuursbeleid en de te verwachten continuïteit(srisico's) uit te breiden. ${ }^{92}$ Brouwer stelt bijvoorbeeld voor om aan het bestuursverslag een paragraaf toe te voegen die vergelijkbaar is met de zogenoemde viability statement uit het Verenigd Koninkrijk: een toekomstbestendigheidsparagraaf. ${ }^{93}$ Daarin moet dan volgens hem informatie worden opgenomen over onder meer het bedrijfs- en verdienmodel van de rechtspersoon, de kansen en bedreigingen voor dit model in de toekomst, de wijze hoe daarop wordt ingespeeld en de levensvatbaarheid van de rechtspersoon. Om ervoor te zorgen dat deze informatie eenvoudig(er) ter beschikking staat aan derden betoogt Brouwer tot slot, evenals Vergoossen en Meershoek, dat de mogelijkheid ex art. 2:394 lid $4 \mathrm{BW}$ wordt geschrapt dat de deponering van het bestuursverslag achterwege kan blijven indien de rechtspersoon deze ten kantore ter inzage houdt en derden op verzoek een volledig of gedeeltelijk afschrift daarvan wordt verstrekt tegen ten hoogste de kostprijs. ${ }^{94}$

In verband met bovengenoemde kanttekeningen zou kunnen worden betoogd dat de informatie in een jaarrekening onvoldoende bijdraagt aan het kunnen

91. Zie Pitlo/Raaijmakers 2017, p. 625-626.

92. Bier 2006, p. 47-48, Hijink 2010, p. 112 en Brouwer 2019, p. 218.

93. Zie ook het White paper Continuïteit p. 15-17 van de Stuurgroep Publiek Belang van de Koninklijke Nederlandse Beroepsorganisaties voor Accountants, waarin wordt voorgesteld om art. 2:391 BW aan te passen zodat in het bestuursverslag een toekomstbestendigheidsparagraaf moet worden opgenomen.

94. Vergoossen \& Meershoek 2018, p. 107 en Brouwer 2019, p. 219. Zie ook het White paper Continuiteit p. 17 van de Stuurgroep Publiek Belang van de Koninklijke Nederlandse Beroepsorganisaties voor Accountants. 
maken van een schatting van het risico dat de rechtspersoon de vordering van een crediteur niet (volledig) zal voldoen, om te rechtvaardigen dat de crediteur moet worden gecompenseerd als hij de jaarrekening niet kan inzien. Dit zou meebrengen dat als een 403-maatschappij gebruikmaakt van de jaarrekeningvrijstelling van het groepsregime en geen jaarrekening openbaar maakt, de crediteuren niet hoeven te worden gecompenseerd. De aansprakelijkstelling van de moedermaatschappij op grond van de 403-verklaring zou dan - als onderdeel van de compensatie - achterwege kunnen blijven. Ik kan mij echter niet vinden in deze redenering.

Ik onderken dat naar huidig recht crediteuren zich op basis van een jaarrekening geen volledig en up-to-date beeld kunnen vormen omtrent de financiële positie van de rechtspersoon en de te verwachten ontwikkelingen voor de toekomst. Daarnaast juich ik de oproep van Hijink en In 't Veld toe voor een fundamentele discussie ten aanzien van financiële verslaggeving. ${ }^{95} \mathrm{Zij}$ vragen zich af of de periodieke financiële verslaggeving in haar huidige vorm (nog) wel voldoende aansluit bij de behoeften van de gebruikers en noemen als mogelijk alternatief dat rechtspersonen op een continue basis verslag moeten doen van de toekomstbestendigheidsrisico's en -kansen. Naar mijn mening staan de genoemde kanttekeningen met betrekking tot het belang van een jaarrekening voor een crediteur om (mede) aan de hand daarvan te kunnen schatten hoe groot het risico is dat zijn vordering niet (volledig) zal worden voldaan en de mogelijke wijzigingen van het jaarrekeningregime om (deels) aan deze bezwaren tegemoet te komen, echter los van het vraagstuk van de compensatie van een crediteur in verband met de jaarrekeningvrijstelling voor een 403-maatschappij. Ik licht dit toe.

Ik heb eerder opgemerkt dat een crediteur wordt gecompenseerd voor het feit dat hij een vordering heeft op een debiteur - de 403-maatschappij - van wie hij de jaarrekening niet kan inzien, met een aanvullende vordering op een andere debiteur - de moedermaatschappij - van wie hij de geconsolideerde jaarrekening wel kan inzien. ${ }^{96}$ Het is aan de wetgever om voor te schrijven aan welke eisen de financiële verslaggeving van een rechtspersoon moet voldoen. Daarbij moeten verschillende afwegingen worden gemaakt, zoals de (te verwachten) administratieve belasting voor de rechtspersoon die de informatie moet delen, of een rechtspersoon periodiek dan wel op continue basis informatie bekend moet maken, en of de te delen informatie retrospectief - en zo ja binnen welke termijn na afloop van de desbetreffende periode - of prospectief moet zijn. Tot slot kan ervoor worden gekozen om niet langer een 'kwantitatieve' verslaggeving voor te schrijven waarbij het doel is om de (financiële) positie en prestaties van rechtspersonen weer te geven op een wijze die onderling gelijkwaardig en vergelijkbaar is, maar in plaats daarvan te kiezen voor een 'kwalitatieve'

95. Hijink \& In ’t Veld 2019a, p. 7 en Hijink \& In ’t Veld 2019b, p. 211 en 221-222.

96. Zie $\S 3.4$. 
verslaggeving die betrekking heeft op factoren en risico's die specifiek zijn gerelateerd aan de desbetreffende rechtspersoon. ${ }^{97}$

De vorm van de financiële verslaggeving doet mijns inziens echter niet af aan de werking van de compensatie voor de crediteuren van een 403-maatschappij. Van belang is dat een crediteur de financiële verslaggeving van de 403-maatschappij - in de huidige of een andere vorm - niet kan inzien, en dat hij daarvoor wordt gecompenseerd met een aanvullende vordering op de moedermaatschappij van wie hij wel de financiële verslaggeving - in de huidige of een andere vorm - kan inzien. Het gaat er dus om dat een crediteur wordt gecompenseerd voor het niet kunnen inzien van de financiële verslaggeving van de ene debiteur, met een aanvullende vordering op een andere debiteur van wie hij de financiële verslaggeving wel kan inzien.

De vraag die ik met dit onderzoek beantwoord, is hoe de regeling met betrekking tot de aansprakelijkheid van een moedermaatschappij op grond van de 403-verklaring moet worden uitgelegd of gewijzigd, bezien vanuit de functie die deze aansprakelijkheid heeft bij de compensatie van de crediteuren van de 403-maatschappij en zodat is gewaarborgd dat de crediteuren niet in een nadeliger positie komen. De discussie of, en zo ja hoe, het jaarrekeningenrecht moet worden aangepast zodat een crediteur (mede) aan de hand van een jaarrekening beter in staat is om te schatten hoe groot het risico is dat de rechtspersoon een vordering niet (volledig) zal voldoen, is een apart vraagstuk dat de functie van de 403-aansprakelijkheid bij de compensatie van de crediteuren niet verandert. Om die reden laat ik dit in het vervolg van dit onderzoek verder rusten.

\subsection{Conclusie}

Als een 403-maatschappij gebruikmaakt van de jaarrekeningvrijstelling van het groepsregime kunnen haar crediteuren de jaarrekening niet inzien. Zij kunnen daardoor niet (mede) aan de hand van de jaarrekening schatten hoe groot het risico is dat hun vordering niet (volledig) zal worden voldaan (§ 3.2 en $\S 3.3$ ). De compensatie die een crediteur hiervoor ontvangt, bestaat uit twee onderdelen die elkaar aanvullen. Ten eerste krijgt de crediteur op grond van de 403-verklaring ook een vordering op de moedermaatschappij. Daarnaast heeft hij de mogelijkheid om de geconsolideerde jaarrekening van de moedermaatschappij in te zien. Het feit dat een crediteur een vordering heeft op een debiteur - de 403-maatschappij - van wie hij de jaarrekening niet kan inzien, wordt gecompenseerd met een aanvullende vordering op een

97. Zie Hijink \& In ’t Veld 2019b, p. 204-205, die spreken van digitale en analoge verslaggeving. 
andere debiteur - de moedermaatschappij - van wie hij de geconsolideerde jaarrekening wel kan inzien. De crediteur heeft geen garantie dat zijn vordering volledig zal worden voldaan. Hij wordt gecompenseerd doordat hij de mogelijkheid heeft om de geconsolideerde jaarrekening van de moedermaatschappij in te zien en hij vervolgens zelf (mede) aan de hand daarvan kan schatten hoe groot het risico is dat zijn vordering niet (volledig) zal worden voldaan. Het is uiteindelijk aan de crediteur zelf of hij dit risico accepteert en al of niet een relatie met de 403-maatschappij aangaat, dan wel dat hij een bestaande relatie al of niet continueert ( $\$ 3.4$ en $\S 3.5)$.

Op grond van art. 2:403 BW is een van de voorwaarden voor de 403-maatschappij om gebruik te mogen maken van de jaarrekeningvrijstelling dat de geconsolideerde jaarrekening van de moedermaatschappij is gedeponeerd bij het handelsregister. Het is niet verplicht dat (ook) de enkelvoudige jaarrekening van de moedermaatschappij is gedeponeerd. Crediteuren kunnen op basis van de informatie in de enkelvoudige jaarrekening beter inschatten hoe groot het risico is dat de moedermaatschappij de vordering op grond van de 403-verklaring niet (volledig) zal voldoen, dan aan de hand van de informatie in de geconsolideerde jaarrekening. Voor een Nederlandse moedermaatschappij geldt dat zij op grond van art. 2:394 BW verplicht is om een enkelvoudige jaarrekening openbaar te maken, wat betekent dat crediteuren deze jaarrekening kunnen inzien als ze bij het handelsregister de informatie met betrekking tot de moedermaatschappij opvragen. Voor een moedermaatschappij naar buitenlands recht geldt de verplichting ex art. 2:394 BW echter niet, waardoor het afhankelijk is van het op de desbetreffende moedermaatschappij toepasselijke recht, of deze al of niet verplicht is om een enkelvoudige jaarrekening openbaar te maken. Daarnaast geldt dat als een buitenlandse moedermaatschappij een enkelvoudige jaarrekening moet deponeren, de crediteuren van de 403-maatschappij deze jaarrekening moeten opvragen bij het equivalent van het Nederlandse handelsregister van het desbetreffende land. Om te waarborgen dat crediteuren altijd eenvoudig inzicht kunnen hebben in de enkelvoudige jaarrekening van de moedermaatschappij moet art. 2:403 BW naar mijn mening op twee plekken worden gewijzigd. Ten eerste moet de deponering van de enkelvoudige jaarrekening van de moedermaatschappij als constitutief vereiste voor het gebruikmaken van de jaarrekeningvrijstelling door de 403-maatschappij aan art. 2:403 BW worden toegevoegd. Daarnaast moet mijns inziens in deze bepaling worden opgenomen dat de 403-maatschappij de enkelvoudige jaarrekening van de moedermaatschappij moet deponeren zodat crediteuren deze kunnen inzien als ze bij het handelsregister de informatie over de 403-maatschappij opvragen - dit doet overigens niet af aan een op de moedermaatschappij rustende verplichting om zelf de jaarrekening te deponeren volgens het op haar van toepassing zijnde jaarrekeningregime (§ 3.4.2). 
Aangezien de crediteuren geen invloed hebben op de keuze van de 403-maatschappij om gebruik te maken van de jaarrekeningvrijstelling, betoog ik dat zij hierdoor niet in een nadeliger positie mogen komen in vergelijking met de situatie dat de 403-maatschappij geen gebruik zou maken van deze vrijstelling. Hetzelfde geldt met betrekking tot de intrekking van de 403-verklaring en de beëindiging van de overblijvende aansprakelijkheid door de moedermaatschappij. Een crediteur mag mijns inziens daardoor niet in een nadeliger positie komen in vergelijking met de situatie dat deze verklaring niet zou zijn ingetrokken, respectievelijk dat de aansprakelijkheid niet zou zijn beëindigd. Omgekeerd moet naar mijn mening ook zo veel mogelijk worden voorkomen dat een crediteur in een voordeliger positie komt doordat de 403-maatschappij gebruikmaakt van de jaarrekeningvrijstelling of doordat de moedermaatschappij de 403-verklaring intrekt of de overblijvende aansprakelijkheid beëindigt (§ 3.6).

De door mij in dit hoofdstuk gegeven uiteenzetting van de compensatie van de crediteuren van een 403-maatschappij en het standpunt dat zij niet in een nadeliger positie mogen komen doordat de 403-maatschappij gebruikmaakt van de jaarrekeningvrijstelling of doordat de moedermaatschappij de 403-verklaring intrekt of de overblijvende aansprakelijkheid beëindigt, vormen samen het door mij bepleite uitgangspunt voor compensatie. Aan de hand van dit uitgangspunt beantwoord ik in het vervolg van dit onderzoek diverse vraagstukken met betrekking tot de aansprakelijkheid van een moedermaatschappij op grond van de 403-verklaring. Ik onderzoek hoe verschillende wettelijke bepalingen moeten worden uitgelegd of gewijzigd, bezien vanuit de functie die deze aansprakelijkheid heeft bij de compensatie van de crediteuren en zodat is gewaarborgd dat de crediteuren niet in een nadeliger positie komen $(\S 3.7)$.

Tot slot heb ik in dit hoofdstuk gewezen op verschillende kanttekeningen met betrekking tot het belang van een jaarrekening voor het inzicht van een crediteur in de financiële positie van de rechtspersoon. Ik onderken dat naar huidig recht crediteuren op basis van een jaarrekening geen volledig en up-to-date beeld kunnen krijgen ten aanzien van de financiële positie van de rechtspersoon en de te verwachten ontwikkelingen voor de toekomst. Deze kanttekeningen staan echter los van onderhavig onderzoek naar hoe de regeling met betrekking tot de 403-aansprakelijkheid van een moedermaatschappij moet worden uitgelegd of gewijzigd, bezien vanuit de functie die deze aansprakelijkheid heeft bij de compensatie van de crediteuren en zodat is gewaarborgd dat de crediteuren niet in een nadeliger positie komen $(\S 3.8)$. 



\section{Hoofdstuk 4. De materiële reikwijdte van de 403-aansprakelijkheid}

\subsection{Inleiding}

Over de precieze reikwijdte van de aansprakelijkheid op grond van een 403-verklaring bestaat veel onduidelijkheid. Een van de vragen is voor welke 'soort' schulden een moedermaatschappij op grond van een 403-verklaring aansprakelijk is. Dit betreft de zogenoemde 'materiële' reikwijdte van de 403-aansprakelijkheid. ${ }^{1}$

Op grond van art. 2:403 lid 1 sub f BW dient een moedermaatschappij zich uit hoofde van een 403-verklaring hoofdelijk aansprakelijk te stellen voor de uit rechtshandelingen van de 403-maatschappij voortvloeiende schulden. Uit deze bepaling zijn drie elementen op te maken met betrekking tot de materiële reikwijdte van de 403-aansprakelijkheid: 'schulden', 'rechtshandelingen' en 'voortvloeien'. In dit hoofdstuk onderzoek ik allereerst hoe deze drie elementen moeten worden uitgelegd ( $\$ 4.2$ tot en met $\S 4.4$ ). Vervolgens ga ik nader in op verschillende schulden ten aanzien waarvan in de literatuur of de jurisprudentie de vraag is gesteld of deze al of niet onder de reikwijdte van de 403-aansprakelijkheid vallen. Met betrekking tot iedere schuld ga ik na of de moedermaatschappij naar huidig recht hiervoor op grond van de 403-verklaring aansprakelijk is en of zij dit volgens het door mij bepleite uitgangspunt voor compensatie zou moeten zijn ( $§ 4.5)$. Aan de hand van de drie onderzochte elementen en de behandelde voorbeelden, kom ik vervolgens tot een algemene regel ter beoordeling of een schuld voortvloeit uit een rechtshandeling van de 403-maatschappij en daarmee onder de materiële reikwijdte van de 403-aansprakelijkheid valt (§ 4.6).

Tot slot komen twee onderwerpen aan bod die samenhangen met het vraagstuk van de materiële reikwijdte van de 403-aansprakelijkheid. Ten eerste onderzoek ik of een aan een vordering op de 403-maatschappij verbonden voorrecht

1. De term 'materiële' reikwijdte van de 403-aansprakelijkheid kan verwarrend zijn omdat er geen 'formele' reikwijdte is. Aangezien de term materiële reikwijdte in de literatuur algemeen is aanvaard, gebruik ik deze ook. Zie onder meer Bartman 2002, p. 23, De Neve 2002, p. 236, Blom 2005, p. 178, De Neve 2011, p. 48-49, Rongen 2012, p. 1299-1302, Van der Sangen 2017, p. 209, Van der Kraan 2018b, p. 31, Van Zoest 2019, p. 22 en Bartman, Dorresteijn \& Olaerts 2020, p. 217. 


\section{HOOFDSTUK 4}

of achterstelling, meebrengt dat ook de vordering op de moedermaatschappij is bevoorrecht, respectievelijk is achtergesteld ( $\$ 4.7$ en $\S 4.8$ ). Daarnaast ga ik in op de situatie dat een 403-maatschappij een overeenkomst aangaat met een crediteur, ter afwikkeling van een schuld uit de wet. Ik onderzoek of de 403-aansprakelijkheid zo moet worden uitgelegd dat aangezien de overeenkomst betrekking heeft op een schuld uit de wet, de schulden die uit die overeenkomst voorvloeien, zijn terug te voeren tot de wet en daarom niet onder de reikwijdte van de 403-aansprakelijkheid vallen (§ 4.9).

\subsection{Het eerste element: schulden}

In de literatuur wordt algemeen aangenomen dat de term 'schulden' uit art. 2:403 lid 1 sub f BW niet slechts ziet op geldschulden maar op alle verplichtingen van de 403-maatschappij. ${ }^{2}$ Ik sluit mij daarbij aan. Hoewel de term schulden op enkele andere plekken in titel 9 van Boek 2 BW wordt gebruikt in de zin van geldschulden - zie bijvoorbeeld art. 2:375 BW en art. 2:388 lid 2 BW -, merkt Nass terecht op dat art. 2:403 BW op dit punt moet worden uitgelegd aan de hand van de in art. 37 van de richtlijn jaarrekeningen gehanteerde term 'verplichtingen'. ${ }^{3}$ Dit houdt in dat een moedermaatschappij zich op grond van de 403-verklaring niet alleen aansprakelijk dient te stellen voor de in geld luidende verplichtingen van de 403-maatschappij, maar bijvoorbeeld ook voor verplichtingen tot het leveren van goederen of diensten. Deze ruime uitleg van de term schulden sluit aan bij het door mij bepleite uitgangspunt voor compensatie. Zowel crediteuren met een vordering in geld - zoals de vordering van een werknemer tot betaling van het salaris - als crediteuren met een niet in geld luidende vordering - zoals de vordering van een afnemer tot het leveren van goederen - hebben er belang bij om de jaarrekening van de 403-maatschappij te kunnen inzien zodat zij (mede) aan de hand daarvan kunnen schatten hoe groot het risico is dat de vordering niet (volledig) zal worden voldaan. Beide groepen crediteuren moeten daarom worden gecompenseerd als deze mogelijkheid ontbreekt. Zij moeten zich op grond van de 403-verklaring (ook) op de moedermaatschappij kunnen verhalen van wie zij de geconsolideerde jaarrekening wel kunnen inzien. ${ }^{4}$ Onjuist zijn mijns inziens daarom de uitspraken van de Rechtbank Rotterdam en de Rechtbank Gelderland uit 2013,

2. Beckman 1987, p. 531, Beckman 1995a, p. 293, Van Solinge 2004, p. 277, Blom 2005, p. 178, Niels 2010, p. 34, Beckman 2014a, p. 157, Van Zoest 2019, p. 23, E.C.A. Nass 2019, p. 97 en 199-200, Bartman, Dorresteijn \& Olaerts 2020, p. 218 en Reimers, in: GS Rechtspersonen, art. 2:403 BW, aant. 9. Zie overigens Reimers, in: GS Rechtspersonen, art. 2:404 BW, aant. 4, waar hij met betrekking tot de gevolgen van de intrekking van de 403-verklaring een afwijkend standpunt inneemt en betoogt dat de term schulden in art. 2:403 BW slechts ziet op geldschulden en niet op niet in geld luidende verplichtingen.

3. E.C.A. Nass 2019, p. 97 en 200.

4. Zie $\S 3.4 .1$. 
respectievelijk 2017 waar zij oordelen dat de moedermaatschappij op grond van de 403-verklaring slechts aansprakelijk is voor de geldschulden van de 403-maatschappij en niet ook voor andere verplichtingen. ${ }^{5} \mathrm{Ik}$ meen met onder meer Beckman dat het wenselijk is dat ter verduidelijking van de reikwijdte van de 403-aansprakelijkheid, de term schulden in art. 2:403 lid 1 sub f BW wordt vervangen door de term verplichtingen. ${ }^{6}$

Niels wijst erop dat een moedermaatschappij doorgaans een holdingmaatschappij is die zich niet bezighoudt met de activiteiten van haar groepsmaatschappij(en). ${ }^{7}$ Hoewel een moedermaatschappij op grond van de 403 -verklaring (ook) ansprakelijk is voor niet in geld luidende verplichtingen van de 403-maatschappij, zal zij dus niet altijd in staat zijn om aan een verplichting te voldoen. Ik merk op dat de moedermaatschappij in dat geval kan proberen om een andere partij die daar wel toe in staat is, deze verplichting te laten voldoen - bijvoorbeeld een andere groepsmaatschappij met vergelijkbare activiteiten als de 403-maatschappij. Blijft de moedermaatschappij echter in gebreke en kan zij geen partij vinden die bereid is de verplichting te voldoen, dan kan de crediteur een vordering tot schadevergoeding instellen tegen de moedermaatschappij. ${ }^{8}$ Overigens merk ik op dat als de crediteur de moedermaatschappij aansprakelijk heeft gesteld voor een niet in geld luidende verplichting die deze niet kan nakomen en de 403-maatschappij vervolgens kenbaar maakt de verplichting te zullen voldoen, de crediteur de nakoming door de 403-maatschappij niet kan weigeren. ${ }^{9}$

\subsection{Het tweede element: rechtshandeling}

\subsubsection{Rechtshandelingen}

De term 'rechtshandeling' uit art. 2:403 lid 1 sub f BW ziet zowel op meerzijdige als eenzijdige rechtshandelingen van de 403 -maatschappij. ${ }^{10}$ Een voorbeeld van een meerzijdige rechtshandeling is als de 403-maatschappij een arbeidsovereenkomst aangaat met een werknemer. Een eenzijdige rechtshandeling is bijvoorbeeld een garantstelling door de 403-maatschappij voor de verplichtingen van een derde.

5. Rb. Rotterdam 24 december 2013, JIN 2014/44, m.nt. Van der Kraan (Vodafone Libertel/ $K P N$ ), r.o. 4.2 en Rb. Gelderland 19 juli 2017, ECLI:NL:RBGEL:2017:4157 (ZZG zorggroep/SITA recycling), r.o. 4.8. Evenzo Raad van Arbitrage voor de Bouw 14 januari 2013, nr. 34.225 , r.o. 22.

6. Beckman 1995a, p. 472, Van Solinge 2004, p. 277 en De Neve 2011, p. 49.

7. Niels 2010, p. 27.

8. Beckman 1995a, p. 293-294, Niels 2010, p. 27, Zwemmer 2011, p. 224 en Bartman, Dorresteijn \& Olaerts 2020, p. 218.

9. Houwen, Schoonbrood-Wessels \& Schreurs 1993, p. 830 en E.C.A. Nass 2019, p. 193.

10. Houwen, Schoonbrood-Wessels \& Schreurs 1993, p. 848, Bartman 2002, p. 23 en Bartman in zijn annotatie onder Hof Den Haag 5 september 2017, JOR 2018/2 (Hoad/Hilson). 
Naar mijn mening kwalificeert ook een stilzwijgende rechtshandeling van de 403-maatschappij als een rechtshandeling in de zin van art. 2:403 lid 1 sub $\mathrm{f}$ BW. Hierbij kan onder meer worden gedacht aan een stilzwijgende bekrachtiging van een rechtshandeling die een derde op grond van een ontoereikende volmacht in naam van de 403-maatschappij heeft verricht. ${ }^{11}$ Een rechtshandeling kan bijvoorbeeld stilzwijgend zijn bekrachtigd als de 403-maatschappij voldoet aan de verplichtingen die uit de desbetreffende rechtshandeling voortvloeien. ${ }^{12}$ De tekst van art. 2:403 lid $1 \mathrm{sub} \mathrm{f} \mathrm{BW}$ laat mijns inziens geen ruimte om schulden die voortvloeien uit een stilzwijgende rechtshandeling van de 403-maatschappij niet onder de reikwijdte van de 403-aansprakelijkheid te scharen. Ook de functie van de 403-aansprakelijkheid bij de compensatie van de crediteuren van de 403-maatschappij geeft hiervoor geen aanleiding. Zowel bij schulden die uit een uitdrukkelijke als die uit een stilzwijgende rechtshandeling voortvloeien, ontbreekt het de crediteur aan de mogelijkheid om de jaarrekening van de 403-maatschappij in te zien. Ik meen daarom dat de crediteuren ook in beide gevallen moeten worden gecompenseerd.

Tot slot wijs ik op een uitspraak van de Rechtbank Arnhem waar de vraag aan de orde kwam of een stilzwijgende verlenging van een huurovereenkomst een aparte rechtshandeling is in de zin van art. 2:403 lid 1 sub f BW. ${ }^{13}$ Anders gezegd; het is de vraag of de huurpenningen die de 403-maatschappij is verschuldigd vanaf de stilzwijgende verlenging, nog steeds voortvloeien uit de huurovereenkomst zelf of uit de verlenging. In casu heeft de moedermaatschappij de 403-verklaring ingetrokken tussen het aangaan van de huurovereenkomst door de 403-maatschappij en de stilzwijgende verlenging daarvan. $\mathrm{Na}$ de intrekking is de moedermaatschappij slechts aansprakelijk voor de schulden die voortvloeien uit de rechtshandelingen die de 403-maatschappij heeft verricht tot het moment dat de moedermaatschappij een beroep kan doen op de intrekking. ${ }^{14}$ Indien de huurpenningen vanaf de stilzwijgende verlenging van de huurovereenkomst uit deze verlenging zouden voortvloeien - in plaats van uit de huurovereenkomst -, dan zou de moedermaatschappij daar dus niet aansprakelijk voor zijn.

Mijns inziens oordeelt de rechtbank terecht dat een stilzwijgende verlenging van een huurovereenkomst niet kwalificeert als een rechtshandeling in de zin van art. 2:403 lid 1 sub f BW. ${ }^{15}$ Ook na de stilzwijgende verlening vloeien de

11. Zie in algemene zin over deze wijze van stilzwijgende bekrachtiging van een door een onbevoegde vertegenwoordiger verrichte rechtshandeling Asser/Kortmann 3-III 2017/86.

12. Asser/Van Olffen \& Rensen 2-IIa 2019/79.

13. Rb. Arnhem 10 oktober 2002, JOR 2003/31, m.nt. Bartman (Resila/Spectro).

14. Zie art. 2:404 lid 1 en lid 2 BW en $\S 7.2$ en $\S$ 8.2. De moedermaatschappij kan deze overblijvende aansprakelijkheid beëindigen als wordt voldaan aan de voorwaarden ex art. 2:404 lid 3 BW (zie $\S 8.3)$.

15. Rb. Arnhem 10 oktober 2002, JOR 2003/31, m.nt. Bartman (Resila/Spectro), r.o. 3.14-3.16. 
huurpenningen van de 403-maatschappij daarom voort uit de desbetreffende huurovereenkomst, en is de moedermaatschappij daarvoor aansprakelijk. Dit geldt naar mijn mening ook voor de verlenging van andere overeenkomsten. De verlening van een overeenkomst - stilzwijgend of uitdrukkelijk - betreft een voortzetting van een rechtsverhouding die door de eerdere overeenkomst in het leven is geroepen.

\subsubsection{Geen aansprakelijkheid voor schulden die uit de wet voortvloeien}

Ingevolge art. 2:403 lid 1 sub f BW hoeft een moedermaatschappij zich op grond van een 403-verklaring slechts aansprakelijk te stellen voor de schulden die voortvloeien uit een rechtshandeling van de 403-maatschappij. De moedermaatschappij hoeft zich dus niet aansprakelijk te stellen voor de schulden die uit de wet voortvloeien, zoals een schuld op grond van zaakwaarneming, onrechtmatige daad, ${ }^{16}$ ongerechtvaardigde verrijking of onverschuldigde betaling. ${ }^{17}$ Ook belastingschulden en strafrechtelijke of bestuursrechtelijke boetes die aan de 403-maatschappij zijn opgelegd, vloeien niet voort uit een rechtshandeling en vallen om die reden niet onder de 403 -aansprakelijkheid. ${ }^{18}$

Daarnaast wijs ik op een tweetal schulden die weliswaar een connectie hebben met een rechtshandeling, maar toch uit de wet voortvloeien: de verplichting tot het betalen van premies voor werknemersverzekeringen en de verplichting tot het betalen van een wettelijke verhoging van het loon wegens niet-tijdige betaling daarvan. ${ }^{19}$ Deze schulden hangen weliswaar samen met een arbeidsovereenkomst, maar uit de jurisprudentie blijkt dat zij toch uit de wet voortvloeien. Ten eerste wijs ik op het Likea-arrest waar de Hoge Raad expliciet oordeelt dat de verplichting tot afdracht van premies sociale verzekeringen niet voortvloeit uit een rechtshandeling, maar uit de wet. ${ }^{20}$ Volgens de Hoge Raad doet daaraan niet af dat de omstandigheid waarop de premieafdracht is gebaseerd - het moeten betalen van loon op grond van een arbeidsovereenkomst voortvloeit uit een rechtshandeling: het aangaan van de arbeidsovereenkomst. Daarnaast heeft de Hoge Raad in het arrest Swaen/Van Hees overwogen dat een wettelijke verhoging van het loon wegens niet-tijdige betaling daarvan, niet is bedoeld als een vergoeding van de schade voor de werknemer wegens de vertraagde uitbetaling, maar als een prikkel voor de werkgever om het loon op tijd

16. Zie voor een voorbeeld Rb. Amsterdam 5 december 2012, RO 2013/25 (Batla Minerals), r.o. 4.1.

17. Beckman 1995a, p. 549, Zwemmer 2011, p. 224, Ten Voorde 2011, p. 197, Asser/Maeijer \& Kroeze $2-I^{*} 2015 / 583$ en E.C.A. Nass 2019, p. 96. Zie respectievelijk art. 6:198, art. 6:162, art. 6:212 en art. 6:203 BW.

18. Van Solinge 2006, p. 252.

19. Zie art. 7:625 BW.

20. HR 4 oktober 1996, NJ 1997/187, m.nt. Maeijer (Likea), r.o. 3.3.2. 


\section{HOOFDSTUK 4}

te betalen. ${ }^{21}$ De Rechtbank Roermond overweegt in een andere procedure dat deze kwalificatie van de wettelijke verhoging van het loon door de Hoge Raad, meebrengt dat deze verhoging moet worden uitgelegd als een boete voor de werkgever. ${ }^{22} \mathrm{Zij}$ oordeelt naar mijn mening terecht dat een dergelijke verhoging om die reden - net zoals een strafrechtelijke of bestuursrechtelijke boete - niet onder de 403-aansprakelijkheid valt.

De minister merkt op dat de reden dat schulden uit de wet niet onder de 403-aansprakelijkheid vallen, is dat het ontstaan en de omvang van deze schulden niet is gebaseerd op een afweging van de crediteur ten aanzien van de financiële positie van de 403-maatschappij. ${ }^{23}$ Crediteuren van wie de vordering uit de wet voortvloeit, zouden geen nadeel ondervinden als de 403-maatschappij gebruikmaakt van de jaarrekeningvrijstelling van het groepsregime en hoeven daarom volgens de minister niet gecompenseerd te worden met een aanvullende vordering op de moedermaatschappij op grond van de 403-verklaring. ${ }^{24}$ Een belastingschuld ontstaat bijvoorbeeld zonder dat daar een afweging van de Belastingdienst aan vooraf gaat of zij een belastingaanslag wil opleggen de Belastingdienst beoordeelt vanzelfsprekend wel op basis van de financiële gegevens over het afgelopen jaar of er een belastingaanslag moet volgen en voor welk bedrag, maar zij kan er niet voor kiezen om geen aanslag op te leggen als dat op basis van de wet wel is voorgeschreven. Ook een vordering uit hoofde van een onrechtmatige daad wordt niet voorafgegaan door een afweging van de crediteur of zij wel of niet een vordering wil op de schuldenaar. De vordering ontstaat direct uit de onrechtmatige gedraging van de schuldenaar.

Het is terecht dat de minister opmerkt dat het ontstaan en de omvang van een vordering die uit de wet voortvloeit niet is gebaseerd op een afweging van de crediteur ten aanzien van de financiële positie van de 403-maatschappij. Het is echter wel zo dat de crediteur er gedurende zijn relatie met de 403-maatschappij belang bij kan hebben om de jaarrekening van de 403-maatschappij in te zien. Hij kan (mede) aan de hand daarvan schatten hoe groot het risico is dat zijn vordering niet (volledig) zal worden voldaan en beoordelen of hij het faillissement van de 403-maatschappij aanvraagt of eventuele zekerheidsrechten uitoefent. Ik merk op dat een crediteur met een vordering uit de wet doorgaans echter geen zekerheidsrechten zal hebben tenzij hij die al heeft uit anderen hoofde - en deze ook kan inroepen. Daarnaast heeft hij ook

21. HR 5 januari 1979, NJ 1979/207, m.nt. Stein (Swaen/Van Hees).

22. Rb. Roermond 20 februari 2008, JOR 2008/92, m.nt. Bartman (Inalfa), r.o. 4.2-4.2.2.

23. Kamerstukken II 1969/70, 10689, 3, p. 14 (MvT) en 4, p. 30 (bijlage 2 MvT). Zie ook Kamerstukken II 2017/18, 33529, 422, p. 2 (Brief aan de voorzitter van de Tweede Kamer), Wibier 2015, p. 779 en Van Zoest 2019, p. 22.

24. De compensatie voor een crediteur bestaat uit twee onderdelen: een vordering op de moedermaatschappij op grond van de 403-verklaring en de mogelijkheid om de geconsolideerde jaarrekening van de moedermaatschappij in te zien. Zie $\S 3.4 .1$. 
niet de mogelijkheid die een crediteur met een vordering die voortvloeit uit een overeenkomst wel heeft, om te proberen de relatie met de 403-maatschappij aan te passen of op te zeggen. Resumerend heeft een crediteur met een vordering uit de wet dus wel enig belang om gedurende de relatie met de 403-maatschappij de jaarrekening te kunnen inzien, maar dit belang is minder groot dan voor een crediteur met een vordering uit een overeenkomst.

Om alle crediteuren te compenseren die een nadeel ondervinden omdat ze de jaarrekening van de 403-maatschappij niet kunnen inzien, zouden ook de crediteuren van wie de vordering uit de wet voortvloeit zich op de moedermaatschappij moeten kunnen verhalen. Niettemin sluit ik mij aan bij Beckman die betoogt dat het te ver gaat om ook schulden uit de wet onder de reikwijdte van de 403-aansprakelijkheid te scharen. ${ }^{25}$ Ik deel zijn mening dat het voor de crediteuren van wie de vordering uit de wet voortvloeit minder van belang is om ieder jaar de nieuwe jaarrekening van de 403-maatschappij te kunnen inzien, dan voor crediteuren van wie de vordering uit een rechtshandeling van de 403-maatschappij voortvloeit. Het jaarlijks kunnen inzien van de nieuwe jaarrekening is namelijk vooral relevant voor crediteuren die een doorlopende relatie met de 403-maatschappij hebben waaruit periodiek nieuwe vorderingen voortvloeien. Zij hebben er in het bijzonder belang bij om ieder jaar te kunnen beoordelen hoe de financiële positie van de 403-maatschappij zich heeft ontwikkeld en hoe groot het risico is dat de vorderingen van de crediteur niet (volledig) zullen worden voldaan. Als een 403-maatschappij bijvoorbeeld een kantoorruimte huurt, krijgt de verhuurder periodiek een nieuwe vorderingen op de 403-maatschappij. Voor hem kan het onder meer van belang zijn om de jaarrekening van de 403-maatschappij te kunnen inzien om (mede) aan de hand daarvan te beoordelen of hij eventuele zekerheidsrechten uitoefent, de overeenkomst met de 403-maatschappij probeert aan te passen of opzegt, en of hij het faillissement van de 403-maatschappij aanvraagt.

Uit de wet ontstaan echter amper doorlopende rechtsverhoudingen waaruit periodiek nieuwe vorderingen voortvloeien. Als voorbeeld wijs ik op erfdienstbaarheid ${ }^{26}$ en de hierboven genoemde verplichting tot het betalen van premies voor werknemersverzekeringen. Uit rechtshandelingen kan daarentegen een veelheid aan doorlopende rechtsverhoudingen ontstaan waaruit periodiek nieuwe vorderingen voortvloeien. Hierbij kan onder meer worden gedacht aan duurovereenkomsten zoals een huurovereenkomst, arbeidsovereenkomst, leveringscontract, licentieovereenkomst of inkoopovereenkomst. Daarnaast vloeien doorlopende zekerheidsrechten zoals een borgstelling uit een rechtshandeling voort. Hoewel het dus niet zo is dat crediteuren met een vordering uit de wet geen belang hebben bij het jaarlijks kunnen inzien van de jaarrekening van de

25. Beckman 1995a, p. 572-573.

26. Zie art. 5:72 BW. 
403-maatschappij, meen ik dat de extra aansprakelijkheid voor de moedermaatschappij - voor de schulden van de 403-maatschappij uit de wet - niet in verhouding staat tot het beperkte gebrek aan inzicht van de desbetreffende crediteuren dat daardoor zou worden gecompenseerd. Daarom is het naar mijn mening gerechtvaardigd dat de aansprakelijkheid van een moedermaatschappij op grond van de 403-verklaring is beperkt tot de schulden die uit een rechtshandeling van de 403-maatschappij voortvloeien. Op dit punt nuanceer ik dus het door mij bepleite uitgangspunt voor de compensatie van de crediteuren van de 403-maatschappij. ${ }^{27}$

\subsection{Het derde element: voortvloeien}

\subsubsection{Primaire en secundaire schulden}

Met betrekking tot schulden die uit een rechtshandeling 'voortvloeien', kan een onderscheid worden gemaakt tussen primaire en secundaire schulden. Een primaire schuld ontstaat direct uit de rechtshandeling zelf. Als een 403-maatschappij bijvoorbeeld een arbeidsovereenkomst met een werknemer aangaat, is het salaris dat zij moet betalen een primaire schuld die uit de overeenkomst voortvloeit. Een secundaire schuld ontstaat indien de oorspronkelijke verbintenis niet wordt nagekomen. ${ }^{28}$ Als de 403-maatschappij de arbeidsovereenkomst ontbindt en de rechter oordeelt dat zij een ontbindingsvergoeding moet betalen aan de werknemer is dat een secundaire schuld. Een moedermaatschappij is op grond van de 403-verklaring zowel aansprakelijk voor de primaire schulden, als voor de secundaire schulden die uit een rechtshandeling van de 403-maatschappij voortvloeien. ${ }^{29}$

Secundaire schulden kunnen weliswaar hun directe ontstaansgrond in de wet hebben, maar dat neemt niet weg dat zij uit een rechtshandeling kunnen voortvloeien. De directe ontstaansgrond van bovengenoemde ontbindingsvergoeding is bijvoorbeeld het oordeel van de rechter dat de 403-maatschappij de vergoeding moet betalen aan de werknemer, maar deze vergoeding vloeit voort uit de arbeidsovereenkomst tussen de 403-maatschappij en de werknemer.

In de parlementaire geschiedenis, jurisprudentie en literatuur zijn verschillende voorbeelden genoemd van secundaire schulden die uit een rechtshandeling voortvloeien en die daarom onder de reikwijdte van de 403-aansprakelijkheid vallen. De minister merkt bijvoorbeeld op dat een moedermaatschappij

27. Zie $\S 3.7$.

28. Houwen, Schoonbrood-Wessels \& Schreurs 1993, p. 849. Zie ook Asser/Sieburgh 6-I 2016/43, met betrekking tot secundaire schulden in het algemeen.

29. Houwen, Schoonbrood-Wessels \& Schreurs 1993, p. 849 en Beckman 1995a, p. 547. 
op grond van de 403-verklaring aansprakelijk is voor een schadevergoeding die de 403-maatschappij moet betalen als deze een overeenkomst vernietigt of ontbindt. ${ }^{30}$ Als de 403-maatschappij een overeenkomst ontbindt, vallen ook de eventueel daardoor ontstane verplichtingen tot terugbetaling uit hoofde van een onverschuldigde betaling ${ }^{31}$ of tot ongedaanmaking ${ }^{32}$ onder de 403 -aansprakelijkheid. Daarnaast wijs ik erop dat uit twee uitspraken van Hof Amsterdam uit 2001 en 2014 volgt dat het feit dat het de rechter is die de arbeidsovereenkomst ontbindt, ${ }^{33}$ respectievelijk dat de werknemer zelf om de ontbinding van de arbeidsovereenkomst heeft verzocht, ${ }^{34}$ geen afbreuk doet aan het oordeel dat de ontbindingsvergoeding uit de arbeidsovereenkomst voortvloeit.

Een ander voorbeeld van een secundaire schuld die voortvloeit uit een arbeidsovereenkomst tussen de 403-maatschappij en een werknemer - en waarvoor de moedermaatschappij op grond van de 403-verklaring aansprakelijk is - betreft de verplichting van de 403-maatschappij tot het betalen van een vergoeding wegens een onregelmatige beëindiging van de arbeidsovereenkomst of een kennelijk onredelijk ontslag. ${ }^{35}$

Voorts is een moedermaatschappij aansprakelijk voor een schadevergoeding die de 403-maatschappij moet betalen indien zij een wanprestatie pleegt door haar verplichtingen uit een overeenkomst niet correct of tijdig na te komen. ${ }^{36}$ Het Hof Den Bosch heeft geoordeeld dat dit ook geldt als de overeenkomst om niet is aangegaan. ${ }^{37}$

Tot slot merk ik op dat ook een schadevergoeding wegens het niet nakomen van een met een overeenkomst samenhangende zorgplicht onder de 403-aansprakelijkheid valt. De Rechtbank Midden-Nederland en in hoger beroep de OK hebben in de Propertize/SNS-procedure geoordeeld dat daaraan niet

30. Kamerstukken II 1973/74, 11005, 64, p. 2 (2eNvW). Ik merk op dat de minister verwijst naar een voorloper van art. 2:403 BW, te weten: art. 38a WJO. Zie $\S 2.2$ voor een bespreking van de wetsgeschiedenis van het groepsregime. Zie ook Rb. Amsterdam 20 december 2000, JOR 2001/53, m.nt. Bartman (Ekelmans/Tevema), r.o. 3.5-3.9, Rb. Gelderland 1 april 2020, ECLI:NL:RBGEL:2020:2680 (DuraMark/SPGPrints), r.o. 4.24, Niels 2010, p. 34, Zwemmer 2011, p. 224, Zwemmer 2012, p. 229 en Bartman, Dorresteijn \& Olaerts 2020, p. 218.

31. Uniken Venema 1969, p. 272. Zie art. 6:203 BW.

32. Hof 's-Hertogenbosch 24 januari 2012, JOR 2012/165, m.nt. Bertrams (Inalfa), r.o. 4.17.

33. Hof Amsterdam 26 juli 2001, JOR 2004/94, m.nt. Bartman (Hemony/Van der Woude), r.o. 4.8. Zie art. 7:686 BW. Zie ook Zwemmer 2011, p. 224 en Zwemmer 2012, p. 229.

34. Hof Amsterdam (OK) 23 juli 2014, JOR 2014/233, m.nt. Bartman (Van Lieshout/Koks), r.o. 3.6, ook gepubliceerd in JAR 2014/209, m.nt. Zwemmer, JIN 2014/156, m.nt. Baghery en JIN 2014/172, m.nt. Van der Kraan.

35. Zwemmer 2011, p. 224 en Zwemmer 2012, p. 229. Zie art. 7:677 lid 4 en art. 7:681 lid 1 BW.

36. Houwen, Schoonbrood-Wessels \& Schreurs 1993, p. 849, Bartman in zijn annotatie onder Rb. Amsterdam 20 december 2000, JOR 2001/53 (Ekelmans/Tevema) en De Neve 2011, p. 49.

37. Hof 's-Hertogenbosch 12 mei 2009, JOR 2009/279, m.nt. Bartman (Inalfa), r.o. 4.7.6-4.7.7. 


\section{HOOFDSTUK 4}

afdoet dat deze zorgplicht voortvloeit uit de eisen van redelijkheid en billijkheid. ${ }^{38}$ De OK overweegt dat op grond van art. 6:248 lid 1 BW de wet, gewoonte en redelijkheid en billijkheid mede de rechtsgevolgen van een overeenkomst bepalen. Dit brengt mee dat een - in casu bancaire - zorgplicht onderdeel is van de overeenkomst. Als de 403-maatschappij tekortschiet in de zorgplicht, schiet zij dus tekort in haar verplichtingen uit de overeenkomst. De moedermaatschappij is mede aansprakelijk voor een schadevergoedingsplicht die daaruit voortvloeit.

\subsubsection{Voortvloeien}

Er is geen eensluidend antwoord op de vraag wanneer een schuld uit een rechtshandeling 'voortvloeit'. Er zal weinig discussie bestaan dat een verplichting die expliciet is opgenomen in een overeenkomst, uit deze overeenkomst voortvloeit - zoals de verplichting tot het betalen van huurpenningen op grond van een huurovereenkomst. Maar hoe meer 'schakels' er zijn tussen de oorspronkelijke rechtshandeling en het ontstaan van de schuld, hoe lastiger het is om te beoordelen of deze schuld nog uit de rechtshandeling voortvloeit of niet. Als bijvoorbeeld de huurder van een kantoorpand schade veroorzaakt aan het pand en daarvoor een schadevergoeding inclusief wettelijke rente moet betalen, vloeit deze wettelijke rente dan nog voort uit de huurovereenkomst? ${ }^{39}$

De vraag of een schuld uit een rechtshandeling van de 403-maatschappij 'voortvloeit', moet mijns inziens worden beantwoord aan de hand van de functie van de 403-aansprakelijkheid van de moedermaatschappij bij de compensatie van de crediteur omdat deze de jaarrekening van de 403-maatschappij niet kan inzien. ${ }^{40}$ Omdat de crediteur niet de mogelijkheid heeft om de jaarrekening in te zien, kan hij niet (mede) aan de hand daarvan schatten hoe groot het risico is dat zijn vordering niet (volledig) zal worden voldaan. Anders gezegd: de crediteur kan zijn keuze inzake het ontstaan, de inhoud en het voortduren van de vordering niet baseren op de informatie in de jaarrekening van de 403-maatschappij. Ter compensatie van dit gebrek aan inzicht krijgt de crediteur ook een vordering

38. Rb. Midden-Nederland 7 mei 2014, JOR 2014/260, m.nt. Harmsen (Curatoren/SNS), r.o. 3.5-3.8 en Hof Amsterdam (OK) 9 december 2015, JOR 2016/7, m.nt. Bartman (Propertize/SNS), r.o. 3.10. Zie instemmend Van der Kraan in zijn annotatie onder Hof Amsterdam (OK) 9 december 2015, JIN 2016/12 (Propertize/SNS).

39. Zie Spierings 2016, p. 217, die deze vraag positief beantwoord. Zie echter E.C.A. Nass 2019 , p. 96, die van mening is dat wettelijke rente niet onder de 403-aansprakelijkheid valt. Zie § 4.5.7 waar ik uitgebreider in ga op het antwoord op de vraag of wettelijke rente onder de reikwijdte van de 403-aansprakelijkheid valt.

40. De compensatie voor een crediteur bestaat uit twee onderdelen: een vordering op de moedermaatschappij op grond van de 403-verklaring en de mogelijkheid om de geconsolideerde jaarrekening van de moedermaatschappij in te zien. Zie $\S 3.4 .1$. 
op de moedermaatschappij, van wie hij de geconsolideerde jaarrekening wel kan inzien.

Als het element 'voortvloeien' uit art. 2:403 lid 1 sub f BW wordt uitgelegd in het licht van bovenstaande compensatie, brengt dat mee dat voor het antwoord op de vraag of een schuld uit een rechtshandeling van de 403-maatschappij voortvloeit - en dus of de moedermaatschappij op grond van de 403-verklaring aansprakelijk is voor deze schuld - van belang is of de crediteur al of niet moet worden gecompenseerd voor een gebrek aan inzicht. Mijns inziens vloeit een schuld daarom voort uit een rechtshandeling als de wil van de crediteur ten aanzien van het ontstaan, de inhoud of het voortduren van de schuld zou kunnen zijn beïnvloed door inzicht in de jaarrekening van de 403-maatschappij - als de 403-maatschappij geen gebruik zou hebben gemaakt van de jaarrekeningvrijstelling van het groepsregime. ${ }^{41}$ Daarbij maakt het geen verschil of de crediteur voorafgaand aan het bepalen van zijn wil omtrent de schuld al of niet bij het handelsregister is nagegaan of de 403-maatschappij gebruikmaakt van de jaarrekeningvrijstelling van het groepsregime en of de moedermaatschappij zich door middel van een 403-verklaring aansprakelijk heeft gesteld. Een crediteur wordt gecompenseerd omdat hij niet de mogelijkheid heeft om de jaarrekening van de 403-maatschappij in te zien en (mede) aan de hand daarvan kan schatten hoe groot het risico is dat zijn vordering niet (volledig) zal worden voldaan. ${ }^{42}$

Ter illustratie van bovenstaande uitleg van het element 'voortvloeien' uit art. 2:403 lid 1 sub f BW, maak ik een vergelijking tussen twee schulden die op elkaar lijken maar uit een andere rechtshandeling voortvloeien. Ten eerste wijs ik op de situatie dat een 403-maatschappij als huurder de huurovereenkomst met de verhuurder ontbindt en een rechter oordeelt dat zij aan de verhuurder een schadevergoeding moet betalen. Ik vergelijk dit met het geval dat de 403-maatschappij de huurovereenkomst niet heeft ontbonden, maar samen met de verhuurder een nieuwe overeenkomst is aangegaan op grond waarvan de huurovereenkomst is beëindigd tegen betaling van een bepaald bedrag door de 403-maatschappij aan de verhuurder.

Ik heb er eerder op gewezen dat een verplichting tot het betalen van een schadevergoeding wegens de ontbinding van een overeenkomst een secundaire schuld is die voortvloeit uit deze overeenkomst. ${ }^{43}$ Bovengenoemde verplichting voor de 403-maatschappij tot het betalen van de schadevergoeding aan de verhuurder vloeit dus voort uit de oorspronkelijke huurovereenkomst. De tweede genoemde verplichting van de 403-maatschappij om een bedrag te betalen tot beëindiging

41. Vgl. Houwen, Schoonbrood-Wessels \& Schreurs 1993, p. 847-848, die een soortgelijk standpunt inneemt maar slechts verwijst naar het ontstaan en de inhoud van de schuld.

42. Zie $\S 3.4 .1$.

43. Zie $\S 4.4 .1$. 
van de huurovereenkomst, vloeit echter niet voort uit de oorspronkelijke huurovereenkomst, maar uit de later aangegane overeenkomst met de verhuurder. Hoewel beide schulden betrekking hebben op het stopzetten van de huurovereenkomst, vloeien zij dus voort uit een andere rechtshandeling van de 403-maatschappij. De reden voor dit onderscheid hangt samen met het moment waarop het kunnen inzien van de jaarrekening van de 403-maatschappij van belang had kunnen zijn voor de verhuurder als crediteur om zijn wil te bepalen ten aanzien van het ontstaan en de omvang van de desbetreffende vordering - als de 403-maatschappij geen gebruik zou hebben gemaakt van de jaarrekeningvrijstelling van het groepsregime.

In het geval dat de 403-maatschappij de huurovereenkomst ontbindt en de rechter oordeelt dat zij een schadevergoeding moet betalen aan de verhuurder, zou de verhuurder niet (mede) aan de hand van de jaarrekening van de 403-maatschappij zijn wil hebben kunnen bepalen of hij de schadevergoeding wil en zo ja wat de inhoud daarvan zou moeten zijn. De verhuurder kan hooguit de schadevergoeding weigeren. De schuld van de 403-maatschappij vloeit daarom voort uit de onderliggende huurovereenkomst ten aanzien waarvan de verhuurder wel (mede) aan de hand van de jaarrekening van de 403-maatschappij zijn wil zou hebben kunnen bepalen of hij deze overeenkomst aan zou gaan en tegen welke voorwaarden - als de 403-maatschappij geen gebruik zou hebben gemaakt van de jaarrekeningvrijstelling.

Met betrekking tot de nieuwe overeenkomst die de 403-maatschappij en de verhuurder zijn aangaan tot beëindiging van de huurovereenkomst tegen betaling van een bepaald bedrag, zou de verhuurder wel (mede) aan de hand van de jaarrekening van de 403-maatschappij zijn wil hebben kunnen bepalen omtrent het aangaan en de voorwaarden van de overeenkomst. Er is als het ware sprake van een nieuw 'keuzemoment' voor de verhuurder waarbij de jaarrekening van de 403-maatschappij van belang had kunnen zijn - als de 403-maatschappij geen gebruik zou hebben gemaakt van de jaarrekeningvrijstelling van het groepsregime. De verplichting van de 403-maatschappij tot het betalen van het overeengekomen bedrag tot beëindiging van de huurovereenkomst vloeit daarom niet voort uit de huurovereenkomst, maar uit de rechtshandeling die met dit keuzemoment samenhangt: de nieuwe overeenkomst tussen de verhuurder en de 403-maatschappij.

Zowel de verplichting van de 403-maatschappij tot het betalen van de schadevergoeding in verband met de ontbinding van de huurovereenkomst, als de verplichting tot het betalen van het in de latere overeenkomst afgesproken bedrag tot beëindiging van de huurovereenkomst, vloeien voort uit een rechtshandeling. Beide schulden van de 403-maatschappij vallen daarom onder de reikwijdte van de 403-aansprakelijkheid en de verhuurder kan zich in beide gevallen ook op de moedermaatschappij verhalen. Waarom is het bovengenoemde 
onderscheid uit welke rechtshandeling een schuld voortvloeit dan toch van belang? Daarvoor wijs ik op de mogelijkheid dat de moedermaatschappij tussentijds de 403-verklaring intrekt.

Als de moedermaatschappij de 403-verklaring intrekt, is zij niet aansprakelijk voor de schulden die voortvloeien uit de rechtshandelingen die de 403-maatschappij verricht vanaf het moment dat de moedermaatschappij een beroep kan doen op de intrekking. ${ }^{44}$ Stel dat de 403-maatschappij ten tijde van het aangaan van de huurovereenkomst gebruik heeft gemaakt van de jaarrekeningvrijstelling van het groepsregime. Maar tussen het aangaan van deze overeenkomst en het moment dat zij die ontbindt, respectievelijk een nieuwe overeenkomst aangaat tot beëindiging van de huurovereenkomst, heeft de 403-maatschappij besloten niet meer gebruik te maken van de vrijstelling en heeft de moedermaatschappij de 403-verklaring ingetrokken.

Als de 403-maatschappij de huurovereenkomst heeft ontbonden, vloeit de schadevergoeding die zij moet betalen voort uit de oorspronkelijke huurovereenkomst en deze valt daarmee onder de overblijvende aansprakelijkheid van de moedermaatschappij na de intrekking van de 403-verklaring. De verhuurder kan in dat geval de moedermaatschappij aansprakelijk stellen tot voldoening van de schadevergoeding. Indien de 403-maatschappij daarentegen met de verhuurder een nieuwe overeenkomst is aangegaan tot beëindiging van de eerdere huurovereenkomst, vloeit het daarin overeengekomen bedrag dat de 403-maatschappij aan de verhuurder moet betalen voort uit de latere overeenkomst en dit valt daardoor niet onder de overblijvende aansprakelijkheid na de intrekking van de 403-verklaring. De verhuurder kan zich in dat geval dus niet op de moedermaatschappij verhalen.

\subsection{Verschillende schulden nader beschouwd}

\subsubsection{Inleiding}

In de literatuur en de jurisprudentie is ten aanzien van verschillende schulden van een 403-maatschappij de vraag gesteld of deze al of niet onder de materiele reikwijdte van de 403 -aansprakelijkheid vallen. Hieronder ga ik voor ieder van deze schulden na of een moedermaatschappij naar huidig recht hiervoor aansprakelijk is op grond van de 403-verklaring en of zij dit volgens het door mij bepleite uitgangspunt voor compensatie zou moeten zijn. ${ }^{45}$

44. Zie art. 2:404 lid 1 en lid 2 BW en $\S 7.2$ en $\S 8.2$. De moedermaatschappij kan deze overblijvende aansprakelijkheid beëindigen als wordt voldaan aan de voorwaarden ex art. 2:404 lid 3 BW (zie $\S 8.3$ ).

45. Zie $\S 3.7$. 


\subsubsection{Intercompany schulden}

Een intercompany schuld is een schuld die de 403-maatschappij heeft tegenover een groepsmaatschappij. De vraag of een dergelijke schuld onder de reikwijdte van de 403-aansprakelijkheid valt, is voor het eerst aan de orde gekomen bij de Rechtbank Almelo in de Hoeveholding-procedure. ${ }^{46}$ In casu is de moedermaatschappij op grond van de 403-verklaring aansprakelijk gesteld door de curator van een failliete groepsmaatschappij tot nakoming van schulden van de 403-maatschappij aan de failliete groepsmaatschappij. De moedermaatschappij verweert zich met de stelling dat intercompany schulden niet onder de reikwijdte van de 403-aansprakelijkheid vallen. Volgens haar hoeven alleen - zoals zij het noemt - 'normale handelscrediteuren' gecompenseerd te worden voor het niet kunnen inzien van de jaarrekening van de 403-maatschappij. Zij meent dat een groepsmaatschappij die een vordering heeft op de 403-maatschappij niet gecompenseerd hoeft te worden omdat deze binnen de groep - op basis van interne financiële gegevens - inzicht heeft in de financiële positie van de 403-maatschappij. De rechtbank gaat echter niet mee in het betoog van de moedermaatschappij. ${ }^{47} \mathrm{Zij}$ oordeelt dat een groepsmaatschappij erop mag vertrouwen dat de 403 -verklaring er ook toe strekt dat de moedermaatschappij aansprakelijkheid aanvaardt voor intercompany schulden. Volgens de rechtbank heeft de 403-aansprakelijkheid niet alleen werking buiten de groep maar ook daarbinnen, en kan een groepsmaatschappij zich daarom onverminderd op de moedermaatschappij verhalen.

Bovenstaand oordeel van de Rechtbank Almelo is later gevolgd door de Rechtbank Rotterdam en tweemaal bevestigd door de OK in het hoger beroep van beide procedures. ${ }^{48}$ Ook in de literatuur wordt zij eensgezind onderschreven. ${ }^{49}$ Ik sluit mij daarbij aan. Ik wijs op twee overwegingen van de OK in het hoger beroep van de Hoeveholding-procedure. ${ }^{50}$ In de eerste plaats is in de tekst van art. 2:403 lid 1 sub $\mathrm{f} \mathrm{BW}$, dat een moedermaatschappij zich hoofdelijk aansprakelijk moet stellen voor de uit rechtshandelingen van de 403-maatschappij voortvloeiende schulden, geen beperking te lezen dat intercompany schulden buiten de reikwijdte van de 403-aansprakelijkheid zouden vallen. Daarnaast hebben groepsmaatschappijen binnen de groep niet altijd toegang

46. Rb. Almelo 24 juni 2008, JOR 2008/227, m.nt. Bartman (Hoeveholding).

47. Rb. Almelo 24 juni 2008, JOR 2008/227, m.nt. Bartman (Hoeveholding), r.o. 6.

48. Rb. Rotterdam 16 april 2009, JOR 2009/161, m.nt. Van der Zanden (BosGijze/Jones Lang LaSalle), r.o. 5.3.1-5.3.2, Hof Amsterdam (OK) 12 januari 2010, JOR 2010/94, m.nt. Bartman (Hoeveholding), r.o. 3.5 en Hof Amsterdam (OK) 30 september 2010, JOR 2010/306, m.nt. Bartman (Jones Lang LaSalle/BosGijze), r.o. 3.16.

49. Niels 2010, p. 35-36, M.J. Janssen 2010, p. 115 en Bartman, Dorresteijn \& Olaerts 2020, p. 218.

50. Hof Amsterdam (OK) 12 januari 2010, JOR 2010/94, m.nt. Bartman (Hoeveholding), r.o. 3.5. 
tot de interne financiële gegevens van de 403-maatschappij. Zeker bij een grote groep met veel groepsmaatschappijen hoeft dit niet altijd het geval te zijn. Het argument dat groepsmaatschappijen per definitie geen gebrek aan inzicht hebben en daarom niet gecompenseerd hoeven te worden, gaat dus niet op. Zij moeten - net als andere crediteuren van wie de schuld uit een rechtshandeling van de 403-maatschappij voortvloeit - worden gecompenseerd met een aanvullende vordering op de moedermaatschappij van wie zij de geconsolideerde jaarrekening wel kunnen inzien. ${ }^{51}$

\subsubsection{Handelen namens een vennootschap in oprichting}

Tenzij uitdrukkelijk anders is bedongen, is degene die een rechtshandeling verricht namens een vennootschap in oprichting op grond van art. 2:93/203 lid 2 BW hoofdelijk aansprakelijk voor de daaruit voortvloeiende schulden totdat de opgerichte vennootschap deze rechtshandeling bekrachtigt. Houwen is van mening dat als een 403-maatschappij een rechtshandeling verricht namens een vennootschap in oprichting, de moedermaatschappij niet op grond van de 403-verklaring aansprakelijk is voor de schulden die uit deze rechtshandeling voortvloeien. Hij meent dat de 403-maatschappij niet in eigen naam handelt, maar als een soort 'vertegenwoordiger' van de op te richten vennootschap. ${ }^{52}$ De hoofdelijke aansprakelijkheid van de 403-maatschappij op grond van art. 2:93/203 lid 2 BW vloeit daarom volgens hem voort uit deze bepaling en niet uit de desbetreffende rechtshandeling.

Bovenstaand standpunt van Houwen is naar mijn mening niet juist. Ik meen met onder meer Beckman en Ten Voorde dat de 403-maatschappij wel zelf de rechtshandeling verricht - voor de nog op te richten vennootschap. ${ }^{53}$ Dit blijkt ook uit art. 2:93/203 lid 1 BW op grond waarvan uit deze rechtshandeling pas rechten en verplichtingen ontstaan voor de vennootschap als deze is opgericht en de rechtshandeling van de 403-maatschappij bekrachtigt. Tot het moment van de bekrachtiging is de 403-maatschappij zelf aansprakelijk. Het is aan de opgerichte vennootschap om te besluiten of zij de rechtshandeling bekrachtigt. $\mathrm{Zij}$ is daar geenszins toe verplicht. ${ }^{54} \mathrm{Ik}$ deel daarom de mening van bovengenoemde auteurs dat de schulden van de 403-maatschappij op grond van

51. Ik merk op dat het mogelijk is dat indien een groepsmaatschappij inzicht heeft gehad in de interne financiële gegevens van de 403-maatschappij, het beroep van de groepsmaatschappij op de 403-verklaring onaanvaardbaar is naar maatstaven van redelijkheid en billijkheid ex art. 6:2 BW. Dit is mijns inziens bijvoorbeeld het geval als vast komt te staan dat de groepsmaatschappij voorafgaand aan het aangaan van een overeenkomst met de 403-maatschappij bewust inzage heeft gekregen in deze financiële gegevens en ook gedurende de looptijd van de overeenkomst op de hoogte is gehouden met actuele cijfers.

52. Houwen 1997, p. 82.

53. Koning 1991, p. 30-31, Beckman 1995a, p. 555-557 en Ten Voorde 2006, p. 112.

54. Asser/Van Olffen \& Rensen 2-IIa 2019/78. 
art. 2:93/203 lid $2 \mathrm{BW}$, die voortvloeien uit een namens een vennootschap in oprichting verrichte rechtshandeling onder de reikwijdte van de 403-aansprakelijkheid vallen.

Bovengenoemd standpunt sluit aan bij het door mij bepleite uitgangspunt voor de compensatie van de crediteuren..$^{55}$ Hierboven merkte ik al op dat als een 403-maatschappij een rechtshandeling verricht namens een vennootschap in oprichting, het de 403-maatschappij zelf is die aansprakelijk is voor de schulden die daaruit voortvloeien totdat de opgerichte vennootschap de rechtshandeling bekrachtigt. Het ontbreekt de desbetreffende crediteur aan de mogelijkheid om de jaarrekening van de 403-maatschappij in te zien. Hij kan niet (mede) aan de hand van daarvan schatten hoe groot het risico is dat de 403-maatschappij de vordering niet (volledig) zal voldoen als de opgerichte vennootschap de rechtshandeling niet bekrachtigt of als de crediteur de 403-maatschappij voor de bekrachtiging aansprakelijk stelt. ${ }^{56}$ Evenals andere crediteuren van de 403-maatschappij moet hij zich ter compensatie van dit gebrek aan inzicht op de moedermaatschappij kunnen verhalen van wie hij de geconsolideerde jaarrekening wel kan inzien.

Als de opgerichte vennootschap de rechtshandeling van de 403-maatschappij bekrachtigt, eindigt de aansprakelijkheid van de 403-maatschappij voor de schulden die uit de rechtshandeling voortvloeien. Ik meen met Beckman dat daardoor de aansprakelijkheid van de 403-maatschappij uit hoofde van die rechtshandeling is 'afgewikkeld', waardoor ook de aansprakelijkheid van de moedermaatschappij voor deze schulden is beëindigd. ${ }^{57}$

In het geval dat een opgerichte vennootschap de verplichtingen uit een bekrachtigde rechtshandeling niet voldoet, is degene die de rechtshandeling namens de vennootschap in oprichting heeft verricht en wist of redelijkerwijs behoorde te weten dat de vennootschap de verplichtingen niet zou kunnen nakomen, op grond van art. 2:93/203 lid 3 BW hoofdelijk ansprakelijk voor de schade die een derde daardoor lijdt. ${ }^{58}$ Evenals Beckman en Ten Voorde ben ik van mening dat een schuld van de 403-maatschappij op grond van deze bepaling niet onder de reikwijdte van de 403 -aansprakelijkheid valt. ${ }^{59} \mathrm{Ik}$ wijs erop dat de minister

55. Zie $\S 3.7$.

56. Zie Asser/Van Olffen \& Rensen 2-IIa 2019/77, die in algemene zin opmerken dat als voor de bekrachtiging al een verplichting wordt voldaan die voortvloeit uit de rechtshandeling die namens de vennootschap in oprichting is verricht, degene die deze verplichting heeft voldaan een regresvordering krijgt op de opgerichte vennootschap.

57. Beckman 1995a, p. 556.

58. Er wordt vermoed dat degene die de rechtshandeling heeft verricht wetenschap heeft dat de vennootschap de verplichtingen niet zou kunnen nakomen indien de vennootschap binnen een jaar na de oprichting failleert.

59. Beckman 1995a, p. 556 en Ten Voorde 2006, p. 112. 
heeft opgemerkt dat dit een wettelijke aansprakelijkheid betreft in verband met onrechtmatig handelen door de partij die de rechtshandeling namens de vennootschap in oprichting heeft verricht. ${ }^{60}$ Deze partij heeft de crediteur misleid ten aanzien van de solvabiliteit van de op te richten vennootschap. Een schuld van de 403-maatschappij op grond van art. 2:93/203 lid $3 \mathrm{BW}$ vloeit daarom niet voort uit de rechtshandeling die namens de op te richten vennootschap is verricht, maar uit de wet.

Tot slot wijs ik op de situatie dat een derde een rechtshandeling namens een 403-maatschappij in oprichting verricht. De moedermaatschappij is op grond van de 403-verklaring niet aansprakelijk voor de schulden die uit deze rechtshandeling voortvloeien. De 403-aansprakelijkheid is namelijk beperkt tot de schulden die voortvloeien uit een rechtshandeling van de 403-maatschappij zelf. Als de 403-maatschappij eenmaal is opgericht en de desbetreffende rechtshandeling bekrachtigt, is dat wel een rechtshandeling van de 403-maatschappij. Het Hof Den Haag heeft mijns inziens daarom terecht geoordeeld dat een moedermaatschappij wel aansprakelijk is voor de schulden die uit deze bekrachtiging voortvloeien, maar (nog) niet als een derde namens de 403-maatschappij in oprichting een rechtshandeling verricht. ${ }^{61}$ Dat de rechten en verplichtingen die voortvloeien uit de rechtshandeling die namens de 403-maatschappij in oprichting is verricht voor rekening en risico komen van de 403-maatschappij makt dit niet anders.

Ik merk op dat als een 403-maatschappij een rechtshandeling bekrachtigt die namens haar in oprichting is verricht door een derde, dit doorgaans op een moment is dat de 403-maatschappij nog niet een jaarrekening openbaar zou hebben moeten maken als ze geen gebruik zou maken van de jaarrekeningvrijstelling van het groepsregime. ${ }^{62}$ Er zou kunnen worden betoogd dat de schulden die uit de bekrachtiging voortvloeien om die reden niet onder de 403-aansprakelijkheid vallen. De crediteur zou namelijk op het moment van de bekrachtiging ook geen inzicht hebben gehad in de jaarrekening van de 403-maatschappij als deze geen gebruik zou maken van de jaarrekeningvrijstelling. Naar mijn mening gaat deze redenering echter niet op. Hoewel de crediteur op het moment van de bekrachtiging weliswaar geen nadeel ondervindt ten opzichte van de situatie dat de 403-maatschappij geen gebruik zou maken van de jaarrekeningvrijstelling, ontbreekt het hem wel aan de mogelijkheid om in de toekomst de jaarrekening(en) van de 403-maatschappij in te zien. Een crediteur kan er belang bij hebben om in de toekomst de jaarrekening(en) in te zien om (mede)

60. Kamerstukken II 1980/81, 16631, 3, p. 12 (MvT).

61. Hof Den Haag 5 september 2017, JOR 2018/2, m.nt. Bartman (Hoad/Hilson), r.o. 4.5, ook gepubliceerd in JIN 2017/178, m.nt. Van Nuland en Schepel. Zie ook Asser/Van Olffen \& Rensen 2-IIa 2019/77.

62. Op grond van art. 2:394 lid $3 \mathrm{BW}$ moet een rechtspersoon uiterlijk twaalf maanden na afloop van het boekjaar de jaarrekening openbaar maken. 
aan de hand daarvan te beoordelen of hij eventuele zekerheidsrechten uitoefent, de overeenkomst met de 403-maatschappij probeert aan te passen of op te zeggen, of dat hij het faillissement van de 403-maatschappij aanvraagt. Dit geldt in het bijzonder in het geval van een duurovereenkomst waaruit periodiek nieuwe vorderingen voor de crediteur voortvloeien. ${ }^{63}$

\subsubsection{Bestuurdersaansprakelijkheid}

\subsection{4.a Inleiding}

Een 403-maatschappij kan bestuurder zijn van een andere rechtspersoon. Het is de vraag of eventuele bestuurdersaansprakelijkheid van de 403-maatschappij, voor schade die is ontstaan door haar handelen als bestuurder, onder de reikwijdte van de 403-aansprakelijkheid valt.

De eerste vraag die moet worden beantwoord, is of het accepteren van het bestuurderschap door de 403-maatschappij een rechtshandeling is. Met Koning en Beckman beantwoord ik deze vraag bevestigend. ${ }^{64}$ Als de 403 -maatschappij het bestuurderschap accepteert, uit zij een op een rechtsgevolg gerichte wil. ${ }^{65}$ Het rechtsgevolg van deze handeling is de totstandkoming van de vennootschapsrechtelijke band tussen de rechtspersoon en de 403-maatschappij als bestuurder. De 403-maatschappij kan haar wil om het bestuurderschap te accepteren zowel uitdrukkelijk als stilzwijgend - bijvoorbeeld door het verrichten van de werkzaamheden als bestuurder - uiten. De volgende vraag is of, en zo ja welke gronden van bestuurdersaansprakelijkheid voortvloeien uit deze rechtshandeling - en daarmee onder de reikwijdte van de 403-aansprakelijkheid vallen.

Met betrekking tot de verschillende gronden voor bestuurdersaansprakelijkheid kan een tweedeling worden gemaakt tegenover wie de 403-maatschappij aansprakelijk is. Enerzijds kan de 403-maatschappij aansprakelijk zijn jegens de rechtspersoon waarvan zij bestuurder is - de interne bestuurdersaansprakelijkheid -, en anderzijds tegenover een derde - de externe bestuurdersaansprakelijkheid. Kort gezegd zijn de standpunten in de literatuur ten aanzien van het antwoord op de vraag welke gronden van bestuurdersaansprakelijkheid onder de reikwijdte van de 403-aansprakelijkheid vallen, terug te brengen tot dit onderscheid. In de regel wordt aangenomen dat aansprakelijkheid van de 403-maatschappij tegenover de door haar bestuurde rechtspersoon wél, en aansprakelijkheid jegens derden níet onder de reikwijdte van

63. Zie $\S 5.6 .4$, waar ik dit als een van de redenen noem waarom de temporele reikwijdte van de 403-aansprakelijkheid mijns inziens de schulden omvat die voortvloeien en zijn voortgevloeid uit een rechtshandeling van de 403-maatschappij.

64. Koning 1991, p. 31 en Beckman 1995a, p. 557.

65. Zie art. 3:33 BW. 
de 403-aansprakelijkheid valt. Hieronder ga ik nader in op beide vormen van bestuurdersaansprakelijkheid.

\subsection{4.b Interne bestuurdersaansprakelijkheid}

Bij interne bestuurdersaansprakelijkheid is de bestuurder aansprakelijk tegenover de door hem bestuurde rechtspersoon. Hierbij kan onder meer worden gedacht aan de aansprakelijkheid op grond van art. 2:9 BW. ${ }^{66}$ Krachtens deze bepaling is iedere bestuurder gehouden tot een behoorlijke vervulling van zijn taak. Indien een bestuurder of een van zijn medebestuurders zijn taak onbehoorlijk vervult, is hij jegens de rechtspersoon aansprakelijk voor het geheel van de schade die deze daardoor lijdt tenzij de bestuurder geen ernstig verwijt kan worden gemaakt en hij niet nalatig is geweest in het treffen van maatregelen om de gevolgen van het onbehoorlijk bestuur af te wenden. Een andere grond voor interne bestuurdersaansprakelijkheid is die uit hoofde van art. 2:216 BW. ${ }^{67}$ Op grond van lid 3 van deze bepaling is een bestuurder van een $\mathrm{BV}$ die ten tijde van een dividenduitkering wist of behoorde te weten dat de BV door die uitkering niet zou kunnen voortgaan met het betalen van de opeisbare schulden, jegens de BV aansprakelijk voor het tekort dat door de uitkering is ontstaan.

In de literatuur wordt mijns inziens terecht aangenomen dat een moedermaatschappij aansprakelijk is voor een schuld van de 403-maatschappij op grond van art. 2:9 $\mathrm{BW} .{ }^{68}$ Deze bepaling geeft naar mijn mening (mede) invulling aan de verhouding tussen de 403-maatschappij en de rechtspersoon waarvan zij bestuurder is. Het betreft een uitwerking van hoe de 403-maatschappij haar bestuurstaak moet uitvoeren. Als de 403-maatschappij deze taak onbehoorlijk vervult, kan zij aansprakelijk worden gesteld voor de schade die de door haar bestuurde rechtspersoon daardoor lijdt. Dit is naar mijn mening vergelijkbaar met de situatie dat de 403-maatschappij tekortschiet in de nakoming van een overeenkomst en de schade moet vergoeden die de wederpartij daardoor lijdt. Ook in dat geval is de moedermaatschappij op grond van de 403-verklaring mede aansprakelijk voor deze schadevergoeding. Zowel de verplichting tot het

66. Zie Asser/Maeijer, Van Solinge \& Nieuwe Weme 2-II* 2009/445, Assink/Slagter 2013/51.9 en 51.14, Van der Heijden/Van der Grinten \& Dortmond 2013/399.1 en Huizink, in: GS Rechtspersonen, art. 2:9 BW, aant. 5.4, die opmerken dat dit een grond voor interne bestuurdersaansprakelijkheid is.

67. Kamerstukken I 2011/12, 31058, E, p. 9 (NMvA) en Boschma \& Schutte-Veenstra - T\&C Burgerlijk Wetboek, art. 2:216 BW, aant. 4, waar wordt opgemerkt dat de bestuurder aansprakelijk is jegens de door hem bestuurde rechtspersoon.

68. Koning 1991, p. 31, Van der Heijden/Van der Grinten 1992/324.2 (zie Van der Heijden/ Van der Grinten \& Dortmond 2013/324.3, waar dit onderwerp wel wordt aangestipt, maar er geen standpunt wordt ingenomen), Houwen, Schoonbrood-Wessels \& Schreurs 1993, p. 849-850 en Beckman 1995a, p. 557-558. 


\section{HOOFDSTUK 4}

vergoeden van de schade als gevolg van een wanprestatie, als de aansprakelijkheid van een 403-maatschappij op grond van art. 2:9 BW zijn mijns inziens een secundaire schuld die ontstaat als de verplichting uit de oorspronkelijk rechtshandeling - het aangaan van de overeenkomst, respectievelijk het accepteren van het bestuurderschap - niet juist wordt nagekomen. ${ }^{69}$

De 403-maatschappij kan op grond van art. 2:9 BW niet alleen aansprakelijk worden gesteld als zij zelf haar taak als bestuurder onbehoorlijk heeft vervuld, maar ook als een van haar medebestuurders daarin tekortschiet. Beckman laat het antwoord op de vraag of de aansprakelijkheid van een 403-maatschappij voor het onbehoorlijk bestuur van een medebestuurder onder de reikwijdte van de 403 -aansprakelijkheid valt in het midden.$^{70}$ Hij meent dat enerzijds verdedigbaar is dat de moedermaatschappij niet aansprakelijk is omdat het niet gaat om eigen tekortschietend gedrag van de 403-maatschappij in de uitvoering van de bestuurstaak. Anderzijds kan volgens hem worden betoogd dat een onderdeel van de bestuurstaak is dat de 403-maatschappij moet zorgdragen voor een goede bestuurlijke organisatie. Ontbreekt een dergelijke organisatie dan is dat aan alle bestuurders toe te rekenen en zijn zij allemaal tekortgeschoten in hun bestuurstaak.

De laatste overweging van Beckman lijkt mij juist. Het besturen van de rechtspersoon komt toe aan het bestuur. ${ }^{71}$ Dit betreft alle bestuurders gezamenlijk. ${ }^{72}$ Een van de onderdelen van de bestuurstaak van een individuele bestuurder is daarom dat hij zorgdraagt voor een goede bestuurlijke organisatie. Het is vanzelfsprekend mogelijk om binnen het bestuur taken te verdelen, maar dat doet niet af aan het uitgangspunt van een collegiaal bestuur. De taakverdeling kan slechts een rol spelen bij de eventuele disculpatie van een bestuurder als deze aansprakelijk wordt gesteld omdat een van de medebestuurder zijn taak onbehoorlijk heeft vervuld. Als de eerste bestuurder mede gelet op de taakverdeling geen ernstig verwijt is te maken en hij daarnaast niet nalatig is geweest in het treffen van maatregelen om de gevolgen van het onbehoorlijk bestuur af te wenden, is hij niet aansprakelijk voor de onbehoorlijke taakvervulling van zijn medebestuurder. Tenzij de 403-maatschappij zich kan disculperen, is de moedermaatschappij mijns inziens dus mede aansprakelijk voor de aansprakelijkheid van de 403-maatschappij op grond van art. 2:9 BW voor een onbehoorlijke taakvervulling door een medebestuurder.

Naast de aansprakelijkheid van een 403-maatschappij op grond van art. 2:9 $\mathrm{BW}$, valt mijns inziens ook de ansprakelijkheid op grond van art. 2:216 BW

69. Zie $\S 4.4 .1$.

70. Beckman 1995a, p. 558.

71. Zie bijvoorbeeld met betrekking tot het bestuur van een BV art. 2:239 lid 1 BW.

72. Van der Heijden/Van der Grinten \& Dortmond 2013/233, Asser/Maeijer \& Kroeze 2-I* 2015/194 en Huizink, in: GS Rechtspersonen, art. 2:9 BW, aant. 11.1. 
onder de reikwijdte van de 403-aansprakelijkheidheid. Ten aanzien van de aansprakelijkheid uit hoofde van art. 2:216 BW is dezelfde redenering van toepassing als op die ex art. 2:9 BW. Ook deze bepaling geeft invulling aan hoe de 403-maatschappij haar taak als bestuurder moet vervullen, namelijk dat een dividenduitkering achterwege moet blijven als zij weet of behoort te weten dat de BV daardoor niet zal kunnen voortgaan met het betalen van de opeisbare schulden. Als de 403-maatschappij tekortschiet in deze bestuurstaak is zij aansprakelijk voor de schade die de door haar bestuurde rechtspersoon daardoor lijdt - zijnde het tekort dat door de uitkering is ontstaan.

\subsection{4.c Externe bestuurdersaansprakelijkheid}

In tegenstelling tot de hierboven behandelde interne bestuurdersaansprakelijkheid, is een bestuurder bij externe bestuurdersaansprakelijkheid niet aansprakelijk tegenover de rechtspersoon waarvan hij bestuurder is, maar tegenover een derde. Met betrekking tot externe bestuurdersaansprakelijkheid kan bijvoorbeeld worden gedacht aan de aansprakelijkheid ingevolge een onrechtmatige daad of de aansprakelijkheid op grond van art. 2:139/249 BW voor het geval dat de gegevens in de jaarrekening, tussentijdse cijfers of het bestuursverslag een misleidende voorstelling van de toestand van de vennootschap geven. Een ander voorbeeld van externe bestuurdersaansprakelijkheid is de aansprakelijkheid van een bestuurder jegens de Belastingdienst op grond van art. 36 Invorderingswet 1990 voor bepaalde door de rechtspersoon verschuldigde maar niet betaalde belastingen indien de betalingsonmacht van de rechtspersoon niet tijdig is gemeld of als het niet betalen van de belastingschuld het gevolg is van aan de bestuurder te wijten kennelijk onbehoorlijk bestuur in de drie jaren voorafgaande aan de mededeling.

Voorts wijs ik op de ansprakelijkheid van een bestuurder op grond van art. 2:69/180 BW. Krachtens deze bepaling is een bestuurder van een vennootschap jegens een crediteur hoofdelijk aansprakelijk voor de schulden die voortvloeien uit een rechtshandeling die de vennootschap heeft verricht voordat de opgave ter eerste inschrijving in het handelsregister is geschied en - in het geval van een NV - voordat het gestorte kapitaal ten minste het bij de oprichting voorgeschreven minimumkapitaal bedraagt en ten minste een vierde van het nominale bedrag van het bij de oprichting geplaatste kapitaal is gestort.

De laatste grond voor externe bestuurdersaansprakelijkheid waar ik op wijs, is die uit hoofde van art. 2:138/248 BW. Krachtens deze bepaling is een bestuurder van een failliete vennootschap jegens de boedel aansprakelijk voor het boedeltekort indien hij zijn taak onbehoorlijk heeft vervuld en aannemelijk is dat dit een belangrijke oorzaak is van het faillissement. Dat de aansprakelijkheid op grond van art. 2:138/248 BW een vorm van externe bestuurdersaansprakelijkheid is, 
wordt in de literatuur breed onderschreven, ${ }^{73}$ waarbij vaak wordt verwezen naar het Simoca-arrest. ${ }^{74}$ Daarin oordeelt de Hoge Raad dat een bestuurder op grond van art. 2:138/248 BW niet aansprakelijk is tegenover de gefailleerde vennootschap waarvan hij bestuurder was, maar jegens de boedel. Het is de curator die als beheerder en vereffenaar van de failliete boedel de vordering op grond van art. 2:138/248 BW instelt namens de gezamenlijke crediteuren.

Hierboven merkte ik al op dat in de regel in de literatuur wordt aangenomen dat externe bestuurdersaansprakelijkheid van de 403-maatschappij niet onder de reikwijdte van de 403 -aansprakelijkheid valt. ${ }^{75}$ Enkel Koning meent dat een schuld van de 403-maatschappij op grond van art. 2:138/248 BW of art. 2:139/249 BW wel onder de 403-aansprakelijkheid valt. ${ }^{76}$ Hij merkt op dat een dergelijke schuld ontstaat als de 403-maatschappij tekortschiet in de uitoefening van haar bestuurstaak. Deze vloeit daarom volgens hem voort uit de rechtshandeling van de 403-maatschappij waarbij deze het bestuurderschap heeft geaccepteerd.

Ik kan mij niet vinden in de opvatting van Koning en onderschrijf de heersende leer in de literatuur dat alle gronden van externe bestuurdersaansprakelijkheid - waaronder schulden op grond van art. 2:138/248 BW en art. 2:139/249 BW niet onder de reikwijdte van de 403 -aansprakelijkheid vallen. Schulden van de 403-maatschappij uit hoofde van externe bestuurdersaansprakelijkheid vloeien mijns inziens nooit voort uit de rechtshandeling waarbij de 403-maatschappij het bestuurderschap heeft geaccepteerd. Dergelijke schulden zouden weliswaar niet zijn ontstaan zonder deze rechtshandeling - als de 403-maatschappij geen bestuurder was geworden, zou zij ook niet uit dien hoofde aansprakelijk kunnen zijn - maar zij vloeien daar niet uit voort. De reden daarvoor is dat de 403-maatschappij bij externe bestuurdersaansprakelijkheid niet aansprakelijk is

73. Asser/Maeijer, Van Solinge \& Nieuwe Weme 2-II* 2009/455, Assink/Slagter 2013/51.9 en 51.14, Van der Heijden/Van der Grinten \& Dortmond 2013/399.1 en Huizink, in: GS Rechtspersonen, art. 2:248 BW, aant. 37.1. Zie echter Faber en Kortmann in hun annotatie onder HR 18 september 2009, JOR 2010/29 (Simoca), die betogen dat een bestuurder op grond van art. 2:138/248 BW wel aansprakelijk is jegens de failliete rechtspersoon.

74. HR 18 september 2009, JOR 2010/29, m.nt. Faber en Kortmann (Simoca), r.o. 3.4.

75. Zie met betrekking tot de aansprakelijkheid op grond van art. 2:139/249 BW Beckman 1995a, p. 558 (zie ook Asser/Maeijer, Van Solinge \& Nieuwe Weme 2-II* 2009/470, die opmerken dat deze grond voor aansprakelijkheid van een bestuurder een species is van de onrechtmatige daad); op grond van art. 36 van de Invorderingswet 1990 Koning 1991, p. 31 en Beckman 1995a, p. 558-559 (zie ook Assink/Slagter 2013/3.5.3, die opmerkt deze aansprakelijkheid niet voortvloeit uit een rechtshandeling maar uit de wet); op grond van art. 2:69/180 BW Beckman 1995a, p. 559; en op grond van art. 2:138/248 BW Honée 1986, p. 120, Van der Heijden/Van der Grinten 1992/324.2 (zie Van der Heijden/Van der Grinten \& Dortmond 2013/324.3, waar dit onderwerp wel wordt aangestipt, maar er geen antwoord wordt gegeven), Houwen, Schoonbrood-Wessels \& Schreurs 1993, p. 850 en Beckman 1995 a, p. 558.

76. Koning 1991, p. 31. 
tegenover de wederpartij bij de rechtshandeling waarbij zij het bestuurderschap heeft geaccepteerd - de door haar bestuurde rechtspersoon - maar tegenover een derde. Schulden op grond van externe bestuurdersaansprakelijkheid vloeien daarom naar mijn mening niet voort uit deze rechtshandeling maar uit de wet. Zij vallen dus niet onder de reikwijdte van de 403-aansprakelijkheid.

Bovenstaande redenering is ook van toepassing als de door de 403-maatschappij bestuurde rechtspersoon op zijn beurt bestuurder is van een andere rechtspersoon en uit dien hoofde aansprakelijk is. Op grond van art. 2:11 BW rust deze aansprakelijkheid dan tevens op de 403-maatschappij. Ook in een dergelijk geval is de 403-maatschappij als bestuurder niet aansprakelijk tegenover de wederpartij bij de rechtshandeling waarbij zij het bestuurderschap heeft aanvaard. Ik meen daarom met Beckman dat de aansprakelijkheid op grond van art. 2:11 BW niet voortvloeit uit deze rechtshandeling maar uit de desbetreffende bepaling. ${ }^{77}$ De moedermaatschappij is om die reden niet op grond van de 403-verklaring aansprakelijk voor een dergelijke schuld van de 403-maatschappij.

\subsection{4.d Tussenconclusie}

Resumerend vallen schulden uit hoofde van interne bestuurdersaansprakelijkheid wel onder de reikwijdte van de 403-aansprakelijkheid, en schulden op grond van externe bestuurdersaansprakelijkheid niet. Dit onderscheid is te verklaren doordat de 403-maatschappij bij interne en externe bestuurdersaansprakelijkheid tegenover andere partijen aansprakelijk is. Bij interne bestuurdersaansprakelijkheid is zij aansprakelijk tegenover de wederpartij bij de rechtshandeling waarbij de 403-maatschappij het bestuurderschap heeft aanvaard, namelijk de door haar bestuurde rechtspersoon. De gronden voor interne bestuurdersaansprakelijkheid zijn te zien als een uitwerking van hoe een bestuurder zijn taak moet uitvoeren. Schiet de 403-maatschappij daarin tekort en moet zij de schade vergoeden die de door haar bestuurde rechtspersoon daardoor lijdt, dan is dat een secundaire schuld die voortvloeit uit de rechtshandeling waarbij zij het bestuurderschap heeft geaccepteerd. Bij externe bestuurdersaansprakelijkheid is de 403-maatschappij niet aansprakelijk tegenover de wederpartij bij de rechtshandeling waarbij zij het bestuurderschap heeft geaccepteerd, maar tegenover een derde. De aansprakelijkheid vloeit daarom niet voort uit deze rechtshandeling, maar uit de wet.

Bovenstaand onderscheid leidt tot de opmerkelijke situatie dat afhankelijk van de grond waarop de 403-maatschappij als bestuurder aansprakelijk is gesteld, de moedermaatschappij soms wel en soms niet mede aansprakelijk is. Als bijvoorbeeld een door de 403-maatschappij bestuurde BV failliet is gegaan en deze

77. Beckman 1995a, p. 559. 
in de jaren voorafgaand aan het faillissement geen jaarrekening openbaar heeft gemaakt, kan de curator de 403-maatschappij aansprakelijk stellen op grond van art. 2:9 BW of op grond van art. 2:248 BW. De curator doet er in dat geval verstandig aan de vordering op de eerste grond te baseren. Als de vordering wordt toegewezen kan hij zich namelijk op grond van de 403-verklaring ook op de moedermaatschappij verhalen. In het geval dat de curator daarentegen een vordering instelt op grond van art. 2:248 BW en deze wordt toegewezen, kan hij zich niet op de moedermaatschappij verhalen.

\subsubsection{Lidmaatschapsverplichtingen}

Een 403-maatschappij kan lid worden van een vereniging, coöperatie of onderlinge waarborgmaatschappij bij de oprichtingshandeling of door later toe te treden. ${ }^{78}$ Aan dit lidmaatschap zijn doorgaans verplichtingen verbonden jegens de vereniging, coöperatie of onderlinge waarborgmaatschappij. Het is de vraag of dergelijke verplichtingen van de 403-maatschappij onder de reikwijdte van de 403-aansprakelijkheid vallen.

Ik maak een onderscheid tussen twee soorten lidmaatschapsverplichtingen. Ten eerste de verplichtingen die bij of krachtens de statuten aan het lidmaatschap zijn verbonden ${ }^{79}$ zoals de verplichting tot het betalen van contributie of dat de leden na afloop van het boekjaar een eventueel verlies van de vereniging, coöperatie of onderlinge waarborgmaatschappij moeten aanvullen. ${ }^{80}$ Ten tweede de verplichtingen van een lid uit een zakelijke overeenkomst met de coöperatie of onderlinge waarborgmaatschappij. Dit zijn overeenkomsten die samenhangen met het doel van de coöperatie of de onderlinge waarborgmaatschappij, om te voorzien in de stoffelijke behoeften van de leden krachtens overeenkomst, respectievelijk het sluiten van verzekeringsovereenkomsten met de leden. ${ }^{81}$ Rensen noemt als voorbeeld dat een kredietcoöperatie een geldleningsovereenkomst met haar leden sluit, of dat een productverwerkende coöperatie koopovereenkomsten aangaat met haar leden. ${ }^{82}$ Bij dit laatste kan bijvoorbeeld worden gedacht aan een zuivelcoöperatie die melk afneemt bij boeren. Bij een onderlinge waarborgmaatschappij geldt dat het lidmaatschap een gevolg is van de verzekeringsovereenkomst. ${ }^{83}$

Het zal niet verbazen dat de schulden die voortvloeien uit een zakelijke overeenkomst die de 403-maatschappij is aangegaan met de coöperatie of onderlinge

78. Zie Rensen 2005, p. 11 en Asser/Rensen 2-III 2017/60, in algemene zin over de toetreding tot een vereniging.

79. Zie art. 2:34a BW.

80. Asser/Rensen 2-III 2017/57.

81. Zie art. 2:53 lid 1 en $2 \mathrm{BW}$.

82. Asser/Rensen 2-III 2017/221.

83. Asser/Rensen 2-III 2017/283. 
waarborgmaatschappij, onder de reikwijdte van de 403-aansprakelijkheid vallen. ${ }^{84} \mathrm{Er}$ is geen reden om een onderscheid te maken tussen dergelijke overeenkomsten en andere zakelijke overeenkomsten die de 403-maatschappij aangaat met een andere partij dan de coöperatie of onderlinge waarborgmaatschappij. Ook de coöperatie of onderlinge waarborgmaatschappij moet worden gecompenseerd voor het niet kunnen inzien van de jaarrekening van de 403-maatschappij.

Het is echter de vraag of ook de verplichtingen die bij of krachtens de statuten aan het lidmaatschap zijn verbonden onder de reikwijdte van de 403-aansprakelijkheid vallen. Met Beckman beantwoord ik deze vraag bevestigend. ${ }^{85}$ Het toetreden als lid bij de vereniging, coöperatie of onderlinge waarborgmaatschappij is een rechtshandeling van de 403 -maatschappij. ${ }^{86}$ Door de toetreding is de 403-maatschappij van rechtswege gehouden tot de verplichtingen jegens de vereniging, coöperatie of onderlinge waarborgmaatschappij die het lidmaatschap met zich brengt. ${ }^{87}$ Naar mijn mening vloeien deze verplichtingen daarom voort uit de rechtshandeling waarbij de 403-maatschappij lid is geworden. Dat de rechtsverhouding tussen de 403-maatschappij en de vereniging, coöperatie of onderlinge waarborgmaatschappij mede wordt beheerst door de statuten maakt dit niet anders.

Houwen is het niet eens met bovenstaand standpunt. ${ }^{88}$ Hij meent dat dit een te ruime uitleg is van de reikwijdte van de 403 -aansprakelijkheid die niet strookt met de strekking van de aansprakelijkheid van de moedermaatschappij. Hij legt echter niet uit waarom het in strijd zou zijn met de strekking van de 403-aansprakelijkheid als de moedermaatschappij aansprakelijk is voor de statutaire lidmaatschapsverplichtingen van de 403-maatschappij tegenover de vereniging, coöperatie of onderlinge waarborgmaatschappij. Ik zie niet in waarom deze statutaire lidmaatschapsverplichtingen op dit punt zouden verschillen van andere verplichtingen die uit een rechtshandeling van de 403-maatschappij voortvloeien. Voor een vereniging, coöperatie of onderlinge waarborgmaatschappij - en indirect voor de leden daarvan - kan het van belang zijn om de jaarrekening van de 403-maatschappij in te zien. Als deze mogelijkheid ontbreekt, moet de vereniging, coöperatie of onderlinge waarborgmaatschappij mijns inziens worden gecompenseerd voor het gebrek aan inzicht. Ik geef hieronder twee voorbeelden met betrekking tot een coöperatie.

84. Beckman 1995a, p. 551-552. Zie ook Houwen 1997, p. 82, die dit standpunt impliciet lijkt te onderschrijven.

85. Beckman 1995a, p. 552.

86. Zie Asser/Rensen 2-III 2017/16 in algemene zin over de toetreding van een lid bij de oprichtingshandeling van de vereniging, respectievelijk Assink/Slagter 2013/83 en Asser/Rensen 2-III 2017/60 in algemene zin over de toetreding van een lid tot een bestaande vereniging.

87. Rensen 2005, p. 50 en Asser/Rensen 2-III 2017/51.

88. Houwen 1997, p. 82. 
Ten eerste is het mogelijk dat een coöperatie op grond van art. 2:60 BW in de statuten heeft opgenomen dat als een lid uittreedt, hij uittreedgeld moet betalen aan de coöperatie. ${ }^{89}$ Een zuivelcoöperatie kan bijvoorbeeld een verplichting tot het betalen van uittreedgeld in de statuten hebben opgenomen om het verlies in omzet op te vangen dat ontstaat doordat een lid na zijn uittreden geen melk meer levert aan de coöperatie. Daarnaast kunnen de leden van een coöperatie statutair verplicht zijn om gezamenlijk ieder boekjaar een eventueel verlies van de coöperatie aan te vullen. In dergelijke situaties is het voor de coöperatie - en indirect voor de leden - van belang dat de jaarrekening van de 403-maatschappij kan worden ingezien om (mede) aan de hand daarvan te schatten of de 403-maatschappij in staat is om aan deze verplichtingen te voldoen. De coöperatie kan in financiële moeilijkheden komen als de 403-maatschappij niet aan haar verplichtingen voldoet, en dit kan weer tot extra aansprakelijkheid leiden voor de overige leden van de coöperatie - bijvoorbeeld omdat zij zelf extra moeten bijbetalen om het verlies van de coöperatie aan te vullen. Als de coöperatie niet de mogelijkheid heeft om de jaarrekening van de 403-maatschappij in te zien en (mede) aan de hand daarvan te schatten hoe groot het risico is dat deze niet aan haar lidmaatschapsverplichtingen zal voldoen, moet de coöperatie hiervoor naar mijn mening worden gecompenseerd met een aanvullende vordering op de moedermaatschappij van wie zij de geconsolideerde jaarrekening wel kan inzien. Hetzelfde geldt voor een vereniging of onderlinge waarborgmaatschappij waarvan de 403-maatschappij lid is.

Tot slot wijs ik nog op de mogelijkheid dat een 403-maatschappij op grond van art. 2:55 lid $1 \mathrm{BW}$ bij de ontbinding van de coöperatie of onderlinge waarborgmaatschappij waarvan zij lid is, of tot minder dan een jaar geleden lid was, aansprakelijk is voor (een statutair vastgesteld deel van) het tekort van de coöperatie of onderlinge waarborgmaatschappij. Beckman is van mening dat deze aanzuiveringsplicht voortvloeit uit art. 2:55 lid $1 \mathrm{BW}$ en daarom niet onder de reikwijdte van de 403 -aansprakelijkheid valt. ${ }^{90}$ Dit lijkt mij echter geen juist oordeel. Ik wijs erop dat een 403-maatschappij op grond van art. 2:55 lid $1 \mathrm{BW}$ niet aansprakelijk is tegenover de crediteuren van de coöperatie of onderlinge waarborgmaatschappij, maar tegenover de coöperatie of onderlinge waarborgmaatschappij zelf. Ik maak op dit punt een vergelijking met de aansprakelijkheid van een 403-maatschappij ex art. 2:9 BW als bestuurder van een andere rechtspersoon. Ik heb eerder opgemerkt dat deze aansprakelijkheid mijns inziens voortvloeit uit de rechtshandeling waarbij de 403-maatschappij het bestuurderschap heeft aanvaard, omdat het een interne aansprakelijkheid betreft tegenover de wederpartij bij deze rechtshandeling: de door haar bestuurde rechtspersoon. ${ }^{91}$ Hetzelfde geldt bij de aansprakelijkheid op

89. Asser/Rensen 2-III 2017/241.

90. Beckman 1995a, p. 552-553.

91. Zie $\S$ 4.5.4.b. 
grond van art. 2:55 lid $1 \mathrm{BW}$. Ook dat betreft een interne verplichting tegenover de wederpartij bij de rechtshandeling waarbij de 403-maatschappij lid is geworden van de coöperatie of onderlinge waarborgmaatschappij. In beide gevallen is de directe ontstaansgrond van de schuld weliswaar de wet - op grond van de wet is de 403-maatschappij onder bepaalde omstandigheden als bestuurder of lid aansprakelijk -, maar de schuld vloeit voort uit de eerdere rechtshandeling van de 403-maatschappij.

\subsubsection{Vennoot in een personenvennootschap}

\subsection{6.a Inleiding}

Enigszins vergelijkbaar met de hierboven genoemde situatie dat een 403-maatschappij lid wordt van een vereniging, coöperatie of onderlinge waarborgmaatschappij, is het geval dat de 403-maatschappij toetreedt tot een personenvennootschap. Opnieuw komt de vraag op in hoeverre de verplichtingen van de 403-maatschappij die zijn verbonden aan het zijn van vennoot in de personenvennootschap onder de reikwijdte van de 403-aansprakelijkheid vallen.

De discussie in de literatuur ten anzien van het antwoord op bovenstaande vraag, richt zich hoofdzakelijk op de aansprakelijkheid van een vennoot voor de schulden van de personenvennootschap tegenover derden. Als bijvoorbeeld een vennoot in een vennootschap onder firma namens de vennootschap een huurovereenkomst aangaat, zijn alle vennoten op grond van art. $18 \mathrm{WvK}$ hoofdelijk aansprakelijk voor de huurpenningen die daaruit voortvloeien. De vraag in hoeverre de moedermaatschappij op grond van de 403-verklaring mede aansprakelijk is voor deze schulden van de 403-maatschappij als vennoot, wordt in de literatuur verschillend beantwoord.

Hoewel het antwoord op bovenstaande vraag van belang is om vast te kunnen stellen in hoeverre de moedermaatschappij op grond van de 403-verklaring aansprakelijk is voor de verplichtingen van de 403-maatschappij die zijn verbonden aan het zijn van vennoot in een personenvennootschap, is dit slechts een deel van het antwoord. Naar mijn mening moet de 'externe' aansprakelijkheid van een vennoot voor de schulden van de personenvennootschap jegens derden, worden onderscheiden van de aansprakelijkheid van de vennoot jegens de personenvennootschap zelf. Ik duid deze laatste grond voor aansprakelijkheid aan als de 'interne' aansprakelijkheid van een vennoot. Ik kom later terug op dit onderscheid. ${ }^{92}$

Voordat ik toekom aan de verschillende standpunten in de literatuur met betrekking tot de aansprakelijkheid van een moedermaatschappij voor de verplichtingen van de 403-maatschappij als vennoot voor de schulden van de

92. Zie $\S$ 4.5.6.c. 
personenvennootschap jegens derden, maak ik eerst nog een algemene opmerking met betrekking tot deze aansprakelijkheid van een vennoot. In hoeverre een vennoot aansprakelijk is voor de schulden van de personenvennootschap jegens een derde, is onder meer afhankelijk van het soort personenvennootschap, de onderlinge afspraken tussen de vennoten en het soort overeenkomst die de personenvennootschap met de wederpartij is aangegaan. Ik wijs bijvoorbeeld op het verschil tussen de aansprakelijkheid voor gelijk delen voor vennoten in een maatschap en de hoofdelijke aansprakelijkheid van vennoten in een vennootschap onder firma. ${ }^{93}$ Daarnaast geldt voor de aansprakelijkheid van vennoten in een maatschap dat er met de wederpartij een andere verdeling van aansprakelijkheid kan zijn afgesproken ${ }^{94}$ en dat de aansprakelijkheid voor schulden die voortvloeien uit een overeenkomst van opdracht die is aangegaan met het oog op een specifieke vennoot afwijkt van de hoofdregel. ${ }^{95}$ Tot slot wijs ik nog op de aansprakelijkheid van toe- en uittredende vennoten, en die van een commanditaire vennoot die het beheersverbod heeft overtreden. ${ }^{96}$ Het voert te ver om de diverse gronden voor aansprakelijkheid en de onderlinge verschillen op deze plek uit te werken. Voor een uiteenzetting hiervan verwijs naar de relevante literatuur. ${ }^{97}$

\subsection{6.b Standpunten in de literatuur}

In de literatuur zijn drie standpunten te onderscheiden ten aanzien van het antwoord op de vraag in hoeverre de externe aansprakelijkheid van een 403-maatschappij als vennoot voor de schulden van de personenvennootschap jegens derden onder de reikwijdte van de 403-aansprakelijkheid valt. Het eerste standpunt wordt verdedigd door Van der Ploeg. ${ }^{98}$ Hij wijst erop dat de aansprakelijkheid van de moedermaatschappij op grond van de 403-verklaring onderdeel is van de compensatie voor de crediteuren omdat zij de jaarrekening van de 403-maatschappij niet kunnen inzien. Volgens hem valt daarom slechts de aansprakelijkheid van de 403-maatschappij voor de schulden die voortvloeien uit de rechtshandelingen die deze zelf namens de personenvennootschap heeft verricht, onder de reikwijdte van de 403-aansprakelijkheid. De aansprakelijkheid van de 403-maatschappij voor de schulden die voortvloeien uit de rechtshandelingen die een van de andere vennoten namens de

93. Zie art. 7A:1680 BW en art. $18 \mathrm{WvK}$.

94. Zie art. 7A:1680 BW.

95. Zie art. 7:404 BW.

96. Zie art. 20 lid 2 jo art. $21 \mathrm{WvK}$.

97. Tervoort 2015, p. 117-156, Stokkermans 2017, p. 91-123, 253-266 en 306-313, Asser/Maeijer \& Van Olffen 7-VII 2017/103-148a en Huizink 2020, p. 27-35 en 51-61.

98. Van der Ploeg 1986, p. 60. Ik merk op dat Van der Ploeg zijn standpunt toespitst op de aansprakelijkheid van een beherend vennoot van een commanditaire vennootschap. Dit standpunt geldt mijns inziens mutatis mutandis ook voor de aansprakelijkheid van een vennoot in een maatschap of een vennootschap onder firma. 
personenvennootschap heeft verricht, valt volgens Van der Ploeg niet onder de reikwijdte van de 403-aansprakelijkheid.

Evenals Houwen en Bartman kan ik mij niet vinden in bovenstaand standpunt. Houwen merkt terecht op dat als een van de vennoten namens de personenvennootschap een rechtshandeling verricht, hij daardoor ook de andere vennoten bindt. ${ }^{99}$ De crediteur heeft er daarom belang bij dat hij kan schatten in hoeverre iedere vennoot in staat zal zijn aan haar verplichting te voldoen. Aangezien de crediteur niet de mogelijkheid heeft om de jaarrekening van de 403-maatschappij in te zien en (mede) aan de hand daarvan te schatten hoe groot het risico is dat de 403-maatschappij tekortschiet in de nakoming van haar verplichting, meen ik met Houwen dat de crediteur voor dit gebrek aan inzicht moet worden gecompenseerd. Hij dient zijn vordering op de 403-maatschappij ook op grond van de 403-verklaring op de moedermaatschappij te kunnen verhalen van wie hij de geconsolideerde jaarrekening wel kan inzien. Daarnaast merkt Bartman terecht op dat de uitleg van de 403-aansprakelijkheid volgens het standpunt van Van der Ploeg mogelijk tot misbruik kan leiden. ${ }^{100}$ De 403-maatschappij zou namelijk een katvanger als vennoot alle rechtshandelingen namens de personenvennootschap kunnen laten verrichten. Hierdoor hoeft de 403-maatschappij zelf geen rechtshandelingen te verrichten namens de personenvennootschap, waardoor er voor de moedermaatschappij op dit punt geen aansprakelijkheid ontstaat.

Het tweede standpunt omtrent de 403-aansprakelijkheid van de moedermaatschappij en de externe aansprakelijkheid van de 403-maatschappij voor de schulden van de personenvennootschap jegens derden, wordt onder meer door Houwen en Bartman verdedigd. ${ }^{101} \mathrm{Zij}$ betogen dat de aansprakelijkheid van de 403-maatschappij voor de schulden die voortvloeien uit alle rechtshandelingen die namens de personenvennootschap zijn verricht, onder de reikwijdte van de 403-aansprakelijkheid valt. Daarbij maakt het niet uit wie van de vennoten de rechtshandeling namens de personenvennootschap heeft verricht. Bartman wijst erop dat de 403-aansprakelijkheid op grond van art. 2:403 lid 1 sub f BW is beperkt tot schulden die uit een rechtshandeling van de 403-maatschappij

99. Houwen, Schoonbrood-Wessels \& Schreurs 1993, p. 848.

100. Bartman 1989, p. 121.

101. Bartman 1989, p. 121-122, Koning 1991, p. 30, Van der Heijden/Van der Grinten 1992/324.2 (zie Van der Heijden/Van der Grinten \& Dortmond 2013/324.3, waar dit onderwerp wel wordt aangestipt, maar geen standpunt wordt ingenomen), Houwen, Schoonbrood-Wessels \& Schreurs 1993, p. 848, Ten Voorde 2006, p. 111-112 en Stokkermans 2017, p. 254. Ik merk op dat enkele auteurs hun standpunt toespitsten op de aansprakelijkheid van een beherend vennoot van een commanditaire vennootschap en/of de aansprakelijkheid van een vennoot in een vennootschap onder firma. Hun standpunt geldt mijns inziens mutatis mutandis ook voor de aansprakelijkheid van een vennoot in een maatschap en een vennoot in een vennootschap onder firma. 
voortvloeien, en dat schulden uit de wet daar niet onder vallen. ${ }^{102}$ Dit onderscheid geldt wat hem betreft ook met betrekking tot de externe aansprakelijkheid van de 403-maatschappij voor de schulden van de personenvennootschap jegens derden. Dit brengt volgens Bartman mee dat de aansprakelijkheid van de 403-maatschappij voor de schulden van de personenvennootschap die uit de wet voortvloeien - zoals de verplichting tot het vergoeden van de schade die is veroorzaakt door een gedraging die als een onrechtmatige daad aan de personenvennootschap kan worden toegerekend ${ }^{103}$ - buiten de reikwijdte van de 403-aansprakelijkheid valt.

Het derde en laatste standpunt wordt verdedigd door Beckman. Hij legt de 403-aansprakelijkheid op dit punt het ruimst uit en betoogt dat de volledige externe aansprakelijkheid van de 403-maatschappij voor de schulden van de personenvennootschap jegens derden daaronder valt. ${ }^{104}$ Dit betreft zowel de schulden van de personenvennootschap die voortvloeien uit een rechtshandeling als die uit de wet. Beckman wijst erop dat de overeenkomst tot samenwerking in een personenvennootschap een rechtshandeling is van de 403-maatschappij. Hij is van mening dat de volledige externe aansprakelijkheid van de 403-maatschappij voor de schulden van de personenvennootschap jegens derden uit die overeenkomst voortvloeit en daarom onder de 403-aansprakelijkheid valt.

\subsection{6.c Eigen standpunt en het onderscheid tussen interne en externe aansprakelijkheid}

Naar mijn mening is de uitkomst van het tweede hierboven genoemde standpunt juist, maar ik onderbouw dit anders dan Bartman en de andere daar genoemde auteurs. Bartman is van mening dat de overeenkomst tot samenwerking in de personenvennootschap de rechtshandeling is waaruit de externe aansprakelijkheid van de 403-maatschappij voor de schulden van de personenvennootschap jegens derden voortvloeit. ${ }^{105}$ Volgens hem moet de reikwijdte van de 403-aansprakelijkheid vervolgens zo worden uitgelegd dat de aansprakelijkheid van de 403-maatschappij voor de schulden van de personenvennootschap die uit de wet voortvloeien, daar niet onder valt. Ik meen echter dat de vennootschapsovereenkomst niet de rechtshandeling is waaruit de externe aansprakelijkheid van de 403-maatschappij voor de schulden van de personenvennootschap jegens derden voortvloeit.

102. Bartman 1989, p. 121-122.

103. Tervoort 2015, p. 133-135 en Asser/Maeijer \& Van Olffen 7-VII 2017/118.

104. Beckman 1987, p. 536 en Beckman 1995a, p. 564.

105. Bartman 1989, p. 121. 
Ik heb eerder opgemerkt dat er een onderscheid kan worden gemaakt tussen de interne aansprakelijkheid van een vennoot jegens de personenvennootschap en de externe aansprakelijkheid van een vennoot voor de schulden van de personenvennootschap jegens derden. ${ }^{106} \mathrm{Ik}$ meen dat als de 403-maatschappij een vennootschapsovereenkomst aangaat, daaruit slechts de interne aansprakelijkheid tegenover de personenvennootschap voortvloeit. Dit betreft bijvoorbeeld de verplichting van de 403-maatschappij tot het inbrengen van hetgeen waartoe zij krachtens de vennootschapsovereenkomst is gehouden, ${ }^{107}$ of het vergoeden van de schade die de personenvennootschap lijdt doordat de 403-maatschappij is tekortgeschoten in de nakoming van de vennootschapsovereenkomst. ${ }^{108}$ De externe aansprakelijkheid van de 403-maatschappij voor de schulden van de personenvennootschap jegens derden staat volgens mij los van de vennootschapsovereenkomst. Deze aansprakelijkheid vloeit mijns inziens niet voort uit het aangaan van de overeenkomst omdat dit schulden zijn van de 403-maatschappij tegenover een partij die niet betrokken was bij de vennootschapsovereenkomst.

Bovenstaande redenering is vergelijkbaar met het onderscheid dat ik heb gemaakt met betrekking tot bestuurdersaansprakelijkheid van een 403-maatschappij als bestuurder van een andere rechtspersoon. Ook daarbij heb ik gewezen op het verschil tussen interne en externe aansprakelijkheid. ${ }^{109} \mathrm{Ik}$ heb betoogd dat enkel de interne bestuurdersaansprakelijkheid tegenover de door de 403-maatschappij bestuurde rechtspersoon voortvloeit uit de rechtshandeling waarbij de 403-maatschappij het bestuurderschap heeft aanvaard. Deze aansprakelijkheid valt daarmee onder de reikwijdte van de 403-aansprakelijkheid. De externe bestuurdersaansprakelijkheid van de 403-maatschappij tegenover een derde valt naar mijn mening niet onder de 403-aansprakelijkheid, omdat dit schulden zijn tegenover een crediteur die geen partij was bij de rechtshandeling waarbij de 403-maatschappij het bestuurderschap heeft aanvaard.

Dat de externe aansprakelijkheid van de 403-maatschappij voor de schulden van de personenvennootschap tegenover derden niet voortvloeit uit de vennootschapsovereenkomst betekent overigens niet dat deze aansprakelijkheid in zijn geheel niet onder de 403-aansprakelijkheid valt. Als een van de vennoten een rechtshandeling verricht namens de personenvennootschap, bindt deze daarmee ook de andere vennoten waaronder de 403-maatschappij. Een dergelijke rechtshandeling geldt mijns inziens als een aparte rechtshandeling van de 403-maatschappij in de zin van art. 2:403 lid $1 \mathrm{sub} \mathrm{fBW}$. De schulden van de 403-maatschappij die uit deze rechtshandeling voortvloeien, vallen daarom onder de

106. Zie Houwen, Schoonbrood-Wessels \& Schreurs 1993, p. 848, waar Houwen ook een dergelijk onderscheid maakt, maar daar verder geen gevolgen aan verbindt.

107. Tervoort 2015, p. 98 en Asser/Maeijer \& Van Olffen 7-VII 2017/54.

108. Tervoort 2015, p. 98 en Asser/Maeijer \& Van Olffen 7-VII 2017/48.

109. Zie $\S 4.5 .4$. 


\section{HOOFDSTUK 4}

reikwijdte van de 403-aansprakelijkheid. Schulden van de personenvennootschap uit de wet, vloeien daarentegen niet voort uit een rechtshandeling van de 403-maatschappij en vallen daarom niet onder de reikwijdte van de 403-aansprakelijkheid. Ik licht dit hieronder toe.

Een personenvennootschap heeft geen rechtspersoonlijkheid. ${ }^{110}$ Dit brengt mee dat als er een rechtshandeling wordt verricht 'namens de personenvennootschap', het niet de vennootschap zelf is die deze handeling verricht en aansprakelijk is voor de daaruit voortvloeiende verplichtingen. In het geval van een maatschap verlenen de vennoten elkaar onderling een volmacht om namens de maatschap - zijnde de gezamenlijke vennoten - te handelen. ${ }^{111}$ En bij een vennootschap onder firma en een commanditaire vennootschap is iedere (beherend) vennoot die daarvan niet is uitgesloten, bevoegd om namens de vennootschap te handelen en deze tegenover derden te binden. ${ }^{112}$ De vennoot vertegenwoordigt daarbij de gezamenlijke vennoten. Als een vennoot dus namens de personenvennootschap een rechtshandeling verricht, is iedere vennoot - waaronder ook de 403-maatschappij - zelf partij bij deze rechtshandeling. ${ }^{113}$ Dit brengt naar mijn mening met zich dat de externe aansprakelijkheid van de 403-maatschappij als vennoot voor de schulden van de personenvennootschap jegens een derde niet voortvloeit uit de vennootschapsovereenkomst, maar uit de rechtshandeling die namens de personenvennootschap en dus namens de 403-maatschappij als vennoot, is verricht en waaruit de schulden zijn voortgevloeid.

Resumerend omvat de 403-aansprakelijkheid naar mijn mening dus de interne aansprakelijkheid van de 403-maatschappij jegens de personenvennootschap voor de schulden die voortvloeien uit de vennootschapsovereenkomst, en de externe aansprakelijkheid van de 403-maatschappij voor de schulden van de personenvennootschap jegens derden die voortvloeien uit de rechtshandelingen die namens de vennootschap zijn verricht. Deze uitleg van de aansprakelijkheid van de moedermaatschappij op grond van de 403-verklaring sluit aan bij de functie van de 403-aansprakelijkheid bij de compensatie van de crediteuren van de 403-maatschappij. ${ }^{114}$

110. Tervoort 2015, p. 7-8, Stokkermans 2017, p. 92, 282 en 300 en Asser/Maeijer \& Van Olffen 7-VII 2017/13. Zie ook Huizink 2020, p. 3-6.

111. Zie art. 7A:1679 en art. 7A:1681 BW.

112. Zie art. $17 \mathrm{WvK}$.

113. Tervoort 2015, p. 118. Zie specifiek met betrekking tot een maatschap Van der Waals 2017, p. 72, Asser/Maeijer \& Van Olffen 7-VII 2017/109-110, Stokkermans 2017, p. 96 en Huizink 2020, p. 27-28; ten aanzien van een vennootschap onder firma Assink/Slagter 2013/99.4 en Stokkermans 2017, p. 247; en met betrekking tot een commanditaire vennootschap Stokkermans 2017, p. 306.

114. De compensatie voor een crediteur bestaat uit twee onderdelen: een vordering op de moedermaatschappij op grond van de 403-verklaring en de mogelijkheid om de geconsolideerde jaarrekening van de moedermaatschappij in te zien. Zie $\S 3.4 .1$. 
De personenvennootschap bestaat uit de gezamenlijke vennoten. De overige vennoten hebben er belang bij dat zij de jaarrekening van de 403-maatschappij kunnen inzien om (mede) aan de hand daarvan te kunnen schatten hoe groot het risico is dat de 403-maatschappij niet (volledig) aan haar verplichtingen uit de vennootschapsovereenkomst jegens de personenvennootschap zal voldoen. Hetzelfde geldt voor een crediteur van wie de vordering voortvloeit uit een rechtshandeling van de personenvennootschap. De vennoten, waaronder de 403-maatschappij, zijn naast de personenvennootschap aansprakelijk tegenover de crediteur voor de schulden die uit deze rechtshandeling voortvloeien. In tegenstelling tot een crediteur die direct een overeenkomst met de 403-maatschappij aangaat, kan een crediteur van wie de vordering voortvloeit uit een rechtshandeling van de personenvennootschap niet alleen de 403-maatschappij als vennoot aanspreken, maar ook de overige vennoten en de personenvennootschap. Desondanks is het voor de crediteur van belang om (mede) aan de hand van de jaarrekening van de 403-maatschappij te kunnen schatten hoe groot het risico is dat deze niet (volledig) aan haar verplichtingen zal kunnen voldoen.

Zowel (de overige vennoten in) de personenvennootschap als de crediteuren van wie de vordering voortvloeit uit een rechtshandeling van de personenvennootschap, moeten daarom volgens het door mij bepleite uitgangspunt voor compensatie worden gecompenseerd als de mogelijkheid ontbreekt om de jaarrekening van de 403-maatschappij in te zien. ${ }^{115}$ Zij moeten zich tevens op de moedermaatschappij kunnen verhalen van wie zij de geconsolideerde jaarrekening wel kunnen inzien. Deze redenering gaat echter niet op voor de crediteuren van de personenvennootschap van wie de vordering voortvloeit uit de wet. Ik ben eerder in dit hoofdstuk tot de conclusie gekomen dat de crediteuren van wie de vordering uit de wet voortvloeit niet gecompenseerd hoeven te worden voor het feit dat zij de jaarrekening van de 403-maatschappij niet kunnen inzien. ${ }^{116}$

Ik maak nog twee afsluitende opmerkingen met betrekking tot de 403-aansprakelijkheid en het onderscheid tussen interne en externe aansprakelijkheid van een vennoot in een personenvennootschap. Ten eerste wijs ik erop dat een commanditaire vennoot op grond van art. 20 lid $3 \mathrm{WvK}$ slechts aansprakelijk is tot het bedrag van zijn inbreng. Dit betreft een interne verplichting tot het inbrengen van hetgeen waartoe hij krachtens de vennootschapsovereenkomst is verplicht. ${ }^{117}$ Indien een 403-maatschappij een commanditaire vennoot is, kan de moedermaatschappij op grond van de 403-verklaring dus enkel door (de overige vennoten in) de personenvennootschap worden aangesproken voor de nakoming van de verplichting tot inbreng. Derden kunnen geen beroep doen

115. Zie $\S 3.7$.

116. Zie $\S 4.3 .2$.

117. Tervoort 2015, p. 51, Stokkermans 2017, p. 306-307, Asser/Maeijer \& Van Olffen 7-VII 2017/385 en Huizink 2020, p. 58-59. 


\section{HOOFDSTUK 4}

op de 403-aansprakelijkheid. Dit wordt mijns inziens niet anders als de commanditaire vennoot het naamvoerings- of beheersverbod ex art. 20 lid 1 en lid 2 WvK schendt en hij op grond van art. $21 \mathrm{WvK}$ hoofdelijk aansprakelijk is voor de schulden van de personenvennootschap jegens derden. De aansprakelijkheid ex art. $21 \mathrm{WvK}$ betreft namelijk een sanctie voor de commanditaire vennoot om te voorkomen dat hij op een in art. $20 \mathrm{WvK}$ genoemde manier onduidelijkheid laat ontstaan over zijn rechtspositie in de commanditaire vennootschap. ${ }^{118}$ De positie van de commanditaire vennoot in de vennootschap verandert niet door het overtreden van het naamvoerings- of beheersverbod. Hij wordt geen beherend vennoot in de commanditaire vennootschap. ${ }^{119}$ Tervoort merkt op dat het feit dat de commanditaire vennoot geen beherend vennoot wordt, meebrengt dat hij voor de vorderingen die hij uit hoofde van zijn aansprakelijkheid op grond van art. $21 \mathrm{WvK}$ voldoet, een regresvordering krijgt op de beherend vennoten. ${ }^{120}$ Mits de beherend vennoten niet failliet zijn of gaan, ondervindt de commanditaire vennoot dus geen financieel nadeel van de sanctie ex art. 21 WvK. Deze duiding van de aansprakelijkheid van een commanditaire vennoot op grond van art. $21 \mathrm{WvK}$ brengt mee dat dit een wettelijke sanctie is en niet een schuld die voortvloeit uit een rechtshandeling in de zin van art. 2:403 lid 1 sub f BW. De aansprakelijkheid valt daarom niet onder de reikwijdte van de 403-aansprakelijkheid.

Ten tweede wijs ik op de mogelijkheid dat een vennoot onbevoegdelijk heeft gehandeld namens de personenvennootschap, maar dat de overige vennoten toch gebonden kunnen zijn. Een vennoot handelt onbevoegdelijk namens een maatschap als hij geen volmacht heeft of zijn volmacht te buiten gaat, en bij een vennootschap onder firma of commanditaire vennootschap als de (beherend) vennoot buiten zijn vertegenwoordigingsbevoegdheid treedt - en de andere vennoten hem ook geen volmacht daartoe hadden gegeven. In beginsel bindt de desbetreffende vennoot dan enkel zichzelf en niet ook de overige vennoten. Tervoort, Van Olffen en Blanco Fernández wijzen er echter op dat de overige vennoten in een dergelijk geval toch gebonden kunnen zijn op grond van zaakwaarneming, ${ }^{121}$ als zij de rechtshandeling bekrachtigen, ${ }^{122}$ indien de wederpartij te goeder trouw is afgegaan op door de andere vennoten gewekte en aan

118. HR 18 april 1980, NJ 1981/377, m.nt. Wachter (Sleephelling Maatschappij Scheveningen/ Buis), Assink/Slagter 2013/99.4, HR 29 mei 2015, NJ 2015/380, m.nt. Van Schilfgaarde (Lunchroom De Katterug), r.o. 3.4.2, ook gepubliceerd in JOR 2015/192, m.nt. Stokkermans, Asser/Maeijer \& Van Olffen 7-VII 2017/379 en Stokkermans 2017, p. 308.

119. Asser/Maeijer \& Van Olffen 7-VII 2017/383, Stokkermans 2017, p. 308 en Tervoort 2015, p. 145.

120. Tervoort 2015, p. 146

121. Zie art. 6:198 BW.

122. Zie art. 3:69 jo. 3:78 BW. 
hen toerekenbare schijn van volmacht ${ }^{123}$ of uit hoofde van baattrekking. ${ }^{124}$ Deze laatste grond houdt in dat de vennoten zijn gebonden aan een onbevoegdelijk namens de personenvennootschap verrichte rechtshandeling, als deze ten voordeel van de vennootschap strekt. ${ }^{125}$

Ik ben van mening dat enkel in het geval dat de 403-maatschappij als vennoot een rechtshandeling bekrachtigt die een andere vennoot onbevoegdelijk namens de personenvennootschap heeft verricht, de schulden die daaruit voortvloeien onder de reikwijdte van de 403-aansprakelijkheid vallen. Slechts bij een bekrachtiging - die zowel uitdrukkelijk als stilzwijgend kan plaatsvinden - is er sprake van een rechtshandeling van de 403-maatschappij. In de andere gevallen heeft de 403-maatschappij geen rechtshandeling verricht, ${ }^{126}$ en vloeit haar aansprakelijkheid voor de schulden van de personenvennootschap jegens de derde voort uit de desbetreffende wettelijke bepaling. De derde kan deze schulden van de 403-maatschappij dus niet op grond van de 403-verklaring verhalen op de moedermaatschappij.

\subsection{6.d Het voorontwerp modernisering personenvennootschappen}

Tot slot wijs ik nog op het voorontwerp inzake de modernisering van personenvennootschappen. ${ }^{127}$ Op grond van het voorgestelde art. 7:801 lid $1 \mathrm{BW}$ blijft een personenvennootschap een overeenkomst tussen de vennoten. Maar in afwijking van het huidige recht krijgt een personenvennootschap uit hoofde van het voorgestelde art. 7:803 lid $1 \mathrm{BW}$ wel rechtspersoonlijkheid. Dit zou tot gevolg hebben dat als er namens de personenvennootschap wordt gehandeld, dit namens de rechtspersoon is en niet meer namens de gezamenlijke vennoten. De vennoten zijn dus niet zelf partij bij een dergelijke handeling. Op grond van het voorgestelde art. 7:809 lid $1 \mathrm{BW}$ zijn de vennoten wel subsidiair hoofdelijk verbonden voor de schulden van de personenvennootschap.

Hierboven heb ik betoogd dat naar huidig recht de externe aansprakelijkheid van de 403-maatschappij voor de schulden van de personenvennootschap jegens derden die voortvloeien uit de rechtshandelingen die namens de vennootschap zijn verricht, onder de reikwijdte van de 403-aansprakelijkheid valt omdat de

123. Zie art. 3:61 lid 2 BW.

124. Tervoort 2015, p. 129-133, Asser/Maeijer \& Van Olffen 7-VII 2017/113-114 en 137 en Blanco Fernández - T\&C Ondernemingsrecht, art. 7A:1681 BW, aant. 2 en 3.

125. Zie art. 7A:1681 BW. Deze bepaling is zowel van toepassing op de vennoten in een maatschap als - op grond van de schakelbepalingen ex art. 1 jo. art. $15 \mathrm{WvK}$ - op de vennoten in een vennootschap onder firma en de beherend vennoten in een commanditaire vennootschap.

126. Zie Stokkermans 2017, p. 121, die terecht opmerkt dat er bij baattrekking geen sprake is van vertegenwoordiging van de vennoten of een vorm van bekrachtiging.

127. Zie internetconsultatie.nl/moderniseringpersonenvennootschap. 
403-maatschappij zelf partij is bij deze rechtshandelingen. ${ }^{128}$ Aangezien de vennoten van een personenvennootschap volgens de voorgestelde regeling geen partij meer zijn bij dergelijke rechtshandelingen, vallen de schulden die daaruit voortvloeien niet onder de 403-aansprakelijkheid. Ook de redenering dat de subsidiaire hoofdelijke aansprakelijkheid van de 403-maatschappij op grond van het voorgestelde art. 7:809 lid $1 \mathrm{BW}$ voor de schulden van de personenvennootschap jegens derden voortvloeit uit de vennootschapsovereenkomst en uit dien hoofde onder de 403-aansprakelijkheid valt, houdt naar mijn mening geen stand. Evenals naar huidig recht vloeit deze externe aansprakelijkheid mijns inziens niet voort uit de vennootschapsovereenkomst omdat het een aansprakelijkheid betreft van de 403-maatschappij tegenover een partij die niet betrokken is bij deze overeenkomst.

Resumerend leidt de voorgestelde regeling voor de modernisering van personenvennootschappen er naar mijn mening toe dat slechts de interne aansprakelijkheid van een 403-maatschappij jegens de personenvennootschap, onder de reikwijdte van de 403-aansprakelijkheid valt. Dit zou mijns inziens een ongewenste verandering zijn ten opzichte van het huidige recht. Ik heb er eerder op gewezen dat de crediteuren van wie de vordering voortvloeit uit een rechtshandeling van de personenvennootschap er belang bij kunnen hebben om de jaarrekening van de 403-maatschappij in te zien, om (mede) aan de hand daarvan te schatten hoe groot het risico is dat de 403-maatschappij niet (volledig) aan haar verplichtingen zal voldoen. ${ }^{129}$ Als deze mogelijkheid ontbreekt, moet een crediteur daarvoor naar mijn mening worden gecompenseerd met een aanvullende vordering op de moedermaatschappij van wie hij de geconsolideerde jaarrekening wel kan inzien. Een mogelijkheid is om het voorgestelde art. 7:809 lid $1 \mathrm{BW}$ te wijzigen zodat de aansprakelijkheid van een 403-maatschappij voor de schulden van de personenvennootschap jegens derden onder de 403-aansprakelijkheid valt. Dit kan worden bereikt door deze bepaling zo aan te passen dat de vennoten niet extern aansprakelijk zijn tegenover de crediteuren, maar dat het een interne aansprakelijkheid betreft tegenover de personenvennootschap indien deze een schuld aan een crediteur niet kan voldoen. ${ }^{130}$ Deze aanpassing zou er overigens toe leiden dat de moedermaatschappij niet alleen aansprakelijk wordt voor de schulden van de personenvennootschap jegens derden die voortvloeien uit een rechtshandeling die namens de vennootschap is verricht, maar ook voor de schulden van de personenvennootschap uit de wet. Ik heb eerder opgemerkt dat de crediteuren van de personenvennootschap van wie de

128. Zie $\S$ 4.5.6.c.

129. Zie $\S 4.5 .6 . c$.

130. Dit is vergelijkbaar met de aansprakelijkheid op grond van art. 2:55 lid 1 BW voor (een statutair vastgesteld deel van) het tekort bij de ontbinding van een coöperatie of onderlinge waarborgmaatschappij waarvan de 403-maatschappij lid is, of tot minder dan een jaar geleden lid was (zie $\S 4.5 .5)$. 
vordering uit de wet voortvloeit niet gecompenseerd hoeven te worden voor het niet kunnen inzien van de jaarrekening van de 403 -maatschappij als vennoot. ${ }^{131}$

Ik ben mij ervan bewust dat bovengenoemde aanpassing van art. 7:809 lid 1 BW een fundamentele wijziging meebrengt ten opzichte van de voorgestelde regeling in het voorontwerp. Dit zou onder meer tot gevolg hebben dat een crediteur niet zelf de vennoten aansprakelijk kan stellen. Hij kan zich slechts op de personenvennootschap verhalen en het faillissement aanvragen als deze de vordering niet kan voldoen. Het is dan aan de curator om een beroep te doen op de interne aansprakelijkheid van de vennoten ex art. 7:809 lid 1 BW.

Hoewel het volgens het door mij bepleite uitgangspunt voor compensatie wenselijk is dat de externe aansprakelijkheid van de 403-maatschappij voor de schulden van de personenvennootschap jegens derden die voortvloeien uit de rechtshandelingen die namens de vennootschap zijn verricht onder de 403-aansprakelijkheid valt, zou ik kunnen begrijpen dat de wetgever het voorgestelde art. 7:809 lid $1 \mathrm{BW}$ ongemoeid laat in verband met de gevolgen voor het personenvennootschapsrecht, en het feit dat een moedermaatschappij dan ook aansprakelijk wordt voor de schulden van de personenvennootschap uit de wet.

\subsubsection{Wettelijke rente}

Als een 403-maatschappij een rechtshandeling heeft verricht op grond waarvan zij een geldsom moet betalen aan een crediteur en zij betaalt dit bedrag niet op tijd, dan kan zij op grond van art. 6:119 BW verplicht zijn tot het betalen van wettelijke rente over deze geldsom. Nass is van mening dat de verplichting tot het betalen van wettelijke rente niet onder de reikwijdte van de 403-aansprakelijkheid valt omdat dit een wettelijke verplichting is die is verbonden aan het niet tijdig voldoen van een geldsom. ${ }^{132}$ Nass zoekt op dit punt aansluiting bij Spierings die in 2012 betoogde dat de wettelijke rente niet voortvloeit uit de rechtshandeling op grond waarvan de 403-maatschappij de geldsom moet betalen, maar dat het een verplichting is die de wet verbindt aan het niet (tijdig) nakomen van deze geldsom. ${ }^{133}$ Ook de Rechtbank Roermond heeft in 2008 in de Inalfa-procedure geoordeeld dat wettelijke rente niet onder de reikwijdte van de 403 -aansprakelijkheid valt. ${ }^{134}$

Ik kan mij niet vinden in bovenstaand standpunt. Ik meen met Spierings - die in 2016 op haar eerdere standpunt is teruggekomen ${ }^{135}$ - en het Hof Den Bosch ${ }^{136}$

131. Zie $\S 4.5 .6 . c$.

132. E.C.A. Nass 2019, p. 96.

133. Spierings 2012, p. 84

134. Rb. Roermond 20 februari 2008, JOR 2008/92, m.nt. Bartman (Inalfa), r.o. 4.2.2 en 4.3.1.

135. Spierings 2016, p. 217.

136. Hof 's-Hertogenbosch 24 januari 2012, JOR 2012/165, m.nt. Bertrams (Inalfa), r.o. 4.17. 


\section{HOOFDSTUK 4}

- in het hoger beroep in de Inalfa-procedure - dat een schuld ex art. 6:119 BW voortvloeit uit de eerdere rechtshandeling op grond waarvan de 403-maatschappij verplicht is tot het betalen van de desbetreffende geldsom. Uit art. 6:119 BW volgt dat de wettelijke rente een schadevergoeding is die de schuldenaar moet betalen wegens de vertraging in de voldoening van de geldsom. Ik heb er eerder op gewezen dat als de 403-maatschappij een schadevergoeding moet betalen omdat zij een verplichting uit een rechtshandeling niet (correct) is nagekomen, deze schadevergoeding onder de reikwijdte van de 403-aansprakelijkheid valt. ${ }^{137}$ Hetzelfde geldt mijns inziens als de 403 -maatschappij een verplichting niet op tijd nakomt. De wettelijke rente is een secundaire schuld die weliswaar zijn directe ontstaansgrond heeft in de wet, maar dat neemt niet weg dat deze schuld nog steeds uit een rechtshandeling voortvloeit. ${ }^{138}$

Tot slot merk ik op dat een verplichting tot het betalen van wettelijke rente alleen onder de reikwijdte van de 403-aansprakelijkheid valt, als de verplichting voor de 403-maatschappij tot het betalen van de geldsom voortvloeit uit een rechtshandeling. Indien een 403-maatschappij wettelijke rente moet betalen wegens het niet tijdig betalen van een geldsom die voortvloeit uit de wet - bijvoorbeeld een schadevergoeding wegens een onrechtmatige daad - dan valt deze verplichting niet onder de 403-aansprakelijkheid omdat er dan geen onderliggende rechtshandeling is waaruit de wettelijke rente voortvloeit.

\subsubsection{Salaris van de curator}

Op grond van art. $1 \mathrm{Fw}$ kan een schuldenaar die is opgehouden te betalen, op verzoek van een crediteur of op eigen aangifte failliet worden verklaard door een rechter. Indien een rechter op verzoek van een crediteur de 403-maatschappij failliet verklaart, valt het salaris van de curator in ieder geval niet onder de reikwijdte van de 403-aansprakelijkheid. Er is dan namelijk geen sprake van een rechtshandeling van de 403-maatschappij die ten grondslag ligt aan het faillissement en daarmee aan het salaris van de curator. Willems betoogt dat als de 403-maatschappij daarentegen op eigen aangifte failliet is verklaard, het salaris van de curator wel onder de reikwijdte van de 403 -aansprakelijkheid valt. ${ }^{139}$ Hij wijst erop dat het aanvragen van het faillissement een rechtshandeling is van de 403-maatschappij. Als de rechter naar aanleiding van dit verzoek de 403-maatschappij failliet verklaart, heeft dat onder meer tot gevolg dat er een curator wordt aangesteld die recht heeft op salaris. Volgens Willems vloeit het salaris van de curator daarom voort uit het aanvragen van het eigen faillissement door de 403-maatschappij en kan de curator zijn salaris ook op de moedermaatschappij verhalen.

137. Zie $\S 4.4$.

138. Zie $\S 4.4$.

139. Willems 1997, p. 17. 
Bartman, Dorresteijn en Olaerts zijn het niet eens met Willems. ${ }^{140} \mathrm{Zij}$ menen dat het salaris van een curator nooit onder de reikwijdte van de 403-aansprakelijkheid valt. Een andere uitkomst zou er volgens hen toe leiden dat er een niet te rechtvaardigen onderscheid ontstaat tussen faillissementen van 403-maatschappijen die zijn uitgesproken op verzoek van een crediteur, en die op eigen aangifte van de 403-maatschappij. Dit zou de moedermaatschappij ertoe kunnen aanzetten om te proberen te voorkomen dat zij aansprakelijk is voor het salaris van de curator door druk uit te oefenen op de 403-maatschappij om niet het eigen faillissement aan te vragen totdat de moedermaatschappij een beroep kan doen op de intrekking van de 403 -verklaring ${ }^{141}$ of door zelf het faillissement van de 403-maatschappij aan te vragen - indien zij een vordering heeft op de 403-maatschappij.

Ik sluit mij aan bij het standpunt van Bartman, Dorresteijn en Olaerts. In aanvulling op de door hen genoemde argumenten, meen ik dat het salaris van een curator niet onder de reikwijdte van de 403-aansprakelijkheid valt omdat dit niet voortvloeit uit de rechtshandeling waarbij de 403-maatschappij haar faillissement aanvraagt, maar uit de wet - art. $1 \mathrm{Fw}$. Ik heb eerder opgemerkt dat een schuld uit een rechtshandeling voortvloeit als de wil van de crediteur ten aanzien van het ontstaan, de inhoud of het voortduren van de schuld zou kunnen zijn beïnvloed door inzicht in de jaarrekening van de 403-maatschappij - als de 403-maatschappij geen gebruik zou hebben gemaakt van de jaarrekeningvrijstelling van het groepsregime. ${ }^{142} \mathrm{Ik}$ wijs erop dat een curator geen invloed heeft op de faillietverklaring van de 403-maatschappij noch op zijn benoeming als curator - hij heeft enkel de mogelijkheid om de benoeming te weigeren wegens conflicterende belangen. De benoeming van de curator en de daaruit voortvloeiende salarisvordering, zijn dus niet afhankelijk van een afweging van de curator op basis de jaarrekening van de 403-maatschappij. Om die reden hoeft de curator volgens het door mij bepleite uitgangspunt niet gecompenseerd te worden voor een gebrek aan inzicht met een aanvullende vordering op de moedermaatschappij. ${ }^{143}$

140. Bartman, Dorresteijn \& Olaerts 2016, p. 203 (dit onderwerp wordt niet behandeld in Bartman, Dorresteijn \& Olaerts 2020).

141. De moedermaatschappij is niet aansprakelijk voor de schulden die voortvloeien uit rechtshandelingen die de 403-maatschappij verricht nadat de moedermaatschappij een beroep kan doen op de intrekking van de 403-verklaring. Zie art. 2:404 lid 2 BW en $\S 7.2$ en $\S 8.2$.

142. Zie $\S 4.4 .2$.

143. De compensatie voor een crediteur bestaat uit twee onderdelen: een vordering op de moedermaatschappij op grond van de 403-verklaring en de mogelijkheid om de geconsolideerde jaarrekening van de moedermaatschappij in te zien. Zie $\S 3.4 .1$. 


\subsubsection{Leegstandschade bij faillissement}

Het is niet ongebruikelijk dat in een (zakelijke) huurovereenkomst een beding wordt opgenomen dat de huurder bij tussentijdse opzegging van de overeenkomst verplicht is tot vergoeding van de zogenoemde leegstandschade van de verhuurder. Dit houdt in dat de huurder de gederfde huurinkomsten van de verhuurder voor het restant van de huurtermijn moet vergoeden. Als een 403-maatschappij een huurovereenkomst opzegt en de leegstandschade van de verhuurder moet vergoeden, vloeit deze schuld voort uit de huurovereenkomst en valt zij daarom onder de reikwijdte van de 403 -aansprakelijkheid. De verhuurder kan zich ook op de moedermaatschappij verhalen. In de jurisprudentie is twee keer de vraag aan de orde gekomen of dit ook het geval is indien de 403-maatschappij failleert en de curator op grond van art. $39 \mathrm{Fw}$ de huurovereenkomst opzegt. Op grond van deze bepaling kan een curator een huurovereenkomst opzeggen waarbij de overeengekomen of gebruikelijke termijn in acht moet worden genomen, met dien verstande dat een termijn van drie maanden in ieder geval voldoende is.

In 2005 beantwoordt de Rechtbank Den Haag bovenstaande vraag bevestigend. ${ }^{144} \mathrm{Zij}$ oordeelt dat een moedermaatschappij op grond van de 403 -verklaring aansprakelijk is voor de verplichting van de failliete 403-maatschappij tot het vergoeden van de leegstandschade als de curator de huurovereenkomst op grond van art. $39 \mathrm{FW}$ heeft opgezegd. Zij overweegt dat de verplichting tot het vergoeden van de leegstandschade in de kern een schadevergoedingsplicht is die ontstaat omdat de 403-maatschappij in gebreke is in de nakoming van de huurovereenkomst. Deze schuld vloeit daarom voort uit de huurovereenkomst tussen de 403-maatschappij en de verhuurder, en valt daarmee onder de 403-aansprakelijkheid. Dat het de curator is die de overeenkomst opzegt, doet daar niet aan af.

In haar noot onder de uitspraak van de Rechtbank Den Haag bekritiseert Harmsen bovenstaand oordeel. ${ }^{145} \mathrm{Zij}$ merkt op dat de opzegging van de huurovereenkomst door de curator op grond van art. $39 \mathrm{Fw}$ een rechtsgeldige beëindiging is van deze overeenkomst. De 403-maatschappij hoeft geen andere huurpenningen te voldoen dan die tot de dag van de opzegging door de curator. Dit brengt volgens Harmsen mee dat de verhuurder ook slechts deze huurpenningen op grond van de 403-verklaring kan verhalen op de moedermaatschappij. Anders zou de moedermaatschappij op grond van de 403-verklaring tot meer zijn gehouden dan de 403-maatschappij. Dit standpunt is later door Janssen onderschreven. ${ }^{146}$

144. Rb. Den Haag 2 maart 2005, JOR 2005/116, m.nt. Harmsen (Uni-Invest/Content Beheer), r.o. 3.3-3.4.

145. Harmsen in haar annotatie onder Rb. Den Haag 2 maart 2005, JOR 2005/116 (Uni-Invest) Content Beheer).

146. M.A.J.G. Janssen 2005, p. 119. 
Vier jaar na de uitspraak van de Haagse rechtbank komt de Rechtbank Rotterdam in een soortgelijke procedure tot een andere uitkomst. ${ }^{147} \mathrm{Zij}$ volgt het standpunt van Harmsen en Janssen en oordeelt dat slechts huurpenningen tot de dag van de opzegging van de huurovereenkomst door de curator op grond van art. $39 \mathrm{Fw}$, voortvloeien uit deze overeenkomst. De verhuurder kan zich daarom enkel voor deze huurpenningen wenden tot de moedermaatschappij.

Ook op deze uitspraak is kritisch gereageerd in de literatuur. Niels vergelijkt de verplichting tot het vergoeden van leegstandschade met een ontslagvergoeding. ${ }^{148}$ Hij wijst erop dat een ontslagvergoeding als secundaire schuld voortvloeit uit de arbeidsovereenkomst die de 403-maatschappij en de werknemer eerder zijn aangegaan en daarom onder de reikwijdte van de 403-aansprakelijkheid valt. ${ }^{149}$ Hetzelfde geldt volgens hem voor de verplichting tot het vergoeden van leegstandschade die de 403-maatschappij is verschuldigd als gevolg van de beëindiging van de huurovereenkomst. Niels betoogt dat deze verplichting daarom in zijn geheel onder de 403-aansprakelijkheid valt, en niet alleen de huurpenningen tot de dag van de opzegging van de huurovereenkomst door de curator.

Een tweetal arresten van de Hoge Raad maakt duidelijk welk van bovenstaande uitspraken juist is. In 2011 oordeelt de Hoge Raad in het Aukema q.q./ Uni-Invest-arrest dat als een curator op grond van art. $39 \mathrm{Fw}$ een huurovereenkomst opzegt, de verhuurder enkel de huurpenningen tot de dag van de opzegging kan verhalen op de boedel van de failliete huurder. ${ }^{150}$ De opzegging door de curator op grond van art. $39 \mathrm{Fw}$ is een rechtmatige beëindiging van de huurovereenkomst die niet tot een schadevergoeding verplicht.

Twee jaar later oordeelt de Hoge Raad dat bovengenoemde rechtsregel uit het Aukema q.q./Uni-Invest-arrest niet wegneemt dat een beding in de huurovereenkomst op grond waarvan de huurder verplicht is tot het vergoeden van leegstandschade bij een tussentijdse opzegging van de overeenkomst, wel geldig is. ${ }^{151}$ De opzegging van de huurovereenkomst door de curator op grond van art. $39 \mathrm{Fw}$ brengt weliswaar mee dat de verhuurder enkel de huurpenningen tot de dag van de opzegging kan verhalen op de boedel. Maar het doet niet af aan de verplichtingen van een derde die zich garant heeft gesteld voor de nakoming van de huurovereenkomst door de huurder. Tenzij anders is bedongen, brengt de opzegging geen verandering in de verplichtingen uit deze garantie.

147. Rb. Rotterdam 16 april 2009, JOR 2009/161, m.nt. Van der Zanden (BosGijze/Jones Lang LaSalle), r.o. 5.6.1-5.6.2.

148. Niels 2010, p. 39.

149. Zie $\S 4.4 .1$.

150. HR 11 januari 2011, JOR 2011/101, m.nt. Van Hees (Aukema q.q./Uni-Invest), r.o. 3.5.13.5.2.

151. HR 15 november 2013, NJ 2014/68, m.nt. Van Schilfgaarde (Romania), r.o. 3.3.2-3.3.4. 


\section{HOOFDSTUK 4}

In navolging van Van Hees merk ik op dat bovenstaande arresten meebrengen dat als een 403-maatschappij een huurovereenkomst is aangegaan waarin een beding tot vergoeding van leegstandschade is opgenomen, de verhuurder een vordering tot betaling van de huurpenningen na de dag van de opzegging door de curator op grond van art. $39 \mathrm{Fw}$ weliswaar niet kan verhalen op de boedel van de failliete 403-maatschappij, maar dat hij deze vordering op grond van de 403-verklaring wel op de moedermaatschappij kan verhalen. ${ }^{152}$ De opzegging door de curator op grond van art. $39 \mathrm{Fw}$ verandert dus niets aan de 403-aansprakelijkheid van de moedermaatschappij. De eerdergenoemde Haagse rechtbank heeft het dus bij het rechte eind. ${ }^{153}$

Bovenstaande uitkomst van de uitleg van de 403-aansprakelijkheid met betrekking tot een vordering tot vergoeding van leegstandschade sluit aan bij de compensatie die deze aansprakelijkheid biedt voor de crediteuren voor het niet kunnen inzien van de jaarrekening van de 403-maatschappij. ${ }^{154}$ Omdat een crediteur deze jaarrekening niet heeft kunnen inzien, heeft hij niet (mede) aan de hand daarvan kunnen schatten hoe groot het risico is dat de 403-maatschappij de huurovereenkomst - waaronder een eventueel daarin opgenomen beding tot het vergoeden van de leegstandschade als de overeenkomst vroegtijdig wordt opgezegd - niet (volledig) zou nakomen. Ter compensatie van dit gebrek aan inzicht heeft de crediteur op grond van de 403-verklaring ook een verhaalsrecht gekregen op de moedermaatschappij. Het feit dat de 403-maatschappij in de tussentijd failliet is gegaan en de curator de huurovereenkomst op grond van art. $39 \mathrm{Fw}$ heeft opgezegd, doet niet af aan dit verhaalsrecht. De crediteur moet zich nog steeds voor alle schulden die uit de overeenkomst voortvloeien - waaronder de verplichting tot het vergoeden van de leegstandschade - op de moedermaatschappij kunnen verhalen. De mogelijkheid om de moedermaatschappij aansprakelijk te stellen, is juist van belang wanneer de 403-maatschappij niet in staat is aan haar verplichtingen te voldoen.

\subsubsection{Schadevergoeding wegens onveilige arbeidsomstandigheden}

Een volgend onderwerp met betrekking tot de materiële reikwijdte van de 403-aansprakelijkheid waarover in de literatuur discussie bestaat, is het antwoord op de vraag of een moedermaatschappij aansprakelijk is voor een verplichting van de 403-maatschappij ex art. 7:658 BW tot het vergoeden van schade die is ontstaan wegens onveilige arbeidsomstandigheden. Bartman

152. Van Hees in zijn annotatie onder HR 22 november 2013, JOR 2014/28 (TEP).

153. Rb. Den Haag 2 maart 2005, JOR 2005/116, m.nt. Harmsen (Uni-Invest/Content Beheer), r.o. 3.3-3.4.

154. De compensatie voor een crediteur bestaat uit twee onderdelen: een vordering op de moedermaatschappij op grond van de 403-verklaring en de mogelijkheid om de geconsolideerde jaarrekening van de moedermaatschappij in te zien. Zie $\S 3.4 .1$. 
beantwoordt deze vraag ontkennend. ${ }^{155}$ Hij betoogt dat de verplichting tot het vergoeden van schade die is ontstaan wegens onveilige arbeidsomstandigheden voortvloeit uit de wet omdat daarover geen consensus is bereikt tussen de werknemer en de werkgever. Een schuld van de 403-maatschappij op grond van art. 7:658 BW valt volgens hem daarom niet onder de reikwijdte van de 403-aansprakelijkheid.

Het meerderheidsstandpunt in de literatuur is echter dat een moedermaatschappij wel aansprakelijk is voor een schuld van de 403-maatschappij tot het vergoeden van schade die is ontstaan wegens onveilige arbeidsomstandigheden. ${ }^{156}$ Ik sluit mij daarbij aan. Naar mijn mening is de zorgplicht van een 403-maatschappij om als werkgever te zorgen voor veilige arbeidsomstandigheden onderdeel van de arbeidsovereenkomst met de werknemer. Ik heb eerder opgemerkt dat een verplichting tot het betalen van een schadevergoeding wegens het niet nakomen van een met een overeenkomst samenhangende zorgplicht een secundaire schuld is die onder de 403 -aansprakelijkheid valt. ${ }^{157}$

Ik meen dat bovenstaande redenering ook van toepassing is op de verplichting voor een 403-maatschappij om zich op grond van art. 7:611 BW als een goed werkgever te gedragen. ${ }^{158}$ Ook deze verplichting is onderdeel van de arbeidsovereenkomst met de werknemer. Als de 403-maatschappij zich niet als een goed werkgever gedraagt en uit dien hoofde een schadevergoeding moet betalen aan de werknemer, vloeit deze schuld voort uit de arbeidsovereenkomst. Ik meen daarom met Zwemmer dat een dergelijke schuld onder de reikwijdte van de 403 -aansprakelijkheid valt. ${ }^{159}$

\subsubsection{Sociaal plan}

Bij een voorgenomen ontslag van verschillende werknemers tegelijkertijd, kan de werkgever hen een sociaal plan aanbieden waarin de gevolgen van deze ontslagen uniform zijn vastgelegd. In het sociaal plan kan onder meer zijn opgenomen dat de werknemers een ontslagvergoeding krijgen, dat hen een andere functie wordt aangeboden of dat zij door middel van omscholing

155. Bartman 2002, p. 23.

156. M.A.J.G. Janssen 2005, p. 118-119, Zwemmer 2011, p. 224, Zwemmer 2012, p. 229 en Van der Ham 2013, p. 22

157. Zie $\S 4.4 .1$.

158. Zie voor andere schulden die samenhangen met een arbeidsovereenkomst § 4.4.1. Daar heb ik erop gewezen dat een moedermaatschappij ook aansprakelijk is voor de verplichting van de 403-maatschappij tot het betalen van een schadevergoeding aan een oud-werknemer wegens een onregelmatige beëindiging van de arbeidsovereenkomst (art. 7:677 lid 4 BW), een kennelijk onredelijk ontslag (art. 7:681 lid $1 \mathrm{BW}$ ) en de vernietiging of ontbinding van de arbeidsovereenkomst (art. 7:686 BW). Zie ook Zwemmer 2011, p. 224 en Zwemmer 2012, p. 229.

159. Zwemmer 2011, p. 224 en Zwemmer 2012, p. 229. 


\section{HOOFDSTUK 4}

worden geholpen bij het vinden van een nieuwe baan. Er bestaat geen verplichting voor de werkgever om een sociaal plan aan te bieden, ${ }^{160}$ maar dit heeft wel als voordeel dat er een algemene regeling is voor de verschillende ontslagen en dat er niet per werknemer een aparte ontslagprocedure hoeft te worden gestart. Een werkgever kan zelfstandig een sociaal plan opstellen en dit aan de desbetreffende werknemers aanbieden, maar het is ook mogelijk om een sociaal plan overeen te komen met de vakbond. Een sociaal plan dat tot stand is gekomen tussen de werkgever en de vakbond kan de bindende kracht van een cao krijgen door dit aan te melden in het kader van art. 4 Wet op de Loonvorming. ${ }^{161}$

In de jurisprudentie is de vraag aan de orde gekomen of de verplichtingen van een 403-maatschappij jegens een - ontslagen - werknemer op grond van een sociaal plan voortvloeien uit de arbeidsovereenkomst die de 403-maatschappij eerder met deze werknemer is aangegaan, of dat deze verplichtingen voorvloeien uit het sociaal plan zelf. Voordat ik aan de beantwoording van deze vraag toekom, is het van belang om op te merken dat zowel het afsluiten van de arbeidsovereenkomst als het aangaan van het sociaal plan een rechtshandeling is van de 403-maatschappij. Uit welk van beide rechtshandelingen de schuld van de 403-maatschappij ook voortvloeit, er is sprake van een schuld die onder de reikwijdte van art. 2:403 lid 1 sub f BW valt. Zolang de moedermaatschappij de 403-verklaring niet intrekt, is zij op grond van deze verklaring mede aansprakelijk voor de verplichtingen van de 403-maatschappij uit hoofde van het sociaal plan. Het antwoord op bovenstaande vraag is daarom slechts van belang als de moedermaatschappij de 403-verklaring heeft ingetrokken tussen het moment dat de 403-maatschappij en de werknemer de arbeidsovereenkomst zijn aangegaan, en het moment dat het sociaal plan is afgesloten. ${ }^{162}$ De moedermaatschappij is namelijk niet aansprakelijk voor de schulden die voortvloeien uit de rechtshandelingen die de 403-maatschappij verricht vanaf het moment dat de moedermaatschappij tegenover de crediteur een beroep kan doen op de intrekking, maar zij blijft wel aansprakelijk voor de schulden die voortvloeien uit de rechtshandelingen die tot dat moment zijn verricht - ook als de schuld pas na de intrekking van de 403-verklaring uit de desbetreffende rechtshandeling

160. Bij een collectief ontslag van ten minste twintig werknemers is de werkgever op grond van art. 3 Wet melding collectief ontslag verplicht om de belanghebbende verenigingen van werknemers te raadplegen over een eventueel sociaal plan.

161. Jacobs 2017, p. 263. Zie ook Jacobs 2017, p. 338, waar hij opmerkt dat het ook mogelijk is dat de werkgever een sociaal plan overeenkomt met de ondernemingsraad. Het is in dat geval echter niet mogelijk om het sociaal plan aan te melden in het kader van art. 4 Wet op de Loonvorming zodat het de bindende kracht van een cao krijgt.

162. Zie $\S 5.6$, waar ik tot de conclusie kom dat een moedermaatschappij op grond van de 403-verklaring aansprakelijk is voor alle schulden die voortvloeien en zijn voortgevloeid uit een rechtshandeling van de 403-maatschappij. Ook als de arbeidsovereenkomst is afgesloten voordat de moedermaatschappij de 403-verklaring heeft gedeponeerd, is zij aansprakelijk voor de schulden die daaruit voortvloeien. 
voortvloeit. ${ }^{163}$ Als de verplichtingen van de 403 -maatschappij voortvloeien uit het sociaal plan en de moedermaatschappij tussentijds de 403-verklaring heeft ingetrokken, is de moedermaatschappij daar dus niet mede voor aansprakelijk. Maar als de verplichtingen voortvloeien uit de arbeidsovereenkomst, is de moedermaatschappij wel mede aansprakelijk.

De Rechtbank Roermond en in hoger beroep het Hof 's-Hertogenbosch hebben in de Inalfa-procedure geoordeeld dat de verplichtingen uit een sociaal plan niet voortvloeien uit de arbeidsovereenkomst die de 403-maatschappij eerder met de werknemer is aangegaan, maar uit het sociaal plan zelf. ${ }^{164}$ In casu is de 403-maatschappij het sociaal plan overeengekomen met een vakbond - namens de werknemers. De rechtbank wijst erop dat het sociaal plan geen onderdeel is van de arbeidsovereenkomst van de 403-maatschappij en de werknemer, maar dat deze tot stand is gekomen door een latere wilsovereenstemming tussen de 403-maatschappij en de vakbond. Er is daarom te weinig connexiteit tussen de verplichtingen uit het sociaal plan en de arbeidsovereenkomst om als 'daaruit voortvloeiend' te kunnen worden aangemerkt. In hoger beroep bevestigt het hof deze uitspraak en overweegt dat de verplichtingen van de 403-maatschappij tegenover een werknemer pas ontstaan als het sociaal plan wordt aanvaard. Deze verplichtingen vloeien daarom voort uit het sociaal plan zelf en niet uit de arbeidsovereenkomst.

Dat de verplichtingen van een 403-maatschappij uit hoofde van een sociaal plan niet voortvloeien uit de arbeidsovereenkomst met de werknemer maar uit het sociaal plan zelf wordt ook in de literatuur onderschreven. ${ }^{165} \mathrm{Ik}$ sluit mij daarbij aan. Ik heb eerder opgemerkt dat mijns inziens een schuld uit een rechtshandeling voortvloeit als de wil van de crediteur ten aanzien van het ontstaan, de inhoud of het voortduren van de schuld zou kunnen zijn beïnvloed door inzicht in de jaarrekening van de 403-maatschappij - als de 403-maatschappij geen gebruik zou hebben gemaakt van de jaarrekeningvrijstelling van het groepsregime. ${ }^{166}$

De werknemer - of de vakbond namens hem - heeft de keuze om het sociaal plan al of niet te aanvaarden. Voor de compensatie uit hoofde van de 403-aansprakelijkheid is het daarom van belang of de werknemer op dat moment de mogelijkheid heeft om de jaarrekening van de 403-maatschappij in te zien of

163. Zie art. 2:404 lid 1 en lid 2 BW en $\S 7.2$ en $\S 8.2$. De moedermaatschappij kan deze overblijvende aansprakelijkheid beëindigen als wordt voldaan aan de voorwaarden ex art. 2:404 lid 3 BW (zie $\S 8.3$ ).

164. Rb. Roermond 20 februari 2008, JOR 2008/92, m.nt. Bartman (Inalfa), r.o. 4.1.2 en 4.4.3 en Hof 's-Hertogenbosch 7 april 2009, JOR 2009/160, m.nt. Bartman (Inalfa), r.o. 4.3.3.

165. Bartman 2002, p. 27, Bartman in zijn annotatie onder Hof 's-Hertogenbosch 7 april 2009, JOR 2009/160 (Inalfa) en Van Wijngaarden 2010, p. 134.

166. Zie $\S 4.4 .2$. 
niet. Op dat moment bepaalt de crediteur namelijk zijn wil omtrent het al of niet accepteren van het sociaal plan, en zo ja tegen welke voorwaarden. Of de werknemer een gebrek aan inzicht heeft gehad bij het aangaan of gedurende de looptijd van de arbeidsovereenkomst met de 403-maatschappij is daarbij niet relevant.

\subsection{Tussenconclusie; vier algemene regels ter beoordeling of een schuld uit een rechtshandeling voortvloeit}

In de vorige paragraaf heb ik verschillende schulden onderzocht ten aanzien waarvan in de literatuur of de jurisprudentie de vraag is gesteld of deze al of niet onder de reikwijdte van de 403-aansprakelijkheid vallen. Dit betreft echter geen uitputtend overzicht van de materiële reikwijdte van de 403-aansprakelijkheid. Er zijn nog vele andere schulden denkbaar ten aanzien waarvan de vraag kan worden gesteld of een moedermaatschappij daarvoor aansprakelijk is op grond van een 403 -verklaring. Om die reden noem ik een viertal algemene regels aan de hand waarvan ook ten aanzien van deze andere schulden van de 403-maatschappij kan worden beoordeeld of deze al of niet onder de reikwijdte van de 403-aansprakelijkheid vallen. Deze algemene regels zijn gebaseerd op de conclusies van het voorgaande onderzoek naar de drie elementen van de materiële reikwijdte van de 403-aansprakelijkheid uit art. 2:403 lid 1 sub f $\mathrm{BW}$ - schulden, rechtshandelingen en voortvloeien ${ }^{167}$ - en de diverse schulden die ik in de vorige paragraaf heb onderzocht. Bij iedere algemene regel die ik noem, geef ik ook een voorbeeld van een schuld die om die reden wel of niet onder de 403-aansprakelijkheid valt.

Ten eerste merk ik op dat een schuld in ieder geval uit de wet voortvloeit, als deze naar zijn aard een sanctie is die is bedoeld om de 403-maatschappij tot bepaald gedrag aan te zetten. ${ }^{168}$ De moedermaatschappij is niet aansprakelijk voor deze schulden van de 403-maatschappij. Als voorbeeld wijs ik op de situatie dat uit het onderzoeksverslag in een enquêteprocedure blijkt dat de 403-maatschappij het verzoek tot het onderzoek niet op redelijke gronden heeft gedaan en zij op grond van art. 2:354 BW in de kosten van het onderzoek wordt veroordeeld. Aangezien op grond van art. 2:350 lid $1 \mathrm{BW}$ voor de toewijzing van een onderzoek in een enqueteprocedure is vereist dat sprake is van gegronde redenen om te twijfelen aan een juist beleid of een juiste gang van zaken, zal een dergelijke kostenveroordeling slechts plaatsvinden bij misleiding van de OK

167. Zie $\S 4.2$ tot en met $\S 4.4$.

168. Zie bijvoorbeeld $\S 4.3 .2$ met betrekking tot een wettelijke verhoging van het loon wegens niet tijdige betaling daarvan en $\S$ 4.5.6.c met betrekking tot de hoofdelijke aansprakelijkheid van een commanditaire vennoot voor de schulden van de commanditaire vennootschap wegens een overtreding van het naamvoerings- of beheersverbod. 
door de verzoeker. ${ }^{169}$ De kostenveroordeling is mijns inziens daarom naar haar aard een wettelijke sanctie, met als doel om onredelijke verzoeken tegen te gaan.

Ten tweede wijs ik erop dat niet alleen primaire schulden, maar ook secundaire schulden uit een rechtshandeling kunnen voortvloeien. ${ }^{170}$ Secundaire schulden ontstaan indien de oorspronkelijke verbintenis niet wordt nagekomen. Ook als de directe ontstaansgrond van de secundaire schuld de wet is, neemt dat niet weg dat deze uit de onderliggende rechtshandeling kan voortvloeien en daarom onder de reikwijdte van de 403-aansprakelijkheid valt. Hierbij kan in het bijzonder worden gedacht aan een schadevergoeding indien de verplichting uit de oorspronkelijke verbintenis niet wordt nagekomen, in het geval dat een met een overeenkomst samenhangende zorgplicht wordt geschonden of als een overeenkomst wordt ontbonden. ${ }^{171}$ Een voorbeeld hiervan is de verplichting voor een 403-maatschappij op grond van art. 7:218 BW tot het vergoeden van schade aan een door haar gehuurde ruimte. Deze schuld vloeit voort uit de oorspronkelijke huurovereenkomst en valt daarom onder de reikwijdte van de 403-aansprakelijkheid.

Een derde algemene regel om te beoordelen of een schuld al of niet onder de 403-aansprakelijkheid valt, is dat een schuld in ieder geval niet uit een bepaalde rechtshandeling voortvloeit als de 403-maatschappij aansprakelijk wordt gesteld door een partij tegenover wie zij zich niet heeft verbonden door de desbetreffende rechtshandeling. ${ }^{172} \mathrm{Ik}$ wijs bijvoorbeeld op de mogelijkheid dat een 403-maatschappij aandeelhouder is in een BV waarbij op grond van art. 2:192 lid 1 sub a BW in de statuten is opgenomen dat de aandeelhouders hoofdelijk aansprakelijk zijn jegens derden voor de schulden van de BV. Een derde kan de 403-maatschappij op grond van deze statutaire bepaling rechtstreeks aansprakelijk stellen voor een schuld van de BV. ${ }^{173}$ Door aandeelhouder te worden van de BV, heeft de 403-maatschappij zich jegens de BV gebonden aan de statutaire verplichtingen die met het aandeelhouderschap samenhangen. Aangezien de derde niet is betrokken bij de rechtshandeling waarbij de 403-maatschappij aandeelhouder is geworden, valt een schuld van de 403-maatschappij op grond van een statutaire bepaling in de zin van art. 2:192 lid 1 sub a BW niet onder de reikwijdte van de 403-aansprakelijkheid.

Tot slot merk ik op dat ik heb betoogd dat voor het antwoord op de vraag of een schuld uit een rechtshandeling 'voortvloeit', moet worden beoordeeld of de wil van de crediteur ten aanzien van het ontstaan, de inhoud of het voortduren

169. Assink/Slagter 2013/93.4

170. Zie $\S 4.4 .1$.

171. Zie bijvoorbeeld $\S 4.5 .7$ met betrekking tot wettelijke rente.

172. Zie bijvoorbeeld $\S$ 4.5.4.c met betrekking tot externe bestuurdersaansprakelijkheid.

173. Asser/Van Olffen \& Rensen 2-IIa 2019/297. 


\section{HOOFDSTUK 4}

van de schuld zou kunnen zijn beïnvloed door inzicht in de jaarrekening van de 403-maatschappij - als de 403-maatschappij geen gebruik zou hebben gemaakt van de jaarrekeningvrijstelling van het groepsregime. ${ }^{174}$ Als voorbeeld verwijs ik naar een situatie die vergelijkbaar is met het hierboven genoemde geval dat een 403-maatschappij aandeelhouder is van een BV waarbij op grond van art. 2:192 lid 1 sub a BW in de statuten is opgenomen dat de aandeelhouders jegens derden aansprakelijk zijn voor de schulden van de BV. In plaats van deze statutaire verplichting, zijn de aandeelhouders een aandeelhoudersovereenkomst aangegaan waarbij ook de BV partij is, op grond waarvan zij zich hebben verplicht om een tekort van de BV aan te vullen. Hoewel de aandeelhouders de facto in beide gevallen aansprakelijk zijn voor dezelfde schulden, namelijk die van de BV tegenover derden, is er een kenmerkend verschil tussen deze twee situaties. In tegenstelling tot bovengenoemde situatie waarbij de 403-maatschappij als aandeelhouder op grond van de statuten aansprakelijk is jegens derden voor de schulden van de BV, is de 403-maatschappij uit hoofde van de aandeelhoudersovereenkomst aansprakelijk tegenover een partij die zelf betrokken is bij de overeenkomst: de BV. Bij het aangaan van deze overeenkomst heeft het de BV ontbroken aan de mogelijkheid om de jaarrekening van de 403-maatschappij in te zien zodat zij niet (mede) aan de hand daarvan haar wil heeft kunnen bepalen ten aanzien van het ontstaan en de inhoud van de schulden die uit de overeenkomst zouden voortvloeien. Ter compensatie van dit gebrek aan inzicht is de moedermaatschappij op grond van de 403-verklaring mede aansprakelijk voor de schulden van de 403-maatschappij die uit de aandeelhoudersovereenkomst voortvloeien. ${ }^{175}$

\subsection{Voorrecht verbonden aan een vordering}

Als een 403-maatschappij failleert, hebben de crediteuren op grond van art. 3:277 lid $1 \mathrm{BW}$ in beginsel onderling een gelijk recht om - na voldoening van de kosten van de executie - zich naar evenredigheid van ieders vordering op de boedel te verhalen. Deze hoofdregel wordt enkel doorbroken bij door de wet erkende redenen van voorrang. Een van de gronden voor voorrang is een aan de vordering verbonden voorrecht.

Ik maak een onderscheid tussen specifieke en algemene voorrechten. Een specifiek voorrecht houdt in dat een crediteur voorrang heeft bij verhaal op een

174. Zie $\S 4.4 .2$.

175. Ik merk op dat het mogelijk is om op grond van art. 2:192 lid 1 sub a BW in de statuten van een BV op te nemen dat de aandeelhouders verplicht zijn om een eventueel tekort van de BV aan te vullen (zie Asser/Van Olffen \& Rensen 2-IIa 2019/297). Een moedermaatschappij is op grond van de 403-verklaring mede aansprakelijk voor een dergelijke verplichting van de 403-maatschappij als aandeelhouder in de BV aangezien dit een interne verplichting betreft jegens de BV. 
bepaald goed van de failliete schuldenaar. Als een crediteur bijvoorbeeld een vordering heeft voor voldoening van kosten die hij heeft gemaakt om een goed te behouden, dan heeft hij voorrang bij het verhaal op het behouden goed. ${ }^{176}$ Als voorbeeld wijs ik op de situatie dat een crediteur kosten heeft gemaakt om te voorkomen dat een bedrijfsgebouw van een derde door een brand wordt verwoest. De crediteur kan zich dan in het faillissement van deze derde met voorrang op het desbetreffende bedrijfsgebouw verhalen. Daarnaast is een vordering tot vergoeding van schade bevoorrecht met betrekking tot het verhaal op de vordering die de failliete schuldenaar heeft op de verzekeringsmaatschappij, voor zover deze laatste vordering de verplichting betreft tot het vergoeden van de schade. ${ }^{177}$ Een algemeen voorrecht houdt daarentegen in dat de crediteur voorrang heeft bij het verhaal op alle goederen van de schuldenaar. Ik wijs bijvoorbeeld op het voorrecht ex art. 3:288 sub e BW, op grond waarvan in het faillissement van een werkgever de vorderingen van een werknemer uit de arbeidsovereenkomst (of de beëindiging daarvan) uit het lopende en het voorafgaande kalenderjaar bevoorrecht zijn bij het verhaal op alle goederen van de werkgever.

Ik merk op dat tot op heden in de literatuur en jurisprudentie enkel de vraag aan de orde is gekomen of een op grond van art. 3:288 sub e BW bevoorrechte vordering van een crediteur jegens de boedel van een failliete 403-maatschappij, automatisch meebrengt dat ook de vordering van de crediteur op de moedermaatschappij is bevoorrecht - indien de moedermaatschappij failliet is. Ik richt mij daarom in het vervolg van deze paragraaf in hoofdzaak op de eventuele doorwerking van een voorrecht ex art. 3:288 sub e BW. Ik kom later terug op het onderscheid tussen een specifiek en algemeen voorrecht.

Een laatste algemene opmerking die ik maak, is dat ik in verband met de leesbaarheid niet telkens zal vermelden dat het gaat om een vordering van een crediteur die is bevoorrecht bij het verhaal op (een deel van) de goederen in de boedel van de failliete moeder- of 403-maatschappij. In plaats daarvan verwijs ik slechts naar een al of niet bevoorrechte vordering op de moeder- of de 403-maatschappij.

Het antwoord op de vraag of een op grond van art. 3:288 sub e BW bevoorrechte vordering van een werknemer op de 403-maatschappij meebrengt dat ook de vordering op de moedermaatschappij is bevoorrecht, kent een bewogen historie. De Rechtbank Haarlem beantwoordde haar in 2005 bevestigend. ${ }^{178}$ De rechtbank overwoog dat het voorrecht niet zou zijn ontstaan

176. Zie art. 3:284 lid $1 \mathrm{BW}$.

177. Zie art. 3:287 lid $1 \mathrm{BW}$.

178. Rb. Haarlem 16 november 2005, JOR 2006/27 (Van der Aa/KPNQwest), r.o. 5.9. In hoger beroep gaat het Hof Amsterdam niet in op deze vraag. Zie Hof Amsterdam 6 september 2007, RI 2008/26 (Van der Aa/KPNQwest). 


\section{HOOFDSTUK 4}

zonder de arbeidsovereenkomst tussen de werknemer en de 403-maatschappij en dat het daarom de arbeidsovereenkomst is die leidt tot het voorrecht. De rechtbank vervolgt dat de hoofdelijke aansprakelijkheid van de moedermaatschappij op grond van de 403-verklaring weliswaar niet tot gevolg heeft dat de moedermaatschappij heeft te gelden als werkgever van de werknemer. Maar het leidt er volgens de rechtbank ook niet toe dat het aan de vordering op de 403-maatschappij verbonden voorrecht komt te vervallen - in de verhouding tussen de werknemer en de moedermaatschappij. Dit voorrecht 'kleeft' als het ware aan de arbeidsovereenkomst tussen de werknemer en de 403-maatschappij. De hoofdelijke aansprakelijkheid van de moedermaatschappij omvat daarom volgens de rechtbank ook het aan de vordering van de werknemer op de 403-maatschappij verbonden voorrecht. Het zou te zeer afbreuk doen aan de compensatie voor de crediteuren op grond van de 403-verklaring als de vordering op de moedermaatschappij een concurrente vordering zou zijn.

Van Wijngaarden heeft zich kritisch uitgelaten over bovenstaand oordeel. ${ }^{179} \mathrm{Hij}$ wijst erop dat de hoofdelijke aansprakelijkheid van de moedermaatschappij op grond van de 403-verklaring een zelfstandige verbintenis in het leven roept. Voorrechten ontstaan enkel uit de wet en niet - zoals de rechtbank overweegt uit een arbeidsovereenkomst of een 403-verklaring. Volgens Van Wijngaarden leidt de uitspraak daarom tot een schending van het beginsel van de paritas creditorum op het niveau van de moedermaatschappij.

De kritiek van Van Wijngaarden lijkt niet aan dovemansoren te zijn gericht. In 2010 komt de Rechtbank Haarlem terug op haar eerdere uitspraak en oordeelt in een andere procedure dat een bevoorrechte vordering op de 403-maatschappij niet automatisch leidt tot een bevoorrechte vordering jegens de moedermaatschappij. ${ }^{180}$ De rechtbank overweegt dat art. 3:288 sub e BW enkel een voorrecht toekent aan de vordering van de werknemer op de 403-maatschappij als werkgever, en niet ook aan de vordering op de moedermaatschappij. Voor een ruimere uitleg van het object van het voorrecht is volgens de rechtbank geen steun te vinden in de wet.

In de literatuur is verschillend gereageerd op de nieuw ingeslagen weg van de Rechtbank Haarlem. Enerzijds wordt het oordeel en de onderbouwing onderschreven, ${ }^{181}$ maar er zijn ook auteurs die het niet eens zijn met deze omslag van de rechtbank. ${ }^{182}$ Bartman noemt twee kritiekpunten. Ten eerste wijst hij erop dat een crediteur van de 403-maatschappij als compensatie voor het niet kunnen

179. Van Wijngaarden 2006b, p. 24.

180. Rb. Haarlem 28 juli 2010, JOR 2010/264, m.nt. Bartman (KPNQwest), r.o. 4.6.

181. Van der Heijden/Van der Grinten \& Dortmond 2013/324.3 en S. Timmerman \& De Winter 2013, p. 358-359.

182. Bartman in zijn annotatie onder Rb. Haarlem 28 juli 2010, JOR 2010/264 (KPNQwest), Beckman 2010a, p. 696, Zwemmer 2011, p. 225 en Zwemmer 2012, p. 230-231. 
inzien van de jaarrekening ook een vordering krijgt op de moedermaatschappij. Volgens hem dient dit een 'volwaardige' compensatie te zijn die mede het voorrecht omvat dat de wet aan de vordering van de crediteur op de 403-maatschappij verbindt. Een bevoorrechte vordering op de 403-maatschappij, brengt daarom volgens hem mee dat ook de vordering op de moedermaatschappij is bevoorrecht. Daarnaast wijst Bartman op art. 57 van de Vierde EEG-richtlijn ${ }^{183}$ inzake de jaarrekeningvrijstelling voor dochterondernemingen. Deze bepaling is in Nederland geïmplementeerd in art. 2:403 BW. Een van de voorwaarden ex art. 57 van de Vierde EEG-richtlijn om gebruik te mogen maken van de jaarrekeningvrijstelling is dat de moederonderneming garant staat voor de aangegane 'verplichtingen' van de dochteronderneming. ${ }^{184}$ Volgens Bartman ziet de term verplichtingen op het hele pakket aan verplichtingen, dus inclusief een wettelijk voorrecht. Een richtlijnconforme uitleg van art. 2:403 lid 1 sub $f$ BW betekent daarom volgens hem dat als de vordering van de crediteur op de 403-maatschappij is bevoorrecht, ook de vordering op de moedermaatschappij is bevoorrecht.

Uiteindelijk heeft een proefprocedure bij de Rechtbank Midden-Nederland gevolgd door sprongcassatie, antwoord gegeven op de vraag of een aan de vordering van een crediteur op de 403-maatschappij verbonden voorrecht doorwerkt ten aanzien van de vordering op de moedermaatschappij. In deze $U W V /$ Econcern-procedure volgen de rechtbank ${ }^{185}$ en de Hoge Raad ${ }^{186}$ de lijn van de Rechtbank Haarlem uit 2010 en oordelen dat een bevoorrechte vordering op de 403-maatschappij niet automatisch leidt tot een bevoorrechte vordering op de moedermaatschappij. ${ }^{187} \mathrm{Zij}$ overwegen dat voorrechten op grond van art. 3:278 lid $2 \mathrm{BW}$ alleen voortvloeien uit de wet en dat art. 2:403 BW, noch enige andere wettelijke bepaling, een voorrecht verbindt aan de vordering van een crediteur op grond van een 403-verklaring. Ook uit de term aangegane 'verplichtingen' uit art. 57 van de Vierde EEG-richtlijn ${ }^{188}$ is volgens de rechtbank en de Hoge

183. Thans art. 37 van de richtlijn jaarrekeningen.

184. In art. 57 van de Vierde EEG-richtlijn werd niet verwezen naar de moeder- en dochteronderneming maar naar de beheersende en de afhankelijke vennootschap. In art. 43 van de Zevende EEG-richtlijn en thans in art. 37 van de richtlijn jaarrekeningen wordt wel verwezen naar de moeder- en dochteronderneming. Omwille van de duidelijkheid hanteer ik de huidige termen.

185. Rb. Midden-Nederland 30 januari 2013, JOR 2013/70, m.nt. Van Dooren (UWV/ Econcern), r.o. 4.3-4.5. Gelijkluidend: Rb. Midden-Nederland 30 januari 2013, ECLI:NL:RBMNE:2013:BZ0341 (X/Econcern). Ook gepubliceerd in JIN 2013/73, m.nt. Van der Kraan (UWV/Econcern). Zie ook E.C.A. Nass 2013, p. 246-248.

186. HR 11 april 2014, NJ2014/309, m.nt. Van Schilfgaarde (UWV/Econcern), r.o. 3.2.2 en 3.4.13.4.2. Ook gepubliceerd in JOR 2014/199, m.nt. Van Dooren (UWV/Econcern). Gelijkluidend: HR 11 april 2014, JOR 2014/198 (X/Econcern).

187. De Hoge Raad volgt op dit punt de conclusie van A-G Timmerman bij het arrest (zie nr. 2.122.16 van de conclusie).

188. Thans art. 37 van de richtlijn jaarrekeningen. 
Raad niet af te leiden dat een voorrecht doorwerkt ten aanzien van de vordering op de moedermaatschappij. ${ }^{189}$

Met bovenstaand arrest heeft de Hoge Raad een einde gemaakt aan de discussie omtrent de doorwerking van een aan een vordering op de 403-maatschappij verbonden voorrecht. Evenals Nass meen ik dat de Hoge Raad terecht heeft geoordeeld dat de 403-aansprakelijkheid het 'gesloten systeem' van voorrechten niet doorbreekt. ${ }^{190}$ Aangezien de wet geen voorrecht toekent aan de vordering van een crediteur op de moedermaatschappij op grond van de 403-verklaring, betreft dit een concurrente vordering. Dat de vordering van de crediteur op de 403-maatschappij wel is bevoorrecht maakt dit niet anders. Daarnaast ben ik van mening dat de Hoge Raad terecht oordeelt dat uit de tekst van art. 57 van de Vierde EEG-richtlijn geen verdergaand oogmerk blijkt dan dat de moederonderneming aansprakelijk is voor een verplichting van de dochteronderneming, los van een eventueel aan die verplichting verbonden voorrecht voor de crediteur. ${ }^{191}$ Ook de considerans van de richtlijn biedt daarvoor naar mijn mening geen aanleiding. Resumerend brengt een bevoorrechte vordering op de 403-maatschappij dus niet mee dat ook de vordering op de moedermaatschappij is bevoorrecht. Laatstgenoemde betreft een concurrente vordering.

Hoewel het oordeel van de Hoge Raad in het UWV/Econcern-arrest naar de wet juist is, meen ik dat deze uitkomst niet aansluit bij de functie van de 403-aansprakelijkheid van de moedermaatschappij bij de compensatie van de crediteuren omdat zij de jaarrekening van de 403-maatschappij niet kunnen inzien. ${ }^{192}$ Kort gezegd wordt een crediteur gecompenseerd voor het feit dat hij een vordering heeft op een debiteur - de 403-maatschappij - van wie hij de jaarrekening niet kan inzien, met een aanvullende vordering op een andere debiteur - de moedermaatschappij - van wie hij de geconsolideerde jaarrekening wel kan inzien. ${ }^{193}$ Voor het overige is er vanuit het oogpunt van de compensatie geen reden dat de verhaalsrechten van de crediteur op de 403-maatschappij en de moedermaatschappij verschillend zijn. Ik heb betoogd dat aangezien een crediteur geen invloed heeft op de keuze van de 403-maatschappij om gebruik te maken van de jaarrekeningvrijstelling van het groepsregime, hij daardoor niet in een nadeliger positie mag komen. ${ }^{194}$ Het is daarom onwenselijk dat een crediteur op grond van de 403-verklaring een vordering met een 'lagere rang' krijgt

\footnotetext{
189. Zie ook Beckman 2014b, p. 410.

190. A.G.S. Nass 2019, p. 178-179.

191. Zie De Neve 2014, p. 37, die dit standpunt onderschrijft met betrekking tot het oordeel van de Rechtbank Midden-Nederland in de UWV/Econcern-procedure.

192. Evenzo in mijn annotatie onder HR 11 april 2014, JOR 2014/199 (UWV/Econcern).

193. Zie $\S 3.4 .1$.

194. Zie $\S 3.6 .1$.
} 
op de moedermaatschappij, dan die hij heeft op de 403-maatschappij. ${ }^{195}$ Naar mijn mening zou een crediteur met een bevoorrechte vordering op de 403-maatschappij, op grond van de 403-verklaring ook een bevoorrechte vordering op de moedermaatschappij moeten krijgen.

Ik ben mij ervan bewust dat bovengenoemde doorwerking van een aan een vordering op de 403-maatschappij verbonden voorrecht ten aanzien van de vordering van de crediteur op de moedermaatschappij, nadelig kan zijn voor de overige crediteuren van de moedermaatschappij - waaronder de crediteuren van wie de vordering niet is gebaseerd op de 403 -verklaring. Indien de moedermaatschappij failleert, kunnen zij zich mogelijk pas op de boedel verhalen nadat de crediteuren met een bevoorrechte vordering op de moedermaatschappij op grond van de 403-verklaring zijn voldaan. Naar mijn mening is deze verschuiving in de volgorde van verhaal gerechtvaardigd omdat ik verdedig dat niet alleen een voorrecht zou moeten doorwerken op grond van de 403-verklaring, maar ook een contractuele achterstelling. Ik kom hier in de volgende paragraaf op terug. ${ }^{196}$

Ik merk nog op dat mogelijk betoogd zou kunnen worden dat uit het $U W V /$ Schäperclaus-Schinkel q.q. c.s.-arrest van de Hoge Raad uit 2019 volgt dat een voorrecht met betrekking tot de vordering van een crediteur op de 403-maatschappij, toch doorwerkt ten aanzien van de vordering op de moedermaatschappij. In dat arrest heeft de Hoge Raad geoordeeld dat een werknemer met een op grond van art. 3:288 sub e BW bevoorrechte vordering op de boedel van een failliete vennootschap onder firma, ook een bevoorrechte vordering heeft in de schuldsaneringsregeling van de individuele vennoten van de vennootschap onder firma. ${ }^{197}$ Faber merkt echter terecht op dat de vergelijking tussen deze casus en de 403-aansprakelijkheid niet opgaat. ${ }^{198}$ Op grond van art. 3:288 sub e BW heeft een werknemer een bevoorrechte vordering voor hetgeen hij van zijn werkgever heeft te vorderen. Bij de 403-aansprakelijkheid sluit de werknemer een arbeidsovereenkomst met de 403-maatschappij en heeft hij daarnaast op grond van de 403-verklaring een zelfstandige vordering op de moedermaatschappij. De moedermaatschappij is in deze verhouding dus zelf geen werkgever. Een personenvennootschap heeft echter geen rechtspersoonlijkheid. ${ }^{199}$ Dit betekent dat als een werknemer een arbeidsovereenkomst sluit met een

195. Zie anders A.G.S. Nass \& E.C.A. Nass 2014, p. 741, die van mening zijn dat de vordering van de crediteur voldoende is gewaarborgd. $\mathrm{Zij}$ lichten dit verder echter niet toe.

196. Zie $\S 4.8$.

197. HR 19 april 2019, NJ 2019/438, m.nt. Verstijlen (UWV/Schäperclaus-Schinkel q.q. c.s.), r.o. 3.6.2, ook gepubliceerd in JOR 2019/173, m.nt. Faber.

198. Faber in zijn annotatie onder HR 19 april 2019, JOR 2019/173 (UWV/Schäperclaus-Schinkel q.q. c.s.).

199. Tervoort 2015, p. 7-8, Stokkermans 2017, p. 92, 282 en 300 en Asser/Maeijer \& Van Olffen 7-VII 2017/13. Zie ook Huizink 2020, p. 3-6. 


\section{HOOFDSTUK 4}

vennootschap onder firma, hij een overeenkomst aangaat met de gezamenlijke vennoten. ${ }^{200}$ Deze zijn zelf als werkgever partij bij de overeenkomst. ${ }^{201}$ De vordering van de werknemer op een vennoot is dus dezelfde als die jegens de vennootschap onder firma. Dit betekent ook dat beide vorderingen zijn bevoorrecht.

Overigens wijs ik erop dat een personenvennootschap op grond van het voorgestelde art. 7:803 lid $1 \mathrm{BW}$ van het voorontwerp inzake de modernisering van personenvennootschappen ${ }^{202}$ wel rechtspersoonlijkheid krijgt. Dit zou onder meer tot gevolg hebben dat een werknemer niet meer een arbeidsovereenkomst aangaat met de vennoten, maar met de personenvennootschap zelf. Aangezien de vennoten niet meer als werkgever kwalificeren, zal een vordering van de werknemer op de vennoten op grond van het voorgestelde art. 7:809 lid 1 BW ook niet bevoorrecht zijn. Indien de wetgever dit als een onwenselijk gevolg ziet van de toekenning van rechtspersoonlijkheid aan een personenvennootschap, zou hij aan de voorgestelde regeling kunnen toevoegen dat de vordering van een crediteur op een vennoot dezelfde positie heeft als de corresponderende vordering op de personenvennootschap.

Resumerend geldt naar huidig recht dat een bevoorrechte vordering van een crediteur op de 403-maatschappij, niet meebrengt dat ook de vordering op de moedermaatschappij is bevoorrecht. Dit sluit mijns inziens echter niet aan bij de functie van de 403-aansprakelijkheid bij de compensatie van de crediteuren van de 403-maatschappij. Om te bewerkstelligen dat een voorrecht ten aanzien van een vordering op de 403-maatschappij wel doorwerkt ten aanzien van de vordering op de moedermaatschappij, moet art. 2:403 BW worden gewijzigd. Hierin kan worden opgenomen dat een vordering op de moedermaatschappij op grond van de 403-verklaring, dezelfde bevoorrechte positie heeft als de corresponderende vordering op de 403-maatschappij.

Overigens merk ik op dat bovenstaande wijziging van art. 2:403 lid 1 sub $\mathrm{f}$ BW er naar mijn mening enkel toe leidt dat een aan een vordering op de 403-maatschappij verbonden algemeen voorrecht doorwerkt ten aanzien van de vordering op de moedermaatschappij, en niet ook een specifiek voorrecht. Als een crediteur voorrang heeft bij het verhaal op alle goederen van de 403-maatschappij - zoals bij een voorrecht van een werknemer op grond van art. 3:288 sub e BW -, dan geldt dat ook bij het verhaal op de moedermaatschappij. Indien een crediteur daarentegen alleen voorrang heeft bij het verhaal op specifiek goed van de 403-maatschappij - zoals een crediteur met een vordering tot

200. Assink/Slagter 2013/99.4, Tervoort 2015, p. 118 en Stokkermans 2017, p. 247.

201. HR 19 april 2019, JOR 2019/173, m.nt. Faber (UWV/Schäperclaus-Schinkel q.q. c.s.), r.o. 3.5.2.

202. Zie internetconsultatie.nl/moderniseringpersonenvennootschap. 
vergoeding van kosten die hij heeft gemaakt om een goed te behouden voorrang heeft bij verhaal op het behouden goed ${ }^{203}$ - brengt dat niet mee dat ook zijn vordering op de moedermaatschappij is bevoorrecht. Hoewel een crediteur met een bevoorrechte vordering op de 403-maatschappij volgens het door mij bepleite uitgangspunt ook een bevoorrechte vordering op de moedermaatschappij zou moeten hebben, is het niet mogelijk dat een voorrecht dat specifiek betrekking heeft op een bepaald goed van de 403-maatschappij doorwerkt ten aanzien van de vordering op de moedermaatschappij.

\subsection{Contractuele achterstelling verbonden aan een vordering}

Een 403-maatschappij kan op grond van art. 3:277 lid 2 BW met een of meer van haar crediteuren overeenkomen dat de vorderingen van deze crediteuren zijn achtergesteld ten aanzien van vorderingen van andere crediteuren. Daarbij kan een vordering worden achtergesteld ten anzien van alle andere vorderingen op de 403-maatschappij, of ten aanzien van een of meer bepaalde vorderingen. Dit betreft een generieke, respectievelijk een specifieke achterstelling. ${ }^{204}$

Een ander onderscheid is dat tussen een eigenlijke en een oneigenlijke achterstelling. ${ }^{205}$ Eerstgenoemde houdt in dat een crediteur zijn achtergestelde vordering in het geval van een faillissement van de schuldenaar pas krijgt voldaan als de vorderingen van de andere crediteuren zijn voldaan. De achtergestelde vordering heeft een lagere rang dan de wet daaraan toekent. Een oneigenlijke achterstelling betekent dat de achtergestelde vordering - ook als de schuldenaar nog niet is gefailleerd - pas mag worden voldaan indien aan een bepaalde voorwaarde is voldaan. Als opschortende voorwaarde kan bijvoorbeeld worden overeengekomen dat de vordering pas mag worden voldaan als de vordering van een andere crediteur volledig is voldaan - of deze crediteur toestemming geeft voor eerdere betaling.

In de jurisprudentie en de literatuur is de vraag aan de orde gekomen of een contractuele achterstelling van de vordering van een crediteur op de 403-maatschappij, meebrengt dat ook zijn vordering op de moedermaatschappij is achtergesteld. Voor het antwoord op deze vraag zijn bovengenoemde verschillen tussen een generieke en specifieke achterstelling, en tussen een eigenlijke en oneigenlijke achterstelling niet van belang. Relevant is slechts dat er telkens sprake is van een overeenkomst tussen de crediteur en de 403-maatschappij op grond waarvan de crediteur zich pas op de 403-maatschappij mag verhalen

203. Zie art. 3:284 lid $1 \mathrm{BW}$.

204. Pannevis 2019, p. 18-19.

205. Pannevis 2019, p. 17-18. 


\section{HOOFDSTUK 4}

als aan een bepaalde voorwaarde is voldaan. In verband met de leesbaarheid verwijs ik daarom enkel naar een al of niet achtergestelde vorderingen op de moeder- en de 403-maatschappij. Ik kom later terug op het onderscheid tussen de verschillenden vormen van achterstelling.

De Hoge Raad heeft in zijn SNS/Curatoren-beschikking geoordeeld dat als een crediteur een achtergestelde vordering heeft op de 403-maatschappij, dit niet meebrengt dat ook zijn vordering op de moedermaatschappij is achtergesteld. ${ }^{206}$ Hij volgt daarmee de lijn van het in de vorige paragraaf behandelde arrest $U W V /$ Econcern, waarin is geoordeeld dat een voorrecht met betrekking tot de vordering van een crediteur op de 403-maatschappij, niet doorwerkt ten aanzien van de vordering op de moedermaatschappij. ${ }^{207}$ De Hoge Raad overweegt in de SNS/Curatoren-beschikking dat een door de 403-maatschappij met een crediteur overeengekomen achterstelling alleen betrekking heeft op de positie van het verhaal van de crediteur op de 403-maatschappij. De aard van een achterstelling brengt met zich dat deze alleen betrekking heeft op de rangorde van het verhaal op het vermogen van degene met wie de crediteur de achterstelling is overeengekomen. Als de achterstelling niets zegt over de verhaalspositie van de crediteur ten opzichte van de moedermaatschappij, valt volgens de Hoge Raad niet in te zien waarom deze daar wel effect op zou hebben. De Hoge Raad vervolgt dat een achterstelling geen eigenschap is van een vordering, maar een van de wettelijke hoofdregel afwijkende volgorde van het verhaal op degene met wie de crediteur de achterstelling is overeengekomen. Een door de crediteur met de 403-maatschappij overeengekomen achterstelling heeft dus geen invloed op het verhaal van deze crediteur op de moedermaatschappij. ${ }^{208}$

De Hoge Raad laat in het midden of een 403-verklaring waarin is opgenomen dat de crediteuren met een achtergestelde vordering op de 403-maatschappij ook een achtergestelde vordering krijgen op de moedermaatschappij, voldoet aan het vereiste van art. 2:403 lid 1 sub $\mathrm{f} \mathrm{BW}^{209}$ Ook in de literatuur is op dit punt geen eensluidend standpunt te vinden. Smelt meent dat een

206. HR 20 maart 2015, JOR 2015/140, m.nt. Josephus Jitta (Minister van Financiën/VEB c.s.), r.o. 4.34.3-4.34.4. De Hoge Raad volgt op dit punt de conclusie van A-G Timmerman bij het arrest (zie nr. 10.15 en 10.16 van de conclusie).

207. HR 11 april 2014, JOR 2014/199, m.nt. Van Dooren (UWV/Econcern), r.o. 3.2.2 en 3.4.13.4.2. Zie $\S 4.7$.

208. Zie Hof Amsterdam (OK) 11 juli 2013, JOR 2013/250, m.nt. Josephus Jitta (Minister van Financiën/VEB c.s.), r.o. 6.61, 6.69 en 6.72, waar de OK oordeelt dat de achterstelling niet doorwerkt op grond van de 403-verklaring maar dat uit de achterstellingsovereenkomst kan worden opgemaakt dat de achterstelling zowel betrekking heeft op de vorderingen op 403-maatschappij SNS Bank als op de vorderingen op moedermaatschappij SNS Reaal. Dit oordeel is in de literatuur terecht bekritiseerd. Zie Van der Kraan 2013, p. 166, Beckman 2013, p. 562, De Neve 2014, p. 38 en A.G.S. Nass \& E.C.A. Nass 2014, p. 740-741.

209. HR 20 maart 2015, JOR 2015/140, m.nt. Josephus Jitta (Minister van Financiën/VEB c.s.), r.o. 4.34 .3 
dergelijke verklaring wel voldoet aan het vereiste van art. 2:403 lid 1 sub f BW omdat de compensatie van de crediteuren voor het niet kunnen inzien van de jaarrekening van de 403-maatschappij niet tot gevolg zou moeten hebben dat de positie van een crediteur verbetert, in die zin dat een contractuele achterstelling van de vordering op de 403-maatschappij niet geldt ten aanzien van de vordering op de moedermaatschappij. ${ }^{210}$ Hoewel ik sympathie voel voor het standpunt van Smelt - ik kom hier later op terug - meen ik met Bartman en Van der Kraan dat als in een 403-verklaring wordt opgenomen dat de crediteuren met een achtergestelde vordering op de 403-maatschappij ook een achtergestelde vordering hebben op de moedermaatschappij, niet wordt voldaan aan het vereiste van art. 2:403 lid 1 sub $\mathrm{f} \mathrm{BW.}{ }^{211}$ Een verklaring van aansprakelijkheid waarin een dergelijke bepaling is opgenomen, kwalificeert naar mijn mening als een ontoereikende 403-verklaring. Ik heb er eerder op gewezen dat dit twee gevolgen met zich brengt. ${ }^{212}$ Kort gezegd, wordt niet voldaan aan de voorwaarde van art. 2:403 lid 1 sub $\mathrm{f} \mathrm{BW}$ waardoor de 403-maatschappij onterecht gebruikmaakt van de jaarrekeningvrijstelling van het groepsregime. Dit kan onder meer leiden tot aansprakelijkheid voor haar bestuurder(s). Daarnaast is de moedermaatschappij - ondanks dat zij geen 403-verklaring heeft gedeponeerd in de zin van art. 2:403 lid 1 sub f BW - aansprakelijk voor zover dat uit de desbetreffende verklaring volgt.

Ik meen met Van der Sangen en Nass dat de Hoge Raad terecht heeft geoordeeld dat een achterstelling ten aanzien van de vordering van een crediteur op de 403-maatschappij niet meebrengt dat ook de vordering op de moedermaatschappij is achtergesteld. ${ }^{213}$ Hoewel deze uitkomst naar de wet juist is, sluit zij naar mijn mening niet aan bij de functie van de 403-aansprakelijkheid van de moedermaatschappij bij de compensatie van de crediteuren voor het niet kunnen inzien van de jaarrekening van de 403-maatschappij. De onderbouwing voor deze kritiek is dezelfde als die ik in de vorige paragraaf heb genoemd met betrekking tot het niet doorwerken van een aan een vordering op de 403-maatschappij verbonden voorrecht ten aanzien van de vordering op de moedermaatschappij. ${ }^{214}$ Kort gezegd wordt een crediteur gecompenseerd voor het feit dat hij een vordering heeft op een debiteur - de 403-maatschappij - van wie hij de jaarrekening niet kan inzien, met een aanvullende vordering op een andere debiteurde moedermaatschappij - van wie hij de geconsolideerde jaarrekening wel kan inzien. ${ }^{215}$ Voor het overige is er vanuit het oogpunt van de compensatie geen reden dat de verhaalsrechten van de crediteur op de 403-maatschappij en de

210. Smelt 2015, p. 37.

211. Bartman 2015, p. 811 en Van der Kraan in zijn annotatie onder HR 20 maart 2015, JIN 2015/82 (Minister van Financiën/VEB c.s.).

212. Zie $\S 2.3 .6 . c$.

213. Van der Sangen 2017, p. 208 en E.C.A. Nass 2019, p. 229-230.

214. Zie $\S 4.7$.

215. Zie $\S 3.4 .1$. 
moedermaatschappij verschillend zijn. Waar het niet doorwerken van een voorrecht ertoe leidt dat de crediteur een vordering met een lagere rang heeft op de moedermaatschappij, krijgt een crediteur met een achtergestelde vordering op de 403-maatschappij een vordering met een hogere rang op de moedermaatschappij - een concurrente vordering. Dit is naar mijn mening onwenselijk. Volgens het door mij bepleite uitgangspunt voor compensatie moet het nadeel dat een crediteur ondervindt omdat hij de jaarrekening van de 403-maatschappij niet kan inzien, worden gecompenseerd, maar het moet ook zo veel mogelijk worden voorkomen dat hij hiervan voordeel heeft. ${ }^{216}$ Overcompensatie is niet wenselijk. Het komt mij vreemd voor dat naar huidig recht een crediteur van wie de vordering op de 403-maatschappij oneigenlijk is achtergesteld bij de vordering van een andere crediteur, deze achterstelling kan omzeilen door zich op de moedermaatschappij te verhalen. Naar mijn mening zou daarom een contractuele achterstelling van de vordering van een crediteur op de 403-maatschappij met zich moeten brengen dat ook de vordering van deze crediteur op de moedermaatschappij is achtergesteld.

Evenals bij de doorwerking van een aan een vordering op de 403-maatschappij verbonden voorrecht ten aanzien van de vordering van de crediteur op de moedermaatschappij, ben ik mij ervan bewust dat bovengenoemde doorwerking van een contractuele achterstelling gevolgen kan hebben voor de overige crediteuren van de moedermaatschappij - waaronder de crediteuren van wie de vordering niet is gebaseerd op de 403 -verklaring. Waar de doorwerking van een voorrecht een negatief gevolg kan hebben voor deze crediteuren omdat zij zich in het faillissement van de moedermaatschappij mogelijk pas op de boedel kunnen verhalen nadat de crediteuren met een bevoorrechte vordering op grond van de 403-verklaring zijn voldaan, heeft de doorwerking van een contractuele achterstelling een positief gevolg voor hen. De crediteuren van wie de vordering op de 403-maatschappij contractueel is achtergesteld, kunnen zich pas op de moedermaatschappij verhalen als de crediteuren - van de moedermaatschappij - van wie de vordering niet is achtergesteld, zijn voldaan.

Met betrekking tot een aan een vordering op de 403-maatschappij verbonden voorrecht heb ik geopperd dat de doorwerking daarvan ten aanzien van de vordering op de moedermaatschappij zou kunnen worden bereikt, door in art. 2:403 lid 1 sub $\mathrm{fBW}$ op te nemen dat een vordering op de moedermaatschappij op grond van de 403-verklaring dezelfde bevoorrechte positie heeft als de corresponderende vordering op de 403-maatschappij. In lijn daarmee zou aan deze bepaling ook kunnen worden toegevoegd dat als een crediteur een contractueel achtergestelde vordering heeft op de 403-maatschappij, zijn vordering op de moedermaatschappij dezelfde achtergestelde positie heeft. De vordering van de crediteur op de moedermaatschappij zou dan onder dezelfde voorwaarden zijn

216. Zie $\S 3.6 .2$. 
achtergesteld als zijn vordering op de 403-maatschappij. Dat betekent bijvoorbeeld dat als er sprake is van een oneigenlijke achterstelling van de vordering op de 403-maatschappij, de vordering van de crediteur op de moedermaatschappij ook oneigenlijk is achtergesteld. Daarnaast geldt dat als de vordering van een crediteur op de 403-maatschappij specifiek is achtergesteld ten opzichte van de vordering van een andere crediteur, de crediteur van wie de vordering is achtergesteld zijn vordering op de moedermaatschappij niet voldaan mag krijgen totdat de andere crediteur een eventuele vordering op de moedermaatschappij voldaan heeft gekregen. Is er daarentegen sprake van een algemene achterstelling van de vordering van een crediteur op de 403-maatschappij bij alle andere vorderingen, dan geldt dat naar mijn mening ook voor zijn vordering op de moedermaatschappij - dus ook ten aanzien van de crediteuren van wie de vordering op de moedermaatschappij niet uit de 403-verklaring voortkomt en die dus zelf geen vordering op de 403-maatschappij hebben.

Tot slot meen ik dat hoewel naar huidig recht een achterstelling van de vordering van een crediteur op de 403-maatschappij niet doorwerkt ten aanzien van de vordering op grond van de 403-verklaring, de moedermaatschappij wel contractueel met de crediteur overeen kan komen dat deze een achtergestelde vordering op haar heeft. De Hoge Raad overweegt in zijn SNS/Curatoren-beschikking dat aangezien in casu de contractuele achterstelling tussen de crediteur en de 403-maatschappij niets zegt ten aanzien van de verhaalspositie van de desbetreffende crediteur tegenover de moedermaatschappij, niet valt in te zien waarom deze daar wel effect op zou hebben. ${ }^{217}$ De Hoge Raad vervolgt dat een achterstelling een van de wettelijke hoofdregel afwijkende volgorde van het verhaal is ten aanzien van degene met wie de crediteur de achterstelling is overeengekomen. Impliciet brengt dit oordeel mee dat het mogelijk is om de vordering van een crediteur op grond van de 403-verklaring contractueel achter te stellen. De moedermaatschappij kan dit zelf met een crediteur afspreken, maar zij kan ook een doorlopende volmacht verlenen aan de 403-maatschappij. Op grond daarvan kan de 403-maatschappij namens de moedermaatschappij met een crediteur overeenkomen, op het moment dat de 403-maatschappij zelf met de desbetreffende crediteur een achterstellingsovereenkomst sluit, dat ook de vordering op grond van de 403-verklaring is achtergesteld. ${ }^{218}$ Indien de crediteur echter weigert hiermee in te stemmen, is het aan de moedermaatschappij om te besluiten of zij bereid is te accepteren dat de crediteur op grond van de 403-verklaring een concurrente vordering op haar krijgt. Zo niet, dan zal zij de 403-maatschappij moeten opdragen geen overeenkomst met de crediteur aan te gaan.

217. HR 20 maart 2015, JOR 2015/140, m.nt. Josephus Jitta (Minister van Financiën/VEB c.s.), r.o. 4.34.4.

218. Zie ook Smelt 2015, p. 36, die een soortgelijke opmerking maakt. Hij stelt echter niet voor dat de moedermaatschappij een volmacht geeft aan de 403-maatschappij, maar dat deze de overeenkomst tussen de 403-maatschappij en de crediteur ter aanvaarding van het achterstellingsbeding mede ondertekent. 


\subsection{Een overeenkomst ter afwikkeling van een schuld uit de wet}

Het is niet ongebruikelijk dat een 403-maatschappij een overeenkomst aangaat ter afwikkeling van een schuld van haar uit de wet. Hierbij kan onder meer worden gedacht aan een schikkingsovereenkomst met betrekking tot een schuld uit een onrechtmatige daad. In een dergelijk geval kan de vraag opkomen of de moedermaatschappij op grond van de 403-verklaring aansprakelijk is voor de schulden die uit deze overeenkomst voortvloeien. Hoewel een dergelijke schuld uit een rechtshandeling van de 403-maatschappij voortvloeit, zou betoogd kunnen worden dat deze is terug te voeren op de wet en daarom niet onder de materiële reikwijdte van de 403 -aansprakelijkheid valt.

Ter illustratie van bovengenoemd vraagstuk wijs ik op de Shell/NAM-casus. ${ }^{219}$ Moedermaatschappij Shell heeft in 1985 een 403-verklaring gedeponeerd op grond waarvan zij zich hoofdelijk aansprakelijk heeft gesteld voor de schulden die voortvloeien uit de rechtshandelingen van de NAM. ${ }^{220}$ Als gevolg van gasboringen door de NAM is in Groningen schade ontstaan. Verschillende gedupeerden hebben een vordering ingesteld tegen de NAM tot vergoeding van zowel materiële schade - bijvoorbeeld aan woonhuizen - als immateriële schade - wegens een inbreuk op een fundamenteel persoonlijkheidsrecht. ${ }^{221}$ Deze schulden van de NAM vloeien voort uit een onrechtmatige daad: de beweging van de bodem als gevolg van de gaswinning. ${ }^{222}$ Shell is daarom op grond van de 403-verklaring niet aansprakelijk voor deze schulden. ${ }^{223}$

Begin 2018 maakt de Minister van Economische Zaken en Klimaat bekend dat de Staat der Nederlanden de vergoeding van de schade voor de gedupeerden in Groningen zal afhandelen. ${ }^{224}$ De NAM is hier niet inhoudelijk bij betrokken, maar draagt wel zorg voor de financiering. De Staat en de NAM hebben daartoe een overeenkomst gesloten.

Ongeveer een half jaar eerder heeft Shell haar 403-verklaring ingetrokken. Zij is daarom niet aansprakelijk voor de schulden die voortvloeien uit de overeenkomst tussen de Staat en de NAM. ${ }^{225}$ Stel echter dat Shell haar 403-verklaring

219. Zie ook $\S 3.5 .3$ en $\S 7.8$, met betrekking tot de Shell-casus.

220. Zie E.C.A. Nass 2018, p. 167.

221. Rb. Noord-Nederland 1 maart 2017, JA 2017/88, m.nt. Van Dorsser (X/NAM), r.o. 4.4.74.4.8. Zie art. 6:106 lid 1 sub b BW.

222. Zie art. 6:177 lid 1 sub b BW.

223. Kamerstukken II 2017/18, 33529, 422, p. 2 (Brief aan de voorzitter van de Tweede Kamer), Van Dooren 2018a, p. 61, E.C.A. Nass 2018, p. 168 en E.C.A. Nass 2020, p. 148. Zie § 4.3.2. 224. Kamerstukken II 2017/18, 33529, 423 (Brief aan de voorzitter van de Tweede Kamer).

225. Van Dooren 2018a, p. 62 en E.C.A. Nass 2018, p. 168. Zie art. 2:404 lid 1 en 2 BW en $\S 7.2$ en $\S 8.2$. Zie ook $\S 7.8$, waar ik tot de conclusie kom dat de intrekking van de 403-verklaring door Shell geen misbruik van recht is. Zie overigens E.C.A. Nass 2020, p. 145, 146, 148 en 149, waar zij erop wijst dat de Staat en (onder meer) Shell nadien een akkoord 
nog niet had ingetrokken op het moment dat de overeenkomst is gesloten. Zou Shell dan wél aansprakelijk zijn geweest voor de schulden van de NAM die uit de overeenkomst voortvloeien?

De tekst van art. 2:403 lid 1 sub f BW, dat een moedermaatschappij zich aansprakelijk moet stellen voor de uit rechtshandelingen van de 403-maatschappij voortvloeiende schulden, laat naar mijn mening geen ruimte om de 403-aansprakelijkheid zo uit te leggen dat schulden die voortvloeien uit een overeenkomst ter afwikkeling van een schuld uit de wet daar niet onder vallen. Ook de functie van de 403-aansprakelijkheid bij de compensatie van de crediteuren omdat zij de jaarrekening van de 403-maatschappij niet kunnen inzien, biedt geen aanknopingspunt voor een dergelijke uitzondering. Als een 403-maatschappij een overeenkomst aangaat met een crediteur ter afwikkeling van een schuld uit de wet, ontbreekt het deze crediteur aan de mogelijkheid om de jaarrekening van de 403-maatschappij in te zien. Hij kan niet (mede) aan de hand daarvan schatten hoe groot het risico is dat de 403-maatschappij de verplichtingen uit deze overeenkomst niet (volledig) zal nakomen. Ter compensatie van dit gebrek aan inzicht dient hij zich op grond van de 403-verklaring ook te kunnen verhalen op de moedermaatschappij van wie hij de geconsolideerde jaarrekening wel kan inzien. Indien Shell haar 403-verklaring niet had ingetrokken voordat de Staat en de NAM de overeenkomst inzake de afwikkeling van de schadevergoedingen voor de gedupeerden in Groningen aangingen, zou zij mijns inziens uit hoofde van die verklaring aansprakelijk zijn geweest voor de schulden die daaruit voortvloeien.

Bovenstaande redenering brengt mee dat als een 403-maatschappij een overeenkomst is aangegaan ter afwikkeling van een schuld uit de wet, de moedermaatschappij indirect aansprakelijk is voor een schuld die in eerste instantie niet onder de 403-aansprakelijkheid viel. Naar mijn mening is het toch gerechtvaardigd dat de crediteur zich voor deze schuld ook op de moedermaatschappij kan verhalen. Een onderdeel van een dergelijke overeenkomst kan zijn dat de crediteur extra risico loopt in het geval dat de 403-maatschappij de verplichtingen uit de overeenkomst niet nakomt - in vergelijking met de situatie dat hij de overeenkomst niet zou zijn aangegaan. Als voorbeeld wijs ik op de hierboven genoemde Shell/NAM-casus. Stel dat op het moment dat de Staat en de NAM de overeenkomst zijn aangegaan, Shell de 403-verklaring nog niet had

op hoofdlijnen hebben gesloten op grond waarvan Shell garanties zal geven waardoor de NAM haar verplichting tot vergoeding van schade te allen tijde kan nakomen (zie Kamerstukken II 2017/18, 33529, 493 (Brief aan de voorzitter van de Tweede Kamer), en Bijlage 1 Akkoord op Hoofdlijnen met Shell en ExxonMobil). Bartman betwijfelt of dit voldoende zekerheid biedt voor de gedupeerden. Zie S.M. Bartman, 'NAM-akkoord: garanties Shell en ExxonMobil bieden maar beperkte zekerheid', Het Financieele Dagblad 2 juli 2018 en J. Kleinnijenhuis, 'Hoogleraar: 'Wiebes liet zich afbluffen bij gasdeal met Shell”, Trouw 1 augustus 2018. 
ingetrokken en de NAM nog steeds gebruikmaakte van de jaarrekeningvrijstelling van het groepsregime. De Staat heeft er belang bij om (mede) aan de hand van de jaarrekening van de NAM te kunnen schatten of deze aan de verplichting tot financiering van de vergoeding van de schade van de gedupeerden in Groningen kan voldoen. Als de NAM daarin tekortschiet, is de Staat namelijk zelf verplicht om deze financiering op zich te nemen. Als de Staat niet de mogelijkheid heeft om (mede) aan de hand van de jaarrekening van de NAM te schatten hoe groot het risico is dat deze de verplichting uit de overeenkomst niet (volledig) zal voldoen, moet zij daarvoor worden gecompenseerd met een aanvullende vordering op Shell van wie zij de geconsolideerde jaarrekening wel kan inzien.

Een tweede voorbeeld van mogelijk extra risico dat een crediteur loopt naar aanleiding van een overeenkomst ter afwikkeling van een schuld van de 403-maatschappij uit de wet, is de situatie dat de crediteur een schikking overeenkomt op grond waarvan de 403-maatschappij een schuld uit de wet deels zal voldoen en partijen elkaar verder finale kwijting verlenen. De crediteur heeft er in dat geval belang bij dat hij (mede) aan de hand van de jaarrekening van de 403-maatschappij kan schatten hoe groot het risico is dat deze het niet-gekwijte deel van de vordering niet (volledig) zal voldoen. Doordat de crediteur deels finale kwijting verleent aan de 403-maatschappij geeft hij een deel van zijn vordering op. Als de 403-maatschappij vervolgens failleert en het niet-gekwijte deel van de schuld niet kan voldoen, kan de crediteur slecht dit deel van de oorspronkelijke vordering in het faillissement indienen waar hij anders de volledige vordering zou hebben kunnen indienen. Mijns inziens moet een crediteur voor dit gebrek aan inzicht worden gecompenseerd met een aanvullende vordering op de moedermaatschappij op grond van de 403-verklaring.

Resumerend geldt dat ook een crediteur die een overeenkomst aangaat ter afwikkeling van een schuld van de 403-maatschappij uit de wet, er belang bij kan hebben om de jaarrekening van de 403-maatschappij in te zien. Als dit inzicht ontbreekt moet hij mijns inziens - net als andere crediteuren van wie de vordering voortvloeit uit een rechtshandeling van de 403-maatschappij - daarvoor worden gecompenseerd met een aanvullende vordering op de moedermaatschappij. Dat de crediteur niet gecompenseerd hoeft te worden voor een gebrek aan inzicht met betrekking tot de oorspronkelijke vordering op de 403-maatschappij uit de wet, ${ }^{226}$ maakt dit niet anders. Indien de moedermaatschappij niet wil dat zij indirect aansprakelijk wordt voor een schuld van de 403-maatschappij uit de wet, kan zij de 403-maatschappij opdragen om geen overeenkomst aan te gaan met de crediteur of te bedingen dat daarin wordt opgenomen dat de crediteur de moedermaatschappij niet aansprakelijk zal stellen op grond van de 403-verklaring. In het laatste geval is een beroep

226. Zie $\S 4.3 .2$. 
van de crediteur op de 403-aansprakelijkheid naar mijn mening onaanvaardbaar naar maatstaven van redelijkheid en billijkheid. ${ }^{227}$

Bovenstaande situatie waarbij de 403-maatschappij en een crediteur een overeenkomst aangaan ter afwikkeling van een schuld uit de wet, moet worden onderscheiden van het geval dat ze een overeenkomst sluiten ter vaststelling van de omvang van een schuld van de 403-maatschappij uit de wet. In het laatste geval kan de crediteur zich niet op grond van de 403-verklaring op de moedermaatschappij verhalen omdat er geen schuld voortvloeit uit de overeenkomst. Er is slechts vastgesteld hoe groot een bepaalde schuld is. Dit is bijvoorbeeld het geval bij een fiscaal compromis tussen de 403-maatschappij en de Belastingdienst. ${ }^{228}$

\subsection{Conclusie}

Op grond van art. 2:403 lid 1 sub f BW dient een moedermaatschappij zich uit hoofde van een 403-verklaring hoofdelijk aansprakelijk te stellen voor de uit rechtshandelingen van de 403-maatschappij voortvloeiende schulden. Uit deze bepaling zijn drie elementen op te maken met betrekking tot de materiële reikwijdte van de 403-aansprakelijkheid: 'schulden', 'rechtshandelingen' en 'voortvloeien'. In dit hoofdstuk heb ik allereerst onderzocht hoe ieder van deze elementen moet worden uitgelegd.

Ik heb geconcludeerd dat de term 'schulden' ziet op geldschulden en op niet in geld luidende verplichtingen van de 403-maatschappij. Zowel crediteuren met een vordering in geld als crediteuren met een niet in geld luidende vordering hebben er belang bij om de jaarrekening van de 403-maatschappij te kunnen inzien om (mede) aan de hand daarvan te schatten hoe groot het risico is dat hun vordering niet (volledig) zal worden voldaan. Naar mijn mening moeten beide groepen crediteuren daarom worden gecompenseerd indien dit inzicht ontbreekt. Ik meen dat het wenselijk is dat ter verduidelijking van de reikwijdte van de 403-aansprakelijkheid, de term schulden in art. 2:403 lid 1 sub f BW wordt vervangen door de term verplichtingen (§ 4.2).

Vorderingen die uit de wet voortvloeien, vallen niet onder de reikwijdte van de 403-aansprakelijkheid. Het ontstaan en de omvang van een vordering uit de wet, is niet gebaseerd op een afweging van de crediteur ten aanzien van de financiële positie van de 403-maatschappij. De crediteuren ondervinden op dit punt dus geen nadeel als de 403-maatschappij gebruikmaakt van de jaarrekeningvrijstelling van het groepsregime en zij hoeven daarom niet gecompenseerd te worden met een vordering op de moedermaatschappij op grond van

227. Zie art. $6: 2 \mathrm{BW}$

228. Van Solinge 2006, p. 253-254. 


\section{HOOFDSTUK 4}

de 403-verklaring. Dit neemt echter niet weg dat deze crediteuren er gedurende hun relatie met de 403-maatschappij wel belang bij kunnen hebben om de jaarrekening van de 403-maatschappij in te zien. Toch meen ik dat het gerechtvaardigd is dat schulden die uit de wet voortvloeien niet onder de reikwijdte van de 403-aansprakelijkheid vallen. Het jaarlijks kunnen inzien van de nieuwe jaarrekening is namelijk vooral van belang voor de crediteuren die een doorlopende relatie met de 403-maatschappij hebben waaruit periodiek nieuwe vorderingen voortvloeien. Aangezien uit de wet amper doorlopende relaties kunnen ontstaan waaruit periodiek nieuwe vorderingen voortvloeien, staat de extra aansprakelijkheid voor de moedermaatschappij - voor de schulden van de 403-maatschappij uit de wet - naar mijn mening niet in verhouding tot het beperkte gebrek aan inzicht voor de desbetreffende crediteuren dat daardoor zou worden gecompenseerd (§ 4.3).

De vraag of een schuld uit een rechtshandeling van de 403-maatschappij 'voortvloeit', moet mijns inziens worden beantwoord in het licht van de functie van de aansprakelijkheid van de moedermaatschappij op grond van de 403-verklaring bij de compensatie van de crediteur omdat deze de jaarrekening van de 403-maatschappij niet kan inzien. Ik betoog daarom dat een schuld uit een rechtshandeling voortvloeit als de wil van de crediteur ten aanzien van het ontstaan, de inhoud of het voortduren van de schuld zou kunnen zijn beïnvloed door inzicht in de jaarrekening van de 403-maatschappij - als de 403-maatschappij geen gebruik zou hebben gemaakt van de jaarrekeningvrijstelling van het groepsregime (§ 4.4).

$\mathrm{Na}$ te hebben onderzocht hoe ieder van de drie genoemde elementen van de materiële reikwijdte van de 403-aansprakelijkheid moet worden uitgelegd, ben ik voor verschillende schulden nagegaan of deze al of niet onder deze reikwijdte vallen (§ 4.5). Ik heb onder meer geconcludeerd dat er met betrekking tot de aansprakelijkheid van een 403-maatschappij als bestuurder van een andere rechtspersoon, een onderscheid moet worden gemaakt tussen interne en externe aansprakelijkheid. Naar mijn mening valt de interne bestuurdersaansprakelijkheid op grond van art. 2:9 BW en art. 2:216 BW wel onder de reikwijdte van de 403-aansprakelijkheid omdat de 403-maatschappij dan aansprakelijk is tegenover degene die de wederpartij is bij de rechtshandeling waarbij zij het bestuurderschap heeft geaccepteerd, te weten: de door haar bestuurde rechtspersoon. Bij de externe bestuurdersaansprakelijkheid - zoals de aansprakelijkheid op grond van art. 6:162 BW en art. 2:138/248 BW - is de 403-maatschappij niet aansprakelijk tegenover de door haar bestuurde rechtspersoon, maar tegenover een derde. Deze schulden vloeien mijns inziens om die reden niet voort uit de rechtshandeling waarbij de 403-maatschappij het bestuurderschap heeft geaccepteerd, maar uit de wet. Zij vallen daardoor buiten de reikwijdte van de 403-aansprakelijkheid (§ 4.5.4). 
Daarnaast heb ik opgemerkt dat als een 403-maatschappij een rechtshandeling heeft verricht op grond waarvan zij een geldsom moet betalen aan een crediteur en zij dit bedrag niet op tijd betaalt, de moedermaatschappij mede aansprakelijk is indien de 403-maatschappij op grond van art. 6:119 BW wettelijke rente moet betalen over dit bedrag. De wettelijke rente heeft weliswaar zijn directe ontstaansgrond in de wet, maar deze vloeit als secundaire schuld voort uit de rechtshandeling op grond waarvan de 403-maatschappij verplicht is tot het betalen van de desbetreffende geldsom. Deze rente valt daarom onder de reikwijdte van de 403-aansprakelijkheid (§ 4.5.7). Als laatste merk ik op dat ik heb geconcludeerd dat hoewel een verhuurder een vordering tot vergoeding van leegstandschade voor huurpenningen na de dag van de opzegging van de huurovereenkomst door de curator op grond van art. $39 \mathrm{Fw}$ niet kan verhalen op de boedel van de failliete 403-maatschappij, hij deze vordering wel op grond van de 403-verklaring op de moedermaatschappij kan verhalen (§ 4.5.9).

Op basis van de conclusies naar aanleiding van het onderzoek naar de drie elementen van de materiële reikwijdte van de 403-aansprakelijkheid uit art. 2:403 lid 1 sub f BW - schulden, rechtshandelingen en voortvloeien - en de diverse schulden die ik heb onderzocht, heb ik een viertal algemene regels opgesteld aan de hand waarvan ook voor andere schulden van de 403-maatschappij kan worden beoordeeld of deze al of niet onder de reikwijdte van de 403-aansprakelijkheid vallen (§ 4.6). Ten eerste vloeit een schuld in ieder geval uit de wet voort als deze naar zijn aard een sanctie is die is bedoeld om de 403-maatschappij tot bepaald gedrag aan te zetten. Daarnaast kunnen zowel primaire als secundaire schulden uit een rechtshandeling voortvloeien. Voorts vloeit een schuld niet uit een bepaalde rechtshandeling voort als de 403-maatschappij aansprakelijk wordt gesteld door een partij tegenover wie zij zich niet heeft verbonden door de desbetreffende rechtshandeling. Tot slot geldt dat een schuld uit een rechtshandeling 'voortvloeit' als de wil van de crediteur ten aanzien van het ontstaan, de inhoud of het voortduren van de schuld zou kunnen zijn beïnvloed door inzicht in de jaarrekening van de 403-maatschappij.

Voorts ben ik ingegaan op het antwoord op de vraag of een aan een vordering op de 403-maatschappij verbonden voorrecht of achterstelling, meebrengt dat ook de vordering op de moedermaatschappij is bevoorrecht, respectievelijk is achtergesteld. Naar mijn mening heeft de Hoge Raad in het UWV/Econcernarrest $^{229}$ en de $S N S /$ Curatoren-beschikking ${ }^{230}$ terecht geoordeeld dat deze vraag naar huidig recht ontkennend moet worden beantwoord. De crediteur heeft in beide gevallen een concurrente vordering op de moedermaatschappij. Deze

229. HR 11 april 2014, JOR 2014/199, m.nt. Van Dooren (UWV/Econcern), r.o. 3.2.2 en 3.4.13.4.2.

230. HR 20 maart 2015, JOR 2015/140, m.nt. Josephus Jitta (Minister van Financiën/VEB c.s.), r.o. 4.34.3-4.34.4. 
uitkomst sluit mijns inziens echter niet aan bij de functie van de 403-aansprakelijkheid bij de compensatie van de crediteuren voor het niet kunnen inzien van de jaarrekening van de 403-maatschappij. Een crediteur wordt gecompenseerd voor het feit dat hij een vordering heeft op een debiteur - de 403-maatschappij van wie hij de jaarrekening niet kan inzien, met een aanvullende vordering op een andere debiteur - de moedermaatschappij - van wie hij de geconsolideerde jaarrekening wel kan inzien. Voor het overige is er vanuit het oogpunt van de compensatie geen reden dat de verhaalsrechten van de crediteur op de 403-maatschappij en de moedermaatschappij verschillend zijn. De compensatie zou er niet toe mogen leiden dat de positie van een crediteur verslechtert doordat een voorrecht ten aanzien van de vordering op de 403-maatschappij niet geldt voor de vordering op de moedermaatschappij, respectievelijk dat de positie van een crediteur verbetert omdat een contractuele achterstelling van de vordering op de 403-maatschappij niet geldt ten aanzien van de vordering op de moedermaatschappij. Ik heb er daarom voor gepleit dat aan art. 2:403 BW wordt toegevoegd dat een vordering op de moedermaatschappij op grond van de 403-verklaring dezelfde bevoorrechte, respectievelijk achtergestelde positie heeft als de corresponderende vordering op de 403-maatschappij ( $\$ 4.7$ en $\S 4.8)$.

Tot slot heb ik de situatie behandeld dat een 403-maatschappij een overeenkomst aangaat ter afwikkeling van een schuld uit de wet. Ik zie in het feit dat de overeenkomst betrekking heeft op een schuld uit de wet, geen reden om de schulden die uit deze overeenkomst voortvloeien niet onder de 403-aansprakelijk te scharen. De tekst van art. 2:403 lid 1 sub f BW, noch de functie van de 403-aansprakelijkheid bij de compensatie van de crediteuren voor het niet kunnen inzien van de jaarrekening van de 403-maatschappij biedt ruimte voor een dergelijke beperking van de 403-aansprakelijkheid (§ 4.9). 


\section{Hoofdstuk 5. De temporele reikwijdte van de 403-aansprakelijkheid}

\section{$5.1 \quad$ Inleiding}

In dit hoofdstuk onderzoek ik de temporele reikwijdte van de 403-aansprakelijkheid. Dit betreft het antwoord op de vraag of, en zo ja in hoeverre, een moedermaatschappij op grond van de 403-verklaring (ook) aansprakelijk is voor schulden die voortvloeien uit een rechtshandeling die de 403-maatschappij heeft verricht voordat deze verklaring is gedeponeerd.

Van alle onderwerpen met betrekking tot de 403-verklaring heeft de temporele reikwijdte van de 403-aansprakelijkheid waarschijnlijk de meeste aandacht gekregen in de literatuur. Dit heeft tot dusver echter nog niet tot consensus geleid. Ook in de - tot op heden uitsluitend lagere - jurisprudentie is verschillend geoordeeld over dit onderwerp.

Het ontbreken van een eensluidende uitleg van de temporele reikwijdte van de 403-aansprakelijkheid leidt tot onduidelijkheid en rechtsonzekerheid. Dit is onwenselijk. Enerzijds is het voor de moedermaatschappij van belang om zekerheid te hebben voor welke schulden van de 403-maatschappij zij op grond van de 403-verklaring aansprakelijk is. Aan de andere kant moeten ook de crediteuren van de 403-maatschappij kunnen weten of zij zich al of niet op de moedermaatschappij kunnen verhalen.

Ik onderzoek vijf standpunten ten aanzien van de temporele reikwijdte van de 403-aansprakelijkheid. Allereerst geef ik een overzicht van deze standpunten (§ 5.2). Vervolgens geef ik antwoord op de vraag of voor de beoordeling of een schuld van de 403-maatschappij onder de reikwijdte van de 403-aansprakelijkheid valt, moet worden aangesloten bij het moment dat de 403-maatschappij de rechtshandeling heeft verricht waaruit de desbetreffende schuld is voortgevloeid, of bij het moment dat de schuld opeisbaar is geworden (§ 5.3). Voorts ga ik nader in op enkele standpunten waarbij ik per standpunt zoek naar aanknopingspunten in de jurisprudentie, parlementaire geschiedenis en Europese richtlijnen. Daarnaast behandel ik per standpunt de voor- en tegenargumenten en analyseer ik welk van de standpunten (het beste) aansluit bij het door mij bepleite uitgangspunt voor de compensatie van de crediteuren van een 403-maatschappij ( $\$ 5.4$ tot en met $§ 5.6$ ). 
In het verlengde van de discussie omtrent de temporele reikwijdte van de 403-aansprakelijkheid ligt het vraagstuk voor welke schulden een moedermaatschappij aansprakelijk is nadat zij de 403 -verklaring heeft ingetrokken. ${ }^{1}$ Dit onderwerp komt in hoofdstuk 8 aan de orde. ${ }^{2}$

\subsection{Vijf standpunten ten aanzien van de temporele reikwijdte van de 403-aansprakelijkheid}

\subsubsection{Inleiding}

Hieronder geef ik een overzicht van vijf standpunten ten aanzien van de temporele reikwijdte van de 403 -aansprakelijkheid. Met betrekking tot deze standpunten is er een tweedeling te maken wat betreft het moment dat bepalend is voor het antwoord op de vraag of een schuld van de 403-maatschappij al of niet onder de reikwijdte van de 403-aansprakelijkheid valt. Bij de eerste drie standpunten die ik noem, wordt daarvoor aangesloten bij het moment dat de 403-maatschappij de rechtshandeling heeft verricht waaruit de desbetreffende schuld is voortgevloeid. ${ }^{3}$ De moedermaatschappij is aansprakelijk voor alle schulden die voortvloeien uit de rechtshandelingen die de 403-maatschappij heeft verricht in de periode waarop de 403-aansprakelijkheid betrekking heeft. Schulden die voortvloeien uit een rechtshandeling die de 403-maatschappij buiten deze periode heeft verricht, vallen niet onder de 403-aansprakelijkheid. Ook niet als de schuld zelf in de desbetreffende periode is ontstaan.

Volgens het vierde en vijfde standpunt is de moedermaatschappij daarentegen aansprakelijk voor alle schulden (die voortvloeien uit een rechtshandeling) van de 403-maatschappij die opeisbaar zijn geworden in de periode waarop de 403-aansprakelijkheid betrekking heeft. Het maakt daarbij niet uit wanneer de rechtshandeling is verricht waaruit de schuld is voortgevloeid. Deze rechtshandeling kan ook zijn verricht voordat de moedermaatschappij de 403-verklaring heeft gedeponeerd.

\subsubsection{Schematisch overzicht}

In afbeelding 5.1 heb ik de temporele reikwijdte van de 403-aansprakelijkheid weergegeven volgens de drie standpunten waarbij wordt aangesloten bij het moment dat de 403-maatschappij de rechtshandeling heeft verricht waaruit de schuld is voortgevloeid. De horizontale pijlen geven de periode weer waarop

1. Zie art. 2:404 lid 1 en lid $2 \mathrm{BW}$ en $\S 7.2$.

2. Zie $\$ 8.2$.

3. Zie $\S 4.4$ voor het antwoord op de vraag wanneer een schuld uit een rechtshandeling 'voortvloeit'. 
de 403-aansprakelijkheid betrekking heeft. De moedermaatschappij is aansprakelijk voor alle schulden die voortvloeien uit de rechtshandelingen die de 403-maatschappij in die periode heeft verricht.

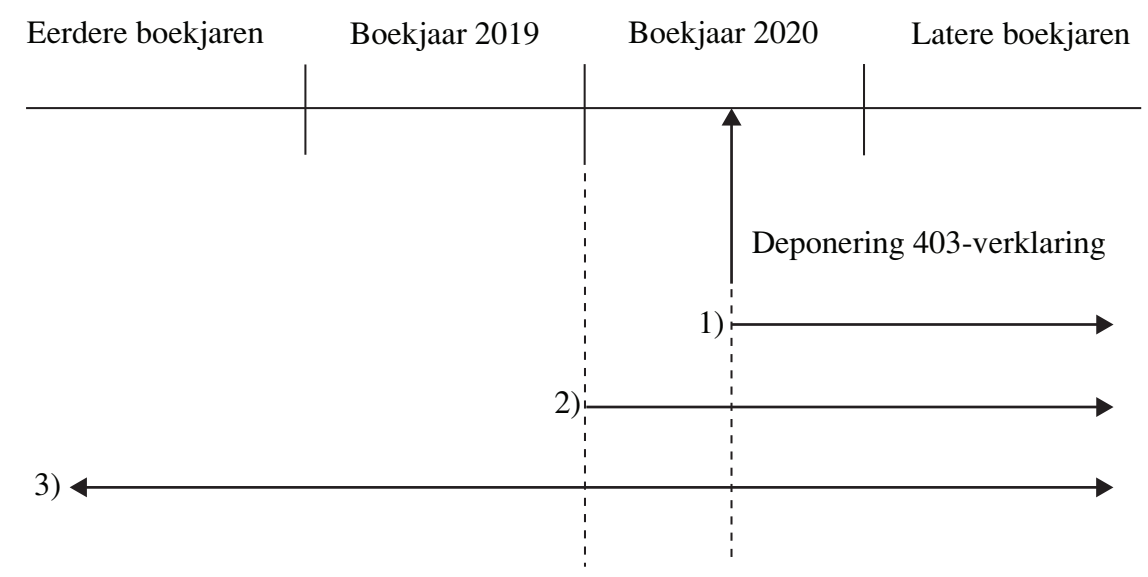

Afbeelding 5.1

1) De moedermaatschappij is aansprakelijk voor de schulden die voortvloeien uit de rechtshandelingen die de 403-maatschappij heeft verricht vanaf het moment dat de 403 -verklaring is gedeponeerd. ${ }^{4}$

2) De moedermaatschappij is aansprakelijk voor de schulden die voortvloeien en zijn voortgevloeid uit de rechtshandelingen die de 403-maatschappij heeft verricht vanaf de eerste dag van het boekjaar waarover de 403-maatschappij een jaarrekening opmaakt waarbij zij (voor het eerst) gebruikmaakt van de jaarrekeningvrijstelling. ${ }^{5}$

3) De moedermaatschappij is aansprakelijk voor alle schulden die voortvloeien en zijn voortgevloeid uit een rechtshandeling die de 403-maatschappij heeft verricht. ${ }^{6}$

4. Honée 1971, p. 202, Jansz 1973, p. 36, Van Achterberg 1989, p. 222, Winter 1989, p. 288 , Winter 1992, p. 25, Houwen, Schoonbrood-Wessels \& Schreurs 1993, p. 853, Franken \& Franken 2008, p. 72, Biemans 2011, p. 308 en Pitlo/Raaijmakers 2017, p. 613. Zie ook Rb. Rotterdam 14 januari 1987, NJ 1988/1050 (Phillips/Van Eijk).

5. Tuit 1985, p. 195, Bartman 1986, p. 106 en Bartman, Dorresteijn \& Olaerts 2020, p. 223.

6. Lubbers \& Scholten 1971, p. 68, Goudsmit 1973, p. 332-333, Raaijmakers 1976, p. 287-288, Beckman 1987, p. 533-535, Beckman 1995a, p. 545, Beckman 1996, p. 255, Asser/Maeijer 2-III 2000/439, Harmsma 2001, p. 113, Winkel 2004, p. 188, M.A.J.G. Janssen 2005, p. 121, Slagter 2005, p. 538, Ten Voorde 2006, p. 115, Ramanna 2008, p. 18, Beckman 2011, p. 252253, Van der Kraan 2012, p. 47, Van der Heijden/Van der Grinten \& Dortmond 2013/324.3, Assink/Slagter 2013/140.3, Asser/Maeijer \& Kroeze 2-I* 2015/583, Van Schilfgaarde/ Winter, Wezeman \& Schoonbrood 2017, p. 376, Beckman - SDU Commentaar Ondernemingsrecht 2019, art. 2:403 BW, aant. C.5.3, Van Zoest 2019, p. 24, Huizink 2019, p. 329, E.C.A. Nass 2019, p. 203, Beckman - Compendium jaarrekening, § 3.8.4.8, Van der Kraan in zijn annotaties onder Hof 's-Hertogenbosch 29 augustus 2017, JIN 2018/7 (Doorwin) 
In afbeelding 5.2 geef ik de temporele reikwijdte van de 403 -aansprakelijkheid weer volgens de twee standpunten waarbij het moment dat een schuld van de 403-maatschappij opeisbaar is geworden, bepalend is. De moedermaatschappij is aansprakelijk voor de schulden (die voortvloeien uit een rechtshandeling) van de 403-maatschappij die opeisbaar zijn geworden in de periode waarop de 403-aansprakelijkheid volgens het desbetreffende standpunt betrekking heeft. Op welk moment de 403-maatschappij de rechtshandeling heeft verricht waaruit de schuld is voortgevloeid, maakt niet uit. Dit kan dus ook zijn voordat de moedermaatschappij de 403-verklaring heeft gedeponeerd. Van belang is slechts dat de schuld opeisbaar is geworden in de desbetreffende periode. Om het onderscheid met de drie eerdergenoemde standpunten ten aanzien van de temporele reikwijdte van de 403-aansprakelijkheid - waarbij wordt aangesloten bij het moment dat de rechtshandeling is verricht waaruit de schuld is voortgevloeid - weer te geven, heb ik de periode waarop de twee onderhavige standpunten betrekking hebben met een stippellijn weergegeven.

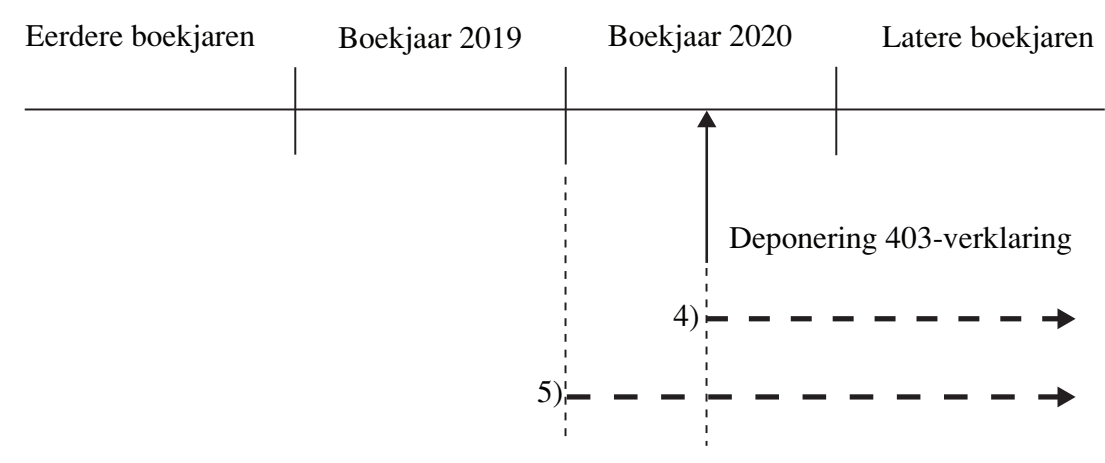

Afbeelding 5.2

4) De moedermaatschappij is aansprakelijk voor de schulden (die voortvloeien uit een rechtshandeling) van de 403-maatschappij die opeisbaar zijn geworden vanaf het moment dat de 403 -verklaring is gedeponeerd. ${ }^{7}$

en Hof Amsterdam 22 oktober 2019, JIN 2019/179 (Maison Zen beheer/Pauw), en Van Dooren in zijn annotatie onder Hof Den Haag 25 juni 2019, JOR 2020/56 (ZOM). Zie ook Hof Amsterdam 26 juli 2001, JOR 2004/94, m.nt. Bartman (Hemony/Van der Woude), r.o. 4.9, Rb. Arnhem 10 oktober 2002, JOR 2003/31, m.nt. Bartman (Resila/Spectro), r.o. 3.83.9, Rb. Roermond 25 oktober 2006, JOR 2006/289, m.nt. Bartman (Oud papiercentrale/ Inalfa), r.o. 4.5, Hof 's-Hertogenbosch 7 april 2009, JOR 2009/160, m.nt. Bartman (Inalfa), r.o. 4.3.3, Hof 's-Hertogenbosch 12 mei 2009, JOR 2009/279, m.nt. Bartman (Oud papiercentrale/Inalfa), r.o. 4.7 en Hof Amsterdam (OK) 23 juli 2014, JOR 2014/233, m.nt. Bartman (Van Lieshout/Koks), r.o. 3.5.

7. Koning 1991, p. 30-31, Niels 2010, p. 34, Zwemmer 2011, p. 228-229 en Zwemmer 2012, p. 234. Vgl. Rb. Amsterdam 20 december 2000, JOR 2001/53, m.nt. Bartman (Tevema), r.o. 3.5, waar de rechtbank oordeelt dat de moedermaatschappij ansprakelijk is voor de 
5) De moedermaatschappij is aansprakelijk voor de schulden (die voortvloeien uit een rechtshandeling) van de 403-maatschappij die opeisbaar zijn geworden vanaf de eerste dag van het boekjaar waarover de 403-maatschappij een jaarrekening opmaakt waarbij zij (voor het eerst) gebruikmaakt van de jaarrekeningvrijstelling. ${ }^{8}$

\subsubsection{Ingangsdatum in een 403-verklaring}

Ik merk op dat een moedermaatschappij een ingangsdatum kan opnemen in de 403-verklaring. ${ }^{9}$ Dit houdt in dat de moedermaatschappij in de 403 -verklaring vermeldt dat deze verklaring pas effect heeft vanaf de genoemde datum. Anders gezegd: het is alsof de verklaring op de desbetreffende datum is gedeponeerd. Mits de ingangsdatum niet later is dan de dag waarop de aandeelhouders van de 403-maatschappij de summiere jaarrekening in de zin van art. 2:403 lid 1 sub a BW vaststellen ${ }^{10}$ of - als de jaarrekening nog niet is vastgesteld - uiterlijk twaalf maanden na afloop van het boekjaar, kan de 403-maatschappij (rechtsgeldig) gebruikmaken van de jaarrekeningvrijstelling van het groepsregime. Op dat moment moet aan alle voorwaarden zijn voldaan om gebruik te maken van de jaarrekeningvrijstelling ${ }^{11}$ en moet de moedermaatschappij dus aansprakelijk zijn op grond van de 403-verklaring.

Als er een ingangsdatum is opgenomen in de 403-verklaring, dan heeft dat gevolgen voor de reikwijdte van de 403-aansprakelijkheid volgens bovenstaande eerste en vierde standpunt. De moedermaatschappij is dan aansprakelijk voor de schulden die voortvloeien uit de rechtshandelingen die de 403-maatschappij vanaf de ingangsdatum heeft verricht, respectievelijk voor de schulden (die voortvloeien uit een rechtshandeling) die vanaf deze datum opeisbaar zijn geworden. Aangezien het opnemen van een ingangsdatum in de 403-verklaring hetzelfde effect heeft als het op de desbetreffende datum deponeren van de 403-verklaring zonder ingangsdatum, laat ik dit verder buiten beschouwing.

schulden die zijn voortgevloeid uit een rechtshandeling van de 403-maatschappij voor zover deze schulden zijn ontstaan door een gedragingen - een handelen of een nalaten - nadat de 403-verklaring is gedeponeerd.

8. Gülcher 1989a, p. 165 en Gülcher 1989b, p. 290. Zie ook Hof 's-Hertogenbosch 29 augustus 2017, JOR 2017/318, m.nt. Van Zoest (Doorwin), r.o. 3.5.8, ook gepubliceerd in JIN 2018/7, m.nt. Van der Kraan. Overigens merk ik op dat het hof niet refereert aan het moment dat de schuld opeisbaar is geworden, maar aan het moment dat de schuld is ontstaan. Hoewel dit in casu niet speelde, kunnen beide momenten verschillen.

9. Beckman 1987, p. 532, Koning 1991, p. 28, Bartman, Dorresteijn \& Olaerts 2020, p. 220 en Kiersch - T\&C Burgerlijk Wetboek, art. 2:403 BW, aant. 1.

10. Art. 2:394 lid 1 en 3 BW.

11. Zie $\S 2.4$. 


\subsubsection{Overige standpunten ten aanzien van de temporele reikwijdte van de 403-aansprakelijkheid en jurisprudentie die ik buiten beschouwing laat}

Naast de vijf bovenstaande standpunten ten aanzien van de temporele reikwijdte van de 403-aansprakelijkheid, noemt Beckman nog een vijftal andere manieren hoe deze reikwijdte kan worden uitgelegd. ${ }^{12}$ De aansprakelijkstelling kan bijvoorbeeld zo worden uitgelegd dat de moedermaatschappij aansprakelijk is voor de schulden die voortvloeien uit een na de deponering van de 403-verklaring door de 403-maatschappij verrichtte rechtshandeling, vermeerderd met de op het moment van de deponering reeds bestaande uit rechtshandelingen voortvloeiende schulden onder tijdsbepaling, onder voorwaarde of periodieke betalingen die nadien opeisbaar worden. Daarnaast kan worden betoogd dat de 403-aansprakelijkheid de opeisbare schulden omvat die op het moment van de deponering van de 403-verklaring zijn voortgevloeid uit een daarvoor door de 403-maatschappij verrichtte rechtshandeling. Voorts kan art. 2:403 lid 1 sub $\mathrm{f} \mathrm{BW}$ zo worden geïnterpreteerd dat een moedermaatschappij op grond van de 403-verklaring aansprakelijk is voor alle schulden die op het moment van de deponering van deze verklaring zijn voortgevloeid uit een daarvoor door de 403-maatschappij verrichtte rechtshandeling. Het is ook mogelijk om de 403-aansprakelijkheid van een moedermaatschappij zo uit te leggen dat deze de schulden omvat die zijn voortgevloeid en in de toekomst nog zullen voortvloeien uit de rechtshandelingen die de 403-maatschappij heeft verricht tot het moment dat de 403 -verklaring is gedeponeerd. Tot slot kan worden betoogd dat de temporele reikwijdte van de aansprakelijkheid op grond van een 403-verklaring de schulden omvat die op het moment van de deponering van de 403-verklaring zijn voortgevloeid uit een daarvoor door de 403-maatschappij verrichtte rechtshandeling en de schulden die voortvloeien uit een nadien verrichtte rechtshandeling. Evenals Beckman laat ik deze standpunten echter buiten beschouwing omdat deze verder niet in de literatuur zijn verdedigd en mij ook geen jurisprudentie bekend is waar volgens een van deze standpunten is geoordeeld. ${ }^{13}$

Naast bovengenoemde standpunten ten aanzien van de temporele reikwijdte van de 403-aansprakelijkheid, laat ik ook een aantal rechterlijke uitspraken buiten beschouwing. ${ }^{14}$ Deze uitspraken hebben betrekking op een verklaring van aansprakelijkheid van de moedermaatschappij waarin expliciet is opgenomen

12. Beckman 1995a, p. 497-513. Beckman duidt deze standpunten aan als de a-2-B, b-1, b-2, b-3 en c-1 opvattingen.

13. Beckman 1995a, p. 530

14. Rb. Den Haag 2 maart 2005, JOR 2005/116, m.nt. Harmsen (Uni-Invest/Content Beheer), r.o. 3.2, Hof Amsterdam (OK) 28 februari 2007, JOR 2007/145, m.nt. Van der Zanden (Van den Wildenberg/Van Wijnen Holding), r.o. 3.5, Rb. Den Haag 7 oktober 2009, ECLI:NL:RBSGR:2009:BL3877 (MFE/Katwijk Farma), r.o. 4.51, 
dat de moedermaatschappij zich slechts aansprakelijk stelt voor de schulden die vanaf een bepaalde datum voortvloeien uit een rechtshandeling van de 403-maatschappij, respectievelijk voor de schulden die voortvloeien uit een rechtshandeling die de 403-maatschappij vanaf een bepaalde datum heeft verricht. Deze beperkingen met betrekking tot de aansprakelijkheid van de moedermaatschappij zijn niet terug te vinden in art. 2:403 lid 1 sub f BW. Op grond van deze bepaling dient een moedermaatschappij zich hoofdelijke aansprakelijk te stellen 'voor de uit rechtshandelingen van de [403-maatschappij] voortvloeiende schulden'. Ik heb eerder opgemerkt dat een dergelijk verklaring daarom niet kwalificeert als een 403-verklaring in de zin van art. 2:403 lid 1 sub f BW. ${ }^{15}$ Het betreft een zogenoemde 'ontoereikende 403-verklaring'.

De rechters in bovengenoemde uitspraken hebben terecht geoordeeld dat de aansprakelijkheid van de moedermaatschappij niet verder reikt dan uit de (tekst van de) desbetreffende verklaring volgt. Dit sluit aan bij het oordeel van de Hoge Raad in de $A k z o / I N G$-beschikking dat crediteuren geen rechten kunnen ontlenen aan art. 2:403 BW, maar uitsluitend aan de gedeponeerde verklaring. ${ }^{16}$ In de uitspraken wordt echter geen oordeel gegeven over de temporele reikwijdte van de aansprakelijkheid van een moedermaatschappij op grond van een 403-verklaring in de zin van art. 2:403 lid 1 sub f BW. Om die reden laat ik deze uitspraken verder buiten beschouwing.

Ik merk op dat ook enkele andere uitspraken die in dit hoofdstuk wel aan de orde komen, betrekking hebben op een 'ontoereikende 403-verklaring'. Bij die uitspraken heeft de rechter echter wel een oordeel gegeven over de temporele reikwijdte van de aansprakelijkheid van een moedermaatschappij op grond van een 403-verklaring in de zin van art. 2:403 lid 1 sub f BW.

\subsubsection{Het onderzoek naar de temporele reikwijdte van de 403-aansprakelijkheid bestaat uit het beantwoorden van twee vragen}

De vraag hoe ver de temporele reikwijdte van de 403-aansprakelijkheid zich uitstrekt, valt blijkens de diverse standpunten die worden verdedigd uiteen in twee vragen. De eerste vraag die moet worden beantwoord, is welk moment bepalend is om te beoordelen of een schuld van de 403-maatschappij al of niet onder de reikwijdte van de 403-aansprakelijkheid valt. Is dit het moment dat de 403-maatschappij de rechtshandeling heeft verricht waaruit de desbetreffende

Hof Amsterdam 22 oktober 2019, JIN 2019/179, m.nt. Van der Kraan (Maison Zen beheer) Pauw), r.o. 3.19 en Hof Den Haag 25 juni 2019, JOR 2020/56, m.nt. van Dooren (ZOM), r.o. $3.20-3.22$

15. Zie $\S 2.3 .6 . c$.

16. HR 28 juni 2002, NJ 2002/447, m.nt. Maeijer (Akzo/ING), r.o. 3.4.3. Ook gepubliceerd in JOR 2002/136, m.nt. Bartman. 
schuld is voortgevloeid, of het moment dat de schuld opeisbaar is geworden? De tweede vraag is op welke periode de 403 -aansprakelijkheid betrekking heeft. Anders gezegd: is, en zo ja in hoeverre, de moedermaatschappij (ook) aansprakelijk voor schulden die voortvloeien uit een rechtshandeling die de 403-maatschappij heeft verricht voordat de 403-verklaring is gedeponeerd, respectievelijk voor schulden die voor dat moment opeisbaar zijn geworden?

In de volgende paragraaf geef ik antwoord op de vraag welk moment volgens mij bepalend is om te beoordelen of een schuld al of niet onder de temporele reikwijdte van de 403-aansprakelijkheid valt. In de daaropvolgende paragrafen komt aan de orde op welke periode de 403-aansprakelijkheid betrekking heeft.

5.3 Is de 403-aansprakelijkheid gerelateerd aan het verrichten van de rechtshandeling of het opeisbaar worden van de schuld?

Op grond van art. 2:403 lid 1 sub f BW moet een moedermaatschappij zich door middel van een 403-verklaring aansprakelijk stellen voor 'de uit rechtshandelingen van de [403-maatschappij] voortvloeiende schulden'. Uit deze formulering is niet duidelijk op te maken welk moment bepalend is bij de beoordeling of een schuld van de 403-maatschappij al of niet onder de temporele reikwijdte van de 403-aansprakelijkheid valt. Enerzijds kan deze bepaling zo worden gelezen dat de moedermaatschappij aansprakelijk is voor alle schulden die voortvloeien uit de rechtshandelingen die de 403-maatschappij in een bepaalde periode heeft verricht. In dat geval is het moment dat de 403-maatschappij de rechtshandeling heeft verricht waaruit de desbetreffende schuld is voortgevloeid bepalend - de eerste drie standpunten die ik in paragraaf 5.2 heb onderscheiden. Aan de andere kant kan art. 2:403 lid 1 sub f BW zo worden uitgelegd dat de moedermaatschappij aansprakelijk is voor de schulden van de 403-maatschappij die in een bepaald periode opeisbaar worden, onafhankelijk van het moment waarop de 403-maatschappij de rechtshandeling heeft verricht waaruit de schuld is voortgevloeid. In dat geval is het moment dat de schuld opeisbaar is geworden bepalend - het vierde en vijfde standpunt uit paragraaf 5.2. Het is dus de vraag of bij de beoordeling of een schuld onder de temporele reikwijdte van de 403-aansprakelijkheid valt, moet worden aangesloten bij het moment dat de 403-maatschappij de rechtshandeling heeft verricht waaruit de schuld is voortgevloeid of het moment dat de schuld opeisbaar is geworden.

De sleutel voor het antwoord op bovenstaande vraag is mijns inziens te vinden in art. 2:404 lid 2 BW. Op grond van deze bepaling is een moedermaatschappij na de intrekking van de 403-verklaring aansprakelijk 'voor schulden die voortvloeien uit rechtshandelingen welke zijn verricht voordat jegens de schuldeiser 
een beroep op de intrekking kan worden gedaan'. ${ }^{17}$ Uit art. 2:404 lid 2 BW blijkt duidelijk dat voor de beoordeling of een schuld van de 403-maatschappij onder de temporele reikwijdte van deze zogenoemde overblijvende aansprakelijkheid valt, wordt aangesloten bij het moment dat de 403-maatschappij de rechtshandeling heeft verricht waaruit de schuld is voortgevloeid. De minister heeft dit ook bevestigd door bij de introductie van art. 2:404 BW op te merken dat de overblijvende aansprakelijkheid ook de schulden omvat die nadien voortvloeien uit een rechtshandeling die de 403-maatschappij heeft verricht voordat de moedermaatschappij tegenover de crediteur een beroep kan doen op de intrekking. ${ }^{18}$ Ook in de jurisprudentie ${ }^{19}$ en de literatuur ${ }^{20}$ wordt dit standpunt eensgezind onderschreven.

De overblijvende aansprakelijkheid van een moedermaatschappij na het intrekken van de 403-verklaring, ligt in het verlengde van de aansprakelijkheid op grond van de 403-verklaring zelf. De vraag of een moedermaatschappij aansprakelijk is voor een bepaalde schuld van de 403-maatschappij, moet mijns inziens daarom op dezelfde manier worden beantwoord. Hoewel uit art. 2:403 lid 1 sub f BW dus niet duidelijk is op te maken of hiervoor moet worden aangesloten bij het moment dat de 403-maatschappij de rechtshandeling heeft verricht waaruit de schuld is voortgevloeid of het moment dat de schuld opeisbaar is geworden, blijkt volgens mij uit art. 2:404 lid 2 BW dat het eerste moment bepalend is.

Dat voor de beoordeling of een schuld onder de temporele reikwijdte van de 403-aansprakelijkheid valt, moet worden aangesloten bij het moment dat de 403-maatschappij de rechtshandeling heeft verricht waaruit de schuld is voortgevloeid, betekent dat het vierde en vijfde standpunt uit paragraaf 5.2 moeten worden afgewezen. Ik laat deze twee standpunten daarom verder rusten.

In onderstaande paragrafen ga ik nader in op de drie overige standpunten ten aanzien van de temporele reikwijdte van de 403-aansprakelijkheid - de eerste drie standpunten die ik in paragraaf $5.2 \mathrm{heb}$ onderscheiden. Ik onderzoek op welke periode de 403-aansprakelijkheid betrekking heeft. Daarbij behandel ik

17. Zie voor een uitgebreide bespreking van de overblijvende aansprakelijkheid § 8.2. De moedermaatschappij kan deze overblijvende aansprakelijkheid beëindigen als zij voldoet aan de voorwaarden van art. 2:404 lid $3 \mathrm{BW}$ (zie $\S 8.3$ tot en met $\S 8.13$ ).

18. Kamerstukken II 1983/84, 16551, 11, p. 15 (NnavhEV).

19. Zie bijvoorbeeld Rb. Rotterdam 16 april 2009, JOR 2009/161, m.nt. Van der Zanden (BosGijze/Jones Lang LaSalle), r.o. 5.5.1-5.5.2.

20. Van Achterberg 1989, p. 229, Bartman 2002, p. 24-25, Van Wijngaarden 2006a, p. 619, Zwemmer 2012, p. 238-239, Beckman - SDU Commentaar Ondernemingsrecht 2019, art. 2:404 BW, aant. C.1, Van Zoest 2019, p. 32-33, E.C.A. Nass 2019, p. 141 en 231 en Bartman, Dorresteijn \& Olaerts 2020, p. 226-227. 
de standpunten in de volgorde van de minste tot de meeste aansprakelijkheid voor de moedermaatschappij.

\subsection{De 403-aansprakelijkheid werkt niet terug in het verleden}

\subsubsection{Inleiding}

De meest beperkte uitleg van de temporele reikwijdte van de 403-aansprakelijkheid houdt in dat de moedermaatschappij slechts aansprakelijk is voor de schulden die voortvloeien uit de rechtshandelingen die de 403-maatschappij heeft verricht vanaf het moment dat de 403 -verklaring is gedeponeerd. ${ }^{21}$ De moedermaatschappij is volgens deze uitleg niet aansprakelijk voor de schulden die voortvloeien uit de rechtshandelingen die de 403-maatschappij heeft verricht voordat deze verklaring is gedeponeerd. Ook niet als een dergelijke schuld na de deponering daarvan ontstaat. ${ }^{22} \mathrm{Bij}$ de eerste uitspraak ten aanzien van de temporele reikwijdte van de 403-aansprakelijkheid in 1987 heeft de Rechtbank Rotterdam volgens dit standpunt geoordeeld. ${ }^{23}$

Naast bovengenoemde uitspraak zijn er twee argumenten die dit standpunt ondersteunen: de parlementaire geschiedenis van het groepsregime en het feit dat de ten tijde van de deponering van de 403-verklaring bestaande crediteuren de mogelijkheid hebben gehad om de jaarrekening van de 403-maatschappij in te zien toen zij met laatstgenoemde een relatie zijn aangegaan.

\subsubsection{De parlementaire geschiedenis van het groepsregime}

Op grond van het voorgestelde art. 42c lid $2 \mathrm{WvK}$ van het wetsvoorstel Regeling van de besloten vennootschap met beperkte aansprakelijkheid zou een groepsmaatschappij gebruik mogen maken van de jaarrekeningvrijstelling van het groepsregime als (onder meer) haar moedermaatschappij zich aansprakelijk had gesteld voor de verbintenissen die de groepsmaatschappij 'zal aangaan'. ${ }^{24}$ In navolging van het advies van de Commissie Vennootschapsrecht ${ }^{25}$ heeft de minister in de memorie van antwoord bij het wetsvoorstel opgemerkt dat de moedermaatschappij zich slechts aansprakelijk zou hoeven stellen voor de toekomstige verplichtingen van de groepsmaatschappij. De

21. Honée 1971, p. 202, Jansz 1973, p. 36, Van Achterberg 1989, p. 222, Winter 1989, p. 288, Winter 1992, p. 25, Houwen, Schoonbrood-Wessels \& Schreurs 1993, p. 850-853, Franken \& Franken 2008, p. 73, Biemans 2011, p. 308 en Pitlo/Raaijmakers 2017, p. 613.

22. Zie $\S 5.3$.

23. Rb. Rotterdam 14 januari 1987, NJ 1988/1050 (Phillips/Van Eijk).

24. Kamerstukken II 1969/70, 10689, 2, p. 4-5 (OvW). Zie $\S 2.2$ voor een uitvoerigere bespreking van de wetshistorie van het groepsregime.

25. Kamerstukken II 1969/70, 10689, 4, p. 31 (bijlage 2 MvT). 
moedermaatschappij zou zich niet aansprakelijk hoeven stellen voor de reeds bestaande verplichtingen omdat dergelijke crediteuren volgens de minister genoegen hebben genomen met de kredietwaardigheid van de groepsmaatschappij, voor zover zij zelf geen garanties hebben bedongen. ${ }^{26}$

Het voorgestelde art. 42c WvK is nooit in de wet opgenomen. Het groepsregime is later in een aangepaste vorm opgenomen in art. 38a WJO. Op grond van deze bepaling moest de moedermaatschappij zich aansprakelijk stellen voor de 'aangegane schulden' van de groepsmaatschappij die gebruikmaakt van de jaarrekeningvrijstelling. ${ }^{27} \mathrm{Bij}$ de beraadslaging in de Tweede Kamer heeft een Kamerlid betoogd dat de aansprakelijkheid van de moedermaatschappij niet beperkt zou moeten zijn tot de toekomstige schulden van de groepsmaatschappij. De minister liet echter in een schriftelijk reactie weten geen reden te zien om de regeling aan te passen. ${ }^{28}$ Hij bevestigt daarmee indirect het eerdere uitgangspunt dat de moedermaatschappij zich slechts aansprakelijk hoeft te stellen voor de toekomstige verplichtingen van de groepsmaatschappij.

Toen het groepsregime later is verplaatst naar art. 2:343 (oud) BW, is de formulering met betrekking tot de aansprakelijkstelling door de moedermaatschappij opnieuw gewijzigd. ${ }^{29}$ Ingevolge deze bepaling moest de moedermaatschappij een verklaring deponeren op grond waarvan zij zich aansprakelijk stelt 'voor de uit rechtshandelingen voortvloeiende schulden' van de groepsmaatschappij. Met deze aanpassing was volgens de minister echter geen inhoudelijke wijziging beoogd ten opzichte van art. 38a WJO. De nieuwe formulering had enkel tot doel om te verduidelijken dat de moedermaatschappij zich slechts aansprakelijk hoefde te stellen voor de schulden die uit een rechtshandeling van de groepsmaatschappij waren voortgevloeid. ${ }^{30}$ Het uitgangspunt dat de moedermaatschappij alleen aansprakelijk is voor de toekomstige verplichtingen van de groepsmaatschappij bleef dus van kracht.

Het groepsregime in Nederland, en art. 38a WJO in het bijzonder, heeft gediend als inspiratie voor de jaarrekeningvrijstelling voor dochterondernemingen op grond van art. 57 van de Vierde EEG-richtlijn - thans art. 37 van de richtlijn jaarrekeningen. ${ }^{31}$ Een van de voorwaarden uit art. 57 van de Vierde EEG-richtlijn om gebruik te mogen maken van deze vrijstelling was dat de moederonderneming zich garant moest stellen voor de 'aangegane verplichtingen' van de

26. Kamerstukken II 1970/71, 10689, 7, p. 7 (MvA).

27. Stb. 1971, 286.

28. Handelingen II 1970/71, p. 2998.

29. Stb. 1976, 228.

30. Kamerstukken II 1973/74, 11005, 64, p. 2 (2eNvW).

31. Houwen, Schoonbrood-Wessels \& Schreurs 1993, p. 854 en Franken \& Franken 2008, p. 74. 
dochteronderneming. ${ }^{32}$ Houwen merkt op dat deze formulering is ontleend aan art. 38a WJO op grond waarvan een moedermaatschappij zich aansprakelijk moest stellen voor de 'aangegane schulden' van de groepsmaatschappij. ${ }^{33}$ Hierboven heb ik erop gewezen dat ten aanzien van deze bepaling wordt aangenomen dat de moedermaatschappij zich slechts aansprakelijk hoefde te stellen voor de toekomstige verplichtingen van de groepsmaatschappij. Dit brengt volgens Houwen mee dat ook de temporele reikwijdte van de aansprakelijkheid van een moedermaatschappij op grond van art. 2:403 BW zo moet worden uitgelegd dat de moedermaatschappij slechts aansprakelijk is voor de schulden die voortvloeien uit de rechtshandelingen die de 403-maatschappij heeft verricht vanaf het moment dat de 403 -verklaring is gedeponeerd. ${ }^{34}$

Ik interpreteer bovenstaande redenering van Houwen aldus dat de aansprakelijkstelling uit art. 57 van de Vierde EEG-richtlijn moet worden uitgelegd overeenkomstig art. 38a WJO, te weten: een aansprakelijkstelling voor toekomstige verplichtingen. Aangezien art. 57 van de Vierde EEG-richtlijn in Nederland is geïmplementeerd in art. 2:403 $\mathrm{BW}^{35}$ moet laatstgenoemde bepaling worden uitgelegd in het licht van de bewoordingen en het doel van de desbetreffende richtlijn. ${ }^{36}$ Dit betekent dat een moedermaatschappij op grond van een 403verklaring ook slechts aansprakelijk is voor de schulden die voortvloeien uit de rechtshandelingen die de 403-maatschappij heeft verricht nadat de 403-verklaring is gedeponeerd.

Bovenstaand betoog is echter niet onomstreden. Ik wijs op drie punten. Ten eerste is de argumentatie in de kern terug te voeren tot een opmerking van de minister in de memorie van antwoord met betrekking tot het voorgestelde art. 42 $\mathrm{WvK}^{37}$ - en het bijbehorende advies van de Commissie Vennootschapsrecht. ${ }^{38}$ Beckman wijst er terecht op dat art. $42 \mathrm{c} \mathrm{WvK}$ nooit in de wet is opgenomen en dat de voorgestelde jaarrekeningvrijstelling op grond van deze bepaling beperkter was dan die uit het latere art. 38a WJO. ${ }^{39}$ Op grond van art. $42 \mathrm{c} \mathrm{WvK}$ zouden slechts bepaalde groepsmaatschappijen gebruik kunnen maken van de jaarrekeningvrijstelling. Daarnaast had deze vrijstelling alleen betrekking op de

32. In art. 57 van de Vierde EEG-richtlijn wordt verwezen naar de beheersende vennootschap en de afhankelijke vennootschap. Thans wordt in art. 37 van de richtlijn jaarrekeningen verwezen naar de moederonderneming en de dochteronderneming. Omwille van de duidelijkheid hanteer ik de huidige termen.

33. Houwen, Schoonbrood-Wessels \& Schreurs 1993, p. 853-854.

34. Houwen, Schoonbrood-Wessels \& Schreurs 1993, p. 853-854. Zie ook Rb. Rotterdam 14 januari 1987, NJ 1988/1050 (Phillips/Van Eijk) en Franken \& Franken 2008, p. 74. Vgl. Bartman in zijn annotatie onder Rb. Amsterdam 20 december 2000, JOR 2001/53 (Tevema).

35. Stb. 1983, 663 .

36. HvJ EG 13 november 1990, NJ 1993/163 (Marleasing), r.o. 7 en 8.

37. Kamerstukken II 1970/71, 10689, 7, p. 7 (MvA).

38. Kamerstukken II 1969/70, 10689, 4, p. 31 (bijlage 2 MvT).

39. Beckman 1995a, p. 121-122. 
openbaarmakingsplicht en niet tevens op de inrichting van de jaarrekening met dien verstande dat als de openbaarmakingsplicht verviel de groepsmaatschappij op grond van art. 13 lid 3 WJO met instemming van de aandeelhouders gebruik zou kunnen maken van de bevoegdheid om af te wijken van de inrichtingsvereisten voor een jaarrekening uit de WJO. Evenals Beckman meen ik daarom dat de 'doorwerking' van de opmerking van de minister met betrekking tot het voorgestelde art. $42 \mathrm{c} \mathrm{WvK}$ ten aanzien van art. 38a WJO - en de andere genoemde bepalingen - slechts op magere grond te verdedigen is. ${ }^{40}$

Een tweede kritiekpunt met betrekking tot de doorwerking van de opmerking van de minister, is dat de Nederlandse parlementaire geschiedenis van het groepsregime niet bepalend is voor de uitleg van art. 57 van de Vierde EEGrichtlijn. Hoewel de aansprakelijkstelling door een moederonderneming op grond van art. 57 van de Vierde EEG-richtlijn is geïnspireerd op de aansprakelijkstelling door een moedermaatschappij op grond van art. 38a WJO, deel ik de mening van Beckman en Zwemmer dat de richtlijn op dit punt niet per se hetzelfde hoeft te worden uitgelegd. De richtlijn is een eigen regeling die op zichzelf moet worden beoordeeld. ${ }^{41}$ Dit betekent overigens niet dat art. 57 uit de richtlijn niet zo kan worden uitgelegd dat de moederonderneming zich slechts aansprakelijk hoeft te stellen voor toekomstige verplichtingen, maar wel dat art. 38a WJO niet doorslaggevend is voor de uitleg van art. 57 van de richtlijn - en daarmee ook niet voor de uitleg van art. 2:403 BW als implementatie van deze bepaling in Nederland. De opmerking van de minister met betrekking tot het voorgestelde art. $42 \mathrm{c} \mathrm{WvK}$ werkt daarom niet door ten aanzien van art. 2:403 BW.

Het derde en laatste punt waar ik op wijs is dat de minister bij het wetsvoorstel Bepalingen voor de jaarrekening van verzekeringsmaatschappijen impliciet heeft bevestigd dat zijn opmerking omtrent de reikwijdte van de aansprakelijkheid op grond van het voorgestelde art. $42 \mathrm{c} \mathrm{WvK}$ niet doorwerkt ten aanzien van art. 2:403 BW. In de memorie van toelichting bij dit wetsvoorstel merkt de minister op dat een verzekeringsmaatschappij gebruik kan maken van de jaarrekeningvrijstelling van het groepsregime op grond van art. 2:403 BW, indien (onder meer) de moedermaatschappij zich aansprakelijk heeft gesteld voor de uit rechtshandelingen van de verzekeringsmaatschappij 'voortvloeiende en voortgevloeide schulden'. ${ }^{42}$ Dat de moedermaatschappij zich volgens de minister ook ansprakelijk moet stellen voor de schulden die al uit een rechtshandeling zijn voortgevloeid, betekent dat de 403-aansprakelijkheid

40. Beckman 1995a, p. 649-650.

41. Beckman 1995a, p. 650 en Zwemmer 2011, p. 226.

42. Kamerstukken II $1992 / 93,22896,3$, p. 25 (MvT). Ik merk op dat een verzekeringsmaatschappij sinds 2015 niet meer gebruik kan maken van de jaarrekeningvrijstelling van het groepsregime (zie art. 2:403 lid 4 BW en $S t b .2015,349$ ). 
niet is beperkt tot de schulden die voortvloeien uit de rechtshandelingen die de 403-maatschappij verricht vanaf het moment dat de 403-verklaring is gedeponeerd. ${ }^{43}$ De minister wijkt dus af van zijn eerdere standpunt ten aanzien van het voorgestelde art. $42 \mathrm{c} \mathrm{WvK}{ }^{44} \mathrm{Hij}$ licht echter niet toe wat ten grondslag ligt aan deze wijziging.

\subsubsection{Bestaande crediteuren hebben geen gebrek aan inzicht}

Naast het argument van de parlementaire geschiedenis wordt er ter onderbouwing van het standpunt dat de temporele reikwijdte van de 403-aansprakelijkheid niet terugwerkt in het verleden op gewezen dat de ten tijde van de deponering van de 403-verklaring bestaande crediteuren de jaarrekening van de 403-maatschappij hebben kunnen inzien toen zij met laatstgenoemde een relatie aangingen. Jansz, Van Achterberg, Franken en Franken zijn van mening dat deze crediteuren daarom geen nadeel ondervinden van het feit dat de 403-maatschappij gebruikmaakt van de jaarrekeningvrijstelling van het groepsregime en dus niet hoeven te worden gecompenseerd. ${ }^{45}$ De moedermaatschappij is om die reden op grond van de 403-verklaring niet aansprakelijk voor de schulden van de 403-maatschappij jegens deze crediteuren. Van Achterberg vult aan dat als deze crediteuren wel een beroep zouden kunnen doen op de 403-verklaring, zij ten onrechte een voordeel krijgen waar zij eerder geen recht op hadden. ${ }^{46}$

De genoemde auteurs betogen dat slechts de crediteuren van wie de vordering voortvloeit uit een rechtshandeling die de 403-maatschappij heeft verricht nadat de 403-verklaring is gedeponeerd, nadeel ondervinden van het feit dat de 403-maatschappij gebruikmaakt van de jaarrekeningvrijstelling van het groepsregime. Deze crediteuren hebben niet de mogelijkheid om de jaarrekening in te zien en (mede) aan de hand daarvan te beoordelen of zij al of niet een relatie met de 403-maatschappij willen aangaan. De auteurs zijn van mening dat daarom ook alleen die crediteuren hoeven te worden gecompenseerd. De temporele reikwijdte van de 403-aansprakelijkheid moet volgens hen om die reden zo worden uitgelegd dat de moedermaatschappij slechts aansprakelijk is voor de schulden die voortvloeien uit een rechtshandeling die de 403-maatschappij heeft verricht vanaf het moment dat de 403 -verklaring is gedeponeerd.

Bovenstaande redenering wordt in de literatuur over het algemeen bestreden. Ik sluit mij aan bij het meerderheidsstandpunt dat ook de crediteuren van wie

43. Harmsma 2001, p. 113, Bartman 2002, p. 22, Franken \& Franken 2008, p. 61 en Zwemmer 2011, p. 226. Zie ook Hof Amsterdam 26 juli 2001, JOR 2004/94, m.nt. Bartman (Hemony/ Van der Woude), r.o. 4.9.

44. Kamerstukken II 1970/71, 10689, 7, p. 7 (MvA).

45. Jansz 1973, p. 36, Van Achterberg 1989, p. 222 en Franken \& Franken 2008, p. 71. Zie ook Rb. Rotterdam 14 januari 1987, NJ 1988/1050 (Phillips/Van Eijk).

46. Van Achterberg 1989, p. 222. 
de vordering voortvloeit uit een rechtshandeling die de 403-maatschappij heeft verricht voordat de 403-verklaring is gedeponeerd, er belang bij kunnen hebben om in de toekomst de nieuwe jaarrekening(en) van de 403-maatschappij in te zien. ${ }^{47}$ Dit geldt in het bijzonder voor crediteuren die een duurovereenkomst zijn aangegaan met de 403-maatschappij, waaruit periodiek nieuwe vorderingen voortvloeien - ook nadat de 403-verklaring is gedeponeerd. Dat deze crediteuren in het verleden geen nadeel hebben ondervonden omdat zij toen de jaarrekening(en) van de 403-maatschappij hebben kunnen inzien, staat niet ter discussie. Maar vanaf het moment dat de 403-maatschappij gebruikmaakt van de jaarrekeningvrijstelling van het groepsregime ontbreekt het ook hun aan de mogelijkheid om de nieuwe jaarrekening(en) in te zien. Een crediteur die bijvoorbeeld - voordat de 403-verklaring is gedeponeerd - een verhuurovereenkomst met de 403-maatschappij heeft afgesloten, heeft er als verhuurder belang bij om de nieuwe jaarrekening(en) van de 403-maatschappij als huurder te kunnen inzien. Hij kan bijvoorbeeld (mede) aan de hand daarvan beoordelen of hij eventuele zekerheidsrechten uitoefent, de overeenkomst met de 403-maatschappij probeert aan te passen of opzegt, of het faillissement van de 403-maatschappij aanvraagt.

Omdat ook de crediteuren van wie de vordering voortvloeit uit een rechtshandeling die de 403-maatschappij heeft verricht voordat de 403-verklaring is gedeponeerd nadeel ondervinden van het feit dat laatstgenoemde gebruikmaakt van de jaarrekeningvrijstelling van het groepsregime, moeten ook deze crediteuren worden gecompenseerd. Ook zij moeten zich op grond van de 403-verklaring op de moedermaatschappij kunnen verhalen. De aansprakelijkheid van de moedermaatschappij op grond van de 403-verklaring mag daarom niet beperkt blijven tot de schulden die voortvloeien uit een rechtshandeling die de 403-maatschappij heeft verricht nadat deze verklaring is gedeponeerd. ${ }^{48}$

\subsubsection{Kritiek: mogelijk misbruik van het groepsregime}

Naast de kritiekpunten die ik in de twee voorgaande paragrafen al heb genoemd met betrekking tot het standpunt dat de 403 -aansprakelijkheid niet terugwerkt in het verleden, wijs ik ook op een ander bezwaar: het risico op misbruik. Een

47. Goudsmit 1973, p. 333, Raaijmakers 1976, p. 288, Beckman 1987, p. 533-535, Gülcher 1989a, p. 164, Beckman 1995a, p. 533-534, Beckman 1995b, p. 95-96, Asser/Maeijer 2-III 2000/439, Harmsma 2001, p. 113, Winkel 2004, p. 188 en M.A.J.G. Janssen 2005, p. 121. Zie ook Niels 2010, p. 33-34, die hieraan echter de conclusie verbindt dat de moedermaatschappij aansprakelijk is voor de schulden (die voortvloeien uit een rechtshandeling) van de 403-maatschappij die opeisbaar zijn geworden vanaf het moment dat de 403-verklaring is gedeponeerd. Dit betreft het vierde standpunt dat ik in $\S 5.2$ heb genoemd. Ik heb echter in $\S 5.3$ geconcludeerd dat dit standpunt moet worden afgewezen.

48. In $\S 5.5$ en $\S 5.6$, onderzoek ik of de 403 -aansprakelijkheid terugwerkt in het verleden en zo $\mathrm{ja}$, in hoeverre. 
moedermaatschappij bepaalt zelf wanneer zij de 403-verklaring deponeert. Daarnaast kan zij deze verklaring ook weer op ieder moment intrekken. ${ }^{49}$ De moedermaatschappij is niet aansprakelijk voor de schulden die voortvloeien uit de rechtshandelingen die de 403-maatschappij verricht vanaf het moment dat zij tegenover de crediteur een beroep kan doen op de intrekking. ${ }^{50}$ Ik ben eerder tot de conclusie gekomen dat als een 403-maatschappij met betrekking tot de jaarrekening over een bepaald boekjaar gebruik wil maken van de jaarrekeningvrijstelling van het groepsregime, aan alle voorwaarden daarvoor moet zijn voldaan uiterlijk op het moment dat de aandeelhouders van de 403-maatschappij de summiere jaarrekening in de zin van art. 2:403 lid 1 sub a BW vaststellen of - als de jaarrekening nog niet is vastgesteld - uiterlijk twaalf maanden na afloop van het boekjaar. ${ }^{51}$ Evenals enkele andere auteurs, waaronder Bartman, wijs ik erop dat een moedermaatschappij de 403-verklaring vlak voor dat moment kan deponeren, om deze verklaring daarna direct weer in te trekken. ${ }^{52}$ Mits dan ook aan de andere voorwaarden is voldaan kan de 403-maatschappij onverkort gebruikmaken van de jaarrekeningvrijstelling van het groepsregime, maar blijft de aansprakelijkheid van de moedermaatschappij tot een minimum beperkt. De moedermaatschappij zou dit ieder jaar opnieuw kunnen doen.

Hoewel mij geen voorbeelden bekend zijn waarbij de moedermaatschappij de 403-verklaring deponeert vlak voordat de aandeelhouders van de 403-maatschappij de summiere jaarrekening in de zin van art. 2:403 lid 1 sub a BW vaststellen of - als de jaarrekening nog niet is vastgesteld - uiterlijk twaalf maanden na afloop van het boekjaar, en de moedermaatschappij deze verklaring direct weer intrekt, kan het niet de bedoeling zijn van het groepsregime dat een 403-maatschappij in een dergelijk geval gebruik kan maken van de jaarrekeningvrijstelling. Ik sluit mij aan bij de eerdergenoemde auteurs die menen dat om deze manier van misbruik van het groepsregime onmogelijk te maken, de temporele reikwijdte van de 403-aansprakelijkheid niet zo kan worden uitgelegd dat de moedermaatschappij in het geheel niet aansprakelijk is voor de schulden die voortvloeien uit de rechtshandelingen die de 403-maatschappij heeft verricht voordat de 403 -verklaring is gedeponeerd. Deze auteurs betogen dat de 403-aansprakelijkheid geheel terugwerkt in het verleden ${ }^{53}$ of tot het begin van het boekjaar. ${ }^{54}$ In die gevallen heeft de moedermaatschappij er geen profijt van als zij de 403-verklaring pas deponeert vlak voordat de aandeelhouders van de 403-maatschappij de summiere jaarrekening in de zin van art. 2:403

49. Zie art. 2:404 lid $1 \mathrm{BW}$ en $\$ 7.2 .1$.

50. Zie art. 2:404 lid 2 BW en $\S 7.2 .3$.

51. Zie $\S 2.4$.

52. Blommaert 2007, p. 273-274, Van Schilfgaarde/Winter, Wezeman \& Schoonbrood 2017, p. 376 en Bartman, Dorresteijn \& Olaerts 2020, p. 223.

53. Van Schilfgaarde/Winter, Wezeman \& Schoonbrood 2017, p. 376 (zie § 5.6).

54. Bartman, Dorresteijn \& Olaerts 2020, p. 223 (zie § 5.5). 
lid 1 sub a BW vaststellen of de twaalfmaandstermijn na afloop van het boekjaar verloopt. ${ }^{55}$ De (gedeeltelijke) terugwerkende kracht van de 403 -aansprakelijkheid brengt mee dat de moedermaatschappij dan voor dezelfde schulden aansprakelijk is als wanneer zij de 403 -verklaring eerder zou hebben gedeponeerd.

Tot slot merk ik op dat voor het geval dat wordt uitgegaan van het standpunt dat de 403-aansprakelijkheid niet terugwerkt in het verleden, er in de literatuur op is gewezen dat het deponeren van een 403-verklaring en deze vrijwel direct daarna weer intrekken mogelijk misbruik van recht is. ${ }^{56}$ De moedermaatschappij misbruikt dan haar bevoegdheid om zelf te kunnen bepalen op welk moment zij de 403-verklaring deponeert en wanneer zij deze weer intrekt. Het gevolg van deze handelswijze is dat de crediteuren de jaarrekening van de 403-maatschappij niet kunnen inzien, maar dat praktisch geen van hen hiervoor wordt gecompenseerd.

Op grond van art. 3:13 lid 2 BW wordt een wettelijke bevoegdheid (onder meer) misbruikt als degene die haar uitoefent, in aanmerking nemende de onevenredigheid tussen het belang bij de uitoefening en het belang van een derde dat daardoor wordt geschaad, naar redelijkheid niet tot die uitoefening had kunnen komen. Er moet sprake zijn van een grote onevenredigheid tussen het gediende en het aangetaste belang, waarbij het niet is vereist dat degene die de bevoegdheid uitoefent dit doet met de bedoeling om de ander te benadelen, maar hij moet de onevenredigheid tussen de belangen wel kennen of behoren te kennen. ${ }^{57}$

Het belang van de moedermaatschappij bij het deponeren van een 403-verklaring en deze vrijwel direct daarna weer intrekken, is tweeledig. Ten eerste kan de 403-maatschappij gebruikmaken van de jaarrekeningvrijstelling van het groepsregime $^{58}$ - mits ook aan de andere voorwaarden hiervoor wordt voldaan. Ten tweede is de aansprakelijkheid van de moedermaatschappij - ervan uitgaande dat de 403-aansprakelijkheid niet terugwerkt in het verleden - beperkt tot de schulden die voortvloeien uit de rechtshandelingen die de 403-maatschappij verricht vanaf het moment dat de 403 -verklaring is gedeponeerd tot

55. Zie ook $\S 7.3$ waar ik betoog dat het wenselijk is dat aan art. 2:404 lid 1 BW wordt toegevoegd dat de intrekking van de 403-verklaring slechts of eerst effect heeft als de 403-maatschappij een jaarrekening openbaar heeft gemaakt die aan de voorschriften van titel 9 van Boek $2 \mathrm{BW}$ voldoet, of als er een nieuwe 403 -verklaring is gedeponeerd ten aanzien van de 403-maatschappij.

56. Assink/Slagter 2013/140.2. Zie ook § 7.8.

57. P.A. Stein, in: GS Vermogensrecht, art. 3:13, aant. 45-47. Zie ook HR 21 mei 1999, NJ 1999/507 (Kerkhof/Spoelstra), r.o. 3.4.

58. Zie $\S 2.6$ waar ik verschillende redenen noem om gebruik te maken van de jaarrekeningvrijstelling van het groepsregime. 


\section{HOOFDSTUK 5}

het moment dat de moedermaatschappij tegenover de crediteur een beroep kan doen op de intrekking. De crediteuren van wie de vordering voortvloeit uit een rechtshandeling die de 403-maatschappij op een ander moment heeft verricht, ondervinden hiervan nadeel omdat zij de jaarrekening van de 403-maatschappij niet kunnen inzien maar daarvoor niet worden gecompenseerd.

Als een moedermaatschappij de 403-verklaring deponeert en vrijwel direct daarna weer intrekt, handelt zij op een wijze waarbij het belang van de crediteuren - bij het kunnen inzien van de jaarrekening van de 403-maatschappij of het gecompenseerd worden als dit inzicht ontbreekt - praktisch uit het oog is verloren. Zeker als de moedermaatschappij dit meerdere jaren achter elkaar doet. De onevenredigheid tussen het belang van de moedermaatschappij en het nadeel voor de crediteuren brengt mijns inziens met zich dat de moedermaatschappij in redelijkheid niet op een dergelijke manier mag handelen. Het deponeren en het vrijwel direct daarna weer intrekken van de 403-verklaring kwalificeert daarom volgens mij als misbruik van recht.

Dat het handelen van de moedermaatschappij misbruik van recht is, zal er bij deze interpretatie van de reikwijdte van de 403-aansprakelijkheid niet toe leiden dat zij alsnog aansprakelijk wordt voor de schulden die voortvloeien uit de rechtshandelingen die de 403-maatschappij heeft verricht voordat de 403-verklaring is gedeponeerd. Uitgaande van het standpunt dat de 403-aansprakelijkheid niet terugwerkt in het verleden zou de moedermaatschappij ook niet aansprakelijk zijn geweest voor deze schulden als zij de 403-verklaring niet zo snel na de deponering had ingetrokken. De moedermaatschappij zal naar mijn mening echter geen beroep kunnen doen op de intrekking van de 403-verkaring. ${ }^{59}$ Dit betekent dat zij aansprakelijk is voor de schulden die voortvloeien uit de rechtshandelingen die de 403-maatschappij heeft verricht vanaf het moment dat de 403-verklaring is gedeponeerd. Ik acht het op goede gronden verdedigbaar dat de moedermaatschappij in een dergelijk geval ten minste aansprakelijk is voor de schulden die voortvloeien uit de rechtshandelingen die de 403-maatschappij verricht totdat laatstgenoemde weer een jaarrekening openbaar heeft gemaakt die voldoet aan de voorschriften van titel 9 van Boek 2 BW. Crediteuren van wie de vordering voortvloeit uit een rechtshandeling die de 403-maatschappij na het openbaar maken van deze jaarrekening heeft verricht, ondervinden geen nadeel van het feit dat de moedermaatschappij in het verleden de 403-verklaring vrijwel direct na de deponering heeft ingetrokken - en de 403-maatschappij gebruik heeft gemaakt van de jaarrekeningvrijstelling.

59. P.A. Stein, in: GS Vermogensrecht, art. 3:13, aant. 28. 


\subsection{De 403-aansprakelijkheid werkt terug tot het begin van het} boekjaar

\subsubsection{Nauwe verbondenheid tussen de jaarrekeningvrijstelling en de 403-aansprakelijkheid}

Enkele auteurs, waaronder Bartman, wijzen op de nauwe verbondenheid tussen de jaarrekeningvrijstelling voor de 403-maatschappij en de aansprakelijkheid van de moedermaatschappij op grond van de 403 -verklaring. Deze nauwe verbondenheid brengt volgens hen met zich dat de reikwijdte van de 403-aansprakelijkheid terugwerkt tot het begin van het boekjaar waarover de 403-maatschappij een jaarrekening opmaakt waarbij zij (voor het eerst) gebruikmaakt van deze jaarrekeningvrijstelling. ${ }^{60}$ De moedermaatschappij is aansprakelijk voor de schulden die voortvloeien uit de rechtshandelingen die de 403-maatschappij vanaf het begin van dat boekjaar heeft verricht.

Het standpunt dat de aansprakelijkheid van een moedermaatschappij terugwerkt tot het begin van het boekjaar, is vergelijkbaar met de reikwijdte van de aansprakelijkstelling bij het Ierse equivalent van het groepsregime. ${ }^{61} \mathrm{Bij}$ de Ierse regeling dient de moederonderneming garant te staan voor de verplichtingen die de dochteronderneming is aangegaan in het boekjaar waarover deze een jaarrekening opmaakt waarbij zij gebruikmaakt van de jaarrekeningvrijstelling. ${ }^{62}$ Ook bij het Duitse equivalent van het groepsregime ${ }^{63}$ is de aansprakelijkheid van de moederonderneming gekoppeld aan een boekjaar van de dochteronderneming. In tegenstelling tot bovenstaand standpunt met betrekking tot de temporele reikwijdte van de 403-aansprakelijkheid en de Ierse regeling, is de aansprakelijkheid van de moederonderneming bij de Duitse regeling niet gekoppeld aan het boekjaar waarover de dochteronderneming een jaarrekening opmaakt waarbij zij gebruikmaakt van de jaarrekeningvrijstelling, maar aan het daaropvolgende boekjaar. De moederonderneming is aansprakelijk voor de aangegane verplichtingen van de dochteronderneming in het boekjaar volgend op het boekjaar waarover deze een jaarrekening opmaakt waarbij zij gebruikmaakt van de jaarrekeningvrijstelling. ${ }^{64,65}$

60. Tuit 1985, p. 195, Bartman 1986, p. 106 en Bartman, Dorresteijn \& Olaerts 2020, p. 223.

61. Zie section 357 Companies Act 2014.

62. MacCann \& Courtney 2007, p. 983 en E.C.A. Nass 2019, p. 90.

63. Zie $\S 264$ lid 3 en 4 Handelsgesetzbuch.

64. Gesetzentwurf 23 januari 2015 van de Bundesrat voor het Bilanzrichtlinie-Umsetzungsgesetz (BilRUG), p. 69, E.C.A. Nass 2019, p. 91, Ruppelt 2020, Beck'scher Online-Kommentar, § 264 Handelsgesetzbuch, nr. 91 en Merkt 2020, Beck'sche Kurz-Kommentare, § 264 Handelsgesetzbuch, nr. 30.

65. Zie E.C.A. Nass 2019, p. 89, voor een bespreking van de aansprakelijkstelling door de moederonderneming krachtens het Luxemburgse equivalent van het groepsregime. De voorwaarde van de aansprakelijkstelling is hetzelfde geformuleerd als in de Franse vertaling van art. 37 van de richtlijn jaarrekeningen. 
Overigens gaat de vergelijking tussen de temporele reikwijdte van de aansprakelijkheid van een moedermaatschappij op grond van de 403-verklaring en de aansprakelijkstelling volgens de Ierse en Duitse regelingen niet helemaal op. Een kenmerkend verschil is dat de aansprakelijkheid van een moederonderneming volgens de Ierse en Duitse equivalenten van het groepsregime is beperkt tot de verplichtingen die de dochteronderneming in een specifiek boekjaar aangaat. Indien de dochteronderneming meerdere jaren gebruik wil maken van de jaarrekeningvrijstelling moet de moederonderneming zich voor ieder jaar opnieuw aansprakelijk stellen. Als een moedermaatschappij zich daarentegen op grond van een 403-verklaring aansprakelijk heeft gesteld, blijft zij aansprakelijk voor de schulden die voortvloeien uit nieuwe rechtshandelingen die de 403-maatschappij verricht totdat zij de 403-verklaring intrekt. ${ }^{66}$

\subsubsection{Kritiek: willekeur en niet alle crediteuren die nadeel ondervinden worden gecompenseerd}

Dat de jaarrekeningvrijstelling voor de 403-maatschappij en de aansprakelijkheid van de moedermaatschappij op grond van de 403-verklaring nauw met elkaar zijn verbonden, staat buiten kijf. Dat deze nauwe verbondenheid ook met zich brengt dat de 403-aansprakelijkheid terugwerkt tot het begin van het boekjaar waarover de 403-maatschappij een jaarrekening opmaakt waarbij zij (voor het eerst) gebruikmaakt van deze jaarrekeningvrijstelling wordt echter door de meeste auteurs niet aangenomen. Ik onderschrijf de kritiek dat deze uitleg van de 403-aansprakelijkheid tot willekeur leidt. ${ }^{67}$ Indien een 403-maatschappij bijvoorbeeld over het boekjaar 2020 een jaarrekening opmaakt waarbij zij (voor het eerst) gebruikmaakt van de jaarrekeningvrijstelling, is de moedermaatschappij níét aansprakelijk voor een schuld die voortvloeit uit een rechtshandeling die de 403-maatschappij op 31 december 2019 heeft verricht - uitgaande van een boekjaar dat gelijkloopt met het kalenderjaar. Maar de moedermaatschappij is wél aansprakelijk voor een schuld die voortvloeit uit een rechtshandeling die de 403-maatschappij op 1 januari 2020 heeft verricht. Beide crediteuren verkeren echter in eenzelfde situatie met betrekking tot het al of niet kunnen inzien van de jaarrekening van de 403-maatschappij. Zij hebben allebei niet de mogelijkheid om de jaarrekening over het boekjaar 2020 in te zien. Ze ondervinden dus hetzelfde nadeel van het feit dat de 403-maatschappij gebruikmaakt van de jaarrekeningvrijstelling van het groepsregime. Ik zie geen reden om de ene crediteur wel en de andere crediteur niet voor dit nadeel te compenseren.

Daarnaast ben ik van mening dat het boekjaar waarover een 403-maatschappij een jaarrekening opmaakt waarbij zij (voor het eerst) gebruikmaakt van de jaarrekeningvrijstelling van het groepsregime niet bepalend is voor het antwoord

66. Zie $\S 7.2$.

67. Winter 1989, p. 288, Ten Voorde 2006, p. 114-115 en Niels 2010, p. 33. 
op de vraag welke crediteuren al of niet gecompenseerd moeten worden voor een gebrek aan inzicht. Als de 403-aansprakelijkheid slechts terugwerkt tot het begin van dat boekjaar zal een deel van de crediteuren die nadeel ondervinden van het feit dat de 403-maatschappij gebruikmaakt van de jaarrekeningvrijstelling hiervoor niet worden gecompenseerd. ${ }^{68}$ De crediteuren van wie de vordering voortvloeit uit een rechtshandeling die de 403-maatschappij voor het desbetreffende boekjaar heeft verricht, hebben weliswaar in het verleden geen nadeel ondervonden omdat zij toen de jaarrekening(en) van de 403-maatschappij hebben kunnen inzien. Maar vanaf het moment dat de 403-maatschappij gebruikmaakt van de jaarrekeningvrijstelling van het groepsregime ontbreekt het ook hun aan de mogelijkheid om de nieuwe jaarrekening(en) in te zien. Deze kritiek komt overeen met de kritiek die ik eerder heb genoemd ten aanzien van het standpunt dat de 403-aansprakelijkheid in het geheel niet terugwerkt in het verleden. ${ }^{69}$ Kort gezegd hebben ook bestaande crediteuren er belang bij om in de toekomst de nieuwe jaarrekening(en) van de 403-maatschappij te kunnen inzien. Dit geldt in het bijzonder voor de crediteuren die een duurovereenkomst zijn aangegaan met de 403-maatschappij waaruit periodiek nieuwe vorderingen voortvloeien. Voor hen kan het onder meer van belang zijn om de jaarrekening in te zien om (mede) aan de hand daarvan te beoordelen of zij eventuele zekerheidsrechten uitoefenen, de overeenkomst met de 403-maatschappij proberen aan te passen of opzeggen, of dat zij het faillissement van de 403-maatschappij aanvragen. Aangezien ook crediteuren van wie de vordering voortvloeit uit een rechtshandeling die de 403-maatschappij heeft verricht voor aanvang van het boekjaar waarover zij een jaarrekening opmaakt waarbij zij (voor het eerst) gebruikmaakt van de jaarrekeningvrijstelling een gebrek aan inzicht hebben, moeten ook deze crediteuren daarvoor worden gecompenseerd. De 403-aansprakelijkheid mag daarom niet beperkt blijven tot de schulden die voortvloeien uit een rechtshandeling die de 403-maatschappij vanaf het begin van dat boekjaar heeft verricht.

\subsection{De 403-aansprakelijkheid werkt onbeperkt terug in het verleden}

\subsubsection{Inleiding}

De meest ruime uitleg van de temporele reikwijdte van de 403-aansprakelijkheid houdt in dat een moedermaatschappij aansprakelijk is voor alle schulden die voortvloeien en zijn voortgevloeid uit een rechtshandeling van de 403-maatschappij - ongeacht wanneer deze rechtshandeling is verricht. Ter onderbouwing van dit standpunt wordt in de eerste plaats gewezen op de tekst

68. Winter 1989, p. 288 en Niels 2010, p. 33.

69. Zie $\S 5.4 .3$. 
en de parlementaire geschiedenis van art. 2:403 lid 1 sub f BW. Daarnaast wordt de compensatie van de crediteuren van de 403-maatschappij genoemd als reden dat de 403-aansprakelijkheid op deze manier moet worden uitgelegd.

Van de verschillende opvattingen ten aanzien van de temporele reikwijdte van de 403-aansprakelijkheid vindt het standpunt dat de moedermaatschappij aansprakelijk is voor alle schulden die voortvloeien en zijn voortgevloeid uit een rechtshandeling van de 403-maatschappij de meeste navolging in de literatuur. ${ }^{70,71}$ Ook in de jurisprudentie tekent zich een dergelijk beeld af. Afgezien van een uitspraak van het Hof 's-Hertogenbosch in $2017,{ }^{72}$ is sinds 2001 bij alle uitspraken met betrekking tot de temporele reikwijdte van de 403-aansprakelijkheid in lijn met dit standpunt geoordeeld. ${ }^{73}$ Drie uitspraken verdienen echter

70. Lubbers \& Scholten 1971, p. 68, Goudsmit 1973, p. 332-333, Raaijmakers 1976, p. 287-288, Beckman 1987, p. 533-535, Beckman 1995a, p. 545, Beckman 1996, p. 255, Asser/Maeijer 2-III 2000/439, Harmsma 2001, p. 113, Winkel 2004, p. 188, M.A.J.G. Janssen 2005, p. 121, Slagter 2005, p. 538, Ten Voorde 2006, p. 115, Ramanna 2008, p. 18, Beckman 2011, p. 252253, Van der Kraan 2012, p. 47, Van der Heijden/Van der Grinten \& Dortmond 2013/324.3, Assink/Slagter 2013/140.3,Asser/Maeijer \& Kroeze 2-I*2015/583, Van Schilfgaarde/Winter, Wezeman \& Schoonbrood 2017, p. 376, Beckman - SDU Commentaar Ondernemingsrecht 2019, art. 2:403 BW, ant. C.5.3, Van Zoest 2019, p. 24, Huizink 2019, p. 329, E.C.A. Nass 2019, p. 203, Beckman - Compendium jaarrekening, § 3.8.4.8, Van der Kraan in zijn annotaties onder Hof 's-Hertogenbosch 29 augustus 2017, JIN 2018/7 (Doorwin) en Hof Amsterdam 22 oktober 2019, JIN 2019/179 (Maison Zen beheer/Pauw), en Van Dooren in zijn annotatie onder Hof Den Haag 25 juni 2019, JOR 2020/56 (ZOM).

71. Zie Van der Heijden/Van der Grinten 1976/323, waar Van der Grinten het standpunt verdedigde dat de 403-aansprakelijkheid niet terugwerkt in het verleden. In Van der Heijden/ Van der Grinten 1984/324.2 en Van der Heijden/Van der Grinten 1989/324.2 laat hij zich niet uit over de temporele reikwijdte van de 403-aansprakelijkheid. Pas in Van der Heijden/ Van der Grinten 1992/324.2 bepleit Van der Grinten het standpunt dat de 403-aansprakelijkheid onbeperkt terugwerkt in het verleden. Zie ook Maeijer 1978, p. 151, waar Maeijer het standpunt verdedigde dat de 403 -aansprakelijkheid niet terugwerkt in het verleden. Vanaf Asser/Maeijer 2-III 1994/439 verdedigt hij het standpunt dat de 403 -aansprakelijkheid onbeperkt terugwerkt in het verleden. Zie ten slotte Van Schilfgaarde 1988, p. 238-239, waar Van Schilfgaarde nog het standpunt innam dat de 403-aansprakelijkheid niet terugwerkt in het verleden. Vanaf Van Schilfgaarde 1990, p. 247, meent hij dat de 403-aansprakelijkheid onbeperkt terugwerkt in het verleden. Uit de verschillende stukken is echter niet op te maken waarom deze auteurs hun standpunt hebben gewijzigd.

72. Hof 's-Hertogenbosch 29 augustus 2017, JOR 2017/318, m.nt. Van Zoest (Doorwin), r.o. 3.5.8. Het hof oordeelt dat een moedermaatschappij op grond van de 403-verklaring aansprakelijk is voor de schulden (die voortvloeien uit een rechtshandeling) van de 403-maatschappij die ontstaan zijn vanaf de eerste dag van het boekjaar waarover de 403-maatschappij een jaarrekening opmaakt waarbij zij (voor het eerst) gebruikmaakt van de jaarrekeningvrijstelling van het groepsregime (dit betreft het vijfde standpunt dat ik in $\S 5.2$ onderscheid).

73. Hof Amsterdam 26 juli 2001, JOR 2004/94, m.nt. Bartman (Hemony/Van der Woude), r.o. 4.9, Rb. Arnhem 10 oktober 2002, JOR 2003/31, m.nt. Bartman (Resila/Spectro), r.o. 3.8-3.9, Rb. Roermond 25 oktober 2006, JOR 2006/289, m.nt. Bartman (Oud papiercentrale/Inalfa), r.o. 4.5, Hof 's-Hertogenbosch 7 april 2009, JOR 2009/160, m.nt. Bartman (Inalfa), r.o. 4.3.3, Hof 's-Hertogenbosch 12 mei 2009, JOR 2009/279, m.nt. Bartman (Oud 
enige toelichting omdat daaruit niet direct is op te maken dat de rechter oordeelt dat de 403-aansprakelijkheid onbeperkt terugwerkt in het verleden. Ik licht deze uitspraken in paragraaf 5.6.3 toe.

\subsubsection{De tekst en de parlementaire geschiedenis van art. 2:403 lid 1 subf $B W$}

De tekst van art. 2:403 lid 1 sub f BW geeft geen reden om aan te nemen dat de 403-aansprakelijkheid niet onbeperkt terugwerkt in het verleden. Op grond van deze bepaling dient een moedermaatschappij schriftelijk te hebben verklaard dat zij hoofdelijk aansprakelijk is voor de uit rechtshandelingen van de 403-maatschappij voorvloeiende schulden. Evenals andere auteurs lees ik hierin niet dat de moedermaatschappij zich slechts aansprakelijk zou hoeven stellen voor de schulden die voortvloeien uit de rechtshandelingen die de 403-maatschappij vanaf een bepaald moment heeft verricht. ${ }^{74}$

Dat de aansprakelijkheid van een moedermaatschappij op grond van art. 2:403 lid 1 sub $\mathrm{f} \mathrm{BW}$ alle schulden omvat die voortvloeien en zijn voortgevloeid uit een rechtshandeling van de 403-maatschappij is ook door de minister bevestigd in de memorie van toelichting bij het wetsvoorstel Bepalingen voor de jaarrekening van verzekeringsmaatschappijen. Ik heb hier eerder al op gewezen als tegenargument ten aanzien van het standpunt dat de 403-aansprakelijkheid niet zou terugwerken in het verleden. ${ }^{75}$ De minister merkt in de memorie van toelichting op dat een verzekeringsmaatschappij gebruik kan maken van de jaarrekeningvrijstelling van het groepsregime op grond van art. 2:403 BW, indien (onder meer) de moedermaatschappij zich hoofdelijk aansprakelijk heeft gesteld voor de uit rechtshandelingen van de verzekeringsmaatschappij 'voortvloeiende en voortgevloeide schulden ${ }^{76}$ In de literatuur en jurisprudentie is dit zo uitgelegd dat de moedermaatschappij zich aansprakelijk moet stellen voor alle schulden die in de toekomst uit een rechtshandeling van de 403-maatschappij zullen voortvloeien en de bestaande schulden die al uit een rechtshandeling zijn voortgevloeid. ${ }^{77}$

papiercentrale/Inalfa), r.o. 4.7 en Hof Amsterdam (OK) 23 juli 2014, JOR 2014/233, m.nt. Bartman (Van Lieshout/Koks), r.o. 3.5.

74. Ten Voorde 2006, p. 113 en Van der Heijden/Van der Grinten \& Dortmond 2013/324.3.

75. Zie $§ 5.4 .2$.

76. Kamerstukken II 1992/93, 22896, 3, p. 25 (MvT). Ik merk op dat een verzekeringsmaatschappij sinds 2015 niet meer gebruik kan maken van de jaarrekeningvrijstelling van het groepsregime (zie art. 2:403 lid 4 BW en Stb. 2015, 349).

77. Hof Amsterdam 26 juli 2001, JOR 2004/94, m.nt. Bartman (Hemony/Van der Woude), r.o. 4.9, Harmsma 2001, p. 113, Bartman 2002, p. 22, Franken \& Franken 2008, p. 61 en Zwemmer 2011, p. 226. 
Tot slot is het van belang dat art. 2:403 BW de implementatie is van art. 57 van de Vierde EEG-richtlijn. ${ }^{78}$ Dit houdt in dat art. 2:403 BW moet worden uitgelegd in het licht van de bewoordingen en het doel van de desbetreffende richtlijn. ${ }^{79}$ In de considerans van de Vierde EEG-richtlijn zijn geen aanknopingspunten te vinden hoe de reikwijdte van de vereiste aansprakelijkstelling ex art. 57 moet worden uitgelegd in het licht van het doel van deze richtlijn. Uit de bewoording van deze bepaling volgt dat de moederonderneming moet verklaren garant te staan voor de 'aangegane verplichtingen' van de dochteronderneming. ${ }^{80}$ Deze bepaling wordt echter verschillend uitgelegd.

In paragraaf 5.4.2 heb ik opgemerkt dat de formulering van de garantstelling is gebaseerd op het Nederlandse art. 38a WJO, ten aanzien waarvan de minister indirect heeft opgemerkt dat de aansprakelijkstelling niet terugwerkt in het verleden. ${ }^{81}$ Er wordt daarom betoogd dat de richtlijn op dit punt overeenkomstig art. 38a WJO moeten worden uitgelegd. Aangezien art. 57 van de Vierde EEG-richtlijn in Nederland is geïmplementeerd in art. 2:403 BW zou hetzelfde moeten gelden voor laatstgenoemde bepaling. ${ }^{82}$

In Ierland ${ }^{83}$ en Duitsland ${ }^{84}$ is art. 57 van de Vierde EEG-richtlijn daarentegen zo geïmplementeerd dat de moedermaatschappij aansprakelijk is voor de verplichtingen die de dochteronderneming is aangegaan in het boekjaar waarover deze een jaarrekening opmaakt waarbij zij gebruikmaakt van de jaarrekeningvrijstelling, respectievelijk het daaropvolgende boekjaar. ${ }^{85}$

Het meerderheidsstandpunt - in de Nederlandse literatuur - is echter dat de (formulering van de) garantstelling op grond van art. 57 van de Vierde EEGrichtlijn geen ruimte laat voor de moederonderneming om zich slechts garant te stellen voor de verplichtingen die de dochteronderneming vanaf een bepaald moment is aangegaan. De op grond van deze bepaling vereiste garantstelling

78. Thans art. 37 van de richtlijn jaarrekeningen.

79. HvJ EG 13 november 1990, NJ 1993/163 (Marleasing), r.o. 7 en 8.

80. In art. 57 van de Vierde EEG-richtlijn wordt verwezen naar de beheersende vennootschap en de afhankelijke vennootschap. Thans wordt in art. 37 van de richtlijn jaarrekeningen verwezen naar de moederonderneming en de dochteronderneming. Omwille van de duidelijkheid sluit ik aan bij de bewoordingen in laatstgenoemde bepaling.

81. Handelingen II 1970/71, p. 2998. Zie ook Houwen, Schoonbrood-Wessels \& Schreurs 1993, p. 850-854 en Franken \& Franken 2008, p. 74. Zo ook Rb. Rotterdam 14 januari 1987, NJ 1988/1050 (Phillips/Van Eijk). Vgl. Bartman in zijn annotatie onder Rb. Amsterdam 20 december 2000, JOR 2001/53 (Tevema).

82. Dit standpunt is echter niet onomstreden. Zie $\S 5.4 .2$ waar ik opmerk dat onder meer wordt betoogd dat de Nederlandse parlementaire geschiedenis van het groepsregime niet bepalend is voor de uitleg van art. 57 van de Vierde EEG-richtlijn.

83. Zie section 357 Companies Act 2014.

84. Zie $\S 264$ lid 3 en 4 Handelsgesetzbuch.

85. Zie $\S 5.5 .1$. 
voor 'aangegane verplichtingen', moet taalkundig worden uitgelegd als verplichtingen die zijn aangegaan, en niet als verplichtingen die worden aangegaan. Ik deel deze mening en sluit mij aan bij Beckman, en verschillende andere auteurs waaronder Maeijer, dat een richtlijnconforme uitleg van art. 2:403 lid 1 sub f BW daarom inhoudt dat de 403 -aansprakelijkheid onbeperkt terugwerkt in het verleden. ${ }^{86}$ Dit brengt ook met zich dat art. 57 van de Vierde EEG-richtlijn in Ierland en Duitsland naar mijn mening niet richtlijnconform is geïmplementeerd.

\subsubsection{Toelichting op de jurisprudentie}

In de Oud papiercentrale/Inalfa-uitspraken van de Rechtbank Roermond en het Hof 's-Hertogenbosch en de uitspraak van de OK inzake Van Lieshout/Koks is telkens geoordeeld dat de moedermaatschappij op grond van de 403-verklaring ook aansprakelijk is voor schulden die na de deponering van deze verklaring voortvloeien uit een daarvoor door de 403-maatschappij aangegane duurovereenkomst. ${ }^{87}$ Uit deze formulering is niet direct op te maken hoe de rechters de temporele reikwijdte van de 403-aansprakelijkheid zien. Vooral het gebruik van de woorden 'ook' en 'duurovereenkomst' is verwarrend omdat deze op twee manieren kunnen worden uitgelegd.

Ten eerste zijn de uitspraken zo te lezen dat de rechters uitgaan van het standpunt dat de 403-aansprakelijkheid niet terugwerkt in het verleden, maar dat zij oordelen dat de aansprakelijkheid moet worden uitgebreid zodat deze ook de schulden omvat die na de deponering van de 403-verklaring voortvloeien uit een daarvoor door de 403-maatschappij aangegane duurovereenkomst. Daarnaast is het mogelijk dat de rechters uitgaan van het standpunt dat de 403-aansprakelijkheid onbeperkt terugwerkt in het verleden, en dat zij oordelen dat daaronder ook de schulden vallen die na de deponering van de 403-verklaring voortvloeien uit een daarvoor door de 403-maatschappij aangegane duurovereenkomst.

86. Beckman 1995a, p. 650, Asser/Maeijer 2-III 2000/439, Harmsma 2001, p. 113, Winkel 2004, p. 188, Ramanna 2008, p. 18 en Beckman \& Van Wijngaarden - SDU Commentaar Ondernemingsrecht 2011, art. 2:403 BW, aant. C.4.3. Zie ook Bartman in zijn annotatie onder Rb. Amsterdam 20 december 2000, JOR 2001/53 (Tevema). Vgl. Berk 2007, p. 16, die opmerkt dat de verwijzing naar 'aangegane' verplichtingen uit art. 57 van de Vierde EEGrichtlijn suggereert dat het uitsluitend gaat om reeds aangegane verplichtingen ten tijde van de garantstelling en niet om verplichtingen die daarna nog worden aangegaan.

87. Rb. Roermond 25 oktober 2006, JOR 2006/289, m.nt. Bartman (Oud papiercentrale/Inalfa), r.o. 4.5, Hof 's-Hertogenbosch 12 mei 2009, JOR 2009/279, m.nt. Bartman (Oud papiercentrale/Inalfa), r.o. 4.7 en Hof Amsterdam (OK) 23 juli 2014, JOR 2014/233, m.nt. Bartman (Van Lieshout/Koks), r.o. 3.5. 
Mijns inziens is de tweede uitleg van bovenstaande uitspraken juist. Ik wijs daarvoor op drie punten. Ten eerste onderbouwt de Rechtbank Roermond haar oordeel met een verwijzing naar een publicatie van Beckman en Van Wijngaarden. ${ }^{88}$ In dat stuk betogen de auteurs uitdrukkelijk dat een moedermaatschappij op grond van de 403-verklaring aansprakelijk is voor alle schulden die uit een rechtshandeling van de 403-maatschappij voortvloeien en zijn voortgevloeid. In hoger beroep heeft het Hof 's-Hertogenbosch deze verwijzing weliswaar niet overgenomen, maar zij bevestigt wel het oordeel van de rechtbank. ${ }^{89}$

Ten tweede wijs ik erop dat het Hof 's-Hertogenbosch een maand voor bovenstaande uitspraak in een andere zaak expliciet heeft geoordeeld dat de moedermaatschappij op grond van de 403-verklaring aansprakelijk is voor alle schulden die uit een rechtshandeling van de 403-maatschappij voortvloeien en zijn voortgevloeid. ${ }^{90}$ Beide arresten van het hof hebben betrekking op dezelfde 403 -verklaring van dezelfde moedermaatschappij. ${ }^{91}$ Het is onwaarschijnlijk dat het hof de 403-aansprakelijkheid in deze uitspraken verschillend heeft uitgelegd.

Tot slot is ook uit het arrest van de OK inzake Van Lieshout/Koks op te maken dat zij ervan uitgaat dat de 403-aansprakelijkheid onbeperkt terugwerkt in het verleden. De OK onderbouwt haar oordeel namelijk met een verwijzing naar een eerdere uitspraak van het Hof Amsterdam, waarin uitdrukkelijk is geoordeeld dat de moedermaatschappij op grond van de 403-verklaring aansprakelijk is voor alle schulden die uit een rechtshandeling van de 403-maatschappij voortvloeien en zijn voortgevloeid. ${ }^{92}$

Concluderend mag worden aangenomen dat de Rechtbank Roermond, het Hof 's-Hertogenbosch en de OK uitgaan van het standpunt dat de 403-aansprakelijkheid onbeperkt terugwerkt in het verleden. Dat dit niet direct uit de uitspraken is op te maken, komt vermoedelijk omdat de rechters hun oordelen specifiek hebben willen toespitsen op de schulden die in casu het twistpunt vormden: schulden die na de deponering van de 403-verklaring zijn voortgevloeid uit een daarvoor door de 403-maatschappij aangegane duurovereenkomst.

88. Rb. Roermond 25 oktober 2006, JOR 2006/289, m.nt. Bartman (Oud papiercentrale/Inalfa), r.o. 4.5, waar de rechtbank verwijst naar Beckman \& Van Wijngaarden - SDU Commentaar Ondernemingsrecht 2006, art. 2:403 BW, aant. C.4.3.

89. Hof 's-Hertogenbosch 12 mei 2009, JOR 2009/279, m.nt. Bartman (Oud papiercentrale) Inalfa), r.o. 4.7 .

90. Hof 's-Hertogenbosch 7 april 2009, JOR 2009/160, m.nt. Bartman (Inalfa), r.o. 4.3.3.

91. Hof 's-Hertogenbosch 7 april 2009, JOR 2009/160, m.nt. Bartman (Inalfa), r.o. 4.1.4 en Hof 's-Hertogenbosch 12 mei 2009, JOR 2009/279, m.nt. Bartman (Oud papiercentrale/Inalfa), r.o. 4.1.

92. Zie Hof Amsterdam (OK) 23 juli 2014, JOR 2014/233, m.nt. Bartman (Van Lieshout/Koks), r.o. 3.5, waar zij verwijst naar Hof Amsterdam 26 juli 2001, JOR 2004/94, m.nt. Bartman (Hemony/Van der Woude), r.o. 4.9. 


\subsubsection{Compensatie voor alle crediteuren die nadeel ondervinden}

Een van de kritiekpunten die ik heb genoemd met betrekking tot de standpunten dat de 403-aansprakelijkheid niet terugwerkt in het verleden of slechts terugwerkt tot het begin van het boekjaar, ${ }^{93}$ is dat dit ertoe leidt dat niet alle crediteuren die nadeel ondervinden van het feit dat de 403-maatschappij gebruikmaakt van de jaarrekeningvrijstelling van het groepsregime hiervoor worden gecompenseerd. Als een 403-maatschappij gebruikmaakt van de jaarrekeningvrijstelling kunnen haar crediteuren niet de nieuwe jaarrekening(en) inzien. Zowel degenen die in de toekomst eventueel een relatie met de 403-maatschappij willen aangaan als de bestaande crediteuren, ondervinden daarvan nadeel. Degenen die in de toekomst eventueel een relatie met de 403-maatschappij willen aangaan, hebben niet de mogelijkheid om deze keuze (mede) te baseren op de informatie in de jaarrekening van de 403-maatschappij. Voor de bestaande crediteuren geldt dat zij er belang bij kunnen hebben om de nieuwe jaarrekening(en) van de 403-maatschappij in te zien om (mede) aan de hand daarvan te beoordelen of zij eventuele zekerheidsrechten uitoefenen, de overeenkomst met de 403-maatschappij proberen aan te passen of opzeggen, of dat zij het faillissement van de 403-maatschappij aanvragen. Dit geldt in het bijzonder voor crediteuren die een duurovereenkomst zijn aangegaan met de 403-maatschappij, waaruit periodiek nieuwe vorderingen voortvloeien - ook nadat de 403-verklaring is gedeponeerd. Ik sluit mij aan bij verschillende auteurs, waaronder Beckman, die van mening zijn dat aangezien zowel de bestaande als de nieuwe crediteuren nadeel ondervinden van het feit dat de 403-maatschappij gebruikmaakt van de jaarrekeningvrijstelling van het groepsregime, beide groepen crediteuren ook hiervoor moeten worden gecompenseerd. ${ }^{94}$ De moedermaatschappij moet daarom op grond van de 403-verklaring aansprakelijk zijn voor alle schulden die voortvloeien en zijn voortgevloeid uit een rechtshandeling van de 403-maatschappij.

De crediteuren hebben geen invloed op de keuze van de 403-maatschappij om gebruik te maken van de jaarrekeningvrijstelling van het groepsregime. Volgens het door mij bepleite uitgangspunt voor compensatie mogen zij om die reden niet in een nadeliger positie komen ten opzichte van de situatie dat de 403-maatschappij geen gebruik zou maken van de vrijstelling. ${ }^{95}$ Dit houdt in dat alle

93. Zie $\S 5.4 .3$, respectievelijk $\S$ 5.5.2.

94. Goudsmit 1973, p. 333, Raaijmakers 1976, p. 288, Beckman 1987, p. 533-535, Gülcher 1989a, p. 164, Beckman 1995a, p. 533-534, Beckman 1995b, p. 95-96, Asser/Maeijer 2-III 2000/439, Harmsma 2001, p. 113, Winkel 2004, p. 188 en M.A.J.G. Janssen 2005, p. 121. Zie ook Niels 2010, p. 33-34, die hieraan echter de conclusie verbindt dat de moedermaatschappij aansprakelijk is voor de schulden (die voortvloeien uit een rechtshandeling) van de 403-maatschappij die opeisbaar zijn geworden vanaf het moment dat de 403 -verklaring is gedeponeerd. Dit betreft het vierde standpunt dat ik in $\S 5.2$ heb genoemd. Ik heb echter in $\S 5.3$ geconcludeerd dat dit standpunt moet worden afgewezen.

95. Zie $\S 3.6 .1$. 
crediteuren die nadeel ondervinden omdat zij de nieuwe jaarrekening(en) van de 403-maatschappij niet kunnen inzien, moeten worden gecompenseerd zodat dit nadeel is weggenomen. Aangezien zowel de bestaande als de toekomstige crediteuren nadeel ondervinden, moeten beide groepen crediteuren zich ter compensatie van dit nadeel ook op de moedermaatschappij kunnen verhalen. ${ }^{96}$ Volgens het door mij bepleite uitgangspunt voor compensatie moet art. 2:403 lid 1 sub $\mathrm{f}$ BW daarom zo worden uitgelegd dat een moedermaatschappij op grond van de 403-verklaring aansprakelijk is voor alle schulden die voortvloeien en zijn voortgevloeid uit een rechtshandeling van de 403-maatschappij.

Voor een moedermaatschappij kan het een groot risico zijn als zij aansprakelijk is voor alle schulden die voortvloeien en zijn voortgevloeid uit een rechtshandeling van de 403-maatschappij. Mijns inziens staat dat er echter niet aan in de weg om de 403-aansprakelijkheid op deze manier uit te leggen. Het is de moedermaatschappij zelf die zich - vrijwillig - door middel van de 403-verklaring aansprakelijk stelt. Zij kan voorafgaand aan de deponering van deze verklaring en ook daarna, op basis van de interne financiële gegevens van de 403-maatschappij beoordelen voor welke schulden zij op grond van deze verklaring aansprakelijk zal zijn, respectievelijk is. ${ }^{97}$ Tot slot merk ik op dat een moedermaatschappij te allen tijde haar 403-verklaring kan intrekken en vervolgens - indien zij aan de desbetreffende voorwaarden voldoet - de overblijvende aansprakelijkheid kan beëindigen. ${ }^{98}$

\subsection{Conclusie}

In dit hoofdstuk heb ik de temporele reikwijdte van de aansprakelijkheid van een moedermaatschappij op grond van de 403-verklaring onderzocht. Allereerst heb ik een overzicht gegeven van vijf standpunten ten aanzien van deze temporele reikwijdte (§ 5.2).

Met betrekking tot deze standpunten is er een tweedeling te maken wat betreft het moment dat bepalend is voor het antwoord op de vraag of een schuld van de 403-maatschappij al of niet onder de reikwijdte van de 403-aansprakelijkheid valt. Enerzijds wordt aangesloten bij het moment dat de 403-maatschappij de rechtshandeling heeft verricht waaruit de schuld is voortgevloeid. Anderzijds wordt betoogd dat het moment waarop de schuld van de 403-maatschappij opeisbaar is geworden hiervoor bepalend is. Ik heb geconcludeerd dat het eerste uitgangspunt het juiste is omdat dit aansluit bij de temporele reikwijdte van

96. De compensatie voor een crediteur bestaat uit twee onderdelen: een vordering op de moedermaatschappij op grond van de 403-verklaring en de mogelijkheid om de geconsolideerde jaarrekening van de moedermaatschappij in te zien. Zie $\S 3.4 .1$.

97. Ten Voorde 2006, p. 115.

98. Zie art. 2:404 BW en hoofdstuk 7 en 8. 
de overblijvende aansprakelijkheid op grond van art. 2:404 lid 2 BW nadat de moedermaatschappij de 403-verklaring heeft ingetrokken (§ 5.3).

Vervolgens ben ik nader ingegaan op de drie standpunten waarbij voor de 403-aansprakelijkheid wordt aangesloten bij het moment dat de 403-maatschappij de rechtshandeling heeft verricht waaruit een schuld is voortgevloeid. Er wordt verdedigd dat de moedermaatschappij aansprakelijk is voor de schulden die voortvloeien uit de rechtshandelingen die de 403-maatschappij heeft verricht vanaf het moment dat de 403 -verklaring is gedeponeerd, vanaf het begin van het boekjaar waarover de 403-maatschappij een jaarrekening opmaakt waarbij zij (voor het eerst) gebruikmaakt van de jaarrekeningvrijstelling, of voor alle schulden die voortvloeien en zijn voortgevloeid uit een rechtshandeling. Voor ieder standpunt heb ik gezocht naar aanknopingspunten in de jurisprudentie, parlementaire geschiedenis en Europese richtlijnen. Daarnaast ben ik ingegaan op de voor- en tegenargumenten met betrekking tot ieder standpunt en heb ik onderzocht welk van de standpunten aansluit bij het door mij bepleite uitgangspunt voor de compensatie van de crediteuren ( 5.4 tot en met $\S 5.6$ ).

Op één uitspraak na, is sinds 2001 in de jurisprudentie consequent geoordeeld dat een moedermaatschappij op grond van de 403 -verklaring aansprakelijk is voor alle schulden die voortvloeien en zijn voortgevloeid uit een rechtshandeling van de 403-maatschappij. ${ }^{99}$ Ook in de parlementaire geschiedenis wordt de 403-aansprakelijkheid op deze wijze uitgelegd. ${ }^{100}$ In eerste instantie merkte de minister nog op dat de aansprakelijkheid van een moedermaatschappij was beperkt tot de toekomstige verplichtingen. Maar later heeft hij het standpunt onderschreven dat een moedermaatschappij op grond van de 403-verklaring aansprakelijk is voor alle uit een rechtshandeling van de 403-maatschappij voortvloeiende en voortgevloeide schulden.

Dat een moedermaatschappij op grond van de 403-verklaring aansprakelijk is voor alle schulden die voortvloeien en zijn voortgevloeid uit een rechtshandeling van de 403-maatschappij, sluit aan bij het door mij bepleite uitgangspunt voor compensatie. Zowel de bestaande als de nieuwe crediteuren ondervinden nadeel omdat zij de nieuwe jaarrekening(en) van de 403-maatschappij niet kunnen inzien. Beide groepen crediteuren moeten daarom worden gecompenseerd en moeten zich op grond van de 403-verklaring op de moedermaatschappij kunnen verhalen. ${ }^{101}$

99. Zie $\S 5.6 .1$.

100. Zie $\S 5.6 .2$.

101. De compensatie voor een crediteur bestaat uit twee onderdelen: een vordering op de moedermaatschappij op grond van de 403 -verklaring en de mogelijkheid om de geconsolideerde jaarrekening van de moedermaatschappij in te zien. Zie $\S 3.4 .1$. 



\title{
Hoofdstuk 6. De duiding van de 403-vordering
}

\author{
$6.1 \quad$ Inleiding
}

Een crediteur van een 403-maatschappij heeft twee vorderingen. Ten eerste heeft hij een vordering op de 403-maatschappij en daarnaast heeft hij op grond van de 403-verklaring een vordering op de moedermaatschappij (hierna: de '403-vordering'). In dit hoofdstuk onderzoek ik hoe de 403-vordering civielrechtelijke wordt geduid. ${ }^{1}$

Allereerst behandel ik vier mogelijke duidingen van de 403-vordering. Ik begin met de duiding van de 403-vordering als een 'hoofdelijke' vordering en als een 'dynamische' vordering. Daarna ga ik in op een analoge toepassing van art. 6:142 BW inzake de overgang van een nevenrecht ten aanzien van de 403-vordering en tot slot komt de analoge toepassing van de bepalingen betreffende borgtocht ten aanzien van de 403-aansprakelijkheid aan de orde (§ 6.2). Vervolgens ga ik voor verschillende situaties na wat de gevolgen zijn van iedere duiding van de 403-vordering ( $\$ 6.3)$. Voorts onderzoek ik voor deze situaties tot welke uitkomst het door mij bepleite uitgangspunt voor de compensatie van crediteuren leidt ${ }^{2}(\S 6.4)$. Tot slot stel ik vast bij welke van de vier duidingen de gevolgen (het meest) overeenkomen met deze uitkomsten en hoe een 403-vordering mijns inziens moet worden geduid ( $\$ 6.5)$.

Om de gevolgen van de verschillende duidingen van de 403-vordering duidelijker te kunnen weergeven, benader ik dit onderwerp grotendeels vanuit het perspectief van de crediteur. Ik onderzoek wat de gevolgen zijn van iedere duiding voor de vordering van een crediteur op de moedermaatschappij. In verband met deze benadering gebruik ik de term 'hoofdelijke vordering'. Strikt genomen is deze benaming niet juist. De term hoofdelijkheid uit art. 6:6 BW e.v. ziet niet op de vordering van een crediteur maar op de schuld of de aansprakelijkheid van de debiteur. Overigens is de term hoofdelijke vordering eerder ook door andere auteurs gebruikt met betrekking tot het groepsregime. ${ }^{3}$

1. Vgl. mijn eerdere bijdrage over de duiding van de 403-vordering: Van Dooren 2015.

2. Zie $\S 3.7$.

3. Wibier 2008, p. 180, Harmsen 2008, p. 472, Rongen 2012, p. 1300, A.G.S. Nass \& E.C.A. Nass 2014, p. 738, Van der Kraan 2015 p. 15-27, Van der Kraan 2016, p. 7 en 13 en Notenboom 2017, p. 126-129 en 131-133. 
Een van de voorwaarden van de regeling ex art. 37 van de richtlijn jaarrekeningen met betrekking tot de jaarrekeningvrijstelling voor dochterondernemingen is dat de moederonderneming zich garant heeft verklaard voor de door de dochteronderneming aangegane verplichtingen. Bij de Luxemburgse, ${ }^{4}$ Ierse $^{5}$ en Duitse $^{6}$ equivalenten van het groepsregime geldt een soortgelijke voorwaarde. ${ }^{7}$ Uit de Nederlandse wetsgeschiedenis volgt niet waarom de Nederlandse wetgever hiervan heeft afgeweken en in plaats daarvan ervoor heeft gekozen om de hoofdelijke aansprakelijkstelling van de moedermaatschappij in twee van de voorlopers van art. 2:403 BW - art. 38a WJO en art. 2:343 (oud) BW - in art. 2:403 BW te handhaven. ${ }^{8}$

Beckman, Den Hoed en A-G Wesseling-van Gent in haar conclusie bij de Akzo/ $I N G$-beschikking wijzen erop dat de hoofdelijke aansprakelijkheid ex art. 2:403 lid 1 sub $\mathrm{f}$ BW een zwaardere vorm van aansprakelijkheid is dan de garantstelling uit de richtlijn. ${ }^{9}$ De richtlijn geeft slechts minimumvoorschriften en laat het aan de wetgever van een lidstaat om eventueel een verderstrekkende aansprakelijkheid voor te schrijven. Ik onderschrijf daarom het standpunt van Niels en A-G Wuisman in zijn conclusie bij het arrest inzake Eikendal q.q./ Lentink, en de overweging van de Hoge Raad in het desbetreffende arrest, dat art. 2:403 BW op dit punt niet in strijd is met de richtlijn jaarrekeningen. ${ }^{10}$

Voor dit onderzoek is niet slechts van belang hoe een 403-vordering naar huidig recht moet worden geduid. Net zo belangrijk is hoe een dergelijke vordering volgens het door mij bepleite uitgangspunt voor compensatie moet worden geduid en dus of een wetswijziging wenselijk is. Een onderzoek naar de gevolgen van de duiding van de 403-vordering als een aanspraak uit hoofde van

4. Zie art. 70 Loi du 19 décembre 2002, Mémorial A-N 149, 31 décembre 2002, met inachtneming van de wijzigingen bij Loi du 18 décembre 2009, art. 99 onder nr. 3, Mémorial A-N 22, 10 février 2010, bij Loi du 30 juillet 2013, onder nr. 29, Mémorial A-N 177, 2 octobre 2013 en bij Loi du 27 mai 2016, art. 1 ${ }^{\text {er }}$ onder nr. 24, Mémorial A-N 94, 30 mai 2016.

5. Zie section 357 Companies Act 2014.

6. Zie § 264 Absatz 3 \& 4 Handelsgesetzbuch.

7. E.C.A. Nass 2019, p. 89-91 en Beckman - Compendium jaarrekening, § 3.8.3.22.

8. Zie met betrekking tot de wetsgeschiedenis van het groepsregime $\S 2.2$. Ik wijs erop dat in art. 13 lid 3 WJO nog geen voorwaarde was opgenomen dat de moedermaatschappij zich aansprakelijk moest stellen en dat het voorgestelde art. 42c WvK nooit in de wet is opgenomen.

9. Beckman 1995a, p. 293, Den Hoed, in: GS Verbintenissenrecht, art. 6:6, aant. 14.1 en A-G Wesseling-van Gent in haar Conclusie onder nr. 2.21 bij HR 28 juni 2002, NJ 2002/447, m.nt. Maeijer (Akzo/ING), r.o. 3.4.3. Ook gepubliceerd in JOR 2002/136, m.nt. Bartman. Beckman en Wesseling-van Gent verwijzen overigens naar voorlopers van art. 37 van de richtlijn jaarrekeningen: art. 57 van de Vierde EEG-richtlijn, respectievelijk art. 43 van de Zevende EEG-richtlijn.

10. Niels 2010, p. 26-27, HR 3 april 2015, JOR 2015/191, m.nt. Faber en Vermunt (Eikendal q.q./Lentink), r.o. 3.6.3 en de conclusie van A-G Wuisman bij dit arrest onder nr. 2.9. Niels verwijst overigens naar een voorloper van art. 37 van de richtlijn jaarrekeningen: art. 43 van de Zevende EEG-richtlijn. 
een garantstelling zou daarom niet misstaan in dit hoofdstuk. Toch laat ik een dergelijk onderzoek achterwege omdat er in de Nederlandse wetgeving geen vaste definitie is van een garantstelling. Ook art. 37 van de richtlijn jaarrekeningen geeft geen omschrijving van een op grond van die bepaling vereiste garantstelling. ${ }^{11}$ Het is daardoor niet mogelijk om eenduidig vast te stellen welke rechtsgevolgen de duiding van de 403-vordering als een aanspraak uit hoofde van een garantstelling met zich brengt. Aan het einde van dit hoofdstuk kom ik hier kort op terug. ${ }^{12}$

\subsection{Vier duidingen van de 403-vordering}

\subsubsection{Duiding van de 403-vordering als een hoofdelijke vordering}

In zijn $A k z o / I N G$-beschikking oordeelt de Hoge Raad dat een 403-verklaring een niet tot een bepaalde partij gerichte, eenzijdige verklaring van hoofdelijke aansprakelijkheid is, op grond waarvan rechtstreeks aansprakelijkheid voor de moedermaatschappij ontstaat. ${ }^{13}$ De Hoge Raad vervolgt dat een dergelijke verklaring geen afhankelijk recht in het leven roept.

De hoofdelijke aansprakelijkheid van de moedermaatschappij brengt met zich dat een crediteur op grond van art. 6:7 BW jegens ieder van de hoofdelijke schuldenaren een vordering heeft tot nakoming van het geheel. De vorderingen op de moeder- en de 403-maatschappij bestaan onafhankelijk van elkaar, met dien verstande dat nakoming door een van beide ook de medeschuldenaar bevrijdt - hetzelfde geldt als een van de vorderingen wordt betaald door inbetalinggeving, verrekening of als een rechter op grond van art. 6:60 BW oordeelt dat de schuldenaar is bevrijd omdat de crediteur zelf in verzuim is. Daarnaast kan de crediteur zelf kiezen welke van de hoofdelijke schuldenaren hij aansprakelijk stelt. Hij hoeft dus niet eerst te proberen om zich op de 403-maatschappij te verhalen, voordat hij de moedermaatschappij op grond van de 403-verklaring aansprakelijk kan stellen.

\subsubsection{Duiding van de 403-vordering als een dynamische vordering}

\subsection{2.a Inleiding}

In zijn annotatie onder de $A k z o / I N G$-beschikking maakt Bartman een kanttekening bij de hierboven aangehaalde overweging van de Hoge Raad dat een

11. Zie Niels 2010, p. 27 en E.C.A. Nass 2019, p. 110, die slechts opmerken dat de garantstelling op grond van art. 37 van de richtlijn jaarrekeningen subsidiair van aard is.

12. Zie $\S 6.5 .2$.

13. HR 28 juni 2002, JOR 2002/136, m.nt. Bartman (Akzo/ING), r.o. 3.4.3 en 3.4.5. 


\section{HOOFDSTUK 6}

403-verklaring geen afhankelijk recht in het leven roept. ${ }^{14}$ Volgens Bartman is de 403-vordering zodanig verbonden met de vordering op de 403-maatschappij, dat zij niet zonder deze vordering kan bestaan. Dit houdt volgens hem in dat als de vordering op de 403-maatschappij overgaat op een derde, deze ook de 403-vordering verkrijgt. De 403-vordering 'volgt' in een dergelijk geval niet de vordering op de 403-maatschappij in de zin van art. 3:82 BW - zoals een afhankelijk recht -, maar zij 'ontspringt' volgens Bartman uit de 403-verklaring.

Ik lees bovenstaande redenering van Bartman aldus, dat hij uitgaat van een hoofdelijke aansprakelijkheid van de moedermaatschappij waarbij slechts degenen met een vordering op de 403-maatschappij ${ }^{15}$ een beroep kunnen doen op de 403-verklaring en uit dien hoofde een vordering hebben op de moedermaatschappij. Anders gezegd: de 403-vordering is een hoofdelijke vordering die altijd toekomt aan degene met de corresponderende vordering op de 403-maatschappij.

Bovenstaande uitleg van de 403-vordering duid ik aan als de dynamische 403-vordering. Hoewel deze duiding is gebaseerd op de eerdergenoemde redenering van Bartman, ${ }^{16}$ merk ik op dat de uitwerking ervan niet in alle gevallen overeen hoeft te komen met het standpunt van Bartman. Ik ga uit van mijn eigen interpretatie van de redenering.

\subsection{2.b De gevolgen van de duiding van de 403-vordering als een dynamische vordering}

Indien de 403-vordering wordt geduid als een dynamische vordering brengt dat met zich dat deze altijd toekomt aan degene met de corresponderende vordering op de 403-maatschappij. Hierdoor is er sprake van een bepaalde mate van verbondenheid tussen beide vorderingen. Het is de vraag hoe deze verbondenheid zich verhoudt tot de vereiste hoofdelijke aansprakelijkheid van een moedermaatschappij op grond van art. 2:403 lid 1 sub f BW. Anders gezegd: is het naar huidig recht mogelijk om de 403 -vordering te duiden als een dynamische vordering?

Mijns inziens rechtvaardigt het karakter van de aansprakelijkheid van een moedermaatschappij op grond van de 403-verklaring dat de 403-vordering kan worden geduid als een dynamische vordering. Ik wijs erop dat op grond van art. 2:403 lid 1 sub f BW is vereist dat een moedermaatschappij 'schriftelijk

14. Bartman in zijn annotatie onder HR 28 juni 2002, JOR 2002/136 (Akzo/ING). Vgl. Blom 2005, p. 180.

15. Mits de vordering onder de materiële en temporele reikwijdte van de 403-aansprakelijkheid valt. Zie hoofdstuk 4 en 5 .

16. Bartman in zijn annotatie onder HR 28 juni 2002, JOR 2002/136 (Akzo/ING). 
heeft verklaard zich hoofdelijk aansprakelijk te stellen voor de uit rechtshandelingen van de [403-maatschappij] voortvloeiende schulden'. Uit deze bepaling volgt wel voor welke schulden de moedermaatschappij aansprakelijk is, maar niet tegenover welke crediteuren. Daarnaast is het van belang dat de aansprakelijkheid van de moedermaatschappij op grond van de 403 -verklaring onderdeel is van de compensatie die een crediteur ontvangt omdat hij de jaarrekening van de 403-maatschappij niet kan inzien. ${ }^{17}$ Het nadeel waarvoor de crediteur wordt gecompenseerd, is dat hij niet de mogelijkheid heeft om (mede) aan de hand van deze jaarrekening te kunnen schatten hoe groot het risico is dat de 403-maatschappij zijn vordering niet (volledig) zal voldoen. ${ }^{18}$ Het betreft dus uitdrukkelijk de compensatie van een nadeel dat een crediteur van de 403-maatschappij ervaart. Hoewel dit niet expliciet in art. 2:403 lid 1 sub f BW staat, kan deze bepaling naar mijn mening daarom zo worden uitgelegd dat een moedermaatschappij op grond van de 403-verklaring enkel hoofdelijk aansprakelijk is tegenover de crediteuren van de 403-maatschappij. Dit betekent dat als een crediteur geen vordering meer heeft op de 403-maatschappij - bijvoorbeeld omdat hij daarvan afstand heeft gedaan ${ }^{19}$-, hij geen beroep meer kan doen op de 403-verklaring en hij daarom ook geen 403-vordering meer heeft op de moedermaatschappij.

Ter illustratie van de gevolgen van de duiding van de 403-vordering als een dynamische vordering deel ik hieronder de cessie van de vordering van een crediteur op de 403-maatschappij op in drie stappen - deze drie stappen vinden bij de cessie tegelijkertijd plaats. Ik kom later uitgebreid terug op de gevolgen van een cessie van een vordering op de 403-maatschappij bij de verschillende duidingen van de 403-vordering - waaronder de duiding als een dynamische vordering. ${ }^{20}$

Voorafgaand aan de cessie heeft de cedent een vordering op de 403-maatschappij en een vordering op de moedermaatschappij. De eerste stap houdt in dat de cedent de vordering op de 403-maatschappij cedeert aan de cessionaris. $\mathrm{Na}$ de cessie heeft de cedent geen vordering meer op de 403-maatschappij, maar heeft hij wel nog zijn vordering op de moedermaatschappij. De vordering op de 403-maatschappij behoort na de cessie toe aan de cessionaris. De tweede stap houdt in dat aangezien de cedent geen vordering meer heeft op de 403-maatschappij, hij geen beroep meer kan doen op de 403-verklaring en hij daardoor geen vordering meer heeft op de moedermaatschappij. De derde en laatste stap is dat de 403-vordering overgaat op de cessionaris - die na de cessie wel een

17. Zie $\S 3.4 .1$.

18. Zie $\S 3.3$.

19. Zie $\S 6.3 .2$.

20. Zie ook $\S 6.3 .6$. 
beroep kan doen op de 403-verklaring. ${ }^{21}$ De 403 -vordering die op de cessionaris is overgegaan, is dezelfde vordering als die de cedent had op de moedermaatschappij.

Resumerend is de duiding van de 403-vordering als een dynamische vordering een variant op de duiding als een hoofdelijke vordering, waarbij de 403-vordering toekomt aan degene die de corresponderende vordering op de 403-maatschappij heeft. Voor het overige gelden de rechtsgevolgen overeenkomstig de duiding als een hoofdelijke vordering.

6.2.2.c Hoe verhoudt de dynamische 403-vordering zich tot de jurisprudentie van de Hoge Raad?

Begin 2013 verkeren SNS Bank en SNS Reaal in financiële moeilijkheden. Indien zij failliet zouden gaan, zou dat het financiële stelsel in Nederland ernstig verstoren. Om dit te voorkomen besluit de Minister van Financiën op 1 februari 2013 om (onder meer) de achtergestelde obligaties en schuldinstrumenten van SNS Bank te onteigenen. ${ }^{22}$ Moedermaatschappij SNS Reaal heeft zich eerder door middel van een 403-verklaring hoofdelijk aansprakelijk gesteld voor de uit de rechtshandelingen van SNS Bank voortvloeiende schulden - waaronder de genoemde achtergestelde schulden.

De minister verzoekt de OK een schadeloosstelling vast te stellen voor de crediteuren. In deze procedure betogen enkele van hen dat de onteigening van de schulden van SNS Bank, hun 403-vorderingen op SNS REAAL ongemoeid heeft gelaten. De OK gaat hier echter niet in mee en oordeelt dat de crediteuren na de onteigening ook geen vordering meer hebben op SNS Reaal. ${ }^{23}$ Zij overweegt dat de onteigening van de vorderingen op SNS Bank ook de daarmee corresponderende vorderingen op SNS Reaal uit hoofde van de 403-verklaring omvat. Daarbij maakt het volgens de OK geen verschil of de onteigening ziet op de passieve zijde van de vorderingen - zoals in casu waardoor SNS Bank niet langer de debiteur is - of de actieve zijde van de vorderingen waardoor de crediteuren niet langer een vordering hebben.

In zijn conclusie bij de beschikking van de Hoge Raad komt A-G Timmerman tot dezelfde uitkomst als de OK, maar hij onderbouwt deze anders. In tegenstelling tot de OK overweegt Timmerman dat enkel de vorderingen op SNS Bank zijn onteigend en niet tevens de 403-vorderingen op SNS REAAL.

21. Anders: Spierings 2016, p. 223-224, die van mening is dat het feit dat een crediteur geen vordering meer heeft op de 403-maatschappij niet met zich brengt dat hij daardoor ook geen 403-vordering meer heeft op de moedermaatschappij.

22. Stcrt. 2013, 3018.

23. Hof Amsterdam (OK) 11 juli 2013, JOR 2013/250, m.nt. Josephus Jitta (Minister van Financiën/VEB c.s.), r.o. 6.52 . 
Maar aangezien SNS Bank na de onteigening jegens de desbetreffende crediteuren geen schulden meer heeft die onder de reikwijdte van de 403-aansprakelijkheid van SNS Reaal vallen, hebben de crediteuren volgens Timmerman ook geen vordering meer op SNS Reaal. ${ }^{24}$ De Hoge Raad onderschrijft deze overweging van Timmerman. ${ }^{25}$ Daarmee legt de Hoge Raad de 403-vordering op dezelfde manier uit als mijn duiding als een dynamische vordering. Hij hanteert het uitgangspunt dat enkel degenen met een vordering op de 403-maatschappij een beroep kunnen doen op de 403-verklaring en uit dien hoofde een vordering hebben op de moedermaatschappij. Beide vorderingen zijn op dit punt dus met elkaar verbonden. In de literatuur is door Beckman, Van Schilfgaarde en Nass positief gereageerd op het oordeel van de Hoge Raad. ${ }^{26}$

Twee weken na bovenstaande beschikking inzake Minister van Financiën/VEB c.s., wijst de Hoge Raad het arrest Eikendal q.q./Lentink. ${ }^{27}$ In casu heeft een crediteur zijn vordering op de 403-maatschappij geschikt tegen gedeeltelijke betaling en hebben zij elkaar over en weer finale kwijting verleend. Hierdoor is de vordering van de crediteur op de 403-maatschappij tenietgegaan. ${ }^{28}$ Vervolgens spreekt de crediteur de moedermaatschappij op grond van de 403-verklaring aan tot betaling van het gekwijte deel van de vordering. De Hoge Raad oordeelt dat de aansprakelijkheid van de moedermaatschappij op grond van de 403-verklaring berust op een zelfstandige verbintenis, waarvan zelfstandig nakoming kan worden gevorderd. ${ }^{29}$ De schikking en de finale kwijting tussen de crediteur en de 403-maatschappij hebben slechts tot gevolg dat de vordering op de moedermaatschappij is verminderd met het bedrag van de schikking. ${ }^{30}$ Ondanks dat de crediteur geen vordering meer heeft op de 403-maatschappij, heeft hij wel nog steeds een 403-vordering op de moedermaatschappij.

In tegenstelling tot de beschikking Minister van Financiën/VEB c.s., sluit het oordeel van de Hoge Raad in het Eikendal q.q./Lentink-arrest niet aan bij de duiding van de 403-vordering als een dynamische vordering. In dat geval zou het tenietgaan van de vordering op de 403-maatschappij ertoe hebben geleid dat de crediteur ook geen 403 -vordering meer zou hebben op de moedermaatschappij. ${ }^{31}$

24. A-G Timmerman in zijn conclusie onder nr. 10.4 en 10.5 bij HR 20 maart 2015, NJ 2015/361, m.nt. Winter en Van Schilfgaarde (Minister van Financiën/VEB c.s.). Ook gepubliceerd in JOR 2015/140, m.nt. Josephus Jitta.

25. HR 20 maart 2015, JOR 2015/140, m.nt. Josephus Jitta (Minister van Financiën/VEB c.s.), r.o. 4.30 .

26. Zie Beckman 2015b, p. 498, Van Schilfgaarde in zijn annotatie onder HR 20 maart 2015, NJ 2015/361 (Minister van Financiën/VEB c.s.) en E.C.A. Nass 2019, p. 230-231.

27. HR 3 april 2015, JOR 2015/191, m.nt. Faber en Vermunt (Eikendal q.q./Lentink).

28. Zie art. 6:160 BW.

29. HR 3 april 2015, JOR 2015/191, m.nt. Faber en Vermunt (Eikendal q.q./Lentink), r.o. 3.6.2.

30. Zie art. 6:7 lid $2 \mathrm{BW}$.

31. Zie ook $\S 6.3 .2$. 
Wat opvalt aan de twee bovengenoemde uitspraken, is dat in beide gevallen de vordering van een crediteur op de 403-maatschappij is verdwenen. Het gevolg van het wegvallen van de vordering op de 403-maatschappij, voor de vordering van de crediteur op de moedermaatschappij is echter verschillend. Bij de beschikking Minister van Financiën/VEB c.s. leidt dit ertoe dat de crediteur ook geen vordering meer heeft op de moedermaatschappij. Maar bij het Eikendal q.q./Lentink-arrest behoudt de crediteur zijn vordering op de moedermaatschappij - met dien verstande dat deze is verminderd door de schikking van de crediteur en de 403-maatschappij. Er zou kunnen worden betoogd dat dit verschil wordt verklaard omdat de onteigening van de vordering op de 403-maatschappij in de beschikking Minister van Financiën/VEB c.s. moet worden gezien als een vorm van volledige betaling van deze vordering - waardoor de moedermaatschappij op grond van art. 6:7 lid $2 \mathrm{BW}$ ook is bevrijd - en de finale kwijting uit Eikendal q.q./Lentink niet. Ik kan mij echter niet vinden in deze redenering. De crediteuren van SNS Bank hebben geen betaling van hun vordering ontvangen, maar zij krijgen op grond van art. 6:8 lid $1 \mathrm{Wft}$ een vergoeding van de schade die zij rechtstreeks en noodzakelijk lijden als gevolg van de onteigening. Evenals Van Zoest zie ik niet hoe het verschil tussen het onteigenen van een vordering en het verlenen van finale kwijting het onderscheid tussen beide uitspraken kan verklaren. ${ }^{32}$ Mijns inziens zijn de beschikking en het arrest op dit punt niet met elkaar te verenigen. Ik laat dit voor nu rusten en kom hier aan het einde van het hoofdstuk op terug, waarbij ik ook een verwachting uitspreek over hoe de Hoge Raad zal oordelen als hij zich opnieuw over de duiding van de 403 -vordering moet uitlaten. ${ }^{33}$

\subsubsection{Analoge toepassing van art. 6:142 BW}

In de wet is geen definitie opgenomen van de term nevenrecht. Uit art. 6:142 BW volgt slechts een niet-limitatieve opsomming van rechten die bij de overgang van een vordering als nevenrecht mee overgaan op de nieuwe crediteur. Ook in de literatuur wordt een nevenrecht verschillend omschreven. Verstijlen ziet nevenrechten bijvoorbeeld als rechten die een zodanige samenhang hebben met een vordering dat het gerechtvaardigd is dat ze met die vordering mee overgaan, tenzij anders is afgesproken. ${ }^{34}$ Deze gezamenlijke overgang kan volgens hem onder meer voortkomen uit het feit dat partijen dit doorgaans voor ogen hebben of dat het efficiënt is gezien de belangen van de cedent en cessionaris bij de desbetreffende vordering en het nevenrecht. ${ }^{35}$

32. Van Zoest 2016a, p. 57-58.

33. Zie $§ 6.5 .4$.

34. Verstijlen 2009, p. 1634.

35. Zie ook Asser/Bartels \& Van Mierlo 3-IV 2013, nr. 345, waar deze definitie van nevenrechten wordt onderschreven. 
Rongen geeft een andere omschrijving van nevenrechten. ${ }^{36}$ Hij ziet een nevenrecht als een bij een vordering als hoofdrecht behorende recht dat in een zeker verband staat met deze vordering en meestal een aan die vordering ondergeschikt, en wat betreft het ontstaan en voortbestaan, onzelfstandig karakter heeft. Tot slot wijs ik op Verheul die nevenrechten definieert als alle van een vordering afhankelijke rechten, evenals de rechten die de inhoud van de vordering nader bepalen of anderszins van belang zijn voor of nauw samenhangen met de vordering - bijvoorbeeld omdat ze de vordering versterken. ${ }^{37}$

Het is - bij mijn weten - De Neve die als eerste de 403-vordering heeft geduid als een nevenrecht. ${ }^{38} \mathrm{Hij}$ is van mening dat zonder vordering op de 403-maatschappij, een crediteur geen vordering op de moedermaatschappij kan hebben. De 403-vordering is daarom volgens hem een afhankelijk recht en in het bijzonder een nevenrecht in de zin van art. 6:142 BW. Ook de Rechtbank Den Haag heeft in 2006 geoordeeld dat de 403-vordering een nevenrecht is. ${ }^{39}$ In tegenstelling tot De Neve ziet de rechtbank de 403-vordering echter niet als een afhankelijk recht - zij sluit daarmee aan bij de eerdergenoemde $A k z o / I N G$-beschikking van de Hoge Raad. ${ }^{40}$ De rechtbank wijst erop dat de opsomming van nevenrechten ex art. 6:142 BW zowel afhankelijke rechten betreft - zoals een pand- of hypotheekrecht - als rechten die niet een afhankelijk recht zijn - zoals het recht op nog niet opeisbare rente en nog niet verbeurde boetes en dwangsommen. ${ }^{41} \mathrm{De}$ rechtbank duidt de 403-vordering als een nevenrecht in laatstbedoelde zin.

Verschillende auteurs kunnen zich echter niet vinden in de duiding van de 403 -vordering als een nevenrecht. ${ }^{42} \mathrm{Zij}$ merken terecht op dat vorderingen die voortvloeien uit een hoofdelijke aansprakelijkstelling geen nevenrecht kunnen zijn omdat daarvoor is vereist dat een van de vorderingen als hoofdvordering kan worden aangemerkt. Volgens Rongen kan de vordering op de 403-maatschappij feitelijk wel als de hoofdvordering worden gezien, maar is deze in juridische zin gelijk aan de 403-vordering op de moedermaatschappij. ${ }^{43}$ De hoofdelijke aansprakelijkstelling van de moedermaatschappij op

36. Rongen 2012, p. 1269-1270.

37. Verheul, in: GS Verbintenissenrecht, art. 6:142, aant. 6.1.

38. De Neve 2002, p. 240.

39. Rb. Den Haag 5 juli 2006, JOR 2007/53, m.nt. Verdaas (NCM/Den Heijer Beheer), r.o. 3.5 en 3.6. Zie Verdaas in zijn annotatie onder deze uitspraak waar hij instemt met het oordeel van de rechtbank. Zie ook Verdaas 2008, p. 306, waar hij de duiding van de 403-vordering als een onafhankelijk nevenrecht een alternatief vindt voor de duiding als een afhankelijk recht.

40. HR 28 juni 2002, JOR 2002/136, m.nt. Bartman (Akzo/ING), r.o. 3.4.5. Zie § 6.2.1.

41. Zie ook Rongen 2012, p. 1270, Pitlo/Reehuis \& Heisterkamp 2019/274, Asser/Van Mierlo \& Krzeminski 3-VI 2020/52 en Verheul, in: GS Verbintenissenrecht, art. 6:142, aant. 6.3.

42. Faber in zijn annotatie onder Hof Den Haag 6 februari 2007, JOR 2007/103 (Citibank International/KPN), Rongen 2012, p. 1299 en 1305 en Verheul, in: GS Verbintenissenrecht, art. 6:142, aant. 8.6.

43. Rongen 2012, p. 1299. 
grond van de 403-verklaring brengt mee dat de crediteur jegens de moeder- en de 403-maatschappij een zelfstandig verhaalsrecht heeft. Beide vorderingen bestaan onafhankelijk van elkaar, met dien verstande dat nakoming door een van de hoofdelijke schuldenaren ook de medeschuldenaar bevrijdt. ${ }^{44}$

Hoewel een 403-vordering dus niet kwalificeert als een nevenrecht, meent Rongen dat er een dusdanige nauwe verbondenheid bestaat tussen de vordering op de 403-maatschappij en die op de moedermaatschappij, dat het gerechtvaardigd is om art. 6:142 $\mathrm{BW}$ analoog toe te passen op de 403-vordering. ${ }^{45}$ In het vervolg van dit onderzoek werk ik deze benadering van Rongen verder uit. Deze duiding van de 403 -vordering is een variant op de duiding als een hoofdelijke vordering met als bijzondere kenmerk dat de overgang van de vordering op de 403-maatschappij met zich brengt dat de 403-vordering mee overgaat. Voor het overige gelden de rechtsgevolgen overeenkomstig de duiding als een hoofdelijke vordering. ${ }^{46}$

Tot slot wijs ik nog op de Akzo/ING-beschikking van de Hoge Raad. Kort gezegd heeft de Hoge Raad geoordeeld dat de houder van een pandrecht op de vordering van een crediteur op de 403-maatschappij, niet in verzet kan komen tegen het voornemen van de moedermaatschappij om de overblijvende aansprakelijkheid na de intrekking van de 403 -verklaring te beëindigen.$^{47}$ Dit oordeel sluit niet aan bij een analoge toepassing van art. 6:142 BW ten aanzien van de 403-vordering omdat de pandhouder in dat geval wel verzet kan instellen - ik kom hier later uitgebreid op terug. ${ }^{48}$ Uit dit arrest kan daarom worden afgeleid dat de Hoge Raad art. 6:142 BW niet analoog van toepassing acht op de 403-vordering.

Ondanks dat de Hoge Raad art. 6:142 BW niet analoog van toepassing acht op de 403-vordering, onderzoek ik in dit hoofdstuk toch wat de gevolgen van deze analoge toepassing zouden zijn. Voor dit onderzoek is namelijk niet alleen van belang hoe de 403 -vordering naar huidig recht moet worden geduid. Net zo belangrijk is hoe deze vordering moet worden geduid volgens het door mij bepleite uitgangspunt voor compensatie en daarmee of een wetswijziging wenselijk is. Om dit te onderzoeken zal ik voor verschillende situaties de gevolgen van enkele duidingen van de 403-vordering - waaronder de analoge toepassing

44. Zie art. 6:7 BW. Ook in het geval dat een van beide vorderingen wordt betaald door inbetalinggeving, verrekening of als een rechter op grond van art. 6:60 BW oordeelt dat de schuldenaar is bevrijd omdat de crediteur zelf in verzuim is, is de andere hoofdelijk schuldenaar bevrijd.

45. Rongen 2012, p. 1305-1306.

46. Zie ook mijn annotatie onder HR 11 april 2014, JOR 2014/199 (UWV/Econcern).

47. HR 28 juni 2002, JOR 2002/136, m.nt. Bartman (Akzo/ING), r.o. 3.5.3. Zie § 8.7.3.

48. Zie $\S$ 6.3.7.c. 
van art. 6:142 BW ten aanzien van deze vordering - vergelijken met de uitkomsten volgens het door mij bepleite uitgangspunt.

\subsubsection{Analoge toepassing van de bepalingen inzake borgtocht}

De OK heeft in de $A k z o / I N G$-procedure geoordeeld dat aan de door de wet beoogde bescherming van een crediteur van de 403-maatschappij voldoende recht wordt gedaan, als de moedermaatschappij tegenover hem in een positie komt te verkeren alsof zij zich tot borg heeft gesteld. ${ }^{49}$ In cassatie heeft de Hoge Raad echter deze beschikking van de OK vernietigd. Hij oordeelt dat hoofdelijke aansprakelijkheid niet op een lijn kan worden gesteld met borgtocht. $^{50}$

Schoordijk is van mening dat de Hoge Raad ten onrechte heeft geoordeeld dat de hoofdelijke aansprakelijkheid van een moedermaatschappij op grond van een 403-verklaring meebrengt dat deze aansprakelijkheid niet een vorm van borgtocht is - zoals bij het oordeel van de OK. ${ }^{51}$ Volgens hem kent hoofdelijke aansprakelijkheid vele modulaties, waaronder borgtocht. Hij wijst erop dat krachtens art. 7:850 lid $3 \mathrm{BW}$ de bepalingen met betrekking tot hoofdelijke aansprakelijkheid van overeenkomstige toepassing zijn op borgtocht voor zover de wet daar niet van afwijkt. Volgens hem is het daarom de vraag of er bij de hoofdelijke aansprakelijkheid van een moedermaatschappij op grond van een 403-verklaring sprake is van hoofdelijkheid 'sec' dan wel een variant daarop: borgtocht.

Schoordijk merkt op dat een kenmerkend verschil tussen hoofdelijke aansprakelijkheid en borgtocht is dat een borg niet zelf draagplichtig is. De borg verbindt zich slechts tot nakoming van een verplichting die de hoofdschuldenaar jegens een derde heeft of zal krijgen. Een dergelijke situatie doet zich volgens Schoordijk ook voor bij de 403-aansprakelijkheid. De moedermaatschappij stelt zich op grond van de 403-verklaring aansprakelijk voor een schuld die de 403-maatschappij tegenover een derde heeft of zal krijgen. Schoordijk is van mening dat de Hoge Raad daarom het oordeel van de OK had moeten bevestigen en had moeten oordelen dat de aard van de hoofdelijke aansprakelijkheid van de moedermaatschappij op grond van de 403-verklaring meebrengt dat deze aansprakelijkheid moet worden uitgelegd als mede borgtocht te bevatten.

Bartman komt tot eenzelfde uitkomst als Schoordijk, maar onderbouwt dit anders. In tegenstelling tot Schoordijk is hij van mening dat de hoofdelijke aansprakelijkheid van een moedermaatschappij op grond van een 403-verklaring

49. Hof Amsterdam (OK) 31 juli 2001, JOR 2001/170, m.nt. Bartman (Akzo/ING), r.o. 4.10.

50. HR 28 juni 2002, JOR 2002/136, m.nt. Bartman $(A k z o / I N G)$, r.o. 3.4.3, 3.4.5 en 3.4.6.

51. Schoordijk 2003, p. 62-65. 
geen ruimte laat om deze aansprakelijkheid uit te leggen als een vorm van borgtocht. ${ }^{52} \mathrm{Hij}$ merkt naar mijn mening terecht op dat het eenzijdige en ongerichte karakter van een 403-verklaring hieraan in de weg staat. De compensatie die de crediteuren van de 403-maatschappij ontvangen uit hoofde van de aansprakelijkheid van de moedermaatschappij moet een collectief en eenzijdig karakter hebben. ${ }^{53}$ Deze moet voor alle crediteuren gelijk zijn en mag geen onderwerp zijn van nadere onderhandelingen tussen de moedermaatschappij en individuele crediteuren. Aangezien borgtocht een overeenkomst is, ${ }^{54}$ kan de aansprakelijkheid van een moedermaatschappij op grond van een 403-verklaring niet worden gezien als een vorm van borgtocht. ${ }^{55}$ Hoewel de aansprakelijkheid van een moedermaatschappij op grond van een 403-verklaring dus geen borgstelling is, ziet Bartman wel ruimte voor analoge toepassing van de bepalingen inzake borgtocht ten aanzien van de 403 -aansprakelijkheid. ${ }^{56}$ Deze benadering van Bartman werk ik in het vervolg van dit onderzoek verder uit.

Hoewel een analoge toepassing van de bepalingen inzake borgtocht ten aanzien van de aansprakelijkheid van een moedermaatschappij op grond van een 403-verklaring contrair is aan het oordeel van de Hoge Raad in de $A k z o / I N G$ beschikking, ${ }^{57}$ zal ik deze duiding van de 403 -vordering toch onderzoeken. Ik heb eerder opgemerkt dat uit de $A$ kzo/ING-beschikking ook kan worden afgeleid dat de Hoge Raad art. 6:142 BW niet analoog toepast ten aanzien van de 403-vordering, maar dat ik deze duiding van de 403-vordering toch onderzoek. ${ }^{58}$ Voor dit onderzoek is namelijk niet slechts van belang hoe de 403 -vordering naar huidig recht moet worden geduid. Net zo belangrijk is hoe

52. Bartman 2004, p. 50-51. Zie ook Blommaert \& Linders 2015, p. 356-358, die van mening zijn dat een moedermaatschappij niet aan het vereiste van art. 2:403 lid 1 sub $\mathrm{fBW}$ voldoet als zij een verklaring deponeert op grond waarvan zij zich tot borg stelt voor de schulden die uit een rechtshandeling van de 403-maatschappij voortvloeien.

53. De compensatie voor een crediteur bestaat uit twee onderdelen: een vordering op de moedermaatschappij op grond van de 403-verklaring en de mogelijkheid om de geconsolideerde jaarrekening van de moedermaatschappij in te zien. Zie $\S$ 3.4.1.

54. Zie art. 7:850 lid $1 \mathrm{BW}$.

55. Anders Rongen 2012, p. 1304, die meent dat dit er niet aan in de weg staat om de aansprakelijkheid van een moedermaatschappij op grond van de 403-verklaring als een borgstelling te kwalificeren. Hij merkt op dat ook bij een hoofdelijke aansprakelijkheid het uitgangspunt is dat dit is gebaseerd op een overeenkomst, maar dat art. 2:403 BW de mogelijkheid biedt aan een moedermaatschappij om zich door middel van een eenzijdige ongerichte rechtshandeling hoofdelijk aansprakelijk te stellen. Rongen is daarom van mening dat art. 2:403 BW het ook mogelijk maakt om borgtocht - in afwijking van art. 7:850 lid $1 \mathrm{BW}$ - te baseren op een eenzijdige ongerichte rechtshandeling. Ik kan mij niet vinden in dit standpunt aangezien in art. 7:850 lid $1 \mathrm{BW}$ expliciet is opgenomen dat borgtocht een overeenkomst is en een dergelijke bepaling ten aanzien van hoofdelijke aansprakelijkheid ontbreekt.

56. Bartman 2004, p. 51. Zie ook Verdaas 2008, p. 305, die instemt met het standpunt van Bartman.

57. HR 28 juni 2002, JOR 2002/136, m.nt. Bartman (Akzo/ING), r.o. 3.4.3, 3.4.5 en 3.4.6.

58. Zie $\S 6.2 .3$. 
deze vordering moet worden geduid volgens het door mij bepleite uitgangspunt voor compensatie en daarmee of een wetswijziging wenselijk is.

Een analoge toepassing van de bepalingen inzake borgtocht ten aanzien van de aansprakelijkheid van een moedermaatschappij op grond van een 403-verklaring leidt er onder meer toe dat deze aansprakelijkheid afhankelijk is van de verbintenis tussen de crediteur en de 403-maatschappij. Daarnaast kan de moedermaatschappij een beroep doen op dezelfde verweermiddelen als die de 403-maatschappij heeft tegenover de crediteur ten aanzien van het bestaan, de inhoud of het moment van nakoming van haar verplichting. Tot slot is de moedermaatschappij slechts subsidiair aansprakelijk. ${ }^{59}$

\subsubsection{Het verhaalsrecht op grond van een 403-verklaring als wilsrecht}

Verschillende auteurs, waaronder Wibier en Van der Kraan, duiden het verhaalsrecht van een crediteur op grond van een 403-verklaring als een 'wilsrecht ${ }^{60}$ Volgens hen heeft een crediteur van de 403-maatschappij op grond van de 403-verklaring het recht om de moedermaatschappij aansprakelijk te stellen. Pas als de crediteur de moedermaatschappij daadwerkelijk aansprakelijk stelt, ontstaat de 403-vordering. Het wilsrecht om de moedermaatschappij op grond van de 403-verklaring aansprakelijk te stellen, komt volgens deze auteurs toe aan degenen met een vordering op de 403-maatschappij. Als een crediteur zijn vordering op de 403-maatschappij overdraagt aan een derde, verliest hij daardoor het recht om de moedermaatschappij aansprakelijk stellen. Dit recht komt dan toe aan de derde op wie de vordering op de 403-maatschappij is overgegaan.

Naar mijn mening is bovenstaand standpunt onjuist. De Hoge Raad heeft in zijn $A k z o / I N G$-beschikking geoordeeld dat een 403 -verklaring een niet tot een bepaalde partij gerichte, eenzijdige verklaring van hoofdelijke aansprakelijkheid is, op grond waarvan rechtstreeks aansprakelijkheid voor de moedermaatschappij ontstaat. ${ }^{61}$ De 403 -vordering van een crediteur ontstaat dus niet pas als hij de moedermaatschappij op grond van de 403 -verklaring aansprakelijk stelt. Onder meer Biemans en Nass onderschrijven dit standpunt. ${ }^{62}$ Daarnaast wijs ik erop dat het Hof Den Haag in haar TPB/Eneco-arrest heeft geoordeeld

59. Zie respectievelijk art. 7:851 lid 1, art. 7:852 lid 1 en art. 7:855 lid $1 \mathrm{BW}$.

60. Wibier 2008, p. 182, Niels 2010, p. 27, Van der Kraan 2012, p. 72, Van der Kraan 2013, p. 156-157, Van der Kraan in zijn annotatie onder Rb. Midden-Nederland 30 januari 2013, JIN 2013/73 (UWV/Econcern), Van der Schee 2014, p. 23, Van der Kraan 2015, p. 20-21 en Booms 2019, p. 435.

61. HR 28 juni 2002, JOR 2002/136, m.nt. Bartman (Akzo/ING), r.o. 3.4.3.

62. Van der Heijden/Van der Grinten 1992/324.2, Houwen, Schoonbrood-Wessels \& Schreurs 1993, p. 829, Biemans 2011, p. 307, E.C.A. Nass 2019, p. 197 en E.C.A. Nass 2020, p. 147. Zie bevestigend in algemene zin over rechtsfeiten waardoor verbintenissen ontstaan Asser/ Sieburgh 6-I 2016/53-54. 
dat de verjaring van een vordering op grond van de 403-verklaring niet pas aanvangt als de crediteur de moedermaatschappij ansprakelijk stelt. ${ }^{63}$ Uit dit oordeel volgt dat ondanks dat een crediteur de moedermaatschappij nog niet aansprakelijk heeft gesteld, hij dus wel al een 403-vordering heeft - waarvan de verjaringstermijn is beginnen te lopen. In het cassatieberoep heeft A-G Timmerman in zijn conclusie het oordeel van het hof onderschreven. ${ }^{64}$

Het duiden van het verhaalsrecht van een crediteur op de moedermaatschappij als een wilsrecht zou mijns inziens ook tot onwenselijke situaties kunnen leiden. De crediteur heeft dan geen rechten tegenover de moedermaatschappij totdat hij haar aansprakelijk heeft gesteld op grond van de 403-verklaring. Van der Kraan geeft zelf het voorbeeld dat een crediteur in een dergelijk geval (nog) niet in verzet kan komen tegen een voorstel tot fusie of splitsing van de moedermaatschappij. ${ }^{65}$ Daarnaast wijst Nass erop dat als de moedermaatschappij failliet gaat voordat zij door de crediteur aansprakelijk is gesteld, er sprake is van een toekomstige vordering die op grond van art. $131 \mathrm{Fw}$ moet worden geverifieerd voor de waarde op de dag der faillietverklaring. ${ }^{66}$ Tot slot merk ik zelf nog op dat een wilsrecht niet verjaart. Er zou dus geen limiet zijn aan de termijn dat de moedermaatschappij aansprakelijk kan worden gesteld op grond van de 403-verklaring. Dit leidt tot rechtsonzekerheid. ${ }^{67}$

In het vervolg van dit onderzoek laat ik de duiding van het verhaalsrecht van een crediteur op de moedermaatschappij als een wilsrecht buiten beschouwing.

\subsection{De gevolgen van de verschillende duidingen van de 403-vordering}

\subsubsection{Inleiding}

Hieronder ga ik voor verschillende situaties na wat de gevolgen zijn van de vier genoemde duidingen van de 403-vordering. ${ }^{68}$ Allereerst ga ik in op het

63. Hof Den Haag 18 maart 2014, JOR 2015/93, m.nt. Bartman (TPB/Eneco), r.o. 8, 9 en 11.

64. Zie A-G Timmerman in zijn conclusie onder nr. 3.3 en 3.5 bij HR 19 juni 2015, ECLI:NL:HR:2015:1691 (TPB/Eneco). De Hoge Raad heeft geoordeeld dat de aangevoerde klachten niet tot cassatie kunnen leiden en niet nopen tot beantwoording van rechtsvragen in het belang van de rechtseenheid of de rechtsontwikkeling.

65. Van der Kraan 2012, p. 70. Zie art. 2:316 BW, respectievelijk art. 2:334k jo. art. 2:3341 BW en $\S 9.3 .1$.

66. E.C.A. Nass 2019, p. 197-198.

67. Zie ook Bartman \& Dorresteijn 2013, p. 240, die zich afvragen wat er gebeurt als de crediteur bij het ontstaan van de vordering op de 403-maatschappij direct opmerkt dat hij zijn wilsrecht uitoefent om de moedermaatschappij aansprakelijk te stellen. Volgens hen heeft de crediteur dan vanaf dat moment een hoofdelijke vordering op de moedermaatschappij.

68. Zie ook mijn eerdere bijdrage over dit onderwerp: Van Dooren 2015. 
geval dat een crediteur afstand doet van zijn vordering op de 403-maatschappij (§ 6.3.2). Vervolgens onderzoek ik of de moedermaatschappij een beroep kan doen op een bepaling in de overeenkomst tussen de 403-maatschappij en de crediteur met betrekking tot het moment dat de 403-maatschappij haar verplichting moet nakomen. Daarna behandel ik de situaties dat de crediteur uitstel van betaling verleent aan de 403-maatschappij, dat de 403-maatschappij haar nakoming opschort en dat de vordering op de 403-maatschappij is verjaard ( $§ 6.3 .3$ en $\S 6.3 .4$ ). Voorts onderzoek ik of de moedermaatschappij al of niet subsidiair aansprakelijk is ( $(6.3 .5)$, en tot slot wijs ik op de gevolgen van de verschillende duidingen met betrekking tot de cessie en de verpanding van de hoofd- en de 403-vordering ( $\$ 6.3 .6$ en $\S 6.3 .7$ ).

Ik heb ervoor gekozen om juist bovenstaande situaties te onderzoeken omdat deze aansluiten bij de huidige jurisprudentie en de discussie in de literatuur met betrekking tot de duiding van de 403 -vordering.

\subsubsection{De crediteur doet afstand van de vordering op de 403-maatschappij}

Als een crediteur afstand doet van zijn vorderingsrecht jegens de 403-maatschappij gaat de verbintenis tussen hen op grond van art. 6:160 BW teniet. Het is de vraag of de crediteur zich in een dergelijk geval nog steeds op grond van de 403-verklaring op de moedermaatschappij kan verhalen.

Als de 403-vordering wordt geduid als een hoofdelijke vordering, moet bovenstaande vraag bevestigend worden beantwoord. ${ }^{69}$ De Hoge Raad heeft in het arrest Eikendal q.q./Lentink geoordeeld dat de hoofdelijke aansprakelijkheid van een moedermaatschappij op grond van een 403-verklaring berust op een zelfstandige verbintenis jegens de crediteur, waarvan zelfstandig nakoming kan worden gevorderd. ${ }^{70}$ Dit brengt volgens de Hoge Raad met zich dat als een crediteur afstand doet van zijn vordering op de 403-maatschappij, zijn vordering op de moedermaatschappij hierdoor niet wordt aangetast. De crediteur kan zich dus nog steeds op de moedermaatschappij verhalen.

De duiding van de 403-vordering als een dynamische vordering houdt in dat slechts degenen met een vordering op de 403-maatschappij een beroep kunnen doen op de 403-verklaring en uit dien hoofde een vordering hebben op de moedermaatschappij. Als een crediteur afstand doet van zijn vordering op de

69. E.C.A. Nass 2019, p. 222. Zie ook Asser/Sieburgh 6-I 2016/100, die in algemene zin over hoofdelijkheid opmerkt dat een crediteur van ieder van zijn vorderingen op de hoofdelijk schuldenaren afzonderlijk afstand kan doen.

70. HR 3 april 2015, JOR 2015/191, m.nt. Faber en Vermunt (Eikendal q.q./Lentink), r.o. 3.6.2. De crediteur en de 403-maatschappij hebben in het kader van de finale kwijting een schikking getroffen waarbij de vordering van de crediteur gedeeltelijk is voldaan. Hoewel de crediteur zijn vordering op de moedermaatschappij behoudt, is deze verminderd met het bedrag van de schikking. Zie ook Beckman 2015a, p. 344. 
403-maatschappij kan hij zich niet meer beroepen op de 403-verklaring en heeft hij daardoor ook geen vordering meer op de moedermaatschappij. ${ }^{71}$

Bij een analoge toepassing van art. 6:142 BW ten aanzien van de 403-vordering leidt de overgang van de vordering op de 403-maatschappij ertoe dat ook de 403 -vordering mee overgaat. Voor het overige gelden de rechtsgevolgen overeenkomstig de duiding als een hoofdelijke vordering. Aangezien het doen van afstand van de vordering op de 403-maatschappij niet leidt tot een overgang van deze vordering, is art. 6:142 BW niet (analoog) van toepassing en gelden op dit punt de rechtsgevolgen volgens de duiding als een hoofdelijke vordering. Dit betekent dat de crediteur zich dus nog steeds op de moedermaatschappij kan verhalen.

Tot slot ga ik in op de gevolgen van een analoge toepassing van de bepalingen inzake borgtocht ten aanzien van de aansprakelijkheid van een moedermaatschappij op grond van een 403-verklaring. In dat geval is deze aansprakelijkheid afhankelijk van de verbintenis tussen de crediteur en de 403-maatschappij. Dit betekent dat als de crediteur afstand doet van zijn vordering op de 403-maatschappij, daardoor ook de 403-vordering op de moedermaatschappij tenietgaat. $^{72}$

In afbeelding 6.1 heb ik de gevolgen van de verschillende duidingen van de 403-vordering uiteengezet:

\begin{tabular}{|l|c|c|c|c|}
\hline \multirow{2}{*}{$\begin{array}{l}\text { Kan de moedermaatschappij een beroep doen } \\
\text { op de omstandigheid dat }\end{array}$} & \multicolumn{4}{|c|}{ Duiding van de 403-vordering } \\
\cline { 2 - 5 } & Hoofdelijk & Dynamisch & Art. 6:142 & Borgtocht \\
\hline $\begin{array}{l}\text { De crediteur afstand heeft gedaan van zijn } \\
\text { vordering op de 403-maatschappij? }\end{array}$ & Nee & Ja & Nee & Ja \\
\hline
\end{tabular}

Afbeelding 6.1

\subsubsection{Overeengekomen moment van nakoming, uitstel van betaling en opschorting van nakoming}

\subsection{3.a Inleiding}

Dat een crediteur een vordering heeft op de 403-maatschappij betekent niet dat hij deze vordering ook per direct te gelde kan maken. Partijen kunnen bijvoorbeeld zijn overeengekomen dat de 403-maatschappij pas na een bepaald

71. E.C.A. Nass 2019, p. 223.

72. E.C.A. Nass 2019 , p. 223. Zie bevestigend met betrekking tot borgtocht in algemene zin Bergervoet 2014, p. 94 en Asser/Van Schaick 7-VIII 2018/92. 
moment aan haar verplichting hoeft te voldoen. Het is ook mogelijk dat de crediteur uitstel van betaling heeft verleend aan de 403-maatschappij of dat de laatstgenoemde de nakoming van haar verplichting opschort omdat de crediteur een opeisbare vordering - van de 403-maatschappij - jegens hem niet nakomt. ${ }^{73}$ De vraag rijst of ook de moedermaatschappij in deze situaties (tijdelijk) niet hoeft na te komen.

\subsection{3.b Duiding van de 403-vordering als een hoofdelijke vordering}

Sieburgh merkt op dat ieder van de hoofdelijk schuldenaren een beroep kan doen op de verweermiddelen die de verbintenis zelf aangaan. ${ }^{74}$ Dit betreft volgens haar onder meer omstandigheden die vanaf de aanvang de werking van de verbintenis beperken - zoals een in de verbintenis opgenomen tijdsbepaling op grond waarvan pas na een bepaald moment aan een verplichting hoeft te worden voldoen. Dit betekent dat als de 403-vordering wordt geduid als een hoofdelijke vordering de moedermaatschappij zich kan beroepen op een bepaling in de overeenkomst tussen de crediteur en de 403-maatschappij op grond waarvan de 403-maatschappij pas na een bepaald moment aan haar verplichting hoeft te voldoen. ${ }^{75}$ Tot dat moment is ook de moedermaatschappij niet gehouden om na te komen.

De moedermaatschappij kan daarentegen geen beroep doen op een aan de 403-maatschappij verleend uitstel van betaling of het feit dat de 403-maatschappij de nakoming van haar verplichting opschort omdat de crediteur een vordering jegens hem niet nakomt. De onafhankelijkheid van de vorderingen van de crediteur op de moeder- en de 403-maatschappij staat daaraan in de weg. Onder meer Sieburgh wijst erop dat het verlenen van uitstel van betaling een eenzijdige rechtshandeling is van een crediteur jegens de debiteur en dat dit uitstel niet voor de overige hoofdelijk schuldenaren geldt tenzij blijkt dat dit de bedoeling is van de crediteur. ${ }^{76}$ Daarnaast merkt zij op dat het recht om de nakoming van een verplichting op te schorten een persoonlijk verweermiddel is van een debiteur, waar enkel degene in wiens persoon dit recht is ontstaan een beroep op kan doen. ${ }^{77}$ Als aan de 403-maatschappij uitstel van betaling is verleend of deze de nakoming van haar verplichting opschort, kan de crediteur zich dus onverminderd verhalen op de moedermaatschappij.

73. Zie art. 6:52 BW. De 403-maatschappij kan de nakoming van haar verplichting enkel opschorten als er voldoende samenhang bestaat tussen deze verplichting en de opeisbare vordering op de crediteur om de opschorting te rechtvaardigen.

74. Asser/Sieburgh 6-I 2016/119.

75. E.C.A. Nass 2019, p. 200

76. Asser/Sieburgh 6-I 2016/117 en Den Hoed, in: GS Verbintenissenrecht, art. 6:9, aant. 11.

77. Asser/Sieburgh 6-I 2016/119. 
6.3.3.c Duiding van de 403-vordering als een dynamische vordering en analoge toepassing van art. 6:142 BW

De duiding van de 403-vordering als een dynamische vordering en de analoge toepassing van art. 6:142 BW ten aanzien van deze vordering, zijn beide varianten op de duiding als een hoofdelijke vordering. Dit betekent dat dezelfde rechtsgevolgen gelden als bij de duiding van de 403-vordering als een hoofdelijke vordering, behalve dat slechts degenen met een vordering op de 403-maatschappij een beroep kunnen doen op de 403-verklaring en uit dien hoofde een vordering hebben op de moedermaatschappij, respectievelijk dat de overgang van de vordering op de 403-maatschappij met zich brengt dat ook de 403-vordering mee overgaat. Beide bijzonderheden van deze duidingen van de 403-vordering zijn echter niet relevant als de 403-maatschappij met de crediteur is overeengekomen dat zij pas na een bepaald moment hoeft na te komen, indien aan de 403-maatschappij uitstel van betaling is verleend, of als de 403-maatschappij de nakoming van haar verplichting opschort. In die gevallen gelden daarom de rechtsgevolgen overeenkomstig de duiding van de 403 -vordering als een hoofdelijke vordering. ${ }^{78}$ Dit betekent dat de moedermaatschappij pas na het overeengekomen moment hoeft na te komen, maar dat zij geen beroep kan doen op het verleende uitstel van betaling of de opschorting van de nakoming.

\subsection{3.d Analoge toepassing van de bepalingen inzake borgtocht}

Op grond van art. 7:852 lid $1 \mathrm{BW}$ kan een borg onder meer een beroep doen op de verweermiddelen die de hoofdschuldenaar heeft met betrekking tot het moment van nakoming van zijn verplichting tegenover de crediteur. In het geval dat de bepalingen inzake borgtocht analoog van toepassing zijn ten aanzien van de aansprakelijkheid van een moedermaatschappij op grond van een 403-verklaring, kan de moedermaatschappij zich dus beroepen op een bepaling in de overeenkomst tussen de crediteur en de 403-maatschappij op grond waarvan de 403-maatschappij pas na een bepaald moment aan haar verplichting hoeft te voldoen.$^{79}$ Daarnaast is de moedermaatschappij op grond van deze bepaling niet gehouden tot nakoming zolang aan de 403-maatschappij uitstel van betaling is verleend ${ }^{80}$ Als de 403 -maatschappij nog niet hoeft na te komen, is ook de moedermaatschappij hier niet toe verplicht.

Tot slot wijs ik erop dat de moedermaatschappij op grond van art. 7:852 lid 3 BW ook bevoegd is de nakoming van haar verplichting op grond van de

78. Zie $\S$ 6.3.3.b.

79. Zie bevestigend met betrekking tot borgtocht in algemene zin Asser/Van Schaick 7-VIII 2018/90 en 91 en Haentjens, in: GS Bijzondere overeenkomsten, art. 7:852, aant. 1.

80. Zie bevestigend met betrekking tot borgtocht in algemene zin Bergervoet 2014, p. 171-172 en Haentjens, in: GS Bijzondere overeenkomsten, art. 7:852, aant. 2. 
403-verklaring op te schorten, zolang de 403-maatschappij - rechtsgeldig - de nakoming van haar verplichting opschort omdat de crediteur een opeisbare vordering - van de 403-maatschappij - jegens hem niet nakomt. ${ }^{81}$ De moedermaatschappij kan echter niet namens de 403-maatschappij de nakoming van de verplichting - van de 403-maatschappij- opschorten. Het is de 403-maatschappij zelf die hier een beroep op moet doen.

In afbeelding 6.2 heb ik de gevolgen van de verschillende duidingen van de 403-vordering uiteengezet:

\begin{tabular}{|l|c|c|c|c|}
\hline \multirow{2}{*}{$\begin{array}{l}\text { Kan de moedermaatschappij een beroep doen } \\
\text { op de omstandigheid dat }\end{array}$} & \multicolumn{3}{|c|}{ Duiding van de 403-vordering } \\
\cline { 2 - 5 } & Hoofdelijk & Dynamisch & Art. 6:142 & Borgtocht \\
\hline $\begin{array}{l}\text { De 403-maatschappij met de crediteur is } \\
\text { overeengekomen dat zij pas na een bepaald } \\
\text { moment hoeft na te komen? }\end{array}$ & Ja & Ja & Ja & Ja \\
\hline $\begin{array}{l}\text { De crediteur uitstel van betaling aan de 403- } \\
\text { maatschappij heeft verleend? }\end{array}$ & Nee & Nee & Nee & Ja \\
\hline $\begin{array}{l}\text { De 403-maatschappij haar nakoming heeft } \\
\text { opgeschort? }\end{array}$ & Nee & Nee & Nee & Ja \\
\hline
\end{tabular}

Afbeelding 6.2

\subsubsection{De vordering op de 403-maatschappij is verjaard}

Als een crediteur een vordering krijgt op de 403-maatschappij op een moment dat de 403-verklaring al is gedeponeerd, krijgt de crediteur gelijktijdig ook een vordering op de moedermaatschappij. ${ }^{82}$ Omdat beide vorderingen op hetzelfde moment zijn ontstaan, zullen zij ook op hetzelfde moment verjaren. ${ }^{83}$ Indien daarentegen de 403-verklaring wordt gedeponeerd op een moment

81. Zie bevestigend met betrekking tot borgtocht in algemene zin Bergervoet 2014, p. 182, Asser/Van Schaick 7-VIII 2018/92 en Haentjens, in: GS Bijzondere overeenkomsten, art. 7:852, aant. 11 .

82. Biemans 2011, p. 307 en E.C.A. Nass 2019, p. 197.

83. Van Zoest 2016a, p. 69-70. Zie voor een voorbeeld hiervan Hof Den Haag 18 maart 2014, JOR 2015/93, m.nt. Bartman (TPB/Eneco), r.o. 8, 9 en 11. Zie Booms 2019, p. 437-438, die meent dat het hof heeft angesloten bij de gezamenlijke opvatting van partijen dat de verjaring van de vordering op de 403-maatschappij inhoudt dat de nakoming van de 403-vordering ook niet meer afdwingbaar is. A-G Timmerman wijst er in zijn conclusie onder nr. 3.3 en 3.5 bij HR 19 juni 2015, ECLI:NL:HR:2015:1691 (TPB/Eneco) echter terecht op dat het hof niet heeft aangenomen dat het feit dat de vordering op de 403-maatschappij is verjaard met zich brengt dat ook de vordering op de moedermaatschappij is verjaard. Het hof heeft het verweer van de moedermaatschappij zo begrepen dat deze zich beroept op de verjaring van de 403-vordering zelf. Timmerman onderschrijft vervolgens het oordeel van het hof. Zie ook E.C.A. Nass 2019, p. 208. 
dat de crediteur al een vordering op de 403-maatschappij heeft, ontstaat de 403 -vordering pas op het moment van de deponering. ${ }^{84,85}$ Aangezien de vordering op de 403-maatschappij eerder is ontstaan, zal deze ook eerder verjaren ${ }^{86}$ Het is dus mogelijk dat de vordering van een crediteur op de 403-maatschappij al is verjaard, maar de 403-vordering op de moedermaatschappij nog niet. ${ }^{87}$ Als de crediteur de moedermaatschappij in een dergelijk geval aansprakelijk stelt, doet zich de vraag voor of de moedermaatschappij de nakoming van de 403-vordering kan afweren met een beroep op de verjaring van de vordering op de 403-maatschappij.

Als de 403-vordering wordt geduid als een hoofdelijke vordering, bestaat deze onafhankelijk van de vordering op de 403-maatschappij - met dien verstande dat nakoming door de moeder- of de 403-maatschappij ook de ander bevrijdt. ${ }^{88}$ Beide vorderingen kunnen dus ook onafhankelijk van elkaar verjaren. ${ }^{89}$ De moedermaatschappij kan de nakoming van de 403-vordering dus niet afweren met een beroep op de verjaring van de vordering op de 403-maatschappij. ${ }^{90}$

Ook als de 403-vordering wordt geduid als een dynamische vordering is de moedermaatschappij gehouden de 403-vordering te voldoen ondanks dat de vordering op de 403-maatschappij al is verjaard. Deze duiding van de 403-vordering is een variant op de duiding als een hoofdelijke vordering met als bijzonder kenmerk dat slechts degenen met een vordering op de 403-maatschappij een beroep kunnen doen op de 403-verklaring en uit dien hoofde een vordering

84. Van Zoest 2016a, p. 69-70, Talacko \& Van Wijngaarden 2016, p. 18 en E.C.A. Nass 2019, p. 197.

85. Ervan uitgaande dat de moedermaatschappij op grond van de 403-verklaring aansprakelijk is voor alle schulden die voortvloeien en zijn voortgevloeid uit een rechtshandeling van de 403-maatschappij (zie hoofdstuk 5 en in het bijzonder $§ 5.6$ ).

86. Op grond van art. 3:322 lid $1 \mathrm{BW}$ mag een rechter niet ambtshalve het middel van verjaring toepassen. De 403-maatschappij moet hier dus een beroep op hebben gedaan.

87. Zie E.C.A. Nass 2019, p. 193, die erop wijst dat een vergelijkbare situatie zich kan voordoen als een van de vorderingen is verjaard, maar de crediteur de verjaring van de andere vordering heeft gestuit.

88. Zie art. 6:7 BW. Ook in het geval dat een van beide vorderingen wordt betaald door inbetalinggeving, verrekening of als een rechter op grond van art. 6:60 BW oordeelt dat de schuldenaar is bevrijd omdat de crediteur zelf in verzuim is, is de andere hoofdelijk schuldenaar bevrijd.

89. Huiskes 2015, p. 43 en E.C.A. Nass 2019, p. 224. Zie bevestigend met betrekking tot hoofdelijkheid in algemene zin Asser/Sieburgh 6-I 2016/100. Anders NAI 26 mei 2015, nr. 4128, r.o. 7.28 (aldus $T v A$ 2016/2), waar is geoordeeld dat als de vordering op de 403-maatschappij wegens verjaring niet meer afdwingbaar is, dit ook geldt voor de 403 -vordering.

90. Zie Asser/Maeijer \& Kroeze 2- $I * 2015 / 583$, waar wordt opgemerkt dat de onafhankelijkheid van de vorderingen op de moeder- en de 403-maatschappij meebrengt dat als de crediteur de verjaring van deze vorderingen wil voorkomen, hij deze verjaring ten aanzien van beide vorderingen moet stuiten. Zie bevestigend met betrekking tot hoofdelijkheid in algemene zin Asser/Sieburgh 6-I 2016/119. 
hebben op de moedermaatschappij. Als de vordering op de 403-maatschappij is verjaard, kan de crediteur de nakoming daarvan niet meer afdwingen. ${ }^{91}$ De vordering zelf is echter niet tenietgegaan. Na de verjaring bestaat er een natuurlijke verbintenis tussen de crediteur en de 403-maatschappij. ${ }^{92}$ Omdat de crediteur nog steeds een vordering heeft op de 403-maatschappij is het bijzondere karakter van de dynamische 403-vordering niet relevant. Dit houdt in dat op dit punt dezelfde rechtsgevolgen gelden als bij de duiding van de 403-vordering als een hoofdelijke vordering. De crediteur kan nog steeds een beroep doen op de 403-verklaring en heeft uit dien hoofde een 403-vordering op de moedermaatschappij. Dit betreft een zelfstandige vordering die onafhankelijk van de vordering op de 403-maatschappij verjaart. ${ }^{93}$

De Rechtbank Den Haag heeft in 2006 de 403 -vordering geduid als een nevenrecht dat geen afhankelijk recht is. ${ }^{94} \mathrm{Zij}$ overweegt dat een crediteur op grond van de 403-verklaring een vordering heeft op de moedermaatschappij die naast en los van de vordering op de 403-maatschappij bestaat, maar die wel op grond van art. 6:142 BW mee overgaat als de vordering op de 403-maatschappij aan een derde wordt overgedragen. Deze duiding van de 403-vordering brengt volgens de rechtbank mee dat de vordering niet op dezelfde voet verjaart als de vordering op de 403-maatschappij.

Ik heb eerder de duiding van de 403-vordering als een nevenrecht afgewezen omdat de vordering op de 403-maatschappij niet kwalificeert als hoofdvordering. ${ }^{95}$ Hoewel ik het dus niet eens ben met de rechtbank dat zij de 403 -vordering als zodanig duidt, laat de uitspraak wel zien wat het gevolg is van het analoog van toepassing zijn van art. 6:142 BW ten aanzien van de 403-vordering. Hoewel de grondslag van de duiding van de 403-vordering verschillend is, zijn de uitkomsten hetzelfde. Dit betekent dat als art. 6:142 BW analoog van toepassing is op de 403-vordering, de moedermaatschappij de nakoming van deze vordering niet kan afweren met een beroep op de verjaring van de vordering op de 403-maatschappij. ${ }^{96}$

De vierde en laatste duiding van de 403-vordering houdt in dat de bepalingen inzake borgtocht analoog van toepassing zijn ten aanzien van de 403-aansprakelijkheid. In dat geval leidt de verjaring van de vordering van een crediteur op de 403-maatschappij er wel toe dat de moedermaatschappij is bevrijd van haar verplichting op grond van de 403-verklaring. Op grond van art. 7:853 BW gaat

91. Asser/Sieburgh 6-II 2017/387 en Sikkema, in: GS Verbintenissenrecht, art. 6:3 BW, aant. 6.

92. Asser/Sieburgh 6-II 2017/390 en Valk - T\&C Burgerlijk Wetboek, art. 6:3 BW, aant. 3.

93. E.C.A. Nass 2019, p. 225.

94. Rb. Den Haag 5 juli 2006, JOR 2007/53, m.nt. Verdaas (NCM/Den Heijer Beheer), r.o. 3.5 en 3.6.

95. Zie $\S 6.2 .3$.

96. E.C.A. Nass 2019, p. 225. 
een aanspraak uit hoofde van borgtocht teniet als de vordering op de hoofdschuldenaar verjaart. $^{97}$

In afbeelding 6.3 heb ik de gevolgen van de verschillende duidingen van de 403-vordering uiteengezet:

\begin{tabular}{|l|c|c|c|c|}
\hline \multirow{2}{*}{$\begin{array}{l}\text { Kan de moedermaatschappij een beroep doen } \\
\text { op de omstandigheid dat }\end{array}$} & \multicolumn{4}{|c|}{ Duiding van de 403-vordering } \\
\cline { 2 - 5 } & Hoofdelijk & Dynamisch & Art. 6:142 & Borgtocht \\
\hline De vordering op de 403-maatschappij is verjaard? & Nee & Nee & Nee & Ja \\
\hline
\end{tabular}

Afbeelding 6.3

\subsubsection{Subsidiaire aansprakelijkheid van de moedermaatschappij}

Als de 403-vordering wordt geduid als een hoofdelijke vordering, heeft de crediteur op grond van art. 6:7 BW jegens de moeder- en de 403-maatschappij een vordering tot nakoming van het geheel. Dat wil zeggen dat hij ook van de moedermaatschappij nakoming kan vorderen van het volledige bedrag van de vordering of de door de 403-maatschappij te leveren prestatie. De crediteur kan naar vrije keuze een van beide aansprakelijk stellen. ${ }^{98}$ Hij is niet gehouden om eerst te proberen om zich op de 403-maatschappij te verhalen voordat hij zich tot de moedermaatschappij kan wenden. Nass wijst erop dat als de crediteur de moedermaatschappij aansprakelijk stelt, deze wel een redelijke termijn moet krijgen om vast te stellen dat de crediteur een rechtsgeldige vordering op haar heeft. ${ }^{99}$

Indien de moedermaatschappij een vordering op grond van de 403-verklaring voldoet, zal zij doorgaans een regresvordering krijgen op de 403-maatschappij en wordt zij gesubrogeerd in de rechten van de crediteur van wie zij de vordering heeft voldaan. ${ }^{100}$ Dit is slechts anders als de desbetreffende vordering de moedermaatschappij geheel of gedeeltelijk aanging. Nass noemt als voorbeeld dat in de onderlinge verhouding tussen de moeder- en de 403-maatschappij afspraken zijn gemaakt over de interne draagplicht. ${ }^{101} \mathrm{Zij}$ merkt daarnaast

97. Bartman 2015, p. 810 . Zie E.C.A. Nass 2019, p. 224, die van mening is dat de verjaring van de vordering op de 403-maatschappij in een dergelijk geval meebrengt dat de 403-vordering is verjaard - en niet dat deze teniet is gegaan.

98. Ramanna 2008, p. 17 en Beckman 2011, p. 251.

99. E.C.A. Nass 2019, p. 201.

100. Houwen, Schoonbrood-Wessels \& Schreurs 1993, p. 830-833, Asser/Maeijer \& Kroeze 2-I* 2015/583 en E.C.A. Nass 2019, p. 233-234.

101. E.C.A. Nass 2019, p. 234. 
op dat de moedermaatschappij de regresvordering op de 403-maatschappij kan verrekenen met een schuld tegenover de 403-maatschappij. ${ }^{102}$

Verschillende auteurs zijn van mening dat de mogelijkheid voor een crediteur om de moedermaatschappij aan te spreken tot nakoming zonder dat hij eerst heeft geprobeerd om de vordering op de 403-maatschappij te verhalen, niet strookt met het idee dat de aansprakelijkheid van de moedermaatschappij dient als compensatie voor de crediteur omdat hij de jaarrekening van de 403-maatschappij niet kan inzien. ${ }^{103}$ Aangezien de crediteur de jaarrekening niet kan inzien, kan hij niet (mede) aan de hand daarvan schatten hoe groot het risico is dat zijn vordering op de 403-maatschappij niet (volledig) zal worden voldaan. Deze auteurs achten het wenselijk dat de crediteur zich pas kan verhalen op de moedermaatschappij als dit risico zich verwezenlijkt en de 403-maatschappij tekortschiet in de nakoming. ${ }^{104}$ Ik kom hier later op terug. ${ }^{105}$

Niels noemt daarnaast nog een andere reden waarom subsidiaire aansprakelijkheid van de moedermaatschappij volgens hem wenselijk is. ${ }^{106}$ Hij merkt op dat de moedermaatschappij vaak een holding is die zich niet bezighoudt met de levering van goederen of diensten. De moedermaatschappij zal doorgaans dus niet in staat zijn om een niet in geld luidende verplichting van de 403-maatschappij te voldoen. ${ }^{107} \mathrm{Zij}$ kan dan hooguit de schade vergoeden die de crediteur lijdt door de niet-nakoming. Overigens merk ik op dat als de crediteur de moedermaatschappij aansprakelijk heeft gesteld voor een niet in geld luidende verplichting die deze niet kan nakomen en de 403-maatschappij vervolgens kenbaar maakt de verplichting te zullen voldoen, de crediteur de nakoming door de 403-maatschappij niet kan weigeren. ${ }^{108}$

Ook als de 403-vordering wordt geduid als een dynamische vordering en als art. 6:142 BW analoog van toepassing is op deze vordering, kan de crediteur direct de moedermaatschappij aansprakelijk stellen zonder eerst te hoeven

102. E.C.A. Nass 2019 , p. 236

103. De compensatie voor een crediteur bestaat uit twee onderdelen: een vordering op de moedermaatschappij op grond van de 403-verklaring en de mogelijkheid om de geconsolideerde jaarrekening van de moedermaatschappij in te zien. Zie $\$ 3.4 .1$.

104. Niels 2010, p. 27-28, Biemans 2011, p. 306 en Wibier 2015, p. 783. Zie ook Schoordijk 2003 , p. 62, die betoogt dat de 403-aansprakelijkheid een vorm van borgtocht is en dat een moedermaatschappij om die reden subsidiair aansprakelijk is. Ik heb eerder echter geconcludeerd dat het eenzijdige en ongerichte karakter van de 403-verklaring eraan in de weg staat om de aansprakelijkheid van de moedermaatschappij als borgtocht te kwalificeren (zie $\S 6.2 .4)$.

105. Zie $\S 6.4 .4$.

106. Niels 2010, p. 27.

107. Een moedermaatschappij is op grond van de 403-verklaring zowel aansprakelijk voor de geldelijke schulden als de niet in geld luidende verplichtingen van de 403 -maatschappij. Zie $\S 4.2$.

108. Houwen, Schoonbrood-Wessels \& Schreurs 1993, p. 830 en E.C.A. Nass 2019, p. 193. 
proberen om zich op de 403-maatschappij te verhalen. Beide duidingen van de 403-vordering zijn een variant op de duiding als een hoofdelijke vordering met als bijzonder kenmerk dat slechts degenen met een vordering op de 403-maatschappij een beroep kunnen doen op de 403-verklaring en uit dien hoofde een vordering hebben op de moedermaatschappij, respectievelijk dat de overgang van de vordering op de 403-maatschappij met zich brengt dat ook de 403-vordering mee overgaat. Aangezien deze kenmerken niet van belang zijn voor het antwoord op de vraag of een crediteur eerst moet proberen om zijn vordering op de 403-maatschappij voldaan te krijgen voordat hij zich tot de moedermaatschappij mag wenden, gelden op dit punt dezelfde rechtsgevolgen als bij de duiding van de 403 -vordering als een hoofdelijke vordering.

In het geval dat de bepalingen inzake borgtocht analoog van toepassing zijn ten aanzien van de aansprakelijkheid van een moedermaatschappij op grond van een 403-verklaring, zal de crediteur zich wel eerst op de 403-maatschappij moeten proberen te verhalen voordat hij de moedermaatschappij aansprakelijk kan stellen. Op grond van art. 7:855 lid $1 \mathrm{BW}$ is een borg slechts gehouden zijn verplichting te voldoen als de hoofdschuldenaar tekortschiet in de nakoming. ${ }^{109}$

In afbeelding 6.4 heb ik de gevolgen van de verschillende duidingen van de 403-vordering uiteengezet:

\begin{tabular}{|l|c|c|c|c|}
\hline \multirow{2}{*}{$\begin{array}{l}\text { Kan de moedermaatschappij een } \\
\text { beroep doen op de omstandigheid dat }\end{array}$} & \multicolumn{3}{|c|}{ Duiding van de 403-vordering } \\
\cline { 2 - 5 } & Hoofdelijk & Dynamisch & Art. 6:142 & Borgtocht \\
\hline $\begin{array}{l}\text { De moedermaatschappij subsidiair } \\
\text { aansprakelijk is }\end{array}$ & Nee & Nee & Nee & Ja \\
\hline
\end{tabular}

Afbeelding 6.4

\subsubsection{Zelfstandig cederen van de vorderingen op de moeder-en de 403-maatschappij}

6.3.6.a Duiding van de 403-vordering als een hoofdelijke vordering

Een crediteur heeft op grond van art. 6:7 BW tegenover ieder van de hoofdelijk schuldenaren recht op nakoming van het geheel. Uit deze bepaling is niet op te maken of dit betekent dat de crediteur één vordering heeft met meerdere schuldenaren of dat er evenzoveel vorderingen zijn als schuldenaren. De heersende leer in de literatuur is echter dat het laatste standpunt moet worden

109. Op grond van art. 7:857 jo. art. 7:862 BW kan ten aanzien van een niet-particuliere borg van deze bepaling worden afgeweken. Zie met betrekking tot borgtocht in algemene zin Bergervoet 2014, p. 103-106. 
gevolgd. ${ }^{110}$ Biemans merkt op dat hoewel de schuldenaren tot dezelfde prestatie verplicht zijn er niettemin verschillen kunnen bestaan met betrekking tot onder meer verjaring, voorrang, voorwaardelijkheid en verweermiddelen. ${ }^{111}$ Het is bijvoorbeeld mogelijk dat een van de hoofdelijk schuldenaren de nakoming van zijn verplichting kan opschorten omdat de crediteur een opeisbare vordering - van de schuldenaar - jegens hem niet nakomt. ${ }^{112}$ Een dergelijk verweermiddel komt enkel toe aan de schuldenaar in wiens persoon dit recht is ontstaan. ${ }^{113}$

Toegepast op het groepsregime betekent bovenstaand standpunt dat een crediteur twee zelfstandige vorderingen heeft. Een op de moeder- en een op de 403-maatschappij. Nass en Nass zijn echter van mening dat het bijzondere karakter van de hoofdelijke aansprakelijkheid van een moedermaatschappij op grond van een 403-verklaring met zich brengt dat daarbij van dit standpunt moet worden afgeweken. Volgens hen is er sprake is van één vordering met twee schuldenaren. ${ }^{114} \mathrm{Zij}$ betogen dat er twee verbintenissen zijn: een verbintenis tussen de crediteur en de 403-maatschappij en een verbintenis tussen de crediteur en de moedermaatschappij, maar dat de crediteur tegenover hen slechts één vordering heeft.

Ik kan mij niet vinden in het standpunt van Nass en Nass. Naar mijn mening volgt uit het arrest Eikendal q.q./Lentink dat een crediteur twee aparte vordering heeft: een op de moeder- en een op de 403-maatschappij. ${ }^{115}$ In casu heeft de crediteur finale kwijting verleend aan de 403-maatschappij. Hierdoor is zijn vordering op de 403-maatschappij tenietgegaan. ${ }^{116}$ De Hoge Raad oordeelt dat de crediteur zich niettemin nog steeds op grond van de 403-verklaring op de moedermaatschappij kan verhalen. Hij overweegt dat de aansprakelijkheid van de moedermaatschappij berust op een zelfstandige verbintenis jegens de crediteur, waarvan zelfstandig nakoming kan worden gevorderd. Als een crediteur afstand doet van zijn vordering op de 403-maatschappij, tast dat zijn vordering op de moedermaatschappij niet aan.

110. Spierings 2016, p. 223 en Van Schilfgaarde in zijn annotaties onder HR 11 april 2014, NJ 2014/309 (UWV/Econcern) en HR 20 maart 2015, NJ 2015/361 (Minister van Financiën/ $V E B$ c.s.). Zie bevestigend met betrekking tot hoofdelijkheid in algemene zin Biemans 2011, p. 286, Van Boom 2016, p. 21 en Asser/Sieburgh 6-I 2016/100.

111. Biemans 2011, p. 286.

112. Zie art. 6:52 BW en $\S 6.3 .3 . \mathrm{b}$

113. Asser/Sieburgh 6-I 2016/119.

114. A.G.S. Nass \& E.C.A. Nass 2014, p. 738-739, A.G.S. Nass \& E.C.A. Nass 2017, p. 152-153 en E.C.A. Nass 2019, p. 215-216.

115. HR 3 april 2015, JOR 2015/191, m.nt. Faber en Vermunt (Eikendal q.q./Lentink), r.o. 3.6.2. Zie uitgebreider over dit arrest $\S 6$ 6.2.2.c en $\S 6.3 .2$.

116. Zie art. 6:160 BW. 
Verschillende auteurs, waaronder Van der Sangen, merken op dat de hoofdelijke aansprakelijkheid van de moedermaatschappij op grond van de 403-verklaring meebrengt dat de vorderingen op de moeder- en de 403-maatschappij onafhankelijk van elkaar bestaan en dat de crediteur deze vorderingen daarom zelfstandig kan cederen. ${ }^{117}$ Een crediteur kan zijn vordering op de 403-maatschappij cederen aan een derde, terwijl hij zelf de vordering op de moedermaatschappij houdt en vice versa.

Ik wijs op twee discussiepunten in de literatuur met betrekking tot de gevolgen van het zelfstandig cederen van de vordering op de moeder- of de 403-maatschappij - los van de andere vordering. Ten eerste is het de vraag of het cederen van de vordering op de 403-maatschappij tot gevolg heeft dat ook de cessionaris op grond van de 403-verklaring een vordering op de moedermaatschappij krijgt - naast de bestaande 403-vordering die bij de cedent is achtergebleven. Onder meer De Neve en Verdaas beantwoorden deze vraag positief. ${ }^{118} \mathrm{Zij}$ merken op dat de 403-maatschappij na de cessie tegenover de cessionaris een schuld heeft die onder de reikwijdte van de 403-aansprakelijkheid valt en dat de cessionaris uit dien hoofde de moedermaatschappij aansprakelijk kan stellen.

Met Biemans ben ik echter van mening dat het cederen van de vordering op de 403-maatschappij niet leidt tot een nieuwe vordering op de moedermaatschappij. ${ }^{119}$ Een 403 -vordering op de moedermaatschappij ontstaat op hetzelfde moment dat de crediteur een vordering op de 403-maatschappij krijgt - of, indien de 403-verklaring nog niet is gedeponeerd op het moment dat de vordering op de 403-maatschappij ontstaat, op het moment dat deze verklaring wordt gedeponeerd. Als een moedermaatschappij eenmaal op grond van de 403-verklaring aansprakelijk is voor een schuld van de 403-maatschappij, ontstaat er nadien voor haar geen nieuwe - extra - aansprakelijkheid meer voor de desbetreffende schuld. Indien de crediteur zijn vordering op de 403-maatschappij cedeert aan een derde, is er geen sprake van een nieuwe schuld voor de 403-maatschappij. Door de cessie verandert slechts degene tegenover wie de 403-maatschappij aansprakelijk is. Het betreft dezelfde schuld van de 403-maatschappij waarvoor de moedermaatschappij reeds op grond van de 403-verklaring aansprakelijk is. Door de cessie ontstaat daarom ook geen nieuwe aansprakelijkheid voor de moedermaatschappij op grond van deze verklaring.

117. Notenboom 2017, p. 127 en Van der Sangen 2017, p. 209. Zie bevestigend met betrekking tot hoofdelijkheid in algemene zin Biemans 2011, p. 287, Asser/Sieburgh 6-I 2016/100. Zie ook A.G.S. Nass \& E.C.A. Nass 2014, p. 738 en E.C.A. Nass 2019, p. 220. Zie Vranken 1999 , p. 270, die erop wijst dat zolang de cessie niet aan de moeder- of de 403-maatschappij is meegedeeld, zij bevrijdend kunnen betalen aan de oorspronkelijke crediteur.

118. De Neve 2002, p. 241, Verdaas 2008, p, 305-306 en E.C.A. Nass 2019, p. 220.

119. Biemans 2011, p. 307-308. 
Een tweede discussiepunt met betrekking tot de gevolgen van het zelfstandig cederen van de vordering op de moeder- of de 403-maatschappij komt van Vranken. Hij betoogt dat als een crediteur twee hoofdelijk schuldenaren heeft en de vordering op een van beide wordt gecedeerd, de crediteur daarmee de bevoegdheid opgeeft om de andere vordering te gelde te maken. ${ }^{120}$ Enkel de cessionaris kan dan nog de aan hem gecedeerde vordering innen. Vranken baseert dit standpunt op een analoge toepassing van de voorrangsregel uit het arrest Zuidgeest/Furness. ${ }^{121}$ Dit arrest heeft betrekking op een deelcessie van een vordering. De Hoge Raad oordeelt dat de cessionaris, in de onderlinge verhouding tot de cedent, voorrang geniet bij de nakoming van de vordering totdat het aan hem gecedeerde deel van de vordering is voldaan.

Toegepast op het groepsregime houdt het standpunt van Vranken in dat als een crediteur zijn vordering op de moeder- of de 403-maatschappij cedeert aan een derde, hij de andere vordering niet meer kan innen. Slechts de cessionaris kan nog de aan hem gecedeerde vordering te gelde maken.

Biemans is het niet eens met het standpunt van Vranken. ${ }^{122}$ Hij merkt terecht op dat dit standpunt in strijd is met het principe van hoofdelijke aansprakelijkheid en kan leiden tot benadeling van de schuldenaar van de overgedragen vordering omdat die als eerste aansprakelijk zal worden gesteld - voor de cessie zou de crediteur zich naar vrije keuze op een van beide hoofdelijk schuldenaren kunnen verhalen. Daarnaast is het volgens Biemans onduidelijk of, en zo ja door wie, de schuldenaar van de niet-overgedragen vordering aansprakelijk kan worden gesteld indien de schuldenaar van de overgedragen vordering niet in staat is deze te voldoen. Ik sluit mij aan bij deze kritiek. Het standpunt van Vranken zou er bijvoorbeeld toe kunnen leiden dat als een crediteur de 403-vordering cedeert aan een derde, de moedermaatschappij voortaan in eerste instantie moet instaan voor de nakoming. Indien de moedermaatschappij niet in staat is om haar schuld te voldoen, is het onduidelijk of de 403-maatschappij alsnog aansprakelijk kan worden gesteld en door wie.

Naast bovengenoemde discussiepunten wijs ik ook op een tweetal kritiekpunten in de literatuur met betrekking tot het zelfstandig cederen van de vordering op de moeder- of de 403-maatschappij - los van de andere vordering. Ten eerste wijzen verschillende auteurs erop dat als de crediteur een van beide vorderingen cedeert aan een derde, terwijl hij zelf de andere vordering houdt, de moedermaatschappij dan op grond van de 403-verklaring aansprakelijk is tegenover een partij die zelf geen vordering (meer) heeft op de 403-maatschappij. ${ }^{123}$ Dit

120. Vranken 1999, p. 270.

121. HR 19 december 1997, NJ 1998/690, m.nt. Kleijn (Zuidgeest/Furness), r.o. 5.1.

122. Biemans 2011, p. 289.

123. Verdaas 2008, p. 306, Wibier 2008, p. 180 en Wibier 2015, p. 783. 
sluit niet aan bij het idee dat de aansprakelijkheid van de moedermaatschappij dient als compensatie voor een crediteur omdat die de jaarrekening van de 403-maatschappij niet kan inzien. ${ }^{124}$ Als een partij geen vordering (meer) heeft op de 403-maatschappij, heeft hij geen gebrek inzicht en hoeft hij dus niet te worden gecompenseerd. Ik kom hier later op terug. ${ }^{125}$

Een tweede kritiekpunt is dat de mogelijkheid om de vorderingen op de moeder- en de 403-maatschappij onafhankelijk van elkaar te cederen, kan worden misbruikt. Een crediteur kan bijvoorbeeld een van beide vorderingen cederen en vervolgens zelf de andere vordering innen. Ten eerste krijgt de crediteur dan tweemaal voordeel, maar daarnaast leidt dit tot benadeling van de cessionaris aangezien de aan hem gecedeerde vordering is tenietgegaan. ${ }^{126,127}$ Een andere mogelijkheid van misbruik is dat de crediteur de vorderingen op de moederen de 403-maatschappij aan twee verschillende partijen cedeert. Hij krijgt dan opnieuw twee keer voordeel en enkel de cessionaris die als eerste de vordering int, krijgt deze voldaan.

\subsection{6.b Duiding van de 403-vordering als een dynamische vordering}

Als de 403-vordering wordt geduid als een dynamische vordering, komt deze toe aan degene met de corresponderende vordering op de 403-maatschappij. Enkel de crediteuren van de 403-maatschappij kunnen een beroep doen op de 403-verklaring en hebben uit dien hoofde een vordering op de moedermaatschappij. Indien een crediteur zijn vordering op de 403-maatschappij cedeert aan een derde, kan hij geen beroep meer doen op de 403-verklaring en heeft hij daarom ook geen 403-vordering meer op de moedermaatschappij. ${ }^{128}$ Het is de cessionaris die vanaf dat moment een beroep kan doen op deze verklaring en uit dien hoofde een vordering heeft op de moedermaatschappij. Omgekeerd is het niet mogelijk om de 403-vordering - onafhankelijk van de vordering op de 403-maatschappij - te cederen.

Ten Voorde en Biemans betogen dat als een crediteur zijn vordering op de 403-maatschappij cedeert nadat de moedermaatschappij de 403-verklaring

124. De compensatie voor een crediteur bestaat uit twee onderdelen: een vordering op de moedermaatschappij op grond van de 403-verklaring en de mogelijkheid om de geconsolideerde jaarrekening van de moedermaatschappij in te zien. Zie $\S 3.4 .1$.

125. Zie $\S 6.4 .5$.

126. De Neve 2002, p. 241 en Schoordijk 2003, p. 67.

127. Ik merk op dat een dergelijke handelswijze mogelijk een onrechtmatige daad is. De cessionaris kan dan een vordering tot schadevergoeding instellen tegen de cedent. Indien de cedent echter is gefailleerd of de vordering niet kan worden geïnd, blijft de cessionaris (grotendeels) met lege handen achter.

128. Zie ook $\S 6.2 .2 . b$. 
heeft ingetrokken, ${ }^{129}$ de cessionaris geen beroep kan doen op deze verklaring en daarom geen 403 -vordering op de moedermaatschappij krijgt. ${ }^{130}$ Hierdoor wordt de cessionaris volgens hen ten onrechte benadeeld. Daarnaast leidt de cessie ertoe dat ook de cedent geen beroep meer kan doen op de 403-verklaring waardoor de moedermaatschappij naar de mening van deze auteurs is bevrijd van haar aansprakelijkheid voor de desbetreffende schuld van de 403-maatschappij.

Bovenstaande redenering is mijns inziens niet juist. Op grond van art. 2:404 lid 2 BW blijft de moedermaatschappij na de intrekking van de 403-verklaring aansprakelijk voor de schulden die voortvloeien uit de rechtshandelingen die de 403-maatschappij heeft verricht tot het moment dat de moedermaatschappij tegenover de crediteur een beroep kan doen op de intrekking. ${ }^{131}$ Aangezien de rechtshandeling waaruit de desbetreffende schuld van de 403-maatschappij is voortgevloeid, is verricht voor de intrekking van de 403-verklaring, blijft de moedermaatschappij hiervoor aansprakelijk. Dat de crediteur zijn vordering op de 403-maatschappij heeft gecedeerd aan een derde doet daar niet aan af. Na de cessie kan de cessionaris onverminderd een beroep doen op de (ingetrokken) 403-verklaring en heeft hij uit dien hoofde een vordering op de moedermaatschappij. Mocht de moedermaatschappij voornemens zijn om de overblijvende aansprakelijkheid na de intrekking van de 403-verklaring te beëindigen, dan kan de cessionaris hiertegen in verzet komen en heeft hij onder omstandigheden recht op een vervangende waarborg voor de voldoening van zijn vordering op de 403-maatschappij. ${ }^{132}$

\subsection{6.c Analoge toepassing van art. 6:142 BW}

Op grond van art. 6:142 BW leidt de overgang van een vordering ertoe dat de bij die vordering behorende nevenrechten mee overgaan. ${ }^{133}$ Als deze bepaling analoog van toepassing is op de 403 -vordering brengt de cessie van de vordering op de 403-maatschappij met zich dat de cessionaris ook de 403-vordering verkrijgt. ${ }^{134}$ Dit volgt ook uit de eerder aangehaalde uitspraak van de

129. Zie art. 2:404 lid $1 \mathrm{BW}$ en $\S 7.2$.

130. Ten Voorde 2006, p. 120 en Biemans 2011, p. 307-308. Zie ook Van der Kraan 2012, p. 73 en Van der Kraan 2013, p. 159, die het recht van een crediteur om de moedermaatschappij op grond van de 403-verklaring aansprakelijk te stellen duidt als een wilsrecht (zie § 6.2.5). Ik merk op dat deze auteurs niet verwijzen naar de 'dynamische' 403-vordering maar naar de opmerking van Bartman in zijn annotatie onder HR 28 juni 2002, JOR 2002/136 (Akzo/ $I N G$ ), dat een 403 -vordering 'ontspringt' uit de 403 -verklaring. Ik heb eerder opgemerkt dat de duiding van de 403-vordering als een dynamische vordering een uitwerking is van deze opmerking van Bartman (zie § 6.2.2.a).

131. Zie $\S 8.2$.

132. Zie art. 2:404 lid 3 tot en met $6 \mathrm{BW}$ en $\S 8.6$ tot en met $\S 8.10$.

133. Asser/Sieburgh 6-II 2017/257 en Pitlo/Reehuis \& Heisterkamp 2019/274.

134. Verdaas 2008, p. 306 en Rongen 2012, p. 1300-1302. 
Rechtbank Den Haag uit 2006 inzake NCM/Den Heijer Beheer. ${ }^{135}$ De rechtbank duidt de 403-vordering als een nevenrecht dat geen afhankelijk recht is. Zij oordeelt dat de cessie van de vordering van de crediteur op de 403-maatschappij betekent dat ook de 403-vordering op de cessionaris is overgegaan. Hoewel ik eerder de duiding van de 403-vordering als een nevenrecht heb afgewezen, ${ }^{136}$ is de uitkomst hetzelfde als bij een analoge toepassing van art. 6:142 $\mathrm{BW}$ ten aanzien van deze vordering. ${ }^{137}$

De analoge toepassing van art. 6:142 BW ten aanzien van de 403-vordering brengt mijns inziens ook mee dat deze vordering naar zijn aard niet zelfstandig overdraagbaar is. ${ }^{138,139}$ De verbondenheid van de 403-vordering met de vordering op de 403-maatschappij - in de zin dat de overgang van de vordering op de 403-maatschappij meebrengt dat de 403-vordering mee overgaat - verhindert dat de 403-vordering zelfstandig kan worden overgedragen. Een andere uitkomst zou ook tot de opmerkelijke situatie kunnen leiden dat een crediteur eerst zijn 403-vordering overdraagt aan een derde, en later zijn vordering op de 403-maatschappij overdraagt aan een andere partij. Dit zou ook verschillende vragen oproepen met betrekking tot het recht van de partij op wie de vordering op de 403-maatschappij is overgegaan om zich op grond van de 403-verklaring op de moedermaatschappij te verhalen. Bijvoorbeeld of de latere overgang van de vordering op de 403-maatschappij meebrengt dat de verkrijgende partij op grond van art. 6:142 BW ook de eerder overgedragen 403-vordering verkrijgt? En maakt het daarbij nog verschil als de 403-vordering door middel van een stille cessie is overgedragen zonder dat degene aan wie de vordering op de 403-maatschappij is overgedragen hiermee bekend is?

\subsection{6.d Analoge toepassing van de bepalingen inzake borgtocht}

Indien de bepalingen inzake borgtocht analoog van toepassing zijn op de 403-aansprakelijkheid, is de aansprakelijkheid van de moedermaatschappij afhankelijk van de verbintenis tussen de crediteur en de 403-maatschappij. ${ }^{140}$ Als de crediteur de vordering op de 403-maatschappij cedeert, leidt dat ertoe dat de 403-vordering mee overgaat. Omgekeerd brengt het afhankelijke

135. Rb. Den Haag 5 juli 2006, JOR 2007/53, m.nt. Verdaas (NCM/Den Heijer Beheer), r.o. 3.53.7. Zie $\S 6.3 .4$.

136. Zie $\S 6.2 .3$.

137. Zie ook E.C.A. Nass 2019, p. 221.

138. Zie art. 3:83 lid $1 \mathrm{BW}$.

139. Zie Van Dooren 2015, p. 383, waar ik nog het standpunt verdedigde dat de crediteur de 403-vordering onafhankelijk van de vordering op de 403-maatschappij kan cederen aan een derde, omdat de gezamenlijke overgang ex art. 6:142 BW niet van toepassing is op de overgang van de 403 -vordering en op dit punt daarom de rechtsgevolgen overeenkomstig de duiding als hoofdelijke vordering zouden gelden. Zie ook E.C.A. Nass 2019, p. 221.

140. Zie art. 7:851 lid $1 \mathrm{BW}$. 
karakter van de aansprakelijkheid van de moedermaatschappij met zich dat de crediteur de 403 -vordering niet zelfstandig kan cederen. ${ }^{141}$

In afbeelding 6.5 heb ik de gevolgen van de verschillende duidingen van de 403-vordering uiteengezet:

\begin{tabular}{|l|c|c|c|c|}
\hline \multirow{2}{*}{$\begin{array}{l}\text { Rechtsgevolgen van de duiding van de } \\
\text { 403-vordering }\end{array}$} & \multicolumn{3}{|c|}{ Duiding van de 403-vordering } \\
\cline { 2 - 5 } & Hoofdelijk & Dynamisch & Art. 6:142 & Borgtocht \\
\hline $\begin{array}{l}\text { Kan de crediteur de vordering op de } \\
\text { 403-maatschappij zelfstandig cederen? }\end{array}$ & Ja & Nee & Nee & Nee \\
\hline $\begin{array}{l}\text { Kan de crediteur de vordering op de } \\
\text { moedermaatschappij zelfstandig cederen? }\end{array}$ & Ja & Nee & Nee & Nee \\
\hline
\end{tabular}

Afbeelding 6.5

\subsubsection{Zelfstandig verpanden van de vorderingen op de moeder-en de 403-maatschappij}

\subsection{7.a Duiding van de 403-vordering als een hoofdelijke vordering}

Hierboven heb ik er al op gewezen dat als de 403-vordering wordt geduid als een hoofdelijke vordering de crediteur de vorderingen op de moeder- en de 403-maatschappij onafhankelijk van elkaar kan cederen. ${ }^{142}$ Verdaas merkt op dat aangezien de vorderingen zelfstandig overdraagbaar zijn, zij op grond van art. 3:228 BW ook zelfstandig kunnen worden verpand. ${ }^{143}$ Als de crediteur de vordering op de 403-maatschappij verpandt, heeft de pandhouder niet tevens een pandrecht op vordering op de moedermaatschappij en vice versa. ${ }^{144}$

Evenals bij het zelfstandig cederen van een hoofdelijke vordering, ${ }^{145}$ pleit Vranken bij het verpanden van een dergelijke vordering voor een analoge toepassing van de voorrangsregel uit het arrest Zuidgeest/Furness. ${ }^{146}$ Als een crediteur een pandrecht vestigt op een van zijn hoofdelijke vorderingen, geeft hij daarmee volgens Vranken het recht op om de andere vordering te gelde te maken. ${ }^{147}$ Dit standpunt moet mijns inziens om dezelfde redenen worden verworpen als bij

141. Verdaas 2008, p. 305, Biemans 2011, p. 306, A.G.S. Nass \& E.C.A. Nass 2014, p. 737 en E.C.A. Nass 2019, p. 221. Zie bevestigend met betrekking tot borgtocht in algemene zin Asser/Van Schaick 7-VIII 2018/87.

142. Zie $\S$ 6.3.6.a.

143. Verdaas 2008 , p. 307.

144. E.C.A. Nass 2019 , p. 219. Zie bevestigend met betrekking tot hoofdelijkheid in algemene zin D.F.H. Stein, in: GS Vermogensrecht, art. 3:227 BW, aant. 6.4.3.2.

145. Zie $\S$ 6.3.6.a.

146. HR 19 december 1997, NJ 1998/690, m.nt. Kleijn (Zuidgeest/Furness), r.o. 5.1.

147. Vranken 1999, p. 269-270. 
cessie. Kort gezegd is de door Vranken betoogde voorrangsregel in strijd met het principe van hoofdelijke aansprakelijkheid en leidt het tot een onevenredige benadeling van de hoofdelijke schuldenaar van de verpande vordering. ${ }^{148}$

Tot slot merk ik nog op dat het vestigen van een pandrecht op de vordering op de moeder- of de 403-maatschappij - zonder dat ook de andere vordering wordt verpand - tot onwenselijke situaties kan leiden. In het geval dat de verpanding van de vordering is meegedeeld aan de schuldenaar, komt het recht om deze vordering te innen op grond van art. 3:246 BW toe aan de pandhouder. De crediteur - als pandgever - is slechts bevoegd om de vordering te innen indien hij daarvoor toestemming van de pandhouder of een machtiging van de kantonrechter heeft gekregen. ${ }^{149}$ Zo wordt voorkomen dat de crediteur naar vrije keuze de vordering kan innen waardoor het pandrecht zou vervallen. Deze waarborg ex art. 3:246 BW wordt echter tenietgedaan doordat de crediteur nog steeds de andere niet-verpande vordering kan innen. Als hij dit doet, verdwijnt alsnog de verpande vordering inclusief het daarop rustende pandrecht.

\subsection{7.b Duiding van de 403-vordering als een dynamische vordering}

Als de 403-vordering wordt geduid als een dynamische vordering komt deze toe aan degene met de corresponderende vordering op de 403-maatschappij. Enkel de crediteuren van de 403-maatschappij kunnen een beroep doen op de 403-verklaring en hebben uit dien hoofde een vordering op de moedermaatschappij. Aangezien de 403-vordering altijd toekomt aan degene met de corresponderende vordering op de 403-maatschappij, is eerstgenoemde vordering niet zelfstandig overdraagbaar en kan deze daarom op grond van art. 3:228 BW ook niet worden verpand.

De omstandigheid dat alleen degenen met een vordering op de 403-maatschappij een beroep kunnen doen op de 403-verklaring en uit dien hoofde een vordering hebben op de moedermaatschappij, is niet relevant bij de verpanding van de vordering op de 403-maatschappij. Aangezien de duiding van de 403-vordering als een dynamische vordering een variant is op de duiding als een hoofdelijke vordering, gelden op dit punt daarom de rechtsgevolgen overeenkomstig laatstgenoemde duiding. ${ }^{150}$ Dit betekent dat de crediteur de vordering op de 403-maatschappij zelfstandig kan verpanden. De pandhouder heeft dan niet tevens een pandrecht op de (dynamische) 403 -vordering. ${ }^{151}$

148. Vgl. Biemans 2011, p. 289, die op basis van deze argumenten het standpunt van Vranken met betrekking tot de cessie van een hoofdelijke vordering afwijst. Zie ook Pors 2002, p. 148 , die van mening is dat de crediteur betaling van de niet-verpande vordering niet kan weigeren.

149. D.F.H. Stein, in: GS Vermogensrecht, art. 3:246 BW, aant. 1.4 en 1.4.1.

150. Zie $\S$ 6.3.7.a.

151. E.C.A. Nass 2019, p. 219. 


\subsection{7.c Analoge toepassing van art. 6:142 BW}

Een meerderheidsstandpunt in de literatuur is dat het vestigen van een pandrecht op een vordering met zich brengt dat de pandhouder tevens een pandrecht krijgt op de aan die vordering verbonden nevenrechten. ${ }^{152}$ Ter onderbouwing van dit standpunt wordt gewezen op art. 3:98 BW. Op grond van deze bepaling is de tweede afdeling van titel 4 van Boek 3 BW met betrekking tot de overdracht van goederen van overeenkomstige toepassing op - onder meer - de vestiging van een beperkt recht op een goed. Onder meer Faber en Rongen betogen dat de nauwe band tussen een hoofdvordering en een daaraan verbonden nevenrecht met zich brengt dat de schakelbepaling ex art. 3:98 BW analoog van toepassing is op art. 6:142 BW. ${ }^{153}$ Hierdoor geldt art. 6:142 BW niet alleen als een vordering overgaat, maar ook bij de vestiging van een beperkt recht op de vordering. Als een vordering wordt verpand, krijgt de pandhouder dus tevens een pandrecht op de aan die vordering verbonden nevenrechten.

In het geval dat art. 6:142 $\mathrm{BW}$ analoog van toepassing is ten aanzien van de 403-vordering, leidt bovenstaande ertoe dat als de vordering op de 403-maatschappij wordt verpand de pandhouder ook een pandrecht krijgt op de 403-vordering. ${ }^{154}$

Ik heb eerder opgemerkt dat de analoge toepassing van art. 6:142 BW ten aanzien van de 403-vordering mijns inziens meebrengt dat deze vordering naar zijn aard niet zelfstandig overdraagbaar is. ${ }^{155}$ Op grond van art. 3:228 BW kan deze vordering daarom ook niet zelfstandig worden verpand. ${ }^{156}$

152. Faber 2005, p. 282, Rongen 2012, p. 1290-1291 en Messelink \& Van den Bosch 2017, p. 138. Zie ook Asser/Van Mierlo \& Krzeminski 3-VI 2020/214. Anders: Verdaas 2008, p. 291.

153. Faber 2005, p. 282, Rongen 2012, p. 1290-1291 en Asser/Van Mierlo \& Krzeminski 3-VI $2020 / 214$.

154. Rongen 2012, p. 1302. Evenzo De Neve 2002, p. 240, die de 403-vordering echter duidt als een nevenrecht dat een afhankelijk recht is. Ik heb eerder de duiding van de 403-vordering als een nevenrecht afgewezen omdat de vordering op de 403-maatschappij niet kwalificeert als hoofdvordering (zie $\S 6.2 .3$ ). Anders: Verdaas 2008, p. 307, die opmerkt dat de houder van een pandrecht op een vordering op een 403-maatschappij niet de crediteur is van de desbetreffende vordering. Volgens hem kan de pandhouder daarom de vordering op de moedermaatschappij op grond van de 403-verklaring niet innen. Zie ook Berk 2007, p. 17, die ten onrechte opmerkt dat de Hoge Raad in HR 28 juni 2002, JOR 2002/136 (Akzo/ING) de 403-vordering duidt als een nevenrecht (zie $\S$ 6.3.7.c). Hij vervolgt dat uit dit arrest zou blijken dat de vestiging van een pandrecht op een vordering op de 403-maatschappij niet meebrengt dat de pandhouder ook een pandrecht op de 403-vordering krijgt.

155. Zie $\S$ 6.3.6.c.

156. Zie Van Dooren 2015, p. 383, waar ik nog het standpunt verdedigde dat de crediteur de 403-vordering onafhankelijk van de vordering op de 403-maatschappij kan verpanden, omdat art. 6:142 BW niet - krachtens analoge toepassing van de schakelbepaling ex art. 3:98 BW of anderszins - op de verpanding van het nevenrecht zelf van toepassing is en 
Tot slot wijs ik naar aanleiding van bovenstaande opmerkingen nog op de Akzo/ $I N G$-beschikking van de Hoge Raad. Ik heb eerder opgemerkt ${ }^{157}$ dat uit deze beschikking kan worden afgeleid dat de Hoge Raad art. 6:142 BW niet analoog toepast ten aanzien van de 403-vordering. Kort gezegd heeft de beschikking betrekking op een crediteur die een pandrecht heeft gevestigd op zijn vordering op de 403-maatschappij. Als de moedermaatschappij vervolgens de overblijvende aansprakelijkheid na de intrekking van de 403-verklaring wil beëindigen, wil de pandhouder hiertegen in verzet komen. De Hoge Raad oordeelt echter dat de houder van het pandrecht op de vordering van de crediteur op de 403-maatschappij, geen verzet kan instellen tegen het voornemen van de moedermaatschappij om de overblijvende aansprakelijkheid te beëindigen. ${ }^{158}$ Indien de Hoge Raad art. 6:142 BW analoog van toepassing zou hebben geacht ten aanzien van de 403-vordering, zou de pandhouder tevens een pandrecht hebben gehad op de 403-vordering. Hij zou dan op grond van art. 3:245 BW ter bescherming van de aan hem verpande vordering in verzet hebben kunnen komen tegen het voornemen van de moedermaatschappij om de overblijvende aansprakelijkheid te beëindigen. ${ }^{159}$

\subsection{7.d Analoge toepassing van de bepalingen inzake borgtocht}

Nass betoogt dat als de bepalingen inzake borgtocht analoog van toepassing zijn op de 403-aansprakelijkheid, dit meebrengt dat als er een pandrecht wordt gevestigd op de vordering van een crediteur op de 403-maatschappij, de pandhouder tevens een pandrecht krijgt op de 403 -vordering. ${ }^{160}$ Dit is mijns inziens echter strikt genomen niet juist. Ik licht dit hieronder toe.

In het arrest Rabobank/Stormpolder heeft de Hoge Raad geoordeeld dat een beslaglegger bevoegd is om een aan de beslagen vordering verbonden hypotheekrecht uit te oefenen als de schuldenaar van de desbetreffende vordering weigert deze te voldoen. ${ }^{161}$ In de literatuur wordt aangenomen dat dit oordeel van de Hoge Raad ook van toepassing is op vergelijkbare situaties. ${ }^{162}$ Niet enkel een beslaglegger, maar iedere inningsbevoegde derde is bevoegd om alle aan een vordering verbonden zekerheidsrechten uit te oefenen. Verschillende auteurs merken op dat dit onder meer betekent dat de houder van een pandrecht op een vordering tevens de beschikking heeft over de aan die vordering verbonden accessoire rechten,

op dit punt daarom de rechtsgevolgen overeenkomstig de duiding van de 403-vordering als hoofdelijke vordering zouden gelden. Zie ook E.C.A. Nass 2019, p. 219.

157. Zie $\S 6.2 .3$.

158. HR 28 juni 2002, JOR 2002/136, m.nt. Bartman (Akzo/ING), r.o. 3.5.3. Zie $\S$ 8.7.3.

159. Bartman in zijn annotatie onder HR 28 juni 2002, JOR 2002/136 (Akzo/ING) en Loesberg in zijn annotatie onder Rb. Rotterdam 30 september 2014, JOR 2014/326 (Pergen/Eneco).

160. E.C.A. Nass 2019, p. 219.

161. HR 11 maart 2005, NJ 2006/362, m.nt. Snijders (Rabobank/Stormpolder), r.o. 3.6. Ook gepubliceerd in JOR 2005/131, m.nt. Kortmann.

162. Snijders in zijn annotatie onder HR 11 maart 2005, NJ 2006/362 (Rabobank/Stormpolder), Kortmann 2005, p. 69, Biemans 2011, p. 245 en Bergervoet 2014, p. 93. 
waaronder die uit borgtocht. ${ }^{163}$ De Hoge Raad heeft de lijn uit het Rabobank/ Stormpolder-arrest nadien bevestigd in zijn arrest $A B N$ Amro/Marell. ${ }^{164}$ In dit arrest oordeelt de Hoge Raad dat een inningsbevoegde pandhouder de bevoegdheid heeft om de aan de verpande vordering verbonden zekerheidsrechten - in casu een pandrecht op een andere vordering - te innen. Faber en Vermunt merken in hun annotatie onder het arrest op - in lijn met de reacties in de literatuur op het arrest Rabobank/Stormpolder - dat een inningsbevoegde pandhouder ook andere aan de verpande vordering verbonden zekerheidsrechten kan innen, waaronder rechten uit borgtocht. ${ }^{165}$

Hoewel ik eerder - in navolging van de Hoge Raad in zijn Akzo/ING-beschikking $^{166}$ - de vergelijking tussen de 403-aansprakelijkheid en borgtocht heb afgewezen, ${ }^{167}$ laten de reacties in de literatuur naar aanleiding van de arresten Rabobank/Stormpolder en ABN Amro/Marell wel zien wat het gevolg is van het analoog toepassen van de bepalingen inzake borgtocht ten aanzien van de 403-aansprakelijkheid. Hoewel de grondslag van de aansprakelijkheid anders is, zijn de uitkomsten hetzelfde. Een (inningsbevoegde) houder van een pandrecht op een vordering op een 403-maatschappij is in dat geval dus bevoegd om de 403 -vordering te gelde te maken. ${ }^{168}$

In tegenstelling tot bovengenoemd standpunt van Nass, leidt de vestiging van een pandrecht op de vordering van een crediteur op de 403-maatschappij er naar mijn mening dus niet toe dat de pandhouder ook een pandrecht krijgt op de 403-vordering. De (inningsbevoegde) pandhouder kan echter wel de 403-vordering te gelde te maken. Strikt genomen betekent dit dus ook dat een vordering op de 403-maatschappij 'zelfstandig' is te verpanden, zonder dat de pandhouder een pandrecht krijgt op de 403-vordering. Ik laat dit onderscheid echter verder rusten.

Als de bepalingen inzake borgtocht analoog van toepassing zijn op de 403-aansprakelijkheid van de moedermaatschappij is deze aansprakelijkheid afhankelijk van de verbintenis tussen de crediteur en de 403-maatschappij. Hierdoor kan een 403-vordering niet zelfstandig worden overgedragen en kan deze daarom op grond van art. 3:228 BW ook niet worden verpand. ${ }^{169}$

163. Biemans 2011, p. 245-246, Bergervoet 2014, p. 90 en Pitlo/Reehuis \& Heisterkamp $2019 / 826$.

164. HR 18 december 2015, JOR 2016/105, m.nt. Faber en Vermunt (ABN Amro/Marell), r.o. 3.5.2.

165. Faber en Vermunt in hun annotatie onder HR 18 december 2015, JOR 2016/105 (ABN Amro/ Marell).

166. HR 28 juni 2002, JOR 2002/136, m.nt. Bartman (Akzo/ING), r.o. 3.4.3, 3.4.5 en 3.4.6.

167. Zie $\S 6.2 .4$.

168. Faber in zijn annotatie onder Hof Den Haag 6 februari 2007, JOR 2007/103 (Citibank International/KPN) en Verdaas 2008, p. 308

169. Faber in zijn annotatie onder Hof Den Haag 6 februari 2007, JOR 2007/103 (Citibank International/KPN) en Verdaas 2008, p. 305. Zie ook Bergervoet 2014, p. 90, die in algemene 
In afbeelding 6.6 heb ik de gevolgen van de verschillende duidingen van de 403-vordering uiteengezet:

\begin{tabular}{|l|c|c|c|c|}
\hline \multirow{2}{*}{$\begin{array}{l}\text { Rechtsgevolgen van de duiding van de } \\
\text { 403-vordering }\end{array}$} & \multicolumn{4}{|c|}{ Duiding van de 403-vordering } \\
\cline { 2 - 5 } & Hoofdelijk & Dynamisch & Art. 6:142 & Borgtocht \\
\hline $\begin{array}{l}\text { Kan de crediteur de vordering op de } \\
\text { 403-maatschappij zelfstandig verpanden? }\end{array}$ & Ja & Ja & Nee & Nee \\
\hline $\begin{array}{l}\text { Kan de crediteur de vordering op de } \\
\text { moedermaatschappij zelfstandig verpanden? }\end{array}$ & Ja & Nee & Nee & Nee \\
\hline
\end{tabular}

Afbeelding 6.6

\subsection{Uitkomsten volgens het door mij bepleite uitgangspunt voor compensatie}

\subsubsection{De crediteur doet afstand van de vordering op de 403-maatschappij}

Als een crediteur afstand doet van zijn vordering op de 403-maatschappij, gaat de verbintenis tussen hen teniet. ${ }^{170}$ De crediteur heeft er dan geen belang meer bij om de jaarrekening van de 403-maatschappij te kunnen inzien om (mede) aan de hand daarvan te schatten hoe groot het risico is dat zijn vordering niet (volledig) zal worden voldaan. Hij hoeft dus ook niet meer gecompenseerd te worden als deze mogelijkheid ontbreekt. Volgens het door mij bepleite uitgangspunt voor compensatie ${ }^{171}$ dient daarom in een dergelijk geval de 403-vordering van de crediteur op de moedermaatschappij te vervallen.

\subsubsection{Overeengekomen moment van nakoming, uitstel van betaling en opschorting van nakoming}

Als de 403-maatschappij gebruikmaakt van de jaarrekeningvrijstelling van het groepsregime kan een crediteur de jaarrekening van de 403-maatschappij niet inzien. De crediteur wordt voor dit gebrek aan inzicht gecompenseerd doordat hij op grond van de 403-verklaring ook een vordering krijgt op de moedermaatschappij van wie hij de geconsolideerde jaarrekening wel kan inzien. ${ }^{172}$ Kort gezegd wordt de crediteur gecompenseerd voor het feit dat hij een vordering heeft op een debiteur - de 403-maatschappij - van wie hij de jaarrekening niet kan inzien, met een aanvullende vordering op een andere

zin over borgtocht opmerkt rechten uit borgtocht niet vatbaar zijn voor verpanding.

170. Zie art. 6:160 BW.

171. Zie $\$ 3.7$.

172. Zie $\$ 3.4 .1$. 
debiteur - de moedermaatschappij - van wie hij de geconsolideerde jaarrekening wel kan inzien. Voor het overige moeten de verhaalsrechten van de crediteur op de 403-maatschappij en de moedermaatschappij zo veel mogelijk hetzelfde zijn. Als de 403-maatschappij en de crediteur zijn overeengekomen dat eerstgenoemde pas na een bepaald moment aan haar verplichting hoeft te voldoen, dan moet dit volgens het door mij bepleite uitgangspunt voor compensatie daarom ook gelden voor de moedermaatschappij. Een andere uitkomst leidt ertoe dat de crediteur de bepaling ten aanzien van het moment van nakoming door de 403-maatschappij kan omzeilen door zich op de moedermaatschappij te verhalen.

Bovenstaande redenering is ook van toepassing als de crediteur uitstel van betaling heeft verleend aan de 403-maatschappij of als de 403-maatschappij de nakoming van haar verplichting opschort omdat de crediteur een opeisbare vordering - van de 403-maatschappij - jegens hem niet nakomt. ${ }^{173}$ Ook in die gevallen is de moedermaatschappij (tijdelijk) niet gehouden haar verplichting op grond van de 403-verklaring na te komen.

\subsubsection{De vordering op de 403-maatschappij is verjaard}

Als een moedermaatschappij haar 403-verklaring deponeert op een moment dat de crediteur al een vordering heeft op de 403-maatschappij, krijgt de crediteur op het moment van de deponering ook een 403-vordering op de moedermaatschappij. ${ }^{174}$ Aangezien de vordering op de 403-maatschappij eerder is ontstaan, zal deze ook eerder verjaren dan de 403 -vordering.

Als de vordering op de 403-maatschappij is verjaard, kan de crediteur de nakoming daarvan niet meer afdwingen. ${ }^{175}$ Voor de crediteur is het daarom niet meer van belang om de jaarrekening van de 403-maatschappij te kunnen inzien om (mede) aan de hand daarvan te schatten hoe groot het risico is dat zijn vordering niet (volledig) zal worden voldaan. De crediteur hoeft dus ook niet meer gecompenseerd te worden als hij deze jaarrekening niet kan inzien. Volgens het door mij bepleite uitgangspunt voor compensatie leidt de verjaring van de vordering op de 403-maatschappij er daarom toe dat de 403-vordering van de crediteur op de moedermaatschappij vervalt.

173. Zie art. 6:52 BW.

174. Ervan uitgaande dat de moedermaatschappij op grond van de 403-verklaring aansprakelijk is voor alle schulden die voortvloeien en zijn voortgevloeid uit een rechtshandeling van de 403-maatschappij (zie hoofdstuk 5 en in het bijzonder $§ 5.6$ ).

175. Asser/Sieburgh 6-II 2017/387 en Sikkema, in: GS Verbintenissenrecht, art. 6:3 BW, aant. 6. 


\subsubsection{Subsidiaire aansprakelijkheid van de moedermaatschappij}

Omdat een crediteur de jaarrekening van de 403-maatschappij niet kan inzien, kan hij niet (mede) aan de hand daarvan het risico schatten dat zijn vordering niet (volledig) zal worden voldaan. Zolang de 403-maatschappij haar schulden voldoet, verwezenlijkt dit risico zich niet. Er is dan geen noodzaak voor de crediteur om zich op de moedermaatschappij te verhalen. Volgens het door mij bepleite uitgangspunt mag een crediteur zich om die reden pas op de moedermaatschappij verhalen als de 403-maatschappij tekortschiet in de nakoming van haar verplichting.

\subsubsection{Zelfstandig cederen van de vorderingen op de moeder-en de 403-maatschappij}

De vordering die een crediteur op grond van de 403-verklaring heeft op de moedermaatschappij is onderdeel van de compensatie die de crediteur ontvangt omdat hij de jaarrekening van de 403-maatschappij niet kan inzien. ${ }^{176}$ Omdat de 403-vordering specifiek is bedoeld ter compensatie van het gebrek aan inzicht van een crediteur van de 403-maatschappij, moet deze vordering volgens het door mij bepleite uitgangspunt altijd toekomen aan degene met de corresponderende vordering op de 403-maatschappij. Beide vorderingen mogen daarom niet onafhankelijk van elkaar worden gecedeerd.

Een tweede reden waarom de vorderingen op de moeder- en de 403-maatschappij volgens het door mij bepleite uitgangspunt voor compensatie niet onafhankelijk van elkaar mogen worden gecedeerd, is dat dit tot misbruik kan leiden. Een crediteur kan een van beide vorderingen cederen aan een derde om vervolgens zelf de andere vordering te gelde te maken. Daarnaast kan hij beide vorderingen aan twee verschillende partijen cederen. ${ }^{177}$ In deze gevallen ontvangt de (oorspronkelijke) crediteur twee keer voordeel, terwijl de cessionaris (die zijn vordering niet als eerste int) met lege handen achterblijft.

\subsubsection{Zelfstandig verpanden van de vorderingen op de moeder-en de 403-maatschappij}

De houder van een pandrecht op de vordering van een crediteur op de 403-maatschappij heeft een direct belang om de jaarrekening van de 403-maatschappij

176. De compensatie voor een crediteur bestaat uit twee onderdelen: een vordering op de moedermaatschappij op grond van de 403-verklaring en de mogelijkheid om de geconsolideerde jaarrekening van de moedermaatschappij in te zien. Zie § 3.4.1.

177. Ik merk op dat een dergelijke handelswijze mogelijk een onrechtmatige daad is. De cessionaris kan dan een vordering tot schadevergoeding instellen tegen de cedent. Indien de cedent echter is gefailleerd of de vordering niet kan worden geïnd, blijft de cessionaris (grotendeels) met lege handen achter. 
te kunnen inzien. Hij kan (mede) aan de hand van deze jaarrekening schatten hoe groot het risico is dat de 403-maatschappij de vordering niet (volledig) zal voldoen als de pandhouder nakoming daarvan vordert. ${ }^{178}$ De pandhouder kan (mede) op basis van deze jaarrekening een beeld vormen van de zekerheid die zijn pandrecht biedt.

De crediteur wordt gecompenseerd voor het feit dat hij de jaarrekening van de 403-maatschappij niet kan inzien, doordat hij op grond van de 403-verklaring een aanvullende vordering heeft op de moedermaatschappij van wie hij de geconsolideerde jaarrekening wel kan inzien. Om ook de pandhouder te compenseren moet deze zich niet alleen kunnen verhalen op de vordering van de crediteur op de 403-maatschappij, maar ook op de 403-vordering op de moedermaatschappij. Volgens het door mij bepleite uitgangspunt voor compensatie moet een (inningsbevoegde) houder van een pandrecht op een vordering op een 403-maatschappij (ook) de 403-vordering te gelde kunnen maken. ${ }^{179}$

Dat de houder van een pandrecht op een vordering op de 403-maatschappij zich moet kunnen verhalen op de 403-vordering, brengt ook met zich dat laatstgenoemde vordering niet (zelfstandig) mag worden verpand. Indien de 403-vordering eerder aan een derde is verpand, kan de houder van het pandrecht op de vordering op de 403-maatschappij zich niet als eerste op de 403-vordering verhalen. Dit zou afdoen aan de compensatie voor deze pandhouder.

\subsection{Analyse van de duidingen van de 403-vordering}

\subsubsection{Schematisch overzicht}

In afbeelding 6.7 heb ik de gevolgen van de verschillende duidingen van de 403-vordering vergeleken met de uitkomsten volgens het door mij bepleite uitgangspunt voor compensatie. ${ }^{180}$

178. Zie art. 3:246 BW. De pandhouder kan alleen nakoming vordering als de verpanding van de vordering is meegedeeld aan de debiteur.

179. Dat de houder van een pandrecht op de vordering op de 403-maatschappij de 403-vordering kan innen, kan op twee manieren worden bewerkstelligd. Ten eerste is het mogelijk dat de pandhouder tevens een pandrecht krijgt op de 403-vordering (zoals bij de analoge toepassing van art. 6:142 BW ten aanzien van de 403-vordering, zie § 6.3.7.c). Daarnaast kan de inningsbevoegdheid voortvloeien uit de nauwe samenhang tussen de bevoegdheid om de vordering op de 403-maatschappij te innen en de bevoegdheid om de 403-vordering te innen (zoals bij de analoge toepassing van de bepalingen inzake borgtocht op de 403-aansprakelijkheid, zie $\S$ 6.3.7.d). Ik laat dit onderscheid hier verder rusten.

180. Zie $\S 3.7$. 
HOOFDSTUK 6

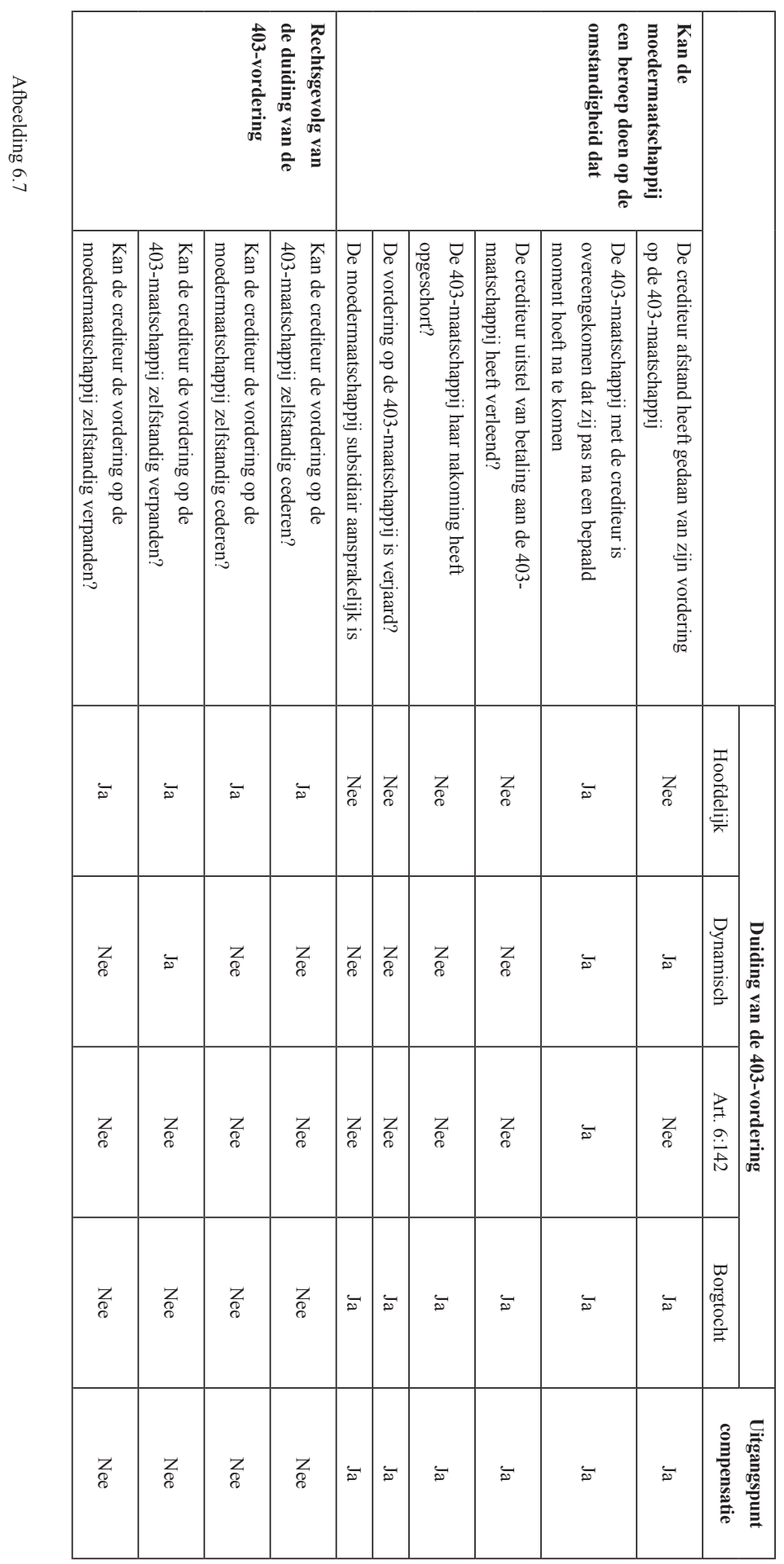


Uit het overzicht in afbeelding 6.7 volgt dat de gevolgen van het analoog toepassen van de bepalingen inzake borgtocht op de aansprakelijkheid van een moedermaatschappij op grond van een 403-verklaring, bij alle onderzochte situaties overeenkomen met de uitkomst volgens het door mij bepleite uitgangspunt voor compensatie. Daarna komen de gevolgen van het analoog toepassen van art. 6:142 BW ten aanzien van de 403-vordering en de gevolgen van de duiding van de 403-vordering als een dynamische vordering het vaakst overeen met de uitkomsten volgens dit uitgangspunt. ${ }^{181}$ De gevolgen van de duiding van de 403 -vordering als een hoofdelijke vordering komen het minst vaak overeen met de uitkomst volgens het door mij bepleite uitgangspunt voor compensatie. ${ }^{182}$

\subsubsection{Analoge toepassing van de bepalingen inzake borgtocht}

De gevolgen van het analoog toepassen van de bepalingen inzake borgtocht op de aansprakelijkheid van een moedermaatschappij op grond van een 403-verklaring komen bij alle onderzochte situaties overeen met de uitkomst volgens het door mij bepleite uitgangspunt voor compensatie. Naar huidig recht kan de 403-aansprakelijkheid van een moedermaatschappij echter niet zo worden uitgelegd dat de bepalingen inzake borgtocht daarop analoog van toepassing zijn. Weliswaar heeft de OK in de $A k z o / I N G$-procedure geoordeeld dat aan de door de wet beoogde bescherming van een crediteur van de 403-maatschappij voldoende recht wordt gedaan, als de moedermaatschappij tegenover hem in een positie komt te verkeren alsof zij zich tot borg heeft gesteld. ${ }^{183}$ Maar in cassatie heeft de Hoge Raad de beschikking van de OK vernietigd en geoordeeld dat hoofdelijke aansprakelijkheid niet op een lijn kan worden gesteld met borgtocht. ${ }^{184}$

Indien de bepalingen inzake borgtocht analoog van toepassing zijn op de 403-aansprakelijkheid, heeft deze aansprakelijkheid een afhankelijk en subsidiaire karakter. Dit is niet te rijmen met de vereiste hoofdelijke aansprakelijkheid ex art. 2:403 lid 1 sub f BW. Teneinde de aansprakelijkheid van een moedermaatschappij op grond van een 403-verklaring als een vorm van borgtocht uit te leggen, moet de wet dus worden gewijzigd. Het is echter geen oplossing om in art. 2:403 lid 1 sub $\mathrm{f} \mathrm{BW}$ op te nemen dat de moedermaatschappij zich tot borg moet stellen voor de schulden die voorvloeien uit een rechtshandeling van de 403-maatschappij. Aangezien borgtocht een overeenkomst is, ${ }^{185}$ zou dat betekenen dat de moedermaatschappij met iedere crediteur van de

181. Ik merk op dat hoewel de gevolgen van deze twee duidingen van de 403-vordering even vaak overeenkomen met de uitkomsten volgens het door mij bepleite uitgangspunt voor compensatie, de gevolgen onderling op enkele punten verschillen.

182. Vgl. Van Dooren 2015.

183. Hof Amsterdam (OK) 31 juli 2001, JOR 2001/170, m.nt. Bartman (Akzo/ING), r.o. 4.10.

184. HR 28 juni 2002, JOR 2002/136, m.nt. Bartman (Akzo/ING), r.o. 3.4.3, 3.4.5 en 3.4.6.

185. Zie art. 7:850 lid $1 \mathrm{BW}$. 


\section{HOOFDSTUK 6}

403-maatschappij een afspraak moet maken over haar aansprakelijkheid. ${ }^{186}$ De aansprakelijkheid van de moedermaatschappij dient echter een collectief en eenzijdig karakter te hebben zodat deze voor alle crediteuren gelijk is. Als een van de crediteuren niet zou instemmen met de voorgestelde aansprakelijkheid van de moedermaatschappij kan de 403-maatschappij niet (meer) gebruikmaken van de jaarrekeningvrijstelling van het groepsregime.

Een alternatief is om in art. 2:403 lid 1 sub f BW op te nemen dat de moedermaatschappij een verklaring moet deponeren op grond waarvan zij zich hoofdelijk aansprakelijk stelt voor de schulden die voortvloeien uit een rechtshandeling van de 403-maatschappij voor zover de 403-maatschappij zelf tekortschiet in de nakoming en dat deze aansprakelijkheid afhankelijk is van de verbintenis van de 403-maatschappij waarvoor deze geldt. Art. 37 van de richtlijn jaarrekeningen biedt daarvoor mijns inziens de ruimte. Een dergelijke subsidiaire en afhankelijke aansprakelijkheid van de moedermaatschappij sluit aan bij de vereiste garantstelling van een moederonderneming op grond van de richtlijn.

Een andere mogelijkheid is om art. 2:403 lid 1 sub $\mathrm{fBW}$ zo aan te passen dat op dit punt de tekst van art. 37 van de richtlijn jaarrekeningen zelf wordt overgenomen. Op grond van de richtlijn moet een moederonderneming verklaren dat zij garant staat voor de door de dochteronderneming aangegane verplichtingen. Art. 2:403 BW zou kunnen worden gewijzigd dat de moedermaatschappij niet meer een verklaring van hoofdelijke aansprakelijkheid moet deponeren, maar een verklaring dat zij garant staat voor de schulden die voortvloeien uit een rechtshandeling van de 403-maatschappij. Ik heb er eerder echter op gewezen dat er geen vaste definitie is van een garantstelling. ${ }^{187}$ Naar huidig recht is het dus niet met zekerheid te zeggen welke rechtsgevolgen een dergelijk garantstelling met zich brengt. Daarom zou de wetgever in de parlementaire stukken bij de wetswijziging ook moeten vermelden hoe de aansprakelijkheid van een moedermaatschappij op grond van de garantieverklaring moet worden geduid. Daarbij zou mijns inziens zo veel mogelijk moeten worden aangesloten bij de bepalingen inzake borgtocht.

Naar mijn mening is het wenselijk dat art. 2:403 BW op een van bovenstaande wijzen wordt gewijzigd. Tot dat moment raad ik een moedermaatschappij aan om de verbintenisrechtelijke weg te bewandelen als zij wil dat haar aansprakelijkheid op grond van de 403-verklaring een afhankelijk en subsidiair karakter heeft. Zij kan dit contractueel overeenkomen met de crediteuren. Om te voorkomen dat de moedermaatschappij zelf met iedere aanstaande crediteur van de 403-maatschappij een overeenkomst moet sluiten, kan zij een doorlopende volmacht verlenen aan de 403-maatschappij. Op grond daarvan kan de

186. Bartman 2004, p. 50-51.

187. Zie $\S 6.1$. 
403-maatschappij namens de moedermaatschappij een overeenkomst aangaan met een crediteur, op het moment dat zij zelf ook een overeenkomst met de desbetreffende crediteur sluit.

De 403-maatschappij kan namens de moedermaatschappij onder meer op grond van art. 3:83 lid $2 \mathrm{BW}$ met de crediteur afspreken dat de 403-vordering op de moedermaatschappij niet onafhankelijk van de vordering op de 403-maatschappij kan worden overgedragen. Ik wijs erop dat de Hoge Raad in het Coface/Intergamma-arrest heeft geoordeeld dat het uitgangspunt bij de uitleg van een beding dat de overdraagbaarheid van een vordering uitsluit is dat dit verbintenisrechtelijke werking heeft, tenzij uit de - naar objectieve maatstaven uit te leggen - formulering blijkt dat daarmee goederenrechtelijke werking is beoogd. ${ }^{188}$ In de overeenkomst zal dus expliciet moeten worden opgenomen dat de beperking van de overdraagbaarheid goederenrechtelijke werking heeft. In dat geval kan de crediteur op grond van art. 3:98 BW de 403-vordering ook niet zelfstandig verpanden.

Naast het uitsluiten van de zelfstandige overdraagbaarheid van de 403-vordering - en daarmee ook het uitsluiten van de verpanding van deze vordering -, kan de 403-maatschappij ook namens de moedermaatschappij met de crediteur overeenkomen dat de aansprakelijkheid van de moedermaatschappij afhankelijk is van de verbintenis tussen de crediteur en de 403-maatschappij. Voorts kan worden afgesproken dat de moedermaatschappij niet is gehouden tot nakoming totdat de 403-maatschappij zelf daarin tekortschiet en dat de moedermaatschappij een beroep kan doen op dezelfde verweermiddelen als die de 403-maatschappij heeft tegenover de crediteur ten aanzien van het bestaan, de inhoud of het moment van nakoming van de verplichting. Tot slot kan met de crediteur worden afgesproken dat de moedermaatschappij bevoegd is de nakoming van haar verplichting op grond van de 403-verklaring op te schorten, zolang de 403-maatschappij - rechtsgeldig - de nakoming van haar verplichting jegens de crediteur op grond van art. 6:52 BW opschort, en dat de verjaring van de vordering van de crediteur op de 403-maatschappij meebrengt dat ook de moedermaatschappij is bevrijd van haar verplichting op grond van de 403-verklaring. Dergelijke bedingen hebben echter slechts verbintenisrechtelijke werking. Het is daarom de vraag of de moedermaatschappij de nakoming hiervan kan afdwingen als de crediteur een beroep doet op de hoofdelijke aansprakelijkheid van de moedermaatschappij uit hoofde van de 403 -verklaring.

Het afdwingen dat de crediteur eerst moet proberen om zich op de 403-maatschappij te verhalen voordat hij zich tot de moedermaatschappij kan wenden, zal naar mijn mening geen bezwaar opleveren. De naleving van deze

188. Zie HR 21 maart 2014, NJ 2015/167, m.nt. Snijders (Coface/Intergamma), r.o. 3.4.2. Ook gepubliceerd in JOR 2014/151, m.nt. Schuijling. 
verplichting leidt mijns inziens niet tot grote bezwaren voor de crediteur, waardoor ik geen reden zie waarom hij zich hier niet aan zou hoeven te houden. Maar wat als de 403-maatschappij de nakoming van haar verplichting opschort, of de vordering van de crediteur op de 403-maatschappij is verjaard terwijl de vordering op de moedermaatschappij nog niet is verjaard? Kan de crediteur zich dan met een beroep op de hoofdelijke aansprakelijkheid uit de 403-verklaring toch op de moedermaatschappij verhalen ${ }^{189}$ - waarbij hij vanzelfsprekend wel een wanprestatie pleegt en de moedermaatschappij de eventuele schade op hem kan verhalen -, of is de crediteur gehouden om zich aan de overeenkomst te houden? Ik meen dat de crediteur ook in die gevallen is gehouden de overeenkomst na te leven en zich niet op de moedermaatschappij kan verhalen. Een beroep van de crediteur op de bepalingen van hoofdelijke aansprakelijkheid is mijns inziens in die gevallen onaanvaardbaar naar maatstaven van redelijkheid en billijkheid ${ }^{190}$ omdat dit ertoe zou leiden dat de crediteur zich op grond van de 403-verklaring op de moedermaatschappij zou kunnen verhalen ondanks dat daarvoor geen reden is gezien de functie van de 403-aansprakelijkheid bij de compensatie van de crediteur voor het niet kunnen inzien van de jaarrekening van de 403-maatschappij. ${ }^{191}$

Een nadeel voor de moedermaatschappij bij bovenstaande constructie waarbij zij met betrekking tot de 403-aansprakelijkheid contractueel wil afwijken van de bepalingen van hoofdelijke ansprakelijkheid, is dat zij afhankelijk is van de crediteur om hiermee in te stemmen. Als de crediteur dit weigert, is het aan de moedermaatschappij of zij desondanks bereid is de hoofdelijke aansprakelijkheid op grond van de 403-verklaring te accepteren voor de schulden die voortvloeien uit de overeenkomst die de 403-maatschappij met de crediteur wil aangaan. Zo niet, dan zal zij de 403-maatschappij moeten opdragen de overeenkomst niet aan te gaan.

Aangezien de 403-aansprakelijkheid naar huidig recht niet zo kan worden uitgelegd dat de bepalingen inzake borgtocht analoog van toepassing zijn, blijft de vraag bestaan hoe een 403 -vordering moet worden geduid. De drie overige door mij onderzochte duidingen van de 403-vordering gaan wel uit van (een variant op) de hoofdelijke aansprakelijkheid van de moedermaatschappij. Deze duidingen komen hieronder aan bod.

$\mathrm{Na}$ de analoge toepassing van de bepalingen inzake borgtocht op de 403-aansprakelijkheid, komen de gevolgen van het analoog toepassen van art. 6:142 BW en van de duiding van de 403-vordering als een dynamische vordering het vaakst overeen met de uitkomsten volgens het door mij bepleite uitgangspunt

189. Zie $\S 6.3 .3$ en $\S 6.3 .4$.

190. Zie art. $6: 2$ lid $2 \mathrm{BW}$.

191. Zie $\S 6.4 .2$ en $\S 6.4 .3$. 
voor compensatie. Ik merk op dat hoewel de gevolgen van deze twee duidingen van de 403-vordering in de door mij onderzochte situaties even vaak overeenkomen met de uitkomsten volgens het door mij bepleite uitgangspunt voor compensatie, de gevolgen onderling op enkele punten verschillen. Ik bespreek eerst de analoge toepassing van art. 6:142 BW ten aanzien van de 403-vordering en daarna de duiding als een dynamische vordering.

\subsubsection{Analoge toepassing van art. 6:142 BW}

De analoge toepassing van art. 6:142 BW ten aanzien van de 403-vordering leidt in een aantal van de onderzochte situaties tot de uitkomst volgens het door mij bepleite uitgangspunt voor compensatie. Als een crediteur bijvoorbeeld de vordering op de 403-maatschappij cedeert of verpandt, gaat daardoor ook de 403-vordering op de cessionaris over, respectievelijk krijgt de pandhouder ook een pandrecht op de 403-vordering. Er zijn echter ook situaties waarbij de analoge toepassing van art. 6:142 $\mathrm{BW}$ niet leidt tot de uitkomst volgens het door mij bepleite uitgangspunt. Een crediteur kan zich bijvoorbeeld op de moedermaatschappij verhalen ondanks dat hij afstand heeft gedaan van zijn vordering op de 403-maatschappij of als hij uitstel van betaling heeft verleend aan de 403-maatschappij.

De Hoge Raad heeft de analoge toepassing van art. 6:142 BW ten aanzien van een 403-vordering impliciet afgewezen in zijn $A k z o / I N G$-beschikking. ${ }^{192}$ De Hoge Raad oordeelt dat de houder van een pandrecht op de vordering van een crediteur op de 403-maatschappij niet in verzet kan komen tegen het voornemen van de moedermaatschappij om de overblijvende aansprakelijkheid te beëindigen. Ik heb echter geconcludeerd dat als art. 6:142 $\mathrm{BW}$ analoog van toepassing zou zijn ten aanzien van de 403-vordering, de pandhouder wél verzet zou hebben kunnen instellen. ${ }^{193} \mathrm{Om}$ art. 6:142 $\mathrm{BW}$ van toepassing te laten zijn op de 403-vordering moet art. 2:403 BW dus worden gewijzigd. Ik heb hierboven echter al opgemerkt dat als de wetgever besluit om art. 2:403 BW te wijzigen, het mijn voorkeur heeft dat hij dan in deze bepaling opneemt dat de aansprakelijkheid van een moedermaatschappij op grond van de 403-verklaring een afhankelijk en subsidiair karakter heeft. ${ }^{194}$

192. HR 28 juni 2002, JOR 2002/136, m.nt. Bartman $(A k z o / I N G)$, r.o. 3.5.3. Zie § 6.3.7.c, waar ik uitgebreider de verhouding tussen de $A k z o / I N G$-beschikking en de analoge toepassing van art. 6:142 BW ten aanzien van de 403-vordering behandel.

193. Zie $\S 6.3 .7 . c$.

194. Zie $\S 6.5 .2$. 


\subsubsection{Duiding van de 403-vordering als een dynamische 403-vordering}

Als de 403-vordering wordt geduid als een dynamische vordering heeft deze te gelden als een hoofdelijke vordering die altijd toekomt aan degene met de corresponderende vordering op de 403-maatschappij. Hierdoor is er sprake van een bepaalde mate van verbondenheid tussen de vordering op de moeder- en die op de 403-maatschappij. Deze verbondenheid leidt er onder meer toe dat een crediteur de vorderingen niet onafhankelijk van elkaar kan cederen en dat als hij afstand doet van zijn vordering op de 403-maatschappij hij daardoor ook zijn vordering op de moedermaatschappij verliest.

Toch leidt de duiding van de 403-vordering als een dynamische vordering niet in alle situaties tot de uitkomst volgens het door mij bepleite uitgangspunt voor compensatie. Als de 403-maatschappij bijvoorbeeld de nakoming van haar verplichting opschort omdat de crediteur een opeisbare vordering - van de 403-maatschappij - jegens hem niet nakomt, ${ }^{195}$ kan de crediteur onverminderd de vordering op de moedermaatschappij te gelde maken. Ook is de crediteur niet gehouden om eerst te proberen om zich op de 403-maatschappij te verhalen voordat hij zich tot de moedermaatschappij kan wenden.

Er bestaat echter onduidelijkheid hoe de Hoge Raad deze duiding van de 403-vordering ziet. Twee uitspraken van de Hoge Raad zijn op dit punt tegenstrijdig aan elkaar. ${ }^{196}$ In de beschikking Minister van Financiën/VEB c.s. oordeelt de Hoge Raad in lijn met de duiding van de 403-vordering als een dynamische vordering. ${ }^{197}$ Maar het oordeel in het Eikendal q.q./Lentink-arrest - dat twee weken later is gewezen - sluit niet aan bij deze duiding van de 403 -vordering. ${ }^{198}$ Het is de vraag hoe de Hoge Raad zal oordelen als hij zich opnieuw over de duiding van de 403-vordering moet uitlaten. Naar mijn mening is het wenselijk dat de Hoge Raad de lijn uit de Minister van Financiën/VEB c.s.-beschikking bevestigt, omdat dit het meest aansluit bij de functie van de 403-aansprakelijkheid bij de compensatie van de crediteuren voor het niet kunnen inzien van de jaarrekening van de 403-maatschappij. Ik verwacht echter dat het oordeel in het arrest Eikendal q.q./Lentink zal worden gevolgd. In laatstgenoemde arrest vormt de duiding van de 403-vordering de kern van het oordeel van de Hoge Raad. Bij de beschikking inzake Minister van Financiën/VEB c.s. is dit slechts een van de vele onderwerpen waarover de Hoge Raad zich heeft uitlaten. Ik denk daarom dat er met betrekking tot de duiding van de 403-vordering meer waarde moet

195. Zie art. 6:52 BW.

196. Zie $\S$ 6.2.2.c, waar ik beide uitspraken uitgebreider behandel.

197. HR 20 maart 2015, JOR 2015/140, m.nt. Josephus Jitta (Minister van Financiën/VEB c.s.), r.o. 4.30. De Hoge Raad verwijst naar de bijbehorende conclusie van A-G Timmerman onder nr. 10.4 en 10.5 .

198. HR 3 april 2015, JOR 2015/191, m.nt. Faber en Vermunt (Eikendal q.q./Lentink), r.o. 3.6.2. 
worden gehecht aan het oordeel van de Hoge Raad in het Eikendal q.q./Lentinkarrest. $^{199}$

\subsubsection{Duiding van de 403-vordering als een hoofdelijke vordering}

De gevolgen van de duiding van de 403-vordering als een hoofdelijke vordering verschillen bij de onderzochte situaties het vaakst van de uitkomst volgens het door mij bepleite uitgangspunt voor compensatie. Een kenmerkend verschil van deze duiding in vergelijking met de andere duidingen van de 403-vordering, is dat de vorderingen van de crediteur op de moeder- en de 403-maatschappij onafhankelijk van elkaar bestaan, behalve dat nakoming door een van beide schuldenaren tevens de ander bevrijdt. ${ }^{200} \mathrm{Bij}$ de andere duidingen van de 403-vordering is er telkens - in meer of mindere mate - sprake van verbondenheid tussen deze vorderingen. Een ander gevolg van de duiding van de 403-vordering als een hoofdelijke vordering - dat overigens ook speelt bij de analoge toepassing van art. 6:142 BW en de duiding als een dynamische vordering - is dat de crediteur naar vrije keuze de moeder- en de 403-maatschappij kan aanspreken tot nakoming. De crediteur kan direct de moedermaatschappij aansprakelijk stellen zonder eerst te hoeven proberen om zich op de 403-maatschappij te verhalen.

Bovengenoemde gevolgen van de duiding van de 403-vordering als een hoofdelijke vordering doen af aan de functie van deze vordering als onderdeel van de compensatie die een crediteur ontvangt omdat hij de jaarrekening van de 403-maatschappij niet kan inzien. ${ }^{201}$ Omdat de crediteur deze jaarrekening niet kan inzien, kan hij niet (mede) aan de hand daarvan schatten hoe groot het risico is dat de 403-maatschappij de vordering niet (volledig) zal voldoen. Aangezien het de crediteur van de 403-maatschappij is die het nadeel ervaart, zou de 403-vordering altijd aan deze crediteur moeten toekomen. Daarnaast is het van belang dat zolang de 403-maatschappij haar schulden voldoet, bovenstaand risico zich niet verwezenlijkt en er geen noodzaak is voor de crediteur om de moedermaatschappij aansprakelijk te stellen. De crediteur zou zich daarom pas op de moedermaatschappij moeten kunnen verhalen als de 403-maatschappij tekortschiet in de nakoming, waarbij het verhaalsrecht van de crediteur tegenover de moedermaatschappij zo veel mogelijk gelijk moet zijn als dat tegenover de 403-maatschappij.

199. Zie ook Van Zoest 2016a, p. 58

200. Zie art. 6:7 BW. Ook in het geval dat een van beide vorderingen wordt betaald door inbetalinggeving, verrekening of als een rechter op grond van art. 6:60 BW oordeelt dat de schuldenaar is bevrijd omdat de crediteur zelf in verzuim is, is de andere hoofdelijk schuldenaar bevrijd.

201. De compensatie voor een crediteur bestaat uit twee onderdelen: een vordering op de moedermaatschappij op grond van de 403-verklaring en de mogelijkheid om de geconsolideerde jaarrekening van de moedermaatschappij in te zien. Zie $\S 3.4 .1$. 


\subsection{Conclusie}

Een crediteur van de 403-maatschappij heeft twee vorderingen: een vordering op de 403-maatschappij en een 403-vordering op de moedermaatschappij op grond van de 403-verklaring. In dit hoofdstuk heb ik de rechtsgevolgen van vier verschillende duidingen van de 403-vordering onderzocht: de 'hoofdelijke' vordering, de 'dynamische' vordering, de analoge toepassing van art. 6:142 BW ten aanzien van de 403-vordering en tot slot de analoge toepassing van de bepalingen inzake borgtocht ten aanzien van de 403-aansprakelijkheid (§ 6.2). Ik heb voor verschillende situaties onderzocht wat de gevolgen zijn van iedere duiding ( $(6.3)$. Vervolgens heb ik deze gevolgen vergeleken met de uitkomst in deze situaties volgens het door mij bepleite uitgangspunt voor compensatie. Hieruit volgt dat een analoge toepassing van de bepalingen inzake borgtocht ten aanzien van de aansprakelijkheid van een moedermaatschappij op grond van een 403-verklaring in alle onderzochte situaties overeenkomt met de uitkomst volgens dit uitgangspunt ( 6.4 en $\S 6.5)$.

In het geval dat de bepalingen inzake borgtocht analoog van toepassing zijn op de 403-aansprakelijkheid, heeft deze aansprakelijkheid een afhankelijk en subsidiair karakter. Dit valt echter niet te rijmen met de vereiste hoofdelijke aansprakelijkheid van de moedermaatschappij ex art. 2:403 lid 1 sub f BW. De Hoge Raad heeft daarom in de $A k z o / I N G$-beschikking de analoge toepassing van de bepalingen inzake borgtocht ten aanzien van de 403-aansprakelijkheid afgewezen. ${ }^{202} \mathrm{Om}$ de 403 -aansprakelijkheid als zodanig te kunnen uitleggen, moet art. 2:403 lid 1 sub f BW dus worden gewijzigd.

De enige mogelijkheid die een moedermaatschappij naar huidig recht heeft om te bewerkstelligen dat haar aansprakelijkheid op grond van de 403-verklaring een afhankelijk en subsidiair karakter heeft, is om dit contractueel met een crediteur overeen te komen. Een praktische manier om dit te bereiken, is door de 403-maatschappij een doorlopende volmacht te geven zodat deze dit namens de moedermaatschappij met een crediteur kan afspreken op het moment dat zij zelf een overeenkomst met de desbetreffende crediteur aangaat (§ 6.5.2).

Binnen de mogelijkheden van het huidige art. 2:403 BW, komen de gevolgen van het analoog toepassen van art. 6:142 BW ten aanzien van de 403-vordering en de gevolgen van de duiding van de 403-vordering als een dynamische vordering het vaakst overeen met de uitkomsten volgens het door mij bepleite uitgangspunt voor compensatie. ${ }^{203}$ De Hoge Raad heeft de analoge toepassing

202. HR 28 juni 2002, JOR 2002/136, m.nt. Bartman (Akzo/ING), r.o. 3.4.3, 3.4.5 en 3.4.6.

203. Ik merk op dat hoewel de gevolgen van deze twee duidingen van de 403 -vordering in de door mij onderzochte situaties even vaak overeenkomen met de uitkomsten volgens het 
van art. 6:142 BW ten aanzien van de 403-vordering echter impliciet afgewezen in zijn $A k z o / I N G$-beschikking ${ }^{204}(§ 6.5 .3)$. Ik pleit er daarom voor dat de 403-vordering naar huidig recht wordt geduid als een dynamische vordering. Deze duiding houdt in dat de 403 -vordering een hoofdelijke vordering is die altijd toekomt aan degene met de corresponderende vordering op de 403-maatschappij. Dit betekent dat er een bepaalde mate van verbondenheid bestaat tussen de vordering op de moeder- en die op de 403-maatschappij. Het is echter niet zeker of de Hoge Raad de duiding van de 403-vordering als een dynamische vordering toestaat omdat twee van zijn uitspraken op dit punt tegenstrijdig zijn aan elkaar. ${ }^{205} \mathrm{Ik}$ spreek de hoop uit dat - zolang de wetgever art. 2:403 BW niet aanpast zodat de 403-aansprakelijkheid een afhankelijk en subsidiair karakter krijgt - de Hoge Raad de mogelijkheid krijgt om de ontstane onduidelijkheid weg te nemen en de 403-vordering duidt als een dynamische vordering (§ 6.5.4). Als de Hoge Raad echter de duiding van de 403-vordering als een dynamische vordering afwijst, moet deze vordering worden geduid als een hoofdelijke vordering $(\S 6.5 .5)$.

door mij bepleite uitgangspunt voor compensatie, de gevolgen onderling op enkele punten verschillen.

204. HR 28 juni 2002, JOR 2002/136, m.nt. Bartman (Akzo/ING), r.o. 3.5.3.

205. HR 20 maart 2015, JOR 2015/140, m.nt. Josephus Jitta (Minister van Financiën/VEB c.s.), r.o. 4.30 en HR 3 april 2015, JOR 2015/191, m.nt. Faber en Vermunt (Eikendal q.q./Lentink), r.o. 3.6.2. 



\section{Hoofdstuk 7. De intrekking van een 403-verklaring}

\subsection{Inleiding}

Een moedermaatschappij kan haar 403-verklaring intrekken door een daartoe strekkende verklaring te deponeren, een zogenoemde 'intrekkingsverklaring'. De moedermaatschappij is niet aansprakelijk voor de schulden die voortvloeien uit de rechtshandelingen die de 403-maatschappij verricht vanaf het moment dat de moedermaatschappij tegenover de crediteur een beroep kan doen op de intrekking.

Ik begin dit hoofdstuk met een algemene uiteenzetting van de intrekking van een 403-verklaring, waarbij ik in het bijzonder aandacht besteed aan het moment dat de moedermaatschappij een beroep kan doen op de intrekking (§ 7.2). Daarna ga ik in op de eventuele periode tussen het moment dat de moedermaatschappij een beroep kan doen op de intrekking van de 403-verklaring en het moment dat de 403-maatschappij een jaarrekening openbaar maakt die voldoet aan de voorschriften van titel 9 van Boek 2 BW (§ 7.3). Voorts onderzoek ik of het mogelijk is dat de moedermaatschappij in de intrekkingsverklaring opneemt dat de 403-verklaring pas op een bepaald moment in de toekomst wordt ingetrokken ( $\$ 7.4$ ), en of de moedermaatschappij de 403-verklaring zodanig kan vormgeven, dat deze tevens heeft te gelden als een intrekkingsverklaring $(\S 7.5)$.

Vervolgens ga ik in op de situatie dat de 403-maatschappij niet meer gebruikmaakt van de jaarrekeningvrijstelling van het groepsregime, maar de moedermaatschappij is vergeten de 403-verklaring in te trekken. Ik onderzoek onder welke omstandigheden een beroep van een crediteur op de vergeten 403-verklaring onaanvaardbaar is naar maatstaven van redelijkheid en billijkheid (§ 7.6), en hoe een moedermaatschappij preventief de aansprakelijkheid op grond van de 403-verklaring kan limiteren voor het geval zij vergeet deze verklaring in te trekken $(\S 7.7)$. Als laatste onderzoek ik of de intrekking van de 403-verklaring door de moedermaatschappij onder omstandigheden misbruik van recht kan zijn (§ 7.8).

1. Bartman, Dorresteijn \& Olaerts 2020, p. 225. 


\subsection{Intrekken van de 403-verklaring}

\subsubsection{De intrekking}

Een moedermaatschappij kan haar 403-verklaring om verschillende redenen intrekken. ${ }^{2} \mathrm{Zij}$ kan dit onder meer doen omdat de 403-maatschappij niet langer gebruikmaakt van de jaarrekeningvrijstelling van het groepsregime, omdat zij niet aansprakelijk wil zijn voor de schulden die voortvloeien uit nieuwe rechtshandelingen die de 403-maatschappij verricht, of omdat de 403-maatschappij door een fusie of zuivere splitsing is verdwenen of binnenkort zal verdwijnen. ${ }^{3}$ De moedermaatschappij kan ook besluiten de 403-verklaring in te trekken omdat een aandeelhouder van de 403-maatschappij niet meer instemt met de afwijking van de jaarrekeningvoorschriften, ${ }^{4}$ of omdat de groepsband met de 403-maatschappij is verbroken of op korte termijn zal verbreken. ${ }^{5}$ Als deze instemming ontbreekt of de groepsband is verbroken, kan de 403-maatschappij niet meer gebruikmaken van de jaarrekeningvrijstelling van het groepsregime. Het is dan niet meer nodig dat de moedermaatschappij - als voorwaarde zodat de 403-maatschappij gebruik kan maken van deze jaarrekeningvrijstelling aansprakelijk is voor de schulden die voortvloeien uit nieuwe rechtshandelingen die de 403-maatschappij verricht. In het jaar 2019 zijn er bij het handelsregister 1256 intrekkingsverklaringen gedeponeerd. ${ }^{6}$

Op grond van art. 2:404 lid 1 BW kan een moedermaatschappij haar 403-verklaring intrekken door een daartoe strekkende verklaring te deponeren bij het handelsregister. ${ }^{7}$ Volgens Beckman en Nass heeft de wetgever het woord kan niet overbodig gebruikt. Zij zijn van mening dat een moedermaatschappij haar 403-verklaring ook op andere manieren kan intrekken. ${ }^{8}$ Beckman en Nass geven echter geen voorbeeld van hoe een 403-verklaring kan worden ingetrokken, anders dan door de deponering van een intrekkingsverklaring. Beckman merkt weliswaar terecht op dat de moedermaatschappij een einddatum in de 403-verklaring kan opnemen waardoor zij niet aansprakelijk is voor de schulden die

2. Beckman 1995a, p. 577-578 en Asser/Maeijer \& Kroeze 2-I*2015/585.

3. Zie $\S 9.7$ en $\S 9.9 .1$

4. Zie art. 2:403 lid 1 sub b BW en $\S 2.3 .4$.

5. Zie de aanhef van art. 2:403 lid $1 \mathrm{BW}$ en $\S 2.3 .2$.

6. Op 22 april 2020 per e-mail aan mij meegedeeld door de afdeling Databeheer Orderbehandeling van de Kamer van Koophandel. Daarnaast heeft de afdeling Databeheer Orderbehandeling mij op 22 februari 2017 per e-mail laten weten dat er in het jaar 2016 bij het handelsregister 1032 intrekkingsverklaringen zijn gedeponeerd.

7. Zie Van Zoest 2019, p. 31, die een voorbeeld geeft hoe een intrekkingsverklaring eruit kan zien.

8. Beckman 1995a, p. 580-582 en E.C.A. Nass 2019, p. 141. Vgl. Asser/Maeijer \& Kroeze $2-I^{*} 2015 / 585$, waar in het midden wordt gelaten of een moedermaatschappij de 403-verklaring op een andere manier - dan door het deponeren van een intrekkingsverklaring - kan intrekken. 
voortvloeien uit een rechtshandeling die de 403-maatschappij nadien verricht. ${ }^{9}$ Maar het verstrijken van de einddatum betekent niet dat de 403-verklaring op dat moment is ingetrokken in de zin van art. 2:404 lid 1 BW - ik kom hier later op terug. ${ }^{10}$ Daarnaast wijzen Beckman en Nass erop dat de moedermaatschappij de crediteuren kan inlichten dat zij geen nieuwe aansprakelijkheid accepteert op grond van de 403-verklaring. Beckman noemt als voorbeeld dat de moedermaatschappij een dergelijke mededeling in een aantal dagbladen publiceert. Hij merkt zelf echter al op dat dit niet hetzelfde effect heeft als de intrekking van een 403-verklaring in de zin van art. 2:404 lid $1 \mathrm{BW}$, omdat crediteuren die geen kennis hebben genomen van een publicatie nog steeds de moedermaatschappij op grond van de 403-verklaring aansprakelijk kunnen stellen.

Evenals Willems kan ik mij niet vinden in bovenstaande uitleg van art. 2:404 lid 1 BW. ${ }^{11}$ Naar mijn mening betekent het woord kan in art. 2:404 lid 1 BW slechts dat de mogelijkheid bestaat om de 403-verklaring in te trekken - door de deponering van een intrekkingsverklaring. Een dergelijke interpretatie van art. 2:404 lid $1 \mathrm{BW}$ biedt rechtszekerheid. Derden hoeven niet bedacht te zijn op andere wijzen van intrekking van de 403-verklaring dan door de deponering van een intrekkingsverklaring. Bijvoorbeeld crediteuren hebben er belang bij om eenvoudig duidelijkheid te kunnen krijgen of de moedermaatschappij de 403-verklaring al of niet heeft ingetrokken door bij het handelsregister na te gaan of er een intrekkingsverklaring is gedeponeerd.

In art. 2:404 lid $1 \mathrm{BW}$ is expliciet opgenomen dat een moedermaatschappij alleen een verklaring van aansprakelijkheid in de zin van art. 2:403 lid 1 sub $\mathrm{f}$ BW kan intrekken. Art. 2:404 lid $1 \mathrm{BW}$ is niet van toepassing op een verklaring die niet voldoet aan het vereiste van art. 2:403 lid 1 sub f BW. ${ }^{12}$ Als de moedermaatschappij een verklaring van aansprakelijkheid heeft gedeponeerd op grond waarvan zij zich beperkter aansprakelijk stelt dan art. 2:403 lid 1 sub f BW vereist - ik heb dit eerder aangeduid als een 'ontoereikende 403-verklaring, ${ }^{13}$-, kan zij deze verklaring dus niet op grond van art. 2:404 lid $1 \mathrm{BW}$ intrekken. Dit neemt niet weg dat de moedermaatschappij in een dergelijk geval nog steeds - buiten art. 2:404 lid $1 \mathrm{BW}$ om - een verklaring kan deponeren dat zij geen nieuwe aansprakelijkheid meer accepteert op grond van de ontoereikende 403 -verklaring. $\mathrm{Zij}$ is dan niet aansprakelijk voor de schulden die voortvloeien uit de rechtshandelingen die de 403-maatschappij verricht vanaf het moment dat de moedermaatschappij tegenover de crediteur een beroep kan

9. Zie in vergelijkbare zin E.C.A. Nass 2019, p. 141, die speekt van tot beëindiging van voortgezette aansprakelijkheid strekkende clausules in de 403-verklaring.

10. Zie $\S 7.5$.

11. Willems 1997, p. 17.

12. Ramanna 2008, p. 19. Vgl. Beckman 2011, p. 256.

13. Zie $\S 2.3 .6 . c$. 
doen op deze verklaring. Hoewel dit hetzelfde effect heeft als de intrekking van een 403-verklaring op grond van art. 2:404 lid $1 \mathrm{BW}$, is er toch een verschil tussen beide vormen van 'intrekking'. Als de moedermaatschappij een verklaring heeft gedeponeerd dat zij geen nieuwe aansprakelijkheid op grond van de ontoereikende 403-verklaring accepteert, kan zij vervolgens niet haar overblijvende aansprakelijkheid op grond van deze verklaring beëindigen. De regeling van de beëindiging van de overblijvende aansprakelijkheid ex art. 2:404 lid 3 $\mathrm{BW}^{14}$ is namelijk alleen van toepassing op de aansprakelijkheid die overblijft nadat een moedermaatschappij haar 403-verklaring - in de zin van art. 2:403 lid 1 sub f BW - op grond van art. 2:404 lid 1 BW heeft ingetrokken. ${ }^{15}$

De term 'intrekken' kan tot verwarring leiden. Als de moedermaatschappij een intrekkingsverklaring deponeert, betekent dat niet dat derden de 403 -verklaring niet meer kunnen opvragen bij het handelsregister. Het deponeren van een intrekkingsverklaring ontneemt het effect aan de 403-verklaring. ${ }^{16}$ De moedermaatschappij is niet aansprakelijk voor de schulden die voortvloeien uit de rechtshandelingen die de 403-maatschappij verricht vanaf het moment dat de moedermaatschappij tegenover de crediteur een beroep kan doen op de intrekking. ${ }^{17}$ De moedermaatschappij blijft - op grond van de ingetrokken 403-verklaring - aansprakelijk voor de schulden die voortvloeien uit de rechtshandelingen die de 403-maatschappij tot dat moment heeft verricht. ${ }^{18}$ Omdat een ingetrokken 403-verklaring nog steeds kan worden opgevraagd bij het handelsregister, kan in plaats van het intrekken van deze verklaring misschien beter worden gesproken van het buiten werking stellen of het deactiveren van de 403-verklaring. Om zo veel mogelijk aan te sluiten bij (de tekst van) art. 2:404 BW zal ik echter toch de term 'intrekken' gebruiken.

Ik wijs erop dat de regeling van art. 37 van de richtlijn jaarrekeningen met betrekking tot de jaarrekeningvrijstelling voor dochterondernemingen geen bepaling kent op grond waarvan de moederonderneming haar garantstelling voor de aangegane verplichtingen van de dochteronderneming kan intrekken. Slagter merkt op dat er daarom gerede twijfel over bestaat of de intrekking van een 403-verklaring zich verdraagt met de richtlijn. ${ }^{19}$ Volgens Bartman laat de richtlijn op dit punt echter enige vrijheid aan de lidstaten. Ik sluit mij bij hem aan dat aangezien de 403-maatschappij na de intrekking van de 403-verklaring

14. Zie hoofdstuk 8 .

15. Ramanna 2008, p. 19. Zie § 8.3. Vgl. Beckman 2011, p. 256.

16. Beckman \& Van der Zanden 2011, p. 811.

17. Zie $\S 7.2 .3$ voor het moment dat de moedermaatschappij een beroep kan doen op de intrekking van de 403-verklaring.

18. Zie art. 2:404 lid 2 BW en $\S 8.2$.

19. Slagter 2005 , p. 541. 
niet meer gebruik kan maken van de jaarrekeningvrijstelling van het groepsregime, de intrekking niet in strijd is met de richtlijn. ${ }^{20}$

De bevoegdheid om te besluiten de 403-verklaring in te trekken, komt toe aan het bestuur van de moedermaatschappij. ${ }^{21,22}$ Het is mogelijk om in de statuten van de moedermaatschappij voorwaarden op te nemen met betrekking tot de besluitvorming tot het intrekken van de 403-verklaring. Bijvoorbeeld dat de raad van commissarissen voorafgaand goedkeuring moet verlenen voordat het bestuur kan besluiten om de 403-verklaring in te trekken. Evenals bij de besluitvorming omtrent het deponeren van een 403 -verklaring, ${ }^{23}$ meen ik dat een dergelijke statutaire voorwaarde enkel interne werking heeft. Het desbetreffende bestuursbesluit kan worden vernietigd en de bestuurders kunnen aansprakelijk worden gesteld voor de eventuele schade - bijvoorbeeld als de moedermaatschappij een schadevergoeding moet betalen omdat zij aan een partij die regelmatig nieuwe overeenkomsten met de 403-maatschappij aangaat, had toegezegd de 403-verklaring niet in te trekken. ${ }^{24}$ Maar als de intrekkingsverklaring is gedeponeerd, is de 403-verklaring daardoor ingetrokken in de zin van art. 2:404 lid $1 \mathrm{BW}$. De moedermaatschappij kan vanzelfsprekend wel een nieuwe 403 -verklaring deponeren. ${ }^{25}$

Hoewel de intrekking van de 403-verklaring gevolgen kan hebben voor de 403-maatschappij - bijvoorbeeld dat een leverancier geen nieuwe overeenkomst wil aangaan omdat de moedermaatschappij niet hoofdelijk aansprakelijk is voor de schulden die uit de overeenkomst voortvloeien -, heeft de 403-maatschappij geen (formele) invloed op de keuze van de moedermaatschappij om

20. Bartman in zijn annotatie onder Hof 's-Hertogenbosch 7 april 2009, JOR 2009/160 (Inalfa). Zie ook Niels 2010, p. 28. Bartman en Niels verwijzen overigens naar een voorloper van art. 37 van de richtlijn jaarrekeningen: art. 57 van de vierde EEG-richtlijn.

21. Asser/Maeijer \& Kroeze 2-I* 2015/585 en Bartman, Dorresteijn \& Olaerts 2020, p. 225.

22. De moedermaatschappij hoeft het voornemen om de 403 -verklaring in te trekken niet ex art. 25 WOR voor advies voor te leggen aan een eventueel door haar ingestelde (centrale of groeps-)ondernemingsraad of een door de 403-maatschappij ingestelde ondernemingsraad. Zie Van het Kaar 2005, p. 36-37, Ten Voorde 2006, p. 63, De Jager 2006, p. 22, Bartman, Dorresteijn \& Olaerts 2020, p. 226 en Rb. Arnhem 21 juli 2004, JIN 2004/27 (Acordis Beheer), r.o. 16. Dit is slechts anders indien de moedermaatschappij hierover toezeggingen heeft gedaan aan de door haar of door de 403-maatschappij ingestelde ondernemingsraad. Zie Hof Amsterdam (OK) 13 juli 2000, JOR 2000/174, m.nt. Van het Kaar (OR EBS/HES Beheer I), r.o. 4.4-4.5 en Hof Amsterdam (OK) 20 februari 2001, JOR 2001/92, m.nt. Van het Kaar (OR EBS/HES Beheer II), r.o. 2.12-2.13. Zie Bartman 2002, p. 27, die van mening is dat het aanbeveling verdient een dergelijk adviesrecht bij overeenkomst aan de ondernemingsraad van de 403-maatschappij toe te kennen.

23. Zie $\S$ 2.3.6.a en E.C.A. Nass 2019, p. 105.

24. Zie art. 2:15 lid 1 sub a BW, respectievelijk art. 2:9 BW.

25. Zie hoofdstuk 5 en in het bijzonder $\S 5.6$, waar ik tot de conclusie kom dat een moedermaatschappij op grond van de 403 -verklaring aansprakelijk is voor alle schulden die voortvloeien en zijn voortgevloeid uit een rechtshandeling die de 403-maatschappij heeft verricht. 
deze verklaring al of niet in te trekken. ${ }^{26}$ Doorgaans zal de moedermaatschappij de 403-maatschappij wel informeren over het voornemen om de 403-verklaring in te trekken zodat laatstgenoemde hier eventueel rekening mee kan houden. Bijvoorbeeld als de 403-maatschappij contractueel verplicht is om een leverancier in te lichten als de moedermaatschappij de 403-verklaring intrekt. De moedermaatschappij is echter niet verplicht om de 403-maatschappij in te lichten over de intrekking van de 403-verklaring. Als bijvoorbeeld de groepsband tussen de moeder- en de 403-maatschappij is verbroken en de moedermaatschappij is vergeten de 403 -verklaring in te trekken ${ }^{27}$ zal zij dit nadien alsnog zo snel mogelijk willen doen om extra aansprakelijkheid zo veel mogelijk te voorkomen. Zij zal dan waarschijnlijk niet eerst de 403-maatschappij inlichten.

\subsubsection{De moedermaatschappij kan de 403-verklaring op ieder moment eenzijdig intrekken}

De moedermaatschappij kan de 403-verklaring op ieder moment eenzijdig intrekken. ${ }^{28} \mathrm{Zij}$ hoeft de crediteuren van de 403-maatschappij hiervoor niet vooraf in te lichten. ${ }^{29}$ Zelfs niet als de moedermaatschappij ervan op de hoogte is dat een bepaalde crediteur op reguliere basis (nieuwe) overeenkomsten met de 403-maatschappij sluit en weet dat de crediteur voor de schulden die uit de nieuwe overeenkomsten voortvloeien geen beroep zal kunnen doen op de 403 -verklaring. Het is de eigen verantwoordelijkheid van degene die een overeenkomst met de 403-maatschappij aangaat om zelf vooraf na te gaan of de 403 -verklaring al of niet is ingetrokken. ${ }^{30}$ Een crediteur die regelmatig nieuwe overeenkomsten met de 403-maatschappij sluit, doet er daarom verstandig aan om met de moedermaatschappij overeen te komen dat hij moet worden ingelicht als de moedermaatschappij de 403-verklaring wil intrekken. De crediteur hoeft dan niet voorafgaand aan iedere overeenkomst met de 403-maatschappij

26. Rb. Den Haag 14 mei 2003, JOR 2003/215, m.nt. Loesberg (Info Opleiders) en Bartman, Dorresteijn \& Olaerts 2020, p. 225.

27. Zie $\S 7.6$ waar ik uitgebreid inga op de vergeten 403 -verklaring.

28. Rb. Arnhem 21 juli 2004, JIN 2004/27 (Acordis Beheer), r.o. 13.

29. Deze situatie moet worden onderscheiden van de casus die ten grondslag liggen aan Hof Amsterdam (OK) 29 juli 1993, NJ 1994/132 (Teeuwissen/Teletrade) en Rb. Rotterdam 30 september 2014, JOR 2014/326, m.nt. Loesberg (Pergen/Eneco), waar is geoordeeld dat de moedermaatschappij een crediteur individueel had moeten inlichten over het voornemen om de overblijvende aansprakelijkheid te beëindigen, respectievelijk dat een beroep van de moedermaatschappij op de overschrijding van de verzetstermijn ex art. 2:404 lid 5 BW heeft te gelden als misbruik van recht. Beide uitspraken zijn terecht kritisch ontvangen in de literatuur. Zie $\S 8.5 .4$ en $\S 8.6 .3$.

30. Het is onder bijzondere omstandigheden mogelijk dat de intrekking van de 403-verklaring misbruik van recht is. De moedermaatschappij kan dan geen beroep doen op de intrekking. Hierbij kan worden gedacht aan de situatie dat de moedermaatschappij actief betrokken is geweest bij het voorbereiden van een overeenkomst tussen de 403-maatschappij en een derde, en de moedermaatschappij een dag voordat de overeenkomst wordt gesloten de 403-verklaring intrekt zodat de derde zich niet op haar kan verhalen. Zie $§ 7.8$. 
na te gaan of de 403-verklaring al of niet is ingetrokken. ${ }^{31}$ Indien de moedermaatschappij in een dergelijk geval toch de 403 -verklaring intrekt zonder dit vooraf aan de crediteur te hebben gemeld, dan is een beroep van de moedermaatschappij op de intrekking tegenover de crediteur naar mijn mening onaanvaardbaar naar maatstaven van redelijkheid en billijkheid. De moedermaatschappij is dan (ook) aansprakelijk voor de schulden die zijn voortgevloeid uit de overeenkomsten die de 403-maatschappij en de desbetreffende crediteur na de intrekking van de 403-verklaring zijn aangegaan.

Als de moedermaatschappij de 403-verklaring heeft ingetrokken, kan de 403-maatschappij niet meer (rechtsgeldig) gebruikmaken van de jaarrekeningvrijstelling van het groepsregime. ${ }^{32}$ In de literatuur bestaat discussie over het antwoord op de vraag over welk boekjaar de 403-maatschappij weer een jaarrekening openbaar moet maken die voldoet aan de voorschriften van titel 9 van Boek 2 BW. Enerzijds wordt verdedigd dat de 403-maatschappij een jaarrekening openbaar moet maken over het boekjaar waarin de 403-verklaring is ingetrokken. ${ }^{33}$ Anderzijds zijn er auteurs die menen dat de 403-maatschappij een jaarrekening openbaar moet maken over het boekjaar volgend op het laatste boekjaar waarover de 403-maatschappij een jaarrekening heeft opgemaakt waarbij zij gebruik heeft gemaakt van de jaarrekeningvrijstelling. ${ }^{34}$ Ik sluit mij aan bij dit laatste standpunt. Indien het eerste standpunt zou worden gevolgd, kan dat ertoe leiden dat de 403-maatschappij een jaarrekening opmaakt waarbij zij gebruikmaakt van de jaarrekeningvrijstelling van het groepsregime, nadat de 403-verklaring al is ingetrokken. Als de moedermaatschappij bijvoorbeeld op 31 januari 2020 de 403-verklaring intrekt, moet de 403-maatschappij volgens het eerstgenoemde standpunt over het boekjaar 2020 een jaarrekening openbaar maken die voldoet aan de voorschriften van titel 9 van Boek 2 BW. Over het boekjaar 2019 mag zij nog steeds een jaarrekening opmaken waarbij zij gebruikmaakt van de jaarrekeningvrijstelling. Deze jaarrekening kan ook na 31 januari 2020 door de aandeelhouders worden vastgesteld - dus nadat de 403-verklaring is ingetrokken. Ik heb er eerder echter op gewezen dat de voorwaarden van art. 2:403 BW constitutief zijn. Als de 403-verklaring is ingetrokken, wordt niet meer voldaan aan het vereiste van art. 2:403 lid 1 sub f

31. Bartman, Dorresteijn \& Olaerts 2020, p. 233. Zie bijvoorbeeld Rb. Rotterdam 18 november 2015, ECLI:NL:RBROT:2015:8545 (Van Gansewinkel/Warmtebedrijven), r.o. 2.15, waar de moedermaatschappij contractueel verplicht is het voornemen om de 403-verklaring in te trekken drie maanden voor de intrekking aan een crediteur te melden en deze een vervangende waarborg te geven voor de nakoming van de verplichtingen van de 403-maatschappij.

32. Beckman \& Van der Zanden 2011, p. 809 en Beckman \& Marseille 2013, p. 286.

33. Asser/Maeijer 2-III 2000/440 en E.C.A. Nass 2019, p. 144, 149-150 en 157.

34. Jansz 1973, p. 39, Beckman 1995b, p. 100, Beckman 2011, p. 255-256, Beckman \& Van der Zanden 2011, p. 809-810, Van der Heijden/Van der Grinten \& Dortmond 2013/324.3, Van Zoest 2019, p. 32 en Beckman - SDU Commentaar Ondernemingsrecht 2019, art. 2:404 BW, aant. C.1. 
BW en mag de 403-maatschappij dus niet meer gebruikmaken van de jaarrekeningvrijstelling van het groepsregime.

Bovenstaande houdt in dat de 403-maatschappij met betrekking tot de jaarrekening over het boekjaar volgend op het laatste boekjaar waarover zij een jaarrekening heeft opgemaakt waarbij zij gebruik heeft gemaakt van de jaarrekeningvrijstelling, weer het reguliere jaarrekeningregime moet volgen en een jaarrekening openbaar moet maken die voldoet aan de voorschriften van titel 9 van Boek 2 BW. Indien in het bovengenoemde voorbeeld het tweede standpunt wordt gevolgd - en de aandeelhouders op 31 januari 2020 nog niet de summiere jaarrekening in de zin van art. 2:403 lid 1 sub a BW over het boekjaar 2019 hebben vastgesteld -, moet de 403-maatschappij over het boekjaar 2019 een jaarrekening openbaar maken die voldoet die voldoet aan de voorschriften van titel 9 van Boek 2 BW.

Nass merkt op dat als een belanghebbende van mening is dat de 403-maatschappij na de intrekking van de 403 -verklaring onterecht nog geen jaarrekening openbaar heeft gemaakt die voldoet aan de voorschriften van titel 9 van Boek $2 \mathrm{BW}$, deze op grond van art. 2:394 lid $7 \mathrm{BW}$ een vordering kan instellen tot nakoming van de openbaarmakingsplicht. ${ }^{35}$ Als de vordering wordt toegewezen en de 403-maatschappij de summiere jaarrekening in de zin van art. 2:403 lid $1 \mathrm{sub}$ a BW openbaar maakt, kan de crediteur vervolgens op grond van art. 2:448 jo. art. 2:447 BW een jaarrekeningprocedure instellen bij de OK. Deze procedure moet hij echter wel instellen binnen twee maanden na het depot van de jaarrekening - als de jaarrekening nog niet is vastgesteld - of binnen twee maanden nadat de jaarrekening is vastgesteld.$^{36}$ Het is niet onwaarschijnlijk dat in het laatste geval deze termijn dan al is verlopen.

Indien de intrekking van de 403-verklaring samenhangt met de overdracht van de aandelen in de 403-maatschappij door de moedermaatschappij en de overnemende rechtspersoon zich ook door middel van een 403-verklaring aansprakelijk stelt, kan de 403-maatschappij onverminderd als groepsmaatschappij van de nieuwe moedermaatschappij gebruik blijven maken van de jaarrekeningvrijstelling - mits ook aan de andere voorwaarden hiervoor is voldaan. ${ }^{37}$

\subsubsection{Het moment dat de moedermaatschappij een beroep kan doen op de intrekking van de 403-verklaring}

Als een moedermaatschappij haar 403-verklaring intrekt, blijft zij aansprakelijk voor de schulden die voortvloeien uit de rechtshandelingen die de 403-maatschappij heeft verricht tot het moment dat de moedermaatschappij tegenover

35. E.C.A. Nass 2019, p. 146 en 150.

36. Zie art. 2:449 lid 1 en $2 \mathrm{BW}$.

37. Beckman - Compendium jaarrekening, § 3.8.5.2. 
de crediteur een beroep kan doen op de intrekking. ${ }^{38}$ De moedermaatschappij kan geen beroep doen op de intrekking zolang de intrekkingsverklaring nog niet in het handelsregister is verwerkt door de Kamer van Koophande ${ }^{39}$ en, voor zover van toepassing, er nog geen mededeling van deze deponering is gedaan. ${ }^{40}$ Deze mededelingsplicht geldt onder meer als het gaat om een NV of een $\mathrm{BV}^{41}$ Een crediteur die aantoont dat hij onmogelijk kennis heeft kunnen nemen van de mededeling van de deponering, krijgt een terme de grâce van maximaal vijftien dagen nadat de mededeling is gedaan. Pas na die periode kan de moedermaatschappij tegenover deze crediteur een beroep doen op de intrekking. ${ }^{42}$ Hierbij kan bijvoorbeeld worden gedacht aan de situatie dat de website van de Kamer van Koophandel niet beschikbaar is wegens een denial of service-aanval. De moedermaatschappij kan dan contact opnemen met de crediteuren en hen de intrekkingsverklaring zelf toesturen. Vanaf dat moment kan de moedermaatschappij tegenover deze crediteuren een beroep doen op de intrekking.

\subsubsection{Een 403-verklaring met een einddatum}

Een moedermaatschappij kan in haar 403-verklaring opnemen dat zij zich slechts aansprakelijk stelt voor de schulden die voortvloeien uit de rechtshandelingen die de 403-maatschappij tot een bepaalde datum verricht. Zij neemt dan als het ware een 'einddatum' op in de 403 -verklaring. Het verstrijken van de einddatum betekent echter niet dat de 403 -verklaring op dat moment is

38. Zie art. 2:404 lid $2 \mathrm{BW}$ en $\S 8.2$.

39. Op 13 maart 2019 heeft een medewerker van de Kamer van Koophandel mij telefonisch meegedeeld dat het verwerken van een gedeponeerde intrekkingsverklaring ongeveer vijf werkdagen duurt.

40. Zie art. 25 lid 1 Handelsregisterwet 2007. Op grond van art. 24 lid 1 Handelsregisterwet 2007 draagt de Kamer van Koophandel er zorg voor dat de mededeling wordt gedaan in een door de minister aangewezen publicatieblad, of een ander even doeltreffend instrument, dat ten minste een systeem omvat dat in chronologische volgorde, via een centraal elektronisch platform, toegang tot de geopenbaarde informatie biedt. Zie Snijder-Kuipers - T\&C Ondernemingsrecht, art. 24 Handelsregisterwet 2007, aant. 2 en Van Zoest 2019, p. 31, die erop wijzen dat het elektronische platform dat wordt gebruikt de website van de Kamer van Koophandel is (www.kvk.nl). Op 13 maart 2019 heeft een medewerker van de Kamer van Koophandel mij telefonisch meegedeeld dat de mededeling van de deponering van de intrekkingsverklaring ongeveer vijf werkdagen nadat deze verklaring is gedeponeerd, wordt gedaan op de website. Daarnaast wijs ik erop dat krachtens art. 3a lid 1 Handelsregisterregeling de Staatscourant is aangewezen als publicatieblad als het gaat om een NV of een BV. In het geval dat van een Europese naamloze vennootschap (SE) of een Europese coöperatieve vennootschap (SCE) met statutaire zetel in Nederland is, schrijft art. 3a lid 2 Handelsregisterregeling voor dat het Publicatieblad van de Europese Unie het aangewezen publicatieblad is. Zie ook Asser/Maeijer \& Kroeze 2-I*2015/585.

41. E.C.A. Nass 2019, p. 142. Zie art. 24 lid 1 Handelsregisterwet 2007.

42. Zie art. 25 lid 2 Handelsregisterwet 2007. 
ingetrokken - ik kom hier later op terug. ${ }^{43}$ De moedermaatschappij zal daarvoor een intrekkingsverklaring ex art. 2:404 lid $1 \mathrm{BW}$ moeten deponeren.

Hoewel het verstrijken van een einddatum in een 403-verklaring niet betekent dat deze verklaring is ingetrokken, heeft dit wel civielrechtelijk effect. De Hoge Raad heeft in zijn $A k z o / I N G$-beschikking geoordeeld dat een crediteur geen rechten kan ontlenen aan art. 2:403 BW zelf, maar slechts aan de door de moedermaatschappij gedeponeerde verklaring van aansprakelijkheid. ${ }^{44}$ De moedermaatschappij is slechts aansprakelijk voor zover dit uit de desbetreffende verklaring volgt. Als in de 403-verklaring een einddatum is opgenomen, betekent dit dus dat de moedermaatschappij niet aansprakelijk is voor de schulden die voortvloeien uit de rechtshandelingen die de 403-maatschappij vanaf die datum verricht. $^{45}$

Een volgende vraag is of een moedermaatschappij die zich door middel van een 403-verklaring met een einddatum aansprakelijk stelt, voldoet aan het vereiste van art. 2:403 lid 1 sub f BW. Kan de 403-maatschappij in een dergelijk geval rechtsgeldig gebruikmaken van de jaarrekeningvrijstelling van het groepsregime? Evenals Beckman en Van Zoest beantwoord ik deze vraag bevestigend. ${ }^{46}$ De einddatum mag mijns inziens echter niet eerder zijn dan de dag dat de aandeelhouders van de 403-maatschappij de summiere jaarrekening in de zin van art. 2:403 lid 1 sub a BW vaststellen of - als de jaarrekening nog niet is vastgesteld - twaalf maanden na afloop van het boekjaar. Op dat moment moet aan alle voorwaarden zijn voldaan om gebruik te mogen maken van de jaarrekeningvrijstelling. ${ }^{47}$ Als de 403 -maatschappij bijvoorbeeld met betrekking tot de jaarrekening over het boekjaar 2019 gebruik wil maken van de jaarrekeningvrijstelling van het groepsregime, en haar aandeelhouders op 1 mei 2020 de summiere jaarrekening in de zin van art. 2:403 lid 1 sub a BW over dat boekjaar vaststellen, moet de moedermaatschappij dus ten minste aansprakelijk zijn voor de schulden die voortvloeien uit de rechtshandelingen die de 403-maatschappij tot en met 1 mei verricht.

Aangezien het verstrijken van een einddatum in de 403-verklaring niet kwalificeert als het intrekken van deze verklaring in de zin van art. 2:404 lid $1 \mathrm{BW}$, kan de moedermaatschappij de aansprakelijkheid op grond van deze verklaring (nog) niet beëindigen. Op grond van art. 2:404 lid 2 en 3 BW is het slechts mogelijk de aansprakelijkheid te beëindigen die overblijft na de intrekking van

43. Zie $\S 7.5$.

44. HR 28 juni 2002, $N J$ 2002/447, m.nt. Maeijer (Akzo/ING), r.o. 3.4.3. Ook gepubliceerd in JOR 2002/136, m.nt. Bartman.

45. Beckman 1995a, p. 540-544, Beckman 1995b, p. 100-101 en Ten Voorde 2011, p. 197-198.

46. Beckman 1995b, p. 100-101 en Van Zoest 2019, p. 24.

47. Zie $\S 2.4$. 
een 403 -verklaring. ${ }^{48}$ De moedermaatschappij zal dus eerst een intrekkingsverklaring in de zin van art. 2:404 lid $1 \mathrm{BW}$ moeten deponeren, voordat zij de overblijvende aansprakelijkheid kan beëindigen.

Indien de 403-maatschappij na het verstrijken van de einddatum gebruik wil blijven maken van de jaarrekeningvrijstelling van het groepsregime moet de moedermaatschappij een nieuwe 403-verklaring deponeren. De moedermaatschappij kan de eerdere 403-verklaring intrekken en later - als de groepsband met de 403-maatschappij is verbroken - de overblijvende aansprakelijkheid beëindigen. Als de moedermaatschappij vergeet een nieuwe 403-verklaring te deponeren en de 403-maatschappij maakt toch gebruik van de jaarrekeningvrijstelling, schendt zij de openbaarmakingsplicht. Het bestuur van de 403-maatschappij kan daarvoor eventueel aansprakelijk worden gesteld.

7.3 De periode tussen het doen van een beroep op de intrekking en de openbaarmaking van een jaarrekening door de 403-maatschappij

Als de 403-maatschappij nog niet een jaarrekening openbaar heeft gemaakt die voldoet aan de voorschriften van titel 9 van Boek 2 BW voordat de moedermaatschappij een beroep kan doen op de intrekking van de 403-verklaring, zal er een periode zijn dat crediteuren de jaarrekening van de 403-maatschappij niet kunnen inzien maar daarvoor niet worden gecompenseerd. ${ }^{49}$ Een crediteur van wie de vordering voortvloeit uit een rechtshandeling die de 403-maatschappij in deze periode heeft verricht, wordt hierdoor benadeeld. Ik licht dit toe aan de hand van een voorbeeld. Stel dat een 403-maatschappij met betrekking tot de jaarrekening over het boekjaar 2018 gebruik heeft gemaakt van de jaarrekeningvrijstelling van het groepsregime. De aandeelhouders van de 403-maatschappij hebben op 1 mei 2019 de summiere jaarrekening in de zin van art. 2:403 lid $1 \mathrm{sub}$ a BW over het boekjaar 2018 vastgesteld. Vervolgens trekt de moedermaatschappij de 403-verklaring op 1 juli 2019 in en kan zij op 5 juli een beroep doen op deze intrekking. De moedermaatschappij is dan aansprakelijk voor de schulden die voortvloeien uit de rechtshandelingen die de 403-maatschappij tot 5 juli heeft verricht. Zij is echter niet aansprakelijk voor de schulden die voortvloeien uit de rechtshandelingen die de 403-maatschappij vanaf 5 juli verricht. Omdat de 403 -verklaring is ingetrokken, kan de 403-maatschappij niet meer gebruikmaken van de jaarrekeningvrijstelling van het groepsregime. Zij zal over het boekjaar 2019 een jaarrekening openbaar moeten maken die aan de voorschriften van titel 9 van Boek $2 \mathrm{BW}$ voldoet. $\mathrm{Zij}$

48. Zie $\S 8.2$ en $\S 8.3$.

49. Blommaert 2007, p. 273-274 en Van der Kraan 2012, p. 53. 
moet deze jaarrekening uiterlijk twaalf maanden na afloop van het boekjaar -31 december 2020 - openbaar maken. ${ }^{50}$

In afbeelding 7.1 heb ik bovenstaand voorbeeld weergegeven.

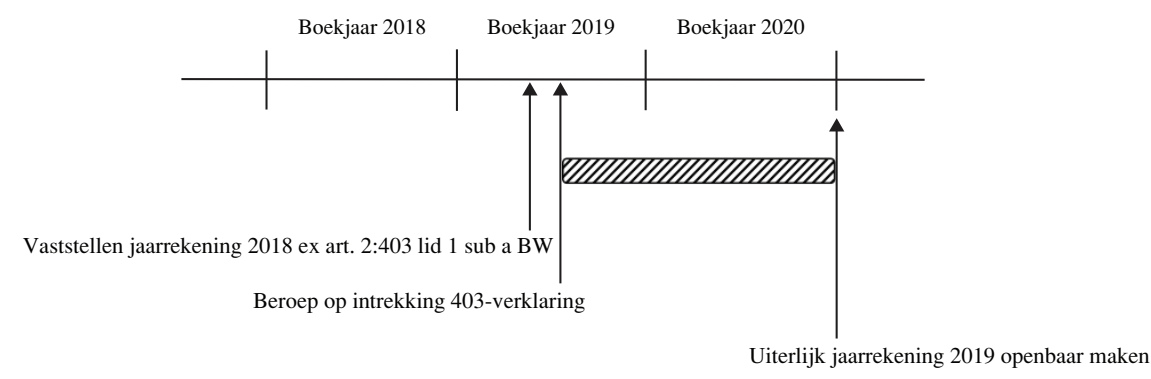

Afbeelding 7.1

In de periode tussen het moment dat de moedermaatschappij tegenover een crediteur een beroep kan doen op de intrekking van de 403-verklaring en het moment dat de 403-maatschappij over het boekjaar 2019 een jaarrekening openbaar maakt die voldoet aan de voorschriften van titel 9 van Boek 2 BW, kan de crediteur de jaarrekening van de 403-maatschappij nog niet inzien, maar wordt hij daarvoor niet gecompenseerd.

Dat de crediteuren in bovenstaand voorbeeld op 5 juli 2019 - de dag dat de moedermaatschappij een beroep kan doen op de intrekking van de 403 -verklaring - de jaarrekening van de 403-maatschappij over het boekjaar 2019 (nog) niet kunnen inzien, is op zichzelf niet opmerkelijk. Ook als de 403-maatschappij geen gebruik zou hebben gemaakt van de jaarrekeningvrijstelling van het groepsregime zouden de crediteuren deze jaarrekening nog niet kunnen inzien. Een verschil met deze laatste situatie is echter dat de crediteuren in dat geval wel de jaarrekening over het boekjaar 2018 zouden kunnen inzien - aangezien in bovenstaand voorbeeld de jaarrekening over het boekjaar 2018 op 1 mei 2019 door de aandeelhouders is vastgesteld, zou deze op grond van art. 2:394 lid $1 \mathrm{BW}$ binnen acht dagen openbaar moeten zijn gemaakt. Een crediteur zou dan (mede) aan de hand daarvan kunnen schatten hoe groot het risico is dat de 403-maatschappij zijn vordering niet (volledig) zal voldoen. Hij heeft in dat geval dus geen gebrek aan inzicht. Omdat de 403-maatschappij in het voorbeeld echter met betrekking tot de jaarrekening over het boekjaar 2018 gebruik heeft gemaakt van de jaarrekeningvrijstelling van het groepsregime, kan de crediteur die jaarrekening niet inzien. Een crediteur van wie de vordering voortvloeit uit een rechtshandeling die de 403-maatschappij vanaf 5 juli 2019 heeft verricht, ontbreekt het dus aan de mogelijkheid om (mede) aan de hand van de

50. Zie art. 2:394 lid 3 BW. 
jaarrekening te schatten hoe groot het risico is dat de 403-maatschappij de vordering niet (volledig) zal voldoen, maar hij wordt hiervoor niet gecompenseerd aangezien de moedermaatschappij niet aansprakelijk is voor de schulden die voortvloeien uit deze rechtshandeling. Zelfs als de 403-maatschappij bereid is om een crediteur die daarom vraagt de jaarrekening over 2018 ter beschikking te stellen, helpt dat de crediteur niet. Over het boekjaar 2018 heeft de 403-maatschappij slechts een summiere jaarrekening hoeven opmaken. ${ }^{51}$ De crediteur zal dus moeten wachten totdat de 403-maatschappij de jaarrekening over het boekjaar 2019 openbaar maakt voordat hij weer de mogelijkheid heeft om een jaarrekening in te zien die voldoet aan de voorschriften van titel 9 van Boek 2 BW.

Dat er een periode kan zijn zoals hierboven omschreven, strookt niet met het door mij bepleite uitgangspunt voor compensatie. ${ }^{52}$ Alle crediteuren die als gevolg van het gebruikmaken van de jaarrekeningvrijstelling door de 403-maatschappij een gebrek aan inzicht hebben omdat zij de jaarrekening van de 403-maatschappij niet kunnen inzien, moeten hiervoor worden gecompenseerd. Zij moeten zich op grond van de 403-verklaring op de moedermaatschappij kunnen verhalen. ${ }^{53}$ Slechts de crediteuren die een relatie met de 403-maatschappij zijn aangegaan nadat deze weer een jaarrekening openbaar heeft gemaakt die voldoet aan de voorschriften van titel 9 van Boek 2 BW, hoeven niet te worden gecompenseerd. Uit de parlementaire geschiedenis is niet op te maken waarom de wetgever er niet voor heeft gekozen om het voortduren van aansprakelijkheid op grond van een 403-verklaring - voor de schulden die voortvloeien uit nieuwe rechtshandelingen van de 403-maatschappij - te koppelen aan het openbaar maken van een jaarrekening door de 403-maatschappij.

Het is mijns inziens wenselijk dat art. 2:404 BW wordt aangepast om bovenstaande lacune in de compensatie van de crediteuren van de 403-maatschappij te verhelpen. Aan lid 1 van art. 2:404 BW kan worden toegevoegd dat de intrekking van de 403 -verklaring slechts of eerst effect ${ }^{54}$ heeft als de 403 -maatschappij een jaarrekening openbaar heeft gemaakt die aan de voorschriften van

51. Zie art. 2:403 lid 1 sub a BW.

52. Zie $\S 3.7$.

53. De compensatie voor een crediteur bestaat uit twee onderdelen: een vordering op de moedermaatschappij op grond van de 403-verklaring en de mogelijkheid om de geconsolideerde jaarrekening van de moedermaatschappij in te zien. Zie $\$ 3.4 .1$.

54. Als art. 2:404 lid $1 \mathrm{BW}$ op de voorgestelde wijze wordt gewijzigd en de moedermaatschappij een intrekkingsverklaring deponeert nadat de 403-maatschappij al een jaarrekening openbaar heeft gemaakt die voldoet aan de voorschriften van titel 9 van Boek 2 BW heeft de intrekking direct effect. Dit neemt niet weg dat de moedermaatschappij aansprakelijk is voor de schulden die voortvloeien uit de rechtshandelingen die de 403-maatschappij verricht totdat de moedermaatschappij tegenover de crediteur een beroep kan doen op de intrekking (zie art. 2:404 lid $2 \mathrm{BW}$ en $§ 7.2 .3$ ). 
titel 9 van Boek 2 BW voldoet, ${ }^{55}$ of als er een nieuwe 403 -verklaring is gedeponeerd ten aanzien van de 403-maatschappij. Deze nieuwe 403-verklaring kan zowel door de moedermaatschappij als door een andere rechtspersoon worden gedeponeerd. De moedermaatschappij kan een nieuwe 403-verklaring deponeren omdat zij bij nader inzien toch wil dat de 403-maatschappij gebruik kan blijven maken van de jaarrekeningvrijstelling van het groepsregime. Een andere rechtspersoon zou een 403-verklaring kunnen deponeren als hij de aandelen in de 403-maatschappij heeft overgenomen van de moedermaatschappij en wil dat de 403-maatschappij gebruik kan blijven maken van de jaarrekeningvrijstelling.

Een mogelijk nadeel als art. 2:404 lid 1 BW op de door mij voorgestelde wijze wordt gewijzigd, is dat een moedermaatschappij bij de intrekking van de 403-verklaring afhankelijk kan zijn van de 403-maatschappij. Als de moedermaatschappij de 403-verklaring intrekt voordat de 403-maatschappij een jaarrekening openbaar heeft gemaakt, zal de intrekking pas effect hebben als laatstgenoemde een jaarrekening openbaar maakt - tenzij er een nieuwe 403-verklaring is of wordt gedeponeerd. Als de 403-maatschappij tot de groep van de moedermaatschappij behoort, zal dit geen bezwaar zijn. De moederen de 403-maatschappij kunnen dan onderling afstemmen wanneer de moedermaatschappij de 403-verklaring intrekt en wanneer de 403-maatschappij een jaarrekening openbaar maakt. Op die manier kan de moedermaatschappij ervoor zorgen dat op het moment dat zij de 403-verklaring intrekt, de 403-maatschappij al een jaarrekening openbaar heeft gemaakt die voldoet aan de voorschriften van titel 9 van Boek $2 \mathrm{BW}$ zodat de intrekking direct effect heeft. Als echter de groepsband tussen de moeder- en de 403-maatschappij is verbroken voordat de 403-maatschappij een jaarrekening openbaar heeft gemaakt, ligt het anders. De moedermaatschappij heeft dan geen doorslaggevende invloed om de 403-maatschappij te dwingen een jaarrekening openbaar te maken.

In het geval dat art. 2:404 lid $1 \mathrm{BW}$ op de hierboven genoemde wijze wordt aangepast en de moedermaatschappij de 403-verklaring wil intrekken nadat de groepsband met de 403-maatschappij is verbroken maar laatstgenoemde nog geen jaarrekening openbaar heeft gemaakt, heeft de moedermaatschappij een paar mogelijkheden om de 403-maatschappij te bewegen om een jaarrekening openbaar te maken. Ik merk op dat de moedermaatschappij mijns inziens

55. Bartman 1986, p. 106, Gülcher 1989a, p. 165, Houwen, Schoonbrood-Wessels \& Schreurs 1993 , p. 842, Berk 2007, p. 18, Franken \& Franken 2008, p. 73 en Van der Kraan 2012, p. 53. In 1969 heeft de Commissie Vennootschapsrecht een vergelijkbaar voorstel gedaan met betrekking tot art. 42c WvK. Zie Kamerstukken II 1969/70, 10689, 4, p. 30 (bijlage 2 MvT). Zie ook E.C.A. Nass 2019, p. 99, die betoogt dat de 403-aansprakelijkheid ten minste zou moeten zien op de schulden die voortvloeien uit de rechtshandelingen die de 403-maatschappij heeft verricht tot het moment zij een jaarrekening openbaar heeft gemaakt die voldoet aan de voorschriften van titel 9 van Boek 2 BW. 
zelf niet kwalificeert als een belanghebbende die een vordering ex art. 2:394 lid 7 BW kan instellen tot nakoming van de openbaarmakingsplicht. Het belang van de moedermaatschappij - dat de intrekking van de 403-verklaring effect krijgt - is naar mijn mening niet een belang dat door de openbaarmaking van de jaarrekening wordt beschermd. ${ }^{56}$ Een crediteur kan echter wel kwalificeren als belanghebbende in de zin van art. 2:394 lid $7 \mathrm{BW} .{ }^{57}$ De moedermaatschappij zou daarom een crediteur van de 403-maatschappij kunnen benaderen om een vordering tot nakoming van de openbaarmakingsplicht in te stellen - indien de moedermaatschappij zelf een vordering op de 403-maatschappij heeft, zou zij zelf uit dien hoofde een dergelijke vordering kunnen instellen. Overigens merk ik op dat als de vordering wordt toegewezen, dit de moedermaatschappij waarschijnlijk op de korte termijn niet helpt. Het is slechts mogelijk om nakoming te vorderen van de verplichting voor de 403-maatschappij om uiterlijk twaalf maanden na afloop van het boekjaar een jaarrekening openbaar te maken. ${ }^{58}$ Een andere mogelijkheid voor de moedermaatschappij om te proberen de 403-maatschappij te bewegen om een jaarrekening openbaar te maken, is door een vordering tot schadevergoeding in te stellen op grond van onrechtmatige daad. ${ }^{59}$ Als de 403-maatschappij bewust wacht met het openbaar maken van de jaarrekening met geen ander doel dan de moedermaatschappij met meer aansprakelijkheid 'op te zadelen', handelt zij mijns inziens in strijd met hetgeen volgens ongeschreven recht in het maatschappelijk verkeer betamelijk is - ook als er nog geen twaalf maanden zijn verstreken na afloop van het boekjaar en de 403-maatschappij nog niet op grond van art. 2:394 lid $3 \mathrm{BW}$ verplicht is de jaarrekening openbaar te maken. De moedermaatschappij kan in een dergelijk geval een schadevergoeding vorderen voor de schade die zij hierdoor lijdt, te weten: het bedrag van de vorderingen die zij op grond van de 403-verklaring heeft moeten voldoen omdat de intrekking van deze verklaring nog geen effect heeft. ${ }^{60}$

Ik onderken dat de door mij voorgestelde wijziging van art. 2:404 lid 1 BW nadelen met zich kan brengen voor de moedermaatschappij. Dit zal in het bijzonder zo zijn als de moedermaatschappij na het verbreken van de groepsband met de 403-maatschappij, de 403-verklaring wil intrekken maar de 403-maatschappij nog niet een jaarrekening openbaar heeft gemaakt die voldoet aan de voorschriften van titel 9 van Boek 2 BW. Voor een moedermaatschappij kan

56. Beckman - SDU Commentaar Ondernemingsrecht 2019, art. 2:394 BW, aant. C.11, in algemene zin over een belanghebbende in de zin van art. 2:394 lid 7 BW.

57. HR 3 februari 1988, NJ 1989/225, m.nt. Maeijer (Naba Beheer), r.o. 4.3. Zie Beckman 1997, p. 166, Assink/Slagter 2013/138.1 en Asser/Maeijer \& Kroeze 2-I*2015/570. Zie ook § 3.8.

58. Zie art. 2:394 lid 3 BW.

59. Zie art. 6:162 BW.

60. Daarnaast kan de moedermaatschappij een vrijwaring vorderen voor de schulden die zij eventueel in de toekomst nog moet voldoen omdat de intrekking van de 403-verklaring nog geen effect heeft. 
het bezwaarlijk zijn om de 403-maatschappij - na het verbreken van de groepsband - te moeten bewegen om een jaarrekening openbaar te maken die voldoet aan de voorschriften van titel 9 van Boek 2 BW. Als de moedermaatschappij een vordering instelt tot vergoeding van de schade die zij lijdt omdat de 403-maatschappij nog niet een jaarrekening openbaar heeft gemaakt, zal het in het bijzonder een uitdaging zijn om te bewijzen dat de 403-maatschappij bewust de jaarrekening nog niet openbaar maakt met geen ander doel dan de moedermaatschappij te benadelen. Dit bezwaar tegen de aanpassing van art. 2:404 lid $1 \mathrm{BW}$ weegt naar mijn mening echter niet op tegen het nadeel voor de crediteuren, dat er op grond van het huidige art. 2:404 BW een periode kan zijn dat zij de jaarrekening van de 403-maatschappij niet kunnen inzien maar daarvoor niet worden gecompenseerd. De crediteuren hebben geen invloed op de intrekking van de 403-verklaring. Mijns inziens mogen zij daarom daardoor niet in een nadeliger positie komen ${ }^{61}$ en dient art. 2:404 lid $1 \mathrm{BW}$ te worden aangepast zodat alle crediteuren die de jaarrekening van de 403-maatschappij niet kunnen inzien, worden gecompenseerd. Het is de moedermaatschappij die de 403-verklaring intrekt. Naar mijn mening is het daarom gerechtvaardigd om van haar extra oplettendheid te verwachten om voordat de groepsband wordt verbroken, met de 403-maatschappij af te stemmen wanneer de 403-verklaring wordt ingetrokken en de 403-maatschappij een jaarrekening openbaar maakt die voldoet aan de voorschriften van titel 9 van Boek 2 BW.

\subsection{Toekomstige intrekking}

Een moedermaatschappij kan in de intrekkingsverklaring opnemen dat de 403-verklaring op een bepaalde datum in de toekomst wordt ingetrokken. ${ }^{62}$ Dit is vergelijkbaar met een toekomstige ingangsdatum in een 403 -verklaring. ${ }^{63}$ In beide gevallen neemt de moedermaatschappij in de desbetreffende verklaring op dat deze pas effect heeft vanaf de genoemde datum. ${ }^{64}$ Het in de intrekkingsverklaring opnemen dat de 403-verklaring op een bepaalde datum in de toekomst wordt ingetrokken, moet overigens worden onderscheiden van het opnemen van een einddatum in de 403 -verklaring. ${ }^{65}$ In het laatste geval stelt de moedermaatschappij zich op grond van de 403-verklaring aansprakelijk voor de schulden die voortvloeien uit de rechtshandelingen die de 403-maatschappij

61. Zie $\S 3.6 .1$.

62. Beckman 1995a, p. 544 en Kiersch - T\&C Burgerlijk Wetboek, art. 2:404 BW, aant. 2.

63. Beckman 1987, p. 532, Koning 1991, p. 28, Bartman, Dorresteijn \& Olaerts 2020, p. 220 en Kiersch - T\&C Burgerlijk Wetboek, art. 2:403 BW, aant. 1 (zie § 5.2.3).

64. Aangezien de intrekkingsverklaring al eerder is gedeponeerd, kan de moedermaatschappij op de genoemde datum meteen tegenover een crediteur een beroep doen op de intrekking. Zie $\S 7.2 .3$.

65. Zie $\S 7.2 .4$. 
tot een bepaalde datum verricht. Door het verstrijken van de einddatum is de 403-verklaring echter niet ingetrokken - ik kom hier later op terug. ${ }^{66}$

Als de moedermaatschappij in de intrekkingsverklaring opneemt dat de 403-verklaring op een bepaalde datum in de toekomst wordt ingetrokken, betekent dat niet dat zij de 403-verklaring niet alsnog op een eerder moment kan intrekken. Zij moet dan een nieuwe intrekkingsverklaring deponeren die de eerdere intrekkingsverklaring - met toekomstige intrekkingsdatum - vervangt. Het kan onder meer van belang zijn om de 403 -verklaring eerder in te trekken als de moedermaatschappij de aandelen in de 403-maatschappij vóór de genoemde intrekkingsdatum wil overdragen aan een derde. Zij zou anders aansprakelijk blijven voor de schulden die voortvloeien uit de rechtshandelingen die de 403-maatschappij - tot de intrekkingsdatum - verricht, terwijl zij geen doorslaggevende zeggenschap meer heeft ten aanzien van de 403-maatschappij. Voor de duidelijkheid kan een moedermaatschappij in de intrekkingsverklaring met een toekomstige intrekkingsdatum opnemen dat de 403-verklaring alsnog op een eerder moment kan worden ingetrokken - door de deponering van een nieuwe intrekkingsverklaring. ${ }^{67}$

Om de datum te achterhalen waarop de 403-verklaring wordt of is ingetrokken, zal een crediteur bij het handelsregister de intrekkingsverklaring moeten opvragen. Het kan gebeuren dat een crediteur bij het handelsregister alleen nagaat óf de moedermaatschappij een intrekkingsverklaring heeft gedeponeerd, zonder dat hij de verklaring zelf opvraagt om te controleren of in deze verklaring een (toekomstige) intrekkingsdatum is opgenomen. Hij gaat er dan ten onrechte van uit dat de 403-verklaring al is ingetrokken. Dit is echter geen groot bezwaar. Als de crediteur besluit om een overeenkomst met de 403-maatschappij aan te gaan - in de veronderstelling dat de 403-verklaring al is ingetrokken - ondervindt hij daarvan geen nadeel. Als hij er naderhand achter komt dat de 403 -verklaring op dat moment toch nog niet was ingetrokken, weet hij dat hij zich ook op de moedermaatschappij kan verhalen.

\subsection{Kan de 403-verklaring tevens gelden als een intrekkingsverklaring?}

Een intrekkingsverklaring is vormvrij. Aangezien de intrekkings- en de 403-verklaring op dezelfde wijze openbaar worden gemaakt - door deponering bij het handelsregister -, menen sommige auteurs dat het mogelijk is om

66. Zie $\S 7.5$.

67. Beckman 1995a, p. 541. Vgl. Ramanna 2008, p. 19 en Van der Kraan 2012, p. 56, die deze opmerking onderschrijven, maar van mening zijn dat een 403 -verklaring met een einddatum tevens geldt als een intrekkingsverklaring (zie $\S 7.5$ ). 
een 403-verklaring zodanig vorm te geven, dat deze tevens als een intrekkingsverklaring geldt - op grond waarvan de 403-verklaring op een datum in de toekomst wordt ingetrokken.$^{68}$ De moedermaatschappij neemt dan in de 403 -verklaring op dat deze op een bepaalde datum wordt ingetrokken.

Evenals de meeste auteurs kan ik mij echter niet vinden in bovenstaand standpunt. ${ }^{69}$ Op grond van art. 2:404 lid 1 BW kan een moedermaatschappij de 403-verklaring intrekken door de deponering van 'een daartoe strekkende verklaring'. Mijns inziens kwalificeert een 403-verklaring waarin is opgenomen dat deze verklaring op een bepaalde datum wordt ingetrokken, niet als 'een daartoe strekkende verklaring' in de zin van art. 2:404 lid 1 BW. Om te gelden als een verklaring die strekt tot de intrekking van de 403-verklaring moet de intrekking mijns inziens de essentie van de verklaring zijn. De intrekking van de 403-verklaring moet de belangrijkste boodschap zijn. Dit kan niet als een 'kanttekening' in de verklaring zijn opgenomen. Aangezien de crediteuren van de 403-maatschappij niet betrokken hoeven te worden bij de intrekking van de 403-verklaring moeten zij zelf bij het handelsregister nagaan of deze verklaring al of niet is ingetrokken. Ik meen dat zij de intrekkingsverklaring daarom ook als zodanig moeten kunnen herkennen bij het handelsregister en dat de intrekking niet 'verstopt' mag zitten in een ander document. Een 403-verklaring waarin is opgenomen dat deze verklaring op een bepaalde datum wordt ingetrokken, voldoet mijns inziens niet aan de attenderingsfunctie die op grond van art. 2:404 lid $1 \mathrm{BW}$ is vereist voor een intrekkingsverklaring. De desbetreffende 403-verklaring is daarom op de genoemde datum niet ingetrokken in de zin van deze bepaling.

Dat een 403-verklaring waarin is opgenomen dat deze verklaring op een bepaalde datum wordt 'ingetrokken', op de desbetreffende datum niet is ingetrokken in de zin van art. 2:404 lid $1 \mathrm{BW}$, betekent overigens niet dat deze passage helemaal zonder gevolgen is. De opmerking dat de 403 -verklaring op een bepaalde datum wordt 'ingetrokken', heeft mijns inziens hetzelfde effect als het opnemen van een einddatum in de 403-verklaring - de mogelijkheid om een einddatum op te nemen, heb ik eerder behandeld. ${ }^{70} \mathrm{Ik}$ noem drie punten die ik eerder ook noemde met betrekking tot een dergelijke einddatum. Ten eerste merk ik op dat een mededeling in de 403-verklaring dat deze op een bepaalde datum wordt 'ingetrokken' civielrechtelijk effect heeft. De Hoge Raad heeft in zijn $A k z o / I N G$-beschikking geoordeeld dat een crediteur geen rechten kan ontlenen aan art. 2:403 BW zelf, maar slechts aan de door de

68. Ramanna 2008, p. 19, Van der Kraan 2012, p. 56 en Spierings 2016, p. 233. Vgl. Niels 2010, p. 40 .

69. Winter 1989, p. 289, Houwen, Schoonbrood-Wessels \& Schreurs 1993, p. 855, Asser/ Maeijer 2-III 2000/440, Blommaert 2007, p. 273 en Bartman, Dorresteijn \& Olaerts 2020, p. 224-225.

70. Zie $\S 7.2 .4$. 
moedermaatschappij gedeponeerde verklaring van ansprakelijkheid. ${ }^{71}$ De moedermaatschappij is dus slechts aansprakelijk voor zover dit uit de desbetreffende verklaring volgt. De mededeling in de 403-verklaring dat deze verklaring op een bepaalde datum wordt 'ingetrokken', moet volgens mij zo worden uitgelegd dat de moedermaatschappij geen aansprakelijkheid accepteert voor de schulden die voortvloeien uit de rechtshandelingen die de 403-maatschappij vanaf die datum verricht. De moedermaatschappij is dus niet aansprakelijk voor de schulden die voortvloeien uit de rechtshandelingen die de 403-maatschappij vanaf de desbetreffende datum verricht.

Ten tweede kan de 403-maatschappij rechtsgeldig gebruikmaken van de jaarrekeningvrijstelling van het groepsregime als de moedermaatschappij zich aansprakelijk stelt door middel van een 403-verklaring waarin is opgenomen dat deze verklaring op een bepaalde datum wordt 'ingetrokken'. De datum waarop de 403-verklaring wordt 'ingetrokken', mag dan echter niet eerder zijn dan de datum waarop de aandeelhouders van de 403-maatschappij de summiere jaarrekening in de zin van art. 2:403 lid 1 sub a BW vaststellen ${ }^{72}$ of - als de jaarrekening nog niet is vastgesteld - twaalf maanden na afloop van het boekjaar. Op dat moment moet aan alle voorwaarden zijn voldaan om rechtsgeldig gebruik te maken van de jaarrekeningvrijstelling. ${ }^{73}$ De moedermaatschappij moet dus ten minste aansprakelijk zijn voor de schulden die voortvloeien uit de rechtshandelingen die de 403-maatschappij tot en met dat moment heeft verricht.

Het derde en laatste gevolg waar ik op wijs, heeft betrekking op de beëindiging van de overblijvende aansprakelijkheid. Aangezien het in de 403-verklaring opnemen dat deze verklaring op een bepaalde datum wordt 'ingetrokken' mijns inziens niet leidt tot een intrekking in de zin van art. 2:404 lid $1 \mathrm{BW}$, kan de moedermaatschappij haar aansprakelijkheid op grond van deze verklaring (nog) niet beëindigen ${ }^{74} \mathrm{Zij}$ zal daarvoor eerst een intrekkingsverklaring ex art. 2:404 lid $1 \mathrm{BW}$ moeten deponeren.

Tot slot merk ik op dat er een alternatief bestaat voor het in de 403-verklaring opnemen dat deze op een bepaalde datum wordt 'ingetrokken', wat wel leidt tot een intrekking in de zin van art. 2:404 lid 1 BW. De moedermaatschappij kan

71. HR 28 juni 2002, JOR 2002/136, m.nt. Bartman (Akzo/ING), r.o. 3.4.3.

72. Zie $\S 7.3$, waar ik tot de conclusie kom dat het wenselijk is dat art. 2:404 lid $1 \mathrm{BW}$ wordt gewijzigd, zodat de intrekking van de 403-verklaring slechts of eerst effect heeft als de 403-maatschappij een jaarrekening openbaar heeft gemaakt die voldoet aan de voorschriften van titel 9 van Boek 2 BW, of als er een nieuwe 403-verklaring is gedeponeerd ten aanzien van de 403-maatschappij. Als art. 2:404 lid $1 \mathrm{BW}$ aldus wordt gewijzigd, volgt daaruit dat de 403-maatschappij slechts rechtsgeldig gebruik kan maken van de jaarrekeningvrijstelling van het groepsregime als de datum waarop de 403-verklaring wordt 'ingetrokken' niet eerder is dan een van beide momenten.

73. Zie $\S 2.4$.

74. Zie art. 2:404 lid 2 en $3 \mathrm{BW}$ en $\S 8.2$ en $\S 8.3$. 


\section{HOOFDSTUK 7}

tegelijk met de 403-verklaring een intrekkingsverklaring deponeren waarin zij opneemt dat de 403-verklaring op een bepaalde datum in de toekomst wordt ingetrokken. ${ }^{75}$ Dit kan de moedermaatschappij onder meer doen als zij al weet dat de 403-maatschappij slechts eenmalig met betrekking tot de jaarrekening over een bepaald boekjaar gebruik wil maken van de jaarrekeningvrijstelling van het groepsregime. $\mathrm{Zij}$ loopt dan niet het risico dat zij uiteindelijk vergeet om de 403 -verklaring in te trekken. ${ }^{76}$

\subsection{Vergeten de 403-verklaring in te trekken}

\subsubsection{Inleiding}

In de jurisprudentie is verschillende keren de situatie aan de orde gekomen dat een 403-maatschappij niet meer gebruikmaakt van de jaarrekeningvrijstelling van het groepsregime, maar de moedermaatschappij is vergeten de 403-verklaring in te trekken. Dit kan zich bijvoorbeeld voordoen als de moedermaatschappij de aandelen in de 403-maatschappij verkoopt maar vergeet de 403-verklaring in te trekken. De vraag die bij al deze uitspraken beantwoord moest worden, is of een crediteur een beroep kan doen op een dergelijke 'vergeten 403-verklaring'.

Hoe vaak het voorkomt dat een moedermaatschappij vergeet haar 403-verklaring in te trekken, is niet bekend. Maar het aantal instemmings- ${ }^{77}$ en 403 -verklaringen die bij het handelsregister zijn gedeponeerd, geven wellicht een indicatie. Als een 403-maatschappij rechtsgeldig gebruik wil maken van de jaarrekeningvrijstelling van het groepsregime moeten beide verklaringen zijn gedeponeerd. ${ }^{78}$ Gedurende het jaar 2019 zijn er 13.603 instemmingsverklaringen bij het handelsregister gedeponeerd. Daarnaast zijn er op 31 december 2019 bij het handelsregister 16.719403 -verklaringen gedeponeerd. ${ }^{79}$

Uit deze cijfers blijkt dat ten anzien van ongeveer een vijfde deel van de 403-maatschappijen wél een 403-verklaring, maar geen (jaarlijkse) instemmingsverklaring is gedeponeerd. Er zijn een paar redenen denkbaar voor deze discrepantie. Ten eerste is het mogelijk dat de moedermaatschappij al

75. Zie $\S 7.4$.

76. Zie $\$ 7.6$ en $\$ 7.7 .4$.

77. Zie art. 2:403 lid 1 sub b BW en $\S 2.3 .4$.

78. Zie art. 2:403 lid $1 \mathrm{sub} b$, f en $\mathrm{g} B W, \S 2.3 .4$ en $\S 2.3 .6$.

79. Op 22 april 2020 per e-mail aan mij meegedeeld door de afdeling Databeheer Orderbehandeling van de Kamer van Koophandel. Daarnaast heeft een medewerker van de Kamer van Koophandel op 10 februari 2017 telefonisch aan mij meegedeeld dat er gedurende het jaar 2016 bij het handelsregister 12.680 instemmingsverklaringen zijn gedeponeerd en dat er op 31 december 2016 bij het handelsregister 16.956 403-verklaringen zijn gedeponeerd. 
een 403-verklaring heeft gedeponeerd, maar dat de aandeelhouders van de 403-maatschappij nog niet hebben ingestemd met de afwijking van de jaarrekeningvoorschriften. Dit kan zich voordoen als de 403-maatschappij met betrekking tot eerdere jaarrekeningen geen gebruik heeft gemaakt van de jaarrekeningvrijstelling van het groepsregime, maar dit ten aanzien van de eerstvolgende jaarrekening wél wil doen. De moedermaatschappij deponeert dan 'alvast' een 403-verklaring in de veronderstelling dat de instemmingsverklaring binnenkort volgt. Een andere reden voor de discrepantie kan zijn dat de 403-maatschappij gebruikmaakt van de jaarrekeningvrijstelling en dat de moedermaatschappij ten behoeve daarvan een 403-verklaring heeft gedeponeerd, maar dat de 403-maatschappij is vergeten om haar aandeelhouders om instemming te vragen voor het afwijken van de jaarrekeningvoorschriften. ${ }^{80}$ De 403 -maatschappij maakt dan onterecht gebruik van de jaarrekeningvrijstelling van het groepsregime, omdat niet aan alle voorwaarden hiervoor is voldaan. Tot slot merk ik op dat een deel van bovenstaand verschil tussen het aantal instemmings- en 403-verklaringen misschien kan worden verklaard doordat de 403-maatschappij in het verleden gebruik heeft gemaakt van de jaarrekeningvrijstelling van het groepsregime, maar dat zij dat tegenwoordig niet meer doet. Aangezien de 403-maatschappij niet meer gebruikmaakt van de jaarrekeningvrijstelling, is er ook geen verklaring gedeponeerd dat haar aandeelhouders instemmen met een afwijking van de jaarrekeningvoorschriften. De moedermaatschappij is sindsdien echter vergeten de 403-verklaring in te trekken.

\subsubsection{Toelichting op de jurisprudentie}

In de jurisprudentie is het vraagstuk omtrent de vergeten 403-verklaring op twee manieren aan de orde gekomen. Ten eerste zijn er uitspraken waarbij de rechter moet oordelen of een crediteur de moedermaatschappij aansprakelijk kan stellen op grond van de vergeten 403 -verklaring. ${ }^{81}$ In de meeste gevallen heeft de moedermaatschappij daarentegen haar - in eerste instantie vergeten 403-verklaring na verloop van tijd alsnog ingetrokken en wil zij de overblijvende aansprakelijkheid beëindigen. ${ }^{82}$ De rechter moet dan oordelen of de crediteur verzet kan instellen tegen dit voornemen om de overblijvende aansprakelijkheid te beëindigen. ${ }^{83}$ Hoewel de rechtsvragen verschillend zijn, is de achterliggende afweging hetzelfde. Het is telkens de vraag of de crediteur

80. Of dat de verklaring van de instemming per abuis niet is gedeponeerd.

81. Rb. Rotterdam 15 april 1999, JOR 1999/119 (Lely Industries/Netagco Holding), Rb. Almelo 24 juni 2008, JOR 2008/227, m.nt. Bartman (Hoeveholding) en Hof Amsterdam (OK) 12 januari 2010, JOR 2010/94, m.nt. Bartman (Hoeveholding).

82. Zie art. 2:404 lid $3 \mathrm{BW}$ en $\S 8.3$.

83. Rb. Utrecht 31 juli 1996, JOR 1996/96 (Manning q.q./Haverkort Bouwgroep), Rb. Rotterdam 16 april 2009, JOR 2009/161, m.nt. Van der Zanden (BosGijze/Jones Lang LaSalle), Hof Amsterdam (OK) 30 september 2010, JOR 2010/306, m.nt. Bartman (Jones Lang LaSalle/BosGijze), Rb. Utrecht 10 november 2010, JOR 2011/16, m.nt. Bartman (De 
een beroep kan doen op de 403-verklaring - inhoudende dat de moedermaatschappij moet nakomen of dat de crediteur verzet kan instellen tegen de beëindiging - of dat het beroep op de 403-verklaring onaanvaardbaar is naar maatstaven van redelijkheid en billijkheid - waardoor de moedermaatschappij niet aansprakelijk is of het verzet is afgewezen. Ik richt mij voor dit onderzoek op het antwoord op de vraag onder welke omstandigheden een beroep van een crediteur op een vergeten 403-verklaring onaanvaardbaar is naar maatstaven van redelijkheid en billijkheid - later in deze paragraaf kom ik op deze rechtsvraag terug. Op welke grond de crediteur een beroep doet op deze verklaring is van ondergeschikt belang. Ik laat dit onderscheid daarom verder rusten.

Tot begin 2010 hebben alle uitspraken met betrekking tot een vergeten 403 -verklaring dezelfde uitkomst. Telkens oordeelt de rechter dat de crediteur onverminderd een beroep kan doen op de vergeten 403 -verklaring. ${ }^{84}$ Vanuit het oogpunt van rechtszekerheid en een redelijke verdeling van verantwoordelijkheden en risico's komt meer gewicht toe aan de gedeponeerde 403-verklaring dan aan de omstandigheden waaruit de crediteur kan afleiden dat de moedermaatschappij is vergeten de 403 -verklaring in te trekken. ${ }^{85}$

De Jones Lang LaSalle-beschikking uit 2010 is de eerste uitspraak waarbij een beroep van een crediteur op een vergeten 403 -verklaring niet wordt gehonoreerd ${ }^{86}$ De feiten die ten grondslag liggen aan deze uitspraak zijn kort gezegd als volgt. De moedermaatschappij heeft haar aandelen in de 403-maatschappij overgedragen aan een derde. Als een gevolg van deze overdracht is de groepsband tussen de moeder- en de 403-maatschappij verbroken. Sindsdien behoort de 403-maatschappij tot de groep van de overnemende rechtspersoon. Vervolgens doen de zustermaatschappijen - uit de nieuwe groep - een beroep op de vergeten 403-verklaring. Zij spreken de - voormalige - moedermaatschappij aan voor zogenoemde 'intercompany vorderingen' op de 403-maatschappij.

With/Lekkerkerker) en Hof Amsterdam (OK) 23 juli 2014, JOR 2014/233, m.nt. Bartman (Van Lieshout/Koks).

84. Hof Amsterdam 24 december 1992, rolnr. 863, 91 (Hypo/Kap) aldus Bartman, Dorresteijn \& Olaerts 2020, p. 230, Rb. Utrecht 31 juli 1996, JOR 1996/96 (Manning q.q./Haverkort Bouwgroep), r.o. 6.3-6.4, Rb. Rotterdam 15 april 1999, JOR 1999/119 (Lely Industries/ Netagco Holding), r.o. 6.1-6.2, Rb. Almelo 24 juni 2008, JOR 2008/227, m.nt. Bartman (Hoeveholding), r.o. 7, Rb. Rotterdam 16 april 2009, JOR 2009/161, m.nt. Van der Zanden (BosGijze/Jones Lang LaSalle), r.o. 5.1.9-5.1.10 en Hof Amsterdam (OK) 12 januari 2010, JOR 2010/94, m.nt. Bartman (Hoeveholding), r.o. 3.9 (zie ook Hof Amsterdam (OK) 12 januari 2010, JOR 2010/93, m.nt. Bartman onder JOR 2010/94 (Hoeveholding), r.o. 3.3).

85. Rb. Rotterdam 15 april 1999, JOR 1999/119 (Lely Industries/Netagco Holding), r.o. 6.1-6.2 en Rb. Almelo 24 juni 2008, JOR 2008/227, m.nt. Bartman (Hoeveholding), r.o. 7.

86. Hof Amsterdam (OK) 30 september 2010, JOR 2010/306, m.nt. Bartman (Jones Lang LaSalle/BosGijze), r.o. 3.13-3.15. 
De OK overweegt dat aangezien de groepsband met de - voormalige - moedermaatschappij is verbroken, de 403-maatschappij niet meer (rechtsgeldig) gebruik kan maken van de jaarrekeningvrijstelling van het groepsregime. Daarnaast wijst de OK erop dat bij de nieuwe groep van de 403-maatschappij sprake is van een (feitelijke) personele unie, waardoor alle rechtspersonen binnen de groep zonder meer geacht moeten worden op de hoogte te zijn van de verbroken groepsband tussen de - voormalige - moeder- en de 403-maatschappij. Volgens de OK brengt een redelijke en op de praktijk toegesneden toepassing van het groepsregime met zich dat onder deze omstandigheden de - voormalige - moedermaatschappij op grond van de vergeten 403-verklaring niet aansprakelijk is voor de intercompany vorderingen van de zustermaatschappijen op de 403-maatschappij. De zustermaatschappijen kunnen daarom geen beroep doen op deze verklaring.

Hoewel de uitkomst van de Jones Lang LaSalle-beschikking positief is ontvangen, ${ }^{87}$ is er in de literatuur een kritische kanttekening geplaatst bij de juridische grondslag van het oordeel van de OK. Verschillende auteurs merken terecht op dat een moedermaatschappij op grond van een 403-verklaring wél aansprakelijk is voor intercompany vorderingen op de 403 -maatschappij. ${ }^{88} \mathrm{De}$ OK had daarom niet moeten oordelen dat de - voormalige - moedermaatschappij op grond van de vergeten 403-verklaring niet aansprakelijk is voor de intercompany vorderingen van de zustermaatschappijen op de 403-maatschappij. In plaats daarvan had zij moeten oordelen dat het beroep van de zustermaatschappijen op de vergeten 403-verklaring onaanvaardbaar is naar maatstaven van redelijkheid en billijkheid ex art. 6:2 lid $2 \mathrm{BW} .{ }^{89}$ Het lijkt erop dat deze kritiek niet aan dovemansoren is gericht. In de twee uitspraken met betrekking tot een vergeten 403 -verklaring die volgden, nam de rechter deze grond als uitgangspunt voor zijn oordeel.

Als eerste heeft de Rechtbank Utrecht het beroep van een crediteur op een vergeten 403-verklaring afgewezen. Evenals de OK in de Jones Lang LaSallebeschikking wijst de rechtbank op de nauwe band tussen de crediteur en de 403-maatschappij. ${ }^{90}$ De rechtbank merkt op dat de crediteur een lening heeft

87. Bartman in zijn annotatie onder Hof Amsterdam (OK) 30 september 2010, JOR 2010/306 (Jones Lang LaSalle/BosGijze), Beckman 2010b, p. 698, Marquenie 2011, p. 109 en A.G.S. Nass 2013, p. 478. Zie ook: Van der Zanden in zijn annotatie onder Rb. Rotterdam 16 april 2009, JOR 2009/161 (BosGijze/Jones Lang LaSalle), Niels 2010, p. 39 en Van Wijngaarden 2010, p. 134. Anders: Stücken 2011, p. 101.

88. Bartman in zijn annotatie onder Hof Amsterdam (OK) 30 september 2010, JOR 2010/306 (Jones Lang LaSalle/BosGijze), De Neve 2011, p. 53, Marquenie 2011, p. 109 en Ohmann 2011, p. 172. Zie $§ 4.5 .2$.

89. Beckman 2010b, p. 698 en Marquenie 2011, p. 109. Vgl. De Neve 2011, p. 54.

90. Rb. Utrecht 10 november 2010, JOR 2011/16, m.nt. Bartman (De With/Lekkerkerker), r.o. 4.13. Zie ook Beckman 2010c, p. 698 en De Neve 2011, p. 55. Anders: Stücken 2011, p. $100-101$. 
verstrekt aan de partij die de aandelen in de 403-maatschappij heeft overgenomen van de moedermaatschappij. Daarnaast wijst zij erop dat de crediteur sinds de overname (middellijk) aandeelhouder is van de 403-maatschappij en dat de 403-maatschappij borg staat voor de terugbetaling van de lening aan de crediteur. Volgens de rechtbank moet de crediteur daarom hebben geweten dat de groepsband tussen de - voormalige - moeder- en de 403-maatschappij is verbroken en dat de moedermaatschappij is vergeten haar 403-verklaring in te trekken. De rechtbank oordeelt dat het beroep van de crediteur op de vergeten 403-verklaring onaanvaardbaar is naar maatstaven van redelijkheid en billijkheid.

De meest recente uitspraak met betrekking tot een vergeten 403 -verklaring is van de $\mathrm{OK} .{ }^{91} \mathrm{Zij}$ herhaalt de eerdergenoemde overweging dat vanuit het oogpunt van rechtszekerheid en een redelijke verdeling van verantwoordelijkheden en risico's meer gewicht toekomt aan de gedeponeerde 403-verklaring dan aan de omstandigheden waaruit de crediteur kan afleiden dat de moedermaatschappij is vergeten de 403 -verklaring in te trekken. Dit is volgens de OK slechts anders indien het beroep van de crediteur op de vergeten 403-verklaring naar maatstaven van redelijkheid en billijkheid onaanvaardbaar is. In casu ziet zij echter geen reden om af te wijken van de hoofdregel en honoreert zij het beroep van de crediteur op de vergeten 403 -verklaring.

Met deze twee laatste uitspraken is een duidelijke lijn ingezet hoe geoordeeld moet worden over (het beroep van een crediteur op) een vergeten 403-verklaring. Het uitgangspunt is dat een crediteur een beroep kan doen op de vergeten 403-verklaring, maar dat een dergelijk beroep onder omstandigheden onaanvaardbaar kan zijn naar maatstaven van redelijkheid en billijkheid. Welke omstandigheden onder meer een rol kunnen spelen, komt hieronder aan bod.

\subsubsection{Omstandigheden die mede bepalen of een beroep op de vergeten 403-verklaring onaanvaardbaar is naar maatstaven van redelijkheid en billijkheid}

\subsection{3.a Inleiding}

In de literatuur en de jurisprudentie zijn verschillende omstandigheden genoemd die van belang kunnen zijn bij de beoordeling of een beroep van een crediteur op een vergeten 403-verklaring onaanvaardbaar is naar maatstaven van redelijkheid en billijkheid. Hieronder ga ik in op vier van deze omstandigheden.

91. Hof Amsterdam (OK) 23 juli 2014, JOR 2014/233, m.nt. Bartman (Van Lieshout/Koks), r.o. 3.10. 
Mijns inziens moet de vraag of een beroep van een crediteur op een vergeten 403-verklaring onaanvaardbaar is naar maatstaven van redelijkheid en billijkheid worden beantwoord aan de hand van de omstandigheden op het moment dat de 403-maatschappij de rechtshandeling heeft verricht waaruit de vordering van de crediteur is voortgevloeid. Dit moment is namelijk bepalend of de moedermaatschappij aansprakelijk is voor een schuld van de 403-maatschappij. ${ }^{92}$ De moedermaatschappij is aansprakelijk voor alle schulden die voortvloeien uit de rechtshandelingen die de 403-maatschappij heeft verricht in de periode waarop de 403 -aansprakelijkheid betrekking heeft. ${ }^{93}$

7.6.3.b De groepsband tussen de moeder- en de 403-maatschappij is verbroken

Een van de voorwaarden om gebruik te kunnen maken van de jaarrekeningvrijstelling van het groepsregime is dat de moeder- en de 403-maatschappij tot dezelfde groep behoren. ${ }^{94}$ Als de groepsband tussen hen is verbroken, kan de 403-maatschappij niet meer (rechtsgeldig) gebruikmaken van de jaarrekeningvrijstelling. Een crediteur kan dus uit het verbroken zijn van de groepsband afleiden dat de moedermaatschappij (waarschijnlijk) is vergeten de 403 -verklaring in te trekken. ${ }^{95}$ Als een crediteur weet of behoort te weten dat de groepsband tussen de moeder- en de 403-maatschappij is verbroken, is het daarom aannemelijker dat zijn beroep op de vergeten 403-verklaring onaanvaardbaar is naar maatstaven van redelijkheid en billijkheid. Als een crediteur bijvoorbeeld bestuurder is van de partij die de aandelen in de 403-maatschappij heeft gekocht van de moedermaatschappij kan hij weten dat de groepsband is verbroken. Ook als een crediteur de geconsolideerde jaarrekening van de moedermaatschappij heeft ingezien en de financiële gegevens van de 403-maatschappij niet daarin zijn geconsolideerd, kan hij daaruit opmaken dat de groepsband is verbroken. ${ }^{96}$ Hetzelfde geldt als de crediteur de geconsolideerde jaarrekening van een andere rechtspersoon dan de moedermaatschappij heef ingezien en de financiële gegevens van de 403-maatschappij daarin wel zijn geconsolideerd. Een crediteur kan deze jaarrekeningen

92. Zie $\S 5.3$ en $\S 8.2 .1$.

93. Zie met betrekking tot de temporele reikwijdte van de 403 -aansprakelijkheid hoofdstuk 5 .

94. Zie de aanhef van art. 2:403 lid $1 \mathrm{BW}$ en $\S 2.3 .2$.

95. Ohmann 2011, p. 172, De Neve 2011, p. 54, Spierings 2012, p. 92-93, A.G.S. Nass 2013, p. 478 en 480, Spierings 2016, p. 232-233 en E.C.A. Nass 2019, p. 149. Zie ook Rb. Utrecht 31 juli 1996, JOR 1996/96 (Manning q.q./Haverkort Bouwgroep), r.o. 6.1. Anders: Willems 1997, p. 16 en Stücken 2011, p. 101.

96. Zie art. 2:406 lid $1 \mathrm{BW}$, op grond waarvan een moedermaatschappij verplicht is om de financiële gegevens van een groepsmaatschappij in haar geconsolideerde jaarrekening te consolideren. Zie ook art. 2:403 lid 1 sub c BW, op grond waarvan een van de voorwaarde om gebruik te mogen maken van de jaarrekeningvrijstelling van het groepsregime is dat de financiële gegevens van de 403-maatschappij zijn geconsolideerd in de geconsolideerde jaarrekening van de moedermaatschappij (zie $\S 2.3 .5$ ). 
bijvoorbeeld inzien als hij als aandeelhouder van de desbetreffende rechtspersoon aanwezig is bij de algemene vergadering waar de jaarrekening is vastgesteld.

Evenals Bartman merk ik op dat een verbroken groepsband tussen de moederen de 403-maatschappij niet per definitie betekent dat de moedermaatschappij is vergeten de 403-verklaring in te trekken. Bartman geeft als voorbeeld dat de moedermaatschappij de aandelen in de 403-maatschappij overdraagt aan een derde en bewust nog enige tijd wacht met het intrekken van de 403-verklaring omdat de economische overdracht pas na de juridische overdracht plaatsvindt. ${ }^{97} \mathrm{Als}$ een crediteur weet, of behoort te weten, dat de groepsband tussen de moeder- en de 403-maatschappij is verbroken, betekent dat dus niet dat hij per definitie daaruit moet afleiden dat de moedermaatschappij is vergeten de 403 -verklaring in te trekken. Hoe meer tijd er echter is verstreken na de verbreking van de groepsband, des te onwaarschijnlijker het is dat de moedermaatschappij bewust haar 403-verklaring nog niet heeft ingetrokken.

Janssen en Nass merken op dat zolang de groepsband niet is verbroken, de moedermaatschappij doorslaggevende zeggenschap heeft ten aanzien van de rechtshandelingen die de 403-maatschappij verricht en de schulden die daaruit voortvloeien - waarvoor de moedermaatschappij op grond van de (vergeten) 403-verklaring aansprakelijk is. ${ }^{98} \mathrm{Zij}$ zijn daarom van mening dat als een moedermaatschappij vergeet de 403-verklaring in te trekken, zij in ieder geval aansprakelijk is voor de schulden die voortvloeien uit de rechtshandelingen die de 403-maatschappij heeft verricht tot het moment dat de groepsband is verbroken. De desbetreffende crediteuren kunnen volgens hen zonder bezwaar een beroep doen op de vergeten 403-verklaring. Mijns inziens is dit standpunt echter te kort door de bocht. Dat de moeder- en de 403-maatschappij (nog steeds) tot dezelfde groep behoren, betekent niet per definitie dat een beroep van een crediteur op de vergeten 403-verklaring niet onaanvaardbaar kan zijn naar maatstaven van redelijkheid en billijkheid. Dit hangt af van alle omstandigheden van het geval. Of de groepsband al of niet is verbroken, is slechts een van de omstandigheden die hierbij een rol speelt. Dit is niet doorslaggevend. Ik wijs bijvoorbeeld op de situatie dat de moeder- en de 403-maatschappij nog steeds tot dezelfde groep behoren, maar de 403-maatschappij geen gebruik meer kan maken van de jaarrekeningvrijstelling van het groepsregime omdat een van de aandeelhouders weigert in te stemmen met de afwijking van de jaarrekeningvoorschriften. ${ }^{99}$ Indien de moedermaatschappij vervolgens vergeet om de 403-verklaring in te trekken en de aandeelhouder een vordering krijgt op de

97. Bartman in zijn annotatie onder Hof Amsterdam (OK) 30 september 2010, JOR 2010/306 (Jones Lang LaSalle/BosGijze). Zie ook Bartman, Dorresteijn \& Olaerts 2020, p. 231.

98. M.J. Janssen 2010, p. 116 en A.G.S. Nass 2013, p. 480.

99. Zie art. 2:404 lid 1 sub b BW en $\S 2.3 .4$. 
403-maatschappij - bijvoorbeeld omdat hij tevens leverancier is -, is het moeilijk voor te stellen dat een beroep van de aandeelhouder op de vergeten 403verklaring niet onaanvaardbaar is wegens strijd met de redelijkheid en billijkheid.

Nass vervolgt dat er volgens haar drie momenten van belang zijn als een crediteur een beroep doet op de vergeten 403 -verklaring nadat de groepsband tussen de moeder- en de 403-maatschappij is verbroken. ${ }^{100}$ Ten eerste het moment dat de moedermaatschappij de 403-verklaring heeft gedeponeerd, vervolgens het moment dat de groepsband tussen de moeder- en de 403-maatschappij is verbroken, en tot slot het moment waarop de moedermaatschappij de 403-verklaring heeft ingetrokken. Volgens Nass moet de duur van de periode tussen de verbreking van de groepsband en de intrekking van de 403 -verklaring worden vergeleken met de duur van de totale periode tussen de deponering en de intrekking van de 403 -verklaring. Hoe meer tijd is verstreken sinds het verbreken van de groepsband - in verhouding tot de totale periode tussen de deponering en de intrekking van de 403-verklaring -, hoe aannemelijker het volgens haar is dat het beroep van de crediteur op de vergeten 403-verklaring onaanvaardbaar is naar maatstaven van redelijkheid en billijkheid.

Ook deze redenering overtuigt mij niet. De verhouding tussen de duur van de verschillende periodes is niet van belang bij de beoordeling of een beroep op de vergeten 403-verklaring al of niet onaanvaardbaar is naar maatstaven van redelijkheid en billijkheid. Relevant is slechts de tijd die is verstreken sinds de groepsband tussen de moeder- en de 403-maatschappij is verbroken. Hierboven merkte ik al op dat hoe meer tijd is verstreken na de verbreking van de groepsband, hoe onwaarschijnlijker het is dat de moedermaatschappij bewust haar 403-verklaring nog niet heeft ingetrokken. Als een crediteur weet, of behoort te weten, dat de groepsband tussen de moeder- en de 403-maatschappij is verbroken, is het daarom aannemelijker dat zijn beroep op de vergeten 403-verklaring onaanvaardbaar is naar maatstaven van redelijkheid en billijkheid naarmate er meer tijd is verstreken sinds de verbreking van de groepsband.

\subsection{3.c De 403-maatschappij heeft een jaarrekening openbaar gemaakt}

Als de 403-maatschappij (weer) een jaarrekening openbaar heeft gemaakt die voldoet aan de voorschriften van titel 9 van Boek $2 \mathrm{BW}$, is dat om twee redenen van belang bij de beoordeling of het beroep van een crediteur op de vergeten 403-verklaring al of niet onaanvaardbaar is naar maatstaven van redelijkheid en billijkheid. Ten eerste is hieruit af te leiden dat de 403-maatschappij niet meer gebruikmaakt van de jaarrekeningvrijstelling van het groepsregime en dat de moedermaatschappij daarom (waarschijnlijk) is vergeten de

100. A.G.S. Nass 2013, p. 480. 
403-verklaring in te trekken. ${ }^{101}$ Daarnaast speelt mee dat een crediteur van wie de vordering voortvloeit uit een rechtshandeling die de 403-maatschappij heeft verricht nadat zij een jaarrekening openbaar heeft gemaakt die voldoet aan de voorschriften van titel 9 van Boek 2 BW, het niet heeft ontbroken aan de mogelijkheid om deze jaarrekening in te zien. Toen hij de relatie met de 403-maatschappij is aangegaan, en gedurende deze relatie, heeft hij de jaarrekening kunnen inzien. Hij heeft dus geen nadeel ondervonden van het feit dat de 403-maatschappij in het verleden gebruik heeft gemaakt van de jaarrekeningvrijstelling.

Evenals Nass ben ik van mening dat het enkele feit dat de 403-maatschappij weer een jaarrekening openbaar heeft gemaakt, op zichzelf niet voldoende is om mee te wegen in de beoordeling of het beroep van een crediteur op de vergeten 403-verklaring onaanvaardbaar is naar maatstaven van redelijkheid en billijkheid. ${ }^{102}$ Alleen als wordt bewezen dat een crediteur ervan op de hoogte is of behoort te zijn dat de 403-maatschappij weer een jaarrekening openbaar heeft gemaakt, kan dat een rol spelen bij deze beoordeling. Aangezien een crediteur geen invloed heeft op de keuze van de 403-maatschappij om gebruik te maken van de jaarrekeningvrijstelling van het groepsregime - of om een jaarrekening openbaar te maken die voldoet aan de voorschriften van titel 9 van Boek 2 BW -, heeft hij ten aanzien hiervan een beperkte onderzoeksplicht. Er moet sprake zijn van aanvullende omstandigheden waaruit blijkt dat de crediteur weet, of behoort te weten, dat de 403-maatschappij een jaarrekening openbaar heeft gemaakt en niet meer gebruikmaakt van de jaarrekeningvrijstelling van het groepsregime. Nass noemt als voorbeelden van mogelijk aanvullende omstandigheden dat de jaarrekening aan de crediteur is toegezonden, of dat de crediteur als aandeelhouder van de 403-maatschappij aanwezig is geweest bij de algemene vergadering waar de jaarrekening is vastgesteld. Als een crediteur weet, of behoort te weten, dat de 403-maatschappij een jaarrekening openbaar heeft gemaakt, is het aannemelijker dat zijn beroep op de vergeten 403-verklaring onaanvaardbaar is naar maatstaven van redelijkheid en billijkheid.

101. E.C.A. Nass 2019 , p. 149

102. A.G.S. Nass 2013, p. 479-480. Zie Rb. Rotterdam 15 april 1999, JOR 1999/119 (Lely Industries/Netagco Holding), r.o. 4.1.c en 6.2 en Hof Amsterdam (OK) 23 juli 2014, JOR 2014/233, m.nt. Bartman (Van Lieshout/Koks), r.o. 3.9-3.10. De laatste uitspraak heeft betrekking op een crediteur die weet dat de 403-maatschappij weer jaarrekeningen openbaar heeft gemaakt. Tijdens de zitting komt echter naar voren dat de crediteur er niet van op de hoogte is geweest dat de moedermaatschappij is vergeten de 403 -verklaring in te trekken. Vgl. Beckman 1995a, p. 592-593. 


\subsection{3.d Professionele partijen}

Volgens de OK moet er bij de verdeling van verantwoordelijkheden en risico's met betrekking tot een vergeten 403-verklaring rekening mee worden gehouden dat de moedermaatschappij een 'professionele' partij is. ${ }^{103} \mathrm{Ik}$ interpreteer deze overweging als volgt dat van bepaalde partijen mag worden verwacht dat zij meer kennis hebben inzake (het intrekken van) een 403-verklaring en dat zij zich daarom bewust(er) moeten zijn van de risico's die de 403-verklaring met zich brengt - waaronder het risico dat ze vergeten deze verklaring in te trekken. Hierbij kan bijvoorbeeld worden gedacht aan het geval dat een moedermaatschappij de aandelen in een 403-maatschappij heeft overgedragen aan een derde - waarna zij is vergeten de 403-verklaring in te trekken - en deze overdracht is begeleid door haar eigen juridische afdeling of dat zij daarbij werd bijgestaan door juridische adviseurs. De gevolgen van het vergeten om de 403-verklaring in te trekken zijn volgens deze redenering dan eerder voor rekening van de moedermaatschappij. Het beroep van een crediteur op de vergeten 403-verklaring is daarom minder snel onaanvaardbaar naar maatstaven van redelijkheid en billijkheid.

Evenals Bartman en Nass ben ik het niet eens met bovenstaande redenering van de OK. ${ }^{104}$ Niet van belang is welke kennis van de moedermaatschappij mag worden verwacht met betrekking tot de 403-verklaring, maar welke kennis van de crediteur mag worden verwacht. Zij wijzen er terecht op dat hoe meer kennis van een crediteur mag worden verwacht met betrekking tot (de intrekking van) een 403-verklaring, hoe sneller deze moet inzien dat de moedermaatschappij is vergeten de 403-verklaring in te trekken. Hierbij kan worden gedacht aan een crediteur die zelf - als moedermaatschappij - op grond van een 403-verklaring aansprakelijk is. Als een dergelijke crediteur een beroep doet op een vergeten 403-verklaring is het aannemelijker dat dit onaanvaardbaar is naar maatstaven van redelijkheid en billijkheid dan wanneer een crediteur die verder onbekend is met het groepsregime een beroep doet op deze verklaring.

7.6.3.e De crediteur heeft een nauwe band met de 403-maatschappij

In de jurisprudentie is een beroep op de vergeten 403-verklaring slechts tweemaal niet gehonoreerd. In beide gevallen gaat het om een crediteur die een nauwe band heeft met de 403-maatschappij. Door deze nauwe band moet de crediteur weten, of behoren te weten, dat de moedermaatschappij is vergeten de 403-verklaring in te trekken.

103. Hof Amsterdam (OK) 12 januari 2010, JOR 2010/94, m.nt. Bartman (Hoeveholding), r.o. 3.9.

104. Bartman in zijn annotatie onder Hof Amsterdam (OK) 12 januari 2010, JOR 2010/94 (Hoeveholding) en A.G.S. Nass 2013, p. 479. 


\section{HOOFDSTUK 7}

Bij de Jones Lang LaSalle-beschikking is er sprake van een (feitelijke) personele unie in het bestuur van de 403-maatschappij en het bestuur van de crediteur die een beroep doet op de vergeten 403 -verklaring. ${ }^{105}$ In verband met deze (feitelijke) personele unie oordeelt de OK dat de crediteur moet hebben geweten dat de moedermaatschappij is vergeten de 403-verklaring in te trekken. Het beroep van de crediteur op de vergeten 403-verklaring is daarom afgewezen. Ik sluit mij aan bij de overwegend positieve reacties in de literatuur op deze uitkomst. ${ }^{106}$

De tweede uitspraak is van de Rechtbank Utrecht inzake De With/Lekkerker$k e r .{ }^{107}$ Deze uitspraak heeft betrekking op een crediteur die een lening heeft verstrekt aan een partij die daarmee de aandelen in de 403-maatschappij heeft overgenomen van de moedermaatschappij. Later heeft de 403-maatschappij zich tegenover de crediteur borg gesteld voor de terugbetaling van deze lening. Tot slot is de crediteur ook (middellijk) aandeelhouder van de 403-maatschappij. In verband met deze nauwe band tussen de crediteur en de 403-maatschappij moet de crediteur hebben geweten dat de moedermaatschappij is vergeten de 403-verklaring in te trekken. De rechtbank oordeelt - naar mijn mening terecht - dat het beroep van de crediteur op deze verklaring daarom onaanvaardbaar is naar maatstaven van redelijkheid en billijkheid. ${ }^{108}$

Een nauwe band van een crediteur met de 403-maatschappij leidt er niet altijd toe dat het beroep van de crediteur op de vergeten 403 -verklaring onaanvaardbaar is naar maatstaven van redelijkheid en billijkheid. Deze band is een van de omstandigheden die meeweegt bij de beoordeling van het beroep, maar hoeft niet doorslaggevend te zijn. Dit blijkt bijvoorbeeld uit de Van Lieshout/Kokbeschikking van de OK. De crediteur is jarenlang adjunct-directeur geweest van de 403-maatschappij, maar kan toch een beroep doen op de vergeten 403-verklaring. Tijdens de zitting is namelijk naar voren gekomen dat de crediteur weliswaar heeft geweten dat de 403-maatschappij niet (meer) gebruikmaakt van de jaarrekeningvrijstelling van het groepsregime, maar dat het niet aannemelijk is dat hij ervan op de hoogte is geweest dat de moedermaatschappij is vergeten

105. Hof Amsterdam (OK) 30 september 2010, JOR 2010/306, m.nt. Bartman (Jones Lang LaSalle/BosGijze), r.o. 3.13

106. Bartman in zijn annotatie onder Hof Amsterdam (OK) 30 september 2010, JOR 2010/306 (Jones Lang LaSalle/BosGijze), Beckman 2010b, p. 698, Marquenie 2011, p. 109 en A.G.S. Nass 2013, p. 478. Zie ook: Van der Zanden in zijn annotatie onder Rb. Rotterdam 16 april 2009, JOR 2009/161 (BosGijze/Jones Lang LaSalle), Niels 2010, p. 39 en Van Wijngaarden 2010, p. 134. Anders: Stücken 2011, p. 101. Zie § 7.6.2, waar ik inga op enkele onduidelijkheden en kanttekeningen bij de uitspraak.

107. Rb. Utrecht 10 november 2010, JOR 2011/16, m.nt. Bartman (De With/Lekkerkerker), r.o. 4.13.

108. Zie ook Beckman 2010c, p. 698, De Neve 2011, p. 55 en A.G.S. Nass 2013, p. 479. 
de 403 -verklaring in te trekken. ${ }^{109}$ Overigens is er in de literatuur kritisch gereageerd op dit oordeel van de OK. Ik sluit mij aan bij verschillende auteurs die betogen dat de crediteur er misschien niet van op de hoogte is geweest dat de moedermaatschappij is vergeten om de 403-verklaring in te trekken, maar dat hij dit als adjunct-directeur wel had moeten zijn. ${ }^{110}$ De OK had daarom moeten oordelen dat het beroep op de vergeten 403-verklaring onaanvaardbaar is naar maatstaven van redelijkheid en billijkheid.

\subsubsection{Een beroep op een vergeten 403-verklaring en het door mij bepleite uitgangspunt voor compensatie}

Aan de hand van het door mij bepleite uitgangspunt voor compensatie onderzoek ik hoe de 403-aansprakelijkheid moet worden uitgelegd in het licht van de functie van deze aansprakelijkheid bij de compensatie van de crediteuren voor het niet kunnen inzien van de jaarrekening van de 403-maatschappij. Strikt genomen heeft dit uitgangspunt dus geen betrekking op de atypische situatie dat een 403-maatschappij weer een jaarrekening openbaar heeft gemaakt, de moedermaatschappij is vergeten de 403-verklaring in te trekken en een crediteur een beroep doet op deze verklaring. Toch zijn er twee grondbeginselen van dit uitgangspunt ${ }^{111}$ die van belang zijn bij de beoordeling onder welke omstandigheden het beroep van een crediteur op een vergeten 403-verklaring onaanvaardbaar is naar maatstaven van redelijkheid en billijkheid. Enerzijds is het van belang dat de aansprakelijkheid van de moedermaatschappij op grond van de 403-verklaring is bedoeld ter compensatie van de crediteuren voor het feit dat zij de jaarrekening van de 403-maatschappij niet kunnen inzien als deze gebruikmaakt van de jaarrekeningvrijstelling van het groepsregime. ${ }^{112}$ Als de 403-maatschappij weer een jaarrekening openbaar heeft gemaakt die voldoet aan de voorschriften van titel 9 van Boek 2 BW, hebben de crediteuren geen gebrek aan inzicht meer. Een crediteur van wie de vordering voortvloeit uit een rechtshandeling die de 403-maatschappij heeft verricht na het openbaar maken van een dergelijke jaarrekening, hoeft dus niet te worden gecompenseerd. Hij zou daarom geen beroep moeten kunnen doen op de vergeten 403-verklaring.

109. Hof Amsterdam (OK) 23 juli 2014, JOR 2014/233, m.nt. Bartman (Van Lieshout/Koks), r.o. 3.9-3.10.

110. Zwemmer, Baghery en Van der Kraan in hun annotaties onder Hof Amsterdam (OK) 23 juli 2014, JAR 2014/209, JIN 2014/156 en JIN 2014/172 (Van Lieshout/Koks) en Huiskes 2015, p. 46.

111. Zie $\S 3.7 .1$.

112. De compensatie voor een crediteur bestaat uit twee onderdelen: een vordering op de moedermaatschappij op grond van de 403-verklaring en de mogelijkheid om de geconsolideerde jaarrekening van de moedermaatschappij in te zien. Zie $\S 3.4 .1$. 
Anderzijds speelt mee dat een crediteur volgens het door mij bepleite uitgangspunt niet in een nadeliger positie mag komen doordat de 403-maatschappij gebruikmaakt of heeft gemaakt van de jaarrekeningvrijstelling van het groepsregime. Hoewel dit beginsel zelf niet wordt geschonden - een crediteur van wie de vordering voortvloeit uit een rechtshandeling die de 403-maatschappij heeft verricht na het openbaar maken van een jaarrekening kan deze jaarrekening inzien en ondervindt dus geen nadeel -, speelt de onderbouwing voor dit beginsel wel een belangrijke rol. Een crediteur heeft geen invloed op de keuze van de 403-maatschappij om al of niet gebruik te maken van de jaarrekeningvrijstelling van het groepsregime noch op de keuze van de moedermaatschappij om de 403 -verklaring in te trekken. ${ }^{113}$ De crediteur heeft daarom een beperkte onderzoeksplicht om na te gaan of de 403-maatschappij nog gebruikmaakt van deze vrijstelling en of de moedermaatschappij is vergeten de 403-verklaring in te trekken. Het uitgangspunt is daarom dat de crediteur moet kunnen vertrouwen op de gedeponeerde 403-verklaring en de moedermaatschappij op grond hiervan aansprakelijk kan stellen. Hiervan kan slechts onder bijzondere omstandigheden worden afgeweken. Het is echter niet aan de crediteur om zelf actief op zoek te gaan naar dergelijke omstandigheden - zoals de omstandigheden die ik in de vorige paragraaf noemde. ${ }^{114}$

Naar mijn mening moet met betrekking tot een beroep op een vergeten 403 -verklaring meer belang worden gehecht aan het feit dat de crediteur geen invloed heeft op de keuze van de moedermaatschappij om de 403-verklaring in te trekken. Van een crediteur mag niet worden verwacht dat hij nagaat of de moedermaatschappij al of niet is vergeten de 403-verklaring in te trekken. De crediteur mag niet de dupe zijn van de onoplettendheid van de moedermaatschappij. Zolang de moedermaatschappij de 403-verklaring niet heeft ingetrokken (en de overblijvende aansprakelijkheid heeft beëindigd), mag de crediteur erop vertrouwen dat de moedermaatschappij aansprakelijk is voor de schulden die voortvloeien uit de rechtshandelingen die de 403-maatschappij (heeft) verricht. Het uitgangspunt is daarom dat een beroep op de vergeten 403-verklaring moet worden gehonoreerd.

Op deze uitkomst van de afweging van de twee genoemde grondbeginselen van het door mij bepleite uitgangspunt voor compensatie, bestaat mijns inziens slechts één uitzondering. Het beroep van een crediteur op een vergeten 403 -verklaring moet worden afgewezen als hij weet, of behoort te weten, dat de moedermaatschappij is vergeten de 403 -verklaring in te trekken. ${ }^{115}$ Als de crediteur namelijk weet, of behoort te weten, dat de moedermaatschappij is vergeten de

113. Zie $\$ 3.6 .1$.

114. Zie $\S 7.6 .3$.

115. Spierings 2012, p. 92 en Bartman, Dorresteijn \& Olaerts 2020, p. 231. 
403-verklaring in te trekken, is het uitgangspunt dat hij een beperkte onderzoeksplicht heeft niet meer van belang. Hij weet dan van de hoed en de rand, of behoort dit te weten, en hoeft dus geen verder onderzoek te doen. De afweging van de twee grondbeginselen valt in dat geval uit in het voordeel van de moedermaatschappij. Het beroep van de crediteur op de vergeten 403-verklaring moet worden afgewezen, omdat hij de jaarrekening van de 403-maatschappij kan inzien en dus niet gecompenseerd hoeft te worden.

Resumerend is mijns inziens voor het antwoord op de vraag of het beroep van een crediteur op de vergeten 403-verklaring onaanvaardbaar is naar maatstaven van redelijkheid en billijkheid ex art. 6:2 lid 2 BW bepalend of de crediteur weet, of behoort te weten, dat de moedermaatschappij is vergeten de 403-verkaring in te trekken. Deze vraag moet worden beantwoord aan de hand van de omstandigheden van het geval op het moment dat de 403-maatschappij de rechtshandeling heeft verricht waaruit de vordering van de crediteur is voortgevloeid. Hierbij kunnen onder meer de eerdergenoemde omstandigheden een rol spelen. ${ }^{116}$

De uitkomst van de afweging van de genoemde grondbeginselen van het door mij bepleite uitgangspunt voor compensatie, sluit aan bij de bestaande jurisprudentie ten aanzien van de vergeten 403-verklaring. De hoofdregel is dat vanuit het oogpunt van rechtszekerheid en een redelijke verdeling van verantwoordelijkheden en risico's meer gewicht toekomt aan de gedeponeerde 403-verklaring dan aan de omstandigheden waaruit de crediteur kan afleiden dat de moedermaatschappij is vergeten de 403 -verklaring in te trekken. ${ }^{117}$ Een beroep op de vergeten 403-verklaring is slechts onaanvaardbaar naar maatstaven van redelijkheid en billijkheid als de crediteur weet, of behoort te weten, dat de moedermaatschappij is vergeten de 403 -verklaring in te trekken. ${ }^{118}$

116. Zie $\S 7.6 .3$.

117. Hof Amsterdam 24 december 1992, rolnr. 863, 91 (Hypo/Kap) aldus Bartman, Dorresteijn \& Olaerts 2020, p. 230, Rb. Utrecht 31 juli 1996, JOR 1996/96 (Manning q.q./Haverkort Bouwgroep), r.o. 6.3-6.4, Rb. Rotterdam 15 april 1999, JOR 1999/119 (Lely Industries/ Netagco Holding), r.o. 6.1-6.2, Rb. Almelo 24 juni 2008, JOR 2008/227, m.nt. Bartman (Hoeveholding), r.o. 7, Rb. Rotterdam 16 april 2009, JOR 2009/161, m.nt. Van der Zanden (BosGijze/Jones Lang LaSalle), r.o. 5.1.9, Hof Amsterdam (OK) 12 januari 2010, JOR 2010/94, m.nt. Bartman (Hoeveholding), r.o. 3.9 en Hof Amsterdam (OK) 23 juli 2014, JOR 2014/233, m.nt. Bartman (Van Lieshout/Koks), r.o. 3.10.

118. Hof Amsterdam (OK) 30 september 2010, JOR 2010/306, m.nt. Bartman (Jones Lang LaSalle/BosGijze), r.o. 3.13 en Rb. Utrecht 10 november 2010, JOR 2011/16, m.nt. Bartman (De With/Lekkerkerker), r.o. 4.13. 


\subsection{Preventief limiteren van de aansprakelijkheid op grond van een vergeten 403 -verklaring}

\subsubsection{Inleiding}

Een moedermaatschappij kan preventief de aansprakelijkheid op grond van de 403-verklaring limiteren. Zij creëert dan als het ware een 'veiligheidsklep' voor het geval dat zij vergeet deze verklaring in te trekken. De moedermaatschappij kan haar aansprakelijkheid limiteren door in de 403-verklaring op te nemen dat zij zich slechts aansprakelijk stelt voor de schulden die voortvloeien uit de rechtshandelingen die de 403-maatschappij tot een bepaalde datum of tot een bepaalde gebeurtenis verricht. Daarnaast kan de moedermaatschappij de aansprakelijkheid limiteren door gelijktijdig met de 403-verklaring een intrekkingsverklaring te deponeren op grond waarvan de 403-verklaring op een bepaalde datum of na een bepaalde gebeurtenis wordt ingetrokken. Mocht de moedermaatschappij vergeten de 403-verklaring in te trekken, dan is haar aansprakelijkheid op grond van deze verklaring in ieder geval beperkt tot de schulden die voortvloeien uit de rechtshandelingen die de 403-maatschappij tot de genoemde datum of de genoemde gebeurtenis heeft verricht.

\subsubsection{Een 403-verklaring met de groepsband als voorwaarde voor aansprakelijkheid}

De moedermaatschappij kan in haar 403-verklaring opnemen dat zij zich slechts aansprakelijk stelt voor de schulden die voortvloeien uit de rechtshandelingen die de 403-maatschappij verricht tot het moment dat de groepsband tussen de moeder- en de 403-maatschappij is verbroken. ${ }^{119}$ Als de groepsband is verbroken kan de 403-maatschappij niet meer (rechtsgeldig) gebruikmaken van de jaarrekeningvrijstelling van het groepsregime. ${ }^{120}$ Het is dan niet meer nodig dat de moedermaatschappij - als een van de voorwaarden zodat de 403-maatschappij gebruik kan maken van de jaarrekeningvrijstelling - aansprakelijk is voor de schulden die voortvloeien uit (nieuwe) rechtshandelingen die de 403-maatschappij verricht.

In 2007 heeft de OK geoordeeld dat als een moedermaatschappij in de 403-verklaring heeft opgenomen dat zij zich slechts aansprakelijk stelt voor de schulden die voortvloeien uit de rechtshandelingen die de 403-maatschappij heeft verricht tot het moment dat de groepsband tussen hen is verbroken, zij niet aansprakelijk is voor de schulden die voortvloeien uit rechtshandelingen die

119. Beckman 1995a, p. 545, Ten Voorde 2011, p. 197-198, Spierings 2016, p. 233-234 en E.C.A. Nass 2019, p. 101.

120. Zie art. 2:403 lid 1 aanhef BW en $\S$ 2.3.2. 
de 403-maatschappij nadien heeft verricht. ${ }^{121}$ De OK laat echter in het midden of een dergelijke verklaring kwalificeert als een 403-verklaring in de zin van art. 2:403 lid 1 sub $\mathrm{fBW} .{ }^{122}$ Naar mijn mening moet deze vraag positief worden beantwoord. Ik heb eerder geconcludeerd dat het opnemen van een einddatum in de 403-verklaring er niet aan in de weg staat dat de 403-maatschappij rechtsgeldig gebruikmaakt van de jaarrekeningvrijstelling van het groepsregime, mits de einddatum niet eerder is dan de dag dat de aandeelhouders van de 403-maatschappij de summiere jaarrekening in de zin van art. 2:403 lid 1 sub a BW vaststellen of - als de jaarrekening nog niet is vastgesteld - twaalf maanden na afloop van het boekjaar. ${ }^{123}$ Deze redenering acht ik van overeenkomstige toepassing als de moedermaatschappij in de 403-verklaring de groepsband als voorwaarde voor (nieuwe) aansprakelijkheid heeft opgenomen. ${ }^{124}$ Mits de groepsband tussen de moeder- en de 403-maatschappij niet is verbroken op het moment dat de aandeelhouders van de 403-maatschappij de summiere jaarrekening in de zin van art. 2:403 lid 1 sub a BW vaststellen of - als de jaarrekening nog niet is vastgesteld - twaalf maanden na afloop van het boekjaar, kan de 403-maatschappij rechtsgeldig gebruikmaken van de jaarrekeningvrijstelling van het groepsregime.

De bewijslast dat de groepsband tussen de moeder- en de 403-maatschappij is verbroken, ligt bij de moedermaatschappij. ${ }^{125}$ Het is de moedermaatschappij die een beroep doet op de beperking van de aansprakelijkheid op grond van de 403-verklaring tot de schulden die voortvloeien uit de rechtshandelingen die de 403-maatschappij heeft verricht tot het moment dat de groepsband is verbroken. Het is dus aan de moedermaatschappij om te bewijzen dat de vordering van de crediteur is voortgevloeid uit een rechtshandeling die de 403-maatschappij na dat moment heeft verricht.

Het opnemen van de groepsband als voorwaarde voor (nieuwe) aansprakelijkheid waarborgt echter niet dat de aansprakelijkheid in alle gevallen dat de moedermaatschappij vergeet de 403-verklaring in te trekken, is gelimiteerd. De moedermaatschappij is dan nog steeds aansprakelijk voor de schulden die

121. Hof Amsterdam (OK) 1 februari 2007, JOR 2007/144 (Fey Holding/Castellum Novum), r.o. 3.4-3.5. In casu heeft de moedermaatschappij in de 403-verklaring opgenomen dat zij zich aansprakelijk stelt voor de schulden die voortvloeien uit de rechtshandelingen die de 403-maatschappij verricht, zolang de groepsband niet is verbroken en de financiële gegevens van de 403-maatschappij worden geconsolideerd in de geconsolideerde jaarrekening van de moedermaatschappij.

122. Zie $\S$ 2.3.6.c, waar ik een verklaring op grond waarvan de moedermaatschappij zich beperkter aansprakelijk stelt dan art. 2:403 lid 1 sub f BW vereist, heb aangeduid als een 'ontoereikende 403-verklaring'.

123. Zie $\S 7.2 .4$.

124. Anders: Ramanna 2008, p. 19, die opmerkt dat het voor een crediteur onduidelijk kan zijn wanneer de groepsband tussen de moeder- en de 403-maatschappij is verbroken.

125. Van Zoest 2011, p. 98 en Van der Kraan 2012, p. 54. 
voortvloeien uit nieuwe rechtshandelingen van de 403-maatschappij. Ik wijs op twee punten. Ten eerste zijn er situaties denkbaar dat de groepsband tussen de moeder- en de 403-maatschappij niet is verbroken, maar de moedermaatschappij toch vergeet de 403 -verklaring in te trekken. Dit doet zich voor als de 403-maatschappij om een andere reden - dan de verbreking van de groepsband - niet meer gebruikmaakt van de jaarrekeningvrijstelling van het groepsregime. Bijvoorbeeld als een van de aandeelhouders niet meer instemt met de afwijking van de jaarrekeningvoorschriften. ${ }^{126} \mathrm{Als}$ de moedermaatschappij vervolgens vergeet om de 403 -verklaring in te trekken, blijft zij aansprakelijk voor de schulden die voortvloeien uit nieuwe rechtshandelingen die de 403-maatschappij verricht.

Ten tweede is het voor een crediteur niet altijd duidelijk of de groepsband tussen de moeder- en de 403-maatschappij is verbroken. ${ }^{127}$ Of de groepsband is verbroken, hangt onder meer af van het antwoord op de vraag of de moedermaatschappij nog steeds de centrale leiding uitoefent ten aanzien van de 403-maatschappij. ${ }^{128}$ Daarbij is niet alleen de juridisch-organisatorische verbondenheid tussen de moeder- en de 403-maatschappij van belang, maar ook de (bedrijfs-)economische werkelijkheid tussen hen. ${ }^{129}$ Vooral deze (bedrijfs) economische verhouding tussen de moeder- en de 403-maatschappij zal voor derden niet altijd bekend zijn. Het is mogelijk dat een crediteur redelijkerwijs niet op de hoogte kan zijn van het feit dat de groepsband tussen de moeder- en de 403-maatschappij is verbroken. Het is niet ondenkbaar dat in een dergelijk geval het beroep van de moedermaatschappij op de beperking van de aansprakelijkheid op grond van de 403-verklaring - tot de schulden die voortvloeien uit de rechtshandelingen die de 403-maatschappij heeft verricht tot het moment dat de groepsband is verbroken - onaanvaardbaar is naar maatstaven van redelijkheid en billijkheid. ${ }^{130}$ De moedermaatschappij is dan toch jegens de crediteur aansprakelijk op grond van de 403-verklaring.

126. Zie art. 2:403 lid 1 sub b BW en $\S 2.3 .4$.

127. Van der Zanden in zijn annotatie onder Hof Amsterdam (OK) 28 februari 2007, JOR 2007/145 (Van den Wildenberg/Van Wijnen Holding), Ramanna 2008, p. 19, Van Zoest 2011, p. 100, Van der Kraan 2012, p. 54-55 en Buijn \& Storm 2013, p. 809.

128. Kamerstukken II 1969/70, 10751, 3, p. 13 (MvT), Kamerstukken II 1979/80, 16326, 3, p. 42 (MvT), Kamerstukken II 1987/88, 19813, 5, p. 4 (MvA), Honée 1981, p. 52, L. Timmerman 1988a, p. 54-55, Van Achterberg 1989, p. 82, Asser/Maeijer, Van Solinge \& Nieuwe Weme 2-II* 2009/816, Krol 2015, p. 144, Asser/Maeijer \& Kroeze 2-I* 2015/261, Van Limpt, Pronk \& Visser 2019, p. 813, E.C.A. Nass 2019, p. 41 en Bartman, Dorresteijn \& Olaerts 2020, p. 33.

129. Asser/Maeijer, Van Solinge \& Nieuwe Weme $2-I I^{*}$ 2009/816 en Asser/Maeijer \& Kroeze $2-I * 2015 / 261$.

130. Zie art. $6: 2$ lid $2 \mathrm{BW}$. 
In de literatuur zijn twee alternatieven genoemd voor de groepsband als voorwaarde voor (nieuwe) aansprakelijkheid op grond van de 403-verklaring. Ten eerste kan de moedermaatschappij in de 403-verklaring opnemen dat zij zich slechts aansprakelijk stelt voor de schulden die voortvloeien uit de rechtshandelingen die de 403-maatschappij verricht, zolang de moedermaatschappij $100 \%$ van de aandelen in de 403-maatschappij houdt. ${ }^{131}$ Daarnaast kan de moedermaatschappij haar aansprakelijkheid op grond van de 403-verklaring limiteren tot de schulden die voortvloeien uit de rechtshandelingen die de 403-maatschappij verricht tot het moment dat de moedermaatschappij een (geconsolideerde) jaarrekening openbaar maakt waarin de financiële gegevens van de 403-maatschappij niet zijn geconsolideerd. ${ }^{132}$ Crediteuren kunnen bij het handelsregister nagaan of de moedermaatschappij nog steeds $100 \%$ van de aandelen in de 403-maatschappij houdt, en of de financiële gegevens van de 403-maatschappij in de geconsolideerde jaarrekening zijn geconsolideerd.

Bovenstaande alternatieven bieden voor de crediteuren weliswaar meer duidelijkheid ten aanzien van de aansprakelijkheid van de moedermaatschappij op grond van de 403-verklaring, maar ook hierbij gelden dezelfde twee kanttekeningen als die ik maakte met betrekking tot de groepsband als voorwaarde voor (nieuwe) aansprakelijkheid. Ten eerste is niet gewaarborgd dat de aansprakelijkheid in alle gevallen dat de moedermaatschappij vergeet deze

131. Van Zoest 2011, p. 101-102.

132. Van der Zanden in zijn annotatie onder Hof Amsterdam (OK) 28 februari 2007, JOR 2007/145 (Van den Wildenberg/Van Wijnen Holding), Buijn \& Storm 2013, p. 809 en E.C.A. Nass 2019, p. 101-102. Zie Hof Amsterdam (OK) 1 februari 2007, JOR 2007/144 (Fey Holding/Castellum Novum), r.o. 3.4-3.5, waar de moedermaatschappij in de 403-verklaring heeft opgenomen dat zij zich aansprakelijk stelt voor de schulden die voortvloeien uit de rechtshandelingen die de 403-maatschappij verricht, zolang de groepsband niet is verbroken en de financiële gegevens van de 403-maatschappij worden geconsolideerd in de geconsolideerde jaarrekening van de 403-maatschappij. De OK laat in het midden of aan het vereiste van art. 2:403 lid 1 sub $\mathrm{fBW}$ is voldaan als de moedermaatschappij zich door middel van een dergelijke verklaring aansprakelijk stelt. Zie $\S 7.2 .4$, waar ik ten aanzien van een 403-verklaring met een einddatum heb geconcludeerd dat de 403-maatschappij rechtsgeldig gebruik kan maken van de jaarrekeningvrijstelling van het groepsregime, mits de einddatum niet eerder is dan de dag dat de aandeelhouders van de 403-maatschappij de summiere jaarrekening in de zin van art. 2:403 lid 1 sub a BW vaststellen of - als de jaarrekening nog niet is vastgesteld - twaalf maanden na afloop van het boekjaar. Deze redenering acht ik van overeenkomstige toepassing als de moedermaatschappij in de 403-verklaring opneemt dat zij slechts aansprakelijk is voor de schulden die voortvloeien uit de rechtshandelingen die de 403-maatschappij verricht tot het moment dat de moedermaatschappij een (geconsolideerde) jaarrekening openbaar maakt waarin de financiële gegevens van de 403-maatschappij niet zijn geconsolideerd. Mits de moedermaatschappij een dergelijke geconsolideerde jaarrekening nog niet openbaar heeft gemaakt op het moment dat de aandeelhouders van de 403-maatschappij de summiere jaarrekening in de zin van art. 2:403 lid 1 sub a BW vaststellen of - als de jaarrekening nog niet is vastgesteld - twaalf maanden na afloop van het boekjaar, kan de 403-maatschappij rechtsgeldig gebruikmaken van de jaarrekeningvrijstelling. 
verklaring in te trekken, is gelimiteerd. Ook als de moedermaatschappij nog steeds $100 \%$ van de aandelen houdt, is het mogelijk dat de 403-maatschappij niet meer gebruikmaakt van de jaarrekeningvrijstelling - opnieuw bijvoorbeeld als een van de aandeelhouders niet meer instemt met de afwijking van de jaarrekeningvoorschriften. En zolang de groepsband tussen de moederen de 403-maatschappij niet is verbroken, moet de moedermaatschappij nog steeds de financiële gegevens van de 403-maatschappij consolideren in haar geconsolideerde jaarrekening. ${ }^{133}$ Dit laatste wordt niet anders als de 403-maatschappij niet meer gebruikmaakt van de jaarrekeningvrijstelling van het groepsregime. Als de moedermaatschappij in deze gevallen vergeet de 403 -verklaring in te trekken, is haar aansprakelijkheid op grond van deze verklaring niet gelimiteerd. Zij blijft aansprakelijk voor de schulden die voortvloeien uit nieuwe rechtshandelingen die de 403-maatschappij verricht.

Ten tweede is het niet ondenkbaar dat het beroep van de moedermaatschappij op een van genoemde beperkingen van de aansprakelijkheid op grond van de 403-verklaring onder omstandigheden onaanvaardbaar is naar maatstaven van redelijkheid en billijkheid. ${ }^{134} \mathrm{Ik}$ betwijfel of van een crediteur mag worden verwacht dat hij regelmatig bij het handelsregister controleert of de moedermaatschappij nog steeds $100 \%$ van de aandelen in de 403-maatschappij houdt, en of de financiële gegevens van de 403-maatschappij zijn geconsolideerd in de geconsolideerde jaarrekening. Dit geldt in het bijzonder in het geval dat de moedermaatschappij geen ruchtbaarheid heeft gegeven aan het feit dat zij (een deel van) haar aandelen in de 403-maatschappij heeft verkocht aan een derde, of dat zij de financiële gegevens van de 403-maatschappij niet meer heeft geconsolideerd in haar geconsolideerde jaarrekening. Als een crediteur geen aanleiding had om aan te nemen dat een van deze omstandigheden zich heeft voorgedaan, is het beroep van de moedermaatschappij op de beperking van de aansprakelijkheid op grond van de 403-verklaring mogelijk onaanvaardbaar naar maatstaven van redelijkheid en billijkheid. De moedermaatschappij is dan nog steeds jegens de crediteur aansprakelijk op grond van de 403-verklaring.

\subsubsection{Een 403-verklaring met een einddatum}

Aangezien het opnemen van bovengenoemde voorwaarden in de 403-verklaring niet in alle gevallen dat de moedermaatschappij vergeet deze verklaring in te trekken de aansprakelijkheid limiteert, is het zaak te zoeken naar een alternatief dat wél in alle gevallen effectief is. Dit kan mijns inziens het

133. Zie art. 2:406 BW.

134. Zie art. $6: 2$ lid $2 \mathrm{BW}$. 
beste worden bereikt door een einddatum op te nemen in de 403-verklaring. ${ }^{135}$ De moedermaatschappij stelt zich dan op grond van de 403-verklaring aansprakelijk voor de schulden die voortvloeien uit de rechtshandelingen die de 403-maatschappij tot een bepaalde datum verricht. Zij is dan in ieder geval niet aansprakelijk voor de schulden die voortvloeien uit de rechtshandelingen die de 403-maatschappij vanaf die datum verricht.

Mijns inziens kan een moedermaatschappij het beste als einddatum in de 403-verklaring opnemen dat zij zich slechts aansprakelijk stelt voor de schulden die voortvloeien uit de rechtshandelingen die de 403-maatschappij verricht tot en met twaalf maanden na afloop van het boekjaar waarover de 403-maatschappij een jaarrekening zal opmaken waarbij zij gebruikmaakt van de jaarrekeningvrijstelling van het groepsregime. Uiterlijk op die datum moet aan alle voorwaarden zijn voldaan om rechtsgeldig gebruik te maken van de jaarrekeningvrijstelling van het groepsregime. ${ }^{136}$ Als de 403-maatschappij op die datum nog niet gebruik heeft gemaakt van deze vrijstelling is het niet meer nodig dat de moedermaatschappij - als een van de voorwaarden zodat gebruik mag worden gemaakt van de vrijstelling - aansprakelijk is voor de schulden die voortvloeien uit (nieuwe) rechtshandelingen die de 403-maatschappij verricht.

Indien de einddatum in de 403-verklaring is verstreken en de 403-maatschappij met betrekking tot de komende jaarrekening gebruik wil blijven maken van de jaarrekeningvrijstelling van het groepsregime, moet de moedermaatschappij er wel op bedacht zijn dat zij een nieuwe 403-verklaring (met einddatum) deponeert. Als de moedermaatschappij vergeet een nieuwe 403-verklaring te deponeren ${ }^{137}$ en de 403 -maatschappij toch gebruikmaakt van de jaarrekeningvrijstelling doet zij dit ten onrechte. Het bestuur van de 403-maatschappij kan dan mogelijk aansprakelijk worden gesteld omdat de openbaarmakingsplicht is geschonden. Hoewel het opnemen van een einddatum in de 403-verklaring dus enerzijds waarborgt dat de aansprakelijkheid van de moedermaatschappij is gelimiteerd indien zij vergeet de 403-verklaring in te trekken, brengt het anderzijds dus ook het risico met zich dat de 403-maatschappij ten onrechte

135. Zie $§ 7.2 .4$, waar ik heb geconcludeerd dat een 403-maatschappij rechtsgeldig gebruik kan maken van de jaarrekeningvrijstelling van het groepsregime als de moedermaatschappij zich door middel van een 403-verklaring met een einddatum aansprakelijk stelt, mits de einddatum niet eerder is dan de dag dat de aandeelhouders van de 403-maatschappij de summiere jaarrekening in de zin van art. 2:403 lid 1 sub a BW vaststellen of - als de jaarrekening nog niet is vastgesteld - twaalf maanden na afloop van het boekjaar.

136. Zie $\S 2.4$.

137. Ik merk op dat de moedermaatschappij doorgaans ook aandeelhouder is van de 403-maatschappij en uit dien hoofde jaarlijks moet instemmen met de afwijking van de jaarrekeningvoorschriften door de 403-maatschappij (zie art. 2:403 lid 1 sub b BW en $\S$ 2.3.4). Deze instemming kan wellicht voor de moedermaatschappij fungeren als een geheugensteuntje om een nieuwe 403-verklaring te deponeren. 
gebruikmaakt van de jaarrekeningvrijstelling. Het is uiteindelijk aan de moeder- en de 403-maatschappij om dit laatste risico af te wegen tegen het risico dat de moedermaatschappij vergeet de 403-verklaring in te trekken en de extra aansprakelijkheid die zij daardoor loopt.

\subsubsection{Preventief intrekken van de 403-verklaring}

In plaats van haar aansprakelijkheid op grond van de 403-verklaring preventief te limiteren door in deze verklaring op te nemen dat zij zich slechts aansprakelijk stelt voor de schulden die voortvloeien uit de rechtshandelingen die de 403-maatschappij tot een bepaalde gebeurtenis of datum verricht, kan de moedermaatschappij de 403-verklaring ook preventief intrekken. De moedermaatschappij deponeert dan gelijktijdig met de 403-verklaring ook een intrekkingsverklaring op grond waarvan de 403 -verklaring wordt ingetrokken als zich een bepaalde gebeurtenis voordoet of op een bepaalde datum. ${ }^{138} \mathrm{De}$ moedermaatschappij kan in de intrekkingsverklaring opnemen dat de 403 -verklaring wordt ingetrokken als de groepsband met de 403-maatschappij is verbroken, als zij niet meer 100\% van de aandelen in de 403-maatschappij houdt, of als zij een jaarrekening openbaar heeft gemaakt waarin de financiële gegevens van de 403-maatschappij niet zijn geconsolideerd. Ik heb eerder echter al opgemerkt met betrekking tot het preventief limiteren van ansprakelijkheid door in de 403-verklaring (een van) deze voorwaarden op te nemen, dat deze clausules niet waarborgen dat de aansprakelijkheid in alle gevallen dat de moedermaatschappij vergeet de 403 -verklaring in te trekken, is gelimiteerd. ${ }^{139}$ Het is mogelijk dat de 403-maatschappij niet meer gebruikmaakt van de jaarrekeningvrijstelling en de moedermaatschappij vergeet de 403 -verklaring in te trekken, zonder dat deze voorwaarden zich hebben voorgedaan. Toegepast op de situatie dat de moedermaatschappij een intrekkingsverklaring heeft gedeponeerd op grond waarvan de 403-verklaring wordt ingetrokken als een van deze voorwaarden zich voordoet, betekent dit dat de 403-verklaring in die gevallen niet is ingetrokken en de moedermaatschappij aansprakelijk blijft voor de schulden die voortvloeien uit nieuwe rechtshandelingen die de 403-maatschappij verricht.

In plaats van de intrekking afhankelijk te maken van een van bovenstaande voorwaarden, kan de moedermaatschappij ook een intrekkingsverklaring deponeren op grond waarvan de 403-verklaring op een bepaalde datum wordt ingetrokken. Ik heb eerder opgemerkt dat het mogelijk is dat een moedermaatschappij in de intrekkingsverklaring opneemt dat deze verklaring pas op een bepaalde datum effect heeft waardoor de 403 -verklaring pas op die datum

138. Zie $\S 7.4$.

139. Zie $\S 7.7 .2$. 
wordt ingetrokken. ${ }^{140}$ In dat geval is de aansprakelijkheid op grond van de 403-verklaring in ieder geval gelimiteerd tot de schulden die voortvloeien uit de rechtshandelingen die de 403-maatschappij tot de genoemde datum verricht. ${ }^{141}$ Met betrekking tot het moment van intrekking van de 403 -verklaring kan worden aangesloten bij hetgeen ik heb voorgesteld bij een 403 -verklaring met een einddatum, ${ }^{142}$ namelijk: na verloop van twaalf maanden na het boekjaar waarover de 403-maatschappij een jaarrekening zal opmaken waarbij zij gebruikmaakt van de jaarrekeningvrijstelling van het groepsregime. Als de 403-maatschappij nadien gebruik wil blijven maken van de jaarrekeningvrijstelling, moet de moedermaatschappij vanzelfsprekend een nieuwe 403-verklaring (en een nieuwe preventieve intrekkingsverklaring) deponeren. Evenals bij een 403-verklaring met een einddatum brengt het deponeren van een intrekkingsverklaring op grond waarvan de 403-verklaring op een bepaalde datum wordt ingetrokken het risico met zich dat de moedermaatschappij vergeet een nieuwe 403-verklaring te deponeren, maar de 403-maatschappij toch - ten onrechte gebruikmaakt van de jaarrekeningvrijstelling van het groepsregime. Het is aan de moeder- en de 403-maatschappij om dit risico af te wegen tegen de waarborg dat de aansprakelijkheid van de moedermaatschappij is gelimiteerd in het geval dat zij vergeet de 403 -verklaring in te trekken.

\subsubsection{Tussenconclusie}

In de voorgaande paragrafen heb ik verschillende mogelijkheden onderzocht hoe een moedermaatschappij preventief de aansprakelijkheid op grond van de 403-verklaring kan limiteren voor het geval zij vergeet deze verklaring in te trekken. Voor een moedermaatschappij is het daarbij van belang dat zij erop kan vertrouwen dat haar aansprakelijkheid onder alle omstandigheden is gelimiteerd. Een deel van de onderzochte mogelijkheden is echter niet in alle gevallen effectief. Dit is het geval als nieuwe aansprakelijkheid van de moedermaatschappij is gekoppeld aan de groepsband met de 403-maatschappij, aan het houden van $100 \%$ van de aandelen in de 403-maatschappij of aan het openbaar maken van een geconsolideerde jaarrekening waarin de financiële gegevens van de 403-maatschappij niet zijn geconsolideerd. Het is dan nog steeds mogelijk dat de moedermaatschappij vergeet de 403-verklaring in te trekken en dat zij aansprakelijk blijft voor de schulden die voortvloeien uit nieuwe rechtshandelingen die de 403-maatschappij verricht.

140. Zie $\S 7.4$.

141. Aangezien de intrekkingsverklaring al eerder is gedeponeerd, kan de moedermaatschappij op de genoemde datum meteen tegenover een crediteur een beroep doen op de intrekking. Zie $\S 7.2 .3$.

142. Zie $\S 7.7 .3$. 
Als een moedermaatschappij zekerheid wil dat haar aansprakelijkheid op grond van de 403-verklaring is gelimiteerd voor het geval zij vergeet deze verklaring in te trekken, kan zij mijns inziens het beste haar aansprakelijkheid beperken tot een bepaalde periode. De moedermaatschappij kan dit bereiken door in de 403-verklaring op te nemen dat zij zich slechts aansprakelijk stelt voor de schulden die voortvloeien uit de rechtshandelingen die de 403-maatschappij tot een bepaalde datum verricht, of door een intrekkingsverklaring te deponeren op grond waarvan de 403-verklaring op een bepaalde datum wordt ingetrokken.

\subsection{Misbruik van de intrekking van de 403-verklaring}

Dat een moedermaatschappij de bevoegdheid heeft om haar 403-verklaring op ieder moment eenzijdig in te trekken, staat niet ter discussie. ${ }^{143}$ Een vervolgvraag is of het uitoefenen van deze bevoegdheid misbruik van recht kan zijn. ${ }^{144}$ De moedermaatschappij kan dan geen beroep doen op de intrekking van de 403 -verkaring. ${ }^{145}$ Deze vraag kan bijvoorbeeld worden gesteld met betrekking tot de intrekking van de 403-verklaring door Shell medio 2017. ${ }^{146}$

Moedermaatschappij Shell heeft zich in 1985 op grond van een 403-verklaring hoofdelijk aansprakelijk gesteld voor de schulden die voortvloeien uit de rechtshandelingen van de NAM. ${ }^{147}$ Als gevolg van gasboringen door de NAM in Groningen is schade ontstaan. Verschillende gedupeerden hebben een vordering ingesteld tegen de NAM tot vergoeding van deze schade. Dit betreft zowel materiële schade - bijvoorbeeld aan woonhuizen - als immateriële schade wegens een inbreuk op een fundamenteel persoonlijkheidsrecht. ${ }^{148}$ Deze schulden van de NAM vloeien voort uit een onrechtmatige daad: de beweging van de bodem als gevolg van de gaswinning. ${ }^{149}$ Shell is op grond van de 403 -verklaring niet aansprakelijk voor deze schulden. ${ }^{150}$

Medio 2017 heeft Shell haar 403-verklaring ingetrokken. Shell is daardoor niet aansprakelijk voor de schulden die voortvloeien uit de rechtshandelingen die de NAM heeft verricht vanaf het moment dat zij tegenover de crediteur een

143. Zie $\S 7.2 .2$.

144. Zie art. 3:13 BW.

145. P.A. Stein, in: GS Vermogensrecht, art. 3:13, aant. 28.

146. Zie ook $\S 3.5 .3$ en $\S 4.9$, met betrekking tot de Shell-casus.

147. Zie E.C.A. Nass 2018, p. 167.

148. Rb. Noord-Nederland 1 maart 2017, JA 2017/88, m.nt. Van Dorsser (X/NAM), r.o. 4.4.74.4.8. Zie art. 6:106 lid $1 \mathrm{sub}$ b BW.

149. Zie art. 6:177 lid 1 sub b BW.

150. Kamerstukken II 2017/18, 33529, 422, p. 2 (Brief aan de voorzitter van de Tweede Kamer), Van Dooren 2018a, p. 61, E.C.A. Nass 2018, p. 168 en E.C.A. Nass 2020, p. 148. Zie $§ 4.3 .2$. 
beroep kan doen op de intrekking. Een half jaar later maakt de Minister van Economische Zaken en Klimaat bekend dat de Staat der Nederlanden de vergoeding van de schade voor de gedupeerden in Groningen zal afhandelen. ${ }^{151}$ De NAM is hier niet inhoudelijk bij betrokken, maar draagt wel zorg voor de financiering. Hiertoe hebben de Staat en de NAM een overeenkomst gesloten. Indien Shell haar 403-verklaring niet zou hebben ingetrokken, zou zij hoofdelijk aansprakelijk zijn voor de schulden van de NAM die uit deze overeenkomst voortvloeien. ${ }^{152}$

Ongeveer op hetzelfde moment dat de minister bekendmaakt dat de Staat bovengenoemde overeenkomst met de NAM heeft gesloten, maken verschillende media melding van het feit dat Shell de 403-verklaring een half jaar daarvoor heeft ingetrokken. De algemene tendens van de berichtgeving in de media is dat Shell de NAM ongemerkt 'op afstand heeft geplaatst', en dat zij (de schijn heeft gewekt dat zij) bewust onder de aansprakelijkheid voor de schulden van de NAM in verband met de vergoeding van de schade in Groningen probeert uit te komen. ${ }^{153}$ Shell weerspreekt deze beschuldiging. Zij verklaart dat zij de 403-verklaring heeft ingetrokken omdat de NAM in het voorjaar van 2017 weer een jaarrekening openbaar heeft gemaakt die voldoet aan de voorschriften van titel 9 van Boek 2 BW, en dus niet meer gebruikmaakt van de jaarrekeningvrijstelling van het groepsregime. Volgens Shell is er daarom geen reden om nog langer op grond van de 403-verklaring aansprakelijk te zijn voor de schulden die voortvloeien uit nieuwe rechtshandelingen van de NAM. ${ }^{154}$

Het is de vraag of de intrekking van de 403-verklaring door Shell misbruik van recht is. Hoewel de media vooral aandacht hebben besteed aan de gedupeerden in Groningen, is hun positie niet van belang bij de beantwoording van deze vraag. Aangezien de schulden van de NAM jegens de gedupeerden voortvloeien uit een onrechtmatige daad, is Shell op grond van de 403-verklaring niet aansprakelijk voor deze schulden. De intrekking van deze verklaring heeft hun positie dus niet veranderd. In plaats daarvan moet worden beoordeeld of Shell de bevoegdheid om de 403-verklaring in te trekken, heeft misbruikt in verband met het belang van de Staat dat daardoor is geschaad nu deze zich niet op grond van de 403-verklaring op Shell kan verhalen.

Op grond van art. 3:13 lid $2 \mathrm{BW}$ wordt een wettelijke bevoegdheid (onder meer) misbruikt als degene die haar uitoefent, in aanmerking nemende de onevenredigheid tussen het belang bij de uitoefening en het belang van een

151. Kamerstukken II 2017/18, 33529, 423 (Brief aan de voorzitter van de Tweede Kamer).

152. Van Dooren 2018a, p. 62 en E.C.A. Nass 2018, p. 168. Zie $\S 4.9$.

153. Zie Van Dooren 2018a, p. 61 en E.C.A. Nass 2020, p. 141, en de daar aangehaalde berichten in de media.

154. Zie Van Dooren 2018a, p. 62. Zie ook E.C.A. Nass 2020, p. 148, die opmerkt dat deze verklaring niet alle argwaan wegneemt. 
derde dat daardoor wordt geschaad, naar redelijkheid niet tot die uitoefening had kunnen komen. Er moet sprake zijn van een grote onevenredigheid tussen het gediende en het aangetaste belang, waarbij het niet is vereist dat degene die de bevoegdheid uitoefent dit doet met de bedoeling om de ander te benadelen, maar hij moet de onevenredigheid tussen de belangen wel kennen of behoren te kennen. ${ }^{155}$

Het belang van Shell bij het intrekken van de 403 -verklaring is dat zij niet aansprakelijk is voor de schulden die voortvloeien uit de rechtshandelingen die de NAM verricht vanaf het moment dat Shell tegenover de crediteur een beroep kan doen op de intrekking - waaronder de schulden van de NAM die voortvloeien uit de overeenkomst met de Staat. Het belang van de Staat dat door de intrekking is geschaad, is dat hij zich niet (ook) op Shell kan verhalen voor de schulden van de NAM die voortvloeien uit de overeenkomst inzake het afhandelen van de schade van de gedupeerden in Groningen. ${ }^{156}$ Deze overeenkomst tussen de Staat en de NAM zal niet van de ene op de andere dag tot stand zijn gekomen. Er zou kunnen worden betoogd dat Shell op de hoogte moet zijn geweest van de onderhandelingen tussen de NAM en de Staat en dat zij op grond van art. 3:13 lid $2 \mathrm{BW}$ de bevoegdheid om de 403-verklaring in te trekken, heeft misbruikt omdat zij moet hebben geweten dat haar belang dat daardoor is gediend niet in verhouding staat tot het nadeel dat de Staat door de intrekking ondervindt.

Ik kan mij niet vinden in bovenstaande redenering. De ansprakelijkheid van een moedermaatschappij op grond van de 403-verklaring is een onderdeel van de compensatie voor de crediteuren omdat zij de jaarrekening van de 403-maatschappij niet kunnen inzien. ${ }^{157}$ Het is belangrijk om de aansprakelijkheid niet op zichzelf te zien, maar als een onderdeel van deze compensatie. ${ }^{158}$ Dat een 403 -verklaring kan worden ingetrokken, is kenmerkend voor de wisselwerking tussen de aansprakelijkheid van de moedermaatschappij en

155. P.A. Stein, in: GS Vermogensrecht, art. 3:13, aant. 45-47. Zie ook HR 21 mei 1999, NJ 1999/507 (Kerkhof/Spoelstra), r.o. 3.4.

156. Zie E.C.A. Nass 2020, p. 145, 146, 148 en 149, waar zij erop wijst dat de Staat en (onder meer) Shell een akkoord op hoofdlijnen hebben gesloten op grond waarvan Shell garanties zal geven waardoor de NAM haar verplichting tot vergoeding van schade te allen tijde kan nakomen (zie Kamerstukken II 2017/18, 33529, 493 (Brief aan de voorzitter van de Tweede Kamer), en Bijlage 1 Akkoord op Hoofdlijnen met Shell en ExxonMobil). Bartman betwijfelt of dit voldoende zekerheid biedt voor de gedupeerden. Zie S.M. Bartman, 'NAMakkoord: garanties Shell en ExxonMobil bieden maar beperkte zekerheid', Het Financieele Dagblad 2 juli 2018 en J. Kleinnijenhuis, 'Hoogleraar: 'Wiebes liet zich afbluffen bij gasdeal met Shell", Trouw 1 augustus 2018.

157. De compensatie voor een crediteur bestaat uit twee onderdelen: een vordering op de moedermaatschappij op grond van de 403-verklaring en de mogelijkheid om de geconsolideerde jaarrekening van de moedermaatschappij in te zien. Zie $\S 3.4 .1$.

158. Zie $\S 3.5$. 
de compensatie voor de crediteuren. ${ }^{159}$ Alle crediteuren die als gevolg van het gebruikmaken van de jaarrekeningvrijstelling door de 403-maatschappij niet de mogelijkheid hebben (gehad) om de jaarrekening van laatstgenoemde in te zien, moeten zich op grond van de 403-verklaring op de moedermaatschappij kunnen verhalen. Als de 403-maatschappij niet meer gebruikmaakt van de jaarrekeningvrijstelling - en een jaarrekening openbaar heeft gemaakt die voldoet aan de voorschriften van titel 9 van Boek 2 BW -, is het niet meer nodig om nieuwe crediteuren te compenseren. De crediteuren van wie de vordering voortvloeit uit een rechtshandeling die de 403-maatschappij heeft verricht nadat zij weer een jaarrekening openbaar heeft gemaakt die voldoet aan de voorschriften van titel 9 van Boek 2 BW ontbreekt het niet aan inzicht. Toen zij de relatie met de 403-maatschappij zijn aangegaan, en gedurende deze relatie, hebben zij de jaarrekening kunnen inzien. Zij hoeven dus niet gecompenseerd te worden met een verhaalsrecht op de moedermaatschappij. Aangezien de NAM in het voorjaar van 2017 een jaarrekening openbaar heeft gemaakt die voldoet aan de voorschriften van titel 9 van Boek 2 BW, heeft het de Staat ten tijde van het sluiten van de overeenkomst met de NAM - en daarna - niet aan inzicht ontbroken. Zij hoeft dus niet gecompenseerd te worden met een verhaalsrecht op Shell.

Het is de eigen verantwoordelijkheid van degene die een overeenkomst met een 403-maatschappij aangaat om zelf vooraf na te gaan of de 403-verklaring al of niet is ingetrokken. ${ }^{160}$ Hoewel het voor de Staat vanzelfsprekend gunstig zou zijn geweest als hij zich (ook) op Shell zou kunnen verhalen, is zijn belang door de intrekking van de 403-verklaring niet onevenredig geschaad. Hij kan slechts geen beroep doen op de compensatie voor een nadeel dat hij niet heeft ondervonden. De Staat heeft na het openbaar maken van de jaarrekening door de NAM ongeveer driekwart jaar de tijd gehad om deze jaarrekening op te vragen, en de informatie daaruit mee te wegen bij zijn besluit om al of niet een overeenkomst met de NAM aan te gaan - onder de huidige voorwaarden. Ik kom daarom tot de conclusie dat de intrekking van de 403-verklaring door Shell geen misbruik van recht is.

Hoewel de intrekking van de 403-verklaring door Shell geen misbruik van recht is, zijn er situaties denkbaar waarbij dat wel het geval is. Dit zal zich echter alleen onder bijzondere omstandigheden voordoen. ${ }^{161}$ Hierbij kan worden gedacht aan de situatie dat de moedermaatschappij actief betrokken is geweest bij de totstandkoming van een overeenkomst tussen de 403-maatschappij en een derde, en de moedermaatschappij een dag voordat de overeenkomst wordt gesloten de 403-verklaring intrekt zodat de derde zich niet op haar kan verhalen.

159. Zie $\S 3.5 .3$.

160. Zie $\$ 7.2 .2$.

161. Vgl. Assink/Slagter 2013/140.2. 


\subsection{Conclusie}

In dit hoofdstuk heb ik de intrekking van de 403-verklaring door de moedermaatschappij onderzocht. Ten eerste heb ik een algemene uiteenzetting gegeven van de intrekking van een 403-verklaring en het moment dat de moedermaatschappij hierop een beroep kan doen (§ 7.2). Als de 403-maatschappij nog niet een jaarrekening openbaar heeft gemaakt die voldoet aan de voorschriften van titel 9 van Boek 2 BW voordat de moedermaatschappij een beroep kan doen op de intrekking van de 403-verklaring, zal er een periode zijn dat crediteuren de jaarrekening van de 403-maatschappij niet kunnen inzien maar daarvoor niet worden gecompenseerd. De crediteuren van wie de vordering voortvloeit uit een rechtshandeling die de 403-maatschappij in deze periode heeft verricht, worden niet gecompenseerd voor het feit dat zij de jaarrekening van de 403-maatschappij niet kunnen inzien. Om deze lacune in de compensatie van de crediteuren te verhelpen, is het mijns inziens gewenst dat art. 2:404 BW wordt gewijzigd. Aan lid 1 van deze bepaling kan worden toegevoegd dat de intrekking van de 403-verklaring slechts of eerst effect heeft als de 403-maatschappij een jaarrekening openbaar heeft gemaakt die aan de voorschriften van titel 9 van Boek 2 BW voldoet, of als er een nieuwe 403-verklaring is gedeponeerd ten aanzien van de 403-maatschappij (§ 7.3).

De moedermaatschappij kan in de intrekkingsverklaring opnemen dat de 403-verklaring op een bepaalde datum in de toekomst wordt ingetrokken (§ 7.4). Maar zij kan haar 403-verklaring niet zo vormgeven, dat deze tevens geldt als intrekkingsverklaring (§ 7.5).

Voorts ben ik ingegaan op de situatie dat een 403-maatschappij niet meer gebruikmaakt van de jaarrekeningvrijstelling van het groepsregime, maar de moedermaatschappij is vergeten de 403-verklaring in te trekken. Het uitgangspunt is dat een crediteur moet kunnen vertrouwen op een bij het handelsregister gedeponeerde 403-verklaring en hier een beroep op kan doen. Een dergelijk beroep is mijns inziens slechts onaanvaardbaar naar maatstaven van redelijkheid en billijkheid als de crediteur weet, of behoort te weten, dat de moedermaatschappij is vergeten de 403 -verklaring in te trekken (§ 7.6). Ik heb vervolgens verschillende mogelijkheden onderzocht hoe een moedermaatschappij preventief de aansprakelijkheid op grond van een 403-verklaring kan limiteren voor het geval zij vergeet deze verklaring in te trekken. De meest effectieve manier hiervoor is om in de 403-verklaring op te nemen dat zij zich slechts aansprakelijk stelt voor de schulden die voortvloeien uit de rechtshandelingen die de 403-maatschappij tot een bepaalde datum verricht, of door een intrekkingsverklaring te deponeren, op grond waarvan de 403-verklaring op een bepaalde datum wordt ingetrokken (§ 7.7). 
Tot slot ben ik ingegaan op de vraag of het intrekken van een 403-verklaring door de moedermaatschappij onder omstandigheden misbruik van recht kan zijn. Ik heb geconcludeerd dat hiervan slechts onder bijzondere omstandigheden sprake zal zijn. Het uitgangspunt is dat de moedermaatschappij de 403-verklaring op ieder moment kan intrekken. Degene die een relatie met de 403-maatschappij aangaat, heeft een eigen verantwoordelijkheid om vooraf na te gaan of de 403-verklaring al of niet is ingetrokken ( $(7.8)$. 



\title{
Hoofdstuk 8. De beëindiging van de overblijvende aansprakelijkheid
}

\author{
$8.1 \quad$ Inleiding
}

Als een moedermaatschappij de door haar gedeponeerde 403-verklaring heeft ingetrokken, blijft zij aansprakelijk voor de schulden die voortvloeien uit de rechtshandelingen die de 403-maatschappij heeft verricht tot het moment dat de moedermaatschappij tegenover de crediteur een beroep kan doen op de intrekking. ${ }^{1}$ Dit betreft de zogenoemde 'overblijvende aansprakelijkheid'. De moedermaatschappij kan deze aansprakelijkheid beëindigen als aan een viertal cumulatieve voorwaarden wordt voldaan.

In dit hoofdstuk ga ik allereerst in op de reikwijdte van de overblijvende aansprakelijkheid ( $\S 8.2$ ). Daarna noem ik de voorwaarden waaraan moet worden voldaan om deze aansprakelijkheid te beëindigen ( $§ 8.3$ ). Vervolgens werk ik deze verder uit. Als eerste komt het vereiste aan de orde dat de groepsband tussen de moeder- en de 403-maatschappij is verbroken ( $\$ 8.4)$. Voorts ga ik in op de voorwaarden dat de moedermaatschappij een mededeling moet deponeren van het voornemen om de overblijvende aansprakelijkheid te beëindigen en een aankondiging moet plaatsen in een landelijk verspreid dagblad dat en waar deze mededeling ter inzage ligt $(\S 8.5)$. Tot slot onderzoek ik het recht van de crediteuren om verzet in te stellen tegen het voornemen van de moedermaatschappij om de overblijvende aansprakelijkheid te beëindigen ( $\$ 8.6$ en $\S 8.7$ ).

Als een crediteur verzet heeft ingesteld, kan hij een vervangende waarborg verlangen voor de voldoening van zijn vordering op de 403-maatschappij. Ik onderzoek onder welke omstandigheden een dergelijke waarborg wordt toegewezen $(\S 8.8)$ en hoe de omvang daarvan wordt vastgesteld ( $\$ 8.9)$. Voorts wijs ik op enkele aandachtspunten bij de beoordeling of een crediteur recht heeft op een vervangende waarborg en de vaststelling van de omvang van een te geven waarborg, met betrekking tot de hoofdelijke aansprakelijkheid van de moedermaatschappij op grond van de ingetrokken 403-verklaring ( $\$ 8.10)$. Vervolgens geef ik drie rekenvoorbeelden waarbij ik naga of een crediteur verzet kan instellen tegen het voornemen van de moedermaatschappij om de

1. Zie art. 2:404 lid 1 en 2 BW. 
overblijvende aansprakelijkheid te beëindigen, of hij recht heeft op een vervangende waarborg en welke omvang die waarborg dan (minimaal) moet hebben (§ 8.11).

Aansluitend ga ik in op de vraag of een moedermaatschappij al kan beginnen met de procedure om de overblijvende aansprakelijkheid te beëindigen voordat de 403-verklaring is ingetrokken ( $\$ 8.12)$, en of er een vaste volgorde is waarin moet worden voldaan aan de voorwaarden om deze aansprakelijkheid te beëindigen (§ 8.13). Tot slot onderzoek ik of het verbreken van de groepsband tussen de moeder- en de 403-maatschappij moet worden geschrapt als voorwaarde voor de beëindiging van de overblijvende ansprakelijkheid (§ 8.14).

\subsection{De reikwijdte van de overblijvende aansprakelijkheid}

\subsubsection{Bestaande en toekomstige schulden}

Als een moedermaatschappij haar 403-verklaring heeft ingetrokken, blijft zij op grond van art. 2:404 lid 2 BW aansprakelijk voor de schulden die voortvloeien uit de rechtshandelingen die de 403-maatschappij heeft verricht tot het moment dat de moedermaatschappij tegenover de crediteur een beroep kan doen op de intrekking. ${ }^{2}$ Dit betreft alle bestaande en toekomstige schulden die voortvloeien uit deze rechtshandelingen. Dus ook de schulden die ontstaan nadat de moedermaatschappij een beroep kan doen op de intrekking van de 403-verklaring. ${ }^{3}$ Als de 403-maatschappij bijvoorbeeld voor de intrekking van de 403-verklaring een arbeidsovereenkomst met een werknemer is aangegaan,

2. Zie $\S 7.2 .3$, voor het moment dat de moedermaatschappij een beroep kan doen op de intrekking van de 403 -verklaring.

3. Kamerstukken II 1983/84, 16551, 11, p. 15 (NnavhEV), Van Achterberg 1989, p. 229, Bartman 2002, p. 24-25, Van Wijngaarden 2006a, p. 619, Zwemmer 2012, p. 238-239, Beckman - SDU Commentaar Ondernemingsrecht 2019, art. 2:404 BW, aant. C.1, Van Zoest 2019, p. 32-33, E.C.A. Nass 2019, p. 141 en 231 en Bartman, Dorresteijn \& Olaerts 2020, p. 226-227. Zie bijvoorbeeld Rb. Rotterdam 16 april 2009, JOR 2009/161, m.nt. Van der Zanden (BosGijze/Jones Lang LaSalle), r.o. 5.5.1-5.5.2. Zie Zwemmer 2011, p. 231-232, die het wenselijk vindt dat art. 2:404 lid 2 BW wordt gewijzigd, zodat een moedermaatschappij slechts aansprakelijk is voor de schulden die tot één jaar na de intrekking van de 403-verklaring voortvloeien uit een rechtshandeling die de 403-maatschappij heeft verricht tot het moment dat de moedermaatschappij tegenover de crediteur een beroep kan doen op de intrekking. In tegenstelling tot Zwemmer zie ik echter geen reden voor deze beperking van de reikwijdte van de overblijvende aansprakelijkheid. De crediteuren hebben weliswaar weer de mogelijkheid om de jaarrekening van de 403-maatschappij in te zien. Maar als daaruit blijkt dat er een aanzienlijk risico is dat de 403-maatschappij niet in staat zal zijn haar schulden te voldoen en de crediteuren zich niet meer op de moedermaatschappij kunnen verhalen, worden zij hierdoor aanzienlijk benadeeld. Dit geldt in het bijzonder voor de crediteuren die een duurovereenkomst zijn aangegaan met de 403-maatschappij waaruit 
is de moedermaatschappij op grond van de 403-verklaring aansprakelijk voor alle bestaande en toekomstige schulden van de 403-maatschappij die uit deze overeenkomst voortvloeien. Dit wordt niet anders als de moedermaatschappij nadien de 403 -verklaring intrekt.

\subsubsection{Standpunten ten aanzien van de reikwijdte van de overblijvende aansprakelijkheid}

In de literatuur zijn twee standpunten te onderscheiden ten aanzien van de reikwijdte van de overblijvende aansprakelijkheid. Ten eerste wordt verdedigd dat een moedermaatschappij aansprakelijk is voor de schulden die voortvloeien uit de rechtshandelingen die de 403-maatschappij heeft verricht in de periode van de deponering van de 403-verklaring tot het moment dat de moedermaatschappij tegenover de crediteur een beroep kan doen op de intrekking van deze verklaring. ${ }^{4}$ Daarnaast wordt betoogd dat een moedermaatschappij na de intrekking van de 403-verklaring aansprakelijk is voor de schulden die voortvloeien uit alle rechtshandelingen die de 403-maatschappij heeft verricht tot het moment dat de moedermaatschappij tegenover de crediteur een beroep kan doen op deze intrekking. ${ }^{5}$

Ter onderbouwing van het eerste standpunt wijzen Bartman, Dorresteijn en Olaerts erop dat een moedermaatschappij op grond van art. 2:404 lid 2 BW na de intrekking van de 403-verklaring aansprakelijk is voor de schulden die 'voortvloeien uit rechtshandelingen welke zijn verricht voordat jegens de schuldeiser een beroep op de intrekking kan worden gedaan' ${ }^{6} \mathrm{Zij}$ menen dat het criterium van art. 2:404 lid 2 BW niet is geschreven voor het tijdvak voordat de moedermaatschappij de 403-verklaring heeft gedeponeerd. Aangezien in die periode nog geen 403-verklaring was gedeponeerd, kon de moedermaatschappij ook geen beroep doen op de intrekking daarvan. Volgens hen is een moedermaatschappij daarom op grond van art. 2:404 lid $2 \mathrm{BW}$ niet ansprakelijk voor de schulden die voortvloeien uit de rechtshandelingen die de 403-maatschappij heeft verricht voordat de 403 -verklaring is gedeponeerd.

Uit bovenstaand standpunt kan mijns inziens worden afgeleid dat Bartman, Dorresteijn en Olaerts menen dat de reikwijdte van de overblijvende aansprakelijkheid na de intrekking van de 403-verklaring, losstaat van de reikwijdte

periodiek nieuwe vorderingen voortvloeien - ook meer dan een jaar na de intrekking van de 403-verklaring.

4. Zwemmer 2012, p. 237 en Bartman, Dorresteijn \& Olaerts 2020, p. 229. Zie ook Bartman in zijn annotaties onder Hof 's-Hertogenbosch 7 april 2009, JOR 2009/160 (Inalfa) en Hof Amsterdam (OK) 23 juli 2014, JOR 2014/233 (Van Lieshout/Koks).

5. Beckman 1995a, p. 583, Beckman 2011, p. 256, Beckman \& Van der Zanden 2011, p. 811, Van der Heijden/Van der Grinten \& Dortmond 2013/324.3 en Beckman - SDU Commentaar Ondernemingsrecht 2019, art. 2:404 BW, aant. C.2.

6. Bartman, Dorresteijn \& Olaerts 2020, p. 229. 
van de aansprakelijkheid van de moedermaatschappij op grond van de 403-verklaring zelf. Ik heb er eerder op gewezen dat zij van mening zijn dat de temporele reikwijdte van de 403-aansprakelijkheid terugwerkt tot het begin van het boekjaar. ${ }^{8}$ Als een moedermaatschappij een 403 -verklaring deponeert, is deze volgens hen aansprakelijk voor de schulden die voortvloeien uit de rechtshandelingen die de 403-maatschappij heeft verricht vanaf het begin van het boekjaar waarover de 403-maatschappij een jaarrekening opmaakt waarbij zij gebruikmaakt van de jaarrekeningvrijstelling van het groepsregime. De door Bartman, Dorresteijn en Olaerts verdedigde standpunten inzake de reikwijdte van de 403-aansprakelijkheid en van de overblijvende aansprakelijkheid, brengen mee dat de intrekking van de 403-verklaring door de moedermaatschappij ertoe leidt dat haar aansprakelijkheid voor de schulden die voortvloeien uit de rechtshandelingen die zijn verricht vanaf het begin van het boekjaar tot de deponering van de 403-verklaring zonder meer 'vervalt'.

Zwemmer legt de reikwijdte van de overblijvende ansprakelijkheid op dezelfde wijze uit als Bartman, Dorresteijn en Olaerts. ${ }^{9}$ Hij merkt op dat de crediteuren van wie de vordering voortvloeit uit een rechtshandeling die de 403-maatschappij heeft verricht voordat de 403-verklaring is gedeponeerd, de mogelijkheid hebben gehad om de jaarrekening van de 403-maatschappij in te zien voordat zij deze relatie zijn aangegaan. Volgens hem is de moedermaatschappij daarom na de intrekking van de 403-verklaring niet aansprakelijk voor de schulden die uit deze rechtshandelingen voortvloeien.

Ik kan mij niet vinden in bovenstaand standpunt ten aanzien van de reikwijdte van de overblijvende aansprakelijkheid. Evenals Beckman meen ik dat een moedermaatschappij na de intrekking van de 403-verklaring aansprakelijk is voor de schulden die voortvloeien uit alle rechtshandelingen die de 403-maatschappij heeft verricht tot het moment dat de moedermaatschappij tegenover de crediteur een beroep kan doen op deze intrekking. De tekst van art. 2:404 lid 2 BW laat geen ruimte om de overblijvende aansprakelijkheid beperkter uit te leggen. ${ }^{10}$

Dat een moedermaatschappij op grond van art. 2:404 lid 2 BW aansprakelijk is voor de schulden die voortvloeien uit alle rechtshandelingen die de 403-maatschappij heeft verricht tot het moment dat de moedermaatschappij tegenover de crediteur een beroep kan doen op de intrekking, sluit aan bij het door

7. Zie expliciet in deze zin Bartman, Dorresteijn \& Olaerts 2016, p. 211.

8. Bartman, Dorresteijn \& Olaerts 2020, p. 223. Zie $\S 5.5$.

9. Zwemmer 2012, p. 237.

10. Beckman 1995a, p. 583, Beckman 2011, p. 256, Beckman \& Van der Zanden 2011, p. 811, Van der Heijden/Van der Grinten \& Dortmond 2013/324.3 en Beckman - SDU Commentaar Ondernemingsrecht 2019, art. 2:404 BW, aant. C.2. 
mij bepleite uitgangspunt voor compensatie. De crediteuren hebben geen invloed op de keuze van de moedermaatschappij om de 403-verklaring in te trekken. Ik heb daarom betoogd dat zij door deze intrekking niet in een nadeliger positie mogen komen ten opzichte van de situatie dat de 403-verklaring niet zou zijn ingetrokken. ${ }^{11}$ Dit betekent dat alle crediteuren die als gevolg van het gebruikmaken van de jaarrekeningvrijstelling door de 403-maatschappij niet de mogelijkheid hebben gehad om de jaarrekening van laatstgenoemde in te zien, zich op grond van de op dat moment ingetrokken 403-verklaring op de moedermaatschappij moeten kunnen verhalen. ${ }^{12}$ Dit betreft niet alleen de crediteuren van wie de vordering voortvloeit uit een rechtshandeling die de 403-maatschappij heeft verricht na de deponering van de 403-verklaring - tot het moment dat de moedermaatschappij tegenover de crediteur een beroep kan doen op de intrekking van deze verklaring -, maar ook de crediteuren van wie de vordering voortvloeit uit een daarvoor verrichte rechtshandeling.

De crediteuren van wie de vordering voortvloeit uit een rechtshandeling die de 403-maatschappij heeft verricht voordat de 403-verklaring is gedeponeerd, hebben de jaarrekening van de 403-maatschappij kunnen inzien toen zij deze relatie zijn aangegaan. Aangezien de 403-maatschappij toen nog niet gebruikmaakte van de jaarrekeningvrijstelling van het groepsregime, hadden zij op dat moment geen gebrek aan inzicht. Maar vanaf het moment dat de 403-maatschappij gebruikmaakt van deze vrijstelling ontbreekt het hun wél aan de mogelijkheid om de jaarrekening in te zien. Voor de crediteuren is het kunnen inzien van de jaarrekening bijvoorbeeld van belang om (mede) aan de hand daarvan te beoordelen of zij eventuele zekerheidsrechten uitoefenen, de overeenkomst met de 403-maatschappij proberen aan te passen of opzeggen, of dat zij het faillissement van de 403-maatschappij aanvragen. Dit geldt in het bijzonder voor crediteuren die een duurovereenkomst zijn aangegaan met de 403-maatschappij, waaruit periodiek nieuwe vorderingen voortvloeien. Ik heb eerder geconcludeerd dat als een moedermaatschappij zich op grond van een 403-verklaring aansprakelijk stelt, zij (mede) om die reden ook aansprakelijk is voor de schulden die voortvloeien uit de rechtshandelingen die de 403-maatschappij heeft verricht voordat de 403 -verklaring is gedeponeerd. ${ }^{13}$ De compensatie die deze crediteuren ontvangen doordat zij zich op grond van de 403-verklaring ook op de moedermaatschappij kunnen verhalen, mag niet zomaar vervallen als de moedermaatschappij deze verklaring intrekt. ${ }^{14} \mathrm{Er}$ zou anders een onterecht onderscheid ontstaan tussen de crediteuren van wie de

11. Zie $\$ 3.6 .1$.

12. De compensatie voor een crediteur bestaat uit twee onderdelen: een vordering op de moedermaatschappij op grond van de 403-verklaring en de mogelijkheid om de geconsolideerde jaarrekening van de moedermaatschappij in te zien. Zie $\S 3.4 .1$.

13. Zie $\S 5.6 .4$.

14. De moedermaatschappij kan de overblijvende aansprakelijkheid slechts beëindigen als zij voldoet aan de voorwaarden ex art. 2:404 lid $3 \mathrm{BW}$. Zie $\S 8.3$ tot en met $\S 8.13$. 
vordering voortvloeit uit een rechtshandeling die de 403-maatschappij vóór of ná de deponering van de 403-verklaring heeft verricht. Art. 2:404 lid 2 BW moet mijns inziens daarom zo worden uitgelegd dat de moedermaatschappij na de intrekking van de 403-verklaring aansprakelijk blijft voor de schulden die voortvloeien uit alle rechtshandelingen die de 403-maatschappij heeft verricht tot het moment dat de moedermaatschappij tegenover de crediteur een beroep kan doen op de intrekking.

\subsubsection{De periode tussen het doen van een beroep op de intrekking en de openbaarmaking van een jaarrekening door de 403-maatschappij}

Als de 403-maatschappij nog niet een jaarrekening openbaar heeft gemaakt die voldoet aan de voorschriften van titel 9 van Boek 2 BW voordat de moedermaatschappij een beroep kan doen op de intrekking van de 403-verklaring, zal er een periode zijn dat crediteuren de jaarrekening van de 403-maatschappij niet kunnen inzien maar daarvoor niet worden gecompenseerd. ${ }^{15}$ Een crediteur van wie de vordering voortvloeit uit een rechtshandeling die de 403-maatschappij heeft verricht in de periode tussen het moment dat de moedermaatschappij tegenover de crediteur een beroep kan doen op de intrekking en het moment dat de 403-maatschappij een jaarrekening openbaar maakt die voldoet aan de voorschriften van titel 9 van Boek 2 BW, wordt dan benadeeld. Hij heeft niet de mogelijkheid om zijn keuze om een relatie met de 403-maatschappij aan te gaan en vervolgens de keuze of hij deze relatie wil continueren, (mede) te baseren op de informatie in de jaarrekening van de 403-maatschappij, maar hij wordt hiervoor niet gecompenseerd met een aanvullende vordering op de moedermaatschappij op grond van de 403 -verklaring.

Er zou betoogd kunnen worden dat het terecht is dat bovengenoemde crediteuren niet worden gecompenseerd, omdat ze zelf bij het handelsregister kunnen nagaan dat de 403-maatschappij nog geen jaarrekening openbaar heeft gemaakt. Ik kan mij echter niet vinden in dit standpunt. Volgens die redenering zou de 403-aansprakelijkheid in zijn geheel achterwege kunnen blijven - ook gedurende de periode dat de 403-maatschappij gebruikmaakt van de jaarrekeningvrijstelling van het groepsregime. Iedere crediteur kan namelijk bij het handelsregister nagaan of de 403-maatschappij wel of niet een jaarrekening openbaar heeft gemaakt. Ik heb eerder opgemerkt dat het voor het antwoord op de vraag of een crediteur een vordering heeft op grond van de 403-verklaring, niet van belang is of hij al of niet bij het handelsregister is nagegaan of de 403-maatschappij gebruikmaakt van de jaarrekeningvrijstelling van het groepsregime en of de moedermaatschappij zich door middel van een 403-verklaring aansprakelijk heeft gesteld. ${ }^{16}$ Een crediteur wordt gecompenseerd omdat hij

15. Blommaert 2007, p. 273-274 en Van der Kraan 2012, p. 53. Zie $§ 7.3$.

16. Zie $\S 3.4 .1$. 
niet de mogelijkheid heeft om de jaarrekening van de 403-maatschappij in te zien en (mede) aan de hand daarvan kan schatten hoe groot het risico is dat zijn vordering niet (volledig) zal worden voldaan. Hetzelfde zou mijns inziens moeten gelden voor een crediteur van wie de vordering voortvloeit uit een rechtshandeling die de 403-maatschappij heeft verricht in de periode tussen het moment dat de moedermaatschappij tegenover de crediteur een beroep kan doen op de intrekking van de 403-verklaring en het moment dat de 403-maatschappij een jaarrekening openbaar maakt die voldoet aan de voorschriften van titel 9 van Boek 2 BW. Ook deze crediteur ontbreekt het aan de mogelijkheid om de jaarrekening van de 403-maatschappij in te zien. Mijns inziens zou hij daarom gecompenseerd moeten worden met een aanvullende vordering op de moedermaatschappij. ${ }^{17}$

Bovenstaande brengt mee dat het niet met het door mij bepleite uitgangspunt voor compensatie ${ }^{18}$ strookt dat er op grond van het huidige art. 2:404 lid $2 \mathrm{BW}$ een periode kan zijn waarbij crediteuren niet de mogelijkheid hebben om de jaarrekening van de 403-maatschappij in te zien, maar dat zij daar ook niet voor worden gecompenseerd. Dit is naar mijn mening een lacune in de huidige regeling met betrekking tot de compensatie van de crediteuren van de 403-maatschappij.

Om alle crediteuren te compenseren die als gevolg van het gebruikmaken van de jaarrekeningvrijstelling door de 403-maatschappij niet de mogelijkheid hebben (gehad) om de jaarrekening van laatstgenoemde in te zien, moet art. 2:404 BW worden gewijzigd. In paragraaf $7.3 \mathrm{heb}$ ik voorgesteld om aan lid 1 van art. 2:404 BW toe te voegen dat de intrekking van de 403-verklaring slechts of eerst effect heeft als de 403-maatschappij een jaarrekening openbaar heeft gemaakt die aan de voorschriften van titel 9 van Boek 2 BW voldoet, ${ }^{19}$ of als er een nieuwe 403 -verklaring is gedeponeerd ten aanzien van de 403-maatschappij. Als deze bepaling aldus wordt gewijzigd, heeft dit ook gevolgen voor de reikwijdte van de overblijvende aansprakelijkheid van de moedermaatschappij als zij de 403-verklaring intrekt. Tenzij de 403-maatschappij voor de intrekking van de 403-verklaring al een jaarrekening openbaar heeft gemaakt, kan de moedermaatschappij pas een beroep doen op deze intrekking, als de 403-maatschappij een jaarrekening openbaar maakt of als er een nieuwe

17. De compensatie voor een crediteur bestaat uit twee onderdelen: een vordering op de moedermaatschappij op grond van de 403-verklaring en de mogelijkheid om de geconsolideerde jaarrekening van de moedermaatschappij in te zien. Zie $\S 3.4 .1$.

18. Zie $\S 3.7$.

19. Bartman 1986, p. 106, Gülcher 1989a, p. 165, Houwen, Schoonbrood-Wessels \& Schreurs 1993, p. 842, Berk 2007, p. 18, Franken \& Franken 2008, p. 73 en Van der Kraan 2012, p. 53. In 1969 heeft de Commissie Vennootschapsrecht een vergelijkbaar advies gegeven met betrekking tot het voorgestelde art. 42c WvK. Zie Kamerstukken II 1969/70, 10689, 4, p. 30 (bijlage 2 MvT). Zie ook E.C.A. Nass 2019, p. 99. 
403-verklaring is gedeponeerd. De moedermaatschappij is in dat geval aansprakelijk voor de schulden die voortvloeien uit de rechtshandelingen die de 403-maatschappij tot dat moment verricht.

\subsection{Voorwaarden voor de beëindiging van de overblijvende aansprakelijkheid}

Om de overblijvende aansprakelijkheid te kunnen beëindigen, moet de 403-verklaring zijn ingetrokken. ${ }^{20}$ Pas als de moedermaatschappij een beroep kan doen op de intrekking van deze verklaring is er sprake van 'overblijvende' aansprakelijkheid. ${ }^{21}$ Op grond van art. 2:404 BW kan een moedermaatschappij alleen de aansprakelijkheid beëindigen die overblijft na de intrekking van een 403-verklaring in de zin van art. 2:403 lid 1 sub f BW. Als de moedermaatschappij een verklaring van ansprakelijkheid heeft gedeponeerd op grond waarvan zij zich beperkter ansprakelijk stelt dan art. 2:403 lid 1 sub f BW vereist - ik heb dit eerder aangeduid als een 'ontoereikende 403-verklaring ${ }^{22}-$, kan zij deze verklaring niet op grond van art. 2:404 lid $1 \mathrm{BW}$ intrekken. ${ }^{23}$ De moedermaatschappij kan in een dergelijk geval wel - buiten art. 2:404 lid $1 \mathrm{BW}$ om - een verklaring deponeren dat zij geen nieuwe aansprakelijkheid meer accepteert op grond van de ontoereikende 403-verklaring. Maar zij kan haar aansprakelijkheid op grond van deze verklaring vervolgens niet beëindigen. ${ }^{24}$

De bevoegdheid om te besluiten de overblijvende ansprakelijkheid te beëindigen, komt toe aan het bestuur van de moedermaatschappij. ${ }^{25,26}$ Het is mogelijk dat in de statuten van de moedermaatschappij voorwaarden zijn opgenomen met betrekking tot deze besluitvorming. Bijvoorbeeld dat de raad van commissarissen voorafgaand goedkeuring moet verlenen voordat het bestuur kan

20. Beckman 2011, p. 257, Asser/Maeijer \& Kroeze 2-I*2015/586, De Neve 2015, p. 91, Van Zoest 2016a, p. 63 en Notenboom 2017, p. 127

21. De Neve 2015, p. 91 en Van Zoest 2016a, p. 63.

22. Zie $\S 2.3 .6 . c$.

23. Zie $\S 7.2 .1$.

24. Ramanna 2008, p. 19. Vgl. Beckman 2011, p. 256.

25. Ten Voorde 2006, p. 60.

26. De moedermaatschappij hoeft het voornemen om de overblijvende aansprakelijkheid te beëindigen niet op grond van art. 25 WOR voor advies voor te leggen aan een eventueel door haar ingestelde (centrale of groeps-)ondernemingsraad of een door de 403-maatschappij ingestelde ondernemingsraad. Een door de moedermaatschappij ingestelde (centrale of groeps-)ondernemingsraad is wel indirect betrokken bij de beëindiging van de overblijvende aansprakelijkheid. Op grond van art. 25 lid 1 sub a WOR moet de moedermaatschappij het voornemen om de groepsband met de 403-maatschappij te verbreken ter advies voorleggen aan de ondernemingsraad. Deze kan in zijn advies mede ingaan op de beëindiging van de overblijvende aansprakelijkheid. Zie Ten Voorde 2006, p. 63. 
besluiten tot het beëindigen van de overblijvende aansprakelijkheid. Evenals bij de besluitvorming omtrent het deponeren en intrekken van een 403-verklaring, ${ }^{27}$ meen ik dat een dergelijke statutaire voorwaarde enkel interne werking heeft. Het besluit van het bestuur om de overblijvende aansprakelijkheid te beëindigen kan worden vernietigd en de bestuurders kunnen aansprakelijk worden gesteld voor de eventuele schade - bijvoorbeeld als de moedermaatschappij een schadevergoeding moet betalen omdat zij aan een crediteur had toegezegd de overblijvende aansprakelijkheid niet te beëindigen. ${ }^{28}$ Maar als aan de voorwaarden van art. 2:404 lid 3 BW is voldaan, is de overblijvende aansprakelijkheid beëindigd. De moedermaatschappij zou zich vanzelfsprekend wel opnieuw door middel van een nieuwe 403-verklaring aansprakelijk kunnen stellen. $^{29}$

De overblijvende aansprakelijkheid van de moedermaatschappij tegenover een crediteur eindigt als aan vier cumulatieve voorwaarden is voldaan. Hiervoor is vereist dat de groepsband tussen de moeder- en de 403-maatschappij is verbroken. Daarnaast moet een mededeling van het voornemen om de overblijvende aansprakelijkheid te beëindigen twee maanden ter inzage hebben gelegen bij het handelsregister. Voorts dienen er twee maanden te zijn verlopen na de aankondiging in een landelijk verspreid dagblad dat en waar deze mededeling ter inzage ligt. Tot slot mag tegen het voornemen tot beëindiging geen verzet zijn ingesteld door de crediteur, dan wel moet diens verzet zijn ingetrokken of door de rechter ongegrond zijn verklaard. Een crediteur die verzet heeft ingesteld, heeft onder omstandigheden recht op een vervangende waarborg.

Volgens de minister is met bovenstaande voorwaarden voor de beëindiging het evenwicht bewaard tussen het belang van de crediteur die heeft vertrouwd op de aansprakelijkheid van de moedermaatschappij en het belang van de moedermaatschappij dat deze aansprakelijkheid niet nog jaren doorloopt nadat de banden met de 403-maatschappij zijn verbroken. ${ }^{30}$

Ik merk op dat de regeling van art. 37 van de richtlijn jaarrekeningen met betrekking tot de jaarrekeningvrijstelling voor dochterondernemingen geen bepaling kent op grond waarvan een moederonderneming haar garantstelling voor de aangegane verplichtingen van de dochteronderneming kan beëindigen. Verschillende auteurs werpen daarom de vraag op of de beëindiging van de overblijvende aansprakelijkheid op grond van art. 2:404 lid 3 BW in strijd

27. Zie § 2.3.6.a, respectievelijk § 7.2.1.

28. Zie art. 2:15 lid $1 \mathrm{sub}$ a BW, respectievelijk art. 2:9 BW.

29. Ervan uitgaande dat een moedermaatschappij op grond van de 403 -verklaring aansprakelijk is voor alle schulden die voortvloeien en zijn voortgevloeid uit een rechtshandeling die de 403-maatschappij heeft verricht (zie § 5.6).

30. Kamerstukken II 1983/84, 16551, 11, p. 15 (NnavhEV). 
is met deze richtlijn. ${ }^{31}$ Evenals Nass ben ik van mening dat aangezien de richtlijn jaarrekeningen op dit punt zwijgt, de lidstaten de vrijheid hebben om te voorzien in een regeling op grond waarvan het mogelijk is dat de moedermaatschappij haar aansprakelijkheid beëindigt, mits de voorwaarden voor de beëindiging een gelijkwaardige waarborg bieden voor de crediteuren. ${ }^{32}$

Met Niels meen ik dat de voorwaarden uit de huidige regeling voor de beëindiging van de overblijvende aansprakelijkheid voldoende waarborgen bieden ten aanzien van de positie van een crediteur en dat deze regeling daarom niet in strijd is met art. 37 van de richtlijn jaarrekeningen. ${ }^{33} \mathrm{Ik}$ wijs daarvoor in het bijzonder op het feit dat een crediteur verzet kan instellen tegen het voornemen van de moedermaatschappij om de overblijvende aansprakelijkheid te beëindigen en hij onder omstandigheden recht heeft op een vervangende waarborg voor de voldoening van zijn vordering op de 403-maatschappij. ${ }^{34}$ Dit betekent overigens niet dat ik geen verbeterpunten zie met betrekking tot de huidige regeling. Om bijvoorbeeld te bewerkstelligen dat crediteuren makkelijker op de hoogte kunnen zijn van het voornemen van de moedermaatschappij om de overblijvende aansprakelijkheid te beëindigen, zou de Kamer van Koophandel een systeem kunnen aanbieden waarbij derden automatisch een notificatie kunnen krijgen als de moedermaatschappij een mededeling deponeert van het voornemen om de overblijvende aansprakelijkheid te beëindigen. Ik ga hier later uitgebreid op in. ${ }^{35}$

\subsection{De groepsband tussen de moeder- en de 403-maatschappij is verbroken}

Om de overblijvende aansprakelijkheid op grond van de ingetrokken 403-verklaring te kunnen beëindigen, moet de groepsband tussen de moeder- en de

31. Burgert, Timmermans \& Joosten 1990, p. 565, Beckman 1995a, p. 611, Beckman 2002, p. 487, Sanders \& Westbroek/Buijn \& Storm 2005, p. 444, Slagter 2005, p. 541, Niels 2010, p. 28, Beckman 2011, p. 256 en Buijn \& Storm 2013, p. 811.

32. E.C.A. Nass 2019, p. 89, 151 en 158-159. Zie in vergelijkbare zin Bartman in zijn annotatie onder Hof 's-Hertogenbosch 7 april 2009, JOR 2009/160 (Inalfa) met betrekking tot de intrekking van een 403-verklaring (\$ 7.2.1).

33. Niels 2010, p. 28. Anders: Van der Kraan 2012, p. 61, die erop wijst dat de richtlijn een garantstelling vereist. Hij is van mening dat aangezien een garantstelling niet eenzijdig kan worden opgezegd, de beëindiging van de overblijvende ansprakelijkheid in strijd is met de richtlijn. Mijns inziens gaat deze redenering niet op omdat de beëindiging van de overblijvende aansprakelijkheid niet is gelijk te stellen met een eenzijdige opzegging van de aansprakelijkheid. Crediteuren hebben de mogelijkheid om hiertegen verzet in te stellen en een vervangende waarborg te verlangen. Niels en Van der Kraan verwijzen overigens naar een voorloper van art. 37 van de richtlijn jaarrekeningen: art. 57 van de vierde EEG-richtlijn.

34. Zie $\S 8.6$ tot en met $\S 8.10$.

35. Zie $\S 8.5 .1$. 
403-maatschappij zijn verbroken. ${ }^{36,37}$ De groepsband is bijvoorbeeld verbroken als de moedermaatschappij haar aandelen in de 403-maatschappij heeft overgedragen aan een derde, als zij haar feitelijke invloed heeft beëindigd, of als de 403-maatschappij is gefailleerd. ${ }^{38}$ Deze groepsband moet mijns inziens uiterlijk zijn verbroken als de verzetstermijn verloopt waarbinnen de crediteuren verzet kunnen instellen tegen het voornemen van de moedermaatschappij om de overblijvende aansprakelijkheid te beëindigen. ${ }^{39}$

Beckman wijst erop dat het voor derden niet altijd duidelijk is of de groepsband tussen de moeder- en de 403-maatschappij is verbroken. ${ }^{40}$ Een voorbeeld hiervan is de casus die ten grondslag ligt aan de uitspraak Pergen/Eneco van de Rechtbank Rotterdam uit 2014. De moedermaatschappij heeft de 403-verklaring ingetrokken en is voornemens om haar overblijvende aansprakelijkheid te beëindigen. Zij houdt (middellijk) alle aandelen in de 403-maatschappij. Deze aandelen draagt zij over aan een stichting administratiekantoor, waarna de stichting certificaten van deze aandelen verstrekt. De moedermaatschappij houdt (middellijk) alle certificaten. In de administratievoorwaarden staat dat een besluit tot decertificering genomen kan worden in een vergadering waar ten minste $95 \%$ van de certificaten is vertegenwoordigd. Daarnaast staat in de statuten van de stichting administratiekantoor dat bij een eventuele ontbinding van de stichting de door haar gehouden aandelen worden overgedragen aan de certificaathouders tegen intrekking van de certificaten. Aangezien de moedermaatschappij (middellijk) alle certificaten houdt, kan zij op ieder moment besluiten tot decertificering. Zij keert dan terug naar de oorspronkelijke situatie waarbij zij (middellijk) alle aandelen houdt. De rechtbank laat in haar uitspraak in het midden of de groepsband tussen de moeder- en de 403-maatschappij is verbroken. ${ }^{41}$

Op het eerste gezicht lijkt het dat de groepsband tussen de moeder- en 403-maatschappij in bovenstaande casus is verbroken. Voor een groepsband is (onder meer) vereist dat de moedermaatschappij de centrale leiding uitoefent

36. Zie art. 2:404 lid 3 sub a BW. Zie $\S 2.3 .2$ voor een uitgebreidere bespreking van de groepsband.

37. Zie Kamerstukken II 1983/84, 16551, 11, p. 16 (NnavhEV), waar de minister opmerkt dat het doorsnijden van de groepsband pas aanleiding geeft om ook de overgebleven banden wegens de eens afgelegde maar later ingetrokken aansprakelijkstelling af te wikkelen. Dit standpunt overtuigt mij niet. Zie $\S 8.14$, waar ik betoog dat de voorwaarde dat de groepsband tussen de moeder- en de 403-maatschappij is verbroken, moet worden geschrapt uit art. 2:404 lid $3 \mathrm{BW}$.

38. Beckman 1995a, p. 344, Van Wijngaarden 2006a, p. 619, Assink/Slagter 2013/140.5, Snijder-Kuipers \& Eliëns 2014, p. 1177-1178 en Beckman - SDU Commentaar Ondernemingsrecht 2019, art. 2:404 BW, aant. C.2.

39. Zie $\S 8.13$.

40. Beckman 1995a, p. 613.

41. Rb. Rotterdam 30 september 2014, JOR 2014/326, m.nt. Loesberg (Pergen/Eneco), r.o. 4.4. 
ten aanzien van de 403-maatschappij. ${ }^{42}$ Aangezien (het bestuur van) de stichting administratiekantoor zelfstandig de aandelen in de 403-maatschappij beheert, lijkt het erop dat de moedermaatschappij geen centrale leiding meer heeft ten aanzien van de 403-maatschappij en dat de groepsband tussen hen is verbroken. Toch is het antwoord op de vraag of de groepsband tussen de moeder- en de 403-maatschappij is verbroken minder duidelijk dan in eerste instantie misschien wordt gedacht. Bij de beoordeling of er sprake is van een centrale leiding is niet alleen de juridisch-organisatorische verbondenheid van belang, maar ook de bedrijfseconomische werkelijkheid tussen de rechtspersonen. ${ }^{43}$ De certificering alleen is dus niet doorslaggevend bij de beoordeling of er nog steeds sprake is van een groepsband. Het is verdedigbaar dat aangezien de moedermaatschappij te allen tijde kan besluiten tot decertificering, waarna zij weer (middellijk) alle aandelen in de 403-maatschappij in handen krijgt, zij feitelijk nog steeds de centrale leiding heeft. ${ }^{44} \mathrm{Als}$ zij deze centrale leiding nog steeds uitoefent, is de groepsband tussen de moeder- en de 403-maatschappij - ondanks de certificering van de aandelen - intact gebleven. Hierbij kan worden gedacht aan de situatie dat het bestuur van de 403-maatschappij in meerderheid bestaat uit personen die ook in het bestuur van de moedermaatschappij zitten. Voor het antwoord op de vraag of in de casus van Pergen/Eneco de groepsband is verbroken, moet dus worden beoordeeld of de moedermaatschappij al of niet nog steeds feitelijk beslissende invloed uitoefent ten aanzien van de 403-maatschappij. Een eenduidig antwoord is op basis van de gegeven informatie in de uitspraak niet te geven.

Resumerend is het antwoord op de vraag of de groepsband tussen de moeder- en de 403-maatschappij is verbroken een beoordeling van de feitelijke situatie. Dit brengt vanzelfsprekend enige onzekerheid met zich. Toch lijkt dit in de praktijk niet tot problemen te leiden. ${ }^{45} \mathrm{Mij}$ is geen andere jurisprudentie bekend met betrekking tot de beëindiging van de overblijvende aansprakelijkheid, waarbij

42. Kamerstukken II 1969/70, 10751, 3, p. 13 (MvT), Kamerstukken II 1979/80, 16326, 3, p. 42 (MvT), Kamerstukken II 1987/88, 19813, 5, p. 4 (MvA), Honée 1981, p. 52, L. Timmerman 1988a, p. 54-55, Van Achterberg 1989, p. 82, Asser/Maeijer, Van Solinge \& Nieuwe Weme 2-II* 2009/816, Krol 2015, p. 144, Asser/Maeijer \& Kroeze 2-I* 2015/261, Van Limpt, Pronk \& Visser 2019, p. 813, E.C.A. Nass 2019, p. 41 en Bartman, Dorresteijn \& Olaerts 2020, p. 33.

43. Asser/Maeijer, Van Solinge \& Nieuwe Weme 2-II* 2009/816 en Asser/Maeijer \& Kroeze $2-I * 2015 / 261$.

44. Zie Van Limpt, Pronk \& Visser 2019, p. 816, die opmerken dat bij de beoordeling of er sprake is van een groepsband ook rekening moet worden gehouden met 'potentiële' stemrechten - zij geven als voorbeeld dat een aandeelhouder op elk moment een call-optie kan uitoefenen om tegen een vooraf vastgestelde prijs aandelen te verwerven. Zie hierover uitgebreid § 2.3.2.

45. Van Zoest 2019, p. 20. 
partijen procederen of de groepsband tussen de moeder- en de 403-maatschappij al of niet is verbroken. ${ }^{46}$

\subsection{Mededeling en aankondiging van het voornemen om de overblijvende aansprakelijkheid te beëindigen}

\subsubsection{Deponeren van een mededeling en het plaatsen van een aankondiging in een landelijk verspreid dagblad}

De beëindiging van de overblijvende aansprakelijkheid kan grote gevolgen hebben voor de crediteuren van de 403-maatschappij. Een crediteur verliest daardoor zijn verhaalsrecht tegenover de moedermaatschappij. Ter bescherming van zijn belang kan een crediteur verzet instellen tegen het voornemen van de moedermaatschappij om de overblijvende aansprakelijkheid te beëindigen. Hij kan dan een vervangende waarborg verlangen voor de voldoening van zijn vordering op de 403-maatschappij. ${ }^{47}$ Om (tijdig) verzet te kunnen instellen, is het van belang dat een crediteur op de hoogte kan zijn van het voornemen van de moedermaatschappij om de overblijvende aansprakelijkheid te beëindigen.

De moedermaatschappij moet haar voornemen om de overblijvende aansprakelijkheid te beëindigen op twee manieren bekendmaken. Allereerst moet zij een mededeling van dit voornemen deponeren bij het handelsregister. ${ }^{48}$ Daarnaast moet zij een aankondiging plaatsen in een landelijk verspreid dagblad dat en waar deze mededeling ter inzage ligt. ${ }^{49}$ De mededeling van het voornemen om de overblijvende aansprakelijkheid te beëindigen moet ten minste twee maanden ter inzage hebben gelegen bij het handelsregister en er moeten ook ten minste twee maanden zijn verlopen sinds de publicatie van de aankondiging in een landelijk verspreid dagblad. In het jaar 2019 zijn bij het handelsregister zeven mededelingen gedeponeerd van een voornemen om de overblijvende aansprakelijkheid te beëindigen. ${ }^{50}$

46. Zie E.C.A. Nass 2019, p. 156, die van mening is dat als een crediteur betwist dat de groepsband is verbroken de bewijslast moet worden omgekeerd en het aan de moedermaatschappij is om dit te bewijzen.

47. Art. 2:404 lid 4 en 5 BW en $\S 8.6$ tot en met $\S 8.10$.

48. Art. 2:404 lid 3 sub b BW. Zie Van Zoest 2019, p. 36, die een voorbeeld geeft hoe een dergelijke mededeling eruit kan zien.

49. Art. 2:404 lid 3 sub c BW. Zie Van Zoest 2019, p. 37, die een voorbeeld geeft hoe een dergelijke aankondiging eruit kan zien.

50. Op 22 april 2020 per e-mail aan mij meegedeeld door de afdeling Databeheer Orderbehandeling van de Kamer van Koophandel. Daarnaast heeft de afdeling Databeheer Orderbehandeling mij op 22 februari 2017 per e-mail laten weten dat er in het jaar 2016 bij het handelsregister 197 mededelingen zijn gedeponeerd van een voornemen om de overblijvende 
Evenals Berk meen ik dat het onwaarschijnlijk is dat een crediteur dagelijks alle landelijk verspreide dagbladen controleert en regelmatig ten aanzien van alle debiteuren nagaat of er een mededeling is gedeponeerd van het voornemen om de overblijvende aansprakelijkheid te beëindigen ${ }^{51}$ Het is daarom mogelijk dat een crediteur het voornemen van de moedermaatschappij om de overblijvende aansprakelijkheid te beëindigen over het hoofd ziet. In navolging van Schutte-Veenstra pleit Berk daarom voor de invoering van een gerichte informatieplicht, waarbij de moedermaatschappij de bekende crediteuren van de 403-maatschappij individueel moet inlichten over het voornemen om de overblijvende aansprakelijkheid te beëindigen. ${ }^{52} \mathrm{Ik}$ heb twee bezwaren tegen dit voorstel. Ten eerste leidt het mijns inziens tot een te grote lastenverzwaring voor de moedermaatschappij. Zeker als de 403-maatschappij een groot en wisselend crediteurenbestand heeft, zal het de moedermaatschappij veel werk kosten om na te gaan wie zij allemaal moet inlichten. Daarnaast wordt de moedermaatschappij hierdoor afhankelijk van de 403-maatschappij als zij de overblijvende aansprakelijkheid wil beëindigen. Als de 403-maaatschappij geen inzage geeft in haar crediteurenbestand weet de moedermaatschappij niet wie zij moet inlichten en kan zij de overblijvende aansprakelijkheid niet beëindigen. Het valt te betwijfel of een 403-maatschappij bereid is om inzicht te geven in haar crediteurenbestand als de moedermaatschappij de overblijvende aansprakelijkheid wil beëindigen nadat de groepsband tussen hen is verbroken.

Mij staat een andere oplossing voor ogen om de crediteuren beter in staat te stellen dat zij bekend kunnen zijn met het voornemen van de moedermaatschappij om de overblijvende aansprakelijkheid te beëindigen. ${ }^{53}$ Evenals Van Zoest meen ik dat de Kamer van Koophandel een systeem moet aanbieden waarbij derden automatisch een notificatie kunnen krijgen als met betrekking tot een bepaalde rechtspersoon stukken zijn gedeponeerd bij het handelsregister. ${ }^{54} \mathrm{Mij}$ staat een systeem voor ogen waarbij derden notificaties kunnen krijgen voor alle stukken die ten aanzien van een bepaalde rechtspersoon worden gedeponeerd bij het handelsregister en, voor zover van toepassing, wanneer deze stukken effect resulteren. ${ }^{55}$ Een derde moet daarbij zelf kunnen instellen met

aansprakelijkheid te beëindigen. Een reden voor het verschil in het aantal mededelingen dat in 2016 en 2019 is gedeponeerd, is mij niet bekend.

51. Berk 2007, p. 18.

52. Schutte-Veenstra 1996, p. 296 en Berk 2007, p. 18. Zie ook Brink 1997, p. 260.

53. Zie ook $\S 8.5 .4$, waar ik opmerk dat een crediteur met de moedermaatschappij overeen kan komen dat hij individueel moet worden ingelicht als de moedermaatschappij een aankondiging plaatst in een landelijk verspreid dagblad dat zij een mededeling heeft gedeponeerd van het voornemen om de overblijvende aansprakelijkheid te beëindigen.

54. Van Zoest 2016a, p. 64.

55. Derden zouden dan niet alleen notificaties moeten kunnen krijgen als er stukken worden gedeponeerd met betrekking tot het groepsregime - zoals een mededeling van het voornemen van de moedermaatschappij om de overblijvende aansprakelijkheid te beëindigen - maar 
betrekking tot welke rechtspersonen hij notificaties wil ontvangen. Dit systeem geeft bijvoorbeeld een crediteur de mogelijkheid dat hij een bericht krijgt als de moedermaatschappij een mededeling deponeert van het voornemen om de overblijvende ansprakelijkheid te beëindigen. Met de huidige technische mogelijkheden is de introductie van een dergelijk systeem geen groot bezwaar.

\subsubsection{Een landelijk verspreid dagblad}

Er bestaat geen overzicht van landelijk verspreide dagbladen in Nederland. Ook de wet kent geen definitie van een landelijk verspreid dagblad. De jurisprudentie biedt wel enig inzicht waaraan een dergelijk dagblad moet voldoen. Zo kwalificeren het Nederlands Dagblad en het Reformatorisch Dagblad niet als een landelijk verspreid dagblad omdat zij een (relatief) beperkte oplage ${ }^{56}$ hebben en zich richten op een specifieke doelgroep in Nederland lezers met een orthodoxe-protestante, respectievelijk een gereformeerde achtergrond. ${ }^{57}$

Op basis van de jurisprudentie zijn drie criteria te noemen waaraan een landelijk verspreid dagblad (ten minste) moet voldoen. Ten eerste moet het dagblad zich richten op een algemeen publiek in Nederland en mag het niet bedoeld zijn voor een specifieke doelgroep van culturele, religieuze of andere aard. Daarnaast moet het dagblad in heel Nederland beschikbaar zijn, en tot slot moet het een relatief grote oplage hebben. ${ }^{58}$ Met betrekking tot de oplage van de krant zou niet alleen rekening moeten worden gehouden met de abonnementen voor de papieren krant en losse verkoop, maar ook met abonnementen voor toegang tot de website. Evenals Ten Voorde meen ik dat een landelijk verspreid dagblad daarnaast al enige tijd moet worden uitgegeven, algemeen bekend moet zijn in Nederland en dat derden oude exemplaren van het dagblad moeten kunnen opzoeken. $^{59}$

In verband met de onduidelijkheid over welke dagbladen kwalificeren als een landelijk verspreid dagblad en de terugloop van de oplages van dagbladen,

ook als er andere stukken worden gedeponeerd zoals een statutenwijziging of een jaarrekening.

56. Het Nederlands Dagblad had in 1991 een oplage van 25.496 abonnees en een losse verkoop van 25 stuks per dag (zie Hof Amsterdam (OK) 29 juli 1993, NJ 1994/132 (Teeuwissen) Teletrade), r.o. 3.14). Het Reformatorisch Dagblad had in 2001 een oplage van circa 57.810 abonnementen en was daarnaast bij enkele tientallen verkooppunten in Nederland los te koop (zie Rb. 's-Hertogenbosch 21 februari 2002, ECLI:NL:RBSHE:2002:AD9620 (Landis/Norted International), r.o. 4.4).

57. Hof Amsterdam (OK) 29 juli 1993, NJ 1994/132 (Teeuwissen/Teletrade), r.o. 6.5 en Rb. 's-Hertogenbosch 21 februari 2002, ECLI:NL:RBSHE:2002:AD9620 (Landis/Norted International), r.o. 4.4.

58. L. Timmerman 1993, p. 328 en Ten Voorde 2006, p. 94-95.

59. Ten Voorde 2006, p. 95. 
kan worden getwijfeld aan de effectiviteit van dit middel om crediteuren te attenderen op de mededeling van een moedermaatschappij van het voornemen om de overblijvende aansprakelijkheid te beëindigen. Ten eerste kunnen crediteuren niet precies weten welke dagbladen ze moeten bijhouden en daarnaast loopt het belang van het dagblad als bron van informatie in zijn algemeenheid steeds verder terug. De digitalisering van de samenleving en de huidige technische mogelijkheden bieden mijns inziens een eenvoudiger en effectiever alternatief. In de vorige paragraaf heb ik opgemerkt dat de Kamer van Koophandel naar mijn mening een systeem zou moeten aanbieden waarbij derden automatisch een notificatie kunnen krijgen als met betrekking tot een bepaalde rechtspersoon stukken zijn gedeponeerd bij het handelsregister. ${ }^{60}$ Een crediteur kan dan instellen dat hij een bericht krijgt als de moedermaatschappij een mededeling deponeert van het voornemen om de overblijvende aansprakelijkheid te beëindigen. In dat geval is mijns inziens voldoende gewaarborgd dat een crediteur op de hoogte kan zijn van dit voornemen. De mogelijkheid om een notificatie te krijgen, zou mijns inziens de aankondiging in een landelijk verspreid dagblad kunnen vervangen. Deze aankondiging kan dan worden geschrapt uit art. 2:404 lid $3 \mathrm{BW}$ als voorwaarde om de overblijvende ansprakelijkheid te beëindigen.

Voor het geval dat het nog een brug te ver is om van de Kamer van Koophandel te vragen om een systeem aan te bieden waardoor derden automatisch notificaties kunnen krijgen, wijs ik ook op een minder ingrijpende aanpassing die Maatman en Verbrugh in 1996, respectievelijk 2007 al hebben genoemd met betrekking tot de aankondiging van partijen in een landelijk verspreid dagblad dat zij voornemens zijn om te fuseren. ${ }^{61} \mathrm{Zij}$ stellen voor dat dergelijke aankondigingen alleen nog mogen worden geplaatst in de Staatscourant. Toegepast op het groepsregime zou art. 2:404 BW zo kunnen worden gewijzigd dat een moedermaatschappij de aankondiging dat en waar de door haar gedeponeerde mededeling van het voornemen om de overblijvende aansprakelijkheid te beëindigen ter inzage ligt, moet plaatsen in de Staatscourant. Dit biedt de moedermaatschappij en de crediteuren meer zekerheid ten opzichte van de huidige regeling. De moedermaatschappij weet waar zij de aankondiging moet plaatsen en de crediteuren weten waar zij deze kunnen opzoeken. Crediteuren hoeven dan niet meer alle landelijk verspreide dagbladen te controleren, maar enkel nog de Staatscourant. Tot slot merk ik op dat de Staatscourant, in tegenstelling tot de meeste landelijk verspreide dagbladen, in zijn geheel digitaal vrij toegankelijk is.

60. Zie $\S 8.5 .1$.

61. Maatman 1996, p. 932 en Verbrugh 2007, p. 69. Zie art. 2:314 lid 3 BW. 


\subsubsection{Informatie in de mededeling en de aankondiging}

Uit hoofde van art. 2:404 BW zijn er amper voorwaarden met betrekking tot de informatie die de moedermaatschappij moet opnemen in de bij het handelsregister te deponeren mededeling en de te plaatsen aankondiging daarvan in een landelijk verspreid dagblad. Op grond van art. 2:404 lid 3 sub b en c BW moet de moedermaatschappij slechts een mededeling deponeren 'van het voornemen tot beëindiging' en een aankondiging plaatsen in een landelijk verspreid dagblad 'dat en waar de mededeling ter inzage ligt'. De moedermaatschappij kan er daarom voor kiezen om deze stukken summier op te stellen. Een voorbeeld hiervan deed zich in 2014 voor bij thuishulpbedrijf TSN. Moedermaatschappij ADG Dienstengroep heeft zich in het verleden door middel van een 403-verklaring hoofdelijk aansprakelijk gesteld voor de schulden die voortvloeien uit de rechtshandelingen van TSN. Zij heeft deze verklaring later ingetrokken en wil de overblijvende aansprakelijkheid beëindigen. Enkele dagen voordat ADG Dienstengroep een aankondiging plaatst in een landelijk verspreid dagblad heeft zij haar naam gewijzigd in Mercares. In de aankondiging staat dat Mercares - met vermelding van haar handelsregisternummer - een mededeling heeft gedeponeerd bij het handelsregister van het voornemen om de overblijvende aansprakelijkheid te beëindigen voor de schulden die zijn voortgevloeid uit de rechtshandelingen van de 403-maatschappijen ten aanzien waarvan zij eerder een 403-verklaring heeft gedeponeerd. In de aankondiging staat niet vermeld ten aanzien van welke 403-maatschappijen zij in het verleden een 403-verklaring heeft gedeponeerd. ${ }^{62}$ De crediteuren van TSN hebben geen verzet ingesteld, waardoor de overblijvende aansprakelijkheid van Mercares na het verstrijken van de verzetstermijn is beëindigd.

Later zijn over bovenstaande gang van zaken Kamervragen gesteld aan de Staatssecretaris van Volksgezondheid, Welzijn en Sport. Hij heeft geantwoord dat de handelwijze van moedermaatschappij Mercares er de schijn van zou kunnen hebben dat zij bewust op een zodanige manier de overblijvende aansprakelijkheid heeft beëindigd, dat de crediteuren van TSN daarvan niet op de hoogte zouden zijn. ${ }^{63}$

De strekking van de bepalingen van art. 2:404 lid 3 sub b en c BW is dat de crediteuren van de 403-maatschappij op de hoogte kunnen zijn van het voornemen van de moedermaatschappij om de overblijvende aansprakelijkheid te beëindigen. $\mathrm{Zij}$ kunnen dan verzet instellen tegen dit voornemen en een vervangende

62. Aldus https://www.ftm.nl/artikelen/eigenaar-tsn-schoonde-zich-achter-de-schermen-vanaansprakelijkheid (laatst gecontroleerd op 24 februari 2016). Ik merk op dat in dit artikel niet staat vermeld of de groepsband tussen Mercares en TSN is verbroken. Aangezien de overblijvende aansprakelijkheid van Mercares uiteindelijk is beëindigd, ga ik ervan uit dat deze groepsband is verbroken.

63. Aanhangsel Handelingen II 2015/16, 1531, p. 2. 
waarborg verlangen voor de voldoening van hun vordering op de 403-maatschappij. In het geval van TSN en Mercares hebben de crediteuren op basis van de informatie in de mededeling bij het handelsregister en de aankondiging daarvan in een landelijk verspreid dagblad, de moeder- en de 403-maatschappij niet als zodanig kunnen herkennen waardoor zij redelijkerwijs niet hebben kunnen achterhalen dat de moedermaatschappij het voornemen had om de overblijvende aansprakelijkheid te beëindigen. Zij konden dus niet weten dat zij verzet konden instellen tegen dit voornemen en een vervangende waarborg konden verlangen voor de voldoening van hun vordering op TSN. Mercares heeft daardoor (al of niet bewust) gehandeld op een manier waardoor het onredelijk benadelend is voor de crediteuren als zij zich op de beëindiging van de overblijvende aansprakelijkheid zou kunnen beroepen. Ik kom daarom tot de conclusie dat een beroep van Mercares op deze beëindiging onaanvaardbaar is naar maatstaven van redelijkheid en billijkheid. ${ }^{64}$

Om te waarborgen dat crediteuren aan de hand van de informatie in de mededeling bij het handelsregister en de aankondiging daarvan in een landelijk verspreid dagblad kunnen achterhalen of hun vordering door de beëindiging van de overblijvende aansprakelijkheid komt te vervallen, is het wenselijk dat art. 2:404 lid 3 sub b en c BW worden gewijzigd. Aan deze bepalingen kan worden toegevoegd welke informatie de moedermaatschappij verplicht moet opnemen in de door haar te deponeren mededeling en de aankondiging daarvan in een landelijk verspreid dagblad.

Voor een crediteur is het van belang dat hij uit de informatie in de mededeling bij het handelsregister en de aankondiging daarvan in een landelijk verspreid dagblad kan opmaken dat de moedermaatschappij haar aansprakelijkheid wil beëindigen voor de schuld van de 403-maatschappij tegenover hem. De crediteur moet beide rechtspersonen daarom als zijn debiteur kunnen herkennen. Om die reden moet mijns inziens aan sub b en c van art. 2:404 lid 3 BW worden toegevoegd dat de namen van de moeder- en de 403-maatschappij expliciet moeten worden vermeld in de mededeling bij het handelsregister en de aankondiging daarvan in een landelijk verspreid dagblad. Daarnaast moet naar mijn mening in deze bepalingen worden opgenomen dat als de naam van de moeder- of de 403-maatschappij sinds de deponering van de 403-verklaring is gewijzigd, ook de oude naam moet worden vermeld. Dit houdt onder meer in dat als de (rechtsopvolger van de) moedermaatschappij de overblijvende aansprakelijkheid wil beëindigen nadat de moeder- of de 403-maatschappij door een fusie of zuivere splitsing is opgehouden te bestaan, ${ }^{65}$ de naam van de verdwenen moeder- of 403-maatschappij expliciet moet worden vermeld.

64. Zie art. $6: 2$ lid $2 \mathrm{BW}$.

65. Zie $\S 9.7$ tot en met $\S 9.9$. 
Bovenstaande wijzigingen van art. 2:404 lid 3 sub b en c BW bieden een moedermaatschappij ook meer houvast bij de beëindiging van haar overblijvende aansprakelijkheid. Voor haar is dan duidelijk welke informatie zij (ten minste) moet opnemen in de te deponeren mededeling en de aankondiging daarvan in een landelijk verspreid dagblad.

Overigens is het naar huidig recht ook al aan te raden dat een moedermaatschappij in de mededeling bij het handelsregister en de aankondiging daarvan in een landelijk verspreid dagblad expliciet melding maakt van haar eigen naam, de naam van de 403-maatschappij en eventuele oude namen van hen indien die sinds de deponering van de 403-verklaring zijn gewijzigd. Hierboven merkte ik ten aanzien van de casus van TSN al op dat als een crediteur op basis van de informatie in de mededeling en aankondiging redelijkerwijs niet op de hoogte heeft kunnen zijn van het voornemen van de moedermaatschappij om de overblijvende aansprakelijkheid te beëindigen, het beroep van de moedermaatschappij op deze beëindiging jegens de crediteur mijns inziens onaanvaardbaar is naar maatstaven van redelijkheid en billijkheid. ${ }^{66}$

\subsubsection{De moedermaatschappij hoeft de crediteuren niet individueel in te lichten dat zij de procedure voor de beëindiging is gestart}

In 1993 heeft de OK - mijns inziens ten onrechte - geoordeeld dat het beroep van een moedermaatschappij op de beëindiging van de overblijvende aansprakelijkheid tegenover een crediteur onaanvaardbaar is naar maatstaven van redelijkheid en billijkheid, omdat de moedermaatschappij de crediteur niet individueel had ingelicht dat zij de procedure was gestart om de overblijvende aansprakelijkheid te beëindigen ${ }^{67}$ De OK merkt op dat de moedermaatschappij weet dat de 403-maatschappij slechts één crediteur heeft, en dat deze een aanzienlijke (grotendeels) opeisbare vordering heeft. Daarnaast wijst de OK erop dat de moedermaatschappij de aankondiging dat en waar de door haar gedeponeerde mededeling van het voornemen om de overblijvende aansprakelijkheid te beëindigen ter inzage ligt, heeft geplaatst in het Nederlands Dagblad. De moedermaatschappij moet zich ervan bewust zijn geweest dat de crediteur waarschijnlijk geen kennis zou nemen van deze aankondiging. Zij weet namelijk dat de crediteur rooms-katholiek is en dat het Nederlands Dagblad zich specifiek richt op orthodox protestantse lezers. Deze omstandigheden brengen volgens de OK mee dat de moedermaatschappij de crediteur erop had moeten wijzen dat zij was begonnen met de procedure om de overblijvende aansprakelijkheid te beëindigen. Aangezien de moedermaatschappij de crediteur niet heeft ingelicht, is het beroep op de beëindiging volgens de

66. Zie art. 6:2 BW

67. Hof Amsterdam (OK) 29 juli 1993, NJ 1994/132 (Teeuwissen/Teletrade), r.o. 6.2 en 6.5. 
OK onaanvaardbaar naar maatstaven van redelijkheid en billijkheid. Ten overvloede overweegt de OK dat het Nederlands Dagblad niet heeft te gelden als een landelijk verspreid dagblad in de zin van art. 2:404 lid 3 sub b BW. ${ }^{68}$

Hoewel ik mij kan vinden in de uitkomst van bovenstaande uitspraak, onderschrijf ik de twee kanttekeningen die in de literatuur ten aanzien van deze uitspraak zijn geplaatst. Ten eerste wijzen verschillende auteurs er terecht op dat de OK de redelijkheid en billijkheid niet in haar oordeel had moeten betrekken. ${ }^{69}$ Aangezien de moedermaatschappij geen aankondiging heeft geplaatst in een landelijk verspreid dagblad, is niet voldaan aan alle voorwaarden voor de beëindiging van de overblijvende aansprakelijkheid. De OK had daarom moeten oordelen dat deze aansprakelijkheid niet is beëindigd. De moedermaatschappij kan dus geen beroep doen op de beëindiging van de overblijvende aansprakelijkheid en een dergelijk beroep is dus ook niet onaanvaardbaar naar maatstaven van redelijkheid en billijkheid.

Een tweede kanttekening ten aanzien van de uitspraak van de OK is dat uit art. 2:404 BW geen verplichting vloeit voor de moedermaatschappij om crediteuren individueel in te lichten dat zij is gestart met de procedure om de overblijvende aansprakelijkheid te beëindigen. ${ }^{70}$ Het is de eigen verantwoordelijkheid van een crediteur om na te gaan of de moedermaatschappij een mededeling heeft gedeponeerd van het voornemen om de overblijvende aansprakelijkheid te beëindigen en een aankondiging daarvan heeft geplaatst in een landelijk verspreid dagblad. Naar mijn mening kan een moedermaatschappij weliswaar onder bijzondere omstandigheden verplicht zijn om een individuele crediteur te informeren over een lopende procedure om de overblijvende aansprakelijkheid te beëindigen, maar deze verplichting ontstaat slechts als gevolg van een bepaalde handeling van de crediteur jegens de moedermaatschappij. Een dergelijk situatie doet zich voor als de crediteur de moedermaatschappij tijdens de verzetstermijn ansprakelijk stelt op grond van de 403-verklaring, of als de crediteur al een keer verzet heeft ingesteld maar de moedermaatschappij een nieuwe procedure is begonnen om de overblijvende ansprakelijkheid te beëindigen - ik kom later terug op deze twee situaties. ${ }^{71}$ Maar op de moedermaatschappij rust geen algemene verplichting om crediteuren zonder meer te moeten informeren dat de procedure voor de beëindiging van de overblijvende aansprakelijkheid is gestart. Dat de moedermaatschappij weet dat de 403-maatschappij slechts één crediteur heeft, maakt dit niet anders.

68. Zie $\S 8.5 .2$.

69. L. Timmerman 1993, p. 328, Beckman 1995a, p. 346-347, Asser/Maeijer \& Kroeze 2-I* 2015/586 en E.C.A. Nass 2019, p. 154-155.

70. Van Zoest 2014, p. 4 en Bungenberg 2015, p. 31.

71. Zie $\S 8.6 .2$, respectievelijk $\S 8.13$. 
Daargelaten dat in de casus van de uitspraak bij de OK de overblijvende aansprakelijkheid niet is beëindigd - waar ik hierboven al op wees -, meen ik dat de OK ten onrechte heeft geoordeeld dat het beroep van de moedermaatschappij op de beëindiging van de overblijvende aansprakelijkheid jegens de crediteur onaanvaardbaar is naar maatstaven van redelijkheid en billijkheid omdat de moedermaatschappij de crediteur niet heeft ingelicht dat zij de procedure daartoe was begonnen. Naar mijn mening had de OK slechts kunnen oordelen dat het beroep op de beëindiging onaanvaardbaar is naar maatstaven van redelijkheid en billijkheid omdat de moedermaatschappij op een zodanige wijze heeft gehandeld dat zij wist of behoorde te weten dat het voor de crediteur redelijkerwijs niet mogelijk zou zijn om de aankondiging in het dagblad op te merken.

Als een crediteur wil dat hij individueel moet worden ingelicht als de moedermaatschappij de overblijvende aansprakelijkheid wil beëindigen, moet hij dat contractueel laten vastleggen. Het is aan te raden dat de crediteur daarvoor een overeenkomst aangaat met de moedermaatschappij in plaats van met de 403-maatschappij. ${ }^{72}$ De eventuele schade die de crediteur lijdt als hij niet vooraf wordt ingelicht over de beëindiging van de overblijvende aansprakelijkheid, is het gedeelte van de vordering op de 403-maatschappij dat niet verhaalbaar is. De 403-maatschappij zal niet in staat zijn deze schade te vergoeden.

De crediteur kan met de moedermaatschappij overeenkomen dat hij individueel moet worden ingelicht als de moedermaatschappij een aankondiging plaatst in een landelijk verspreid dagblad dat zij een mededeling heeft gedeponeerd van het voornemen om de overblijvende aansprakelijkheid te beëindigen. ${ }^{73,74}$ De dag na de publicatie van deze aankondiging begint namelijk de termijn van twee maanden te lopen waarin de crediteur verzet kan instellen tegen

72. Van Zoest 2016a, p. 67-68, De Haan in zijn annotatie onder HR 31 maart 2017, JOR 2017/221 (SNS/Curatoren) en Van Zoest 2019, p. 54. De crediteur kan ook een driepartijenovereenkomst aangaan met de moeder- én de 403-maatschappij.

73. Ramanna 2008, p. 20, Van der Kraan 2012, p. 60, Van der Kraan 2018b, p. $33-34$ en Van Zoest 2019, p. 54.

74. Zie $\S 7.2 .2$, waar ik opmerk dat een crediteur met de moedermaatschappij kan overeenkomen dat hij moet worden ingelicht als de moedermaatschappij de 403-verklaring wil intrekken. Dat de moedermaatschappij de crediteur moet inlichten als zij de 403-verklaring wil intrekken, zal de crediteur niet in alle gevallen helpen om tijdig verzet in te stellen tegen het voornemen om de overblijvende aansprakelijkheid te beëindigen. Dat de moedermaatschappij de 403-verklaring heeft ingetrokken, betekent niet dat zij ook (meteen) de overblijvende aansprakelijkheid zal beëindigen. Tussen de intrekking en de beëindiging kan een lange periode zitten. Het is voor een crediteur daarom het veiligst om te bedingen dat hij individueel moet worden ingelicht als de moedermaatschappij de 403-verklaring wil intrekken én als deze een aankondiging plaatst in een landelijk verspreid dagblad dat zij een mededeling heeft gedeponeerd van het voornemen om de overblijvende aansprakelijkheid te beëindigen. 
het voornemen van de beëindiging van de overblijvende aansprakelijkheid. ${ }^{75}$ Indien de moedermaatschappij vervolgens de crediteur niet vooraf individueel inlicht, pleegt zij een wanprestatie. De crediteur kan dan een vordering tot schadevergoeding instellen tegen de moedermaatschappij. Daarnaast is verdedigbaar dat in een dergelijk geval het beroep van de moedermaatschappij op de beëindiging van de overblijvende aansprakelijkheid jegens de crediteur onaanvaardbaar is naar maatstaven van redelijkheid en billijkheid. De crediteur kan de moedermaatschappij dan nog steeds aansprakelijk stellen op grond van de ingetrokken 403-verklaring.

\subsection{Verzet instellen tegen het voornemen om de overblijvende aansprakelijkheid te beëindigen}

\subsubsection{Het recht van verzet en de mogelijkheid om een vervangende waarborg te verzoeken: drie vraagstukken}

Een crediteur kan verzet instellen tegen het voornemen van de moedermaatschappij om de overblijvende aansprakelijkheid te beëindigen door een verzoek daartoe in te dienen bij de rechtbank van de woonplaats van de 403-maatschappij. ${ }^{76}$ De crediteur kan dan een vervangende waarborg verlangen voor de voldoening van zijn vordering op de 403-maatschappij. ${ }^{77}$

Het onderzoeken van het recht van crediteuren om verzet in te stellen en een vervangende waarborg te verzoeken, valt uiteen in de beantwoording van drie vragen. Ten eerste onderzoek ik welke crediteuren verzet kunnen instellen ( 8 8.6.2, $\S 8.6 .3$ en $\S 8.7)$. Vervolgens geef ik antwoord op de vraag onder welke omstandigheden een crediteur die verzet heeft ingesteld recht heeft op een vervangende waarborg ( $\S 8.8)$. Aansluitend onderzoek ik welke omvang deze vervangende waarborg moet hebben ( $\$ 8.9$ en $\S 8.10$ ). Ter verduidelijking van de beantwoording van deze drie vragen en om hun onderlinge samenhang te illustreren, zal ik tot slot een drietal rekenvoorbeelden geven waarbij ik telkens naga of de crediteur verzet kan instellen, of hij recht heeft op een vervangende waarborg en welke omvang die waarborg dan (minimaal) moet hebben (§ 8.11).

75. Zie art. 2:404 lid $5 \mathrm{BW}$ en $\S 8.6 .3$.

76. Zie art. 2:404 lid 3 sub d en lid 5 BW. Tegen de uitspraak van de rechtbank staat hoger beroep open bij de OK en vervolgens cassatieberoep bij de Hoge Raad. Zie Assink/Slagter 2013/140, Van der Heijden/Van der Grinten \& Dortmond 2013/324.3 en Asser/Maeijer \& Kroeze 2-I*2015/586.

77. Zie art. 2:404 lid 4 BW. 


\subsubsection{Het recht van verzet}

Het instellen van verzet tegen het voornemen van de moedermaatschappij om de overblijvende ansprakelijkheid te beëindigen, heeft een privatieve werking. Slechts ten aanzien van de crediteuren die verzet hebben ingesteld, eindigt de overblijvende aansprakelijkheid van de moedermaatschappij (nog) niet. De moedermaatschappij is wel bevrijd van haar aansprakelijkheid tegenover de crediteuren die geen verzet hebben ingesteld. ${ }^{78}$

In de literatuur wordt terecht aangenomen dat een crediteur geen verzet hoeft in te stellen tegen de beëindiging van de overblijvende aansprakelijkheid als hij de moedermaatschappij reeds voor aanvang van de verzetstermijn aansprakelijk heeft gesteld op grond van de (ingetrokken) 403-verklaring. ${ }^{79}$ De regeling voor de beëindiging van de overblijvende aansprakelijkheid is niet van toepassing op schulden ten aanzien waarvan de moedermaatschappij op dat moment al is aangesproken tot voldoening. Een dergelijke crediteur behoudt zijn vordering op de moedermaatschappij als de overblijvende aansprakelijkheid wordt beëindigd. ${ }^{80}$

Daarnaast wijs ik op het geval dat een crediteur de moedermaatschappij gedurende de verzetstermijn aansprakelijk stelt. In tegenstelling tot de hierboven genoemde situatie, meen ik dat de regeling voor de beëindiging van de overblijvende ansprakelijkheid wel van toepassing is op een schuld van de moedermaatschappij tegenover een dergelijke crediteur. Een andere uitkomst zou ertoe kunnen leiden dat crediteuren bewust geen verzet instellen, maar in plaats daarvan de moedermaatschappij aansprakelijk stellen. Een crediteur zou dan namelijk altijd zijn vordering op de moedermaatschappij behouden, terwijl hij bij het instellen van verzet het risico loopt dat dit verzet niet gegrond wordt verklaard en hij op grond van art. 2:404 lid $4 \mathrm{BW}$ geen recht heeft op een vervangende waarborg omdat hij al voldoende waarborgen heeft dat zijn vordering

78. Beckman 1995a, p. 347, Beckman \& Marseille 2013, p. 286, Snijder-Kuipers \& Eliëns 2014, p. 1179, Asser/Maeijer \& Kroeze 2-I*2015/586, Huiskes 2015, p. 44, Notenboom 2017, p. 128 en Van Zoest 2019, p. 39.

79. Slagter 2005, p. 541, Beckman 2011, p. 251, Asser/Maeijer \& Kroeze 2-I* 2015/583, Beckman - SDU Commentaar Ondernemingsrecht 2019, art. 2:404 BW, aant. C.2 en E.C.A. Nass 2019, p. 148.

80. Zie Rb. Rotterdam 15 april 1999, JOR 1999/119 (Lely Industries/Netagco Holding), r.o. 6.3-6.4, waar de rechtbank oordeelt dat het beroep van de moedermaatschappij op de beëindiging van de overblijvende aansprakelijkheid onaanvaardbaar is naar maatstaven van redelijkheid en billijkheid tegenover een crediteur die de moedermaatschappij al aansprakelijk heeft gesteld op grond van de 403-verklaring. Evenals Beckman 2011, p. 251, Asser/ Maeijer \& Kroeze 2-I*2015/583, Beckman - SDU Commentaar Ondernemingsrecht 2019, art. 2:404 BW, aant. C.2 en E.C.A. Nass 2019, p. 148, meen ik dat de rechtbank de redelijkheid en billijkheid niet in haar oordeel had moeten betrekken omdat de aansprakelijkheid van de moedermaatschappij jegens de crediteur niet is beëindigd. 
op de 403-maatschappij zal worden voldaan. ${ }^{81}$ Het is naar mijn mening aan de moedermaatschappij om een crediteur die haar aansprakelijk stelt gedurende de verzetstermijn er zo snel mogelijk op te wijzen dat zij de procedure is begonnen om de overblijvende aansprakelijkheid te beëindigen en tot wanneer de crediteur daartegen verzet kan instellen. Doet de moedermaatschappij dit niet, dan is een beroep op de beëindiging van de overblijvende aansprakelijkheid tegenover de desbetreffende crediteur naar mijn mening onaanvaardbaar naar maatstaven van redelijkheid en billijkheid. ${ }^{82}$ De crediteur kan zich dan onverminderd op de moedermaatschappij verhalen.

\subsubsection{De verzetstermijn}

Een crediteur heeft twee maanden ${ }^{83}$ de tijd om verzet in te stellen tegen het voornemen van de moedermaatschappij om de overblijvende aansprakelijkheid te beëindigen. Deze termijn vangt aan op de eerste dag nadat de moedermaatschappij een aankondiging heeft geplaatst in een landelijk verspreid dagblad dat en waar de door haar gedeponeerde mededeling van het voornemen om de overblijvende aansprakelijkheid te beëindigen ter inzage ligt. ${ }^{84} \mathrm{Als}$ een moedermaatschappij bijvoorbeeld op 15 oktober de aankondiging plaatst in een landelijk verspreid dagblad, begint de verzetstermijn voor crediteuren op 16 oktober te lopen. ${ }^{85}$ De termijn eindigt ultimo 15 december en heeft dus per 16 december effect. Op de verzetstermijn is de Algemene termijnenwet van toepassing. Dit brengt mee dat in het geval dat de verzetstermijn eindigt op een dag in het weekend of een algemeen erkende feestdag, ${ }^{86}$ de termijn op grond van art. 1 lid 1 Algemene termijnenwet wordt verlengd tot en met de eerstvolgende dag die geen weekenddag of algemeen erkende feestdag is. De verzetstermijn kan wel op een dergelijke dag aanvangen.

81. Zie $\S 8.8$.

82. Zie art. 6:2 lid $2 \mathrm{BW}$.

83. Zie art. 2:404 lid 5 BW. Het oorspronkelijke wetsvoorstel kende een verzetstermijn van slechts één maand (zie Kamerstukken II 1983/84, 16551, 12, p. 10 (2eNvW)). Verschillende Kamerleden hebben amendementen ingediend om deze termijn te verlengen. Eerst tot drie maanden en later tot twee maanden (zie Kamerstukken II 1984/85, 16551, 18, p. 1 (Amendement) en Kamerstukken II 1984/85, 16551, 20, p. 1 (Amendement)). Uiteindelijk heeft de minister het laatste voorstel overgenomen (zie Kamerstukken I 1984/85, 16551, 237, p. 17 $(3 \mathrm{eNgvvW}))$.

84. Zie Kamerstukken II 1983/84, 16551, 11, p. 17 (NnavhEV), waar de minister opmerkt dat de verzetstermijn op dezelfde manier wordt ingeluid als die op grond van art. 2:316 BW met betrekking tot een voorgenomen fusie. Ten aanzien van de verzetstermijn ex art. 2:316 BW wordt aangenomen dat deze gaat lopen op de dag na de aankondiging van de nederlegging of openbaarmaking van het voorstel tot fusie in een landelijk verspreid dagblad (zie onder meer Assink/Slagter 2013/121.4 en Asser/Maeijer \& Kroeze 2-I*2015/435).

85. Vgl. Quist 2019, p. 400-401, die een soortgelijke uitwerking geeft met betrekking tot de verzetstermijnen op grond van art. 2:316 en 2:3341 BW.

86. Zie art. 3 Algemene termijnenwet voor een overzicht van de erkende feestdagen en dagen die daarmee worden gelijkgesteld. 
Gedurende de verzetstermijn kunnen er nog steeds nieuwe vorderingen op de moedermaatschappij ontstaan op grond van de ingetrokken 403-verklaring. De moedermaatschappij is op grond van deze verklaring aansprakelijk voor de schulden die voortvloeien uit de rechtshandelingen die de 403-maatschappij heeft verricht tot het moment dat de moedermaatschappij tegenover de crediteur een beroep kan doen op de intrekking. Dit betreft ook schulden die gedurende de verzetstermijn ontstaan. ${ }^{87}$ De desbetreffende crediteuren kunnen vanzelfsprekend verzet instellen tegen het voornemen van de moedermaatschappij om de overblijvende aansprakelijkheid te beëindigen, maar zij zijn gebonden aan de reeds aangevangen verzetstermijn.

De tweemaandstermijn om verzet in te stellen is een fatale termijn. Na het verstrijken van deze termijn kan een crediteur geen verzet meer instellen. In de jurisprudentie is hierop één keer een uitzondering gemaakt door de Rechtbank Rotterdam. ${ }^{88}$ Naar mijn mening is dit oordeel onjuist. Ik kom hier later in deze paragraaf op terug. De feiten die ten grondslag liggen aan deze uitspraak zijn kort gezegd als volgt. De moedermaatschappij heeft op 13 februari 2014 een mededeling gedeponeerd van het voornemen om de overblijvende aansprakelijkheid te beëindigen. Twee dagen later plaatst zij een aankondiging in een landelijk verspreid dagblad dat en waar deze mededeling ter inzage ligt. De moedermaatschappij heeft de 403-verklaring bijna twee maanden na de publicatie van deze aankondiging - op 14 april 2014 - ingetrokken. ${ }^{89}$ De dag na de intrekking van de 403-verklaring stuurt de 403-maatschappij een brief aan haar enige crediteur, waarin zij melding maakt van enige 'organisatorische wijzigingen'. Op 17 april 2014 wordt de groepsband tussen de moeder- en de 403-maatschappij verbroken ${ }^{90}$ en een dag later stelt de desbetreffende crediteur

87. Bartman in zijn annotatie onder Hof Amsterdam (OK) 9 december 2015, JOR 2016/7 (Curatoren/SNS).

88. Rb. Rotterdam 30 september 2014, JOR 2014/326, m.nt. Loesberg (Pergen/Eneco).

89. Zie $\S 8.12$, waar ik tot de conclusie kom dat een moedermaatschappij pas een aankondiging kan plaatsen in een landelijk verspreid dagblad dat en waar de door haar gedeponeerde mededeling van het voornemen om de overblijvende ansprakelijkheid te beëindigen ter inzage ligt, nádat ze een beroep kan doen op de intrekking van de 403 -verklaring. Dit houdt in dat de verzetstermijn in casu niet is aangevangen en de overblijvende aansprakelijkheid niet is beëindigd. Aangezien de rechtbank hier niet op ingaat, laat ik het op deze plek ook buiten beschouwing. Ik kom hierop terug in $\S 8.12$.

90. Het is onduidelijk of de groepsband tussen de moeder- en de 403-maatschappij in casu daadwerkelijk is verbroken. De rechter laat dit in het midden (zie Rb. Rotterdam 30 september 2014, JOR 2014/326, m.nt. Loesberg (Pergen/Eneco), r.o. 4.4) en op basis van de gegeven feiten ten aanzien van de casus is geen eenduidig antwoord te geven (zie $\S 8.4)$. Indien zou worden aangenomen dat in casu de groepsband tussen de moeder- en de 403-maatschappij is verbroken, is van belang dat dit heeft plaatsgevonden nadat de tweemaandstermijn is verlopen waarbinnen de crediteuren verzet konden instellen tegen het voornemen van de moedermaatschappij om de overblijvende aansprakelijkheid te beëindigen. In $\S 8.13 \mathrm{kom}$ ik tot de conclusie dat voor een rechtsgeldige beëindiging van de overblijvende aansprakelijkheid de groepsband moet zijn verbroken uiterlijk op het moment dat de verzetstermijn verloopt. 
verzet in tegen de beëindiging van de overblijvende aansprakelijkheid. ${ }^{91}$ De moedermaatschappij stelt zich op het standpunt dat de verzetstermijn drie dagen daarvoor - op 15 april - is verlopen en dat het verzet daarom niet rechtsgeldig is ingesteld.

De rechtbank wijst erop dat de moedermaatschappij de aankondiging dat en waar de gedeponeerde mededeling van het voornemen om de overblijvende aansprakelijkheid te beëindigen ter inzage ligt, heeft gepubliceerd op pagina 31 van de zaterdageditie van het dagblad Trouw. Dit is een landelijk verspreid dagblad met een relatief kleine oplage. Daarnaast merkt de rechtbank op dat de 403-maatschappij in de brief aan haar enige crediteur slechts melding maakt van enkele organisatorische wijzigingen. Hierbij is de belangrijkste wijziging niet gemeld: het voornemen van de moedermaatschappij om de overblijvende aansprakelijkheid te beëindigen. Dit klemt volgens de rechtbank te meer omdat de 403-maatschappij contractueel verplicht is om voorafgaand goedkeuring te vragen aan de crediteur voor 'any change in the ownership'. ${ }^{92}$ Volgens de rechtbank heeft de moedermaatschappij er doelbewust op aangestuurd dat de verzetstermijn zou verstrijken zonder dat de crediteur hiervan op de hoogte zou geraken. Zij oordeelt dat het beroep van de moedermaatschappij op de overschrijding van de verzetstermijn daarom heeft te gelden als misbruik van recht. De crediteur wordt geacht tijdig verzet te hebben ingesteld. ${ }^{93}$

Hierboven merkte ik al op dat het oordeel van de Rechtbank Rotterdam naar mijn mening onjuist is. Ten eerste is niet van belang in welk landelijk verspreid dagblad en op welke pagina de moedermaatschappij de aankondiging plaatst dat en waar de door haar gedeponeerde mededeling van het voornemen om de overblijvende aansprakelijkheid te beëindigen ter inzage ligt. Relevant is slechts óf de moedermaatschappij een dergelijke aankondiging heeft geplaatst in een landelijk verspreid dagblad. Ten tweede kan ik mij niet vinden in het oordeel van de rechtbank dat het beroep van de moedermaatschappij op de overschrijding van de verzetstermijn misbruik van recht is. Daardoor wordt de verzetstermijn ten onrechte 'opgerekt', zodat een te laat ingesteld verzet toch geldig is. In verband met de rechtszekerheid is het van belang dat de verzetstermijn

Dat betekent dat de overblijvende aansprakelijkheid in casu dus niet is beëindigd. Omdat de rechtbank hier niet op ingaat, laat ik het op deze plek ook buiten beschouwing. Ik kom hier in $\S 8.13$ op terug.

91. Rb. Rotterdam 30 september 2014, JOR 2014/326, m.nt. Loesberg (Pergen/Eneco), r.o. 2.10-2.12, 2.14 en 2.17 .

92. Rb. Rotterdam 30 september 2014, JOR 2014/326, m.nt. Loesberg (Pergen/Eneco), r.o. 2.7. De 403-maatschappij is contractueel verplicht om voorafgaand goedkeuring te vragen aan de crediteur voor 'any change of ownership' van 50\% of meer van de stemrechten in de algemene vergadering van de 403-maatschappij.

93. Rb. Rotterdam 30 september 2014, JOR 2014/326, m.nt. Loesberg (Pergen/Eneco), r.o. 4.84.9. 
een fatale termijn is. De moedermaatschappij moet duidelijkheid hebben welke crediteuren (tijdig) verzet hebben ingesteld en voor welke vorderingen zij eventueel een vervangende waarborg moet geven. ${ }^{94}$ Dit is bijvoorbeeld van belang als de moedermaatschappij voornemens is om uiterlijk met het verstrijken van de verzetstermijn de aandelen in de 403-maatschappij over te dragen aan een derde. ${ }^{95} \mathrm{Zij}$ moet erop kunnen vertrouwen dat crediteuren dan geen verzet meer kunnen instellen.

In plaats van te oordelen dat het beroep van de moedermaatschappij op de overschrijding van de verzetstermijn misbruik van recht is, had de rechtbank moeten oordelen dat aan alle voorwaarden voor de beëindiging van de overblijvende aansprakelijkheid is voldaan, maar dat het beroep daarop jegens de crediteur onaanvaardbaar is naar maatstaven van redelijkheid en billijkheid. Het beroep op de beëindiging is in casu onaanvaardbaar omdat de crediteur niet om goedkeuring is gevraagd voor de 'change in the ownership' met betrekking tot de 403-maatschappij. Hoewel het de 403-maatschappij is die contractueel verplicht is om goedkeuring te vragen aan de crediteur, moet de moedermaatschappij hebben geweten van het bestaan van deze verplichting. Ten eerste had de moedermaatschappij volledige controle over de 403-maatschappij gedurende de periode dat deze met de crediteur onderhandelde over de overeenkomst tussen hen - waaronder het goedkeuringsrecht van de crediteur. Daarnaast is een onderdeel van deze overeenkomst dat de moedermaatschappij een zogenoemde parent company guarantee van $€ 10$ miljoen heeft afgegeven voor de schulden van de 403-maatschappij - uit hoofde van de desbetreffende overeenkomst. ${ }^{96}$ Aangezien de crediteur niet om goedkeuring is gevraagd voor het verbreken van de groepsband tussen de moeder- en de 403-maatschappij hoefde hij er niet op bedacht te zijn dat de moedermaatschappij de overblijvende aansprakelijkheid zou beëindigen. Het zou daarom onredelijk benadelend zijn voor de crediteur als de moedermaatschappij een beroep zou kunnen doen op de beëindiging van de overblijvende aansprakelijkheid.

\subsection{Partijen die verzet kunnen instellen tegen het voornemen} om de overblijvende aansprakelijkheid te beëindigen

\subsubsection{Een crediteur voor wiens vordering nog aansprakelijkheid loopt}

Op grond van art. 2:404 lid 5 BW kan een crediteur 'voor wiens vordering nog aansprakelijkheid loopt' verzet instellen tegen het voornemen van de

94. Zie $\S 8.8$.

95. Zie $\S 8.13$ waar ik betoog dat voor een rechtsgeldige beëindiging van de overblijvende aansprakelijkheid de groepsband moet zijn verbroken uiterlijk op het moment de verzetstermijn verloopt.

96. Rb. Rotterdam 30 september 2014, JOR 2014/326, m.nt. Loesberg (Pergen/Eneco), r.o. 4.9. 
moedermaatschappij om de overblijvende aansprakelijkheid te beëindigen. De 'vordering' waarnaar in deze bepaling wordt verwezen, is de vordering van de crediteur op de 403-maatschappij - waarvoor de moedermaatschappij op grond van de 403-verklaring aansprakelijk is. ${ }^{97}$

Hoewel er nog onduidelijkheid is over hoe een vordering op grond van een 403 -verklaring moet worden geduid, ${ }^{98}$ merk ik op dat als deze vordering wordt geduid als een 'hoofdelijke vordering' een crediteur zijn vorderingen op de moeder- en de 403-maatschappij onafhankelijk van elkaar kan cederen aan een derde. ${ }^{99}$ Als een crediteur zijn vordering op de 403-maatschappij heeft gecedeerd aan een derde, terwijl hij zelf rechthebbende is gebleven van de vordering op de moedermaatschappij, kan hij geen verzet instellen tegen het voornemen van de moedermaatschappij om de overblijvende aansprakelijkheid te beëindigen. Hij heeft dan geen vordering meer op de 403-maatschappij waarvoor nog aansprakelijkheid loopt. Daarnaast meen ik met Notenboom dat als de crediteur zijn vordering op de moedermaatschappij heeft gecedeerd aan een derde, terwijl hij zelf rechthebbende is gebleven van de vordering op de 403-maatschappij, hij doorgaans ook geen verzet kan instellen tegen het voornemen van de beëindiging. ${ }^{100}$ Aangezien de beëindiging van de overblijvende aansprakelijkheid geen gevolgen heeft voor de vordering op de 403-maatschappij, heeft de crediteur in beginsel geen belang bij het instellen van verzet. Dit is slechts anders als de crediteur bijvoorbeeld contractueel verplicht is - tegenover de cessionaris aan wie hij de vordering op de moedermaatschappij heeft gecedeerd - om verzet in te stellen.

\subsubsection{Het verzetsrecht van een crediteur met een niet-vaststaande vordering}

In de jurisprudentie is een aantal keer de vraag aan de orde gekomen of een crediteur ${ }^{101}$ met een niet-vaststaande vordering op de 403-maatschappij verzet kan instellen tegen het voornemen van de moedermaatschappij om de overblijvende aansprakelijkheid te beëindigen. In 2015 heeft de Rechtbank Rotterdam geoordeeld dat de enkele betwisting van het bestaan van de vordering op de

97. Notenboom 2017, p. 128 en Bartman 2015, p. 809. Zie Rb. Utrecht 31 juli 1996, JOR 1996/96 (Manning q.q./Haverkort Bouwgroep), r.o. 5.2, waar de rechtbank oordeelt dat een curator niet bevoegd is om namens de gezamenlijke crediteuren verzet in te stellen tegen het voornemen om de overblijvende aansprakelijkheid te beëindigen. De crediteuren moeten zelfstandig verzet instellen.

98. Zie hoofdstuk 6 en in het bijzonder $\S 6.5$.

99. Zie $\S$ 6.3.6.a.

100. Notenboom 2017, p. 128-129. Zie ook Bartman 2015, p. 809. Hetzelfde geldt voor de eerdergenoemde situatie dat een crediteur zijn vordering op de 403-maatschappij heeft gecedeerd aan een derde, en de derde verzet wil instellen.

101. Het gebruik van de term crediteur is op dit punt strikt genomen niet correct omdat de desbetreffende partij nog geen (vaststaande) vordering op de 403-maatschappij heeft. In verband met de leesbaarheid zal ik deze term toch gebruiken. 
403-maatschappij in ieder geval niet per definitie meebrengt dat de crediteur geen verzet kan instellen. Om verzet te kunnen instellen, is volgens de rechtbank vereist dat het bestaan van de vordering voldoende aannemelijk is. ${ }^{102}$

Later is bovenstaande rechtsvraag ook aan de orde gekomen bij de beschikking van de Hoge Raad inzake SNS/Curatoren.$^{103}$ Deze beschikking heeft betrekking op crediteuren met verschillende niet-vaststaande vorderingen op de 403-maatschappij, die verzet hebben ingesteld tegen het voornemen van de moedermaatschappij om de overblijvende aansprakelijkheid te beëindigen. Ten eerste is verzet ingesteld door crediteuren die menen een vordering tot schadevergoeding te hebben op de 403-maatschappij wegens een schending van de bancaire zorgvuldigheidsverplichting door laatstgenoemde. De 403-maatschappij betwist deze vorderingen. Ten tijde van het verzet zijn de vorderingen nog niet in rechte aan de crediteuren toegewezen. Daarnaast is verzet ingesteld door een crediteur met een voorwaardelijke vordering op grond van een door de 403-maatschappij afgegeven garantieverklaring. De 403-maatschappij heeft zich uit hoofde van deze garantieverklaring subsidiair aansprakelijk gesteld voor de verplichtingen van een derde, maar de crediteur heeft nog geen beroep gedaan op de garantie.

De Hoge Raad merkt op dat de regeling inzake het instellen van verzet tegen het voornemen van de moedermaatschappij om de overblijvende aansprakelijkheid te beëindigen mede is ontleend aan het recht van verzet van een crediteur tegen een voorgenomen kapitaalvermindering bij een $\mathrm{BV} .{ }^{104}$ Laatstgenoemde procedure is op haar beurt weer ontleend aan het recht van verzet van een crediteur tegen een voorgenomen kapitaalvermindering bij een NV. ${ }^{105}$ Met betrekking tot deze laatste regeling heeft de minister opgemerkt dat het onredelijk zou zijn als een crediteur met een betwiste vordering geen verzet zou kunnen instellen tegen het voornemen van de kapitaalvermindering. Dit is volgens de minister slechts anders als de rechter die over het verzet oordeelt de betwiste vordering bij voorbaat niet erkent. ${ }^{106}$ De Hoge Raad legt het recht van een crediteur om verzet in te stellen tegen het voornemen van de moedermaatschappij om de overblijvende aansprakelijkheid te beëindigen op een soortgelijke

102. Rb. Rotterdam 29 september 2015, JOR 2015/295, m.nt. Bartman (Iemants/Hertel Beheer), r.o. 4.7 .

103. HR 31 maart 2017, NJ 2018/26, m.nt. Van Schilfgaarde (SNS/Curatoren). Ook gepubliceerd in JOR 2017/221, m.nt. De Haan.

104. HR 31 maart 2017, JOR 2017/221, m.nt. De Haan (SNS/Curatoren), r.o. 5.1.4, waar hij verwijst naar Kamerstukken II 1983/84, 16551, 11, p. 16 (NnavhEV). Zie art. 2:208 en art. 2:209 (oud) BW.

105. Kamerstukken II 1980/81, 16551, 3, p. 12 (MvT). Zie art. 2:100 (oud) BW.

106. Kamerstukken II 1978/79, 15304, 3, p. 46 (MvT). Zie ook Hof Amsterdam (OK) 14 oktober 1982, NJ 1983/637, m.nt. Maeijer (X BV/A), r.o. 2, waar de OK oordeelt dat een crediteur met een betwiste vordering verzet kan instellen tegen het voornemen van een kapitaalvermindering bij een $\mathrm{BV}$, tenzij de vordering op voorhand ongegrond voorkomt. 


\section{HOOFDSTUK 8}

wijze uit. ${ }^{107}$ Hij merkt op dat de regeling inzake de beëindiging van de overblijvende aansprakelijkheid het evenwicht bewaart tussen enerzijds het belang van de crediteur die heeft vertrouwd op de aansprakelijkheid van de moedermaatschappij, en anderzijds het belang van de moedermaatschappij die deze aansprakelijkheid wil beëindigen. De Hoge Raad overweegt dat dit vertrouwen van de crediteur - op de aansprakelijkheid van de moedermaatschappij bescherming verdient bij beëindiging van de overblijvende aansprakelijkheid. Aangezien in de verzetsprocedure niet wordt geoordeeld over de toewijsbaarheid van de vordering van de crediteur op de 403-maatschappij, moet de rechter - als het bestaan van de vordering niet vaststaat - het verzet van de crediteur in beginsel erkennen, tenzij en voor zover de vordering onmiskenbaar ongegrond is. ${ }^{108,109}$

In de literatuur zijn bovenstaande uitspraken verschillend ontvangen. Een minderheidsstandpunt wordt ingenomen door Bartman en Van der Kraan. ${ }^{110}$ Zij zijn het niet eens zijn met de genoemde uitspraken en vragen zich af of het recht om verzet in te stellen niet te ruimhartig wordt toegekend. Zij wijzen erop dat op grond van art. 2:404 lid $5 \mathrm{BW}$ crediteuren 'voor wiens vordering nog aansprakelijkheid loopt' verzet kunnen instellen. Volgens hen moet deze bepaling strikt worden gelezen en zouden alleen crediteuren met een vaststaande vordering op de 403-maatschappij - waarvoor ansprakelijkheid loopt - verzet moeten kunnen instellen. Bartman merkt op dat het groepsregime een faciliteit is voor groepsstructuren, op grond waarvan een groepsmaatschappij gebruik kan maken van een jaarrekeningvrijstelling. De moedermaatschappij moet zich daarom betrekkelijk eenvoudig kunnen kwijten van de aansprakelijkheid op grond van een in het verleden vrijwillig gedeponeerde 403-verklaring. Daarbij past volgens hem een restrictieve uitleg van de kring van verzetsgerechtigden. ${ }^{111}$ Van der Kraan vult aan dat als het recht om verzet in te stellen

107. Zie Bartman \& Van der Kraan 2017, p. 925, die menen dat deze vergelijking niet opgaat omdat de minister met betrekking tot het instellen van verzet tegen het voornemen van een kapitaalvermindering bij een NV slechts spreekt van vorderingen die worden betwist. Bij de beschikking inzake $S N S /$ Curatoren gaat het daarentegen ook om vorderingen die ten tijde van het verzet nog niet bestaan.

108. HR 31 maart 2017, JOR 2017/221, m.nt. De Haan (SNS/Curatoren), r.o. 5.1.6.

109. Zie A-G Timmerman in nr. 4.24-4.26 van zijn conclusie bij de beschikking van de Hoge Raad, die meent dat het verzet in beginsel erkend moet worden, en dat een rechter het tegen de desbetreffende vordering gevoerde verweer pas mag honoreren als het hoogstwaarschijnlijk is dat de vermeende vordering ondeugdelijk of te hoog is. Vgl. Van Dooren 2017, p. 514 en De Haan in zijn annotatie onder HR 31 maart 2017, JOR 2017/221 (SNS/Curatoren).

110. Bartman in zijn annotaties onder Rb. Rotterdam 29 september 2015, JOR 2015/295 (Iemants/ Hertel Beheer) en Hof Amsterdam (OK) 9 december 2015, JOR 2016/7 (Curatoren/SNS), Van der Kraan in zijn annotatie onder Hof Amsterdam (OK) 9 december 2015, JIN 2016/12 (Curatoren/SNS), Van der Kraan 2016, p. 11-14, Bartman \& Van der Kraan 2017, p. 924-926 en Van der Kraan 2018a, p. 8-9.

111. Bartman in zijn annotaties onder Rb. Rotterdam 29 september 2015, JOR 2015/295 (Iemants/ Hertel Beheer) en Hof Amsterdam (OK) 9 december 2015, JOR 2016/7 (Curatoren/SNS). 
te gemakkelijk wordt erkend, crediteuren hiervan misbruik kunnen maken. ${ }^{112}$ Onder druk van het mogelijk tegen zich moeten dulden van het verzet van een crediteur met een summier onderbouwde vordering, kan een moedermaatschappij wellicht worden bewogen om te schikken met de crediteur, terwijl zij hier eerder weinig voor voelde.

In tegenstelling tot Bartman en Van der Kraan hebben de meeste auteurs het oordeel van de Hoge Raad wel positief ontvangen. ${ }^{113}$ Ik sluit mij hierbij an. De beëindiging van de overblijvende aansprakelijkheid is onomkeerbaar. Dit betekent dat als een crediteur geen verzet kan instellen - omdat zijn vordering op de 403-maatschappij (nog) niet vaststaat -, hij zich nooit (op grond van de 403-verklaring) op de moedermaatschappij zal kunnen verhalen. Zelfs niet als later blijkt dat hij een rechtsgeldige vordering op de 403-maatschappij heeft. Er zou onterecht afbreuk worden gedaan aan de bescherming uit hoofde van art. 2:404 lid 5 BW als crediteuren met een betwiste of voorwaardelijke vordering op de 403-maatschappij geen verzet kunnen instellen tegen het voornemen van de moedermaatschappij om de overblijvende aansprakelijkheid te beëindigen. Daarnaast merk ik op dat deze uitleg van het recht van verzet ex art. 2:404 lid $5 \mathrm{BW}$ ansluit aan bij het verzetsrecht voor crediteuren op grond van art. 2:316 en art. 2:3341 BW als een rechtspersoon wil fuseren of splitsen. Ook bij een voorgenomen fusie of splitsing wordt aangenomen dat een crediteur met een betwiste of voorwaardelijke vordering hiertegen verzet kan instellen, tenzij de vordering op voorhand ongegrond voorkomt. ${ }^{114}$

Bovenstaande uitleg van het verzetsrecht ex art. 2:404 lid 5 BW sluit aan bij het door mij bepleite uitgangspunt voor compensatie. ${ }^{115}$ Een crediteur van de 403-maatschappij heeft geen invloed op de keuze van de moedermaatschappij om de overblijvende aansprakelijkheid te beëindigen noch op het moment dat de moedermaatschappij hiertoe over gaat. De crediteur mag daarom door de beëindiging niet in een nadeliger positie komen ten opzichte van de situatie dat de overblijvende aansprakelijkheid niet zou zijn beëindigd. Het feit dat de moedermaatschappij de procedure om de overblijvende aansprakelijkheid te beëindigen begint op een moment dat de vordering van de crediteur op de 403-maatschappij (nog) niet vaststaat, mag er niet toe leiden dat de crediteur zonder meer zijn (potentiële) verhaalsrecht tegenover de moedermaatschappij verliest. Hij moet de mogelijkheid hebben om gebruik te maken van de waarborgen die zijn bedoeld om dit (potentiële) verhaalsrecht te beschermen. De crediteur moet verzet kunnen instellen en een vervangende waarborg kunnen

112. Van der Kraan 2016, p. 10 en Van der Kraan 2018a, p. 8-9.

113. Van Zoest 2017, p. 63, Bakker 2018, p. 18-20, Hanegraaf 2019, p. 186, en Van Schilfgaarde, De Haan en Schepel in hun annotaties onder HR 31 maart 2017, NJ 2018/26, JOR 2017/221 en JIN 2017/97 (SNS/Curatoren). Zie ook Van Dooren 2017, p. 514.

114. Asser/Maeijer \& Kroeze $2-I^{*} 2015 / 435$ en 479.

115. Zie $\S 3.7$. 
verlangen. Art. 2:404 lid $5 \mathrm{BW}$ moet daarom zo worden uitgelegd dat ook crediteuren met een niet-vaststaande vordering op de 403-maatschappij verzet kunnen instellen tegen het voornemen van de moedermaatschappij om de overblijvende aansprakelijkheid te beëindigen.

Ik erken dat het nadelig kan zijn voor de moedermaatschappij dat crediteuren met een niet-vaststaande vordering op de 403-maatschappij verzet kunnen instellen tegen het voornemen om de overblijvende aansprakelijkheid te beëindigen. De moedermaatschappij loopt het risico dat zij een tegen dit voornemen ingesteld verzet tegen zich moet dulden, terwijl later blijkt dat de crediteur geen (rechtsgeldige) vordering op de 403-maatschappij heeft. De (mogelijke) overblijvende aansprakelijkheid van de moedermaatschappij tegenover de crediteur is dan niet beëindigd of de crediteur moet een (voorwaardelijke) vervangende waarborg worden gegeven. ${ }^{116}$ Op het moment dat vast komt te staan dat de crediteur geen (rechtsgeldige) vordering op de 403-maatschappij heeft, vervalt ook de vermeende vordering op de moedermaatschappij of de gegeven (voorwaardelijke) vervangende waarborg. Dit nadeel weegt mijns inziens echter niet op tegen het nadeel dat een crediteur met een niet-vaststaande vordering op de 403-maatschappij zou ondervinden als hij geen verzet zou kunnen instellen tegen het voornemen van de moedermaatschappij om de overblijvende aansprakelijkheid te beëindigen. Hij verliest dan de mogelijkheid om de moedermaatschappij aansprakelijk te stellen indien naderhand blijkt dat hij een rechtsgeldige vordering heeft op de 403-maatschappij.

Vanzelfsprekend moet niet iedereen die pretendeert een vordering te hebben op de 403-maatschappij verzet kunnen instellen tegen het voornemen van de moedermaatschappij om de overblijvende aansprakelijkheid te beëindigen. Er moet een bepaalde drempel zijn. Ik onderschrijf op dit punt het oordeel van de Hoge Raad in de SNS/Curatoren-beschikking dat het verzet van een crediteur moet worden erkend, tenzij de vordering onmiskenbaar ongegrond is. ${ }^{117}$ Een dergelijke beperkte toets past bij het feit dat een crediteur geen invloed heeft op de keuze van de moedermaatschappij om de overblijvende aansprakelijkheid te beëindigen en dat deze beëindiging onherroepelijk is zelfs als naderhand blijkt dat de crediteur een rechtsgeldige vordering op de 403-maatschappij heeft. ${ }^{118}$

\subsubsection{Het verzetsrecht van een pandhouder}

De Hoge Raad heeft in zijn Akzo/ING-beschikking geoordeeld dat de houder van een openbaar pandrecht op de vordering van een crediteur op de 403-maatschappij geen verzet kan instellen tegen het voornemen van de

116. Zie $\S 8.8$ en 8.9 .

117. HR 31 maart 2017, JOR 2017/221, m.nt. De Haan (SNS/Curatoren), r.o. 5.1.6.

118. Zie ook Van Dooren 2017, p. 514. 
moedermaatschappij om de overblijvende aansprakelijkheid te beëindigen. ${ }^{119}$ De vordering op de 403-maatschappij - en het daarop rustende pandrecht wordt namelijk niet aangetast door de beëindiging van de overblijvende aansprakelijkheid. ${ }^{120}$ Dit betekent echter niet dat de pandhouder er geen belang bij kan hebben dat de vordering van de crediteur op de moedermaatschappij niet vervalt. Hierdoor verslechtert namelijk de vermogenstoestand van de crediteur. Als de pandhouder bijvoorbeeld het pandrecht heeft gekregen als zekerheid in verband met een lening die hij aan de crediteur heeft verstrekt, loopt hij hierdoor een groter risico dat de crediteur deze lening niet (volledig) terugbetaalt. Een dergelijk (indirect) belang van de pandhouder brengt echter niet met zich dat hij verzet kan instellen tegen het voornemen van de moedermaatschappij om de overblijvende aansprakelijkheid te beëindigen.

Evenals Bartman en De Neve meen ik dat de contractuele relatie tussen de pandhouder en de crediteur als pandgever, op grond van de aanvullende werking van de redelijkheid en billijkheid ex art. 6:248 lid $1 \mathrm{BW}$, onder omstandigheden kan meebrengen dat de crediteur verplicht is om verzet in te stellen tegen het voornemen van de moedermaatschappij om de overblijvende aansprakelijkheid te beëindigen. ${ }^{121}$ Dit kan het geval zijn als door het vervallen van de vordering van de crediteur op de moedermaatschappij zeker is dat de crediteur zijn verplichtingen tegenover de pandhouder niet kan voldoen - bijvoorbeeld omdat de vordering van de crediteur op de 403-maatschappij oninbaar is en hij verder geen activa heeft. Als de pandhouder zeker wil zijn dat de crediteur verplicht is om verzet in te stellen en een vervangende waarborg te verlangen als de moedermaatschappij de overblijvende aansprakelijkheid wil beëindigen, moet hij dit contractueel vastleggen. Ondanks deze afspraak blijft echter het risico bestaan dat de pandhouder en de crediteur over het hoofd zien dat de moedermaatschappij voornemens is om de overblijvende aansprakelijkheid te beëindigen. Na verloop van de verzetstermijn kan de crediteur geen verzet meer instellen en een vervangende waarborg verzoeken. Om ook dit risico weg te nemen, kan de pandhouder proberen om met de crediteur en de moedermaatschappij een meerpartijenovereenkomst te sluiten, op grond waarvan de moedermaatschappij verplicht is de pandhouder en de crediteur in te lichten als zij een aankondiging plaatst in een landelijk verspreid dagblad dat zij een mededeling heeft gedeponeerd van het voornemen om de overblijvende aansprakelijkheid te beëindigen. ${ }^{122}$ Om dit te bewerkstelligen zal de pandhouder

119. HR 28 juni 2002, $N J 2002 / 447$, m.nt. Maeijer $(A k z o / I N G)$, r.o. 3.5.3-3.5.4. Ook gepubliceerd in JOR 2002/136, m.nt. Bartman.

120. Loesberg in zijn annotatie onder Rb. Rotterdam 30 september 2014, JOR 2014/326 (Pergen/ Eneco), Bartman 2015, p. 808 en Van Schilfgaarde/Winter, Wezeman \& Schoonbrood 2017, p. 377.

121. Bartman in zijn annotatie onder Rb. Arnhem 1 februari 2001, JOR 2001/88 (ING/Akzo) en De Neve 2002, p. 242.

122. Zie $\S 8.5 .4$. 
wel een sterke onderhandelingspositie moeten hebben tegenover de crediteur, die op zijn beurt weer een sterke onderhandelingspositie moet hebben tegenover de 403-maatschappij en de moedermaatschappij.

In tegenstelling tot de houder van een openbaar pandrecht op een vordering van een crediteur op de 403-maatschappij, kan de houder van een openbaar pandrecht op een vordering van een crediteur op de moedermaatschappij wél verzet instellen tegen het voornemen om de overblijvende aansprakelijkheid te beëindigen. ${ }^{123}$ Hij heeft een direct belang dat de vordering van de crediteur op de moedermaatschappij niet vervalt. Als deze vordering vervalt, gaat ook zijn daarop rustende pandrecht teniet. De pandhouder kan daarom op grond van art. 3:245 $\mathrm{BW}$ ter bescherming van de an hem verpande vordering verzet instellen tegen het voornemen van de moedermaatschappij om de overblijvende aansprakelijkheid te beëindigen. Hij moet in dat geval ook de crediteur als pandgever in het geding betrekken. De crediteur wordt daardoor ook partij in de onderhavige procedure. ${ }^{124}$

Toch is de pandhouder er nog niet als hij verzet heeft ingesteld tegen het voornemen van de moedermaatschappij om de overblijvende aansprakelijkheid te beëindigen. De kans bestaat dat hij alsnog een deel van zijn zekerheden verliest of helemaal met lege handen achterblijft. Ik wijs op drie mogelijke uitkomsten naar aanleiding van het verzet. De eerste - en voor de pandhouder meest voordelige - uitkomst is dat het verzet gegrond wordt verklaard. In dat geval blijft de vordering van de crediteur op de moedermaatschappij bestaan inclusief het daarop rustende pandrecht. Voor de pandhouder is er in dat geval niets veranderd ten opzichte van de situatie die bestond voordat de moedermaatschappij de overblijvende aansprakelijkheid wilde beëindigen.

Een andere mogelijke uitkomst van het verzet is dat de crediteur een vervangende waarborg krijgt. ${ }^{125}$ Hierdoor vervalt de vordering van de crediteur op de moedermaatschappij, inclusief het daarop rustende pandrecht. ${ }^{126} \mathrm{Ik}$ acht het verdedigbaar dat de vervangende waarborg op grond van zaaksvervanging ex art. 3:229 BW in de plaats treedt van de vordering van de crediteur die door de beëindiging van de overblijvende aansprakelijkheid is vervallen. De pandhouder krijgt dan een pandrecht op deze waarborg. Spath merkt op dat met zaaksvervanging wordt voorkomen dat er een vermogensverschuiving optreedt in gevallen waarin verrijking van de ene partij zou leiden tot verarming van een andere partij. ${ }^{127}$ Toegepast op bovenstaande situatie zou de positie van de

123. Bartman in zijn annotatie onder HR 28 juni 2002, JOR 2002/136 (Akzo/ING) en Loesberg in zijn annotatie onder Rb. Rotterdam 30 september 2014, JOR 2014/326 (Pergen/Eneco).

124. D.F.H. Stein, in: GS Vermogensrecht, art. 3:245 BW, aant. 6. Zie ook art. 118 Rv.

125. Zie art. 2:404 lid 4 BW en $\S 8.8 .2$ en $\S 8.8 .3$.

126. Notenboom 2017, p. 129.

127. Spath 2010, p. 153-155. 
pandhouder door de beëindiging van de overblijvende aansprakelijkheid verarmen omdat zijn pandrecht op de vordering op de moedermaatschappij vervalt. De positie van de crediteur zou daarentegen verrijken als hij een vervangende waarborg verkrijgt die niet is bezwaard met een pandrecht. Daarbij is mede van belang dat de verarming en verrijking direct met elkaar samenhangen en zijn terug te voeren op dezelfde gebeurtenis - het geven van een vervangende waarborg aan de crediteur waardoor de overblijvende aansprakelijkheid beëindigt -, en dat de pandhouder er geen invloed op heeft of de crediteur al of niet een vervangende waarborg krijgt - en dus of hij al of niet zijn pandrecht verliest.

Ook Verdaas lijkt niet afwijzend te staan tegen het standpunt dat de houder van een pandrecht op een vordering van een crediteur op de moedermaatschappij op grond van zaaksvervanging een pandrecht krijgt op een eventuele vervangende waarborg als de overblijvende aansprakelijkheid wordt beëindigd. Hij meent dat als een vordering waarop een pandrecht rust, tenietgaat anders dan door inning en de pandgever vanwege dit tenietgaan een andere vordering krijgt, de pandhouder dan een pandrecht krijgt op deze laatste vordering. ${ }^{128}$ Daarbij speelt de oorzaak van het tenietgaan van de vordering volgens hem geen rol. Toegepast op de beëindiging van de overblijvende aansprakelijkheid brengt dit met zich dat als de vordering van de crediteur op de moedermaatschappij vervalt en de crediteur als vervangende waarborg een andere vordering ontvangt, de pandhouder dan een pandrecht krijgt op deze laatste vordering.

Als de pandhouder op grond van zaaksvervanging een pandrecht krijgt op de vervangende waarborg van de crediteur is het mogelijk dat hij daardoor minder zekerheid heeft dan die hij had toen hij nog een pandrecht had op de vordering van de crediteur op de moedermaatschappij. Later in dit hoofdstuk betoog ik uitgebreid dat de omvang van de vervangende waarborg mijns inziens mede afhankelijk is van de waarborgen die de crediteur al heeft, uit hoofde van de vermogenstoestand van de 403-maatschappij of uit anderen hoofde, dat zijn vordering op de 403-maatschappij zal worden voldaan. ${ }^{129}$ De waarborgen uit hoofde van de vermogenstoestand van de 403-maatschappij, eventuele waarborgen uit anderen hoofde en de vervangende waarborg moeten gezamenlijk evenveel waarborgen bieden dat de vordering op de 403-maatschappij zal worden voldaan, als de waarborgen die de crediteur heeft dat zijn vordering op de moedermaatschappij zal worden voldaan. Het is dus mogelijk dat de crediteur een vervangende waarborg wordt gegeven die minder omvangrijk is dan zijn vordering op de moedermaatschappij. Het pandrecht op deze vervangende waarborg biedt de pandhouder dan minder zekerheid dan het eerdere pandrecht op de vordering van de crediteur op de moedermaatschappij.

128. Verdaas 2008 , p. 235.

129. Zie $\S 8.9 .3$. 
De derde en laatste mogelijke uitkomst naar aanleiding van het verzet van de pandhouder tegen de beëindiging van de overblijvende aansprakelijkheid is dat het verzet wordt afgewezen omdat de crediteur voldoende waarborgen heeft, uit hoofde van de vermogenstoestand van de 403-maatschappij of uit anderen hoofde, dat zijn vordering op de 403-maatschappij zal worden voldaan. ${ }^{130}$ In dat geval vervalt de vordering van de crediteur op de moedermaatschappij inclusief het daarop rustende pandrecht. De pandhouder blijft dan met lege handen achter.

Hoewel de houder van een openbaar pandrecht op een vordering van een crediteur op de moedermaatschappij dus verzet kan instellen tegen het voornemen van de beëindiging van de overblijvende aansprakelijkheid bestaat de kans dat hij alsnog een deel van zijn zekerheden verliest of helemaal met lege handen achterblijft. Het is daarom aan te raden dat de houder van een dergelijk pandrecht bij de crediteur - als pandgever - bedingt dat deze hem een vervangende zekerheid geeft als de moedermaatschappij de overblijvende aansprakelijkheid beëindigt.

\subsection{Heeft de crediteur recht op een vervangende waarborg?}

\subsubsection{Een crediteur heeft geen recht op een vervangende waarborg als hij voldoende andere waarborgen heeft}

Een crediteur die verzet instelt tegen het voornemen van de moedermaatschappij om de overblijvende aansprakelijkheid te beëindigen, kan een vervangende waarborg verlangen voor de voldoening van zijn vordering op de 403-maatschappij. Op grond van art. 2:404 lid 4 BW heeft de crediteur geen recht op een vervangende waarborg als hij na de beëindiging van de overblijvende aansprakelijkheid voldoende (andere) waarborgen heeft, uit hoofde van de vermogenstoestand van de 403-maatschappij of uit anderen hoofde, dat zijn vordering op de 403-maatschappij zal worden voldaan. Van een waarborg uit anderen hoofde is bijvoorbeeld sprake als de crediteur een recht van pand of hypotheek heeft tot zekerheid van nakoming van de vordering of als een andere rechtspersoon - die de aandelen in de 403-maatschappij heeft overgenomen van de moedermaatschappij - zich ook door middel van een 403-verklaring aansprakelijk heeft gesteld voor de schulden die voortvloeien uit de rechtshandelingen van de 403-maatschappij. ${ }^{131}$

130. Zie art. 2:404 lid 4 BW en $\S 8.8 .1$.

131. Ten Voorde 2006, p. 143. Ervan uitgaande dat de aansprakelijkheid op grond van een 403-verklaring alle schulden omvat die voortvloeien en zijn voortgevloeid uit een rechtshandeling die de 403-maatschappij heeft verricht. Zie § 5.6. 
Welke waarborg de vermogenstoestand van de 403-maatschappij biedt dat de vordering van de crediteur zal worden voldaan, moet worden beoordeeld aan de hand van de omstandigheden van het geval. ${ }^{132}$ In de jurisprudentie is onder meer gewezen op het eigen vermogen, de liquiditeit en de solvabiliteit van de 403-maatschappij. ${ }^{133}$ Daarnaast is niet alleen de huidige vermogenstoestand van de 403-maatschappij van belang, maar spelen ook de te verwachten toekomstige ontwikkelingen een rol. Tot slot moeten eventuele toezeggingen of verwachtingen dat de 403-maatschappij in de toekomst financieel ondersteund zal worden, voldoende concreet zijn. ${ }^{134}$

\subsubsection{Een crediteur heeft recht op een vervangende waarborg als zijn positie verzwakt}

De Hoge Raad oordeelt in zijn SNS/Curatoren-beschikking dat voor de beantwoording van de vraag of een crediteur na de beëindiging van de overblijvende aansprakelijkheid voldoende waarborgen heeft dat zijn vordering op de 403-maatschappij zal worden voldaan, beoordeeld moet worden of zijn positie door deze beëindiging al of niet verzwakt. ${ }^{135}$ Dit oordeel past bij het door mij bepleite uitgangspunt voor compensatie. Ik heb betoogd dat aangezien een crediteur geen invloed heeft op de keuze van de moedermaatschappij om de overblijvende aansprakelijkheid te beëindigen, hij daardoor niet in een nadeliger positie mag komen ten opzichte van de situatie dat de overblijvende aansprakelijkheid niet zou zijn beëindigd. ${ }^{136}$ Als de crediteur door de beëindiging in een nadeliger positie komt, heeft hij recht op een vervangende waarborg, waardoor dit nadeel wordt weggenomen.

Bartman en Van der Kraan zijn van mening dat de positie van een crediteur door de beëindiging van de overblijvende aansprakelijkheid altijd verzwakt omdat hij daardoor zijn vordering op de moedermaatschappij verliest. In plaats

132. Beckman - Compendium jaarrekening, § 3.8.6.c.

133. Rb. Midden-Nederland 5 november 2014, ECLI:NL:RBMNE:2014:5519 (Curatoren/SNS), r.o. 2.2-2.3 en Hof Amsterdam (OK) 9 december 2015, JOR 2016/7, m.nt. Bartman (Curatoren/SNS), r.o. 3.25 en 3.38-3.39.

134. Zie Rb. Rotterdam 29 september 2015, JOR 2015/295, m.nt. Bartman (Iemants/Hertel Beheer), r.o. 4.12, waar de rechtbank oordeelt dat het feit dat de ultimate beneficial owners van de 403-maatschappij kapitaalkrachtig zijn en eerder een kapitaalstorting ten behoeve van de moedermaatschappij hebben gedaan, op zichzelf onvoldoende waarborg biedt. Zie ook Rb. Midden-Nederland 7 mei 2014, JOR 2014/260, m.nt. Harmsen (Curatoren/SNS), r.o. 3.18 en Hof Amsterdam (OK) 9 december 2015, JOR 2016/7, m.nt. Bartman (Curatoren) $S N S)$, r.o. 3.25, dat de verwachting dat de Nederlandse Staat wegens macro-economische redenen 403-maatschappij SNS Bank niet failliet zal laten gaan, onvoldoende waarborg biedt.

135. HR 31 maart 2017, JOR 2017/221, m.nt. De Haan (SNS/Curatoren), r.o. 5.1.4. Vgl. Kamerstukken II 1983/84, 16551, 11, p. 16 (NnavhEV).

136. Zie $\S 3.6 .1$ en $\S 3.7$. 
van een vordering op de moeder- en op de 403-maatschappij, heeft de crediteur na de beëindiging alleen nog een vordering op de 403-maatschappij. ${ }^{137}$ Omdat volgens hen de positie van een crediteur per definitie verzwakt door de beëindiging van de overblijvende aansprakelijkheid, menen zij dat iedere crediteur die verzet instelt altijd recht heeft op een vervangende waarborg. Bartman en Van der Kraan zijn daarom van mening dat het oordeel van de Hoge Raad in strijd is met de toets ex art. 2:404 lid 4 BW op grond waarvan expliciet wél de mogelijkheid bestaat dat een crediteur die verzet instelt geen recht heeft op een vervangende waarborg.

Evenals Hanegraaf ben ik het niet eens met bovenstaande interpretatie van het oordeel van de Hoge Raad door Bartman en Van der Kraan. ${ }^{138}$ Juist omdat de interpretatie van Bartman en Van der Kraan betekent dat het oordeel van de Hoge Raad in strijd is met art. 2:404 lid 4 BW, denk ik dat dit oordeel anders moet worden uitgelegd. De toets ex art. 2:404 lid 4 BW of een crediteur die verzet heeft ingesteld recht heeft op een vervangende waarborg is onderdeel van de procedure om de compensatie te beëindigen die de crediteuren ontvangen omdat zij de jaarrekening van de 403-maatschappij niet (hebben) kunnen inzien. Ik meen dat deze toets en het oordeel van de Hoge Raad daarom moeten worden uitgelegd in het licht van de functie die de aansprakelijkheid van de moedermaatschappij vervult bij deze compensatie. De compensatie die een crediteur ontvangt, is tweeledig. Het niet kunnen inzien van de jaarrekening van de 403-maatschappij wordt gecompenseerd met een aanvullende vordering op de moedermaatschappij op grond van de 403-verklaring én de mogelijkheid om de geconsolideerde jaarrekening van de moedermaatschappij in te zien. ${ }^{139}$ Dit betekent niet dat de crediteur zekerheid heeft dat zijn vordering op de moedermaatschappij volledig zal worden voldaan. Hij wordt gecompenseerd omdat hij de mogelijkheid heeft om (mede) aan de hand van de jaarrekening van zijn debiteur - de moedermaatschappij - te schatten hoe groot het risico is dat zijn vordering niet (volledig) zal worden voldaan. De crediteur besluit uiteindelijk zelf of hij dit risico accepteert of niet.

De crediteur heeft zijn beslissing om een relatie met de 403-maatschappij aan te gaan of een bestaande relatie te continueren, niet (mede) kunnen baseren op de informatie uit de jaarrekening van de 403-maatschappij. In plaats daarvan heeft hij deze beslissing (mede) kunnen baseren op de informatie uit de geconsolideerde jaarrekening van de moedermaatschappij. Het risico dat de crediteur (onbewust) heeft geaccepteerd toen hij de relatie met de 403-maatschappij is aangegaan of heeft gecontinueerd, is het risico dat de moedermaatschappij de

137. Zie Bartman \& Van der Kraan 2017, p. 926, Van der Kraan 2018a, p. 9 en Van der Kraan 2018 b, p. 35.

138. Hanegraaf 2019, p. 187.

139. Zie $\S 3.4 .1$. 
vordering op grond van de 403-verklaring niet (volledig) voldoet. De vraag of de positie van de crediteur door de beëindiging van de overblijvende aansprakelijkheid verzwakt, moet naar mijn mening tegen bovenstaande achtergrond worden beantwoord. Dit betekent dat de waarborgen die de crediteur heeft dat zijn vordering op de moedermaatschappij zal worden voldaan, moeten worden vergeleken met de waarborgen die hij - na de beëindiging van de overblijvende aansprakelijkheid - heeft dat zijn vordering op de 403-maatschappij zal worden voldaan. Anders gezegd: een crediteur heeft recht op een vervangende waarborg als hij na de beëindiging van de overblijvende aansprakelijkheid niet minimaal dezelfde waarborgen heeft - uit hoofde van de vermogenstoestand van de 403-maatschappij of uit anderen hoofde - dat zijn vordering op de 403-maatschappij zal worden voldaan, als de waarborgen die hij heeft dat zijn vordering op de moedermaatschappij zal worden voldaan. ${ }^{140}$ Als bijvoorbeeld het vooruitzicht is dat de moedermaatschappij de vordering van de crediteur op grond van de 403-verklaring voor de helft zal kunnen voldoen, en het is daarnaast te verwachten dat de vordering op de 403-maatschappij volledig zal worden voldaan, heeft de crediteur geen recht op een vervangende waarborg. Maar ook als niet is te verwachten dat de vordering van de crediteur op de 403-maatschappij volledig zal worden voldaan, is het mogelijk dat de crediteur geen recht heeft op een vervangende waarborg. Dit doet zich bijvoorbeeld voor als de verwachting is dat de vordering op de 403-maatschappij voor twee derde zal worden voldaan, maar dat de moedermaatschappij de vordering op grond van de 403-verklaring slechts voor een kwart zal kunnen voldoen.

Overigens maak ik wel nog een nuancering met betrekking tot bovenstaande norm dat een crediteur recht heeft op een vervangende waarborg als hij na de beëindiging van de overblijvende aansprakelijkheid niet minimaal dezelfde waarborgen heeft - uit hoofde van de vermogenstoestand van de 403-maatschappij of uit anderen hoofde - dat zijn vordering op de 403-maatschappij zal worden voldaan, als de waarborgen die hij heeft dat zijn vordering op de moedermaatschappij zal worden voldaan. Het is mogelijk dat er op basis van de vermogenstoestand van de 403-maatschappij en eventuele waarborgen uit anderen hoofde, redelijkerwijs geen twijfel over bestaat dat de vordering van de crediteur op de 403-maatschappij volledig zal worden voldaan, maar dat dit de crediteur desondanks minder waarborgen biedt dan de waarborgen die hij heeft dat zijn vordering op de moedermaatschappij zal worden voldaan - omdat de moedermaatschappij er financieel beter voor staat. Indien een crediteur redelijkerwijs geen risico loopt dat zijn vordering op de 403-maatschappij niet zal worden voldaan, heeft hij naar mijn mening geen recht op een vervangende

140. Ten Voorde 2006, p. 148-149. Anders: Van Zoest 2017, p. 65-66, die van mening is dat de vraag of een crediteur voldoende waarborgen heeft dat zijn vordering op de 403-maatschappij zal worden voldaan op zichzelf moet worden beantwoord, zonder een vergelijking te maken met de situatie dat de crediteur zich op de moedermaatschappij kan verhalen. Van Zoest specificeert echter niet wat in een dergelijk geval 'voldoende waarborgen' zijn. 
waarborg. Een dergelijke redenering is ook terug te vinden bij twee uitspraken met betrekking tot het recht van verzet van een crediteur op grond van art. 2:316 en art. 2:334k BW bij een voorgenomen fusie, respectievelijk splitsing van zijn debiteur. ${ }^{141}$ Op grond van deze bepalingen heeft een crediteur die verzet heeft ingesteld, recht op een waarborg voor de nakoming van zijn vordering, tenzij hij al voldoende waarborgen heeft of de vermogenstoestand van de rechtspersoon die na de fusie, respectievelijk de splitsing zijn debiteur zal zijn niet minder waarborgen zal bieden dat de vordering zal worden voldaan, dan de vermogenstoestand van zijn huidige debiteur. Bij beide uitspraken bood de rechtspersoon die de debiteur was voor de fusie, respectievelijk de splitsing meer waarborgen dat de vordering van de crediteur zou worden voldaan, dan de rechtspersoon die daarna de debiteur zou zijn. Het verzet van de crediteur is in beide gevallen echter afgewezen omdat het de verwachting was dat de crediteur na de fusie, respectievelijk de splitsing zijn vordering volledig voldaan zou krijgen. In 2003 oordeelt de Rechtbank Amsterdam dat het vermogen waarop de crediteur zich voor en na de splitsing kan verhalen niet gelijk hoeft te zijn, maar dat dit wel een even grote waarborg moet bieden dat de vordering zal worden voldaan. Hieraan is ook voldaan als zowel voor als na de splitsing voor de crediteur uitzicht bestaat op volledige voldoening van zijn vordering. ${ }^{142}$ Daarnaast heeft de Rechtbank Den Bosch in 2019 met betrekking tot een door een crediteur ingesteld verzet tegen een voorgenomen fusie geoordeeld dat het feit dat de crediteur na de fusie minder waarborgen zal hebben dat zijn vordering zal worden voldaan, niet zonder meer meebrengt dat het verzet gegrond wordt verklaard als het de verwachting is dat hij ook na de fusie zijn vordering volledig voldaan zal krijgen. ${ }^{143}$

Tot slot merk ik op dat aangezien het de moedermaatschappij is die een beroep doet op de beëindiging van de overblijvende aansprakelijkheid de bewijslast dat de crediteur geen recht heeft op een vervangende waarborg bij haar ligt. Uit de jurisprudentie volgt dat de moedermaatschappij moet bewijzen dat de crediteur na de beëindiging van de overblijvende aansprakelijkheid voldoende waarborgen heeft dat zijn vordering op de 403-maatschappij zal worden voldaan. ${ }^{144}$ Dat de moedermaatschappij niet altijd inzicht heeft in de vermogenstoestand

141. Rb. Amsterdam 4 april 2003, JOR 2003/105, m.nt. Wintgens-van Luyn (Dexia Bank Nederland) en Rb. 's-Hertogenbosch 21 februari 2019, JOR 2019/131, m.nt. Koster (Optas/ Aegon).

142. Rb. Amsterdam 4 april 2003, JOR 2003/105, m.nt. Wintgens-van Luyn (Dexia Bank Nederland), r.o. 4.11.

143. Rb. 's-Hertogenbosch 21 februari 2019, JOR 2019/131, m.nt. Koster (Optas/Aegon), r.o. 4.10-4.13.

144. Hof Amsterdam (OK) 31 juli 2001, JOR 2001/170, m.nt. Bartman (ING/Akzo), r.o. 4.12, Rb. Midden-Nederland 5 november 2014, ECLI:NL:RBMNE:2014:5519 (Curatoren/SNS), r.o. 2.2, Rb. Rotterdam 29 september 2015, JOR 2015/295, m.nt. Bartman (Iemants/Hertel Beheer), r.o. 4.11 en Hof Amsterdam (OK) 9 december 2015, JOR 2016/7, m.nt. Bartman (Curatoren/SNS), r.o. 3.19. 
van de 403-maatschappij - bijvoorbeeld omdat de groepsband tussen de moeder- en de 403-maatschappij is verbroken en de 403-maatschappij nog geen jaarrekening openbaar heeft gemaakt - maakt dit niet anders. ${ }^{145}$

\subsubsection{Beoordelen of een crediteur recht heeft op een vervangende waarborg nadat de 403-maatschappij een jaarrekening openbaar heeft gemaakt}

Er zou kunnen worden betoogd dat de toets of een crediteur recht heeft op een vervangende waarborg anders moet worden uitgelegd als de 403-maatschappij weer een jaarrekening openbaar heeft gemaakt die voldoet aan de voorschriften van titel 9 van Boek 2 BW. Een crediteur kan in dat geval niet alleen (mede) aan de hand van de jaarrekening van de moedermaatschappij schatten hoe groot het risico is dat zijn vordering op de moedermaatschappij niet (volledig) zal worden voldaan. Hij kan dan ook (mede) aan de hand van de jaarrekening van de 403-maatschappij schatten hoe groot het risico is dat zijn vordering op de 403-maatschappij niet (volledig) zal worden voldaan. Een crediteur zou zich op het standpunt kunnen stellen dat hij zijn keuze om de relatie met de 403-maatschappij aan te gaan of te continueren niet alleen heeft gebaseerd op de waarborgen die hij heeft dat zijn vordering op de moedermaatschappij zal worden voldaan, maar dat hij ook rekening heeft gehouden met de waarborgen die hij heeft dat zijn vordering op de 403-maatschappij zal worden voldaan. ${ }^{146} \mathrm{Bij}$ de beantwoording van de vraag of de positie van de crediteur door de beëindiging van de overblijvende aansprakelijkheid al of niet verzwakt, zou daarom niet alleen rekening gehouden moeten worden met de waarborgen die de crediteur heeft dat zijn vordering op de moedermaatschappij zal worden voldaan, maar ook met de waarborgen die hij heeft dat zijn vordering op de 403-maatschappij zal worden voldaan.

Bovenstaande redenering zou meebrengen dat een crediteur recht heeft op een vervangende waarborg als hij na de beëindiging van de overblijvende aansprakelijkheid minder waarborgen heeft dat de vordering op de 403-maatschappij zal worden voldaan, dan de waarborgen die hij heeft dat de vorderingen op de moeder- én op de 403-maatschappij zullen worden voldaan. De uitkomst van deze toets is praktisch altijd negatief wat betekent dat in beginsel iedere crediteur die verzet instelt tegen het voornemen van de moedermaatschappij om de overblijvende aansprakelijkheid te beëindigen recht heeft op een vervangende waarborg. Slechts in het geval dat een crediteur geen enkele waarborg heeft dat zijn vordering op de moedermaatschappij zal worden voldaan, verzwakt zijn positie niet door de beëindiging van de overblijvende aansprakelijkheid

145. Rb. Rotterdam 29 september 2015, JOR 2015/295, m.nt. Bartman (Iemants/Hertel Beheer), r.o. 4.11 .

146. Waarbij de crediteur in totaal slechts eenmaal volledig kan worden voldaan. 
en heeft hij geen recht op een vervangende waarborg. Dit kan zich voordoen als de moedermaatschappij op het punt staat te failleren en haar activa onvoldoende zijn om de vorderingen van de crediteuren met een hogere rang in het aanstaande faillissement te voldoen.

Bovenstaand standpunt ten aanzien van de toets of een crediteur recht heeft op een vervangende waarborg is mijns inziens niet juist. Deze uitleg van art. 2:404 lid 4 BW stimuleert namelijk dat de moedermaatschappij de overblijvende aansprakelijkheid beëindigt voordat de 403-maatschappij weer een jaarrekening openbaar heeft gemaakt die voldoet aan de voorschriften van titel 9 van Boek 2 BW. Hierboven heb ik opgemerkt dat als een moedermaatschappij de overblijvende aansprakelijkheid wil beëindigen nadat de 403-maatschappij weer een jaarrekening openbaar heeft gemaakt, een crediteur die verzet instelt, volgens de daar genoemde uitleg van art. 2:404 lid 4 BW praktisch altijd recht heeft op een vervangende waarborg. Een moedermaatschappij zou dit bewust kunnen proberen te voorkomen door de overblijvende aansprakelijkheid te beëindigen voordat de 403-maatschappij de jaarrekening openbaar heeft gemaakt. In dat geval heeft de crediteur alleen recht op een vervangende waarborg als zijn positie door de beëindiging verzwakt. ${ }^{147}$

Dat een moedermaatschappij wordt gestimuleerd om de overblijvende aansprakelijkheid te beëindigen voordat de 403-maatschappij weer een jaarrekening openbaar heeft gemaakt, is in strijd met het door mij bepleite uitgangspunt voor compensatie. Als de moedermaatschappij voor dat moment de 403 -verklaring intrekt en de overblijvende aansprakelijkheid beëindigt, is er namelijk een periode waarin crediteuren de jaarrekening van de 403-maatschappij niet kunnen inzien, maar daarvoor niet worden gecompenseerd. Dit leidt tot benadeling van de crediteuren van wie de vordering voortvloeit uit een rechtshandeling die de 403-maatschappij heeft verricht in de periode tussen het moment dat de moedermaatschappij tegenover de crediteur een beroep kan doen op de intrekking van de 403-verklaring en het moment dat de 403-maatschappij een jaarrekening openbaar maakt die voldoet aan de voorschriften van titel 9 van Boek 2 BW. ${ }^{148}$ Naar mijn mening moet de toets of een crediteur recht heeft

147. Zie $\S 8.8 .2$.

148. Zie $\S 7.3$ en $\S 8.2 .3$, waar ik eerder heb gewezen op deze lacune in de compensatie van de crediteuren. Ik heb betoogd dat aan art. 2:404 lid $1 \mathrm{BW}$ moet worden toegevoegd dat de intrekking van de 403-verklaring slechts of eerst effect heeft als de 403-maatschappij een jaarrekening openbaar heeft gemaakt die aan de voorschriften van titel 9 van Boek 2 BW voldoet, of als er een nieuwe 403-verklaring is gedeponeerd ten aanzien van de 403-maatschappij. Als art. 2:404 lid 1 BW op deze manier wordt gewijzigd, kan de moedermaatschappij de overblijvende aansprakelijkheid niet beëindigen voordat de 403-maatschappij een jaarrekening openbaar heeft gemaakt, of er een nieuwe 403-verklaring is gedeponeerd ten aanzien van de 403-maatschappij. Ook in het geval dat de wet op de door mij voorgestelde manier wordt gewijzigd, meen ik dat de toets of een crediteur recht heeft op een vervangende waarborg niet anders moet worden uitgelegd als de 403-maatschappij weer een jaarrekening 
op een vervangende waarborg daarom niet anders worden uitgelegd als de 403-maatschappij weer een jaarrekening openbaar heeft gemaakt die voldoet aan de voorschriften van titel 9 van Boek 2 BW. In beide gevallen moet voor de beantwoording van de vraag of de positie van de crediteur door de beëindiging van de overblijvende ansprakelijkheid wordt verzwakt, de waarborgen die hij na de beëindiging heeft dat zijn vordering op de 403-maatschappij zal worden voldaan enkel worden vergeleken met de waarborgen die hij heeft dat zijn vordering op de moedermaatschappij zal worden voldaan.

\subsection{De vervangende waarborg}

\subsubsection{Inleiding}

Als een crediteur verzet heeft ingesteld tegen het voornemen van de moedermaatschappij om de overblijvende aansprakelijkheid te beëindigen en recht heeft op een vervangende waarborg, stelt de rechter vast wat voor een waarborg moet worden gegeven en binnen welke termijn. ${ }^{149}$ Doorgaans zal de moedermaatschappij de mogelijkheid krijgen om een voorstel te doen met betrekking tot de te geven waarborg. Indien de crediteur akkoord gaat met het voorstel kan de rechter in zijn oordeel daarbij aansluiten. Als de crediteur echter niet akkoord gaat - en de moedermaatschappij en de crediteur er na verder overleg ook niet uitkomen - moet de rechter de knoop doorhakken en bepalen of de voorgestelde waarborg voldoende is en zo niet, wat voor een vervangende waarborg de moedermaatschappij moet geven.

Indien de moedermaatschappij de vervangende waarborg niet heeft gegeven binnen de door de rechter gestelde termijn, wordt het verzet gegrond verklaard en is de overblijvende aansprakelijkheid van de moedermaatschappij tegenover de crediteur niet beëindigd. ${ }^{150}$ De duur van de termijn waarbinnen de vervangende waarborg moet worden gegeven, hangt af van de omstandigheden van het geval. Hierbij kan onder meer van belang zijn welke omvang de te geven vervangende waarborg moet hebben, welke partij de waarborg zal geven en wat voor soort waarborg zal worden gegeven. Als de moedermaatschappij

openbaar heeft gemaakt die voldoet aan de voorschriften van titel 9 van Boek 2 BW. De compensatie voor de crediteur voor het niet (hebben) kunnen inzien van de jaarrekening van de 403-maatschappij bestaat namelijk specifiek uit de 403-aansprakelijkheid in combinatie met de mogelijkheid om de geconsolideerde jaarrekening van de moedermaatschappij in te zien, zodat alleen het mogelijk wegvallen van de (waarborgen met betrekking tot de) vordering op de moedermaatschappij moet worden vergeleken met de situatie dat de crediteur zich enkel op de 403-maatschappij kan verhalen.

149. Zie art. 2:404 lid 5 en lid 6 BW

150. E.C.A. Nass 2019, p. 156. Zie bijvoorbeeld Rb. Midden-Nederland 14 januari 2015, ECLI:NL:RBMNE:2015:51 (Curatoren/SNS), r.o. 2.2. 
bijvoorbeeld een hypotheekrecht op een pand als vervangende waarborg wil geven, moet zij de tijd krijgen om de executiewaarde van het pand vast te stellen zodat kan worden beoordeeld of het hypotheekrecht voldoende waarborg biedt. In 2006 heeft de Rechtbank 's-Hertogenbosch de termijn voor het geven van een vervangende waarborg van bijna $€ 27$ miljoen vastgesteld op een maand en twee dagen, ${ }^{151}$ de Rechtbank Rotterdam heeft in 2014 een moedermaatschappij twee maanden de tijd gegeven om een vervangende waarborg van $€ 805$ miljoen te geven ${ }^{152}$ en een jaar later heeft zij de termijn voor het geven van een vervangende waarborg van $€ 15$ miljoen vastgesteld op één maand. ${ }^{153}$

Niet alleen de moedermaatschappij, maar ook een derde kan de vervangende waarborg geven aan de crediteur. Als een derde bijvoorbeeld de aandelen in de 403-maatschappij overneemt, kan zij met de moedermaatschappij hebben afgesproken dat zij eventuele vervangende waarborgen geeft aan de crediteuren, zodat de moedermaatschappij na de overdracht geen verdere aansprakelijkheid loopt. ${ }^{154}$

De crediteur moet zonder moeite verhaal kunnen halen op de vervangende waarborg. ${ }^{155}$ Deze waarborg kan iedere vorm van persoonlijke of zakelijke zekerheid zijn. ${ }^{156}$ Hierbij kan onder meer worden gedacht aan een borgstelling of een pand- of hypotheekrecht. Maar ook het ter beschikking stellen van een geldbedrag op de derdenrekening van een notaris of het geven van een bankgarantie kunnen een vervangende waarborg zijn.

\subsubsection{Een vervangende waarborg voor toekomstige vorderingen}

Een crediteur heeft niet alleen recht op een vervangende waarborg voor de vorderingen die hij op de 403-maatschappij heeft op het moment dat hij verzet instelt tegen het voornemen van de moedermaatschappij om de overblijvende aansprakelijkheid te beëindigen. Als de verwachting is dat er in de toekomst nog meer vorderingen uit de rechtsverhouding tussen de crediteur en de 403-maatschappij zullen voortvloeien - waarvoor de moedermaatschappij op grond van de ingetrokken 403-verklaring aansprakelijk is -, dienen deze ook door de waarborg gedekt te worden. ${ }^{157}$ Indien de rechtsverhouding tussen de

151. Rb. 's-Hertogenbosch 3 maart 2006, JOR 2006/201 (De Plaet/NRE), r.o. 4.3.

152. Rb. Rotterdam 30 september 2014, JOR 2014/326, m.nt. Loesberg (Pergen/Eneco), r.o. 4.19.

153. Rb. Rotterdam 29 september 2015, JOR 2015/295, m.nt. Bartman (Iemants/Hertel Beheer), r.o. 4.14 .

154. Kamerstukken II 1983/84, 16551, 11, p. 16 (NnavhEV).

155. Rb. Rotterdam 30 september 2014, JOR 2014/326, m.nt. Loesberg (Pergen/Eneco), r.o. 4.19 en Rb. Rotterdam 29 september 2015, JOR 2015/295, m.nt. Bartman (Iemants/ Hertel Beheer), r.o. 4.15. Anders: Notenboom 2017, p. 131-132.

156. Ten Voorde 2006, p. 143. Zie ook E.C.A. Nass 2019, p. 155.

157. Beckman - SDU Commentaar Ondernemingsrecht 2019, art. 2:404 BW, aant. C.2. 
crediteur en de 403-maatschappij een lange resterende looptijd heeft waaruit periodiek grote vorderingen voortvloeien, zal aan de crediteur een omvangrijke vervangende waarborg moeten worden gegeven. Een voorbeeld hiervan is de uitspraak Pergen/Eneco. In casu heeft de overeenkomst tussen de crediteur en de 403-maatschappij een resterende looptijd van 115 maanden. Op grond van deze overeenkomst heeft de crediteur iedere maand een vordering van gemiddeld $€ 7$ miljoen op de 403-maatschappij. ${ }^{158}$ De rechtbank stelt de te geven vervangende waarborg vast door de resterende maanden te vermenigvuldigen met het maandelijks gemiddeld te vorderen bedrag. Zij oordeelt dat de moedermaatschappij een bedrag van $€ 805$ miljoen als vervangende waarborg moet geven aan de crediteur. ${ }^{159}$

In een geval als bij bovenstaande uitspraak, waarbij de crediteur een vervangende waarborg van een dergelijke omvang moet worden gegeven, is het moeilijk voor te stellen dat de moedermaatschappij - of een derde - dit bedrag in een keer volledig aan de crediteur ter beschikking kan stellen. ${ }^{160}$ In plaats daarvan kan de crediteur een vervangende waarborg worden gegeven waarop hij gedurende de looptijd van de overeenkomst met de 403-maatschappij een beroep kan doen. Hierbij kan worden gedacht aan een bankgarantie. De crediteur kan slechts een beroep doen op de bankgarantie voor zover en tot het bedrag waarvoor hij openstaande vorderingen heeft op de 403-maatschappij. De partij die de vervangende waarborg verstrekt, kan met de bank overeenkomen dat zij de kosten van de bank vergoedt als de crediteur een beroep doet op de bankgarantie. ${ }^{161}$ Aldus hoeft deze partij niet in één keer het totaalbedrag van de vervangende waarborg ter beschikking te stellen, maar wordt dit bedrag 'uitgesmeerd' over de resterende looptijd van de overeenkomst.

Tot slot wijs ik nog op de situatie dat een vervangende waarborg moet worden gegeven aan een crediteur die een overeenkomst voor onbepaalde tijd is aangegaan met de 403-maatschappij. In een dergelijk geval is het niet mogelijk om een vast bedrag als vervangende waarborg vast te stellen op grond waarvan alle bestaande en toekomstige vorderingen die uit de overeenkomst voortvloeien, zijn gedekt. In plaats daarvan kan de moedermaatschappij - of een derde - zich

158. Op grond van de overeenkomst hebben de 403-maatschappij en de crediteur iedere maand over en weer vorderingen op elkaar. In de overeenkomst is opgenomen dat deze vorderingen met elkaar verrekend worden. Na verrekening heeft de crediteur gemiddeld een vordering van $€ 7$ miljoen op de 403-maatschappij. Zie Rb. Rotterdam 30 september 2014, JOR 2014/326, m.nt. Loesberg (Pergen/Eneco), r.o. 2.8-2.9.

159. Rb. Rotterdam 30 september 2014, JOR 2014/326, m.nt. Loesberg (Pergen/Eneco), r.o. 4.19 .

160. In casu heeft de moedermaatschappij de crediteur uiteindelijk geen vervangende waarborg gegeven. De overblijvende aansprakelijkheid van de moedermaatschappij tegenover de crediteur is daarom niet beëindigd.

161. Daarnaast zal deze partij aan de bank een provisie moeten betalen voor het beschikbaar stellen van de bankgarantie. 
bijvoorbeeld (hoofdelijk) aansprakelijk stellen voor alle bestaande en toekomstige schulden die uit de desbetreffende overeenkomst voortvloeien.

\subsubsection{De omvang van de vervangende waarborg}

Volgens Beckman moet een vervangende waarborg overeenkomen met het bedrag van de nog openstaande vorderingen, evenals de in de toekomst nog te verwachten vorderingen van de crediteur op de 403-maatschappij. ${ }^{162}$ Dit standpunt wordt ondersteund door de jurisprudentie. Tot op heden hebben rechters telkens de te geven vervangende waarborg vastgesteld op het bedrag van de bestaande en toekomstige vorderingen van de crediteur op de 403-maatschappij. ${ }^{163}$

Volgens het door mij bepleite uitgangspunt voor compensatie is het echter niet juist om de te geven vervangende waarborg zonder meer vast te stellen op het bedrag van de bestaande en toekomstige vorderingen van de crediteur op de 403-maatschappij. Rechters moeten de te geven vervangende waarborg naar mijn mening op een andere manier vaststellen.

Een crediteur heeft geen invloed op de keuze van de moedermaatschappij om de overblijvende aansprakelijkheid te beëindigen. Ik heb daarom betoogd dat hij daardoor niet in een nadeliger positie mag komen ten opzichte van de situatie dat de overblijvende aansprakelijkheid niet zou zijn beëindigd. ${ }^{164}$ Anderzijds moet ook zo veel mogelijk worden voorkomen dat hij hierdoor in een voordeliger positie komt. Het nadeel dat de crediteur ondervindt als gevolg van de beëindiging van de overblijvende aansprakelijkheid moet worden weggenomen, maar 'overcompensatie' moet worden voorkomen. ${ }^{165}$ De omvang van de te geven vervangende waarborg moet mijns inziens daarom mede worden vastgesteld aan de hand van de waarborgen die de crediteur al heeft, uit hoofde van de vermogenstoestand van de 403-maatschappij of uit anderen hoofde, dat zijn bestaande en toekomstige vorderingen op de 403-maatschappij zullen worden voldaan. De vervangende waarborg moet een aanvulling zijn op

162. Beckman - SDU Commentaar Ondernemingsrecht 2019, art. 2:404 BW, aant. C.2.

163. Rb. 's-Hertogenbosch 3 maart 2006, JOR 2006/201 (De Plaet/NRE), r.o. 4.2, Rb. Rotterdam 30 september 2014, JOR 2014/326, m.nt. Loesberg (Pergen/Eneco), r.o. 4.19, Rb. MiddenNederland 5 november 2014, ECLI:NL:RBMNE:2014:5519 (Curatoren/SNS), r.o. 2.3, Rb. Rotterdam 29 september 2015, JOR 2015/295, m.nt. Bartman (Iemants/Hertel Beheer), r.o. 4.13-4.14 en Hof Amsterdam (OK) 9 december 2015, JOR 2016/7, m.nt. Bartman (Curatoren/SNS), r.o. 3.11. Bij de Iemants/Hertel Beheer-uitspraak is de vervangende waarborg overigens lager vastgesteld dan het bedrag van de vordering van de crediteur omdat de 403-maatschappij een deel van het bedrag van de vordering in escrow heeft geplaatst.

164. Zie $\S 3.6 .1$.

165. Zie $\S 3.6 .2$. 
deze waarborgen die de crediteur al heeft. In plaats van de term 'vervangende' waarborg kan beter worden gesproken van een 'aanvullende' waarborg.

De vraag welk nadeel de crediteur door de beëindiging van de overblijvende aansprakelijkheid ondervindt, en wat dus met de te geven vervangende waarborg moet worden gecompenseerd, moet naar mijn mening worden beantwoord in het licht van de functie van de 403-aansprakelijkheid bij de compensatie van de crediteur voor het niet (hebben) kunnen inzien van de jaarrekening van de 403-maatschappij. Omdat de crediteur de jaarrekening van de 403-maatschappij niet heeft kunnen inzien, heeft hij zijn beslissing om een relatie met de 403-maatschappij aan te gaan of een bestaande relatie te continueren, niet (mede) kunnen baseren op de informatie in deze jaarrekening. In plaats daarvan heeft hij deze beslissing (mede) kunnen baseren op de informatie in de geconsolideerde jaarrekening van de moedermaatschappij. Dit brengt mee dat het risico dat de crediteur (onbewust) heeft geaccepteerd toen hij de relatie met de 403-maatschappij is aangegaan of heeft gecontinueerd, het risico is dat de moedermaatschappij de vordering op grond van de 403-verklaring niet (volledig) voldoet. Na de beëindiging van de overblijvende aansprakelijkheid kan de crediteur zich alleen nog tot de 403-maatschappij wenden om verhaal te halen. Het nadeel dat de crediteur door de beëindiging van de overblijvende aansprakelijkheid ondervindt, betreft mijns inziens daarom het verschil in de waarborgen die de crediteur heeft dat zijn vordering op de moedermaatschappij zal worden voldaan, en de waarborgen die hij heeft dat zijn vordering op de 403-maatschappij zal worden voldaan.

Ik heb eerder betoogd dat een crediteur recht heeft op een vervangende waarborg als hij na de beëindiging van de overblijvende aansprakelijkheid niet minimaal dezelfde waarborgen heeft - uit hoofde van de vermogenstoestand van de 403-maatschappij of uit anderen hoofde - dat zijn vordering op de 403-maatschappij zal worden voldaan, als de waarborgen die hij heeft dat zijn vordering op de moedermaatschappij zal worden voldaan. ${ }^{166}$ Maar de crediteur kan op grond van de vermogenstoestand van de 403-maatschappij of uit anderen hoofde, wel enige waarborgen hebben dat zijn vordering op de 403-maatschappij zal worden voldaan. Om het nadeel weg te nemen dat de crediteur door de beëindiging van de overblijvende aansprakelijkheid ondervindt, moeten deze waarborgen door de vervangende waarborg worden aangevuld tot (ten minste) het niveau van de waarborgen die de crediteur heeft dat zijn vordering op de moedermaatschappij zal worden voldaan. Anders gezegd: de waarborgen die de crediteur heeft uit hoofde van de vermogenstoestand van de 403-maatschappij, uit anderen hoofde en de vervangende waarborg moeten gezamenlijk, (minimaal) evenveel waarborgen bieden dat de vordering van de crediteur op de 403-maatschappij zal worden voldaan, als de waarborgen die hij heeft dat zijn

166. Zie $\S 8.8 .2$. 
vordering op de moedermaatschappij zal worden voldaan. ${ }^{167} \mathrm{Ik}$ licht dit toe aan de hand van een voorbeeld.

Stel dat de verwachting is dat de moedermaatschappij de vordering van de crediteur op grond van de 403-verklaring volledig zal voldoen. Daarnaast is te verwachten dat de 403-maatschappij de vordering van de crediteur voor twee derde zal voldoen. Ten aanzien van beide vorderingen gelden dezelfde voorwaarden omtrent de nakoming. De crediteur heeft verder geen waarborgen uit anderen hoofde dat zijn vordering op de 403-maatschappij zal worden voldaan. Aangezien de crediteur na de beëindiging van de overblijvende aansprakelijkheid minder waarborgen zal hebben dat zijn vordering op de 403-maatschappij zal worden voldaan, dan de waarborgen die hij heeft dat zijn vordering op de moedermaatschappij zal worden voldaan, heeft hij recht op een vervangende waarborg. Indien de huidige lijn in de jurisprudentie wordt gevolgd, moet de crediteur een vervangende waarborg worden gegeven die overeenkomt met het volledige bedrag van de vordering op de 403-maatschappij. Na de beëindiging van de overblijvende aansprakelijkheid heeft de crediteur dan een vordering op de 403-maatschappij - waarvan de verwachting is dat de 403-maatschappij deze voor twee derde zal voldoen - en een vervangende waarborg die gelijk is aan het volledige bedrag van deze vordering.

Volgens het door mij bepleite uitgangspunt voor compensatie moet de crediteur na de beëindiging van de overblijvende aansprakelijkheid (minimaal) dezelfde waarborgen hebben dat zijn vordering op de 403-maatschappij zal worden voldaan, als de waarborgen die hij heeft dat zijn vordering op de moedermaatschappij zal worden voldaan. Om dit te bereiken moet de crediteur in bovenstaand voorbeeld een vervangende waarborg worden gegeven die (minimaal) overeenkomt met een derde van het bedrag van de vordering op de 403-maatschappij. De crediteur heeft dan evenveel waarborgen, uit hoofde van de vermogenstoestand van de 403-maatschappij en de vervangende waarborg gezamenlijk, dat zijn vordering op de 403-maatschappij zal worden voldaan, als de waarborgen die hij heeft dat zijn vordering op de moedermaatschappij op grond van de ingetrokken 403-verklaring zal worden voldaan. Het resultaat van het op deze manier vaststellen van de omvang van de te geven vervangende waarborg is dat de crediteur geen nadeel ondervindt ten opzichte van de situatie dat de overblijvende aansprakelijkheid niet zou zijn beëindigd, maar dat het minder belastend is om de overblijvende aansprakelijkheid te beëindigen omdat de crediteur een minder omvangrijke vervangende waarborg hoeft te worden gegeven.

Op grond van art. 2:404 lid 6 BW is het de rechter die de te geven vervangende waarborg vaststelt. In deze bepaling zijn geen voorschriften opgenomen met betrekking tot de omvang van een dergelijke waarborg. Een rechter heeft dus de

167. Vgl. Notenboom 2017, p. 133. 
ruimte om de omvang van de vervangende waarborg op bovenstaande manier vast te stellen. Een wetswijziging is hiervoor niet vereist.

\subsubsection{Het vaststellen van de omvang van de vervangende waarborg nadat de 403-maatschappij een jaarrekening openbaar heeft gemaakt}

Evenals bij de beoordeling of een crediteur recht heeft op een vervangende waarborg, ${ }^{168}$ zou er kunnen worden betoogd dat de omvang van een te geven vervangende waarborg anders moet worden vastgesteld als de 403-maatschappij weer een jaarrekening openbaar heeft gemaakt die voldoet aan de voorschriften van titel 9 van Boek 2 BW. De redenering daarvoor is vergelijkbaar met die ten aanzien van de beoordeling of een crediteur recht heeft op een vervangende waarborg. Kort gezegd zou een crediteur zich op het standpunt kunnen stellen dat hij zijn keuze om een relatie met de 403-maatschappij aan te gaan of een bestaande relatie te continueren niet alleen heeft gebaseerd op de informatie in de geconsolideerde jaarrekening van de moedermaatschappij, maar ook op de informatie in de jaarrekening van de 403-maatschappij. De crediteur zou kunnen stellen dat hij aan de hand van beide jaarrekeningen een schatting heeft gemaakt hoe groot het risico is dat zijn vorderingen op de moeder- en de 403-maatschappij niet (volledig) zullen worden voldaan. ${ }^{169} \mathrm{Bij}$ de beantwoording van de vraag welke nadeel de crediteur ondervindt door de beëindiging van de overblijvende aansprakelijkheid, zou daarom niet alleen rekening gehouden moeten worden met de waarborgen die de crediteur voor de beëindiging heeft dat zijn vordering op de moedermaatschappij zal worden voldaan, maar ook met de waarborgen die hij heeft dat zijn vordering op de 403-maatschappij zal worden voldaan.

Toegepast op de door mij bepleite uitleg van de omvang van de vervangende waarborg zou bovenstaande redenering meebrengen dat de vervangende waarborg een zodanige omvang moet hebben dat de waarborgen die de crediteur heeft op grond van de vermogenstoestand van de 403-maatschappij en uit anderen hoofde dat zijn vordering op de 403-maatschappij zal worden voldaan, moeten worden aangevuld tot het niveau van de waarborgen die hij heeft dat zijn vorderingen op de moeder- én de 403-maatschappij zullen worden voldaan. Dit betekent dat de crediteur altijd een vervangende waarborg moet worden gegeven die overeenkomt met de waarborgen die hij heeft dat de vordering op de moedermaatschappij zal worden voldaan. Deze uitleg van de omvang van de vervangende waarborg moet naar mijn mening echter om dezelfde reden worden afgewezen als die ik noemde bij de beoordeling of een crediteur recht heeft op een vervangende waarborg. ${ }^{170}$

168. Zie $\S 8.8 .3$.

169. Waarbij de crediteur in totaal slechts eenmaal volledig kan worden voldaan.

170. Zie $\S 8.8 .3$. 
Bovengenoemd onderscheid bij het vaststellen van de omvang van de vervangende waarborg voor en nadat de 403-maatschappij een jaarrekening openbaar heeft gemaakt die voldoet aan de voorschriften van titel 9 van Boek 2 BW, stimuleert dat de moedermaatschappij de overblijvende aansprakelijkheid beëindigt voordat deze jaarrekening openbaar is gemaakt. Indien de overblijvende aansprakelijkheid wordt beëindigd voordat de jaarrekening openbaar is gemaakt, moet de omvang van de vervangende waarborg volgens het door mij bepleite uitgangspunt zodanig zijn dat de waarborgen die de crediteur heeft op grond van de vermogenstoestand van de 403-maatschappij of uit anderen hoofde dat zijn vordering op de 403-maatschappij zal worden voldaan, worden aangevuld tot (ten minste) het niveau van de waarborgen die de crediteur heeft dat zijn vordering op de moedermaatschappij zal worden voldaan. ${ }^{171}$ In het geval dat de beëindiging daarentegen plaatsvindt nadat de jaarrekening openbaar is gemaakt, zouden de waarborgen dat de vordering op de 403-maatschappij zal worden voldaan, moeten worden aangevuld tot het niveau van de waarborgen die de crediteur heeft dat zijn vorderingen op de moeder- én de 403-maatschappij zullen worden voldaan. ${ }^{172}$ In het laatste geval zal de crediteur dus altijd een omvangrijkere vervangende waarborg moeten worden gegeven, tenzij het zeker is dat de 403-maatschappij de vordering in het geheel niet zal kunnen voldoen - bijvoorbeeld als zij op het punt staat te failleren en haar activa onvoldoende zijn om de vorderingen van de crediteuren met een hogere rang in het faillissement te voldoen.

Om te voorkomen dat zij een omvangrijkere vervangende waarborg moet geven, kan een moedermaatschappij geneigd zijn om haar 403-verklaring in te trekken en de overblijvende aansprakelijkheid te beëindigen voordat de 403-maatschappij een jaarrekening openbaar heeft gemaakt. Dit is in strijd met het door mij bepleite uitgangspunt voor compensatie omdat er dan een periode is waarin crediteuren de jaarrekening van de 403-maatschappij niet kunnen inzien, maar daarvoor niet worden gecompenseerd. Dit leidt tot benadeling van de crediteuren van wie de vordering voortvloeit uit een rechtshandeling die de 403-maatschappij heeft verricht in de periode tussen het moment dat de moedermaatschappij tegenover de crediteur een beroep kan doen op de intrekking van de 403-verklaring en het moment dat de 403-maatschappij een jaarrekening openbaar maakt die voldoet aan de voorschriften van titel 9 van Boek $2 \mathrm{BW} .{ }^{173} \mathrm{Om}$ die reden moet de omvang van de vervangende waarborg mijns

171. Zie $\S 8.9 .3$.

172. Waarbij de crediteur in totaal slechts eenmaal volledig kan worden voldaan.

173. Zie $\S 7.3$ en $\S 8.2 .3$, waar ik eerder heb gewezen op deze lacune in de compensatie van de crediteuren. Ik heb betoogd dat aan art. 2:404 lid $1 \mathrm{BW}$ moet worden toegevoegd dat de intrekking van de 403-verklaring slechts of eerst effect heeft als de 403-maatschappij een jaarrekening openbaar heeft gemaakt die aan de voorschriften van titel 9 van Boek $2 \mathrm{BW}$ voldoet, of als er een nieuwe 403-verklaring is gedeponeerd ten aanzien van de 403-maatschappij. Als art. 2:404 lid 1 BW op deze manier wordt gewijzigd, kan de moe- 
inziens niet op een andere manier worden vastgesteld als de 403-maatschappij weer een jaarrekening openbaar heeft gemaakt die voldoet aan de voorschriften van titel 9 van Boek 2 BW. Zowel voor als nadat de 403-maatschappij een jaarrekening openbaar heeft gemaakt, moet de omvang van de vervangende waarborg zodanig zijn dat hierdoor de waarborgen van de crediteur op grond van de vermogenstoestand van de 403-maatschappij of uit anderen hoofde dat zijn vordering op de 403-maatschappij zal worden voldaan, worden aangevuld tot het niveau van de waarborgen die de crediteur heeft dat zijn vordering op de moedermaatschappij zal worden voldaan.

\subsubsection{Complicaties bij het vaststellen van de vervangende waarborg volgens het door mij bepleite uitgangspunt voor compensatie}

Het zal vaak niet eenvoudig zijn om de omvang van de te geven vervangende waarborg vast te stellen volgens het door mij bepleite uitgangspunt voor compensatie. Dit heeft verschillende redenen. Ten eerste kan het lastig zijn om precies vast te stellen welke waarborgen de crediteur heeft dat zijn vorderingen op de moeder- en de 403-maatschappij zullen worden voldaan. Dit geldt des te meer als ook beoordeeld moet worden welke waarborgen de crediteur heeft dat toekomstige vorderingen zullen worden voldaan. Een tweede complicerende factor is dat per individuele crediteur - die verzet heeft ingesteld en recht heeft op een vervangende waarborg - moet worden beoordeeld welke waarborgen hij heeft dat zijn vorderingen op de moeder- en de 403-maatschappij zullen worden voldaan.

Tot slot speelt mee dat de moedermaatschappij geen toegang (meer) heeft tot de interne financiële gegevens van de 403-maatschappij omdat zij de groepsband met laatstgenoemde heeft moeten verbreken in het kader van de beëindiging van de overblijvende aansprakelijkheid. ${ }^{174}$ Aangezien het de moedermaatschappij is

dermaatschappij de overblijvende aansprakelijkheid niet beëindigen voordat de 403-maatschappij een jaarrekening openbaar heeft gemaakt, of er een nieuwe 403-verklaring is gedeponeerd ten aanzien van de 403-maatschappij. Ook in het geval dat de wet op de door mij voorgestelde manier wordt gewijzigd, meen ik dat de omvang van een te geven vervangende waarborg niet anders moet worden vastgesteld als de 403-maatschappij weer een jaarrekening openbaar heeft gemaakt die voldoet aan de voorschriften van titel 9 van Boek 2 BW. De compensatie voor de crediteur voor het niet (hebben) kunnen inzien van de jaarrekening van de 403-maatschappij bestaat namelijk specifiek uit de 403-aansprakelijkheid in combinatie met de mogelijkheid om de geconsolideerde jaarrekening van de moedermaatschappij in te zien, zodat alleen het nadeel door het wegvallen van de (waarborgen met betrekking tot de) vordering op de moedermaatschappij moet worden gecompenseerd met de vervangende waarborg.

174. Zie art. 2:404 lid 3 sub a BW en $\S 8.4$. Zie ook $\S 8.13$, waar ik tot de conclusie kom dat de groepsband tussen de moeder- en de 403-maatschappij moet zijn verbroken uiterlijk op het moment dat de tweemaandstermijn ex art. 2:404 lid 5 BW verloopt waarbinnen crediteuren verzet kunnen instellen tegen het voornemen van de moedermaatschappij om de overblijvende 
die de overblijvende aansprakelijkheid wil beëindiging, ligt naar mijn mening ook bij haar de bewijslast dat de aan de crediteur te geven vervangende waarborg lager mag zijn dan het bedrag van de bestaande en toekomstige vorderingen van de crediteur op de 403-maatschappij. ${ }^{175}$ De moedermaatschappij kan dit standpunt niet onderbouwen door te wijzen op de interne financiële gegevens van de 403-maatschappij en aan de hand daarvan inzichtelijk te maken welke waarborg de vermogenstoestand van de 403-maatschappij biedt dat de vordering van de crediteur zal worden voldaan. Indien de 403-maatschappij zelf weer een jaarrekening openbaar heeft gemaakt die voldoet aan de voorschriften van titel 9 van Boek 2 BW, kan de moedermaatschappij aan de hand van de financiële gegevens uit deze jaarrekening inzichtelijk maken welke waarborg de vermogenstoestand van de 403-maatschappij biedt. Als de 403-maatschappij nog niet een jaarrekening openbaar heeft gemaakt, kan de moedermaatschappij gebruikmaken van de financiële gegevens van de 403-maatschappij die zijn geconsolideerd in haar geconsolideerde jaarrekening ${ }^{176}$ - mits de moedermaatschappij sindsdien zelf geen nieuwe (geconsolideerde) jaarrekening openbaar heeft gemaakt waarin de desbetreffende gegevens niet zijn geconsolideerd. Tot slot kan de moedermaatschappij de 403-maatschappij verzoeken of deze de interne financiële gegevens over haar vermogenstoestand beschikbaar wil stellen.

Resumerend; het zal vaak niet eenvoudig om de te geven vervangende waarborg vast te stellen volgens het door mij bepleite uitgangspunt voor compensatie. Dit betekent echter niet dat de te geven vervangende waarborg daarom maar - volgens de huidige lijn in de jurisprudentie ${ }^{177}$ - moet worden vastgesteld op het bedrag van de bestaande en toekomstige vorderingen van de crediteur op de 403-maatschappij. Mij staat op dit punt een middenweg voor ogen.

Indien de te geven vervangende waarborg niet precies is vast te stellen volgens het door mij bepleite uitgangspunt, kan de rechter deze waarborg vaststellen op basis van een schatting van de waarborgen die de crediteur heeft dat zijn vorderingen op de moeder- en de 403-maatschappij zullen worden voldaan. De rechter stelt de te geven vervangende waarborg dan niet vast op het

aansprakelijkheid te beëindigen. Zie tot slot ook $\S 8.14$, waar ik betoog dat de voorwaarde dat de groepsband tussen de moeder- en de 403-maatschappij is verbroken, moet worden geschrapt uit art. 2:404 lid $3 \mathrm{BW}$.

175. Dit sluit aan bij de jurisprudentie op grond waarvan op de moedermaatschappij de bewijslast rust dat een crediteur helemaal geen recht heeft op een vervangende waarborg. Zie $\S 8.8$.2, waar ik verwijs naar Hof Amsterdam (OK) 31 juli 2001, JOR 2001/170, m.nt. Bartman (ING/ Akzo), r.o. 4.12, Rb. Midden-Nederland 5 november 2014, ECLI:NL:RBMNE:2014:5519 (Curatoren/SNS), r.o. 2.2, Rb. Rotterdam 29 september 2015, JOR 2015/295, m.nt. Bartman (Iemants/Hertel Beheer), r.o. 4.11 en Hof Amsterdam (OK) 9 december 2015, JOR 2016/7, m.nt. Bartman (Curatoren/SNS), r.o. 3.19.

176. Zie art. 2:403 lid $1 \mathrm{sub} \mathrm{c}$ BW en $\S 2.3 .5$.

177. Zie $\S 8.9 .3$. 
bedrag van de bestaande en toekomstige vorderingen van de crediteur op de 403-maatschappij, maar hij maakt een schatting in hoeverre dit bedrag verminderd kan worden. Als de rechter een voorzichtige schatting maakt, waarbij hij in het bijzonder rekening houdt met het belang van de crediteur, is mijns inziens (voldoende) gewaarborgd dat de crediteur door de beëindiging van de overblijvende aansprakelijkheid niet in een nadeliger positie komt. De crediteur ondervindt in dat geval geen nadeel ten opzichte van de situatie dat de overblijvende aansprakelijkheid niet zou zijn beëindigd, maar het is minder belastend om deze aansprakelijkheid te beëindigen omdat de crediteur een minder omvangrijke vervangende waarborg hoeft te worden gegeven.

Als de moedermaatschappij onvoldoende informatie aanlevert met betrekking tot de waarborgen die de crediteur heeft dat de vorderingen op de moeder- en de 403-maatschappij zullen worden voldaan, aan de hand waarvan de omvang van de te geven vervangende waarborg op de door mij voorgestelde wijze kan worden vastgesteld, kan altijd worden teruggevallen op de huidige lijn in de jurisprudentie waarbij de vervangende waarborg wordt vastgesteld op het bedrag van de bestaande en toekomstige vorderingen van de crediteur op de 403-maatschappij. ${ }^{178}$

\subsection{Een vervangende waarborg en de hoofdelijke aansprakelijkheid}

Ik heb eerder opgemerkt dat een vervangende waarborg iedere vorm van persoonlijke of zakelijke zekerheid kan zijn. ${ }^{179}$ In tegenstelling tot de aansprakelijkheid van een moedermaatschappij op grond van een 403-verklaring is dus niet vereist dat de partij die de vervangende waarborg geeft zich hoofdelijk aansprakelijk stelt. Indirect is de hoofdelijke ansprakelijkheid van de moedermaatschappij op grond van de 403-verklaring naar mijn mening wel van belang bij de beoordeling of een crediteur recht heeft op een vervangende waarborg en - indien dit het geval is - bij het vaststellen van de te geven waarborg. Volgens het door mij bepleite uitgangspunt voor compensatie is in beide gevallen onder meer relevant welke waarborgen de crediteur heeft dat zijn vordering op de moedermaatschappij zal worden voldaan. ${ }^{180}$ De waarborgen die de crediteur heeft dat zijn vordering op de moedermaatschappij zal worden voldaan, worden mede bepaald door het feit dat de moedermaatschappij op grond van de ingetrokken 403-verklaring hoofdelijk aansprakelijk is. Deze hoofdelijke aansprakelijkheid brengt mee dat de vordering van de crediteur op de moedermaatschappij onafhankelijk bestaat van

178. Zie $\S 8.9 .3$.

179. Zie $\S 8.9 .1$ en Ten Voorde 2006, p. 143.

180. Zie $\S 8.8 .2$ en $\S 8.9 .3$. 
de vordering op de 403-maatschappij - behalve dat nakoming door de ene schuldenaar tevens de andere schuldenaar bevrijdt. ${ }^{181}$ Dat de vordering op de moedermaatschappij onafhankelijk bestaat van de vordering op de 403-maatschappij, kan gevolgen hebben voor de verhaalspositie van de crediteur tegenover de moedermaatschappij en daarmee van invloed zijn op de waarborgen die hij heeft dat deze vordering zal worden voldaan. Deze waarborgen zijn op hun beurt weer van invloed bij de beoordeling of een crediteur recht heeft op een vervangende waarborg en - indien dit het geval is - bij het vaststellen van de te geven waarborg. Ik licht dit toe aan de hand van een voorbeeld.

Stel dat een 403-maatschappij drie crediteuren heeft. Een van de crediteuren heeft een vordering die contractueel is achtergesteld, een ander heeft een concurrente vordering en de laatste heeft een vordering die is bevoorrecht. Voor het overige zijn de vorderingen identiek. Op grond van de 403-verklaring hebben alle drie de crediteuren een - identieke - concurrente vordering op de moedermaatschappij. ${ }^{182}$ Als de moedermaatschappij de overblijvende aansprakelijkheid wil beëindigen, kunnen de crediteuren hiertegen verzet instellen en verlangen dat zij een vervangende waarborg krijgen voor de voldoening van hun vordering op de 403-maatschappij. Ik heb eerder opgemerkt dat volgens mijn lezing van het oordeel van de Hoge Raad in de SNS/Curatoren-beschikking, ${ }^{183}$ een crediteur recht heeft op een vervangende waarborg als hij na de beëindiging van de overblijvende aansprakelijkheid niet minimaal dezelfde waarborgen heeft - uit hoofde van de vermogenstoestand van de 403-maatschappij of uit anderen hoofde - dat zijn vordering op de 403-maatschappij zal worden voldaan, als de waarborgen die hij heeft dat zijn vordering op de moedermaatschappij zal worden voldaan. ${ }^{184}$ Als andere omstandigheden met betrekking tot de waarborgen die de crediteuren hebben dat hun vorderingen op de moederen de 403-maatschappij zullen worden voldaan buiten beschouwing worden gelaten, ${ }^{185}$ heeft de crediteur met de achtergestelde vordering op de 403-maatschappij de minste waarborgen dat deze vordering zal worden voldaan. De crediteur met de bevoorrechte vordering zal de meeste waarborgen hebben. Daar tussenin zit de crediteur met de concurrente vordering. Aangezien alle drie

181. Zie art. 6:7 BW. Ook in het geval dat een van beide vorderingen wordt betaald door inbetalinggeving, verrekening of als een rechter op grond van art. 6:60 BW oordeelt dat de schuldenaar is bevrijd omdat de crediteur zelf in verzuim is, is de andere hoofdelijk schuldenaar bevrijd.

182. Zie met betrekking tot de bevoorrechte en de achtergestelde vorderingen HR 11 april 2014, NJ 2014/309, m.nt. Van Schilfgaarde (UWV/Econcern), r.o. 3.2.2 en 3.4.1. Ook gepubliceerd in JOR 2014/199, m.nt. Van Dooren (UWV/Econcern), respectievelijk HR 20 maart 2015, JOR 2015/140, m.nt. Josephus Jitta (Minister van Financiën/VEB c.s.), r.o. 4.30 en 4.34.4. Zie ook $\S 4.7$ en $\S 4.8$.

183. HR 31 maart 2017, JOR 2017/221, m.nt. De Haan (SNS/Curatoren), r.o. 5.1.4.

184. Zie $\S 8.8 .2$.

185. Hierbij kan onder meer worden gedacht aan de omvang van de vorderingen, de liquiditeit van de moeder- en de 403-maatschappij en of andere crediteuren zekerheidsrechten hebben. 
de crediteuren een concurrente vordering op de moedermaatschappij hebben, heeft de crediteur met de achtergestelde vordering op de 403-maatschappij dus eerder recht op een vervangende waarborg dan de twee andere crediteuren, daarna de crediteur met de concurrente vordering en tot slot de crediteur met de bevoorrechte vordering.

Als de moedermaatschappij naar aanleiding van het verzet een vervangende waarborg moet geven aan de crediteuren, zijn de waarborgen die zij hebben dat hun vorderingen op de moeder- en de 403-maatschappij zullen worden voldaan opnieuw van belang. Ik heb eerder betoogd dat de omvang van een te geven vervangende waarborg mede afhankelijk is van de waarborgen die de crediteur al heeft, uit hoofde van de vermogenstoestand van de 403-maatschappij en eventuele waarborgen uit anderen hoofde, dat zijn vordering op de 403-maatschappij zal worden voldaan. ${ }^{186}$ Gezamenlijk moeten de waarborgen die de crediteur heeft, uit hoofde van de vermogenstoestand van de 403-maatschappij, eventuele waarborgen uit anderen hoofde en de vervangende waarborg, (minimaal) dezelfde waarborgen bieden dat zijn vordering op de 403-maatschappij zal worden voldaan, als de waarborgen die hij heeft dat zijn vordering op de moedermaatschappij zal worden voldaan. Als opnieuw de andere omstandigheden met betrekking tot de waarborgen die de crediteuren hebben dat hun vorderingen op de moeder- en de 403-maatschappij zullen worden voldaan buiten beschouwing worden gelaten, zal de crediteur met de achtergestelde vordering op de 403-maatschappij de meest omvangrijke vervangende waarborg moeten worden gegeven. De crediteur met de concurrente vordering op de 403-maatschappij heeft recht op een minder omvangrijke vervangende waarborg en de crediteur met de bevoorrechte vordering heeft recht op de minst omvangrijke vervangende waarborg.

\subsection{Het verzetsrecht en de vervangende waarborg: drie rekenvoorbeelden}

In paragraaf 8.6.1 heb ik opgemerkt dat het vraagstuk omtrent het recht van een crediteur om verzet in te stellen tegen de beëindiging van de overblijvende aansprakelijkheid en een vervangende waarborg te verzoeken, uiteenvalt in de beantwoording van drie vragen. Ten eerste de vraag of de crediteur verzet kan instellen. Voorts of hij recht heeft op een vervangende waarborg en tot slot welke omvang de te geven vervangende waarborg moet hebben. Ik heb in de daaropvolgende paragrafen onderzocht hoe deze vragen moeten worden beantwoord volgens het door mij bepleite uitgangspunt voor de compensatie van de crediteuren van een 403 -maatschappij. ${ }^{187}$

186. Zie $\$ 8.9 .3$.

187. Zie $\S 8.6$ tot en met $\S 8.10$. 
Om de door mij gegeven antwoorden op de drie bovengenoemde vragen te verduidelijken en om hun onderlinge samenhang te illustreren, geef ik hieronder een drietal rekenvoorbeelden waarbij een moedermaatschappij voornemens is om haar overblijvende aansprakelijkheid te beëindigen en een crediteur daartegen verzet wil instellen. Ik ga telkens na of de crediteur volgens het door mij bepleite uitgangspunt verzet kan instellen, of hij recht heeft op een vervangende waarborg en welke omvang de te geven waarborg in dat geval (minimaal) moet hebben.

Het eerste rekenvoorbeeld houdt in dat een crediteur een vordering heeft van $€ 100.000$,- op de moeder- en op de 403-maatschappij. De verwachting is dat de moedermaatschappij de vordering volledig zal kunnen voldoen. De 403-maatschappij zal de vordering echter maar voor een kwart kunnen voldoen. Tot zekerheid van de nakoming van de vordering op de 403-maatschappij, heeft de crediteur een pandrecht op verschillende activa. De verwachting is dat de executieopbrengt daarvan $€ 40.000$,- is.

Als de moedermaatschappij de overblijvende aansprakelijkheid wil beëindigen, kan de crediteur hiertegen verzet instellen omdat hij een vordering heeft op de 403-maatschappij waarvoor de moedermaatschappij op grond van de 403-verklaring aansprakelijk is (§ 8.7.1). Volgens het door mij bepleite uitgangspunt voor compensatie heeft een crediteur recht op een vervangende waarborg als hij na de beëindiging van de overblijvende aansprakelijkheid niet minimaal dezelfde waarborgen heeft - uit hoofde van de vermogenstoestand van de 403-maatschappij of uit anderen hoofde - dat zijn vordering op de 403-maatschappij zal worden voldaan, als de waarborgen die hij heeft dat zijn vordering op de moedermaatschappij zal worden voldaan (§ 8.8.2). In casu is de verwachting dat de moedermaatschappij de vordering van $€ 100.000$,- volledig kan voldoen. Met betrekking tot de vordering op de 403-maatschappij is echter de verwachting dat de 403-maatschappij zelf maar $€ 25.000$,- kan voldoen en dat de crediteur daarnaast voor $€ 40.000$,- verhaal kan halen op de verpande activa. Dit betekent dat de crediteur recht heeft op een vervangende waarborg. De omvang van de te geven waarborg moet zodanig zijn dat hierdoor de waarborgen die de crediteur al heeft dat zijn vordering op de 403-maatschappij zal worden voldaan, worden aangevuld tot het niveau van de waarborgen die de crediteur heeft dat zijn vordering op de moedermaatschappij zal worden voldaan - zijnde dat de volledige vordering van $€ 100.000$,- zal worden voldaan (§ 8.9.3). Dit betekent dat de crediteur een vervangende waarborg moet worden gegeven van ten minste $€ 35.000,-$.

In het tweede rekenvoorbeeld heeft de 403-maatschappij zich contractueel tot een bedrag van maximaal $€ 200.000$,- tot borg gesteld voor de nakoming van de verplichtingen van een derde tegenover een crediteur. Tot op heden is de derde niet tekort geschoten in de nakoming van zijn verplichtingen en heeft de 
crediteur nog geen beroep gedaan op de borgstelling door de 403-maatschappij. Zowel de moeder- als de 403-maatschappij kan een eventuele vordering van de crediteur van maximaal $€ 200.000$,- probleemloos betalen. Aangezien de vermogenstoestand van de moedermaatschappij beter is dan die van de 403-maatschappij, zal zij daar nog minder moeite mee hebben dan de 403-maatschappij.

Tenzij een vordering onmiskenbaar ongegrond is, kan ook een crediteur met een niet-vaststaande vordering op de 403-maatschappij verzet instellen tegen het voornemen van de moedermaatschappij om de overblijvende aansprakelijkheid te beëindigen ( 8 8.7.2). Aangezien de 403-maatschappij zich in onderhavige casus contractueel tot borg heeft gesteld, zal de crediteur in verzet kunnen komen. Volgens het door mij bepleite uitgangspunt voor compensatie heeft een crediteur recht op een vervangende waarborg als hij na de beëindiging van de overblijvende aansprakelijkheid niet minimaal dezelfde waarborgen heeft dat zijn vordering op de 403-maatschappij zal worden voldaan, als de waarborgen die hij heeft dat zijn vordering op de moedermaatschappij zal worden voldaan. Hierboven merkte ik op dat de moeder- en de 403-maatschappij beide de vordering van de crediteur volledig kunnen voldoen, maar dat de moedermaatschappij hier nog beter toe in staat is dan de 403-maatschappij. Dit betekent dat de crediteur na de beëindiging van de overblijvende aansprakelijkheid minder waarborgen zal hebben dat zijn vordering zal worden voldaan en dat hij dus recht heeft op een vervangende waarborg. Ik heb echter bovenstaande norm voor het toekennen van een vervangende waarborg genuanceerd voor het geval dat de crediteur redelijkerwijs geen risico loopt dat zijn vordering op de 403-maatschappij niet zal worden voldaan. In een dergelijk geval heeft een crediteur naar mijn mening geen recht op een vervangende waarborg, ondanks dat de crediteur meer waarborgen heeft dat zijn vordering op de moedermaatschappij zal worden voldaan, dan dat zijn vordering op de 403-maatschappij zal worden voldaan (§ 8.8.2).

Het derde en laatste rekenvoorbeeld dat ik behandel, houdt in dat de 403-maatschappij en een crediteur een overeenkomst zijn aangegaan op grond waarvan de 403-maatschappij maandelijks $€ 2$ miljoen is verschuldigd aan de crediteur. De overeenkomst heeft een resterende looptijd van vijftien jaar. De vermogenstoestand van de 403-maatschappij biedt minder waarborgen dat zij de vorderingen van de crediteur zal voldoen, dan de vermogenstoestand van de moedermaatschappij. De crediteur heeft geen andere waarborgen dat zijn vorderingen op de 403-maatschappij zullen worden voldaan. Aangezien de moedermaatschappij haar aandelen in de 403-maatschappij wil overdragen aan een rechtspersoon buiten de groep is zij voornemens om de overblijvende aansprakelijkheid te beëindigen. 
Daar de moedermaatschappij op grond van de 403-verklaring aansprakelijk is voor de schulden van de 403-maatschappij die uit de overeenkomst voortvloeien, kan de crediteur in verzet komen tegen het voornemen van de moedermaatschappij om de overblijvende aansprakelijkheid te beëindigen (§ 8.7.1). Aangezien de crediteur minder waarborgen heeft dat zijn vorderingen op de 403-maatschappij zullen worden voldaan, dan dat zijn vorderingen op de moedermaatschappij zullen worden voldaan, heeft de crediteur recht op een vervangende waarborg ( $\S 8.8 .2)$. De te geven vervangende waarborg heeft betrekking op alle bestaande schulden die uit de overeenkomst zijn voortgevloeid en die daar naar verwachting nog uit zullen voortvloeien. In plaats van in een keer aan de crediteur een totaalbedrag als vervangende waarborg te geven voor de volledige looptijd van de overeenkomst, is het ook mogelijk dat aan de crediteur een vervangende waarborg wordt gegeven waarop hij gedurende de looptijd een beroep kan doen ( $\S 8.9 .2$ ). Het is bijvoorbeeld mogelijk dat de overnemende partij toezegt een eigen 403-verklaring te zullen deponeren op grond waarvan zij zich hoofdelijk aansprakelijk stelt voor de schulden die voortvloeien en zijn voortgevloeid uit een rechtshandeling van de 403-maatschappij - waaronder de desbetreffende overeenkomst tussen de 403-maatschappij en de crediteur. ${ }^{188}$ Het is dan wel vereist dat de vermogenstoestand van de overnemende partij zodanig is dat hierdoor de waarborgen die de crediteur heeft dat zijn vorderingen op de 403-maatschappij zullen worden voldaan, zijn aangevuld tot het niveau van de waarborgen die hij heeft dat zijn vorderingen op de moedermaatschappij zullen worden voldaan (§ 8.9.3).

\subsection{Aankondiging plaatsen in een landelijk verspreid dagblad nadat de moedermaatschappij een beroep kan doen op de intrekking}

Op grond van art. 2:404 lid 5 BW kan een crediteur voor wiens vordering nog aansprakelijkheid loopt tot twee maanden nadat de moedermaatschappij een aankondiging heeft geplaatst in een landelijk verspreid dagblad dat en waar de door haar gedeponeerde mededeling van het voornemen om de overblijvende aansprakelijkheid te beëindigen ter inzage ligt, verzet instellen tegen dit voornemen. ${ }^{189}$ Evenals De Neve meen ik dat deze bepaling zo moet worden uitgelegd dat iedere crediteur twee maanden de tijd moet hebben om verzet te kunnen instellen. Dit betekent dat een moedermaatschappij de aankondiging in het landelijk verspreid dagblad pas mag plaatsen nadat zij een beroep kan

188. Dit houdt in dat de 403-aansprakelijkheid terugwerkende kracht heeft. Zie § 5.6.

189. Zie art. 2:404 lid 5 BW en $\S 8.6 .3$. Zie ook Kamerstukken II 1983/84, 16551, 11, p. 17 (NnavhEV). 
doen op de intrekking van de 403-verklaring. ${ }^{190,191}$ Pas als de moedermaatschappij een beroep kan doen op de intrekking staat vast voor welke vorderingen nog aansprakelijkheid loopt in de zin van art. 2:404 lid 5 BW. Op dat moment staat dus ook pas vast welke crediteuren verzet kunnen instellen tegen het voornemen van de moedermaatschappij om de overblijvende aansprakelijkheid te beëindigen.

Een andere uitleg van art. 2:404 lid 5 BW kan ertoe leiden dat de tweemaandstermijn waarin crediteuren verzet kunnen instellen wel al is aangevangen maar dat de moedermaatschappij nog geen beroep kan doen op de intrekking van de 403 -verklaring. Crediteuren van wie de vordering voortvloeit uit een rechtshandeling die de 403-maatschappij heeft verricht in de periode vanaf de aanvang van de verzetstermijn tot het moment dat de moedermaatschappij een beroep kan doen op de intrekking van de 403-verklaring, krijgen op grond van deze verklaring een vordering op de moedermaatschappij maar zij hebben minder dan twee maanden de tijd om verzet in te stellen. Zij zijn gebonden aan de reeds aangevangen verzetstermijn. Dit betekent dat zij onterecht beperkt zouden worden in de mogelijkheid om gebruik te maken van de waarborgen bij de beëindiging van de overblijvende aansprakelijkheid om hun verhaalsrecht tegenover de moedermaatschappij te beschermen. Een dergelijke situatie deed zich voor bij de eerdergenoemde Pergen/Eneco-uitspraak van de Rechtbank Rotterdam. Deze uitspraak heeft betrekking op een moedermaatschappij die op 15 februari 2014 een aankondiging heeft geplaatst in een landelijk verspreid dagblad dat en waar de door haar gedeponeerde mededeling van het voornemen om de overblijvende aansprakelijkheid te beëindigen ter inzage ligt. Bijna twee maanden later, op 14 april 2014, heeft de moedermaatschappij de 403-verklaring ingetrokken. Evenals De Neve en Van Zoest concludeer ik dat de rechtbank ten onrechte heeft geoordeeld dat de termijn voor het instellen van verzet tegen het voornemen van de moedermaatschappij om de overblijvende aansprakelijkheid te beëindigen op 15 april is verlopen. ${ }^{192}$ In plaats daarvan had zij moeten oordelen dat deze termijn nog niet was aangevangen. ${ }^{193} \mathrm{Om}$ de

190. De Neve 2015, p. 91.

191. Zie $\S 7.3$, waar ik heb geconcludeerd dat het wenselijk is dat aan art. 2:404 lid $1 \mathrm{BW}$ wordt toegevoegd dat de intrekking van de 403-verklaring slechts of eerst effect heeft als de 403-maatschappij een jaarrekening openbaar heeft gemaakt die aan de voorschriften van titel 9 van Boek 2 BW voldoet, of als er een nieuwe 403-verklaring is gedeponeerd ten aanzien van de 403-maatschappij. Als art. 2:404 lid $1 \mathrm{BW}$ op deze manier wordt gewijzigd, kan de moedermaatschappij pas een beroep doen op de intrekking van de 403 -verklaring als een van beide gebeurtenissen heeft plaatsgevonden.

192. Zie Rb. Rotterdam 30 september 2014, JOR 2014/326, m.nt. Loesberg (Pergen/Eneco), r.o. 2.10-2.12 en 4.9. Overigens heeft de rechtbank geoordeeld dat het beroep van de moedermaatschappij op het verstrijken van de verzetstermijn misbruik van recht is, waardoor het verzet van de crediteur - dat hij drie dagen na het verlopen van de verzetstermijn heeft ingesteld - toch is erkend. Zie $\S 8.6 .3$ waar ik enkele kanttekeningen plaats bij deze uitspraak.

193. De Neve 2015, p. 91 en Van Zoest 2016a, p. 63. 
overblijvende aansprakelijkheid te beëindigen zou de moedermaatschappij - nadat zij een beroep op de intrekking van de 403-verklaring kan doen - een (nieuwe) aankondiging in een landelijk verspreid dagblad hebben moeten plaatsen.

Dat de moedermaatschappij de aankondiging dat en waar de door haar gedeponeerde mededeling van het voornemen om de overblijvende aansprakelijkheid te beëindigen ter inzage ligt pas kan plaatsen in een landelijk verspreid dagblad nadat zij een beroep kan doen op de intrekking van de 403-verklaring, betekent overigens niet dat zij daarvoor niet al aan andere voorwaarden voor deze beëindiging kan voldoen. De moedermaatschappij kan alvast de groepsband met de 403-maatschappij verbreken ${ }^{194}$ en de mededeling deponeren van het voornemen om de overblijvende aansprakelijkheid te beëindigen.

\subsection{Geen vaste volgorde waarin aan de voorwaarden voor de beëindiging van de overblijvende aansprakelijkheid moet worden voldaan}

De vier voorwaarden waaraan moet worden voldaan om de overblijvende aansprakelijkheid te beëindigen, staan in art. 2:404 lid 3 sub a tot en met d BW. ${ }^{195}$ Onder meer Beckman is van mening dat aan deze voorwaarden moet worden voldaan in de volgorde waarin zij in sub a tot en met $\mathrm{d}$ staan. ${ }^{196}$ De tekst van art. 2:404 lid $3 \mathrm{BW}$ laat volgens hem geen ruimte voor een afwijkende volgorde. Daarnaast noemt Beckman twee bezwaren indien niet in deze volgorde aan de

194. Zie $\S 8.13$, waar ik opmerk dat het voor een moedermaatschappij risico's met zich kan brengen als zij de groepsband al verbreekt terwijl het nog een tijd duurt voordat de termijn verloopt waarbinnen de crediteuren verzet kunnen instellen tegen het voornemen om de overblijvende aansprakelijkheid te beëindigen. De moedermaatschappij heeft dan geen doorslaggevende invloed meer op de handelingen van de 403-maatschappij, maar daaruit kan wel nog nieuwe aansprakelijkheid voor haar ontstaan. Om dit risico weg te nemen, kan de moedermaatschappij de groepsband verbreken vlak voordat de verzetstermijn verloopt.

195. Hiervoor is vereist dat de groepsband tussen de moeder- en de 403-maatschappij is verbroken (sub a). Daarnaast moet een mededeling van het voornemen om de overblijvende aansprakelijkheid te beëindigen twee maanden ter inzage hebben gelegen bij het handelsregister (sub b). Voorts dienen er twee maanden te zijn verlopen na de aankondiging in een landelijk verspreid dagblad dat en waar deze mededeling ter inzage ligt (sub c). Tot slot mag tegen het voornemen tot beëindiging geen verzet zijn ingesteld door de crediteur, dan wel moet diens verzet zijn ingetrokken of door de rechter ongegrond zijn verklaard (sub d).

196. Beckman 1995a, p. 344-345 en 613-614, Beckman 1996, p. 257, Beckman 2011, p. 257, Schepel 2016, p. 67, Beckman - SDU Commentaar Ondernemingsrecht 2019, art. 2:404 BW, aant. C.2 en E.C.A. Nass 2019, p. 152-153. Vgl. Beckman \& Van Wijngaarden - SDU Commentaar Ondernemingsrecht 2011, art. 2:404 BW, aant. C.2, waar zij opmerken dat er geen overwegende bezwaren zijn tegen het in gang zetten van de procedure om de overblijvende aansprakelijkheid te beëindigen, voordat de groepsband definitief is verbroken. De wettekst biedt volgens hen deze mogelijkheid echter niet. 
voorwaarden voor de beëindiging zou moeten worden voldaan. Ten eerste kan de beëindiging van de overblijvende aansprakelijkheid volgens hem worden misbruikt als niet eerst aan de voorwaarde wordt voldaan dat de groepsband tussen de moeder- en de 403-maatschappij is verbroken, voordat aan de andere voorwaarden wordt voldaan. De moedermaatschappij zou dan bij een dreigend faillissement van de 403-maatschappij alvast aan de overige voorwaarden voor de beëindiging kunnen voldoen. Als vervolgens de 403-maatschappij failleert, is ook de groepsband tussen hen verbroken en eindigt de overblijvende aansprakelijkheid. ${ }^{197}$

Ten tweede wijst Beckman erop dat het voor crediteuren onduidelijk kan zijn op welk moment de groepsband tussen de moeder- en de 403-maatschappij is verbroken. ${ }^{198}$ Voor een groepsband is (onder meer) vereist dat de moedermaatschappij de centrale leiding heeft ten aanzien van de 403-maatschappij. ${ }^{199}$ Daarbij is niet alleen de juridisch-organisatorische verbondenheid tussen de moeder- en de 403-maatschappij van belang, maar (vooral) ook de (bedrijfs-) economische werkelijkheid tussen hen. ${ }^{200}$ Dit zal voor een crediteur niet altijd kenbaar zijn. Indien het verbreken van de groepsband tussen de moeder- en de 403-maatschappij de laatste voorwaarde is waaraan wordt voldaan, kan de overblijvende aansprakelijkheid zijn beëindigd zonder dat de crediteur dat weet.

Evenals de meeste andere auteurs lees ik art. 2:404 lid 3 BW echter zo dat er geen vaste volgorde is waarin aan de voorwaarden voor de beëindiging van de overblijvende aansprakelijkheid moet worden voldaan. De voorwaarden zijn volgens deze lezing nevengeschikt. ${ }^{201}$ Dit volgt ook uit de opmerking van de minister bij de introductie van art. 2:404 lid 3 BW dat een moedermaatschappij de mededeling van het voornemen om de overblijvende aansprakelijkheid te beëindigen, kan deponeren 'in het vooruitzicht' van de verbreking

197. Zie Beckman 1995a, p. 345, waar hij opmerkt dat de moedermaatschappij in een dergelijk geval op grond van onrechtmatige daad aansprakelijk gehouden kan worden.

198. Beckman 1995a, p. 613-614.

199. Kamerstukken II 1969/70, 10751, 3, p. 13 (MvT), Kamerstukken II 1979/80, 16326, 3 , p. 42 (MvT) en Kamerstukken II 1987/88, 19813, 5, p. 4 (MvA). Zie ook Honée 1981, p. 52, L. Timmerman 1988a, p. 54-55, Van Achterberg 1989, p. 82, Asser/Maeijer, Van Solinge \& Nieuwe Weme 2-II* 2009/816, Krol 2015, p. 144, Asser/Maeijer \& Kroeze 2-I* 2015/261, Van Limpt, Pronk \& Visser 2019, p. 813, E.C.A. Nass 2019, p. 41 en Bartman, Dorresteijn \& Olaerts 2020, p. 33. Zie $\S 2.3 .2$, voor een uitgebreidere bespreking van de groepsband.

200. Asser/Maeijer, Van Solinge \& Nieuwe Weme $2-I^{*}$ 2009/816 en Asser/Maeijer \& Kroeze $2-I^{*} 2015 / 261$.

201. Burgert, Timmermans \& Joosten 1990, p. 564, Van Wijngaarden 2006a, p. 619, Ten Voorde 2011, p. 198, Snijder-Kuipers \& Eliëns 2014, p. 1178-1179, Van Zoest 2016a, p. 61, Van Zoest 2016b, p. 70, Talacko \& Van Wijngaarden 2016, p. 18, Van der Kraan 2018b, p. 34, Holtman 2019, p. 162, Bartman, Dorresteijn \& Olaerts 2020, p. 229 en Reimers, in: GS Rechtspersonen, art. 2:404 BW, aant. 4. 
van de groepsband met de 403-maatschappij. ${ }^{202}$ Dit betekent dat voor de beëindiging van de overblijvende aansprakelijkheid niet is vereist dat als eerste aan de voorwaarde van de verbreking van de groepsband tussen de moeder- en de 403-maatschappij ex art. 2:404 lid 3 sub a BW hoeft te worden voldaan, voordat aan de andere voorwaarden uit lid 3 kan worden voldaan. Dit standpunt wordt ook in de jurisprudentie gevolgd. Ik wijs op de beschikking van de Rechtbank Rotterdam inzake Iemants/Hertel Beheer en de SNS/Curatorenbeschikking van de Hoge Raad waar de procedure tot de beëindiging van de overblijvende aansprakelijkheid al in gang is gezet voor de verbreking van de groepsband. ${ }^{203}$

Daarnaast merk ik op dat als aangenomen zou worden dat aan de voorwaarden voor de beëindiging van de overblijvende aansprakelijkheid moet worden voldaan in de volgorde waarin zij in art. 2:404 lid 3 sub a tot en met d BW staan, dit risico's meebrengt voor de moedermaatschappij. Evenals Van Zoest wijs ik erop dat als de moedermaatschappij eerst de groepsband met de 403-maatschappij moet verbreken - voordat zij aan de andere voorwaarden kan voldoen -, het daarna nog minimaal twee maanden duurt voordat de overblijvende aansprakelijkheid is beëindigd. ${ }^{204}$ Dit kan tot onzekerheid leiden in de overnamepraktijk. De moedermaatschappij weet pas op zijn vroegst twee maanden na de overdracht van de aandelen in de 403-maatschappij of haar overblijvende aansprakelijkheid is beëindigd en of zij eventueel vervangende waarborgen moet geven aan crediteuren die verzet hebben ingesteld. Vanaf de verbreking van de groepsband tot het moment dat de verzetstermijn verloopt, heeft de moedermaatschappij geen doorslaggevende invloed op de handelingen - of het nalaten te handelen - van de 403-maatschappij, maar hieruit kunnen wel nog steeds schulden ontstaan waarvoor zij op grond van de ingetrokken 403-verklaring aansprakelijk is. Totdat aan alle voorwaarden van art. 2:404 lid 3 BW is voldaan - en de overblijvende aansprakelijkheid is beëindigd -, is de moedermaatschappij aansprakelijk voor (nieuwe) schulden die voortvloeien uit de rechtshandelingen die de 403-maatschappij heeft verricht tot het moment dat de moedermaatschappij tegenover de crediteur een beroep kan doen op de intrekking van de 403-verklaring. ${ }^{205}$ Als de 403-maatschappij bijvoorbeeld ná de verbreking van de groepsband, maar vóór de beëindiging van de overblijvende aansprakelijkheid een overeenkomst met een crediteur ontbindt - tegen de wil van de moedermaatschappij -, kan zij verplicht zijn tot het betalen van een schadevergoeding. De moedermaatschappij is dan op grond van de

202. Kamerstukken II 1983/84, 16551, 11, p. 16 (NnavhEV).

203. Rb. Rotterdam 29 september 2015, JOR 2015/295, m.nt. Bartman (Iemants/Hertel Beheer), r.o. 2.10-2.12 en 4.6 en HR 31 maart 2017, JOR 2017/221, m.nt. De Haan (SNS/Curatoren), r.o. 3.1.

204. Van Zoest 2019, p. 40. Zie art. 2:404 lid 3 sub b en c BW.

205. Zie $\S$ 8.6.3. Zie ook Bartman in zijn annotatie onder Hof Amsterdam (OK) 9 december 2015, JOR 2016/7 (Curatoren/SNS). 
ingetrokken 403-verklaring hoofdelijk aansprakelijk voor de nakoming van deze schadevergoeding. ${ }^{206}$ Als de desbetreffende crediteur vervolgens verzet instelt tegen het voornemen van de moedermaatschappij om de overblijvende aansprakelijkheid te beëindigen, kan de moedermaatschappij onder omstandigheden verplicht zijn om een vervangende waarborg te geven voor de voldoening van deze schadevergoeding. ${ }^{207}$ Doet zij dat niet, dan eindigt de overblijvende aansprakelijkheid tegenover de crediteur niet.

Dat niet in een vaste volgorde aan de voorwaarden ex art. 2:404 lid 3 sub a tot en met d BW hoeft te worden voldaan, betekent mijns inziens niet dat op een willekeurig moment aan ieder van de vier voorwaarden kan worden voldaan. Ik leg art. 2:404 lid 3 BW zo uit dat uiterlijk op het moment dat de tweemaandstermijn verloopt waarbinnen de crediteuren verzet kunnen instellen tegen het voornemen van de moedermaatschappij om de overblijvende aansprakelijkheid te beëindigen aan alle voorwaarden voor deze beëindiging moet zijn voldaan, behoudens de afwikkeling van een eventueel ingesteld verzet. ${ }^{208}$ Uiterlijk op dat moment moet dus ook de groepsband tussen de moeder- en de 403-maatschappij zijn verbroken. ${ }^{209}$ Deze uitleg van art. 2:404 lid 3 BW ondervangt de twee bezwaren van Beckman. Ten eerste kan de moedermaatschappij niet alvast aan de overige voorwaarden voldoen, waarna de overblijvende aansprakelijkheid eindigt als de groepsband met de 403-maatschappij wordt verbroken. De groepsband moet uiterlijk zijn verbroken als de verzetstermijn afloopt. Ten tweede ondervindt een crediteur geen nadeel als het onduidelijk is op welk moment de groepsband tussen de moeder- en de 403-maatschappij is verbroken. Hoewel de crediteur in een dergelijk geval niet precies weet wanneer de groepsband is verbroken, weet hij wel dat deze in ieder geval moet zijn verbroken als de verzetstermijn afloopt - of dat anders de overblijvende aansprakelijkheid blijft bestaan.

206. Zie $\S 4.4 .2$.

207. De crediteur heeft recht op een vervangende waarborg tenzij hij, uit hoofde van de vermogenstoestand van de 403-maatschappij of uit anderen hoofde, voldoende waarborgen heeft dat zijn vordering op de 403-maatschappij zal worden voldaan. Zie art. 2:404 lid 4 BW en $\S 8.8$.

208. Burgert, Timmermans \& Joosten 1990, p. 564.

209. Indien het wetsvoorstel Wet continuïteit ondernemingen I wordt aangenomen, kan een moedermaatschappij in het vooruitzicht van een faillissement van de 403-maatschappij in verband met een pre-pack, alvast de procedure voor de beëindiging van de overblijvende aansprakelijkheid in gang zetten. Zij kan er op die manier voor zorgen dat zo snel mogelijk na het faillissement van de 403-maatschappij - waardoor de groepsband tussen de moederen de 403-maatschappij is verbroken (zie § 8.4) - aan alle vereisten van art. 2:404 lid 3 BW wordt voldaan en de overblijvende aansprakelijkheid is beëindigd, behoudens de afwikkeling van een eventueel ingesteld verzet. 
Als de groepsband tussen de moeder- en de 403-maatschappij niet is verbroken op het moment dat de verzetstermijn verstrijkt, is de overblijvende aansprakelijkheid niet beëindigd. ${ }^{210} \mathrm{Om}$ deze aansprakelijkheid alsnog te beëindigen, moet de moedermaatschappij een nieuwe aankondiging plaatsen in een landelijk verspreid dagblad dat en waar de door haar gedeponeerde mededeling van het voornemen om de overblijvende aansprakelijkheid te beëindigen ter inzage ligt. Op dat moment begint een nieuwe verzetstermijn te lopen en heeft de moedermaatschappij opnieuw de mogelijkheid om de groepsband met de 403-maatschappij te verbreken voordat deze termijn verstrijkt. Dit betekent echter ook dat de crediteuren die eerder nog geen verzet hebben ingesteld tegen het voornemen van de moedermaatschappij om de overblijvende aansprakelijkheid te beëindigen een nieuwe mogelijkheid krijgen om dit te doen. Ik meen daarnaast dat de moedermaatschappij aan de crediteuren die eerder wel al verzet hebben ingesteld, moet laten weten dat zij de procedure om de overblijvende aansprakelijkheid te beëindigen opnieuw is gestart en tot wanneer de crediteuren daartegen verzet kunnen instellen. Als de moedermaatschappij dit nalaat, is een beroep op de beëindiging van de overblijvende aansprakelijkheid tegenover de desbetreffende crediteuren naar mijn mening onaanvaardbaar naar maatstaven van redelijkheid en billijkheid. ${ }^{211}$ De crediteuren behouden dan hun vordering op de moedermaatschappij.

\subsection{Schrappen van de voorwaarde dat de groepsband tussen de moeder- en de 403-maatschappij is verbroken}

Verschillende auteurs zijn van mening dat de voorwaarde dat de groepsband tussen de moeder- en de 403-maatschappij is verbroken, onnodig belastend is om de overblijvende aansprakelijkheid te kunnen beëindigen. ${ }^{212}$ Houwen

210. Zie Rb. Rotterdam 30 september 2014, JOR 2014/326, m.nt. Loesberg (Pergen/Eneco), r.o. 2.10-2.12, 2.14, 2.17, 4.4 en 4.9. In casu is onduidelijk of de groepsband tussen de moeder- en de 403-maatschappij daadwerkelijk is verbroken. De rechter laat dit in het midden en op basis van de gegeven feiten ten aanzien van de casus is geen eenduidig antwoord te geven (zie § 8.4). Indien zou worden aangenomen dat de groepsband tussen de moeder- en de 403-maatschappij is verbroken, is het van belang om op te merken dat dit is gebeurd twee dagen nadat de tweemaandstermijn is verlopen waarbinnen de crediteuren verzet konden instellen tegen het voornemen van de moedermaatschappij om de overblijvende aansprakelijkheid te beëindigen. Daarom is de overblijvende aansprakelijkheid mijns inziens niet verbroken. De rechtbank is hier echter niet op ingegaan. Zij heeft geoordeeld dat de overblijvende aansprakelijkheid is beëindigd maar dat het beroep van de moedermaatschappij op het verlopen van de verzetstermijn misbruik van recht is. Zie $\S 8.6 .3$ waar ik enkele kanttekeningen plaats bij deze uitspraak.

211. Zie art. 6:2 lid $2 \mathrm{BW}$.

212. Houwen, Schoonbrood-Wessels \& Schreurs 1993, p. 856-857, Beckman 1995b p. 99, Blommaert 2007, p. 276 en Van Zoest 2016a, p. 62. 
merkt op dat deze voorwaarde een overblijfsel is van het oude art. 2:403 lid $2 \mathrm{BW}$; de voorloper van de huidige regeling inzake de beëindiging van de overblijvende aansprakelijkheid. ${ }^{213}$ Op grond van die bepaling eindigde de overblijvende aansprakelijkheid van de moedermaatschappij drie jaar nadat de groepsband met de 403-maatschappij was verbroken. Volgens Houwen is de gedachte achter deze regeling dat de moedermaatschappij niet voor altijd aansprakelijk moet blijven als zij geen doorslaggevende zeggenschap meer heeft ten aanzien van de 403-maatschappij. Vanuit die optiek is het verbreken van de groepsband volgens hem geen onbegrijpelijke voorwaarde voor de beëindiging van de overblijvende aansprakelijkheid. Met de invoering van de huidige regeling van art. 2:404 lid 3 tot en met lid 6 BW zijn echter waarborgen geïntroduceerd met betrekking tot het verhaalsrecht van een crediteur tegenover de moedermaatschappij. Op grond daarvan kan een crediteur verzet instellen tegen het voornemen van de moedermaatschappij om de overblijvende aansprakelijkheid te beëindigen en een vervangende waarborg verlangen voor de voldoening van zijn vordering op de 403-maatschappij. Volgens Houwen zijn de belangen van de crediteuren zodanig gewaarborgd in de huidige regeling, dat de moedermaatschappij de overblijvende aansprakelijkheid moet kunnen beëindigen ongeacht of de groepsband met de 403-maatschappij is verbroken.

Ik sluit mij aan bij bovenstaand standpunt dat de voorwaarde dat de groepsband tussen de moeder- en de 403-maatschappij is verbroken onnodig belastend is om de overblijvende aansprakelijkheid te beëindigen. Op grond van het door mij bepleite uitgangspunt voor compensatie mag een crediteur door de beëindiging van de overblijvende aansprakelijkheid niet in een nadeliger positie komen ten opzichte van de situatie dat de overblijvende aansprakelijkheid niet zou zijn beëindigd. ${ }^{214}$ Dit betekent in de eerste plaats dat de crediteur weer de mogelijkheid moet hebben om de jaarrekening van de 403-maatschappij in te zien. Daarnaast moet hij een vervangende waarborg kunnen krijgen waardoor hij na de beëindiging (minimaal) dezelfde waarborgen heeft - uit hoofde van de vermogenstoestand van de 403-maatschappij, eventuele waarborgen uit anderen hoofde en de vervangende waarborg - dat zijn vordering op de 403-maatschappij zal worden voldaan, als de waarborgen die hij had dat zijn vordering op de moedermaatschappij zou worden voldaan. Als aan deze twee vereisten is voldaan, zou verder niets in de weg moeten staan aan de beëindiging van de overblijvende aansprakelijkheid. De voorwaarde dat de groepsband tussen de moeder- en de 403-maatschappij is verbroken, speelt ten aanzien van beide vereisten geen rol en is volgens het door mij bepleite uitgangspunt dus

213. Houwen, Schoonbrood-Wessels \& Schreurs 1993, p. 856-857. Zie $§ 2.2$ voor een bespreking van de wetsgeschiedenis van het groepsregime.

214. Zie $\S 3.6 .1$. 
overbodig. Ik betoog daarom dat deze voorwaarde moet worden geschrapt uit art. 2:404 lid $3 \mathrm{BW}$.

Dat de groepsband met de 403-maatschappij moet worden verbroken om de overblijvende aansprakelijkheid te kunnen beëindigen, kan een moedermaatschappij zelfs afschrikken om zich op grond van een 403-verklaring aansprakelijk te stellen voor de schulden die voortvloeien uit een rechtshandeling van de 403-maatschappij. Ik wijs op twee situaties die nadelig kunnen zijn voor de moedermaatschappij. Ten eerste is het mogelijk dat de 403-maatschappij binnen de groep een bepaald (deel)product in de productieketen levert. Als de groepsband met de 403-maatschappij wordt verbroken, kan dat leiden tot verlies van synergie wat negatieve gevolgen met zich brengt voor de rest van de groep. De overgebleven groepsmaatschappijen moeten het (deel)product dan voortaan van buiten de groep inkopen. Dit is waarschijnlijk duurder en minder goed afgestemd op de rest van de productieketen. Daarnaast wijs ik op de mogelijkheid dat de 403-maatschappij zich omzet in een rechtspersoon die geen gebruik mag maken van de jaarrekeningvrijstelling van het groepsregime, zoals een stichting ${ }^{215}$ of een Belgische BV. ${ }^{216}$ Bij de omzetting blijft de groepsband met de moedermaatschappij intact. Omdat de 403-maatschappij geen gebruik meer mag maken van de jaarrekeningvrijstelling zal de moedermaatschappij de 403-verklaring - als een van de voorwaarden zodat de 403-maatschappij van de vrijstelling gebruik mag maken - intrekken. Ondanks dat de moedermaatschappij aan de overige voorwaarden van art. 2:404 lid 3 BW kan en wil voldoen, kan zij de overblijvende aansprakelijkheid in dat geval niet beëindigen.

Het is niet ondenkbaar dat een moedermaatschappij besluit dat de aansprakelijkheid op grond van de 403-verklaring en de voorwaarden om deze aansprakelijkheid later te beëindigen - waaronder het verbreken van de groepsband met de 403-maatschappij- niet opwegen tegen het voordeel dat zij verwacht te behalen door zich op grond van deze verklaring aansprakelijk te stellen. Hierdoor kan de 403-maatschappij niet gebruikmaken van de jaarrekeningvrijstelling van het groepsregime. Het zou de toegankelijkheid van de jaarrekeningvrijstelling vergroten als de voorwaarde dat de groepsband tussen de moeder- en de 403-maatschappij is verbroken, wordt geschrapt uit art. 2:404 lid 3 BW.

215. Zie $\S 2.3 .4 . \mathrm{b}$ waar ik betoog dat art. 2:403 BW moet worden aangepast zodat ook stichtingen gebruik kunnen maken van de jaarrekeningvrijstelling van het groepsregime. Zie ook E.C.A. Nass 2019, p. 57.

216. Zie respectievelijk $\S 9.11$ en $\S 9.12$. 


\subsection{Conclusie}

Als een moedermaatschappij haar 403-verklaring intrekt, blijft zij aansprakelijk voor de schulden die voortvloeien uit de rechtshandelingen die de 403-maatschappij heeft verricht tot het moment dat de moedermaatschappij tegenover de crediteur een beroep kan doen op de intrekking. Ik heb geconcludeerd dat deze overblijvende aansprakelijkheid alle bestaande en toekomstige schulden omvat die voortvloeien uit de rechtshandelingen die de 403-maatschappij tot dat moment heeft verricht $(\S 8.2)$.

Als een moedermaatschappij haar overblijvende aansprakelijkheid tegenover een crediteur wil beëindigen, moet zij aan een viertal cumulatieve voorwaarden voldoen $(\S 8.3)$. Hiervoor is vereist dat de groepsband tussen de moeder- en de 403-maatschappij is verbroken $(\S 8.4)$. Daarnaast moet een mededeling van het voornemen om de overblijvende aansprakelijkheid te beëindigen twee maanden ter inzage hebben gelegen bij het handelsregister. Voorts dienen er twee maanden te zijn verlopen na de aankondiging in een landelijk verspreid dagblad dat en waar deze mededeling ter inzage ligt ( $\$ 8.5$ ). Tot slot mag tegen het voornemen van de moedermaatschappij om de overblijvende aansprakelijkheid te beëindigen geen verzet zijn ingesteld door de crediteur, dan wel moet diens verzet zijn ingetrokken of door de rechter ongegrond zijn verklaard $(\S 8.6)$.

In art. 2:404 lid 3 sub b en c BW worden geen voorwaarden genoemd met betrekking tot de informatie die een moedermaatschappij moet opnemen in haar mededeling bij het handelsregister dat zij voornemens is om de overblijvende aansprakelijkheid te beëindigen en de aankondiging daarvan in een landelijk verspreid dagblad. Ik acht het wenselijk dat aan deze bepalingen wordt toegevoegd dat een moedermaatschappij in de mededeling bij het handelsregister en de aankondiging in een landelijk verspreid dagblad expliciet melding moet maken van haar eigen naam, de naam van de 403-maatschappij en eventuele oude namen van hen indien die sinds de deponering van de 403-verklaring zijn gewijzigd. Deze toevoeging aan art. 2:404 lid 3 sub b en c BW biedt de moedermaatschappij houvast bij het opstellen van deze stukken en waarborgt dat de crediteuren aan de hand van de informatie in de stukken kunnen achterhalen of hun vordering door de beëindiging van de overblijvende aansprakelijkheid komt te vervallen $(\S 8.5 .3)$.

De mededeling bij het handelsregister en de aankondiging daarvan in een landelijk verspreid dagblad hebben tot doel dat een crediteur op de hoogte kan zijn van het voornemen van de moedermaatschappij om de overblijvende aansprakelijkheid te beëindigen, zodat de crediteur hiertegen verzet kan instellen. Aangezien het onwaarschijnlijk is dat een crediteur dagelijks alle landelijk verspreide dagbladen controleert en regelmatig ten aanzien van alle debiteuren 
nagaat of er een mededeling is gedeponeerd van het voornemen om de overblijvende aansprakelijkheid te beëindigen, is het goed mogelijk dat hij dit voornemen over het hoofd ziet. Als een crediteur geen verzet heeft ingesteld tegen de beëindiging van de overblijvende aansprakelijkheid, is deze zijn verhaalsrecht tegenover de moedermaatschappij kwijt. Om een crediteur beter in staat te stellen dat hij bekend kan zijn met het voornemen van de moedermaatschappij om de overblijvende aansprakelijkheid te beëindigen, zou de Kamer van Koophandel een systeem kunnen aanbieden waarbij derden automatisch een notificatie kunnen krijgen als met betrekking tot een bepaalde rechtspersoon stukken zijn gedeponeerd bij het handelsregister. Een crediteur kan dan instellen dat hij een bericht krijgt als de moedermaatschappij een mededeling deponeert van het voornemen om de overblijvende aansprakelijkheid te beëindigen. In dat geval kan de voorwaarde dat de moedermaatschappij een aankondiging moet plaatsen in een landelijk verspreid dagblad dat en waar deze mededeling ter inzage ligt mijns inziens worden geschrapt uit art. 2:404 lid 3 BW (§ 8.5.1 en $\S 8.5 .2)$.

Crediteuren voor wier vordering nog aansprakelijkheid loopt, kunnen verzet instellen tegen het voornemen van de moedermaatschappij om de overblijvende aansprakelijkheid te beëindigen. Dit betreft ook crediteuren met een niet-vaststaande vordering op de 403-maatschappij, tenzij de vordering onmiskenbaar ongegrond is. Daarnaast kan de houder van een openbaar pandrecht op de vordering van een crediteur op de moedermaatschappij verzet instellen (§ 8.7). Als een crediteur verzet instelt, kan hij een vervangende waarborg verlangen voor de nakoming van zijn vordering op de 403-maatschappij. Ik heb verdedigd dat een crediteur recht heeft op een vervangende waarborg als hij na de beëindiging van de overblijvende aansprakelijkheid, uit hoofde van de vermogenstoestand van de 403-maatschappij of uit anderen hoofde, niet (minimaal) dezelfde waarborgen heeft dat zijn vordering op de 403-maatschappij zal worden voldaan, als de waarborgen die hij heeft dat zijn vordering op de moedermaatschappij zal worden voldaan, tenzij de crediteur redelijkerwijs geen risico loopt dat zijn vordering op de 403-maatschappij niet zal worden voldaan (§ 8.8). Tot op heden is in de jurisprudentie een te geven vervangende waarborg telkens vastgesteld op het bedrag van de bestaande en toekomstige vorderingen van de crediteur op de 403-maatschappij. ${ }^{217}$ Op grond van het door mij bepleite uitgangspunt voor compensatie is het echter niet juist om de vervangende waarborg zonder meer op dit bedrag vast te stellen. Ik betoog dat een te geven vervangende waarborg mede moet worden vastgesteld aan de hand van de waarborgen die de crediteur al heeft, uit hoofde van de vermogenstoestand van de 403-maatschappij of uit anderen hoofde, dat zijn vordering op de 403-maatschappij zal

217. Rb. 's-Hertogenbosch 3 maart 2006, JOR 2006/201 (De Plaet/NRE), r.o. 4.2, Rb. MiddenNederland 5 november 2014, ECLI:NL:RBMNE:2014:5519 (Curatoren/SNS), r.o. 2.3, Rb. Rotterdam 29 september 2015, JOR 2015/295, m.nt. Bartman (Iemants/Hertel Beheer), r.o. 4.13-4.14 en Hof Amsterdam (OK) 9 december 2015, JOR 2016/7, m.nt. Bartman (Curatoren/SNS), r.o. 3.11. 
worden voldaan. De vervangende waarborg vult deze waarborgen die de crediteur al heeft aan. Gezamenlijk moeten de waarborgen die de crediteur heeft, uit hoofde van de vermogenstoestand van de 403-maatschappij, eventuele waarborgen uit anderen hoofde en de vervangende waarborg, (minimaal) dezelfde waarborgen bieden dat zijn vordering op de 403-maatschappij zal worden voldaan, als de waarborgen die hij heeft dat zijn vordering op de moedermaatschappij zal worden voldaan $(\S 8.9)$.

Pas als de moedermaatschappij een beroep kan doen op de intrekking van de 403-verklaring, kan zij naar mijn mening een aankondiging plaatsen in een landelijk verspreid dagblad dat en waar de door haar gedeponeerde mededeling van het voornemen om de overblijvende aansprakelijkheid te beëindigen ter inzage ligt (§ 8.12). Uiterlijk op het moment dat de tweemaandstermijn verloopt waarbinnen de crediteuren verzet kunnen instellen tegen het voornemen van de moedermaatschappij om de overblijvende aansprakelijkheid te beëindigen, moet - mijns inziens - aan alle voorwaarden voor deze beëindiging zijn voldaan, behoudens de afwikkeling van een eventueel ingesteld verzet. In welke volgorde aan de verschillende voorwaarden hiervoor wordt voldaan, maakt niet uit (§8.13).

Voorts heb ik geconcludeerd dat de voorwaarde voor de beëindiging van de overblijvende aansprakelijkheid dat de groepsband tussen de moeder- en de 403-maatschappij is verbroken, overbodig is en het onnodig belastend maakt om deze aansprakelijkheid te beëindigen. Het is daarom wenselijk dat deze voorwaarde wordt geschrapt uit art. 2:404 lid $3 \mathrm{BW}(\S 8.14)$.

Ter afsluiting van dit hoofdstuk merk ik op dat op basis van bovenstaande opmerkingen met betrekking tot de regeling van de beëindiging van de overblijvende aansprakelijkheid gedacht zou kunnen worden dat mij een regeling voor ogen staat die vooral in het voordeel is van de crediteuren. Zo ben ik van mening dat de Kamer van Koophandel een systeem zou moeten aanbieden waarbij crediteuren automatisch een notificatie kunnen krijgen als de moedermaatschappij een mededeling deponeert van het voornemen om de overblijvende aansprakelijkheid te beëindigen. Hierdoor zullen waarschijnlijk meer crediteuren verzet instellen. Daarnaast onderschrijf ik het oordeel van de Hoge Raad dat ook crediteuren met een niet-vaststaande vordering verzet kunnen instellen, tenzij de vordering onmiskenbaar ongegrond is. ${ }^{218}$ Toch staat mij een regeling voor ogen die in haar geheel gezien, het voor een moedermaatschappij minder belastend maakt om de overblijvende aansprakelijkheid te beëindigen dan tot op heden het geval is. Hoewel ik inderdaad vind dat crediteuren meer in de gelegenheid moeten worden gesteld om verzet in te stellen, meen ik ook

218. HR 31 maart 2017, JOR 2017/221, m.nt. De Haan (SNS/Curatoren), r.o. 5.1.6. 
dat het afwikkelen van verzet minder belastend moet zijn voor de moedermaatschappij. Als een moedermaatschappij de overblijvende aansprakelijkheid makkelijker kan beëindigen, is het voor haar ook minder bezwaarlijk om op grond van een 403-verklaring aansprakelijk te zijn.

De huidige lijn in de jurisprudentie is dat een te geven vervangende waarborg wordt vastgesteld op het bedrag van de bestaande en toekomstige vorderingen van de crediteur op de 403-maatschappij. Als een crediteur verzet instelt en recht heeft op een vervangende waarborg kan deze uitleg van de omvang van de waarborg ertoe leiden dat de moedermaatschappij in één keer een groot bedrag als vervangende waarborg moet geven aan de crediteur. Dit stimuleert de moedermaatschappij om de procedure voor de beëindiging van de overblijvende aansprakelijkheid zo in te steken dat de kans dat de crediteuren hiervan op de hoogte raken zo klein mogelijk is. Als een crediteur niet op de hoogte is van het voornemen van de moedermaatschappij om de overblijvende aansprakelijkheid te beëindigen, zal deze ook geen verzet instellen. De moedermaatschappij hoeft dan geen vervangende waarborg te geven en is bevrijd van haar aansprakelijkheid.

Ik leg de regeling voor de beëindiging van de overblijvende aansprakelijkheid echter zo uit dat een moedermaatschappij wordt gestimuleerd om ervoor te zorgen dat de 403-maatschappij financieel gezond is als de overblijvende aansprakelijkheid wordt beëindigd. Ik wijs op twee punten. Ten eerste meen ik dat het oordeel van de Hoge Raad in de SNS/Curatoren-beschikking ${ }^{219}$ zo moet worden uitgelegd dat een crediteur recht heeft op een vervangende waarborg als hij na de beëindiging van de overblijvende aansprakelijkheid, uit hoofde van de vermogenstoestand van de 403-maatschappij of uit anderen hoofde, niet (minimaal) dezelfde waarborgen heeft dat zijn vordering op de 403-maatschappij zal worden voldaan, als de waarborgen die hij heeft dat zijn vordering op de moedermaatschappij zal worden voldaan, tenzij de crediteur redelijkerwijs geen risico loopt dat zijn vordering op de 403-maatschappij niet zal worden voldaan.

Daarnaast meen ik dat de omvang van een te geven vervangende waarborg anders moet worden vastgesteld dan tot op heden in de jurisprudentie is gedaan. Een te geven vervangende waarborg dient mijns inziens een aanvulling te zijn op de waarborgen die de crediteur al heeft, uit hoofde van de vermogenstoestand van de 403-maatschappij of uit anderen hoofde, dat zijn vordering op de 403-maatschappij zal worden voldaan. Gezamenlijk moet dit de crediteur (minimaal) dezelfde waarborgen bieden dat zijn vordering op de 403-maatschappij zal worden voldaan, als de waarborgen die hij heeft dat zijn vordering

219. HR 31 maart 2017, JOR 2017/221, m.nt. De Haan (SNS/Curatoren), r.o. 5.1.4. Vgl. Kamerstukken II 1983/84, 16551, 11, p. 16 (NnavhEV). 
op de moedermaatschappij zal worden voldaan. Deze uitleg van de vervangende waarborg betekent dat de crediteur praktisch altijd een minder omvangrijke vervangende waarborg hoeft te worden gegeven, dan in het geval dat de huidige lijn in de jurisprudentie wordt gevolgd. Dit is slechts anders als de verwachting is dat de moedermaatschappij de vordering op grond van de 403-verklaring volledig zal voldoen en de 403-maatschappij de vordering van de crediteur in het geheel niet zal voldoen.

De door mij bepleite uitleg van het recht van een crediteur op een vervangende waarborg en de omvang van deze waarborg, stimuleren een moedermaatschappij om ervoor te zorgen dat de 403-maatschappij financieel gezond is als de overblijvende aansprakelijkheid wordt beëindigd. Hoe beter de vermogenstoestand van de 403-maatschappij, hoe minder waarschijnlijk het is dat een crediteur recht heeft op een vervangende waarborg en - indien toch een waarborg moet worden gegeven - hoe kleiner de vervangende waarborg is die de moedermaatschappij moet geven.

In aanvulling op de hierboven genoemde uitleg van het recht van een crediteur op een vervangende waarborg en de omvang van deze waarborg, meen ik ook dat de voorwaarde dat de groepsband tussen de moeder- en de 403-maatschappij is verbroken, moet worden geschrapt als vereiste om de overblijvende aansprakelijkheid te kunnen beëindigen. Hierdoor wordt het voor een moedermaatschappij eenvoudiger om de overblijvende aansprakelijkheid te beëindigen, en wordt voorkomen dat de beëindiging ten koste gaat van synergie binnen de groep. 



\title{
Hoofdstuk 9. Fusie, splitsing en omzetting
}

\author{
$9.1 \quad$ Inleiding
}

Als een moeder- of een 403-maatschappij fuseert of splitst, ${ }^{1}$ roept dit verschillende vragen op met betrekking tot de aansprakelijkheid op grond van de 403-verklaring. Kan er na de fusie of de splitsing nog nieuwe aansprakelijkheid ontstaan op grond van deze verklaring? Wat gebeurt er met de bestaande aansprakelijkheid? En is het nog mogelijk om na het intrekken van de 403-verklaring de overblijvende aansprakelijkheid te beëindigen? Deze en andere vragen komen in dit hoofdstuk aan de orde.

Ten eerste onderzoek ik of de 403-aansprakelijkheid van de moedermaatschappij onder algemene titel kan overgaan op een verkrijgende rechtspersoon (§ 9.2). Daarna ga ik in op het recht van een crediteur ex art. 2:316 lid 2 BW, respectievelijk art. 2:3341 $\mathrm{BW}$ om in verzet te komen tegen een voorstel tot fusie of splitsing van de moeder- of de 403-maatschappij. Als een crediteur in verzet komt, kan hij op grond van art. 2:316 lid $1 \mathrm{BW}$, respectievelijk art. 2:334k BW verlangen dat hem een waarborg wordt gegeven voor de voldoening van zijn vordering. Een crediteur heeft geen recht op een waarborg als hij al voldoende waarborgen heeft of de vermogenstoestand van de rechtspersoon die na de fusie of de splitsing zijn debiteur zal zijn niet minder waarborgen zal bieden dat de vordering zal worden voldaan, dan de vermogenstoestand van zijn huidige debiteur. Ik onderzoek hoe de aansprakelijkheid van de moedermaatschappij op grond van de 403-verklaring van invloed is op het recht van de crediteur om in verzet te komen en of hij recht heeft op een waarborg voor de voldoening van zijn vordering $(\S 9.3)$.

Vervolgens ga ik in op de voorwaarde ex art. 2:404 lid 3 sub a BW voor de beëindiging van de overblijvende aansprakelijkheid dat de groepsband tussen de moeder- en de 403-maatschappij is verbroken. Ik onderzoek hoe deze voorwaarde moet worden uitgelegd in het licht van een fusie of een splitsing van de moeder- of de 403-maatschappij (§ 9.4).

1. Ik richt mij in dit hoofdstuk alleen op de juridische fusie, zuivere splitsing en afsplitsing in de zin van art. 2:309 en art. 2:334a BW. Ik ga niet in op een fusie of een (af)splitsing door middel van de overdracht van aandelen of door de overdracht van activa en passiva. 


\section{HOOFDSTUK 9}

Voorts werk ik verschillende casus uit waarbij de moeder- of de 403-maatschappij fuseert of splitst. Met betrekking tot splitsing behandel ik zowel de zuivere splitsing als de afsplitsing. Ik pretendeer niet uitputtend te zijn in de bespreking van de casus. Er is een veelheid aan casus denkbaar waarbij de moeder- of de 403-maatschappij fuseert of splitst. Ik beperk mij tot enkele 'standaard'-casus om de hoofdlijnen van de gevolgen van een fusie, zuivere splitsing of afsplitsing voor de aansprakelijkheid op grond van een 403 -verklaring te onderzoeken. ${ }^{2}$ De eerste casus die ik bespreek betreft een fusie van de moeder- of de 403-maatschappij waarbij deze het vermogen van een andere (verdwijnende) rechtspersoon verkrijgt (§9.6). Vervolgens komt een fusie aan de orde waarbij de moeder- of de 403-maatschappij ophoudt te bestaan ( 9.7 en $\S 9.8$ ). Tot slot ga ik in op een zuivere splitsing en een afsplitsing van de moeder- of de 403-maatschappij ( 99.9 en $\S 9.10)$. Voor de duidelijkheid introduceer ik iedere casus met een afbeelding waarmee ik het resultaat laat zien van de desbetreffende fusie of splitsing van de moeder- of de 403-maatschappij.

Voor ieder van bovengenoemde casus onderzoek ik welke partij na de fusie of de splitsing op grond van de 403-verklaring aansprakelijk is voor de schulden die voortvloeien uit de rechtshandelingen die de 403-maatschappij tot dat moment heeft verricht. Daarnaast ga ik na of er na de fusie of de splitsing nog nieuwe aansprakelijkheid op grond van deze verklaring kan ontstaan. Tot slot onderzoek ik of het mogelijk is om na de fusie of de splitsing de 403-verklaring in te trekken en de overblijvende aansprakelijkheid te beëindigen. Met betrekking tot de beëindiging van de overblijvende aansprakelijkheid richt ik mij in het bijzonder op het antwoord op de vraag of door de fusie of de splitsing is voldaan aan het vereiste ex art. 2:404 lid 3 sub a BW dat de groepsband tussen de moeder- en de 403-maatschappij is verbroken.

Tot slot ga ik op het einde van dit hoofdstuk nog in op een omzetting van de moeder- of de 403-maatschappij ( $\$ 9.11$ ), en een grensoverschrijdende fusie, splitsing of omzetting van de moeder- of de 403-maatschappij (§9.12). Ik onderzoek of de 403-maatschappij nadien nog steeds gebruik kan blijven maken van de jaarrekeningvrijstelling.

Tenzij anders vermeld, ga ik er bij de bespreking van de verschillende casus van uit dat een verkrijgende rechtspersoon op wie (een deel van) het vermogen van de moeder- of de 403-maatschappij bij een fusie of splitsing overgaat, niet gebruikmaakt van de jaarrekeningvrijstelling van het groepsregime of aansprakelijk is op grond van een 403 -verklaring. Ik laat deze mogelijkheid buiten beschouwing omdat hierdoor duidelijker de gevolgen van een fusie of een

2. Ik ga bijvoorbeeld niet in op een driehoeksfusie of - splitsing. Zie daarvoor E.C.A. Nass 2019, p. 169-170, 179-180, 182-183 en 185-186. 
splitsing van de moeder- of de 403-maatschappij voor de 403-aansprakelijkheid uiteen kunnen worden gezet.

\subsection{Overgang onder algemene titel van de 403-aansprakelijkheid}

\subsubsection{Het vermogen gaat onder algemene titel over}

De minister merkt op dat alle activa en passiva van een rechtspersoon als onderdeel van zijn vermogen door een juridische fusie of splitsing onder algemene titel kunnen overgaan op een verkrijgende rechtspersoon. ${ }^{3}$ Dit betreft alle rechten en verplichtingen van deze rechtspersoon waaronder ook zijn positie bij een rechtsverhouding - zoals een (duur)overeenkomst. Slechts persoonlijke rechten gaan volgens de minister niet onder algemene titel over. ${ }^{4}$ Een bestuurder of commissaris van een rechtspersoon die door een fusie of een zuivere splitsing verdwijnt, wordt bijvoorbeeld niet automatisch bestuurder of commissaris van de verkrijgende rechtspersoon. ${ }^{5}$ Ook actieve en passieve benoemingsrechten voor bestuurders en doorlopende volmachten die niet verbonden zijn aan een vermogensbestanddeel zijn volgens de minister niet vatbaar voor overgang onder algemene titel. ${ }^{6}$

In de literatuur wordt aangenomen dat de overgang onder algemene titel van (een deel van) het vermogen van een rechtspersoon met zich brengt dat de verkrijgende rechtspersoon alle vermogensbestanddelen overneemt tenzij de wet, de statuten, de daaraan ten grondslag liggende overeenkomst of de aard van de rechtsverhouding zich daartegen verzetten. ${ }^{7}$ Verschillende auteurs merken op dat een rechtsverhouding naar haar aard niet voor overgang onder algemene titel vatbaar is als deze een hoogstpersoonlijk karakter heeft en zodanig eigen is aan de desbetreffende rechtspersoon - van wie het vermogen overgaat -,

3. Kamerstukken II 1983/84, 18285, 3, p. 4 (MvT) en Kamerstukken II 1995/96, 24702, 3, p. 5 (MvT).

4. Kamerstukken II 1983/84, 18285, 3, p. 4 (MvT). Zie ook Kamerstukken II 1985/86, 18285, 6 , p. 8 (MvA), waar de minister opmerkt dat een rechtspersoon geen rechten of verplichtingen heeft die zodanig persoonsgebonden zijn dat ze niet onder algemene titel mee over kunnen gaan. Zie Verstappen 1996, p. 273 en Verstappen 2002, p. 68, die opmerkt dat de minister zichzelf tegenspreekt.

5. Kamerstukken II 1995/96, 24702, 6, p. 4 (NnavhV). Zie Van Solinge 1994, p. 74, Verstappen 2002, p. 70, Zaman, Van Eck \& Roelofs 2009, p. 272 en Van Eck - SDU Commentaar Ondernemingsrecht 2019, art. 2:309 BW, aant. C.2.4, die opmerken dat dit niet wegneemt dat een eventuele arbeidsovereenkomst tussen de verdwijnende rechtspersoon en de bestuurder of commissaris wél overgaat.

6. Kamerstukken II 1995/96, 24702, 6, p. 15-16 (NnavhV).

7. Van Solinge 1994, p. 67 en 70, Verstappen 1996, p. 279, Verstappen 2002, p. 71, Van Olffen, Buijn \& Simonis 2004, p. 98, Zaman, Van Eck \& Roelofs 2009, p. 268, Van Eck - SDU Commentaar Ondernemingsrecht 2019, art. 2:309 BW, aant. C.2 en Holtman 2019, p. 157. 
dat zij niet zonder deze rechtspersoon kan bestaan. ${ }^{8}$ De rechtsverhouding kan dan niet ongewijzigd overgaan op de verkrijgende rechtspersoon. Een voorbeeld van een rechtsverhouding die naar haar aard niet vatbaar is voor een overgang onder algemene titel is de functie die een rechtspersoon heeft als bestuurder van een andere rechtspersoon. ${ }^{9}$ De verkrijgende rechtspersoon op wie het vermogen overgaat, neemt deze bestuursfunctie niet over. Ook vergunningen die aan een rechtspersoon zijn uitgegeven, kunnen onder omstandigheden naar hun aard niet vatbaar zijn voor overgang onder algemene titel. ${ }^{10,11}$

\subsubsection{Overgang onder algemene titel van de 403-aansprakelijkheid}

In de literatuur bestaat discussie over het antwoord op de vraag of de 403-aansprakelijkheid van de moedermaatschappij onder algemene titel kan overgaan op een verkrijgende rechtspersoon. Het staat niet ter discussie dat de aansprakelijkheid van de moedermaatschappij op grond van de 403-verklaring onderdeel is van het vermogen van de moedermaatschappij. Het betreft een rechtsverhouding tussen de moedermaatschappij en de crediteuren - van de 403-maatschappij - op grond waarvan de moedermaatschappij aansprakelijk is voor de schulden die voortvloeien uit een rechtshandeling van de 403-maatschappij. Het is echter de vraag of de aard van deze aansprakelijkheid zich verzet tegen een overgang onder algemene titel.

Er zijn in de literatuur drie standpunten te onderscheiden met betrekking tot het antwoord op bovenstaande vraag. Ten eerste wordt verdedigd dat de 403-aansprakelijkheid niet onder algemene titel kan overgaan op een verkrijgende rechtspersoon. ${ }^{12}$ Onder meer Portengen en Crouwers zijn van mening dat de 403-aansprakelijkheid een hoogstpersoonlijk karakter heeft en specifiek betrekking heeft op de moedermaatschappij. Zij wijzen hiervoor op het eenzijdige

8. Van Solinge 1994, p. 73-74, Verstappen 1996, p. 274-275 en 279, Verstappen 2002, p. 71, Van Olffen, Buijn \& Simonis 2004, p. 98, Zaman, Van Eck \& Roelofs 2009, p. 271 en Van Eck - SDU Commentaar Ondernemingsrecht 2019, art. 2:309 BW, aant. C.2.4.

9. Verstappen 1996, p. 275, Van Olffen, Buijn \& Simonis 2004, p. 99 en Zaman, Van Eck \& Roelofs 2009, p. 272-273. Zie ook Van Solinge 1994, p. 74, die van mening is dat de functie die een rechtspersoon - die door een fusie ophoudt te bestaan - heeft als bestuurder van een andere rechtspersoon, geen vermogensbestanddeel is en daarom niet onder algemene titel op de verkrijgende rechtspersoon overgaat.

10. Zie Van Olffen, Buijn \& Simonis 2004, p. 99, die verwijzen naar CBb 26 september 1990, KG 1990/367 (Taxibedrijf Mart Hof), r.o. 6.3-6.4, waar is geoordeeld dat de aan een taxibedrijf verstrekte taxivergunning bij de fusie niet onder algemene titel op de verkrijgende rechtspersoon is overgegaan.

11. Zie voor een overzicht van vermogensbestanddelen die al of niet onder algemene titel overgaan Wessels 1997, p. 179-180 en Koster, in: GS Rechtspersonen, art. 2:309 BW, aant. 7.

12. Portengen \& Crouwers 2005, p. 44-45, Zaman, Van Eck \& Roelofs 2009, p. 281, Van Eck - SDU Commentaar Ondernemingsrecht 2019, art. 2:309 BW, aant. C.2.7, Holtman 2019, p. 158 en Raaijmakers \& Van der Sangen, in: GS Rechtspersonen, art. 2:316 BW, aant. 7. 
karakter van de 403-verklaring en de mogelijkheid om deze op ieder moment weer in te trekken. ${ }^{13}$ Enkel in het geval dat een crediteur de moedermaatschappij al aansprakelijk heeft gesteld op grond van de 403-verklaring, kan de desbetreffende schuld van de moedermaatschappij volgens deze auteurs onder algemene titel op een verkrijgende rechtspersoon overgaan. Voor het overige vervalt de 403-aansprakelijkheid als de moedermaatschappij door een fusie of een zuivere splitsing ophoudt te bestaan - in het geval van een afsplitsing blijft de moedermaatschappij bestaan en blijft zij dus ook aansprakelijk op grond van de 403-verklaring. De auteurs die dit standpunt verdedigen zijn van mening dat de crediteuren - die de moedermaatschappij nog niet aansprakelijk hebben gesteld op grond van de 403-verklaring - hierdoor niet worden benadeeld omdat zij op grond van art. 2:316 BW, respectievelijk art. 2:334k jo. art. 2:3341 BW in verzet kunnen komen tegen het voorstel tot fusie of splitsing van de moedermaatschappij en een vervangende waarborg kunnen verlangen voor de voldoening van hun vordering. ${ }^{14}$

Evenals Verbrugh kan ik mij niet vinden in de verwijzing naar het recht van een crediteur om in verzet te komen tegen het voorstel tot fusie of splitsing van de moedermaatschappij. ${ }^{15} \mathrm{Als}$ een crediteur in verzet komt, kan hij verlangen dat hem een waarborg wordt gegeven voor de voldoening van zijn vordering. De crediteur heeft hier geen recht op als hij al voldoende waarborgen heeft of de vermogenstoestand van de verkrijgende rechtspersoon niet minder waarborg zal bieden dat de vordering zal worden voldaan dan de vermogenstoestand van de moedermaatschappij. Als de 403-aansprakelijkheid van de moedermaatschappij echter niet onder algemene titel overgaat op de verkrijgende rechtspersoon, vervalt de vordering van de crediteur. De vergelijking tussen de waarborgen die de vermogenstoestand van de moedermaatschappij en de verkrijgende rechtspersoon bieden dat deze vordering van zal worden voldaan, gaat dus niet op.

Ik ben het daarnaast niet eens met bovenstaande opmerking dat een schuld van de moedermaatschappij op grond van de 403-verklaring alleen onder algemene titel kan overgaan op een verkrijgende rechtspersoon, als de crediteur de moedermaatschappij voor de fusie of de splitsing al aansprakelijk heeft gesteld op grond van deze verklaring. Ik wijs erop dat de Hoge Raad in zijn Akzo/INGbeschikking heeft geoordeeld dat een moedermaatschappij op grond van de 403-verklaring rechtstreeks aansprakelijk is voor de schulden die voortvloeien

13. Portengen \& Crouwers 2005, p. 44. Portengen en Crouwers noemen echter niet waarom het eenzijdige karakter van de 403-verklaring en de mogelijkheid om deze verklaring in te trekken met zich brengen dat de 403 -aansprakelijkheid een hoogstpersoonlijk karakter heeft en specifiek betrekking heeft op de moedermaatschappij.

14. Portengen \& Crouwers 2005, p. 44-45, Zaman, Van Eck \& Roelofs 2009, p. 281, Van EckSDU Commentaar Ondernemingsrecht 2019, art. 2:309 BW, aant. C.2.7 en Holtman 2019, p. 158.

15. Verbrugh 2007, p. 101. 
uit een rechtshandeling van de 403-maatschappij. ${ }^{16}$ Deze aansprakelijkheid ontstaat dus niet pas als de crediteur de moedermaatschappij aansprakelijk stelt. ${ }^{17}$

Het tweede standpunt ten aanzien van de overgang van de 403-aansprakelijkheid houdt in dat als de moedermaatschappij door een fusie of een zuivere splitsing verdwijnt, de aansprakelijkstelling op grond van de 403 -verklaring voor de toekomst zijn effect verliest - bij een afsplitsing blijft de moedermaatschappij bestaan en blijft de ansprakelijkstelling op grond van de 403-verklaring voor de toekomst van kracht. ${ }^{18}$ De verkrijgende rechtspersoon is niet aansprakelijk voor de schulden die voortvloeien uit de rechtshandelingen die de 403-maatschappij vanaf het moment van de fusie of de zuivere splitsing van de moedermaatschappij verricht. De aansprakelijkheid van de moedermaatschappij voor de schulden die voortvloeien uit de rechtshandelingen die de 403-maatschappij tot dat moment heeft verricht, gaat wel onder algemene titel over op de verkrijgende rechtspersoon.

Ik kan mij niet vinden in bovenstaande twee standpunten. Ik sluit mij aan bij onder meer Beckman, Verbrugh en Nass die betogen dat de aansprakelijkheid van een moedermaatschappij op grond van een 403-verklaring wel onder algemene titel kan overgaan op een verkrijgende rechtspersoon. ${ }^{19}$ Verbrugh merkt op dat bij een fusie of een splitsing niet slechts vermogen overgaat, maar dat de verkrijgende rechtspersoon de rechtspositie voortzet van degene van wie het vermogen is overgegaan. ${ }^{20} \mathrm{Hij}$ wijst erop dat de verkrijgende rechtspersoon bijvoorbeeld de contractuele rechtspositie voortzet en bij juridische procedures in de plaats treedt van de rechtspersoon van wie het vermogen is overgegaan. Ik deel zijn mening dat de 403-verklaring na de fusie of de splitsing van de moedermaatschappij heeft te gelden als verklaring van de verkrijgende rechtspersoon.

16. HR 28 juni 2002, $N J 2002 / 447$, m.nt. Maeijer (Akzo/ING), r.o. 3.4.3. Ook gepubliceerd in JOR 2002/136, m.nt. Bartman.

17. Zie ook $\S 6.2 .5$ met betrekking tot de duiding van het verhaalsrecht op grond van de 403 -verklaring als een 'wilsrecht'.

18. Van Olffen, Buijn \& Simonis 2004, p. 89-90. Ik merk op dat Van Olffen, Buijn en Simonis slechts de zuivere splitsing en de afsplitsing van een moedermaatschappij behandelen. Hetzelfde geldt naar mijn mening mutatis mutandis voor een fusie van de moedermaatschappij.

19. Beckman 1995a, p. 618, Verbrugh 2006, p. 52, Verbrugh 2007, p. 100-101, Van der Kraan 2012, p. 95-98 en 146-147, E.C.A. Nass 2019, p. 170-171, 178 en 189 en Beckman - Compendium jaarrekening, § 3.8.3.40. Zie ook mijn eerdere bijdrage over dit onderwerp Van Dooren 2018b. Zie Asser/Maeijer \& Kroeze 2-I* 2015/585, waar dit standpunt ook lijkt te worden ingenomen met de opmerking dat de verkrijgende rechtspersoon na de fusie of de splitsing de 403-verklaring kan intrekken.

20. Verbrugh 2006, p. 52 en Verbrugh 2007, p. 100. 
Mijns inziens blijkt uit de functie die de ansprakelijkheid van een moedermaatschappij op grond van een 403-verklaring vervult bij de compensatie van de crediteuren voor het niet kunnen inzien van de jaarrekening van de 403-maatschappij, dat deze aansprakelijkheid geen hoogstpersoonlijk karakter heeft en niet zodanig eigen is aan de moedermaatschappij dat deze niet zonder haar kan bestaan. De 403-aansprakelijkheid heeft tot doel dat de crediteuren een aanvullende vordering krijgen op een andere debiteur - de moedermaatschappij - van wie zij de geconsolideerde jaarrekening wel kunnen inzien. Een crediteur kan (mede) aan de hand van de geconsolideerde jaarrekening schatten hoe groot het risico is dat zijn vordering op de moedermaatschappij niet (volledig) wordt voldaan. Het is uiteindelijk aan de crediteur zelf of hij dit risico accepteert of niet. ${ }^{21}$ Voor de compensatie van de crediteuren van de 403-maatschappij is het daarom van belang dat zij een vordering krijgen op een rechtspersoon die een geconsolideerde jaarrekening deponeert. Dat de wetgever niet een specifieke rechtspersoon op het oog heeft die zich op grond van een 403-verklaring aansprakelijk moet stellen en een geconsolideerde jaarrekening moet deponeren, blijkt ook uit het feit dat de 403-verklaring kan worden gedeponeerd door iedere rechtspersoon binnen de groep - waartoe de 403-maatschappij behoort -, die de financiële gegevens van de 403-maatschappij kan consolideren in een geconsolideerde jaarrekening. ${ }^{22}$ Dit hoeft dus niet per se de rechtspersoon te zijn die rechtstreeks de aandelen in de 403-maatschappij houdt. Stel bijvoorbeeld dat een groep verschillende 'lagen' heeft met een groepsmaatschappij, moedermaatschappij, grootmoedermaatschappij en overgrootmoedermaatschappij. Als de groepsmaatschappij gebruik wil maken van de jaarrekeningvrijstelling van het groepsregime kunnen de moeder-, grootmoeder- en overgrootmoedermaatschappij alle drie voldoen aan de vereisten van de aansprakelijkstelling door middel van een 403-verklaring en de deponering van een geconsolideerde jaarrekening - waarbij vanzelfsprekend maar door een van hen aan deze voorwaarden hoeft te worden voldaan.

Het standpunt dat de 403-aansprakelijkheid van de moedermaatschappij onder algemene titel kan overgaan op een verkrijgende rechtspersoon sluit ook aan bij het door mij bepleite uitgangspunt voor compensatie. De compensatie die een crediteur ontvangt doordat hij zich op grond van de 403-verklaring op de moedermaatschappij kan verhalen, mag niet zomaar vervallen. Dat zou hetzelfde gevolg hebben als een beëindiging van deze aansprakelijkheid buiten art. 2:404 $\mathrm{BW}^{23} \mathrm{om}$. De crediteur kan dan geen beroep doen op de procedures en waarborgen uit deze bepaling die beogen zijn verhaalsrecht te beschermen. ${ }^{24}$ Hij kan dan onder meer geen verzet instellen tegen de beëindiging en

21. Zie $\S 3.4 .1$.

22. Zie art. 2:406 BW en $\S 2.3 .5$.

23. Zie hoofdstuk 7 en 8 met betrekking tot de intrekking van de 403-verklaring en de beëindiging van de overblijvende aansprakelijkheid.

24. Verbrugh 2006, p. 52 en Verbrugh 2007, p. 101. 
verlangen dat hem een vervangende waarborg wordt gegeven. De crediteur kan hierdoor in een nadeliger positie komen zonder dat hij daar invloed op heeft. ${ }^{25}$

Ik wijs erop dat het mogelijk is dat een verkrijgende rechtspersoon op wie de 403-aansprakelijkheid onder algemene titel zal overgaan minder waarborg zal bieden dat de vordering van een crediteur op grond van de 403-verklaring zal worden voldaan. In een dergelijk geval kan de crediteur op grond van art. 2:316 BW, respectievelijk art. 2:334l jo. art. 2:334k BW in verzet komen tegen de voorgestelde fusie of splitsing van de moedermaatschappij en kan hij verlangen dat hem een waarborg wordt gegeven voor de voldoening van zijn vordering. ${ }^{26}$ Hierdoor heeft een crediteur de mogelijkheid om te waarborgen dat de compensatie die hij ontvangt uit hoofde van zijn vordering op grond van de 403 -verklaring niet tegen zijn wil wordt aangetast.

\subsubsection{Onderscheid tussen overgang van de bestaande en toekomstige 403-aansprakelijkheid}

Naar mijn mening staat de overgang van de bestaande aansprakelijkheid van een moedermaatschappij op grond van een 403-verklaring ten tijde van de fusie of de splitsing, los van de overgang van de 403-aansprakelijkheid voor de toekomst. De moedermaatschappij is op het moment van de fusie of de splitsing op grond van de 403-verklaring aansprakelijk voor de schulden die voortvloeien uit de rechtshandelingen die de 403-maatschappij tot dat moment heeft verricht. Dit zijn naar mijn mening zelfstandige vermogensbestanddelen van de moedermaatschappij die onafhankelijk van elkaar en onafhankelijk van de toekomstige 403-aansprakelijkheid kunnen overgaan op een verkrijgende rechtspersoon. ${ }^{27}$ Deze mogelijke zelfstandige overgang onder algemene titel speelt geen rol als de moedermaatschappij fuseert waarbij haar vermogen overgaat op een verkrijgende rechtspersoon. In dat geval neemt de verkrijgende rechtspersoon het volledige vermogen van de moedermaatschappij over, waaronder zowel de bestaande als de toekomstige aansprakelijkheid op grond van de 403-verklaring.

Bij een zuivere splitsing of een afsplitsing van de moedermaatschappij moet daarentegen in de splitsingsakte zijn opgenomen welke vermogensbestanddelen op welke verkrijgende rechtspersoon zijn overgegaan of zijn achtergebleven

25. Zie $\S 3.6 .1$.

26. Portengen \& Crouwers 2005, p. 45, Verbrugh 2006, p. 53, Verbrugh 2007, p. 101, 268 en 270, E.C.A. Nass 2019, p. 165-166 en Raaijmakers \& Van der Sangen, in: GS Rechtspersonen, art. 2:316 BW, aant. 7. Vgl. Van der Kraan 2012, p. 111-112.

27. Art. 2:334j BW, op grond waarvan een rechtsverhouding waarbij een splitsende rechtspersoon partij is slechts in haar geheel mag overgaan, is om die reden niet van toepassing op een overgang onder algemene titel van de aansprakelijkheid van een moedermaatschappij op grond van een 403 -verklaring. 
bij de moedermaatschappij. ${ }^{28}$ Ik meen dat het daarom bijvoorbeeld mogelijk is dat bij een zuivere splitsing van de moedermaatschappij een deel van de bestaande aansprakelijkheid op grond van de 403-verklaring is overgegaan op de ene verkrijgende rechtspersoon, en dat de rest van de bestaande 403-aansprakelijkheid en de toekomstige 403-aansprakelijkheid zijn overgegaan op de andere verkrijgende rechtspersoon.

Dit kan tot een onwenselijke situatie leiden voor eerstgenoemde verkrijgende rechtspersoon. $\mathrm{Na}$ de zuivere splitsing heeft de 403 -verklaring te gelden als verklaring van de andere verkrijgende rechtspersoon op wie de toekomstige 403-aansprakelijkheid is overgegaan. Het leidt geen twijfel dat de verkrijgende rechtspersoon op wie de toekomstige 403-aansprakelijkheid is overgegaan de 403 -verklaring kan intrekken. Het is echter de vraag of de verkrijgende rechtspersoon op wie slechts een deel van de bestaande 403-aansprakelijkheid is overgegaan, deze verklaring kan intrekken. Als deze vraag ontkennend wordt beantwoord, houdt dat in dat deze verkrijgende rechtspersoon afhankelijk is van de andere verkrijgende rechtspersoon om de 403 -verklaring in te trekken, als hij de overblijvende aansprakelijkheid wil beëindigen.

Overigens is het niet waarschijnlijk dat bovengenoemde situatie zich zal voordoen. Als partijen willen dat een deel van de 403-aansprakelijkheid op de ene verkrijgende rechtspersoon overgaat en een ander deel van de 403-aansprakelijkheid op de andere verkrijgende rechtspersoon, dan moet dat expliciet in de splitsingsakte zijn opgenomen. Het ligt voor de hand dat de moedermaatschappij in een dergelijk geval - als onderdeel van de voorbereiding voor de splitsing - de 403-verklaring voorafgaand aan de splitsing intrekt. De verkrijgende rechtspersonen kunnen dan zelfstandig het gedeelte van de overblijvende aansprakelijkheid dat op hen is overgegaan, beëindigen - indien aan de voorwaarden daarvoor wordt voldaan. Als de 403-maatschappij gebruik wil blijven maken van de jaarrekeningvrijstelling van het groepsregime - als groepsmaatschappij van een van de verkrijgende rechtspersonen - zal er wel een nieuwe 403-verklaring ten aanzien van haar moeten worden gedeponeerd.

Ik laat het onderscheid tussen de bestaande en de toekomstige 403-aansprakelijkheid verder buiten beschouwing. Tenzij anders vermeld, ga ik er in het vervolg van dit onderzoek van uit dat alle aansprakelijkheid op grond van de 403-verklaring op dezelfde partij rust.

28. Zie art. 2:334n lid 2 jo. art. 2:334f lid 2 sub d BW. 


\section{HOOFDSTUK 9}

\subsubsection{Overgang onder algemene titel van de overblijvende aansprakelijkheid}

Hetgeen ik in de voorgaande paragrafen heb opgemerkt met betrekking tot de overgang onder algemene titel van de 403-aansprakelijkheid op een verkrijgende rechtspersoon, geldt naar mijn mening ook ten aanzien van de overblijvende ansprakelijkheid van de moedermaatschappij als zij de 403-verklaring voor de fusie of de splitsing heeft ingetrokken. ${ }^{29}$ Dit betekent dat de verkrijgende rechtspersoon na de fusie of de splitsing aansprakelijk is voor de schulden die voortvloeien uit de rechtshandelingen die de 403-maatschappij heeft verricht tot het moment dat de moedermaatschappij tegenover de crediteur een beroep heeft kunnen doen op de intrekking van de 403 -verklaring. ${ }^{30}$

\subsection{Verzet tegen het voorstel tot fusie of splitsing}

\subsubsection{Het recht om in verzet te komen en een waarborg te verlangen}

Als een rechtspersoon een voorstel doet tot fusie of splitsing, kunnen de crediteuren op grond van art. 2:316 lid $2 \mathrm{BW}$, respectievelijk art. 2:3341 BW tegen dit voorstel in verzet komen. Als een crediteur in verzet komt, kan hij op grond van art. 2:316 lid $1 \mathrm{BW}$, respectievelijk art. 2:334k BW verlangen dat hem een waarborg wordt gegeven voor de voldoening van zijn vordering. Een crediteur heeft hier geen recht op als hij al voldoende waarborgen heeft of de vermogenstoestand van de rechtspersoon die na de fusie of de splitsing zijn debiteur zal zijn, niet minder waarborg zal bieden dat de vordering zal worden voldaan dan de vermogenstoestand van de rechtspersoon die zijn huidige debiteur is.

Als een moedermaatschappij een voorstel doet tot fusie of splitsing, kunnen (ook) de crediteuren met een vordering op grond van de 403-verklaring hiertegen in verzet komen. ${ }^{31}$

In het geval dat een 403-maatschappij een voorstel doet tot fusie of splitsing en een crediteur hiertegen in verzet komt, moet de vraag of de crediteur recht heeft op een waarborg voor de voldoening van zijn vordering mijns inziens niet worden beantwoord aan de hand van de waarborg die de vermogenstoestand van de (rechtsopvolger van de) 403-maatschappij biedt dat de vordering zal worden voldaan. In plaats daarvan moet deze vraag worden beantwoord

29. Zie art. 2:404 lid $2 \mathrm{BW}$ en $\S 8.2$.

30. Beckman 1995a, p. 618-619.

31. Portengen \& Crouwers 2005, p. 45, Verbrugh 2006, p. 53, Verbrugh 2007, p. 101, 268 en 270, E.C.A. Nass 2019, p. 176 en Raaijmakers \& Van der Sangen, in: GS Rechtspersonen, art. 2:316 BW, aant. 7. Vgl. Van der Kraan 2012, p. 111-112. 
aan de hand van de waarborg die de vermogenstoestand van de moedermaatschappij biedt dat de vordering van de crediteur op grond van de 403-verklaring zal worden voldaan. Aangezien de 403-maatschappij gebruikmaakt van de jaarrekeningvrijstelling van het groepsregime kan de crediteur de jaarrekening van de 403-maatschappij niet inzien en (mede) aan de hand daarvan schatten hoe groot het risico is dat zijn vordering niet (volledig) zal worden voldaan. ${ }^{32}$ Ter compensatie van dit gebrek aan inzicht heeft de crediteur op grond van de 403-verklaring ook een vordering op de moedermaatschappij en kan hij de geconsolideerde jaarrekening van de moedermaatschappij inzien. ${ }^{33}$ Hij heeft dus wel de mogelijkheid om (mede) aan de hand van deze geconsolideerde jaarrekening te schatten hoe groot het risico is dat zijn vordering op de moedermaatschappij niet (volledig) zal worden voldaan.

Het risico dat een crediteur (onbewust) accepteert als hij een relatie met de 403-maatschappij aangaat en continueert, is het risico dat zijn vordering op de moedermaatschappij niet (volledig) zal worden voldaan. Volgens het door mij bepleite uitgangspunt voor compensatie moet de vraag of een crediteur recht heeft op een waarborg voor de voldoening van zijn vordering daarom niet worden beantwoord aan de hand van de waarborg die de vermogenstoestand van de (rechtsopvolger van de) 403-maatschappij voor en na de fusie of de splitsing biedt dat de vordering van de crediteur zal worden voldaan. In plaats daarvan moet deze vraag worden beantwoord aan de hand van de waarborg die de vermogenstoestand van de moedermaatschappij voor en na de fusie of de splitsing - van de 403-maatschappij - biedt dat de vordering op grond van de 403-verklaring zal worden voldaan.

Mijns inziens moeten art. 2:316 lid $1 \mathrm{BW}$ en art. 2:334k BW in het licht van bovenstaande overwegingen worden uitgelegd. Dit houdt in dat een crediteur die in verzet komt tegen een voorstel tot fusie of splitsing van de 403-maatschappij, geen recht heeft op een waarborg voor de voldoening van zijn vordering als hij al voldoende waarborgen heeft of de vermogenstoestand van de moedermaatschappij na de fusie of de splitsing niet minder waarborg zal bieden dat de vordering op grond van de 403-verklaring zal worden voldaan, dan de waarborg die de vermogenstoestand van de moedermaatschappij voor de fusie of de splitsing biedt dat deze vordering zal worden voldaan. Als een crediteur recht heeft op een waarborg voor de voldoening van zijn vordering, moet hem een waarborg worden gegeven met betrekking tot de voldoening van zijn vordering op de moedermaatschappij op grond van de 403-verklaring en niet zijn vordering op de 403-maatschappij.

32. Zie Brat 2002, p. 170, Zaman, Van Eck \& Roelofs 2009, p. 69 en 142 en Vrielink \& Kuipers 2017 , p. 96, die opmerken dat de 403-maatschappij ook is vrijgesteld van de verplichting ex art. 2:314 lid $1 \mathrm{BW}$, respectievelijk art. 2:334h lid $1 \mathrm{BW}$ om de laatste drie vastgestelde jaarrekeningen en andere financiële stukken van zichzelf openbaar te maken.

33. Zie $\S 3.4 .1$. 
Bovenstaande uitleg van de norm of een crediteur recht heeft op een waarborg voor de voldoening van zijn vordering, geldt mijns inziens ook in het geval dat een crediteur van een rechtspersoon van wie (een deel van) het vermogen door een fusie of een splitsing onder algemene titel zal overgaan op de 403-maatschappij, in verzet komt tegen het voorstel voor deze fusie of splitsing. Ook voor een dergelijke crediteur geldt dat hij de jaarrekening van de 403-maatschappij niet kan inzien en ter compensatie daarvan na de fusie of de splitsing op grond van de 403-verklaring een vordering op de moedermaatschappij zal krijgen - mits de vordering voortvloeit uit een rechtshandeling van de rechtspersoon van wie het vermogen overgaat op de 403-maatschappij. ${ }^{34}$ Hierboven heb ik al opgemerkt dat volgens het door mij bepleite uitgangspunt voor compensatie de vraag of een crediteur recht heeft op een waarborg voor de voldoening van zijn vordering niet moet worden beantwoord aan de hand van de waarborg die de vermogenstoestand van de 403-maatschappij na de fusie of de splitsing zal bieden dat de vordering van de crediteur zal worden voldaan. In plaats daarvan moet deze vraag worden beantwoord aan de hand van de waarborg die de vermogenstoestand van de moedermaatschappij na de fusie of de splitsing zal bieden dat de vordering op grond van de 403-verklaring zal worden voldaan. Dit betekent dat als de crediteur verzet instelt tegen het voorstel tot fusie of splitsing, hij mijns inziens geen recht heeft op een waarborg voor de voldoening van zijn vordering als hij al voldoende waarborgen heeft of de vermogenstoestand van de moedermaatschappij na de fusie of de splitsing niet minder waarborg zal bieden dat de vordering op grond van de 403 -verklaring zal worden voldaan, dan de waarborg die de vermogenstoestand van de rechtspersoon van wie het vermogen zal overgaan biedt dat de vordering van de crediteur zal worden voldaan. Aangezien de crediteur na de fusie of de splitsing op grond van de 403-verklaring een aanvullende vordering krijgt op de moedermaatschappij - naast zijn huidige vordering die hij na de fusie of splitsing op de 403-maatschappij kan verhalen -, zal hij doorgaans geen recht hebben op een waarborg.

Ik merk op dat als (een deel van) het vermogen van de 403-maatschappij bij een fusie of een splitsing op een verkrijgende rechtspersoon overgaat, dit doorgaans geen negatieve gevolgen heeft voor de waarborg die de vermogenstoestand van de moedermaatschappij biedt dat een vordering op grond van de 403-verklaring zal worden voldaan. Een dergelijke fusie of splitsing heeft geen invloed op (de omvang van) de aansprakelijkheid van de moedermaatschappij op grond van de 403-verklaring. Aangezien de crediteuren hun vordering op de moedermaatschappij op grond van de 403-verklaring behouden, zal een crediteur van

34. Ervan uitgaande dat een moedermaatschappij op grond van de 403 -verklaring aansprakelijk is voor alle schulden die voortvloeien en zijn voortgevloeid uit een rechtshandeling die de 403-maatschappij heeft verricht (zie $\S 5.6$ ). Zie bijvoorbeeld $\S 9.6 .1$, met betrekking tot een fusie waarbij het vermogen van een verdwijnende rechtspersoon overgaat op de 403-maatschappij. 
de 403-maatschappij die verzet instelt tegen het voorstel tot fusie of splitsing doorgaans geen recht hebben op een waarborg voor de voldoening van deze vordering.

Als de 403-maatschappij daarentegen door een fusie of een splitsing vermogen krijgt, zal dit wel gevolgen hebben voor de waarborg die de vermogenstoestand van de moedermaatschappij biedt dat een vordering op grond van de 403-verklaring zal worden voldaan. Na de fusie of de splitsing is de moedermaatschappij op grond van de 403-verklaring (ook) aansprakelijk voor de schulden die voortvloeien uit een rechtshandeling van de rechtspersoon van wie het vermogen overgaat op de 403-maatschappij - mits de desbetreffende rechtsverhouding onder algemene titel is overgegaan op de 403-maatschappij. ${ }^{35}$ Aangezien de activa van de moedermaatschappij gelijk blijven, heeft deze extra aansprakelijkheid op grond van de 403-verklaring een negatief gevolg voor de waarborg die de vermogenstoestand van de moedermaatschappij biedt dat de vordering van de crediteur op grond van de 403-verklaring zal worden voldaan - in het bijzonder als de rechtspersoon van wie vermogen overgaat op de 403-maatschappij veel crediteuren heeft met grote vorderingen. Ik meen daarom dat een crediteur van de 403-maatschappij die verzet heeft ingesteld recht heeft op een waarborg voor de voldoening van deze vordering, tenzij de afname van de waarborg die de vermogenstoestand van de moedermaatschappij biedt, ongedaan wordt gemaakt door het extra vermogen dat de 403-maatschappij verkrijgt.

Overigens merk ik op dat uit twee uitspraken van de Rechtbanken Amsterdam en Den Bosch volgt dat het verzet van een crediteur tegen een voorgenomen fusie of splitsing wordt afgewezen ondanks dat de vermogenstoestand van de rechtspersoon die na de fusie of splitsing zijn debiteur zal zijn minder waarborgen zal bieden dat zijn vordering wordt voldaan dan de vermogenstoestand van zijn huidige debiteur, als de crediteur redelijkerwijs geen risico loopt dat zijn vordering na de fusie of splitsing niet zal worden voldaan. ${ }^{36}$ Toegepast op bovenstaande situatie met betrekking tot een fusie of splitsing van de 403-maatschappij betekent dit dat het verzet van een crediteur wordt afgewezen als deze redelijkerwijs geen risico loopt dat zijn vordering op de moedermaatschappij op grond van de 403-verklaring na deze fusie of splitsing niet zal worden voldaan.

35. Ervan uitgaande dat een moedermaatschappij op grond van de 403 -verklaring aansprakelijk is voor alle schulden die voortvloeien en zijn voortgevloeid uit een rechtshandeling die de 403-maatschappij heeft verricht (zie $\S 5.6$ ).

36. Rb. Amsterdam 4 april 2003, JOR 2003/105, m.nt. Wintgens-van Luyn (Dexia Bank Nederland), r.o. 4.11 en Rb. 's-Hertogenbosch 21 februari 2019, JOR 2019/131, m.nt. Koster (Optas/Aegon), r.o. 4.10-4.13. Zie ook $\S 8.8 .2$ met betrekking tot het recht van verzet van een crediteur tegen een voorgenomen beëindiging van de overblijvende aansprakelijkheid door de moedermaatschappij, ten aanzien waarvan ik een vergelijkbaar standpunt heb verdedigd. 


\section{HOOFDSTUK 9}

\subsubsection{Verschil met het instellen van verzet tegen de beëindiging van de overblijvende aansprakelijkheid}

Het recht van een crediteur om in verzet te komen tegen een voorstel tot fusie of splitsing van de moedermaatschappij lijkt op het eerste gezicht op het recht om verzet in te stellen tegen het voornemen van de moedermaatschappij om de overblijvende aansprakelijkheid na intrekking van de 403-verklaring te beëindigen. ${ }^{37}$ De crediteur kan in beide gevallen verlangen dat hem een waarborg wordt gegeven voor de voldoening van zijn vordering. Daarnaast is in beide gevallen voor de beoordeling of de crediteur recht heeft op deze waarborg van belang welke waarborgen hij na de fusie of de splitsing, respectievelijk na de beëindiging van de overblijvende aansprakelijkheid zal hebben dat zijn vordering zal worden voldaan.

Toch verschillen bovengenoemde gronden voor verzet met betrekking tot een voorstel tot fusie of splitsing, respectievelijk het voornemen om de overblijvende aansprakelijkheid te beëindigen. Naast het verschil in de verzetstermijn - een maand ${ }^{38}$ tegenover twee maanden - verschilt ook de norm op basis waarvan wordt beoordeeld of de crediteur recht heeft op een waarborg voor de voldoening van zijn vordering. Als een crediteur in verzet komt tegen een voorstel tot fusie of splitsing van de moedermaatschappij, heeft hij recht op een waarborg tenzij hij al voldoende waarborgen heeft of de vermogenstoestand van de rechtspersoon die na de fusie of de splitsing zijn debiteur zal zijn niet minder waarborg zal bieden dat zijn vordering zal worden voldaan, dan de vermogenstoestand van de moedermaatschappij voor de fusie of de splitsing. ${ }^{39}$ Met betrekking tot het instellen van verzet tegen het voornemen van de moedermaatschappij om de overblijvende aansprakelijkheid te beëindigen, heeft de Hoge Raad daarentegen in de SNS/Curatoren-beschikking geoordeeld dat een crediteur recht heeft op een vervangende waarborg als zijn positie door de beëindiging verzwakt. ${ }^{40} \mathrm{Ik}$ heb betoogd dat deze overweging zo moet worden uitgelegd dat een crediteur recht heeft op een vervangende waarborg als hij na

37. Zie art. 2:404 lid 3 tot en met lid 6 BW en $\S 8.3$ tot en met $\S 8.13$.

38. Ik merk op dat op 1 januari 2020 de richtlijn 2019/2121/EU is vastgesteld. Op grond van deze richtlijn zijn de in de EU bestaande regels voor grensoverschrijdende fusie aangepast, en is onder meer een regeling geïntroduceerd voor grensoverschrijdende splitsing. Lidstaten moeten er op grond van art. 126 ter lid 1 en art. 160 undecies lid 1 van de richtlijn voor zorgen dat crediteuren de mogelijkheid hebben om tot drie maanden na de openbaarmaking van een voorstel voor een grensoverschrijdende fusie of splitsing hiertegen verzet in te stellen. Uiterlijk op 31 januari 2023 moet de Nederlandse wet aan de richtlijn zijn aangepast. Het is denkbaar dat de Nederlandse wetgever de verzetstermijn voor een grensoverschrijdende en een niet-grensoverschrijdende fusie of splitsing gelijktrekt en de termijn ex art. 2:316 lid 2 en art. 2:3341 BW verlengt van een maand naar drie maanden.

39. Zie art. 2:316 lid 1 en art. 2:334k BW.

40. HR 31 maart 2017, NJ 2018/26, m.nt. Van Schilfgaarde (SNS/Curatoren), r.o. 5.1.4. Ook gepubliceerd in JOR 2017/221, m.nt. De Haan. 
de beëindiging van de overblijvende aansprakelijkheid niet minimaal dezelfde waarborgen heeft - uit hoofde van de vermogenstoestand van de 403-maatschappij of uit anderen hoofde - dat zijn vordering op de 403-maatschappij zal worden voldaan, als de waarborgen die hij heeft dat zijn vordering op de moedermaatschappij zal worden voldaan. ${ }^{41}$

Als een crediteur in verzet komt tegen een voorstel tot fusie of splitsing van de moedermaatschappij, is de norm of hij recht heeft op een waarborg voor de voldoening van zijn vordering dus gebaseerd op de waarborg die de vermogenstoestand van de moedermaatschappij (en de eventuele rechtsopvolger), voor en na de fusie of de splitsing biedt dat de desbetreffende vordering zal worden voldaan. Het gaat om de waarborg die de vermogenstoestand van de rechtspersoon biedt die voor en na de fusie of de splitsing de debiteur is ten aanzien van dezelfde vordering van de crediteur. Bij een verzet tegen het voornemen om de overblijvende aansprakelijkheid te beëindigen, wordt daarentegen niet vergeleken welke waarborg de vermogenstoestand van de moedermaatschappij voor en na de beëindiging biedt dat de vordering van de crediteur op grond van de 403 -verklaring zal worden voldaan. Door de beëindiging van de overblijvende aansprakelijkheid vervalt namelijk deze vordering op de moedermaatschappij. In plaats daarvan wordt de waarborg die de crediteur voor de beëindiging van de overblijvende aansprakelijkheid heeft dat zijn vordering op de moedermaatschappij zal worden voldaan, vergeleken met de waarborg die hij na de beëindiging heeft dat de vordering op de 403-maatschappij zal worden voldaan. Resumerend wordt bij een verzet tegen een voorstel tot fusie of splitsing dus vergeleken welke waarborg de crediteur voor en na de fusie of de splitsing heeft dat dezelfde vordering zal worden voldaan. Bij de beëindiging van de overblijvende aansprakelijkheid wordt daarentegen vergeleken welke waarborgen de crediteur heeft dat twee verschillende vorderingen zullen worden voldaan.

Door een fusie of splitsing van de moedermaatschappij kan de groepsband met de 403-maatschappij worden verbroken. In een dergelijk geval is het mijns inziens mogelijk dat op het moment van de fusie of splitsing ook de overblijvende aansprakelijkheid wordt beëindigd - ik kom hier later op terug. ${ }^{42}$ Een crediteur kan dus tegelijkertijd in verzet komen tegen een voorstel tot fusie of splitsing van de moedermaatschappij, en daarnaast verzet instellen tegen het voornemen van de moedermaatschappij om de overblijvende aansprakelijkheid te beëindigen.

Ik richt mij met dit onderzoek in het bijzonder op de gevolgen van een fusie of een splitsing van de moeder- of de 403-maatschappij op de aansprakelijkheid

41. Zie $\S 8.8 .2$.

42. Zie $\S 9.4 .2$. 
op grond van de 403-verklaring. In het vervolg van dit onderzoek laat ik daarom het recht van een crediteur om in verzet te komen tegen een voorstel tot fusie of splitsing van de moeder- of de 403-maatschappij buiten beschouwing.

9.4 Het verbreken van de groepsband tussen de moeder- en de 403-maatschappij

\subsubsection{Uitleg van de voorwaarde ex art. 2:404 lid 3 sub a BW dat de groepsband is verbroken}

Als een moedermaatschappij de door haar gedeponeerde 403-verklaring heeft ingetrokken, blijft zij aansprakelijk voor de schulden die voortvloeien uit de rechtshandelingen die de 403-maatschappij heeft verricht tot het moment dat de moedermaatschappij tegenover de crediteur een beroep kan doen op de intrekking. ${ }^{43} \mathrm{Om}$ deze overblijvende aansprakelijkheid te beëindigen moet (onder meer) de groepsband tussen de moeder- en de 403-maatschappij zijn verbroken. ${ }^{44}$ Het is de vraag hoe deze voorwaarde ex art. 2:404 lid 3 sub a BW moet worden uitgelegd als de moeder- of de 403-maatschappij fuseert of splitst.

In de literatuur bestaat onenigheid over de uitleg van art. 2:404 lid 3 sub a BW in het kader van een fusie of een splitsing van de moeder- of de 403-maatschappij. Enkele auteurs leggen deze bepaling zo uit dat aan de voorwaarde van art. 2:404 lid 3 sub a BW is voldaan als de moeder- of de 403-maatschappij door een fusie of een splitsing is opgehouden te bestaan. ${ }^{45}$ Dit is volgens mij echter een te strikte uitleg van deze bepaling. Deze uitleg leidt er bijvoorbeeld toe dat aan het vereiste van art. 2:404 lid 3 sub a BW is voldaan als de moederof de 403-maatschappij verdwijnt door een fusie of een splitsing waarbij het vermogen onder algemene titel overgaat op een groepsmaatschappij. Mij staat daarom een andere uitleg voor ogen.

Dat aan het vereiste van art. 2:404 lid 3 sub a BW is voldaan als de moeder- of de 403-maatschappij door een fusie of een splitsing is verdwenen en het vermogen onder algemene titel is overgegaan op een of meer verkrijgende rechtspersonen buiten de groep, terwijl de ander bij de oorspronkelijke groep is achtergebleven,

43. Zie art. 2:404 lid 1 en 2 BW.

44. Zie $\S 8.4$. Zie ook $\S 8.14$, waar ik tot de conclusie ben gekomen dat het wenselijk is dat de voorwaarde dat de groepsband tussen de moeder- en de 403-maatschappij is verbroken, wordt geschrapt uit art. 2:404 lid 3 BW.

45. Van Wijngaarden 2006a, p. 619-620, Snijder-Kuipers \& Eliëns 2014, p. 1177-1178 en Holtman 2019, p. 160. Vgl. Zaman, Van Eck \& Roelofs 2009, p. 282 en Van der Kraan 2012, p. 102-103, die opmerken dat naar de letter van de wet de groepsband is verbroken, maar dat naar de strekking van de wet niet is voldaan aan de voorwaarde ex art. 2:404 lid 3 sub a BW. 
zal niemand ontkennen. Hiervan is bijvoorbeeld sprake als een 403-maatschappij door een fusie verdwijnt en haar vermogen onder algemene titel overgaat op een verkrijgende rechtspersoon buiten de groep. ${ }^{46}$ De moedermaatschappij kan in dat geval de overblijvende aansprakelijkheid beëindigen, mits zij ook aan de overige voorwaarden van art. 2:404 lid $3 \mathrm{BW}$ voldoet. $^{47}$

Een situatie waarbij het lastiger is om te beoordelen of aan de voorwaarde ex art. 2:404 lid 3 sub a BW is voldaan, doet zich voor als de moedermaatschappij door een fusie of splitsing verdwijnt en haar vermogen onder algemene titel overgaat op een of meer verkrijgende rechtspersonen buiten de groep, waarna er een groepsband tot stand komt tussen de verkrijgende rechtsperso(o) $\mathrm{n}(\mathrm{en})$ en de 403-maatschappij. Verbrugh en Van der Kraan merken op dat formeel gezien de groepsband is verbroken aangezien de moedermaatschappij is verdwenen in een of meer verkrijgende rechtspersonen buiten de groep. Maar er is volgens hen ook wat voor te zeggen dat de groepsband materieel is blijven bestaan. $^{48}$

Naar mijn mening is in bovengenoemde situatie niet voldaan aan het vereiste van art. 2:404 lid 3 sub a BW. Mijns inziens moet deze voorwaarde zo worden uitgelegd dat hieraan slechts is voldaan indien na de fusie of de splitsing van de moeder- of de 403-maatschappij, de rechtspersoon op wie de overblijvende aansprakelijkheid rust niet tot dezelfde groep behoort als de rechtspersoon van wie de handelingen tot aansprakelijkheid op grond van de ingetrokken 403-verklaring kunnen leiden. Ter ondersteuning van deze uitleg van art. 2:404 lid 3 sub a BW wijs ik op een opmerking van de minister bij de introductie van de huidige regeling voor de beëindiging van de overblijvende aansprakelijkheid. Volgens hem bewaart deze regeling het evenwicht tussen het belang van de crediteuren en dat van de moedermaatschappij. ${ }^{49}$ Hij wijst erop dat de crediteuren niet zomaar hun verhaalsrecht op de moedermaatschappij mogen verliezen. Daarnaast heeft de moedermaatschappij er volgens de minister belang bij dat de aansprakelijkheid op grond van de ingetrokken 403-verklaring niet nog jaren doorloopt nadat de groepsband met de 403-maatschappij is verbroken.

Het belang van de moedermaatschappij waar de minister op doelt, is dat zij na het verbreken van de groepsband met de 403-maatschappij geen doorslaggevende invloed meer heeft op de handelingen - of het nalaten te handelen van de 403-maatschappij, maar dat door deze handelingen wel nog steeds

46. Zie $\S$ 9.7.2.c.

47. Ten Hove 2004, p. 169, Van Wijngaarden 2006a, p. 619, Verbrugh 2006, p. 53, Verbrugh 2007, p. 103, Zaman, Van Eck \& Roelofs 2009, p. 282, Van der Kraan 2012, p. 103 en 120, Snijder-Kuipers \& Eliëns 2014, p. 1177-1178 en E.C.A. Nass 2019, p. 167-168.

48. Verbrugh 2006, p. 53-54, Verbrugh 2007, p. 103-104 en 268-270 en Van der Kraan 2012, p. $151-152$ en $156-157$.

49. Kamerstukken II 1983/84, 16551, 11, p. 15 (NnavhEV). 


\section{HOOFDSTUK 9}

schulden kunnen ontstaan waarvoor zij aansprakelijk is. Als de 403-maatschappij bijvoorbeeld tegen de wil van de moedermaatschappij een huurovereenkomst - die zij voor de intrekking van de 403-verklaring met een verhuurder is aangegaan - ontbindt, kan zij verplicht zijn tot het betalen van een schadevergoeding aan de verhuurder. De moedermaatschappij is dan op grond van de ingetrokken 403-verklaring hoofdelijk aansprakelijk voor de nakoming van deze schadevergoeding. ${ }^{50}$

Ik meen dat de voorwaarde ex art. 2:404 lid 3 sub a BW moet worden uitgelegd in het licht van bovengenoemde opmerking van de minister. Dit houdt in dat degene op wie de overblijvende aansprakelijkheid rust de mogelijkheid moet hebben om deze aansprakelijkheid te beëindigen als de rechtspersoon van wie de handelingen tot aansprakelijkheid op grond van de ingetrokken 403-verklaring kunnen leiden niet tot dezelfde groep behoort en hij daarom geen invloed meer heeft op deze handelingen. Voor de beantwoording van de vraag of aan deze voorwaarde is voldaan, is naar mijn mening niet van belang of het de oorspronkelijke moedermaatschappij is die de overblijvende aansprakelijkheid ten aanzien van de oorspronkelijke 403-maatschappij wil beëindigen, of dat zij door een fusie of een splitsing zijn verdwenen en het vermogen onder algemene titel is overgegaan op een verkrijgende rechtspersoon. Daarnaast maakt het volgens mij ook niet uit of zij nog steeds tot de oorspronkelijke groep behoren of dat zij door een fusie of een splitsing onderdeel zijn geworden van een andere groep. Van belang is mijns inziens slechts of degene op wie de overblijvende ansprakelijkheid rust al of niet tot dezelfde groep behoort als de rechtspersoon van wie de handelingen tot aansprakelijkheid op grond van de ingetrokken 403-verklaring kunnen leiden.

\subsubsection{Beëindiging van de overblijvende aansprakelijkheid op het moment van de fusie of de splitsing}

Als vaststaat dat de groepsband tussen de moeder- en de 403-maatschappij zal worden verbroken door een aanstaande fusie of splitsing van een van beide, zullen partijen doorgaans willen dat de aansprakelijkheid op grond van de 403 -verklaring voor de fusie of de splitsing wordt beëindigd. De moedermaatschappij - of haar rechtsopvolger - heeft na het verbreken van de groepsband geen doorslaggevende invloed meer ten aanzien van de 403-maatschappij - of haar rechtsopvolger-, maar zij is wel aansprakelijk voor de schulden die voortvloeien uit de rechtshandelingen die de 403-maatschappij (heeft) verricht.

In hoofdstuk 8 heb ik geconcludeerd dat er geen vaste volgorde is waarin aan de voorwaarden voor de beëindiging van de overblijvende aansprakelijkheid ex

50. Zie $\S 4.4 .2$. 
art. 2:404 lid 3 sub a tot en met d BW ${ }^{51}$ moet worden voldaan. ${ }^{52}$ Dit betekent dat als de moedermaatschappij de overblijvende aansprakelijkheid wil beëindigen zij niet als eerste aan de voorwaarde ex art. 2:404 lid 3 sub a BW hoeft te voldoen dat de groepsband met de 403-maatschappij is verbroken, voordat aan de andere voorwaarden uit lid 3 kan worden voldaan. De moedermaatschappij kan voor het verbreken van de groepsband al beginnen met de procedure om de overblijvende aansprakelijkheid te beëindigen. Zij kan al een mededeling deponeren van het voornemen om de overblijvende aansprakelijkheid te beëindigen en een aankondiging plaatsen in een landelijk verspreid dagblad dat en waar deze mededeling ter inzage ligt. ${ }^{53}$ De dag nadat de moedermaatschappij deze aankondiging heeft geplaatst in een landelijk verspreid dagblad begint de tweemaandstermijn te lopen waarbinnen de crediteuren verzet kunnen instellen tegen het voornemen van de moedermaatschappij om de overblijvende aansprakelijkheid te beëindigen ${ }^{54} \mathrm{Ik}$ heb eerder opgemerkt dat ik art. 2:404 lid $3 \mathrm{BW}$ zo uitleg dat uiterlijk op het moment dat deze tweemaandstermijn verloopt aan alle voorwaarden voor de beëindiging van de overblijvende aansprakelijkheid moet zijn voldaan, behoudens de afwikkeling van een eventueel ingesteld verzet. ${ }^{55}$ Uiterlijk op dat moment moet dus ook de groepsband tussen de moeder- en de 403-maatschappij zijn verbroken.

Het is mogelijk om de fusie of de splitsing van de moeder- of de 403-maatschappij - waarbij de groepsband tussen hen wordt verbroken - te laten samenvallen met het moment dat de verzetstermijn ex art. 2:404 lid $5 \mathrm{BW}$ voor de crediteuren verstrijkt. De moedermaatschappij moet dan twee maanden voor de dag waarop de fusie of splitsing van kracht wordt ${ }^{56}$ een aankondiging plaatsen in een landelijk verspreid dagblad dat en waar de door haar gedeponeerde mededeling van het voornemen om de overblijvende aansprakelijkheid te beëindigen ter inzage ligt. Als vervolgens door de fusie of de splitsing de groepsband tussen de moeder- en de 403-maatschappij verbreekt, is op dat moment aan

51. Hiervoor is vereist dat de groepsband tussen de moeder- en de 403-maatschappij is verbroken (sub a). Daarnaast moet een mededeling van het voornemen om de overblijvende aansprakelijkheid te beëindigen twee maanden ter inzage hebben gelegen bij het handelsregister (sub b). Voorts dienen er twee maanden te zijn verlopen na de aankondiging in een landelijk verspreid dagblad dat en waar deze mededeling ter inzage ligt (sub c). Tot slot mag tegen het voornemen tot beëindiging geen verzet zijn ingesteld door de crediteur, dan wel moet diens verzet zijn ingetrokken of door de rechter ongegrond zijn verklaard (sub d).

52. Zie $\S 8.13$.

53. Zie art. 2:404 lid 3 sub b en c BW.

54. Zie art. 2:404 lid 5 BW, $\S 8.6 .3$ en Kamerstukken II 1983/84, 16551, 11, p. 17 (NnavhEV). Zie ook Rb. Rotterdam 30 september 2014, JOR 2014/326, m.nt. Loesberg (Pergen/Eneco), r.o. 4.6 .

55. Zie $\S 8.13$.

56. Zie art. 2:318 BW, respectievelijk art. 2:334n BW. 
alle voorwaarden van art. 2:404 lid 3 BW voldaan en is de overblijvende aansprakelijkheid beëindigd, behoudens de afwikkeling van een eventueel ingesteld verzet ex art. 2:404 lid 5 BW. ${ }^{57}$

\subsection{Verschillende casus met betrekking tot een fusie of splitsing van de moeder- of de 403-maatschappij}

In de volgende paragrafen werk ik verschillende casus uit waarbij de moederof de 403-maatschappij fuseert, zuiver splitst of afsplitst. Ik beperk mij tot enkele 'standaard'-casus om de hoofdlijnen van de gevolgen van een fusie, zuivere splitsing of afsplitsing voor de aansprakelijkheid op grond van een 403-verklaring te onderzoeken.

Als eerste ga ik in op een fusie van de moeder- of de 403-maatschappij waarbij deze het vermogen van een andere (verdwijnende) rechtspersoon verkrijgt ( $\$$ 9.6). Vervolgens behandel ik een fusie waarbij de moeder- of de 403-maatschappij ophoudt te bestaan ( $\$ 9.7$ en $\S 9.8$ ). Voorts komt een zuivere splitsing van de moeder- of de 403-maatschappij aan de orde ( $\$ 9.9$ ). Tot slot ga ik in op een afsplitsing van de moeder- of de 403-maatschappij (§ 9.10). Voor de duidelijkheid introduceer ik iedere casus met een afbeelding waarmee ik het resultaat laat zien van de desbetreffende fusie of splitsing.

Met betrekking tot iedere casus geef $i k$ antwoord op drie vragen. Ten eerste ga ik na welke partij na de fusie of de splitsing op grond van de 403-verklaring aansprakelijk is voor de schulden die voortvloeien uit de rechtshandelingen die de 403-maatschappij tot dat moment heeft verricht. Vervolgens onderzoek ik of er na de fusie of de splitsing nog nieuwe aansprakelijkheid op grond van deze verklaring kan ontstaan. Tot slot geef ik antwoord op de vraag of het mogelijk is om na de fusie of de splitsing de 403-verklaring in te trekken en de overblijvende aansprakelijkheid te beëindigen. Bij de beantwoording van deze laatste vraag onderzoek ik in het bijzonder of door de fusie of de splitsing is voldaan aan de voorwaarde ex art. 2:404 lid 3 sub a BW voor de beëindiging van de overblijvende aansprakelijkheid dat de groepsband tussen de moeder- en de 403-maatschappij is verbroken.

Ik verwijs bij de beantwoording van bovengenoemde vragen naar mijn eerdere conclusies met betrekking tot de overgang van de 403 -aansprakelijkheid onder algemene titel ${ }^{58}$ en de uitleg van de voorwaarde ex art. 2:404 lid 3 sub a BW dat de groepsband tussen de moeder- en de 403-maatschappij is verbroken. ${ }^{59} \mathrm{Ik}$

57. Verbrugh 2006, p. 53-54.

58. Zie $\S 9.2$.

59. Zie $\S 9.4$. 
behandel ook afwijkende standpunten ten aanzien van deze onderwerpen. Ik ga bij de verschillende casus echter niet in op het recht van een crediteur op grond van art. 2:316 BW, respectievelijk art. 2:3341 jo. art. 2:334k BW om in verzet te komen tegen de desbetreffende fusie of splitsing en te verlangen dat hem een waarborg wordt gegeven voor de voldoening van zijn vordering. De norm of een crediteur recht heeft op een waarborg is te casuïstisch voor een algemene bespreking van een casus zonder nadere uitwerking van fictieve vermogensposities van de desbetreffende partijen. Ik verwijs hiervoor naar mijn eerdere opmerkingen over dit onderwerp. ${ }^{60}$

\subsection{Fusie waarbij de moeder- of de 403-maatschappij vermogen verkrijgt}

\subsubsection{Fusie waarbij de 403-maatschappij vermogen verkrijgt}

In afbeelding 9.1 heb ik een fusie weergegeven waarbij het vermogen van een verdwenen rechtspersoon - niet zijnde de moedermaatschappij - onder algemene titel is overgegaan op de 403-maatschappij.

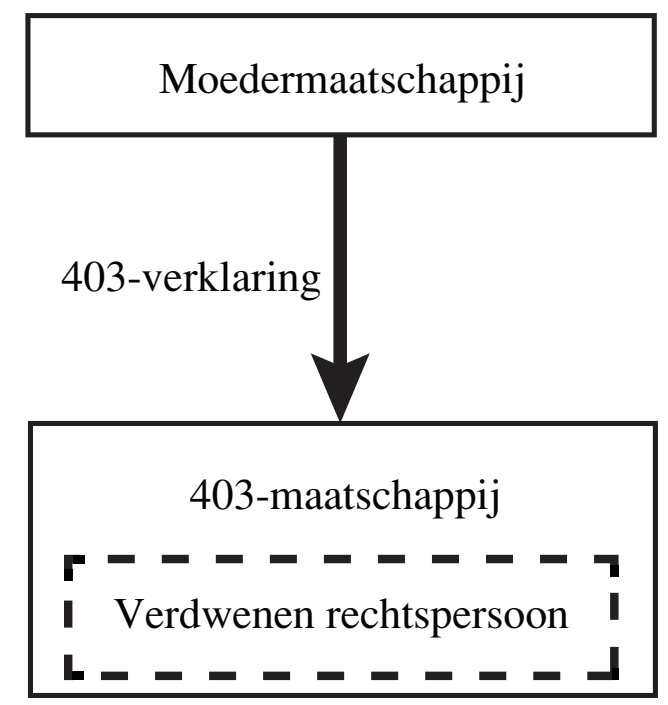

Afbeelding 9.1

Door de fusie is het vermogen van de verdwenen rechtspersoon onder algemene titel overgegaan op de 403-maatschappij. Hierdoor is de 403-maatschappij de debiteur geworden van de crediteuren van de verdwenen rechtspersoon.

60. Zie $\S 9.3$. 
De crediteuren van wie de vordering voortvloeit uit een rechtshandeling die de verdwenen rechtspersoon voor de fusie heeft verricht, krijgen op grond van de 403-verklaring ook een vordering op de moedermaatschappij.

Er zou mogelijk kunnen worden betoogd dat de moedermaatschappij op grond van de 403-verklaring niet aansprakelijk is voor de schulden die voortvloeien uit de rechtshandelingen van de verdwenen rechtspersoon. Tot de fusie konden de desbetreffende crediteuren de jaarrekening van de verdwenen rechtspersoon inzien. Er kan worden betoogd dat zij daarom niet gecompenseerd hoeven te worden voor een gebrek aan inzicht. Na de fusie moeten de crediteuren zich echter op de 403-maatschappij verhalen. Zij kunnen de jaarrekening van de 403-maatschappij niet inzien en (mede) aan de hand daarvan schatten hoe groot het risico is dat de 403-maatschappij de vordering niet (volledig) zal voldoen. Voor de crediteuren kan het onder meer van belang zijn om de jaarrekening van de 403-maatschappij in te zien om (mede) aan de hand daarvan te beoordelen of zij eventuele zekerheidsrechten uitoefenen, de overeenkomst met de 403-maatschappij proberen aan te passen of opzeggen, of dat zij het faillissement van de 403-maatschappij aanvragen. Dit geldt in het bijzonder voor crediteuren die een duurovereenkomst zijn aangegaan waaruit periodiek nieuwe vorderingen voortvloeien. Een crediteur die bijvoorbeeld een verhuurovereenkomst heeft afgesloten met de rechtspersoon die door de fusie is verdwenen, heeft er als verhuurder belang bij om de jaarrekening van de 403-maatschappij als nieuwe huurder te kunnen inzien - en om in de toekomst de nieuwe jaarrekeningen van de 403-maatschappij in te zien. Ter compensatie van dit gebrek aan inzicht moeten de crediteuren zich mijns inziens na de fusie op grond van de 403 -verklaring op de moedermaatschappij kunnen verhalen. ${ }^{61}$

De positie van een crediteur van de verdwenen rechtspersoon is vergelijkbaar met de positie van een crediteur die een vordering op de 403-maatschappij heeft voordat de moedermaatschappij de 403 -verklaring deponeert. Toen laatstgenoemde crediteur de relatie aanging met de 403-maatschappij kon hij nog de jaarrekening van de 403-maatschappij inzien. Maar vanaf het moment dat de 403-maatschappij gebruikmaakt van de jaarrekeningvrijstelling van het groepsregime ontbreekt het hem aan deze mogelijkheid. In hoofdstuk 5 heb ik geconcludeerd dat als een moedermaatschappij zich op grond van een 403-verklaring aansprakelijk stelt, zij (mede) om die reden ook aansprakelijk is voor de schulden die voortvloeien uit de rechtshandelingen die de 403-maatschappij heeft verricht voordat de 403 -verklaring is gedeponeerd. ${ }^{62}$

61. De compensatie voor een crediteur bestaat uit twee onderdelen: een vordering op de moedermaatschappij op grond van de 403-verklaring en de mogelijkheid om de geconsolideerde jaarrekening van de moedermaatschappij in te zien. Zie $\S 3.4 .1$.

62. Zie $\S 5.6 .4$. 


\subsubsection{Fusie waarbij de moedermaatschappij vermogen verkrijgt}

In afbeelding 9.2 heb ik een fusie weergegeven waarbij het vermogen van een verdwenen rechtspersoon - niet zijnde de 403-maatschappij - onder algemene titel is overgegaan op de moedermaatschappij.

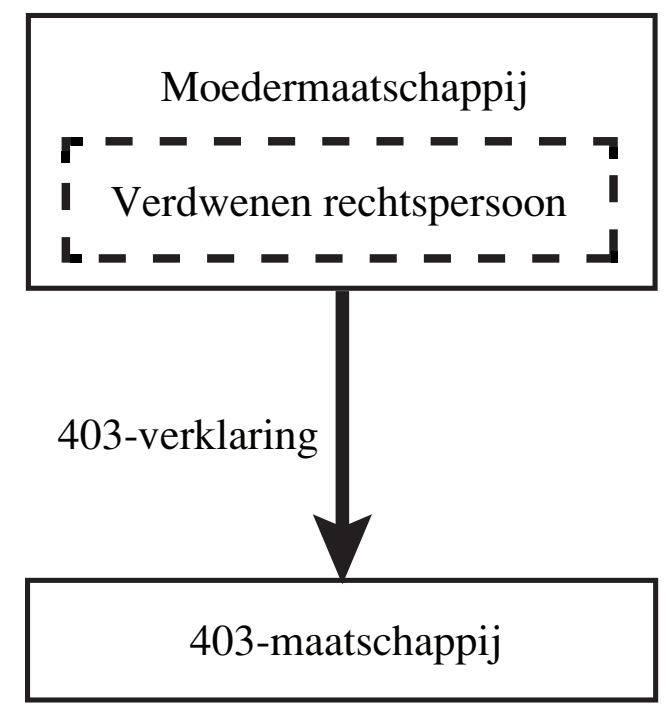

Afbeelding 9.2

De fusie heeft geen gevolgen voor de jaarrekeningvrijstelling voor de 403-maatschappij of voor de mogelijkheid voor de crediteuren om een beroep te doen op de aansprakelijkheid van de moedermaatschappij op grond van de 403-verklaring. De 403-maatschappij kan gebruik blijven maken van de vrijstelling en de moedermaatschappij blijft aansprakelijk voor de schulden die voortvloeien uit een rechtshandeling van de 403-maatschappij. ${ }^{63}$

63. Zie $\S 9.3 .1$, waar ik heb opgemerkt dat de crediteuren met een vordering op de moedermaatschappij op grond van de 403-verklaring in verzet kunnen komen tegen het voorstel tot fusie en een waarborg kunnen verlangen voor de voldoening van hun vordering. Dit is bijvoorbeeld van belang als de moedermaatschappij wil fuseren met een rechtspersoon die er financieel slecht(er) voor staat. Het recht om in verzet te komen, geeft een crediteur de mogelijkheid om te waarborgen dat de compensatie die hij ontvangt uit hoofde van de 403-verklaring niet tegen zijn wil wordt aangetast. 


\subsection{Fusie waarbij de 403-maatschappij verdwijnt}

\subsubsection{Fusie van de 403-maatschappij met de moedermaatschappij}

\subsection{1.a Inleiding}

In afbeelding 9.3 heb ik een fusie van de moeder- en de 403-maatschappij weergegeven waarbij de 403-maatschappij is verdwenen en haar vermogen onder algemene titel is overgegaan op de moedermaatschappij. ${ }^{64}$

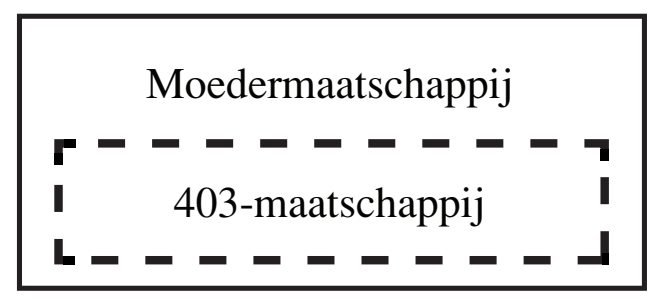

Afbeelding 9.3

\subsection{1.b Aansprakelijkheid op grond van de 403-verklaring}

Door de fusie is de 403 -verklaring voor de toekomst zinledig geworden. ${ }^{65}$ Aangezien de 403-maatschappij is opgehouden te bestaan, kan zij geen rechtshandelingen meer verrichten waaruit schulden voortvloeien waarvoor de moedermaatschappij op grond van deze verklaring ansprakelijk is. De moedermaatschappij kan de 403-verklaring voor de duidelijkheid intrekken.

Een andere vraag is welke gevolgen de fusie heeft voor de aansprakelijkheid van de moedermaatschappij voor de schulden die voortvloeien uit de rechtshandelingen die de 403-maatschappij heeft verricht tot het moment van de fusie. Door de fusie is het vermogen van de 403-maatschappij, waaronder de desbetreffende schulden, onder algemene titel overgegaan op de moedermaatschappij. Dit betekent dat de moedermaatschappij op grond van de 403-verklaring aansprakelijk is voor haar eigen schulden. Het is de vraag of dit met zich brengt dat de 403-aansprakelijkheid is vervallen.

64. Zie E.C.A. Nass 2019, p. 164, met betrekking tot het boekjaar waarover de 403-maatschappij voor het laatst gebruik kan maken van de jaarrekeningvrijstelling van het groepsregime.

65. Beckman 1995a, p. 616, Ten Hove 2004, p. 169, Verbrugh 2006, p. 53, Verbrugh 2007, p. 102 en Holtman 2019, p. 159. 
In de literatuur wordt aangenomen, naar mijn mening terecht, dat een crediteur na de fusie twee vorderingen heeft op de moedermaatschappij - waarbij de crediteur in totaal vanzelfsprekend maar één keer (volledig) kan worden voldaan. ${ }^{66,67}$ Ten eerste heeft de crediteur een vordering op de moedermaatschappij die voortvloeit uit de oorspronkelijke rechtsverhouding met de 403-maatschappij - waarbij de moedermaatschappij door de fusie de positie van de 403-maatschappij heeft overgenomen. Daarnaast heeft de crediteur een vordering op de moedermaatschappij op grond van de 403-verklaring.

Ik ben van mening dat de moedermaatschappij na de fusie op grond van de 403-verklaring niet alleen aansprakelijk is voor de schulden die ten tijde van de fusie al uit een rechtshandeling van de 403-maatschappij zijn voortgevloeid, maar ook voor de schulden die daarna voortvloeien uit een daarvoor verrichte rechtshandeling. In hoofdstuk 5 heb ik met betrekking tot de temporele reikwijdte van de 403-ansprakelijkheid geconcludeerd dat de aansprakelijkheid van de moedermaatschappij is gerelateerd aan het moment waarop de 403-maatschappij de rechtshandeling heeft verricht waaruit een schuld voortvloeit. ${ }^{68}$ Als de desbetreffende rechtshandeling onder de reikwijdte van de 403-aansprakelijkheid valt, is de moedermaatschappij aansprakelijk voor alle schulden die daaruit voortvloeien. Mijns inziens vervalt deze aansprakelijkheid van de moedermaatschappij niet als gevolg van de fusie met de 403-maatschappij. Als bijvoorbeeld een werknemer in het verleden een arbeidsovereenkomst heeft gesloten met de 403-maatschappij en er na de fusie een loonvordering voortvloeit uit deze overeenkomst, heeft de werknemer mijns inziens dus twee vorderingen op de moedermaatschappij. Ten eerste kan de werknemer zich op de moedermaatschappij verhalen op grond van de oorspronkelijke rechtsverhouding met de 403-maatschappij - waarbij de moedermaatschappij door de fusie de positie van de 403-maatschappij heeft overgenomen. Daarnaast kan hij zich op grond van de 403-verklaring op de moedermaatschappij verhalen. Een andere uitkomst zou hetzelfde gevolg hebben als een gedeeltelijke beëindiging van de 403-aansprakelijkheid buiten art. 2:404 $\mathrm{BW}^{69} \mathrm{om}$. Een crediteur kan dan geen beroep doen op de procedures en waarborgen uit deze bepaling die beogen zijn verhaalsrecht te beschermen. Hij kan dan onder meer geen verzet instellen en verlangen dat hem een vervangende waarborg

66. Ten Hove 2004, p. 169, Zaman, Van Eck \& Roelofs 2009, p. 281-282 en E.C.A. Nass 2019, p. 165. Vgl. Van der Kraan 2012, p. 99, die van mening is dat een crediteur alleen zijn vordering op grond van de 403-verklaring behoudt als hij voor de fusie de moedermaatschappij al aansprakelijk heeft gesteld.

67. Een crediteur heeft mijns inziens ook twee vorderingen op dezelfde rechtspersoon als de moedermaatschappij door een fusie met de 403-maatschappij is verdwenen en haar vermogen onder algemene titel is overgegaan op de 403-maatschappij. Zie $\S$ 9.8.1.b.

68. Zie $\S 5.3$.

69. Zie hoofdstuk 7 en 8 met betrekking tot de intrekking van de 403 -verklaring en de beëindiging van de overblijvende aansprakelijkheid. 
wordt gegeven voor de voldoening van zijn vordering. ${ }^{70}$ De crediteur zou dan in een nadeliger positie kunnen komen zonder dat hij daar invloed op heeft. ${ }^{71}$ Een moedermaatschappij zou een fusie met de 403-maatschappij zelfs kunnen misbruiken om ervoor te zorgen dat er geen nieuwe schulden meer onder de 403-aansprakelijkheid vallen.

Een andere reden waarom het voor de crediteuren van belang is dat zij hun verhaalsrecht op de moeder- en de 403-maatschappij - waarbij de moedermaatschappij door de fusie de positie van de 403-maatschappij heeft ingenomen - behouden, is omdat er verschillende voorwaarden kunnen gelden met betrekking tot de nakoming van de vordering op grond van de 403 -verklaring en de vordering uit hoofde van de oorspronkelijke rechtsverhouding met de 403-maatschappij. Ik heb eerder opgemerkt dat de hoofdelijke aansprakelijkheid van de moedermaatschappij op grond van de 403 -verklaring betekent dat beide vorderingen onafhankelijk van elkaar bestaan. ${ }^{72}$ Als een crediteur een bevoorrechte of een achtergestelde vordering heeft op de 403-maatschappij, heeft hij op grond van de 403-verklaring een concurrente vordering op de moedermaatschappij. ${ }^{73}$ Daarnaast leidt de verjaring van de vordering op de 403-maatschappij er niet automatisch toe dat ook de vordering op de moedermaatschappij op grond van de 403 -verklaring is verjaard. ${ }^{74}$ Tot slot is het mogelijk dat aan de 403-maatschappij uitstel van betaling is verleend, of dat zij haar nakoming opschort. De moedermaatschappij kan hier geen beroep op doen als zij wordt aangesproken om de vordering op grond van de 403-verklaring te voldoen. ${ }^{75}$ Als een crediteur door de fusie van de moeder- en de 403-maatschappij zijn verhaalsrecht tegenover een van beide zou verliezen, bestaat het risico dat hij de vordering met een sterker verhaalsrecht verliest en slechts de vordering met een zwakker verhaalsrecht overhoudt. Dit zou een ongerechtvaardigde benadeling zijn van de crediteur.

70. Zie $\S 8.6$ tot en met $\S 8.10$.

71. Zie $\S 3.6 .1$.

72. In hoofdstuk 6 heb ik vier mogelijke duidingen van de vordering van een crediteur op de moedermaatschappij op grond van een 403-verklaring onderzocht. Drie van deze duidingen zijn gebaseerd op de hoofdelijke aansprakelijkheid van de moedermaatschappij: de 'hoofdelijke' vordering, de 'dynamische' vordering en de analoge toepassing van art. 6:142 BW ten aanzien van de 403-vordering (zie $\S 6.2 .1$ tot en met $\S 6.2 .3$ ).

73. Zie $\S 4.7$ en HR 11 april 2014, NJ 2014/309, m.nt. Van Schilfgaarde (UWV/Econcern), r.o. 3.2.2 en 3.4.1, respectievelijk $\S 4.8$ en HR 20 maart 2015, JOR 2015/140, m.nt. Josephus Jitta (Minister van Financiën/VEB c.s.), r.o. 4.34.3 en 4.34.4.

74. Zie $\S 6.3 .4$.

75. Zie $\S 6.3 .3 . b$ en $\S$ 6.3.3.c. 


\subsection{1.c Beëindiging van de overblijvende aansprakelijkheid}

Als de moedermaatschappij de 403 -verklaring na de fusie intrekt, ${ }^{76}$ kan zij de overblijvende aansprakelijkheid beëindigen door te voldoen aan de voorwaarden van art. 2:404 lid $3 \mathrm{BW}$. Het is de vraag of door de fusie tussen de moeder- en de 403-maatschappij is voldaan aan de voorwaarde ex art. 2:404 lid 3 sub a BW, dat de groepsband tussen hen is verbroken. Nass is van mening dat deze vraag ontkennend moet worden beantwoord. ${ }^{77}$

In tegenstelling tot Nass meen ik dat door de fusie van de moeder- en de 403-maatschappij wel is voldaan aan de voorwaarde ex art. 2:404 lid 3 sub a BW. ${ }^{78}$ Een andere uitkomst leidt ertoe dat de moedermaatschappij de overblijvende aansprakelijkheid nooit meer kan beëindigen. De 403-maatschappij is door de fusie namelijk verdwenen waardoor er geen groepsband meer is tussen de moeder- en de 403-maatschappij die kan worden verbroken. Dit sluit niet aan bij de functie van de aansprakelijkheid op grond van de 403-verklaring - en de overblijvende aansprakelijkheid als deze verklaring is ingetrokken - als onderdeel van de compensatie voor de crediteuren omdat zij de jaarrekening van de 403-maatschappij niet (hebben) kunnen inzien. ${ }^{79}$ Door de fusie zijn de schulden van de 403-maatschappij onder algemene titel overgegaan op de moedermaatschappij. De crediteuren kunnen hun vorderingen vanaf dat moment dus op de moedermaatschappij verhalen. Aangezien de moedermaatschappij niet gebruikmaakt van de jaarrekeningvrijstelling van het groepsregime, hebben de crediteuren na de fusie geen gebrek aan inzicht meer. Daarom moet het mijns inziens mogelijk zijn dat de moedermaatschappij de overblijvende aansprakelijkheid kan beëindigen en meen ik dat art. 2:404 lid 3 sub a BW zo moet worden uitgelegd dat door een fusie tussen de moeder- en de 403-maatschappij aan deze voorwaarde is voldaan.

76. Beckman 1995a, p. 616, Ten Hove 2004, p. 169 en Zaman, Van Eck \& Roelofs 2009, p. 282. Zie art. 2:404 lid $1 \mathrm{BW}$.

77. E.C.A. Nass 2019 , p. 165

78. Zie ook Snijder-Kuipers \& Eliëns 2014, p. 1177-1178. Vgl. Van der Kraan 2012, p. 109.

79. De compensatie voor een crediteur bestaat uit twee onderdelen: een vordering op de moedermaatschappij op grond van de 403-verklaring en de mogelijkheid om de geconsolideerde jaarrekening van de moedermaatschappij in te zien. Zie $\S 3.4 .1$. 
HOOFDSTUK 9

\subsubsection{Fusie van de 403-maatschappij met een andere rechtspersoon dan de moedermaatschappij}

\subsection{2.a Inleiding}

In afbeelding 9.4 heb ik een fusie weergegeven waarbij de 403-maatschappij is opgehouden te bestaan en haar vermogen onder algemene titel is overgegaan op een verkrijgende rechtspersoon die niet de moedermaatschappij is. ${ }^{80}$

Aangezien de 403-maatschappij is verdwenen, kan zij geen nieuwe rechtshandelingen verrichten waaruit schulden voortvloeien waarvoor de moedermaatschappij op grond van de 403-verklaring aansprakelijk is. De moedermaatschappij is op grond van deze verklaring vanzelfsprekend ook niet aansprakelijk voor de schulden die voortvloeien uit de rechtshandelingen die de verkrijgende rechtspersoon na de fusie verricht. ${ }^{81}$ Om die reden is de 403-verklaring niet in onderstaande afbeelding weergegeven. Deze verklaring is door de fusie echter niet verdwenen. Derden kunnen de 403-verklaring nog steeds opvragen bij het handelsregister - ook als de moedermaatschappij de verklaring intrekt. ${ }^{82}$

\section{Moedermaatschappij}

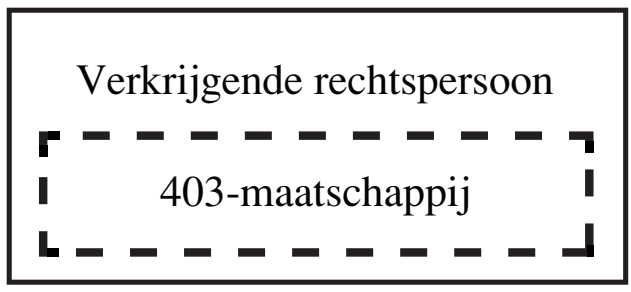

Afbeelding 9.4

80. Zie E.C.A. Nass 2019, p. 166, met betrekking tot het boekjaar waarover de 403-maatschappij voor het laatst gebruik kan maken van de jaarrekeningvrijstelling van het groepsregime.

81. Verbrugh 2006, p. 54, Verbrugh 2007, p. 269, Van der Kraan 2012, p. 160 en Beckman Compendium jaarrekening, $\S 3.8 .1 .9$.

82. Zie $§ 7.2 .1$. 


\subsection{2.b Aansprakelijkheid op grond van de 403-verklaring}

Het lijdt geen twijfel dat de moedermaatschappij na de fusie van de 403-maatschappij aansprakelijk blijft voor de schulden die tot het moment van de fusie uit een rechtshandeling van de 403-maatschappij zijn voortgevloeid. ${ }^{83}$ Dit is ook op te maken uit de uitspraak van het Hof Den Haag inzake TPB/Eneco, waar het hof overweegt dat deze aansprakelijkheid van de moedermaatschappij is blijven bestaan ondanks de fusie van de 403-maatschappij. ${ }^{84}$ Het is echter de vraag of de moedermaatschappij op grond van de 403-verklaring ook aansprakelijk is voor de schulden die na de fusie voortvloeien uit een rechtshandeling die de 403-maatschappij daarvoor heeft verricht. Er zou verdedigd kunnen worden dat aangezien de 403-maatschappij door de fusie is verdwenen, de moedermaatschappij niet aansprakelijk is voor deze schulden. Ik meen echter met Beckman dat de moedermaatschappij niet alleen aansprakelijk is voor de bestaande schulden van de 403-maatschappij op het moment van de fusie, maar ook voor de schulden die na de fusie voortvloeien uit een daarvoor verrichtte rechtshandeling. ${ }^{85} \mathrm{Ik}$ heb eerder met betrekking tot de temporele reikwijdte van de 403-aansprakelijkheid geconcludeerd dat deze aansprakelijkheid is gerelateerd aan het moment waarop de 403-maatschappij de rechtshandeling heeft verricht waaruit een schuld voortvloeit. ${ }^{86}$ Als de desbetreffende rechtshandeling onder de reikwijdte van de 403-aansprakelijkheid valt, is de moedermaatschappij aansprakelijk voor alle schulden die daaruit voortvloeien. Deze aansprakelijkheid vervalt niet als de 403-maatschappij tussentijds fuseert.

Ik merk op dat als de moedermaatschappij niet aansprakelijk zou zijn voor de schulden die na de fusie van de 403-maatschappij voortvloeien uit een daarvoor verrichte rechtshandeling dit hetzelfde gevolg zou hebben als een gedeeltelijke beëindiging van de 403-aansprakelijkheid buiten art. 2:404 BW om. Een crediteur kan dan geen beroep doen op de procedures en waarborgen uit deze bepaling $^{87}$ die beogen zijn verhaalsrecht te beschermen. De crediteur kan onder meer geen verzet instellen tegen de beëindiging en verlangen dat hem een vervangende waarborg wordt gegeven voor de voldoening van zijn vordering. Hij

83. Beckman 1995a, p. 624, Verbrugh 2007, p. 102, Zaman, Van Eck \& Roelofs 2009, p. 281282, Beckman - SDU Commentaar Ondernemingsrecht 2019, art. 2:404 BW, aant. C.1, E.C.A. Nass 2019, p. 168 en Beckman - Compendium jaarrekening, § 3.8.1.9. Vgl. Raaijmakers \& Van der Sangen, in: GS Rechtspersonen, art. 2:316 BW, aant. 5.

84. Hof Den Haag 18 maart 2014, JOR 2015/93, m.nt. Bartman (TPB/Eneco), r.o. 3 en 8.

85. Beckman - SDU Commentaar Ondernemingsrecht 2019, art. 2:404 BW, aant. C.1. Zie ook Beckman 1995a, p. 624, Zaman, Van Eck \& Roelofs 2009, p. 281-282 en Beckman - Compendium jaarrekening, §3.8.1.9, waar wordt opgemerkt dat de 403-aansprakelijkheid ongewijzigd blijft bestaan. Zie in vergelijkbare zin $\S 9.9 .1 . b$ en $\S 9.10 .1$.b met betrekking tot een zuivere splitsing en een afsplitsing van de 403-maatschappij.

86. Zie $§ 5.3$

87. Zie hoofdstuk 7 en 8 met betrekking tot de intrekking van de 403 -verklaring en de beëindiging van de overblijvende aansprakelijkheid. 
kan daardoor in een nadeliger positie komen zonder dat hij daar invloed op heeft. Dit strookt niet met het door mij bepleite uitgangspunt voor compensatie. $^{88}$

\subsection{2.c Beëindiging van de overblijvende aansprakelijkheid}

Als de moedermaatschappij haar 403-verklaring heeft ingetrokken, kan zij de overblijvende aansprakelijkheid beëindigen als zij voldoet aan de voorwaarden van art. 2:404 lid $3 \mathrm{BW}$. Het is de vraag of door de fusie van de 403-maatschappij met de verkrijgende rechtspersoon is voldaan aan de voorwaarde ex art. 2:404 lid 3 sub a BW dat de groepsband tussen de moeder- en de 403-maatschappij is verbroken.

Als de 403-maatschappij fuseert met een rechtspersoon buiten de groep, lijdt het geen twijfel dat de groepsband met de - voormalige - moedermaatschappij is verbroken. ${ }^{89} \mathrm{Als}$ ook aan de overige voorwaarden van art. 2:404 lid $3 \mathrm{BW}$ wordt voldaan, is de overblijvende aansprakelijkheid van de moedermaatschappij beëindigd.

In de literatuur bestaat echter discussie over het antwoord op de vraag of aan de voorwaarde ex art. 2:404 lid 3 sub a BW is voldaan als de 403-maatschappij is verdwenen door een fusie met een groepsmaatschappij. ${ }^{90}$ Enkele auteurs leggen deze bepaling strikt uit. Zij zijn van mening dat in een dergelijk geval aan de voorwaarde ex art. 2:404 lid 3 sub a BW is voldaan omdat de 403-maatschappij door de fusie is opgehouden te bestaan. ${ }^{91}$ Ik ben eerder echter tot de conclusie gekomen dat art. 2:404 lid 3 sub a BW ruimer moet worden uitgelegd. ${ }^{92}$ Voor het antwoord op de vraag of aan de voorwaarde ex art. 2:404 lid 3 sub a BW is voldaan, moet niet slechts worden beoordeeld of de band is verbroken tussen de moeder- en de 403-maatschappij, zoals beide rechtspersonen bestonden voor de fusie. De mogelijkheid om de overblijvende aansprakelijkheid te beëindigen, is mijns inziens bedoeld voor de gevallen dat de rechtspersoon op

88. Zie $\S 3.6 .1$.

89. Ten Hove 2004, p. 169, Van Wijngaarden 2006a, p. 619, Verbrugh 2006, p. 53, Verbrugh 2007, p. 103, Zaman, Van Eck \& Roelofs 2009, p. 282, Van der Kraan 2012, p. 103 en 120, Snijder-Kuipers \& Eliëns 2014, p. 1177-1178 en E.C.A. Nass 2019, p. 167-168.

90. Zie in vergelijkbare zin $\S 9.9 .1$.d met betrekking tot een zuivere splitsing van de 403-maatschappij waarbij haar vermogen onder algemene titel is overgegaan op groepsmaatschappijen. Zie Verbrugh 2006, p. 54, Verbrugh 2007, p. 269-270 en Van der Kraan 2012, p. 153 en 161, die opmerken dat in een dergelijk geval niet is voldaan aan de voorwaarde ex art. 2:404 lid 3 sub a BW.

91. Van Wijngaarden 2006a, p. 620, Snijder-Kuipers \& Eliëns 2014, p. 1177-1178 en Holtman 2019, p. 160. Vgl. Zaman, Van Eck \& Roelofs 2009, p. 282 en Van der Kraan 2012, p. 102103 , die opmerken dat naar de letter van de wet de groepsband is verbroken, maar dat naar de strekking van de wet niet is voldaan aan de voorwaarde ex art. 2:404 lid 3 sub a BW.

92. Zie $\S 9.4 .1$. 
wie deze aansprakelijkheid rust niet tot dezelfde groep behoort als de rechtspersoon van wie de handelingen tot aansprakelijkheid op grond van de ingetrokken 403-verklaring kunnen leiden. Een dergelijke situatie doet zich niet voor als de 403-maatschappij is gefuseerd met een groepsmaatschappij, waarbij haar vermogen onder algemene titel op deze groepsmaatschappij is overgegaan. Ik ben daarom van mening, evenals onder meer Beckman en Verbrugh, ${ }^{93}$ dat niet aan de voorwaarde ex art. 2:404 lid 3 sub a BW is voldaan als de 403-maatschappij is verdwenen als gevolg van een fusie met een groepsmaatschappij. ${ }^{94}$ De moedermaatschappij kan de overblijvende aansprakelijkheid dus niet beëindigen. Een andere uitkomst zou er ook toe kunnen leiden dat een fusie van de 403-maatschappij met een groepsmaatschappij wordt misbruikt om aan de voorwaarde van art. 2:404 lid 3 sub a BW te voldoen. ${ }^{95}$

\subsection{Fusie waarbij de moedermaatschappij verdwijnt}

\subsubsection{Fusie van de moedermaatschappij met de 403-maatschappij}

\subsection{1.a Inleiding}

In afbeelding 9.5 heb ik een fusie van de moeder- en de 403-maatschappij weergegeven. Door de fusie is de moedermaatschappij verdwenen en is haar vermogen onder algemene titel overgegaan op de 403-maatschappij. ${ }^{96}$

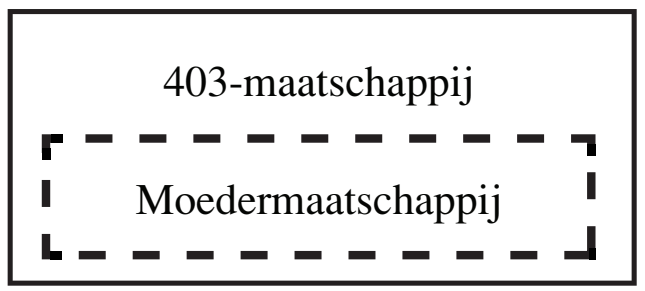

Afbeelding 9.5

93. Beckman 1995a, p. 621, Van der Arend 1999, p. 155, Verbrugh 2006, p. 53 en E.C.A. Nass 2019, p. 163-164.

94. Zie Beckman 1995a, p. 621-622 en Van der Kraan 2012, p. 113, die terecht opmerken dat ook niet aan de voorwaarde ex art. 2:404 lid 3 sub a BW is voldaan als de 403-maatschappij is gefuseerd met een groepsmaatschappij die behoort tot een ander groepsdeel.

95. Verbrugh 2006, p. 53 en Van der Kraan 2012, p. 103.

96. Zie E.C.A. Nass 2019, p. 174, met betrekking tot het boekjaar waarover de 403-maatschappij voor het laatst gebruik kan maken van de jaarrekeningvrijstelling van het groepsregime. 


\subsection{1.b Aansprakelijkheid op grond van de 403-verklaring}

Door de fusie is de 403-verklaring voor de toekomst zinledig geworden. ${ }^{97}$ De 403-maatschappij zou anders op grond van deze verklaring aansprakelijk zijn voor de schulden die voortvloeien uit de rechtshandelingen die ze zelf vanaf het moment van de fusie verricht. Voor de duidelijkheid kan de 403-maatschappij - als rechtsopvolger van de moedermaatschappij - de 403-verklaring intrekken. ${ }^{98} \mathrm{Na}$ de fusie kan de 403-maatschappij geen gebruik meer maken van de jaarrekeningvrijstelling van het groepsregime, tenzij een andere rechtspersoon binnen de groep een nieuwe 403-verklaring ten aanzien van de 403-maatschappij deponeert - mits ook aan de andere voorwaarden hiervoor wordt voldaan.

Een andere vraag is welke gevolgen de fusie heeft voor de aansprakelijkheid van de moedermaatschappij op grond van de 403-verklaring voor de schulden die voortvloeien uit de rechtshandelingen die de 403-maatschappij heeft verricht tot het moment van de fusie. Voor de fusie hebben de crediteuren van de 403-maatschappij twee vorderingen. Een vordering op de 403-maatschappij en een vordering op de moedermaatschappij op grond van de 403-verklaring. Het is de vraag of de crediteuren na de fusie beide vorderingen op de 403-maatschappij kunnen verhalen.

In de literatuur zijn op dit punt twee standpunten te onderscheiden. Beckman, Verbrugh en Nass zijn van mening dat de vorderingen van de crediteuren op grond van de 403-verklaring door de fusie teniet zijn gegaan. ${ }^{99}$ Daarnaast verdedigt Van der Kraan het standpunt dat als een crediteur de moedermaatschappij voor de fusie al aansprakelijk heeft gesteld op grond van de 403-verklaring de desbetreffende schuld van de moedermaatschappij onder algemene titel is overgegaan op de 403-maatschappij. ${ }^{100}$ Volgens hem heeft een dergelijke crediteur na de fusie twee vorderingen op de 403-maatschappij: een vordering uit hoofde van de oorspronkelijke rechtsverhouding met de 403-maatschappij en een vordering op grond van de 403-verklaring. De crediteur kan in totaal vanzelfsprekend maar één keer volledig worden voldaan. Van der Kraan vervolgt dat er na de fusie echter geen nieuwe verbintenissen meer uit de 403-verklaring kunnen voortvloeien.

97. Holtman 2019, p. 158

98. Asser/Maeijer \& Kroeze 2-I* 2015/585 en Beckman - Compendium jaarrekening, $\S 3.8 .5 .10$.

99. Beckman 1995a, p. 617, Verbrugh 2006, p. 52, Verbrugh 2007, p. $98-99$ en E.C.A. Nass 2019, p. 173.

100. Van der Kraan 2012, p. 107-108. 
Bovenstaande standpunten spreken mij niet aan. Een vergelijkbaar vraagstuk doet zich voor bij een fusie van de moeder- en de 403-maatschappij waarbij de 403-maatschappij verdwijnt. Ten aanzien van die situatie wordt in de literatuur aangenomen dat een crediteur na de fusie twee vorderingen heeft op de moedermaatschappij - waarbij hij vanzelfsprekend maar een keer volledig kan worden voldaan. ${ }^{101}$ Ik meen dat hetzelfde geldt in het geval dat de moeder- en de 403-maatschappij fuseren waarbij de moedermaatschappij verdwijnt. Dit betekent dat de 403-aansprakelijkheid voor de schulden die voortvloeien uit de rechtshandelingen die de 403-maatschappij heeft verricht tot het moment van de fusie onverminderd blijft bestaan en onder algemene titel is overgegaan op de 403-maatschappij. Dit betreft niet alleen de aansprakelijkheid voor de schulden die ten tijde van de fusie al uit een rechtshandeling van de 403-maatschappij zijn voortgevloeid, maar ook de aansprakelijkheid voor de schulden die daarna voortvloeien uit een daarvoor verrichte rechtshandeling. Ter onderbouwing van dit standpunt wijs ik kort op dezelfde twee punten als die ik noemde met betrekking tot een fusie van de moeder- en de 403-maatschappij waarbij de 403-maatschappij verdwijnt.

Ten eerste merk ik op dat ik in hoofdstuk 5 heb geconcludeerd dat de aansprakelijkheid van de moedermaatschappij op grond van de 403-verklaring is gerelateerd aan het moment waarop de 403-maatschappij de rechtshandeling heeft verricht waaruit een schuld voortvloeit. ${ }^{102}$ Als een rechtshandeling onder de reikwijdte van de 403-aansprakelijkheid valt, is de moedermaatschappij aansprakelijk voor alle schulden die daaruit voortvloeien. Deze aansprakelijkheid vervalt mijns inziens niet als de moedermaatschappij door een fusie met de 403-maatschappij verdwijnt, maar gaat onder algemene titel over op de 403-maatschappij. ${ }^{103}$ Hieraan staat niet in de weg dat de 403-maatschappij op grond van de 403-verklaring aansprakelijk wordt voor haar eigen schulden. Een andere uitkomst zou hetzelfde gevolg hebben als een gedeeltelijke beëindiging van de 403-aansprakelijkheid buiten art. 2:404 $\mathrm{BW}^{104} \mathrm{om}$. Een crediteur kan dan geen beroep doen op de procedures en waarborgen uit deze bepaling die beogen zijn verhaalsrecht te beschermen. Hij kan dan onder meer geen verzet instellen en verlangen dat hem een vervangende waarborg wordt gegeven voor de voldoening van zijn vordering. ${ }^{105}$ De crediteur zou dan in een nadeliger positie kunnen komen zonder dat hij daar invloed op heeft. ${ }^{106}$

101. Ten Hove 2004, p. 169, Zaman, Van Eck \& Roelofs 2009, p. 281-282 en E.C.A. Nass 2019, p. 165. Vgl. Van der Kraan 2012, p. 99. Zie § 9.7.1.b.

102. Zie $\S 5.3$.

103. Zie $\S 9.2 .2$.

104. Zie hoofdstuk 7 en 8 met betrekking tot de intrekking van de 403 -verklaring en de beëindiging van de overblijvende aansprakelijkheid.

105. Zie $\S 8.6$ tot en met $\S 8.10$.

106. Zie $\S 3.6 .1$. 
De tweede reden waarom het voor een crediteur van belang is dat hij zijn verhaalsrecht op grond van de 403-verklaring behoudt - waarbij de 403maatschappij door de fusie de positie van de moedermaatschappij heeft ingenomen - is omdat daarbij andere voorwaarden kunnen gelden met betrekking tot de nakoming als bij het verhaalsrecht op grond van de oorspronkelijke rechtsverhouding met de 403-maatschappij. De hoofdelijke aansprakelijkheid op grond van de 403 -verklaring brengt onder meer met zich dat als de crediteur een achtergestelde vordering heeft uit hoofde van de oorspronkelijke rechtsverhouding met de 403-maatschappij, hij op grond van de 403-verklaring een concurrente vordering heeft. ${ }^{107}$ Daarnaast leidt de verjaring van de vordering uit hoofde van de oorspronkelijke rechtsverhouding met de 403-maatschappij er niet automatisch toe dat ook de vordering op grond van de 403-verklaring is verjaard. ${ }^{108}$ Als de crediteur door de fusie van de moeder- en de 403-maatschappij zijn verhaalsrecht op grond van de 403 -verklaring zou verliezen, zou dit tot een ongerechtvaardigde benadeling zijn van positie kunnen leiden.

\subsection{1.c Beëindiging van de overblijvende aansprakelijkheid}

Na de fusie kan de 403-maatschappij - als rechtsopvolger van de moedermaatschappij - de 403-verklaring intrekken. ${ }^{109}$ Om vervolgens de overblijvende aansprakelijkheid te beëindigen, moet worden voldaan aan de voorwaarden ex art. 2:404 lid 3 BW. Het is de vraag of door de fusie van de moeder- en de 403-maatschappij is voldaan aan de voorwaarde ex art. 2:404 lid 3 sub a BW dat de groepsband tussen hen is verbroken.

Van der Kraan is van mening dat als de moeder- en de 403-maatschappij onderdeel zijn van een grotere groep met andere groepsmaatschappijen, de fusie tussen hen er niet toe leidt dat is voldaan aan de voorwaarde ex art. 2:404 lid 3 sub a BW. ${ }^{110}$ Volgens hem maken de 403-maatschappij en - het vermogen van - de moedermaatschappij dan nog steeds deel uit van dezelfde groep. Als de groep daarentegen enkel bestaat uit de moeder- en de 403-maatschappij meent Van der Kraan dat er na de fusie geen sprake meer is van een groep. Hij is van mening dat er dan naar de letter van de wet is voldaan aan de voorwaarde ex art. 2:404 lid 3 sub a BW maar dat dit niet in lijn is met de bedoeling van de wetgever.

107. Zie $\S 4.8$ en HR 20 maart 2015, JOR 2015/140, m.nt. Josephus Jitta (Minister van Financiën/VEB c.s.), r.o. 4.34 .3 en 4.34.4.

108. Zie $\S$ 6.3.4.

109. Asser/Maeijer \& Kroeze $2-I^{*} 2015 / 585$ en Beckman - Compendium jaarrekening, $\S$ 3.8.5.10.

110. Van der Kraan 2012, p. 107. 
Ik ben het deels eens met Van der Kraan. Naar mijn mening leidt een fusie van de moeder- en de 403-maatschappij er in alle gevallen toe dat is voldaan aan de voorwaarde ex art. 2:404 lid 3 sub a BW. Ook als er naast de moederen de 403-maatschappij nog andere groepsmaatschappijen zijn. Daarnaast meen ik dat dit juist wel ansluit bij de regeling van de 403-aansprakelijkheid en de beëindiging van de overblijvende aansprakelijkheid na intrekking van de 403-verklaring. Mijn onderbouwing voor dit standpunt komt overeen met de onderbouwing die ik eerder heb genoemd met betrekking tot de beëindiging van de overblijvende aansprakelijkheid na een fusie van de moeder- en de 403-maatschappij waarbij de 403-maatschappij is verdwenen. ${ }^{111}$ Een andere uitkomst zou tot gevolg hebben dat de 403-maatschappij de overblijvende aansprakelijkheid nooit meer kan beëindigen. De moedermaatschappij is namelijk door de fusie verdwenen waardoor er geen groepsband meer is tussen de moeder- en de 403-maatschappij die kan worden verbroken. Ik heb er hierboven op gewezen dat de 403-maatschappij na de fusie met de moedermaatschappij geen gebruik meer maken van de jaarrekeningvrijstelling van het groepsregime. ${ }^{112}$ De aansprakelijkheid op grond van de 403-verklaring - en de overblijvende aansprakelijkheid als deze verklaring is ingetrokken - is echter bedoeld als onderdeel van de compensatie voor de crediteuren omdat zij de jaarrekening van de 403-maatschappij niet (hebben) kunnen inzien. ${ }^{113}$ Aangezien de crediteuren geen gebrek aan inzicht meer hebben, moet het mijns inziens mogelijk zijn dat de overblijvende aansprakelijkheid kan worden beëindigd. Ik meen daarom dat art. 2:404 lid 3 sub a BW zo moet worden uitgelegd dat door een fusie tussen de moeder- en de 403-maatschappij aan deze voorwaarde is voldaan.

\subsubsection{Fusie van de moedermaatschappij met een andere rechtspersoon dan de 403-maatschappij}

\subsection{2.a Inleiding}

In afbeelding 9.6 heb ik een fusie weergegeven waarbij de moedermaatschappij is opgehouden te bestaan en haar vermogen onder algemene titel is overgegaan op een verkrijgende rechtspersoon die niet de 403-maatschappij is.

111. Zie $\S 9.7 .1 . c$

112. Zie $\S 9.8 .1 . b$.

113. De compensatie voor een crediteur bestaat uit twee onderdelen: een vordering op de moedermaatschappij op grond van de 403-verklaring en de mogelijkheid om de geconsolideerde jaarrekening van de moedermaatschappij in te zien. Zie $\S 3.4 .1$. 


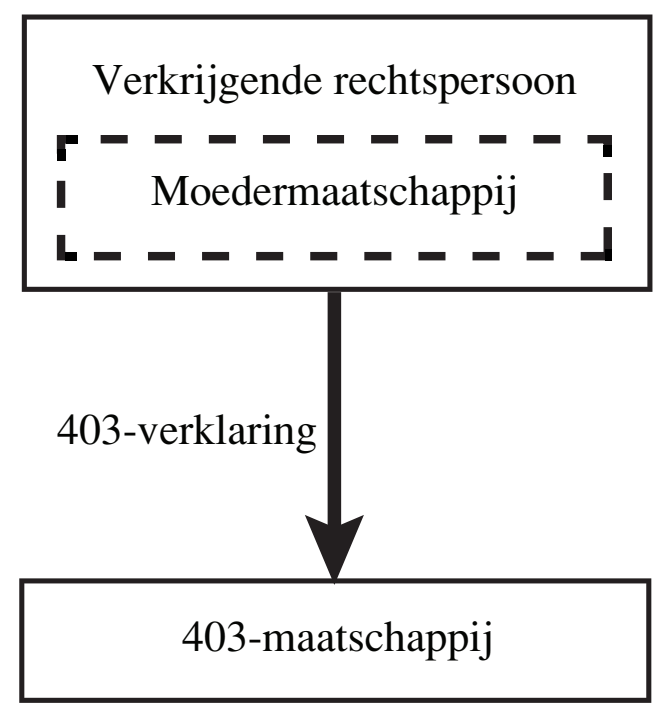

Afbeelding 9.6

\subsection{2.b Aansprakelijkheid op grond van de 403-verklaring}

Bij de fusie is het vermogen van de moedermaatschappij, waaronder de 403-aansprakelijkheid, onder algemene titel op de verkrijgende rechtspersoon overgegaan. ${ }^{114}$ De 403 -verklaring heeft na de fusie te gelden als verklaring van de verkrijgende rechtspersoon. ${ }^{115}$ Laatstgenoemde zet de aansprakelijkheid van de moedermaatschappij op grond van deze verklaring voort en is aansprakelijk voor de schulden die voortvloeien en zijn voortgevloeid uit een rechtshandeling van de 403-maatschappij. ${ }^{116}$ Daaronder vallen ook de schulden die voortvloeien uit een rechtshandeling die de 403-maatschappij verricht na de fusie van de moedermaatschappij en de verkrijgende rechtspersoon.

114. Beckman 1995a, p. 618, Verbrugh 2006, p. 52, Verbrugh 2007, p. 100, Van der Kraan 2012, p. 110, E.C.A. Nass 2019, p. 170-171, 176 en 178 en Beckman - Compendium jaarrekening, $\S$ 3.8.3.40. Zie § 9.2.2 waar ik tot de conclusie kom dat de 403-aansprakelijkheid onder algemene titel kan overgaan op een verkrijgende rechtspersoon. Dit standpunt wordt echter niet door iedereen onderschreven. Zie met betrekking tot onderhavige casus: Portengen \& Crouwers 2005, p. 44, Zaman, Van Eck \& Roelofs 2009, p. 281, Van Eck - SDU Commentaar Ondernemingsrecht 2019, art. 2:309 BW, aant. C.2.7 en Raaijmakers \& Van der Sangen, in: GS Rechtspersonen, art. 2:316 BW, aant. 7.

115. Ter verduidelijking dat de 403-aansprakelijkheid op de verkrijgende rechtspersoon rust, kan deze mijns inziens met betrekking tot de 403-verklaring een addendum deponeren dat zij op grond van deze verklaring aansprakelijk is.

116. Zie $\S 5.6$. 
Beckman, Verbrugh en Van der Kraan wijzen erop dat er na de fusie van de moedermaatschappij en de verkrijgende rechtspersoon doorgaans een groepsband bestaat tussen de verkrijgende rechtspersoon en de 403-maatschappij. ${ }^{17}$ Door de fusie heeft de verkrijgende rechtspersoon onder meer de aandelen van de moedermaatschappij in de 403-maatschappij overgenomen. Ook de meeste statutaire bevoegdheden en andere zeggenschapsrechten van de moedermaatschappij ten aanzien van de 403-maatschappij zullen op de verkrijgende rechtspersoon zijn overgegaan. Dit is slechts anders als deze bevoegdheden en rechten een hoogstpersoonlijk karakter hadden en specifiek waren toegekend aan de moedermaatschappij. ${ }^{118}$ Als de moedermaatschappij bijvoorbeeld bestuurder was van de 403-maatschappij heeft de verkrijgende rechtspersoon deze functie niet automatisch overgenomen. ${ }^{119}$ Hoewel er doorgaans dus een groepsband bestaat tussen de verkrijgende rechtspersoon en de 403-maatschappij, hoeft dit niet altijd het geval te zijn. ${ }^{120}$

Als er een groepsband bestaat tussen de verkrijgende rechtspersoon en de 403-maatschappij, kan de 403-maatschappij gebruik blijven maken van de jaarrekeningvrijstelling van het groepsregime - mits ook aan de andere voorwaarden hiervoor is voldaan. ${ }^{121}$

9.8.2.c Beëindiging van de overblijvende aansprakelijkheid

Als de verkrijgende rechtspersoon na de fusie de 403 -verklaring intrekt, ${ }^{122}$ kan hij onder voorwaarden de overblijvende ansprakelijkheid beëindigen. Op grond van art. 2:404 lid 3 sub a BW is daarvoor onder meer vereist dat de groepsband met de 403-maatschappij is verbroken. ${ }^{123}$

Als er na de fusie geen groepsband bestaat tussen de verkrijgende rechtspersoon en de 403-maatschappij lijdt het geen twijfel dat aan de voorwaarde van art. 2:404 lid 3 sub a BW is voldaan. ${ }^{124}$ Indien er na de fusie wel een groepsband bestaat tussen hen, wordt er in de literatuur een onderscheid gemaakt of de verkrijgende rechtspersoon wel of niet tot dezelfde groep behoort als de verdwenen moedermaatschappij. Ik deel de mening van Beckman, Verbrugh en

117. Beckman 1995a, p. 623, Verbrugh 2006, p. 53, Verbrugh 2007, p. 104 en Van der Kraan 2012, p. 116.

118. Zie $\S 9.2 .1$.

119. Verstappen 1996, p. 275, Van Olffen, Buijn \& Simonis 2004, p. 99 en Zaman, Van Eck \& Roelofs 2009, p. 272-273. Vgl. Van Solinge 1994, p. 74.

120. Van der Kraan 2012, p. 117.

121. E.C.A. Nass 2019, p. 176 en 178.

122. Asser/Maeijer \& Kroeze 2-I* 2015/585 en Beckman - Compendium jaarrekening, $\S 3.8 .5 .10$.

123. Zie in vergelijkbare zin $\S 9.9 .2$.d met betrekking tot een zuivere splitsing van de moedermaatschappij.

124. Beckman 1995a, p. 622. 


\section{HOOFDSTUK 9}

Van der Kraan dat als de moedermaatschappij is gefuseerd met een groepsmaatschappij niet is voldaan aan de voorwaarde ex art. 2:404 lid 3 sub a BW. ${ }^{125}$ De 403-maatschappij is dan als het ware binnen de groep 'verhangen'. De verkrijgende rechtspersoon kan de overblijvende aansprakelijkheid in een dergelijk geval niet beëindigen.

Ook als de moedermaatschappij is gefuseerd met een verkrijgende rechtspersoon buiten de groep, kan de verkrijgende rechtspersoon na de fusie de overblijvende aansprakelijkheid niet beëindigen. Ik sluit mij aan bij onder meer Beckman en Van der Kraan die terecht opmerken dat aangezien er een groepsband tot stand is gekomen tussen de verkrijgende rechtspersoon en de 403-maatschappij, de verkrijgende rechtspersoon deze groepsband zal moeten verbreken om de overblijvende aansprakelijkheid te beëindigen. ${ }^{126}$ Beckman en Van der Kraan zien echter wel een mogelijkheid voor de moedermaatschappij om de overblijvende aansprakelijkheid te beëindigen op het moment van de fusie. ${ }^{127} \mathrm{Zij}$ merken op dat aangezien de moedermaatschappij door de fusie ophoudt te bestaan, op dat moment de groepsband met de 403-maatschappij is verbroken. Als de moedermaatschappij voor de fusie al is begonnen met de procedure om de overblijvende aansprakelijkheid te beëindigen en de fusie samenvalt met het moment dat de verzetstermijn verloopt waarbinnen de crediteuren verzet kunnen instellen tegen het voornemen van de beëindiging, is volgens hen op dat moment aan alle voorwaarden van art. 2:404 lid 3 BW voldaan. ${ }^{128}$ Zij zijn van mening dat de overblijvende aansprakelijkheid dan is beëindigd, behoudens de afwikkeling van een eventueel ingesteld verzet. Daarna komt er pas een nieuwe groepsband tot stand tussen de verkrijgende rechtspersoon en de 403-maatschappij.

Ik kan mij niet vinden in bovenstaand standpunt van Beckman en Van der Kraan. Naar mijn mening is op het moment van de fusie niet (kortstondig) voldaan aan de voorwaarde van art. 2:404 lid 3 sub a BW. Ik heb eerder opgemerkt dat de beëindiging van de overblijvende aansprakelijkheid mijns inziens is bedoeld voor de gevallen dat de rechtspersoon op wie deze aansprakelijkheid rust niet tot dezelfde groep behoort als de rechtspersoon van wie de handelingen tot aansprakelijkheid op grond van de ingetrokken 403 -verklaring kunnen leiden. ${ }^{129}$

125. Beckman 1995a, p. 619, Verbrugh 2006, p. 53, Verbrugh 2007, p. 101-102, Van der Kraan 2012, p. 111 en Beckman - Compendium jaarrekening, § 3.8.4.19.

126. Beckman 1995a, p. 623, Verbrugh 2006, p. 53, Verbrugh 2007, p. 104, Van der Kraan 2012, p. 118 en E.C.A. Nass 2019, p. 173.

127. Beckman 1995a, p. 623 en Van der Kraan 2012, p. 118. Vgl. Verbrugh 2006, p. 53 en Verbrugh 2007, p. 104, die in het midden laat of op het moment van de fusie wordt voldaan aan de voorwaarde ex art. 2:404 lid 3 sub a BW.

128. Zie $\S 9.4 .2$, voor een uitgebreidere bespreking van de mogelijkheid dat de beëindiging van de overblijvende aansprakelijkheid samenvalt met een fusie of een splitsing van de moederof de 403-maatschappij.

129. Zie $\S 9.4 .1$. 
Hiervan is geen sprake in onderhavige casus waarbij de moedermaatschappij ophoudt te bestaan als gevolg van een fusie met een verkrijgende rechtspersoon buiten de groep waarna er een groepsband tot stand komt tussen deze verkrijgende rechtspersoon en de 403-maatschappij. Tot het moment van de fusie is de moedermaatschappij aansprakelijk op grond van de ingetrokken 403-verklaring en heeft zij een groepsband met de 403-maatschappij. Na de fusie rust de overblijvende aansprakelijkheid op de verkrijgende rechtspersoon die vanaf dat moment ook in een groepsverhouding staat met de 403-maatschappij. De overblijvende aansprakelijkheid en de groepsband met de 403-maatschappij lopen dus parallel aan elkaar. Degene op wie deze aansprakelijkheid rust, staat ook in een groepsverhouding met de 403-maatschappij. Naar mijn mening moet art. 2:404 lid 3 sub a BW daarom zo worden uitgelegd dat op het moment van de fusie niet (kortstondig) is voldaan aan de voorwaarde uit deze bepaling. De moedermaatschappij kan de overblijvende aansprakelijkheid dus niet op dat moment beëindigen.

Naar mijn mening is er wel een andere manier waarmee voorkomen kan worden dat een verkrijgende rechtspersoon buiten de groep de 403-aansprakelijkheid overneemt van de moedermaatschappij. ${ }^{130}$ Dit kan worden bereikt als de moedermaatschappij vlak voor de fusie de aandelen in de 403-maatschappij apart overdraagt aan de verkrijgende rechtspersoon. Hierdoor wordt de groepsband tussen de moeder- en de 403-maatschappij verbroken. Ik heb eerder betoogd dat de moedermaatschappij de procedure voor de beëindiging van de overblijvende aansprakelijkheid al kan beginnen voordat de groepsband met de 403-maatschappij is verbroken. ${ }^{131} \mathrm{Ik}$ heb art. 2:404 lid $3 \mathrm{BW}$ zo uitgelegd dat uiterlijk op het moment dat de tweemaandstermijn verloopt waarbinnen de crediteuren verzet kunnen instellen tegen het voornemen van de moedermaatschappij om de overblijvende aansprakelijkheid te beëindigen aan alle voorwaarden voor deze beëindiging moet zijn voldaan, behoudens de afwikkeling van een eventueel ingesteld verzet. Als de moedermaatschappij de aandelen in de 403-maatschappij overdraagt op het moment dat de verzetstermijn verloopt, is op dat moment aan alle voorwaarden van art. 2:404 lid $3 \mathrm{BW}$ voldaan en is de overblijvende aansprakelijkheid beëindigd. Vervolgens kunnen de moedermaatschappij en de verkrijgende rechtspersoon met elkaar fuseren waarbij (de rest van) het vermogen van de moedermaatschappij onder algemene titel overgaat op de verkrijgende rechtspersoon. Het is aan te raden dat de moedermaatschappij en de verkrijgende rechtspersoon vooraf afspraken maken over de afwikkeling van een eventueel ingesteld verzet tegen de beëindiging van de overblijvende aansprakelijkheid. ${ }^{132}$

130. Zie in vergelijkbare zin $\S$ 9.9.2.d en $\S$ 9.10.2.d met betrekking tot een zuivere splitsing van de moedermaatschappij, respectievelijk een afsplitsing van vermogen van de moedermaatschappij.

131. Zie $\S 8.13$.

132. Zie $\S 8.6$ tot en met $\S 8.10$. 
Overigens wijs ik erop dat ik eerder tot de conclusie ben gekomen dat de voorwaarde van de verbreking van de groepsband tussen de moeder- en de 403-maatschappij, het onnodig belastend maakt om de overblijvende aansprakelijkheid te beëindigen. Naar mijn mening moet deze voorwaarde daarom worden geschrapt uit art. 2:404 lid 3 BW. ${ }^{133}$

\subsection{Zuivere splitsing van de moeder- of de 403-maatschappij}

\subsubsection{Zuivere splitsing van de 403-maatschappij}

\subsection{1.a Inleiding}

In afbeelding 9.7 heb ik een zuivere splitsing van de 403-maatschappij weergegeven. De 403-maatschappij is opgehouden te bestaan en haar vermogen is onder algemene titel overgegaan op twee verkrijgende rechtspersonen. ${ }^{134}$

Aangezien de 403-maatschappij is verdwenen, kan zij geen nieuwe rechtshandelingen verrichten waaruit schulden voortvloeien waarvoor de moedermaatschappij op grond van de 403-verklaring aansprakelijk is. De moedermaatschappij is op grond van deze verklaring vanzelfsprekend ook niet aansprakelijk voor de schulden die voortvloeien uit de rechtshandelingen die de verkrijgende rechtspersonen na de splitsing verrichten. ${ }^{135} \mathrm{Om}$ die reden is de 403 -verklaring niet in onderstaande afbeelding weergegeven. Deze verklaring is door de splitsing echter niet verdwenen. Derden kunnen de 403-verklaring nog steeds opvragen bij het handelsregister.

Moedermaatschappij

Verkrijgende rechtspersoon 1

Verkrijgende rechtspersoon 2

Afbeelding 9.7

133. Zie $\S 8.14$.

134. Zie E.C.A. Nass 2019, p. 181-182, met betrekking tot het boekjaar waarover de 403-maatschappij voor het laatst gebruik kan maken van de jaarrekeningvrijstelling van het groepsregime.

135. Verbrugh 2006, p. 54, Verbrugh 2007, p. 269, Van der Kraan 2012, p. 160 en Beckman Compendium jaarrekening, $\S 3.8 .1 .9$. 


\subsection{1.b Aansprakelijkheid op grond van de 403-verklaring}

Beckman merkt op dat een moedermaatschappij na de zuivere splitsing van de 403-maatschappij op grond van de 403-verklaring aansprakelijk is voor alle schulden die voortvloeien en zijn voortgevloeid uit de rechtshandelingen die de 403-maatschappij tot het moment van de zuivere splitsing heeft verricht. ${ }^{136}$ Daaronder vallen ook de schulden die na de zuivere splitsing voortvloeien uit een daarvoor verrichte rechtshandeling. ${ }^{137}$ Ik sluit mij daarbij aan. Ik heb eerder geconcludeerd dat de reikwijdte van de aansprakelijkheid van een moedermaatschappij op grond van de 403-verklaring is gerelateerd aan het moment waarop de 403-maatschappij de rechtshandeling heeft verricht waaruit een schuld voortvloeit. ${ }^{138}$ Als de desbetreffende rechtshandeling onder de reikwijdte van de 403-aansprakelijkheid valt, is de moedermaatschappij aansprakelijk voor alle schulden die daaruit voortvloeien. Dat de 403-maatschappij nadien zuiver splitst, maakt dit niet anders. Als de 403-maatschappij bijvoorbeeld in het verleden een arbeidsovereenkomst is aangegaan met een werknemer, is de moedermaatschappij dus niet alleen aansprakelijk is voor de bestaande schulden van de 403-maatschappij die ten tijde van de zuivere splitsing uit de arbeidsovereenkomst zijn voortgevloeid, maar ook voor de schulden die na de splitsing uit deze overeenkomst voortvloeien.

Een andere uitkomst zou hetzelfde gevolg hebben als een gedeeltelijke beëindiging van de 403-aansprakelijkheid buiten art. 2:404 BW om. Een crediteur kan dan geen beroep doen op de procedures en waarborgen uit deze bepaling ${ }^{139}$ die beogen zijn verhaalsrecht te beschermen. Hij zou dan onder meer geen verzet kunnen instellen en een vervangende waarborg kunnen verlangen voor de voldoening van zijn vordering. De crediteur kan daardoor in een nadeliger positie komen zonder dat hij daar invloed op heeft. Dit strookt niet met het door mij bepleite uitgangspunt voor compensatie. ${ }^{140}$ Het is zelfs denkbaar dat een zuivere splitsing van de 403-maatschappij wordt misbruikt om ervoor te zorgen dat er geen nieuwe schulden meer onder de 403-aansprakelijkheid vallen.

136. Beckman - SDU Commentaar Ondernemingsrecht 2019, art. 2:404 BW, aant. C.1. Zie ook Beckman - Compendium jaarrekening, § 3.8.1.9, waar wordt opgemerkt dat de 403-aansprakelijkheid ongewijzigd blijft bestaan. Vgl. Verbrugh 2006, p. 54 en Verbrugh 2007, p. 269.

137. Zie in vergelijkbare zin $\S 9.7 .2 . b$ en $\S 9.10 .1$.b met betrekking tot een fusie waarbij de 403-maatschappij is verdwenen en haar vermogen onder algemene titel is overgegaan op een verkrijgende rechtspersoon, respectievelijk een afsplitsing van vermogen van de 403-maatschappij.

138. Zie $\S 5.3$.

139. Zie hoofdstuk 7 en 8 met betrekking tot de intrekking van de 403 -verklaring en de beëindiging van de overblijvende aansprakelijkheid.

140. Zie $\S 3.6 .1$. 


\section{HOOFDSTUK 9}

9.9.1.c Subsidiaire aansprakelijkheid van de verkrijgende rechtspersoon op wie een schuld niet is overgegaan

Op grond van art. 2:334t BW zijn beide verkrijgende rechtspersonen aansprakelijk voor de schulden van de 403-maatschappij ten tijde van de zuivere splitsing. ${ }^{141}$ De verkrijgende rechtspersoon op wie een schuld bij de zuivere splitsing niet onder algemene titel is overgegaan, is slechts subsidiair aansprakelijk voor de nakoming van deze schuld. Ik merk op dat de aansprakelijkheid ex art. 2:334t BW slechts ziet op de bestaande schulden van de 403-maatschappij op het moment van de zuivere splitsing, al hoeven deze nog niet opeisbaar te zijn. ${ }^{142}$ Schulden die na de splitsing voortvloeien uit een daarvoor aangegane rechtsverhouding vallen hier niet onder.

Verbrugh en Van der Kraan wijzen erop dat een crediteur die op het moment van de zuivere splitsing een vordering heeft op de 403-maatschappij, daarna drie mogelijkheden heeft om zijn vordering voldaan te krijgen. ${ }^{143}$ Ten eerste kan hij de verkrijgende rechtspersoon ansprakelijk stellen op wie de schuld bij de zuivere splitsing onder algemene titel is overgegaan. Daarnaast is de moedermaatschappij op grond van de 403-verklaring hoofdelijk aansprakelijk voor de nakoming van deze schuld - de crediteur kan naar vrije keuze de verkrijgende rechtspersoon op wie de schuld is overgegaan en de moedermaatschappij aansprakelijk stellen. Tot slot is de andere verkrijgende rechtspersoon op wie de schuld bij de zuivere splitsing niet is overgegaan op grond van art. 2:334t BW subsidiair aansprakelijk. ${ }^{144}$ Ik ben het met Verbrugh en Van der Kraan eens dat de subsidiaire aansprakelijkheid ex art. 2:334t BW met zich brengt, dat de crediteur hier pas een beroep op kan doen als de verkrijgende rechtspersoon op wie de schuld wel is overgegaan en de moedermaatschappij tekortschieten in de nakoming.

\subsection{1.d Beëindiging van de overblijvende aansprakelijkheid}

Als de moedermaatschappij de 403-verklaring intrekt, kan zij de overblijvende aansprakelijkheid beëindigen als zij voldoet aan de voorwaarden van art. 2:404 lid $3 \mathrm{BW}$. Het is de vraag of door de zuivere splitsing van de 403-maatschappij

141. Op grond van art. 2:334t lid 2 en $3 \mathrm{BW}$ zijn de verkrijgende rechtspersonen voor het geheel aansprakelijk voor ondeelbare verbintenissen van de 403-maatschappij. Met betrekking tot deelbare verbintenissen is de rechtspersoon op wie de verbintenis niet onder algemene titel is overgegaan slechts aansprakelijk tot de waarde van het vermogen dat bij de zuivere splitsing op hem is overgegaan. Ik laat dit verschil in aansprakelijkheid verder buiten beschouwing.

142. Verbrugh 2007, p. 229 en Asser/Maeijer \& Kroeze 2-I* 2015/587. Zie ook Kamerstukken II 1996/97, 24702, 6, p. 10 (NnavhV).

143. Verbrugh 2006, p. 54 en Van der Kraan 2012, p. 160-161.

144. Zie in vergelijkbare zin $\S 9.10 .1$.c met betrekking tot een afsplitsing van vermogen van de 403-maatschappij. 
is voldaan aan de voorwaarde van art. 2:404 lid 3 sub a BW dat de groepsband tussen de moeder- en de 403-maatschappij is verbroken.

Als de verkrijgende rechtspersonen niet tot de groep van de moedermaatschappij behoren, lijdt het geen twijfel dat aan de voorwaarde van art. 2:404 lid 3 sub a BW is voldaan. ${ }^{145}$ Als ook aan de andere voorwaarden van art. 2:404 lid 3 BW wordt voldaan, is de overblijvende aansprakelijkheid van de moedermaatschappij beëindigd.

Indien de verkrijgende rechtspersonen wel tot de groep van de moedermaatschappij behoren, wordt in de literatuur aangenomen dat niet is voldaan aan het verbreken van de groepsband in de zin van art. 2:404 lid 3 sub a BW. ${ }^{146}$ Ik deel dit standpunt. Er zou mogelijk nog kunnen worden betoogd dat aan de voorwaarde van art. 2:404 lid 3 sub a BW is voldaan omdat de 403-maatschappij door de zuivere splitsing is opgehouden te bestaan. Een soortgelijk standpunt wordt door enkele auteurs verdedigd als de 403-maatschappij door een fusie met een groepsmaatschappij ophoudt te bestaan. ${ }^{147}$ Evenals bij een dergelijke fusie meen ik echter dat dit een te strikte uitleg is van art. 2:404 lid 3 sub a BW. De mogelijkheid om de overblijvende aansprakelijkheid te beëindigen, is mijns inziens bedoeld voor de gevallen dat de rechtspersoon op wie deze aansprakelijkheid rust niet tot dezelfde groep behoort als de rechtspersoon - of rechtspersonen - van wie de handelingen tot aansprakelijkheid op grond van de ingetrokken 403 -verklaring kunnen leiden. ${ }^{148}$ Een dergelijke situatie doet zich niet voor als de 403-maatschappij zuiver splitst waarbij haar vermogen onder algemene titel overgaat op verkrijgende rechtspersonen die tot dezelfde groep behoren. Na de zuivere splitsing zijn het de handelingen van de verkrijgende rechtspersonen die tot aansprakelijkheid op grond van de ingetrokken 403-verklaring kunnen leiden. Deze rechtspersonen maken onderdeel uit van dezelfde groep als de moedermaatschappij op wie de overblijvende aansprakelijkheid rust.

9.9.1.e Een van de verkrijgende rechtspersonen behoort tot een andere groep

Het is mogelijk dat bij een zuivere splitsing van de 403-maatschappij een deel van het vermogen onder algemene titel is overgegaan op een groepsmaatschappij en het overige deel op een rechtspersoon buiten de groep. Ik meen met Verbrugh en Van der Kraan dat de moedermaatschappij in een dergelijk geval het gedeelte van de overblijvende aansprakelijkheid kan beëindigen dat

145. Verbrugh 2006, p. 54, Verbrugh 2007, p. 269-270, Van der Kraan 2012, p. 161 en E.C.A. Nass 2019, p. 182.

146. Verbrugh 2006, p. 54, Verbrugh 2007, p. 269-270 en Van der Kraan 2012, p. 161.

147. Zie § 9.7.2.c en zie Van Wijngaarden 2006a, p. 620, Snijder-Kuipers \& Eliëns 2014, p. 11771178 en Holtman 2019, p. 160.

148. Zie $\S 9.4 .1$. 
betrekking heeft op het vermogen van de verdwenen 403-maatschappij dat is overgegaan op de verkrijgende rechtspersoon buiten de groep. ${ }^{149}$

Mijns inziens staat art. 2:404 lid 3 BW er niet aan in de weg dat de moedermaatschappij een deel van haar overblijvende aansprakelijkheid beëindigt, terwijl zij de rest ongemoeid laat. Op grond van deze bepaling heeft een moedermaatschappij de mogelijkheid om haar overblijvende aansprakelijkheid tegenover een schuldeiser te beëindigen. Het is dus niet vereist dat zij in een keer de overblijvende aansprakelijkheid ten aanzien van alle schuldeisers beëindigt.

Indien de moedermaatschappij in onderhavige situatie niet het gedeelte van haar overblijvende aansprakelijkheid zou kunnen beëindigen dat betrekking heeft op het deel van het vermogen van de verdwenen 403-maatschappij dat onder algemene titel is overgegaan op de verkrijgende rechtspersoon buiten de groep, zou dit mijns inziens in strijd zijn met de bedoeling van deze regeling. De desbetreffende rechtspersoon behoort niet tot de groep van de moedermaatschappij, maar zijn handelingen kunnen wel nog tot aansprakelijkheid leiden voor de moedermaatschappij op grond van de ingetrokken 403 -verklaring. ${ }^{150}$ Als de moedermaatschappij deze aansprakelijkheid niet zou kunnen beëindigen, brengt dat voor haar onnodige risico's met zich.

Als een moedermaatschappij een gedeelte van haar overblijvende aansprakelijkheid wil beëindigen, moet uit de te deponeren mededeling van het voornemen hiertoe en de aankondiging in een landelijk verspreid dagblad dat en waar deze mededeling ter inzage ligt ${ }^{151}$ duidelijk zijn op te maken ten aanzien van welke crediteuren de moedermaatschappij haar aansprakelijkheid wil beëindigen. Om aan te duiden voor welke schulden zij haar aansprakelijkheid wil beëindigen, kan de moedermaatschappij verwijzen naar de beschrijving bij het splitsingsvoorstel van de 403-maatschappij, waarin is opgenomen welke vermogensbestanddelen op iedere verkrijgende rechtspersoon zijn overgegaan. ${ }^{152}$ Indien een crediteur op basis van de informatie in de gedeponeerde mededeling en de aankondiging daarvan in een landelijk verspreid dagblad redelijkerwijs niet heeft kunnen opmaken dat zijn vordering op de moedermaatschappij zou komen te vervallen, is het beroep van de moedermaatschappij op de beëindiging van de overblijvende aansprakelijkheid tegenover deze crediteur naar mijn mening onaanvaardbaar naar maatstaven van redelijkheid en billijkheid. ${ }^{153}$

149. Verbrugh 2006, p. 54, Verbrugh 2007, p. 269-270 en Van der Kraan 2012, p. 161. Zie in vergelijkbare zin $\S 9.10 .1$.d met betrekking tot een afsplitsing van vermogen van de 403-maatschappij.

150. Zie $\S 9.4 .1$.

151. Zie art. 2:404 lid 3 sub b en c BW. Zie ook $\S 8.5$.

152. Zie art. 2:334f lid 2 sub d en art. 2:334h lid 1 sub a BW.

153. Zie $\S 8.5 .3$. 


\subsubsection{Zuivere splitsing van de moedermaatschappij}

\subsection{2.a Inleiding}

In afbeelding 9.8 heb ik een zuivere splitsing van de moedermaatschappij weergegeven. De moedermaatschappij is opgehouden te bestaan en haar vermogen is onder algemene titel overgegaan op twee verkrijgende rechtspersonen.

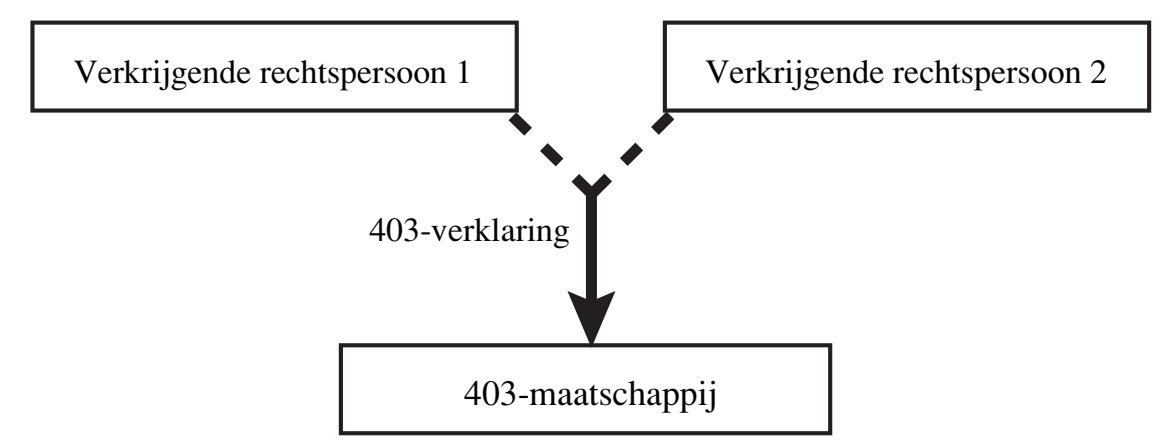

Afbeelding 9.8

\subsection{2.b Aansprakelijkheid op grond van de 403-verklaring}

In de splitsingsakte moet zijn opgenomen op welke van de verkrijgende rechtspersonen de 403-aansprakelijkheid - als onderdeel van het vermogen van de verdwenen moedermaatschappij - onder algemene titel is overgegaan. ${ }^{154,155}$ $\mathrm{Na}$ de zuivere splitsing heeft de 403-verklaring te gelden als verklaring van de desbetreffende verkrijgende rechtspersoon. ${ }^{156}$ Deze rechtspersoon is aansprakelijk voor de schulden die voortvloeien en zijn voortgevloeid uit een rechtshandeling van de 403-maatschappij. ${ }^{157}$ Daaronder vallen ook de schulden die voortvloeien uit een rechtshandeling die de 403-maatschappij verricht na de zuivere splitsing van de moedermaatschappij.

154. Zie art. 2:334n lid 2 jo. art. 2:334f lid 2 sub d BW.

155. Verbrugh 2007, p. 268, Van der Kraan 2012, p. 146 en 155, E.C.A. Nass 2019, p. 184 en Beckman - Compendium jaarrekening, § 3.8.3.40. Zie § 9.2.2 waar ik tot de conclusie kom dat de 403-aansprakelijkheid onder algemene titel kan overgaan op een verkrijgende rechtspersoon. Dit standpunt wordt echter niet door iedereen onderschreven. Zie met betrekking tot onderhavige casus: Van Olffen, Buijn \& Simonis 2004, p. 89 en Zaman, Van Eck \& Roelofs 2009, p. 281.

156. Ter verduidelijking dat de 403 -aansprakelijkheid op de verkrijgende rechtspersoon rust, kan deze mijns inziens met betrekking tot de 403 -verklaring een addendum deponeren dat zij op grond van deze verklaring aansprakelijk is.

157. Zie $\S 5.6$. 


\section{HOOFDSTUK 9}

Als aan de hand van de splitsingsakte niet kan worden bepaald op welke verkrijgende rechtspersoon de 403-aansprakelijkheid onder algemene titel is overgegaan, zijn de verkrijgende rechtspersonen gezamenlijk op grond van de 403-verklaring hoofdelijk ansprakelijk voor de schulden die voortvloeien uit een rechtshandeling van de 403-maatschappij. ${ }^{158}$ In de praktijk zal deze situatie zich echter niet vaak voordoen omdat in een splitsingsakte doorgaans een restbepaling wordt opgenomen op grond waarvan de vermogensbestanddelen waarvan niet expliciet is vermeld op welke verkrijgende rechtspersoon ze overgaan, op een van de verkrijgende rechtspersonen overgaan.

Als er na de zuivere splitsing van de moedermaatschappij een groepsband bestaat tussen de verkrijgende rechtspersoon op wie de 403 -aansprakelijkheid is overgegaan en de 403-maatschappij, kan laatstgenoemde gebruik blijven maken van de jaarrekeningvrijstelling van het groepsregime - mits ook aan de overige voorwaarden hiervoor is voldaan. ${ }^{159}$

9.9.2.c Subsidiaire aansprakelijkheid van de verkrijgende rechtspersoon op wie een schuld niet is overgegaan

Op grond van art. 2:334t BW zijn beide verkrijgende rechtspersonen aansprakelijk voor de schulden van de moedermaatschappij ten tijde van de zuivere splitsing. Daaronder vallen ook de schulden op grond van de 403 -verklaring. ${ }^{160}$ De verkrijgende rechtspersoon op wie een schuld niet onder algemene titel is overgegaan, is slechts subsidiair aansprakelijk voor de nakoming van deze schuld. De aansprakelijkheid ex art. 2:334t BW ziet alleen op de bestaande schulden van de moedermaatschappij op het moment van de zuivere splitsing, al hoeven deze nog niet opeisbaar te zijn. ${ }^{161}$ Schulden die na de zuivere splitsing voortvloeien uit een voor de splitsing aangegane rechtsverhouding vallen hier niet onder.

158. Zie art. 2:334s lid 2 en $4 \mathrm{BW}$.

159. E.C.A. Nass 2019, p. 184 en Beckman - Compendium jaarrekening, § 3.8.3.40

160. Van Olffen, Buijn \& Simonis 2004, p. 89-90, Verbrugh 2006, p. 54 en Verbrugh 2007, p. 268. Vgl. Van der Kraan 2012, p. 152 en 156 en Holtman 2019, p. 164, die van mening zijn dat een crediteur pas een vordering op de moedermaatschappij krijgt als hij haar op grond van de 403-verklaring aansprakelijk heeft gesteld. Art. 2:334t BW is volgens hen daarom niet van toepassing als een crediteur de moedermaatschappij ten tijde van de zuivere splitsing nog niet aansprakelijk heeft gesteld. Dit standpunt is echter niet juist. Zie HR 28 juni 2002, JOR 2002/136, m.nt. Bartman (Akzo/ING), r.o. 3.4.3, waar de Hoge Raad oordeelt dat een moedermaatschappij op grond van de 403-verklaring rechtstreeks aansprakelijk is. Deze aansprakelijkheid ontstaat dus niet pas als de crediteur de moedermaatschappij aansprakelijk stelt. Zie ook $\S 6.2 .5$.

161. Verbrugh 2007, p. 229 en Asser/Maeijer \& Kroeze 2-I*2015/587. Zie ook Kamerstukken II 1996/97, 24702, 6, p. 10 (NnavhV). 
De crediteuren van de 403-maatschappij die op het moment van de zuivere splitsing van de moedermaatschappij op grond van de 403 -verklaring een vordering hebben op de moedermaatschappij, hebben daarna drie mogelijkheden om hun vordering voldaan te krijgen. ${ }^{162}$ Ten eerste kan een crediteur de 403-maatschappij zelf aansprakelijk stellen. Daarnaast is de verkrijgende rechtspersoon op wie de 403-aansprakelijkheid van de moedermaatschappij onder algemene titel is overgegaan hoofdelijk aansprakelijk voor de desbetreffende schuld van de 403-maatschappij - de crediteur kan naar vrije keuze de 403-maatschappij en de verkrijgende rechtspersoon op wie de 403 -aansprakelijkheid is overgegaan aansprakelijk stellen. Tot slot is ook de andere verkrijgende rechtspersoon op wie de 403-aansprakelijkheid niet is overgegaan op grond van art. 2:334t BW subsidiair aansprakelijk voor de nakoming van deze schuld. In vergelijkbare zin als bij een zuivere splitsing van de 403-maatschappij ${ }^{163}$ ben ik van mening dat de subsidiaire aansprakelijkheid ex art. 2:334t BW met zich brengt dat de crediteur de verkrijgende rechtspersoon op wie de 403-aansprakelijkheid niet is overgegaan pas aansprakelijk kan stellen als de 403-maatschappij en de verkrijgende rechtspersoon op wie de 403-aansprakelijkheid wel is overgegaan, tekortschieten in de nakoming.

Tot slot merk ik op dat als de verkrijgende rechtspersoon op wie de 403-aansprakelijkheid onder algemene titel is overgegaan de 403-verklaring intrekt en de overblijvende aansprakelijkheid beëindigt, daardoor ook de subsidiaire aansprakelijkheid van de andere verkrijgende rechtspersoon ex art. 2:334t BW voor de desbetreffende schulden eindigt. ${ }^{164}$

\subsection{2.d Beëindiging van de overblijvende aansprakelijkheid}

Na de zuivere splitsing van de moedermaatschappij kan de verkrijgende rechtspersoon op wie de 403-aansprakelijkheid onder algemene titel is overgegaan de 403 -verklaring intrekken. ${ }^{165}$ Om vervolgens de overblijvende aansprakelijkheid te beëindigen moet onder meer zijn voldaan aan de voorwaarde ex art. 2:404 lid 3 sub a BW dat de groepsband met de 403-maatschappij is verbroken.

162. Zie in vergelijkbare zin $\S 9.10 .2$.c met betrekking tot een afsplitsing van vermogen van de moedermaatschappij.

163. Zie $\S 9.9 .1 . c$.

164. Van Olffen, Buijn \& Simonis 2004, p. 90, Verbrugh 2006, p. 54 en Verbrugh 2007, p. 269. Zie in vergelijkbare zin $\S 9.10 .2$.c met betrekking tot een afsplitsing van vermogen van de moedermaatschappij.

165. Asser/Maeijer \& Kroeze 2-I* 2015/585 en Beckman - Compendium jaarrekening, $\S 3.8 .5 .10$. 
Doorgaans bestaat er na de zuivere splitsing van de moedermaatschappij een groepsband tussen de verkrijgende rechtspersoon op wie de 403-aansprakelijkheid onder algemene titel is overgegaan en de 403-maatschappij. Ten eerste kan de 403-maatschappij dan gebruik blijven maken van de jaarrekeningvrijstelling van het groepsregime - mits ook aan de andere voorwaarden hiervoor is voldaan. Daarnaast heeft de desbetreffende verkrijgende rechtspersoon in dat geval doorslaggevende invloed op de 403-maatschappij en daarmee indirect op de handelingen van laatstgenoemde die tot nieuwe aansprakelijkheid op grond van de 403-verklaring kunnen leiden.

Het is echter mogelijk dat de 403-aansprakelijkheid op de ene verkrijgende rechtspersoon is overgegaan, maar dat er een groepsband is ontstaan tussen de 403-maatschappij en de andere verkrijgende rechtspersoon. Dit kan zich bijvoorbeeld voordoen als in de splitsingsakte is opgenomen dat de aandelen van de moedermaatschappij in de 403-maatschappij op een bepaalde verkrijgende rechtspersoon overgaan, maar dat niet is opgenomen op wie de 403-aansprakelijkheid overgaat en deze daarom op basis van een restbepaling - op grond waarvan alle vermogensbestanddelen waarvan niet expliciet is vermeld op wie ze overgaan, aan een bepaalde verkrijgende rechtspersoon worden toegekend - is overgaan op de andere verkrijgende rechtspersoon. Dit is echter geen waarschijnlijk scenario.

Tot slot is het denkbaar dat de 403-maatschappij met geen van beide verkrijgende rechtspersonen een groepsband heeft. Dit doet zich bijvoorbeeld voor als de verkrijgende rechtspersonen niet tot dezelfde groep behoren en de 403-maatschappij na de zuivere splitsing van de moedermaatschappij een 50/50-joint venture is geworden van hen waarbij geen van de partijen de centrale leiding uitoefent. ${ }^{166}$

Als er na de zuivere splitsing van de moedermaatschappij geen groepsband bestaat tussen de verkrijgende rechtspersoon op wie de 403-aansprakelijkheid is overgegaan en de 403-maatschappij, is voldaan aan de voorwaarde ex art. 2:404 lid 3 sub a BW en kan de overblijvende aansprakelijkheid worden beëindigd - mits ook aan de andere voorwaarden hiervoor wordt voldaan. In het geval dat er wel een groepsband is tussen de verkrijgende rechtspersoon op wie de 403-aansprakelijkheid is overgegaan en de 403-maatschappij, wordt er in de literatuur een onderscheid gemaakt of de verkrijgende rechtspersoon al of niet tot de groep behoort van de verdwenen moedermaatschappij. Ik onderschrijf het standpunt van Verbrugh en Van der Kraan die opmerken dat als de verkrijgende

166. Kamerstukken II 1981/82, 16326, 7, p. 18 (VV), Kamerstukken II 1987/88, 20583, 3, p. 12 (MvT), Van Achterberg, 1989, p. 74-75, E.C.A. Nass 2019, p. 46, E.C.A. Nass 2020, p. 149 en Bartman, Dorresteijn \& Olaerts 2020, p. 35. Anders Raaijmakers 1976, p. 295, die meent dat een 50/50-joint venture tot twee groepen behoort. Zie ook $\S 2.3 .2$. 
rechtspersoon tot dezelfde groep behoort als de verdwenen moedermaatschappij, dat dan niet is voldaan aan de voorwaarde van art. 2:404 lid 3 sub a BW dat de groepsband met de 403-maatschappij is verbroken. ${ }^{167}$ De 403-maatschappij is in een dergelijk geval als het ware 'verhangen' binnen de groep. De overblijvende aansprakelijkheid kan dan dus niet worden beëindigd.

Verbrugh en Van der Kraan twijfelen of er is voldaan aan de voorwaarde ex art. 2:404 lid 3 sub a BW als de 403-maatschappij na de zuivere splitsing van de moedermaatschappij een groepsband heeft met een verkrijgende rechtspersoon buiten de groep. ${ }^{168}$ Volgens hen is de groepsband tussen de 403-maatschappij en de moedermaatschappij formeel gezien verbroken. Maar aangezien er een (nieuwe) groepsband tot stand is gekomen met de verkrijgende rechtspersoon op wie de 403-aansprakelijkheid is overgegaan, menen zij dat er ook wat voor te zeggen is dat niet is voldaan aan de voorwaarde van art. 2:404 lid 3 sub a BW.

Ik ben het eens met de opmerking van Verbrugh dat de overblijvende aansprakelijkheid niet kan worden beëindigd als de groepsband tussen de verkrijgende rechtspersoon en de 403-maatschappij eenmaal een feit is. ${ }^{169}$ Daarvoor moet dan deze groepsband tussen hen worden verbroken. Verbrugh merkt op dat indien aangenomen zou worden dat op het moment van de zuivere splitsing van de moedermaatschappij de groepsband (kortstondig) is verbroken voordat de groepsband tussen de verkrijgende rechtspersoon en de 403-maatschappij tot stand komt, de overblijvende aansprakelijkheid dan alleen op dat moment zou kunnen worden beëindigd. Een dergelijk standpunt wordt ook verdedigd met betrekking tot een fusie waarbij de moedermaatschappij ophoudt te bestaan en haar vermogen onder algemene titel overgaat op een verkrijgende rechtspersoon buiten de groep. ${ }^{170}$ Toegepast op een zuivere splitsing van de moedermaatschappij betekent dit kort gezegd het volgende. Op het moment dat de moedermaatschappij door de zuivere splitsing ophoudt te bestaan, is de groepsband met de 403-maatschappij verbroken. Daarna komt er een nieuwe groepsband tot stand tussen de verkrijgende rechtspersoon en de 403-maatschappij. Als de moedermaatschappij voor de geplande splitsing al start met de procedure om de overblijvende aansprakelijkheid te beëindigen ${ }^{171}$ en het moment van de zuivere splitsing samenvalt met het moment dat de verzetstermijn verloopt waarbinnen de crediteuren verzet kunnen instellen tegen de beëindiging van de overblijvende aansprakelijkheid, zou verdedigd kunnen worden dat op dat moment is voldaan aan alle voorwaarden van art. 2:404 lid 3

167. Verbrugh 2006, p. 54, Verbrugh 2007, p. 268 en Van der Kraan 2012, p. 155-156.

168. Verbrugh 2006, p. 54, Verbrugh 2007, p. 268-269 en Van der Kraan 2012, p. 156-157.

169. Verbrugh 2006, p. 54 en Verbrugh 2007, p. 269.

170. Zie § 9.8.2.c, Beckman 1995a, p. 623 en Van der Kraan 2012, p. 118. Vgl. Verbrugh 2006, p. 53 en Verbrugh 2007, p. 104.

171. Zie $\S 8.13$. 
BW. ${ }^{172}$ De overblijvende aansprakelijkheid zou dan zijn beëindigd, behoudens de afwikkeling van een eventueel ingesteld verzet.

Evenals bij een fusie waarbij de moedermaatschappij ophoudt te bestaan en haar vermogen onder algemene titel overgaat op een verkrijgende rechtspersoon buiten de groep meen ik dat op het moment van de zuivere splitsing niet (kortstondig) is voldaan aan de voorwaarde ex art. 2:404 lid 3 sub a BW. Naar mijn mening moet art. 2:404 lid 3 sub a BW zo worden uitgelegd dat de overblijvende aansprakelijkheid alleen kan worden beëindigd als de rechtspersoon op wie deze aansprakelijkheid rust niet tot dezelfde groep behoort als de rechtspersoon van wie de handelingen tot aansprakelijkheid op grond van de ingetrokken 403-verklaring kunnen leiden. ${ }^{173}$ Een dergelijke situatie doet zich in onderhavige casus niet voor. Tot het moment van de zuivere splitsing is de moedermaatschappij aansprakelijk op grond van de ingetrokken 403-verklaring en heeft zij een groepsband met de 403-maatschappij. Na de zuivere splitsing rust de overblijvende aansprakelijkheid op de verkrijgende rechtspersoon. Vanaf dat moment bestaat er ook een groepsband tussen de verkrijgende rechtspersoon en de 403-maatschappij. De overblijvende aansprakelijkheid en de groepsband met de 403-maatschappij lopen dus parallel aan elkaar. Degene op wie de aansprakelijkheid rust, heeft ook een groepsband met de 403-maatschappij. Mijns inziens is het daarom niet mogelijk om de overblijvende aansprakelijkheid te beëindigen op het moment van de zuivere splitsing van de moedermaatschappij.

Evenals bij een fusie waarbij de moedermaatschappij verdwijnt, ${ }^{174}$ is er mijns inziens wel een andere manier waarmee kan worden bereikt dat de 403 -aansprakelijkheid niet overgaat op een van de verkrijgende rechtspersonen buiten de groep. Vlak voor de zuivere splitsing kan de moedermaatschappij de andelen in de 403-maatschappij apart overdragen aan een van de verkrijgende rechtspersonen. Hierdoor wordt de groepsband tussen de moeder- en de 403-maatschappij verbroken. Ik heb eerder betoogd dat de moedermaatschappij de procedure voor de beëindiging van de overblijvende ansprakelijkheid al kan beginnen voordat de groepsband met de 403-maatschappij is verbroken. ${ }^{175} \mathrm{Ik}$ heb art. 2:404 lid 3 BW zo uitgelegd dat uiterlijk op het moment dat de tweemaandstermijn verloopt waarbinnen de crediteuren verzet kunnen instellen tegen het voornemen van de moedermaatschappij om de overblijvende aansprakelijkheid te beëindigen aan alle voorwaarden voor deze beëindiging moet zijn voldaan,

172. Zie $\S 9.4 .2$, voor een uitgebreidere bespreking van de mogelijkheid dat de beëindiging van de overblijvende aansprakelijkheid samenvalt met een fusie of een splitsing van de moederof de 403-maatschappij.

173. Zie $\S 9.4 .1$.

174. Zie $\S 9.8 .2 . c$. Zie in vergelijkbare zin $\S 9.10 .2$.d met betrekking tot een afsplitsing van vermogen van de moedermaatschappij.

175. Zie $\S 8.13$. 
behoudens de afwikkeling van een eventueel ingesteld verzet. Als de moedermaatschappij de aandelen in de 403-maatschappij overdraagt op het moment dat de verzetstermijn verloopt, is op dat moment aan alle voorwaarden van art. 2:404 lid 3 BW voldaan en is de overblijvende aansprakelijkheid beëindigd. Vervolgens kan de moedermaatschappij zuiver splitsen waarbij (de rest van) haar vermogen onder algemene titel op de verkrijgende rechtspersonen overgaat. Het is aan te raden dat de moedermaatschappij en de verkrijgende rechtspersonen vooraf afspraken maken over de afwikkeling van een eventueel ingesteld verzet tegen de beëindiging van de overblijvende aansprakelijkheid. ${ }^{176}$

Overigens wijs ik erop dat ik eerder tot de conclusie ben gekomen dat de voorwaarde van de verbreking van de groepsband tussen de moeder- en de 403-maatschappij, het onnodig belastend maakt om de overblijvende aansprakelijkheid te beëindigen. Naar mijn mening moet deze voorwaarde daarom worden geschrapt uit art. 2:404 lid 3 BW. ${ }^{177}$

\subsection{Afsplitsing}

\subsubsection{Afsplitsing van vermogen van de 403-maatschappij}

9.10.1.a Inleiding

In afbeelding 9.9 heb ik een afsplitsing van vermogen van de 403-maatschappij weergegeven. De 403-maatschappij is blijven bestaan en een deel van haar vermogen is onder algemene titel overgegaan op een verkrijgende rechtspersoon.

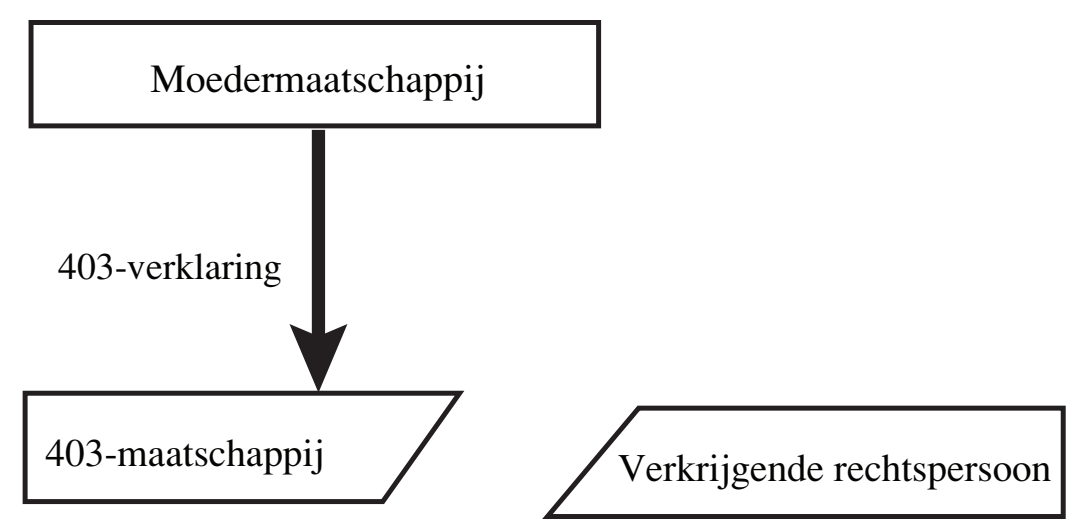

Afbeelding 9.9

176. Zie $\S 8.6$ tot en met $\S 8.10$.

177. Zie $\S 8.14$. 


\subsection{1.b Aansprakelijkheid op grond van de 403-verklaring}

De afsplitsing van vermogen van de 403-maatschappij heeft geen gevolgen voor de aansprakelijkheid van de moedermaatschappij op grond van de 403-verklaring. De moedermaatschappij blijft aansprakelijk voor de schulden die voortvloeien uit een rechtshandeling die de 403-maatschappij (heeft) verricht. Daaronder vallen ook de schulden die voortvloeien uit een rechtsverhouding waarbij de verkrijgende rechtspersoon door de afsplitsing de positie van de 403-maatschappij heeft ingenomen. Ik heb er eerder al op gewezen dat de aansprakelijkheid van de moedermaatschappij is gerelateerd aan het moment waarop de 403-maatschappij de rechtshandeling heeft verricht waaruit een schuld voortvloeit. ${ }^{178}$ Als de desbetreffende rechtshandeling onder de reikwijdte van de 403-aansprakelijkheid valt, is de moedermaatschappij aansprakelijk voor alle schulden die daaruit voortvloeien. Indien de 403-maatschappij in het verleden bijvoorbeeld een huurovereenkomst met een verhuurder heeft gesloten en de verkrijgende rechtspersoon door de afsplitsing de huurder wordt, blijft de moedermaatschappij aansprakelijk voor de bestaande en toekomstige huurschulden die uit deze overeenkomst voortvloeien. Voor de volledigheid merk ik nog op dat de moedermaatschappij op grond van de 403-verklaring vanzelfsprekend niet aansprakelijk is voor de schulden die voortvloeien uit de rechtshandelingen die de verkrijgende rechtspersoon zelf (heeft) verricht.

Ik wijs erop dat het Hof Amsterdam in haar Erjeebee/Coltex-uitspraak heeft geoordeeld dat een afsplitsing van vermogen van een 403-maatschappij niet tot gevolg heeft dat de 403-verklaring van de moedermaatschappij is ingetrokken. ${ }^{179}$ Daarvoor is een aparte handeling van de moedermaatschappij vereist. Aangezien ook de groepsband tussen de moeder- en de 403-maatschappij bij de afsplitsing blijft bestaan, kan de 403-maatschappij gebruik blijven maken van de jaarrekeningvrijstelling van het groepsregime - mits ook aan de andere voorwaarden hiervoor is voldaan. ${ }^{180}$

9.10.1.c Subsidiaire aansprakelijkheid van de 403-maatschappij en de verkrijgende rechtspersoon

De 403-maatschappij en de verkrijgende rechtspersoon zijn op grond van art. 2:334t BW beide aansprakelijk voor de schulden van de 403-maatschappij ten tijde van de afsplitsing. Als een schuld bij de afsplitsing onder algemene

178. Zie $\S 5.3$. Zie in vergelijkbare zin $\S 9.7 .2 . \mathrm{b}$ en $\S 9.9 .1 . \mathrm{b}$ met betrekking tot een fusie en een zuivere splitsing van de 403-maatschappij waarbij haar vermogen onder algemene titel overgaat op een of meer verkrijgende rechtspersonen.

179. Hof Amsterdam (OK) 7 juni 2016, JIN 2016/196, m.nt. Schepel (Erjeebee/Coltex), r.o. 3.6.2.

180. Van der Kraan 2012, p. 162. 
titel is overgegaan op de verkrijgende rechtspersoon, blijft de 403-maatschappij subsidiair aansprakelijk voor de nakoming hiervan. Omgekeerd geldt dat de verkrijgende rechtspersoon subsidiair aansprakelijk is voor de nakoming van een schuld die bij de afsplitsing bij de 403-maatschappij is achtergebleven. Ik merk op dat de aansprakelijkheid ex art. 2:334t BW is beperkt tot de bestaande schulden van de 403-maatschappij op het moment van de afsplitsing, al hoeven deze nog niet opeisbaar te zijn. ${ }^{181}$ Schulden die na de afsplitsing voortvloeien uit een voor de afsplitsing aangegane rechtsverhouding vallen hier niet onder.

Van der Kraan wijst erop dat de crediteuren die op het moment van de afsplitsing een vordering hebben op de 403-maatschappij, daarna drie mogelijkheden hebben om hun vordering voldaan te krijgen. ${ }^{182,183}$ Als bijvoorbeeld een schuld van de 403-maatschappij bij de afsplitsing onder algemene titel op de verkrijgende rechtspersoon is overgegaan, kan de crediteur in de eerste plaats deze rechtspersoon aansprakelijk stellen. Daarnaast is de moedermaatschappij op grond van de 403-verklaring hoofdelijke aansprakelijk - de crediteur kan naar vrije keuze de verkrijgende rechtspersoon op wie de schuld is overgegaan en de moedermaatschappij aansprakelijk stellen. Tot slot is de 403-maatschappij krachtens art. 2:334t BW subsidiair aansprakelijk voor de nakoming van de schuld.

Ik ben het met Van der Kraan eens dat de subsidiaire aansprakelijkheid ex art. 2:334t BW met zich brengt dat de crediteur hier als laatste van de drie gronden een beroep op kan doen. In bovenstaand voorbeeld zal de crediteur dus eerst moeten proberen om zijn vordering voldaan te krijgen bij de verkrijgende rechtspersoon en de moedermaatschappij voordat hij de 403-maatschappij op grond van art. 2:334t BW aansprakelijk kan stellen.

9.10.1.d Beëindiging van de overblijvende aansprakelijkheid

Als de moedermaatschappij de 403-verklaring na de afsplitsing van vermogen van de 403-maatschappij intrekt, kan zij onder voorwaarden de overblijvende aansprakelijkheid beëindigen. Daarbij moet een onderscheid worden gemaakt tussen de beëindiging van de overblijvende aansprakelijkheid van de moedermaatschappij met betrekking tot het vermogen dat bij de afsplitsing bij de 403-maatschappij is achtergebleven en het vermogen dat onder algemene titel is overgegaan op de verkrijgende rechtspersoon.

181. Verbrugh 2007, p. 229 en Asser/Maeijer \& Kroeze 2-I*2015/587. Zie ook Kamerstukken II 1996/97, 24702, 6, p. 10 (NnavhV).

182. Van der Kraan 2012, p. 162.

183. Zie in vergelijkbare zin $\S 9.9 .1$.c met betrekking tot een zuivere splitsing van de 403-maatschappij. 
Dat de moedermaatschappij haar overblijvende aansprakelijkheid met betrekking tot het gedeelte van het vermogen dat bij de afsplitsing bij de 403-maatschappij is achtergebleven niet kan beëindigen, staat buiten kijf. Er wordt in dat geval niet voldaan aan de voorwaarde ex art. 2:404 lid 3 sub a BW dat de groepsband tussen de moeder- en de 403-maatschappij is verbroken. ${ }^{184}$

Wat betreft de beëindiging van de overblijvende aansprakelijkheid van de moedermaatschappij met betrekking tot het gedeelte van het vermogen dat bij de afsplitsing van de 403-maatschappij is overgegaan op de verkrijgende rechtspersoon, moet er opnieuw een onderscheid worden gemaakt of de verkrijgende rechtspersoon al of niet een groepsmaatschappij is van de moederen de 403-maatschappij. In het geval dat de verkrijgende rechtspersoon tot de groep van de moeder- en de 403-maatschappij behoort, kan er geen twijfel over bestaan dat de moedermaatschappij de overblijvende aansprakelijkheid niet kan beëindigen. Ook in dat geval is niet voldaan aan het vereiste ex art. 2:404 lid 3 sub a BW dat de groepsband is verbroken.

Als de verkrijgende rechtspersoon daarentegen niet tot de groep van de moederen de 403-maatschappij behoort, kan de moedermaatschappij haar overblijvende aansprakelijkheid met betrekking tot het vermogen dat op deze rechtspersoon is overgegaan wel beëindigen. ${ }^{185}$ Evenals Van der Kraan ben ik van mening dat het feit dat de 403-maatschappij van wie het vermogen is afgesplitst, nog steeds tot dezelfde groep behoort als de moedermaatschappij daar niet aan in de weg staat. ${ }^{186}$ Een vergelijkbare situatie doet zich voor als de 403-maatschappij zuiver splitst en een deel van het vermogen onder algemene titel is overgegaan op een groepsmaatschappij en het overige deel op een verkrijgende rechtspersoon buiten de groep. ${ }^{187}$ Ten aanzien van die situatie heb ik eerder opgemerkt dat een moedermaatschappij op grond van art. 2:404 lid 3 BW het deel van haar overblijvende aansprakelijkheid kan beëindigen dat betrekking heeft op het vermogen dat bij de splitsing is overgegaan op de verkrijgende rechtspersoon buiten de groep. De rest van de overblijvende aansprakelijkheid van de moedermaatschappij blijft dan bestaan.

Indien de moedermaatschappij niet haar overblijvende aansprakelijkheid zou kunnen beëindigen met betrekking tot het vermogen dat bij de afsplitsing van de 403-maatschappij onder algemene titel is overgegaan op de verkrijgende

184. E.C.A. Nass 2019, p. 183.

185. Van der Kraan 2012, p. 162 en Holtman 2019, p. 164. Zie Verbrugh 2006, p. 55, waar hij betoogt dat de moedermaatschappij haar overblijvende aansprakelijkheid kan beëindigen met betrekking tot het vermogen dat bij de afsplitsing is overgegaan op een verkrijgende rechtspersoon buiten de groep. Vgl. echter Verbrugh 2007, p. 271, waar hij opmerkt dat dit naar de letter van de wet niet mogelijk is.

186. Van der Kraan 2012, p. 162.

187. Zie $\S 9.9 .1 . e$. 
rechtspersoon buiten de groep, zou dat mijns inziens in strijd zijn met de bedoeling van de regeling van de beëindiging. De verkrijgende rechtspersoon behoort niet tot de groep van de moedermaatschappij, maar zijn handelingen kunnen wel nog tot aansprakelijkheid leiden voor de moedermaatschappij op grond van de ingetrokken 403 -verklaring. ${ }^{188}$ De moedermaatschappij zou onnodig risico lopen als zij deze aansprakelijkheid niet zou kunnen beëindigen.

Als de moedermaatschappij een deel van haar overblijvende aansprakelijkheid wil beëindigen, is het voor haar belangrijk dat zij in de te deponeren mededeling van dit voornemen en de aankondiging in een landelijk verspreid dagblad dat en waar deze mededeling ter inzage ligt, duidelijk uiteenzet ten aanzien van welke crediteuren zij haar aansprakelijkheid wil beëindigen. ${ }^{189}$ De moedermaatschappij kan hiervoor verwijzen naar de beschrijving bij het splitsingsvoorstel van de 403-maatschappij, waarin is opgenomen welke vermogensbestanddelen op de verkrijgende rechtspersoon zijn overgegaan. ${ }^{190}$ Als een crediteur op basis van de informatie in de gedeponeerde mededeling en de aankondiging daarvan in een landelijk verspreid dagblad redelijkerwijs niet heeft kunnen opmaken dat zijn vordering op de moedermaatschappij zou komen te vervallen, is het beroep van de moedermaatschappij op de beëindiging van de overblijvende aansprakelijkheid tegenover deze crediteur naar mijn mening onaanvaardbaar naar maatstaven van redelijkheid en billijkheid. ${ }^{191}$

Ik wijs er tot slot nog op dat als de moedermaatschappij na de afsplitsing van vermogen van de 403-maatschappij haar overblijvende aansprakelijkheid wil beëindigen met betrekking tot het vermogen dat is overgegaan op de verkrijgende rechtspersoon buiten de groep, zij de 403-verklaring moet hebben ingetrokken. Als de 403-maatschappij gebruik wil blijven maken van de jaarrekeningvrijstelling van het groepsregime, moet de moedermaatschappij ten aanzien van haar een nieuwe 403-verklaring deponeren.

\subsubsection{Afsplitsing van vermogen van de moedermaatschappij}

\subsection{2.a Inleiding}

In afbeelding 9.10 heb ik een afsplitsing van vermogen van de moedermaatschappij weergegeven. De moedermaatschappij is blijven bestaan en een deel van haar vermogen is onder algemene titel overgegaan op een verkrijgende rechtspersoon.

188. Zie $\S 9.4 .1$.

189. Zie art. 2:404 lid 3 sub b en c BW. Zie ook $\S 8.5$.

190. Zie art. 2:334f lid 2 sub d en art. 2:334h lid 1 sub a BW.

191. Zie $\S 8.5 .3$. 


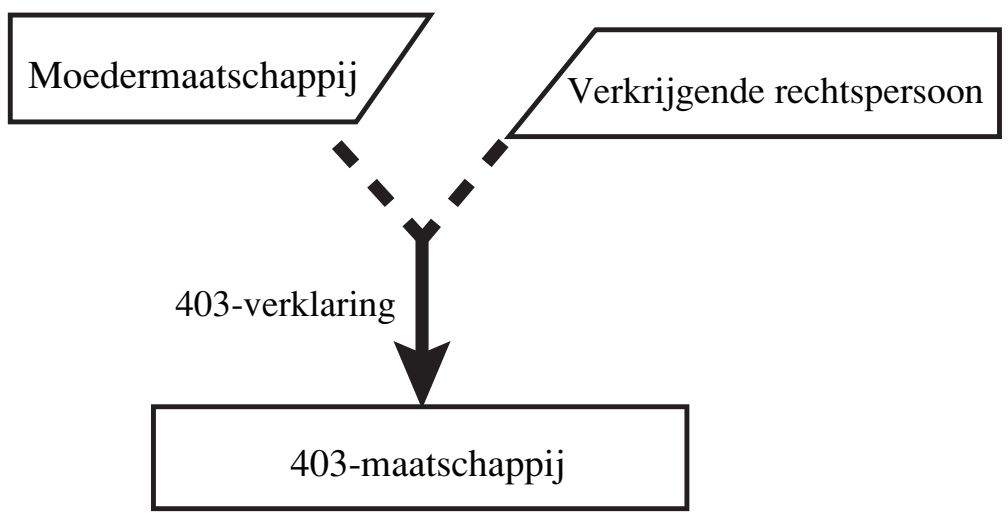

Afbeelding 9.10

\subsection{2.b Aansprakelijkheid op grond van de 403-verklaring}

In de splitsingsakte moet zijn opgenomen welke vermogensbestanddelen van de moedermaatschappij bij de afsplitsing onder algemene titel op de verkrijgende rechtspersoon zijn overgegaan en welke bij de moedermaatschappij zijn achtergebleven. ${ }^{192}$ Indien de betrokken partijen willen dat de 403-aanprakelijkheid van de moedermaatschappij overgaat op de verkrijgende rechtspersoon moeten zij dat in de splitsingsakte opnemen. ${ }^{193}$ Als uit de splitsingsakte niet blijkt dat de 403-aansprakelijkheid wel of niet op de verkrijgende rechtspersoon is overgegaan, is deze bij de moedermaatschappij achtergebleven. ${ }^{194}$

Mits ook aan de andere voorwaarden hiervoor is voldaan, kan de 403-maatschappij gebruik blijven maken van de jaarrekeningvrijstelling van het groepsregime als zij na de afsplitsing van vermogen van de moedermaatschappij een groepsband heeft met de rechtspersoon bij wie de 403-aansprakelijkheid is achtergebleven - de moedermaatschappij -, respectievelijk op wie deze aansprakelijkheid is overgegaan - de verkrijgende rechtspersoon.

Ik merk op dat als de 403-aansprakelijkheid onder algemene titel is overgegaan op de verkrijgende rechtspersoon, deze verklaring vanaf dat moment heeft te gelden als verklaring van deze rechtspersoon. In de 403-verklaring zelf staat echter dat de moedermaatschappij aansprakelijk is. Om duidelijk te maken dat

192. Zie art. $2: 334 \mathrm{n}$ lid 2 jo. art. $2: 334 \mathrm{f}$ lid 2 sub d BW.

193. Van der Kraan 2012, p. 158. Zie $\S 9.2$.2 waar ik tot de conclusie kom dat de 403-aansprakelijkheid onder algemene titel kan overgaan op een verkrijgende rechtspersoon. Dit standpunt wordt echter niet door iedereen onderschreven. Zie met betrekking tot onderhavige casus: Van Olffen, Buijn \& Simonis 2004, p. 89 en Holtman 2019, p. 164.

194. Zie art. 2:334s lid 3 BW. 
de verkrijgende rechtspersoon aansprakelijk is op grond van de 403-verklaring, kan deze mijns inziens een addendum deponeren dat de 403-aansprakelijkheid op haar rust. Als er geen addendum is gedeponeerd, acht ik het verdedigbaar dat als een crediteur te goeder trouw de moedermaatschappij aansprakelijk stelt op grond van de 403-verklaring, deze moet instaan voor de gewekte verwachtingen. Ik meen dat van een crediteur van wie de vordering voortvloeit uit een rechtshandeling die de 403-maatschappij heeft verricht na de afsplitsing van vermogen van de moedermaatschappij, niet kan worden verwacht dat als hij bij het handelsregister de 403-verklaring opvraagt waarin staat dat de moedermaatschappij aansprakelijk is, hij daarna alsnog nagaat of de 403-aansprakelijkheid niet toch is overgegaan op de verkrijgende rechtspersoon. ${ }^{195}$ Een crediteur die de moedermaatschappij aansprakelijk stelt, zal een betaling van de 403-maatschappij of de verkrijgende rechtspersoon niet kunnen weigeren, maar als deze de vordering van de crediteur niet kunnen voldoen, is de moedermaatschappij mijns inziens hiertoe gehouden. Overigens krijgt de moedermaatschappij in dat geval een regresvordering op de 403-maatschappij en de verkrijgende rechtspersoon, ${ }^{196}$ maar als deze de oorspronkelijke vordering van de crediteur niet hebben kunnen voldoen, zullen zij de regresvordering ook niet kunnen voldoen.

Om eventuele verwarring omtrent de 403-aansprakelijkheid in zijn geheel te voorkomen, kan de moedermaatschappij haar 403-verklaring voor de afsplitsing intrekken. Als de verkrijgende rechtspersoon wil dat de 403-maatschappij gebruik kan blijven maken van de jaarrekeningvrijstelling van het groepsregime moet zij zelf een nieuwe 403-verklaring deponeren.

\subsection{2.c Subsidiaire aansprakelijkheid van de moedermaatschappij en de} verkrijgende rechtspersoon

De moedermaatschappij en de verkrijgende rechtspersoon zijn op grond van art. 2:334t BW beide aansprakelijk voor de schulden van de moedermaatschappij ten tijde van de afsplitsing. Dit betreft ook de schulden op grond van de 403-verklaring. ${ }^{197}$ Als een schuld bij de afsplitsing op de verkrijgende

195. Ook als een moedermaatschappij is verdwenen door een fusie of een zuivere splitsing, is een verkrijgende rechtspersoon op grond van de 403-verklaring aansprakelijk, terwijl in de verklaring staat dat de moedermaatschappij aansprakelijk is (zie $\S 9.8 .2$.b en $\S 9.9 .2$.b). In die gevallen zal dit echter niet tot onduidelijkheid leiden, omdat de moedermaatschappij door de fusie of de zuivere splitsing is opgehouden te bestaan.

196. Zie art. 6:10 BW.

197. Van Olffen, Buijn \& Simonis 2004, p. 89, Verbrugh 2006, p. 55 en Verbrugh 2007, p. 270. Vgl. Van der Kraan 2012, p. 158 en Holtman 2019, p. 164, die van mening zijn dat een crediteur pas een vordering op de moedermaatschappij krijgt als hij haar op grond van de 403-verklaring aansprakelijk heeft gesteld. Art. 2:334t BW is volgens hen daarom niet van toepassing als een crediteur de moedermaatschappij ten tijde van de afsplitsing nog niet aansprakelijk heeft gesteld. Dit standpunt is echter niet juist. Zie HR 28 juni 2002, 
rechtspersoon is overgegaan, blijft de moedermaatschappij subsidiair aansprakelijk voor de nakoming van deze schuld. Is een schuld daarentegen bij de moedermaatschappij achtergebleven dan is de verkrijgende rechtspersoon subsidiair ansprakelijk. De ansprakelijkheid ex art. 2:334t BW is beperkt tot de bestaande schulden van de moedermaatschappij op het moment van de afsplitsing, al hoeven deze nog niet opeisbaar te zijn. ${ }^{198}$ Schulden die na de afsplitsing voortvloeien uit een daarvoor door de moedermaatschappij aangegane rechtsverhouding vallen hier niet onder.

De crediteuren van de 403-maatschappij die op het moment van de afsplitsing van vermogen van de moedermaatschappij op grond van de 403-verklaring een vordering hebben op de moedermaatschappij, hebben daarna drie mogelijkheden om hun vordering voldaan te krijgen. Ten eerste kan een dergelijke crediteur verhaal halen op de 403-maatschappij zelf. Afhankelijk van het antwoord op de vraag of de 403-aansprakelijkheid bij de moedermaatschappij is achtergebleven of op de verkrijgende rechtspersoon is overgegaan, kan de crediteur ook deze partij aansprakelijk stellen - de crediteur kan naar vrije keuze de 403-maatschappij of de moedermaatschappij, respectievelijk de verkrijgende rechtspersoon aansprakelijk stellen. Tot slot is de verkrijgende rechtspersoon of de moedermaatschappij op grond van art. 2:334t BW subsidiair aansprakelijk voor de nakoming van deze schuld - afhankelijk van het antwoord op de vraag of de 403-aansprakelijkheid bij de moedermaatschappij is achtergebleven of op de verkrijgende rechtspersoon is overgegaan. Evenals bij een zuivere splitsing van de moedermaatschappij ${ }^{199}$ meen ik dat de subsidiaire aansprakelijkheid ex art. 2:334t BW met zich brengt dat de crediteur hier als laatste van deze drie gronden pas een beroep op kan doen. Als bijvoorbeeld een schuld van de moedermaatschappij op grond van de 403-verklaring bij de afsplitsing onder algemene titel op de verkrijgende rechtspersoon is overgegaan, zal de crediteur eerst moeten proberen om zijn vordering voldaan te krijgen bij de 403-maatschappij en de verkrijgende rechtspersoon. Pas als deze tekortschieten in de nakoming, kan de crediteur de moedermaatschappij aansprakelijk stellen op grond van art. 2:334t BW.

Ik sluit af met de opmerking dat als na de afsplitsing de 403-verklaring wordt ingetrokken - door de moedermaatschappij als de 403-aansprakelijkheid bij haar is achtergebleven, of door de verkrijgende rechtspersoon als deze aansprakelijkheid op haar is overgegaan - en de overblijvende aansprakelijkheid

JOR 2002/136, m.nt. Bartman (Akzo/ING), r.o. 3.4.3, waar de Hoge Raad oordeelt dat een moedermaatschappij op grond van de 403 -verklaring rechtstreeks aansprakelijk is. Deze aansprakelijkheid ontstaat dus niet pas als de crediteur de moedermaatschappij aansprakelijk stelt. Zie ook $\S 6.2 .5$.

198. Verbrugh 2007, p. 229 en Asser/Maeijer \& Kroeze 2-I* 2015/587. Zie ook Kamerstukken II 1996/97, 24702, 6, p. 10 (NnavhV).

199. Zie $\S 9.9 .2 . c$. 
wordt beëindigd, daardoor ook de subsidiaire ansprakelijkheid ex art. 2:334t BW van de moedermaatschappij of de verkrijgende rechtspersoon voor deze schulden eindigt. ${ }^{200}$

\subsection{2.d Beëindiging van de overblijvende aansprakelijkheid}

Afhankelijk van het antwoord op de vraag of de 403-aansprakelijkheid bij de afsplitsing bij de moedermaatschappij is achtergebleven of op de verkrijgende rechtspersoon is overgegaan, kan de moedermaatschappij, respectievelijk de verkrijgende rechtspersoon deze verklaring intrekken. ${ }^{201}$ Om vervolgens de overblijvende aansprakelijkheid te beëindigen moet onder meer op grond van art. 2:404 lid 3 sub a BW de groepsband met de 403-maatschappij zijn verbroken.

Doorgaans zal er na de afsplitsing van vermogen van de moedermaatschappij een groepsband bestaan tussen de rechtspersoon op wie de 403-aansprakelijkheid rust en de 403-maatschappij. De 403-maatschappij kan dan gebruik blijven maken van de jaarrekeningvrijstelling van het groepsregime - mits ook aan de andere voorwaarden hiervoor is voldaan. Daarnaast heeft de rechtspersoon die aansprakelijk is op grond van de 403-verklaring in dat geval doorslaggevende invloed op de 403-maatschappij en daarmee indirect op de handelingen van laatstgenoemde die tot nieuwe aansprakelijkheid op grond van deze verklaring kunnen leiden.

Het kan echter voorkomen dat na de afsplitsing van vermogen van de moedermaatschappij de 403-maatschappij een groepsband heeft met de rechtspersoon op wie de 403-aansprakelijkheid niet rust. Dit doet zich bijvoorbeeld voor als de aandelen in de 403-maatschappij bij de afsplitsing op de verkrijgende rechtspersoon zijn overgegaan, maar dat in de splitsingsakte niet is vermeld dat ook de 403-aansprakelijkheid op hem overgaat. Op grond van art. 2:334s lid 3 BW is de 403-aansprakelijkheid dan achtergebleven bij de moedermaatschappij.

Tot slot is het mogelijk dat na de afsplitsing van vermogen van de moedermaatschappij, de 403-maatschappij noch met de moedermaatschappij noch met de verkrijgende rechtspersoon een groepsband heeft. Hiervan is bijvoorbeeld sprake als de moedermaatschappij en de verkrijgende rechtspersoon niet tot dezelfde groep behoren en de 403-maatschappij een 50/50-joint venture is van hen gezamenlijk waarbij geen van beide de centrale leiding uitoefent. ${ }^{202}$

200. Zie in vergelijkbare zin $\S$ 9.9.2.c met betrekking tot een zuivere splitsing van een moedermaatschappij.

201. Asser/Maeijer \& Kroeze 2-I*2015/585.

202. Kamerstukken II 1981/82, 16326, 7, p. 18 (VV), Kamerstukken II 1987/88, 20583, 3, p. 12 (MvT), Van Achterberg, 1989, p. 74-75, E.C.A. Nass 2019, p. 46, E.C.A. Nass 2020, p. 149 
Als de rechtspersoon op wie de 403-aansprakelijkheid na de afsplitsing van vermogen van de moedermaatschappij rust niet in een groepsverhouding staat met de 403-maatschappij, kan eerstgenoemde de overblijvende aansprakelijkheid beëindigen - mits ook aan de andere voorwaarden hiervoor wordt voldaan. ${ }^{203}$ Verbrugh noemt als voorbeeld dat de 403 -aansprakelijkheid bij de afsplitsing bij de moedermaatschappij is achtergebleven, maar de aandelen in de 403-maatschappij op de verkrijgende rechtspersoon zijn overgegaan. ${ }^{204}$

Als er na de afsplitsing van vermogen van de moedermaatschappij wel een groepsband is tussen de rechtspersoon op wie de 403-aansprakelijkheid rust en de 403-maatschappij, kan de overblijvende aansprakelijkheid volgens mij niet worden beëindigd. Ik heb er eerder op gewezen dat de beëindiging van de overblijvende aansprakelijkheid mijns inziens is bedoeld voor de gevallen dat de rechtspersoon op wie deze aansprakelijkheid rust niet tot dezelfde groep behoort als de rechtspersoon van wie de handelingen tot aansprakelijkheid op grond van de ingetrokken 403 -verklaring kunnen leiden. ${ }^{205}$ Daarbij maakt het geen verschil of de moedermaatschappij na de afsplitsing nog steeds aansprakelijk is op grond van de 403-verklaring of dat de 403-aansprakelijkheid onder algemene titel op de verkrijgende rechtspersoon is overgegaan.

In het geval dat de 403-aansprakelijkheid bij de afsplitsing overgaat op een verkrijgende rechtspersoon buiten de groep en deze rechtspersoon dan ook een groepsband krijgt met de 403-maatschappij, zou nog betoogd kunnen worden dat de moedermaatschappij de overblijvende aansprakelijkheid kan beëindigen op het moment van de afsplitsing. Een dergelijk standpunt wordt ook verdedigd als een moedermaatschappij door een fusie ophoudt te bestaan en haar vermogen onder algemene titel overgaat op een verkrijgende rechtspersoon buiten de groep. ${ }^{206}$ Met betrekking tot een afsplitsing van vermogen van de moedermaatschappij betekent dit kort gezegd dat op het moment van de afsplitsing de groepsband tussen de moeder- en de 403-maatschappij is verbroken. Vervolgens komt er een nieuwe groepsband tot stand tussen de 403-maatschappij en de verkrijgende rechtspersoon. Als de moedermaatschappij voor de afsplitsing al is gestart met de procedure om de overblijvende aansprakelijkheid

en Bartman, Dorresteijn \& Olaerts 2020, p. 35. Anders Raaijmakers 1976, p. 295, die meent dat een 50/50-joint venture tot twee groepen behoort. Zie ook $\S 2.3 .2$.

203. E.C.A. Nass 2019, p. 186

204. Verbrugh 2006, p. 55.

205. Zie $\S 9.4 .1$.

206. Zie § 9.8.2.c, Beckman 1995a, p. 623 en Van der Kraan 2012, p. 118. Zie ook Verbrugh 2006, p. 54 en Verbrugh 2007, p. 269 die het in het midden laat of door een zuivere splitsing van de moedermaatschappij waarbij het vermogen onder algemene titel overgaat op verkrijgende rechtspersonen buiten de groep (kortstondig) is voldaan aan het vereiste ex art. 2:404 lid 3 sub a BW (zie § 9.9.2.d). 
te beëindigen ${ }^{207}$ en het moment van de afsplitsing samenvalt met het moment dat de verzetstermijn verloopt waarbinnen de crediteuren verzet kunnen instellen tegen het voornemen om de overblijvende aansprakelijkheid te beëindigen, zou verdedigd kunnen worden dat op dat moment is voldaan aan alle voorwaarden van art. 2:404 lid 3 BW. ${ }^{208}$ De overblijvende aansprakelijkheid zou dan zijn beëindigd, behoudens de afwikkeling van een eventueel ingesteld verzet.

Ik kan mij echter niet vinden in bovenstaande redenering. Naar mijn mening is op het moment van de afsplitsing niet (kortstondig) voldaan aan de voorwaarde ex art. 2:404 lid 3 sub a BW. Tot het moment van de afsplitsing rust de overblijvende aansprakelijkheid op de moedermaatschappij en heeft zij een groepsband met de 403-maatschappij. Na de afsplitsing is de verkrijgende rechtspersoon aansprakelijk op grond van de ingetrokken 403-verklaring. Vanaf dat moment bestaat er ook een groepsband tussen de verkrijgende rechtspersoon en de 403-maatschappij. De overblijvende aansprakelijkheid en de groepsband met de 403-maatschappij lopen dus parallel aan elkaar. Degene die aansprakelijk is, heeft ook een groepsband met de 403-maatschappij. Daarom wordt mijns inziens in een dergelijk geval niet voldaan aan de voorwaarde ex art. 2:404 lid 3 sub a BW en kan de overblijvende aansprakelijkheid niet worden beëindigd.

Evenals bij een fusie en een zuivere splitsing waarbij de moedermaatschappij verdwijnt, ${ }^{209}$ is er mijns inziens wel een andere manier waarmee kan worden bereikt dat de 403-aansprakelijkheid niet overgaat op een verkrijgende rechtspersoon buiten de groep. Het is mogelijk dat de moedermaatschappij voorafgaand aan de afsplitsing de aandelen in de 403-maatschappij apart overdraagt aan de verkrijgende rechtspersoon. Hierdoor wordt de groepsband tussen de moeder- en de 403-maatschappij verbroken. Ik heb eerder betoogd dat de moedermaatschappij de procedure voor de beëindiging van de overblijvende aansprakelijkheid al kan beginnen voordat de groepsband met de 403-maatschappij is verbroken. ${ }^{210} \mathrm{Ik}$ heb art. 2:404 lid $3 \mathrm{BW}$ zo uitgelegd dat uiterlijk op het moment dat de tweemaandstermijn verloopt waarbinnen de crediteuren verzet kunnen instellen tegen het voornemen van de moedermaatschappij om de overblijvende aansprakelijkheid te beëindigen aan alle voorwaarden voor deze beëindiging moet zijn voldaan, behoudens de afwikkeling van een eventueel ingesteld verzet. Als de moedermaatschappij de aandelen

207. Zie $\S 8.13$.

208. Zie $\S 9.4 .2$, voor een uitgebreidere bespreking van de mogelijkheid dat de beëindiging van de overblijvende aansprakelijkheid samenvalt met een fusie of een splitsing van de moederof de 403-maatschappij.

209. Zie $\S 9.8 .2$.c en $\S 9.9 .2$.d.

210. Zie $\S 8.13$. 
in de 403-maatschappij overdraagt op het moment dat de verzetstermijn verloopt, is op dat moment aan alle voorwaarden van art. 2:404 lid 3 BW voldaan en is de overblijvende aansprakelijkheid beëindigd. Vervolgens kan de moedermaatschappij alsnog afsplitsen waarbij een deel van haar vermogen onder algemene titel op de verkrijgende rechtspersonen overgaat. Het is aan te raden dat de moedermaatschappij en de verkrijgende rechtspersoon voorafgaand aan de afsplitsing afspraken maken over de afwikkeling van een eventueel ingesteld verzet.

Ik wijs erop dat ik eerder heb betoogd dat de voorwaarde van de verbreking van de groepsband tussen de moeder- en de 403-maatschappij het onnodig belastend maakt om de overblijvende aansprakelijkheid te beëindigen. Naar mijn mening moet deze voorwaarde daarom worden geschrapt uit art. 2:404 lid 3 $\mathrm{BW}^{211}$

\subsection{Omzetting}

Een (Nederlandse) moeder- of 403-maatschappij kan zich op grond van art. 2:18 BW omzetten in een andere rechtsvorm. Als een moeder- of 403-maatschappij zich omzet, heeft dat geen gevolgen voor de 403 -aansprakelijkheid. ${ }^{212}$ De moedermaatschappij blijft aansprakelijk voor de schulden die voortvloeien uit de rechtshandelingen die de 403-maatschappij tot het moment van de omzetting heeft verricht, en zolang de moedermaatschappij de 403-verklaring niet intrekt, is zij ook aansprakelijk voor de schulden die voortvloeien uit nieuwe rechtshandelingen van de 403-maatschappij. Aangezien door de omzetting de groepsband tussen de moeder- en de 403-maatschappij niet wordt verbroken, kan de moedermaatschappij de overblijvende aansprakelijkheid na intrekking van de 403-verklaring niet beëindigen.

De omzetting van de moeder- of de 403-maatschappij kan er wel toe leiden dat de 403-maatschappij niet meer gebruik mag maken van de jaarrekeningvrijstelling van het groepsregime. Ik heb er in hoofdstuk 2 op gewezen dat de jaarrekeningvrijstelling slechts openstaat voor bepaalde rechtsvormen. ${ }^{213}$ Als een 403-maatschappij zich omzet, mag zij slechts gebruik blijven maken van deze vrijstelling als zij nadien een van de volgende rechtsvormen heeft: NV, $\mathrm{BV}$, commerciële vereniging, ${ }^{214}$ coöperatie, onderlinge waarborgmaatschappij, commanditaire vennootschap of vennootschap onder firma waarvan alle

211. Zie $\S 8.14$.

212. E.C.A. Nass 2019, p. 187-188.

213. Zie $\S 2.3 .1$.

214. Die een of meer ondernemingen in stand houdt die in het handelsregister moeten worden ingeschreven en die aan bepaalde financiële drempelwaarden voldoen. Zie art. 2:360 lid 3 BW. 
vennoten die volledig jegens schuldeisers aansprakelijk zijn voor de schulden kapitaalvennootschappen naar buitenlands recht zijn, SE of SCE met statutaire zetel in Nederland, of een formeel buitenlandse vennootschap die niet aan het recht van een andere lidstaat is onderworpen. ${ }^{215}$

Met betrekking tot de omzetting van een moedermaatschappij geldt dat de 403-maatschappij niet meer gebruik mag maken van de jaarrekeningvrijstelling als de moedermaatschappij hierdoor niet meer kan voldoen aan het vereiste ex art. 2:403 lid 1 sub c BW. Op grond van deze bepaling dienen de financiële gegevens van de 403-maatschappij te zijn geconsolideerd in de geconsolideerde jaarrekening van de moedermaatschappij waar krachtens het toepasselijke recht de in deze bepaling genoemde Europese richtlijnen of de verordening EU IFRS op van toepassing zijn. ${ }^{216}$

Nass geeft als voorbeeld dat een 403-maatschappij niet meer gebruik mag maken van de jaarrekeningvrijstelling van het groepsregime, als zij is omgezet in een stichting of als de moedermaatschappij is omgezet in een vereniging die niet onder art. 2:360 lid $3 \mathrm{BW}$ valt. ${ }^{217}$

\subsection{Grensoverschrijdende fusie, splitsing en omzetting}

Op grond van art. 2:333c BW kan een NV, BV, SE of SCE (met statutaire zetel in Nederland) fuseren met een kapitaalvennootschap die is opgericht naar het recht van een andere lidstaat van de EU of de EER. ${ }^{218}$ Hoewel een vergelijkbare bepaling ontbreekt voor een grensoverschrijdende splitsing of omzetting, wordt aangenomen dat dit binnen de EU mogelijk is op grond van de vrijheid van vestiging ex art. 49 en 54 Verdrag betreffende de werking van de Europese Unie. ${ }^{219}$ In de nabije toekomst zal er echter ook een wettelijke basis komen voor een grensoverschrijdende splitsing of omzetting. Op 1 januari 2020 is de richtlijn 2019/2121/EU (hierna: 'de mobiliteitsrichtlijn') vastgesteld. ${ }^{220}$ Op grond van deze richtlijn zijn de in de EU bestaande regels voor grensoverschrijdende fusie aangepast, en is een regeling geïntroduceerd voor grensoverschrijdende

215. Daarnaast mag de 403-maatschappij geen rechtspersoon van openbaar belang zijn in de zin van art. 2:398 lid 7 BW.

216. Zie $\S 2.3 .5$.

217. E.C.A. Nass 2019, p. 187-188.

218. Hoewel de SE niet wordt genoemd in art. 2:333c BW, is deze bepaling toch op de SE van toepassing op grond van art. 9 lid $1 \mathrm{sub}$ c onder ii Verordening (EG) 2157/2001 van de Raad van 8 oktober 2001 betreffende het statuut van de Europese Vennootschap (SE), PbEG 2001, L 294/1. Zie Asser/Maeijer \& Kroeze 2-I* 2015/459.

219. Asser/Maeijer \& Kroeze $2-I^{*} 2015 / 503$.

220. Richtlijn (EU) 2019/2121 van het Europees Parlement en de Raad van 27 november 2019 tot wijziging van Richtlijn (EU) 2017/1132 met betrekking tot grensoverschrijdende omzettingen, fusies en splitsingen, PbEU 2019, L 321/1, zoals gerectificeerd in PbEU L 20/24. 
splitsing en omzetting. Schutte-Veenstra en Verbrugh merken op dat de richtlijn enkel voorziet in de mogelijkheid dat bij een splitsing vermogen overgaat op een nieuw opgerichte verkrijgende rechtspersoon. ${ }^{221}$ Uiterlijk op 31 januari 2023 moet de Nederlandse wet aan de richtlijn zijn aangepast. ${ }^{222}$

Het gaat de reikwijdte van dit onderzoek te buiten om na te gaan welke gevolgen een grensoverschrijdende fusie, splitsing of omzetting van een moeder- of 403-maatschappij heeft met betrekking tot de 403-aansprakelijkheid. Ik onderzoek niet welke partij aansprakelijk is voor de schulden die voortvloeien uit de rechtshandelingen die de 403-maatschappij tot het moment van de grensoverschrijdende fusie, splitsing of omzetting heeft verricht, of er nadien nog nieuwe aansprakelijkheid op grond van 403-verklaring kan ontstaan, en of het mogelijk is om na de intrekking van de 403-verklaring de overblijvende aansprakelijkheid te beëindigen. Dit onderzoek is in het bijzonder gericht op het Nederlandse recht. Hetgeen ik in de vorige paragrafen heb geschreven met betrekking tot een niet-grensoverschrijdende fusie, splitsing of omzetting, ${ }^{223}$ kan als uitgangspunt dienen voor de beoordeling van de gevolgen van een grensoverschrijdende fusie, splitsing of omzetting met betrekking tot de 403-aansprakelijkheid, maar het gaat te ver om de eerder door mij onderzochte casus in grensoverschrijdend opzicht en voor verschillende landen uit te werken. Ik wijs op twee vragen die in een dergelijke situatie kunnen opkomen. Als een moedermaatschappij bijvoorbeeld verdwijnt als gevolg van een fusie met een Duitse $\mathrm{GmbH}$ en de 403-verklaring nadien heeft te gelden als verklaring van deze $\mathrm{GmbH}$, is dan het Duitse recht van toepassing op de uitleg van (de tekst van) de 403-verklaring? En als een 403-maatschappij zuiver splitst en haar vermogen onder algemene titel overgaat op twee Belgische BV's, moet dan op basis van Nederlands of Belgisch recht worden beoordeeld of de moedermaatschappij en de Belgische BV's al of niet tot dezelfde groep behoren? Voor een uiteenzetting van een grensoverschrijdende fusie, splitsing, of omzetting verwijs naar de relevante literatuur. ${ }^{224}$

Evenals bij een niet-grensoverschrijdende omzetting, ${ }^{225}$ dienen partijen er bij een grensoverschrijdende fusie, splitsing of omzetting op bedacht te zijn dat de (rechtsopvolger van de) 403-maatschappij nadien mogelijk geen gebruik mag maken van de jaarrekeningvrijstelling van het groepsregime omdat de (rechtsopvolger van de) moeder- of 403-maatschappij niet meer een daarvoor vereiste rechtsvorm heeft.

221. Schutte-Veenstra \& Verbrugh 2020, p. 217. Zie art. 160 ter lid 3 en lid 4 sub a en b mobiliteitsrichtlijn.

222. Zie art. 3 lid 1 mobiliteitsrichtlijn.

223. Zie $\S 9.6$ tot en met $\S 9.11$.

224. Van Boxel 2011, Roelofs 2014 en Van den Broek \& Rensen 2018.

225. Zie $\S 9.11$. 
Als een 403-maatschappij door een grensoverschrijdende fusie of splitsing vermogen verkrijgt, of als bij een grensoverschrijdende afsplitsing een deel van haar vermogen overgaat op een verkrijgende rechtspersoon, blijft de 403-maatschappij bestaan en kan zij gebruik blijven maken van de jaarrekeningvrijstelling van het groepsregime. Als een 403-maatschappij daarentegen door een grensoverschrijdende fusie of zuivere splitsing verdwijnt en haar vermogen overgaat op een of meer verkrijgende rechtspersonen naar het recht van een andere lidstaat van de EU of EER, is dat vanzelfsprekend niet meer mogelijk. Ook voor de verkrijgende rechtsperso(o)n(en) is het niet toegestaan om gebruik te maken van de jaarrekeningvrijstelling van het groepsregime. De jaarrekeningvrijstelling staat niet open voor een dergelijke rechtspersoon. ${ }^{226}$ Hetzelfde geldt als een 403-maatschappij zich omzet in een rechtspersoon naar het recht van een andere lidstaat van de EU of EER. ${ }^{227}$ Overigens is het voor een verkrijgende rechtspersoon naar het recht van Luxemburg, Ierland of Duitsland, of als de 403-maatschappij zich heeft omgezet in een dergelijke rechtspersoon, wel mogelijk om onder voorwaarden gebruik te maken van de jaarrekeningvrijstelling van de equivalenten van het groepsregime in die landen. $^{228}$

Een grensoverschrijdende fusie, splitsing of omzetting van de moedermaatschappij heeft doorgaans geen gevolgen voor de jaarrekeningvrijstelling van de 403-maatschappij. Als een moedermaatschappij door een grensoverschrijdende fusie of splitsing vermogen verkrijgt, kan de 403-maatschappij zonder meer gebruik blijven maken van de jaarrekeningvrijstelling van het groepsregime. In het geval van een grensoverschrijdende afsplitsing waarbij een deel van het vermogen van de moedermaatschappij overgaat op een verkrijgende rechtspersoon naar het recht van een andere lidstaat van de EU of EER, maar de groepsband tussen de moeder- en de 403-maatschappij blijft bestaan, kan de 403-maatschappij ook onverminderd gebruik blijven maken van deze vrijstelling. Indien de 403-maatschappij na de grensoverschrijdende afsplitsing van vermogen van de moedermaatschappij tot de groep van de verkrijgende rechtspersoon behoort, of als de moedermaatschappij door een grensoverschrijdende fusie of zuivere splitsing verdwijnt en haar vermogen overgaat op een of meer

226. Zie $\S 2.3 .1$.

227. Zie Asser/Maeijer \& Kroeze $2-I^{*} 2015 / 375$, met betrekking tot enkele mogelijkheden voor een grensoverschrijdende omzetting in een rechtsvorm van een rechtspersoon van buiten de EU en EER. Ook in dat geval zal de rechtsopvolger van de 403-maatschappij, of de omgezette rechtspersoon geen gebruik kunnen maken van de jaarrekeningvrijstelling.

228. Zie respectievelijk art. 70 Loi du 19 décembre 2002, Mémorial A-N 149, 31 décembre 2002, met inachtneming van de wijzigingen bij Loi du 18 décembre 2009, art. 99 onder nr. 3, Mémorial A-N 22, 10 février 2010, bij Loi du 30 juillet 2013, onder nr. 29, Mémorial A-N 177, 2 octobre 2013 en bij Loi du 27 mai 2016, art. 1er onder nr. 24, Mémorial A-N 94, 30 mai 2016 (Luxemburg), section 357 Companies Act 2014 (Ierland), en § 264 Absatz 3 \& 4 Handelsgesetzbuch (Duitsland). 
verkrijgende rechtspersonen naar het recht van een andere lidstaat van de EU of EER, kan de 403-maatschappij doorgaans ook gebruik blijven maken van de jaarrekeningvrijstelling van het groepsregime. Hetzelfde geldt als de moedermaatschappij zich omzet in een dergelijke rechtspersoon. ${ }^{229}$ Met betrekking tot die situaties is het van belang dat de 403-maatschappij gebruik mag blijven maken van de jaarrekeningvrijstelling als haar financiële gegevens op grond van art. 2:403 lid 1 sub c BW zijn geconsolideerd in een geconsolideerde jaarrekening waar krachtens het toepasselijke recht de in deze bepaling genoemde Europese richtlijnen of de verordening EU IFRS op van toepassing zijn. ${ }^{230}$ Van Zoest merkt op dat deze jaarrekeningvoorschriften van toepassing zijn op de meest bekende en veelvoorkomende Europese commerciële rechtsvormen. ${ }^{231}$ De verkrijgende rechtspersoon, of de moedermaatschappij na omzetting, zal doorgaans aan dit vereiste kunnen voldoen, waardoor de 403-maatschappij gebruik mag blijven maken van de jaarrekeningvrijstelling.

\subsection{Conclusie}

Als een moeder- of een 403-maatschappij fuseert of splitst, kan dit verschillende gevolgen met zich brengen voor de aansprakelijkheid op grond van de 403-verklaring. Ten eerste heb ik geconcludeerd dat als een moedermaatschappij fuseert of splitst haar aansprakelijkheid op grond van deze verklaring onder algemene titel op een verkrijgende rechtspersoon kan overgaan (§ 9.2). Dit betreft mijns inziens zowel de aansprakelijkheid voor de bestaande schulden van de 403-maatschappij die op het moment van de fusie of de splitsing van de moedermaatschappij al uit een rechtshandeling zijn voortgevloeid, als de aansprakelijkheid voor de schulden die nadien voortvloeien uit een rechtshandeling van de 403-maatschappij. Als de 403-aansprakelijkheid onder algemene titel op een verkrijgende rechtspersoon overgaat, heeft de 403-verklaring vanaf dat moment te gelden als verklaring van deze verkrijgende rechtspersoon.

Vervolgens heb ik onderzocht hoe de aansprakelijkheid op grond van de 403-verklaring van invloed is op het recht van een crediteur ex art. 2:316 lid $2 \mathrm{BW}$ en art. 2:3341 BW om in verzet te komen tegen een voorstel tot fusie of splitsing van de moeder- of de 403-maatschappij en het recht ex art. 2:316 lid 1

229. Zie Asser/Maeijer \& Kroeze $2-I^{*} 2015 / 375$, met betrekking tot enkele mogelijkheden voor een grensoverschrijdende omzetting in een rechtsvorm van een rechtspersoon van buiten de EU en EER. In dat geval zal de 403-maatschappij geen gebruik kunnen maken van de jaarrekeningvrijstelling, omdat niet kan worden voldaan aan de voorwaarde ex art. 2:403 lid 1 sub c BW dat haar financiële zijn geconsolideerd in een geconsolideerde jaarrekening waarop krachtens het toepasselijke recht de in deze bepaling genoemde Europese richtlijnen of de verordening EU IFRS op van toepassing zijn (zie § 2.3.5).

230. Zie $\S 2.3 .5$.

231. Van Zoest 2019, p. 21-22. 
BW en art. 2:334k BW op een waarborg voor de voldoening van zijn vordering (§ 9.3). Ten eerste kunnen (ook) de crediteuren met een vordering op grond van de 403-verklaring in verzet komen tegen een voorstel tot fusie of splitsing van de moedermaatschappij. Daarnaast heb ik betoogd dat als een 403-maatschappij een voorstel doet tot fusie of splitsing, de vraag of een crediteur recht heeft op een waarborg voor de voldoening van zijn vordering niet moet worden beantwoord aan de hand van de waarborg die de vermogenstoestand van de (rechtsopvolger van de) 403-maatschappij biedt dat de vordering zal worden voldaan. In plaats daarvan moet deze vraag worden beantwoord aan de hand van de waarborg die de vermogenstoestand van de moedermaatschappij biedt dat de vordering van de crediteur op grond van de 403-verklaring zal worden voldaan.

In het geval dat vermogen van de 403-maatschappij door een fusie of splitsing op een verkrijgende rechtspersoon overgaat, zullen haar crediteuren die in verzet zijn gekomen doorgaans geen recht hebben op een waarborg. Een dergelijke fusie of splitsing heeft geen gevolgen voor (de omvang van) de aansprakelijkheid van de moedermaatschappij op grond van de 403-verklaring. Aangezien de crediteuren hun vordering op de moedermaatschappij op grond van de 403-verklaring behouden, zal een crediteur van de 403-maatschappij die verzet instelt tegen het voorstel tot fusie of splitsing doorgaans geen recht hebben op een waarborg voor de voldoening van deze vordering.

Indien de 403-maatschappij vermogen verkrijgt door een fusie of splitsing, moet er een onderscheid worden gemaakt tussen de crediteuren van de 403-maatschappij en die van de rechtspersoon van wie het vermogen overgaat. Voor een crediteur van de 403-maatschappij die in verzet is gekomen, geldt mijns inziens dat hij recht heeft op een waarborg als de extra aansprakelijkheid die de moedermaatschappij door de fusie of splitsing van de 403-maatschappij op grond van de 403-verklaring krijgt, een negatief effect heeft op de waarborg dat zijn vordering op grond van de 403-verklaring zal worden voldaan, tenzij dit negatieve gevolg ongedaan wordt gemaakt door het extra vermogen dat de 403-maatschappij verkrijgt. Als een crediteur van de rechtspersoon van wie het vermogen overgaat in verzet is gekomen, heeft deze mijns inziens recht op een waarborg voor de voldoening van zijn vordering tenzij hij al voldoende waarborgen heeft of de vermogenstoestand van de moedermaatschappij na de fusie of de splitsing niet minder waarborg zal bieden dat de vordering op grond van de 403-verklaring zal worden voldaan, dan de waarborg die de vermogenstoestand van de rechtspersoon van wie het vermogen zal overgaan biedt dat de vordering van de crediteur zal worden voldaan.

Voorts ben ik ingegaan op de voorwaarde ex art. 2:404 lid 3 sub a BW dat voor de beëindiging van de overblijvende aansprakelijkheid na intrekking van de 403-verklaring, de groepsband tussen de moeder- en de 403-maat- 
schappij moet zijn verbroken (§ 9.4). Ik heb onderzocht hoe deze voorwaarde moet worden uitgelegd in het licht van een fusie of een splitsing van de moeder- of de 403-maatschappij. Ik ben tot de conclusie gekomen dat aan deze voorwaarde is voldaan indien na de fusie of de splitsing van de moeder- of de 403-maatschappij, de rechtspersoon op wie de overblijvende aansprakelijkheid rust niet tot dezelfde groep behoort als de rechtspersoon van wie de handelingen tot aansprakelijkheid op grond van de ingetrokken 403-verklaring kunnen leiden. Mijns inziens is daarnaast ook aan deze voorwaarde voldaan als de moeder- en de 403-maatschappij met elkaar zijn gefuseerd waarbij een van hen is verdwenen en het vermogen op de ander is overgegaan. ${ }^{232}$

Vervolgens heb ik verschillende casus behandeld waarbij de moeder- of de 403-maatschappij fuseert, zuiver splitst of afsplitst (§9.6 tot en met $\S 9.10$ ). Met betrekking tot iedere casus heb ik onderzocht welke partij na de fusie, zuivere splitsing of afsplitsing op grond van de 403-verklaring aansprakelijk is voor de schulden die voortvloeien uit de rechtshandelingen die de 403-maatschappij tot dat moment heeft verricht. Daarnaast ben ik nagegaan of er nadien nog nieuwe aansprakelijkheid op grond van de 403-verklaring kan ontstaan en wie daarvoor aansprakelijk is. Tot slot heb ik antwoord gegeven op de vraag of het mogelijk is om de overblijvende aansprakelijkheid te beëindigen als de 403-verklaring na de fusie, zuivere splitsing of afsplitsing, is ingetrokken. Met betrekking tot deze laatste vraag heb ik in het bijzonder onderzocht of door de fusie, zuivere splitsing of afsplitsing is voldaan aan de voorwaarde ex art. 2:404 lid 3 sub a BW dat de groepsband tussen de moeder- en de 403-maatschappij is verbroken.

Ik heb geconcludeerd dat de aansprakelijkheid op grond van de 403-verklaring bij een fusie, zuivere splitsing of afsplitsing van de moeder- of de 403-maatschappij onverminderd blijft bestaan. De (rechtsopvolger van de) moedermaatschappij is aansprakelijk voor alle schulden die voortvloeien en zijn voortgevloeid uit een rechtshandeling die de 403-maatschappij (heeft) verricht. Een andere uitkomst zou hetzelfde gevolg hebben als een beëindiging van (een deel van) deze aansprakelijkheid buiten art. 2:404 BW om. Een crediteur zou dan onterecht geen beroep kunnen doen op de procedures en waarborgen uit deze bepaling die beogen zijn verhaalsrecht te beschermen. Ook als de moeder- en de 403-maatschappij met elkaar fuseren vervalt de 403-aansprakelijkheid naar mijn mening niet. ${ }^{23}$ Een crediteur heeft dan twee vorderingen op de moeder- of de 403-maatschappij: een vordering op grond van de oorspronkelijke rechtsverhouding met de 403-maatschappij en een vordering op grond van de 403 -verklaring.

232. Zie § 9.7.1.c en $\S 9.8 .1 . c$.

233. Zie $\S 9.7 .1 . b$ en $\S 9.8 .1 . b$. 
Tot slot ben ik ingegaan op een omzetting van de moeder- of de 403-maatschappij (§ 9.11), en een grensoverschrijdende fusie, splitsing of omzetting van de moeder- of de 403-maatschappij ( $\$ 9.12$ ). Ik heb daarbij in het bijzonder onderzocht of de (rechtsopvolger van de) 403-maatschappij nadien nog steeds gebruik mag maken van de jaarrekeningvrijstelling van het groepsregime. Als een 403-maatschappij zich omzet in een in art. 2:360 BW genoemde rechtspersoon waarvoor de jaarrekeningvrijstelling openstaat, ${ }^{234}$ of als de 403-maatschappij bij een grensoverschrijdende fusie of splitsing vermogen verkrijgt, kan zij gebruik blijven maken van de jaarrekeningvrijstelling. Dit geldt ook voor een grensoverschrijdende afsplitsing waarbij een deel van het vermogen van de 403-maatschappij overgaat op een verkrijgende rechtspersoon, maar de 403-maatschappij voor het overige blijft bestaan. In het geval dat de 403-maatschappij daarentegen door een grensoverschrijdende fusie of zuivere splitsing verdwijnt en haar vermogen overgaat op een of meer verkrijgende rechtspersonen naar het recht van een andere lidstaat van de EU of EER, is het voor de verkrijgende rechtsperso(o)n(en) niet toegestaan om gebruik te maken van de jaarrekeningvrijstelling van het groepsregime. Hetzelfde geldt als de 403-maatschappij zich omzet in een dergelijke rechtspersoon.

Indien een moedermaatschappij door een grensoverschrijdende fusie of splitsing vermogen verkrijgt, kan de 403-maatschappij zonder meer gebruik blijven maken van de jaarrekeningvrijstelling van het groepsregime. Ook als de moedermaatschappij zich omzet in een rechtspersoon waarop het Nederlandse recht of het recht van een andere lidstaat van de EU of EER van toepassing is, in het geval dat bij een grensoverschrijdende afsplitsing een deel van het vermogen van de moedermaatschappij overgaat op een verkrijgende rechtspersoon naar het recht van een andere lidstaat van de EU of EER, of als de moedermaatschappij door een grensoverschrijdende fusie of zuivere splitsing verdwijnt en haar vermogen overgaat op een of meer dergelijke verkrijgende rechtspersonen, mag de 403-maatschappij doorgaans gebruik blijven maken van de jaarrekeningvrijstelling. Dit is slechts anders als de (rechtsopvolger van de) moedermaatschappij de financiële gegevens van de 403-maatschappij niet kan consolideren in een geconsolideerde jaarrekening waar krachtens het toepasselijke recht de in art. 2:403 lid 1 sub c BW genoemde Europese richtlijnen of de verordening EU IFRS op van toepassing zijn.

234. Zie $\S 2.3 .1$ welke rechtspersonen gebruik mogen maken van de jaarrekeningvrijstelling. 



\title{
Hoofdstuk 10. Conclusies en aanbevelingen
}

\author{
10.1 Het groepsregime en de problematiek rond de \\ 403-aansprakelijkheid
}

Dat de regeling van het groepsregime voorziet in een behoefte in de praktijk blijkt onder meer uit het feit dat op 31 december 2019 bij het handelsregister 16.719 403-verklaringen zijn gedeponeerd. ${ }^{1}$ Ik wijs bijvoorbeeld op Bol.com die begin 2020 heeft verklaard dat zij gebruikmaakt van de jaarrekeningvrijstelling om te voorkomen dat concurrent Amazon inzicht heeft in haar jaarrekening. ${ }^{2}$ Hierdoor kan Bol.com onder meer verhinderen dat Amazon ziet hoe groot de Nederlandse markt voor online verkopen is - waardoor deze misschien eerder de Nederlandse markt zou hebben betreden dan zij heeft gedaan - en kan worden voorkomen dat bekend wordt dat de omzet van Bol.com eventueel is gedaald als gevolg van de concurrentie van Amazon.

Hoewel in de praktijk veelvuldig gebruik wordt gemaakt van de jaarrekeningvrijstelling van het groepsregime is deze regeling naar mijn mening niet zonder gebreken. Ik wijs op drie bezwaren. Ten eerste sluit de huidige regeling naar mijn mening niet op alle punten aan bij, of wordt deze niet uitgelegd vanuit de functie die de 403-aansprakelijkheid vervult bij de compensatie van de crediteuren van de 403-maatschappij. Ten tweede schiet de compensatie die de crediteuren ontvangen mijns inziens in sommige gevallen tekort waardoor het nadeel dat de crediteuren ondervinden doordat zij de jaarrekening van de 403-maatschappij niet (hebben) kunnen inzien niet volledig wordt weggenomen. Tot slot meen ik dat de compensatie voor de crediteuren op andere plekken te ruimhartig is wat ertoe leidt dat de regeling onnodig belastend is voor de moeder- en de 403-maatschappij. Deze drie bezwaren ten aanzien van de huidige regeling van het groepsregime zijn goed te illustreren aan de hand van een drietal rechterlijke uitspraken van de afgelopen jaren.

1. Op 22 april 2020 per e-mail aan mij meegedeeld door de afdeling Databeheer Orderbehandeling van de Kamer van Koophandel.

2. J. Braaksma en L. Van der Velden, 'Prestaties Bol.com blijven geheim uit angst voor rivaal Amazon', Het Financieele Dagblad 11 februari 2020. 
Ten eerste wijs ik op het arrest van de Hoge Raad uit 2015 inzake Eikendal q.q./ Lentink. ${ }^{3}$ Dit arrest is een voorbeeld dat de huidige regeling van het groepsregime op sommige punten niet aansluit bij de functie van de 403 -aansprakelijkheid bij de compensatie van de crediteuren van de 403-maatschappij. De feiten die ten grondslag liggen aan dit arrest houden kort gezegd in dat een crediteur zijn vordering op de 403-maatschappij heeft geschikt tegen gedeeltelijke betaling en dat partijen elkaar over en weer finale kwijting hebben verleend. Als gevolg van de finale kwijting is de vordering van de crediteur op de 403-maatschappij tenietgegaan. ${ }^{4}$ De Hoge Raad oordeelt dat de hoofdelijke aansprakelijkheid van de moedermaatschappij ex art. 2:403 lid 1 sub f BW met zich brengt dat de crediteur zich desondanks voor het restant van de vordering op de moedermaatschappij kan verhalen. ${ }^{5}$ Deze uitkomst sluit niet aan bij de functie van de aansprakelijkheid van de moedermaatschappij bij de compensatie van de crediteur omdat deze de jaarrekening van de 403-maatschappij niet kan inzien. Aangezien de crediteur geen vordering meer heeft op de 403-maatschappij, heeft hij er geen belang meer bij om de jaarrekening van de 403-maatschappij te kunnen inzien om (mede) aan de hand daarvan te schatten hoe groot het risico is dat zijn vordering niet (volledig) zal worden voldaan. Hij hoeft dus ook niet meer gecompenseerd te worden als deze mogelijkheid ontbreekt. ${ }^{6}$ Het is daarom niet (meer) nodig dat hij zich op de moedermaatschappij kan verhalen.

Het tweede arrest waar ik op wijs, is het UWV/Econcern-arrest van de Hoge Raad uit 2014. ${ }^{7}$ Dit arrest laat zien dat de compensatie die de crediteuren ontvangen omdat zij de jaarrekening van de 403-maatschappij niet kunnen inzien, niet altijd toereikend is om het nadeel dat zij daardoor ondervinden weg te nemen. De Hoge Raad heeft in dit arrest geoordeeld dat als een crediteur een bevoorrechte vordering heeft op de 403-maatschappij, dit niet meebrengt dat ook de vordering op de moedermaatschappij is bevoorrecht. ${ }^{8}$ De crediteur heeft op grond van de 403-verklaring een concurrente vordering op de moedermaatschappij. Dit betekent dat een crediteur wordt gecompenseerd voor het feit dat hij een bevoorrechte vordering heeft op een debiteur-de 403-maatschappijvan wie hij de jaarrekening niet kan inzien, met een aanvullende vordering met een zwakker verhaalsrecht op een andere debiteur - de moedermaatschappij van wie hij de geconsolideerde jaarrekening wel kan inzien.

3. HR 3 april 2015, NJ2015/255, m.nt. Van Schilfgaarde (Eikendal q.q./Lentink). Ook gepubliceerd in JOR 2015/191, m.nt. Faber en Vermunt.

4. Zie art. 6:160 BW.

5. HR 3 april 2015, JOR 2015/191, m.nt. Faber en Vermunt (Eikendal q.q./Lentink), r.o. 3.6.2. Zie $\S 6.3 .2$.

6. Zie $\S 6.4 .1$.

7. HR 11 april 2014, NJ 2014/309, m.nt. Van Schilfgaarde (UWV/Econcern). Ook gepubliceerd in JOR 2014/199, m.nt. Van Dooren (UWV/Econcern).

8. HR 11 april 2014, JOR 2014/199, m.nt. Van Dooren (UWV/Econcern), r.o. 3.2.2 en 3.4.1-3.4.2. 
De derde en laatste uitspraak die ik noem, is de uitspraak Pergen/Eneco van de Rechtbank Rotterdam uit 2014. ${ }^{9}$ Deze uitspraak is een voorbeeld dat de compensatie die de crediteuren krijgen soms te ruimhartig wordt uitgelegd. In casu heeft een crediteur verzet ingesteld tegen het voornemen van de moedermaatschappij om de overblijvende aansprakelijkheid te beëindigen. De rechtbank oordeelt dat de crediteur een vervangende waarborg moet worden gegeven. $\mathrm{Zij}$ stelt de omvang van de te geven vervangende waarborg vast door de resterende maanden van de looptijd van de overeenkomst tussen de crediteur en de 403-maatschappij, te vermenigvuldigen met het maandelijks gemiddeld door de crediteur te vorderen bedrag. Zij oordeelt dat de moedermaatschappij een bedrag van $€ 805$ miljoen als vervangende waarborg moet geven aan de crediteur. $^{10}$

De uitspraak Pergen/Eneco sluit aan bij de huidige lijn in de jurisprudentie dat de omvang van een te geven vervangende waarborg wordt vastgesteld op het bedrag van de bestaande en toekomstige vorderingen van de crediteur op de 403-maatschappij. ${ }^{11}$ Een dergelijke uitleg van de vervangende waarborg maakt het mijns inziens onnodig moeilijk voor een moedermaatschappij om de overblijvende aansprakelijkheid te beëindigen. Dit stimuleert een moedermaatschappij om de procedure voor de beëindiging zo in te steken dat de kans dat de crediteuren hiervan op de hoogte raken zo klein mogelijk is. Daarnaast kan dit er zelfs toe leiden dat een moedermaatschappij besluit om zich in het geheel niet aansprakelijk te stellen op grond van een 403-verklaring omdat zij van mening is dat het te belastend is om later de overblijvende aansprakelijkheid na intrekking van deze verklaring weer te beëindigen. Dit maakt de jaarrekeningvrijstelling van het groepsregime minder toegankelijk.

In dit onderzoek heb ik gewerkt aan een oplossing voor bovengenoemde bezwaren ten aanzien van de huidige regeling van het groepsregime. Ik heb onderzocht hoe de 403-aansprakelijkheid moet worden uitgelegd in het licht van de functie van deze aansprakelijkheid bij de compensatie van de crediteuren omdat zij de jaarrekening van de 403-maatschappij niet (hebben) kunnen inzien, waarbij ik als maatstaf voor de compensatie heb gehanteerd dat het nadeel moet worden weggenomen dat een crediteur ondervindt doordat de 403-maatschappij gebruikmaakt van de jaarrekeningvrijstelling, of doordat de moedermaatschappij de 403-verklaring intrekt of de overblijvende aansprakelijkheid beëindigt. Daarnaast heb ik onderzocht hoe de 403-aansprakelijkheid moet worden uitgelegd om zo veel mogelijk te voorkomen dat een crediteur in een voordeliger positie komt door de compensatie die hij ontvangt. Indien

9. Rb. Rotterdam 30 september 2014, JOR 2014/326, m.nt. Loesberg (Pergen/Eneco).

10. Rb. Rotterdam 30 september 2014, JOR 2014/326, m.nt. Loesberg (Pergen/Eneco), r.o. 4.19.

11. Zie $\S 8.9 .3$. 
ik tot de conclusie ben gekomen dat het huidige recht niet leidt tot een situatie waarbij de crediteuren van de 403-maatschappij (voldoende) worden gecompenseerd voor het niet (hebben) kunnen inzien van de jaarrekening van de 403maatschappij, of als ik meen dat de crediteuren overgecompenseerd worden, heb ik een voorstel gedaan om het huidige recht op het desbetreffende punt te wijzigen.

Afgezien van het inleidende hoofdstuk, heb ik de voorgaande hoofdstukken van dit onderzoek afgesloten met een conclusie, waarin ik de bevindingen uit het desbetreffende hoofdstuk heb samengevat. Hieronder zet ik de belangrijkste uitkomsten van ieder hoofdstuk op een rij.

\subsection{Het groepsregime (hoofdstuk 2)}

De regeling van het groepsregime heeft in verschillende wetsartikelen gestaan en is door de jaren heen diverse keren gewijzigd. ${ }^{12}$ Als een 403-maatschappij gebruikmaakt van de jaarrekeningvrijstelling van het groepsregime, is zij onder meer vrijgesteld van de verplichting om een jaarrekening openbaar te maken. ${ }^{13}$ De twee belangrijkste voorwaarden waaraan moet worden voldaan opdat een 403-maatschappij gebruik mag maken van de jaarrekeningvrijstelling, zijn dat haar moedermaatschappij een geconsolideerde jaarrekening deponeert en zich door middel van een 403-verklaring hoofdelijk aansprakelijk stelt voor de schulden die voortvloeien uit een rechtshandeling van de 403-maatschappij. ${ }^{14}$ Een 403-maatschappij kan onder meer gebruikmaken van de jaarrekeningvrijstelling van het groepsregime om informatie af te schermen van derden. ${ }^{15}$ Daarnaast levert deze vrijstelling een administratieve lastenverlichting op.

\subsection{De compensatie van crediteuren (hoofdstuk 3)}

Als een 403-maatschappij gebruikmaakt van de jaarrekeningvrijstelling van het groepsregime kunnen haar crediteuren de jaarrekening niet inzien. Zij kunnen daardoor niet (mede) aan de hand van de jaarrekening schatten hoe groot het risico is dat hun vordering niet (volledig) zal worden voldaan. ${ }^{16}$ De compensatie die een crediteur voor dit gebrek aan inzicht ontvangt, bestaat uit twee onderdelen die elkaar aanvullen. Ten eerste krijgt de crediteur op grond van de 403-verklaring een aanvullende vordering op de moedermaatschappij.

12. Zie $\$ 2.2$.

13. Zie $\S 2.5$.

14. Zie $\$ 2.3$.

15. Zie $\S 2.6$.

16. Zie $\S 3.2$ en $\S 3.3$. 
Daarnaast heeft hij de mogelijkheid om de geconsolideerde jaarrekening van de moedermaatschappij in te zien. Hierdoor wordt een crediteur gecompenseerd voor het feit dat hij een vordering heeft op een debiteur - de 403-maatschappij - van wie hij de jaarrekening niet kan inzien, met een aanvullende vordering op een andere debiteur - de moedermaatschappij - van wie hij de geconsolideerde jaarrekening wel kan inzien. De crediteur heeft niet de garantie dat zijn vordering volledig zal worden voldaan. Hij wordt gecompenseerd doordat hij de mogelijkheid heeft om de geconsolideerde jaarrekening van de moedermaatschappij in te zien en hij vervolgens (mede) aan de hand daarvan kan schatten hoe groot het risico is dat zijn vordering niet (volledig) zal worden voldaan. Het is uiteindelijk aan de crediteur zelf of hij dit risico accepteert en al of niet een relatie met de 403-maatschappij aangaat, dan wel dat hij een bestaande relatie al of niet continueert. ${ }^{17}$

Op grond van art. 2:403 BW is een van de voorwaarden voor de 403-maatschappij om gebruik te mogen maken van de jaarrekeningvrijstelling dat de geconsolideerde jaarrekening van de moedermaatschappij is gedeponeerd bij het handelsregister. Het is niet verplicht dat (ook) de enkelvoudige jaarrekening van de moedermaatschappij is gedeponeerd. De informatie in de enkelvoudige jaarrekening stelt een crediteur beter in staat om te schatten hoe groot het risico is dat de moedermaatschappij de vordering op grond van de 403-verklaring niet (volledig) zal voldoen, dan de informatie in de geconsolideerde jaarrekening. Voor een Nederlandse moedermaatschappij geldt dat zij op grond van art. 2:394 BW verplicht is om een enkelvoudige jaarrekening openbaar te maken, wat betekent dat crediteuren deze jaarrekening kunnen inzien als ze bij het handelsregister de informatie met betrekking tot de moedermaatschappij opvragen. Deze verplichting ex art. 2:394 BW geldt niet voor een moedermaatschappij naar buitenlands recht, waardoor het afhankelijk is van het op de buitenlandse moedermaatschappij toepasselijke recht of deze al of niet verplicht is om een enkelvoudige jaarrekening openbaar te maken. Daarnaast geldt dat als een buitenlandse moedermaatschappij een enkelvoudige jaarrekening deponeert, de crediteuren van de 403-maatschappij deze jaarrekening moeten opvragen bij het equivalent van het Nederlandse handelsregister van het desbetreffende land. Om ervoor te zorgen dat crediteuren altijd eenvoudig inzicht kunnen hebben in de enkelvoudige jaarrekening van de moedermaatschappij, meen ik dat art. 2:403 BW op twee plaatsen moet worden gewijzigd. Ten eerste moet de deponering van de enkelvoudige jaarrekening van de moedermaatschappij als constitutief vereiste voor het gebruikmaken van de jaarrekeningvrijstelling door de 403-maatschappij aan art. 2:403 BW worden toegevoegd. Daarnaast zou in deze bepaling moeten worden opgenomen dat het de 403-maatschappij is die de enkelvoudige jaarrekening van de moedermaatschappij moet deponeren zodat crediteuren deze jaarrekening kunnen inzien als ze bij het handelsregister

17. Zie $\S 3.4$. 
de informatie over de 403-maatschappij opvragen - dit doet overigens niet af aan een op de moedermaatschappij rustende verplichting om zelf deze jaarrekening te deponeren volgens het op haar van toepassing zijnde jaarrekeningregime. ${ }^{18}$

Aangezien de crediteuren geen invloed hebben op de keuze van de 403-maatschappij om gebruik te maken van de jaarrekeningvrijstelling, heb ik als maatstaf voor de compensatie gehanteerd dat deze zodanig moet zijn dat hierdoor het nadeel wordt weggenomen dat een crediteur ondervindt in vergelijking met de situatie dat de 403-maatschappij geen gebruik zou maken van deze vrijstelling. Hetzelfde geldt als de moedermaatschappij de 403-verklaring intrekt of haar overblijvende aansprakelijkheid beëindigt. Het nadeel dat de crediteur daardoor ondervindt in vergelijking met de situatie dat deze verklaring niet zou zijn ingetrokken, respectievelijk dat de aansprakelijkheid niet zou zijn beëindigd, moet naar mijn mening door de compensatie worden weggenomen. Omgekeerd meen ik ook dat zo veel mogelijk moet worden voorkomen dat een crediteur overgecompenseerd wordt en in een voordeliger positie komt doordat de 403-maatschappij gebruikmaakt van de jaarrekeningvrijstelling of doordat de moedermaatschappij de 403-verklaring intrekt of de overblijvende aansprakelijkheid beëindigt. ${ }^{19}$

Bovengenoemde functie van de 403-aansprakelijkheid bij de compensatie van de crediteuren en het standpunt dat zij niet in een nadeliger positie mogen komen doordat de 403-maatschappij gebruikmaakt van de jaarrekeningvrijstelling of doordat de moedermaatschappij de 403-verklaring intrekt of de overblijvende aansprakelijkheid beëindigt, vormen samen het door mij bepleite uitgangspunt voor compensatie. Aan de hand van dit uitgangspunt heb ik onderzocht hoe verschillende wettelijke bepalingen met betrekking tot de 403-aansprakelijkheid moeten worden uitgelegd of worden gewijzigd. ${ }^{20}$

\subsection{De materiële reikwijdte van de 403-aansprakelijkheid (hoofdstuk 4)}

Op grond van art. 2:403 lid 1 sub f BW dient een moedermaatschappij zich uit hoofde van een 403-verklaring hoofdelijk aansprakelijk te stellen voor de uit rechtshandelingen van de 403-maatschappij voortvloeiende schulden. Uit deze bepaling zijn drie elementen op te maken met betrekking tot de materiële reikwijdte van de 403-aansprakelijkheid: 'schulden', 'rechtshandelingen' en 'voortvloeien'.

\footnotetext{
18. Zie $\$ 3.4 .2$.

19. Zie $\S 3.6$.

20. Zie $\S 3.7$.
} 
De term schulden ziet op geldschulden en op niet in geld luidende verplichtingen van de 403-maatschappij. Zowel crediteuren met een vordering in geld als crediteuren met een niet in geld luidende vordering hebben er belang bij om de jaarrekening van de 403-maatschappij te kunnen inzien en moeten mijns inziens om die reden worden gecompenseerd indien dit inzicht ontbreekt. Ik meen dat het wenselijk is dat ter verduidelijking van de reikwijdte van de 403-aansprakelijkheid, de term schulden in art. 2:403 lid 1 sub f BW wordt vervangen door de term verplichtingen. ${ }^{21}$

Aangezien een moedermaatschappij zich op grond van art. 2:403 lid 1 sub f BW slechts aansprakelijk hoeft te stellen voor schulden die uit een rechtshandeling van de 403-maatschappij voortvloeien, vallen schulden uit de wet niet onder de reikwijdte van de 403-aansprakelijkheid. ${ }^{22}$ Het ontstaan en de omvang van een vordering uit de wet, is niet gebaseerd op een afweging van de crediteur ten aanzien van de financiële positie van de 403-maatschappij. De crediteuren ondervinden op dit punt dus geen nadeel als de 403-maatschappij gebruikmaakt van de jaarrekeningvrijstelling van het groepsregime en zij hoeven daarom niet gecompenseerd te worden met een aanvullende vordering op de moedermaatschappij. Dit neemt echter niet weg dat deze crediteuren er gedurende hun relatie met de 403-maatschappij wel belang bij kunnen hebben om de jaarrekening van de 403-maatschappij in te zien. Toch meen ik dat het gerechtvaardigd is dat schulden die uit de wet voortvloeien niet onder de reikwijdte van de 403-aansprakelijkheid vallen. Het jaarlijks kunnen inzien van de nieuwe jaarrekening is namelijk vooral van belang voor de crediteuren die een doorlopende relatie met de 403-maatschappij hebben waaruit periodiek nieuwe vorderingen voortvloeien. Aangezien uit de wet amper doorlopende relaties kunnen ontstaan waaruit periodiek nieuwe vorderingen voortvloeien, staat de extra aansprakelijkheid voor de moedermaatschappij - voor de schulden van de 403-maatschappij uit de wet - naar mijn mening niet in verhouding tot het beperkte gebrek aan inzicht voor de desbetreffende crediteuren dat daardoor zou worden gecompenseerd.

Een schuld vloeit mijns inziens uit een rechtshandeling voort indien de wil van de crediteur ten aanzien van het ontstaan, de inhoud of het voortduren van de schuld zou kunnen zijn beïnvloed door inzicht in de jaarrekening van de 403-maatschappij - als de 403-maatschappij geen gebruik zou hebben gemaakt van de jaarrekeningvrijstelling van het groepsregime. ${ }^{23}$

21. Zie $\S 4.2$.

22. Zie $\S 4.3$.

23. Zie $\S 4.4$. 
De Hoge Raad heeft in het UWV/Econcern-arrest ${ }^{24}$ en de SNS/Curatorenbeschikking ${ }^{25}$ terecht geoordeeld dat een aan een vordering op de 403-maatschappij verbonden voorrecht of achterstelling, naar huidig recht niet meebrengt dat ook de vordering op de moedermaatschappij is bevoorrecht, respectievelijk is achtergesteld. Vanuit het oogpunt van de compensatie van crediteuren is er echter geen reden dat de verhaalsrechten van een crediteur op de 403-maatschappij en de moedermaatschappij verschillend zijn. De compensatie zou er niet toe mogen leiden dat de positie van een crediteur verslechtert doordat een voorrecht ten aanzien van de vordering op de 403-maatschappij niet geldt voor de vordering op de moedermaatschappij, respectievelijk dat zijn positie verbetert omdat een contractuele achterstelling van de vordering op de 403-maatschappij niet geldt ten aanzien van de vordering op de moedermaatschappij. Ik heb er daarom voor gepleit dat aan art. 2:403 BW wordt toegevoegd dat een vordering op de moedermaatschappij op grond van de 403-verklaring dezelfde bevoorrechte, respectievelijk achtergestelde positie heeft als de corresponderende vordering op de 403-maatschappij. ${ }^{26}$

\subsection{De temporele reikwijdte van de 403-aansprakelijkheid (hoofdstuk 5)}

In de literatuur bestaat discussie of - en zo ja in hoeverre - een moedermaatschappij op grond van een 403 -verklaring aansprakelijk is voor schulden die voortvloeien uit de rechtshandelingen die de 403-maatschappij heeft verricht voordat de 403-verklaring is gedeponeerd. Met betrekking tot de verschillende standpunten die in de literatuur op dit punt worden verdedigd, is er een tweedeling te maken wat betreft het moment dat bepalend is voor het antwoord op de vraag of een schuld van de 403-maatschappij al of niet onder de reikwijdte van de 403-aansprakelijkheid valt. Enerzijds wordt aangesloten bij het moment dat de 403-maatschappij de rechtshandeling heeft verricht waaruit de schuld is voortgevloeid. Anderzijds wordt betoogd dat het moment waarop de schuld van de 403-maatschappij opeisbaar is geworden hiervoor bepalend is. Ik heb geconcludeerd dat het eerste uitgangspunt het juiste is omdat dit aansluit bij de temporele reikwijdte van de overblijvende aansprakelijkheid op grond van art. 2:404 lid 2 BW als de moedermaatschappij de 403-verklaring heeft ingetrokken. ${ }^{27}$

24. HR 11 april 2014, JOR 2014/199, m.nt. Van Dooren (UWV/Econcern), r.o. 3.2.2 en 3.4.1-3.4.2.

25. HR 20 maart 2015, JOR 2015/140, m.nt. Josephus Jitta (Minister van Financiën/VEB c.s.), r.o. 4.34.3-4.34.4.

26. Zie $\S 4.7$ en $\S 4.8$.

27. Zie $\S 5.3$. 
De discussie in de literatuur ten aanzien van de temporele reikwijdte van de 403-aansprakelijkheid is mede veroorzaakt doordat in de (lagere) jurisprudentie verschillend over dit onderwerp is geoordeeld. Sinds 2001 is echter op één uitspraak na in de jurisprudentie consequent geoordeeld dat een moedermaatschappij op grond van de 403-verklaring aansprakelijk is voor alle schulden die voortvloeien en zijn voortgevloeid uit een rechtshandeling van de 403-maatschappij. ${ }^{28}$ Ook in de parlementaire geschiedenis wordt de 403-aansprakelijkheid op deze wijze uitgelegd. ${ }^{29}$ In eerste instantie merkte de minister nog op dat de aansprakelijkheid van een moedermaatschappij was beperkt tot de toekomstige verplichtingen. Maar later heeft hij het standpunt onderschreven dat een moedermaatschappij op grond van de 403-verklaring aansprakelijk is voor alle uit een rechtshandeling van de 403-maatschappij voortvloeiende en voortgevloeide schulden.

Dat een moedermaatschappij op grond van de 403-verklaring aansprakelijk is voor alle schulden die voortvloeien en zijn voortgevloeid uit een rechtshandeling van de 403-maatschappij, sluit aan bij het door mij bepleite uitgangspunt voor compensatie. ${ }^{30}$ Zowel de bestaande als de nieuwe crediteuren ondervinden nadeel omdat zij de nieuwe jaarrekening(en) van de 403-maatschappij niet kunnen inzien. Beide groepen crediteuren moeten daarom worden gecompenseerd met een aanvullende vordering op de moedermaatschappij van wie zij de geconsolideerde jaarrekening wel kunnen inzien.

\subsection{De duiding van de 403-vordering (hoofdstuk 6)}

Een crediteur van de 403-maatschappij heeft twee vorderingen: een vordering op de 403-maatschappij en een 403-vordering op de moedermaatschappij op grond van de 403-verklaring. In de literatuur bestaat discussie over de civielrechtelijke duiding van de 403 -vordering op de moedermaatschappij. Ook in de jurisprudentie is deze vordering verschillend geduid.

Ik heb de rechtsgevolgen van vier verschillende duidingen van de 403-vordering onderzocht: de 'hoofdelijke' vordering, de 'dynamische' vordering, de analoge toepassing van art. 6:142 BW ten aanzien van de 403-vordering en tot slot de analoge toepassing van de bepalingen inzake borgtocht ten aanzien van de 403 -aansprakelijkheid. ${ }^{31}$ Ik ben voor verschillende situaties nagegaan wat de gevolgen zijn van iedere duiding. Ik heb onder meer onderzocht of een crediteur zich op de moedermaatschappij kan verhalen als de vordering

\footnotetext{
28. Zie $\S 5.6 .1$.

29. Zie $\$ 5.6 .2$

30. Zie $\$ 5.6 .4$.

31. Zie $\S 6.2$.
} 
op de 403-maatschappij is verjaard, als de crediteur afstand heeft gedaan van deze vordering, en als de 403-maatschappij de nakoming van haar verplichting heeft opgeschort. Daarnaast heb ik antwoord gegeven op de vraag of een crediteur zijn vorderingen op de moeder- en de 403-maatschappij onafhankelijk van elkaar kan cederen en verpanden. ${ }^{32}$ Vervolgens heb ik de gevolgen van de verschillende duidingen van de 403-vordering vergeleken met de uitkomst in deze situaties volgens het door mij bepleite uitgangspunt voor compensatie. ${ }^{33}$ Hieruit volgt dat een analoge toepassing van de bepalingen inzake borgtocht ten aanzien van de 403-aansprakelijkheid in alle onderzochte situaties overeenkomt met de uitkomst volgens dit uitgangspunt. ${ }^{34}$ De Hoge Raad heeft echter in de $A k z o / I N G$-beschikking de analoge toepassing van de bepalingen inzake borgtocht ten aanzien van de 403 -aansprakelijkheid afgewezen. ${ }^{35} \mathrm{Om}$ de aansprakelijkheid van de moedermaatschappij als zodanig te kunnen uitleggen, moet art. 2:403 lid 1 sub f BW dus worden gewijzigd.

Het is echter geen oplossing om in art. 2:403 lid $1 \mathrm{sub} f \mathrm{BW}$ op te nemen dat de moedermaatschappij zich tot borg moet stellen voor de schulden die voorvloeien uit een rechtshandeling van de 403-maatschappij. Aangezien borgtocht een overeenkomst is, ${ }^{36}$ zou dat betekenen dat de moedermaatschappij met iedere crediteur van de 403-maatschappij een afspraak moet maken over haar aansprakelijkheid. De aansprakelijkheid van de moedermaatschappij dient echter een collectief en eenzijdig karakter te hebben zodat deze voor alle crediteuren gelijk is. Ik heb twee alternatieven genoemd waarmee kan worden bereikt dat de aansprakelijkheid van de moedermaatschappij een afhankelijk en subsidiair karakter heeft. Ten eerste kan in art. 2:403 lid 1 sub f BW worden opgenomen dat de moedermaatschappij een verklaring moet deponeren op grond waarvan zij zich hoofdelijk aansprakelijk stelt voor de schulden die voortvloeien uit een rechtshandeling van de 403-maatschappij voor zover de 403-maatschappij zelf tekortschiet in de nakoming en dat deze aansprakelijkheid afhankelijk is van de verbintenis van de 403-maatschappij waarvoor deze geldt. Een tweede mogelijkheid is om art. 2:403 lid $1 \mathrm{sub} f \mathrm{BW}$ zo aan te passen dat de moedermaatschappij moet verklaren dat zij garant staat voor de schulden die voortvloeien uit een rechtshandeling van de 403-maatschappij. Aangezien er naar huidig recht echter geen vaste definitie is van een garantstelling zou de wetgever in aanvulling op deze wijziging in de parlementaire stukken moeten vermelden hoe de aansprakelijkheid van een moedermaatschappij op grond van de garantieverklaring moet worden geduid, waarbij mijns inziens zo veel mogelijk moet worden aangesloten bij de bepalingen inzake borgtocht.

32. Zie $\S 6.3$.

33. Zie $\S 6.4$ en $\S 6.5$.

34. Zie $\S 6.5 .2$.

35. HR 28 juni 2002, NJ 2002/447, m.nt. Maeijer ( $A k z o / I N G)$, r.o. 3.4.3, 3.4.5 en 3.4.6. Ook gepubliceerd in JOR 2002/136, m.nt. Bartman.

36. Zie art. 7:850 lid $1 \mathrm{BW}$. 
Zolang art. 2:403 lid 1 sub f BW niet op een van bovengenoemde wijzen wordt aangepast, is de enige mogelijkheid die een moedermaatschappij heeft om te bewerkstelligen dat haar aansprakelijkheid op grond van de 403-verklaring een afhankelijk en subsidiair karakter heeft, om dit contractueel met een crediteur overeen te komen. Een praktische manier om dit te bereiken, is door de 403-maatschappij een doorlopende volmacht te geven zodat deze dit namens de moedermaatschappij met een crediteur kan afspreken op het moment dat zij zelf een overeenkomst met de desbetreffende crediteur aangaat. De moedermaatschappij kan dit echter niet afdwingen. De crediteur zal zelf moeten instemmen.

Binnen de mogelijkheden van het huidige art. 2:403 BW, komen de gevolgen van het analoog toepassen van art. 6:142 BW ten aanzien van de 403-vordering en de gevolgen van de duiding van de 403-vordering als een dynamische vordering het vaakst overeen met de uitkomsten volgens het door mij bepleite uitgangspunt voor compensatie. ${ }^{37}$ De Hoge Raad heeft de analoge toepassing van art. 6:142 BW ten aanzien van de 403-vordering echter impliciet afgewezen in zijn $A k z o / I N G$-beschikking. ${ }^{38}$ Naar mijn mening moet de 403 -vordering daarom naar huidig recht worden geduid als een dynamische vordering. ${ }^{39}$ Deze duiding houdt in dat de 403-vordering een hoofdelijke vordering is die altijd toekomt aan degene met de corresponderende vordering op de 403-maatschappij. Het is echter niet zeker of de Hoge Raad de duiding van de 403-vordering als een dynamische vordering toestaat omdat twee van zijn uitspraken op dit punt tegenstrijdig zijn aan elkaar. ${ }^{40}$ Indien de duiding van de 403 -vordering als een dynamische vordering wordt afgewezen, moet deze vordering worden geduid als een hoofdelijke vordering. ${ }^{41}$

\subsection{De intrekking van een 403-verklaring (hoofdstuk 7)}

Een moedermaatschappij kan haar 403-verklaring intrekken door een daartoe strekkende verklaring te deponeren. De moedermaatschappij is niet aansprakelijk voor de schulden die voortvloeien uit de rechtshandelingen die de 403-maatschappij verricht vanaf het moment dat zij tegenover de crediteur een

37. Ik merk op dat hoewel de gevolgen van deze twee duidingen van de 403-vordering in de door mij onderzochte situaties even vaak overeenkomen met de uitkomsten volgens het door mij bepleite uitgangspunt voor compensatie, de gevolgen onderling op enkele punten verschillen.

38. Zie $\S 6.5 .3$ en HR 28 juni 2002, JOR 2002/136, m.nt. Bartman (Akzo/ING), r.o. 3.5.3.

39. Zie $\S 6.5 .4$.

40. HR 20 maart 2015, JOR 2015/140, m.nt. Josephus Jitta (Minister van Financiën/VEB c.s.), r.o. 4.30 en HR 3 april 2015, JOR 2015/191, m.nt. Faber en Vermunt (Eikendal q.q./Lentink), r.o. 3.6.2.

41. Zie $\S$ 6.5.5. 
beroep kan doen op de intrekking. De moedermaatschappij kan in de intrekkingsverklaring opnemen dat de 403-verklaring op een bepaalde datum in de toekomst wordt ingetrokken. ${ }^{42}$ Maar zij kan haar 403-verklaring naar mijn mening niet zo vormgeven, dat deze tevens geldt als intrekkingsverklaring. ${ }^{43}$

Als de 403-maatschappij nog niet een jaarrekening openbaar heeft gemaakt die voldoet aan de voorschriften van titel 9 van Boek 2 BW voordat de moedermaatschappij een beroep kan doen op de intrekking van de 403-verklaring, zal er een periode zijn dat crediteuren de jaarrekening van de 403-maatschappij niet kunnen inzien maar daarvoor niet worden gecompenseerd. De crediteuren van wie de vordering voortvloeit uit een rechtshandeling die de 403-maatschappij in deze periode heeft verricht, worden niet gecompenseerd voor het feit dat zij de jaarrekening van de 403-maatschappij niet kunnen inzien. Om deze lacune in de compensatie van de crediteuren te verhelpen, is het mijns inziens gewenst dat art. 2:404 BW wordt gewijzigd. Aan lid 1 van deze bepaling kan worden toegevoegd dat de intrekking van de 403-verklaring slechts of eerst effect heeft als de 403-maatschappij een jaarrekening openbaar heeft gemaakt die aan de voorschriften van titel 9 van Boek 2 BW voldoet, of als er een nieuwe 403-verklaring is gedeponeerd ten aanzien van de 403-maatschappij. ${ }^{44}$

In het geval dat een 403-maatschappij niet meer gebruikmaakt van de jaarrekeningvrijstelling van het groepsregime maar de moedermaatschappij is vergeten de 403-verklaring in te trekken, is het uitgangspunt dat een crediteur desondanks een beroep kan doen op de vergeten 403 -verklaring. Een dergelijk beroep is naar mijn mening slechts onaanvaardbaar naar maatstaven van redelijkheid en billijkheid als de crediteur weet, of behoort te weten, dat de moedermaatschappij is vergeten de 403 -verklaring in te trekken. ${ }^{45}$

Een moedermaatschappij kan preventief de aansprakelijkheid op grond van een 403-verklaring limiteren voor het geval zij vergeet deze verklaring in te trekken. ${ }^{46}$ De meest effectieve manier hiervoor is om in de 403 -verklaring op te nemen dat zij zich slechts aansprakelijk stelt voor de schulden die voortvloeien uit de rechtshandelingen die de 403-maatschappij tot een bepaalde datum verricht, of door een intrekkingsverklaring te deponeren op grond waarvan de 403-verklaring op een bepaalde datum wordt ingetrokken.

\footnotetext{
42. Zie $\S 7.4$.

43. Zie $\S 7.5$.

44. Zie $\$ 7.3$.

45. Zie $\S 7.6 .4$.

46. Zie $\S 7.7 .5$.
} 


\subsection{De beëindiging van de overblijvende aansprakelijkheid (hoofdstuk 8)}

Als een moedermaatschappij haar 403-verklaring intrekt, blijft zij aansprakelijk voor de schulden die voortvloeien uit de rechtshandelingen die de 403-maatschappij heeft verricht tot het moment dat de moedermaatschappij tegenover de crediteur een beroep kan doen op de intrekking. Ik heb geconcludeerd dat deze overblijvende aansprakelijkheid alle bestaande en toekomstige schulden omvat die voortvloeien uit de rechtshandelingen die de 403-maatschappij tot dat moment heeft verricht. ${ }^{47}$

Een moedermaatschappij kan haar overblijvende aansprakelijkheid tegenover een crediteur beëindigen als zij aan een viertal cumulatieve voorwaarden voldoet. Hiervoor is vereist dat de groepsband tussen de moeder- en de 403-maatschappij is verbroken. Daarnaast moet een mededeling van het voornemen om de overblijvende aansprakelijkheid te beëindigen twee maanden ter inzage hebben gelegen bij het handelsregister. Voorts dienen er twee maanden te zijn verlopen na de aankondiging in een landelijk verspreid dagblad dat en waar deze mededeling ter inzage ligt. Tot slot mag tegen het voornemen van de moedermaatschappij om de overblijvende aansprakelijkheid te beëindigen geen verzet zijn ingesteld door de crediteur, dan wel moet diens verzet zijn ingetrokken of door de rechter ongegrond zijn verklaard.

In art. 2:404 lid 3 sub b en c BW worden geen voorwaarden genoemd met betrekking tot de informatie die een moedermaatschappij moet opnemen in haar mededeling bij het handelsregister dat zij voornemens is om de overblijvende aansprakelijkheid te beëindigen en de aankondiging daarvan in een landelijk verspreid dagblad. Ik acht het wenselijk dat aan deze bepalingen wordt toegevoegd dat een moedermaatschappij in de mededeling bij het handelsregister en de aankondiging daarvan in een landelijk verspreid dagblad expliciet melding moet maken van haar eigen naam, de naam van de 403-maatschappij en eventuele oude namen van hen indien die sinds de deponering van de 403 -verklaring zijn gewijzigd. ${ }^{48}$ Deze wetswijziging biedt een moedermaatschappij houvast bij het opstellen van deze stukken en waarborgt dat de crediteuren aan de hand van de informatie in de stukken kunnen achterhalen of hun vordering door de beëindiging van de overblijvende aansprakelijkheid komt te vervallen.

Aangezien het onwaarschijnlijk is dat een crediteur regelmatig ten aanzien van alle debiteuren nagaat of er een mededeling is gedeponeerd van het voornemen om de overblijvende aansprakelijkheid te beëindigen, en dagelijks alle landelijk verspreide dagbladen controleert of er een aankondiging van een

47. Zie $\S 8.2$.

48. Zie $\S 8.5 .3$. 
dergelijke mededeling is gedaan, is het goed mogelijk dat een crediteur het voornemen van de moedermaatschappij om de overblijvende aansprakelijkheid te beëindigen over het hoofd ziet. Om een crediteur beter in staat te stellen dat hij bekend kan zijn met het voornemen van de moedermaatschappij om de overblijvende aansprakelijkheid te beëindigen, heb ik ervoor gepleit dat de Kamer van Koophandel een systeem aanbiedt waarbij derden automatisch een notificatie kunnen krijgen als met betrekking tot een bepaalde rechtspersoon stukken zijn gedeponeerd bij het handelsregister. Een crediteur kan dan instellen dat hij een bericht krijgt als de moedermaatschappij een mededeling deponeert van het voornemen om de overblijvende aansprakelijkheid te beëindigen. Indien de Kamer van Koophandel een dergelijk systeem aanbiedt, kan de voorwaarde dat de moedermaatschappij een aankondiging moet plaatsen in een landelijk verspreid dagblad dat en waar deze mededeling ter inzage ligt mijns inziens worden geschrapt uit art. 2:404 lid $3 \mathrm{BW}^{49}$

Crediteuren voor wier vordering nog aansprakelijkheid loopt, kunnen verzet instellen tegen het voornemen van de moedermaatschappij om de overblijvende aansprakelijkheid te beëindigen. Dit betreft ook crediteuren met een niet-vaststaande vordering op de 403-maatschappij, tenzij de vordering onmiskenbaar ongegrond is. Daarnaast kan de houder van een openbaar pandrecht op de vordering van een crediteur op de moedermaatschappij verzet instellen. ${ }^{50} \mathrm{Als}$ een crediteur verzet instelt, kan hij een vervangende waarborg verlangen voor de nakoming van zijn vordering op de 403-maatschappij. Ik heb verdedigd dat een crediteur recht heeft op een vervangende waarborg als hij na de beëindiging van de overblijvende aansprakelijkheid, uit hoofde van de vermogenstoestand van de 403-maatschappij of uit anderen hoofde, niet (minimaal) dezelfde waarborgen heeft dat zijn vordering op de 403-maatschappij zal worden voldaan, als de waarborgen die hij heeft dat zijn vordering op de moedermaatschappij zal worden voldaan, tenzij de crediteur redelijkerwijs geen risico loopt dat zijn vordering op de 403-maatschappij niet zal worden voldaan. ${ }^{51}$

De huidige lijn in de jurisprudentie is dat de omvang van een te geven vervangende waarborg wordt vastgesteld op het bedrag van de bestaande en toekomstige vorderingen van de crediteur op de 403-maatschappij. ${ }^{52}$ Naar mijn mening is het niet juist om de vervangende waarborg zonder meer op dit bedrag vast te stellen. Ik betoog dat deze waarborg mede moet worden vastgesteld aan de hand van de waarborgen die de crediteur al heeft, uit hoofde van de vermogenstoestand van de 403-maatschappij of uit anderen hoofde, dat zijn vordering op de 403-maatschappij zal worden voldaan. Mijns inziens moet de

\footnotetext{
49. Zie $\S 8.5 .1$ en $\S 8.5 .2$.

50. Zie $\$ 8.7$.

51. Zie $\S 8.8$.

52. Zie $\S 8.9 .3$.
} 
vervangende waarborg deze waarborgen die de crediteur al heeft, aanvullen tot het niveau dat deze gezamenlijk (minimaal) dezelfde waarborgen bieden dat de vordering van de crediteur op de 403-maatschappij zal worden voldaan, als de waarborgen die hij heeft dat zijn vordering op de moedermaatschappij zal worden voldaan.

Ik heb geconcludeerd dat pas als een moedermaatschappij een beroep kan doen op de intrekking van de 403-verklaring, zij een aankondiging kan plaatsen in een landelijk verspreid dagblad dat en waar de door haar gedeponeerde mededeling van het voornemen om de overblijvende aansprakelijkheid te beëindigen ter inzage ligt. ${ }^{53}$ Mijns inziens moet uiterlijk op het moment dat de tweemaandstermijn verloopt waarbinnen de crediteuren verzet kunnen instellen tegen het voornemen van de moedermaatschappij om de overblijvende aansprakelijkheid te beëindigen aan alle voorwaarden voor deze beëindiging zijn voldaan, behoudens de afwikkeling van een eventueel ingesteld verzet. In welke volgorde aan deze voorwaarden is voldaan, is daarvoor naar mijn mening niet van belang. $^{54}$

Tot slot meen ik dat de voorwaarde voor de beëindiging van de overblijvende aansprakelijkheid dat de groepsband tussen de moeder- en de 403-maatschappij is verbroken, overbodig is en het onnodig bezwarend maakt om deze aansprakelijkheid te beëindigen. Ik acht het daarom wenselijk dat deze voorwaarde wordt geschrapt uit art. 2:404 lid 3 BW. ${ }^{55}$

\subsection{Fusie, splitsing en omzetting (hoofdstuk 9)}

Ik meen dat de aard van de 403-aansprakelijkheid er niet aan in de weg staat dat deze bij een fusie of een splitsing van de moedermaatschappij onder algemene titel kan overgaan op een verkrijgende rechtspersoon. Dit betreft mijns inziens zowel de aansprakelijkheid voor de bestaande schulden van de 403-maatschappij die op het moment van de fusie of de splitsing van de moedermaatschappij al uit een rechtshandeling zijn voortgevloeid, als de aansprakelijkheid voor de schulden die nadien voortvloeien uit een rechtshandeling van de 403-maatschappij. De 403-verklaring heeft vanaf de fusie of splitsing te gelden als verklaring van de verkrijgende rechtspersoon. ${ }^{56}$

De aansprakelijkheid op grond van een 403-verklaring is naar mijn mening op verschillende manieren van invloed op het recht van een crediteur ex art. 2:316 en art. 2:3341 jo. art. 2:334k BW om in verzet te komen tegen een

53. Zie $\S 8.12$.

54. Zie $\S 8.13$.

55. Zie $\S 8.14$.

56. Zie $\S 9.2$. 
voorstel tot fusie of splitsing waarbij de moeder- of de 403-maatschappij is betrokken, en of de crediteur in dat geval recht heeft op een waarborg voor de voldoening van zijn vordering. ${ }^{57}$ In het geval dat een moedermaatschappij wil fuseren of splitsen kunnen ook de crediteuren met een vordering op grond van de 403-verklaring daartegen in verzet komen. Daarnaast heb ik betoogd dat als een 403-maatschappij een voorstel doet tot fusie of splitsing, de vraag of een crediteur recht heeft op een waarborg voor de voldoening van zijn vordering niet moet worden beantwoord aan de hand van de waarborg die de vermogenstoestand van de (rechtsopvolger van de) 403-maatschappij biedt dat de vordering zal worden voldaan. Deze vraag moet naar mijn mening in plaats daarvan worden beantwoord aan de hand van de waarborg die de vermogenstoestand van de moedermaatschappij biedt dat de vordering van de crediteur op grond van de 403-verklaring zal worden voldaan. Indien vermogen van de 403-maatschappij door een fusie of splitsing op een verkrijgende rechtspersoon overgaat, zullen haar crediteuren die in verzet zijn gekomen doorgaans geen recht hebben op een waarborg. Een dergelijke fusie of splitsing heeft geen gevolgen voor (de omvang van) de aansprakelijkheid van de moedermaatschappij op grond van de 403-verklaring. Aangezien de crediteuren hun vordering op de moedermaatschappij op grond van de 403-verklaring behouden, zal een crediteur van de 403-maatschappij die verzet heeft ingesteld daarom doorgaans geen recht hebben op een waarborg voor de voldoening van deze vordering.

Indien de 403-maatschappij vermogen verkrijgt door een fusie of splitsing, moet er een onderscheid worden gemaakt tussen de crediteuren van de 403-maatschappij en die van de rechtspersoon van wie het vermogen overgaat. Voor een crediteur van de 403-maatschappij die in verzet is gekomen, geldt mijns inziens dat hij recht heeft op een waarborg als de extra aansprakelijkheid die de moedermaatschappij door de fusie of splitsing van de 403-maatschappij op grond van de 403-verklaring krijgt, een negatief effect heeft op de waarborg dat zijn vordering op grond van de 403-verklaring zal worden voldaan, tenzij dit negatieve effect ongedaan wordt gemaakt door het extra vermogen dat de 403-maatschappij verkrijgt. Als een crediteur van de rechtspersoon van wie het vermogen overgaat in verzet is gekomen, heeft deze doorgaans geen recht op een waarborg omdat hij na de fusie of splitsing op grond van de 403-verklaring een aanvullende vordering op de moedermaatschappij krijgt.

Naar mijn mening blijft de aansprakelijkheid op grond van de 403-verklaring bij een fusie of een splitsing van de moeder- of de 403-maatschappij onverminderd bestaan. De (rechtsopvolger van de) moedermaatschappij is aansprakelijk voor alle schulden die voortvloeien en zijn voortgevloeid uit de rechtshandelingen die de 403-maatschappij (heeft) verricht. Een andere uitkomst zou hetzelfde gevolg hebben als de beëindiging van (een deel van) de

57. Zie $\S 9.3$. 
403-aansprakelijkheid buiten artikel 2:404 BW om. Een crediteur zou dan onterecht geen beroep kunnen doen op de procedures en waarborgen uit deze bepaling die beogen zijn verhaalsrecht te beschermen. Ook als de moederen de 403-maatschappij met elkaar fuseren vervalt de 403-aansprakelijkheid naar mijn mening niet. ${ }^{58}$ Een crediteur heeft dan twee vorderingen op de moeder- of de 403-maatschappij: een vordering op grond van de oorspronkelijke rechtsverhouding met de 403-maatschappij en een vordering op grond van de 403-verklaring.

Als de 403-verklaring is ingetrokken, kan de overblijvende aansprakelijkheid worden beëindigd als aan bepaalde voorwaarden wordt voldaan. Hiervoor is op grond van art. 2:404 lid 3 sub a BW onder meer vereist dat de groepsband tussen de moeder- en de 403-maatschappij is verbroken. Ik heb onderzocht hoe deze voorwaarde moet worden uitgelegd in het licht van een fusie of een splitsing van de moeder- of de 403-maatschappij. ${ }^{59} \mathrm{Ik}$ ben tot de conclusie gekomen dat aan deze voorwaarde is voldaan indien na de fusie of de splitsing van de moeder- of de 403-maatschappij, de rechtspersoon op wie de overblijvende aansprakelijkheid rust niet tot dezelfde groep behoort als de rechtspersoon van wie de handelingen tot aansprakelijkheid op grond van de ingetrokken 403-verklaring kunnen leiden. Mijns inziens is ook aan deze voorwaarde voldaan als de moeder- en de 403-maatschappij met elkaar fuseren waarbij een van beide is verdwenen en het vermogen op de ander is overgegaan. ${ }^{60}$

Een (grensoverschrijdende) omzetting, en een grensoverschrijdende fusie of splitsing van de moeder- of de 403-maatschappij kan ertoe leiden dat de (rechtsopvolger van de) 403-maatschappij geen gebruik mag maken van de jaarrekeningvrijstelling van het groepsregime. ${ }^{61}$ Om gebruik te mogen maken van deze vrijstelling dient de (rechtsopvolger van de) 403-maatschappij een in art. 2:360 BW genoemde rechtspersoon te zijn waarvoor de jaarrekeningvrijstelling openstaat, ${ }^{62}$ en moet de (rechtsopvolger van de) moedermaatschappij de financiële gegevens van de (rechtsopvolger van de) 403-maatschappij kunnen consolideren in een geconsolideerde jaarrekening waar krachtens het toepasselijke recht de in art. 2:403 lid 1 sub c BW genoemde Europese richtlijnen of de verordening EU IFRS op van toepassing zijn.

\footnotetext{
58. Zie $\S$ 9.7.1.b en $\S$ 9.8.1.b.

59. Zie $\S 9.4$.

60. Zie $\S 9.7 .1 . c$ en $\S 9.8 .1 . c$

61. Zie $\S 9.11$ en $\S 9.12$.

62. Zie $\S 2.3 .1$ welke rechtspersonen gebruik mogen maken van de jaarrekeningvrijstelling.
} 


\subsection{Aanbevelingen}

\subsubsection{Inleiding}

Ik heb onderzocht hoe de 403-aansprakelijkheid moet worden uitgelegd in het licht van de functie van deze aansprakelijkheid bij de compensatie van de crediteuren omdat zij de jaarrekening van de 403-maatschappij niet kunnen inzien. Ik heb als maatstaf voor de compensatie gehanteerd dat het nadeel moet worden weggenomen dat een crediteur ondervindt doordat de 403-maatschappij gebruikmaakt van de jaarrekeningvrijstelling, of doordat de moedermaatschappij de 403-verklaring intrekt of de overblijvende aansprakelijkheid beëindigt. Daarnaast heb ik onderzocht hoe de 403 -aansprakelijkheid moet worden uitgelegd om zo veel mogelijk te voorkomen dat een crediteur overgecompenseerd wordt en in een voordeliger positie komt door de compensatie die hij ontvangt.

Indien ik tot de conclusie ben gekomen dat het huidige recht niet leidt tot een situatie waarbij de crediteuren van de 403-maatschappij (voldoende) worden gecompenseerd voor het nadeel dat zij ondervinden, of de compensatie ertoe leidt dat zij overgecompenseerd worden, heb ik een voorstel gedaan hoe het huidige recht op het desbetreffende punt door de wetgever kan worden gewijzigd. Daarnaast heb ik aanbevelingen gedaan aan de rechterlijke macht hoe mijns inziens moet worden geoordeeld over het moment waarop diverse stappen in de procedure voor de beëindiging van de overblijvende aansprakelijkheid zijn gezet, onder welke omstandigheden een crediteur die verzet heeft ingesteld tegen de beëindiging recht heeft op een vervangende waarborg, en welke omvang een te geven vervangende waarborg (minimaal) moet hebben. Voorts heb ik ervoor gepleit dat de Kamer van Koophandel een systeem aanbiedt waardoor derden een notificatie kunnen krijgen als stukken bij het handelsregister worden gedeponeerd.

Naast bovengenoemde aanbevelingen, heb ik ook verschillende opmerkingen gemaakt voor partijen in de praktijk, waarbij ik erop heb gewezen welke stappen zij naar huidig recht kunnen zetten ter versterking van hun positie of om mogelijk nadeel te voorkomen. Dit betreft aanbevelingen voor onder meer de moedermaatschappij, de 403-maatschappij, crediteuren en eventuele minderheidsaandeelhouders van de 403-maatschappij.

Bovenstaande brengt mij tot in totaal twintig aanbevelingen. In onderstaande paragrafen noem ik eerst de aanbevelingen die ik doe aan partijen in de praktijk met betrekking tot de stappen die zij naar huidig recht kunnen zetten. Vervolgens geef ik een overzicht van de belangrijkste door mij bepleite aanpassingen van art. 2:403 en art. 2:404 BW. Daarna doe ik enkele aanbevelingen aan de 
rechterlijke macht en tot slot maak ik nog een opmerking met betrekking tot de Kamer van Koophandel.

\subsubsection{Aanbevelingen aan de praktijk}

Als een 403-maatschappij gebruikmaakt van de jaarrekeningvrijstelling van het groepsregime, heeft dat verschillende gevolgen voor partijen die daarbij zijn betrokken. Een van de voorwaarden om gebruik te mogen maken van de vrijstelling is bijvoorbeeld dat de moedermaatschappij zich op grond van een 403-verklaring aansprakelijk heeft gesteld voor de schulden die voortvloeien uit een rechtshandeling van de 403-maatschappij. Dit brengt mee dat de desbetreffende crediteuren zich vanaf dat moment ook op de moedermaatschappij kunnen verhalen. De diverse betrokken partijen hebben allemaal hun eigen belang dat doorgaans niet verenigbaar is met het belang van een andere partij. Een moedermaatschappij zal bijvoorbeeld niet meer aansprakelijkheid willen lopen dan nodig is. En een crediteur wil voorkomen dat de moedermaatschappij zonder zijn weten de 403-verklaring intrekt en de overblijvende aansprakelijkheid beëindigt.

Hieronder geef ik een overzicht van zes aanbevelingen die ik doe aan partijen voor wie het gebruikmaken van de jaarrekeningvrijstelling door de 403-maatschappij gevolgen heeft. Deze aanbevelingen helpen de desbetreffende partijen om hun positie te versterken of om mogelijk nadeel te voorkomen. Ik doe aanbevelingen aan onder meer de moedermaatschappij, de 403-maatschappij, crediteuren en eventuele minderheidsaandeelhouders van de 403-maatschappij. Ik merk op dat een deel van de aanbevelingen die ik doe, inhouden dat een partij een overeenkomst moet sluiten met een andere partij. Het is vanzelfsprekend mede afhankelijk van de onderhandelingspositie van een partij of het lukt om een dergelijke overeenkomst tot stand te brengen.

1. Een minderheidsaandeelhouder van de 403-maatschappij kan voorwaarden verbinden aan de door hem te geven instemming voor de afwijking van de jaarrekeningvoorschriften door de 403-maatschappij. Hij kan bijvoorbeeld eisen dat hem inzicht wordt gegeven in de interne financiële gegevens van de 403-maatschappij. Aangezien iedere aandeelhouder moet instemmen, heeft een minderheidsaandeelhouder een sterke onderhandelingspositie bij het stellen van voorwaarden. ${ }^{63}$

2. Als een moedermaatschappij wil voorkomen dat zij een verklaring van aansprakelijkheid deponeert die niet voldoet aan het vereiste van art. 2:403 lid 1 sub f BW, kan zij bij het opstellen van de 403-verklaring het beste de tekst van deze bepaling volgen. Daarnaast raad ik het

63. Zie $\S 2.3 .4 . d$. 
bestuur van een 403-maatschappij aan om zelf de tekst van een door de moedermaatschappij te deponeren of in het verleden gedeponeerde 403-verklaring te controleren, om zich ervan te vergewissen dat wordt voldaan aan de voorwaarde van art. 2:403 lid $1 \mathrm{sub} f \mathrm{BW}$ en de 403-maatschappij niet onterecht gebruikmaakt van de jaarrekeningvrijstelling. Omgekeerd is het voor de curator van een failliete 403-maatschappij van belang om na te gaan of de door de moedermaatschappij gedeponeerde verklaring van aansprakelijkheid voldoet aan het vereiste van art. 2:403 lid 1 sub f BW. Als dit niet het geval is en de 403-maatschappij onterecht gebruik heeft gemaakt van de jaarrekeningvrijstelling van het groepsregime kan de curator mogelijk het bestuur van de 403-maatschappij aansprakelijk stellen op grond van art. 2:9 BW of art. 2:138/248 BW. ${ }^{64}$

3. Een moedermaatschappij kan een doorlopende volmacht verlenen aan de 403-maatschappij zodat deze op het moment dat ze zelf met een crediteur een overeenkomst aangaat, namens de moedermaatschappij afspraken kan maken met betrekking tot de vordering op grond van de 403-verklaring. De 403-maatschappij kan namens de moedermaatschappij met de crediteur overeenkomen dat de vordering op de moedermaatschappij niet onafhankelijk van de vordering op de 403-maatschappij kan worden overgedragen - waardoor ook de verpanding van deze vordering is uitgesloten. Daarnaast kan worden afgesproken dat de aansprakelijkheid van de moedermaatschappij afhankelijk is van de verbintenis tussen de crediteur en de 403-maatschappij, dat de moedermaatschappij niet is gehouden tot nakoming totdat de 403-maatschappij zelf daarin tekortschiet en dat de moedermaatschappij een beroep kan doen op dezelfde verweermiddelen als die de 403-maatschappij heeft tegenover de crediteur ten aanzien van het bestaan, de inhoud of het moment van nakoming van de verplichting. Voorts kan met de crediteur worden afgesproken dat de moedermaatschappij bevoegd is de nakoming van haar verplichting op grond van de 403-verklaring op te schorten, zolang de 403-maatschappij - rechtsgeldig - de nakoming van haar verplichting jegens de crediteur op grond van art. 6:52 BW opschort, en dat de verjaring van de vordering van de crediteur op de 403-maatschappij meebrengt dat ook de moedermaatschappij is bevrijd van haar verplichting op grond van de 403-verklaring. ${ }^{65}$ Tot slot is het mogelijk dat de 403-maatschappij namens de moedermaatschappij met de crediteur overeenkomt dat de vordering op grond van de 403-verklaring contractueel is achtergesteld. ${ }^{66}$

64. Zie $\S 2.3 .6 . c$.

65. Zie $\S 6.5 .2$.

66. Zie $\S 4.8$. 
4. Ik adviseer een moedermaatschappij om preventief de aansprakelijkheid op grond van de 403-verklaring te limiteren voor het geval dat zij vergeet deze verklaring in te trekken. De meest effectieve manier hiervoor is om in de 403-verklaring op te nemen dat zij zich slechts aansprakelijk stelt voor de schulden die voortvloeien uit de rechtshandelingen die de 403-maatschappij tot een bepaalde datum verricht, of door een intrekkingsverklaring te deponeren op grond waarvan de 403-verklaring op een bepaalde datum wordt ingetrokken. Als einddatum voor de aansprakelijkheid, respectievelijk de datum dat de 403-verklaring wordt ingetrokken, adviseer ik de dag na verloop van twaalf maanden na het boekjaar waarover de 403-maatschappij een jaarrekening zal opmaken waarbij zij gebruikmaakt van de jaarrekeningvrijstelling van het groepsregime. De moeder- en de 403-maatschappij dienen er wel op bedacht te zijn dat als de 403-maatschappij nadien gebruik wil blijven maken van de jaarrekeningvrijstelling, de moedermaatschappij een nieuwe 403-verklaring (en eventueel een nieuwe preventieve intrekkingsverklaring) deponeert. ${ }^{67}$

5. Een crediteur kan laten vastleggen dat hij individueel moet worden ingelicht als de moedermaatschappij de 403-verklaring intrekt en als zij een aankondiging plaatst in een landelijk verspreid dagblad dat en waar de gedeponeerde mededeling van het voornemen om de overblijvende aansprakelijkheid te beëindigen ter inzage ligt. Het is aan te raden dat een crediteur een dergelijk overeenkomst sluit met de moedermaatschappij. ${ }^{68}$

6. Ik adviseer dat de houder van een openbaar pandrecht op een vordering van een crediteur op de moedermaatschappij bij de crediteur - als pandgever - bedingt dat deze hem een vervangende zekerheid geeft als de moedermaatschappij de overblijvende aansprakelijkheid beëindigt. ${ }^{69}$

\subsubsection{Aanbevelingen aan de wetgever}

In mijn onderzoek ben ik tot de conclusie gekomen dat het huidige recht niet in alle gevallen leidt tot een situatie waarbij de crediteuren van de 403-maatschappij (voldoende) worden gecompenseerd voor het nadeel dat zij ondervinden doordat zij de jaarrekening van de 403-maatschappij niet (hebben) kunnen inzien, of dat de compensatie ertoe leidt dat zij overgecompenseerd worden. In die gevallen heb ik een voorstel gedaan hoe het huidige recht op het desbetreffende punt kan worden gewijzigd. Hieronder heb ik de belangrijkste door mij voorgestelde wijzigingen bij elkaar gezet. De onderstreepte tekst verwijst naar de aanbevolen wijziging ten opzichte van de huidige bepaling.

67. Zie $\S 7.7 .3$ en $\S 7.7 .4$

68. Zie $\S 7.2 .2$ en $\S 8.5 .4$.

69. Zie $\S 8.7 .3$. 
7. Voeg als voorwaarde om gebruik te mogen maken van de jaarrekeningvrijstelling aan art. 2:403 BW toe dat de moedermaatschappij haar enkelvoudige jaarrekening moet hebben gedeponeerd. ${ }^{70}$

8. Neem in art. 2:403 lid 1 sub g BW op dat de 403-maatschappij de in art. 2:403 BW genoemde verklaringen en (vertalingen van) stukken moet deponeren. $^{71}$

9. Pas art. 2:403 lid 1 sub $\mathrm{fBW}$ aan zodat een moedermaatschappij schriftelijk moet verklaren dat zij hoofdelijk aansprakelijk is voor de uit de rechtshandelingen van de 403-maatschappij voortgevloeide en voortvloeiende ${ }^{72}$ verplichtingen, $^{73}$ voor zover de 403-maatschappij zelf tekortschiet in de nakoming en dat deze aansprakelijkheid afhankelijk is van de verbintenis van de 403-maatschappij waarvoor deze geldt. $^{74}$

10. Voeg aan art. 2:403 BW toe dat een vordering op de moedermaatschappij op grond van de 403-verklaring dezelfde bevoorrechte, respectievelijk achtergestelde positie heeft als de corresponderende vordering op de 403-maatschappii. ${ }^{75}$

11. Neem in art. 2:404 lid 1 BW op dat de intrekking van een 403-verklaring slechts of eerst effect heeft als de 403-maatschappij een jaarrekening openbaar heeft gemaakt die aan de voorschriften van titel 9 van Boek 2 BW voldoet, of als er een nieuwe 403-verklaring is gedeponeerd ten aanzien van de 403-maatschappij. ${ }^{76}$

12. Voeg aan art. 2:404 lid 3 sub b en c BW toe dat een moedermaatschappij in de mededeling bij het handelsregister van het voornemen om de overblijvende aansprakelijkheid te beëindigen en de aankondiging daarvan in een landelijk verspreid dagblad melding moet maken van haar eigen naam, de naam van de 403-maatschappij en eventuele oude namen van hen indien die sinds de deponering van de 403-verklaring zijn gewijzigd. ${ }^{77}$

\footnotetext{
70. Zie $\S 3.4 .2$.

71. Zie $\S 2.3 .5$ en $\S 3.4 .2$.

72. Zie $\S 5.6$.

73. Zie $\S 4.2$.

74. Zie $\S 6.5 .2$.

75. Zie $\S 4.7$ en $\S 4.8$.

76. Zie $\S 7.3$.

77. Zie $\S 8.5 .3$.
} 
13. Schrap de voorwaarde ex art. 2:404 lid 3 sub a BW voor de beëindiging van de overblijvende aansprakelijkheid, dat de 403-maatschappij niet meer tot de groep van de moedermaatschappij behoort. ${ }^{78}$

\subsubsection{Aanbevelingen aan de rechterlijke macht}

Naast bovenstaande aanbevelingen om de tekst van art. 2:403 en art. 2:404 BW te wijzigen, doe ik zes aanbevelingen aan de rechterlijke macht met betrekking tot de uitleg van de huidige regeling omtrent de beëindiging van de overblijvende aansprakelijkheid. Deze aanbevelingen hebben betrekking op hoe mijns inziens moet worden geoordeeld over het moment waarop diverse stappen in de procedure voor de beëindiging van de overblijvende aansprakelijkheid zijn gezet, onder welke omstandigheden een crediteur die verzet heeft ingesteld tegen de beëindiging recht heeft op een vervangende waarborg, en welke omvang een te geven vervangende waarborg (minimaal) moet hebben.

14. Als een moedermaatschappij een aankondiging plaatst in een landelijk verspreid dagblad dat en waar de door haar gedeponeerde mededeling van het voornemen om de overblijvende aansprakelijkheid te beëindigen ter inzage ligt, voordat zij een beroep kan doen op de intrekking van de 403-verklaring, moet een rechter naar mijn mening oordelen dat de termijn waarbinnen de crediteuren verzet kunnen instellen tegen de beëindiging van de overblijvende aansprakelijkheid niet is aangevangen. Deze verzetstermijn vangt pas aan als de moedermaatschappij een nieuwe aankondiging plaatst in een landelijk verspreid dagblad - nadat zij een beroep kan doen op de intrekking van de 403 -verklaring. ${ }^{79}$

15. Ik leg art. 2:404 lid 3 BW zo uit dat uiterlijk op het moment dat de tweemaandstermijn verloopt waarbinnen de crediteuren verzet kunnen instellen tegen het voornemen van de moedermaatschappij om de overblijvende aansprakelijkheid te beëindigen aan alle voorwaarden voor deze beëindiging moet zijn voldaan, behoudens de afwikkeling van een eventueel ingesteld verzet. Als op dat moment niet aan alle voorwaarden is voldaan, moet een rechter mijns inziens oordelen dat de overblijvende aansprakelijkheid niet kan worden beëindigd tenzij de moedermaatschappij een nieuwe aankondiging plaatst in een landelijk verspreid dagblad dat en waar de door haar gedeponeerde mededeling van het voornemen om de overblijvende aansprakelijkheid te beëindigen ter inzage ligt. Door deze aankondiging begint een nieuwe verzetstermijn te lopen en heeft de moedermaatschappij opnieuw de mogelijkheid om voor het verstrijken van deze termijn

78. Zie $\S 8.14$.

79. Zie $\S 8.12$. 
aan alle voorwaarden van art. 2:404 lid $3 \mathrm{BW}$ te voldoen, behoudens de afwikkeling van een eventueel ingesteld verzet. ${ }^{80}$

Als een crediteur verzet instelt tegen het voornemen van de moedermaatschappij om de overblijvende ansprakelijkheid te beëindigen, kan hij op grond van art. 2:404 lid $4 \mathrm{BW}$ verlangen dat hem een vervangende waarborg wordt gegeven voor de voldoening van zijn vordering op de 403-maatschappij. Een crediteur heeft geen recht op een vervangende waarborg indien hij na de beëindiging, gezien de vermogenstoestand van de 403-maatschappij of uit anderen hoofde, voldoende waarborgen heeft dat zijn vordering op de 403-maatschappij zal worden voldaan. De Hoge Raad heeft in zijn SNS/Curatoren-beschikking geoordeeld dat voor de beantwoording van de vraag of een crediteur na de beëindiging van de overblijvende aansprakelijkheid voldoende waarborgen heeft dat zijn vordering op de 403-maatschappij zal worden voldaan, beoordeeld moet worden of zijn positie door deze beëindiging al of niet verzwakt. ${ }^{81}$

16. Of de positie van een crediteur door de beëindiging van de overblijvende aansprakelijkheid verzwakt, moet naar mijn mening zo worden uitgelegd dat moet worden beoordeeld of hij na de beëindiging, uit hoofde van de vermogenstoestand van de 403-maatschappij of uit anderen hoofde, niet (minimaal) dezelfde waarborgen heeft dat zijn vordering op de 403-maatschappij zal worden voldaan, als de waarborgen die hij heeft dat zijn vordering op de moedermaatschappij zal worden voldaan, tenzij de crediteur redelijkerwijs geen risico loopt dat zijn vordering op de 403-maatschappij niet zal worden voldaan. ${ }^{82}$

De huidige lijn in de jurisprudentie is dat als een crediteur recht heeft op een vervangende waarborg, de rechter de te geven waarborg vaststelt op het bedrag van de bestaande en toekomstige vorderingen van de crediteur op de 403-maatschappij. ${ }^{83}$ Naar mijn mening is het niet juist om de vervangende waarborg zonder meer op dit bedrag vast te stellen.

17. De omvang van een te geven vervangende waarborg moet naar mijn mening mede worden vastgesteld aan de hand van de waarborgen die de crediteur al heeft, uit hoofde van de vermogenstoestand van de 403-maatschappij of uit anderen hoofde, dat zijn vordering op de 403-maatschappij zal worden voldaan. De vervangende waarborg moet deze waarborgen die de crediteur al heeft, aanvullen tot het niveau dat deze gezamenlijk (minimaal) dezelfde waarborgen bieden dat de vordering van de crediteur op de

80. Zie $\S 8.13$.

81. HR 31 maart 2017, NJ 2018/26, m.nt. Van Schilfgaarde (SNS/Curatoren), r.o. 5.1.4. Ook gepubliceerd in JOR 2017/221, m.nt. De Haan.

82. Zie $\S 8.8$.

83. Zie $§ 8.9 .3$. 
403-maatschappij zal worden voldaan, als de waarborgen die hij heeft dat zijn vordering op de moedermaatschappij zal worden voldaan. ${ }^{84}$

18. Indien de omvang van een te geven vervangende waarborg niet precies is vast te stellen volgens bovenstaande norm, kan de rechter deze waarborg vaststellen op basis van een schatting van de waarborgen die de crediteur heeft dat zijn vorderingen op de moeder- en de 403-maatschappij zullen worden voldaan. De rechter stelt de te geven waarborg dan niet vast op het bedrag van de bestaande en toekomstige vorderingen van de crediteur op de 403-maatschappij, maar hij maakt een schatting in hoeverre dit bedrag verminderd kan worden. De rechter moet in een dergelijk geval naar mijn mening een voorzichtige schatting maken, waarbij hij in het bijzonder rekening houdt met het belang van de crediteur. ${ }^{85}$

19. Als een vervangende waarborg moet worden gegeven voor vorderingen die een crediteur naar verwachting in de toekomst op de 403-maatschappij zal krijgen, hoeft mijns inziens niet in één keer een totaalbedrag als vervangende waarborg te worden gegeven. In plaats daarvan kan de rechter oordelen dat de crediteur een vervangende waarborg moet worden gegeven waarop hij gedurende de looptijd van de overeenkomst met de 403-maatschappij een beroep kan doen. Hierbij kan worden gedacht aan een bankgarantie. De crediteur kan slechts een beroep doen op deze waarborg voor zover en tot het bedrag waarvoor hij openstaande vorderingen heeft op de 403-maatschappij. ${ }^{86}$

\subsubsection{Aanbeveling aan de Kamer van Koophandel}

Een laatste aanbeveling die ik doe, is aan de Kamer van Koophandel. Ik meen dat de vereisten ex art. 2:404 lid 3 sub b en c BW dat een moedermaatschappij bij het handelsregister een mededeling moet deponeren van het voornemen om de overblijvende aansprakelijkheid te beëindigen en een aankondiging daarvan moet plaatsen in een landelijk verspreid dagblad, een crediteur onvoldoende in staat stellen om van dit voornemen op de hoogte te zijn. Het is onwaarschijnlijk dat een crediteur dagelijks alle landelijk verspreide dagbladen controleert en regelmatig ten aanzien van alle debiteuren nagaat of er een mededeling is gedeponeerd van het voornemen om de overblijvende aansprakelijkheid te beëindigen. Hierdoor is het goed mogelijk dat een crediteur dit voornemen over het hoofd ziet. Als een crediteur geen verzet instelt tegen de beëindiging van de overblijvende aansprakelijkheid, verliest hij zonder meer zijn verhaalsrecht tegenover de moedermaatschappij.

84. Zie $§ 8.9 .3$.

85. Zie $\$ 8.9 .5$.

86. Zie $\S 8.9 .2$. 


\section{HOOFDSTUK 10}

20. Ik acht het wenselijk dat de Kamer van Koophandel een systeem aanbiedt waarbij derden automatisch een notificatie kunnen krijgen als met betrekking tot een bepaalde rechtspersoon stukken zijn gedeponeerd bij het handelsregister. Een crediteur is dan beter in staat om op de hoogte te zijn van de deponering van deze stukken. Hij kan onder meer instellen dat hij een bericht krijgt als de moedermaatschappij een mededeling deponeert van het voornemen om de overblijvende aansprakelijkheid te beëindigen. Indien de Kamer van Koophandel een dergelijk systeem aanbiedt, kan de voorwaarde dat de moedermaatschappij een aankondiging moet plaatsen in een landelijk verspreid dagblad dat en waar deze mededeling ter inzage ligt mijns inziens worden geschrapt uit art. 2:404 lid $3 \mathrm{BW}^{87}$

\subsection{Mogelijk vervolgonderzoek}

In mijn onderzoek heb ik mij in het bijzonder gericht op een van de voorwaarden waaraan moet zijn voldaan als een 403-maatschappij gebruikmaakt van de jaarrekeningvrijstelling van het groepsregime: de aansprakelijkheid van de moedermaatschappij op grond van de 403-verklaring. Ik heb onderzocht hoe de 403-aansprakelijkheid moet worden uitgelegd in het licht van de functie van deze aansprakelijkheid bij de compensatie van de crediteuren omdat zij de jaarrekening van de 403-maatschappij niet kunnen inzien. Ik heb als maatstaf voor de compensatie gehanteerd, dat het nadeel moet worden weggenomen dat een crediteur ondervindt doordat de 403-maatschappij gebruikmaakt van de jaarrekeningvrijstelling, of doordat de moedermaatschappij de 403-verklaring intrekt of de overblijvende aansprakelijkheid beëindigt. Daarnaast heb ik onderzocht hoe de 403-aansprakelijkheid moet worden uitgelegd om zo veel mogelijk te voorkomen dat een crediteur overgecompenseerd wordt en in een voordeliger positie komt door de compensatie die hij ontvangt.

Naar mijn mening sluit mijn studie goed aan bij de eerdere proefschriften met betrekking tot het groepsregime van Beckman ${ }^{88}$ en Nass. ${ }^{89}$ Zij hebben in de eerste plaats onderzoek gedaan naar de aanvaardbaarheid van de jaarrekeningvrijstelling, waarbij zij uitgebreid de verschillende voorwaarden hebben onderzocht waaraan moet worden voldaan opdat een 403-maatschappij gebruik mag maken van deze vrijstelling. Daarbij hebben zij in het bijzonder aandacht besteed aan de wetshistorie van het groepsregime, respectievelijk de relevante Europese richtlijnen en de equivalenten van het groepsregime in Luxemburg, Ierland en Duitsland.

87. Zie $\S 8.5 .1$ en $\S 8.5 .2$.

88. Beckman 1995a.

89. E.C.A. Nass 2019. 
Ondanks de studies van Beckman, Nass en mijzelf resteert er naar mijn mening nog een blinde vlek met betrekking tot de kennis inzake het groepsregime die zich goed leent voor een vervolgonderzoek: een empirische studie naar het gebruik van de jaarrekeningvrijstelling van het groepsregime en de aansprakelijkheid op grond van de 403-verklaring. Een mogelijke vervolgstudie kan zijn om bestuurders en legal counsels van 403-maatschappijen te interviewen, om te achterhalen wat de belangrijkste redenen zijn waarom van de jaarrekeningvrijstelling van het groepsregime gebruik wordt gemaakt. Daarnaast kunnen bestuurders en legal counsels van moedermaatschappijen worden geïnterviewd om na te gaan hoe zij de reikwijdte van de 403-aansprakelijkheid uitleggen, waarna de uitkomsten kunnen worden vergeleken met de heersende leer in de literatuur en jurisprudentie.

Tot slot kan aan de hand van een representatieve steekproef van bij het handelsregister gedeponeerde 403-verklaringen, onderzocht worden hoe deze verklaringen in de praktijk zijn geformuleerd. Indien blijkt dat de formulering van een verklaring afwijkt van de tekst van art. 2:403 lid 1 sub f BW, kan worden onderzocht of de verklaring nog voldoet aan het vereiste uit deze bepaling of dat er sprake is van een zogenoemde 'ontoereikende 403-verklaring' ${ }^{90}$ waardoor de 403-maatschappij onterecht gebruikmaakt van de jaarrekeningvrijstelling.

90. Zie $\S 2.3 .6$.c. 



\section{English summary}

The financial statements exemption pursuant to section 2:403 DCC and the compensation of creditors

Pursuant to section 2:403 of the Dutch Civil Code (hereinafter: 'DCC') a group company can, under certain conditions, avail itself of a financial statements exemption. The group company (hereinafter: '403-company') is then, among other things, exempt from the obligation to publish the financial statements. ${ }^{1}$ The two main conditions to be met for the 403-company to avail itself of the financial statements exemption are that the financial information of the 403-company has been consolidated in the consolidated financial statements of a legal entity within the group (hereinafter: 'parent company') and that this parent company has declared in writing that it has assumed joint and several liability for the debts arising from the legal acts of the 403-company (hereinafter: '403-statement').

If a 403-company avails itself of the financial statements exemption pursuant to section 2:403 DCC, its creditors cannot consult the financial statements to assess the risk level that their claim will not (fully) be satisfied. ${ }^{3}$ The compensation a creditor receives for this lack of insight is comprised of two complementary elements. Firstly, the 403 -statement gives the creditor an additional claim on the parent company. In addition, he has the opportunity to inspect the consolidated financial statements of the parent company. This compensates a creditor for the fact that he has a claim on a debtor - the 403-company - whose financial statements he cannot inspect, with an additional claim on another debtor - the parent company - whose consolidated financial statements he can inspect. The creditor has no guarantee that his claim will be paid in full. He is compensated by the fact that he has the possibility to inspect the consolidated financial statements of the parent company and that he can then assess the risk level that his claim will not (fully) be satisfied. Ultimately, it is up to the creditor himself whether or not to accept this risk and whether or not to enter into a relationship with the 403-company or continue an existing relationship. ${ }^{4}$

1. See $\S 2.5$.

2. Section 2:403(1) under (c) and (f) DCC, respectively. See $\S 2.3$.

3. See $\S 3.2$ and $\S 3.3$.

4. $\quad$ See $\S 3.4 .1$ and $\S 3.5$. 


\section{ENGLISH SUMMARY}

I have examined how the 403-liability should be interpreted in the light of its function in compensating creditors for not being able to inspect the financial statements of the 403-company. The criterion I used for the compensation is that the disadvantage must be removed that is suffered by a creditor as a result of the 403-company availing itself of the financial statements exemption, or as a result of the parent company withdrawing the 403 -statement or terminating the remaining liability. ${ }^{5}$ I also examined how the 403-liability should be interpreted in order to prevent, as far as possible, a creditor being overcompensated and placed in a more advantageous position by the compensation he receives. I refer to this as the principle for compensation that I advocate.

If I came to the conclusion that current legislation does not lead to a situation in which the creditors of the 403-company are (sufficiently) compensated for not being able - or not having been able - to inspect the financial statements of the 403-company, or where I felt that the creditors are being overcompensated, I made a proposal to amend the current law on this point.

\section{The separate financial statements of the parent company}

There is no requirement pursuant to section 2:403 DCC for the parent company to (also) have filed its separate financial statements - which does not alter the fact that a parent company may be required to do so under the financial reporting regime applicable to it. A creditor can better assess the risk that the parent company will not (fully) satisfy the claim under the 403-statement on the basis of the information in the separate financial statements than the information in the consolidated financial statements. To ensure that creditors can always easily inspect the separate financial statements of the parent company, I believe that section 2:403 DCC should be amended in two ways. First of all, the filing of the separate financial statements of the parent company should be added to section 2:403 DCC as a constitutive requirement for the use by the 403-company of the financial statements exemption. Also, it should be included in this provision that it is the 403-company that must file the separate financial statements of the parent company, so that creditors can inspect those financial statements when they request information about the 403 -company from the trade register. ${ }^{6}$

\section{The material scope of the 403-liability}

Pursuant to section 2:403(1)(f) DCC, a parent company must, under a 403-statement, assume joint and several liability for the debts arising from legal acts of the 403-company. In this provision, three elements can be identified with regard to the material scope of the 403-liability: 'debts', 'legal acts' and 'arising'.

\footnotetext{
5. $\quad$ See $\S 3.6$.
}

6. See $\S 3.4 .2$. 
The term debts refers to monetary debts and to obligations in forms other than currency of the 403-company. In my view, in order to clarify the scope of the 403-liability, it would be desirable to replace the term 'debts' in sections 2:403(1)(f) DCC with the term 'obligations'. ' Since a parent company, under section 2:403(1)(f) DCC, only has to assume liability for the debts arising from a legal act of the 403-company, debts arising from the law - for instance taxes or a debt arising from an unlawful act - do not fall within the scope of the 403-liability. ${ }^{8}$

In my opinion, a debt arises from a legal act if the will of the creditor with regard to the creation, substance or continuation of the debt could have been influenced by insight into the financial statements of the 403-company - if the 403-company had not availed itself of the financial statements exemption under section 2:403 DCC. ${ }^{9}$

Under the law as it stands, a preferential or subordinated claim against the 403-company does not entail that the claim against the parent company is also preferential or subordinated. However, viewed from the perspective of compensation of creditors, there is no reason why a creditor's rights of recourse against the 403-company and those against the parent company should be different. I therefore argue in favour of adding a provision to section 2:403 DCC to the effect that a claim against the parent company on the basis of the 403 -statement has the same position of preference or subordination as the corresponding claim against the 403-company. ${ }^{10}$

\section{The temporal scope of the 403-liability}

The debate in the literature as to whether - and if so to what extent - a parent company is liable on the basis of a 403 -statement for debts arising from the legal acts carried out by the 403-company before the 403 -statement was filed, is partly caused by the fact that case law - hitherto only at a lower level - has decided differently on this subject. Since 2001, however, with the exception of one judgment, case law has consistently held that a parent company is liable under the 403-statement for all debts that arise or have arisen from a legal act of the 403-company. ${ }^{11}$ In parliamentary history, too, the 403-liability has been interpreted this way. ${ }^{12}$ Initially, the Minister stated that the liability of a parent company was limited to future obligations. But later he declared that on the

\footnotetext{
7. See $\S 4.2$.

8. See $\S 4.3$.

9. See $\$ 4.4$.

10. See $\S 4.7$ and $\S 4.8$.

11. See $\S 5.6 .1$.

12. See $\S 5.6 .2$.
} 


\section{ENGLISH SUMMARY}

basis of a 403-statement, a parent company is liable for all debts that arise or have arisen from a legal act of the 403-company.

That, under the 403-statement, a parent company is liable for all debts that arise or have arisen from a legal act of the 403-company is in line with the principle for compensation that I advocate. ${ }^{13}$ Both the existing and the new creditors are disadvantaged, because they cannot inspect the new financial statement(s) of the 403-company. Both groups of creditors should therefore be compensated by means of an additional claim on the parent company whose consolidated accounts they can inspect.

\section{Interpretation under civil law of a claim based on the 403-statement}

A creditor of the 403-company has two claims: a claim against the 403-company and a claim against the parent company based on the 403-statement (hereinafter: '403-claim'). In the literature there is a debate concerning the civil-law interpretation of the 403-claim against the parent company. This claim has also been interpreted differently in case law.

I have examined the legal consequences of four different interpretations of the 403-claim: the 'joint and several' claim, the 'dynamic' claim, the analogous application of section 6:142 DCC with regard to the 403-claim, and finally the analogous application of the provisions on surety with respect to the 403-liability. ${ }^{14} \mathrm{I}$ have, for various different situations, examined the consequences of each interpretation. ${ }^{15}$ Next, I compared the consequences of the various different interpretations of the 403-claim with the outcome in these situations in accordance with the principle for compensation that I advocate. ${ }^{16}$ The conclusion is that an analogous application of the provisions on suretyship in respect of the 403-liability corresponds, in all the situations examined, to the outcome according to this principle. ${ }^{17}$ The Dutch Supreme Court, though, in the Akzo v. ING decision, rejected the analogous application of the provisions on suretyship in respect of the 403-liability. ${ }^{18}$ To be able to interpret the liability of the parent company as such, section 2:403(1)(f) DCC must therefore be amended.

However, it is not a solution to change section 2:403(1)(f) DCC so that the parent company must act as surety for the debts arising from a legal act of

13. See $\S 5.6 .4$.

14. See $\S 6.2$.

15. See $\S 6.3$.

16. See $\S 6.4$ and $\S 6.5$.

17. See $\S 6.5 .2$.

18. HR 28 June 2002, JOR 2002/136, with commentary from Bartman (Akzo v. ING), grounds for the decision 3.4.3, 3.4.5 and 3.4.6. 
the 403-company. Since suretyship is an agreement, ${ }^{19}$ this would mean that the parent company would have to make arrangements regarding its liability with each creditor of the 403-company. I have identified two alternatives for achieving that the liability of the parent company is of a dependent and subsidiary nature. Firstly, it could be included in section 2:403(1)(f) DCC that the parent company must file a statement under which it assumes joint and several liability for the debts arising from a legal act of the 403-company, to the extent that the 403-company itself fails to perform and this liability is dependent on the obligation of the 403-company to which it applies. A second option is to amend section 2:403(1)(f) DCC thus, that the parent company must declare that it guarantees the debts arising from a legal act of the 403-company.

As long as section 2:403(1)(f) DCC is not amended in one of the above-mentioned ways, the only possibility a parent company has to achieve that its liability under the 403-statement is of a dependent and subsidiary nature, is to enter into an agreement with a creditor. A practical way to achieve this is to give the 403-company a standing power of attorney so that it can conclude the agreement with the creditor on behalf of the parent company, the moment the 403-company itself enters into an agreement with the creditor. However, the parent company cannot enforce this. The creditor will have to agree himself.

Within the possibilities of the current section 2:403 DCC, the consequences of the analogous application of section 6:142 DCC with regard to the 403-claim and the consequences of the interpretation of the 403-claim as a dynamic claim most often correspond to the outcomes according to the principle for compensation that I advocate. ${ }^{20}$ The Dutch Supreme Court, though, implicitly rejected the analogous application of section 6:142 DCC with respect to the 403-claim in its $A k z O$ v. ING decision. ${ }^{21}$ In my opinion, the 403-claim should therefore under the law as it stands be interpreted as a dynamic claim. ${ }^{22}$ This interpretation means that the 403-claim is a joint and several claim which always accrues to the creditor with the corresponding claim on the 403-company. It is, however, not certain whether the Dutch Supreme Court will allow the 403claim to be interpreted as a dynamic claim because two of its judgments contradict each other on this point. ${ }^{23}$ If the interpretation of the 403 -claim as a

19. Section 7:850(1) DCC.

20. I note that, although the consequences of these two interpretations of the 403-claim in the situations I have examined, are just as often in line with the results in accordance with the principle for compensation that I advocate, the consequences differ among themselves in some respects.

21. See $\S 6.5 .3$ and HR 28 June 2002, JOR 2002/136, with commentary from Bartman (Akzo v. $I N G$ ), ground for the decision 3.5.3.

22. See $\S 6.5 .4$.

23. HR 20 March 2015, JOR 2015/140, with commentary from Josephus Jitta (Minister of Finance v. VEB et al.), ground for the decision 4.30 and HR 3 April 2015, JOR 2015/191, 


\section{ENGLISH SUMMARY}

dynamic claim is dismissed, this claim should be interpreted as a joint and several claim. ${ }^{24}$

\section{Withdrawal of a 403-statement}

A parent company may withdraw its 403 -statement by filing a statement to that effect. ${ }^{25}$ The parent company is not liable for the debts arising from the legal acts performed by the 403-company from the moment it can invoke the withdrawal against the creditor. ${ }^{26}$ The parent company may include in the statement of withdrawal a provision that the 403 -statement will be withdrawn on a certain date in the future. ${ }^{27}$ But it cannot, in my opinion, draw up its 403 -statement in such a way that it also serves as a statement of withdrawal. ${ }^{28}$

If the 403-company has not yet published financial statements that comply with the requirements of title 9 of Book 2 DCC before the parent company can invoke the withdrawal of the 403 -statement, there will be a period during which creditors will not be able to inspect the financial statements of the 403-company while at the same time they will not be compensated for this. The creditors whose claim arises from a legal act performed by the 403-company during this period are not compensated for the fact that they were unable to inspect the financial statements of the 403-company. In order to fill this gap in the compensation of creditors it is desirable, in my view, to amend section 2:404 DCC. It could be added to subsection (1) that the withdrawal of the 403-statement only has effect, or will only start having effect, if the 403-company has published financial statements that meet the requirements of title 9 of Book 2 DCC, or if a new 403-statement has been filed in respect of the 403-company. ${ }^{29}$

In the event that a 403-company no longer avails itself of the financial statements exemption under section 2:403 DCC but the parent company has forgotten to withdraw the 403 -statement, the starting point is that a creditor can nevertheless invoke the forgotten 403 -statement. In my opinion, this is only unacceptable under the standards of reasonableness and fairness if the creditor knows, or should know, that the parent company has forgotten to withdraw the 403-statement. ${ }^{30}$

with commentary from Faber and Vermunt (Eikendal q.q. v. Lentink), ground for the decision 3.6.2.

24. See $\S 6.5 .5$.

25. Section 2:404(1) DCC. See $\S 7.2$.

26. Section 2:404(2) DCC. See $\$ 7.3$.

27. See $\S 7.4$.

28. See $\$ 7.5$

29. See $\S 7.3$.

30. See $\S 7.6 .4$. 
A parent company may preventively limit liability on the basis of a 403-statement in the event that it fails to withdraw that statement. ${ }^{31}$ The most effective way of doing this is to include in the 403-statement a provision to the effect that the parent company assumes liability only for debts arising from the legal acts performed by the 403-company up to a certain date, or by filing a statement of withdrawal on the basis of which the 403-statement is withdrawn on a certain date.

The termination of the remaining liability after the withdrawal of the 403-statement

If a parent company withdraws its 403-statement, it remains liable for the debts arising from the legal acts performed by the 403-company until such time as the parent company can invoke the withdrawal against the creditor. ${ }^{32}$ I have concluded that this remaining liability covers all existing and future debts arising from the legal acts carried out by the 403-company up to that point. ${ }^{33}$

A parent company may terminate its remaining liability towards a creditor if it meets the four cumulative conditions under section 2:404(3)(a) through (d) DCC. This requires that the group relationship between the parent company and the 403-company has been severed. In addition, a notification of the intention to terminate the remaining liability must have been available for inspection at the trade register for two months. Also, at least two months must have elapsed since publication of an announcement in a national daily newspaper that the notification is available for inspection and where it may be inspected. Finally, no objection may have been lodged by the creditor against the intention of the parent company to terminate the remaining liability, or the creditor's objection must have been withdrawn or declared unfounded by the court.

I consider it desirable to add to section 2:404(3)(b) and (c) DCC that a parent company, in the notification for the trade register and its announcement in a national daily newspaper, must explicitly state its own name, the name of the 403-company and any old names of them, if these have changed since the 403-statement was filed. ${ }^{34}$

In order to make it easier for a creditor to be aware of the parent company's intention to terminate the remaining liability, I have advocated that the Chamber of Commerce should offer a system whereby third parties can automatically receive a notice if documents relating to a particular legal entity

31. See $\S 7.7 .5$.

32. Section 2:404(2) DCC.

33. See $\S 8.2$.

34. See $\S 8.5 .3$. 


\section{ENGLISH SUMMARY}

have been filed with the trade register. A creditor can then arrange that he receives a message if the parent company files a notification of its intention to terminate the remaining liability. If the Chamber of Commerce offers such a system, the condition that the parent company must publish an announcement in a national daily newspaper that and where this notification is available for inspection can, in my view, be deleted from section 2:404(3) DCC. ${ }^{35}$

Creditors in respect of whose claims the liability still exists, may lodge an objection against the intention of the parent company to terminate the remaining liability. ${ }^{36}$ This includes creditors who have a claim that has not yet been established against the 403-company, unless the claim is manifestly unfounded. In addition, the holder of a disclosed pledge on a claim of a creditor against the parent company, may lodge an objection against the intention of the parent company to terminate the remaining liability. ${ }^{37}$ If a creditor lodges an objection, he may demand a replacement guarantee for his claim on the 403-company. ${ }^{38}$ I have defended that a creditor is entitled to a replacement guarantee if, after the termination of the remaining liability, he does not have (at least) the same assurances, on the basis of the 403-company's financial position or otherwise, that his claim against the 403-company will be satisfied, as the assurances he has that his claim against the parent company will be satisfied, unless the creditor does not reasonably run the risk that his claim against the 403-company will not be satisfied. ${ }^{39}$

The current doctrine in case law is that the extent of a replacement guarantee to be given, is fixed at the amount of the creditor's existing and future claims against the 403-company. In my opinion, it is not right to always set the replacement guarantee at this amount. In my view, the replacement guarantee should add to the guarantees that the creditor already has, on the basis of the 403-company's financial position or otherwise, up to the level that they collectively provide (at least) the same guarantees that the creditor's claim against the 403-company will be met, as the guarantees that he has that his claim against the parent company will be satisfied. ${ }^{40}$ If it is not possible to determine precisely the extent of the replacement guarantee to be given in accordance with this interpretation of the guarantee, the court may determine the extent of the guarantee on the basis of an estimate of the guarantees the creditor has that his claims against the 403-company and the parent company will be satisfied. ${ }^{41}$

\footnotetext{
35. See $\S 8.5 .1$ and $\S 8.5 .2$.

36. Section 2:404(5) DCC.

37. See $\S 8.7$.

38. Section 2:404(4) DCC.

39. See $\S 8.8$.

40. See $\S 8.9 .3$.

41. See $\S 8.9 .5$.
} 
If a replacement guarantee must be given for claims that a creditor expectedly will have against the 403-company in the future, then in my view there is no need to give a total amount as a replacement guarantee all at once. Instead, the court may rule that the creditor must be given a replacement guarantee to which he can have recourse during the term of the agreement with the 403-company. ${ }^{42}$

I have concluded that only when a parent company can invoke the withdrawal of the 403-statement, it can publish an announcement in a national daily newspaper that and where the notification it has filed of its intention to terminate the remaining liability is available for inspection. If a parent company has already published an announcement to that effect in a national daily newspaper, a court must, in my opinion, rule that the period within which creditors can lodge an objection to the termination of the remaining liability has not begun. ${ }^{43}$

I believe that, at the latest by the expiry of the period within which creditors can lodge an objection against the intention of the parent company to terminate the remaining liability, all the conditions for the termination must have been met, save for the settlement of any lodged objections. In my opinion, the order in which these conditions are being met, is irrelevant. ${ }^{44}$ If, at the time of expiry of the objection period, not all the conditions have been met, a court must, in my opinion, rule that the remaining liability has not been terminated. The parent company will then have to initiate a new procedure for this purpose.

Finally, I believe that the condition for terminating the remaining liability that the group relationship between the parent company and the 403-company has been severed, is superfluous and makes it unnecessarily onerous to terminate this liability. I therefore consider it advisable to delete this condition from section 2:404(3) DCC. ${ }^{45}$

\section{Merger, demerger and conversion}

I believe that the nature of the 403-liability does not prevent it from being transferred under a universal title to an acquiring legal entity in the event of a merger or demerger of the parent company. In my opinion, this concerns both the liability for the existing debts of the 403-company which have already arisen from a legal act at the time of the merger or the demerger of the parent company, as well as the liability for the debts which subsequently arise from a legal act of the 403-company. From the moment of the merger or demerger, the 403-statement must be considered to be a statement of the acquiring legal entity. ${ }^{46}$

42. See $\$ 8.9 .2$.

43. See $\S 8.12$.

44. See $\S 8.13$.

45. See $\S 8.14$.

46. See $\S 9.2$. 


\section{ENGLISH SUMMARY}

In the event that a parent company wishes to merge or demerge, creditors with a claim under the 403 -statement may also lodge an objection. ${ }^{47}$ If a 403 -company submits a proposal for a merger or demerger, the question of whether a creditor is entitled to a guarante ${ }^{48}$ for the satisfaction of his claim should, in my opinion, not be answered on the basis of the guarantee offered by the financial position of the (legal successor of the) 403-company that the claim will be satisfied. Instead, in my view, it is necessary to assess what guarantee is offered by the financial position of the parent company that the creditor's claim under the 403 -statement will be satisfied. ${ }^{49}$

In my opinion, in the event of a merger or demerger of the parent company or the 403-company, the liability under the 403-statement continues to exist in full. The (legal successor of the) parent company is liable for all debts that arise and have arisen from the legal acts that the 403-company performs or has performed. Any other outcome would have the same effect as the termination of (part of) the 403-liability outside of section 2:404 DCC. A creditor would then unjustifiably be deprived of the procedures and safeguards set out in this section, which were designed to protect his right of recourse. In my view the 403-liability also doesn't cease to exist if the parent company and the 403-company merge. ${ }^{50} \mathrm{~A}$ creditor then has two claims against the parent company or the 403-company: a claim based on the original legal relationship with the 403-company and a claim based on the 403-statement.

If the 403-statement has been withdrawn, the remaining liability may be terminated if certain conditions are met. Pursuant to section 2:404(3)(a) DCC this requires, among other things, that the group relationship between the parent company and the 403-company has been severed. I have reached the conclusion that this condition is fulfilled if, following the merger or the demerger of the parent company or the 403-company, the legal entity on who the remaining liability rests, does not belong to the same group as the legal entity whose actions may give rise to liability under the withdrawn 403 -statement. ${ }^{51}$ In my opinion, this condition is also met if the parent company and the 403-company merge, with one of them disappearing and the assets being transferred under a universal title to the other. ${ }^{52}$

A (cross-border) conversion, and a cross-border merger or demerger of the parent company or the 403-company, may result in the (legal successor of the) 403-company not being allowed to avail itself of the financial statements

47. Section 2:316(2) and 2:3341 DCC, respectively.

48. Section 2:316(1) and 2:334k DCC, respectively.

49. See $\S 9.3$.

50. See $\S$ 9.7.1.b and $\S$ 9.8.1.b.

51. See $\$ 9.4$.

52. $\quad$ See $\S$ 9.7.1.c and $\S$ 9.8.1.c. 
exemption pursuant to section 2:403 DCC. ${ }^{53}$ To be allowed to avail itself of this exemption, the (legal successor of the) 403-company must be a legal entity referred to in section 2:360 DCC that qualifies for the financial statements exemption, ${ }^{54}$ and the (legal successor of the) parent company must be able to consolidate the financial information of the (legal successor of the) 403-company in consolidated financial statements to which the European Directives referred to in section 2:403(1)(c) DCC or the EU IFRS Regulation apply pursuant to the applicable law.

\section{Recommendations to the practice}

In addition to the above-mentioned recommendations for the legislator, the judiciary and the Chamber of Commerce, I have also made various recommendations to the parties in practice as to what steps they can take under current legislation in order to strengthen their position or to avoid possible disadvantage. Firstly, a minority shareholder may attach conditions to the consent to be given by it pursuant to section 2:403(1)(b) DCC if the 403-company wants to avail itself of the financial statements exemption. ${ }^{55}$ In addition, I advise a parent company to follow the text of section 2:403(1)(f) DCC when drawing up the 403-statement. ${ }^{56}$

Also, a creditor can try to come to an agreement with the parent company, that the creditor must individually be informed if the parent company withdraws the 403 -statement and if it publishes an announcement in a daily national newspaper that and where the filed notification of the intention to terminate the remaining liability is available for inspection.$^{57}$ Finally, I recommend that the holder of a disclosed pledge on a claim of a creditor against the parent company, demand from the creditor - as pledgor - that he give this holder a replacement security if the parent company terminates the remaining liability. ${ }^{58}$

53. See $\S 9.11$ and $\S 9.12$

54. See $\S 2.3 .1$ which legal entities may avail themselves of the financial statements exemption.

55. See $\S 2.3 .4 . d$.

56. See $\$ 2.3 .6 . c$.

57. See $\S 7.2 .2$ and $\S 8.5 .4$.

58. See $\S 8.7 .3$. 



\title{
Literatuurlijst
}

\author{
Van Achterberg 1989 \\ M.P. van Achterberg, De juridische definitie van het economisch verschijnsel \\ concern in het ondernemingsrecht, een beschouwing over de problemen die \\ samenhangen met de juridische definiëring van het economisch verschijnsel \\ concern, mede aan de hand van de definitieproblematiek die in de gecon- \\ solideerde jaarrekening naar voren komt (diss. Amsterdam VU), Deventer: \\ Kluwer 1989.
}

\section{Adler/Düring \& Schmaltz 2001}

K.-H. Forster e.a., Rechnungslegung und Prüfung der Unternehmen, 6. Auflage, Stuttgart: Schäffer-Poeschel 2001.

\section{Van der Arend 1999}

D.G.A. van der Arend, 'Enkele juridische aspecten van de 403-aansprakelijkheidsverklaring', De Accountant 1999, afl. 3, p. 152-155.

\section{Asser/Bartels \& Van Mierlo 3-IV 2013}

S.E. Bartels \& A.I.M. van Mierlo (met medewerking van H.D. Ploeger), $M r$. C. Assers Handleiding tot de beoefening van het Nederlands Burgerlijk Recht. 3. Vermogensrecht algemeen. Deel IV. Algemeen goederenrecht, Deventer: Kluwer 2013.

\section{Asser/Kortmann 3-III 2017}

S.C.J.J. Kortmann (met medewerking van J.S. Kortmann), Mr. C. Assers Handleiding tot de beoefening van het Nederlands Burgerlijk Recht. 3. Deel III. Vermogensrecht algemeen. Volmacht en vertegenwoordiging, Deventer: Wolters Kluwer 2017.

\section{Asser/Maeijer 2-III 1994}

J.M.M. Maeijer (met medewerking van P.J. Dortmond), Mr. C. Asser's Handleiding tot de beoefening van het Nederlands Burgerlijk Recht. 2. Vertegenwoordiging en rechtspersoon. Deel III. De naamloze en besloten vennootschap, Zwolle: Tjeenk Willink 1994.

\section{Asser/Maeijer 2-III 2000}

J.M.M. Maeijer (met medewerking van F.J.P. van der Ingh), Mr. C. Asser's Handleiding tot de beoefening van het Nederlands Burgerlijk Recht. 2. Vertegenwoordiging en rechtspersoon. Deel III. De naamloze en besloten vennootschap, Deventer: Kluwer 2000. 


\section{LITERATUURLIJST}

\section{Asser/Maeijer \& Kroeze 2-I* 2015}

M.J. Kroeze (met medewerking van H. Beckman \& M.A. Verbrugh), $M r$. C. Assers Handleiding tot de beoefening van het Nederlands Burgerlijk Recht. 2. Rechtspersonenrecht. Deel I*. De rechtspersoon, Deventer: Wolters Kluwer 2015.

\section{Asser/Maeijer \& Van Olffen 7-VII 2017}

M. van Olffen, Mr. C. Assers Handleiding tot de beoefening van het Nederlands Burgerlijk Recht. 7. Bijzondere overeenkomsten. Deel VII. Maatschap, vennootschap onder firma en commanditaire vennootschap, Deventer: Wolters Kluwer 2017.

\section{Asser/Maeijer, Van Solinge \& Nieuwe Weme 2-II* 2009}

G. van Solinge \& M.P. Nieuwe Weme (met medewerking van R.G.J. Nowak), Mr. C. Assers Handleiding tot de beoefening van het Nederlands Burgerlijk Recht. 2. Rechtspersonenrecht. Deel II*. De naamloze en besloten vennootschap, Deventer: Kluwer 2009.

\section{Asser/Van Mierlo \& Krzeminski 3-VI 2020}

A.I.M. van Mierlo \& K.J. Krzeminski, Mr. C. Assers Handleiding tot de beoefening van het Nederlands Burgerlijk Recht. 3. Vermogensrecht algemeen. Deel VI. Zekerheidsrechten, Deventer: Wolters Kluwer 2020.

\section{Asser/Van Olffen \& Rensen 2-IIa 2019}

M. van Olffen \& G.J.C. Rensen, Mr. C. Assers Handleiding tot de beoefening van het Nederlands Burgerlijk Recht. 2. Rechtspersonenrecht. Deel IIa. NV en BV. Oprichting, vermogen en aandelen, Deventer: Wolters Kluwer 2019.

\section{Asser/Rensen 2-III 2017}

G.J.C. Rensen (met medewerking van J.M. Blanco Fernández), Mr. C. Assers Handleiding tot de beoefening van het Nederlands Burgerlijk Recht. 2. Rechtspersonenrecht. Deel III. Overige rechtspersonen. Vereniging, coöperatie, onderlinge waarborgmaatschappij, stichting, kerkgenootschap en Europese rechtsvormen, Deventer: Wolters Kluwer 2017.

\section{Asser/Van Schaick 7-VIII 2018}

A.C. van Schaick, Mr. C. Assers Handleiding tot de beoefening van het Nederlands Burgerlijk Recht. 7. Bijzondere overeenkomsten. Deel VIII. Bewaarneming, borgtocht, vaststellingsovereenkomst, bruikleen, altijddurende rente, spel en weddenschap, Deventer: Wolters Kluwer 2018. 


\section{Asser/Sieburgh 6-I 2016}

C.H. Sieburgh, Mr. C. Assers Handleiding tot de beoefening van het Nederlands Burgerlijk Recht. 6. Verbintenissenrecht. Deel I. De verbintenis in het algemeen, eerste gedeelte, Deventer: Wolters Kluwer 2016.

\section{Asser/Sieburgh 6-II 2017}

C.H. Sieburgh, Mr. C. Assers Handleiding tot de beoefening van het Nederlands Burgerlijk Recht. 6. Verbintenissenrecht. Deel II. De verbintenis in het algemeen, tweede gedeelte, Deventer: Wolters Kluwer 2017.

\section{Assink/Slagter 2013}

B.F. Assink, Slagter. Compendium ondernemingsrecht, Deventer: Kluwer 2013.

\section{Bakker 2018}

P.S. Bakker, 'Enige opmerkingen over de 403-verklaring en de maatstaf bij verzet tegen de intrekking van overblijvende aansprakelijkheid', ORP 2018, afl. 3, p. 14-21.

\section{Bartman 1986}

S.M. Bartman, Inleiding concernrecht, Alphen aan den Rijn: Samsom H.D. Tjeenk Willink 1986.

\section{Bartman 1989}

S.M. Bartman, 'De BV-CV en de werking van artikel 403, lid 1 sub f, Boek 2 BW’, TVVS 1989, afl. 5, p. 118-122.

\section{Bartman 2002}

S.M. Bartman, 'Werkgeversverplichtingen onder de art. 403-verklaring', ArbeidsRecht 2002, afl. 6/7, p. 22-27.

\section{Bartman 2004}

S.M. Bartman, '403-verklaring blijft een bron van misverstand', Ondernemingsrecht 2004/16, p. 48-52.

\section{Bartman 2015}

S.M. Bartman, 'De 403-verklaring: hoofdelijkheid of borgtocht? Een napleitexercitie', $A A$ 2015, afl. 10, p. 806-812.

\section{Bartman 2019}

S.M. Bartman, 'Reactie op "Blokkers boekhoudkundige truc", Ondernemingsrecht 2019/32, p. 188-189. 


\section{LITERATUURLIJST}

\section{Bartman \& Dorresteijn 2013}

S.M. Bartman \& A.F.M. Dorresteijn (met medewerking van C. de Groot), Van het concern, Deventer: Kluwer 2013.

\section{Bartman, Dorresteijn \& Olaerts 2016}

S.M. Bartman, A.F.M. Dorresteijn \& M. Olaerts, Van het concern, Deventer: Wolters Kluwer 2016.

\section{Bartman, Dorresteijn \& Olaerts 2020}

S.M. Bartman, A.F.M. Dorresteijn \& M. Olaerts, Van het concern, Deventer: Wolters Kluwer 2020.

\section{Bartman \& Van der Kraan 2017}

S.M. Bartman \& J. van der Kraan, 'Beëindiging overblijvende aansprakelijkheid conform artikel 2:404 BW? Anders de Hoge Raad', AA 2017, afl. 11, p. 921-927.

\section{Beckman 1987}

H. Beckman, 'Aansprakelijkstelling in het vennootschapsrecht', MAB 1987, afl. 12 , p. $526-538$.

\section{Beckman 1990}

H. Beckman, 'Artikel 2:403 BW (groepsregime), de instemmingsverklaring van aandeelhouders en enkele andere toepassingsvraagstukken', TVVS 1990, afl. 12 , p. 307-310.

\section{Beckman 1995a}

$\mathrm{H}$. Beckman, De jaarrekeningvrijstelling voor afhankelijke groepsmaatschappijen. Een analyse van artikel 2:403 BW en zijn voorgangers (diss. Groningen), Deventer: Kluwer 1995.

\section{Beckman 1995b}

H. Beckman, 'Dient artikel 2:403 BW (groepsregime) in huidige vorm te worden geschrapt?', in: P. van Schilfgaarde e.a. (red.), Knelpunten in de vennootschapswetgeving, is met het oog hierop wijziging van de vennootschapswetgeving wenselijk?, Deventer: Kluwer 1995.

\section{Beckman 1996}

H. Beckman, 'Art. 2:403 BW (groepsregime) en acquisities', De NV 1996, afl. 10, p. $253-259$.

\section{Beckman 1997}

H. Beckman, 'Knelpunten in de jaarrekeningprocedure', in: P. van Schilfgaarde e.a., Rechtspleging in het ondernemingsrecht, Deventer: Kluwer 1997. 


\section{Beckman 2002}

H. Beckman, 'Verklaring van hoofdelijke aansprakelijkstelling ex art. 2:403 $\mathrm{BW}$ is een eenzijdige ongerichte rechtshandeling. Uitsluitend aan de door de moedermaatschappij gedeponeerde verklaring kunnen schuldeisers van de desbetreffende groepsmaatschappij rechten ontlenen', Ondernemingsrecht 2002/57, p. 485-487.

\section{Beckman 2003}

H. Beckman, 'Jaarrekening en kapitaalbescherming', in: H. Beckman, L.G. van der Tas \& P.M. van der Zanden, Jaarrekeningenrecht (Preadvies van de Vereeniging 'Handelsrecht'), Deventer: Kluwer 2003.

\section{Beckman 2004}

H. Beckman, 'Minimumkapitaal, aansprakelijkheid en publiciteit: wat moet de crediteur hiermee?', Ondernemingsrecht 2004/7, p. 22-24.

\section{Beckman 2010a}

H. Beckman, '403-aansprakelijkheid en wettelijke bevoorrechte vorderingen uit Sociaal Plan (art. 3:288 BW)’, Ondernemingsrecht 2010/147, p. 695-697.

\section{Beckman 2010b}

H. Beckman, 'Vergeten intrekking 403-verklaring voor een vennootschap die door overdracht groepsmaatschappij is geworden van de kopende maatschappij met dochter die nadien vorderingen op die vennootschap heeft verkregen', Ondernemingsrecht 2010/148, p. 697-698.

\section{Beckman 2010c}

H. Beckman, 'Vergeten intrekking 403-verklaring voor een vennootschap die door overdracht groepsmaatschappij van de kopende maatschappij is geworden waarbij op de dag van de overdracht de kopende partij een lening van een aandeelhouder van de kopende partij verkrijgt', Ondernemingsrecht 2010/149, p. 698 .

\section{Beckman 2011}

H. Beckman, 'De 403-maatschappij en de voor haar aansprakelijke maatschappij', in: A.H. van der Boom, M.N. Hoogendoorn, R. van der Wal \& L.L. Scholte (red.), Toezicht op inzicht. Liber amicorum aangeboden aan prof. $d r$. M.A. van Hoepen, Rotterdam: Erasmus School of Economics/Erasmus School of Accounting \& Assurance 2011.

\section{Beckman 2013}

H. Beckman, 'Benoeming deskundigen ter waardebepaling van onteigende aandelen SNS Reaal, andere door SNS Reaal respectievelijk SNS Bank uitgegeven - al dan niet beursgenoteerde en/of achtergestelde - effecten, en onderhands door SNS Reaal respectievelijk SNS Bank opgenomen achtergestelde 


\section{LITERATUURLIJST}

leningen, aangezien het aanbod van de tot schadeloosstelling onvoldoende is toegelicht en aannemelijk is dat dit aanbod geen volledige vergoeding voor de door de onteigening geleden schade vormt', Ondernemingsrecht 2013/110, p. $557-563$.

\section{Beckman 2014a}

H. Beckman, 'Afwijzing in kort geding van contractuele 403-vordering, omdat de 403-verklaring slechts ziet op aansprakelijkstelling van de moedermaatschappij voor uit rechtshandelingen voortvloeiende schulden van de dochtermaatschappij', Ondernemingsrecht 2014/31, p. 156-157.

\section{Beckman 2014b}

H. Beckman, 'Geen doorwerking van aan vorderingen op 403-maatschappij verbonden voorrechten in een uit een 403 -aansprakelijkheidsverklaring voortvloeiende anspraak', Ondernemingsrecht 2014/83, p. 409-410.

\section{Beckman 2015a}

H. Beckman, '403-aansprakelijkheid en art. 6:7 BW, gevolgen dading met groepsmaatschappij voor moedermaatschappij, relatie verhouding garantieverklaring in Europese jaarrekeningrichtlijn tot hoofdelijke aansprakelijkstelling', Ondernemingsrecht 2015/66, p. 343-345.

\section{Beckman 2015b}

H. Beckman, 'Onteigeningsbesluit vermogensbestanddelen/effecten SNS. Formele rechtskracht onteigeningsbesluit. Zelfstandige vaststelling schadeloosstelling door OK. Waardemaatstaf en uitgangspunten. Achterstelling en 403-verklaring', Ondernemingsrecht 2015/97, p. 495-498.

\section{Beckman 2015c}

H. Beckman, 'Het groepsregime in communautair/unitair en vergelijkend perspectief en de aansprakelijkstelling', in: B.F. Assink, K.F. Haak, J.M. de Jongh, M.J. Kroeze \& A.J.P. Schild (red.), De toekomst van het ondernemingsrecht. Het ondernemingsrecht van de toekomst, Deventer: Wolters Kluwer 2015.

\section{Beckman 2018}

H. Beckman, 'Blokkers boekhoudkundige truc', Ondernemingsrecht 2018/129, p. $733-734$.

\section{Beckman 2019}

H. Beckman, 'Naschrift bij reactie op "Blokkers boekhoudkundige truc", Ondernemingsrecht 2019/33, p. 189. 


\section{Beckman - Compendium jaarrekening}

H. Beckman, Compendium voor de jaarrekening, Deventer: Wolters Kluwer (bijgewerkt 1 januari 2020).

Beckman - SDU Commentaar Ondernemingsrecht 2019, art. 2:394 BW H. Beckman, commentaar op art. 2:394 BW, in: M.J. van Ginneken, M. Olaerts, P.P. de Vries e.a. (red.), SDU Commentaar Ondernemingsrecht, Den Haag: Sdu Uitgevers 2019.

\section{Beckman - SDU Commentaar Ondernemingsrecht 2019, art. 2:403 BW}

H. Beckman, commentaar op art. 2:403 BW, in: M.J. van Ginneken, M. Olaerts, P.P. de Vries e.a. (red.), SDU Commentaar Ondernemingsrecht, Den Haag: Sdu Uitgevers 2019.

Beckman - SDU Commentaar Ondernemingsrecht 2019, art. 2:404 BW H. Beckman, commentaar op art. 2:404 BW, in: M.J. van Ginneken, M. Olaerts, P.P. de Vries e.a. (red.), SDU Commentaar Ondernemingsrecht, Den Haag: Sdu Uitgevers 2019.

\section{Beckman \& Marseille 2013}

H. Beckman \& E.A. Marseille, Hoofdlijnen van het jaarrekeningenrecht in Nederland, Deventer: Kluwer 2013.

Beckman \& Van Wijngaarden - SDU Commentaar Ondernemingsrecht 2006, art. 2:403 BW

H. Beckman \& T. van Wijngaarden, commentaar op art. 2:403 BW, in: M.J. van Ginniken, M.J. Kroeze, H.M. Vletter-van Dort e.a. (red.), SDU Commentaar Ondernemingsrecht, Den Haag: Sdu Uitgevers 2006.

Beckman \& Van Wijngaarden - SDU Commentaar Ondernemingsrecht 2011, art. 2:403 BW

H. Beckman \& T. van Wijngaarden, commentaar op art. 2:403 BW, in: B. Bier, M.J. van Ginniken, M.J. Kroeze e.a. (red.), SDU Commentaar Ondernemingsrecht, Den Haag: Sdu Uitgevers 2011.

Beckman \& Van Wijngaarden - SDU Commentaar Ondernemingsrecht 2011, art. 2:404 BW

H. Beckman \& T. van Wijngaarden, commentaar op art. 2:404 BW, in: B. Bier, M.J. van Ginniken, M.J. Kroeze e.a. (red.), SDU Commentaar Ondernemingsrecht, Den Haag: Sdu Uitgevers 2011. 


\section{LITERATUURLIJST}

\section{Beckman \& Van der Zanden 2011}

H. Beckman \& P.M. van der Zanden, 'De jaarrekening als verantwoordingsdocument', in: W.D. Kolkman \& L.C.A. Verstappen (red.), Handboek ondernemingsrecht, Zutphen: Walburg Pers: 2011.

\section{Bergervoet 2014}

G.J.L. Bergervoet, Borgtocht (diss. Nijmegen), Deventer: Kluwer 2014.

\section{Berk 2007}

J.W. Berk, 'Enkele opmerkingen bij artikel 403 boek 2 burgerlijk wetboek', $O \& F$ 2007, afl. 76, p. 12-18.

\section{Biemans 2011}

J.W.A. Biemans, Rechtsgevolgen van stille cessie (diss. Nijmegen), Deventer: Kluwer 2011.

\section{Bier 2006}

B. Bier, 'De marge van de décharge', in: M.J. Kroeze, C.M. Harmsen, M.W. Josephus Jitta, L. Timmerman, J.B. Wezeman \& P.M. van der Zanden (red.), Verantwoording aan Hans Beckman, Deventer: Kluwer 2006.

\section{Blanco Fernández - T\&C Ondernemingsrecht, art. 7A:1681 BW}

J.M. Blanco Fernández, commentaar op art. 7A:1681 BW, in: C.D.J. Bulten, A.F.J.A. Leijten \& M.L. Lennarts (red.), Tekst \& Commentaar Ondernemingsrecht, Deventer: Wolters Kluwer (bijgewerkt 1 juli 2019).

\section{Blom 2005}

W.M. Blom, 'Het schuldbegrip in de zin van artikel 2:403 lid 1 sub f BW', $V \& O 2005$, afl. 10, p. 177-180.

\section{Blommaert 2007}

M.J. Blommaert, 'Beëindiging van de 403-aansprakelijkheid', Journaal IF\&Z 2007, afl. $7 / 8$, p. $272-278$.

\section{Blommaert \& Linders 2015}

M.J. Blommaert \& F.W. Linders, 'De 403-verklaring: enkele opmerkingen bij HR 3 april 2015 (Eikendal q.q./Lentink)', TvI 2015/53, p. 353-358.

\section{Van Boom 2016}

W.H. van Boom, Hoofdelijke verbintenissen, Den Haag: Boom juridisch 2016.

\section{Booms 2019}

T.E. Booms, Aanvullen van subjectieve rechten (diss. Nijmegen), Deventer: Wolters Kluwer 2019. 


\section{Boschma \& Schutte-Veenstra - T\&C Burgerlijk Wetboek, art. 2:216 BW}

H.E. Boschma \& J.N. Schutte-Veenstra, commentaar op art. 2:216 BW, in: H.B. Krans, C.J.J.M. Stolker \& W.L. Valk (red.), Tekst \& Commentaar Burgerlijk Wetboek, Deventer: Wolters Kluwer (bijgewerkt 18 mei 2020).

\section{Van Boxel 2011}

H.J.M.M. van Boxel, Grensoverschrijdende fusies van kapitaalvennootschappen naar Nederlands recht (diss. Nijmegen), Deventer: Kluwer 2011.

\section{Brink 1997}

L. Brink, 'Kanttekeningen bij "Enkele kanttekeningen bij het vennootschappelijk verzetrecht van crediteuren"”, TVVS 1997, afl. 8, p. 260.

\section{Van den Broek \& Rensen 2018}

J.J. van den Broek \& G.J.C. Rensen, Grensoverschrijdende omzetting van rechtspersonen, Deventer: Wolters Kluwer 2018.

\section{Brouwer 2019}

A.J. Brouwer, 'Organisatiecontinuïteit en de jaarrekening', Ondernemingsrecht 2019/38, p. 215-220.

\section{Buijn \& Storm 2013}

F.K. Buijn \& P.M. Storm, Ondernemingsrecht BV en NV in de praktijk, Deventer: Kluwer 2013.

\section{Bungenberg 2015}

K. Bungenberg, 'De verzettermijn van artikel 2:404 lid 5 BW - fataal of toch flexibel?', $V \& O 2015$, afl. 2, p. 29-31.

\section{Burgert, Timmermans \& Joosten 1990}

R. Burgert, C.W.A. Timmermans \& H.F.J. Joosten, De jaarrekening nieuwe stijl, deel 2, Alphen aan den Rijn: Samsom H.D. Tjeenk Willink 1990.

\section{Commissie Vennootschapsrecht 1973}

Rapport van de Commissie Vennootschapsrecht inzake het voorstel voor een Vierde Richtlijn van de Raad van de Europese Gemeenschappen betreffende de jaarrekening van kapitaalvennootschappen, 's-Gravenhage: Staatsuitgeverij 1973.

\section{Van Dooren 2015}

E.A. van Dooren, 'De 403-vordering; mogelijkheden binnen de hoofdelijkheid?', Ondernemingsrecht 2015/72, p. 380-386. 


\section{LITERATUURLIJST}

\section{Van Dooren 2017}

E.A. van Dooren, 'Ontvankelijkheid cassatieberoep; verzet tegen de beëindiging van overblijvende aansprakelijkheid', Ondernemingsrecht 2017/91, p. 512-514.

\section{Van Dooren 2018a}

E.A. van Dooren, 'De ingetrokken 403-verklaring van Shell: een tactische zet?', $M v O$ 2018, afl. 3, p. 61-62.

\section{Van Dooren 2018b}

E.A. van Dooren, 'De overgang onder algemene titel van een 403-verklaring', JBN 2018/52, p. 11-13.

Van Eck - SDU Commentaar Ondernemingsrecht 2019, art. 2:309 BW

G.C. van Eck, commentaar op art. 2:309 BW, in: M.J. van Ginneken, M. Olaerts, P.P. de Vries e.a. (red.), SDU Commentaar Ondernemingsrecht, Den Haag: Sdu Uitgevers 2019.

\section{Faber 2005}

N.E.D. Faber, Verrekening (diss. Nijmegen), Deventer: Kluwer 2005.

Förschle \& Deubert 2012, Beck'scher Bilanz-Kommentar, Handels- und Steuerbilanz, § 264 Handelsgesetzbuch

G. Förschle \& M. Deubert, in: H. Ellrott, G. Förschle e.a. (red.), Beck'scher Bilanz-Kommentar, Handels- und Steuerbilanz, München: C.H. Beck 2012.

\section{Franken \& Franken 2008}

J.M.W.M. Franken \& M.J.M. Franken, 'De temporele reikwijdte van de 403-aansprakelijkheid. Substance over form?!', in: P.M. van der Zanden e.a. (red.), Vereniging Jaarrekeningenrecht: bundel 2008/2009, Den Haag: Boom Juridische uitgevers 2008.

\section{Goudsmit 1973}

J.J. Goudsmit, 'Het ontstaan van hoofdelijke aansprakelijkheid op grond van artikel 38a WJO', TVVS 1973, afl. 12, p. 330-335.

Graf \& Bisle 2013, Münchener Kommentar zum Bilanzrecht, § 264 Handelsgesetzbuch

H. Graf \& M. Bisle, in: J. Hennrichs, D. Kleindiek, C. Watrin e.a. (red.), Münchener Kommentar zum Bilanzrecht, München: C.H. Beck 2013.

\section{Gülcher 1989a}

G.J. Gülcher, 'Reikwijdte van de aansprakelijkverklaring in het kader van de groepsvrijstellingsregeling', TVVS 1989, afl. 7, p. 161-166. 


\section{Gülcher 1989b}

G.J. Gülcher, 'Naschrift bij reactie op "Reikwijdte van de aansprakelijkverklaring in het kader van de groepsvrijstelling"', TVVS 1989, afl. 11, p. 289-290.

\section{Haentjens, in: GS Bijzondere overeenkomsten, art. 7:852 BW}

M. Haentjens, commentaar op art. 7:852 BW, in: C.G. Breedveld-de Voogd \& S.E. Bartels (red.), Groene Serie Bijzondere overeenkomsten, Deventer: Kluwer (bijgewerkt 1 mei 2010).

\section{Van der Ham 2013}

R.J. van der Ham, 'Moeder help! Aansprakelijkheidsrisico’s voor sociale maatregelen bij reddingsoperaties van een dochter', ArbeidsRecht 2013/26, p. 21-25.

\section{Hanegraaf 2019}

C.E.J.M. Hanegraaf, 'SNS, een drama in drie bedrijven. Tweede Bedrijf: de 403-verklaring en de (voorgenomen) beëindiging van de overblijvende aansprakelijkheid ex artikel 2:404 BW', Bb 2019, afl. 13, p. 181-188.

\section{Harmsen 2008}

C.M. Harmsen, 'Geconsolideerde behandeling van insolventies', Ondernemingsrecht 2008/136, p. 467-473.

\section{Harmsma 2001}

L.J. Harmsma, 'De temporele reikwijdte van de aansprakelijkstelling ex artikel 2:403 BW', $V \& O$ 2001, afl. 6, p. 112-114.

\section{Van der Heijden/Van der Grinten 1976}

W.C.L. van der Grinten, Mr. E.J.J. van der Heijdens Handboek voor de naamloze en besloten vennootschap, Zwolle: Tjeenk Willink 1976.

\section{Van der Heijden/Van der Grinten 1984}

W.C.L. van der Grinten, Mr. E.J.J. van der Heijdens handboek voor de naamloze en besloten vennootschap, Zwolle: Tjeenk Willink 1984.

\section{Van der Heijden/Van der Grinten 1989}

W.C.L. van der Grinten (met medewerking van H.J.M.N. Honée \& H.M.N. Schonis), Mr. E.J.J. van der Heijdens Handboek voor de naamloze en de besloten vennootschap, Zwolle: Tjeenk Willink 1989.

\section{Van der Heijden/Van der Grinten 1992}

W.C.L. van der Grinten (met medewerking van H.J.M.N. Honée \& Th.C.M. Hendriks-Jansen), Mr. E.J.J. van der Heijdens Handboek voor de naamloze en de besloten vennootschap, Zwolle: Tjeenk Willink 1992. 


\section{LITERATUURLIJST}

\section{Van der Heijden/Van der Grinten \& Dortmond 2013}

P.J. Dortmond (mede bewerkt door H. Beckman, B. Bier, C.D.J. Bulten, M.W. Josephus Jitta, A.F.J.A. Leijten, R.P. Raas, J.M. van Slooten \& G.J. Vossestein), Handboek voor de naamloze en de besloten vennootschap, Deventer: Kluwer 2013.

\section{Hijink 2010}

J.B.S. Hijink, Publicatieverplichtingen voor beursvennootschappen (diss. Amsterdam UvA), Deventer: Kluwer 2010.

\section{Hijink \& In 't Veld 2019a}

J.B.S. Hijink \& L. in 't Veld, 'De (toekomst)bestendigheid van de toekomstbestendigheidsparagraaf, $T v J 2019$, afl. 1, p. 5-12.

\section{Hijink \& In 't Veld 2019b}

J.B.S. Hijink \& L. in 't Veld, 'Toekomstbestendige verslaggeving \& de RoboAudit. Over de digitale (?) toekomst van (de controle van) verslaggeving', in: C.J.H. Jansen, B.A. Schuijling \& I.V. Aronstein (red.), Onderneming en digitalisering, Deventer: Wolters Kluwer 2019.

\section{Den Hoed, in: GS Verbintenissenrecht, art. 6:6 BW}

J. den Hoed, commentaar op art. 6:6 BW, in: R.J.Q. Klomp \& H.N. Schelhaas (red.), Groene Serie Verbintenissenrecht, Deventer: Wolters Kluwer (bijgewerkt 1 januari 2020).

\section{Den Hoed, in: GS Verbintenissenrecht, art. 6:9 BW}

J. den Hoed, commentaar op art. 6:9 BW, in: R.J.Q. Klomp \& H.N. Schelhaas (red.), Groene Serie Verbintenissenrecht, Deventer: Wolters Kluwer (bijgewerkt 1 januari 2020).

\section{Holtman 2019}

E. Holtman, 'Enkele aandachtspunten bij juridische fusie of splitsing en een 403-verklaring', $T v J 2019$, afl. 4, p. 156-165.

\section{Honée 1971}

H.J.M.N. Honée, 'Enige opmerkingen betreffende de vrijstellingsregeling voor dochtervennootschappen in art. 38a Wet Jaarrekening', De NV 1971, p. 201-205.

\section{Honée 1981}

H.J.M.N. Honée, Concernrecht en medezeggenschapsregelingen (diss. Nijmegen), Deventer: Kluwer 1981. 


\section{Honée 1986}

H.J.M.N. Honée, 'Aansprakelijkheid in concernverhoudingen', in: P. van Schilfgaarde e.a., De nieuwe misbruikwetgeving, Deventer: Kluwer 1986.

\section{Houwen 1997}

L.G.H.J. Houwen, 'Boekbespreking, Prof. mr. drs. H. Beckman, De jaarrekeningvrijstelling voor afhankelijke groepsmaatschappijen, serie Uitgaven vanwege het Instituut voor Ondernemingsrecht, dissertatie RUG, 812 blz., f 99,00', $S \& V 1997$, p. 80-83.

\section{Houwen, Schoonbrood-Wessels \& Schreurs 1993}

L.G.H.J. Houwen, A.P. Schoonbrood-Wessels \& J.A.W. Schreurs, Aansprakelijkheid in concernverhoudingen, een rechtsvergelijkende studie naar de positie van crediteuren van concernafhankelijke vennootschappen in Duitsland, Frankrijk, Engeland en Nederland (diss. Nijmegen), Deventer: Kluwer 1993.

\section{Ten Hove 2004}

W. ten Hove, 'De werking van de 403-verklaring in geval van een juridische fusie’, $V \& O 2004$, afl. 10, p. 166-170.

\section{Huiskes 2015}

C.R. Huiskes, 'Enige beschouwingen omtrent de "403-verklaring", TvJ 2015, afl. 2, p. 38-46.

\section{Huizink 2019}

J.B. Huizink, Rechtspersonen, vennootschap en onderneming, Deventer: Wolters Kluwer 2019.

\section{Huizink 2020}

J.B. Huizink, Contractuele samenwerkingsvormen in beroep en bedrijf, Deventer: Wolters Kluwer 2020.

\section{Huizink, in: GS Rechtspersonen, art. 2:9 BW}

J.B. Huizink, commentaar op art. 2:9 BW, in: J.B. Huizink (red.), Groene Serie Rechtspersonen, Deventer: Wolters Kluwer (bijgewerkt 22 juni 2018).

\section{Huizink, in: GS Rechtspersonen, art. 2:248 BW}

J.B. Huizink, commentaar op art. 2:248 BW, in: J.B. Huizink (red.), Groene Serie Rechtspersonen, Deventer: Wolters Kluwer (bijgewerkt 19 november 2019).

Jacobs 2017

A.T.J.M. Jacobs, Collectief arbeidsrecht, Deventer: Wolters Kluwer 2017. 


\section{LITERATUURLIJST}

\section{De Jager 2006}

M.A. de Jager, 'Het adviesrecht van de ondernemingsraad bij financiële besluiten', $O \& F$ 2006, afl. 72, p. 22-26.

\section{M.A.J.G. Janssen 2005}

M.A.J.G. Janssen, 'Enkele aspecten van de 403-verklaring', Journaal IF\&Z 2005, afl. 4, p. 115-123.

\section{M.J. Janssen 2010}

M.J. Janssen, 'De 403-verklaring voor uitgevaren dochters: alertheid geboden', $V \& O$ 2010, afl. 6, p. 114-116.

\section{Jansz 1973}

H.J. Jansz, 'Enige vragen rond de verklaring van aansprakelijkheid', TVVS 1973, afl. 2, p. 33-40.

\section{De Jong \& Nieuwe Weme 2006}

B.J. de Jong \& M.P. Nieuwe Weme, Publicatie van de jaarrekening, onderzoek in opdracht van het Ministerie van Economische Zaken naar (i) de bevoegdheid om ontheffing te verlenen van de verplichting om de jaarrekening op te maken, over te leggen en vast te stellen en (ii) de naleving van de verplichting om de jaarrekening openbaar te maken, Deventer: Kluwer 2006.

\section{Van het Kaar 2005}

R.H. van het Kaar, 'De medezeggenschap in 2004', in: G. van Solinge, M. Holtzer \& A.F.J.A. Leijten (red.), Geschriften vanwege de Vereniging Corporate Litigation 2004-2005, Deventer: Kluwer 2005.

\section{Kiersch - T\&C Burgerlijk Wetboek, art. 2:403 BW}

E.D.G. Kiersch, commentaar op art. 2:403 BW, in: H.B. Krans, C.J.J.M. Stolker \& W.L. Valk (red.), Tekst \& Commentaar Burgerlijk Wetboek, Deventer: Wolters Kluwer (bijgewerkt 12 juni 2020).

\section{Kiersch - T\&C Burgerlijk Wetboek, art. 2:404 BW}

E.D.G. Kiersch, commentaar op art. 2:404 BW, in: H.B. Krans, C.J.J.M. Stolker \& W.L. Valk (red.), Tekst \& Commentaar Burgerlijk Wetboek, Deventer: Wolters Kluwer (bijgewerkt 12 juni 2020).

\section{Koning 1991}

S.C.H. Koning, 'De aansprakelijkheid uit artikel 403 BW 2', in: Liber amicorum NBW. Opstellen aangeboden aan Mr. Drs. B.C. de Bie, Arnhem/Deventer/ Zwolle: Gouda Quint/Kluwer/W.E.J. Tjeenk Willink 1991. 


\section{Kortmann 2005}

S.C.J.J. Kortman, 'Inning van andermans gesecureerde vordering', $T v I 2005$, afl. 3, p. 67-69.

\section{Koster, in: GS Rechtspersonen, art. 2:309 BW}

H. Koster, commentaar op art. 2:309 BW, in: J.B. Huizink (red.), Groene Serie Rechtspersonen, Deventer: Wolters Kluwer (bijgewerkt 10 september 2018).

\section{Van der Kraan 2012}

J. van der Kraan, De groepsvrijstelling op basis van artikel 2:403 BW, aansprakelijkheid van de moedervennootschap en de positie van schuldeisers, Tilburg: Celsus Juridische Uitgeverij 2012.

\section{Van der Kraan 2013}

J. van der Kraan, 'Actuele vraagstukken rondom de groepsvrijstelling: over de samenloop van artikel 2:403 BW met preferentie en achterstelling', TVR 2013, afl. 5, p. 149-166.

\section{Van der Kraan 2015}

J. van der Kraan, 'De verjaring van een 403-vordering', $O \& F$ 2015, afl. 2, p. 15-27.

\section{Van der Kraan 2016}

J. van der Kraan, 'De toetsing van de hardheid van een vordering in een verzetprocedure op basis van artikel 2:404 lid 5 BW', $M v O$ 2016, afl. 1, p. 6-15.

\section{Van der Kraan 2017}

J. van der Kraan, 'Een 403-verklaring als redmiddel voor een te late jaarrekening?’, WPNR 2017/7146, p. 322-326.

\section{Van der Kraan 2018a}

J. van der Kraan, 'Het toelaten en het toekennen van schuldeisersverzet op grond van art. 2:404 BW', JBN 2018/3, p. 8-10.

\section{Van der Kraan 2018b}

J. van der Kraan, 'De groepsvrijstelling van art. 2:403 BW, enkele actualiteiten en aandachtspunten', TOP 2018/165, p. 29-35.

\section{Kraft 2001}

E.T. Kraft, 'Die Mitwirkung der Gesellschafter bei der Befreiung nach $\S 264$ Abs. 3 HGB', in: P. Hommelhoff, R. Zätzsch \& B. Erle (red.), Gesellschaftsrecht, Rechnungslegung, Steuerrecht. Festschrift für Welf Müller zum 65. Geburtstag, München: C.H. Beck 2001. 


\section{LITERATUURLIJST}

\section{Krol 2015}

A.N. Krol, 'Groepsbegrip in het kader van consolidatie', TvJ 2015, afl. 6, p. $143-148$.

\section{Lennarts 2006}

M.L. Lennarts, De Twilight Zone: het schemergebied tussen vennootschaps-en insolventierecht, Deventer: Kluwer 2006.

\section{Lennarts \& Schutte-Veenstra 2004}

M.L. Lennarts \& J.N. Schutte-Veenstra, Versoepeling van het BV-kapitaalbeschermingsrecht, Deventer: Kluwer 2004.

Van Limpt, Pronk \& Visser 2019

T. van Limpt, M. Pronk \& S. Visser e.a. (red.), EY Handboek jaarrekening 2019, Deventer: Wolters Kluwer 2019.

\section{Lubbers \& Scholten 1971}

A.G. Lubbers \& Y. Scholten, De besloten vennootschap (Preadvies van de Vereeniging 'Handelsrecht'), Zwolle: Tjeenk Willink 1971.

\section{Maatman 1996}

R.H. Maatman, 'Verlos ons van het landelijk verspreid dagblad', WPNR 1996/6250, p. 930-932.

\section{MacCann \& Courtney 2007}

L. MacCann \& T.B. Courtney e.a., Companies Acts 1963-2006, Dublin: Tottel Publishing 2007.

\section{Maeijer 1978}

J.M.M. Maeijer, Vennootschapsrecht in beweging, Alphen aan den Rijn/Brussel: Samson Uitgeverij 1978.

\section{Marquenie 2011}

H.J.C. Marquenie, 'Redelijkheid en billijkheid bij beëindiging overblijvende aansprakelijkheid uit 403-verklaring', $V \& O 2011$, afl. 5, p. 107-110.

Merkt 2020, Beck'sche Kurz-Kommentare, § 264 Handelsgesetzbuch H. Merkt, in: A. Baumbach \& K.J. Hopt e.a. (red.), Beck'sche Kurz-Kommentare, München: C.H. Beck 2020.

\section{Messelink \& Van den Bosch 2017}

K.A. Messelink \& R. van den Bosch, Juridisch handboek intensief beheer, Deventer: Wolters Kluwer 2017. 


\section{Nagelkerke 1985}

J.J. Nagelkerke, 'Aansprakelijkheidsverklaring en groepsvrijstellingsregeling’, $M A B$ 1985, afl. 5, p. 209-219.

\section{A.G.S. Nass 2013}

A.G.S. Nass, 'De vergeten 403-verklaring en de redelijkheid en billijkheid', Ondernemingsrecht 2013/95, p. 474-481.

A.G.S. Nass \& E.C.A. Nass 2014

A.G.S. Nass \& E.C.A. Nass, 'De vordering uit hoofde van een 403-verklaring', Ondernemingsrecht 2014/145, p. 735-742.

\section{A.G.S. Nass \& E.C.A. Nass 2017}

A.G.S. Nass \& E.C.A. Nass, 'Persoonlijke zekerheden in groepsverband en faillissement: letter of comfort, groepsgarantie en 403-verklaring', in: Ph.W. Schreurs, E.L. Zetteler, E.J.R. Verwey \& R.F. Feenstra (red.), De curator en het concern, Deventer: Wolters Kluwer 2017.

\section{E.C.A. Nass 2013}

E.C.A. Nass, '403-aansprakelijkheid en de wettelijke bevoorrechte vordering ex art. 3:288 onder e BW', Ondernemingsrecht 2013/48, p. 246-248.

\section{E.C.A. Nass 2018}

E.C.A. Nass, 'Shell staat achter, maar niet (meer) naast NAM', Ondernemingsrecht 2018/28, p. 167-168.

\section{E.C.A. Nass 2019}

E.C.A. Nass, Groepsregime, jaarrekening en 403-aansprakelijkheid (diss. Groningen), Deventer: Wolters Kluwer 2019.

\section{E.C.A. Nass 2020}

E.C.A. Nass, 'NAM, haar aandeelhouders en de 403-verklaring', $M v V 2020$, afl. 4, p. 141-149.

\section{De Neve 2002}

A.G. de Neve, 'De concernvrijstellingsregeling: de 403-aansprakelijkstelling volgens de Hoge Raad', TvI 2002, afl. 5, p. 235-242.

\section{De Neve 2011}

A.G. de Neve, 'Onzekerheid omtrent de materiële reikwijdte van de 403 -aansprakelijkheidstelling of een storm in een glas water?', $T v J$ 2011, afl. 2, p. 48-55. 


\section{De Neve 2014}

A.N. Krol \& A.G. de Neve, 'Jurisprudentie jaarrekeningenrecht 2013', TvJ 2014, afl. 1/2, p. 30-41.

\section{De Neve 2015}

A.N. Krol \& A.G. de Neve, 'Jurisprudentie jaarrekeningenrecht 2014', TvJ 2015, afl. 3/4, p. 82-93.

\section{Niels 2010}

B. Niels, 'Aansprakelijkheid op grond van de 403-verklaring. Een bespreking van enkele aspecten van de 403-verklaring aan de hand van de Jones Lang LaSalle-uitspraak', $O \& F 2010$, afl. 1, p. 25-40.

\section{Notenboom 2017}

K. Notenboom, 'Het verzetrecht van artikel 2:404 BW', $M v O$ 2017, afl. 5/6, p. 126-134.

\section{Ohmann 2011}

D.O. Ohmann, 'Uit het oog..., voormalige groepsmaatschappijen en de vergeten 403-verklaring', $B b$ 2011, afl. 22, p. 171-173.

\section{Van Olffen 2001}

M. van Olffen, 'Een 403-verklaring is nog geen 403-verklaring omdat dat erop staat', WPNR 2001/6460, p. 833-834.

\section{Van Olffen, Buijn \& Simonis 2004}

M. van Olffen, F.K. Buijn \& P.H.M. Simonis, Splitsing van ondernemingen, Den Haag: Boom Juridische uitgevers 2004.

\section{Pannevis 2019}

N.B. Pannevis, Achtergestelde vorderingen (diss. Nijmegen), Deventer: Wolters Kluwer 2019.

\section{Pitlo/Raaijmakers 2017}

M.J.G.C. Raaijmakers (met medewerking van G.T.M.J. Raaijmakers \& W.J.M. van Veen), Pitlo. Het Nederlands burgerlijk recht. Deel 2. Ondernemingsrecht, Deventer: Wolters Kluwer 2017.

\section{Pitlo/Reehuis \& Heisterkamp 2019}

W.H.M. Reehuis \& A.H.T. Heisterkamp (met bijdragen van G.E. van Maanen \& G.T. de Jong), Pitlo. Het Nederlands burgerlijk recht. Deel 3. Goederenrecht, Deventer: Wolters Kluwer 2019. 


\section{Van der Ploeg 1986}

T.J. van der Ploeg, 'De commanditaire vennootschap met een beherende b.v.', TVVS 1986, afl. 3, p. 57-63.

\section{Pors 2002}

A.J.J. Pors, 'Verpanding van slechts een van de hoofdelijke verbonden vorderingen', $V \& O 2002$, afl. 9, p. 146-149.

\section{Portengen \& Crouwers 2005}

H.J. Portengen \& N.R.M. Crouwers, 'Juridische fusie en 403-verklaring', $V \& O 2005$, afl. 3, p. 42-45.

\section{Quist 2019}

P.H.N. Quist, 'Countdown. Een cursus aftellen voor juristen', WPNR 2019/7239, p. 399-401.

\section{Raaijmakers 1976}

M.J.G.C. Raaijmakers, Joint ventures (diss. Nijmegen), Deventer: Kluwer 1976.

\section{Raaijmakers 1985}

M.J.G.C. Raaijmakers, 'Een rechtsvergelijkende analyse (met inbegrip van de negende richtlijn)', in: H. Biron, D. van den Bulcke, P. van Ommeslaghe e.a., Rechten en plichten van moeder- en dochtervennootschappen, Antwerpen: Kluwer 1985.

\section{Raaijmakers \& Van der Sangen, in: GS Rechtspersonen, art. 2:316 BW}

M.J.G.C. Raaijmakers \& G.J.H. van der Sangen, commentaar op art. 2:316 BW, in: J.B. Huizink (red.), Groene Serie Rechtspersonen, Deventer: Kluwer (bijgewerkt 1 februari 2007).

\section{Ramanna 2008}

A. Ramanna, 'Kwalificatie van de 403-verklaring', $T v J$ 2008, afl. 1/2, p. 17-21.

\section{Rensen 2005}

G.J.C. Rensen, Extra-verplichtingen van leden en aandeelhouders (diss. Nijmegen), Deventer: Kluwer 2005.

\section{Reimers, in: GS Rechtspersonen, art. 2:403 BW}

H.K.O. Reimers, commentaar op art. 2:403 BW, in: J.B. Huizink (red.), Groene Serie Rechtspersonen, Deventer: Kluwer (bijgewerkt 1 januari 2013). 


\section{LITERATUURLIJST}

\section{Reimers, in: GS Rechtspersonen, art. 2:404 BW}

H.K.O. Reimers, commentaar op art. 2:404 BW, in: J.B. Huizink (red.), Groene Serie Rechtspersonen, Deventer: Kluwer (bijgewerkt 1 januari 2013).

\section{Roelofs 2014}

E.R. Roelofs, Grensoverschrijdende juridische splitsing van kapitaalvennootschappen (diss. Utrecht), Deventer: Kluwer 2014.

\section{Rongen 2012}

M.H.E. Rongen, Cessie. Beschouwingen over kernthema's van de overdracht van vorderingen op naam tegen de achtergrond van de hedendaagse (internationale) financiële praktijk en securitisation in het bijzonder (diss. Nijmegen), Deventer: Kluwer 2012.

Ruppelt 2020, Beck'scher Online-Kommentar, § 264 Handelsgesetzbuch

D. Ruppelt, in: M. Häubelein \& R. Hoffmann-Theinert e.a. (red.), Beck'scher Online-Kommentar, München: C.H. Beck 2020.

\section{Sanders \& Westbroek/Buijn \& Storm 2005}

F.K. Buijn \& P.M. Storm, Sanders en Westbroek. BV en NV, Deventer: Kluwer 2005.

\section{Van der Sangen 2017}

G.J.H. van der Sangen, 'Vraagpunten betreffende de 403-verklaring. Spijkers met koppen of spijkers op laag water?', TvOB 2017, afl. 6, p. 202-210.

\section{Schepel 2016}

M.C. Schepel, 'De dwingende volgorde bij de beëindiging van de 403-aansprakelijkheid', $O \& F$ 2016, afl. 2, p. 65-68.

\section{Van Schilfgaarde 1988}

P. van Schilfgaarde, Van de BV en de NV, Arnhem: Gouda Quint 1988.

\section{Van Schilfgaarde 1990}

P. van Schilfgaarde, Van de BV en de NV naar het recht van 1992, Arnhem: Gouda Quint 1990.

\section{Van Schilfgaarde/Winter, Wezeman \& Schoonbrood 2017}

J. Winter, J.B. Wezeman \& J.D.M. Schoonbrood, Van Schilfgaarde. Van de BV en de NV, Deventer: Wolters Kluwer 2017. 


\section{Schoonbrood-Wessels 1996}

A.P. Schoonbrood-Wessels, 'De aansprakelijkheid van de moeder voor schulden van de dochter: de stand van zaken', De NV 1996, afl. 1 en 2, p. 2-7 en $37-48$.

\section{Schoordijk 2003}

H.C.F. Schoordijk, 'Hoofdelijkheid in het algemeen en de 2:403 lid 1 sub f verklaring in het bijzonder', in: M.J.G.C. Raaijmakers (red.), Trust en onderneming, opstellen aangeboden aan prof. mr. C. A. Uniken Venema, Den Haag: Boom Juridische uitgevers 2003.

\section{Schutte-Veenstra 1996}

J.N. Schutte-Veenstra, 'Enkele kanttekeningen bij het vennootschappelijk verzetrecht van crediteuren', TVVS 1996, afl. 11, p. 293-298.

\section{Schutte-Veenstra 2005}

J.N. Schutte-Veenstra, 'Versoepeling van het BV-kapitaalbeschermingsrecht vanuit rechtsvergelijkend perspectief', in: P. van Schilfgaarde e.a., Vereenvoudiging en flexibilisering van het Nederlandse $B V$-recht, Deventer: Kluwer 2005.

\section{Schutte-Veenstra \& Verbrugh 2020}

J.N. Schutte-Veenstra \& M.A. Verbrugh, 'De Richtlijn betreffende grensoverschrijdende omzetting, fusie en splitsing nader beschouwd', Ondernemingsrecht 2020/40, p. 208-218.

SER-advies 1974 no. 14, inzake het voorstel voor een richtlijn van de raad van de Europese Gemeenschappen betreffende de jaarrekening van kapitaalvennootschappen

Advies inzake het voorstel voor een richtlijn van de Raad van de Europese Gemeenschappen betreffende de jaarrekening van kapitaalvennootschappen (advies van 18 oktober 1974, SER 74/14), Den Haag: SER 1974.

SER-advies 1976 no. 20, inzake de verstrekking door de ondernemer van informatie aan de ondernemingsraad

Advies inzake de verstrekking door de ondernemer van informatie aan de ondernemingsraad (advies van 15 oktober 1976, SER 76/20), Den Haag: SER 1976.

SER-advies 1979 no. 12, inzake een voorstel voor een zevende richtlijn van de raad van de Europese gemeenschappen betreffende de concernjaarrekening

Advies inzake een voorstel voor een zevende richtlijn van de Raad van de Europese gemeenschappen betreffende de concernjaarrekening (advies van 15 juni 1979, SER 79/12), Den Haag: SER 1979. 


\section{LITERATUURLIJST}

Sikkema, in: GS Verbintenissenrecht, art. 6:3 BW

T.H. Sikkema, commentaar op art. 6:3 BW, in: R.J.Q. Klomp \& H.N. Schelhaas (red.), Groene Serie Verbintenissenrecht, Deventer: Wolters Kluwer (bijgewerkt 16 juli 2019).

\section{Slagter 2005}

W.J. Slagter, Compendium van het ondernemingsrecht, Deventer: Kluwer 2005.

\section{Smelt 2015}

W.M. Smelt, '403-verklaring en achterstelling; een (on)rustig bezit', TOP 2015, afl. 6, p. 34-37.

Snijder-Kuipers - T\&C Ondernemingsrecht, art. 24 Handelsregisterwet 2007

B. Snijder-Kuipers, commentaar op art. 24 Handelsregisterwet 2007, in: C.D.J. Bulten, A.F.J.A. Leijten \& M.L. Lennarts (red.), Tekst \& Commentaar Ondernemingsrecht, Deventer: Wolters Kluwer (bijgewerkt 6 januari 2020).

\section{Snijder-Kuipers \& Eliëns 2014}

B. Snijder-Kuipers \& M.F. Eliëns, 'Praktische vraagstukken bij beëindiging van overblijvende aansprakelijkheid (2:404 BW)', WPNR 2014/7042, p. 11761180 .

\section{Van Solinge 1994}

G. van Solinge, Grensoverschrijdende fusie. Beschouwingen aan de hand van de derde en tiende EEG-richtlijn inzake het vennootschapsrecht (diss. Nijmegen), Deventer: Kluwer 1994.

\section{Van Solinge 2004}

G. van Solinge, 'Vragen uit de rechtspraktijk (6). Schulden en de 403-verklaring', Ondernemingsrecht 2004/98, p. 277.

\section{Van Solinge 2006}

G. van Solinge, 'Over belastingschulden en de 403-verklaring', in: G.T.K. Meussen (red.), Gedreven, eigenzinnig, creatief en honkvast (Schonis-bundel), Deventer: Kluwer 2006.

\section{Spath 2010}

J.B. Spath, Zaaksvervanging (diss. Nijmegen), Deventer: Kluwer 2010.

\section{Spierings 2012}

C. Spierings, 'Verbintenisrechtelijke aspecten van de 403-verklaring', NTBR 2012/14, p. 83-94. 


\section{Spierings 2016}

C. Spierings, De eenzijdige rechtshandeling (diss. Nijmegen), Deventer: Wolters Kluwer 2016.

D.F.H. Stein, in: GS Vermogensrecht, art. 3:227 BW

D.F.H. Stein, commentaar op art. 3:227 BW, in: J. Hijma (red.), Groene Serie Vermogensrecht, Deventer: Wolters Kluwer (bijgewerkt 4 oktober 2019).

\section{D.F.H. Stein, in: GS Vermogensrecht, art. 3:245 BW}

D.F.H. Stein, commentaar op art. 3:246 BW, in: J. Hijma (red.), Groene Serie Vermogensrecht, Deventer: Wolters Kluwer (bijgewerkt 1 augustus 2018).

D.F.H. Stein, in: GS Vermogensrecht, art. 3:246 BW

D.F.H. Stein, commentaar op art. 3:246 BW, in: J. Hijma (red.), Groene Serie Vermogensrecht, Deventer: Wolters Kluwer (bijgewerkt 1 augustus 2018).

\section{P.A. Stein, in: GS Vermogensrecht, art. 3:13 BW}

P.A. Stein, commentaar op art. 3:13 BW, in: J. Hijma (red.), Groene Serie Vermogensrecht, Deventer: Wolters Kluwer (bijgewerkt 15 december 2018).

\section{Stokkermans 2017}

Chr.M. Stokkermans, Sleutels voor personenvennootschapsrecht (diss. Rotterdam), Deventer: Wolters Kluwer 2017.

\section{Stücken 2011}

M.A.M.J. Stücken, 'De vergeten 403-verklaring en intercompany-vorderingen', FIP 2011, afl. 4, p. 98-101.

\section{Talacko \& Van Wijngaarden 2016}

J. Talacko \& T. van Wijngaarden, 'Valkuilen rondom de 403-verklaring', JutD 2016, afl. 10, p. 16-19.

\section{Tervoort 2015}

A.J.S.M. Tervoort, Het Nederlandse personenvennootschapsrecht, Deventer: Wolters Kluwer 2015.

\section{Timmerman 1988a}

L. Timmerman, Over multinationale ondernemingen en medezeggenschap van werknemers (diss. Groningen), Deventer: Kluwer 1988.

\section{Timmerman 1988b}

L. Timmerman, 'Het aan ondernemingen toekomende recht op geheimhouding', in: J.H. Christiaanse e.a. (red.), Tot vermaak van Slagter. Feestbundel 
aangeboden aan prof. mr. W.J. Slagter, ter gelegenheid van zijn 65e verjaardag, Deventer: Kluwer 1988.

\section{Timmerman 1990}

L. Timmerman, 'De aansprakelijkheid van de moeder voor schulden van de dochter', De NV 1990, afl. 1, p. 13-20.

\section{Timmerman 1993}

L. Timmerman, 'Problemen rond de intrekking van een aansprakelijkheidsverklaring. Wat is een landelijk verspreid dagblad?', TVVS 1993, afl. 12, p. 328329.

\section{Timmerman 2003}

L. Timmerman, 'Van digitaal naar analoog vennootschapsrecht en de gevolgen daarvan voor de concurrentie tussen vennootschapssystemen', Ondernemingsrecht 2003, afl. 2, p. 38-42.

\section{S. Timmerman \& De Winter 2013}

S. Timmerman \& R.M. de Winter, 'Van 403-verklaringen, achterstelling en afhankelijkheid', $M v V$ 2013, afl. 12, p. 355-361.

\section{Tuit 1985}

P. Tuit, 'De inrichting, controle en publicatie van de jaarrekening van de geconsolideerde en gegarandeerde concernvennootschappen volgens artikel 403 boek 2 BW', TVVS 1985, afl. 8, p. 189-196.

\section{Uniken Venema 1969}

C.Æ. Uniken Venema, 'Concernrecht', in: Op de grenzen van komend recht. Beekhuis-bundel, Deventer/Zwolle: Kluwer/Tjeenk Willink 1969.

\section{Valk - T\&C Burgerlijk Wetboek, art. 6:3 BW}

W.L. Valk, commentaar op art. 6:3 BW, in: H.B. Krans, C.J.J.M. Stolker \& W.L. Valk (red.), Tekst \& Commentaar Burgerlijk Wetboek, Deventer: Wolters Kluwer (bijgewerkt 1 juli 2019).

\section{Verbrugh 2006}

M.A. Verbrugh, 'De gevolgen van een 403-verklaring voor schuldeisers bij juridische fusie en juridische splitsing', $T v J$ 2006, afl. 2, p. 49-55.

\section{Verbrugh 2007}

M.A. Verbrugh, Structuurwijzigingen bij kapitaalvennootschappen en de positie van schuldeisers. Een rechtsvergelijkend onderzoek naar juridische fusie, splitsing en omzetting (diss. Rotterdam), Deventer: Kluwer 2007. 


\section{Verdaas 2008}

A.J. Verdaas, Stil pandrecht op vorderingen op naam (diss. Nijmegen), Deventer: Kluwer 2008.

\section{Vergoossen \& Meershoek 2018}

R.G.A. Vergoossen \& T. Meershoek, 'De gedeponeerde jaarstukken van controleplichtige rechtspersonen', MAB 2018, afl. 3/4, p. 97-109.

\section{Verheul, in: GS Verbintenissenrecht, art. 6:142 BW}

E.R. Verheul, commentaar op art. 6:142 BW, in: R.J.Q. Klomp \& H.N. Schelhaas (red.), Groene Serie Verbintenissenrecht, Deventer: Wolters Kluwer (bijgewerkt 20 juni 2019).

\section{Verstappen 1996}

L.C.A. Verstappen, Rechtsopvolging onder algemene titel, Deventer: Kluwer 1996.

\section{Verstappen 2002}

M.J.C.C. Raaijmakers \& L.C.A. Verstappen, Onderneming en overdracht onder algemene titel (Preadvies van de Vereeniging 'Handelsrecht'), Deventer: Tjeenk Willink 2002.

\section{Verstijlen 2009}

F.M.J. Verstijlen, 'De directe actie in het vermogensrecht', NJB 2009/1258, p. $1630-1635$.

\section{Ten Voorde 2006}

$\mathrm{H}$. ten Voorde, Deponering, publicatie en verzet. Een onderzoek naar de procedures rond vereffening, omzetting, kapitaalvermindering, fusie, splitsing en beëindiging van de overblijvende aansprakelijkheid uit een 403-verklaring (diss. Nijmegen), Deventer: Kluwer 2006.

\section{Ten Voorde 2011}

H. ten Voorde, 'De vergeten verklaring, intercompany-vorderingen en andere praktische aandachtspunten rond de 403-verklaring', TOP 2011, afl. 5, p. 195199.

\section{Vranken 1999}

J.B.M. Vranken, 'Verpanding, hoofdelijkheid en de nieuwe voorrangsregel van Zuidgeest/Furness', WPNR 1999/6353, p. 267-271.

\section{Van der Waals 2017}

S.E. van der Waals, De optimale rechtsvorm voor de samenwerking in het beroep. Confectie of maatpak (diss. Utrecht), Deventer: Wolters Kluwer 2017. 


\section{LITERATUURLIJST}

\section{Wessels 1997}

B. Wessels, 'Splitsing van het onsplitsbare?', $S \& V$ 1997, p. 175-185.

\section{Wibier 2008}

R.M. Wibier, '403-perikelen vanuit een goederenrechtelijk perspectief', Ondernemingsrecht 2008/52, p. 180-185.

\section{Wibier 2015}

R.M. Wibier, 'De aard van de aansprakelijkheid uit hoofde van een 403-verklaring', $A A$ 2015, afl. 10, p. 778-783.

\section{Van Wijngaarden 2006a}

T. van Wijngaarden, 'Verantwoording over het groepsregime', in: M.J. Kroeze, C.M. Harmsen, M.W. Josephus Jitta, L. Timmerman, J.B. Wezeman \& P.M. van der Zanden (red.), Verantwoording aan Hans Beckman, Deventer: Kluwer 2006.

\section{Van Wijngaarden 2006b}

T. van Wijngaarden, 'Kan een 403-verklaring preferentie scheppen?', JutD 2006, afl. 12, p. 22-24.

\section{Van Wijngaarden 2010}

T. van Wijngaarden, 'Jurisprudentie jaarrekeningenrecht 2009, jaarrekening en het groepsregime', TvJ 2010, afl. 4, p. 125-134.

\section{Willems 1997}

M.A.L.M. Willems, ‘403 = 403. Of toch niet?’, TvI 1997, afl. 1, p. 14-17.

\section{Winkel 2004}

D. Winkel, 'Duidelijkheid omtrent de temporele reikwijdte van de 403-verklaring? Een overzicht', $T v O B$ 2004, afl. 4, p. 184-188.

\section{Winter 1989}

J.W. Winter, 'Reactie op "Reikwijdte van de aansprakelijkverklaring in het kader van de groepsvrijstelling", TVVS 1989, afl. 11, p. 288-289.

\section{Winter 1992}

J.W. Winter, Concernfinanciering (diss. Groningen), Deventer: Kluwer 1992.

\section{Winter 2001}

R.E. van Esch, J.W. Winter \& G.J. van der Ziel, Afscheid van papier (Preadvies van de Vereeniging 'Handelsrecht'), Zwolle: Tjeenk Willink 2001. 


\section{Zaman, Van Eck \& Roelofs 2009}

D.F.M.M. Zaman, G.C. van Eck \& E.R. Roelofs, Nationale en grensoverschrijdende juridische fusies \& juridische splitsingen van kapitaalvennootschappen, Den Haag: SDU Uitgevers 2009.

\section{Van Zoest 2011}

M.R.C. van Zoest, 'De automatisch vervallende 403-verklaring', $O \& F 2011$, afl. 4, p. 95-103.

\section{Van Zoest 2014}

M.R.C. van Zoest, 'Moeten bekende grote schuldeisers separaat op de hoogte worden gebracht van beëindiging van de overblijvende 403-aansprakelijkheid?', $V \& O 2014$, afl. 1, p. 1-4.

\section{Van Zoest 2015}

M.R.C. van Zoest, 'Bestuurdersaansprakelijkheid als gevolg van enkele veelgemaakte vergissingen in het kader van de concernvrijstelling: de instemmingsverklaring en de algemene boekhoudplicht van art. 2:10 BW', TOP 2015, afl. 1, p. 39-44.

\section{Van Zoest 2016a}

M.R.C. van Zoest, '(Beëindiging van) 403-aansprakelijkheid. De stand van zaken anno 2016', $O \& F 2016$, afl. 1, p. 55-71.

\section{Van Zoest 2016b}

M.R.C. van Zoest, 'Naschrift bij de dwingende volgorde bij de beëindiging van de 403-aansprakelijkheid', $O \& F$ 2016, afl. 2, p. 69-71.

\section{Van Zoest 2017}

M.R.C. van Zoest, 'De nieuwe maatstaf van de Hoge Raad bij 403-aansprakelijkheid: 'onmiskenbaar ongegrond”, $O \& F$ 2017, afl. 2, p. 60-67.

\section{Van Zoest 2019}

M.R.C. van Zoest, De groepsvrijstelling in de praktijk, Zutphen: Uitgeverij Paris 2019.

\section{Zwemmer 2011}

J.P.H. Zwemmer, 'De 403-verklaring en de aansprakelijkheid voor uit arbeidsovereenkomsten (en andere duurovereenkomsten) voortvloeiende verplichtingen', Ondernemingsrecht 2011/45, p. 223-232.

\section{Zwemmer 2012}

J.P.H. Zwemmer, Pluraliteit van werkgeverschap, Deventer: Kluwer 2012. 



\section{Rechtspraakregister}

\section{Hof van Justitie van de Europese Gemeenschappen}

- HvJ EG 13 november $1990 \quad$ NJ 1993/163 (Marleasing)

- HvJ EG 9 maart 1999 NJ 2000/48, m.nt. Vlas; JOR 1999/117, m.nt. Van Solinge (Centros)

- HvJ EG 30 september 2003 JOR 2003/249, m.nt. Vossestein (Inspire Art)

\section{Hoge Raad}

- $\quad$ HR 5 januari 1979

NJ 1979/207, m.nt. Stein (Swaen/Van Hees)

- $\quad$ HR 18 april 1980

NJ1981/377, m.nt. Wachter(Sleephelling Maatschappij Scheveningen/Buis)

- $\quad$ HR 3 februari 1988 NJ 1989/225, m.nt. Maeijer (Naba Beheer)

- $\quad$ HR 11 juni 1993

- $\quad$ HR 4 oktober 1996 NJ 1993/713, m.nt. Maeijer (Kempers en Sarpers)

- HR 19 december 1997

- $\quad$ HR 21 mei 1999

NJ 1997/187, m.nt. Maeijer (Likea)

NJ 1998/690, m.nt. Kleijn (Zuidgeest) Furness)

- HR 23 november 2001

NJ 1999/507 (Kerkhof/Spoelstra)

NJ 2002/95, m.nt. Maeijer; JOR 2002/4, m.nt. Blanco Fernández (Mefigro)

- HR 28 juni 2002

NJ 2002/447, m.nt. Maeijer; JOR 2002/ 136, m.nt. Bartman; Ondernemingsrecht 2002/57, p. 485-487 m.comm. Beckman; Ondernemingsrecht 2004/16, p. 48-52 m.comm. Bartman (Akzo/ING)

- HR 11 maart 2005

NJ 2006/362, m.nt. Snijders; JOR 2005/131, m.nt. Kortmann (Rabobank/ Stormpolder)

- $\quad$ HR 18 september 2009

JOR 2010/29, m.nt. Faber en Kortmann (Simoca)

- HR 11 januari 2011 JOR 2011/101, m.nt. Van Hees (Aukema q.q./Uni- Invest) 
- $\quad$ HR 15 november 2013

- HR 22 november 2013

- HR 21 maart 2014

- HR 11 april 2014

- HR 11 april 2014

- HR 20 maart 2015

- HR 3 april 2015

- $\quad$ HR 29 mei 2015

- $\quad$ HR 19 juni 2015

- HR 18 december 2015

- HR 31 maart 2017

- $\quad$ HR 19 april 2019
NJ 2014/68, m.nt. Van Schilfgaarde (Romania)

JOR 2014/28, m.nt. Van Hees (TEP)

NJ 2015/167, m.nt. Snijders; JOR 2014/ 151, m.nt. Schuijling (Coface/Intergamma)

JOR 2014/198; Ondernemingsrecht 2014/ 83, p. 409-410 m.comm. Beckman (X/ Econcern)

NJ 2014/309, m.nt. Van Schilfgaarde; JOR 2014/199, m.nt. Van Dooren; Ondernemingsrecht 2014/83, p. 409-410 m.comm. Beckman (UWV/Econcern)

NJ 2015/361, m.nt. Winter en Van Schilfgaarde; JOR 2015/140, m.nt. Josephus Jitta; JIN 2015/82, m.nt. Van der Kraan; Ondernemingsrecht 2015/97, p. 495-498 m.comm. Beckman (Minister van Financiën/VEB c.s.)

NJ 2015/255, m.nt. Van Schilfgaarde; JOR 2015/191, m.nt. Faber en Vermunt; Ondernemingsrecht 2015/66, p. 343-345 m.comm. Beckman; $A A$ 2015, afl. 10, p. 806-811 m.comm. Bartman (Eikendal q.q./Lentink)

NJ 2015/380, m.nt. Van Schilfgaarde; JOR 2015/192, m.nt. Stokkermans (Lunchroom De Katterug)

ECLI:NL:HR:2015:1691 (TPB/Eneco)

JOR 2016/105, m.nt. Faber en Vermunt (ABN Amro/Marell)

NJ 2018/26, m.nt. Van Schilfgaarde; JOR 2017/221, m.nt. De Haan; JIN 2017/97, m.nt. Schepel; Ondernemingsrecht 2017/ 91, p. 512-514 m.comm. Van Dooren (SNS/Curatoren)

NJ 2019/438, m.nt. Verstijlen; JOR 2019/ 173, m.nt. Faber (UWV/SchäperclausSchinkel q.q. c.s.) 


\section{College van Beroep voor het bedrijfsleven}

- $\quad$ CBb 26 september 1990

\section{Hof}

- Hof Amsterdam (OK) 14 oktober 1982

- Hof Amsterdam 24 december 1992

- Hof Amsterdam (OK) 29 juli 1993

- Hof Amsterdam (OK) 13 juli 2000

- Hof Amsterdam (OK) 20 februari 2001

- Hof Amsterdam 26 juli 2001

- Hof Amsterdam (OK) 31 juli 2001

- Hof Amsterdam (OK) 1 februari 2007

- Hof Den Haag 6 februari 2007

- Hof Amsterdam (OK) 28 februari 2007

- Hof Amsterdam 6 september 2007

- Hof 's-Hertogenbosch 7 april 2009

- Hof 's-Hertogenbosch 12 mei 2009

- Hof Amsterdam (OK) 12 januari 2010

- Hof Amsterdam (OK) 12 januari 2010

- Hof Amsterdam (OK) 30 september 2010
KG 1990, 367 (Taxibedrijf Mart Hof)

\author{
NJ 1983/637, m.nt. Maeijer (XBV/A) \\ rolnr. 863, 91 (Hypo/Kap)
}

NJ 1994/132; TVVS 1993, afl. 12, p. 328329 m.comm. Timmerman (Teeuwissen/ Teletrade)

JOR 2000/174, m.nt. Van het Kaar (OR EBS/HES Beheer I)

JOR 2001/92, m.nt. Van het Kaar (OR EBS/HES Beheer II)

JOR 2004/94, m.nt. Bartman (Hemony/ Van der Woude)

JOR 2001/170, m.nt. Bartman (ING/ Akzo)

JOR 2007/144 (Fey Holding/Castellum Novum)

JOR 2007/103, m.nt. Faber (Citibank International/KPN)

JOR 2007/145, m.nt. Van der Zanden (Van den Wildenberg/Van Wijnen Holding)

Ondernemingsrecht 2010/147, p. 695697 m.comm. Beckman; RI 2008, 26 (Van der Aa/KPNQwest)

JOR 2009/160, m.nt. Bartman (Inalfa)

JOR 2009/279, m.nt. Bartman (Inalfa)

JOR 2010/93, m.nt. Bartman onder JOR 2010/94 (Hoeveholding)

JOR 2010/94, m.nt. Bartman (Hoeveholding)

JOR 2010/306, m.nt. Bartman; Ondernemingsrecht 2010/148, p. 697-698 m.comm. Beckman (Jones Lang LaSalle) BosGijze) 


\section{RECHTSPRAAKREGISTER}

- Hof 's-Hertogenbosch 24 januari 2012

- Hof Amsterdam (OK) 11 juli 2013

- Hof Den Haag 18 maart 2014

- Hof Amsterdam (OK) 23 juli 2014

- Hof Amsterdam (OK) 9 december 2015

- Hof Amsterdam (OK) 7 juni 2016

- Hof 's-Hertogenbosch 29 augustus 2017

- Hof Den Haag 5 september 2017

- Hof Den Haag 25 juni 2019

- Hof Amsterdam 22 oktober 2019

\section{Rechtbank}

- Rb. Rotterdam 14 januari 1987

- Rb. Utrecht 31 juli 1996

- Rb. Rotterdam 16 januari 1997

- Rb. Rotterdam 15 april 1999

- Rb. Amsterdam 20 december 2000
JOR 2012/165, m.nt. Bertrams (Inalfa)

JOR 2013/250, m.nt. Josephus Jitta; Ondernemingsrecht 2013/110, p. 557563 m.comm. Beckman (Minister van Financiën/VEB c.s.)

JOR 2015/93, m.nt. Bartman (TPB/ Eneco)

JOR 2014/233, m.nt. Bartman; JAR 2014/ 209, m.nt. Zwemmer; JIN 2014/156, m.nt. Baghery; JIN 2014/172, m.nt. Van der Kraan (Van Lieshout/Koks)

JOR 2016/7, m.nt. Bartman; JIN 2016/12 (Curatoren/SNS)

JIN 2016/196, m.nt. Schepel (Erjeebee/ Coltex)

JOR 2017/318, m.nt. Van Zoest; JIN 2018/7, m.nt. Van der Kraan (Doorwin)

JOR 2018/2, m.nt Bartman; JIN 2017/ 178, m.nt. Van Nuland en Schepel (Hoad/ Hilson)

JOR 2020/56, m.nt. Van Dooren (ZOM)

JIN 2019/179, m.nt. Van der Kraan (Maison Zen beheer/Pauw)

\section{NJ 1988/1050 (Phillips/Van Eijk)}

JOR 1996/96; TvI 1997, afl. 1, p. 14-17 m.comm. Willems (Manning q.q./ Haverkort Bouwgroep)

KG 1997, 55 (Wannemakers/Vetus den Ouden)

JOR 1999/119; Ondernemingsrecht 1999/ 50,p. 250-251 m.comm. Winter(LelyIndustries/Netagco Holding)

JOR 2001/53, m.nt. Bartman; JAR 2001/36, m.nt. Thierry (Ekelmans/Tevema) 
- $\mathrm{Rb}$. Arnhem 1 februari 2001

- Rb. 's-Hertogenbosch 21 februari 2002

- $\mathrm{Rb}$. Arnhem 10 oktober 2002

- $\mathrm{Rb}$. Amsterdam 4 april 2003

- $\quad \mathrm{Rb}$. Den Haag 14 mei 2003

- Rb. Arnhem 21 juli 2004

- Rb. 's-Gravenhage 2 maart 2005

- Rb. Haarlem 16 november 2005

- Rb. 's-Hertogenbosch 3 maart 2006

- $\quad \mathrm{Rb}$. Den Haag 5 juli 2006

- Rb. Roermond 25 oktober 2006

- Rb. Roermond 20 februari 2008

- $\quad$ Rb. Almelo 24 juni 2008

- $\mathrm{Rb}$. Rotterdam 16 april 2009

- Rb. Den Haag 7 oktober 2009

- $\mathrm{Rb}$. Haarlem 28 juli 2010

- Rb. Utrecht 10 november 2010

- $\quad \mathrm{Rb}$. Groningen 27 juni 2012
JOR 2001/88, m.nt. Bartman (ING/Akzo)

ECLI:NL:RBSHE:2002:AD 9620

(Landis/Norted International)

JOR 2003/31, m.nt. Bartman (Resila/ Spectro)

JOR 2003/105, m.nt. Wintgens-van Luyn (Dexia Bank Nederland)

JOR 2003/215, m.nt. Loesberg (Info Opleiders)

JIN 2004/27 (Acordis Beheer)

JOR 2005/116, m.nt. Harmsen (Uni-Invest/Content Beheer)

JOR 2006/27; Ondernemingsrecht 2010/ 147 , p. 695-697 m.comm. Beckman; JutD 2006-12, p. 22-24 m.comm. Van Wijngaarden (Van der Aa/KPNQwest)

JOR 2006/201 (De Plaet/NRE)

JOR 2007/53, m.nt. Verdaas (NCM/Den Heijer Beheer)

JOR 2006/289, m.nt. Bartman (Oud papiercentrale/Inalfa)

JOR 2008/92, m.nt. Bartman (Inalfa)

JOR 2008/92, m.nt. Bartman (Hoeveholding)

JOR 2009/161, m.nt. Van der Zanden (BosGijze/Jones Lang LaSalle)

ECLI:NL:RBSGR:2009:BL3877 (MFE/ Katwijk Farma)

JOR 2010/264, m.nt. Bartman; Ondernemingsrecht 2010/147, p. 695697 m.comm. Beckman (KPNQwest)

JOR 2011/16, m.nt. Bartman; Ondernemingsrecht 2010/149, p. 698 m.comm. Beckman (De With/Lekkerkerker)

JOR 2012/350, m.nt. Bartman (De Heer) KHE) 


\section{RECHTSPRAAKREGISTER}

- Rb. Amsterdam 5 december 2012

- $\quad \mathrm{Rb}$. Midden-Nederland 30 januari 2013

- $\quad \mathrm{Rb}$. Midden-Nederland 30 januari 2013

- Rb. Rotterdam 24 december 2013

- $\quad$ Rb. Midden-Nederland 7 mei 2014

- Rb. Rotterdam 30 september 2014

- $\quad \mathrm{Rb}$. Midden-Nederland 5 november 2014

- Rb. Midden-Nederland 14 januari 2015

- Rb. Rotterdam 29 september 2015

- $\quad \mathrm{Rb}$. Rotterdam 18 november 2015

- $\quad \mathrm{Rb}$. Noord-Nederland 1 maart 2017

- $\quad$ Rb. Gelderland 19 juli 2017

- Rb. 's-Hertogenbosch 21 februari 2019

- $\quad$ Rb. Gelderland 1 april 2020

RO 2013/25 (Batla Minerals)

JOR 2013/70, m.nt. Van Dooren; JIN 2013/73, m.nt. Van der Kraan; Ondernemingsrecht 2013/48, p. 246-248 m.comm. Nass (UWV/Econcern)

ECLI:RBMNE:2013:BZ0341

$(X /$

Econcern)

JIN 2014/44, m.nt. Van der Kraan; Ondernemingsrecht 2014/31, p. 157 m.comm. Beckman (Vodafone Libertel/KPN)

JOR 2014/260, m.nt. Harmsen (Curatoren/SNS)

JOR 2014/326, m.nt. Loesberg (Pergen/ Eneco)

E C L I : N L : R B M N E : 2014 : 5519 (Curatoren/SNS)

ECLI:NL:RBMNE:2015:51 (Curatoren/ $S N S)$

JOR 2015/295, m.nt. Bartman (Iemants/ Hertel Beheer)

ECLI:NL:RBROT:2015:8545 (Van Gansewinkel/Warmtebedrijven)

JA 2017/88, m.nt. Van Dorsser (X/NAM)

ECLI:NL:RBGEL:2017:4157(ZZGzorggroep/SITA recycling)

JOR 2019/131, m.nt. Koster (Optas/ Aegon)

E C L I : N L : R B G E L : $2020: 2680$

(DuraMark/SPGPrints)

\section{Arbitrage}

- Raad van Arbitrage voor de Bouw 14 januari 2013, nr. 34.225

- Nederlands Arbitrage Instituut 26 mei 2015, nr. 4128 


\section{Curriculum Vitae}

Etzel Alcuin van Dooren (1985) behaalde in 2004 zijn gymnasiumdiploma aan het Sint-Maartenscollege te Maastricht. In 2011 voltooide hij aan de Radboud Universiteit Nijmegen de masters burgerlijk recht en ondernemingsrecht. Na afronding van zijn studie is hij in dienst getreden als docent en promovendus bij het Van der Heijden Instituut van de Radboud Universiteit Nijmegen. Sinds 2017 werkt hij bij het Molengraaff Instituut voor Privaatrecht van de Universiteit Utrecht waar de dissertatie is afgerond. Tijdens zijn promotieonderzoek verbleef Etzel twee periodes als gastonderzoeker bij het Max Planck Institute for Comparative and International Private Law in Hamburg.

Van 2013 tot en met 2016 was hij secretaris van de Werkgroep Personenvennootschappen. Daarnaast zit hij in de redactie van het Maandblad voor Ondernemingsrecht en in de boekenraad privaatrecht van Ars Aequi. Hij is tevens hoofddocent van de cursus Ondernemingsrecht voor de Beroepsopleiding Advocaten.

Etzel van Dooren heeft diverse artikelen gepubliceerd op het gebied van het ondernemingsrecht. 



\section{UITGAVEN VANWEGE HET INSTITUUT VOOR ONDERNEMINGSRECHT, RIJKSUNIVERSITEIT GRONINGEN EN ERASMUS UNIVERSITEIT ROTTERDAM}

1. Prof. mr. P. van Schilfgaarde, prof. mr. W.J. Slagter, mr. R.A.A. Duk, prof. mr. C.W.A. Timmermans, prof. mr. W.C.L. van der Grinten, Geschillen in de onderneming, 1984.

2. Prof. mr. P. van Schilfgaarde, mr. P.J. Dortmond, mr. P.C. van den Hoek, mr. H.L.J. Roelvink, prof. mr. H.J.M.N. Honée. De nieuwe misbruikwetgeving, 1986.

3. Prof. mr. P. van Schilfgaarde, Misbruik van rechtspersonen, 1986.

4. Mr. L. Timmerman, Over multinationale ondernemingen en medezeggenschap van werknemers, 1988.

5. Prof. mr. J.M.M. Maeijer, prof. mr. P. van Schilfgaarde, mr. M.W. den Boogert, prof. mr. M.R. Mok, prof. mr. E. Aardema, Aandelen, 1988.

6. Mr. S.M. Bartman, Concernbeleid en aansprakelijkheid, 1989.

7. Mr. J.B. Huizink, Bestuurders van rechtspersonen, 1989

8. Mr. A.F.M. Dorresteijn, Tegenstrijdig belang van bestuurders en commissarissen, 1989.

9. Prof. mr. L. Timmerman, prof. mr. P.J. Dortmond, prof. mr. C.A. Boukema, mr. H.J.M.N. Honée, mr. H.L.J. Roelvink, mr. A.L. Mohr, prof. mr. P. van Schilfgaarde, Piercing Van Schilfgaarde, 1990.

10. Mr. B.H.A. van Leeuwen, Beginselen van behoorlijk ondernemingsbestuur, 1990.

11. Prof. mr. W.J. Slagter, mr. Karin C. Th. Schouwenberg, mr. A.G. van Solinge, mr. A.L. Mohr, prof. dr. L.G.M. Stevens, mr. A.J.S.M. Tervoort, mr. M.E. Koppenol-Laforce, Aspecten van het EESV, 1990.

12. Mr. J.N. Schutte-Veenstra, Harmonisatie van het kapitaalbeschermingsrecht in de EEG, 1991.

13. Mr. B.T.M. Steins Bisschop, De beperkte houdbaarheid van beschermingsmaatregelen bij beursvennootschappen, 1991.

14. Prof. mr. L. Timmerman, prof. mr. P. van Schilfgaarde, mr. H.J.M.N. Honée, mr. S.E. Eisma, prof. dr. H.P. Westermann, mr. M.W. den Boogert, mr. P.C. van den Hoek, prof. mr. P.F. van der Heijden, prof. mr. W.C.L. van der Grinten, Ondernemingsrechtelijke contracten, 1991.

15. Mr. J.W. Winter, Concernfinanciering, 1992.

16. Prof. mr. L. Timmerman, prof. mr. J.M.M. Maeijer, prof. mr. P. van Schilfgaarde, mr. S.E. Eisma, prof. G.K. Morse, mr. L.H. Slijkhuis, prof. mr. A.L. Mohr en mr. T. Drion, De dubbelrol in het vennootschapsrecht, 1993.

17. Dr. R.H. van het Kaar, Medezeggenschap bij fusie en ontvlechting, 1993.

18. Mr. J.W. Winter, mr. drs. H. Langman, prof. mr. M.J.G.C. Raaijmakers, mr. H.J.M.N. Honée, Beschouwingen over concernfinanciering, 1993.

19. Mr. J.M. Blanco Fernández, De raad van commissarissen bij nv en bv, 1993.

20. Mr. G.M. ter Huurne, Nieuwe regels voor de levering van aandelen op naam, 1994.

21. Mr. H.M. Vletter-van Dort, Meldingsplicht voor beursvennootschappen, 1994.

22. Mr. R.C. van Dongen, Identificatie in het rechtspersonenrecht, 1995.

23. Mr. M.Y. Nethe, De ontbinding van lege besloten en naamloze vennootschappen, 1995. 
24. Prof. mr. P. van Schilfgaarde, prof. mr. P.J. Dortmond, prof. mr. L. Timmerman, prof. mr. P.C. van den Hoek, mr. D.C. Buijs, prof. mr. drs. H.P.J. Ophof, prof. mr. drs. H. Beckman en mr. J.W. Winter, Knelpunten in de vennootschapswetgeving, 1995.

25. Prof. mr. H. Beckman, De jaarrekeningvrijstelling voor afhankelijke groepsmaatschappijen, 1995.

26. Prof. mr. P. van Schilfgaarde, prof. mr. S.C.J.J. Kortmann, prof. mr. H.J.M.N. Honée, prof. mr. L. Timmerman, prof. mr. W.D.H. Asser, mr. J.B. Huizink, mr. O.L.O. deWitt Wijnen, mr. M.W. den Boogert, prof. mr. drs. H. Beckman, Rechtspleging in het ondernemingsrecht, 1997.

27. Mr. W.J. Oostwouder, Management Buy-out, 1996

28. Mr. H.E. Boschma, De eenpersoons-bv, 1997.

29. Mr. J.B. Wezeman, Aansprakelijkheid van bestuurders, 1998.

30. Prof. mr. P.C. van den Hoek, prof. mr. P. van Schilfgaarde, prof. mr. H.J.M.N. Honée, prof. mr. M.W. den Boogert, prof. dr. E. Wymeersch, mr. J.W. Winter, prof. mr. L. Timmerman, mr. J.B. Huizink, Corporate Governance voor juristen, 1998.

31. Mr. S.H.M.A. Dumoulin, Besluitvorming in rechtspersonen, 1999.

32. Mr. M.L. Lennarts, Concernaansprakelijkheid, 1999.

33. Mr. M. Koelemeijer, Redelijkheid en billijkheid in kapitaalvennootschappen, 1999.

34. Mr. E.E.G. Gepken-Jager, Vertegenwoordiging bij NV en BV, 2000.

35. Peter van Schilfgaarde Select, 2000.

36. Prof. mr. J.W. Winter, mr. J.W.G. Vink, mr. A.W.H. Docters van Leeuwen, prof. mr. H.J.M.N. Honée, prof. mr. M.W. den Boogert, prof. mr. S.E. Eisma, prof. mr. S. Perrick, prof. mr. G. van Solinge, prof. mr. J.B. Huizink, prof. mr. L. Timmerman, De beursvennootschap, 2001

37. Mr. H.M. Vletter-van Dort, Gelijke behandeling van beleggers bij informatieverstrekking, 2001.

38. Mr. Th. Groenewald, Doeloverschrijding bij NV en BV, 2001.

39. Mr. G.N.H. Kemperink, Fusies, overnames en medezeggenschapsrechten, 2002.

40. Mr. L.J. Hijmans van den Bergh, prof. mr. Gerard van Solinge, mr. T. de Waard, prof. mr. J.W. Winter, prof. mr. L. Timmerman, prof. mr. H.J. de Kluiver, prof. mr. P.J. Dortmond, mr. J.N. Schutte-Veenstra, mr. E.D.G. Kiersch, prof. Jonathan Rickford, Nederlands ondernemingsrecht in grensoverschrijdend perspectief, 2003

41. Marius Josephus Jitta, Vino Timmerman, Guus Kemperink, Richard Norbruis, Anthony Driessen, Peter van der Zanden en HuubWillems, The Companies and Business Court from a comparative law perspective, 2003.

42. Mr. B. Bier, Uitkeringen aan aandeelhouders, 2003.

43. Mr. M. Meinema, Dwingend recht voor de besloten vennootschap, 2003.

44. LT, Verzamelde 'Groninger' opstellen aangeboden aan Vino Timmerman, 2003.

45. Mr. M.J. Kroeze, Afgeleide schade en afgeleide actie, 2004.

46. Mr. P.G.F.A. Geerts, Enkele formele aspecten van het enquêterecht, 2004.

47. Mr. M.L. Lennarts en mr. J.N. Schutte-Veenstra, Versoepeling van het BV-kapitaalbeschermingsrecht, 2004.

48. Mr. K.I.J. Visser, Zeggenschapsrechten van houders van een recht van pand of vruchtgebruik op aandelen op naam, 2004.

49. Mr. J.G. Groeneveld-Louwerse, Publieke wenselijkheid of private beleidsvrijheid, 2004.

50. Mr. Hanny Schutte-Veenstra, mr. Hylda Boschma, prof. mr. Marie-Louise Lennarts, Alternative systems for capital protection 2005.

51. Prof. mr. Peter van Schilfgaarde, mr. Hanny Schutte-Veenstra, prof. mr. P.J. Dortmond, prof. mr. L. Timmerman, mr. Brian Mezas, prof. mr. Jan Berend Wezeman, mr. Ellen Kiersch, prof. mr. Jaap Winter, prof. mr. Harm-Jan de Kluiver, Vereenvoudiging en flexibilisering van het Nederlandse BV-recht, 2005. 
52. Mr. S. Parijs, Fairness opinions and liability, 2005.

53. Mr. J.B.W.M. Kemperink, Vraagstukken rond (terug)storting op nv/bv-aandelen en van coöperatierecht, 2006.

54. Mr. A. Haan-Kamminga, Supervision on takeover bids, 2006.

55. Mr. dr. H.H. Voogsgeerd, Corporate Governance Codes, Markt- of rechtsarrangement?, 2006.

56. Xiaoning Li, A comparative study of shareholders' derivative actions, 2007.

57. Prof. mr. Hans Beckman, mr. Herman L. Kaemingk, mr. drs. Charles Honée, prof. mr. L. Timmerman, prof. mr. A.F. Verdam, prof. mr. Maarten Kroeze, prof. mr. Jan Berend Wezeman, mr. Barbara Bier, prof. mr. Jaap Winter, prof. mr. M.W. den Boogert, De nieuwe macht van de kapitaalverschaffer, 2007.

58. Mr. M.A. Verbrugh, Structuurwijzigingen bij kapitaalvennootschappen en de positie van schuldeisers, 2007.

59. Mr. drs. B.F. Assink, Rechterlijke toetsing van bestuurlijk gedrag, 2007.

60. Mr. A.G.H. Klaassen, Bevoegdheden van de algemene vergadering van aandeelhouders, 2007.

61. Mr. M.L.H. Reumers, Samengevoegde afwikkeling van faillissementen, 2007.

62. Ondernemingsrecht door en voor Mick den Boogert, 2008.

63. Mr. S.N. de Valk, Aansprakelijkheid van leidinggevenden. Naar privaatrechtelijke, strafrechtelijke en bestuursrechtelijke maatstaven, 2009.

64. Mr. A. van der Krans LLM, De virtuele aandeelhoudersvergadering, 2009

65. Prof. dr. K. Cools RA, mr. P.G.F.A. Geerts, prof. mr. M.J. Kroeze, mr. drs. A.C.W. Pijls, Het recht van enquête, een empirisch onderzoek, 2009.

66. Prof. dr. Thomas Blanke, dr. Edgar Rose, dr. Herman Voogsgeerd, prof. dr. Wijnand Zondag, Recasting Worker Involvement?, 2009.

67. Prof. mr. M.J. Kroeze, dr. E.M.H. Hirsch Ballin, dr. A.H.G Rinnooy Kan, prof. mr. L. Timmerman, prof. mr. M. van Olffen, mr. M. Holtzer, prof. dr. M. Wyckaert, prof. dr. K. Geens, prof. mr. J.B. Wezeman, prof. mr. M.L. Lennarts, mr. P.D. Olden, prof. mr. H.M. Vletter-van Dort, Bestuur en toezicht, 2009.

68. Mr. H. Koster, De Nederlandse juridische splitsing in Europees en rechtsvergelijkend perspectief, 2009.

69. Mr. F. Veenstra, Impassezaken en verantwoordelijkheden binnen het enquêterecht, 2010.

70. Mr. B. Snijder-Kuipers, Omzetting als rechtsvormwijziging, 2010.

71. Europees ondernemingsrecht: 50 jaar na Sanders' Europese NV, 2010.

72. Mr. P.P. de Vries, Exit rights of minority shareholders in a private limited company, 2010.

73. Mr. D.A.M.H.W. Strik, Grondslagen bestuurdersaansprakelijkheid, 2010.

74. Mr. J.B.S. Hijink, Publicatieverplichtingen voor beursvennootschappen, 2010.

75. Mr. J.B.S. Hijink en mr. M.A. Verbrugh e.a., Grensoverschrijdend ondernemen na Cartesio, 2010.

76. Prof. mr. B.F. Assink e.a., Evolutie van het bestuurdersaansprakelijkheidsrecht, 2011.

77. Mr. T.E. Lambooy, Corporate Social Responsibility, 2010.

78. Mr. H.M. Punt, Het vennootschapsrecht van Holland, 2010.

79. Mr. M.J. van Ginneken, Vijandige overnames, 2010.

80. Prof. mr. M.J. Kroeze, prof. mr. J.B. Wezeman, prof. mr. L. Timmerman, prof. mr. B.F. Assink, prof. mr. J.W. Winter, prof. mr. L.G. Verburg, prof. mr. H.M. Vletter-van Dort, mr. drs. H.H. Kersten, prof. mr. W.J.M. van Veen, mr. P. Glazener, prof. mr. H. Beckman, SamenWerken in het ondernemingsrecht, 2011.

81. Mr. drs. I.S. Wuisman, Een Nederlandse personenvennootschap met beperkte aansprakelijkheid: wenselijk?, 2011.

82. Qiuju Wang, Exit remedies for minority shareholders in close companies, 2011. 
83. Mr. M. Mussche, Vertrouwen op informatie bij bestuurlijke taakvervulling, 2011.

84. Prof. mr. L. Timmerman, Harry Honée-bundel, 2011.

85. Mr. W.J.L. Calkoen, The One-Tier Board in the changing and converging world of corporate governance, 2012.

86. Mr. J.G.C.M. Galle, Consensus on the comply or explain principle within the EU corporate governance framework: legal and empirical research, 2012.

87. Mr. drs. T.M.C. Arons, Cross-border enforcement of listed companies' duties to inform, 2012.

88. Mr. M.C. Schouten, The Decoupling of Voting and Economic Ownership, 2012.

89. Mr. A.J.M. Klein Wassink, Toetsing van besluiten in het rechtspersonenrecht, 2012.

90. Mr. drs. N.J.M. van Zijl, The Importance of Board Independence - A Multidisciplinary Approach, 2012.

91. Mr. A.J.P. Schild, De invloed van het EVRM op het ondernemingsrecht, 2012.

92. Mr. G.N.H. Kemperink, Vennootschappelijk toezicht op de doelvennootschap bij openbare biedingen, 2013.

93. Mr. A.J.S.M. Tervoort, Het bestuursverbod bij de commanditaire vennootschap, 2013.

94. Mr. J.M. de Jongh, Tussen societas en universitas, De beursvennootschap en haar aandeelhouders in historisch perspectief, 2014.

95. Mr. M. Holtzer, De invloed van werknemers op de strategie van de vennootschap, 2014.

96. Prof. mr. P. van Schilfgaarde, prof. mr. H.E. Boschma, prof. mr. J.B.S. Hijink, prof. mr. J.W. Winter, prof. mr. J.H.M. Willems, prof. dr. J.A. van Manen RA, mr. A.R.J. Croiset van Uchelen, mr. C.W.M. Lieverse, prof. mr. L. Timmerman, Ondernemingsrecht in tijden van crisis, 2014.

97. Mr. P.P.D. Mathey-Bal, De positie van de vennootschap onder firma. In civielrechtelijk, vennootschapsrechtelijk, publiekrechtelijk en Europeesrechtelijk perspectief, 2016.

98. Prof. mr. L. Timmerman, mr. dr. J.N. Schutte-Veenstra, mr. dr. J.M. de Jongh, mr. dr. C.H.C. Overes, mr. dr. A.J.S.M. Tervoort, prof. mr. J.B. Wezeman, prof. mr. B.F. Assink, prof. mr. J.B.S. Hijink, prof. mr. J.H.M. Willems, Eenheid en verscheidenheid in het ondernemingsrecht, 2016

99. De toekomst van het ondernemingsrecht - het ondernemingsrecht van de toekomst, Opstellen voor Prof. mr. L. (Vino) Timmerman, ter gelegenheid van zijn $65^{\text {ste }}$ verjaardag en $25+$ jaar hoogleraarschap, 2015.

100. Prof. mr. P. van Schilfgaarde, De redelijkheid en billijkheid in het ondernemingsrecht, 2016.

100a. Bacchus Rietveld, Glimlachjes en andere weemoedigheden, 2019.

101. Mr. drs. N.T. Pham, Directors' liability. A legal and empirical study, 2017.

102. Mr. Chr.M. Stokkermans, Sleutels voor personenvennootschapsrecht, 2017.

103. Mr. F.G.K. Overkleeft, De positie van aandeelhouders in beursvennootschappen, 2017.

104. Prof. mr. B.F. Assink, mr. M.J. van Ginneken, prof. mr. L. Timmerman, prof. mr. H.M. Vletter-van Dort (Red.), De vele gezichten van Maarten Kroeze's 'bange bestuurders', 2017.

105. Mr. F. Eikelboom, De (onmiddellijke) voorzieningen van de enquêteprocedure, 2017.

106. Mr. C.E.J.M. Hanegraaf, Art. 2:11 BW, doorgeefluik van bestuurdersaansprakelijkheid. Hoe diep kan een bestuurder vallen?, 2017.

107. Mr. dr. A.J.S.M. Tervoort, prof. mr. Bastiaan F. Assink, mr. dr. P.P. de Vries, prof. mr. M.L. Lennarts, mr. P. Schütte, prof. mr. C.A. Schwarz, mr. M.H.C. Sinninghe Damsté, prof. mr. W.J.M. van Veen, mr. dr. B. Snijder-Kuipers, Familievennootschappen, 2017.

108. Mr. W.A. Westenbroek, Bestuurdersaansprakelijkheid en ernstig verwijt in theorie, 2017.

109. Mr. drs. R.E. van Lambalgen, State aid to banks, 2018.

110. Prof. mr. H.E. Boschma, prof. mr. M.L. Lennarts, prof. mr. J.N. Schutte-Veenstra, dr. K. van Veen, Evaluatie Wet bestuur en toezicht, 2018.

111. Mr. A. Argyrou, Social enterprises in the EU: Law in promoting stakeholder participation in social enterprises, 2018. 
112. Mr. M.J. van Uchelen-Schipper, De rol en positie van de raad van toezicht van de stichting, 2018.

113. Mr. E.C.H.J. Lokin, De bezoldiging van bestuurders van beursgenoteerde vennootschappen, 2018.

114. Mr. E.V.A. Eijkelenboom, Vertrouwen voorop. Een onderzoek naar kwaliteitsbevorderende wetgeving voor Nederlandse accountantsorganisaties, 2019.

115. Mr. B. Kemp, mr. dr. H. Koster \& prof. mr. C.A. Schwarz (red.), De betekenis en functies van het vennootschappelijk belang, 2019.

116. Mr. drs. E.C.A. Nass, Groepsregime, jaarrekening en 403-aansprakelijkheid, 2019.

117. Mr. dr. M.Y. Nethe (Red.), prof. dr. H. de Wulf, mr. dr. J. Barneveld, mr. dr. D.A.M.W.H. Strik, prof. mr. J.N. Schutte-Veenstra, prof. mr. C.D.J. Bulten, prof. dr. M. Wyckaert, prof. mr. H.J. de Kluiver, mr. dr. F.G.K. Overkleeft, mr. A.F.J.A. Leijten, Ondernemingsrecht in de lage landen, 2020.

118. Mr. A.C. Faber, Onmiddellijke voorzieningen en hun externe werking, 2020.

119. Prof. mr. L. Timmerman \& mr. Chr.M. Stokkermans, Oprichten zonder omwegen. Digitalisering en fraudebestrijding als game changers voor de oprichtingsprocedures van vennootschappen, 2020

120. Mr. S.B. Garcia Nelen, De beursvennootschap, corporate governance en strategie, 2020.

121. Mr. T.A. Keijzer, Vote and Value, 2020.

122. Mr. E.A. van Dooren, De aansprakelijkheid op grond van een 403-verklaring, 2021. 
